\title{
De vaststelling van de reikwijdte van de rechten van de mens : een bespreking aan de hand van de rechterlijke praktijk naar aanleiding van de artikelen 8 lid 1 en 6 lid 1 (eerste zin) ECRM en de artikelen 1, 6 lid 1, 7 leden 1 en 3 en artikel 9 lid 1 Grondwet
}

Citation for published version (APA):

Staal, C. J. (1995). De vaststelling van de reikwijdte van de rechten van de mens : een bespreking aan de hand van de rechterlijke praktijk naar aanleiding van de artikelen 8 lid 1 en 6 lid 1 (eerste zin) ECRM en de artikelen 1, 6 lid 1, 7 leden 1 en 3 en artikel 9 lid 1 Grondwet. [Doctoral Thesis, Maastricht University]. Ars Aequi Libri. https://doi.org/10.26481/dis.19951221cs

Document status and date:

Published: 01/01/1995

DOI:

10.26481/dis.19951221cs

Document Version:

Publisher's PDF, also known as Version of record

Please check the document version of this publication:

- A submitted manuscript is the version of the article upon submission and before peer-review. There can be important differences between the submitted version and the official published version of record. People interested in the research are advised to contact the author for the final version of the publication, or visit the DOI to the publisher's website.

- The final author version and the galley proof are versions of the publication after peer review.

- The final published version features the final layout of the paper including the volume, issue and page numbers.

Link to publication

\footnotetext{
General rights rights.

- You may freely distribute the URL identifying the publication in the public portal. please follow below link for the End User Agreement:

www.umlib.nl/taverne-license

Take down policy

If you believe that this document breaches copyright please contact us at:

repository@maastrichtuniversity.nl

providing details and we will investigate your claim.
}

Copyright and moral rights for the publications made accessible in the public portal are retained by the authors and/or other copyright owners and it is a condition of accessing publications that users recognise and abide by the legal requirements associated with these

- Users may download and print one copy of any publication from the public portal for the purpose of private study or research.

- You may not further distribute the material or use it for any profit-making activity or commercial gain

If the publication is distributed under the terms of Article $25 \mathrm{fa}$ of the Dutch Copyright Act, indicated by the "Taverne" license above,

Download date: 26 Apr. 2023 
ARS AEQUI LIBRI, onderdeel van de Stichting Ars Aequi, geeft sinds 1975 boeken uit en richt zich daarbij op de juridische opleiding en praktijk. Een deel van het fonds bestaat uit studieboeken, terwijl ernaar wordt gestreefd ook boeken uit te geven die nuttig kunnen zijn voor

praktijkjuristen, zoals rechtshulpverleners. Er zal voorrang worden gegeven aan boeken die vernieuwend werken in het onderwijs of de praktijk, de ontwikkeling van het recht in positieve zin sturen, danwel het betreffende vakgebied kritisch bezien. Belangrijke motivering om een dergelijk boek uit te geven kan zijn dat een andere uitgever het slechts tegen een onaanvaardbaar hoge priis op de markt zal willen brengen.

Alvorens Ars Aequi Libri tot uitgave van een boek besluit wordt het manuscript door een commissie uit de Boekenraad getoetst aan de doelstelling.

Deze Boekenraad is een adviescollege bestaande vit juristen uit wetenschap en praktijk. Het dagelijks bestuur, de Uitvoeringsraad, bestaat uit de uitgever en (oud)redactieleden van Ars Aequi (juridisch maandblad). Voor de samenstelling van deze raden zie men hiernaast.

Aangezien de Stichting Ars Aequi geen winststreven heeft, worden de kost- en verkoopprijzen van de publikaties zo laag mogelijk gehouden. Dit wordt mede mogelijk gemaakt doordat schrijvers, adviseurs, redactieleden en bestuursleden geen aanspraak maken op honoraria.

\section{UTTVOERINGSRAAD}

\section{Steven Bartels}

Gerard van Bussel (uitgever)

Ivo Giesen

Herman Kaemingk

Jeroen Kortmann

Hugo van Kooten

Maarten Kroeze

Aidan van Veen

\section{BOEKENRAAD}

\section{Privaatrecht}

Ton Hartlief

Frank van den Ingh

René Klomp

Geert Lankhorst

Marie Hélène Schutjens:

Reinout Vriesendorp

Marc Ynzonides

\section{Rechtstheorie}

Freek Bruinsma

Ton $\mathrm{Hol}$

Corjo Jansen

Jan Vranken

Laurens Winkel

Rechtsvergelijking, i.p.r., internationaal handelsrecht en Europees privaatrecht

Gerrit Betlem

Gerard-René de Groot

Willem Grosheide

Martijn Hesselink

Filip De Ly

Christa van de Paverd

Sociaal economisch recht

Dienand Christe

Guus Heerma van Voss

Kees Hellingman

Yvonne Konijn

Bernadette van Leeuwen

Staats-, bestuars- en vreemdelingenrecht

Leo Damen

Aalt Willem Heringa

Henk Kummeling

Frank van Ommeren

Lodewijk Rogier

\section{Strafrecht}

Ybo Buruma

Stijn Franken

Dorothé Garé

Paul Mevis

Sibo van Ruiller

Sandra van Woensel 


\section{DE VASTSTELLING VAN DE REIKWIJDTE VAN DE RECHTEN VAN DE MENS}


Co-promotor: Dr. A.W. Heringa

Beoordelingscommissie:

Prof.mr. Th.C. van Boven (voorzitter)

Dr. P. van Dijk (lid Raad van State)

Prof.mr. H.G. Schermers (lid ECieRM; Rijksuniversiteit Leiden)

Prof.mr. F.A.M. Stroink

Dr. R.E. de Winter

\section{CIP-GEGEVENS KONINKLIJKE BIBLIOTHEEK, DEN HAAG}

Staal, Claudia Johanna

De vaststelling van de reikwijdte van de rechten van de mens : een bespreking aan de hand van de rechterlijke praktijk naar aanleiding van de artikelen 8 lid 1 en 6 lid 1 (eerste zin) ECRM en de artikelen 1,6 lid 1, 7 leden 1 en 3 en artikel 9 lid 1 Grondwet / Claudia Johanna Staal.

- Nijmegen : Ars Aequi Libri

Proefschrift Rijksuniversiteit Limburg Maastricht. - Met

lit. opg.

ISBN 90-6916-212-1

Trefw.: Europese conventie ter bescherming van de rechten van de mens / Grondwet / rechten van de mens.

C 1995 Ars Aequi Libri, Nijmegen

Behoudens uitzondering door de wet gesteld mag zonder schriftelijke toestemming van de rechthebbende(n) op het auteursrecht, (c.q. de uitgever, door de rechthebbende(n) gemachtigd namens hem (hen/haar) op te treden), niets uit deze uitgave worden verveelvoudigd en/of openbaar gemaakt door middel van druk, fotocopie, microfilm of anderszins, hetgeen ook van toepassing is op de gehele of gedeeltelijke bewerking.

De uitgeefster (uitgever) is met uitsluiting van ieder ander gerechtigd de in artikel 17, lid 2, Auteurswet 1912 en in het KB van 20 juni 1974 (Stb. 351) bedoelde vergoeding te innen en/of daartoe in en buiten rechte op te treden. 


\section{Voorwoord}

Bij het schrijven van een proefschrift wordt door de auteur vanzelfsprekend getracht originele en interessante vraagstellingen te formuleren, naar aanleiding waarvan dan na gedegen onderzoek standpunten kunnen worden ingenomen. Het voorwoord bij een proefschrift vormt de grote uitzondering op deze originaliteits-regel, aangezien het de aangewezen plek is om enkele opmerkingen vooraf te maken, die door velen in hun voorwoord worden gemaakt. En terecht. Deze opmerkingen zijn essentieel als redengeving voor het feit dat dit boek voor $U$ ligt zoals het er ligt.

Wat ik bij het schrijven van dit boek als het moeilijkste probleem heb ervaren, is het ophouden met schrijven. Over ieder onderwerp viel wel meer te onderzoeken en te schrijven. Er was altijd nog wel meer jurisprudentie of literatuur over te vinden, die al dan niet bruikbaar zou kunnen zijn. Als je hoge eisen aan je eigen werk stelt, is het moeilijk er een punt achter te zetten. Dat die punt achter mijn proefschrift uiteindelijk is gezet, is te danken aan het feit dat er zoveel andere interessante onderwerpen zijn om over te schrijven dat de wens groter wordt daaraan onderzoek te wijden. Bovendien zijn er vanzelfsprekend andere werkzaamheden die tijd gaan opeisen. En niet in de laatste plaats doet ook de behoefte om je sociale leven wat op te krikken zich steeds sterker voelen.

Het onderzoek voor dit boek is afgesloten op 1 januari 1995, al zijn - waar mij dat nodig leek - incidenteel ook rechterlijke uitspraken opgenomen van na die datum.

Zonder de steun van anderen, zou dit boek niet geworden zijn tot wat het is (wat dat is, staat ter beoordeling van de lezer). Er zijn vele mensen die ik zou willen en kunnen bedanken, maar ter voorkoming van het tekort doen van personen door ze niet te noemen, noem ik maar een klein aantal van hen bij naam.

Allereerst wil ik Aalt-Willem Heringa en Kees Flinterman bedanken voor het feit dat zij mij de afgelopen jaren met raad en daad hebben bijgestaan bij het klaren van deze klus en de wijze waarop zij dat hebben gedaan. Enerzijds, is het van groot belang geweest dat zij mij - in het begin - de tijd hebben gegund me het onderzceksterrein eigen te maken en me bij de invulling van het onderwerp van het proefschrift grote vrijheid hebben gelaten. Anderzijds, zijn hun aansporingen om tot een afronding te komen van zowel de afzonderlijke onderdelen als het geheel, noodzakelijk geweest om de omvang van het onderzoek en de tijd die ik ervoor nodig had, nog enigszins binnen de perken te houden. Hun opbouwende kritiek was van zeer grote waarde voor de totstandkoming en, met name, de inhoud van dit boek.

Ik bedank Prof.mr. Th.C. van Boven, dr. P. van Dijk, Prof.mr. H.G. Schermers, Prof.mr. F.A.M. Stroink en dr. R.E. de Winter voor het zitting nemen in de beoordelingscommissie. 



\section{Inhoudsopgave}

Voorwoord

Inhoudsopgave

Lijst met afkortingen

1

1.1

1.2

1.3

1.3.1

1.3 .2

1.3.3

1.3.4

1.4

2

2.1

2.2

2.3

2.4

2.4.1

2.4 .2

2.4.2.1

2.4.2. 2

2.4.2.3

\section{Inleiding}

Onderwerp en doeistelling van het onderzoek

Afbakening van het onderzoek

Interpretatie van (mensen)rechten in het algemeen

Inleiding

Interpretatie-methoden

Rechterlijke beoordelingsruimte; belangenafweging

Gevolgen van de vaststelling van de reikwijdte van grondrechten

Plan van behandeling

De beperkingssystematiek in de Europese Conventie ter Bescherming van de Rechten van de Mens en de Fundamentele Vrijheden

Inleiding

Historische context

Het totstandkomingsproces van de Europese Conventie ter Bescherming van de Rechten van de Mens en de fundamentele vrijheden

De beperkingssystematiek in de ECRM en de inhoudelijke fundering daarvan

De inhoudelijke fundering van de formulering van de rechten en de beperkingssystematiek in de ECRM

Beperkingen op rechten en vrijheden in vredestijd en tijden van rust

De beperkingsmogelijkheden, opgenomen in de artikelen 8-11 ECRM en artikel 2 Protocol IV ECRM

Inhoudelijke omschrijving van rechten en vrijheden op zodanige wijze, dat in die omschrijving de beperkingsmogelijkheden besloten liggen

Inhoudelijke omschrijving van de rechten en vrijheden waarbij bepaalde gevallen of situaties van verdragsrechtelijke bescherming zijn uitgesloten 
Afbakening van de rechten in de Europese Conventie door de Europese en nationale instanties; jurisprudentie naar aanleiding van artikel 6 lid 1 ECRM

5.1 De rechtspraak van de Straatsburgse instanties met betrekking tot artikel 6 lid 1 (eerste zin) ECRM

5.1.1 The right to access to court; introductie

De grondslag van het recht op "access to court"

De reikwijdte van het recht op "access to court"

Afstand van recht

5.1.3.3 Positieve verplichtingen

De betekenis van de term "court" in het recht op "access to court"

5.1.4.1 Introductie

5.1.4.2 Tribunal

Established by law

De rechtspraak van de Nederlandse rechterlijke instanties met betrekking tot artikel 6 lid 1 (eerste zin) ECRM

5.2.1 De reikwijdte van het recht op toegang

5.2.1.2 Verzekering van een effectief recht op toegang tot de rechter

5.2.2 Toegang tot "een onafhankelijk en onpartijdig gerecht dat bij de wet is ingesteld"

5.2.2.1 Introductie; verplichtingen voor de staat in geval van 404 beslissingen genomen door niet-onafhankelijke en onpartijdige, administratieve organen

5.2.2.2 Een onafhankelijk en onpartijdig gerecht dat bij de wet is ingesteld

5.3 Evaluatie; een vergelijking van de criteria van de Nederlandse met de Straatsburgse instanties voor de afbakening van het recht op toegang tot de rechter onder artikel 6 lid 1 ECRM 
6

6.1 De rechtspraak met betrekking tot artikel 1 Grondwet

6.1.1 Gelijke gevallen

6.1 .2

6.1 .3

6.1 .4

6.1 .5

6.1.6

6.1.7

6.1 .8

6.1 .9

6.1 .10

6.1 .11

6.1 .12

6.2

6.2 .1

6.2.1.1

6.2.1.2

6.2 .1 .3

6.2.1.4

6.2 .1 .5

6.2.1.6

6.2.1.7

6.2.1.8

6.2 .2

Afbakening van de rechten in de Grondwet van 1983; jurisprudentie naar aanleiding van de artikelen 1, 6 lid 1, 7 leden 1 en 3 en artikel 9 lid 1 Grondwet

Ongelijke gevallen, ongelijke behandeling

Commentaar op de toetsing aan het gelijkheidsbeginsel

De reikwijdte van het gelijkheidsbeginsel in het overheidsbeleid en ten aanzien van besluiten van verschillende overheidsorganen

Het discriminatieverbod; de pejoratieve betekenis van het verbod

De jurisprudentie en het verschil tussen het gelijkheidsbeginsel en het discriminatie-verbod

Zwaarte van de toetsing en verschillen tussen nondiscriminatiegronden

Indirect onderscheid

Verschil tussen de termen onderscheid en discriminatie; de Algemene wet gelijke behandeling

De non-discriminatiegronden

Conclusies ten aanzien van de afbakening van artikel 1 Grondwet

De rechtspraak met betrekking tot de artikelen 6 lid 1 , 7 leden 1 en 3, en 9 lid 1 Grondwet Artikel 6 lid 1

Het begrip "godsdienst"

Het begrip "levensovertuiging" en de nevenschikking van de vrijheid van godsdienst en de vrijheid van levensovertuiging

Het begrip "belijden"

Wie kan een beroep doen op de vrijheid van godsdienst en levensovertuiging? De term "jeder"

De reikwijdte van het recht in zijn geheel

Inspanningsverplichting bij uitoefening van het onderhavige recht

Beleidsvrijheid van de overheid

441

442

443

447

451

467

473

476 
6.2.2.1 De interpretatie van de reikwijdte van artikel 7 lid 1 bij de grondwetsherziening

6.2.2.2 De reikwijdte van artikel 7 lid 3 volgens de grondwetgever

6.2.2.3 Behandelplan ten aanzien van de rechtspraak met betrekking tot de reikwijdte van artikel 7 lid 1 en lid 3 eerste zin

6.2.2.4 Gedachten en gevoelens

6.2.2.5 De grens tussen het openbaringsrecht en het verspreidingsrecht in artikel 7 lid 1

6.2.2.6 Lid 3: de grens tussen inhoud en vorm van het geopenbaarde

6.2.2.7 Zelfstandig middel van bekendmaking

6.2.2.8 Algemeen verbod

Voorafgaand verlof

Gebruik van enige betekenis

Samenvatting

Wie komt het recht op vergadering en betoging toe?

573

6.2 .3 .2

Het begrip "vergadering" en de reikwijdte van het vergaderrecht

6.2.3.3 De term "betoging" en de reikwijdte van het betogingsrecht

6.2.3.4 Een zorgplicht van de overheid in geval van een "hostile audience"

584

6.2.3.5 Enkele opmerkingen ten aanzien van beperkingen op het recht tot vergadering en betoging

6.2.3.6 Conclusie

588

6.3 Evaluatie

Rechterlijke interpretatie van de artikelen 6 lid 1, 7 leden 1 en 3 en 9 lid 1 Grondwet

6.3.2 Vergelijking tussen de rechterlijke afbakening van enerzijds artikel 1 en anderzijds de artikelen 6,7 en 9

592

Samenvatting en conclusies

7.2 Beantwoording van de hoofdvraag: hoe stelt de rechter de reikwijdte van mensenrechten vast? 

vaststelling van de reikwijdte vañ mensenrechten en de beperking van de uitoefening van mensenrechten en de beperking van mensenrechten roept een spanning op tussen de argumentatie achter de formulering van de rechten en de beperkingsmogelijkheden enerzijds en de rechterlijke praktijk anderzijds

7.4.1 Conclusies ten aanzien van de tweede stelling met betrekking tot de Europese Conventie

7.4.2 Conclusies ten aanzien van de tweede stelling met betrekking tot de Grondwet

7.5 Mogelijke alternatieven voor de gevallen waarin de rechterlijke praktijk spanining met de bedoelingen van de verdragspartijen respectievelijk de grondwetgever oplevert

7.5.1 Een alternatief voor de toetsing van positieve verplichtingen onder de Conventie

7.5.2 Een alternatief voor de rechterlijke praktijk ten aanzien van ongeschreven, algemene beperkingen en andere niet toegestane beperkingsmethoden

Samenvatting

Summary

Literatuurlijst

Documenten inzake de totstandkoming van de Europese Conventie en de grondwetsherziening van 1983 (chronologisch) 
Jurisprudentieregister

Arresten van het Europese Hof voor de Rechten van de Mens

Rapporten van de Europese Commissie voor de Rechten van de Mens

Ontvankelijkheidsbeslissingen van de Europese Commissie voor de Rechten van de Mens Uitspraken van de (Voorzitter van de) Afdeling Rechtspraak van de Raad van State

Uitspraken van andere (al dan niet) rechterlijke instanties en de Nationale Ombudsman 


\section{Lijst met afkortingen}

a.m.v.b.

AA

$A B$

ABW

AGvBRS

AOW

ARRS

$\operatorname{art}(\mathrm{t})$.

AWB

AWGB

AWR

Besl.Comm.

BNB

BW

CBB

CBS

Coll.

CRvB

$D \& R$

DD

ECRM

EG

EHRM

ESH

EUGRZ

e.v.

EVRM

FED

FJR

Gem.wet

Gw

HR

IACRM algemene maatregel van bestuur

Ars Aequi

Nederlandse Jurisprudentie, Administratiefrechtelijke Beslissingen

Algemene Bijstandswet

Afdeling Geschillen van Bestuur van de Raad van State Algemene Ouderdomswet

Afdeling Rechtspraak van de Raad van State artikel(en)

Algemene Wet Bestuursrecht

Algemene Wet Gelijke Behandeling

Algemene Wet Rijksbelastingen

Ontvankelijkheidsbeslissing van de Europese Commissie voor de Rechten van de Mens

Beslissingen in belastingzaken, Nederlandse belastingrechtspraak

Burgerlijk Wetboek

College van Beroep voor het Bedrijfsleven

College van Beroep Studiefinanciering

Collection of Decisions of the European Commission

of Human Rights, Council of Europe

Centrale Raad van Beroep

Decisions and Reports, European Commission of Human Rights, Council of Europe

Delikt en Delinkwent

Europese Conventie voor de Rechten van de Mens en de Fundamentele Vrijheden

Europese Gemeenschap(pen)

Europees Hof voor de Rechten van de Mens

Europees Sociaal Handvest

Europäische Grundrechte Zeitschrift

en verder

Europees Verdrag voor de Rechten van de Mens

Fiscaal Weekblad FED

Tijdschrift voor Familie- en Jeugdrecht

Gemeentewet

Grondwet

Hoge Raad der Nederlanden

Inter-Amerikaanse Conventie voor de Rechten van de Mens

ILO 
IVBPR

IVESCR

jo.

Jur.

KB

KG

KGK

Ktg.

MRT

LBR

MvA

MvT

Ned.Gem.

NJ

NJB

NJCM

NJV

NJW

NTB

NTOR

NVIR

NYIL

OWN

Pres.

Prot.

PS

Publ. A.

Publ. B.

Rapp.Comm.

$\mathrm{Rb}$.

RM Themis

Ro

RSV

$\mathrm{Rv}$

Internationaal Verdrag inzake Burgerrechten en Politieke Rechten

Internationaal Verdrag inzake Economische, Sociale en Culturele Rechten

juncto

Jurisprudentie van het Hof van Justitie van de Europese Gemeenschap(pen)

Koninklijk Besluit

Kort Geding

Kort Geding Kort

Kantongerecht

Militair-rechtelijk tijdschrift

Landelijk Bureau Racismebestrijding

Memorie van Antwoord

Memorie van Toelichting

Nederlandse Gemeente

Nederlandse Jurisprudentie, uitspraken in burgerlijke en strafzaken

Nederlands Juristenblad

Nederlands Juristencomité voor de Mensenrechten

Nederlandse Juristenvereniging

Neue Juristische Wochenschrift

Nederlands Tijdschrift voor Bestuursrecht

Nederlands Tijdschrift voor Onderwijsrecht

Nederlandse Vereniging voor Internationaal Recht

Netherlands Yearbook of International Law

Oorlogswet voor Nederland

President

Protocol

Periodiek voor sociale verzekeringen, sociale voorzieningen en arbeidsrecht

Publications of the European Court of Human Rights, Series A

Publications of the European Court of Human Rights, Series B

Rapport van de Europese Commissie voor de Rechten van de Mens

Arrondissementsrechtbank

Rechtsgeleerd Magazijn Themis

Wet op de Rechterlijke Organisatie

Rechtspraak Sociale Verzekering

Wetboek van Burgerlijke Rechtsvordering 
RV

RvB

RvdW

SEW

Sr.

Stb.

Stcrt.

Sv.

TAR

IB/S

Trb.

TvO

TWK

$\mathrm{vgl}$.

VN

Vol.

$\mathrm{Vz}$.

WAHV

Wet AROB

Wet bbbg

Wet MB/WMRB

Wet RO/WRO

WFR

WGB $\mathrm{m} / \mathrm{v}$

WOM

WPR

WROM

Yearbook
Rechtspraak Vreemdelingenrecht

Raad van Beroep

Rechtspraak van de Week

Sociaal Economische Wetgeving

Wetboek van Strafrecht

Staatsblad

Staatscourant

Wetboek van Strafvordering

Tijdschrift voor Ambtenarenrecht

ten Berge/Stroink, Administratieve rechtspraak overheidbeschikkingen

Tractatenblad

Tijdschrift voor Openbaar Bestuur

Tijdelijke Wet Kroongeschillen

vergelijk

Verenigde Naties

Volume

Voorzitter

Wet administratieve handhaving verkeersdelicten

Wet Administratieve Rechtspraak overheidsbeschikkingen

Wet buitengewone bevoegdheden burgerlijk gezag

Wet Motorrijtuigenbelasting

Wet op de Ruimtelijke Ordening

Weekblad voor Fiscaal Recht

Wet gelijke behandeling van mannen en vrouwen

Wet Openbare Manifestaties

Wet Persoonsregistraties

Wet Rechtsbijstand on- en minvermogenden

Yearbook of the European Convention on Human

Rights, Council of Europe 


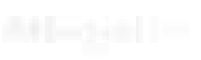

chat

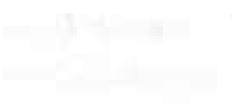

. 


\subsection{Onderwerp en doelstelling van het onderzoek}

Grondrechten' hebben diverse functies. Allereerst kan een grondrecht gericht zijn op de bescherming tegen overheidsingrijpen in de staatsvrije sfeer van de burger; in deze sfeer dient de overheid zich te onthouden van bemoeienis met het (niet-)handelen en de zelfontplooiing van de burger. Naast deze opvatting van grondrechten als individuele, subjectieve rechten verlenende normen, kunnen grondrechten ook gezien worden als objectieve waardenormen, die aan al het overheidshandelen ten grondslag liggen. De in het grondrecht vervatte waarde dient in deze opvatting als richtsnoer voor zowel wetgeving als rechtstoepassing, met name via de interpretatie van vage normen als goede zeden en openbare orde. Voorts worden grondrechten ook wel opgevat als waarborgen ten behoeve van instituten op het terrein van het openbare, statelijke, politieke, religieuze en privéleven. Bij dit soort instituten kan men denken aan het gezin als hoeksteen van de samenleving met betrekking tot het recht op eerbiediging van het gezinsleven en het onafhankelijke en gedifferentieerde perswezen met betrekking tot de persvrijheid. Vervolgens kunnen grondrechten uitgelegd worden als rechten die aanspraak verlenen op overheidshandelen ten einde de gelijke bescherming van alle burgers door de grondrechten te garanderen. Deze uitleg vloeit voort uit de opvatting dat vrijheidsrechten zonder meer, dus functionerend in het maatschappelijke krachtenveld, ongelijkheden tussen burgers scheppen, die door overheidshandelen gladgestreken dienen te worden. Tenslotte kan men grondrechten zien als aanspraken op (financiële) prestaties van de overheid. ${ }^{2}$

Deze diversiteit van functies van grondrechten en de veelheid aan terreinen waarop grondrechten betrekking hebben, brengen echter met zich mee, dat de mogelijkheid van een conflict tussen realisering van het docl van eun

I De termen grondrechten en mensenrechten beschouw ik, althans wat betreft dit onderzoek, als synoniemen en zullen derhalve door elkaar worden gebruikt. Ik kan mij grotendeels verenigen met de verschillen die Alkema tussen beide begrippen aangeeft. $\mathrm{Vgl}$. E.A. Alkema, Het internationale recht inzake de rechten van de mens en de Nederlandse rechtsorde, pp. 203-204.

2 F. Ossenbühl, Die Interpretation der Grundrechte in der Rechtsprechung des Bundesverfassungsgerichts, pp. 2100-2105. Ossenbühl spreekt respectievelijk van "Grundrechte als Abwehrrechte", "Grundrechte als wertentscheidende Grundsatznormen", "Grundrechte als institutionelle Gewährleistungen", "Grundrechte als Teillaberechte" en "Grundrechte als Anspruchsnormen".

Vgl.: Albert Bleckmann, Allgemeine Grundrechtslehren, p. 155 e.v.. 
bepaald grondrecht en een ander beschermenswaardig belang zich voordoet. ${ }^{3}$ Anders gezegd, grondrechten werken niet in een vacuüm, maar functioneren in een maatschappelijk kader. In geval van een dergelijk conflict, zal slechts één van beide belangen geheel gerealiseerd kunner worden. Welk belang dit is, hangt mede af van de opstellers van he document waarin het desbetreffende grondrecht is vervat; deze zuller uitzonderingen op het grondrecht moeten formuleren. Reeds bij he opstellen van de Déclaration des droits de l'homme et du citoyen van 1785 werd deze noodzaak tot beperking van grondrechten onderkend.

Artikel 4 van dit document luidt: "La liberté consiste à pouvoir faire tou ce, qui ne nuit pas à autrui: ainsi l'exercice des droits naturels de chaque homme n'a de bornes que celles, qui assurent aux autres membres de li société la jouissance de ces mêmes droits. Ces bornes ne peuvent êtrt déterminées que par la loi."

Bij het opstellen van de Grondwet en de diverse mensenrechtenverdrage zijn bij de formulering van grondrechten dan ook verscheident beperkingsmogelijkheden gecreëerd. Zo zijn veelal beperkingsclausules bi de gegarandeerde rechten opgenomen, volgens welke de Staat bevoegd i onder bepaalde voorwaarden de uitoefening van dat recht te beperken Bijvoorbeeld in artikel 8 lid 2 ECRM is de volgende beperkingsclausul opgenomen: "There shall be no interference by a public authority with the exercise of this right except such as is in accordance with the law and is necessary in a democratic society in the interests of national security, public safety or the economic well-being of the country, for the prevention of disorder or crime, for the protection of health or morals, or for the protection of the rights and freedoms of others. "Volgens deze clausule is de Staat derhalve bevoegd het in het eerste lid vervatte recht te beperken onder de voorwaarden dat dit geschiedt in overeenstemming met de wet, noodzakelijk is in een democratische samenleving en gebeurt met het oog op een bepaald belang. Er zijn ook nog andere soorten beperkingsmogelijkheden in de Grondwet en mensenrechtenverdragen opgenomen. Deze zullen in hoofdstuk 2 en 3 aan de orde komen bij de bespreking van de beperkingssystematiek in de Europese Conventie voor de Rechten van de Mens en de Grondwet 1983. Deze beperkingsmogelijkheden zijn van belang in het geval tegemoetgekomen dient te worden aan een bepaalde situatie waarin de uitoefening van een grondrecht tot onaanvaardbare consequenties zou leiden. Hiervoor werd al gewezen op een mogelijk conflict tussen realisering van het doel van een 
bepaald grondrecht en een ander beschermenswaardig belang. Men denke hierbij bijvoorbeeld aan het geval dat een gescheiden ouder met een beroep op zijn recht op respect voor zijn gezinsleven (artikel 8 lid 1 ECRM) om een omgangsregeling met zijn kind verzoekt. Wanneer het kind hiervan ernstige schade zou ondervinden, zou het volstrekt onaanvaardbaar zijn indien het verzoek van de ouder wegens diens beroep op artikel 8 ECRM zou moeten worden ingewilligd. Het dient daarom mogelijk te zijn het recht van de betrokken ouder te beperken. Hierin wordt voorzien door de hierboven geciteerde beperkingsclausule.

De rechter zal - vóór hij aan de uitdrukkelijk vastgelegde beperkingsmogelijkheden toekomt - echter allereerst moeten nagaan of een bepaalde wet of maatregel een beperking op een grondrecht inhoudt of niet, en voordien of het te beschermen belang wel binnen de reikwijdte van het ingeroepen recht valt.

De grondwets- en verdragsbepalingen bevatten hoogst zelden expliciete criteria, door middel waarvan de reikwijdte van een grondrecht kan worden afgebakend. Derhalve zal de rechter door middel van interpretatie van het grondrecht criteria moeten vaststellen. Deze taak biedt de rechter enerzijds de mogelijkheid, om door het opstellen van criteria het geldingsbereik van een grondrecht zodanig te verengen ten opzichte van een voorheen vastgestelde reikwijdte, dat gesproken kan worden van beperking van dat grondrecht. ${ }^{4}$ Een in dit proefschrift te behandelen voorbeeld hiervan is het volgende: volgens een uitspraak van de Hoge Raad uit 1985 was het bestaan van biologisch vaderschap voldoende voor het bestaan van "family life" tussen de vader en zijn kind in de zin van artikel 8 ECRM. In 1989 was dit niet meer voldoende en werden bijkomende omstandigheden geëist, zoals het bijgedragen hebben in de opvoeding en verzorging van het kind of het daarmee samengeleefd hebben. ${ }^{3}$ Anderzijds kan de rechter zulke vage criteria vaststellen, dat de overheid een grote - weliswaar aan rechterlijke controle onderworpen vrijheid geniet om de reikwijdte van een grondrecht te beperken. Het hierna nog te noemen "openbaarheids"-criterium ter afbakening van het begrip "privé-leven" in artikel 8 ECRM is hiervan een voorbeeld.

4 Vgl. Koekkoek en Konijnenbelt, Het raam van hoofdstuk 1 van de herziene Grondwet, p. 27: wanneer in geval van "redelijke interpretatie" een grondrecht restrictief geïnterpreteerd wordt, dan zijn "de vraagstukken van interpretatie van grondrechtsbepalingen en van het beperken van grondrechten in wezen twee aanduidingen van dezelfde zaak..." ".

5 Respectievelijk HR 22 februari 1985, NJ 1986, 3 en HR 10 november 1989, NJ 1990, 628; NJCM-Bulletin 15-5 (1990), pp. 581-588, beide arresten in de NJ met noten van E.A. Alkema en E.A.A. Luijten. 
Op tegenovergestelde wijze is het ook mogelijk de reikwijdte van eer grondrecht op te rekken.

Overigens kan ook van beperking door middel van de vaststelling van $d t$ reikwijdte gesproken worden indien men de abstracte rechtsnorm die aar de basis van het grondrecht ligt ${ }^{6}$, als uitgangspunt neemt. Deze abstractt norm moet nog nader worden geconcretiseerd om te kunnen worder toegepast. Bij die concretisering vindt een afbakening van de reikwijdtt van het recht plaats, die beperkter is dan de abstracte norm. Dt concretisering in een positiefrechtelijke norm kan daarom worden gezier als een beperking door middel van interpretatie. Als voorbeeld hiervar behoeft men slechts te denken aan de verschillende formuleringen er betekenissen die een recht als de vrijheid betreffende de "geestelijkt overtuiging" in verschillende mensenrechten-instrumenten heeft gekregen In de Grondwet is dat de vrijheid van godsdienst en levensovertuigin (artikel 6), in de Conventie (artikel 9 ECRM) en het Internationalt Verdrag inzake Burgerrechten en Politieke Rechten (artikel 18 IVBPR) dt vrijheid van gedachte, geweten en godsdienst. Deze vrijheden omvatter onder meer het recht om de godsdienst of overtuiging alleen of ir gemeenschap met anderen te belijden. In de Inter-Amerikaanse Conventit voor de rechten van de mens wordt de vrijheid van geweten en godsdiens (artikel 12 IACRM) gegarandeerd. In dit laatste verdrag wordt aan de formulering van het recht toegevoegd, dat het ook omvat het recht om van godsdienst of overtuiging te veranderen. In artikel 1 van de Verklaring inzake de uitbanning van alle vormen van intolerantie en van discriminatie op grond van godsdienst en overtuiging (en evenzo in artikel 18 IVBPR) wordt de vrijheid van een ieder gegarandeerd "to have a religion or whatever belief of his choice". Al deze bepalingen hebben verschillende formuleringen en verschillende betekenissen. Het is, bijvoorbeeld, bekend dat het in veel Islamitische staten volstrekt onaanvaardbaar wordt geacht dat iemand (althans een islamiet) van godsdienst kan veranderen. Ondanks al die verschillende formuleringen en betekenissen wordt de grondnorm, volgens welke men de vrijheid heeft er een "geestelijke overtuiging" op na te houden of aan te nemen, overal geaccepteerd. Alleen de concretisering ervan varieert.

Bij vaststelling van de reikwijdte van het grondrecht moet de rechter allereerst beoordelen of het belang waarvan bescherming wordt gevraagd,

6 Dat willen zeggen, het onderliggende rechtsbeginsel. Scheltens spreekt van een prejuridische ethische rechtsnorm. D.F. Scheltens, Rechtsbeginselen en mensenrechten, p. 82 . 
wel bestreken wordt door de materie van het ingeroepen grondrecht. Heeft een ingeroepen belang deze eerste test doorstaan, dan nog is het mogelijk dat dit belang bescherming door het grondrecht moet ontberen.

In de praktijk blijkt het namelijk voor te komen, dat de rechter aan een bepaalde persoon of de groep, waarvan die persoon deel uitmaakt, de bescherming door een bepaald grondrecht ontzegt, vanwege de bijzondere rechtsverhouding waarin die persoon of groep, ten opzichte van de overheid verkeert. Dit wordt dan afgeleid uit de aard van het desbetreffende recht en de bijzondere status van de groep. Deze vorm van beperking van een grondrecht wordt inherente beperking genoemd.

De beperking van de reikwijdte van grondrechten, zowel door middel van een restrictieve begrenzing van de materie die het recht bestrijkt als via inherente beperking, is een wijze van beperking van de uitoefening van grondrechten die gehanteerd wordt in het kader van de interpretatietaak van de rechter.

Zoals gezegd, gaat het bij beperking van grondrechten door middel van de inperking van de reikwijdte van het grondrecht om een beperkingsmethode, die gehanteerd kan worden vóórdat men toekont aan de veelal wél in de Europese Conventie c.q. Grondwet voorziene beperkingsmethoden.' Zo de in de desbetreffende documenten uitdrukkelijk opgenomen beperkingsmethoden al zijn gebonden aan bepaalde restricties, die de burger bescherming moeten bieden tegen een té gretig gebruik door de: overheid van de geboden beperkingsmogelijkheden, dan gelden deze - strikt genomen - niet voor de hiervoor genoemde beperking door middel van inperking van de reikwijdte van grondrechten. Toch spreekt het voor zich, dat de grenzen van een recht niet volstrekt willekeurig kunnen worden vastgesteld, al naar gelang die het beste uitkomen. In tegendeel, juist om willekeur te voorkomen en rechtszekerheid te bieden is het de taak: van de rechter - bij gebrek aan een maatstaf in de verdrags- of Grondwetsbepaling - om een ingeroepen recht te definiëren. De hoofdvraagstelling die dan ook aan dit proefschrift ten grondslag ligt, luidt:

"Op welke wijze stelt de rechter de reikwijdte van de rechten van de mens vast?"

Vgl. E.A. Alkema, Studies over Europese grondrechten, p. 35: "De toepassing van grondrechten verloopt meestal in twee fasen: de uitleg van het grondrechi en - zo daar nog aanleiding toe is - de uitleg van de toegestane beperking. De vaststelling van hetgeen wel en niet tot het grondrecht moet worden gerekend kan al vrij ingrijpende en restriktieve gevolgen hebben." 
Nader toegespitst: stelt hij nauwkeurige of open criteria vast en waaraan ontleent hij die? En wat voor rol spelen de beperkingsmogelijkheden hierbij?

Met het oog op de behandeling en de beantwoording van de hierboven geformuleerde vraagstelling, zal in dit onderzoek van twee stellingen worden uitgegaan. De eerste stelling is de volgende:

"Er bestaat een verband tussen de vaststelling van de reikwijdte van mensenrechten en de beperking van de uitoefening van die rechten."

We zagen al dat via de afbakening van een recht, in feite, een beperking van de uitoefening van dat recht plaats kan vinden. Dit is een eerste voorbeeld van het bestaan van een verband tussen de vaststelling van de reikwijdte en de beperking van de uitoefening van mensenrechten. Er zijn echter meer redenen om het bestaan van dit verband aan te nemen. In dit proefschrift zullen verschillende hiervan naar voren komen zoals het feit dat één van de criteria die in het kader van de afbakening van het recht op respect voor het privé-leven wordt gehanteerd overeenkomsten vertoon met de doelcriteria "openbare orde" en "rechten van anderen" in de beperkingsclausule in het tweede lid van artikel $8 \mathrm{ECRM}$. En het feit dat verschilĺfende elementen uit de beperkingsclausule van artikel 8 lid 2 ECRM worden gebruikt voor de afbakening van de uit lid 1 van dit artikel voor de Staat voortvloeiende positieve verplichtingen. Of dat het proportionaliteitsbeginsel een rol speelt bij de begrenzing van de beoordelingsmarge van de (nationale) overheid bij zowel de beperking van de gegarandeerde rechten als bij de vaststelling van de reikwijdte van die rechten.

Wanneer echter de juistheid van de stelling omtrent het bestaan van een verband tussen de vaststelling van de reikwijdte en de beperking van de uitoefening van mensenrechten moet worden aangetoond, dan ligt het voor de hand, dat niet alleen gekeken wordt naar op welke wijze de rechten geïnterpreteerd en beperkt worden, maar ook naar de fundering van deze methoden. Aan de in de Conventie en Grondwet voorziene beperkingssystematiek liggen bepaalde keuzes ten grondslag. Voor bepaalde beperkingsmethoden is wel gekozen, voor andere methoden niet. Deze keuzes moeten gebaseerd zijn op bepaalde argumenten; beperkingsmethoden moeten kennelijk aan bepaalde eisen voldoen. Indien men deze eisen kan identificeren, dan kan men vervolgens nagaan, of de rechtspraktijk aan deze eisen voldoet. Als uitgangspunt voor dit deel van het onderzoek heb ik de volgende stelling gekozen: 
"Tengevolge van het verband tussen de vaststelling van de reikwijdte en de beperking van de uitoefening van mensenrechten bestaat er een spanning tussen de rechterlijke praktijk ten aanzien van de reikwijdteafbakening en beperking van mensenrechten enerzijds en de argumentatie die aan de beperkingssystematiek ten grondslag ligt anderzijds."

Zo is bijvoorbeeld in de herziene Grondwet gekozen voor een beperkingssystematiek van - hoofdzakelijk - bijzondere beperkingen en worden niet tot de Grondwet herleidbare algemene beperkingen afgewezen. De rechterlijke praktijk wijst er echter op dat toch van algemene beperkingen gebruik gemaakt wordt in gevallen waarin de beperkingsclausules in de Grondwet geen soelaas bieden. Een ander voorbeeld is de keuze van de opstellers van de Europese Conventie voor nauwkeurig gedefinieerde beperkingsclausules, verbonden aan nauwkeurig geformuleerde rechten. In de praktijk zien we echter regelmatig dat door de rechter over de nauwkeurige afbakening van een recht wordt heengestapt en direct wordt getoetst aan een beperkingsclausule. In het eerder genoemde voorbeeld van de positieve verplichtingen die uit de gegarandeerde rechten kunnen voortvloeien valt het verschil in de toetsing aan het eerste lid van artikel 8 ECRM aan de ene kant en de toepassing van de beperkingsclausule in het tweede lid aan de andere kant, geheel weg.

De doelstelling van dit proefschrift komt er derhalve samengevat op neer dat, door middel van een onderzoek naar zowel de fundering van de beperkingssystematiek van de Conventie en de Grondwet van 1983 als de rechtspraktijk naar aanleiding van enkele in deze instrumenten gewaarborgde rechten, getracht zal worden de gegrondheid van de hierboven weergegeven stellingen aan te tonen en tot een beantwoording van de geformuleerde hoofdvraagstelling te komen.

\subsection{Afbakening van het onderzoek}

Hiervoor werd al enkele malen de nadruk gelegd op de beperkingssystematiek in en de praktijk naar aanleiding van de Europese Conventie voor de Rechten van de Mens en de Grondwet. Dit onderzoek zal zich op deze documenten concentreren. Reden hiervoor is, dat de Grondwet de hoogste nationale grondrechtsnormen bevat die in onze rechtsorde gelden. Echter, om verschillende redenen moet de Europese Conventie in het onderzoek betrokken worden. 
Volgens artikel 93 van de Grondwet werken verdragsbepalingen bínnen de Nederlandse rechtsorde door (dat wil zeggen, dat zij interne werking hebben) indien zij directe werking hebben, derhalve wanneer de burgers voor de rechter direct een beroep op deze bepalingen kunnen doen zonder dat eerst nadere uitwerking door een (inter)nationale instantie noodzakelijk is. Voor de meeste bepalingen van de Europese Conventie geldt, dat zij directe werking hebben. Daarenboven genieten deze verdragsbepalingen voorrang boven de nationale wetgeving op grond van artikel 94 van de Grondwet. Dit betekent niet alleen dat formele wetgeving buiten toepassing moet blijven in geval van strijd met de Conventiebepalingen, maar ook grondwetsbepalingen!" Het is dan ook aannemelijk, dat de interpretatie van grondwettelijke grondrechten invloed zal ondergaan van de Conventiebepalingen. Bij de toetsing aan en toepassing van grondwettelijke grondrechten zal er immers altijd rekening mee moeten worden gehouden, dat er geen strijd bestaat met de toepasselijke bepalingen in de Conventie. De kans bestaat, dat de grondwettelijke grondrechten "naar de Conventie toe geïnterpreteerd" zullen worden. Een voorbeeld hiervan is artikel 10 Grondwet. In de jurisprudentie, die in hoofdstuk 4 zal worden behandeld, wordt bij de interpretatie van dit artikel gebruik gemaakt van artikel 8 ECRM en de naar aanleiding van dat artikel tot stand gekomen rechtspraak. Vergelijking van de Grondwet en de Conventie wijst er ook op dat er zekere overeenkomsten bestaan tussen de in de Europese Conventie opgenomen rechten en een deel van de Grondwettelijke grondrechten. Zo is bijvoorbeeld het discriminatie-verbod opgenomen in artikel 1 Grondwet en artikel 14 ECRM, het kiesrecht in artikel 4 Grondwet en artikel 3 Protocol I ECRM, de vrijheid van godsdienst en levensovertuiging in artikel 6 Grondwet en artikel 9 ECRM, de vrijheid van meningsuiting in artikel 7 Grondwet en artikel 10 ECRM, de verenigingsvrijheid in artikel 8 Grondwet en artikel 11 ECRM, het recht op bescherming van het privé-leven, de woning en de correspondentie in de artikelen 10 tot en met 13 Grondwet en artikel 8 ECRM. ${ }^{9}$ Daar komt

8 Zie echter artikel 60 ECRM: "Nothing in this Convention shall be construed as limiting or derogating from any of the human rights and fundamental freedoms which may be ensured under the laws of any High Contracting Party or under any other agreement to which it is a Party." Op grond van dit artikel gaat de regel, die de meest vergaande bescherming inhoudt, voor boven een andere, minder vergaande regel. Biedt een grondwettelijk grondrecht derhalve meer bescherming dan een Conventiebepaling dan geld de grondwettelijke norm.

9 Dit is slechts een selectie van rechten die in beide documenten zijn opgenomen. Anderzijds is het recht van petitie well in de Grondwet (artikel 5) opgenomen en niet in de Conventie. Hetzelfde geldt voor de (sociale) grondrechten opgenomen in de artikelen 18 tot en met 22 van de Grondwet en het recht op openbaarheid van bestuur 
nog bij dat de Conventie onontbeerlijk is voor de grondrechtelijke toetsing van formele wetgeving, omdat deze ingevolge artikel 120 Grondwet niet aan de grondwettelijke grondrechten mag worden getoetst.

Derhalve zal in dit onderzoek de beperkingssystematiek van zowel de Grondwet als de Conventie aan bod komen, evenals de Straatsburgse en Nederlandse jurisprudentie ten aanzien van enkele rechten in de Conventie en de rechtspraak met betrekking tot enkele grondrechten in de Grondwet.

Andere - voor de Nederlandse rechtsorde relevante mensenrechtenverdragen, zoals het Internationale Verdrag inzake Burgerrechten en Politieke Rechten (IVBPR) blijven hier voornamelijk om pragmatische redenen buiten beschouwing. Hoewel ten aanzien van het IVBPR de opvatting gerechtvaardigd is, dat de meeste daarin opgenomen bepalingen directe werking hebben, is er aanzienlijk minder Nederlandse rechtspraak met betrekking tot dit verdrag voor handen dan ten aanzien van de Europese Conventie. Omdat dit onderzoek voor een belangrijk deel betrekking heeft op jurisprudentie meen ik mede daarom dit verdrag buiten beschouwing te moeten laten. Dit argument geldt nog sterker voor andere mensenrechtenverdragen. Voorts laat ook de omvang van dit onderzoek een uitbreiding tot andere verdragen niet toe.

Men kan binnen de grondrechten onderscheid maken tussen rechten, die de overheid verplichten zich van bemoeienis te onthouden en rechten, die een bepaald actief optreden van de overheid verlangen. ${ }^{10}$ Ten aanzien van de eerste soort rechten houdt beperking van grondrechten in, dat de overheid legitiem op deze rechten beperkingen kan aanbrengen. De overheid behoeft zich dan niet van bemoeienis te onthouden. Wat betreft de tweede soort rechten, zou beperking inhouden, dat de overheid kan volstaan met de nakoming van slechts een deel van haar verplichting tot actief handelen. Volgens Burkens zou dit impliceren, dat tevoren de omvang van deze positieve verplichting zou vaststaan, met andere woorden, dat in het grondrecht als normatieve bepaling de gehele reikwijdte van de aanspraak zou moeten zijn vastgelegd. Dit acht hij slechts in uitzonderingsgevallen mogelijk."

(artikel 110). Ook zijn een aantal rechten wel in de Conventie of de Protocollen daarbij, opgenornen en niet in de Grondwet. Ik doe! hierbij op bijvoorbeeld het recht op leven (artikel 2 ECRM), het verbod van slavernij en dwangarbeid (artikel 4 ECRM), de vrijheid van geweten (artikel 9 ECRM), het recht orn te huwen en cen gezin te stichten (artikel 12 ECRM), de vrijheid van eigendom (artikell I Protocol I ECRM), de bewegingsvrijheid (artikel 2 Prot. IV ECRM) en het recht op hoger beroep in strafzaken (artikel 2 Prot. VII ECRM).

10 Hiervoor werd reeds gewezen op de verschillende functies van grondrechten.

11 M.C. Burkens, Beperking van grondrechten, p. 7. 
Hierover valt het volgende op te merken. De opvatting van Burkens impliceert, dat ten aanzien van rechten, die de overheid verplichten to onthouding van bemoeienis, wél de reikwijdte van tevoren zou vaststaan Dit zou ik willen bestrijden. Juist de opvatting, dat die reikwijdte nie vaststaat ligt aan de basis van dit onderzoek. Ten eerste zou - indien de reikwijdte vast zou staan - de beperking van een grondrecht door middel van inperking van de reikwijdte van dat grondrecht niet mogelijk zijn Zoals de te onderzoeken rechtspraak zal laten zien is dit wél mogelijk. Ten tweede verandert het positieve recht in de loop der tijd en moet het ook veranderen om de maatschappelijke ontwikkelingen bij te houden. Ook hierdoor verandert de reikwijdte van een vrijheidsrecht van tijd tot tijd.

Het verschil tussen rechten, die verplichten tot overheidsonthouding en die een verplichting tot overheidsoptreden bevatten, waardoor aan de tweede soort verplichtingen veel moeilijker een beperkingssystematiek ten grondslag kan worden gelegd dan aan de eerste, is mijns inziens nitt gelegen in het al dan niet vaststaan van de reikwijdte van beide soorten rechten, maar in de methoden van de rechter om deze reikwijdte vast te stellen. In geval van negatieve overheidsverplichtingen kan de rechter via interpretatie de grenzen vaststellen van de sfeer waarin de overheid zich in beginsel van optreden dient te onthouden. Dit is veel moeilijker bij positieve overheidsverplichtingen. ${ }^{12}$ Het gaat daar namelijk niet alleen on afbakening van het terrein waarop de overheid moet optreden, maar ook om wélke handelingen de overheid moet plegen. Hier komen veelal politieke keuzes bij kijken, die de rechter niet kan maken. Als de rechter al in zeer beperkte mate een beslissing kan nemen over de omvang en aard van de te nemen overheidsmaatregelen, dan is het nog veel moeilijker voor te stellen dat hij kan beoordelen in hoeverre en op welke wijze de positieve overheidsverplichtingen beperkt mogen worden. ${ }^{13}$ Kijkt men. bijvoorbeeld, naar de in de Grondwet opgenomen sociale grondrechten

12 De opvatting dat de rechter in het geheel geen grenzen aan de reikwijdte van positieve verplichtingen kan stellen gaat, mijns inziens, te ver. De rechter kan wel een uitspraak doen over een soort "minimum-grenzen", dat wil zeggen dat er wel een soort minimum-verplichting voor de overheid zou kunnen bestaan. Deze minimumverplichting is de "kern" of "essentie" van het recht. Zie het laatste hoofdstuk ten aanzien van mijn commentaar op de Straatsburgse jurisprudentie met betrekking tot positieve verplichtingen die uit de Conventie-rechten worden afgeleid.

13 Albert Bleckmann. Allgemeine Grundrechtslehren, p. 227: "Das Problem der Grundrechtsbeschränkung spielt grundsätzlich nur für die Abwehrfunktion der Grundrechte eine Rolle. Bei den Grundrechten als positive Teilhabeansprüche ... stellt sich dagegen diese Problematik nicht." Naar mijn mening is deze opvatting wat al te stellig - zie mijn opmerking in de vorige noot - maar de kern van het onderhavige probleem blijkt uit dit citaat wèl. 
(bijvoorbeeld artikel 21), dan zijn op deze artikelen geen explicíete beperkingen aangebracht.

Hiermee bedoel ik geen uitspraak te doen omtrent het rechtskarakter van de laatste soort rechten; ik beoog slechts duidelijk te maken, dat beide soorten rechten van elkaar verschillen. En op grond van deze verschillen acht ik het gerechtvaardigd om de rechten, die de overheid verplichten tot actief optreden zoveel mogelijk buiten het kader van dit onderzoek te houden, dit mede gezien het feit dat ten aanzien van deze rechten nauwelijks jurisprudentie voor handen is. Derhalve zullen grondrechten, die een positieve verplichting aan de overheid opleggen, slechts behandeld worden, voorzover deze verplichting voortvloeit uit rechten, die in hoofdzaak een negatieve verplichting inhouden en slechts in enkele gevallen een positieve verplichting opleggen.

In het voorgaande heb ik de begrippen "klassieke grondrechten" en "sociale grondrechten" zoveel mogelijk vermeden. Dit zou ik voor de rest van dit onderzoek willen voortzetten. Dit onderscheid wordt wel verklaard uit het verschil in karakter tussen beide soorten rechten: "klassieke grondrechten" zouden verplichtingen zijn die de overheid verplichten tot het onthouden van bemoeienis en "sociale grondrechten" zouden juist verplichten tot overheidsoptreden. Tot zóver lijkt mij dit aanvaardbaar, zoals ook blijkt uit de voorgaande alinea's.

Maar wanneer hieraan de conclusie verbonden wordt, dat klassieke grondrechten wél en sociale grondrechten niet een rechtens afdwingbare aanspraak verlenen wordt dit al dubieuzer. Bovendien worden vaak klassieke grondrechten vereenzelvigd met de in de Europese Conventie opgenomen rechten en de overeenkomstige rechten in de Grondwet en de sociale grondrechten met de in het Europees Sociaal Handvest geformuleerde grondrechten en hun grondwettelijke tegenhangers. Het is inmiddels echter genoegzaam bekend, dat veel van deze rechten een gemengd karakter dragen. ${ }^{14}$ Om verwarring te voorkomen zal daarom zo min mogelijk van de termen "klassieke" en "sociale" grondrechten gebruik gemaakt worden.

Tot slot wat betreft de afbakening van het onderzoek: in dit onderzoek is geen rekening gehouden met het onderscheid tussen verticale en horizontale werking van grondrechten. De reden hiervoor is, dat het voor de reikwijdte van de rechten van de mens niets uit zou moeten maken of het gaat om een recht dat wordt ingeroepen tegenover de overheid dan wel 
ten aanzien van particulieren. Dit verschil tussen verticale en horizontale werking zou zich, naar mijn mening, pas kunnen voordoen bij de toepassing van deze rechten. De onderzochte rechterlijke uitspraken kunnen derhalve zowel casus tussen burgers en de overheid als tussen privé-personen onderling betreffen.

\subsection{Interpretatie van (mensen)rechten in het algemeen}

\subsubsection{Inleiding}

Zoals in de vorige paragrafen is aangeduid, is het hoofdthema van dit boek de vaststelling van de reikwijdte van mensenrechten. Het onderzoek zal zich hoofdzakelijk richten op de wijze waarop de rechter deze rechten interpreteert. Ook zal, vanwege het uitgangspunt dat er een verband bestaat tussen de vaststelling van de reikwijdte en de beperking van mensenrechten, ingegaan worden op de beperkingssystematiek in de Conventie en de Grondwet. Hierbij zal, onder andere, onderzocht worden hoe de rechter de in die documenten voorziene beperkingsmogelijkheden interpreteert. De bedoeling van de onderhavige paragraaf is om de diverse interpretatie-methoden die de rechter (en ook de wetgever) ten dienste staan bij die interpretatie, de beoordelingsruimte die de rechter daarbij heeft en de gevolgen van de afbakening van de reikwijdte van mensenrechten, te bespreken. Aangezien het hier gaat om een opstapje naar het eigenlijke onderwerp, zal deze bespreking noodzakelijkerwijs in omvang beperkt zijn. ${ }^{\text {is }}$ Zo zal met betrekking tot de interpretatie van de Conventie, alleen ingegaan worden op de door het Hof gehanteerde interpretatie-methoden. ${ }^{16}$

15 Voor een completere behandeling van (rechterlijke) toetsing (van grondrechten) verwijs ik naar: $\boldsymbol{R}$. de Lange. Publiekrechtelijke rechtsvinding, diss. Amsterdam 1991, W.E.J. Tjeenk Willink: Zwolle 1991.

16 Zie noot 35. Zo zal niet behandeld worden de vraag of de Straatsburgse organen klachten abstract of concreet toetsen, dat wil zeggen of ze de nationale wetgeving in abstracto op verenigbaarheid met de Conventie beoordeten of alleen de concrete toepassing hiervan (vgl. EHRM 21 februari 1975, Golder Case, §39, p. 19: "It is not the function of the Court to elaborate a general theory of the limitations admissible in the case of convicted prisoners, nor even to rule in abstracto on the compatibility of ... with the Convention. "). Deze vraag hangt samen met het vereiste in artikel 25 dat de klager slachtoffer moet zijn van de beweerde schending en geen actio popularis kan worden ingesteld. Zie hieromtrent Y.S. Klerk, Het ECRM-toezichtmechanisme, pp. 215-231. Zie voorts, bijvoorbeeld, de uitspraak in EHRM 7 juli 1989. Gaskin Case, $\S \S 36-37$, p. 15 op pp. 201-202. Zie ook pp. 338 en 375. 


\subsubsection{Interpretatie-methoden}

Zoals bij praktisch al het recht, is de toepassing van grondrechten meer dan de logische toepassing van de regel op de feiten, aangezien de grondrechtsbepalingen nooit geheel duidelijk noch volledig zijn. Uitleg en eventueel ook aanvulling ${ }^{17}$ van deze bepalingen is daarom noodzakelijk. De Memorie van Toelichting bij wetsontwerp 13872 stelde de regering met betrekking tot dit onderwerp het volgende vast:

"De in de Grondwet geformuleerde grondrechten nemen in de hiërarchie van rechtsregels in het rechtssysteem een hoge plaats in, doch zijn wat hun inhoud betreft, onderworpen aan het proces van interpretatie, rechtsvinding en rechtsvorming dat voor alle geschreven recht geldt. In dat proces is er een voortdurende wisselwerking tussen de behoeften van de samenleving en de inhoud van de grondrechtelijke norm. Elke beslissing komt tot stand binnen een kader waarin factoren als tekst, wordingsgeschiedenis, rechtspraak, doctrine, rechtsovertuiging, maatschappelijke en andere behoefte of de functie van het grondrecht een rol spelen. Dit is in het algemeen het procédé van rechtsvinding en er is geen reden om aan te nemen, dat dit bij de grondrechten anders zou liggen."

De regering is derhalve van mening, dat de grondwettelijke grondrechten weliswaar van een hogere rang zijn in de rechtsorde dan andere rechten, maar desondanks zijn zij aan een zelfde interpretatie-proces onderworpen als deze andere rechten. Volgens van der Hoeven, ontlenen de grondwettelijke grondrechten hun grotere betekenis aan "het directer betrokken zijn" van deze grondrechten "op de actuele visie op de wijze en mate van verwerkelijking van de zedelijke en godsdienstige eis van autonomie der persoonlijkheid, welke in de samenleving wordt erkend". Naarmate deze betrokkenheid echter afneemt, verzwakken en uiteindelink verdwijnen, aldus van der Hoeven, de bijzondere kenmerken van het grondrecht waardoor er geen enkel verschil meer bestaat met andere subjectieve rechten. ${ }^{" i 8}$ Van der Hoeven lijkt zich hier voornamelijk te richten op (klassieke) grondrechten, die een subjectieve aanspraak verlenen. Het beginsel-karakter van (sociale) rechten die door ingrijpen

17 Bijvoorbeeld via een a contrario redenering of analogie.

18 J. van der Hoeven, De plaats van de grondwet in het constitutionele recht, pp. 244245. 
van de overheid moeten worden gerealiseerd is er volgens van der Hoeven echter niet minder om. ${ }^{19}$

Dit verschil tussen grondwettelijke grondrechten en "gewone" rechten, dat erin bestaat dat de grondrechten hun oorsprong vinden in in de samenleving levende, essentiële waarden, brengt echter wél een verschil teweeg ten aanzien van het belang van positivering van grondrechten en andere rechten. Zoals onder meer van der Hoeven schrijft, ontleent een grondrecht anders dan een "gewoon" recht, zijn inhoud en functie niet aan een door de overheid in de (grond)wet toegekende aanspraak, maar aan een eigen aanspraak van de individu. De gelding van een grondrecht is "niet afhankelijk ... van zijn erkenning in de geschreven constitutie". Evenmin kan de formulering in de grondwet van een grondrecht het geldingsbereik van dat grondrecht bepalen. ${ }^{20}$ Mijns inziens geldt hetzelfde ten aanzien van de mogelijkheden tot beperking van een grondwettelijk gegarandeerd grondrecht. Een illustratie van het voorgaande is, bijvoorbeeld, de in hoofdstuk 3 te beschrijven praktijk ten aanzien van (algemene) beperkingen en redelijke wetsuitleg. Uit die praktijk blijkt, dat de mogelijkheden tot beperking van een grondrecht soms te restrictief zijn geformuleerd. Zo kan het zijn, dat een op een gemeentelijke regeling gebaseerde maatregel strijdt met een door een grondrecht beschermd belang. De grondwettelijke bepaling waarin dat grondrecht is gegarandeerd staat echter alleen beperkingen bij formele wet toe, waarbij die wet specifiek het te beperken grondrecht dient aan te wijzen en de omvang van de beperkingsmogelijkheid moet aangeven. Het gaat hier dan om een beperking die niet kan worden herleid tot een grondwettelijke beperkingsclausule en derhalve niet is toegestaan. De oplossing die dan in een aantal gevallen wordt gehanteerd is dat een grondrecht dat een belang of gedraging normaal gesproken beschermt, restrictief wordt uitgelegd waardoor het belang of de gedraging niet langer binnen de reikwijdte van het grondrecht valt. De bewuste overheidsmaatregel raakt in dat geval het desbetreffende grondrecht niet. Een ander voorbeeld uit de praktijk dat aantoont dat soms vanwege de toepassing van een grondrecht een met een grondwetsbepaling strijdige uitspraak tot stand komt, biedt het Harmonisatiewet-arrest. ${ }^{21}$ In deze uitspraak werd in een obiter dictum

$19 J$, van der Hoeven, De plaats van de grondwet in het constitutionele recht, p. 206. Op die grondrechten, die geen subjectieve aanspraak inhouden, zal wat betreft de interpretatie-methoden niet ingegaan worden.

$20 \mathrm{~J}$. van der Hoeven. De plaats van de grondwet in het constitutionele recht, p. 245.

21 HR 14 april 1989, AB 1989, 207: NJCM-Bulletin 14-5 (1989) met noot A.W. Heringa, pp. 581-591. Zie ook: A.W' Heringa, Constitutionele schijnbewegingen, pp. $67-81$. 
ondanks het toetsingsverbod van artikel 120 Grondwet de in het geding zijnde regeling in de Harmonisatiewet ongrondwettig geoordeeld. Strikt genomen mocht de Hoge Raad zich vanwege het toetsingsverbod niet over de (on)grondwettigheid van de bestreden regeling uitlaten. Omdat de Raad dit toch wenste te doen, deed hij dat toen in een obiter dictum, waardoor het - met name voor de wetgever - duidelijk was, wat het standpunt van de Raad hieromtrent was en hier in de toekomst rekening mee kon worden gehouden. Kortom, hier geldt wat Kortmann opmerkt ten aanzien van de socialiserende interpretatie van grondrechten: "de ... achtergrond van deze interpretatie is dat de uitoefening van grondrechten niet alleen juridisch mogelijk moet zijn doch ook feitelijk gerealiseerd moet kunnen worden. "22 Om grondrechten feitelijk te realiseren zal het derhalve noodzakelijk kunnen zijn een grondrecht uit te oefenen op een wijze die strikt genomen juridisch niet mogelijk lijkt te zijn. Omgekeerd zal het soms mogelijk moeten zijn de uitoefening van een grondrecht te beperken waar dat strikt genomen juridisch niet is toegestaan. Het verschil tussen grondrechten en andere rechten ${ }^{2}$ is mijns inziens dan ook niet zozeer verklaarbaar uit een verschil in interpretatie-methoden, maar uit een verschil in oorsprong van deze rechten: de grondrechten vloeien voort uit een eigen aanspraak van de individu en de andere rechten ontlenen hun gelding aan positivering in een wetsbepaling.

De noodzaak van interpretatie en eventueel aanvulling van grondrechten geldt voor zowel de reikwijdte van het grondrecht waarvan de bescherming wordt ingeroepen, als wel de beperking daarvan. Zowel de wetgever als de rechter worden met deze noodzaak tot interpretatie geconfronteerd. De wetgever dient grondrechtelijke regels te interpreteren teneinde de betekenis van die regels vast te kunnen stellen voor de te regelen materie, de rechter moet overgaan tot interpretatie in het concrete voorgelegde geval. Zoals reeds kan worden afgeleid uit de hiervoor geciteerde overweging uit de Memorie van Toelichting, kan de uitleg van grondrechtsbepalingen - weer net als bij iedere wets- of verdragsregel plaatsvinden via verschillende interpretatiemethoden. De opsomming in de Memorie van Toelichting van factoren die een rol spelen in het proces van

22 C.A.J.M. Kortmann, Grondrechten in de nieuwe grondwet: vijf jaren toepassing in wetgeving en rechtspraak, p. 238.

23 Waaronder hier met name begrepen word thet verschil in interpretatie-resultaat: het rechterlijk oordeel dat niet door de Grondwet toegelaten algemene beperkingen toch zijn toegestaan, is weliswaar in strijd met die Grondwet, maar hoeft niet per se inconstitutioneel te zijn; de interpretatie van een niet-grondrecht in strijd met het positieve recht zou dat wèl zijn. 
interpretatie, rechtsvinding en rechtsvorming wijst tevens op het gebruik van dezelfde interpretatiemethoden, die ook in bijvoorbeeld het privaat- of strafrecht worden gehanteerd.

Allereerst valt te denken aan de grammaticale interpretatie-methode. ${ }^{24} \mathrm{Bij}$ grammaticale interpretatie van grondrechtsbepalingen denke men, met name, aan de tekstuele uitleg van begrippen als discriminatie, levensovertuiging, persoonlijke levenssfeer, "family life" of "civil rights and obligations".

Echter, de betekenis van nagenoeg geen enkel grondrecht is regelrecht - via grammaticale interpretatie - uit de tekst van de betreffende bepaling af te leiden. Om die reden zal men allereerst te rade moeten gaan bij de interpretatie die bij de desbetreffende grondrechtsbepaling is gegeven in de Memorie van Toelichting. ${ }^{25.26}$

Een voorbeeld van een zaak waarin de Hoge Raad zich bediende van de wetshistorische interpretatie-methode is te vinden in een uitspraak van 9 januari 1987. Hierin bepaalde de Hoge Raad dat - voor de begrenzing van het recht op eerbiediging van de persoonlijke levenssfeer in artikel 10 Grondwet - aansluiting diende te worden gezocht bij de redenering in de Memorie van Toelichting ten aanzien van dat artikel. Daarna ging de Hoge Raad over tot het citeren van enkele overwegingen uit de Memorie van Toelichting. ${ }^{27}$ Ook de Raad van State maakte in het advies ten aanzien van de Algemene wet op het binnentreden gebruik van de wetshistorische interpretatiemethode. Zo meende de Raad, onder andere, dat uit de geschiedenis van de totstandkoming van artikel 12 Grondwet viel op te maken, dat niet was gedacht aan situaties waarin het voldoen aan de procedurele vereisten in lid 2 van dat artikel ernstig gevaar zou kunnen

24 Grammaticale interpretatie: uitleg van een wetsbepaling op grond van de bewoordingen van die bepaling. Zie: P. Scholten, Algemeen Deel, pp. 36-41.

25 Wetshistorische interpretatie: onderzoek van de wetsgeschiedenis, om vast te stellen wat de stand van het recht was volgens de wetgevende macht op het ogenblik van het opstellen van de wet. en om na te gaan welke strekking werd toegekend aan de bewoordingen van de wet door de auteurs ervan. P. Scholten, Algemeen Deel, p. 43.

26 Van de wetshistorische interpretatie-methode kan de rechtshistorische interpretatiemethode worden onderscheiden. Bij rechtshistorische interpretatie wordt de rechtsnorm uitgelegd naar zijn herkomst; onderzocht wordt de ontwikkelingsgang van de rechtsnorm als "schakel in een keten, ... die zich soms over eeuwen uitstrekt." Het gaat hier om de ontwikkeling van de regel zelf, van rechtsinstellingen, van de rechtspraak en het maatschappelijk leven. P. Scholten, Algemeen Deel, pp. 35. 77-85 $(78,84)$.

27 HR 9 januari 1987. NJ 1987, 928 met noot E.A. Alkema; AB 1987, 231 met noot F.H. van der Burg. Uiteraard wordt gedoeld op de Memorie van Toelichting op wetsontwerp 13872, zie: Algehele grondwetsherziening, deel Ia Grondrechten. 
opleveren voor de binnentredende ambtenaren of voor anderen. In het advies stelde de Raad dat de tekst van dit artikel geen ruimte bood voor afwijking van de procedurele vereisten. Artikel 12 lid 2 staat de wetgever slechts toe de wijze van legitimatie, van het doen van mededeling van het doel en van het opmaken van het verslag verder uit te werken: "(d)e gevallen waarin voorafgaande legitimatie en mededeling van het doel van het binnentreden zijn vereist zijn evenwel in de Grondwet bepaald. " Hier bestond derhalve geen ruimte voor nadere uitwerking door de wetgever. De Raad achtte het echter niet aannemelijk, dat de grondwetgever heeft gewild (lees: zou hebben gewild, namelijk indien de grondwetgever wel aan de bedoelde gevaarlijke situaties had gedacht) dat in dergelijke situaties aan de procedurele vereisten zou worden voldaan. Het in artikel 1 lid 2 van het ontwerp van de Algemene wet op het binnentreden maken van uitzonderingen op de procedurele vereisten van artikel 12 lid 2 Grondwet beschouwde de Raad dan ook niet als een beperking van artikel 12 lid 2 Grondwet die níet door de grondwetgever zou zijn gewild. Echter, artikel 12 lid 2 Grondwet bleef op dit punt rechtstreekse werking behouden. De Raad van State kwam vervolgens tot de conclusie, dat "... enige clausulering (dat wil zeggen, afwijking van de aan binnentreden gestelde procedurele vereisten, $C S$ ) aan de wetgever zou moeten worden toegestaan door middel van een wijziging van artikel 12 van de Grondwet, dit met het oog op de toekomst en in het belang van de rechtszekerheid. ${ }^{28}$

Echter, veelal bevatten de documenten waarin de wetsgeschiedenis is neergelegd, eveneens woorden of passages die voor nadere uitleg vatbaar zijn. Of zij verschaffen in het geheel geen duidelijkheid omtrent de interpretatie van het desbetreffende grondrecht, hetzij omdat eventuele problemen omtrent de interpretatie over het hoofd zijn gezien, hetzij omdat de onduidelijkheden naderhand pas zijn gerezen, bijvoorbeeld, tengevolge van maatschappelijke ontwikkelingen. Zelfs afgezien van latere maatschappelijke ontwikkelingen kan worden aangenomen, dat naarmate een wet ouder is, van een wetshistorische interpretatie minder overtuigingskracht uitgaat dan van andere interpretatiemethoden. In deze gevallen zal de rechter met name aansluiting moeten zoeken bij de teleologische interpretatiemethode. ${ }^{29}$

28 Advies van de Raad van State bij wetsvoorstel 19073. Algemene wet op het binnentreden, pp. 6-7.

29 M.M. den Boer. Grondwettelijke grondrechten geïnterpreteerd, pp. 63-79(67). Teleologische(-sociologische) interpretatie: onderzoek naar het maatschappelijk verkeer, waaruit een regel wordt afgeleid, aan de hand waarvan een doelmatige inrichting van het maatschappelijk leven dient plaats te vinden. Is het de wetgever, 
Van de in de hoofdstukken 3 en 6 nader te bespreken gevallen waarin sprake is van redelijke wetstoepassing of het impliciet toepassen van algemene beperkingen, kan gesteld worden dat hierin gebruik is gemaakt van de teleologische interpretatie-methode. Het gebruik van deze interpretatie-methode getuigt van een dynamische en actieve houding ten aanzien van de (grond)wetsuitleg en -toepassing. ${ }^{30}$ Een dergelijke dynamische houding is onontbeerlijk indien men streeft naar een maximale grondrechten-bescherming.

Ook kan wellicht gekeken worden naar de interpretatie van andere bepalingen van nationaal of internationaal recht, waarmee de te interpreteren bepaling samenhangt. Gedoeld wordt op de systematische interpretatie-methode die inhoudt dat een rechtsregel geïnterpreteerd wordt als onderdeel van het systeem van het recht, waarvan de bepalingen onderling min of meer hecht samenhangen en een eenheid vormen. ${ }^{31}$ Ook deze methode werd door de Raad van State toegepast in het bovengenoemde advies naar aanleiding van de Algemene wet op het binnentreden. Uit het vastleggen van andere grondrechten, zoals het recht op "persoonlijke integriteit" in artikel 11 en het "recht op vrijheid" in artikel 15 Grondwet, "die als gevolg van het onder alle omstandigheden vasthouden aan de vereisten van artikel 12 , tweede lid, in het gedrang kunnen komen" leidt de Raad af, dat "de grondwetgever, was hij op de gestelde problematiek gestuit, een beperkingsmogelijkheid zou hebben opgenomen." Zoals eerder gezegd, kwam de Raad van State tot de bovengenoemde conclusie, dat - teneinde de spanning tussen de strikte vereisten van artikel 12 lid 2 en de in andere bepalingen vereiste bescherming van de menselijke integriteit op te heffen - enige clausulering aan de wetgever zou moeten worden toegestaan door middel van een wijziging van artikel 12 van de Grondwet. ${ }^{32}$ Een voorbeeld van een rechterlijke uitspraak waarin deze interpretatie-methode wordt gehanteerd is de uitspraak van de Hoge Raad in de zaak Valkenhorst (II). ${ }^{3}$ Het recht

die bij conflicterende belangen in het matschappelijk leven, de beslissing neemt welk doelen (belangen) zullen worden nagestreefd; het is de rechter, die binnen de grenzen door de wetgever gesteld, die zal moeten nagaan hoe (volgens welke regel) deze doeleinden conform de maatschappelijke ontwikkelingen het best bereikt kunnen worden. $P$. Scholten, Algemeen Deel, p. 118-119.

30 Zie hierover o.a. ook: F.A.M. Stroink. De plaats van de rechter in het staatsbestel.

31 P. Scholten, Algemeen Deel, p. 34.

32 Zie noot 28.

33 HR 15 april 1994, NJ 1994, 608 met noot WH-S; vgl. ook Gerechtshof 'sHertogenbosch 18 september 1991 (Valkenhorst I). NJ 1991, 796 met noot $F$. Kuitenbrouwer, in: Computerrecht 1992/2, p. 73 e.v. 
van appellante om te weten van welke ouders zij afstamt vloeit volgens de Hoge Raad voort uit het algemene persoonlijkheidsrecht dat aan grondrechten als het recht op respect voor het privé-leven, het recht op vrijheid van gedachte, geweten en godsdienst en het recht op vrijheid van meningsuiting ten grondslag ligt. Naast de voornoemde grondrechten interpreteert de Raad het door appellante ingeroepen recht ook nog in het kader van artikel 7 van het toen nog niet door Nederland geratificeerde Verdrag inzake de rechten van het kind.

Er is nog een andere mogelijkheid op grond waarvan de wetshistorische interpretatiemethode onvoldoende kan zijn voor de uitleg van een grondrecht. Het is mogelijk dat bepalingen van nationaal of internationaal recht wel een interpretatie van het grondrecht geven, echter deze is door maatschappelijke ontwikkelingen achterhaald. Ook dan ligt de teleologische interpretatiemethode voor de hand.

Hoe het ook zij, de rechter heeft meer beoordelingsruimte naarmate de grondrechtsbepaling onduidelijker is en naarmate de wetsgeschiedenis onvoldoende houvast biedt of verder in het verleden ligt. Veel zal afhangen van de omstandigheden van het geval. Hieruit vloeit een zekere casuïstische toepassing van de diverse interpretatie-methoden voort. ${ }^{\text {I4 }}$

De hierboven besproken toepassing van interpretatie-methoden heeft betrekking op grondwettelijke grondrechten. Er is geen reden om aan te nemen, dat in het internationale en met name het Europese recht andere interpretatie-methoden worden gehanteerd. ${ }^{\text {ss }}$

Anders dan in het nationale recht, kunnen bij de interpretatie van verdragen algemene regels van verdragsinterpretatie, die zijn neergelegd in het Weens Verdragenverdrag van $1969^{36}$, behulpzaam zijn. ${ }^{37}$

34 Zie M.M. den Boer. Grondwettelijke grondrechten geinteipreteerd, pp. 77-78.

35 Wellicht is het beter te stellen, dat aangenomen kan worden dat in het Nederlandse recht geen andere interpretatiemethoden worden gehanteerd dan in het europese en internationale recht, aangexien het Nederlandse recht eerder invloed ondergaat van het europese/internationale recht dan andersom. Deze invloed strekt zich, naar ik aanneem, behalve over het resultaat van het interpretatie-proces ook uit over het gebruik van interpretatie-methoden. Zie de eerste vier alinea's van par. 1.2 wat betreft de invloed van de Europese Conventie op de interpretatie van grondwettelijke grondrechten.

36 Het Nederlandse recht kent alleen de Wet houdende algemene bepalingen der wetgeving van het Koninkrijk (Wet AB), waarin de verhouding tussen rechter en wetgever is vastgelegd. De meest relevante artikelen zijn de artikelen 11 en 12 . Artikel 11 Wet AB bepaalt dat de rechter volgens de wet recht moet spreken en verbiedt de rechter de innerlijke waarde of billijkheid van de wet te beoordelen. Artikel 12 Wet $\mathrm{AB}$ verbiedt de rechter om als wetgever op te treden: "bij wege van 
Zoals hierna zal blijken moet wat betreft de toepassing van deze algemene regels van verdragsinterpretatie op de uitleg van de Europese Conventie voor de Rechten van de Mens overigens wel rekening gehouden worden met de specifieke karaktertrekken van de Conventie. ${ }^{38}$

De Engelstalige en Franstalige tekst van de Conventie zijn gelijkelijk authentiek. Indien deze versies van elkaar afwijken, moet ingevolge artikel 33 lid 4 van het Verdragenverdrag díe tekst aangehouden worden die "best reconciles the texts, having regard to the object and purpose of the treaty. ${ }^{39}$

Volgens Jacobs zijn de algemene regels van verdragsinterpretatie met name ontwikkeld als richtlijnen voor interpretatie door de partijen bij een verdrag. De Conventie voorziet, echter, in een stelsel van internationale rechtspraak, dat tot doel heeft een objectieve interpretatie van de Conventiebepalingen tot stand te brengen "and not to interpret the Convention by reference to what may have been the understanding of one Party at the time of its ratification", aldus de Commissie in de zaak Golder. ${ }^{40}$ Eerder had de Commissie al in de zaak Pfunders uitgesproken, dat de verplichtingen van Staten op grond van de Conventie "essentially of an objective character, being designed rather to protect the fundamental rights of individual human beings from infringement by any of the High Contracting Parties than to create subjective and reciprocal rights of the High Contracting Parties themselves" zijn." Bovendien wordt er volgens

algemene verordening, dispositie of reglement uitspraak te doen". De rechter mag niet een regel vaststellen die ook geldt in andere dan het hem voorgelegde geval. Zie verder kort: F.P.C.L. Tonnaer, Schets van het Nederlandse rechtsstelsel, pp. 4654(47-48). Goede richtlijnen voor interpretatie bevat de Wet AB niet.

37 Zie over de interpretatie van de Conventie aan de hand van het Weens Verdragenverdrag ook: M.L.W.M. Viering. Het toepassingsgebied van artikel 6 EVRM. pp. 18 31.

38 F.G. Jacobs, The European Convention on Human Rights, p. 16. Zie Rapp.Comm. 1 juni 1973. Golder Case, \$44, p. 33: "The question of applying these and other commonly invoked principles of treaty interpretation to the Human Rights Convention should, however, be answered only after taking into account the special nature of this Convention."

39 Vergelijk de uitspraak van het Hof in de zaak Wemhoff: "Thus confronted with two versions of a treaty which are equally authentic but not exactly the same the Court must, following established international law precedents, interpret them in a way that will reconcile them as far as possible." EHRM 27 juni 1968, Wemhoff Case (N.B.: het Weens Verdragenverdrag is van 1969). \$8, p. 23.

40 Rapp.Comm. 1 juni 1973. Golder Case, \$44, p. 34. Zie ook: F.G. Jacobs, The European Convention on Human Rights, p. 17 en F. G. Jacobs, Varieties of approach to treaty interpretation: with special reference to the Draft Convention on the Law of Treaties before the Vienna Diplomatic Conference, p. 342.

41 Besl.Comm. 11 januari 1961, Austria v. Italy (Pfunders Case), p. 140. 
Jacobs in het algemeen van uit gegaan, dat verdragsverplichtingen restrictief geïnterpreteerd moeten worden omdat er sprake is van een inmenging in de soevereiniteit van de Staten. Dit uitgangspunt, zo stelt hij mijns inziens terecht, is niet van toepassing op de Conventie. Dit zou voortvloeien uit artikel 31 lid 1 van het Verdragenverdrag, waarin staat dat "A treaty shall be interpreted in good faith in accordance with the ordinary meaning to be given to the terms of the treaty in their context and in the light of its object and purpose. "2. Volgens het Hof in de zaak Wemhoff is het noodzakelijk "to seek the interpretation that is most appropriate in order to realise the aim and achieve the object of the treaty, not that which would restrict to the greatest possible degree the obligations undertaken by the Parties." ${ }^{43}$

Wat moet worden verstaan onder de context van een verdrag(sartikel)? Volgens de Commissie is de relevante context van een bepaling niet beperkt tot het (onderdeel van het) artikel waarin een regeling is neergelegd. In de nationale wetgeving moet soms "the whole existing body of legislation" en niet slechts de bepaalde wet tot de relevante context gerekend worden. "This is so at least as far as one may assume that the legislator was not unaware of the existing legislation other than that with which he was concerned." Op grond van artikel 31 lid 2 van het Verdragenverdrag moet bij vaststelling van de context van een verdrag rekening gehouden worden met "the special nature of inter-State relations where the subjects, being the States, are only bound by written law to which they have given their consent." ${ }^{4}$ De verwijzing naar de context van de te interpreteren verdragsbepaling komt overeen met de systematische interpretatiemethode.

Het voorwerp en doel van het verdrag waarnaar verwezen wordt bij de interpretatie van verdragsbepalingen zijn met name van belang omdat ze de kern van de inhoud van de wil van de verdragspartijen weergeven. Verder zijn volgens Reuter "l'objet et le but du traité ... les éléments essentiels qui sont pris en considération par la volonté des parties, on doit donc toujours supposer que les parties se sont mutuellement refusé d'admettre toutes les libertés qui porteraient atteinte à ce but et à cet objet qu'elles ont librement choisi comme leur bien commun. " Het voorwerp en doel van een verdrag kunnen onder meer worden afgeleid uit de Preambule. Volgens de Commissie in haar rapport in de zaak Golder is het

42 F.G. Jacobs. The European Convention on Human Rights, p. 17.

43 EHRM 27 juni 1968. Wemhoff Case, §8, p. 23. Zie ook Rapp.Comm. 1 juni 1973. Golder Case, §57, p. 40.

44 Rapp.Comm. 1 juni 1973, Golder Case, \$47, p. 36.

45 P. Reuter. La Convention de Vienne sur le droits des traités, pp. 16-17. 
vereiste van de "rule of law" volgens de Preambule één van de "main objects and purposes of the Convention". ${ }^{46}$ Het Hof is het hier niet mee eens en beschouwt de verwijzing naar de "rule of law" als een van de karakteristieken die behoren tot het gemeenschappelijke erfgoed van de Lid-Staten. Echter, volgens het Hof

"it would be a mistake to see in this reference a merely 'more or less rhetorical reference', devoid of relevance for those interpreting the Convention. ... It seems both natural and in conformity with the principle of good faith (Article $31 \$ 1$ of the Vienna Convention) to bear in mind this widely proclaimed consideration when interpreting the terms of Article $6 \$ 1$. $^{\text {4 }}$

Een (andere) doelstelling van de Conventie is volgens de Preambule "de eerste stappen te doen voor de collectieve handhaving van sommige der in de Universele Verklaring vermelde rechten." Verwezen wordt voorts naar het doel van de Raad van Europa, namelijk het bereiken van een grotere eenheid tussen de Lid-Staten, waarbij een van de middelen om dit doel te bereiken de handhaving en de verdere verwezenlijking van de rechten van de mens en de fundamentele vrijheden is (= het voorwerp van de Conventie)..$^{48}$ De verwijzing naar het voorwerp en doel van de Conventie, zijnde de kern van de inhoud van de wil van de verdragspartijen, duidt op de wetshistorische interpretatie-methode. Echter daarop niet alleen. Uit het volgende blijkt ook dat deze verwijzing naar het voorwerp en doel van de Conventie de hantering van de teleologische interpretatie-methode met zich meebrengt.

De formuleringen "de eerste stappen voor de collectieve handhaving van" en "de verdere verwezenlijking van de rechten en vrijheden" duiden op een evolutief en dynamisch karakter van de Conventie. Bijgevolg dient ook de interpretatie van de Conventie dynamisch en evolutief te zijn: "it must be interpreted in the light of developments in social and political attitudes. Its effects cannot be confined to the conceptions of the period when it was drafted or entered into force. ${ }^{149}$ Jacobs noemt onder andere de volgende

46 Rapp.Comn. 1 juni 1973, Colder Case. \$54. p. 38

47 EHRM 21 rebruari 1975, Golfer Case, \$34, p. 17.

48 Zie ook de Preambule en de artikelen 1 en 3 van het Statuut van de Raad yan Europa, weergegeven op p. 36 (par. 2.2).

49 F.G. Jacobs, The European Convention on Human Rights, p. 18. Zie ook: W.J. Ganshof van der Meersch, Las Méthodes d'interprétation de la Cour Européenne des Droits de l'Homme, pp. 198-199 en M.M. den Boer, Grondwettelijke grondrechten geinterpreteerd, noot 17, p. 69 . Vgl. ook artikel 31 , derde lid, Weens Verdragenverdrag. 
voorbeelden van dynamische interpretatie: de onder artikel 3 van de Conventie verboden vernederende behandeling bestrijkt onder meer ook rassendiscriminatie, alhoewel de opsteliers van het verdrag hieraan waarschijniijk niet hebben gedacht; veranderende opvattingen over het gezin, over onderwijs, over dwangarbeid of over vakbondsvrijheid. ${ }^{50}$ In de Belgische Taal-zaak overwoog het Hof

"that the general aim set for themselves by the Contracting Parties through the medium of the European Convention on Human Rights, was to provide effective protection of fundamental human rights, and this, without doubt not only because of the historical context in which the Convention was concluded, but also of the social and technical developments in our age which offer to States considerable possibilities for regulating the exercise of these rights. " ${ }^{11}$

In de zaak Marckx merkte het Hof op, "that this Convention musi be interpreted in the light of present-day conditions". ${ }^{.2}$

Er zijn in de jurisprudentie van het Hof nog meer voorbeelden van uitspraken te vinden waarin met de rechtsontwikkeling rekening wordt gehouden. Zo zien we dat het Hof in de zaak Cossey, die wat betreft de feiten grote overeenkomsten vertoonde met de zaak Rees, naging of er reden was om van de laatstgenoemde uitspraak af te wijken. Het Hof stelde in de zaak Cossey, dat het niet gebonden is aan zijn eerdere uitspraken, doch dat het in verband met de rechtszekerheid en een goede ontwikkeling van de Conventie-rechtspraak wenselijk is dat het Hof zijn eigen precedenten volgt. Dit verhindert volgens het Hof niet dat het Hof afwijkt van een eerdere uitspraak

"if it was persuaded that there were cogent reasons for doing so. Such a departure might, for example, be warranted in order to ensure that the interpretation of the Convention reflects societal changes and remains in line with present-day conditions." ${ }^{33}$

50 F.G. Jacobs, The European Convention on Human Rights, p. 18.

51 EHRM 23 juli 1968, Belgian Linguïstic Case, 85, p. 32.

52 EHRM 13 juni 1979, Marckx Case, \$4 1, p. 19. Zie voor overwegingen met dezelfde strekking ook: EHRM 25 aprii 1978, Tyrer Case, 83i, pp. 15-16; EHRM 6 november 1980, Guzzardi Case, 895, p. 34 en EHRM 22 oktober 1981, Dudgeon Case, §60, pp. 23-24.

53 EHRM 27 september 1990, Cossey Case, 835, p. 14. Zie ook EHRM 25 maart 1992, Case of B v. France, \$48, p. 49. 
Volgens Jacobs is het gevolg van het in acht nemen van ontwikkelingen in de rechtsopvattingen in de Lid-Staten dat de verplichtingen van deze staten meer omvatten dan aanvankelijk bedoeld was. $\mathrm{Hij}$ acht dit - mijns inziens terecht - niet bezwaarlijk, maar juist noodzakelijk "if effect is to be given to their intentions, in a general sense. They did not intend solely to protect the individual against the threats to human rights which were then prevalent, with the result that, as the nature of the threats changed, the protection gradually fell away. Their intention was to protect the individual against the threats of the future, as well as the threats of the past. ${ }^{n 4}$ Deze wijze van interpretatie-wijze past in die van de teleologische interpretatiemethode.

Ook met deze teleologische interpretatie-methode in overeenstemming is het autonome karakter van de interpretatie, die door het Hof wordt toegepast. Deze autonome interpretatie van verdragsbepalingen heeft zich vooral voorgedaan ten aanzien van de begrippen "civil rights and obligations" en "criminal charge" in artikel 6 van de Conventie. Autonome interpretatie wil zeggen, dat de betekenis van de genoemde bewoordingen "niet afhankelijk is van de kwalificatie van de desbetreffende rechten en verplichtingen in het nationale recht; de verdragstekst heeft hier een eigen autonome betekenis." ${ }^{35}$ Hier is overigens geen sprake van (puur) grammaticale interpretatie van de verdragstekst, aangezien - zoals gezegd de interpretatie plaatsvindt in het licht van de context en het voorwerp en doel van de Conventie. Ook vormt deze autonome interpretatie geen belemmering voor de Commissie en het Hof om zich bij de vaststelling van de reikwijdte van gegarandeerde rechten te baseren op vergelijkende onderzoeken naar het recht van de Lid-Staten. ${ }^{56}$

54 F.G. Jacobs, The European Convention on Human Rights, p. 18.

55 G.J. Wiarda, Extensieve en restrictieve verdragstoepassing door het Europese Hof voor de rechten van de mens; een middenkoers?, pp. 375-376 en Ganshof van der Meersch, Les Méthodes d'interprétation de la Cour Européenne des Droits de IHomme, pp. 191-195. Zie verder: A.W. Heringa, De reikwijdte van artikel 6 lid 1 EVRM, pp. 654-665 en mijn annotatie bij het arrest van het Hof in de zaak Powell and Rayner van 21 februari 1990, NJCM-Bulletin 15-6/7 (1990), pp. 692-703(699, laatste alinea).

56 Zie, bijvoorbeeld, Rapp.Comm. 19 juli 1969, De Wilde, Ooms en Versyp cases ("Vagrancy cases"), waaraan een bijlage (Appendix IV) is toegevoegd, waarin een "Outline of Vagrancy legislation in force in European countries" is opgenomen. (pp. 143-160) Zie verder met betrekking tot de verwijzing naar "the general practice of the Member States of the Council of Europe": F.G. Jacobs, The European Convention on Human Rights, pp. 19-20 en hierna, pp. 56-57. 


\subsubsection{Rechterlijke beoordelingsruimte; belangenafweging}

In de voorgaande paragraaf ging het om de wijze waarop (volgens welke methode) een rechter een grondrecht kan interpreteren. In deze paragraaf gaat het om de beoordelingsruimte die de rechter heeft zowel bij de keuze van die interpretatie-methoden als bij de toepassing van een dergelijke methode, derhalve bij de interpretatie van een recht.

Zoals in paragraaf 1.3.1 al werd opgemerkt, kan pas een oordeel over al dan niet geoorloofde beperking van mensenrechten uitgesproken worden, wanneer vaststaat dat het desbetreffende recht van toepassing is. Kortom, eerst moet worden vastgesteld of een bepaald recht de materie in kwestie bestrijkt, of deze materie binnen de reikwijdte van dat recht valt.

$\mathrm{Bij}$ de vaststelling van de reikwijdte van een recht heeft de rechter een beoordelingsruimte; hij kan de reikwijdte zowel ruim als beperkt uitleggen. Deze beoordelingsruimte heeft haar weerslag op de diverse (in de volgende hoofdstukken te bespreken) methoden van beperking van grondrechten. Wordt de reikwijdte van een grondrecht ruim uitgelegd, dan zal er meer aanleiding kunnen zijn de beperkingsmogelijkheden ook ruim te interpreteren. Zo zullen we bijvoorbeeld zien, dat in de gevallen waarin bij een beroep op het recht op eerbiediging van het gezinsleven, de als "family life" aan te merken betrekkingen (onder bepaalde voorwaarden) worden uitgebreid tot de betrekkingen tussen de natuurlijke vader en zijn kind of tussen grootouders en hun kleinkind, de verzochte omgangsregeling veelal afstuit op grond van de belangen van het (klein)kind. ${ }^{57}$

Het is derhalve van groot belang om te laten zien, hoe de rechter omgaat met de beoordelingsruimte die hij heeft bij de bepaling van de reikwijdte van grondrechten. Duidelijk zal dienen te worden dat wanneer de rechter bij de afweging van de diverse belangen die bij de interpretatie plaatsvindt ${ }^{58}$, aan deze belangen een ánder gewicht had toegekend dan hij in het desbetreffende geval heeft gedaan, dit had kúnnen resulteren in een andere afbakening van het desbetreffende grondrecht. Wordt bijvoorbeeid het belang van bescherming door een bepaald grondrecht afgewogen tegen het belang van de overheid bij een bepaalde maatregel, dan kan het interpretatieproces zó uitvallen, dat aan het eerstgenoemde belang het $z$ waarste gewicht wordt toegekend, waardoor de overheidsmaatregel alleen nog gerechtvaardigd zou kunnen worden door een beroep op een beperkingsclausule. Maar ook zou het resultaat kunnen zijn, dat aan de

Zie verder hoofdstuk 2 ten aanzien van de beperkingsmogelijkheden in de Conventie, p. 31 
overheidsmaatregel zodanig gewicht wordt toegekend, dat het belang waarvoor een beroep op het grondrecht werd gedaan, buiten de reikwijdte van dit grondrecht valt. Een dergelijke restrictieve interpretatie zou onder andere plaats kunnen vinden wanneer het overheidshandelen niet gericht is op de beperking van grondrechten of om een andere reden niet onder een beperkingsclausule te brengen is.

Een vergelijking is hier mogelijk met de in hoofdstuk 3 (p. 188) te bespreken "inherente grenzen van grondrechten". Wel dient erop gewezen te worden, dat er een belangrijk verschil bestaat tussen het vaststellen van inherente grenzen in de zin van dit hoofdstuk enerzijds en de in hoofdstuk 3 bedoelde betekenis anderzijds: in het onderhavige hoofdstuk gaat het niet om het oneigenlijk inperken van het bereik van grondrechten met het oog op bepaalde overheidsmaatregelen - omdat die niet op beperkingsclausules gebaseerd kunnen worden - maar om de afbakening van de reikwijdte van grondrechten in eigenlijke zin. ${ }^{59}$ Zoals reeds is opgemerkt in paragraaf 1.1 kán hierin een grondrechtenbeperking gelegen zijn, namelijk in het geval er met betrekking tot de desbetreffende materie nog in het geheel geen interpretatie van het grondrecht heeft plaatsgevonden (en er derhalve nog geen grenzen aan het grondrecht op dat terrein zijn gesteld) of wanneer door de rechter ten opzicht van reeds aan het grondrecht gestelde grenzen een striktere interpretatie van het grondrecht wordt gegeven. Deze grondrechten-beperking is echter, anders dan bij de "inherente grenzen van grondrechten" in de zin van hoofdstuk 3, niet bedoeld om het gebrek aan beperkingsbevoegdheden te omzeilen.

\subsubsection{Gevolgen van de vaststelling van de reikwijdte van grondrechten}

Wat betreft de gevolgen van de vaststelling van de reikwijdte van een grondrecht: of de uitspraak in een concreet geval nu volgt uit een restrictieve interpretatie van een recht of niet, het oordeel dat een bepaald belang of een bepaalde gedragsvorm, een betekenis van een begrip of recht niet onder de reikwijdte van een bepaald grondrecht valt, heeft als consequentie, dat de garanties met betrekking tot procedures, voorwaarden en bevoegde organen wat betreft de beperking van dat grondrecht, buiten toepassing blijven. ${ }^{60}$

59 Wanneer in de hoofdstukken 4 tot en met 6 ingegaan wordt op de interpretatie van mensenrechten, wordt de afbakening van de reikwijdte van grondrechten in eigenlijke zin bedoeld.

60 Vgl. Albert Bleckmann, Allgemeine Grundrechtslehren, p. 228. Bleckmann spreekt bij deze beperkingsmethode van "immanenten Schranken im engeren Sinne". 
Hierbij valt niet alleen te denken aan de garanties die onder andere opgenomen zijn in de artikelen 13, 14 en 18 ECRM, maar ook voor wat betreft de bevoegde organen aan de regel, dat beperkingen op grondrechten bij wet voorzien moeten worden (zie onder andere de artikelen $8,9,10 \mathrm{en}$ 11 lid 2 ECRM en de artikelen 2 lid 4, 4, 8, 10 lid 1 Grondwet); voor wat betreft de procedurevoorschriften aan bepalingen als artikel 12 lid 2 Grondwet, waarin voor het binnentreden in een woning tegen de wil van de bewoner (beperking van het huisrecht) eerst een legitimatie en mededeling van het doel van het binnentreden geẻist wordt; en met betrekking tot overige voorwaarden aan de eis dat een beperking ingevolge de tweede leden van genoemde bepalingen van de ECRM noodzakelijk moet zijn in een democratische samenleving en aan het feit dat artikel 6 lid 2 Grondwet alleen beperking van de godsdienstvrijheid toestaat voorzover het gaat om het belijden buiten gebouwen en besloten plaatsen. Dit soort waarborgen is van generlei waarde wanneer het grondrecht zelf al niet van toepassing wordt verklaard.

De vaststelling van de reikwijdte van een grondrecht dient dus op zeer zorgvuldige wijze plaats te vinden. Er mag niet lichtvaardig besloten worden, dat een grondrecht niet van toepassing is. Wordt het noodzakelijk geacht dat een bepaald grondrecht niet kan worden uitgeoefend, dan verdient het de voorkeur, dit niet de bewerkstelligen door de reikwijdte van dat grondrecht in te perken. Andere beperkingsmogelijkheden kunnen dan beter worden aangewend, omdat dan de aan het grondrecht verbonden garanties tot gelding kunnen komen.

Dit laatste geldt des te meer in de procedure op grond van het ECRM. Deze is zodanig opgezet, dat in eerste instantie een klacht op zijn ontvankelijkheid wordt beoordeeld door de Commissie. Wordt een klacht niet-ontvankelijk verklaard, dan is de zaak daarmee onherroepelijk beëindigd. In een dergelijk geval volgt geen uitspraak over de hoofdzaak door het Hof of het Comité van Ministers. Niet in overeenstemming met deze bevoegdheidsverdeling is dat door de Commissie regelmatig een uitspraak gedaan wordt over de hoofdzaak, wat blijkt uit de praktijk ten aanzien van de ontvankelijkheidsvoorwaarde, dat het verzoekschrift niet kennelijk-ongegrond mag zijn (artikel 27(2)). Het zou nog conform de genoemde bevoegdheidsverdeling zijn, indien de Commissie zich er toe zou beperken om die klachten af te wijzen, waarvan de ongegrondheid manifest is of wanneer de Commissie zich bij haar beslissing zou baseren op de constante jurisprudentie van het Hof. Bij veel zaken is dat echter niet het geval. Meermalen is de Commissie ertoe overgegaan te treden in een 
vergaande interpretatie van de ingeroepen verdragsbepaling. ${ }^{61}$ Van Dijk en van Hoof noemen als voorbeeld de zaak Iversen, waarin de klacht - over het feit dat pas afgestudeerde tandartsen in Noorwegen gedwongen konden worden een tijd in overheidsdienst te werken - kennelijk ongegrond verklaard werd, terwijl deze gecompliceerde vragen met betrekking tot artikel 4 opriep. $^{62}$ Ook met betrekking tot de ontvankelijkheidsvoorwaarde, dat een klacht niet onverenigbaar met de bepalingen van de Conventie mag zijn (artikel 27(2)) kan worden opgemerkt dat veelal tot een diepgaand onderzoek naar de interpretatie van een of meer der bepalingen van Titel I van de Conventie wordt overgegaan. Valt het belang waarvoor bescherming wordt gevraagd volgens de Commissie niet binnen de reikwijdte van de ingeroepen verdragsbepaling, kortom is deze verdragsbepaling niet van toepassing, dan wordt de klacht wegens "incompatibility ratione materiae" niet-ontvankelijk verklaard.

In dergelijke gevallen bereikt een klacht nooit het Comité van Ministers of met name het Hof. De Commissie neemt dus de definitieve beslissing, beroep hiertegen is niet mogelijk. ${ }^{63.64}$

Het voorgaande leidt tot twee uitgangspunten voor het te verrichten jurisprudentie-onderzoek:

* niet alleen uitspraken over de hoofdzaak - niet zijnde ontvankelijkheidsbeslissingen - moeten in het onderzoek betrokken worden, maar ook

61 Zie P. van Dijk en G.J.H. van Hoof, De europese conventie in theorie en praktijk, pp. 115-118.

62 Besl.Comm. 17 december 1963, zaak nr. 1468/62. Iversen v. Norway, pp. 326-330.

63 Zie omtrent het voorgaande met name P. van Dijk en G.J.H. van Hoof. De europese conventie in theorie en praktijk, pp. 115-116. Vgl. ook o.a. EHRM 18 december 1986, Case of Johnston and others. $\$ 48$, p. 23, waarin het Hof bepaalde, dat "... the matters in question do not fall outside the compass of the case brought before the Court, which compass is delimited by the Commission's admissibility decision."

Zie ook: EHRM 8 juli 1987, Case of W v. UK, §57, p. 26; EHRM 8 juli 1987, Case of $B$ v. $U K$, §58, p. 71; EHRM 8 juli 1987, Case of $R$ v. $U K, \S 62$, p. 116.

64 Op de vraag hoe deze praktijk van de Commissie, waarin - anders dan de bevoegdheidsverdeling in de Conventie lijkt te impliceren - regelmatig in vergaande mate wordt ingegaan op de interpretatie van een recht in het kader van de ontvankelijkheidsbeslissing, overigens moet worden gewaardeerd zal hier niet worden ingegaan. Ik verwijs hiervoor naar $P$. van Dijk en G.J.H. van Hoof, De europese conventie in theorie en praktijk, pp. 115-118(118) en, vooral, Y.S. Klerk, Het ECRMtoezichtmechanisme, pp. 118-124 en 388-395. 
ontvankelijkheidsbeslissingen aangezien deze een onderzoek naar de hoofdzaak met zich mee kunnen brengen";

* bij de behandeling van de jurisprudentie zal behalve de rechtspraak van het Hof en de nationale rechter, ook de jurisprudentie van de Commissie onder de loep genomen worden, omdat zaken die niet-ontvankelijk verklaard worden door de Commissie in laatste instantie worden beoordeeld. ${ }^{*}$

De keuze bij dit jurisprudentie-onderzoek is hierbij gevallen op verdragsen grondwetsartikelen die niet alleen interessant zijn vanuit de optiek van de reikwijdte-afbakening van het desbetreffende recht, maar die ook in verband met de beperkingsproblematiek aandacht verdienen. Voor wat betreft de Conventie is de keuze gevallen op de eerste leden van de artikelen 6 en 8 . Het eerst-genoemde artikel is een artikel dat niet vergezeld gaat van een beperkingsbevoegdheid/clausule, maar wel zodanig uitvoerig is omschreven, dat in die omschrijving enige beperkingsmogelijkheden besloten liggen. Artikel 8 daarentegen is voorzien van een beperkingsclausule in lid 2 .

$\mathrm{Na}$ deze Conventie-artikelen zullen een aantal grondwetsbepalingen aan bod komen, naar aanleiding waarvan rechtspraak tot stand is gekomen, die interessant is wat betreft de afbakening van de reikwijdte van het gegarandeerde grondrecht. In hoofdstuk $6 \mathrm{zal}$ de keuze voor de desbetreffende grondwetsartikelen worden gemotiveerd.

\subsection{Plan van behandeling}

Een en ander leidt ertoe, dat dit onderzoek er als volgt uit za! gaan zien.

Zoals aangegeven, wordt - in verband met de vraag naar de wijze van vaststellen van de reikwijdte van mensenrechten - uitgegaan van de stelling dat er een verband bestaat tussen de reikwijdte-afbakening en de beperking van mensenrechten en van de stelling dat tengevolge hiervan spanningen bestaan tussen de rechterlijke praktijk ten aanzien van de vaststelling van

65 Hoewel dit uitgangspunt gebaseerd is op overwegingen naar aanleiding van de praktijk van de Europese Commissie, kan dit uitgangspunt ook aangehouden worden voor de nationale rechterlijke praktijk.

66 Dit uitgangspunt is voor de nationale rechtspraktijk niet relevant, omdat de Nederlandse rechter zowel over de ontvankelijkheid als over de hoofdzaak oordeelt. Overigens zullen behalve de ontvankelijkheidsbeslissingen van de Commissie ook, waar nodig, de rapporten die worden opgesteld op grond van artikel 31 ECRM, worden behandeld. 
de reikwijdte en de beperking van mensenrechten enerzijds en de argumentatie die aan de beperkingssystematiek ten grondslag ligt anderzijds. Dit brengt met zich mee dat de interpretatie van mensenrechten - de vaststelling van de reikwijdte van die rechten - beschouwd dient te worden in het licht van die argumentatie en van de rechterlijke praktijk ten aanzien van de beperking van mensenrechten. Daarom zal allereerst in hoofdstuk 2 ingegaan worden op de in de Europese Conventie opgenomen beperkingssystematiek. Hetzelfde gebeurt in hoofdstuk 3 ten aanzien van de beperkingssystematiek in de Grondwet van 1983. Besproken zal worden welke beperkingsmethoden in deze documenten zijn opgenomen, welke juist niet en waarom. Deze bespreking zal in beide hoofdstukken - voor zover van belang voor de wijze van formuleren van de gegarandeerde rechten en de voorziene beperkingsmogelijkheden - vooraf gegaan worden door een behandeling van de totstandkomingsgeschiedenis van respectievelijk de Conventie en de herziene Grondwet.

In de hoofdstukken 4 en 5 zal de vaststelling van de reikwijdte van respectievelijk artikel 8 en artikel 6 lid 1 ECRM onder de loep genomen worden. Dit geschiedt aan de hand van de rechtspraak van de Straatsburgse instanties en de Nederlandse rechterlijke organen. In hoofdstuk 6 wordt de rechterlijke afbakening van enkele grondwettelijke grondrechten behandeld. De keuze voor de desbetreffende rechten zal aldaar worden gemotiveerd. De hoofdstukken 4 tot en met 6 zullen elk worden beëindigd met een evaluatie-paragraaf waarin de hoofdlijnen van de rechtspraak zullen worden samengevat en - wat betreft de hoofdstukken 4 en 5 - de Europese en Nederlandse rechtspraak zal worden vergeleken.

In het slot-hoofdstuk - hoofdstuk 7 - zullen de grote lijnen van de voorgaande hoofdstukken worden herhaald en zal worden teruggekoppeld naar de in dit inleidende hoofdstuk (par. 1.1) geformuleerde hoofdvraag en stellingen. Daarbij zal een antwoord gegeven worden op deze hoofdvraag, zullen conclusies kumnen worden getrokken ten aanzien van de houdbaarheid van de bedoelde stellingen en zullen aanbevelingen worden gedaan voor de toekomstige rechtspraktijk. 


\section{De beperkingssystematiek in de Europese Conventie ter Bescherming van de Rechten van de Mens en de Fundamentele Vrijheden}

\subsection{Inleiding}

In hoofdstuk 1 is als hoofdvraag gesteld de vraag hoe de rechter de reikwijdte van de rechten van de mens vaststelt. Ter beantwoording van deze hoofdvraag is als eerste standpunt ingenomen, dat er een nauwe relatie bestaat tussen de vaststelling van de reikwijdte van mensenrechten en de beperking van die rechten. Deze relatie is duidelijk herkenbaar in het geval dat de rechter niet meer aan toetsing aan beperkingsclausules toekomt, omdat hij een klacht reeds niet ontvankelijk heeft verklaard. Dit kan onder meer gebeuren in het geval dat een belang ter bescherming waarvan een bepaald grondrecht wordt ingeroepen, niet onder de reikwijdte van dit grondrecht te brengen valt.

Dit verband bestaat echter ook wanneer een beroep op een grondrecht wel ontvankelijk is. Wanneer na een restrictieve interpretatie van een ingeroepen grondrecht, dat recht van toepassing wordt geacht, zal een beroep op een beperkingsclausule door de aangeklaagde Staat ook een strikte toets moeten doorstaan. Hierbij wordt er dan vanuit gegaan, dat er bij de toepassing van een grondrecht een bepaalde "kern" van het recht beschermd wordt. Blijft er bij de reikwijdte-bepaling van het recht al niet veel meer over dan de "kern" van het recht, dan zal er niet veel ruimte voor beperking van de toepassing van het recht overblijven, omdat anders deze kern aangetast zal worden.'

En andersom wanneer aan het bereik van een grondrecht ruime grenzen worden gesteld, valt het te verwachten, dat ook de beperkingsclausules ruim zullen worden geinterpreteerd. Dit met het oog op de overweging, die reeds in hoofdstuk 1 werd besproken, dat gezien het functioneren van grondrechten in een maatschappelijk kader, het stellen van beperkingen op de toepassing van grondrechten ter voorkoming van belangenconflicten noodzakelijk is.

Ten aanzien van dit nauwe verband tussen de vaststelling van de reikwijdte van grondrechten en de beperking van grondrechten werd in hoofdstuk 1 als tweede stelling naar voren gebracht, dat dit verband spanning oplevert met de argumenten die ten grondslag liggen aan de beperkingssystematiek in de Europese Conventie en de Grondwet. Het is 
nu de vraag of de houdbaarheid van de twee bovengenoemde stellingen kan worden aangetoond.

Voor de beantwoording van die vraag is onder meer van belang, dat onderzocht wordt wèlke argumenten aan de - in de Europese Conventie respectievelijk in de Nederlandse Grondwet 1983 - bestaande beperkingssystematiek ten grondslag liggen en hoe die beperkingssystematiek in de praktijk toegepast wordt. Aan dit onderzoek zullen hoofdstuk 2 en 3 gewijd worden; in hoofdstuk 2 met betrekking tot de Europese Conventie en in hoofdstuk 3 wat betreft de Grondwet.

Aan de orde zullen komen de historische context waarbinnen de Conventie respectievelijk hoofdstuk I van de Grondwet 1983 tot stand zijn gekomen en de totstandkomingsprocedure van beide documenten. Vervolgens zal - voor zover van belang voor het onderwerp van dit hoofdstuk, zoals dat in de vorige alinea is geformuleerd - ingegaan worden op de discussies, die hebben plaatsgevonden bij de formulering van de tekst van de Conventie respectievelijk de Grondwet 1983. Getracht zal worden te achterhalen, op welke argumenten de in die documenten vastgelegde beperkingssystematiek is gebaseerd. Tenslotte zal besproken worden hoe de beperkingssystematiek van respectievelijk de Conventie en de Grondwet in de praktijk toepassing vindt.

\subsection{Historische context}

Als startpunt voor de ontwikkeling van de Europese Conventie voor de Rechten van de Mens wordt vaak genoemd het Europees Congres, dat werd georganiseerd door het "International Committee of the Movements for European Unity". ${ }^{2}$ Dit Congres vond van 8 tot 10 mei 1948 in Den Haag plaats en had tot doel de brede steun voor de zaak van de Europese eenheid te demonstreren en om praktische aanbevelingen te doen voor de vervulling van de gestelde doelen. Op de laatste plenaire bijeenkomst werd de "Message to Europeans" aangenomen, waarin de afgevaardigden verklaarden:

"We desire a united Europe, throughout whose area the free movement of persons, ideas and goods is restored:

Bijvoorbeeld: A.H. Robertson, The Political Background and Historical Development of the European Convention on Human Rights, p. $24 ;$ Y. Klerk. De ontstaansgeschiedenis van de Europese Conventie, p. 3. Zie ook: Y.S. Klerk, Het ECRM-toezichtmechanisme, p. 7. 
We desire a charter of Human Rights guaranteeing liberty of thought, assembly and expression as well as the right to form a political opposition;

We desire a Court of Justice with adequate sanctions for the implementation of this Charter;

We desire a European Assembly where the live forces of all our nations shall be represented;

And pledge ourselves in our home and in public, in our political and religious life, in our professional and trade union circles, to give our fullest support to all persons and governments working for this lofty cause, which offers the last chance of peace and the one promise of a great future for this generation and those that will succeed it."

Dit streven kwam natuurlijk niet zomaar "uit de lucht vallen". In het Atlantic Charter van 1941 introduceerden Churchill en Roosevelt de volgende vier vrijheden: freedom of life, freedom of religion, freedom from want en freedom from fear. ${ }^{4}$ Het Handvest van de Verenigde Naties van 1945 was één van de eerste verdragen waarin het streven naar de bescherming van mensenrechten werd neergelegd. ${ }^{5}$ In de Preambule staat:

\section{"WE THE PEOPLES OF THE UNITED NATIONS DETERMINED}

to reaffirm faith in fundamental human rights, in the dignity and worth of the human person, in the equal rights of men and women and of nations large and small,..."

A.H. Roberison. The Political Background and Historical Development of the European Convention on Human Rights, pp. 24-25.

4 P. van Dijk en G.J.H. van Hoof, De europese conventie in theorie en praktijk, p.1.

5 Alhoewel er geen algemene mensenrechten-bepalingen in eerdere verdragen waren opgenomen, waren er wel verdragsbepalingen, die van belang waren voor de ontwikkeling voor de internationale bescherming van de rechten van de mens. Binnen het Mandaten-systeem van de Volkenbond golden bepalingen ter bescherming van de bevolking van de mandaat-gebieden; binnen het Minderheden-systeem van dezelfde organisatie kwamen verscheidene verdragen tot stand ter bescherming van etnische, linguïstieke en religieuze minderheden. Verder bestonden er reeds internationale arbeidsnormen, aanvankelijk tot stand gebracht door de Volkenbond, later met name door de ILO. Verder waren er verdragen op het ierrein van het humanitair recht, zoals de Geneefse Conventie van 1864 en de Haagse Conventie no. III van 1899 (de voorlopers van de Geneefse Conventies van 1949 en de daarbij behorende Protocollen). Zie o.a. Th. Bürgenthal, International Human Rights in a nutshell, pp. $1-16$. 
Artikel 1 van het VN Handvest vermeldt als één van de doelstellingen van de VN het tot stand brengen van internationale samenwerking bij de bevordering van de eerbiediging van de rechten van de mens en de fundamentele vrijheden. Een juridische garantie van mensenrechten biedt het Handvest echter niet, omdat het geen opsomming van mensenrechten bevat. De Universele Verklaring voor de Rechten van de Mens, die op 10 december 1948 door de Algemene Vergadering van de VN werd aangenomen, bevat een dergelijke opsomming wél, maar de mate van juridische binding is discutabel. ${ }^{6}$

Als uitvloeisel van de Universele Verklaring werd op verschillende fronten vervolgens een proces in gang gezet, dat zou leiden tot de totstandkoming van verschillende (rechtens bindende) verdragen ter waarborging van de rechten van de mens. Als eerste vallen natuurlijk te noemen de twee - binnen het kader van de VN tot stand gekomen Internationale Verdragen inzake de Rechten van de Mens, en verscheidene meer specifieke verdragen, zoals de VN Conventies inzake de politieke rechten van vrouwen en inzake de nationaliteit van gehuwde vrouwen, de ILO Conventies inzake dwangarbeid en inzake discriminatie in arbeid en beroep en de UNESCO Conventie inzake discriminatie in het onderwijs.

Voorts werd de garantie van de rechten van de mens - door middel van een verdrag - ook door regionale organisaties ter hand genomen.'

Hierna zal verder de Europese ontwikkeling inzake de garantie van mensenrechten centraal staan.

Reeds voor het bovengenoemd Europees Congres te Den Haag, was de Brussels Treaty Organisation (de voorloper van de Westeuropese Unie) opgericht. In het oprichtingsverdrag van deze organisatie van 17 maart 1948 verklaarden de ondertekenaars - na het bevestigen van hun vertrouwen in de idealen, zoals die waren uitgedrukt in het VN Handvest dat zij overeenkwamen

Niet ingegaan zal worden op het rechtskarakter van de Universele Verklaring; hier wordt slechts vermeld, dat regelmatig in academische en politieke kringen de opvatting verkondigd wordt, dat de Universele Verklaring via het gewoonterecht bindende verplichtingen aan de Lid-Staten oplegt.

7 Zie, voor een uitgebreidere bespreking van, met name, de Universele Verklaring en de verdragen en verklaringen, die als uitvloeisel van de Universele Verklaring in de periode na 1948 tot stand kwamen, onder meer: Sir Humphrey Waldock, Human Rights in Contemporary International Law and the Significance of the European Convention, pp. 1-23. 
"To fortify and preserve the principles of democracy, personal freedom and political liberty, the constitutional traditions and the rule of law, which are their common heritage."

$\mathrm{Na}$ het Europees Congres werden de uitkomsten van dit congres overgebracht aan de Raadgevende Vergadering van de Brussels Treaty Organisation. ${ }^{8}$

Naast de aanname van de "Message to Europeans", werd tijdens het Europees Congres ook de Europese Beweging, een organisatie waarin vooraanstaande personen verenigd waren, die zich actief wilden inzetten voor een federaal West-Europa, opgericht. ${ }^{\circ}$ Overeenkomstig de wensen die op het Europees Congres waren geuit, ging de Europese Beweging zich - middels studies, discussiegroepen en bijeenkomsten van ministers, juristen en politieke leiders - actief toeleggen op de formulering van een Europees Handvest voor de Rechten van de Mens. Op een bijeenkomst in februari 1949 van de Internationale Raad van de Europese Beweging werd besloten het ontwerpen van een dergelijk Handvest op te dragen aan een Internationale Juridische Sectie.

De ontwerp-Conventie ${ }^{10}$, die enkele maanden daarna tot stand zou komen en op 12 juli 1949 aan het Comité van Ministers van de toen pas opgerichte Raad van Europa werd aangeboden, diende als uitgangspunt bij de opstelling van de mensenrechten-conventie waaraan spoedig binnen het kader van de Raad van Europa werd begonnen."

De Raad van Europa werd opgericht enkele maanden na de zojuist vermelde bijeenkomst van de Internationale Raad van de Europese Beweging. In het Statuut van de Raad van Europa, dat op 5 mei 1949 werd ondertekend, kregen de aan de oprichting voorafgaande gebeurtenissen - zoals deze zojuist kort zijn samengevat - hun weerslag.

In de Preambule van het Statuut verklaarden de Lid-Staten

8 A.H. Robertson, Human Rights in Europe, p. 3; en A.H. Robertson, The Political Background and Historical Development of the European Convention on Human Rights, p. 25.

9 E.A. Alkema, De betekenis van het EVRM voor de Nederlandse constitutie, p. 3.

10 Zie voor de tekst van deze ontwerp-conventie: Appendix: Draft European Convention on Human Rights, in: Council of Europe, Collected Edition of the "Travaux Préparatoires" of the European Convention on Human Rights, Vol. I, pp. 296-320.

11. Y. Klerk, De ontstaansgeschiedenis van de Europese Conventie, p. 1. 
"Reaffirming their devotion to the spiritual and moral values which are the common heritage of their peoples and the true source of individual freedom, political liberty and the rule of law, principles which form the basis of all genuine democracy;"

Vervolgens werden in artikel 1 van het Statuut als middelen om de doelstelling van de Raad van Europa (het bereiken van een grotere eenheid tussen de Lid-Staten) te realiseren, "the maintenance and further realisation of human rights and fundamental freedoms" genoemd. ${ }^{12}$ Verder blijkt uit artikel 3 van het Statuut, dat de verplichtingen van de Lid-Staten verder gaan dan een beginselverklaring om de mensenrechten te bevorderen. Artikel 3 bevat de handhaving van de mensenrechten en de eerbiediging van de "rule of law" als doelstellingen van de Raad van Europa en als voorwaarde voor lidmaatschap van deze organisatie. Artikel 3 Statuut luidt:

"Every Member of the Council of Europe must accept the principles of the rule of law and of the enjoyment by all persons within its jurisdiction of human rights and fundamental freedoms, and collaborate sincerely and effectively in the realisation of the aim of the Council as specified in Chapter I."

Waarom nam de bescherming van de rechten van de mens een zo grote rol in, in het ontstaan van de Raad van Europa (en eerder al in dat van de Verenigde Naties)?

Als eerste reden valt te noemen het feit, dat kort daarvoor - in 1945 een einde gekomen was aan een periode, waarin de meest grove schendingen van mensenrechten hadden plaatsgevonden. Vele van de leidende staatslieden in deze periode hadden zelf - op wat voor wijze dan ook - deelgenomen aan de strijd tegen de Hitler-dictatuur en de gruwelen, die door dat regime werden begaan. Anderen waren direct slachtoffer geweest van de begane onmenselijkheden. Een herhaling van wat er voor en tijdens de Tweede Wereldoorlog had plaatsgevonden moest tegen elke prijs voorkomen worden.

Een andere - vooral voor Europa - belangrijke oorzaak was gelegen in het ideologische conflict waarin Oost en West waren verwikkeld ten tijde van de oprichting van de Raad van Europa. De naoorlogse beweging voor Europese eenheid was niet alleen een gevolg van de opvatting dat dit een wenselijk politiek doel was; het was ook een reactie op de

12 Zie Y.S. Klerk, Het ECRM-toezichtmechanisme, p. 8, die uit artikel 1 van het Statuut afleidt dat het de bedoeling van de ondertekenaars ervan was, om een intergouvernementele organisatie op te richten en niet een supranationale. 
"communistische dreiging" vanuit Oost-Europa. In het jaar dat verstreken was tussen het Europees Congres te Den Haag in mei 1948 en de ondertekening van het Statuut van de Raad van Europa in het voorjaar van 1949, hadden de communisten de macht in (het voormalige) Tsjechoslowakije overgenomen, woedde er een burgeroorlog in Griekenland en vond de blokkade van Berlijn plaats. Toen de Europese naties zich de druk van het communisme bewust werden, achtten zij bevestiging van hun eigen politieke beginselen geboden. Het gevaar van de dictatuur makte hen bewust van de waarde van de democratie. ${ }^{13}$

De leiders van de democratische Europese staten meenden, dat de eerste stappen op weg naar een dictatuur gelegen waren in de geleidelijke onderdrukking van de individuele rechten en dat, zodra dit proces op gang gekomen zou zijn, het moeilijk zou zijn het te stoppen. Om die reden achtten deze staatslieden het noodzakelijk, vooraf vast te leggen welke rechten en vrijheden zouden moeten worden eerbiedigd in een democratische samenleving en een mechanisme te scheppen, dat zou moeten verzekeren dat deze rechten en vrijheden zouden worden gerespecteerd. ${ }^{14}$

Naar aanleiding van de genoemde politieke ontwikkelingen en de opvattingen van de politieke leiders hierover, werd binnen de Raad van Europa een proces in gang gezet, dat leidde tot de totstandkoming van de Europese Conventie ter Bescherming van de Rechten van de Mens en de Fundamentele Vrijheden.

Dat totstandkomingsproces zal in de volgende paragraaf beschreven worden.

\subsection{Het totstandkomingsproces van de Europese Conventie ter Bescherming van de Rechten van de Mens en de fundamentele vrijheden}

Toen de ontwerp-Conventie ${ }^{15}$, die binnen de Europese Beweging was opgesteld, aan het Comité van Ministers van de Raad van Europa werd aangeboden, werd daarbij de aanbeveling gedaan om de kwestie van de

13 A.H. Robertson, Human Rights in Europe, pp. 4-5.

14 A.H. Robertson, Human Rights in Europe, p. 5.

15 Zie over dit ontwerp van de Europese Beweging: Y.S. Klerk, Het ECRM-toezichtmechanisme, pp. 9-13. 
mensenrechten op de agenda van de eerste sessie van de Raadgevende Vergadering van de Raad van Europa te zetten.

Het Comité van Ministers besloot dit niet te doen. De meerderheid van het Comité was van mening, dat het mensenrechten-vraagstuk al genoeg aandacht kreeg binnen de $\mathrm{VN}$ en dat de resultaten van de werkzaamheden aldaar eerst maar moesten worden afgewacht. ${ }^{16}$

De Raadgevende Vergadering stelde vervolgens voor het onderwerp "Measures for the fulfilment of the declared aim of the Council of Europe in accordance with Article 1 of the Statute with regard to the maintenance and further realisation of human rights and fundamental freedoms" wél op de agenda te zetten. ${ }^{17}$

Het Comité van Ministers ging hiermee akkoord en plaatste de kwestie alsnog op de agenda. ${ }^{18}$

Op 19 augustus 1949 vond een algemeen debat plaats in de Raadgevende Vergadering. Tijdens dit debat werd voorgesteld een aanbeveling aan het Comité van Ministers op te stellen, waarin zou worden aangedrongen op a) het sluiten van een verdrag waarbij alle Lid-Staten zich zouden verplichten tot het waarborgen van de mensenrechten, die reeds in hun constitutie, wetgeving en bestuurspraktijk werden beschermd op het moment van de sluiting van het verdrag;

b) de instelling van een Europese Commissie voor de Rechten van de Mens en een Europees Hof voor de Rechten van de Mens, die de inachtneming van het bedoelde verdrag zouden verzekeren. ${ }^{19}$

16 Eerste Sessie van het Comité van Ministers, 8-13 augustus 1949. Tweede Bijeenkomst van 9 augustus 1949, Report of the second meeting (Papers of the First Session of the Committee of Ministers, pp. 34-37, in: Council of Europe, Collected Edition of the "Travaux Préparatoires", Vol. I, pp. 10-12. Zie verder Y.S. Klerk, Het ECRM-toezichtmechanisme, pp.13-15.

17 Eerste Sessie van de Raadgevende Vergadering, 10 augustus - 8 september 1949 , Vierde zitting van 13 augustus 1949. Report of the Sitting (Report of the Consultative Assembly, 1st Session, Part I, 4th Sitting, p. 61), in: Council of Europe, Collected Edition of the "Travaux Préparatoires", Vol. I, p. 18.

18 Eerste Sessie van het Comité van Ministers, 8-13 augustus 1949, Vijfde bijeenkomst van 13 augustus 1949, Report of the fifth meeting (Papers of the First Session of the Committee of Ministers, pp. 52-55), in: Council of Europe, Collected Edition of the "Travaux Préparatoires", Vol. I, pp. 22-26(26).

19 Motion to recommend to the Committee of Ministers an organisation within the Council of Europe to ensure the collective guarantee of human rights proposed by Mr. Teitgen, Sir David Maxwell-Fyfe and other representatives (Doc. 3, Consultative Assembly, First Session, 19 August 1949, pp. 19-20), Achtste zitting van 19 augustus 1949, in: Council of Europe, Collected Edition of the "Travaux Préparatoi- 
Dit voorstel vond veel steun in de Raadgevende Vergadering, maar over de vragen, wèlke rechten zouden moeten worden gegarandeerd, hòe deze rechten zouden moeten worden geformuleerd en wat de taak en bevoegdheden van Commissie en Hof zouden moeten zijn, bestonden grote meningsverschillen. ${ }^{20}$

Tijdens het algemeen debat werd besloten het opstellen van de voorgestelde aanbeveling en van een eerst ontwerp-Conventie over te laten aan de Commissie voor Juridische en Administratieve Zaken ${ }^{21}$. De opdracht luidde:

"(...) to recommend the Member States to organise a collective guarantee within the Council of Europe of all or some of the rights and liberties of man and of citizens."

Bij deze opdracht werd een "questionnaire" aan de Juridische Commissie voorgelegd, met onder andere de volgende vragen:

1 a) moeten de door de collectieve garantie te waarborgen rechten nauwkeurig gedefinieerd worden in voor alle Lid-Staten gemeenschappelijke, identieke en dwingende bewoordingen; of

res", Vol. I, pp. 36-38.

20 Zo kon men het er bijvoorbeeld niet over eens worden of, er een speciaal aan nationale minderheden gewijd artikel moesi woiden opgenomen, of bijvoorbeeld het recht op onderwijs of op vrije, geheime verkiezingen. Verder was men het oneens over de vraag of de op te nemen rechten algemeen geformuleerd moesten worden, dan wel de rechten nauwkeurig gedefinieerd moesten worden. Voorts waren de afgevaardigden het ook oneens over de vraag of er een Commissie of Hof moest komen en zoja, of deze organen klachten van individuele burgers zouden mogen behandelen. Zie: General debate on measures for the fulfilment of the declared aim of the Council of Europe in accordance with Article I of the Statute in regard to the maintenance and further realisation of human rights and fundamental freedoms. Achtste zitting van 19 augustus 1949, Report of the Sitting (Reports of the Consultative Assembly, First: Session, Part I, 8th Sitting, p.210-241), in: Council of Europe, Collected Edition of the "Travaux Préparatoires", Vol. I, pp. 38-154.

21 Officiële engelstalige benaming: Committee on Legal and Administrative Questions. Hierna zal deze Commissie ook wel als de "Juridische Commissie" aangehaald worden.

22 Bijeenkomst van de Commissie voor Juridische en Administratieve Zaken, 22 augustus - 5 september 1949, zitting van 22 augustus 1949, Minutes of the Sitring (Doc. A 9), in: Council of Europe, Collected Edition of the "Travaux Préparatoires", Vol. I. p. 154. 
b) zal er een lijst opgesteld worden, waarin in algemene termen fundamentele rechten en vrijheden worden omschreven, die reeds op het grondgebied van de Lid-Staten worden beschermd?

2) welke rechten zouden door de collectieve garantie gewaarborgd moeten worden?

5) moet de collectieve garantie inroepbaar zijn voor een Gerechtsh of opgericht en functionerend binnen het kader van de Raad van Europa?

7) wie mogen een klacht indienen bij het Hof in geval van schending ven een recht?

8) moet een dergelijke klacht eerst onderzocht worden door een special comité om de volstrekt ongegronde klachten eruit te kunnen selecteren? 9 en 10) wat zijn de bevoegdheden van het Hof in geval van schendirg (schadevergoeding?) en niet naleven van de uitspraak? ${ }^{23}$

Op 5 september 1949 werden de beraadslagingen van de Juridiscle Commissie afgesloten met de aanname van een rapport. ${ }^{24}$

Op 7 september 1949 werd dit rapport aan de Raadgevende Vergadering gepresenteerd. ${ }^{25}$ In dit rapport werd een aanbeveling aan het Comité vân Ministers voorgesteld ten aanzien van een verdrag, dat een collectieve garantie zou moeten zijn voor de rechten van de mens.

Met betrekking tot het probleem van de formulering van de te garanderen rechten werd aansluiting gezocht bij de Universele Verklaring voor de Rechten van de Mens. De redenen, die hiervoor werden gegeven, waren de wenselijkheid om de activiteiten van de Raad van Europa te coördineren met die van de Verenigde Naties en de morele autoriteit en de technische waarde van de Universele Verklaring. Verder zou een instrument voor de collectieve garantie van rechten en vrijheden díe essentiële rechten en vrijheden moeten bevatten, die reeds geruime tijd in

23 Letter addressed 22nd August 1949 by Mr. P.H. Teitgen to the Chairman of the Legal Committee with a list of questions proposed for examination by the Legal Committee as appendix. (Doc. A 14), Bijeenkomst van de Commissie voor Juridische en Administratieve Zaken, 22 augustus - 5 september 1949, zitting van 22 augustus 1949. in: Council of Europe. Collected Edition of the "Travaux Préparatoires", Vol.

I. pp. 156-162.

24 Doc. 77 of the Consultative Assembly: First Session; 15th Sitting; 5 th September 1949: pp. 197-209, in: Council of Europe. Collected Edition of the "Travaux Préparatoires". Vol. I. pp. 216-238.

25 Presentation of the Report of the Committee on Legal and Administrative Questions, zeventiende zitting van de Raadgevende Vergadering op 7 september 1949, verslag van de zitting (Report of the Consultative Assembly, First Session, part II, pp. 575584), in: Council of Europe, Collected Edition of the "Travaux Préparatoires", Vol. I. pp. 264-294. 
de rechtspraktijk van alle democratische landen aanvaard en gedefinieerd waren.

Deze overwegingen leidden tot een selectie uit de in de Universele Verklaring opgenomen rechten en vrijheden, die door de te ontwerpen Europese Conventie zouden moeten worden gegarandeerd. Vervolgens verbond de Commissie haar goedkeuring aan het internationale rechtsbeginsel volgens welk het aan iedere Staat zelf is voorbehouden de uitoefening van de bedoelde rechten en vrijheden op zijn grondgebied te regelen. Daarbij zouden de Staten echter wel de volgende principes in acht moeten nemen: het verbod van willekeurige discriminatie/onderscheid en het verbod van elke beperking op een gegarandeerd recht, die niet gebaseerd is op redenen van algemeen belang, maar op de zogenaamde "reasons of State". Dat wil zeggen, dat wanneer een Staat een recht beperkt

"to protect itself according to the political tendency which it represents, against an opposition which it considers dangerous; to destroy fundamental freedoms which it ought to make itself responsible for coordinating and guaranteeing, then it is against public interest if it intervenes. Then the laws which it passes are contrary to the principle of the international guarantee. ${ }^{126}$

Het toezichtmechanisme zou naar de opvatting van de Juridische Commissie een getrapt karakter moeten krijgen: klachten, ingediend door Staten of individuen zouden worden ingediend bij een Commissie; die Commissie zou de klacht onderzoeken en trachten een vreedzame schikking tot stand te brengen; lukte het niet tot een schikking te komen, dan zouden de Commissie - namens de individuele klager - of een Staat de klacht kunnen voorleggen aan een Hof. De individuele klager zou zelf geen klacht aan het Hof kunnen voorleggen. Het Hof zou juridisch bindende beslissingen kunnen nemen. ${ }^{27}$

26 Presentation of the Report of the Committee on Legal and Administrative Questions, zeventiende zitting van de Raadgevende Vergadering op 7 september 1949, verslag van de zitting (Report of the Consultative Assernbly, First Session, part II, pp. 575584), in: Council of Europe, Collected Edition of the "Travaux Préparatoires", Vol. I. pp. 264-294(272-280).

27 Zeventiende zitting van de Raadgevende Vergadering op 7 september 1949, verslag van de zitting (Report of the Consultative Assembly, First Session, part II, pp. 575584), in: Council of Europe, Collected Edition of the "Travaux Préparatoires", Vol.

I, pp. 264-294(280-294). 
Het was voor het eerst, dat er een voorstel werd gedaan om een effectief rechtsmiddel te scheppen voor een burger wiens rechten waren geschonden door een soevereine staat: de burger zou als individu direct toegang krijgen tot een internationaal orgaan (de Commissie) en - ondanks het ontbreken van locus standi voor het Hof - kon een Staat voor het Hof ter verantwoording geroepen worden, indien de individuele klacht aan het Hof werd voorgelegd door de Commissie of een andere Staat. ${ }^{28}$

Tijdens het debat dat op 8 september 1949 in de Raadgevende Vergadering over het rapport van de Juridische Commissie werd gehouden bleken de gedelegeerden in grote lijnen met de ontwerp-aanbeveling te kunnen instemmen. Het grootste verschil van mening bestond over de opneming van twee rechten: het recht van ouders om te kiezen welke opvoeding zij hun kinderen zouden geven ${ }^{29}$ en het recht op eigendom. Ten eerste kon men het niet eens worden over de formulering van deze rechten en ten tweede achtte men geen gegronde redenen aanwezig waarom men het recht op eigendom wél zou opnemen en andere sociale rechten - zoals het recht op arbeid - niet. ${ }^{30}$ Men besloot uiteindelijk deze rechten uit het ontwerp te schrappen en voor herformulering opnieuw aan de Juridische Commissie voor te leggen. ${ }^{3 i}$ Uiteindelijk werd het rapport van de Juridische Commissie door de Raadgevende Vergadering aanvaard. Dit resulteerde in de "Recommendation No.38 to the Committee of Ministers adopted 8th September $1949^{\circ}$ on the conclusion of the debates ${ }^{3 .}{ }^{32}$

In tegenstelling tot de uitgesproken wens van de Raadgevende Vergadering, besloot het Comité van Ministers op 5 november 1949 om een Comité van juridische experts te belasten met het formuleren van een

28 A.H. Robertson, Human Rights in Europe, p. 10. Zie uitgebreider hierover: Y.S. Klerk. Het ECRM-toezichtmechanisme, pp. 18-24.

29 In de loop van het totstandkomingsproces van de Conventie veranderde de formulering van dit recht in die van het naderhand in het Eerste Protocol neergelegde recht op onderwijs.

30 Door verschillende afgevaardigden werd het recht op eigendom opgevat als een sociaal recht.

31 Achttiende zitting van de Raadgevende Vergadering op 8 september 1949, Official Report of the Sitting (Reports of the Consultative Assembly, First Session, part II, 18th Sitting, pp. 1164-1299 and 1308-1327), in: Council of Europe. Collected Edition of the "Travaux Préparatoires" of the European Convention on Human Rights, Vol. II, pp. 14-274.

32 Doc. No. 108, Consultative Assembly, First Session, 18th Sitting, pp. 261-264, in: Council of Europe, Collected Edition of the "Travaux Préparatoires", Vol. II, pp. 274-282. 
ontwerp-conventie. ${ }^{33}$ Hierbij zou rekening gehouden moeten worden met de voortgang die reeds was geboekt binnen de Verenigde Naties bij het opstellen van een mensenrechtenverdrag.

Tijdens de eerste bijeenkomst van het Committee of Experts werd al spoedig duidelijk, dat er binnen het comité twee groepen te onderscheiden waren. De ene groep was van mening, dat het ontwerp van de Raadgevende Vergadering niet als basis voor de discussie kon dienen, omdat de te garanderen rechten en met name de beperkingen daarop niet nauwkeurig waren gedefinieerd. Aangesloten zou moeten worden bij de werkwijze van de Commission on Human Rights van de VN, door de fundamentele rechten en hun beperkingen zoveel mogelijk tot in detail te formuleren. De andere groep van deskundigen meende, dat de methode, zoals die gevolgd was door de Raadgevende Vergadering, opsomming van de rechten in algemene termen, even goede of zelfs betere resultaten zou opleveren, dan de methode gevolgd door de VN Commissie.

Gedurende de discussie bleken de standpunten niet dichter tot elkaar gebracht te kunnen worden. Ook op andere punten meenden de experts niet tot een keuze te kunnen komen, omdat de desbetreffende kwesties te politiek van karakter waren. Het ging hier met name om de vraag of er nu wel of niet een Europees Hof voor de Rechten van de Mens moest komen.

Om het Comité van Ministers in staat te stellen een keuze te maken tussen de diverse standpunten, werden de uiteenlopende voorstellen in de vorm van alternatieve ontwerpen toegevoegd aan het rapport, dat van de bijeenkomsten van het Committee of Experts werd opgemaakt.

Alternatief "A" volgde de hoofdlijnen van het voorstel van de Raadgevende Vergadering. Alternatief " $B$ " deed hetzelfde ten aanzien van de instelling van de Commissie en het Hof, maar week van het voorstel van de Raadgevende Vergadering af met betrekking tot de kwestie van de formulering van de rechten. Alternatief " $B$ " bevatte op dat punt het voorstel van het Verenigd Koninkrijk, waarin de rechten en de beperkingen daarop in nauwkeurige definities waren vervat. De alternatieven " $\mathrm{A} / 2$ " en "B/2" voorzagen in het geval waarin de instelling van het Hof niet

33 Derde zitting van het Comitê van Ministers op 5 november 1949, verslag van de zitting (Report of the sitting, Doc. Committee of Ministers, 2nd session, item: $f$, pp. 70-75), en de brief van de voozzitter van het Comité van Ministers, Rasmussen, aan de president van de Raadgevende Vergadering, Spaak, van 5 november 1949 (Doc. Committee of Ministers, 2nd session, Appendix 3, pp. 104-105 and Doc. Ne. 116, para. 6, Consultative: Assembly 1st session, p. 288), in: Council of Europe, Collected Edition of the "Travaux Préparatoires", Vol. II, pp. 290-296. 
aanvaard zou worden. Voor het overige stemden zij overeen met respectievelijk alternatief " $\mathrm{A}$ " en alternatief " $\mathrm{B}$ ". ${ }^{\text {34.35 }}$

Tijdens de derde sessie van het Comité van Ministers, van 30 maart tot 1 april 1950, werd besloten, dat aan een "Conference of senior officials" zou worden opgedragen een beslissing voor te bereiden op de diverse ingediende voorstellen. De reden voor dit besluit was, dat het Committee of Experts vier verschillende voorstellen aan het Comité van Ministers had voorgelegd, waardoor het onmogelijk was voor het Comité om nog tijdens deze sessie tot een keuze tussen de diverse voorstellen te komen.

De taakstelling van de in te stellen commissie van ambtelijke deskundigen zou zodanig geformuleerd moeten worden, dat het voor het Comité van Ministers mogelijk zou zijn tot een besluit te komen tijdens de volgende bijeenkomst. Daartoe zou bijdragen als het Comité slechts een enkele tekst in beschouwing zou hoeven nemen. ${ }^{36}$

De Senior officials kwamen bijeen van 8 tot 17 juni 1950. Besloten werd om, voordat zou worden overgegaan tot het opstellen van één tekst van de ontwerp-conventie, eerst een algemeen debat te wijden aan de diverse bestaande politieke geschilpunten. ${ }^{37}$ Deze punten betroffen de formulering van de rechten (nauwkeurige definiëring of algemene opsomming van de

34 Bijeenkomsten van het Committee of Experts, 2-8 februari en 6-10 maart 1950, Report to the Committee of Ministers submitted by the Committee of Experts instructed to draw up a Draft Convention of collective guarantee of Human Rights and Fundamental Freedoms (Doc. CM/WP 1 (50) 15; A 924 of 16 March 1950), in: Council of Europe, Collected Edition of the "Travaux Préparatoires" of the European Convention on Human Rights, Vol.IV. pp. 2-50(8-i6), Zie verder Y.S. Klerk. Het ECRM-toezichtmechanisme, pp. 25-30.

35 Voor de tekst van de alternatieve voorstellen, zie: Appendix to the Report of the Committee of Experts on Human Rights: Draft Convention of Protection of Human Rights and Fundamental Freedoms (Doc. CM/WP 1 (50) 15 appendix: CM/WP I (50) 14 revised. A 925 of 16 th March 1950), in: Council of Europe, Collected Edition of the "Travaux Préparatoires". Vol. IV. pp. 50-78.

36 Derde sessie van het Comité van Ministers. gehouden op 1 april 1950. Minutes of the meeting (Doc. Committee of Ministers. 3rd session; point II, p. 12) en Report of the meeting (Doc. Committee of Ministers, 3rd session, point II. pp. 60-62), in: Council of Europe, Collected Edition of the "Travaux Préparatoires", Vol. IV, pp. 84-90(84-86). Overigens werd het wenselijk geacht, dat de officials onder instructie van hun regeringen zouden werken. Hierdoor zou het tijdens de volgende bijeenkomst van het Comité van Ministers makkelijker zijn om tot een beslissing te komen.

37 Conference of Senior Officials, 8-17 June 1950. Verslag van de zittingen van $8 \mathrm{t} / \mathrm{m}$ 12 juni 1950 (Doc. CM/WP 1 (50) 16 of 9 June 1950: Doc. CM/WP 4 (50) 3; en niet nader aangeduide documenten), in: Council of Europe, Collected Edition of the "Travaux Préparatoires", Vol. IV, pp. 106-168. 
rechten), de instelling van een Hof, de bevoegdheden van de Commissie en het Hof indien het werd ingesteld, het individueel klachtrecht en de opneming van een bepaling inzake democratische instituties.

Uiteindelijk werd naar aanleiding van de discussies één enkel ontwerp tot stand gebracht, dat de diverse - aan de senior officials voorgelegde voorstellen integreerde. ${ }^{37}$ Welk onderdeel van welk alternatief voorstel in het ontwerp terecht kwam, werd bepaald door het standpunt van de meerderheid van de officials ten aanzien van de diverse kwesties. Ten aanzien van de eerste twee geschilpunten kwam het hiernavolgende compromis tot stand.

Sectie II van het ontwerp bevatte de bepalingen, waarin de te garanderen rechten werden geformuleerd. Alternatief B (nauwkeurige definiëring) werd als uitgangspunt genomen, omdat het mogelijk werd geacht om bepaalde algemene beginselen uit alternatief $\mathbf{A}$ hierin op te nemen, zoals de verwijzing in het nieuwe ontwerp naar het begrip "democratic society" in artikel 9 en 10 en het beginsel volgens welk de beperkingen op fundamentele rechten alleen mogen dienen voor het doel waarvoor ze zijn geschreven (toepassing van de theorie van détournement de pouvoir) in artikel 13 lid 2 .

Met betrekking tot de instelling van een Hof, werd gekozen voor een optionele jurisdictie van het Hof: er zou een Hof worden ingesteld als orgaan van de Raad van Europa, aan wiens jurisdictie alleen díe staten zouden zijn onderworpen, die de dwingende rechtsmacht van het Hof aanvaarden.

De overige kwesties werden aan de beslissing van het Comité van Ministers overgelaten.

Op 23 juni 1950 werd het rapport van de Conference of Senior Officials gestuurd naar het Comité van Ministers en naar de Commissie voor Juridische en Administratieve Zaken (Juridische Commissie) van de Raadgevende Vergadering.

De Juridische Commissie kwam bijeen op 23 en 24 juni 1950. Het Comite van Ministers had er op 1 april mee ingestemd, dat de Juridische

38 Report of the Conference of Senior Officials, (a) text of the report submitted by the Conference to the Committee of Ministers (doc. CM/WP 4 (50) 19;CM/WP 4 (50) 16 rev.;A 1431), met name $\S$ III, "Problems considered by the Conference" en $\$$ IV, "Commentary on the single text of the Convention proposed by the Conference" en

(b) Draft Convention annexed to the Report (Doc. CM/WP 4 (50) 19 annexe; CM/WP 4 (50) 16 rév; A 1452), in: Councii of Europe, Collected Edition of the "Travaux Préparatoires", Vol. IV, pp. 242-294(246-272 en 274-294). Zie verder ook Y.S. Klerk, Het ECRM-toezichtmechanisme, pp. 30-34. 
Commissie zou worden geconsulteerd, nadat de Senior Officials het rapport zouden hebben overlegd. ${ }^{39}$ Overigens zouden de standpunten van de Juridische Commissie met betrekking tot het rapport van de Committee of Experts en van de Senior Officials niet bindend zijn voor de betrokken regeringen. ${ }^{40} \mathrm{De}$ Juridische Commissie meende in het algemeen te kunnen instemmen met het rapport van de Senior Officials, en het daarin opgenomen ontwerp. De Commissie-leden hadden nog wel enige kritiek,onder andere wegens het ontbreken van een bepaling ter garantie van democratische instituties. Zij stelden het Comité van Ministers daarom enige wijzigingen van het ontwerp voor. ${ }^{41}$

Van 3 tot 9 augustus 1950 werd de vijfde sessie van het Comité van Ministers gehouden. Tijdens de eerste bijeenkomst van 3 augustus nam het Comité van Ministers het besluit om, aangezien het ontwerp nog een aantal zwakheden vertoonde, een aantal punten voor te leggen aan een Committee of Governmental Experts. ${ }^{42}$ Dit sub-comité van regerings-experts zou een herziene tekst voor de Conventie moeten opstellen op basis van de voorliggende tekst van de Senior Officials en de door de diverse delegaties ingediende amendementeri.

De beraadslagingen in het sub-comité leidden tot enkele wijzigingen in het ontwerp; op sommige punten kon nog geen overeenstemming worden bereikt. ${ }^{43}$

39 Derde sessie van het Comité van Ministers, gehouden op 1 april 1950, Report of the meeting (Doc. Committee of Ministers, 3rd session, point III, pp. 60-62), in: Council of Europe, Collected Edition of the "Travaux Préparatoires", Vol. IV, pp. 84-90(90).

40 Vierde sessie van het Comité van Ministers, gehouden op 3 juni 1950. Minutes of the meeting (Doc, Committee of Ministers, 4th session; point VI, p. 8) en Official report of the meeting (Doc. Committee of Ministers, 4th session; point VI, p. 34), in: Council of Europe, Collected Edition of the "Travaux Préparatoires", Vol. IV. pp. 96-98.

41 Brief van 24 juni 1950 van Sir David Maxwell-Fyfe, Voorzitter van de Commissie voor Juridische en Aưministratieve Zaken, aan de Voorzitter van het Comité van. Ministers (Ref.D 280/3/50; Doc. CM (50) 29), in: Council of Europe, Collected Edition of the "Travaux Préparatoires" of the European Convention on Human. Rights, Vol. V, pp. 32-40.

42 Eerste bijeenkomst van het Comité van Ministers op 3 augustus 1950, Report of the meeting (Doc. Committee of Ministers, 5th session, point II; pp. 24-28), in: Council of Europe, Collected Edition of the "Travaux Préparatoires", Vol. V, p. 56.

43 Meeting of the sub-committee on human rights, gehouden op 4 augustus 1950, Text of amended articles after deliberation at the sitting of 4th August 1950 (Doc. CM 1 (50) 9) en Draft Convention adapted by the Sub-committee (Doc. CM (50) 52 of 7th August 1950; A 1884), in: Council of Europe, Collected Edition of the "Travaux Préparatoires", Vol. V, pp. 74-76 en 76-98. 
Tijdens de vierde bijeenkomst van het Comité van Ministers op 7 augustus 1950 wisten de ministers wél overeenstemming te bereiken, ook al waren de uiteindelijk geformuleerde artikelen bij wijze van compromis tot stand gekomen. ${ }^{4}$ Bij brief van dezelfde datum, werd het aldus geamendeerde ontwerp aan de Raadgevende Vergadering voorgelegd. ${ }^{*}$

Op 7 en 8 augustus 1950 kwamen de door de Raadgevende Vergadering voor nadere beschouwing terugverwezen artikelen met betrekking tot het recht op eigendom en het recht van ouders met betrekking tot de opvoeding van hun kinderen aan de orde in de daarvoor aangewezen commissies. Op 8 augustus kwam een herziene tekst van deze artikelen tot stand. ${ }^{46}$

Van 11 tot en met 16 augustus 1950 kwam de Raadgevende Vergadering bijeen om het rapport van het Comité van Ministers, met daarin de ontwerp-Conventie, te bespreken. In het algemeen werd het facuitatieve karakter van zowel het individueel klachtrecht als van de rechtsmacht van het Hof betreurd. Ook vonden enkele afgevaardigden, dat alsnog het recht op eigendom en het recht van ouders met betrekking tot de opvoeding van hun kinderen in het ontwerp moesten worden opgenomen, evenals een bepaling ten aanzien van democratische instituties. Verder kwam de wijze van formulering van de rechten nog aan bod. ${ }^{47}$

44 Vierde bijeenkomst van het Comité van Ministers op 7 augustus 1950, Report of the meeting (Doc. Committee of Ministers, 5th session, point II; pp. 64-70), in: Council of Europe, Collected Edition of the "Travaux Préparatoires", Vol. V, pp. 110120(116-120).

45 Brief van 7 ạugustus 1950 van MacBride, Voorzitter van het Comité van Ministers, aan Spaak, President van de Raadgevende Vergadering, (Doc., Consultative Assembly, No. 11, 8th August 1950, pp. 600-619), in: Council of Europe, Collected Edition of the "Travaux Préparatoires", Vol. V, pp. 144-170(144-146).

46 Zie p. 42, voor noot 31. Aanvullend rapport van 8 augustus 1950 inzake de Ontwerp-Conventie voor de bescherming van de mensenrechten en fundamentele vrijheden van Teitgen, namens de Commissie voor Juridische en Administratieve Zaken (Doc. Consultative Assembly, no, 30, 8th August 1950, p. 744), in: Council of Europe. Collected Edition of the "Travaux Préparatoires", Vol. V, p. 208.

47 Zesde zitting van 14 augustus, Report of the sitting (Reports Consultative Assembly, second session, Volume II, Sixth Sitting, pp. 322-355), "General Debate on the Draft Convention for the Protection of Human Rights and Fundamental Freedoms", en negende zitting van 16 augustus 1950, Report of the sitting (Report, Consultative Assembly, Second Session, Volume II, Ninth Sitting, pp. 494-543), "Continuation of the General Debate ...", in: Council of Europe, Collected Edition of the "Travaux Préparatoires", Vol. V, pp. 216-270(222-270) en 272-350(272-286). 
Uiteindelijk werd de ontwerp-Conventie teruggestuurd naar de Juridische Commissie, inclusief de kritiek die door de afgevaardigden tijdens de beraadslagingen was geuit. ${ }^{48}$ Binnen de Commissie zouden onder meer enkele ingediende amendementen besproken worden. Deze amendementen hadden betrekking op de in de vorige alinea reeds genoemde kritiekpunten. Naar aanleiding van de zittingen van de Juridische Commissie werd op 24 augustus 1950 een rapport opgesteld door de voorzitter, Maxwell-Fyfe, namens deze Commissie. ${ }^{49}$

In dit rapport raadde de Juridische Commissie de Raadgevende Vergadering aan, aan het ontwerp van het Comité van Ministers in het algemeen haar goedkeuring te verlenen. Wel zou er bij het Comité van Ministers op aangedrongen moeten worden bepaalde toevoegingen te doen of essentiële wijzigingen door te voeren, die door de Commissie wenselijk werden geacht, ook al liepen de standpunten binnen de Commissie hierover uiteen. ${ }^{50}$

De voorstellen van de Juridische Commissie hielden, onder meer, het volgende in:

- de toevoeging van een preambule aan het begin van de Conventie;

- het opnemen van een artikel gewijd aan:

* het recht op eigendom; het voorgestelde artikel was een poging om het recht te definiëren, zoals verzocht door de Raadgevende Vergadering in september 1949; enkele tegenstanders vonden het onterecht om dit sociale recht in de Conventie op te nemen en andere sociale rechten buiten beschouwing te laten.

* het recht van ouders met betrekking tot de opvoeding van hun kinderen;

48 Tweede sessie van de Raadgevende Vergadering, 7-28 augustus 1950, bijeenkomst van de Commissie voor Juridische en Administratieve Zaken, 17-23 augustus 1950. in: Council of Europe, Collected Edition of the "Travaux Préparatoires" of the European Convention on Human Rights, Vol.VI, pp. 2-72.

49 Rapport van 24 augustus 1950 inzake de ontwerp-Coniventic voor de Bescherming van de Rechten van de Mens en de Fundamentele Vrijheden, aangeboden namens de Commissie voor Juridische en Administratieve Zaken door Sir David Maxwell-Fyfe, (a) Text of the Report (Doc. Consultative Assembly, No. 93, 24 August 1950; pp. 980-987), in: Council of Europe, Collected Edition of the "Travaux Préparatoires", Vol. VI, pp. 58-72.

50 Zie noot 49, p. 60: "In drawing up these proposals, the Committee has taken into consideration those divergent opinions that had been brought to light within the Committee of Ministers. The agreennent reached by it on most points encourages the hope that the Committee of Ministers will rally to its suggestions and that the Draft Convention may be modified without any substantial delay being incurred." 
* het recht op vrije verkiezingen; dit artikel werd voorgesteld bij wijze van compromis tussen het door de Raadgevende Vergadering in 1949 voorgestelde artikel ten aanzien van democratische instituties en de afwijzing daarvan door een meerderheid van het Comite van Ministers. - het vestigen van de aandacht van het Comité van Ministers op de noodzaak, dat de Europese Commissie en het Europese Hof de algemene rechtsbeginselen, waarnaar wordt verwezen in artikel 38 van het Statuut van het Internationaal Gerechtshof, zouden moeten toepassen. Opname in de Conventie van een clausule met die strekking werd niet noodzakelijk geacht.

- de opheffing van de beperking (facultativiteit) op het individueel klachtrecht; een andere oplossing om de bezwaren weg te nemen was, dat een Staat bij toetreding tot het verdrag, van tevoren zou kunnen aangeven, bij welke rechten de indiening van een individuele klacht op bezwaren zou stuiten.

- de vermindering van het aantal benodigde Staten, dat de dwingende rechtsmacht van het Hof zou moeten erkennen teneinde het Hof te kunnen laten functioneren. ${ }^{\text {s! }}$

Vervolgens werd in het rapport een ontwerp-aanbeveling - van de Raadgevende Vergadering aan het Comité van Ministers - geformuleerd, waarin de bovenstaande aanbevelingen waren verwerkt.

Tijdens de zestiende en zeventiende zitting van 25 augustus 1950 werd het rapport van de Juridische Commissie besproken in de Raadgevende Vergadering. ${ }^{52}$ Aan het einde van de zitting werd gestemd over de diverse voorstellen, die alle werden aangenomen. Vervolgens werd een aanbeveling aan het Comité van Ministers opgesteld, die overeen kwam met het advies van de Juridische Commissie. ${ }^{33}$

51 Zie noot 49 , pp. $60-66$

52 Tweede sessie van de Raadgevende Vergadering, 7-28 augustus 1950, zestiende zitting van 25 augustus 1950, (b) Report of the Sitting (Reports of the Consultative Assembly, second session. Part III, Sixteenth Sitting, pp. 884-919), "General Debate on the Report of the Committee on Legal and Administrative Questions" en zeventiende zitting van 25 augustus 1950, (b) Report of the Sitting (Reports of the Consuitative Assembly, Second Session, Part III, Seventeenth Sitting, pp. 924-949), "Continuation of the Genera! Debate", in: Council of Europe, Collected Edition of the "Travaux Préparatoires", Vol. VI, pp. 74-140 en 144-190.

53 (c) Recommendation No. 24 to the Committee of Ministers on the Draft Convention for the Protection of Human Rights and Fundamental Freedoms, adopted 25 August 1950, at the conclusion of the Debate on the Report from the Committee on Lega! and Administrative Questions, (ii) Text published in the Collected Documents of the Consultative Assembly (Doc. 104, 26 August 1950, pp. 1028-1045), en "Text of the Draft amended by the Consultative Assembly including notes on the articles not yet 
Tijdens de daarop volgende bijeenkomst van 3 en 4 november 1950 , $\mathrm{k}_{\mathrm{wam}}$ het Comité van Ministers tot de slotsom, dat voor het einde vah de bijeenkomst geen overeenstemming meer zou kunnen worden bereikt over met name de bepalingen inzake het recht op eigendom, het recht van ouders betreffende de opvoeding van hun kinderen en het recht op vrije verkiezingen. Deze en enkele andere kwesties werden voor verdere siudie voorgelegd aan een Committee of Experts en zouden opgenomen worden in een apart Protocol bij het verdrag.

De voorstellen - ten aanzien van de opname van een preambule $e_{n}$ ter vermindering van het aantal Staten, dat de jurisdictie van het Hof zou moeten accepteren voordat dit orgaan zou kunnen worden opgericht werden met algemene instemming aanvaard..$^{54}$

Uiteindelijk werd op 4 november 1950 de Conventie te Fome ondertekend. ${ }^{.5}$ Het verdrag is op 3 september 1953 in werkinggetreden. ${ }^{56}$

approved by the Committee of Ministers and the adoption of which is urged by the Consultative Assembly" (Doc. A 2838), in: Council of Europe, Collected Edition of the "Travaux Préparatioires", Vol. VI, pp. 198-228 resp. pp. 238-272. Zie ook pp. 192-196 voor een overzicht van de aangebrachte wijzigingen.

54 Brief van 5 novemiber 1950 van Count Sforza, Voorzitter van het Comité van Ministers, aan Spaak, President van de Raadgevende Vergadering, bevattende de antwoorden van het Comité van Ministers op de aanbevelingen, aangenomen door de Vergadering gedurende het eerste deel van de tweede sessie (Doc. Consultative Assembly no. 136, 18th November 1950), Appendix: Resolutions of the Committee of Ministers adopted in connection with the Recommendations of the Consultative Assembly during their Sixth Session, 1. Convention on the Protection of Human Rights and Fundamental Freedoms, in: Council of Europe, Collected Edition of the "Travaux Préparatoires" of the European Convention on Human Rights, Vol. VII, pp. $42-44$.

55 Communication made 15th November 1950 by the Directorate of Information to journalists (Doc. IP/180 - PL/Gd B; A 3033), 4. Signatlire of the Convention on Human Rights, in: Council of Europe, Collectedl Edition of the "Travaux Préparatoires", Vol. VII, p. 46. Zie voor de definitieve tekst van de Conventie en de ondertekenaars, pp. 48-80.

56 Voor Nederland is de Conventie op 31 augustus 1954 in werking getreden. Zie voorts voor de publikatie van de verdragstekst in Trb. 1951, 154 en 1990, 156. 


\subsection{De beperkingssystematiek in de ECRM en de inhoudelijke fundering daarvan}

\subsubsection{De inhoudelijke fundering van de formulering van de rechten en de beperkingssystematiek in de ECRM}

De in de Conventie terug te vinden beperkingssystematiek is voor een groot deel de resultante van één van de belangrijkste discussiepunten bij de totstandkoming van de Conventie, zoals beschreven in paragraaf 2.3 , namelijk de wijze van formuleren van de in de Conventie op te nemen rechten.

Twee zienswijzen stonden hierbij tegenover elkaar. Volgens de eerste zienswijze diende men de aanpak van de Commission on Human Rights van de VN bij de opstelling van een Verdrag inzake de Rechten van de Mens te volgen, aan de andere kant heerste de opvatting dat men nauw diende aan te sluiten bij de toen pas binnen het kader van de VN tot stand gekomen Universele Verklaring voor de Rechten van de Mens.

Het eerste standpunt ging uit van een nauwkeurige definiëring van de te garanderen rechten en tevens van de beperkingen daarop.

Het tweede standpunt betekende, dat men in navolging van de Universele Verklaring bij de formulering van de Conventie zou volstaan met een opsomming van mensenrechten, die door de Staten zouden moeten worden nageleefd.

Voorstanders van nauwkeurige definiëring van de rechten voerden onder meer aan, dat met de opstelling van de Conventie beoogd werd om, in afwijking van de Universele Verklaring voor de Rechten van de Mens, een juridisch bindend document tot stand te brengen en niet een politiek instrument. Het toezichtmechanisme, dat op de naleving van de Conventie zou moeten toezien, zou echter alleen kunnen functioneren als de opgenomen rechten voldoende gedefinieerd waren. ${ }^{57}$

57 Redevoering van de Britse gedelegeerde Ungoed-Thomas, Eerste Sessie van de Raadgevende Vergadering, 10 augustus - 8 september 1949, Achtste zitting van 19 augustus 1949, in: Council of Europe, Collected Edition of the "Travaux Préparatoires", Vol. I, pp. 80-82. Rede van de Brit Hoare, Conference of Senior Officials, 8 17 June 1950, Minuten van de zitting van 8 juni 1950 (Doc. CM/WP 1 (50) 16 of 9 June 1950), in: Council of Europe, Collected Edition of the "Travaux Préparatoires", Vol. rV, p. 106. 
Dit strookte niet met de opvatting van de tegenstanders van gedetailleerde normen, dat elke nadere concretisering van een opgesomd recht het gevaar met zich mee zou brengen, dat men hierdoor de reikwijdte beperkte."

De voorstanders waren echter van mening, dat de rechten en de beperkingen op die rechten in gedetailleerde juridische normen moesten worden neergelegd, om de aard en de reikwijdte van de verdragsverplichtingen duidelijk te maken aan de Staten, die partij zouden worden bij de voorgestelde Conventie."

De tegenstanders van definiëring meenden voorts, dat het wenselijk was de activiteiten van de Raad van Europa te coördineren met die van de Verenigde Naties; gezien de morele autoriteit en de technische waarde van de Universele Verklaring, zou bij dit document aansluiting moeten worden gezocht. ${ }^{*}$

Volgens de voorstanders zou een document waarin de rechten alleen algemeen omschreven zouden worden, juist niets toevoegen aan de Universele Verklaring voor de Rechten van de Mens. Nauwkeurige en specifieke regels waren noodzakelijk, omdat anders het risico zou bestaan, dat er een vage verklaring tot stand zou komen, die slechts bruikbaar zou zijn voor propaganda-doeleinden en die makkelijker omzeild zou kunnen worden dan een nauwkeurig, gedetailleerd instrument. ${ }^{61}$

De tegenstanders voerden echter aan, dat de rechten die in het ontwerp van de Raadgevende Vergadering ${ }^{62}$ waren opgesomd en die verwezen naar

58 Teitgen, rapporteur van de Juridische Commissie, Achttiende zitting van de Raadgevende Vergadering op 8 september 1949, Official Report of the Sitting (Reports of the Consultative Assembly, First Session, part II. 18th Sitting, pp. 11641299 and 1308-1327), in: Council of Europe, Collected Edition of the "Travaux Préparatoires", Vol. II, pp. 44-46.

59 Standpunt van het Verenigd Koninkrijk, Bijeenkomsten van het Committee of Experts, 2-8 februari en 6-10 maart 1950, Report to the Committee of Ministers submitted by the Committee of Experts instructed to draw up a Draft Convention of collective guarantee of Human Rights and Fundamental Freedoms (Doc. CM/WP I (50) 15: A 92.4 of 16 March 1950), in: Council of Europe. Collected Edition of the "Travaux Prêparatoires". Vol. IV, pp. 2-50(8).

60 Doc. 77 of the Consultative Assembly: First Session; 15th Sitting: 5th September 1949: pp. 197-209, in: Council of Europe, Collected Edition of the "Travaux Préparatoires", Vol. I, pp. 216-238(218-222).

61 Respectievelijk Patijn (Nederland), Sund (Noorwegen) en Hoare (Verenigd Koninkrijk), Conference of Senior Officials, 8 - 17 June 1950, Minuten van de zitting van 8 juni 1950 (Doc. CM/WP 1 (50) 16 of 9 June 1950) en van 9 juni 1950 (Doc. CM/WP 4 (50) 3), in: Council of Europe, Collected Edition of the "Travaux Préparatoires". Vol. IV, respectievelijk pp. 108, 110-111 en 106. 
de Universele Verklaring, inclusief de algemene regels betreffende de beperking van deze rechten, voor West-Europa een voldoende nauwkeurige betekenis hadden om het aan de Lid-Staten zelf over te laten de voorwaarden voor uitoefening van deze rechten, en hun bescherming, in het nationale recht van die staten vast te leggen. ${ }^{6}$

Volgens de voorstanders van definiëring vereiste de diversiteit van vormen waarin vrijheidswaarborgen - en de beperkingen daarop - in de verschillende landen waren gegoten, een nauwkeurige definiëring van die vrijheden, teneinde deze te kunnen garanderen overeenkomstig de in artikel 1 van het Statuut van de Raad van Europa weergegeven doelstelling van een grotere eenheid tussen de Lid-Staten. ${ }^{\text {at }}$

Ondanks de bezwaren van voorstanders van definiëring van de rechten en vrijheden in de tot stand te brengen Conventie, slaagde de Juridische Commissie van de Raadgevende Vergadering er binnen een maand in, een ontwerp-verdrag op te stellen, dat voor de meerderheid van de Raadgevende Vergadering aanvaardbaar was. In dit ontwerp werden de rechten en vrijheden algemeen omschreven evenals de in algemene beginselen vervatte beperkingen en uitzonderingen en werd nauw aangesloten bij de Universele Verklaring voor de Rechten van de Mens."

Heel wat moeizamer ging het bij het Comité van Ministers. Binnen het op verzoek van het Comité bijeengekomen Comité van Experts lagen de standpunten zover uiteen, dat men besloot een aantal alternatieve voorstellen aan het Comité van Ministers voor te leggen. ${ }^{\text {thi }}$ Vervolgens gaf het Comité van Ministers aan de Conference of Senior Officials de opdracht om de verschillende voorstellen om te vormen in één enkel voorstel. Hiervoor was het nodig, dat op de verschillende geschilpunten compromissen tot stand zouden komen. Zoals reeds uiteengezet in paragraaf $2.3^{67} \mathrm{kwam}$ er een compromis-ontwerp tot stand. Dit ontwerp

63 Standpunt van België, Bijeenkomsten van het Committee of Experts, 2-8 februari en 6-10 maart 1950, Report to the Committee of Ministers submitted by the Comminte of Experts instructed to draw up a Draft Convention of collective guarantee of Human Rights and Fundamental Freedons (Doc. CM/WP 1 (50) 15: A 924 of 16 March 1950), in: Council of Europe, Collected Edition of the "Travaux Préparatoires", Voi. IV, pp. 12-14.

64 Redevoering van de Belgische gedelegeerde Fayat, Eerste Sessie van de Raadgevende Vergadering, 10 augustus - 8 september 1949, Achtste zitting van 19 augustus 1949 , in: Council of Europe, Collected Edition of the "Travaux Préparatoires", Vol. I, p. 88.

Zie pp. 39-42 en noot 32.

66 Zie pp. 43-44 en de noten 34 en 35.

Zie pp. 44-45 en noot 38 . 
ging uit van nauwkeurige definiëring van de te garanderen rechten en vrijheden en van de beperkingen en uitzonderingen daarop, maar om an de bezwaren van de tegenstanders van deze methode tegemoet te komen, werden enkele algemene beginselen in het ontwerp opgenomen.

Dit voorstel kon in het algemeen de goedkeuring wegdragen van het Comité van Ministers, de Juridische Commissie van de Raadgevende Vergadering en de Raadgevende Vergadering. Zo noemde Maxwell-Fyfe het een voordeel van het compromis-voorstel, dat - in tegenstelling tot het ontwerp van de Raadgevende Vergadering - de verwijzing vermeden werd naar een document dat niet bedoeld was rechtens afdwingbare rechten te bevatten, maar slechts wenselijke rechten (namelijk de Universele Verklaring). Volgens de Juridische Commissie waren de door de Senior Officials geformuleerde rechten, niet zó excessief gedetailleerd, dat het "might tie unduly either a judicial or a non-judicial agency which had to enforce the Convention. " ${ }^{68}$ Slechts enkele tegenstanders van nauwkeurige definiëring bleven aan hun bezwaren vasthouden. ${ }^{69}$

Al met al werd de Conventie op 4 november 1950 door de Lid-Staten van de Raad van Europa ondertekend, dat wil zeggen binnen 1 jaar en 3 maanden nadat met de opstelling van het verdrag was begormen. Hiermee werd afgedaan met het meest geuite argument tegen nauwkeurige definiëring van de verdragsrechten, namelijk dat dit teveel tijd zou vergen. ${ }^{70}$

68 Zesde zitting van de Raadgevende Vergadering van 14 augustus, Report of the sitting (Reports Consultative Assembly, second session, Volume II, Sixth Sitting, pp. $322-$ 355), "General Debate on the Draft Convention for the Protection of Human Rights and Fundamental Freedoms", in: Council of Europe, Collected Edition of the "Travaux Préparatoires". Vol. V, pp. 216-270(222).

69 Bijvoorbeeld Teitgen. Negende zitting van de Raadgevende Vergadering van 16 augustus 1950, Report of the sitting (Report, Consultative Assembly "Second Session, Volume II, Ninth Sitting, pp. 494-543), "Continuation of the General Debate ...", in: Council of Europe. Collected Edition of the "Travaux Préparatoires", Vol. V, pp. 272-350(284-286).

70 Redevoering van de Britse gedelegeerde Sir David Maxwell-Fyfe. Eerste Sessie van de Raadgevende Vergadering. 10 augustus - 8 september 1949. Achtste zitting van 19 augustus 1949, in: Council of Europe. Collected Edition of the "Travaux Préparatoires", Vol. I, pp. 114-124(118-120). Gesuggereerd werd, dat eventueel na het tot stand brengen van de Conventie met daarin de algemeen omschreven rechten, verder gewerkt zou kunnen worden aan een supplementaire overeenkomst, waarin een nadere definitie van de rechten zou kunnen worden afgesproken. Zie verder de brief (Doc. A14) van P.H. Teitgen van 22 augustus 1949 aan de Voorzitter van de Juridische Commissie, op pp. 156-162(156-158). 
In het navolgende zal de beperkingssystematiek zoals die in definitieve tekst van de Conventie is neergelegd", worden weergegeven. De verschillende beperkingsmethoden zullen worden ingedeeld al naar gelang ze kunnen worden toegepast zowel in tijden van oorlog of noodtoestand als in vredestijd, dan wel slechts toegepast kunnen worden in tijden van oorlog of noodtoestand. Vervolgens zullen ook de Conventie-bepalingen waarop geen beperkingen toegestaan zijn worden aangegeven ${ }^{n}$

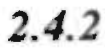

Beperkingen op rechten en vrijheden in vredestijd en
tijden van rust

2.4.2.1

De beperkingsmogelijkheden, opgenomen in de artikelen 8-11 ECRM en artikel 2 Protocol IV ECRM

Overeenkomstig het uiteindelijk gekozen standpunt van definiëring van de te garanderen rechten, zijn ook de beperkingen en uitzonderingen gedefinieerd. De bekendste vorm van beperking treffen we aan in de artikelen 8 tot en met 11 van de Conventie, artikel 2 van het vierde Protocol, artikel 1 van het Eerste Protocol en artikel 1 van het zevende Protocol ${ }^{73}$, waar in de eerste leden de rechten zijn gedefinieerd en in de tweede leden de beperkingen (lees voor artikel 2 Protocol IV: derde lid in plaats van tweede lid). De op grond van deze tweede leden aan de Staat verleende bevoegdheid om de in het eerste leden genoemde rechten te beperken is echter aan een aantal voorwaarden gebonden. Ten eerste moet de beperkingsmogelijkheid voorzien zijn bij wet. Ten tweede moet de beperking nodig zijn met het oog op een bepaald beschermenswaardig

71 Zie de noten 55 en 56.

72 Vgl. Th.L. Bellekom, Het Hof voor de Rechten van de Mens en de beperkingsclausules van het EVRM, pp. 59-67. Bellekom spreekt respectievelijk van niet-absolute aanspraken, enkelvoudig-absolute aanspraken en tweevoudig-absolute aanspraken.

73 De twee laatstgenoemde artikelen zullen, in verband met een aantal afwijkingen in de formulering en de gestelde voorwaarden voor beperking, verder buiten beschouwing worden gelaten. 
belang. ${ }^{74}$ En ten derde moet de beperking noodzakelijk zijn in een democratische samenleving.

Deze voorwaarden waren reeds in het "beperkings-artikel" - artikel 6 - van het ontwerp van de Raadgevende Vergadering opgenomen en werden ook in de latere ontwerpen overgenomen. Eén van de motieven, die aan dat artikel (evenals aan de artikel 5 en 7 van dat ontwerp) ten grondslag lagen, was, dat geen enkele Staat

"shall in fact aim at suppressing the guaranteed freedoms by means of minor measures which, while made with the pretext of organising the exercise of these freedoms on its territory, or safeguarding the letter of the law, have the opposite effect. "7s

Verder werd het als de legitieme en noodzakelijke taak van de Staat gezien

"to limit, sometimes even to restrain, individual freedoms, to allow everyone the peaceful exercise of their freedom and to ensure the maintenance of morality, of the general well-being, of the common good and of public need."

Artikel 6 bood hiertoe de mogelijkheid en stelde tegelijkertijd een verbod op díe beperkingen op een gegarandeerd recht, die niet gebaseerd zijn op redenen van algemeen belang, maar op "reasons of State". ${ }^{76}$

74 Als zodanige belangen worden genoemd: national security (artt. 8, 10, 11 ECRM en art. 2 lid 3 Prot. IV ECRM en art. 1 Prot. VII ECRM), public safety (artt. 8, 9, 10. 11 ECRM en art. 2 lid 3 Prot. IV ECRM), economic well-being of the country (art. 8 ECRM). prevention of disorder or crime (artt. 8, 10, 11 ECRM en art. 2 lid 3 Prot. IV ECRM), protection of health or morals (artt. 8, 9.10, 11 ECRM en art. 2 lid 3 Prot. IV ECRM), protection of rights and freedoms of others (artt. 8, 9, 10. 11 ECRM en art. 2 lid 3 Prot. IV ECRM), protection of public order (art. 9 ECRM en art. 2 lid 3 Prot. IV en I Prot. VII ECRM), territorial integrity, protection of the reputation of others, prevention of disclosure of information received in confidence. maintaining the authority and impartiality of the judiciary (art. 10 ECRM), public interest (art. 2 lid 4 Prot. IV ECRM). Zie pp. 40-47 voor een bespreking van een aantal van deze doelcriteria.

75 Presentation of the Report of the Committee on Legal and Administrative Questions, zeventiende zitting van de Raadgevende Vergadering op 7 september 1949, verslag van de zitting (Report of the Consultative Assembly. First Session, part II, pp. 575584), in: Council of Europe. Collected Edition of the "Travaux Préparatoires", Vol. I. pp. 264-294(276).

76 Zie het citaat op p. 41 en noot 26. 
Ook in het eerste aangenomen ontwerp waarbij werd uitgegaan van definiëring van de rechten en beperkingen (alternatief B van het Comité van Experts), zijn formuleringen vergelijkbaar aan die van de tweede leden van artikel 8-11 van de definitieve tekst, terug te vinden. Eén element ontbrak daar echter: de verwijzing naar de "democratische samenleving". Dit element werd naderhand door de Conference of Senior Officials aan de desbetreffende artikelen toegevoegd." Over het "waarom" van het toevoegen van dit element geven de "Travaux Préparatoires" geen uitsluitsel. Vermoedelijk moet de herkomst van dit element gezocht worden in artikel 29 lid 2 van de Universele Verklaring voor de Rechten van de Mens." Ook de debatten binnen de VN-Commissie verschaffen echter weinig duidelijkheid over de motieven voor opneming van het begrip "democratische samenleving". Volgens Elens werd tijdens die debatten de verwijzing naar het woord "samenleving" verdedigd op grond van de noodzaak om de sociale functie van mensenrechten te benadrukken en tegelijkertijd de plichten van het individu binnen de samenleving te rechtvaardigen. Voorts zou de opneming van het woord "democratische" vooral ingegeven zijn door de angst voor het fascisme van voor en tijdens de Tweede Wereldoorlog.

De verwijzing naar een "democratische samenleving" in artikel 29 lid 2 Universele Verklaring zou dan geïnterpreteerd kunnen worden als een verwijzing naar een stelsel van sociale relaties, dat is gebaseerd op politieke vrijheden en individuele rechten, en waarin ieder zich bewust is, dat elk recht een verplichting impliceert tegenover de lokale, nationale en internationale samenleving. De veronderstelling is volgens Elens mogelijk, dat deze betekenis ook aan dit element "in een democratische samenleving" werd gehecht door de opstellers van de Europese Conventie. ${ }^{79}$

Naar aanleiding van de beperkingsclausules van de artikelen $\overline{8}-11$ ECRM is een omvangrijke jurisprudentie tot stand gekomen. ${ }^{* 0}$ De kern van deze. jurisprudentie zal hierna worden weergegeven. ${ }^{81}$ Hierbij dient er wel aan gedacht te worden, dat deze beperkingsclausules slechts van toepassing zijn indien sprake is van een inmenging door de nationale autoriteiten

77 Zie de eerste twee volledige alinea's op p. 45 en noot 38.

78 Françoise Elens, La notion de démocratie dans le cadre des limitations aux đroits, de T'homme, pp. 167-173.

79 Zie noot 78.

80 Aangenomen wordt dat de conclusies die uit deze jurisprudentie kunnen worden getrokken ook gelden voor beperkingen op grond van het derde lid van artikel 2 . Prot. IV ECRM.

81 Zie, onder andere, ook P. van Dijk en G.J.H. van Hoof, De europese conventie in theorie en praktijk, hoofdstuk $7, \S 8, \mathrm{pp} .631-674$. 
("interference by a public authority", artikel 8 lid 2) in het desbetreffende gegarandeerde recht. ${ }^{.2}$ Over de exacte inhoud van de term "interference" is weinig rechtspraak voor handen. Veelal wordt volstaan met de constatering dat een bepaalde, beperkende maatregel een "interference" oplevert en derhalve gerechtvaardigd dient te worden op grond van het tweede lid van de desbetreffende verdragsbepaling. Overigens blijkt wèl duidelijk uit de rechtspraak, dat niet alleen beperkingen die daadwerkelijk plaatsvinden of hebben plaatsgevonden onder deze term worden begrepen. Ook in het geval van wetgeving die niet uitsluit dat een "interference" zich in de toekomst kan voordoen, wordt onder dit begrip gebracht. Zo is, bijvoorbeeld, sprake van een inmenging op het recht op privéleven in het geval van wetgeving die homoseksuele handelingen tussen al dan niet meerderjarige mannen verbiedt, ook indien in praktijk niet op grond van dit verbod tot strafvervolging wordt overgegaan. Het Hof heeft hieromtrent in de zaak Modinos overwogen dat "the existence of the prohibition continuously and directly affects the applicant's private life" ${ }^{83}$

Op de voorwaarden waaraan voldaan moet worden om een inmenging op de in de artikelen 8-11 ECRM en artikel 2 Protocol IV ECRM gegarandeerde rechten te kunnen rechtvaardigen, zal nu worden ingegaan.

\section{* De eerste voorwaarde: Prescribed by law/ in accordance with the law}

Op grond van de jurisprudentie van het Hof moet ervan worden uitgegaan, dat deze beide formuleringen dezelfde betekenis hebben. Hierbij is van belang, dat beide Engelstalige zinsneden in de Franstalige tekst op dezelfde wijze geformuleerd zijn: "prévues par la loi". In de zaak Sunday Times heeft het Hof bepaald, dat wanneer het geconfronteerd wordt met twee versies van het verdrag, die gelijkelijk authentiek zijn maar niet geheel qua tekst overeenstemmen, het Hof deze formuleringen moet interpreteren "in a way that reconciles them as far as possible and is most appropriate in order to realise the aim and achieve the object of the treaty".

82 De andere beperkingsclausules hebben een iets andere formulering, maar in de praktijk wordt doorgaans de term "interference" gehanteerd.

83 EITRM 22 april 1993, Modinos Case, \$24, p. 11. Aan de basis van deze uitspraak ligt EHRM 22 oktober 1981, Dudgeon Case, $\$ \$ 40-41$, pp. 18-19. Zie ook EHRM 26 oktober 1988. Norris Case, $\$ \$ 35-38$, pp. 17-18.

84 EHRM 26 april 1979, The Sunday Times Case (no. 1), \$48, p. 30. Het Hof verwijst hier vervolgens naar EHRM 27 juni 1968. Wemhoff Case, §8, p. 23 en artikel 33 lid 4 van het Weens Verdragenverdrag van 23 mei 1969. 
Het Hof hanteert twee uitgangspunten bij de interpretatie van de zinsnedes "prescribed by law" en "in accordance with the law". Ten eerste acht het Hof het de primaire taak van de nationale autoriteiten - en met name de nationale rechter - om nationaal recht te interpreteren en toe te passen. Het Hof zal daarom niet van een tegengesteide mening uitgaan wat betreft de verenigbaarheid van de beperkende maatregel(en) met het nationale recht. Om die reden beperkt het Hof zich tot de vaststelling of "(i)n the light of the wording of the provisions in question and the state of its own case-law at the time, the Court finds this interpretation to be reasonable ...". ss Het tweede uitgangspunt is door het Hof in de zaak Malone geformuleerd: "that the phrase 'in accordance with the law' does not merely refer back to domestic law but also relates to the quality of law, requiring it to be compatible with the rule of law, which is expressiy mentioned in the preamble to the Convention". Dit betekent volgens het Hof, dat de onderhavige zinsnede met zich meebrengt, dat "there must be a measure of legal protection in domestic law against arbitrary interferences by public authorities with the rights safeguarded by paragraph 1 ". ${ }^{\text {"6 }}$ Derhalve dient bij de beoordeling of sprake is van een beperking die "in accordance with the law" of "prescribed by law" is, vastgesteld worden of de volgende algemene beginselen in acht zijn genomen:"

a.- "the interference in question must have some basis in domestic law", Wat onder "domestic law" moet worden verstaan, blijkt uit het volgende: Het Hof hanteert het begrip in een inhoudelijke betekenis en niet in een formele. Dit heeft tot gevolg, dat het begrip "law" ziet op formele wetten, maar ook op lagere wetgeving. Als wettelijke grondslag wordt doorgaans door de Commissie en het Hof beschouwd, wat door de nationale autoriteiten als wet wordt aangemerkt. Zo zouden koninklijke besluiten, noodverordeningen en op een wet gebaseerde interne reglementen ook

85 Zie o.a. EHRM 2 augustus 1984, Malone Case, 879, p. 36; EHRM 22 juni 1989, Eriksson Case, §62, p. 25; EHRM 24 april 1990, Kruslin Case, 829, pp. 21-22, NJ 1991, 523; EHRM 25 februari 1992, Case of Margareta and Roger Andersson, 882 , p. 28; EHRM 25 mei 1993, Kokkinakis Case, 840, p. 19; EHRM 25 augustus 1993 , Chorherr Case, §25, p. 36 en (voor voorgaand citaat:) EHRM 24 februari 1994, Case of Casado Coca, \$43, p. 18. Zie verder EHRM 20 september 1994, Case of Otto-Preminger-Institut, \$845, p. 17.

86 EHRM 2 augustus 1984, Malone Case, 867, p. 32. Zie ook EHRM 24 september 1992, Herczegfalvy Case, §89, p. 27.

87 Zie samenvattend $\$ 75$ van EHRM 25 februari 1992, Case of Margareta and Roger Andersson, p. 25.

88 EHRM 25 maart 1983, Case of Silver and others, 8886, p. 33 en EHRM 2 augustus 1984, Malone Case, §66, p. 31. 
onder het begrip "law" kunnen vallen." Voorts wordt onder "law"/"loi" niet alleen geschreven maar ook ongeschreven recht begrepen. Als dit niet het geval zou zijn, dan zou dit volgens het Hof indruisen tegen de bedoelingen van de opstellers van de Conventie. Staten met een "common law"-rechtssysteem zouden, namelijk, in dat geval nooit een beroep kunnen doen op de tweede leden van de artikelen 8-11 van de Conventie. Dit wil echter niet zeggen, dat ongeschreven recht alleen in "common law"-landen als basis voor beperkingen kan gelden. Het Hof heeft in de zaak Kruslin uitgesproken, dat het verkeerd zou zijn een te scherp onderscheid te maken tussen "common law"-staten en staten met een continentaal rechtsstelsel. Geschreven recht kan toch belang hebben in "common law"-landen, en evenzo speelt jurisprudentieel recht traditioneel in continentale landen een dusdanig belangrijke rol dat hele onderdelen van het positieve recht de uitkomst zijn van rechterlijke beslissingen. Indien het Hof ten aanzien van dergelijke staten voorbij zou gaan aan de jurisprudentie, dan zou het de rechtsstelsels van die staten evenzeer ondermijnen, als wanneer het Hof in de Sunday Times-zaak "would have 'struck at the very roots' of the United Kingdom's legal system if it had excluded the common law from the concept of "law'", aldus het Hof. Op terreinen waarop geschreven recht geldt, moet "law" begrepen worden als het geldende recht (de geschreven wet) in de betekenis die de bevoegde rechters daaraan hebben gegeven in het licht van nieuwe ontwikkelingen in de praktijk. ${ }^{90}$

Of en in hoeverre het Hof vereist, dat de beperkende wettelijke maatregel een democratische grondslag moet hebben, wordt uit de jurisprudentie niet duidelijk; verschillende auteurs vinden deze grondslag. een noodzakelijke voorwaarde om te kunnen voldoen aan het vereiste "prescribed by law"/"in accordance with the law". ." Veelal wordt daarbij de link gelegd met artikel 3 van het eerste Protocol.

Wat moet worden verstaan onder "the quality of the law" is uitgewerkt in de volgende twee principes:

b.- het beginsel van toegankelijkheid: "the law must be adequately accessible: the citizen must be able to have an indication that is adequate,

89 Zie P. van Dijk en G.J.H. van Hoof. De europese conventie in theorie en praktijk. p. 637 en EHRM 18 juni 1971, De Wilde. Ooms and Versyp cases, \$93, p. 45 en EHRM 24 april 1990, Krustin Case, \$29. pp. 21-22.

90 EHRM 24 april 1990, Kruslin Case, \$29. p. 22; EHRM 26 april 1979, The Sunday Times Case (no. 1), \$47, p. 30.

91 Zie bijvoorbeeld E.A. Alkema, Studies over Europese grondrechten, p. 42 en $P$. van Dijk en G.J.H. van Hoof, De europese conventie in theorie en praktijk, p. 639. 
in the circumstances, of the legal rules applicable to a given case". ${ }^{92}$ Uit de jurisprudentie lijkt men te kunnen concluderen dat nodig is dat de desbetreffende regels gepubliceerd zijn of anderszins bekend zijn geworden, zoals via rechterlijke uitspraken (met name van belang in op "common law" gebaseerde rechtssystemen, zie a.) of publikaties. Zo heeft het Hof, bijvoorbeeld, in de zaak Silver overwogen ten aanzien van de in die zaak in het geding zijnde regelgeving: "Clearly, the Prison Act and the Rules met this criterion, but the Orders and Instructions were not published $^{m 93}$

c.- het beginsel van voorzienbaarheid: "a norm cannot be regarded as 'law' unless it is formulated with sufficient precision to enable the citizen to regulate his conduct: he must be able - if need be with appropriate advice to foresee, to a degree that is reasonable in the circumstance, the consequences which a given action may entail"." De mate van precisie van de "law" hang af van het onderwerp ervan, de inhoud van de regel, het terrein waarop deze regel van toepassing is en het aantal en de status van de personen op wie de regel is gericht. Echter, veel wetten laten onvermijdelijk ruimte voor een zekere beoordelingsvrijheid; de bewoordingen zijn in meerdere of mindere mate vaag. Dit is noodzakelijk om te voorkomen dat een wet in een buitensporige mate omlijnd is en om te bewerkstelligen dat een wet in de pas kan blijven met veranderende omstandigheden. In zo'n geval moet de wet de "scope of discretion" en de manier waarop die discretie wordt uitgeoefend, voldoende duidelijk aangeven, met het oog op het legitieme doel van de maatregel in kwestie. ${ }^{95}$ Waarborgen die worden gegeven teneinde een juist gebruik van die beoordelingsvrijheid te garanderen behoeven echter niet in die wet zélf te staan. ${ }^{\circ}$ Ondanks de bedoelde beoordelingsvrijheid moet het Hof om te

92 EHRM 26 april 1979, The Sunday Times Case (no. 1), 849, p. 31 en EHRM 25 maart 1983. Silver Case, \$87. p. 33.

93 EHRM 25 maart 1983. Case of Silver a.o.. \$887, p.33, cursivering CS. Zie, bijvoorbeeld, ook EHRM 26 maart 1987, Leander Case, 853, p. 24 en P. van Dijk en G.J.H. van Hoof. De europese conventie in theorie en praktijk, pp. 639-640.

94 EHRM 26 april 1979. The Sunday Times Case (no. 1). 849, p. 31. Zie ook EHRM 26 novernber 1991, Case of The Observer and Guardian, \$53, p. 28.

95 EHRM 25 maart 1983, Silver Case, \$88, p. 33 en EHRM 24 november 1986, Gillow Case, p. 21. Zie ook o.a. EHRM 24 april 1990. Kruslin Case, 830, pp. 22-25; EHRM 24 september 1992. Herczegfalvy Case, $\$ \$ 89$ en 91, p. 27; EHRM 25 mei 1993, Kokkinakis Case. 8 40, p. 19 en EHRM 25 augustus 1993, Chorherr Case, 825, pp. 35-36.

96 EHRM 25 maart 1983, Silver Case, $\$ 90$, p. 34. De eisen, die aan de desbetreffende wet worden gesteld, zijn echter anders in het geval waarin sprake is van inbreuk op een recht of vrijheid door middel van geheime maatregelen, zie EHRM 2 augustus 1984, Malone Case, \$67, p. 32 en EHRM 26 maan 1987, Leander Case, \$51, p. 23. 
kunnen vaststellen of de gemaakte inbreuk "in accordance with the law" is

"inevitably assess the relevant ... law in force at the time in relation to the requirement of the fundamental principle of the rule of law. Such a review necessarily entails some degree of abstraction." 97

Overigens moet als laatste opmerking met betrekking tot de zinsnedes "prescribed by law" en "in accordance with the law" worden opgemerkt, dat in veel zaken het voldaan zijn aan deze voorwaarde niet wordt betwist en derhalve door het Hof niet aan dit punt wordt getoetst.

\section{* De tweede voorwaarde: in the interest of.../ for the protection of.../ for the prevention of...etc.}

Zoals hierna zal blijken, vindt de interpretatie van de doeleinden ten behoeve waarvan een Staat een inbreuk pleegt op een bepaald recht of een bepaalde vrijheid veelal plaats in het kader van het onderzoek naar de noodzaak van de inbreuk. Op deze plaats wordt derhalve volstaan met een korte bespreking van de belangrijkste (de meest voorkomende) beperkingsgronden, voor zover deze afzonderlijk in de uitspraken van de Commissie en het Hof aan de orde zijn gekomen. ${ }^{98}$

Wél is het essentieel dat de desbetreffende regels duidelijk en gedetailleerd zijn en bovendien moeten ze adequate bescherming bieden tegen allerlei mogelijke vormen van misbruik. EHRM 24 april 1990, Kruslin Case, \$30, \$33 en \$35, p. 23. EHRM 24 april 1990, Kruslin Case. \$32, p. 23.

98 Zie voor een uitgebreidere bespreking van de afzonderlijke beperkingsgronden, $A$. Kiss, Les clauses de limitation et de dérogation dans la Convention Européenne des Droits de l'Homme, pp. 125-130 en Jan Velaers. De beperkingen van de vrijheid van meningsuiting, pp. 275-309 (nrs. 273-318): zie voor een kort overzicht van de jurisprudentie, P. van Dijk en G.J.H. van Hoof. De europese conventie in theorie en praktiijk, p. 643 (laatste alinea) en p. 644 (bovenaan). Zie voorts voor de verder niet te bespreken beperkingsgrond "algemeen belang" in artikel 1 van het Eerste Protocol, EHRM 18 februari 1991, Fredin Case, \$48, p. 16 ("protection of the environment") en EHRM 22 september 1994, Hentrich Case, \$39, p. 19: "the notion of "public interest" is necessarily extensive ... It (het Hof, CS) recognises that the prevention of tax evasion is a legitimate objective which is in the public interest. ...". 
"national security"

Op de beperkingsgrond "nationale veiligheid" is een beroep gedaan in verschillende zaken, maar een echte definitie wordt in die zaken niet gegeven. Wèl blijkt uit een aantal uitspraken wat voor soort maatregelen zoal onder dit begrip kunnen vallen: het bestraffen van het schenden van staats- en militaire geheimen ${ }^{100}$, de veroordeling wegens verspreiding van opruiende geschriften (onder militairen) ${ }^{101}$, bestraffing van het oproepen tot en het goedkeuren van het gebruik van geweld ${ }^{102}$, veroordeling wegens neo-nazistische activiteiten ${ }^{103}$; geheim toezicht op ienands post, telefoon en andere telecommunicatiemiddelen in verband met de voorkoming van terroristische activiteiten ${ }^{104}$ en een verbod op publikatie van (geheime informatie in) geschriften die schade kunnen toebrengen aan het functioneren van de staatsveiligheidsdienst van een land ${ }^{105}$.

Ten aanzien van het woord "nationale" in "nationale veiligheid" bepleit Kiss dat dit moet dienen ter aanduiding van de tegenstelling met "internationale veiligheid" en "lokale of regionale veiligheid". ${ }^{106}$ Zo zou de internationale veiligheid meer een onderwerp zijn dat zijn bescherming vindt in het Handvest van de Verenigde Naties. En wat betreft de "lokale en regionale veiligheid": het woord "nationale" zou betrekking hebben op een "land". Daarom zou volgens Kiss - terecht - het motief dat aan de beperking ten grondslag ligt evenredig moeten zijn aan een bedreiging van een zekere omvang. Een bedreiging van de veiligheid op lokaal of regionaal niveau zou, mijns inziens, immers kunnen worden gekeerd door een grondrechtenbeperking die wordt gemotiveerd op grond van de bescherming van de openbare orde die hieronder ter sprake zal worden.

99 Deze grond is opgenomen in de tweede leden van de artikelen 8, 10, 11 en 1 Prot. VII en lid 3 van artikel 2 Prot. IV.

100 Besl.Comm. 13 december 1984, zaak nr. 10078/82. M v. France, p. 122.

101 Impliciet in Rapp.Comm. 12 oktober 1978, zaak nr. 7050/75, Arrowsmith Case, \$85. p. 22.

102 Besl.Comm. 14 december 1972, zaak nr. 5321/71, X v. Austria, p. 107.

103 Besl.Comm. 13 december 1963, zaak nr. 1747/62, X v. Ausiria, p. 54.

104 EHRM 6 september 1978 , Klass Case, $\$ \$ 4.5-46,48$, pp. 22-23.

105 EHRM 26 november 1991, Case of The Observer and Guardian, \$56, p. 29.

106 A. Kiss, Les Clauses de limitation et de dérogation dans la Convention européenne des droits de l'Homme, p. 125. 
"public safery"

Voorbeelden uit de jurisprudentie van de Commissie waarin beperkingen op deze grond werden goedgekeurd zijn: de veroordeling wegens neonazistische activiteiten en het verbod tot heroprichting van fascistische partijen $^{108}$, het gebruik van disciplinaire bevoegdheden door klager's superieuren ter verzekering van het goede functioneren van het politiekorps ${ }^{109}$; beperking van het recht op familieleven van gedetineerden ter verzekering van het goede functioneren van het gevangeniswezen ${ }^{110}$, bestraffing van het oproepen tot en het goedkeuren van het gebruik van geweld"' of de veroordeling wegens het bezit en daarmee verhindering van de verspreiding van opruiende geschriften (onder militairen) ${ }^{112}$.

Het begrip "openbare veiligheid" lijkt, aldus Kiss, de bescherming van individuele personen tegen gevaren die hun leven, hun fysieke integriteit of hun gezondheid zouden kunnen bedreigen, te omvatten. ${ }^{113}$ Volgens Velaers ziet de term "openbare veiligheid" op het voortbestaan van de natie als zodanig en het functioneren van instellingen die van vitaal belang zijn voor de democratische rechtsstaat. ${ }^{114}$ Qua reikwijdte zou het begrip volgens Kiss enger zijn dan het begrip "public order" ("ordre public"), maar ruimer dan de "prevention of crime" ("prévention des infractions pénales"), terwijl het bereik van de "openbare veiligheid" volgens Velears ruimer is dan beide andere, voornoemde beperkingsgronden. Uit de opvattingen van beide auteurs ten aanzien van de inhoud van de hierna te bespreken beperkingsgrond "protection of public order" meen ik te kunnen

107 Deze grond is opgenomen in de tweede leden van de artikelen 8, 9, 10 en 11 en het derde lid van artikel 2 Prot. IV.

108 Respectievelijk Besl.Comm. 13 december 1963, zaak nr. 1747/62. X v. Austria, p. 54 en Besl.Comm. 21 mei 1976, zaak nr. 6741/74, X v. Italy, p. 85.

109 Besl.Comm. 16 maart 1970, zaak nr. $4121 / 69 . X$ v. FRG. p. 26.

110 Besl.Comm. 9 oktober 1978, zaak nr. 7610/76, $X$ v. UK. niet gepubliceerd: Besl.Comm. 24 maart 1972. zaak nr. 4992/71, $X$ v. UK, niet gepubliceerd: Besl.Comm. 21 mei 1975, zaak nr. 6564/74, X v. UK. p. 106; Besl.Comm. 3 oktober 1978, zaak nr. 8166/78, $X$ and $Y$ v. Swirzerland.p. 243. In laatstgenoemde zaak was ook een beperkingsgrond de "prevention of disorder in prison".

111 Best.Comm. 14 december 1972, zaak nr. 5321/71, X v. Austria, p. 107.

112 Besl.Comm. I okwober 1975, zaak nr. 6084/73, X v. UK, p. 65. In die geschriften werd aangezet tot desertie en insubordinatie en tot toetreding tot het IRA. Ook als beperkingsgrond werden erkend: "public safety". "prevention of disorder or crime". "rights of other members of the armed forces" onder artikel 10 lid 2 en "protection of public order" en "rights of others" onder artikel 9 lid 2.

113 A. Kiss, Les Clauses de limitation et de dérogation dans la Convention européenne des droits de I'Homme, p. 126.

$114 J$ Velaers, De beperkingen van de vrijheid van meningsuiting, p. 279. 
afleiden, dat dit verschil in opvatting kan worden verklaard uit het feit, dat de betekenis die Kiss geeft aan die grond, door Velaers lijkt te worden omvat door de term "public safety". Gezien de interpretatie die het Hof in de zaak Engel geeft aan de beperkingsgrond "prevention of disorder" meen ik mij te moeten aansluiten bij de opvatting van Kiss. Op deze beperkingsgrond zal nu in worden gegaan.

\section{"protection of public order"/"prevention of disorder"11s}

In de rechtspraak heeft onderzoek plaatsgevonden naar het verschil in betekenis tussen de zinsnede "protection of public order" ("protection de l'ordre", "bescherming van de openbare orde", artikel 9 lid 2) enerzijds en het begrip "prevention of disorder" ("défense de l'ordre", "het voorkomen van wanordelijkheden", de tweede leden van de artikelen 8,10 en 11) anderzijds. In de zaak Engel besliste het Hof, dat "disorder" niet alleen het begrip "public order" omvat, maar "also covers the order that must prevail within the confines of a special social group". Als voorbeeld nam het Hof het geval waarin in een bepaalde groep, zoals de gewapende macht, wanordelijkheden voorkomen, die hun weerslag kunnen hebben op de orde in de samenleving in zijn geheel. ${ }^{116}$ Deze overweging impliceert dat de beperkingsgrond "the protection of public order" een beperktere reikwijdte heeft dan de grond "prevention of disorder". Met het begrip "openbare orde" ("public order") wordt geduid op de handhaving van de orde in openbare plaatsen, terwijl het begrip "orde" (in negatieve zin uitgedrukt in de Engelstalige tekst als "disorder" en in de officiële Nederlandstalige tekst als "wanordelijkheden") zich ook uitstrekt tot de orde binnen bepaalde groepen in de samenleving, derhalve ziet op de "orde" in het algemeen. 11

115 Deze grond is opgenomen in de tweede leden van de artikelen 8, 9, 10, 11 en 1 Prot. VII en in het derde lid van artikel 2 Prot. IV

116 EHRM 8 juni 1976, Case of Engel and others, \$98, p. 41 en herhaald in Rapp.Comm. 12 oktober 1978, Arrowsmith Case. pp. 22-23.

117 Zo ook $J$. Velaers, De beperking van de vrijheid van meningsuiting, pp. 281-282 (nr. 287). Het voorgaande brengt met zich mee dat, hoewel het Franse woord "ordre" in beide beperkingsgronden voorkomt zonder toevoeging van het bijvoeglijk naamwoord "public", dezze laatste term wèl in artikel 9 lid 2 ingelezen dient te worden. Een andere uitleg van de diverse formuleringen van het opentbare ordecriterium en een andere rangorde in de omvang van deze begirippen is te vinden bij A.M.F. Loof-Donker e.a., De openbare orde: een te nemen horde?, pp. 506-509, overigens zonder dat alle hier van belang zijnde uitspraken van het Hof en de Commissie in hun beschouwing betrokken worden. 
Ook aan het verschil in de Franse tekst van de tweede leden van de artikelen 8,10 en 11 , waarin deze beperkingsgrond in een positieve formulering voorkomt ("à la défense de l'ordre") en de Engelse tekst waarin de grond in een negatieve formulering is opgenomen ("prevention of disorder") is in de zaak Engel aandacht besteed en wel door de Commissie. Volgens de Commissie komt aan beide formuleringen dezelfde draagwijdte toe. ${ }^{118}$ Ditzelfde zal derhalve hebben te gelden voor de negatieve formulering in de Nederlandse tekst.

Aan welke beperkingen moet men denken bij deze beperkingsgronden? Allereerst kan worden gewezen op beperkingen ter handhaving van de orde op de voor ieder toegankelijke plaatsen, ofwel de "algemene toestand van rust op straten en pleinen". ${ }^{19}$ Gedacht kan worden aan het verbod op het aanbrengen van schilderingen op openbare gebouwen of privéeigendommen ${ }^{120}$ en beperking in verband met betogingen op de openbare weg (al dan niet met het oog op het wegverkeer). Een voorbeeld hiervan biedt de zaak Ezelin waarin aan klager een disciplinaire berisping werd opgelegd op grond van het feit dat hij zich als advocaat niet had gedistantieerd van de agressieve en beledigende daden van mededemonstranten. ${ }^{121}$

Voorts kan hier, opnieuw, genoemd worden de veroordeling wegens het bezit en daarmee verhindering van de verspreiding van opruiende geschriften onder militairen ${ }^{12}$. Verder kan genoemd worden de uitvoering van een bevel tot uitzetting van een vreemdelingen-echtpaar (in casu

118 Rapp.Comm. 19 juli 1974, Case of Engel a.o., $\$ \$ 167-169$. pp. 81-82. Of het voorstaande ook geldt voor de begrippen "ordre" en "public order" blijkt niet uit de jurisprudentie. A.M.F. Loof-Donker e.a. leiden uit de totstandkomingsgeschiedenis van artikel 2 Prot. IV af dat de Franse term "ordre public" (in het Engels omschreven als "public policy" en in het Nederlands aangeduid als de "beginselen van een positief rechtsstelsel met bijzondere waarde") een ruimere reikwijdte toekomt dan het Engelse begrip "public order" (dat de betekenis krijgt van "de afwezigheid van publieke wanorde"). A.M.F. Loof-Donker e.a., De openbare orde: een te nemen horde?, pp. 506-509.

119 E.A. Alkema, Studies over Europese grondrechten, p. 43; E.A. Alkema, De Europese Conventie en het Nederlandse recht, p. 127.

120 Besl.Comm. 13 oktober 1983, zaak nr. 9870/82, $N$ v. Switzerland, p. 212. Vanzelfsprekend vormde hier ook de "protection of the rights and freedoms of others" een geldige beperkingsgrond.

121 EHRM 26 april 1991, Ezelin Case, \$47, p. 22. Zie verder Besi.Comm. 16 juli 1980, zaak nr. 8440/78, Christians against racism and facism v. UK, p. 149.

122 Besl.Comm. 1 oktober 1975, zaak nr. 6084/73, X v. UK, p. 65; Rapp.Comm. 12 oktober 1978, zaak nr. 7050/75, Arrowsmith Case, §85, pp. 22-23 en EHRM 8 juni 1976, Case of Engel and others, \$98, p. 41. 
echtgenoten) vanwege door één van hen gepleegde strafbare feiten. ${ }^{123}$ Voorts is door het Hof uitgesproken in de zaak Castells, dat de strafprocedure - die werd ingesteld wegens de publikatie door klager van een artikel waarin hij de autoriteiten van laksheid beschuldigt in verband met de vervolging van de plegers van verschillende moorden, en waarin hij de overheid medeplichtig acht aan de, van rechts-extremistische zijde beraamde, moordaanslagen - ook gericht was op de "prevention of disorder" en niet alleen de bescherming van de goede naam van anderen. ${ }^{124}$ Ten slotte werd ook de arrestatie van een demonstrant, waardoor deze in de onmogelijkheid kwam te verkeren pamfletten uit te delen, geacht te zijn geschied in verband met de voorkoming van wanordelijkheden, doordat hij het zicht van toeschouwers op een militaire parade verstoorde, wat enige onrust in de menigte veroorzaakte. ${ }^{125}$

Volgens Kiss kan het begrip "ordre public" aldus begrepen worden, dat het een grond vormt voor het stellen van beperkingen in het belang van het goede functioneren van de staat en staatsinstellingen. ${ }^{126}$ Eén van die instellingen is de krijgsmacht. Zoals het Hof vaststelt in de zaak Engel, kunnen wanordelijkheden in het leger hun weerslag hebben op de samenleving als geheel. Functioneert het leger niet, dan kan dit van grote invloed zijn op het functioneren van de Staat en daarmee het bestaan van de rechtsstaat bedreigen. In die zin geeft de uitspraak in de zaak Engel steun aan de opvatting van Kiss.

Omdat de hierboven beschreven invullingen die aan de grond "openbare orde" gegeven worden - naar mijn mening - niet al te veel houvast bieden bij de toetsing van beperkingen, meen ik, dat ik met Alkema erop moet wijzen dat het te snel accepteren van een beroep op deze beperkingsgrond ertoe kan leiden dat het gaat functioneren als een soort "passe-partout". ${ }^{127}$ Voorzichtigheid bij toepassing van deze grond als motief voor beperkingen is derhalve geboden.

123 EHRM 26 maar 1992, Beldjoudi Case, \$70, p. 26.

124 EHRM 23 april 1992, Castells Case; §39, p. 22; NJ 1994, 102.

125 EHRM 25 augustus 1993, Chorherr Case, \$28, p. 36.

126 A. Kiss, Les Clauses de limitation et de dérogation dans la Convention européenne des droits de l'Homme, pp. 127-128.

127 E.A. Alkema, De Europese Conventie en het Nederlandse recht, p. 127. 


\section{"prevention of crime $e^{1128}$}

Deze beperkingsgrond lijkt mij weinig aanleiding tot discussie te geven. De grond wordt, onder meer, toegepast ter rechtvaardiging van het bestraffen van het bezit van opruiende geschriften onder militairen ${ }^{129}$, het aanmoedigen en het bevorderen van illegale praktijken ${ }^{130}$ en het goedkeuren van strafbare feiten. ${ }^{131}$ Een ander voorbeeld biedt de zaak Murray, waarin het Hof de huiszoeking in de woning van personen die verdacht werden van terroristische activiteiten alsmede het noteren van hun persoonsgegevens en het nemen van hun foto in het belang van de voorkoming van strafbare feiten oordeelde. ${ }^{132}$ Ook wordt deze grond nogal eens toegepast, al dan niet in combinatie met de grond "prevention of disorder", ten aanzien van de beperking van grondrechten van gedetineerden - onder andere, teneinde recidive of ontvluchting te voorkomen en de procesvoering te beïnvloeden ${ }^{133}$ - en van 2 wervers ${ }^{134}$ en personen ten aanzien van wie een bevel tot uitzetting of uitlevering is uitgevaardigd of toelating is geweigerd. ${ }^{13}$

\section{"protection of health"136}

Blijkens een aantal uitspraken van de Commissie gaat het hier om de gezondheid van de samenleving als geheel als ook die van individuen binnen die samenleving en daarbij gaat het om zowel de fysieke als geestelijke gezondheid van die individuen. ${ }^{137}$

128 Deze grond is opgenomen in de tweede leden van de artikelen 8. 10 en 11 en het derde lid van artikel 2 Prot. IV.

129 Opnieuw Besl.Comm. 1 oktober 1975, zaak nr. 6084/73, X v. UK, p. 65.

130 Besl.Comm. 4 december 1978, zaak nr. 8266/78, X v. UK, p. 192. De bedoelde illegale praktijken waren uitzendingen door een radio-piraat.

131 Besl.Comm. 14 december 1972, zaak nr. 5321/71, $X$ v. Austria, p. 107.

132 EHRM 28 oktober 1994, Murray Case. $\$ 89$.

133 Besl.Comm. 6 februari 1967, zaak nr. 2566/65, X v. FRG, pp. 35-37 en EHRM 25 maart 1983. Silver Case, $\$ \$ 101-103$, p. 34 en EHRM 20 juni 1988, Case of Schönenberger and Durmaz, \$25, p. 13.

134 EHRM 18 juni 1971, De Wilde, Ooms and Versyp cases. \$93, p. 45. Ook de "prevention of disorder". "protection of health and morals" en "protection of rights and freedoms of others" waren geldige doelcriteria in deze zaak.

135 EHRM 26 maart 1992, Beldjoudi Case, \$70, p. 26.

136 Deze grond is opgenomen in de tweede leden van de artikelen 8, 9, 10 en 11 en het derde lid van artikel 2 Prot. IV.

137 Besl.Comm. 10 april 1961, zaak nr. 911/60, X v. Sweden, p. 18; Besl.Comm. 23 mei 1966, zaak nr. 2516/65, X v. FRG. p. 39; Besl.Comm. 6 februari 1968, zaak nr. 2648/65, $X$ v. the Netherlands, p. 31: en Besl.Comm. 6 februari 1968, zaak nr. 
Voorbeelden van beperkingen die, volgens de Straatsburgse organen, terecht op deze grond zijn gebaseerd: verplicht lidmaatschap van een gezondheidsdienst opgelegd aan veehouders ter voorkoming van tuberculose onder runderen ${ }^{138}$, regelingen met betrekking tot publiciteit voor geneesmiddelen ${ }^{139}$, de bestraffing van het publiceren van informatie omtrent te verkrijgen hulp bij zelfdoding ${ }^{140}$ en uithuisplaatsing van een kind, het verbod opgelegd aan ouders om hun uithuisgeplaatste kinderen weg te halen bij de pleeggezinnen waar de kinderen verbleven en de beperking van de omgang van deze ouders met hun kinderen ${ }^{14 !}$.

\section{"morals"12}

Zoals bij de bespreking van de derde voorwaarde nog ter sprake zal komen, is het begrip "morals" geen helder begrip en kan het qua inhoud van tijd tot tijd en van plaats tot plaats variëren. Ten aanzien van deze notie bestaat derhalve geen uniforme Europese standaard. Dit geldt des te meer in deze tijd van snelle en verstrekkende evolutie van opvattingen omtrent morele waarden. ${ }^{143} \mathrm{Net}$ als bij de beperkingsgrond "health" gaat het ook bij de onderhavige grond om de bescherming van de morele waarden van de gemeenschap als geheel als ook de morele belangen van bepaalde individuen of groepen van individuen - met name kwetsbare. Men denke bij deze kwetsbare groepen aan personen die (nog) niet geestelijk

2822/66, X v. FRG, p. 45; Besl.Comm. 14 december 1972, zaak nr. 5608/72, $X v$. UK, p. 68; Besl.Comm. 12 december 1977, zaak nr. 7911/77, X v. Sweden, p. 193; en Besl.Comm. 10 juli 1978, zaak nr. $8257 / 78, X$ v. Switzerland, p. 253. Ten anzien van kinderen wordt met dit criterium, onder meer, de geestelijke stabiitteit van het kind en vrijwaring van ernstige psychische verwarring ("a chiid's menta! stability and freedom from serious psychic disturbance") bedoeld.

138 Besl.Comm. 14 december 1962. zaak nr. 1068/61, X v. the Netherlands, p. 285.

139 Besl.Comm. 1 maart 1983, zaak nr. 9664/82, niet gepubliceerd.

140 BesI.Comm. 4 juli 1983, zaak nr. 10083/82, $R$ v. UK, p. 272. Ook een geldige beperkingsgrond in deze zaak was "the prevention of crime".

141 EHRM 27 november 1992, Olsson Case (no.2), \$̧\$84-85, p. 33. Het ging vanzelfsprekend om de bescherming van de gezondheid van de kinderen. Zo ook, onder andere, EHRM 25 februari 1992, Case of Margareta and Roger Andersson, \$87, p. 28 en EHRM 22 april 1992, Rieme Case, \$66, p. 70 . Zie ook de beslissingen genoemd in noot 137 . Ook als geldige beperkingsgronden werd, onder andere, geaccepteerd "the protection of the rights or freedoms of others".

142 Deze grond is opgenomen in de tweede leden van de artikelen 8, 9, 10 en 11 en het derde lid van artikel 2 Prot. IV.

143 Zie p. 51 en EHRM 7 december 1976, Handyside Case, 848, p. 22; EHRM 24 mei 1988, Case of Müller a.o., \$30, p. 20; EHRM 20 september 1994, Case of OttoPreminger-Institut, $\$ 50$, p. 19. 
rijp zijn, die geestelijke handicaps hebben of zich in een afhankelijke positie bevinden. ${ }^{144}$

Ter beantwoording van de vraag aan wat voor "soort" morele waarden gedacht moet worden bij de term "morals": de rechtspraak heeft vrijwel uitsluitend betrekking op de seksuele moraal. Daarbij gaat het dan, onder meer, om - niet altijd door de Straatsburgse instanties toegestane beperkingen bestaande uit het verbieden, inbeslagnemen en bestraffen van publikatie van bepaalde literatuur ${ }^{145}$, kunst ${ }^{146}$ of (video)films ${ }^{147}$ of het verbieden van de export daarvan ${ }^{i s}$ en het verbieden of bestraffen van bepaalde gedragspatronen, met name, in het seksuele verkeer tussen personen $^{109}$.

Mijns inziens zou de grond "moraal" behalve op seksuele moraal, echter, ook betrekking moeten kunnen hebben op morele waarden terzake van, bijvoorbeeld, geweld of het omgaan met mens, dier en milieu. Hieromtrent heb ik helaas slechts een klein aantal uitspraken aangetroffen. Eén daarvan is de uitspraak van het Hof in de zaak van Open Door Counselling Ltd. en Dublin Well Woman Centre Ltd. tegen Ierland. ${ }^{150}$ In het geding was een maatregel die door de Ierse rechtbanken was opgelegd aan beide genoemde organisaties, waardoor het aan deze werd verboden bepaalde informatie aan zwangere vrouwen te verschaffen over abortusmogelijkheden buiten lerland. Het Hof overwoog omtrent deze beperking op de vrijheid om informatie te verspreiden en te ontvangen, dat deze gericht was op de

144 Zie bijvoorbeeld ten aanzien van jeugdigen EHRM 7 december 1976, Handyside Case, $\$ 52$, p. 25 en Besl.Comm. 10 april 1961, zaak nr. 911/60, X v. Sweden, p. 18 .

145 O.a. Besi.Comm. 1 maart 1977, zaken nrs. 6782, 6783 en 6784/74, $X, Y$ and $Z$ v. Belgium, p. 20; Besl.Comm. 13 juli 1978, zaak nr. 8035/77, X v. FRG, p. 202; Besl.Comm. 12 oktober 1978, zaak nr. 7308/75, $X$ v. UK, p. 35 en EHRM 7 december 1976, Handyside Case, \$52, pp. 24-25.

146 EHRM 24 mei 1988, Case of Müller a.o., \$\$35-36, pp. 22-23.

147 EHRM 20 november 1989, Case of Markt Intern Verlag GmbH and Klaus Beermann, $\$ 31$, p. 19. Aithans, anvankelijk werd deze grond als rechtvaardigingsgrond aangevoerd. Uiteindelijk deed de Duitse regering voor het Hof alleen nog een beroep op de bescherming van de goede naam en de rechten van anderen.

148 Besl.Comm. 5 maart 1983, zaak nr. 9615/81, X. Company v. UK, pp. 233-234.

149 Zie o.a. Besl.Comm. 19 mei 1976, zaak nr. 6959/75, Brüggemann and Scheuten, p. 115; Rapp.Comm. 1 maart 1979, Van Oosterwijck Case, \$5 i en EHRM 22 oktober 1981, Dudgeon Case, \$47, p. 20 en EHRM 26 oktober 1988, Norris Case, $\$ 40$, p. 18.

150 EHRM 29 oktober 1992, Case of Open Door and Dublin Well Woman, §63, p. 27; NJ 1993, 544. Zie omtrent deze ruime uitleg van het begrip "morals" de annotatie van J. Van Nieuwenhove bij dit arrest, in: NJCM-Bulletin 18-6 (1993), pp. 710-715 (met name punt 4). 
bescherming van het recht op leven van de ongeborene. Deze bescherming was gebaseerd op de morele waarden van de meerderheid van het lerse volk ten aanzien van de aard van het leven. Het legitieme doel dat derhalve door onderhavige beperking werd nagestreefd, was de bescherming van de goede zeden ("morals") waarvan de bescherming, in Ierland, van het recht op leven van de ongeborene één aspect is.

Een ander voorbeeld is de al eerder genoemde beperking op het recht op omgang van ouders met hun uithuisgeplaatste kind(eren) ${ }^{15 !}$.

Omdat de grens tussen de bescherming van de goede zeden enerzijds en, met name, de bescherming van de rechten van anderen anderzijds, niet altijd scherp te trekken valt, worden deze gronden nogal eens gezamenlijk aangevoerd. ${ }^{152}$ Laatstgenoemde grond zal nu worden besproken.

\section{"rights and freedoms of others"153}

Men kan de vraag stellen wat bedoeld wordt met de begrippen "rights and freedoms". Zien deze termen louter op al dan niet in de Conventie gegarandeerde grondrechten of moeten ze ruimer geïnterpreteerd worden? De jurisprudentie duidt in de richting van het laatste standpunt. Ieder belang van een derde lijkt voor bescherming op deze grond in aanmerking te kunnen komen en aldus als beperkingsgrond dienst te kunnen doen. ${ }^{\text {is }}$ Dit blijkt uit de volgende voorbeelden ${ }^{\text {iss }}$ van op grond van dit doelcriterium toegestane beperkingen uit de rechtspraak van de Commissie en het Hof: censuur op de briefwisseling (artikel 8) van een gedetineerde waarin met geweld gedreigd wordt ${ }^{156}$ of die beledigend is voor

151 EHRM 25 februari 1992, Case of Margareta and Roger Andersson, §87, p. 28.

152 Zie, bijvoorbeeid, EHRM 18 juni 1971, De Wilde, Ooms and Versyp cases, 893, p. 45; EHRM 24 maart 1988, Olsson Case (no. 1), \$\$64-65, p. 31 en EHRM 22 juni 1989, Eriksson Case, $\S \S 66-67$, p. 26. Zie voorts EHRM 24 mei 1988, Case of Müller a.o., $\$ 30$, p. 20: " $\ldots$ there is a natural link between protection of morais and protection of the rights of others."

153 Deze grond is opgenomen in de tweede leden van de artikelen 8, 9, 10 en 11 en het derde lid van artikel 2 Prot. IV. Vergelijk ook artikel 5 Prot. ViI: "in the interests of the children".

154 Zo ook J. Velaers, De beperking van de vrijheid van meningsuiting, pp. 299-300 en p. 304 en $A$. Kiss, Les clauses de limitation et de dérogation, p. 130.

155 Deze en andere voorbeelden kunnen tevens worden aangetroffen bij $J$. Velears, De beperkingen van de vrijheid van meningsuiting, pp. 299-304 (nrs. 306-310).

156 Besl.Comm. 4 oktober 1977, zaak nr. 5947/72, Silver a.o. v. UK, \$413, p. 97 . Ook als doelcriterium werden aanvaard: "the prevention of disorder or crime" en "the protection of health or morals". 
anderen ${ }^{157}$; uithuisplaatsing van een kind, het verbod opgelegd aan ouders om hun uithuisgeplaatste kinderen weg te halen bij de pleeggezinnen waar de kinderen verbleven en de beperkingen op de omgang tussen ouders en hun uithuisgeplaatste kinderen ${ }^{158}$; de weigering van het ter beschikking stellen van een boek over krijgskunst en verdedigingstechnieken aan een Boeddhistisch Taoïstische gedetineerde in verband met de veiligheid van gevangenisbewaarders onder het tweede lid van artikel $9^{159}$; een veroordeling wegens bekeringsijver ("proselytism") in verband met de religieuze gevoelens van anderen ${ }^{160}$; de beperking op de vrijheid van een leraar om zijn godsdienstige opvattingen omtrent abortus voor de klas te uiten (artikel 10) kon worden gerechtvaardigd op grond van de rechten van ouders op eerbiediging van hun godsdienstige en filosofische overtuiging in het onderwijs ${ }^{161}$; de strafrechtelijke veroordeling wegens het verspreiden van geschriften onder dienstplichtige militairen waarin wordt aangezet tot desertie en insubordinatie in verband met de rechten van die militairen ${ }^{162}$; veroordeling wegens smaad en vanwege het feit dat betrokkene iemand een misdrijf had verweten waarvoor diegene reeds zijn straf had uitgezeten ${ }^{163}$; een veroordeling wegens hulp bij de verspreiding van racistische uitlatingen ${ }^{164}$; een verbod op publikaties die leiden tot oneerlijke concurrentie op grond van het recht op eerlijke mededingingsverhoudingen van beoefenaars van een vrij beroep ${ }^{165}$; de oplegging van een tuchtrechtelijke maatregel wegens overtreding van het verbod in Spanje op professionele reclame voor praktiserende advocaten in verband met "the interests of the public" ${ }^{166}$; een beperking op handelsreclame in verband

157 Besl.Comm. 6 februari 1970, zaak nr. 3717/68, $X$ v. Ireland, pp. 104-105.

158 EHRM 25 februari 1992. Case of Margareta and Roger Andersson, \$87. p. 28 en EHRM 22 april 1992, Rieme Case, \$66, p. 70.

159 Besl.Comm. 18 mei 1976, zaak nr. 6886/75, $X$ v. UK, p. 101.

160 EHRM 25 mei 1993, Kokkinakis Case, §44, p. 20. Vergelijk EHRM 20 september 1994. Case of Otto-Preminger-Institut, §48, p. 18.

161 Besl.Comm. 1 maart 1979, zaak nr. 8010/77, X v. UK, p. 103.

162 Eerdergenoemde Besl.Comm. 1 oktober 1975, zaak nr. 6084/73, $X$ v. UK, p. 65.

163 EHRM 28 augustus 1992. Schwabe Case. \$25, p. 32. Het ging hier niet alleen om de bescherming van de "rechten" van anderen, maar ook om de bescherming van de goede naam van anderen ("protection of the reputation or rights of others"). Zie verder, onder andere, ook EHRM 23 mei 1991. Oberschlick Case, \$54, p. 24: NJ 1992, 456 en het hierboven reeds onder "prevention of disorder" genoemde EHRM 23 april 1992, Castells Case, \$39. p. 22.

164 EHRM 23 september 1994, Jersild Case, \$27. p. 20.

165 EHRM 25 maart 1985, Barthold Case, \$51, p. 23 en EHRM 20 november 1989. Case of Markt Intern Verlag GmbH and Klaus Beermann, \$31, p. 19 en EHRM 23 juni 1994. Jacubowski Case, §25, pp. 13-14.

166 EHRM 24 februari 1994, Casado Coca Case, \$46, p. 19. 
met het recht van de consument op eerlijke handelsvoorlichting ${ }^{167}$; op grond van artikel 11 lid 2 het verbod tot oprichting van een fascistische partij ${ }^{1 s}$; ontslag wegens lidmaatschap van de Centrumpartij met het oog op de rechten van de andere personeelsleden van een Stichting (de Limburgse Immigratie Stichting) en personen behorende tot de doelgroep aan wie de Stichting haar diensten aanbiedt ${ }^{160}$ en het verplicht lidmaatschap voor taxichauffeurs van een vakvereniging ${ }^{170}$.

Wie met "others" bedoeld wordt hangt af van het concrete geval. Naar aanleiding van de gegeven voorbeelden kunnen, onder andere, genoemd worden: de geadresseerde van een omstreden brief of voorstel, degenen wier veiligheid in het geding is bij een bepaalde uitoefening van een grondrecht (mogelijke slachtoffers van te plegen misdrijven); de ouders van de kinderen wier leraar omstreden godsdienstige uitspraken voor de klas wenste te doen en de concurrenten van degene die zich aan oneerlijke concurrentie schuldig maakt.

Tot slot kan ten aanzien van de legitieme doelen, waarop beperkingen van de rechten in de artikelen 8-11 ECRM, artikel 2 Protocol IV ECRM en artikel 1 Protocol VII ECRM moeten zijn gericht, worden geconcludeerd, dat hun inhoud en reikwijdte niet uitdrukkelijk zijn afgebakend door de Straatsburgse instanties. Een uitzondering is, deels, de grond "protection of public order"/"prevention of disorder". Wel wordt - op grond van de gegeven voorbeelden van beperkingen die door de Commissie of het Hof geacht werden te zijn gericht op één van de in de beperkingsclausules opgenomen gronden - duidelijk, dat de reikwijdte van de beperkingsgronden ruim moet worden opgevat. Dit zou bezwaarlijk kunnen zijn, omdat zo aan de Staten grote ruimte zou worden geboden om beperkingen op de gegarandeerde rechten te rechtvaardigen, ware het niet dat - zoals reeds eerder werd geconstateerd - het accent van de toetsing van de rechtvaardiging van beperkingen ligt op de voorwaarde "noodzakelijk in een democratische samenleving". Deze voorwaarde zal nu behandeld worden.

167 Besi.Comm, 5 mei 1979, zaak nr. 7805/77, X and Church of Scientology v. Sweden, p. 73.

168 Besl.Comm. 21 mei 1976, zaak nr. 6741/71, X v. Italy, p. 85.

169 Besl.Comm, 8 maart 1985, zaak nr. $11002 / 84$, Van der Heijden $v$. the Netherlands, p. 271.

170 EHRM 30 juni 1993, Sigurb̊ur A. Sigurjónsson Case, 839. p. 17; NJ 1994, 223. 
*

De derde voonwaarde: Necessary in a democratic society in the interest of../for the protection of.."

Zoals van Dijk en van Hoof terecht opmerken, ligt op deze voorwaarde het zwaartepunt van de toetsing door de Straatsburgse organen. Volgens hen valt het onderzoek naar de vraag of er sprake is van de bescherming van een gerechtvaardigd belang in feite meestal samen met het onderzoek naar de noodzaak van de inbreuk (op de in het eerste lid van de desbetreffende bepaling vervatte recht). Als een gevolg daarvan zouden de onder voorwaarde twee bedoelde beschermenswaardige belangen in de rechtspraak maar weinig afzonderlijke aandacht hebben gekregen. Dit gebrek aan een afzonderlijke interpretatie van de doelcriteria bleek uit de voorgaande sub-paragraaf. "Hun omlijning vindt plaats in relatie tot de vaststelling van wat noodzakelijk geacht kan worden in een democratische samenleving." 171

Bij de beantwoording van de vraag of een bepaalde beperking op een recht noodzakelijk is in een democratische samenleving, en daarmee ook bij de interpretatie van de belangen met het oog waarop een inmenging in dit recht plaatsvindt, genieten de nationale instanties een zeer ruime beoordelingsvrijheid, een "margin of appreciation". Volgens Jacobs vindt dit begrip zijn oorsprong in het Franse concept "power of appreciation" uit de doctrine betreffende de Franse Conseil d'Etat:

"For the purposes of judicial review of administrative action ... the question is not whether the reasons given by the authorities actually did justify the measures taken. The question is whether, in the circumstance, they could in principle justify it."172

Volgens van Dijk en van Hoof zou toepassing van de doctrine van de "margin of appreciation" beperkt dienen te worden tot de vaststelling van de feiten - inclusief de interpretatie van nationaal recht - en rechtsvragen, die zodanig door de feiten worden bepaald, dat daarop de doctrine ook dient te worden toegepast. ${ }^{173}$

171 P. van Dijk en G.J.H. van Hoof, De europese conventie in theorie en praktijk, pp. 642-643: volgens deze auteurs is het arrest van 22 oktober 1981 in de zaak Dudgeon (pp : 18-25) illustratief voor de in Straatsburg gevolgde benadering.

$172 F, G$. Jacobs, The European Convention on Human Rights, p. 201; cursivering van mij, CS.

173 P. van Dijk en G.J.H. van Hoof, De europese conventie in theorie en praktijk, p. 645 . 
Met betrekking tot de toepassing van de leer van de "margin of appreciation" vallen uit de jurisprudentie van het Hof de volgende uitgangspunten af te leiden.

a.- Volgens het Hof verkeren de nationale instanties in principe in een betere positie dan de internationale rechter om een oordeel te vellen over de vraag, of er een noodzaak bestaat tot een bepaalde beperking (of sanctie). Na te hebben vastgesteld dat het begrip "necessary" enerzijds niet synoniem is met de begrippen "indispensable", "absolutely necessary" en "strictly necessary" en anderzijds weer de flexibiliteit mist van de begrippen "admissible", "ordinary", "useful", "reasonable" en "desirable" (die allen ook in de Conventie voorkomen) komt het Hof tot de conclusie, dat "it is for the national authorities to make the initial assessment of the reality of the pressing social need implied by the notion of "necessity" in this context", ${ }^{174}$

b.- Het Hof komt vervolgens tot het oordeel, dat de beoordelingsvrijheid van de nationale autoriteiten niet onbeperkt is. Op grond van artikel 19 van de Conventie zijn de Commissie en het Hof belast met het toezicht op het naleven van de verdragsverplichtingen door de verdiragsluitende Staten. Daarmee zijn deze organen gemachtigd om een eindoordeel te geven over de vraag of een beperking verenigbaar is met het in het eerste lid (i.c. van art.10) gegarandeerde recht.

"The domestic margin of appreciation thus goes hand in hand with a European supervision. Such supervision concerns both the aim of the measure challenged and its 'necessity'; it covers not only the basic legislation but also the decision applying it, even one given by an independent court. (...)"175

174 EHRM 7 december 1976, Handyside Case, §48, p. 22, NJ 1978, 236. Zo ook EHRM 26 april 1979. The Sunday Times Case (no. 1), 859, pp. 35-36. Van Dijk en van Hoof bestempelen de eerste groep begrippen ("indispensable" etc.) als meer absolute begrippen in vergelijking met de term "necessary", en de tweede groep begrippen ("admissible" etc.) als zwakkere begrippen. Zie De europese conventie in theorie en praktijk, p. 648. Zie ten aanzien van de eerste zin van punt a ook EHRM 20 september 1994, Case of Otto-Preminger-Institut, 856, p. 21. Vergelijk verder EHRM 28 oktober 1994, Murray Case, $\$ 90$.

175 EHRM 7 december 1976, Handyside Case, \$49, p. 23. Zo ook o.a. EHRM 22 februari 1989, Barfod Case, §28, p. 12; EHRM 22. mei 1990, Weber Case, \$47. p. 22; EHRM 26 november 1991, Case of The Observer and Guardian, \$59(c), p. 30; EHRM 25 februari 1993, Funke Case, \$55, p. 24, NJ 1993, 485; EHRM 25 februari 1993. Crémieux Case, \$38, p. 62; EHRM 25 februari 1993, Miailhe Case, \$36, p. 89; EHRM 25 mei 1993, Kokkinakis Case, 847, p. 21; EHRM 25 augustus 1993, Chorherr Case, 831, p. 37; EHRM 24 november 1993. Case of Informationsverein Lentia and others, \$35, p. 15; NJ 1994, 559; EHRM 24 februari 
c.- Uit het citaat opgenomen aan het eind van punt a. blijkt, dat er voor de - door de Staat gemaakte - beperking een "pressing social need" moet bestaan. ${ }^{176}$

d.- Voorts eist het begrip "necessary in a democratic society", dat de gestelde beperking "proportionate to the legitimate aim pursued" is. Dit zou met name volgen uit de beginselen waaraan voldaan moet zijn, wil er sprake zijn van een democratische samenleving ("principles characterising a 'democratic society'"). ${ }^{177}$

e.- Het Hof kan zich niet beperken tot een oordeel over de individuele, nationale beslissingen op zichzelf, maar dient deze te beschouwen "in the light of the case as a whole $(\ldots)^{\prime \prime} .{ }^{178}$

f.- De redenen die voor de beperking worden gegeven moeten relevant en voldoende ("relevant and sufficient") zijn. ${ }^{179}$

1994, Case of Casado Coca, §50, p. 20; EHRM 23 juni 1994, Jacubowski Case, §26, p. 14; EHRM 20 september 1994. Case of Otto-Preminger-Institut, §50, p. 19.

176 Zie ook o.a. EHRM 22 oktober 1981, Dudgeon Case, \$\$48 e.v., pp. 20-22; EHRM 26 november 1991, Case of The Observer and Guardian, 859(c), p. 30; EHRM 25 mei 1993, Kokkinakis Case, $\$ 47$ en $\$ 49$, p. 21.

177 EHRM 7 december 1976, Handyside Case, \$49, p. 23. Zie verder o.a. EHRM 22 oktober 1981, Dudgeon Case, $\$ \$ 48$ e.v., pp. 20-22; EHRM 26 april 1991, Ezelin Case, 851, p. 23; NJ 1992, 455; EHRM 26 november 1991, Case of The Observer and Guardian, \$59(d), §64, pp. 30, 32; EHRM 22 april 1992, Rieme Case, \$69, p. 71; EHRM 25 mei 1993, Kokkinakis Case, \$47 en \$49, p. 21; EHRM 30 juni 1993. Case of Sigurour A. Sigurjónsson, \$41, pp. 19-20: EHRM 25 augustus 1993, Chorherr Case, \$§32-33, pp. 37-38; EHRM 24 november 1993, Case of Informationsverein Lentia and others, \$39 en \$43, pp. 16, 17; EHRM 20 september 1994, Case of Otto-Preminger-Institut, \$49. p. 19; EHRM 23 september 1994. Jersild Case, \$31, pp. 23-24.

178 EHRM 7 december 1976. Handyside Case, \$49. p. 23. Zo ook o.a. EHRM 22 februari 1989, Barfod Case, \$28. p. 12: EHRM 26 april 1991. Ezelin Case. \$51. p. 23: EHRM 25 mei 1993, Kokkinakis Case. \$47, p. 21; EHRM 24 februari 1994. Case of Casado Coca, \$51, p. 20: EHRM 23 september 1994, Jersild Case. $\$ 31$. p. 23.

179 EHRM 7 december 1976. Handyside Case. \$50, pp. 23-24: EHRM 26 november 1991. Case of The Observer and Guardian, \$59(d). \$\$62-63. \$\$68-69. pp. 30-32. 34: EHRM 23 september 1994. Jersild Case, \$31. p. 23.

Hoewel de beginselen a tot en met $f$ door het Hof ontwikkeld zijn in het kader van artikel 10, zijn deze beginselen - zoals deels uit de voorgaande noten blijkt - ook van toepassing in het kader van de artikelen 8.9 en 11. Dit volgt onder meer uit EHRM 24 mei 1988, Miller a.o. $\$ \$ 31-37$ en $\$ \$ 40-44$, pp. $21-23$ en pp. 24-25; EHRM 26 oktober 1988, Norris Case, p. 19 (expliciet): EHRM 25 februari 1992. Case of Margareta and Roger Andersson, $\$ \$ 95-97$ (beginselen d, e en f). p. 31; EHRM 22 april 1992, Rieme Case. \$\$71-75 (d en f), pp. 71-72 (artikel 8); EHRM 25 mei 1993. Kokkinakis Case, $\$ \$ 47-49$ (b. c. d en e), p. 21 (artikel 9) en EHRM 30 juni 1993. Case of Sigurour A. Sigurjónsson, $\$ 41$ (d en f), p. 18 (artikel 11). 
g.- Verder moeten die leden van verdragsbepalingen, die voorzien in een beperkingsmogelijkheid, eng geïnterpreteerd worden. ${ }^{150}$

Ondanks het feit, dat in de jurisprudentie van het Hof een aantal maatstaven is ontwikkeld, aan de hand waarvan kan worden beoordeeld of op een juiste wijze van de "margin of appreciation" gebruik is gemaakt, ontbreekt een vaste jurisprudentie over de reikwijdte van dit begrip. Hierbij gaat het met name om de vraag hoever de Straatsburgse organen kunnen gaan bij hun toetsing van de nationale beslissingen. Volgens van Dijk en van Hoof kunnen er in de jurisprudentie van het Hof drie benaderingen worden onderscheiden: de "enge benadering", de redelijkheidstest en de "not-unreasonable"-test.

De enge benadering zou de volledige toetsing benaderen: het Hof en de Commissie zouden ondanks het bestaan van "a certain measure of appreciation" toch een uitvoerig zelfstandig onderzoek instellen naar de vraag, of aan de eis van noodzakelijkheid is voldaan, "klaarblijkelijk zonder zich daarbij al te zeer te laten leiden door de opvattingen van de nationale autoriteiten." Als voorbeeld wordt de zaak Sunday Times genoemd. In deze zaak bepaalt het Hof, dat het zich bij zijn onderzoek er niet toe hoeft te beperken "to [ascertain] whether a respondent State exercised its discretion reasonably, carefully and in good faith" ${ }^{\text {"* }}$ Volgens het Hof betekent dit, dat "an objective standard has to be applied in this connection". ${ }^{182}$

De redelijkheidstest zou neerkomen op een zeer marginale toetsing van de wijze waarop een Staat van zijn beoordelingsvrijheid gebruik maakt. Als een voorbeeld van een zaak waar deze redelijkheidstest werd gehanteerd, noemen van Dijk en van Hoof opnieuw het arrest van het Hof in de zaak Sunday Times, maar dan nu het minderheidsstandpunt ( 9 rechters):

180 EHRM 6 september 1978, Klass Case, \$42, p. 21 . Zo ook EHRM 25 februari 1993, Funke Case, 855, p. 24; EHRM 25 februari 1993, Crémieux Case, 838, p. 62 en EHRM 25 februari 1993, Miailhe Case, \$36, p. 89.

18! P. van Dijk en G.J.H. van Hoof, De europese conventie in theorie en praktijk, pp. 649-650; EHRM 26 april 1979, The Sunday Times Case (no. 1), 88, p. 36. Zo ook EHRM 26 november 1991. Case of The Observer and Guardian, 859(d), p. 30.

182 EHRM 24 maart 1988, Olsson Case, 882, p. 37. 
"This [European] supervision is concerned, in the first place, with determining whether the national authorities have acted in good faith, with due care and in a reasonable manner (...). ${ }^{183}$

In deze lijn lijkt ook de uitspraak van het Hof te liggen in de zaak Markt Intern Verlag GmbH and Klaus Beermann. Daarin overwoog het Hof dat

"The Court must confine its review to the question whether the measures taken on the national level are justifiable in principle and proportionate. (...)"

"(...) the European Court of Human Rights should not substitute its own evaluation for that of the national courts in the instant case, where those courts, on reasonable grounds, had considered the restrictions to be necessary. "184

Zou de redelijkheidstest nog vereisen, dat de overheid aantoont dat de nationale autoriteiten in redelijkheid tot de door hen gemaakte afweging hebben kunnen komen, volgens van Dijk en van Hoof brengt de "notunreasonable"-test met zich mee, dat de last om te bewijzen dat dit níet het geval is op de klager (of wellicht de Straatsburgse instanties) komt te liggen. Voorbeelden van zaken waar deze "not-unreasonable"-test zou zijn gehanteerd, zijn: de zaak James ${ }^{185}$ en de zaak Lithgow ${ }^{186}$.

183 Joint dissenting opinion bij EHRM 26 april 1979. The Sunday Times Case (no. 1), \$8, pp. 47-56(50). In de onderhavige zaak moest volgens deze rechters "the domestic couris' (...) assessment of the necessity of the measure to be taken within the context of the domestic law, (...) be regarded as reasonable". (p. 54)

184. EHRM 20 november 1989, Case of Markt Intern Verlag GmbH and Klaus Beermann, $\$ \$ 33,37$, pp. 20, 21. De joint dissenting opinion wekt daarentegen weer de indruk, dat deze ruime beoordelingsvrijheid voor de Staat hier alleen geaccepteerd wordt omdat de zaak betrekking heeft op commerciële aangelegenheden. Joint dissenting opinion of Judges Gölcüklü, Pettiti, Russo. Spielman, De Meyer, Carrillo Salcedo and Valticos, pp. 23-25. Zie ook EHRM 24 februari 1994, Case of Casado Coca, $\$ 50$, p. 20 en EHRM 23 juni 1994, Jacubowski Case, §26, p. 14. Deze arresten bevestigen bovenstaande indruk dat de ruime beoordelingsvrijheid door het Hof aanvaard wordt vanwege de context waarin de meningsuiting gedaan wordt: "Such a margin of appreciation is particularly essential in the complex and fluctuating area of unfair competition. The same applies to advertising." In de dissenting opinions van de rechters Walsh, Macdonald en Wildhaber wordt kritiek geleverd op de "excessieve" "betekenis die aan de leer van de "margin of appreciation" wordt gegeven (pp. 16-17). Zie verder: J.G.C. Schokkenbroek, Commerciële informatie, margin of appreciation en de vrijheid van meningsuiting, pp. 85-87.

185 EHRM 21 februari 1986, Case of James and others, $\$ \S 46$ e.v., met name pp. 32-34.

186 EHRM 8 juili 1986, Case of Lithgow and others, $\$ \S 121-122$, pp. 50-51. 
"The Court, finding it natural that the margin of appreciation available to the legislature in implementing social and economic policies should be a wide one, will respect the legislature's judgment as to what is 'in the public interest' unless that judgment be manifestly without reasonable foundation. "187

Ondanks het ontbreken van een vaste praktijk ten aanzien van de reikwijdte van de "margin of appreciation", kan volgens van Dijk en van Hoof uit de jurisprudentie worden afgeleid, dat de vrije beleidsmarge van de nationale autoriteiten afhankelijk is van de beantwoording van de volgende vragen: 1. wat is de aard van de beweerde schending? Hiertoe dienen de volgende sub-vragen te worden beantwoord: op welke beperkingsgrond beroept de aangeklaagde Staat zich en op welk recht of op welke vrijheid is een inbreuk gemaakt?

2. in hoeverre kan er uit de nationale rechtsstelsels van de lidstaten van de Raad van Europa een Europese maatstaf worden afgeleid? ${ }^{\text {s }}$

Het belang van de onder 1. genoemde sub-vragen blijkt bijvoorbeeld uit de zaak Dudgeon:

"... not only the nature of the aim of the restriction but also the nature of the activities involved will affect the scope of the margin of appreciation. " 189

Uit de jurisprudentie kunnen ten aanzien van de eerste vraag de volgende conclusies worden getrokken:

- Of de "margin of appreciation" ruim of eng is in een bepaald geval, zou met name afhangen van de mate waarin de beperkingsgrond op grond waarvan de aangeklaagde Staat de inbreuk op een recht probeert te rechtvaardigen, objectiveerbaar is. Zo zou de beperkingsgrond "morals" (goede zeden) een veel minder objectief begrip zijn dan de grond "maintaining the authority and impartiality of the judiciary". ${ }^{190}$ Hierbij is onder meer van belang, dat er geen uniforme Europese maatstaf bestaat ten aanzien van het begrip "morals":

187 EHRM 21 februari 1986, Case of James a.o., \$46, p. 32. Cursivering toegevoegd. 188 P. van Dijk en G.J.H. van Hoof, De: europese conventie in theorie en praktijk, p. 652 .

189 EHRM 22 oktober 1981, Dudgeon Case, \$52, p. 21.

190 EHRM 26 april 1979, The Sunday Times Case (no. 1), \$59, p. 36. 
"The view taken by their (de verdragsstaten, $C S$ ) respective laws of the requirements of morals varies from time to time and from place to place, especially in our era which is characterised by a rapid and farreaching evolution of opinions on the subject. "19t

In een dergelijke situatie zou een Staat in principe in een betere positie verkeren dan de internationale rechter om zowel de exacte inhoud van dit vereiste als de noodzakelijkheid van de beperking vast te stellen. ${ }^{192}$ Daarom zou de Staat, in het geval deze een beroep zou doen op de beperkingsgrond "protection of morals", een grotere beoordelingsvrijheid genieten, dan wanneer de andere zojuist genoemde beperkingsgrond ("maintaining the authority ...") zou worden ingeroepen. Met betrekking tot deze laatste grond

"The domestic law and practice of the Contracting States reveal a fairly substantial measure of common ground $(\ldots)^{193}$

- Echter, ook met betrekking tot de grond "morals" heeft het Hof het standpunt ten aanzien van de "margin of appreciation" genuanceerd. Zoals al blijkt uit bovenstaand citaat uit de zaak Dudgeon ${ }^{194}$, speelt behalve de beperkingsgrond ook de aard van het ingeroepen recht een rol. Wanneer het gaat on

"a most intimate aspect of private life (...) there must exist particularly serious reasons before interferences on the part of the public authorities can be legitimate for the purposes of paragraph 2 of Article 8. "195

191 EHRM 7 december 1976, Hanctyside Case, \$48, p. 22; zie ook EHRM 24 mei 1988, Case of Müller a.o., \$30. p. 20. Evenzo is het - in verband met de beperkingsgrond "the rights of others" - niet mogelijk "to descern throughout Europe a uniform conception of the significance of religion in society. "Daarom is het niet mogelijk vast te stellen of sprake is van een gerechtvaardigde inmenging in de vrijheid van meningsuiting wanneer een dergelijke uiting gericht is tegen de religieuze opvattingen van anderen. EHRM 20 september 1994, Case of Otto-Preminger-Institut, $\$ 50$, p. 19.

192 EHRM 7 december 1976, Handyside Case, \$48. p. 22. Zie ook EHRM 20 september 1994. Case of Ono-Preminger-Institut, \$50, p. 19.

193 EHRM 26 april 1979. The Sunday Times Case (no. 1). \$59, p. 36.

194 Zie de tekst voor noot 189.

195 EHRM 22 oktober 1981, Dudgeon Case, \$52, p. 21. Zo ook EHRM 26 oktober 1988, Norris Case, $\$ 46$, p. 20. 
Uit de jurisprudentie blijkt dan ook, dat wanneer bijvoorbeeld het recht op privéleven van artikel $8^{1 \%}$, of de vrijheid van meningsuiting van artikel $10^{197}$ in het geding is, een minder ruime beoordelingsvrijheid aan de aangeklaagde Staat wordt overgelaten, dan wanneer het gaat om de economische orde van deze Staat, zoals bij artikel 1 van het eerste Protocol (recht op eigendom). ${ }^{198}$

In een aantal zaken waarin geklaagd werd over schending van artikel 8 , ging het om de uithuisplaatsing, ondertoezichtstelling en daarmee in verband staande maatregelen met betrekking tot kinderen. Volgens het Hof vormt "( $t$ )he mutual enjoyment by parent and child of each other's company ... a fundamental element of family life." Het onder toezicht stellen van een kind maakt geen einde aan de natuurlijke gezinsband ("natural family relationship"). Het gaat hier derhalve om een maatregel die een inmenging in het familie- en gezinsleven van betrokkenen oplevert, die gerechtvaardigd moet worden onder het tweede lid van artikel $8 .^{19}$ In de zaken $W, B$ en $R$ tegen het Verenigd Koninkrijk ${ }^{200}$ treffen we bij de toetsing aan het tweede lid, onder meer, de volgende overwegingen aan:

196. Zie opnieuw EHRM 22 oktober 1981, Dudgeon Case, §52, p. 21 en EHRM 26 oktober 1988, Norris Case, §46, p. 20.

197 EHRM 7 december 1976, Handyside Case, 849, p. 23 en EHRM 24 mei 1988, Case of Müller a.o., p. 22 en EHRM 24 november 1993, Case of Informationsverein Lentia a.o., §35, p. 15. In deze laatste zaak overweegt het Hof: "... the supervision must be strict because of the importance - frequently stressed by the Court - of the rights in question. The necessity for any restriction must be convincingly established." Zo ook eerder al EHRM 22 mei 1990, Weber Case, 847, p. 22 en verder EHRM 20 september 1994, Case of Otto-Preminger-Institut, 850 , p. 19. Dit geldt vooral voor preventieve beperkingen: Het Hof overweegt in de zaak Observer en The Guardian - na geconstateerd te hebben dat de bewoordingen van artike! 10 en eerdere jurisprudentie preventieve beperkingen op publikaties op zich niet uitsluiten - dat "the dangers, inherent in prior restraints are such that they cali for the most careful scrutiny on the part of the Court. This is especially so as far as the press is concerned, for news is a perishable commodity and to delay its publication, even for a short period, may well deprive it of all its value and interest. " EHRM 26 november 1991. Case of The Observer and Guardian, 860, p. 30.

198 E.HRM 21 februari 1986, Case of James a.o., $\$ \$ 46$ e.v., pp. 32 e.v.; EHRM 8 juli 1986, Case of Lithgow a.o., $\$ \$ 120$ e.v., met name pp. 50-51, EHRM 16 december 1992. Niemietz Case, \$31., p. 34 en Bes!.Comm. 25 februari 1991, Beckers v, the Netherlands, \$1, p. 186.

199 EHRM 8 juli 1987, Case of $W v . U K, 859$, p. 27; EHRM 8 juli 1987, Case of $B v$. UK, $\$ 60$, p. 72 en EHRM 8 juli 1987, Case of $R$ v. UK, \$64, p. 117.

200 E.HRM 8 juli 1987, Case of $W v$. UK, $\$ \S 60$ (c), 61-65, pp. 27-29; EHRM 8 juli 1987, Case of B v. UK, $8 \S 61$ (c), 62-65, pp. $72 .-74$ en EHRM 8 juli 1987, Case of $R^{\prime} v . U K, \S \S 65(\mathrm{c}), 66-70$, pp. 117-119. 
Alhoewel de kern van artikel 8 erop gericht is de individu te beschermen tegen willekeurige inmenging in zijn gezinsleven door de overheid, kan er in aanvulling daarop een positieve verplichting uit die bepaling voortvloeien die inherent is aan een effectief "respect" voor het gezinsleven. Bij de bepaling of een inmenging noodzakelijk is in een democratische samenleving of dat sprake is van de schending van een positieve verplichting moet het Hof rekening houden met de beoordelingsvrijheid die aan de Verdragsstaten is overgelaten. De centrale vraag in deze zaken is, of de gevolgde procedures klagers' gezinsleven respecteerden ofwel een inmenging opleverden in de uitoefening van het recht op respect voor het gezinsleven die niet gerechtvaardigd kon worden als zijnde noodzakelijk in een democratische samenleving. ${ }^{201}$

Ter beantwoording van deze vraag overweegt het Hof, onder andere, dat de beleidsvrijheid die de overheid ook bij het volgen van een besluitvormingsprocedure met betrekking tot de uithuisplaatsing, ondertoezichtstelling of de toegang van ouders tot hun kind(eren) heeft, beperkt is. Van doorslaggevende betekenis is, namelijk, dat de beslissingen die in het kader van dit soort procedures genomen worden onomkeerbaar kunnen blijken te zijn. Immers, wordt een kind uithuisgeplaatst en aan de zorg van anderen toevertrouwd, dan kan het kind na verloop van tijd een band hebben gekregen met zijn nieuwe verzorgers. Het zou dan in strijd met de belangen van het kind kunnen zijn als die nieuwe band verstoord of verbroken wordt doordat de voorgaande beslissing(en) worden teruggedraaid.

Het Hof overweegt vervolgens, dat artikel 8 weliswaar geen expliciete procedurele vereisten bevat, maar dat dit niet doorslaggevend is. Onder de relevante factoren, die bij de besluitvorming omtrent kinderen, die de overheid onder haar hoede heeft genomen, een rol moeten spelen, zijn ook de opvattingen en belangen van de natuurlijke ouders. Dit betekent dat het besluitvormingsproces zodanig moet zijn, dat het de natuurlijke ouders de gelegenheid biedt, hun opvattingen en belangen kenbaar te maken en dat deze ook in overweging genomen worden. Deze rol van de ouders bij de besluitvorming kan slechts achterwege gelaten worden in gevallen, waarin de deelname van de natuurlijke ouders aan het besluitvormingsproces niet mogelijk is of van geen betekenis zal zijn - het Hof noemt als voorbeeld het geval van fysieke of geestelijke invaliditeit; gevallen van een voortdurend toezicht van de zijde van overheidsfunctionarissen en gevallen waarin door regelmatig contact tussen de verantwoordelijke maatschappelijk werkers en de ouders voorzien wordt in een geschikt 
middel om de opvattingen van de ouders aan de autoriteiten kenbaar te maken.

Samenvattend moet derhalve volgens het Hof worden vastgesteld, of

"... having regard to the particular circumstances of the case and notably the serious nature of the decisions to be taken, the parents have been involved in the decision-making process, seen as a whole, to a degree sufficient to provide them with the requisite protection of their interests. If they have not, there will have been a failure to respect their family life and the interference resulting from the decision will not be capable of being regarded as 'necessary' within the meaning of Article 8." ${ }^{202}$

Bij de toetsing van het besluitvormingsproces aan artikel 8 kan ook de duur van de procedure in overweging worden genomen.

"... the Court considers that in conducting its review in the context of Article 8 it may also have regard to the length of the local authority's decision-making process and of any related judicial proceedings. ... in cases of this kind there is always the danger that any procedural delay will result in the de facto determination of the issue submitted to the court before it has held its hearing. And an effective respect for family life requires that future relations between parent and child be determined solely in the light of all relevant considerations and not by the mere effluxion of time. "203

202 Zo ook. EHRM 24 februari 1995, McMichael Case, $\$ 87$.

203 EHRM 8 juli 1987, Case of $W v$. UK, $\S 65$, p. 29 en EHRM 8 juli 1987, Case of $R$ v. UK, \$70, p. 119. Zie voorts EHRM 8 juli 1987, Case of $H$ v. UK, $\$ \$ 87-90$, pp. 63-64.

Zie verder Besl.Comm. 9 maart 1977, zaak 7048/75, Xv. UK, p.42(43-44), waarin geklaagd werd over "the long delay in granting an entry clearance to his (klagers) wife and the family separation arising therefrom":

"... It is alleged, however, that the procedure of entry for the spouse interferes with Article 8. The Commission considers that, even if it is accepted that entry procedures may raise an issue under Article 8 (1), the period required by the United Kingdom authorities for granting an entry clearance to the applicant's wife cannot in the circumstances of this case be regarded as so unreasonably long that it constitutes a violation of the applicant's rights under this provision ..." 
Uit deze uitspraken kan derhalve geconcludeerd worden, dat wanneer het gaat om een zodanig essentieel element van het recht op respect voor het gezinsleven als het wederzijds genot dat ouders en kinderen kunnen hebben van elkaars gezelschap, een inbreuk op dit recht alleen noodzakelijk in een democratische samenleving kan zijn indien de beslissing tot het maken van een dergelijke inbreuk is genomen in een besluitvormingsprocedure die met bepaalde waarborgen is omgeven. Dit brengt, ten eerste, met zich mee dat vanwege de mogelijke onomkeerbaarheid van de te nemen beslissingen de beoordelingsvrijheid van de autoriteiten in dit soort zaken beperkt is. Ten tweede, vloeit blijkens voorgaande overwegingen, uit het noodzakelijkheidsvereiste in lid 2 van artikel 8 voort dat, wanneer beslissingen omtrent maatregelen van kinderbescherming moeten worden genomen, artikel 8 lid 1 eveneens een met waarborgen omklede procedure garandeert. Wanneer de nationale wetgeving niet in een dergelijke procedure voorziet dan rust, mijns inziens, op de overheid de (positieve) verplichting om deze procedurele waarborgen te scheppen. ${ }^{204}$ Blijkens de uitspraak in de zaak McMichael gaat het hier om een garantie die inherent is aan artikel 8 en die zowel administratieve als juridische procedures omvat. Daaraan wordt echter wel toegevoegd dat

"it (de procedurele waarborg, $C S$ ) is ancillary to the wider purpose of ensuring proper respect for, inter alia, family life. "205

Dit citaat wijst er, mijns inziens, op dat de hier besproken procedurele waarborg beschouwd moet worden als een recht dat connex is aan het recht op respect voor het familie- en gezinsleven én - blijkens de woorden "inter alia" - mogelijk ook aan de andere in artikel 8 opgenomen rechten.

In de zaken met betrekking tot artikel 10 wordt, met name, het belang van dit recht benadrukt in een "democratische samenleving": gesproken wordt van "one of the essential foundations". ${ }^{206}$ Zonder vrijheid van meningsuiting zou niet kunnen worden voldaan aan de eisen van een dergelijke samenleving: "pluralism, tolerance and broadmindedness". Dit

204 Zie ook par. 5.2.3 waarin ook uit de toepassing van de beperkingsclausule bij artikel 9 lid 2 Grondwet wordt afgeleid, dat het in artikel 9 lid 1 vervatte recht mede een positieve overheidsverplichting omvat, teneinde een effectieve uitoefening van het gegarandeerde betogingsrecht (en eventueel het vergaderrecht) mogelijk te maken.

205 EHRM 24 februari 1995, McMichael Case, $\$ 91$.

206 EHRM 7 december 1976, Handyside Case, §49, p. 23. Zie o.a. ook EHRM 26 november 1991, Case of The Observer and Guardian, \$59(a), p. 30; EHRM 23 april 1992, Castells Case, \$42, p. 22: EHRM 20 september 1994, Case of OttoPreminger-Institut, \$49, p. 18; EHRM 23 september 1994, Jersild Case, \$31, p. 23. 
geldt niet alleen voor uitingen die informatie of meningen betreffen waarop met instemming zal worden gereageerd of die beschouwd zullen worden als onschadelijk of waartegenover met onverschillig staat. Het geldt ook voor uitingen die aanstootgevend zijn, die schokken of verwarring zaaien. ${ }^{207}$ Met name de persvrijheid ${ }^{200}$ is hier volgens het Hof van belang: deze vrijheid dient ter verspreiding van informatie en ideeën van algemeen belang; het publiek heeft bovendien het recht ze te ontvangen. Ware dit anders, dan zou de pers zijn rol van "public watchdog" niet kunnen vervullen. ${ }^{209}$ Zo verschaft de persvrijheid het publiek de beste mogelijkheden om zich een mening te vormen over de ideeën en gedragingen van politieke leiders.

Omdat de vrijheid van politieke discussie de kern van het concept van de democratische samenleving vormt, zijn de grenzen van aanvaardbare kritiek ruimer in het geval van een politicus in zijn publieke hoedanigheid dan met betrekking tot een privé-persoon. Alhoewel ook een politicus er recht op heeft dat zijn reputatie beschermd wordt, ook wanneer hij niet als privé-persoon handelt, dienen de vereisten die die bescherming stelt volgens het Hof afgewogen te worden tegen de belangen van een openbare discussie over politieke zaken. ${ }^{210}$ Hier zien we derhalve dat zelfs binnen de vrijheid van meningsuiting, afhankelijk van de situatie, de beoordelingsvrijheid van de Staat ruimer of kleiner kan zijn. De Staat zal minder beoordelingsvrijheid hebben met betrekking tot de beperking van de vrijheid van meningsuiting wanneer het gaat om de uitoefening van dit recht ten aanzien van politieke figuren dan met betrekking tot

207 EHRM 7 december 1976. Handyside Case, \$49, p. 23; EHRM 8 juli 1986, Lingens Case. \$41. p. 26. NJ 1987. 901; EHRM 24 mei 1983, Case of Müller a.o., §33, p. 22: EHRM 23 mei 1991. Oberschlick Case, \$57, p. 25, NJ 1992, 456: EHRM 26 november 1991. Case of The Ohserver and Guardian, 859(a), p. 30; E.HRM 23 april 1992. Castells Case, \$42, pp. 22-23; EHRM 24 november 1993, Case of Informationsverein Lentia a.o. \$38, p. 16; EHRM 20 september 1994, Case of OtoPreminger-Institut, \$49, p. 19.

208 Overwegingen met betrekking tot de persvrijheid gelden des te sterker voor de audiovisuete media, omdat hun uitzendingen vaak een erg groot bereik hebben. EHRM 24 november 1993. Case of Informationsverein Lentia a.o. 838, p. 16.

209 EHRM 26 november 1991, Case of The Observer and Guardian, \$59(a), pp. 29-30; EHRM 23 september 1994, Jersild Case, $\$ 31$ en \$35. pp. 23 en 24 en de overige in de volgende noot te noemen uitspraken.

210 EHRM 8 juli 1986, Lingens Case, \$42, p. 26; EHRM 23 mei 1991, Oberschlick Case, §§58-59, pp. 25-26. Zie ook EHRM 26 november 1991, Case of The Observer and Guardian, §60, p. 30 . 
privépersonen ${ }^{211}$, en tevens zal minder beleidsruimte bestaan in verband met deze grondrechtenbeperking, indien het kritiek op een politicus in zijn publieke hoedanigheid betreft dan wanneer het gaat om een politicus in zijn hoedanigheid als privé-persoon. In de gevallen waarin de Staat een minder ruime beoordelingsvrijheid toekomt "reserveert (het $\mathrm{Hof}$ ) een eigen Europese beoordelingsruimte van nationale beslissingen", om met de woorden van Dommering te spreken. ${ }^{212}$

Overigens kan het ook binnen een verdragsbepaling, die verschillende onderdelen van een recht expliciet garandeert, nog verschil uitmaken welk onderdeel van die bepaling aan de orde is. Zo is de beoordelingsvrijheid van de Staat groter wanneer het gaat om een inbreuk op het recht op eerbiediging van de woning ${ }^{213}$, dan bij een inmenging in het recht op eerbiediging van het privéleven (artikel 8).

Op grond van de ontwikkelingen in de jurisprudentie komen van Dijk en van Hoof tot de conclusie, dat sprake is van een "ingewikkelde wisselwerking ... tussen de aard van het betrokken recht en de aard van de door de regering aangevoerde rechtvaardigingsgrond voor de inbreuk." Een verstoring van fiet evenwicht tussen beide elementen zou plaatsvinden wanneer de inbreuk op een recht of vrijheid zover zou gaan, dat de Staat daarvoor geen redelijke rechtvaardiging meer zou kunnen aanvoeren. ${ }^{216}$ In dat geval zou er derhalve sprake zijn van een schending van de desbetreffende Conventie-bepaling.

Uit het bovenstaande volgt, dat er - in het kader van het principe, dat het begrip "necessary in a democratic society" impliceert dat de inbreuk op een recht of vrijheid ingegeven moet zijn door een "pressing social need" en proportioneel moet zijn aan het doel ten behoeve waarvan deze inbreuk wordt gepleegd (zie hierboven punt $c$ en d) - een weging zal moeten

$2 ! 1$ Vgl. ook EHRM 23 april ! 992 , Castells Case, $\$ \$ 42-44, \$ 46, p p .22-24$, waarin het ging om een politicus die in de pers kritiek leverde op de regering. Het Hof acht de vrijheid van meningsuiting met name voor volksvertegenwoordigers van belang, omdat "(h)e represents his electorate, draws attention to their preoccupations and defends their interests." (\$42) De grenzen on kritiek te leveren zijn, indien die kritiek op de regering gericht is, nog ruimer (en derhalve de beleidsvrijheid van de autoriteiten bij beperking kleiner) dan bij kritiek op een politicus. Zie verder $\$ 46$ e.v. van deze uitspraak.

212 Zie punt 6(a) van zijn annotatie bij het arrest in de zaak Oberschlick, NJ 1992, 456. Zie ook punt 6 (b) van die noot.

213 EHRM 24 november 1986, Gillow Case, \$\$57-58, pp. 23-24.

214 P. van Dijk en G.J.H. van Hoof. De europese conventie in theorie en praktijk, p. 655 . 
plaatsvinden van de belangen van de klager en de (openbare) belangen van de aangeklaagde Staat, teneinde te kunnen vaststellen of de Staat de grenzen van zijn beoordelingsvrijheid in acht heeft genomen. ${ }^{215}$ Dit blijkt ook uit het volgende citaat uit de uitspraak in de zaak Ezelin:

"The proportionality principle demands that a balance be struck between the requirements of the purposes listed in Art. 11 par. 2 and those of the free expression of opinions by word, gesture or even silence by persons assembled on the streets or in other public places."

In het geval van botsende grondrechten dient een dergelijke afweging ook plaats te vinden. Zo ging het, bijvoorbeeld, in de zaak Otto-PremingerInstitut om de afweging van enerzijds de vrijheid van klager controversiële zienswijzen te verspreiden en inherent daaraan, het recht van geïnteresseerden om daarvan kennis te nemen, en anderzijds de vrijheid van andere personen op respect voor hun vrijheid van gedachte, geweten en godsdienst. ${ }^{217}$

Volgens van Dijk en van Hoof volgt uit artikel 19, dat uiteindelijk alleen de Commissie en het Hof bevoegd zijn de afweging tussen de diverse in de Conventie geregelde belangen te maken. Volgens hen zou het overlaten van deze afweging aan de nationale autoriteiten er uiteindelijk toe leiden, dat de gehele structuur van de Conventie zou worden ondermijnd. ${ }^{218}$

$215 \mathrm{Vgl}$. EHRM 20 september 1994, Case of Otto-Preminger-Institut, \$56, p. en EHRM 23 juni 1994. Jacubowski Case, \$27, p. 14.

216 EHRM 26 april 1991, Ezelin Case, \$52, p. 23. Het Hof voegt hier nog aan toe, dat "(t)he pursuit of a just balance must not result in avocats being discouraged, for fear of disciplinary sanctions, from making clear their beliefs on such occasions. "Zie ook EHRM 25 mei 1993, Kokkinakis Case, \$\$47-49, p. 21 en EHRM 28 oktober 1994. Murray Case, \$91.

217 EHRM 20 september 1994, Case of Oto-Preminger-Institut, \$\$55-56, pp. 20-21.

218 P. van Dijk en G.J.H. van Hoof, De europese conventie in theorie en praktijk, p. 662. Vgl. het citaat op p. 48 uit de Handyside-zaak dat de "initial assessment of the reality of the pressing social need" aan de nationale autoriteiten toekomt en het eindoordeel daarover aan de Straatsburgse organen (p. 22). Een voorbeeld van een zaak waarin een dergelijke afweging plaatsvindt, biedt EHRM 18 februari 1991 . Moustaquim Case, \$46, p. 20. Zie voorts EHRM 25 februari 1993, Funke Case, \$56, pp. 24-25; EHRM 25 februari 1993, Crémieux Case, \$39. p. 62 en EHRM 25. februari 1993, Miailhe Case, 837, pp. 89-90, waarin (in navolging van EHRM 6 september 1978 , Klass Case, $\$ 50$, p. 23) bij de desbetreffende belangenafweging ook in aanmerking werd genomen, de vraag of de relevante wetgeving en praktijk ten aanzien van - op zich zelf mogelijk noodzakelijke - maatregelen als huiszoeking en 
Wat betreft de tweede vraag, die hierboven werd geformuleerd met betrekking tot de afbakening van de "margin of appreciation": uit artikel 19 vloeit volgens van Dijk en van Hoof tevens voort, dat de Straatsburgse organen Europese maatstaven voor de interpretatie van de Conventie behoren te ontwikkelen. Volgens hen blijkt echter uit de jurisprudentie, dat slechts mondjesmaat gebruik gemaakt wordt van dergelijke gemeenschappelijke, uniforme Europese standaarden en dat waar dat wel gebeurt, deze standaarden niet berusten op een erg sterke basis. Uit de zaak Müller zou blijken, dat "het bestaan of ontbreken van gemeenschappelijke standaarden in de verdragsstaten de ruimte van de 'margin of appreciation' beïnvloedt." 219 Deze constatering lijkt mij terecht, gezien de volgende overwegingen van het Hof in deze zaak:

"Today, ..., it is not possible to find in the legal and social orders of the Contracting States a uniform European conception of morals (...)" "having regard to the margin of appreciation left to them (...), the Swiss courts were entitled to consider it necessary for the protection of morals to impose a fine on the applicants for publishing obscene material." 220

In de zaak Informationsverein Lentia en anderen gaat het om de weigering van een vergunning voor het via een kabelnet verspreiden van programma's. ${ }^{21}$ Deze weigering vloeit voort uit het monopolie dat de Staat heeft op de publieke omroepen, doordat door de federale wetgever slechts één keer een dergelijke vergunning is verstrekt, namelijk aan de nationale Oostenrijkse omroep. Volgens het Hof vormt een publiek monopolie de grootst mogelijke beperking op de vrijheid van meningsuiting en dient derhalve gerechtvaardigd te worden een daarmee corresponderende dwingende noodzaak ("pressing need"). Bij de toetsing van die noodzaak, constateert het Hof dat niet verdedigd kan worden dat er geen soortgelijke, minder restrictieve oplossingen te vinden zijn. Ter onderbouwing van dit standpunt wijst het Hof vervolgens op de praktijk in andere Europese staten, met name die van een ongeveer gelijke omvang als Oostenrijk, waar het wèl mogelijk is dat particuliere en publieke

inbeslagneming, adequate en effectieve garanties tegen misbruik bood. Zie ook de punten 5 en 6 van de annotatie bij deze arresten in NJ 1993. 485.

219 P. van Dijk en G.J.H. van Hoof. De europese conventie in theorie en praktijk. pp. 662-664.

220 EHRM 24 mei 1988, Case of Müller a.o., \$\$35-36, p. 22 en p. 23: zie ook het al eerder opgenomen citaat uit de zaak Handyside voorafgaande aan noot 191.

221 EHRM 24 november 1993, Case of Informationsverein Lentia and others, \$39 en \$42. pp. 16-17. 
omroepen naast elkaar bestaan, zonder dat er particuliere monopolies ontstaan welke de objectiviteit en onafhankelijkheid van de verslaggeving, de pluriformiteit in de te verspreiden meningen en dergelijke zouden kunnen bedreigen. Het Hof wijst er in deze zaak expliciet op, dat de regels - met betrekking tot voormeld naast elkaar bestaan van particuliere en publieke omroepen - verschillen van land tot land en daaruit valt te concluderen dat er geen gemeenschappelijke Europese standaard bestaat in de zin van uniforme regelgeving bestaat. Echter, er bestaat kennelijk wèl een gemeenschappelijke Europese norm inhoudende dat een staatsmonopolie op de omroep een te ver gaande beperking op de omroepvrijheid vormt.

Voorts kan gewezen worden op de uitspraak in de zaak Stjerna, waarin door het Hof geconcludeerd wordt dat er geen gemeenschappelijke norm bestaat in de nationale rechtsstelsel van de verdragsstaten ten aanzien van de voorwaarden voor naamsverandering. Op grond hiervan bepaalt het Hof dat de verdragsstaten met betrekking tot deze materie een ruime beleidsvrijheid genieten. ${ }^{m}$

Ten slotte wat betreft het begrip "democratic society": hierboven werd al opgemerkt, dat dit begrip - met name in zaken waarin artikel 10 wordt ingeroepen - een rol speelt bij de afbakening van de "margin of appreciation". Een democratische samenleving zou met name gekenmerkt moeten worden door "pluralism, tolerance and broadmindedness". ${ }^{2 m}$ Echter, dit begrip "democratic society" heeft volgens de rechtspraak nog een andere kant:

"whoever exercises his freedom of expression undertakes "duties and responsibilities" the scope of which depends on his situation and the technical means he uses."

Met deze "duties" en "responsibilities" wordt rekening gehouden bij de vaststelling. of de beperkingen op het uitgeoefende recht "noodzakelijk" waren in een "democratische samenleving". 24

222 EHRM 25 november 1994, Stjerna Case, \$39. Vergelijk EHRM 24 februari i 994 , Case of Casado Coca. $\$ \$ 54-55$, p. 21.

223 Zie noot 207.

224 EHRM 7 december 1976, Handyside Case, 849, p. 23. Zie ook Besl.Comm. ! oktober 1975, zaak nr. 6084/73, X v. UK, p. 65 en EHRM 20 september 1994, Case of Otto-Preminger-Institut. $\$ 49$. p. 19 en hierboven de laatste ailinea op p. 84. Hiermee wordt derhalve de eerder genoemde opvatting van Elens bevestigd, dat in navolging van artikel 29 lid 2 Universele Verklaring, an de verwijzing naar het 
In de uitspraak van het Hof in de zaak Jersild treffen we overwegingen aan ten aanzien van de bovenbedoelde verplichtingen en verantwoordelijkheden, die specifiek zien op de uitoefening van de vrijheid van meningsuiting. ${ }^{25}$ Wellicht valt niet uit te sluiten dat deze overwegingen ook enige betekenis hebben voor andere grondrechten, zoals bijvoorbeeld de vrijheid van godsdienst en levensovertuiging en de betogingsvrijheid.

Bij de beoordeling van de verplichtingen en verantwoordelijkheden die de uitoefening van de vrijheid van meningsuiting met zich brengt, is volgens het Hof de mogelijke impact die het desbetreffende medium teweeg kan brengen een belangrijke factor. Van algemene bekendheid is dat audio-visuele media veelal een directer en krachtiger effect sorteren dan de schrijvende pers. Tegelijkertijd, aldus het Hof, vertonen de methoden van objectieve en evenwichtige verslaggeving aanzienlijke variatie, onder meer, afhankelijk van het gebruikte medium. Noch het Hof, noch nationale rechters kunnen hun opvattingen over welke verslaggevingstechniek zou moeten worden gehanteerd, in de plaats stellen voor die van de pers. Hierbij roept het Hof in herinnering, dat artikel 10 niet alleen bescherming biedt aan de inhoud van de geuite meningen en informatie, maar ook aan de vorm waarin ze zijn gegoten.

Uit het voorgaande kan worden afgeleid, dat het gewicht van de verplichtingen en verantwoordelijkheden - die rusten op degene die de vrijheid van meningsuiting uitoefent-bij de beoordeling van de noodzakelijkheid van een beperking van die uitoefening, af kan hangen van de wijze waarop (door middel van welke methode) het recht wordt uitgeoefend, doch dat de keuze voor de desbetreffende methode zelf niet ter beoordeling staat. Bezien in de casus van de zaak Jersild betekent dit, dat de ene ondervragings- of verslaggevingstechniek confronterender kan zijn dan de andere en derhalve bij gebruik van de meer confronterende methode zwaardere verplichtingen en verantwoordelijkheden op de journalist rusten. De zwaarte van deze verplichtingen en verantwoordelijkheden speelt een rol bij de beoordeling van de noodzakelijkheid van een beperking op de meningsuitingen van deze journalist, een beperking zal vermoedelijk sneller gerechtvaardigd zijn wanneer de verplichtingen en verantwoordelijkheden van groter gewicht zijn.

begrip "democratic society" de betekenis moet worden gehecht van "een stelsel van een stelsel van sociale relaties. ... warin ieder zich bewust is, dat elk recht een verplichting impliceert tegenover de locale, nationale en internationale samenleving". Zie p. 57 en noot 78.

225 EHRM 23 september 1994, Jersild Case, \$31, pp. 23-24; zie ook de annotatie van F. Janssens, in: NJCM-Bulletin 20-2 (1995), pp. 124-141, met name punt 3. 
Tot slot wat betreft de beperkingsmogelijkheden, opgenomen in de artikelen 8-11 ECRM, artikel 2 Protocol IV ECRM en artikel 1 Protocol VII ECRM:

Niet getracht zal worden het voorgaande geheel samen te vatten. Kernpunten in de bespreking van deze beperkingsmogelijkheden zijn de volgende:

- indien geconstateerd is dat sprake is van een inmenging ("interference") in een recht dat wordt gegarandeerd in de genoemde bepalingen, dan is sprake van een schending van de toepasselijke verdragsbepaling, tenzij deze inmenging kan worden gerechtvaardigd op grond van de opgenomen beperkingsclausules. Deze beperkingsclausules bevatten de volgende voorwaarden voor rechtvaardiging van de inmenging:

- de beperking is voorzien bij wet ("prescribed by law") dan well in overeenstemming met de wet ("in accordance with the law"). De wet - geschreven of ongeschreven, in formele of in materiële zin - moet voldoende toegankelijk ("adequately accessible") en voorzienbaar ("foreseeable") zijn. Dit wil zeggen dat de beperking een basis moet hebben in het nationale recht, doch de toepasselijkheid van een regel moet voldoende duidelijk zijn voor de justitiabele en ook moet die regel van voldoende precisie zijn zodat hij zijn gedrag erop af kan sternmen; - de beperking moet zijn gericht op een legitiem doel ("legitimate aim"). Deze legitieme doeleinden staan limitatief opgesomd. in de beperkingsclausules;

- de beperking moet noodzakelijk zijn in een democratische samenleving ("necessary in a democratic society"). Ten aanzien van deze noodzaak bezitten de Verdragsstaten een doorgaans ruime beoordelingsvrijheid ("margin of appreciation"), echter die vrijheid is niet onbegrensd want het is het Hof dat het laatste oordeel over de noodzaak van een beperking velt. Hiertoe hanteert het Hof een aantal criteria: er moet sprake zijn van een dwingende sociale noodzaak ("pressing social need") om tot de beperking over te gaan, de regering van de betrokken Staat dient relevante en voldoende redenen ("relevant and sufficient reasons") ter rechtvaardiging van de beperking aan te dragen en de beperking op het gegarandeerde recht dient proportioneel te zijn aan het met die beperking nagestreefde legitieme doel. Deze proportionaliteitseis brengt met zich mee dat er een afweging van het belang van de rechtzoekende (bij eerbiediging van zijn grondrecht) tegen de door de Staat ingeroepen beperkingsgrond dient plaats te vinden. Ondanks de toepassing van deze vaste criteria, blijkt dit niet te leiden tot een nauwkeurige afbakening van de beoordelingsvrijheid van de Staat. Deze blijkt in de praktijk, namelijk, mede af te hangen van de aard van het recht dat de Staat wenst te beperken, de aard van de ingeroepen 
beperkingsgrond en de mate waarin er een uniforme, Europese standaard bestaat voor de interpretatie van een verdragsrecht. $\mathrm{Zo}_{0}$ is de beoordelingsvrijheid van de Staat kleiner naarmate het ingeroepen recht fundamenteler is voor het functioneren van een democratische samenleving of nauwer verbonden is met de intieme aspecten van het leven van de rechtzoekende; verder is de beoordelingsvrijheid kleiner naarmate de inhoud van een ingeroepen beperkingsgrond objectiever is vast te stellen en derhalve geen nadere invulling door de nationale autoriteiten behoeft en voorts is de beoordelingsvrijheid van de Staat beperkter wanneer op het desbetreffende gebied een uniforme, Europese maatstaf is ontwikkeld. Ten slotte is de beoordelingsvrijheid van de overheid kleiner indien het gaat om beslissingen omtrent maatregelen die een inmenging vormen op een fundamenteel element van het familie- en gezinsleven van de betrokkene(n) (het wederzijds genot dat ouder(s) en kind(eren) van elkaars gezelschap kunnen hebben) en die een onomkeerbaar proces in gang kunnen zetten. In die gevallen dienen die maatregelen ten einde noodzakelijk in een democratische samenleving te kunnen zijn, genomen te zijn in een met waarborgen omklede besluitvormingsprocedure. Het noodzakelijkheidsvereiste in het tweede lid van artikel 8 brengt in dit soort zaken met zich mee, dat het eerste lid van die bepaling mede een - aan het daarin beschermde recht accessoir - procedureel recht garandeert. Is dit accessoire recht niet gerespecteerd, dan is de genomen maatregel niet noodzakelijk in een democratische samenleving.

2.4.2.2

Inhoudelijke omschrijving van rechten en vrijheden op zodanige wijze, dat in die omschrijving de beperkingsmogelijkheden besloten liggen

Een aantal rechten en vrijheden is in de Conventie niet voorzien van aparte beperkingsclausules, maar is wel dusdanig inhoudelijk omschreven, dat uit de formulering een beperking van deze rechten en vrijheden kan worden afgeleid. Door de nauwkeurige afbakening van de bedoelde rechten en vrijheden, is min of meer duidelijk aan te geven welke gevallen of situaties buiten de reikwijdte van deze rechten en vrijheden zullen vallen en daarmee verdragsrechtelijke bescherming zullen ontberen. Voorbeelden hiervan zijn de rechten en vrijheden vervat in de artikelen 4 lid 2 en lid 3 en 6 (behoudens lid 2) van de Conventie en de artikelen 1,2 en 3 van het eerste Protocol.

Het moge duidelijk zijn, dat een dergelijke nauwkeurige omschrijving van de rechten en plichten direct terug te voeren is op de keuze voor definiëring van de rechten en vrijheden, die uiteindelijk werd gemaakt 
tijdens de Conference of Senior Officials (zie hierboven). Een omschrijving als van de bovengenoemde rechten is reeds terug te vinden in het alternatieve ontwerp "B" van het Comité van Experts ${ }^{26}$, maar vanzelfsprekend niet in het ontwerp van de Raadgevende Vergadering, waarin bij de opgesomde rechten slechts verwezen wordt naar de Universele Verklaring.

In die Universele Verklaring valt slechts in artikel 9 ten aanzien van het verbod van willekeurige vrijheidsbeneming - opgenomen in het definitieve artikel 5 van de Conventie - en in artikel 10 ten aanzien van het fair trialvereiste - opgenomen in het definitieve artikel 6 van de Conventie - een eerste aanzet tot definiëring te vinden. Deze definiëring werd echter wat betreft het verbod van willekeurige vrijheidsbeneming niet overgenomen in het later door het Comité van Experts opgestelde alternatief "A".

In tegenstelling tot wat deze beperkingsmethode suggereert, namelijk dat de rechten dusdanig nauwkeurig zijn geformuleerd dat daaruit vrij eenvoudig de reikwijdte van het recht zou kunnen worden afgeleid, is de inhoud van de desbetreffende verdragsrechten niet altijd gemakkelijk vast te stellen. De desbetreffende rechten en vrijheden zijn weliswaar inhoudelijk omschreven, maar dit is niet altijd gebeurd in termen die eenduidig zijn uit te leggen. Men kan hier denken aan bijvoorbeeld de termen "compulsory labour" in artikel 4 lid 2 of "normal civic obligations" in artikel 4 lid 3 sub c; of de term "deprivation of liberty" in artikel 5 of de termen "civil rights and obligations" en "criminal charge" in artikel 6 etc..

Deze termen behoeven derhalve nog rechterlijke interpretatie, net als de overige vage termen die in de Conventie voorkomen. Het past niet in het kader van dit onderzoek, om voor elk van de hier aan de orde zijnde verdragsrechten aan te geven, welke interpretatie de Straatsburgse instanties aan deze rechten hebben gegeven. Daarom zal worden volstaan met de volgende opmerking.

Onder paragraaf 2.4.2.1 werd ingegaan op het leerstuk van de "margin of appreciation", volgens welke de Staten een zekere beoordelingsvrijheid genieten ten aanzien van de interpretatie en toepassing van bepaalde (onderdelen van) verdragsbepalingen. De toepasselijkheid van dit leerstuk beperkt zich blijkens de Straatsburgse jurisprudentie niet tot de expliciete beperkingsclausules. Zo bepaalde de Commissie al in 1965 in de Belgische Taal-zaak: 
"(...) Sometimes the Convention uses expressions or ideas which, in themselves, have no exact and generally accepted meaning and which cannot be given such a meaning by process of interpretation. Such provisions leave States a certain margin of appreciation with regard to the fulfilment of their obligations. If a measure taken by a State is within this margin, it is generally in accordance with the Convention; if it exceeds it, there is a violation. "227

In de latere praktijk van het Hof zien we dan ook de toepassing van het leerstuk van de "margin of appreciation" op de hier aan de orde zijnde verdragsbepalingen, bijvoorbeeld op artikel 1 Eerste Protocol (de termen "public interest" en "general interest") 228.

Inhoudelijke omschrijving van de rechten en vrijheden waarbij bepaalde gevallen of situaties van verdragsrechtelijke bescherming zijn uitgesloten.

In een aantal artikelen worden bepaalde gevallen en situaties expliciet van de gelding van het desbetreffende artikel uitgesloten. Voorbeelden zijn te vinden in artikel 5 (behoudens het recht van een ieder op veiligheid van zijn persoon) en artikel 2 van de Conventie en artikel 2 lid 2 van het zevende Protocol. Aan deze beperkingsmethode ligt waarschijnlijk dezelfde motivering ten grondslag als aan die genoemd onder paragraaf 2.4.2.2.

Voor deze beperkingsmethode geldt hetzelfde als wat ten aanzien van de jurisprudentie is opgemerkt in paragraaf 2.4.2.2. Ook in de hier aan de orde zijnde verdragsbepalingen komen termen voor, die nadere interpretatie behoeven en waarbij de nationale instanties enige mate van beoordelingsvrijheid genieten. Dit laatste kan worden afgeleid uit het in paragraaf 2.4.2.2 reeds aangehaalde rapport van de Commissie in de Belgische Taal-zaak:

227 Rapp.Comm. 24 juni 1965, Belgian Linguistic Case. \$400, p. 306.

228 EHRM 21 februari 1986, Case of James a.o., §46, p. 32 en EHRM 19 december 1989. Case of Mellacher and others, \$45, p. 26. Dit en andere voorbeelden van de toepassing van het leerstuk van de "margin of appreciation zijn te vinden in: J.G.C. Schokkenbroek, De margin of appreciation-doctrine in de jurisprudentie van het Europese Hof, p. 52. 
"A certain margin of appreciation is also allowed to the Contracting States under several Articles which authorise restrictions on, or exceptions to, the rights guaranteed. "229

Ten aanzien van artikel 5 is het leerstuk van de "margin of appreciation" met name toegepast met betrekking tot de vraag ten aanzien van lid 1 sub e of iemand als zijnde geestesziek gevangen mag worden gehouden ${ }^{20}$ of met betrekking tot de term "vrijheidsberoving" in artikel 5 in relatie tot militaire tuchtstraffen ${ }^{23 !}$. of vrijheid aan de nationale instanties overlaten

Bij dit soort verdragsbepalingen wordt het aan de nationale instanties en daarmee wordt met name gedoeld op de nationale wetgever, overgelaten de uitoefening én de beperking van een recht of vrijheid te regelen. Een duidelijk voorbeeld is artikel 12 van de Conventie. Verder valt te denken aan artikel 10 lid 1, laatste zin.

Deze beperkingsmethode past van alle genoemde of nog te noemen beperkingsmethoden nog het minst in de beperkingssystematiek, die - zoals gezegd - gebaseerd is op de keuze voor definiëring van de rechten en vrijheden. In de onderhavige beperkingsmethode valt het rechtsbeginsel terug te vinden, dat - naast andere - aan de basis lag van het op algemene omschrijving gebaseerde ontwerp van de Raadgevende Vergadering. Dit beginsel luidde, dat het aan iedere Staat zelf voorbehouden was de uitoefening van de in de Conventie opgenomen rechten en vrijheden op zijn grondgebied te regelen. Dit beginsel werd opgenomen in artikel 4 van het ontwerp van de Raadgevende Vergadering. ${ }^{232}$

Voorstanders van definiëring van de rechten in de Conventie verwierpen opneming van dit beginsel in de Conventie op grond van de in artikel 1 van het. Statuut van de Raad van Europa weergegeven doelstelling van een grotere eenheid tussen de Lid-Staten van deze organisatie. ${ }^{233}$ Artikel 12 is er het bewijs van, dat toch - zij het slechts in dit uitzonderlijke geval aan de wensen van tegenstanders van definiëring is tegemoetgekomen door regeling van het recht om te huwen aan de nationale wetgever over te

230 E.HRM 24 oktober 1979. Winterwerp Case, \$40, p. 18 en EHRM 23 februari 1984. Luberti Case, \$27, pp. 12-13.

231 EHRM 8 juni 1976, Engel Case, §59, p. 25.

232 Zie de eerste volledige alinea op p. 41.

233 Zie de eerste volledige alinea op p. 53 en noot 64 . 
laten. Waarom voor dit recht een uitzondering werd gemaakt op het uitgangspunt van definiëring van de rechten en vrijheden wordt uit de Travaux Préparatoires niet duidelijk.

Dat de Staten ten aanzien van de in deze categorie vallende bepalingen een grote "margin of appreciation" hebben zal geen verwondering wekken. De Conventie staat derhalve toe, dat de diverse rechtssystemen van de Staten nogal van elkaar verschillen. De formuleringen van artikel 12 en van artikel 10 lid 1, laatste zin wekken zelfs de verwachting op, dat de beoordelingsvrijheid van de Staten onbeperkt is. Dit is echter niet het geval, zo blijkt uit de jurisprudentie ${ }^{24}$.

Ten aanzien van artikel 12 zijn enkele gemeenschappelijke normen ontwikkeld, waarmee het nationale recht van de Lid-Staten en de toepassing ervan in overeenstemming dienen te zijn.

Volgens de Commissie in de Van Oosterwijck-zaak, kan de verwijzing in artikel 12 naar het nationale recht van de Lid-Staten "not authorise States completely to deprive a person or category of persons of the right to marry." In navolging van de jurisprudentie van het Hof naar aanleiding van het recht op onderwijs (artikel 2 Protocol I) en het recht op toegang tot de rechter (artikel 6 lid 1) overwoog de Commissie:

"It recalls in particular that the Court has stated that a measure which regulates the exercise of a right must not entail an interference with the substance of the right itself. "23s

In de zaak Hamer omschreef de Commissie als de essentie van het recht om te huwen

" $(\ldots)$ the formation of a legally binding association between a man and a woman. ${ }^{236}$

234 Deze jurisprudentie zal alleen besproken worden voorzover die van helang is voor de bevoegdheid van de Staat om regelingen op te stellen met betrekking tot de aan de orde zijnde verdragsrechten. Verder zal niet worden ingegaan op de interpretatie van de betrokken rechten, noch aan de gevolgen van de toepasselijkheid van deze rechten.

235 Rapp.Comm. I maart 1979, Van Oosterwijck Case, \$56, p. 27. Verwezen wordt naar EHRM 23 juli 1968, Belgian Linguïstic Case, §5. p. 32 en EHRM 21 februari 1975. Golder Case, \$38. pp. 18-19.

236 Rapp.Comm. 13 december 1979, zaak nr. 7114/75, Hamer v. UK, p. 16. Deze uitspraak bevestigde de Commissie in Rapp.Comm. 10 juli 1980, zaak nr. 8186/78, Draperv. UK, p. 81. 
Aan de essentie van dit recht wordt geen afbreuk gedaan, aldus van Dijk en van Hoof, wanneer de Staat grenzen stelt aan het recht om te huwen op grond van leeftijd indien er een redelijke relatie bestaat tussen die leeftijdsgrens en het begrip "huwbare leeftijd". Maar indien het recht om te huwen beperkt wordt op grond van het bezitten van beperkte geestelijke vermogens, gezondheidstoestand, of financièle situatie, dan kan in het geval de getroffen personen wel in staat waren hun vrije wil te bepalen dit nationale recht niet gerechtvaardigd worden met een beroep op artikel $12 .^{237}$

Volgens de jurisprudentie van het Hof beperkt of vermindert de onmogelijkheid voor mensen van hetzelfde geslacht om met elkaar te huwen het recht niet zodanig of niet zover, dat daardoor de essentie van het recht om te huwen wordt aangetast, omdat

"the right to marry guaranteed by Article 12 refers to the traditional marriage between persons of the opposite biological sex. This appears also from the wording of the Article which makes it clear that Article 12 is mainly concerned to protect marriage as the basis of the family." 238

Vanwege deze verbinding van het recht om te huwen aan het recht om een gezin te vormen, stellen van Dijk en van Hoof zich - mijns inziens terecht de vraag, waarin dan het essentiële verschil is gelegen tussen enerzijds partners van hetzelfde geslacht en anderzijds partners van verschillend geslacht die geen gezin willen of kunnen stichten. ${ }^{23}$

237 P. van Dijk en G.J.H. van Hoof, De europese conventie in theorie en praktijk, p. 442. Een voorbeeld van een zaak waarin een leeftijdsgrens in het geding was, is Besl.Comm. 7 juli 1986, zaak nr. 11579/85, Khan v. UIK, pp. 255.

238 EHRM 17 oktober 1986, Rees Case, \$49, p. 19. Herhaald in Rapp.Comm. 7 maan 1989, zaak nr. 11095/84, W v. UK, p. 47 en in Best.Comm. 9 november 1989, zaak nr, 14573/89, Eriksson and Goldschmidr v. Sweden, p. 215. In deze laatste beslissing heeft de Commissie bepaald dat op grond van artikel 12 ook geen recht om te huwen bestaat wanneer de betrokken personen biologisch van verschillend geslacht, maar juridisch van hetzelfde geslachı zijn omdat één van hen, vrijwillig en erkend door het nationale recht, een geslachtsverandering heeft ondergaan (pp. 215-216).

239 P. van Dijk en G.J.H. van Hoof, De europese conventie in theorie en praktijk. p. 491. Zie ook Rapp.Comm. 1 maart 1979, Van Oosterwijck Case, 859, p. 28. Vgl. de dissenting opinion van rechter Martens bij EHRM 27 september 1990, Cassey Case, \$4, pp. 30-34. 
In een andere zaak benaderde het Hof de vraag, of er sprake was van aantasting van de essentie van het recht om te huwen, genuanceerder.

Volgens vaste rechtspraak van het Hof, kan uit artikel 12 geen recht op echtscheiding worden afgeleid. Het Hof baseert dit standpunt op het feit, dat deze mogelijkheid al bij de opstelling van de Conventie bewust werd uitgesloten waardoor ook een evolutieve interpretatie van het recht om te huwen niet mogelijk was. ${ }^{240}$ De onmogelijkheid van echtscheiding onder het nationale recht werd derhalve niet gezien als "injuring the substance of the right to marry". ${ }^{241}$ Echter, als het nationale recht wél echtscheiding toestaat, dan

\section{"(..) Article 12 secures for divorced persons the right to remarry without unreasonable restrictions. "222}

Volgens het Hof was de hier in het geding zijnde maatregel - namelijk, het verbod om te hertrouwen voor een periode van één tot drie jaar, op te leggen door de rechter aan de veroordeelde partij in het geval van echtscheiding op grond van overspel ("adultery") - die de essentie van het recht om te huwen raakte, disproportioneel aan het legitieme doel - de bescherming van de rechten van anderen waaronder de aanstaande echtgenote - dat ermee werd nagestreefd. ${ }^{23}$ Het Hof lijkt hier derhalve een extra criterium voor de beoordelingsvrijheid van de Staat te introduceren, namelijk dat van proportionaliteit.

Overigens heeft de Commissie de mogelijkheid geopend voor Staten om de rechten onder artikel 12 te beperken op grond van artikel 8 lid 2, in gevallen waarin deze beide verdragsartikelen van toepassing zijn. In een zaak waarin de beide echtgenoten zich in voorarrest bevonden, ging de klacht over het feit dat hun detentie in dezelfde cel was geweigerd. De Commissie nam hier een verband aan tussen het recht op privé- en familieleven in artikel 8 en het recht om een gezin te stichten in artikel 12. De Commissie was van oordeel dat beperkingen die niet in strijd zijn met artikel 8 (lid 2) - zoals in deze zaak - ook niet in strijd kunnen zijn met

240 EHRM 18 december 1986, Case of Johnston and others, \$53, p. 25.

241 loem, p. 18.

242 EHRM 18 december 1987, Case of $F$. v. Switzerland, 838, p. 18.

243 EHRM 18 december 1987, Case of $F$. v. Swizzerland, $\$ 40, p .19$. 
artikel 12. ${ }^{24}$ Van Dijk en van Hoof keren zich tegen deze argumentatie van de Commissie. Ten eerste neemt artikel 12 een onafhankelijke positie in in de Conventie naast artikel 8 . Voorts is artikel 12 door de opstellers van de Conventie niet voorzien van een opsomming van beperkingen en kan daarom ook niet worden onderworpen aan het regime van lid 2 van artikel 8. ${ }^{205}$ Mijns inziens had de Commissie zich ertoe kunnen beperken om - in overeenstemming met eerdere uitspraken - artikel 12 niet van toepassing te verklaren, omdat gezien de tijdelijke aard van de detentie de essentie van het recht in kwestie niet was aangetast. ${ }^{206}$ In gevallen van maatregelen van langere duur zou waarschijnlijk wel de essentie van het recht om een gezin te stichten worden geraakt ${ }^{26}$. In die gevallen zou de desbetreffende maatregel kunnen worden getoetst aan het bovengenoemde criterium van proportionaliteit.

Deze kwestie is overigens - voor zover mij bekend - nog niet voorgelegd aan het oordeel van het Hof.

Overigens kan men constateren, dat sommige artikelen beperkingsmogelijkheden bieden, die elementen bevatten van meerdere van de hierboven genoemde beperkingsmethoden. Zo bevatten de onder paragraaf 2.4.2.1 genoemde artikelen 10 en 11 ook nadere omschrijvingen, die gebracht kunnen worden onder de methoden genoemd in de paragrafen 2.4.2.3 of 2.4.2.4.

Artikel 10 lid 1, laatste zin, dat hierboven al enkele keren werd genoemd, luidt: "This article shall not prevent States from requiring the licensing of broadcasting, television or cinema enterprises." Hoewel dit artikel wel specifiek aangeeft voor welke media een Lid-Staat een vergunningenstelsel in het leven kan roepen, lijkt verder de regeling van dit vergunningenstelsel geheel aan de discretie van de Staat te worden overgelaten, net als bij de regeling van het recht om te huwen in artikel 12 van de Conventie.

244 Besl.Comm. 3 oktober 1978 , zaak nr. 8166/78, $X$ and $Y$ v. Switzerland, pp. 242-244. Zo ook de Besi.Comm. 5 februari 1973, zaken nrs. 5260 en 5277/71, $X$ and $Y v$. Austria, niet gepubliceerd. Naar eerstgenoemde zaak wordt bovendien verwezen in Besl.Comm. 7 juli 1986, zaak nr. 11579/85, Khan v. UK, p. 255.

245 P. van Dijk en G.J.H. van Hoof, De europese conventie in theorie en praktijk, p. 500 .

246 Zie Besl.Comm. 21 mei 1975, zaak nr. 6564/74, Xv. UK, p. 106 en Rapp.Comm. 13 december 1979, zaak nr. 7114/75, Hamer Case, pp. 14-16. Vgl. ook P. van Dijk en G.J.H. van Hoof, De europese conventie in theorie en praktijk, p. 501.

247 Zoals in de zaak Hamer, waarin de Commissie overwoog: "In the Commission's opinion the imposition by the State of any substantial period of delay on the exercise of this right must in general be seen as an injury to its substance. $\$ 72$, p. 16. 
Artikel 11 lid 2 laatste zin maakt een uitzondering op het in dit artikel geformuleerde verbod voor rechtmatige beperkingen op de uitoefening - van de in artikel 11 gegarandeerde rechten - door leden van de krijgsmacht, van de politie of van het ambtelijk apparaat van de Staat.

Verder bevat het in paragraaf 2.4.2.2 genoemde artikel 1 van het Eerste Protocol ook elementen van de beperkingsmethode genoemd in paragraaf 2.4.2.1. Volgens dit artikel kan het ontnemen van eigendom alleen plaatsvinden in het algemeen belang en onder de voorwaarden voorzien in de wet (en in de algemene beginselen van internationaal recht). De verwijzing naar het algemeen belang vertoont overeenstemming met de in paragraaf 2.4.2.1 als tweede aan beperkingen gestelde voorwaarde, dat de beperking nodig moet zijn met het oog op een bepaald beschermenswaardig belang. Ook het aldaar vermelde vereiste, dat de beperkingsmogelijkheid moet zijn voorzien bij wet is terug te vinden in de zojuist aangehaalde zin van artikel 1 van het Eerste Protocol.

Wat betreft artikel 10 lid 1, laatste zin, heeft het Hof in de zaak Groppera Radio $A G$ and others geoordeeld, dat

"The object and purpose of the third sentence of Article $10 \S 1$ and the scope of its application must however be considered in the context of the Article as a whole and in particular in relation to the requirements of paragraph 2."248

Op het eerste gezicht lijkt het er volgens het Hof op, dat beperkingen, die gebaseerd zijn op deze laatste zin van artikel 10 lid 1 , niet onderworpen zijn aan de vereisten in de eerste zin van lid 2 - met uitzondering van de eis van "lawfulness". Toch is het Hof van oordeel - met name na de overweging dat een dergelijke uitzonderingsclausule in artikel 19 IVBPR ontbreekt, dat deze laatste zin van artikel 10 lid 1 slechts tot doel heeft duidelijk te maken, dat het aan Staten toegestaan is om de organisatie van uitzendingen op hun grondgebied te controleren door middel van vergunningenstelsels, met name voor zover het de technische aspecten van die uitzendingen betreft. Echter, artikel 10 lid 1, laatste zin

"does not, (...) provide that licensing measures shall not otherwise be subject to the requirements of paragraph 2 , for that would lead to a 
result contrary to the object and purpose of Article 10 taken as a whole. "209

Derhalve zullen vergunningenstelsel voor radio-, omroep-, bioscoop- en televisieondernemingen niet alleen aan het vereiste van "lawfulness" moeten voldoen, maar ook aan de overige vereisten die in artikel $10 \mathrm{lid} 2$ worden genoemd.

2.4.2.5

Beperking van de rechten van vreemdelingen op grond van artikel 16 ECRM

Op grond van artikel 16 van de Conventie is het aan Staten toegestaan beperkingen te stellen aan de politieke activiteiten van vreemdelingen, zonder dat dit een schending oplevert van de artikelen 10,11 en 14 van het verdrag.

Een artikel met de strekking van het huidige artikel 16 treffen we voor het eerst aan in de alternatieven A en B van het Comité van Experts. De opneming van artikel 7 sub $\mathrm{c}$ in alternatief $\mathrm{A}$ werd als volgt gemotiveerd:

"The aim of paragraph (c) is to make provision for the fact that, in accordance with a universally admitted practice, the exercise of the fundamental rights by foreigners (non-nationals) may be subject to certain restrictions not applicable to nationals."

De door de Staat gestelde beperkingen moesten echter wel in overeenstemming zijn met de door beschaafde volken erkende algemene rechtsbeginselen (artikel 10 alternatief $\mathrm{A}$ )

De in artikel 16 neergelegde beperkingsbevoegdheid betekent, dat de politieke activiteiten van vreemdelingen met betrekking tot de artikelen 10

249 EHRM 28 maart 1990, Case of Groppera Radio $A G$ a.o., \$61, p. 24. Deze overweging van het Hof is bevestigd in ElHRM 22 mei 1990, Autronic AG case, 852 , p. 24 en EHRM 24 november 1993, Case of Lentia a.o., \$29, p. 14. (Cursivering. CS.)

250 Bijeenkomsten van het Committee of Experts, 2-8 februari en 6-10 maart 1950, Report to the Committee of Ministers submitted by the Committee of Experts instructed to draw up a Draft Convention of collective guarantee of Human Rights and Fundamental Freedoms (Doc. CM/WP 1 (50) 15; A 924 of 16 March 1950), in: Council of Europe, Collected Edition of the "Travaux Préparatoires", Vol. IV, pp. 250(28).

Een motivering bij de opneming van het overeenkomstige artikel in het alternatieve ontwerp B (art. 12) of het ontwerp van de Senior Officials (art. 16) ontbreekt. 
en 11 ook beperkt mogen worden, zonder dat het gaat om de bescherming van de belangen die in de tweede leden van deze artikelen staan en zonder dat aan de in deze tweede leden genoemde voorwaarden hoeft te zijn voldaan.

Voorts mogen niet alleen de rechten, die in artikel 10 en 11 bescherming vinden, beperkt worden, maar alle rechten, voor zover beperking van de politieke activiteiten van vreemdelingen wordt beoogd.

Verder blijven de artikelen 10, 11 en 14 aan vreemdelingen gewoon bescherming bieden in gevallen waarin het geen politieke activiteiten betreft. Het hangt derhalve van de interpretatie van het begrip "political activity" af, of een beperking van een recht is toegestaan. En wat de door de beperking getroffen persoon of personen betreft, dient te worden vastgesteld of zij onder het begrip "vreemdeling" vallen. In de zaak Piermont, wordt door het Hof een curieuze uitleg gegeven aan het begrip "vreemdeling". In deze zaak ging het om een Duits lid van het Europees Parlement, dat op Frans Polynesië een toespraak had gehouden, tijdens een verkiezingsbijeenkomst van het Frans-Polynesische Bevrijdingsfront. In deze toespraak uitte zij kritiek ten aanzien van de nucleaire tests die Frankrijk nog steeds uitvoerde en de voortdurende Franse aanwezigheid in het Pacifisch gebied. Naar aanleiding hiervan werd een uitzettingsbevel tegen haar uitgevaardigd en ook werd haar naderhand toelating tot Nieuw Caledonië geweigerd. Naar aanleiding van Piermont's klacht over schending van artikel 10 voerde de Franse regering aan, dat de inmenging op klaagster's vrijheid van meningsuiting gerechtvaardigd was. Hierbij beriep de regering zich op artikel 63 ECRM dat eist dat het Verdrag in de gebieden waarop de Conventie van toepassing is verklaard, wordt toegepast met inachtneming van de plaatselijke behoeften ("local requirements"), op artikel 16 (alleen ten aanzien van het uitzettingsbevel) en op artikel 10 lid 2 ECRM. Het beroep van de Franse regering op artikel 16 werd door het Hof als volgt verworpen:

"... it (het Hof, CS) considers that Mrs Piermont's possession of the nationality of a member State of the European Union and, in addition to that, her status as a member of the European Parliament do not allow Article 16 of the Convention to be raised against her, especially as the people of the OTs ("Overseas Territories", CS) take part in the European Parliament elections. "251 
De conclusie die uit deze overwegingen kan worden getrokken, is dat het Hof blijkbaar het woord "vreemdeling" zo eng opvat dat daar niet alleen degenen buiten vallen die het staatsburgerschap van de betrokken staat (in casu Frankrijk) bezitten, maar ook staatsburgers van andere lidstaten van de Europese Unie. ${ }^{252}$ Dit wordt nog versterkt door het feit dat het in dit geval ging om een lid van het Europees Parlement, waarvan de leden mede gekozen worden door de onderdanen van de Franse overzeese gebiedsdelen, waar de bewuste inbreuk op artikel 10 had plaatsgevonden.

Deze uitspraak is om meerdere redenen aanvechtbaar. Ten eerste omdat het het (nationale) nationaliteits- of vreemdelingenrecht van de lidstaten van de Europese Unie is, dat bepaalt of iemand een vreemdeling is of niet. ${ }^{253}$ Nationaliteitsverlening (of -vaststelling) is een onderwerp dat (nog) niet overgeheveld is naar het communautaire terrein en behoort derhalve niet tot de (uitsluitende) bevoegdheden van de Unie. Het Hof te Straatsburg verbindt aan het lidmaatschap van de Europese Unie de consequentie dat - ten aanzien van politieke activiteiten - op de rechten van onderdanen van een lidstaat van de Unie geen verdergaande beperkingen mogen worden aangebracht (en niet onder minder strikte voorwaarden) dan ten aanzien van dezelfde rechten van eigen onderdanen. Een dergelijk verbod van non-discriminatie op grond van nationaliteit bij de uitoefening van politieke rechten vloeit niet voort uit het communautaire recht. ${ }^{24}$ De interpretatie van het Hof van het begrip "vreemdeling" is derhalve niet te baseren op het Europese gemeenschapsrecht, al lijkt de verwijzing naar het zijn van onderdaan van een lidstaat van de Unie er op te wijzen dat het Hof hier anders over denkt. Mijns inziens, had het Hof de vaststelling van de status van vreemdeling van een persoon van het nationale recht moeten laten afhangen. ${ }^{255}$

252 Hoewel het Hof terecht vaststelt dat klaagster geen beroep kan doen op haar status als Europees burger ("European citizen") omdat ten tijde van de bestreden beslissingen het Europees burgerschap nog niet door de. Gemeenschapsverdragen werd erkend, spreekt het in de geciteerde overweging wel van het feit dat Piermont de nationaliteit bezit van een lidstaat van de Europeșe Unie, terwijl die toen ook nog niet bestond.

253 Dit geldt blijkens de dissenting, opinion in ieder geval voor het Franse recht. Zie de joint partly dissenting opinion van de rechters Ryssdal, Matscher, Sir John Freeland en Jungwiert bij EHRM 27 april 1995, Piermont Case, \$4.

254 Vergelijk Carlos Closa, Citizenship and nationality, $\$ 3.2$, pp. 497-501.

255. Ter aanvulling: de kwestie van de verlening of erkenning van de status van vreemdeling (of staatsburger) wordt ook niet bestreken door enig recht in de Conventie of de Protocollen daarbij. De Conventie en Protocollen bevatten hooguit bepalingen waarbij de status van vreemdeling van belang kan zijn voor de toepasselijkheid van de bepaling of de reikwijdte van de daaruit voor de overheid voortvloeiende verplichtingen, zoals artikel 4 Protocol IV' of artikel 8 ECRM (zie 
Ten tweede, omdat het begrip "vreemdeling" blijkens bovenstaande uitspraak van het Hof alleen nog vreemdelingen omvat, die géén onderdaan zijn van een Unie-staat, wordt een ongelijkheid geschapen tussen onderdanen van Staten die partij zijn bij het ECRM die níet en die wél lid zijn van de Europese Unie. Mijns inziens is het onaanvaardbaar, dat aan beperkingen op rechten - in het geval van politieke activiteiten - minder strenge eisen worden gesteld als die rechten worden uitgeoefend door, bijvoorbeeld, IJslanders, Maltezers, Turken of Zwitsers dan wanneer sprake is van uitoefening van dezelfde rechten onder dezelfde omstandigheden door Belgen, Grieken, Fransen of Nederlanders.

Vooralsnog is dit, voor zover mij bekend, de enige uitspraak van het Hof over artikel 16 en staat deze uitspraak op zichzelf. Wellicht kan dit een reden zijn om niet een al te grote betekenis aan de uitspraak van het Hof, voor wat betreft de interpretatie van artikel 16, te hechten, mede gezien het feit dat de uitspraak dat artikel 10 in deze zaak was geschonden door een minimale meerderheid van de rechters werd gesteund (vijf tegen vier stemmen). ${ }^{256}$

Het verbod van misbruik van de in de Conventie neergelegde rechten en vrijheden in artikel 17 ECRM

In artikel 17 staat het verbod voor Staten, groepen en personen om activiteiten te ondernemen die gericht zijn op het tenietdoen van de gegarandeerde rechten en vrijheden of op het verder beperken van deze rechten en vrijheden dan de Conventie toestaat. Dit laatstgenoemde aspect biedt geen beperkingsmogelijkheid aan de Staat, maar stelt een grens aan de beperkingsmogelijkheden van de Staat en zal daarom later besproken worden. Hier gaat het om de mogelijkheid van Staten (en individuen) om zich te verweren tegen het inroepen van de gegarandeerde rechten en vrijheden door individuen wanneer dit inroepen geschiedt met het oogmerk om de rechten en vrijheden van anderen aan te tasten of te beperken. In wezen verschilt deze beperkingsmogelijkheid ten opzichte van de eerder

\section{hoofdstuk 4).}

256 Zie verder Recommendation 799 (1977) on the political rights and position of aliens, 25 januari 1977. Council of Europe. Parl. Assembly, 28th Ord. Sess., Third Part. Texts Adopted (1977): aangedrongen werd bij het Comité van Ministers "to instruct the competent committee of experts to make proposals for the amendment of the European Convention (...) in such a way as to exclude restrictions at present authorized by Article 16 with respect to political activity on the exercise by aliens of the freedoms guaranteed by Article 10 (...) and Article 11 (..)." Zie ook P. van Dijk en G.J.H. van Hoof. De europese conventie in theorie en praktijk, hoofdstuk 7. \$5. pp. 617-619. 
genoemde beperkingsmogelijkheden hierin, dat die andere beperkingsmogelijkheden de Staat toestaan de rechten en vrijheden actief te beperken, terwijl artikel 17 slechts een passief afweermiddel biedt. Een Staat zal zich pas - bij wijze van rechtvaardigingsgrond voor een bepaalde inmenging in een recht van een individu - op artikel 17 kunnen beroepen als die individu de Staat beschuldigt van schending van het desbetreffende recht. ${ }^{25}$

Artikel 17 valt terug te voeren tot artikel 6 van het ontwerp van de Raadgevende Vergadering. Volgens Eissen lag de al eerder in dit hoofdstuk genoemde angst voor het fascisme en communisme aan de basis van dit artikel 6 (ontwerp RV). ${ }^{2 s s}$ Desondanks werd aan het alternatieve ontwerp A van het Comité van Experts een afzonderlijke bepaling toegevoegd, artikel 7 sub a, waarmee het huidige artikel 17 qua formulering overeenstemt. Volgens de toelichting bij dit alternatieve voorstel werd artikel 7 sub a opgenomen teneinde de Staten te beschermen tegen activiteiten, die een bedreiging zouden vormen voor het handhaven van democratische rechten en vrijheden. Dit artikel was ontleend aan artikel 30 van de Universele Verklaring en artikel 22 van het toenmalige ontwerp van het Internationale Verdrag inzake de Mensenrechten van de Verenigde Naties (het huidige artikel 5 in beide Covenants). Een verdere toelichting op het huidige artikel 17 van de Conventie is in de Travaux Préparatoires niet terug te vinden. Volgens Eissen geeft artikel 17 beter dan het oorspronkelijke (ontwerp)artikel 6 de zorg weer ten aanzien van het "totalitaire gevaar". 259

Uit artikel 17 leidt deze schrijver vervolgens ook de verplichting van een ieder af om de rechten van zijn naaste te respecteren en zijn vrijheid te gebruiken op een wijze die zich verdraagt met de Vrijheid. ${ }^{200}$

Uit de rechtspraak van de Commissie en het Hof kan worden afgeleid, dat het van belang is na te gaan voor welk doel de verdragsrechten worden ingeroepen. In deze jurisprudentie wordt namelijk benadrukt, dat artikel 17 "a pour objectif la sauvegarde des droits que cette Convention énumère, par la protection du libre fonctionnement des institutions démocratiques". Hierbij werd in de zaak Kommunistische Partei Deutschland verwezen naar

$257 \mathrm{Vgl}$. P. van Dijk en G.J.H. van Hoof, De europese conventie in theorie en praktijk, p. 620 .

258 M.-A. Eissen, La Convention et les devoirs de l'ináividu, p. 175. Zie ook de bespreking van artikei 6 (ontwerp RV) in par. 2.4.2.1. Vgl. verder Heumann, Les droits garantis par la Convention Européenne des Droits de I'Homme: Etude des limitations de ces droits, pp. 152-153.

259 M.-A. Eissen, La Convention et les devoirs de l'individu, p. 176.

260 M.-A. Eissen, La Convention et les devoirs de l'individu, pp. 176-177. 
de bovenbedoelde overwegingen in de Travaux Préparatoires, dat "Il s'agit d'empêcher que les courants totalitaires puissent exploiter en leur faveur les principes posés par la Convention, c'est-à-dire invoquer les droits de liberté pour supprimer les Droits de l'Homme". ${ }^{261}$ Verder blijkt uit de jurisprudentie, dat het onvoldoende is voor de toepassing van artikel 17, dat de klager in het verléden een totalitaire regering heeft gesteund. ${ }^{262}$

In de praktijk van de Commissie vallen twee benaderingswijzen van artikel 17 te zien. Ten eerste heeft de Commissie in een aantal zaken artikel 17 van toepassing verklaard op de grond dat de klager de rechten inriep teneinde de rechten van anderen te schaden en kwam vervolgens tot de beslissing, dat de klacht niet kon worden gebaseerd op een van de Conventie-bepalingen en daarom als onverenigbaar met de Conventie nietontvankelijk moest worden verklaard. ${ }^{203}$

Aan de andere kant heeft de Commissie in een aantal andere zaken de beoordeling van het beroep door de Staat op artikel 17 gevoegd bij de hoofdzaak. ${ }^{264}$ Volgens van Dijk en van Hoof verdient deze laatste benadering de voorkeur, omdat dan in tegenstelling tot de eerste benadering, tevens wordt vastgesteld of sprake is van een schending van de ingeroepen rechten en bovendien de eindbeslissing in de zaak niet bij de Commissie maar bij het Hof of het Comité van Ministers komt te liggen. ${ }^{265}$

Overigens valt er in meer recente zaken de ontwikkeling van een (derde) benaderingswijze te bespeuren die tussen beide voornoemde benaderingen in ligt. ${ }^{206}$ In deze zaken wordt naar aanleiding van een beroep op artikel 17 niet geconcludeerd dat de ingeroepen verdragsrechten niet toepasselijk zijn (onverenigbaarheids-argument), maar komt de Commissie na een inhoudelijke toetsing aan de ingeroepen rechten - met artikel 17 als

261 Besl.Comm. 20 juli 1957, zaak nr. 250/57, Kommunistische Partei Deutschland, p. 224.

262 Rapp.Comm. 8 januari 1960, De Becker Case, \$279, pp. 137-138.

263 Besl.Comm. 20 juli 1957, zaak nr. 250/57, Kommunistische Partei Deutschland, p. 225 en Besl.Comm. 11 oktober 1979, zaken nrs. 8348 en 8406/78, Glimmerveen en Hagenbeek, pp. 196-197.

264 Bijv. Besl.Comm. 30 augustus 1958, zaak nr. 332/57, Lawless, p. 340 en Besl.Comm. 9 juni 1958, zaak nr. 214/56, De Becker, pp. 214-254.

265 P. van Dijk en G.J.H. van Hoof, De europese conventie in theorie en praktijk, p. 621 .

266 Zie Besl.Comm. 12 mei 1988, zaak nr. 12194/86, Kühnen v, FRG, p. 210 en Besl.Comm. 16 april 1991, zaak nr. 15404/89, Purcell and others v. Ireland, pp. 277-280 naar aanleiding van artikel 10 en Besl.Comm. 12 oktober 1989, zaak nr. 12774/87, H, W, P and $K$ v. Austria, pp. 220-221 met betrekking tot artikel 14 . 
maatstaf - tot de conclusie dat de inbreuk op het recht waarover geklaagd werd gerechtvaardigd was. Daarop volgt dan de gevolgurekking dat de desbetreffende klacht kennelijk ongegrond is en derhalve niet-ontvankelijk moet worden verklaard. In zekere zin wordt door een dergelijke toetsing wel een (inhoudelijke) uitspraak over de hoofdzaak gedaan, maar kan dit niet leiden tot een eindbeslissing van het Hof of het Comité van Ministers.

In de jurisprudentie van de Commissie en het Hof in zaken waarin de tweede benaderingswijze werd gevolgd, is de mogelijkheid voor Staten om artikel 17 in te roepen als rechtvaardiging voor een inbreuk op een Conventie-recht, aan banden gelegd. Volgens deze jurisprudentie brengt het feit, dat de klager zich tot doel heeft gesteld de rechten van anderen te vernietigen of te beperken of lid is van een groepering die dit doel nastreeft, nog niet mee dat hem daarom het genot van álle in de Conventie opgenomen rechten en viijheden kan worden ontnomen. Slechts het genot van díe rechten, die hij direct voor het verwezenlijken van zijn bovengenoemde doelstelling misbruikt, zal hij moeten ontberen.

In de zaak Lawless werd de klager ervan beschuidigd betrokken te zijn geweest bij activiteiten van de IRA en werd hem op die grond door de autoriteiten de bescherming van de artikelen 5 en 6 van de Conventie onthouden. 'Toen het Verenigd Koninkrijk zich naar aanleiding van Lawless' klacht op grond van de artikelen 5 en 6 , beriep op artikel 17 , waren de Commissie en het Hof van oordeel dat Lawless' beroep op de artikelen 5 en 6 niet ten doel had de hem verweten activiteiten uit te oefenen. ${ }^{267}$

\subsubsection{Beperkingen in geval van oorlog of noodtoestand}

Bij de beschrijving van de beperkingsmethoden in paragraaf 2.4 .2 werd uitgegaan van de normale situatie, dat een land in een toestand van vrede of rust verkeert. De onder deze punten genoemde rechten en vrijheden kunnen echter ook worden beperkt in tijden van oorlog en andere noodtoestand op grond van artikel 15 van de Conventie. Onder dergelijke omstandigheden mogen staten maatregelen nemen, die afwijken van de verplichtingen, die de Conventie aan de Staten oplegt. Deze maatregelen mogen echter niet verder gaan dan "the extent strictly required by the 
exigencies of the situation, provided that such measures are not inconsistent with its other obligations under international law" (lid 1).

Maakt een Staat gebruik van de beperkingsmogelijkheid van lid 1, dan moet de Secretaris-Generaal van de Raad van Europa op de hoogte gesteld worden van de getroffen maatregelen en de redenen daarvoor. Die verplichting heeft de Staat ook wanneer de desbetreffende beperkende maatregelen weer zijn ingetrokken (lid 3).

Een bepaling met dezelfde strekking als het huidige artikel 15 werd opgenomen in de alternatieven A (artikel 8) en B (artikel 2) van het Comité van Experts en in artikel 14 van het ontwerp van de Conference of Senior Officials. In de toelichting op alternatief A rechtvaardigt het Comité de opname van deze bepaling als volgt. Het opnemen van een bepaling als artikel 8 (alternatief A) zou als voordeel hebben, dat zelfs in tijden van oorlog of gevaar voor het bestaan van de natie elke beperking zou zijn uitgesloten op bepaalde fundamentele rechten. Bovendien zou de in lid 3 voorgeschreven procedure nuttig ("useful") zijn voor de bescherming van mensenrechten in uitzonderlijke omstandigheden. ${ }^{268}$

Bij de overige ontwerpen geven de Travaux Préparatoires geen nadere toelichting.

Uit de jurisprudentie komt naar voren, dat de eerste aanzet tot het leerstuk van de "margin of appreciation", zoals dit hierboven is besproken, al wordt gegeven in de eerste uitspraken met betrekking tot artikel 15 . Toepassing van de leer van de "margin of appreciation" op artikel 15 betreft met name de volgende twee voorwaarden:

a. er moet sprake zijn van "time of war or other public emergency threatening the life of the nation" en

b. de derogerende maatregel moet "strictly required by the exigencies of the situation" zijn.

In de zaak Greece v. United Kingdom - met betrekking tot de situatie op Cyprus - heeft de Commissie bepaald, dat ze bevoegd is om vast te stellen of aan de bovengenoemde voorwaarden is voldaan. Daaraan heeft de Commissie vervolgens toegevoegd, dat 
"the Government should be able to exercise a certain measure of discretion in assessing the extent strictly required by the exigencies of the situation". 200

In navolging van de overwegingen van het Hof in de zaak Lawless ${ }^{270}$ en op grond van de jurisprudentie inzake de tweede leden van de artikelen 8 tot en met 11, bepaalde het Hof in de zaak Ireland' $v$. United Kingdom, dal het in eerste instantie aan de Staat moet worden overgelaten om vast te stellen of aan de onder a. en b. genoemde voorwaarden is voldaan. De nationale autoriteiten zijn in beginsel in een betere positie dan de internationale rechter om te beslissen over het bestaan van een "public emergency threatening the life of the nation" en over de aard en de reikwijdte van "derogations necessary to avert it." Hierbij verwijst het Hof naar het directe en voortdurende contact dat de Staten onderhouden met "the pressing needs of the moment". De Staten genieten bij de toepassing van artikel 15 derhalve een ruime beoordelingsvrijheid.

Echter, deze beoordelingsvrijheid van de Staten is niet onbeperkt:

"The Court, which, with the Commission, is responsible for ensuring the observance of the States' engagements (Article 19), is empowered to rule on whether the States have gone beyond the 'extent strictly required by the exigencies' of the crisis. "231

Ondanks deze toch wel marginale toetsingsbevoegdheid van de Straatsburgse organen, zijn er enkele criteria ontwikkeld ter concretisering van de nogal vage termen "public emergency threatening the life of the nation" en "strictly required by the exigencies of the situation".

Zal men bij het begrip oorlog ("war") vrijwel onmiddellijk denken aan een internationaal gewapend conflict al dan niet voorafgegaan door een officiele oorlogsverklaring, het begrip "public emergency threatening the life of the nation" is minder duidelijk. Het Hof had met dit begrip in de zaak Lawless echter niet zo'n moeite:

"(...) the natural and customary meaning of the words (...) is sufficiently clear; whereas they refer to an exceptional situation of crisis or emergency (/une situation de crise ou de danger exceptionnel

269 Bespreking van het rapport van de Commissie in zaak nr. 176/56, Greece v. United Kingdom, p. 176.

270 EHRM 1 juli 1961 , Lawless Case, $\$ 22$ op p. 55 en $\$ \$ 36-38$ op pp. $57-59$.

271 EHRM 18 januari 1978, Case of Ireland v, the United Kingdom, \$207, pp. 78-79 en EHRM 26 mei 1993, Brannigan and McBride, 843, pp. 49-50. 
et imminent) which affects the whole population and constitutes a threat to the organised life of the community of which the State is composed (...)." 272

In een zaak tegen Griekenland heeft de Commissie deze uitleg nader uitgewerkt in een aantal criteria. Wil er sprake zijn van een "public emergency" in de zin van artikel 15 dan moet de heersende toestand

"(1) ... be actual or imminent.

(2) Its effects must involve the whole nation.

(3) The continuance of the organised life of the community must be threatened.

(4) The crisis or danger must be exceptional, in that the normal measures or restrictions, permitted by the Convention for the maintenance of public safety, health and order, are plainly inadequate. "273

Is aan de hand van deze criteria vastgesteld, dat sprake is van een "public emergency threatening the life of the nation", dan moet worden nagegaan of de genomen maatregelen "strictly required by the exigencies of the situation" zijn. Volgens Van Dijk en van Hoof spelen daarbij drie elementen een rol:

1. de noodzaak van de afwijkende maatregelen om aan de dreiging het hoofd te bieden;

2. de proportionaliteit van de maatregelen ten opzicht van de dreiging;

3. de duur van de afwijkende maatregelen. ${ }^{274}$

De eerste twee elementen kwamen aan bod in de zaak Lawless ${ }^{275}$ en het derde element in de zaak lerland $v$. the United Kingdom, zij het dat het Hof de Staat, die zich op artikel 15 beriep, hier een ruime beoordelingsruimte toekende. De lerse regering stelde in haar klacht, dat de Britse maatregelen in het kader van de terrorisme-bestrijding na verloop van tijd

272 EHRM 1 juii 1961, Lawless Case, \$28, p. 56.

273 Rapp.Comm. 5 november 1969, The Greek Case. \$153, p. 72.

274 P. van Dijk en G.J.H. van Hoof, De europese conventie in theorie en praktijk, p. 609. Ten aanzien van het laatste element: dit element is expliciet opgenomen in art. 27 lid 3 van de Inter-Amerikaanse Conventie voor de Rechten van de Mens: "Any State Party availing itself of the right of suspension shall' immediately inform the other States Parties, through the Secretary General of the Organisation of American States, of (...) the date set for the determination of such suspension. " Zie ook: A. Kiss, Les clauses de limitation et de dérogation dans la Convention Européenne des Droits de l'Homme, p. 135. 
ondoelmatig waren gebleken en daarna ook niet meer waren toegepast, waaruit zou blijken dat de desbetreffende maatregeien de vereiste noodzakelijkheid ontbeerden. Het Hof bepaalde echter, na een verwijzing naar de Britse beoordelingsvrijheid bij het beleid inzake de terrorismebestrijding, dat

"The Court must do no more than review the lawfulness, under the Convention, of the measures adopted by that Government (...). For this purpose the Court must arrive at its decision in the light, not of a purely retrospective examination of the efficacy of those measures, but of the conditions and circumstances reigning when they were originally taken and subsequently applied."

Vervolgens kwam het Hof tot de conclusie, dat het Verenigd Koninkrijk niet de grenzen van de beoordelingsvrijheid had overschreden bij de beoordeling van de noodzakelijkheid van de desbetreffende maatregelen in de desbetreffende periode. ${ }^{276}$

Wat betreft de overige voorwaarden van artikel 15 wordt volstaan met het volgende ${ }^{27}$.

Bij de zinsnede "provided that such measures are not inconsistent with its other obligations under international law" kan men met name denken aan verplichtingen op grond van het International Covenant on Civil and Political Rights. De in dat verdrag in artikel 4 opgenomen derogatiebepaling zondert namelijk meer rechten van de werking van dit artikel uit, dan artikel 15 lid 2 van de Conventie. Volgens artikel 4 lid 2 van het Covenant mag naast de rechten genoemd in artikel 15 lid 2 Conventie ook niet afgeweken worden van artikel 11 ("No one shall be imprisoned merely on the ground of inability to fulfil a contractual obligation."), artikei 16 ("Everyone shall have the right to recognition everywhere as a person before the law.") en artikel 18 ("(..) freedom of thought, conscience and religion. (...)).

Verder kan men bij verplichtingen ingevolge het internationale recht onder andere denken aan het humanitaire recht (de Geneefse Conventies), het VN-Verdrag inzake de Uitbanning van Alle Vormen van Rassendiscriminatie, het VN-Verdrag inzake de Uitbanning van Alle

276 EHRM 18 januari 1978, Case of Ireland v. the United Kingdom, \$214, p. 82.

277 Zie voor het overige: A. Kiss, Les clauses de limitation et de dérogation dans la Convention Européenne des Droits de l'Homme, pp. 133-138 en P. van Dijk en G.J.H. van Hoof. De europese conventie in theorie en praktijk, pp. 611-616. 
Vormen van Discriminatie van Vrouwen en het Verdrag inzake de Voorkoming en Bestraffing van de Misdaad van Volkenmoord. Volgens Van Dijk en van Hoof valt ook te denken aan internationaal gewoonterecht en algemeen erkende rechtsbeginselen. $\mathrm{Zij}$ voegen mijns inziens daar wel terecht aan toe, dat de Straatsburgse organen zich niet snel buiten het terrein van het verdragenrecht zullen wagen, tenzij er een duidelijke internationale jurisprudentie voor handen is waarop zij zich kunnen beroepen ofwel er een duidelijke consensus binnen de Statengemeenschap

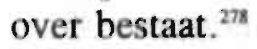

\subsubsection{Beperkingen, alléén in geval van oorlog of noodtoestand}

De in paragraaf 2.4 .2 besproken beperkingsmethoden voorzien in beperkingsmogelijkheden zowel in tijden van oorlog of andere noodtoestand (op grond van artikel 15 ECRM) als in normale situaties. Er staan echter ook rechten en vrijheden in de Conventie, die geen beperkingsmogelijkheden kennen, zoals die vermeld staan in de paragrafen 2.4.2.1 tot en met 2.4.2.6. Deze artikelen zijn niet voorzien van een beperkingsclausule, en zijn niet dusdanig geformuleerd, dat in de omschrijving van het recht reeds een beperking besloten ligt. Noch zijn de uitzonderingen expliciet weergegeven of is de regeling van de uitoefening van het recht min of meer vrij aan de nationale autoriteiten overgelaten. Op grond van artikel 15 ECRM kunnen deze rechten wel - tenzij ze vallen onder de bepalingen die in lid 2 van artikel 15 zijn uitgezonderd - beperkt worden in geval van oorlog of andere noodtoestand. Voorbeelden van bepalingen die tot deze categorie kunnen worden gerekend zijn Artikel 6 lid 2 ECRM. en de artikelen 1, 3 en 4 van het vierde Protocol. Onder normale omstandigheden kunnen de in deze artikelen vervatte rechten en vrijheden derhalve niet worden beperkt, maar wel in een oorlogs- of noodsituatie op grond van artikel 15 .

\subsubsection{Rechten en vrijheden waarvan noch in tijden van oorlog of noodtoestand noch in situaties van vrede en rust kan worden afgeweken}

In artikel 15 lid 2 ECRM zijn enkele bepalingen van de beperkingsbevoegdheid van de Staten in perioden van oorlog of noodtoestand 
uitgezonderd. Op de rechten en vrijheden, die zijn vervat in de artikelen 3, 4 lid 1 en 7 van de Conventie (en in artikel 2 voorzover het niet de dood van iemand betreft tengevolge van rechtmatige oorlogshandelingen) is volgens dit tweede lid van artikel 15 geen beperking in tijden van oorlog of noodtoestand mogelijk. De Travaux Préparatoires geven geen informatie over de motieven achter de keuze voor juist deze artikelen met betrekking tot de uitzondering op de beperkingsbevoegdheid van de Staat van lid 1.

Van de rechten en vrijheden, die in de artikelen 3, 4 lid 1 en 7 ECRM zijn opgenomen, kan derhalve in het geheel niet door middel van beperkingen worden afgeweken.

Artikel 1 van het zesde Protocol (afschaffing van de doodstraf) en artikel 4 van het zevende Protocol (het ne bis in idem-beginsel) nemen in de beperkingssystematiek een wat afwijkende plaats in. Aan de ene kant behoren ze tot de artikelen waarvan niet op grond van artikel 15 van de Conventie kan worden afgeweken (zie artikel 3 Protocol VI en artikel 4 lid 3 Protocol VII); aan de andere kant kunnen ze niet zonder meer beschouwd worden als rechten waarop geen beperkingen mogelijk zijn. Zo staat artikel 2 van het zesde Protocol onder bepaalde voorwaarden toe, dat Staten bepalingen in hun wetgeving opnemen, waarin de doodstraf wordt gesteld op feiten, begaan in oorlogstijd of in tijd van oorlogsdreiging. Voorts maakt artikel 4 lid 2 van het zevende Protocol de heropening van een zaak mogelijk in het geval, dat er aanwijzingen zijn van nieuwe of pas aan het licht gekomen feiten, of indien er sprake was van een fundamenteel gebrek in het vorige proces, die de uitkomst van de zaak zouden of zou kunnen beïnvloeden. Wat deze beperkingsmogelijkheden betreft, passen de genoemde artikelen ook thuis in paragraaf 2.4.2.3 ("Inhoudelijke omschrijving van de rechten en vrijheden waarbij bepaalde gevallen of situaties van verdragsirechtelijke bescherming zijn uitgesloten.").

\subsubsection{De grenzen van de beperkingsbevoegdheden: Artikel 14, 17 en 18 ECRM}

In het voorgaande werd ingegaan op de diverse beperkingsmogelijkheden waarin de Conventie voorziet. In sommige gevallen betrof de beperking de reikwijdte (materie) van een recht of werd mogelijk gemaakt, dat bepaalde groepen personen van de toepassing van een recht werden uitgezonderd. In andere gevailen werd de beperking van toepassing van rechten en vrijheden zélf mogelijk gemaakt. Veelal was dat soort beperkingsmogelijkheden aan bepaalde voorwaarden verbonden (bijvoorbeeld de vereisten van noodzakelijkheid in een democratische samenleving en de proportionaliteit tussen de beperking en het daarmee 
beoogde doel; voorts de eis dat in oorlogssituaties de beperkingen in overeenstemming moeten zijn met de ernst van de situatie etc.).

De artikelen 14, 17 en 18 van de Conventie stellen nog een paar grenzen aan de beperkingsbevoegdheid van de Staten. ${ }^{279}$

\subsubsection{Artikel 14 ECRM}

Artikel 14 verbiedt discriminatie bij de toepassing van de door de Conventie gegarandeerde rechten en vrijheden op grond van geslacht, ras, kleur, taal, godsdienst, politieke of andere mening, nationale of maatschappelijke afkomst, het behoren tot een nationale minderheid, vermogen, geboorte of andere status. De motivering voor opneming van dit artikel vinden we reeds bij artikel 5 van het ontwerp van de Raadgevende Vergadering. Het gaat om hetzelfde motief als dat ten grondslag lag aan artikel 6 van dat ontwerp (dat reeds besproken werd onder in par. 2.4.2.1 $)^{280}$

Vervolgens werd een soortgelijk artikel als artikel 14 opgenomen in artikel 5 van alternatief $A$ en artikel 14 van alternatief $B$ van het Comité van Experts en artikel 13 van het ontwerp van de Senior Officials. Een nadere toelichting werd in deze ontwerpen niet verschaft.

De meest opvallende trekken van artikel 14 zijn gelegen in het feit, dat dit artikel alleen ingeroepen kan worden ten aanzien van de toepassing van in de Conventie opgenomen rechten en vrijheden en in het feit, dat de nondiscriminatiegronden niet limitatief zijn opgesomd.

De betekenis van artikel 14 voor de beperking van grondrechten is hierin gelegen, dat niet alleen de uitoefening van de gegarandeerde rechten en vrijheden zonder discriminatie dient te worden gewaarborgd, maar dat ook bij de beperking van die rechten en vrijheden geen discriminatie plaats mag vinden. ${ }^{281}$

Het zojuist genoemde kenmerk van artikel 14, dat het discriminatie-verbod alleen kan worden ingeroepen ten aanzien van in de Conventie gegarandeerde rechten en vrijheden, heeft in de jurisprudentie de volgende betekenis gekregen.

Artikel 14 heeft geen onafhankelijke betekenis, omdat er een zekere relatie moet bestaan met de in de Conventie opgenomen rechten en

279 Overigens niet alleen aan beperkingen, maar ook aan de uitoefening van de rechten in het algemeen.

280 Zie p. 56 en noot 75.

281 F. Jacobs, To what extent have restrictions on the enjoyment of freedoms evolved?, p. 200. 
vrijheden. Deze relatie houdt in, dat de feiten van de zaak binnen het bereik van een verdragsrecht moeten vallen. Het is echter niet nodig, dat dit recht ook geschonden is. Aan de basis voor deze interpretatie, ligt de uitspraak van het Hof in de zaak Relating to certain aspects of the laws on the use of languages in education in Belgium (Belgische Taal-zaak). Hierin bepaalde het Hof, dat

"While it is true that this guarantee has no independent existence in the sense that under the terms of Article 14 it relates solely to 'rights and freedoms set forth in the Convention', a measure which in itself is in conformity with the requirements of the Article enshrining the right or freedom in question may however infringe this Article when read in conjunction with Article 14 for the reason that it is of a discriminatory nature. "...

"It is as though the latter (artikel 14, CS) formed an integral part of each of the Articles laying down rights and freedoms. No distinctions should be made in this respect according to the nature of these rights and freedoms and of their correlative obligations, and for instance as to whether the respect due to the rights concerned implies positive action or mere abstention. "282

Op grond van deze uitspraak heeft het Hof in latere zaken een standaardformulering ontwikkeld, die luidt als volgt:

"Article 14 complements the other substantive provisions of the Convention and the Protocols. It has no independent existence since it has effect solely in relation to the enjoyment of the rights and freedoms safeguarded by those provisions'. Although the application of Article 14 does not necessarily presuppose a breach of those provisions - and to this extent it has an autonomous meaning - there can be no room for its application unless the facts at issue fall within the ambit of one or more of the latter. "283

Is eenmaal vastgesteld, dat artikel 14 van toepassing is, dan moet worden nagegaan of sprake is van schending van het in dit artikel vervatte nondiscriminatiebeginsel.

282. EHRM 23 juli 1968, Belgian Linguïstic Case, \$9, pp. 33-34.

283 EHRM 28 november 1984, Rasmussen Case, \$29, p. 12; zie ook EHRM 23 november 1983, Van der Mussele Case, 843, p. 22; EHRM 28 mei 1985, Case of Abdulaziz, Cabales and Balkandali, \$771, p. 35; EHRM 28 oktober 1987, Inze Case, §36-40, pp. 17-18 en (impliciet) EHRM 23 oktober 1990, Darby Case, §30, p. 12. 
In de Belgische Taal-zaak heeft het Hof vastgesteld, dat in tegenstelling tot wat de Franstalige tekst van artikel 14 suggereert ("sans distinction aucune") niet ieder verschil in behandeling verboden wordt door artikel 14 :

\begin{abstract}
"The competent national authorities are frequently confronted with situations and problems which, on account of differences inherent therein, call for different legal solutions; moreover, certain legal inequalities tend only to correct factual inequalities. "284
\end{abstract}

In dit soort situaties of bij dit soort problemen zou men volgens het Hof absurde resultaten bereiken, wanneer men artikel 14 aldus zou interpreteren, dat geen enkele ongelijke behandeling geoorloofd is. Uit bovenstaand citaat blijkt derhalve, dat alleen gelijke gevallen gelijk behandeld moeten worden en dat ongelijke gevallen ongelijk behandeld dienen te worden.

Echter, wanneer spreken we van gelijke gevallen? In het arrest Van der Mussele bepaalde het Hof, dat artikel 14 individuen die zich in analoge situaties ("analogous situations") bevinden, beschermt tegen discriminatie. ${ }^{285}$ Dit wordt in het arrest in de zaak Fredin toegespitst tot "relevantly' similar situations". ${ }^{286}$ Uit de jurisprudentie blijkt voorts, dat bij de vergelijking van die situaties, met name gekeken wordt naar hoe die situaties geregeld zijn. In de zaak Van der Mussele betrof het onder andere de juridische status van advocaten enerzijds en andere functies anderzijds, de voorwaarden voor toelating tot het beroep, de aard van de uit te oefenen taken en de wijze van uitvoering van die taken. Het Hof bepaalde ten aanzien van de te vergelijken situaties, dat

"each one is characterised by a corpus of rights and obligations of which it would be artificial to isolate one specific aspect. ${ }^{287}$

284 EHRM 23 juli 1968, Belgian Linguistic Case. \$10. p. 34.

285. EHRM 23 november 1983, Van der Mussele Case, \$46, p. 22. Zo oolk o.a. EHRM 18 december 1986. Case of Johnston a.o., $\$ 60$, p. 26. In de zaak Van der Mussele baseert het Hof zich wat dit aspect betreft op EHRM 13 juni 1979. Marckx Case, $\$ 32$, p. 15, waarin het Hof niet spreekt van "analogous situations" maar van "similar situations". Zo ook EHRM 23 oktober 1990. Darby Case, \$31, p. 12 en EHRM 18 februari 1991, Moustaquim Case, \$49, p. 20. Vooralsnog geeft dit verschil in de formulering geen aanleiding tot de conclusie, dat het Hof hiermee een verschil in betekenis suggereert.

286 EHRM 18 februari 1991, Fredin Case, §60, p. 19. Cursivering, CS.

287 EHRM 23 november 1983, Van der Mussele Case, §46, p. 23. 
In veel zaken, is geen aandacht besteed aan de vraag of sprake is van gelijke gevallen, die gelijk behandeld dienen te worden. Veelal gaan de Straatsburgse instanties direct over tot het onderzoek naar de eventuele rechtvaardiging van een ongelijke behandeling. Impliciet wordt hierbij dan kennelijk aangenomen, dat sprake is van de ongelijke behandeling van gelijke gevallen!

Voor de vraag of een ongelijke behandeling in strijd is met artikel 14, heeft het Hof criteria ontwikkeld in de Belgische Taal-zaak:

1. er is sprake van schending van het gelijkheidsbeginsel, indien aan het verschil in behandeling geen objectieve en redelijke rechtvaardigingsgrond ten grondslag ligt. Het bestaan van een dergelijke rechtvaardigingsgrond moet worden vastgesteld met het oog op het doel en de effecten van de desbetreffende maatregel;

2. er is tevens sprake van schending van artikel 14 , indien duidelijk kan worden vastgesteld, dat er geen redelijk proportionaliteitsverband ("reasonable relationship of proportionality") aanwezig is tussen de aangewende middelen en het nagestreefde doel. ${ }^{28 s}$

In de zaak Marckx vatte het Hof de bovenstaande criteria als volgt samen:

"(...) a distinction is discriminatory if it 'has no objective and reasonable justification', that is, if it does not pursue a "legitimate aim" or if there is not a 'reasonable relationship of proportionality between the means employed and the aim sought to be realised' ". ${ }^{289}$

Deze formulering fungeert sindsdien als standaardcriterium. Bij de toepassing van dit criterium komt echter naar voren, dat een objectieve en redelijke rechtvaardigingsgrond veelal gevonden wordt in de waarborging van een bepaald algemeen belang. In de Belgische Taal-zaak stelde het Hof vast, dat artikel 14 geen ongelijke behandeling verbied die gebaseerd is op

"an objective assessment of essentially different factual circumstances and which, being based on the public interest strike a fair balance between the protection of the interests of the community and respect for the rights and freedoms safeguarded by the Convention. ${ }^{290}$

288 EHRM 23 juli 1968, Belgian Linguïstic Case, \$10, p. 34.

289 EHRM 13 juni 1979. Marckx Case, \$33, p. 16.

290 EHRM 23 juli 1968, Belgian Linguïstic Case, \$7, p. 44. Zie echter voor een zaak waarin een belang als legitiem wordi aangemerkt, dat niet per definitie een. "algemeen" belang vormt: de bescherming van de gezondheid en rechten van de 
In de zaak Abdulaziz, Cabales and Balkandali ging het om een onderscheid tussen vrouwelijke onderdanen van het Verenigd Koninkrijk die geboren waren in het Koninkrijk of die een ouder hadden die daar geboren was en vrouwelijke onderdanen bij wie dat niet het geval was. Alleen aan de eerste groep vrouwen was het toegestaan hun niet-Britse echtgenoot te laten overkomen om zich in het Verenigd Koninkrijk te vestigen. Volgens Balkandali was hier sprake van discriminatie op grond van geboorte. De Britse regering stelde dat het desbetreffende onderscheid gerechtvaardigd werd "by the concern to avoid the hardship which women having close ties to the UK would encounter if, on marriage, they were obliged to move abroad in order to remain with their husbands." Volgens het Hof was dit een legitiem doel onder artikel 14.

"(...) there are in general persuasive social reasons for giving special treatment to those whose link with a country stems from birth within it. The difference of treatment must therefore be regarded as having had an objective and reasonable justification and, in particular, its results have not been shown to transgress the principle of proportionality. "291

Overigens werd wel discriminatie op grond van geslacht vastgesteld, met betrekking tot de immigratieregels die het moeilijker maakten voor vrouwen dan voor mannen om toestemming te krijgen voor hun buitenlandse echtgenoten het land binnen te komen of er te blijven teneinde zich er te vestigen. ${ }^{292}$

In de zaak Moustaquim werd het feit dat België als Lidstaat van de Europese Gemeenschap tot een speciale rechtsorde behoorde als objectieve en redelijke rechtvaardigingsgrond geaccepteerd voor de voorkeursbehandeling (met betrekking tot uitzetting van delinquenten) die België gaf aan niet-Belgische onderdanen van andere EG-Lidstaten boven andere niet-Belgen. ${ }^{293}$

kinderen die na klager's echtscheiding aan haar ex-echtgenoot waren toegewezen, zie EHRM 23 juni 1993, Hoffmann Case, \$34, p. 59.

291 EHRM 28 mei 1985, Case of Abdulaziz, Cabales and Balkandali, $\$ 88$, p. 41.

292 EHRM 28 mei 1985, Case of Abdulaziz, Cabales and Balkandali, \$\$ $\$ 4-83$, pp. 3639. De overweging ten aanzien van deze non-discriminatiegrond komt hieronder nog aan de orde.

293 EHRM 18 februari 1991, Moustaquim Case, §49, p. 20. 
Van Dijk en van Hoof plaatsen kritische kanttekeningen bij de hierboven aangegeven praktijk, waarin objectieve en redelijke rechtvaardigingsgronden voor ongelijke behandeling gebaseerd worden op aan het algemeen belang ontleende argumenten. Volgens hen is het twijfelachtig of het in overeenstemming met de tekst en de geest van artikel 14 is, dat individuele belangen min of meer automatisch ondergeschikt worden aan het algemeen belang. Artikel 14, dat het zonder discriminatie kunnen uitoefenen van de gegarandeerde rechten. en vrijheden door de individu beoogt te waarborgen, bevat geen clausule die de Staat de bevoegdheid verleend om deze waarborg te beperken op grond van het algemeen belang. Dit soort clausules treffen we bij verschillende bepalingen van de Conventie aan, maar niet bij artikel 14. Het in de rechtspraak ontwikkelde criterium van een objectieve en redelijke rechtvaardigingsgrond vormt echter wel een dergelijke beperking van de bovenbedoelde waarborg. Alleen díe ongelijke gevallen, die niet aan dit criterium voldoen, worden geacht in strijd met artikel 14 te zijn. ${ }^{294}$

Mijns inziens kan de kritiek van Van Dijk en van Hoof tot op zekere hoogte worden onderschreven. Zij stellen terecht, dat de Conventie niet slechts beoogt bescherming te bieden tegen de onredelijke, maar ook tegen de redelijke overheid. ${ }^{295}$ Immers, een gemaakt onderscheid kan dan wel worden gebaseerd op redelijke en objectieve gronden, maar dat wil niet zeggen dat die gronden dat onderscheid ook altijd rechtvaardigen. Dit blijkt overigens ook uit de uitspraak van het Hof in de zaak Abdulaziz, Cabales and Balkandali. Zoals gezegd, kwam het Hof tot het oordeel dat wel door artikel 14 verboden discriminatie had plaatsgevonden op grond van geslacht. Hier had de Britse regering onder andere als rechtvaardigingsgrond aangevoerd de bescherming van de binnenlandse arbeidsmarkt. Op zich was dit doel volgens het Hof legitiem. Echter hiermee was het gemaakte onderscheid nog niet gerechtvaardigd. Het Hof was er met name niet van overtuigd,

"that the difference (...) between the respective impact of men and of women on the domestic labour market is sufficiently important to justify the difference in treatment $(.$.$) as to the possibility for a person$ settled in the United Kingdom to be joined by, as the case may be, his wife or her husband." 296

294 P. van Dijk en G.J.H. van Hoof, De europese conventie in theorie en praktijk, pp. 5977-600.

295 P. van Dijk en G.J.H. van Hooj, De europese conventie in theorie en praktijk, p. 602 .

296 EHRM 28 mei 1985, Case of Abdulaziz, Cabales and Balkandali, \$79, p. 38. 
Ondanks het gebruik van het standaardcriterium van een redelijke en objectieve rechtvaardigingsgrond, waarmee doorgaans een aan het algemeen belang ontleende grond wordt bedoeld, is het dus mogelijk dat het Hof een dergelijke grond niet accepteert als rechtvaardiging voor ongelijke behandeling. In zoverre moeten mijns inziens de bezwaren van Van Dijk en van Hoof worden genuanceerd. Veel zal hier afhangen van de soort en mate van toetsing die het Hof toepast. De jurisprudentie zou erop kunnen wijzen, dat dit een marginale toetsing is, omdat veelal een ruime beoordelingsvrijheid aan de Staten wordt toegekend bij de vaststelling óf en in welke mate verschillen in overigens vergelijkbare gevallen een ongelijke behandeling rechtvaardigen. ${ }^{297}$ Wat betreft de reikwijdte van de "margin of appreciation" bepaalde het Hof - onder verwijzing naar de zaak Sunday Times ${ }^{298}$ - in de zaak Rasmussen dat

"The scope of the margin of appreciation will vary according to the circumstances, the subject-matter and its background; in this respect, one of the relevant factors may be the existence or non-existence of common ground between the laws of the Contracting States. "299

In de zaak Inze voegde het Hof hier nog aan toe:

"In this respect, the Court recalls that the Convention is a living instrument, to be interpreted in the light of present-day conditions. " 100

De hierboven weergegeven richtlijnen ten aanzien van de betekenis van het leerstuk van de "margin of appreciation" in verband met artikel 14 doen vermoeden, dat aangesloten kan worden bij de praktijk die met betrekking tot dit leerstuk is ontwikkeld naar aanleiding van de toepassing van de tweede leden van de artikelen 8 tot en met $11 .{ }^{301}$

Overigens kan hieraan, tot slot, worden toegevoegd, dat de "margin of appreciation" van de overheid vandaag de dag zeer klein is, wanneer het

297 Zie, onder andere. EHRM 6 februari 1976. Swedish Engine Drivers' Union Case, $\$ \$ 46-47$. p. 17; EHRM 28 november 1984. Rasmussen Case. \$40. p. 15 en EHRM 28 oktober 1987. Inze Case. \$41. p. 18.

298 EHRM 26 april 1979. The Sunday Times Case (no. I). \$59. p. 36.

299 EHRM 28 november 1984. Rasmussen Case, $\$ 40$. p. 15; 20 ook verscheidene andere zaken wasronder EHRM 28 oktober 1987, Inze Case, \$41, p. 18.

300 EHRM 28 oktober 1987, Inze Case, \$41, p. 18: zie voor oudere uitspraken, onder andere. FHRM 13 juni 1979. Marckx Case, \$58, p. 26 en EHRM 18 december 1986. Case of Johnston a.o., \$53, p. 25.

301 Zie hierboven pp. 75 e.v.. 
gaat om onderscheid naar geslacht. Onder verwijzing naar de zaak Abdulaziz, heeft het Hof in de zaak Schuler-Zgraggen overwogen dat

"( $t$ he advancement of the equality of the sexes is today a major goal in the member States of the Council of Europe and very weighty reasons would have to be put forward before such a difference of treatment could be regarded as compatible with the Convention. "302

Zoals onder paragraaf $2 \cdot 4 \cdot 2.6^{\text {vos }}$ reeds werd opgemerkt stelt artikel 17 een grens aan de beperkingsmogelijkheden van de Staat. Kiss leidt hieruit af, dat artikel 17 dan ook een strikte interpretatie voorschrijft van de clausules, die de Staten toestaan gegarandeerde rechten al dan niet tijdelijk, te beperken. ${ }^{.04}$ De essentie van de rechten en vrijheden mag niet worden aangetast, noch mag er een grotere beperking op worden aangebracht dan de Conventie toestaat. ${ }^{30 s}$ Op dit "begrenzings"-aspect van artikel 17 wordt in de Travaux Préparatoires geen enkele toelichting gegeven.

Met betrekking tot artikel 17 is - voorzover dit de begrenzing van de beperkingsbevoegdheden van de Staat betreft - weinig jurisprudentie voor handen.

Uit de uitspraak van het Hof in de zaken van Dona and Schul valt op te maken, dat artikel 17 een accessoir karakter heeft. Het Hof vond het niet nodig de klacht onder artikel 17 te onderzoeken, omdat het reeds had geoordeeld, dat de bestreden beperking van de vrijheid van meningsuiting van de klagers gerechtvaardigd kon worden op grond van artikel 10 lid 2. ${ }^{306}$ Volgens van Dijk en van Hoof betekent dit niet alleen dat artikel 17 niet geschonden is als de bestreden beperking haar rechtvaardiging vindt in een andere Conventiebepaling, maar ook dat artikel 17 wél geschonden is als tevens een der rechten of vrijheden geschonden is. ${ }^{307}$ In dit laatste

302 EHRM 24 juni 1993, Schuler-Zgraggen Case, \$67, p. 22. Zo ook EHRM 22 februari 1994, Burghartz Case, §27, p. 29.

303 Zie hiervoor op p. 104.

304 A. Kiss, Les clauses de limitation et de dérogation dans la Convention Européenne des Droits de I'Homme, p. 123.

$305 \mathrm{Vgl}$. P. van Dijk en G.J.H. van Hoof, De europese conventie in theorie en praktijk, p. 620 .

306 EHRM 8 juni 1976, Case of Engel a.o., \$104, pp. 42-43.

307 P. van Dijk en G.J.H. van Hoof, De europese conventie in theorie en praktijk, p. 623. 
geval wordt een klacht overigens op dezelfde wijze afgedaan als het eerste: ook hier acht het Hof het overbodig om aan artikel 17 te toetsen. ${ }^{308}$

Een beroep op artikel 17 lijkt derhalve alleen van nut te kunnen zijn in verband met een klacht op grond van een artikel dat niet voorzien is van ruime beperkingsmogelijkheden. Men zou daarbij met name kunnen denken aan bepalingen waarin geen beperkingsgronden zijn opgenomen of waarin "deze minder uitdrukkelijk of minder ruim zijn omschreven". ${ }^{309}$ Uit een paar rapporten van de Commissie lijkt men te kunnen opmaken, dat artikel 1 van Protocol I een voorbeeld van een bepaling is, waarbij artikel 17 nog een rol zou kunnen spelen. Nadat de Commissie de bestreden maatregelen in overeenstemming met artikel 1 Protocol I had geoordeeld, werd daarna nog overwogen of deze maatregelen de rechten vain de klagers onder dit en andere ingeroepen artikelen verder beperkten dan is voorzien bij de Conventie. In de bedoelde zaken kwam de Commissic overigens tot de conclusie, dat artikel 17 niet geschonden was. Of zoals de Commissie dit in de zaak Lithgow formuleert

"It does not consider that the enactment and application of the 1977 Act is shown to have been aimed at the destruction or excessive limitation of the applicants' rights under these provisions (...)."110

\subsubsection{Artikel 18 HC.RM}

Artikel 18 verbiedt de Staten de beperkingsmogelijkheden, die de Conventie hen biedt, voor een ander doel te gebruiken dan waarvoor ze bedoeld zijn. Over het "waarom" van artikel 18 is niet veel bekend. Een artikel met deze strekking werd voor het eerst in het ontwerp van de Conference of Senior Officials opgenomen (artikel 13 lid 2). En soortgelijk artikel valt niet terug te vinden in de Universele Verklaring of in beide VN-verdragen. En het rapport van de Senior Officials verschaft geen duidelijkheid, over de redenen die aan opname van dit artikel ten grondslag hebben gelegen. Artikel 18 lijkt op zich ook niet veel meer te bieden dan nog eens expliciet de eis te stellen, dat beperkingen alleen maar op bepaalde rechten en vrijheden mogen worden aangebracht overeenkomstig de doeleinden waarvoor die beperking is toegestaan.

308 Rapp.Comm. 5 novembei 1969, The Greek Case, \$229, p. 113 (i.c. al schending van artikel 15 vastgesteld).

309 P. van Dijk en G.J.H. van Hoof, De europese conventie in theorie en praktijk, p. 624.

310 Rapp.Comm. 7 maant 1984, Case of Lithgow a.o., \$448, p. 116. Zie ook Rapp.Comm. 8 oktober 1980, Case of Sporrong and Lönnroth, \$123, p. 53. 
Impliciet ligt de toetsing aan een dergelijke eis echter al besloten in het feit, dat de beperkingsmogelijkheden aan bepaalde doeleinden zijn verbonden. Volgens Jacobs is artikel 18 echter

"useful as putting beyond doubt the scope of the restrictions permitted and as making clear the requirement of good faith in the application of these restrictions. "

Overigens zal het moeilijk zijn aan te tonen, dat de Staat zich schuldig gemaakt heeft aan "détournement de pouvoir". Men zal moeten weten wat de motieven voor een bepaald overheidsoptreden zijn; de Staat zal de motieven voor een inmenging in een bepaald recht expliciet gemaakt moeten hebben. Het is naïef te veronderstellen, dat een Staat dit zal doen wanneer zij de beperkingsmogelijkheid bewust gebruikt voor een ander doel dan waarvoor de beperking is toegestaan. ${ }^{3.2}$

Uit de jurisprudentie volgt, dat evenals de twee hiervoor besproken. artikelen (14 en 17), ook artikel 18 niet zelfstandig kan worden ingeroepen. Er dient een samenhang met een der verdragsrechten te bestaan. ${ }^{313}$ Blijkens de jurisprudentie van de Commissie hoeft dit andere verdragsrecht echter niet geschonden te zijn. Dit blijkt onder meer uit het rapport van de Commissie in de zaak Kamma, waarin de Commissie overging tot toetsing aan artikel 18 in verband met artikel 5 lid 1 aanhef en onder $\mathrm{c}$, ondanks het feit dat de Commissie al eerder had geconstateerd dat de vrijheidsberoving waarover geklaagd werd in overeenstemming met. artikel 5 was. ${ }^{3 / 4}$

We zien echter ook hier - net als bij de bespreking van artikel 14 en 17 , dat het Hóf niet overgaat tot toetsing aan artikel 18, indien het heeft geoordeeld dat het ingeroepen verdragsrecht geschonden is ${ }^{315}$, ofwel indien het het desbetreffende recht juist niet geschonden acht en bij de behandeling van de beperkingsmogelijkheden is ingegaan op de door de

311 F. Jacobs, To what extent have restrictions on the enjoyment of freedoms evolved?, p. 202.

312 Vgl. P. van Dijk en G.J.H. van Hoof, De europese conventie in theorie en praktijk, pp. 625-631(627).

313 Rapp.Comm. 14 juli 1974, zaak nr. 4771/71, Kamma v. the Netherlands, p. 316 en Besl.Comm. 15 mei 1984, zaak nr. 9990/82, Bozano v. France "p. 141.

314 Rapp.Comm. 14 juli 1974, zaak nr. 4771/71, Kamma v. the Netherlands, p. 316. Zie ook Rapp.Comm. 30 september 1975, Handyside Case. \$175, p. 52 en Rapp.Comm. 8 oktober 1980, Case of Sporrong and Lönnroth, \$123, p. 53.

315 Zie EHRM 8 juni 1976, Case of Engel a.o., \$93, p. 39-40 en EHRM 18 december 1986, Bozano Case, §61, p. 27. 
beperking beoogde doeleinden ${ }^{316}$. Toetsing aan artikel 18 vindt in het laatste geval in feite plaats bij de beoordeling van de desbetreffende beperkingsclausule, alhoewel het Hof in de desbetreffende zaken bij de beoordeling van de ingeroepen rechten artikel 18 niet expliciet aanhaalt. Anders ging dit in het rapport van de Commissie in de zaak Bozano. Met betrekking tot artikel 5 heeft de Commissie in díe zin een bijzondere uitspraak in verband met artikel 18 gedaan, dat de toetsing van de rechtmatigheid ("lawfulness") van de bestreden vrijheidsberoving in het kader van artikel 5 mede gebeurde aan de hand van artikel 18. De Commissie kwam uiteindelijk tot de conclusie, dat

"(...) the Limoges Administrative Court found that the enforcement of the deportation order - and hence the applicant's detention - was unlawful also on the ground that the executive (...) had sought to circumvent the competent judicial authority's veto on extraditing the applicant, which was binding on the French Government. The Commission consequently considers that since detention with a view to extradition was no longer possible in French law, the applicant's detention had a purpose different from detention with a view to deportation, as provided for in Article $5 \S 1$ (f)."

Het laatstgenoemde artikel was derhalve volgens de Commissie geschonden. Over de al dan niet schending van artikel 18 zelf heeft de Commissie in deze zaak niet explicíet een uitspraak gedaan. ${ }^{317}$

Alhoewel de praktijk van de Commissie ook niet zonder kritiek is gebleven ${ }^{318}$. geeft met name het oordeel van de Commissie in de zaak Bozano hoop voor de toepassing van artikel 18. Van Dijk en van Hoof merken hieromtrent op:

"Aldus is artikel 18, evenals artikel 14, in feite tot een integraal onderdeel gemaakt van al die bepalingen van de Conventie, waarin de rechten en vrijheden geregeld zijn, althans voor zover deze bepalingen

31.6 Zie EHRM 8 juni 1976, Case of Engel a.o., $\$ 104$, pp. $42-43$ en EHRM 7 december 1976. Handyside Case, \$64, p. 30.

317 Zie Rapp.Comm. 7 december 1984, Bozano Case, $\$ \$ 72$ e.v., p. 33 e.v..

318 Zie bijvoorbeeld P. van Dijk en G.J.H. van Hoof, De europese conventie in theorie en praktijk, pp. 627-629 ten aanzien van de zaak Kamma. 
enige beperking van de daar geregelde rechten en vrijheden toelaten. ${ }^{319}$

Toch moet niet uit het oog verloren worden dat, zoals ook al uit het bovenstaande blijkt, dat men wat betreft de toetsing aan artikel $18 \mathrm{nu}(\mathrm{nog})$ niet al te veel van het Hof hoeft te verwachten, omdat het tot nu toe nog geen afzonderlijk onderzoek naar de naleving van artikel 18 heeft ingesteld. Naar aanleiding van de praktijk van het Hof zou men de vraag kunnen stellen wat de extra betekenis van artikel 18 is naast de beperkingsmogelijkheden in de overige bepalingen van de Conventie. Zoals van Dijk en van Hoof mijns inziens terecht opmerken gaat het Hof er op deze manier aan voorbij, dat artikel 18 niet spreekt van "any purpose in violation of the said rights and freedoms", maar van "any purpose other than those for which they have been prescribed". Mocht er op grond van een onderzoek in het kader van artikel 10 lid 2 geconcludeerd worden dat artikel 10 niet geschonden is, dan moet het toch mogelijk zijn dat de conclusie op grond van artikel 18 anders is. Van Dijk en van Hoof:

"Toetsing aan het tweede lid van artikel 10 geeft immers alleen antwoord op de vraag, of de overheid van mening kon zijn dat de maatregel nodig was ter bescherming van een der daar genoemde waarden. Op de werkelijke motieven van de instantie die die maatregel heeft genomen, wordt daarbij dan nog niet ingegaan; die komen aan de orde bij de toetsing aan de hand van artikel 18."

Wijziging van de houding van het Hof ten aanzien van artikel $18 \mathrm{zou}$ derhalve zeer welkom zijn. ${ }^{321}$

Aangezien artikel 18 spreekt van "restrictions permitted under this Convention" lijkt het alsof hiermee alle beperkingsmogelijkheden worden bedoeld, waarin de Conventie voorziet. Echter, omdat gesproken wordt van het voor een bepaald "doel" gebruiken van een beperkingsmogelijkheid, is het aannemelijk, dat artikel 18 alleen betrekking kan hebben op beperkingsmogelijkheden, die gekoppeld zijn aan een bepaald doel. Artikel 18 zal derhalve nooit in verband met de rechten

319 P. van Dijk en G.J.H. van Hoof, De europese conventie in theorie en praktijk, p. 631 .

320 P. van Dijk en G.J.H. van Hoof, De europese conventie in theorie en praktijk, pp. 629-630.

32.1 Anders: $J$. Velears, De beperkingen van de vrijheid van meningsuiting, p. 312 (nr. 321). 
en vrijheden, die worden genoemd in paragraaf 2.4 .4 worden ingeroepen, omdat deze rechten en vrijheden niet zijn voorzien van beperkingsmogelijkheden. Hetzelfde zal gelden voor de artikelen genoemd in paragraaf 2.4.3.2 indien geen sprake is van een toestand van oorlog of noodtoestand op grond van artikel $15 .^{322}$ Ook lijkt het inroepen van artikel 18 in verband met de rechten genoemd in paragraaf 2.4.2.2 niet erg zinvol, omdat de hier besproken omschrijvingen van rechten en vrijheden niet gekoppeld zijn aan een bepaald doel. De toepassing van artikel 18 lijkt derhalve alleen mogelijk te zijn in verband met de rechten genoemd in de paragrafen $2.4 .2 .1,2.4 .2 .5,2.4 .2 .6,2.4 .3 .2$ - in geval van oorlog of noodtoestand - en eventueel 2.4 .2 .3 en 2.4.2.4.

\subsubsection{Voorbehouden: artikel 64 ECRM $^{23}$}

In de paragrafen 2.4.2.1 tot en met 2.4.4 zijn diverse methoden besproken volgens welke een Staat een beperking kan aanbrengen op bepaalde rechten en vrijheden en daarmee op de uit die rechten en vrijheden voor de Staat voortvloeiende verplichtingen. Deze methoden veronderstellen derhalve, dat de Staat volledig aan bepaalde verdragsverplichtingen is gebonden.

Door middel van het maken van een voorbehoud beperkt een Staat niet zijn verdragsverplichtingen, maar aanvaardt hij die verplichtingen niet: die verplichtingen bestaan niet voor die desbetreffende Staat. Het gaat hier om een "beperking" van rechten en vrijheden, die niet mogelijk is voor alle Staten, maar slechts voor bepaalde Staten, namelijk voor díe Staten die een bepaald voorbehoud hebben gemaakt. ${ }^{324}$

Een voorbehoud dat een Staat maakt bij ondertekening of ratificatie van de Conventie, moet volgens artikel 64 betrekking hebben op een bepáálde verdragsbepaling en een bepáálde nationale wet, die op dat moment van kracht is en in strijd met de desbetreffende verdragsbepaling is.

Een artikel betreffende het maken van voorbehouden $\mathrm{kwam}$ voor het eerst ter sprake bij het Comité van Experts naar aanleiding van een Deens

322 Zie, bijvoorbeeld, Rapp.Comm. 14 juli 1974. zaak nr. 4771/71, Kamma v. the Netherlands, p. 316: "The 'right of security' of person is guaranteed in absolute terms. This means that there can be no violation of Article 18 in conjunction with this right."

323 Zie vooi voorbehouden in het algemeen en in het bijzonder in verband met (VN)verdragen inzake de Rechten van de Mens: L. Lijnzaad, Reservations to UNHuman Rights Treaties.

324 A. Kiss, Les clauses de limitation et de dérogation dans la Convention Européenne des Droits de l'Homme, pp. 121-122. Vergelijk artikel 2, eerste lid, sub d Weens Verdragenverdrag. 
voorstel bij de Commission on Human Rights van de Verenigde Naties. Of een dergelijk artikel in de Conventie zou moeten worden opgenomen, was echter een zodanig politieke kwestie, dat het Comité van Experts zich beperkte tot het doen van enkele suggesties aan het Comité van Ministers. Naar aanleiding van een Brits voorstel, kwam vervolgens de kwestie van de voorbehouden ter sprake tijdens de Conference of Senior Officials in samenhang met de vraag of er een artikel moest worden opgenomen betreffende een "solemn declaration by which the internal laws of the High Contracting Parties shall give full effect to the provisions of the Convention". De laatstbedoelde vraag werd ontkennend beantwoord. Volgens de Senior Officials

"[is] ... in the absence of any provision to the contrary, every signatory State ... presumed to give full effect to the provisions of the Convention from the moment the State has given its adherence."

Anderzijds achtten de Senior Officials het wel noodzakelijk te voorzien in een bepaling, die het de Verdragsstaten zou toestaan om voorbehouden te maken met betrekking tot de handhaving van bepaalde bestaande nationale wetten, die niet in overeenstemming waren met een bepaalde verdragsbepaling. ${ }^{325}$ Deze bepaling werd neergelegd in artikel 60 van het ontwerp van de Conference on Senior Officials. De Commissie voor Juridische en Administratieve Zaken stelde naar aanleiding van het ontwerp van de Senior Officials nog voor om aan het maken van een voorbehoud de voorwaarde te stellen, dat dit voorbehoud zou worden aanvaard door een gekwalificeerde meerderheid van de andere Partijen bij het Verdrag. Dit voorstel werd gedaan omdat men vreesde dat door het maken van voorbehouden de Conventie zou worden ontdaan "of its practical effect and in any case of its moral authority. ${ }^{\text {326 }}$

Het Comité van Ministers ging niet in op dit voorstel van de Juridische Commissie en nam artikel 60 van het ontwerp van de Conference of Senior Officials over in het huidige artikel 64.

325 Report of the Conference of Senior Officials, (a) text of the report submitted by the Conference to the Committee of Ministers (doc. CM/WP 4 (50) 19;CM/WP 4 (50) 16 rev.;A 1431), met name \& III. "Problems considered by the Conference", in: Council of Europe, Collected Edition of the "Travaux Préparatoires", Vol. IV, pp. 242-294(256).

326. Brief van 24 juni 1950 van Sir David Maxwell-Fyfe, Voorzitter van de Commissie voor Juridische en Adrninistratieve Zaken, aan de Voorzitter van het Comité van Ministers (Ref. D 280/3/50; Doc. CM (50) 29), in: Council of Europe, Collected Edition of the "Travaux Préparatoires", Vol. V, p. 60. 
Wat betreft de bovengenoemde voorwaarde met betrekking tot de aanvaarding van voorbehouden door andere Verdragsstaten, kan worden opgemerkt dat de niet-opneming van deze voorwaarde in artikel 64 niet verhinderd heeft, dat Verdragsstaten bij hun beroep op artikel 64 meermalen verwezen hebben naar het gebrek aan bezwaren bij die andere Verdragspartijen tegen het desbetreffende voorbehoud..$^{327}$

Overigens blijkt uit de jurisprudentie, dat het al dan niet aanvoeren van bezwaren door andere Verdragspartijen of zelfs de Secretaris-Generaal, geen enkel effect heeft op de beantwoording van de vraag of de Straatsburgse organen bevoegd zijn om voorbehouden en de zogeheten "interpretatieve verklaringen" aan artikel 64 te toetsen. De bevoegdheid van deze organen vloeit namelijk voort uit de specifieke aard van de Conventie. Volgens de Commissie in de zaak Temeltasch was het niet de bedoeling van de Verdragsstaten om door middel van de Conventie

"(...) to concede to each other reciprocal rights and obligations in pursuance of their individual national interests, but ... to establish a common public order of the free democracies of Europe with the object of safeguarding their common heritage of political traditions, ideals, freedom and the rule of law. "32s

Volgens de Commissie zijn de door de Staten aangegane verplichtingen van een wezenlijk objectief karakter, wat onder meer duidelijk wordt uit het toezichtmechanisme dat door de Conventie is ingesteld. Uit het systeem van de Conventie vloeit derhalve, aldus de Commissie, haar bevoegdheid voort om in een bepaald geval vast te stellen, of een voorbehoud of een interpretatieve verklaring al dan niet in overeenstemming is met de Conventie. Dit zou tevens blijken uit het feit dat, alhoewel er nog niet eerder een uitspraak was gedaan over de geldigheid van een voorbehoud of interpretatieve verklaring, de Commissie en het Hof wèl in verscheidene zaken waren overgegaan tot interpretatie van een voorbehoud of een interpretatieve verklaring. ${ }^{329}$

327 Zie Rapp.Comm. 5 mei 1982, zaak nr. 9116/80, Temeltasch Case, $\$ 50$, p. 144 en EHRM 29 april 1988, Belilos Case, \$47, p. 23. Beide zaken betroffen overigens geen voorbehouden, maar "interpretatieve verklaringen". Zie hierna.

328 Idem, pp. 144-145.

329 Idem, p. 145. Zie ook. EHRM 29 april 1988, Belilos Case, §50, p. 24, waar het Hof met name verwijst naar artikel 19,45 en 49 . Zie verder $L$. Lijnzaad, Reservations to UN-Human Rights Treaties, pp. 114, 122. 
In het voorgaande werd al een aantal keren de interpretatieve verklaring genoemd. Artikel 64 spreekt alleen van voorbehouden, maar in praktijk blijken Staten bij ondertekening, ratificatie, toetreding, aanvaarding of goedkeuring van een verdrag een verklaring af te leggen met betrekking tot hun opvatting over een bepaalde onderwerp of met betrekking tot hun interpretatie van een specifieke verdragsbepaling. Een dergelijke verklaring kan bestaan uit louter een verheldering van de standpunten van de Staat, maar kan ook

\section{"(...) amount to a reservation, according as it does not vary or exclude the application of the terms of the treaty as adopted. "330}

In het geval een Staat ter afwering van een klacht een beroep doet op een dergelijke interpretatieve verklaring, zullen de Straatsburgse organen derhalve eerst moeten vaststellen of het hier gaat om een verklaring, die gelijk kan worden gesteld met een voorbehoud op grond van artikel 64 . Deze kwestie kwam aan de orde in de zaak Belilos. Uit deze zaak wordt in ieder geval duidelijk dat het voor de bepaling van de aard van een interpretatieve verklaring niet van belang is, dat deze verklaring volgens dezelfde procedure is opgesteld als een voorbehoud. Volgens het Hof is dit de normale procedure. ${ }^{31}$ Verder was het Hof van mening dat het ontbreken van een uniforme terminologie, zowel in voorbehouden en interpretatieve verklaringen als in de Conventie zelf, op zichzelf geen rechtvaardiging biedt om een verklaring als een voorbehoud te karakteriseren. $^{332}$

De beantwoording van de vraag of een als interpretatief gekenmerkte verklaring als voorbehoud beschouwd moet worden was in casu met name moeilijk omdat de desbetreffende Verdragsstaat, Zwitserland, zowel voorbehouden als interpretatieve verklaringen in het instrument van ratificatie had neergelegd..$^{333}$

Volgens het Hof is het noodzakelijk om vast te stellen wat de corspronkelijke bedoeling was van degenen die de verklaring hebben opgesteld. ${ }^{34}$ Dit stemt overeen met de opvatting van de Commissie in de

330. Aldus de International Law Commission van de Verenigde Naties in: United Nations Conference on the Law of Treaties, official records, New York, 1971, p.10. Zie ook artikel 2 lid 1 sub d van het Weens Verdragenverdrag.

331 EHRM 29 aprill 1988, Belilos Case, $\$ 45$, p. 22.

332 EHRM 29 april 1988, Betilos Case, \$46, p. 23.

333 EHRM 29 april 1988, Belilos Case, \$49, p. 24.

334 EHRM 29 april. 1988, Belilos Case, \$\$48-49, pp. 23-24. 
zaak Temeltasch. De Commissie acht het van belang de bedoeling van de opstellers van de verklaring te achterhalen, omdat de Commissie

"(...) considers that where a State makes a declaration, presenting it as a condition of its consent to be bound by the Convention and intending to exclude or alter the legal effect of some of its provisions, such a declaration, whatever it is called, must be assimilated to a reservation within the meaning of Article 64 of the Convention."

De Commissie interpreteert vervolgens de bedoeling van de betrokken Staat door zowel de bewoordingen van de interpretatieve verklaring in beschouwing te nemen als ook de travaux préparatoires bij de Zwitserse ratificatie van de Conventie. ${ }^{335}$

In de zaak Belilos, bepaalt het Hof, dat gebleken is, dat Zwitserland oorspronkelijk van plan was een formeel voorbehoud te maken, maar later gekozen heeft voor de term "verklaring", zonder hiervoor de redenen geheel duidelijk te maken. ${ }^{336}$

Wat betreft de substantiële inhoud van de verklaring stelt het Hof vast, dat de bedoeling van Zwitserland was om bepaalde categorieën procedures uit het bereik van artikel 6 lid 1 te halen om zichzelf te beschermen tegen interpretaties van dat artikel, die het te ruim achtte. Vervolgens gaat het Hof ertoe over de geldigheid van de interpretatieve verklaring aan de hand van de vereisten in artikel 64 te onderzoeken als ware het een voorbehoud. Het Hof geeft derhalve geen antwoord op de hierboven geformuleerde vraag of de desbetreffende interpretatieve verklaring gelijk kan worden gesteld met een voorbehoud. ${ }^{337}$

Artikel 64 lid 1 bepaalt onder meer dat een gemaakt voorbehoud niet algemeen van aard mag zijn. Deze eis werd door de Commissie in de Temeltasch-zaak geïnterpreteerd aan de hand van de internationale juridische doctrine en de relevante bepalingen van het Weens Verdragenverdrag. Volgens de Commissie is een voorbehoud algemeen van aard indien het niet verwijst naar een specifieke bepaling van de

335 Rapp.Comm. 5 mei 1982, zaak nr. 9116/80, Temeltasch Case, $\$ \$ 73-74$, p. 147. Zie ook artikel 2, eerste lid, sub d Weens Verdragenverdrag, waarnaar de Commissie uitdrukkelijk verwijst, en $L$. Lijnzaad, Reservations to UN-Human Rights Treaties. p. 118 (bovenaan).

336 EHRM 29 april 1988. Belilos Case, \$48, p. 23.

337 Idem, p. 24. De Commissie deed dit overigens wel in Rapp.Comm. 5 mei 1982, zaak nr. 9116/80, Temeltasch Case, \$82, p. 148. Zie oak L. Lijnzaad, Reservations to UN-Human Rights Treaties, pp. 121-122. 
Conventie of indien het op zodanige wijze is geformuleerd, dat de reikwijdte van het voorbehoud niet kan worden vastgesteld. ${ }^{38}$ Het Hof bepaalde in de Belilos-zaak dat de woorden "reservation of a general character" verwijzen naar een voorbehoud dat vervat in bewoordingen die te vaag of te ruim zijn om de vaststelling van de exacte betekenis en reikwijdte van dat voorbehoud mogelijk te maken. ${ }^{39}$ Hiervan is, zo blijkt uit het arrest in de zaak Chorherr, geen sprake indien, zoals in deze zaak, het voorbehoud een aantal wetten bestrijkt die "constitute a well-defined and coherent body of substantive and procedural administrative provisions". 300

Artikel 64 lid 2 verplicht de Staat die een voorbehoud wenst te maken om in het voorbehoud een korte uiteenzetting te geven van de desbetreffende wetgeving. Volgens de Commissie moet deze verplichting gezien worden als supplementaire voorwaarde bij en in het licht gelezen worden van lid 1, dat eist dat het voorbehoud betrekking heeft op de op dat moment geldende wetgeving en dat het voorbehoud niet algemeen van aard is. Bovendien stelt een dergelijke uiteenzetting van de desbetreffende wetgeving de andere Verdragsstaten, de Verdragsorganen en enig andere betroffen persoon in de gelegenheid kennis te nemen van deze wetgeving. ${ }^{341}$ Het Hof heeft daar nog aan toegevoegd,

"(...) that the 'brief statement of the law concerned' both constitutes an evidential factor and contributes to legal certainty. The purpose of Article $64 \S 2$ is to provide a guarantee (...) that a reservation does not go beyond the provisions expressly excluded by the State concerned."

Dit is volgens het Hof niet slechts een puur formeel vereiste maar een substantiële voorwaarde. ${ }^{342}$

In de zaak Temeltasch overwoog de Commissie nog, dat de noodzaak om een uiteenzetting van de desbetreffende wetgeving in het voorbehoud op te nemen veel groter was in het geval dat het een zeer ruime verdragsbepaling betrof - zoals artikel 10, dan wanneer het ging om een bepaling met een veel smallere reikwijdte-zoals artikel 6 lid 3 sub e. In

338. Rapp.Comm. 5 mei 1982, zaak nr. 9116/80, Temeltasch Case. \$84, p. 149.

339 EHRM 29 april 1988. Belilos Case, \$55, p. 26. Zo ook EHRM 25 augustus 1993, Chorherr Case, $\$ 18$, p. 34.

340 EHRM 25 augustus 1993, Chorherr Case, $\$ 18$, p. 34.

341 Rapp.Comm. 5 mei 1982, zaak nr. 9116/80, Temeltasch Case, \$90, p. 150.

342. EHRM 29 april 1988, Belilos Case, 859, pp. 27-28. Zie ook EHRM 22 mei 1990, Weber Case, §38, p. 19 en EHRM 25 augustus 1993, Chorherr Case, §20, p. 34. 
het eerste geval was het mogelijk dat een voorbehoud, dat niet in overeenstemming was met het vereiste van artikel 64 lid 2, in strijd was met de Conventie en niet het effect had dat door de betrokken Verdragsstaat werd beoogd. In de desbetreffende zaak ging het echter om artikel 6 lid 3 sub 3, dat een erg specifiek beginsel bevat: de gratis bijstand van een tolk. Onder de omstandigheden van dit geval was het Zwitserse verzuim om een uiteenzetting van de desbetreffende wetgeving die in strijd was met het bedoelde beginsel te geven, niet van doorslaggevende betekenis. In dit geval waren de bewoordingen van de interpretatieve verklaringen voldoende om aan de klager of zijn advocaat duidelijk te maken dat het beginsel van gratis bijstand van een tolk niet zou kunnen worden ingeroepen tegen Zwitserland. ${ }^{343}$

Of het Hof, door in de zaak Belilos geen onderscheid te maken tussen voorbehouden die een ruime of een strikte bepaling van de Conventie betreffen, daarmee de hiervoor beschreven overweging van de Commissie afkeurt is niet zeker. In de zaak Belilos ging het namelijk om een voorbehoud dat betrekking had op een ruime verdragsbepaling - artikel 6 lid 1 - en dat bovendien van invloed zou kunnen zijn op de toepassing van artikel 6 lid 2 en lid 3 . Volgens de redenering van de Commissie zou het achterwege laten van een uiteenzetting van de desbetreffende wetgeving in het voorbehoud in dit geval dus wel beslissend moeten zijn. Omdat het Hof echter deze redenering van de Commissie niet overneemt en zonder meer overgaat tot de conclusie, dat niet aan het vereiste van artikel 64 lid 2 is voldaan, kan daarmee niet worden vastgesteld wat het standpunt van het Hof ten aanzien van deze redenering van de Commissie is. Mijns inziens is het twijfelachtig of het bij de toepassing van artikel 64 lid 2 onderscheid maken tussen ruime en strikte bepalingen van de Conventie zich verdraagt met de zojuist uit de zaak Belilos geciteerde overweging, dat het vereiste in het tweede lid niet slechts een puur formeel vereiste is maar een substantiële voorwaarde. Nu het geval zich - zeker in Nederland, maar waarschijnlijk ook in de andere Verdragsstaten - vaak voordoet, dat een wet alleen maar een kader schept, dat in nadere regelingen wordt ingevuld, lijkt het mij met het oog op het hierboven beschreven doel van artikel 64 lid 2 zeer wenselijk, dat een voorbehoud dat een dergelijke wet betreft kort de inhoud van de desbetreffende wetgeving weergeeft. Dit geldt des te sterker in federale landen - zoals de aangeklaagde Staat in de hier besproken zaken, Zwitserland - waar in de verschillende kantons/ staten andere wetgeving van kracht is. Niet voor niets vonden zowel de Commissie als het Hof de praktische moeilijkheden die Zwitserland zou 
ondervinden wanneer het een uiteenzetting van de wetgeving van alle kantons zou moeten geven in de desbetreffende interpretatieve verklaring, geen rechtvaardiging voor het niet voldoen aan artikel 64 lid $2{ }^{3.4}$

De vraag blijft, hoever een uiteenzetting van de bedoelde wetgeving in het voorbehoud moet gaan. Deze vraag wordt beantwoord in het arrest in de zaak Chorherr. Volgens het Hof is het niet noodzakelijk om een beschrijving, zelfs een beknopte, te geven van de inhoud van de desbetreffende teksten. In deze zaak achtte het Hof de verwijzing naar het blad waarin, in Oostenrijk, wetgeving officieel bekend wordt gemaakt en vooraf gegaan door een indicatie van het onderwerp van de relevante bepalingen, voldoende om het iedereen mogelijk te maken de bedoelde wetten te identificeren en informatie omtrent deze wetten te verkrijgen. Volgens het Hof bood het Oostenrijkse voorbehoud een waarborg tegen elke interpretatie "which would unduly extend the field of application of the reservation". Bijgevolg achtte het Hof dit voorbehoud niet in strijd met artikel 64 lid $2 .{ }^{\text {.as }}$

Ten aanzien van de zinsnede "any law then in force in its territory" heeft het Hof een uitspraak gedaan in de zaak Campbell and Cosans. Het ging hier om een voorbehoud met betrekking tot artikel 2 van het Eerste Protocol (recht op onderwijs). De desbetreffende wetgeving die in strijd was met deze verdragsbepaling en derhalve in het voorbehoud genoemd werd, stamde uit 1946 (Education (Scotland) Act 1946). De klacht betrof echter een wet uit 1962 (Education (Scotland) Act 1962), derhalve een wet die ná het maken van het voorbehoud tot stand gekomen was. Normaal gesproken zou het voorbehoud ten aanzien van deze wet geen gelding hebben gehad en had het Hof kunnen toetsen aan artikel 2 van het Eerste Protocol, ware het niet dat het Hof tot het oordeel kwam dat

\footnotetext{
"(...) section 29 (1) was no more than a re-enactment of an identical provision in the Education (Scotland) Act 1946 and therefore goes no further than a law in force at the time when the reservation was made. " 306
}

344 EHRM 29 april 1988, Belilos Case, \$\$58-59, p. 27. Zie ook Rapp.Comm. 5 mei 1982, zaak nr. 9116/80, Temeltasch Case, \$\$85-86, p. 149. Zie, anders, L. Lijnzaad, Reservations to UN-Human Rights Treaties, p. 118.

345 EHRM 25 augustus 1993, Chorherr Case, \$20, p. 34.

346 EHRM 25 februari 1982, Case of Campbell and Cosans, \$37, p. 17. Zie ook Besl.Comm. 7 april 1967, zaak nr. 2432/65, X v. Austria, p. 127. 
Hiervoor is slechts ingegaan op het maken van voorbehouden en interpretatieve verklaringen ten aanzien van de materiële bepalingen van de Conventie. Niet ingegaan zal worden op de vraag naar de toepasselijkheid van artikel 64 op de andere verdragsbepalingen, namelijk die welke het genot en de beperking van de rechten en vrijheden (artikelen 1 en 13 tot en met 18) en die welke het toezichtmechanisme (artikelen 19 tot en met 57 ) betreffen. ${ }^{3.47}$

\subsubsection{Korte samenvatting}

Aan het begin van deze paragraaf werd ingegaan op de achtergronden van de beperkingssystematiek, die in de Conventie is neergelegd. De belangrijkste grond is gelegen in de uiteindelijke keuze van de opstellers van de Conventie voor het nauwkeurig definiëren van de te waarborgen rechten en vrijheden in plaats van in algemene termen omschrijven ervan. Evenals de formulering van de rechten en vrijheden vallen ook de mogelijkheden tot beperking van deze rechten en vrijheden - behoudens een enkele uitzondering (zie par. 2.4.2.4) - tot deze keuze voor nauwkeurig definiëring terug te voeren.

Bij de bespreking van de diverse beperkingsmethoden in de Conventie werd een onderscheid gemaakt tussen rechten en vrijheden, die zowel in tijden van oorlog of noodtoestand als in tijden van rust kunnen worden beperkt; rechten en vrijheden, die alleen in tijden van oorlog en noodtoestand kunnen worden beperkt en rechten en vrijheden, waarbij in geen enkele beperkingsmogelijkheid is voorzien.

Vervolgens kwamen Conventie-bepalingen aan de orde, die grenzen stellen aan de uitoefening van de beperkingsbevoegdheden van de Staat. Tot slot kwam ook de mogelijkheid tot het maken van een voorbehoud ter sprake.

In deze paragraaf ging het om expliciet in de Conventie voorziene mogelijkheden om de rechten en vrijheden van individuen te beperken. Echter, zowel in het geval van "absolute" rechten als in het geval van rechten, die beperkt kunnen worden, is er nog plaats voor een nietuitdrukkelijk voorziene, maar desondanks belangrijke beperkingsmogelijkheid. Wanneer de rechter een bepaling interpreteert teneinde deze te kunnen toepassen, dan stelt de rechter daarbij de grenzen van het in deze bepaling vervatte recht vast. Volgens Kiss

347 Zie daarvoor onder andere P. van Dijk en G.J.H. van Hoof, De europese conventie in theorie en praktijk, pp. 672-674 en kort, ten aanzien van artikel 25, F.G. Jacobs, The European Convention on Human Rights, p. 214. 
"... il n'existe pas de droit subjectif qui serait illimite. D'une part, chaque droit subjectif comporte ses propres limites qui sont fixées, le cas échéant, par l'interprétation donnée par un juge." "as

Er is derhalve een beperkingsmogelijkheid gelegen in de rechterlijke interpretatietaak. De eerst als absoluut aangeduide rechten - omdat ze niet expliciet van een beperkingsmogelijkheid zijn voorzien - zijn dus toch niet zo absoluut. Ook de artikelen 3, 4 lid 1 en 7 ECRM (zie par. 2.4.4) zijn niet onbeperkt, de rechter zal ook via interpretatie de grenzen van de in deze bepalingen opgenomen rechten moeten vaststellen. Waar bijvoorbeeld artikel 4 lid 2 de rechter al criteria biedt om de grenzen vast te stellen van het verbod van dwangarbeid, zo zal de rechter deze criteria bij de interpretatie van het in lid 1 vervatte verbod van slavernij of dienstbaarheid zelf moeten ontwikkelen.

Het is derhalve van belang te onderzoeken hoe de rechter - de Straatsburgse instanties en de nationale rechter - in de praktijk met die interpretatietaak omgaat, hoe de rechter die criteria vaststelt. Daarbij is het met name interessant te onderzoeken of de rechterlijke instanties, net als bij diverse van de hierboven besproken beperkingsmogelijkheden, aan de Staten een zekere beoordelingsvrijheid ("margin of appreciation") overlaten - door vage of geen afbakeningscriteria te hanteren - ofwel hier zelf strikt de grenzen van de rechten vaststellen. Dit onderzoek zal in de hoofdstukken 4 en 5 gebeuren. Eerst zal in het volgende hoofdstuk ingegaan worden op de beperkingssystematiek in het eerste hoofdstuk van de Grondwet 1983 en de achtergronden daarvan. 


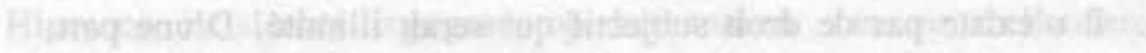

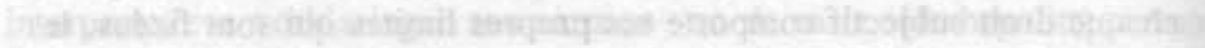

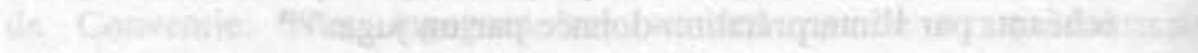

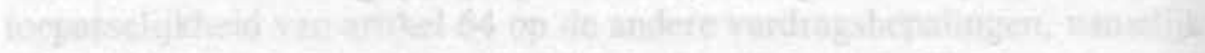

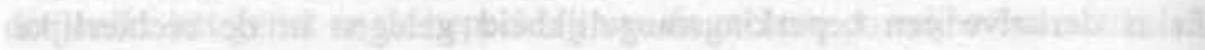

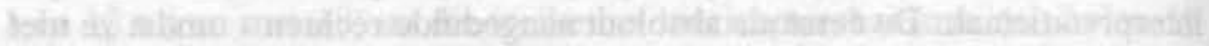

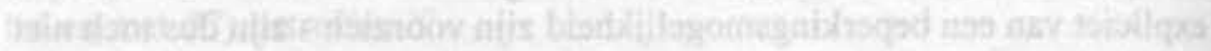

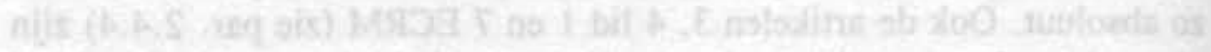

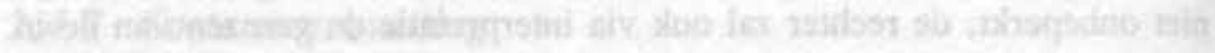

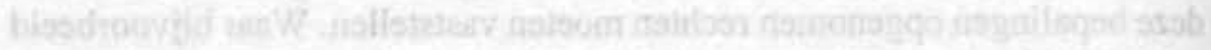

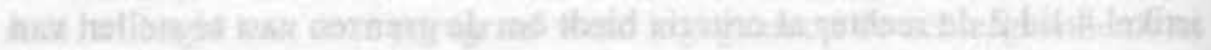

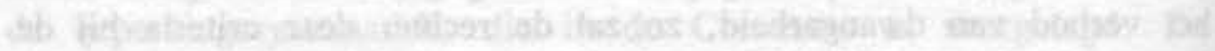

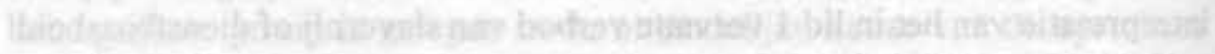

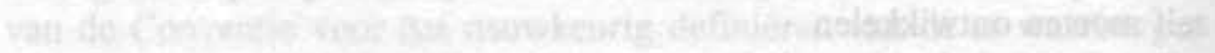

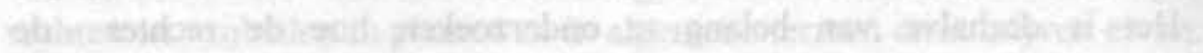

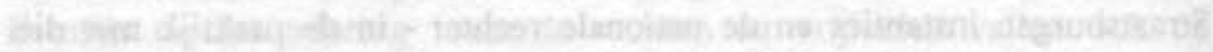

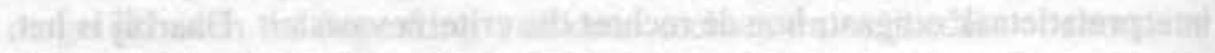

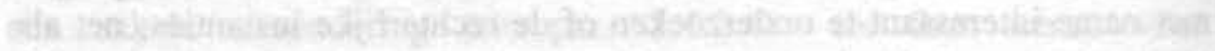

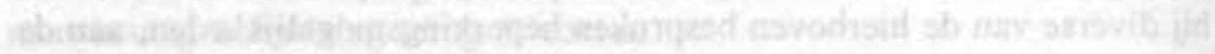

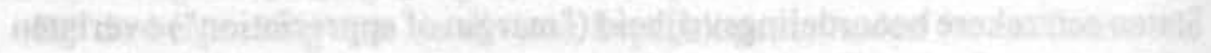

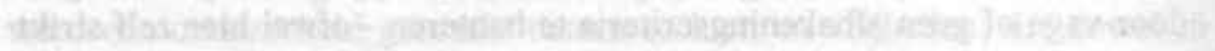

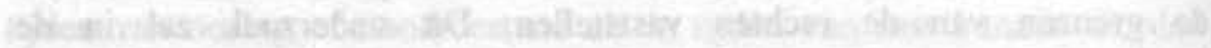

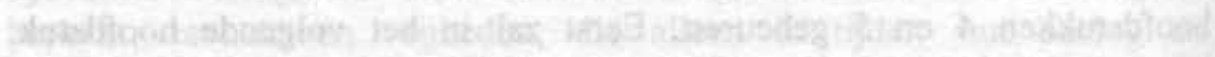

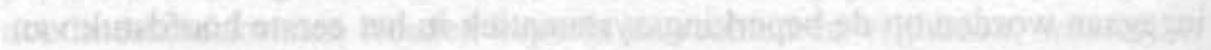

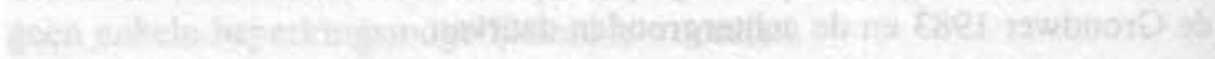

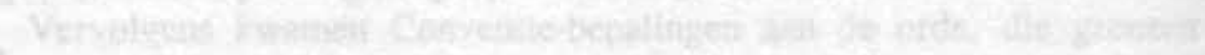




\section{De beperkingssystematiek in Hoofdstuk I van de Grondwet van 1983}

Zoals aangekondigd in paragraaf 2.1 wordt in dit hoofdstuk de Grondwet van 1983 in een historische context geplaatst en zal hierbij met name gekeken worden naar de totstandkomingsprocedure van de algehele grondwetsherziening in 1983. De nadruk komt vanzelfsprekend te liggen op de in de Grondwet opgenomen grondrechten. Dit alles gebeurt in paragraaf 3.1 .

In de daaropvolgende paragraaf 3.2 wordt de beperkingssystematiek ten aanzien van de in de Grondwet opgenomen grondrechten onder de loep genomen worden. Daarbij zal ook gekeken worden naar de inhoudelijke fundering van deze beperkingssystematiek en naar de praktijk ten aanzien van de voorziene beperkingsmogelijkheden.

\subsection{Achtergronden van de herziening van de Grondwet in 1983 en met name van Hoofdstuk I}

De Grondwet van 1814 bevatte slechts enkele grondrechten. Hieronder waren, onder andere, de gelijke benoembaarheid voor Nederlanders in de openbare dienst, gelijkheid voor de wet, de vrijheid van godsdienst, van drukpers en de zorg voor het onderwijs. In 1948 werden de vrijheid van onderwijs en van vereniging en vergadering opgenomen. Pas bij de algehele grondwetsherziening van 1983 is de grondrechtencatalogus uitgebreid.' Deze algehele grondwetsherziening werd op gang gebracht in de jaren vijftig. Hierna zal kort de ontwikkeling van de grondwetsherziening van 1983 beschreven worden.

Een algehele grondwetsherziening komt voor het eerst ter sprake in de Troonrede van 1946, waarin deze herziening wordt aangekondigd. In 1950 wordt de Staatscommissie Van Schaik ingesteld. Deze commissie krijgt de opdracht om advies aan de regering uit te brengen omtrent de herziening van de grondwet. Hiermee wordt volgens de formele taakopdracht vooral gedoeld op een tot stand te brengen nieuwe rechtsorde, waarmee men reeds van start gegaan is. Uit de installatierede van de (toenmalige) minister-president Drees, blijkt echter dat het in de bedoeling ligt om een algehele grondwetsherziening voor te bereiden. Volgens Drees, is een Grondwet in belangrijke mate de juridische neerslag van de 
maatschappelijke ontwikkeling. Deze maatschappelijke ontwikkeling is door de schok van de oorlog en de bezetting sterk versneld. Zo zijn er veranderingen in de internationale positie, de internationale verhoudingen en de rechtsvorming van Nederland opgetreden evenals in de militaire positie, de verhouding tot de vroegere koloniale gebieden en de betekenis van het economische en sociale bestel. Er is sprake van de opkomst van een tijdperk waarin de nadruk ligt op het belang van de grotere en kleinere gemeenschappen, waarbij de bescherming per persoonlijkheid bijzondere aandacht vraagt.

Naar de mening van Drees kunnen de hoofdbeginselen van onze constitutionele instellingen beproefd geacht worden en behoeven daarom geen heroverweging. De uitwerking van deze hoofdbeginselen beschouwt hij wel als voor wijziging vatbaar. Een van de vragen die dan ook door de Staatscommissie onderzocht moeten worden is in hoeverre de formulering van "door de staten te eerbiedigen of te verzekeren menselijke rechten" wijziging behoeft en of ook een aantal sociale rechten met grondwettelijke waarborgen dienen te worden omgeven. ${ }^{2}$

Op 6 januari 1954 brengt de Staatscommissie Van Schaik een rapport uit. Bij de opstelling van het rapport is de commissie uitgegaan van de gedachte van de historische continuiteit, wat wil zeggen dat men zich er van onthouden heeft het historisch gegroeide zonder meer af te breken. Wat betreft de systematiek van de Grondwet heeft de Staatscommissie zich laten leiden door historische motieven én praktische overwegingen en is daarbij afgeweken van de systematiek van de bestaande Grondwet. Teneinde de in de Grondwet geregelde onderwerpen zodanig te rangschikken, dat een praktisch overzicht ontstaat, is de Grondwet in hoofdstukken en afdelingen onderverdeeld. ${ }^{3}$

De grondrechten zijn terug te vinden in de hoofdstukken $1,6,7,8,9$ en 10 van het ontwerp van de Staatscommissie. ${ }^{4}$ Hoewel de verschillende bepalingen met betrekking tot grondrechten nog over een aantal hoofdstukken verspreid zijn, zijn de meeste terug te vinden in het zevende hoofdstuk, zoals, onder andere, het nieuw ontworpen non-discriminatieartikel (artikel 4c), het gelijkheidsbeginsel (artikel 4), het petitierecht (artikel 8), de drukpersvrijheid (artikel 7) en de vrijheid van vereniging en

2 De parlementaire geschiedenis van de Proeve van een nieuwe Grondwet (1950 begin 1967), pp. 1-4.

3 Eindrapport van de Staatscommissie tot herziening van de Grondwet, pp. 15-19.

4 Dit zijn respectievelijk de hoofdstukken "Van het Koninkrijk", "Van de justitie". "Van de rechtswaarborgen", "Van de godsdienst", "Van het onderwijs" en "Van het maatschappelijk welzijn". 
vergadering (artikel 9). Overigens mag uit het feit, dat de meeste grondrechten in hoofdstuk 7 zijn terug te vinden volgens de Staatscommissie niet worden afgeleid dat de commissie op principiële gronden er de voorkeur aan heeft gegeven de grondrechten in de Grondwet als een speciale groep van artikelen te ordenen.

Tenslotte kan hier ook nog het streven van de Staatscommissie naar uniformiteit in het taalgebruik genoemd worden. Met name ten aanzien van het vraagstuk van de delegatie wordt hieraan door de commissie grote waarde gehecht. Volgens de commissie dient de grondwetgever zich te bedienen van een terminologie die een duidelijk onderscheid mogelijk maakt tussen grondwetsbepalingen die beogen dat de wetgever de aangewezen taak zelf geheel verricht en bepalingen waarin deze strekking niet besloten ligt. ${ }^{6}$

Het rapport van de Staatscommissie zal echter niet leiden tot de beoogde algehele herziening van de Grondwet. De kritiek die op het rapport wordt geuit, luidt, onder andere, dat het rapport geen visie op de toekomst uitstraalt, dat de Staatscommissie meer broddelwerk dan perspectief op een bevredigend staatsbestel opent en dat de voorgestelde Grondwet toekomstige ontwikkelingen eerder zal tegenhouden dan bevorderen. Ook de politieke belangstelling voor hervorming van de staatsrechtelijke structuren is inmiddels aanzienlijk afgenomen. Het uitgebrachte rapport kan hierin geen verandering aanbrengen. Wel leidt het rapport tot partiële grondwetsherzieningen in 1953, 1956 en 1963.

Naar aanleiding van deze laatste grondwetsherziening barst een storm van protest los. Vele leden van de Staten-Generaal betreuren het feit, dat de voorstellen van de Staatscommissie Van Schaik tot zo weinig geleid hebben. Een groot aantai parlementariërs meent, dat de bestaande Grondwet hopeloos verouderd is. Anderen hebben bezwaren tegen de herhaalde kamerontbindingen die plaatsvinden ter gelegenheid van incidentele grondwetswijzigingen. Dit zou de continuïteit en de stabiliteit van het staatkundige leven aantasten. Aangedrongen wordt op de instelling van een nieuwe staatscommissie ter voorbereiding van een algehele grondwetsherziening. Anderen willen verdere grondwetsherzieningen een halt toe roepen, omdat men vindt dat ofwel de Grondwet wél aan de eisen 
des tijds voldoet, ofwel dat het klimaat voor een ingrijpende grondwetswijziging niet aanwezig is."

De minister van Binnenlandse Zaken, Toxopeus, gaat op 25 november 1963 over tot de instelling van een afdeling grondwetszaken. Deze afdeling moeten zich gaan bezighouden met "bestaande verlangens tot wijziging van de Grondwet". Een discussiestuk moeten worden opgesteld over de gewenste veranderingen in de Grondwet. Ook wordt overgegaan tot de vorming van een werkgroep van staatsrechtsgeleerden, waarmee de afdeling contacten moet onderhouden teneinde de adviezen in te kunnen winnen van deskundigen op staatsrechtelijk terrein. ${ }^{10}$

Op 15 september 1964 wordt in de Troonrede een Proeve tot grondwetswijziging aangekondigd. " De bedoeling is niet om meteen een nieuwe Grondwet tot stand te brengen: de aard van de Proeve zal een discussiestuk zijn en niet een voorontwerp. ${ }^{12}$ De Proeve wordt in het voorjaar van 1966 gepubliceerd.

Bij de opstelling van de Proeve hebben de opstellers gebruik gemaakt van het rapport van de Staatscommissie Van Schaik. Echter, anders dan deze commissie is bij de opstelling van de Proeve niet zonder meer uitgegaan van de bestaande Grondwet. De Staatscommissie had dit wel gedaan, omdat ze in de bestaande verhouding tussen het grondwettelijke recht en het overige geschreven of ongeschreven constitutionele recht in beginsel geen verandering aan wilde brengen. Dit had er echter wel toe geleid, dat de omvang van de Grondwet in het ontwerp van de Staatscommissie aanzienlijk was toegenomen. ${ }^{13}$ Mede om die reden hebben de opstellers van de Proeve een ander uitgangspunt gekozen. Niet alleen het tot stand brengen van staatkundige hervormingen zal het doel zijn van de grondwetsherziening, maar ook een "technische modernisering

8 De parlementaire geschiedenis van de Proeve van een nieuwe Grondwet, hoofdstuk VI Rondom de grondwetsherziening van 1963. pp. 111-173.

9 De parlementaire geschiedenis van de Proeve van een nieuwe Grondwet. p. 135.

10 De parlementaire geschiedenis van de Proeve van een nieuwe Grondwel. pp. 154155.

11 De parlementaire geschiedenis van de Proeve van een nieuwe Grondwet, p. 174.

12 Reactie van minister Toxopeus op gemaakte opmerkingen tijdens de behandeling van. het wetsvoorstel tot vaststelling van hoofdstuk VII (Binnenlandse Zaken) in de Vaste Commissie voor Binnenlandse Zaken II m.b.t. de Rijksbegroting van 1965 (Zitting 1964-1965 II. p. C 41 e.v.), in: De parlementaire geschiedenis van de Proeve van een nieuwe Grondwet, pp. 185-186.

13 Toelichting op de ontwerp-Grondwet, in: Proeve van een nieuwe grondwet, pp. 21$33(31)$. 
en besnoeiing" van de grondwetsbepalingen. ${ }^{14}$ Volgens de opstellers van de Proeve is namelijk gebleken, dat gedetailleerde regelingen van de bestaande grondwet geen voordeel brengen bij de versnelling van de ontwikkeling in staat en maatschappij. Om de Grondwet meer te doen aansluiten bij de "hedendaagse beweeglijkheid van de verhoudingen en ontwikkelingen" willen de opstellers van de Proeve de inhoud van de Grondwet tot een minimum beperken. De grondwetsbepalingen moeten alleen rechtsregels bevatten, zodat de noodzaak tot aanpassing van de Grondwet aan veranderende omstandigheden vermindert. Daarbij blijft de "bijzondere bevestiging van een aantal grondslagen van het constitutioneel bestel" in de Grondwet behouden. ${ }^{15}$ Een ander uitgangspunt van de opstellers van de Proeve is bovendien, dat ze de band met de bestaande staatkundige structuur niet hebben willen loslaten, omdat een fundamentele wijziging van het staatsbestel niet wordt beoogd..$^{16}$

In vergelijking met de bestaande Grondwet zijn de volgende punten karakteristiek voor de Proeve: 1 . bekorting en vereenvoudiging; 2 . modernisering qua terminologie en qua redactionele opzet van de bepalingen; 3 . een meer overzichtelijke systematiek; 4 . een versterking van het normatieve karakter doordat de programmatische en niet-juridische bepalingen zijn vervallen en 5. een grotere "openheid" van de voorschriften door schrapping van overbodige details, waardoor met name de wetgever ruimere vrijheid krijgt. ${ }^{17}$

Volgens de opstellers is de hergroepering van het constitutionele recht mogelijk de meest vèrstrekkende vernieuwing in de proeve. Een deel van het huidige grondwettelijke recht is overgeheveld naar de constitutionele sfeer buiten de Grondwet. ${ }^{18}$ Deze hergroepering is ook waarneembaar in de systernatiek van de in de Proeve voorgestelde Grondwer. Hoewel in navolging van de Staatscommissie Van Schaik de "historische gedaante" van de Grondwet niet moet worden aangetast en daarnaast de indeling van de Grondwet overzichtelijk moet zijn. is de systematiek in dit ontwerp anders dan in dat van de Staatscommissie. Het ontwerp in de Proeve toont een andere hoofdstukindeling. Zo springt met name de samenvatting van de grondrechten in een afzonderlijk hoofdstuk in het oog. Door de plaatsing van dit hoofdstuk aan het begin van de Grondwet wordt 
bovendien reliëf gegeven aan de betekenis van deze grondrechten. ${ }^{13}$ Toch zijn ook buiten dit hoofdstuk bepalingen met betrekking tot grondrechten terug te vinden, zoals ten aanzien van het kiesrecht (artikelen 37 en 39), de gelijkstelling van het openbaar en bijzonder onderwijs (artikel 71, de vrijheid van onderwijs staat wél in het hoofdstuk Grondrechten, in artikel 6), gewetensbezwaren bij militaire dienst (artikel 72) en derogatie van grondrechten in geval van een uitzonderingstoestand (artikel 73). Opvallend is echter, dat in dit grondrechten-hoofdstuk geen sociale grondrechten zijn opgenomen. De Proeve bevat slechts een raambepaling (artikel 69), die spreekt van "maatschappelijke "rechten". Deze raambepaling verplicht de wetgever niet om de desbetreffende rechten te vestigen en te regelen, maar houdt een grondwettelijke erkenning van deze rechten in. Volgens de opstellers van de Proeve ligt de betekenis van de bepaling in de erkenning van maatschappelijke rechten als juridische aanspraken van de individuele mens en in het feit dat deze rechten hoofdzakelijk "onder de hoede van de nationale wetgever worden gesteld". ${ }^{20}$

De publikatie van de Proeve wordt gevolgd door een stroom van adviezen van politieke partijen, maatschappelijke organisaties, officiële adviesinstanties en kerkelijke organen, die op uitnodiging van de Minister van Binnenlandse Zaken worden uitgebracht. ${ }^{21}$

Op 26 juli 1967 wordt op initiatief van de regering De Jong de Staatscommissie Cals/Donner ingesteld. De taak van deze commissie is het adviseren van de regering over de herziening van de Grondwet en de Kieswet. De commissie zal voorstellen moeten uitwerken "tot vernieuwing van onze Kieswet en Grondwet, om deze passend te maken voor het huidige Nederlandse volk." 22 De Proeve en de naar aanleiding daarvan uitgebrachte adviezen zullen als uitgangspunt voor het werk van de Staatscommissie dienen. Bij de voorbereiding van de herziening van de Grondwet zal de commissie oog moeten hebben voor allerlei belangrijke constitutionele onderwerpen zoals de vraag of de Grondwet alleen rechtsnormen moet bevatten dan wel ook de premissen van onze staatsopvatting; de strijd tussen dualisme en monisme in ons bestel; de

19 Proeve van een nieuwe grondwet, pp. 45-46.

20 Proeve van een nieuwe grondwet, pp. 159-160.

21 Zie voor een - naar onderwerp gerangschikt - overzicht van deze adviezen. J.P. Mulder en D.J. Hoekstra, De grondwet in de steigers.

22 Installatierede van Minister-President De Jong, in: Eerste rapport van de Staatscommissie van advies inzake de Grondwet en de Kieswet, p. 13. 
rechten van de mens, rechtstreekse verkiezingen van de Minister-President etc.. Daarbij moet de Staatscommissie tevens rekening houden met internationale ontwikkelingen van vervagende landsgrenzen en een toenemende Europese integratie en verder met de voortgang van de wetenschap, techniek en massa-communicatie. ${ }^{23}$

Op 8 juli 1968 presenteert de Staatscommissie haar eerste rapport, dat gewijd is aan wijziging van de Kieswet. ${ }^{24}$ Op 12 februari 1969 verzoekt de Minister van Binnenlandse Zaken de Staatscommissie om bij haar werkzaamheden voorrang te geven aan vier onderwerpen: 1. de klassieke grondrechten, en daarbij de grondwettelijke aspecten van de financiële verhouding tussen het rijk en de kerkgenootschappen, 2. de grondwettelijke regeling van het inkomen van de Kroon en van de geldelijke voorzieningen ten behoeve van de leden der Staten-Generaal, 3. de grondwettelijke regeling van het kiesrecht en, voorzover daarmede samenhangend, de verhouding tussen regering en Staten-Generaal en 4. de vraag of voorzien moet worden in bijzondere procedurevoorschriften met eenmalige werking ten behoeve van een algehele grondwetsherziening in de parlementaire periode na 1971. Reden voor dit verzoek van de Minister is, dat de verwezenlijking van een algehele grondwetsherziening ter gelegenheid van de periodieke verkiezingen van 1971 niet mogelijk wordt geacht, maar wel een gedeeltelijke herziening. Aan de bovengenoemde onderwerpen kent de Minister prioriteit toe. Aldus wordt op 19 september 1969 het Tweede rapport van de Staatscommissie uitgebracht waarin voorstellen zijn opgenomen met betrekking tot de vier genoemde onderwerpen. ${ }^{25}$ Op 29 maart 1971 brengt de Staatscommissie haar Eindrapport uit, waarin voorstellen worden gedaan tot een algehele grondwetsherziening. In dit rapport wordt onder meer ook een hoofdstuk met betrekking tot sociale grondrechten opgenomen. ${ }^{26}$

De voorstellen van de Staatscommissie gaan op verschillende belangrijke punten verder dan die in de Proeve. Het voornaamste verschil is gelegen in het feit dat de Staatscommissie zich anders dan de opstellers van de Proeve niet tot technische en formele gezichtspunten heeft beperkt, maar ook tot voorstellen van verandering en vernieuwing is overgegaan, na

23. Eerste rapport van de Staatscommissie van advies inzake de Grondwet en de Kieswet, p. 16.

24 Zie noot 22 voor de vindplaats van de tekst van het rapport.

25 Tweede rapport van de Staatscomnissie van advies inzake de Grondwet en de Kieswet, pp. 13-14. Zie voor de tekst van de brief van de Minister van 12 februari 1969, pp. 15-19. De tekst van het rapport met betrekking tot de klassieke grondrechten staat op pp. 25-127 en de tekst van het ontwerp op pp. 112-115.

26 Eindrapport van de Staatscommissie van advies inzake de Grondwet en de Kieswet, waarvan hoofdstuk VI gewijd is aan sociale grondrechten, pp. 212-239. 
uiteenlopende staatkundige verlangens tegen elkaar te hebben afgewogen. ${ }^{27}$ Wat betreft de systematiek sluit het voorstel van de Staatscommissie aan bij die van de Proeve. Uitgangspunt is de vooropstelling van de drie voornaamste elementen van de staatkundige samenleving: 1 . het volk; 2 . de regering en 3 . de volksvertegenwoordiging. Hierdoor is als eerste een hoofdstuk over de klassieke grondrechten opgenomen. De sociale grondrechten staan pas in hoofdstuk 7, na de hoofdstukken over wetgeving en bestuur. De reden hiervoor is, dat sociale grondrechten een belangrijk stuk taakstelling van wetgever en bestuur bevatten. $\mathrm{Ze}$ bevatten overwegend "opdrachten aan de wetgever en het bestuur om hun zorg uit te strekken over bepaalde belangen, bepaalde wetten en voorzieningen tot stand te brengen en bepaalde doeleinden na te streven" ${ }^{28}$ Verder is in tegenstelling tot de Proeve, in het voorstel van de Staatscommissie het ius de non evocando niet in het hoofdstuk I Klassieke grondrechten opgenomen, maar in het hoofdstuk VII Rechtsbedeling (artikel 86 lid 2). Voorts zijn wel het actief en het passief kiesrecht in het eerste hoofdstuk opgenomen.

Naar aanleiding van de adviezen van de Staatscommissie Cals/Donner komt een aantal wetsvoorstellen tot stand ten behoeve van de partiële grondwetsherziening van 1972 . Slechts enkele van die voorstellen leiden daadwerkelijk tot wijziging van de Grondwet. Zo wordt -, onder andere, de kiesgerechtigde leeftijd wat betreft het actief kiesrecht verlaagd van 21 tot 18 jaar (artikelen 90, 137 en 152) naar aanleiding van een initiatiefvoorstel van Van Thijn c.s. (wetsvoorstel 10579) ${ }^{29}$ en wordt de bevoegdheid tot onderzoek naar de bekwaamheid en zedelijkheid van onderwijsgevenden uitgebreid tot alle bij de wet hiertoe aangewezen vormen van onderwijs (artikel 208, tweede lid; wetsvoorstel 11101). ${ }^{30}$

Onder de voorstellen, die het niet halen bij de eerste lezing in de Tweede Kamer en derhalve niet bij de grondwetsherziening van 1972 worden

27 Algemene inleiding bij het Eindrapport van de Staatscommissie, in: Eindrapport van de Staatscommissie van advies inzake de Grondwet en de Kieswet, pp. 19-20. De inleiding geeft niet concreet aan op welke punten het voorstel van de Staatscommissie verder gaat dan de Proeve.

28 Hoofdstuk VI Sociale grondrechten, Algemeen, $\S 4$ Plaats in de Grondwet van de sociale grondrechten, in: Eindrapport van de Staatscommissie van advies inzake de Grondwet en de Kieswet, p. 219.

29 Wet van 11 maart 1972. Staatsblad 1972. 104. Zie De grondwetsherziening 1972. deel I verlaging kiesgerechtigde leeftijd, passief kiesrecht etc., hoofdstuk I Verlaging kiesgerechtigde leeftijd, pp. 1-91.

30 Wet van 10 februari 1972, Staatsblad 106, 1972. Zie De grondwetsherziening 1972, deel V grondrechten, hoofdstuk III Vrijheid van onderwijs, pp. 93 e.v.. 
"meegenomen" zijn twee wetsvoorstellen met betrekking tot grondrechten: wetsvoorstel 11051 inzake klassieke grondrechten en wetsvoorstel 11052 inzake toelating, uitzetting en uitlevering, het Nederlanderschap en ingezetenschap. Tijdens haar vergadering van 23 december 1970 besluit de bijzondere commissie Grondwet/Kieswet uit de Tweede Kamer om aan het Presidium te verzoeken de termijn voor het uitbrengen van een verslag over wetsvoorstel $1105 !$ te verlengen. Tevens adviseert de commissie de Tweede Kamer dit ontwerp niet meer voor de verkiezingen van 1971 te behandelen onder meer omdat ze het onmogelijk acht voor de Kamer zich in de resterende tijd grondig over de voorstellen te beraden." Op 13 januari 1971 besluit het Presidium aan het verzoek van de commissie gehoor te geven. Het bovengenoemde artikel inzake het onderwijs wordt er met het oog op de dringendheid van dit artikel uitgelicht en opgenomen in een apart wetsvoorstel $(11101)^{12}$. Het kabinet Den Uyl meent vervolgens de wetsvoorstellen 11051 en 11052 niet ongewijzigd te kunnen handhaven en gaat over tot intrekking van deze wetsvoorstellen in 1976 en vervangt ze door gewijzigde voorstellen., ${ }^{3}$

Wat betreft de kwestie van de algehele grondwetsherziening: op basis van het eindrapport van de Staatscommissie wordt onder het kabinet Biesheuvel, dat na de verkiezingen van 1971 is aangetreden, een begin gemaakt met een Nota inzake het grondwetsherzieningsbeleid. $\mathrm{Na}$ de kabinetscrisis van juli 1972 wordt dit werk door het kabinet Den Uyl voortgezet. Op 4 juni 1974 wordt de Nota inzake het grondwetsherzieningsbeleid aan de Staten-Generaal voorgelegd, tezamen met het door de Raad van State over de Nota uitgebrachte advies. Tijdens de daarna volgende behandeling van de Nota in de Tweede en Eerste Kamer blijkt. dat voor verschillende voorstellen van de regering geen meerderheid gevonden kan worden. Met name de bij de voorstellen van de Staatscommissie Cals/Donner aansluitende voorstellen inzake de gekozen kabinetsformateur, inzake de positie en bevoegdheden van de Eerste Kamer en inzake de methode van aanwijzing van de Commissaris van de Koning

31 Zie kamerstuk 1970-1971-9181, nr. 23, en in: De parlementaire geschiedenis rond de algehele grondwetsherziening, pp. 270 e.v..

32 Zoals hierboven al bleek, werd dit wetsvoorstel wél aanvaard. Zie: De grondwetsherziening 1972, deel V grondrechten, pp. 93 e.v..

33 Dit zijn wetsvoorstel 13872 betreffende de vrijheidsrechten en wetsvoorstel 13873 betreffende sociale grondrechten; zie hierna. Zie voorts: De grondwetsherziening 1972, deel V grondrechten, p. 71 en p. 91. Verder verloop behandeling .... en Algehele grondwetsherziening, deel la Grondrechten, p. XIII. 
en de burgemeester stranden op moties vanuit de Tweede Kamer. ${ }^{34}$ Ten aanzien van de overige door de regering gedane voorstellen is wel voldoende steun in het parlement te vinden. ${ }^{35}$ Aangezien de regering in beide Kamers overwegend positieve reacties heeft gehad op het voornemen tot een algemene grondwetsherziening, neemt zij zich voor om met betrekking tot de laatstbedoelde voorstellen wetsontwerpen aan de StatenGeneraal voor te leggen. Ook tal van andere onderwerpen zullen middels wetsvoorstellen aan het parlement worden voorgelegd. ${ }^{36}$

Slechts drie van de 37 ingediende wetsvoorstellen halen de eindstreep niet, waaronder die met betrekking tot het onderwijsartikel (artikel 1.22). ${ }^{37} \mathrm{De}$ andere wetsvoorstellen komen - al naar gelang hun onderwerp - terecht in de diverse hoofdstukken van de Grondwet. Hoofdstuk I van de Grondwet zal worden gewijd aan grondrechten. Het is grotendeels gebaseerd op wetsvoorstel 13872 inzake klassieke grondrechten en wetsvoorstel 13873 inzake sociale grondrechten. Anders dan de Staatscommissie Cals/ Donner, geeft de regering er de voorkeur aan de sociale grondrechten in hetzelfde hoofdstuk op te nemen als de klassieke grondrechten. Beide wetsvoorstellen worden in december 1976 in eerste lezing door de Tweede Kamer aanvaard. Tijdens de behandeling in de Eerste Kamer valt echter het kabinet-Den Uyl. Daarom besluit de Eerste kamer op 17 maart 1977 de wetsvoorstellen betreffende grondwetsherziening niet verder te behandelen. Het kabinet-Van Agt zet de werkzaamheden aan de grondwetsherziening voort door middel van een Nader voorlopig verslag van 18 april 1979. Op 26 juni 1979 worden beide voorstellen door de Eerste Kamer aanvaard. ${ }^{38}$

Het wetsvoorstel inzake de toelating, uitzetting en uitlevering, het Nederlanderschap en het ingezetenschap (14200, R 1048) volgt ongeveer dezelfde weg als de twee hiervoor genoemde wetsvoorstellen. Het wordt

34 Respectievelijk de moties van Van der Sanden, van De Kwaadsteniet en van Tilanus, in: Nota inzake het grondwetsherzieningsbeleid, deel II, respectievelijk pp. 543, 539 en 541 .

35 Zie voor een overzichtje van deze voorstellen: Nota inzake het grondwetsherzieningsbeleid, deel II, p. 629. Zie voor de tekst van de Nota, het advies van de Raad van State en de behandeling in de Tweede en Eerste Kamer, ook: Nota inzake het grondwetsherzieningsbeleid, deel I.

36 Nota inzake het grondwetsherzieningsbeleid, deel II, pp. 629-630.

37 Wetsvoorstel !3874 werd door de Tweede Kamer verworpen in december 1976. Zie voor de parlementaire behandeling van dit voorstel: Algehele grondwetsherziening, deel Ic Grondrechten.

38 De behandeling van de wetsvoorstellen 13872 en 13873 in de Tweede Kamer (in eerste iezing) is opgenomen in: Algehele grondwetsherziening, deel la. Grondrechten. Zie voorts de aldus tot stand gekomen wetten in respectievelijk Stb. 1979, 387 en 1979, 388. 
op 2 februari 1977 door de Tweede Kamer aanvaard en op 26 juni 1979 door de Eerste Kamer en krijgt kracht van wet op 28 juni 1979."

Naar aanleiding van de behandeling van het wetsvoorstel inzake klassieke grondrechten (13872) in de Tweede Kamer, wordt op 22 januari 1979 aan de Tweede Kamer een nota toegezonden over de vraag of het recht op onaantastbaarheid van het menselijk lichaam in de Grondwet moet worden opgenomen (15463). Voorts wordt op 1 februari 1979 een nota aan de Tweede Kamer voorgelegd over de vraag of het recht op bewegingsvrijheid aan de klassieke grondrechten moet worden toegevoegd (15474). In beide nota's wordt de gestelde vraag door de regering negatief beantwoord. Het regeringsstandpunt met betrekking tot de bewegingsvrijheid wordt door de bijzondere commissie Grondwet/Kieswet uit de Tweede Kamer gedeeld. Wel wordt tijdens de openbare vergadering van deze commissie een motie aanvaard - ingediend door Kappeyne van de Coppello - waarin de regering wordt verzocht een wetsvoorstel in te dienen strekkende tot opneming in de Grondwet van het recht op onaantastbaarheid van het menselijk lichaam. ${ }^{40}$ Overeenkomstig deze motie dient de regering op 5 maart 1980 een wetsvoorstel (16086) in. Dit wordt door de Tweede Kamer aanvaard op 17 juni 1980 en door de Eerste Kamer op 16 december $1980 .{ }^{41}$

\section{Op 6 mei 1981 aanvaardt de Eerste Kamer de laatste herzienings-} voorstellen in eerste lezing. Alle 34 in eerste lezing aanvaarde, voorstellen worden door het demissionaire kabinet-Van Agt op 15 juni 1981 bij de Tweede Kamer ingediend voor de vereiste tweede lezing, na de kamerverkiezingen. Op 12 november 1981 worden alle 34 voorstellen tegelijk aangenornen door de Tweede Kamer. ${ }^{42}$

Stb. 1979, 389.

40 Openbare commissievergadering van 14 mei 1979, Zitting 1978-1979, opgenomen in: Algehele grondwetsherziening, deel Ib Grondrechten, op respectievelijik pp. 335342 en pp. 391-408. Zie voor de mondelinge behandeling van de genoemde motie door de Tweede Kamer op 25 juni 1979, op p. 343 en p. 409.

41 Stb. 1980, 672. De parlementaire behandeling, in de Eerst Kamer van de wetsvoorstellen 13872 (klassieke grondrechten) en 13873 (sociale grondrechten), de gehele parlementaire behandeling van de wetsvoorstellen 14200, R 1048 (toelating, uitzetting en uitlevering etc.) en 16086 (recht op onaantastbaarheid van het menselijk lichaam) en de behandeling in de Tweede Kamer van de nota's inzake de bewegingsvrijheid (15474) en het recht op onaantastbaarheid van het menselijk lichaam (15463) zijn opgenomen in: Algemene grondwetsherziening, deel Ib.

42 Zie voor de parlementaire behandeling van de voorstellen in tweede lezing: Algehele grondwetsherziening, tweede lezing (eerste gedeelte). 
De Eerste Kamer kan echter niet met alle voorstellen instemmen. Het voorstel inzake het recht op inlichtingen en het enquêterecht krijgt niet de vereiste meerderheid.

Vanwege het niet-aannemen van 4 herzieningsvoorstellen ${ }^{43}$, worden ten aanzien van de aldus niet-gewijzigde grondwetsartikelen op grond van additioneel artikel IX (in de Grondwet opgenomen bij de herziening van 1972) door de regering vier zogenaamde aanpassingsvoorstellen ingediend. Deze hebben betrekking op het ongewijzigd gebleven onderwijsartikel (17450), op de bepaling over het voorzitterschap van de verenigde vergadering (17451), op de gehandhaafde defensiebepalingen (17452, $R$ 1207) en op de bepalingen inzake inlichtingenplicht en enquêterecht (17490, R 1211). Deze aanpassingsvoorstellen worden op 2 november 1982 door de Tweede Kamer aanvaard. Na opnieuw een kabinetswisseling worden de aanpassingsvoorstellen op 18 januari 1983 in de Eerste Kamer aangenomen. ${ }^{4}$

Overeenkomstig het Koninklijk Besluit van 1 februari 1983, worden op grond van het oude artikel 212 Grondwet de wijzigingswetten plechtig afgekondigd door middel van plaatsing in de buitengewone Staatscourant van 17 februari 1983. Daarmee treedt de herziene Grondwet in werking. Tevens wordt bij Koninklijk Besluit van 17 februari 1983 bepaald, dat de tekst van de herziene Grondwet doorlopend wordt genummerd en bekend wordt gemaakt door plaatsing in het Staatsblad en het Publicatieblad van de Nederlandse Antillen. ${ }^{45}$

In 1985 worden nog enkele wijzigingsvoorstellen ingediend om de herziening van 1983 op een aantal punten te voltooien. Hieronder zijn voorstellen ten aanzien van enkele van de onderwerpen, die het bij de herziening van 1983 niet gehaald hebben. Ook nu komen de meeste van die voorstellen niet door de Tweede of Eerste Kamer. Uiteindelijk komt in 1987 alleen een wijziging van artikel 12 lid 2 inzake het binnentreden

43 Zoals gezegd sneuvelden er drie voorstellen in de Tweede Kamer (in eerste lezing) en één voorstel in de Eerste Kamer (in tweede lezing).

44 Bekrachtiging van de vier aanpassingswetten (gepubliceerd in Stb. 1983, nrs. 15-18) en de 33 in tweede lezing aanvaarde herzieningsvoorstellen (gepubliceerd in Stb. 1983. nrs. 19-51) vindt plaats op 19 januari 1983. Zie voor de parlementaire behandeling van de aanpassingswetten: Algehele grondwetsherziening, tweede lezing (tweede gedeelte).

45 Zie voor de tekst van deze KB's: De algehele grondwetsherziening, tweede lezing (tweede gedeelte), pp. $224-225$ respectievelijk pp. 228 . Het KB van 17 jebruari 1983 en de tekst van de herziene Grondwet zijn opgenomen in Stb. 1983, 70 en in het Publicatieblad van de Nederlandse Antillen 1983, 24. 
van woningen en van de bepaling inzake het geven van inlichtingen door de ministers en staatssecretarissen (artikelen 68) tot stand. ${ }^{46}$

Tot slot kan hier nog worden opgemerkt, dat ondanks de plaatsing van de meeste grondrechten in hoofdstuk I van de Grondwet, er nog steeds een aantal bepalingen ten aanzien van grondrechten buiten dit hoofdstuk zijn te vinden. Het betreft hier bepalingen ten aanzien van de uitsluiting van actief en passief kiesrecht in geval van bepaalde strafrechtelijke veroordelingen (artikel 54 lid 2), gewetensbezwaren bij militaire dienst (artikel 99), derogatie van grondrechten in geval van een uitzonderingstoestand (artikel 103), de openbaarheid van bestuur (artikel 110), de onafhankelijkheid van de rechterlijke macht (artikel 112 e.v.), het verbod van de doodstraf (artikel 114) en de openbaarheid van terechtzittingen (artikel 121).

\subsection{De beperkingssystematiek in de Grondwet 1983, de inhoudelijke fundering daarvan en de uitwerking in de rechtspraktijk}

\subsubsection{Inleiding}

Hoewel ook al in de voorstellen tot wijziging van de Grondwet, die tussen 1950 en 1970 tot stand kwamen, aan de kwestie van de beperking van grondrechten aandacht wordt besteed, komt de discussie over dit onderwerp pas goed op gang naar aanleiding van het proefschrift van Burkens. ${ }^{47} \mathrm{Bij}$ de totstandkoming van de beperkingssystematiek in de - in 1983 herziene - Grondwet heeft onder meer dit proefschrift een belangrijke rol gespeeld.

In het navolgende zal eerst een beschrijving gegeven worden van de beperkingssystematiek in de Grondwet. Daarna zal aan het eind van dit hoofdstuk ingegaan worden op de kritiek, die op deze beperkingssystematiek kan worden uitgeoefend.

In zijn onderzoek gaat Burkens uit van een beperkingsbegrip, dat beperkter is dan het begrip dat in het onderhavige onderzoek wordt gehanteerd.

46 Wet van 3 juni 1987, gepubliceerd in Stb. 1987, nr. 270. De wijzigingen bestaan in toevoeging van de zinsnede "behoudens bij de wet gestelde uitzonderingen" aan artikel 12 lid 2 en van onder meer de zinsnede "door een of meer leden" aan artikel 68 Grondwet.

47 M.C. Burkens, Beperking van grondrechten, Kluwer: Deventer 1971, dissertatie Leiden 1971. 
Burkens gaat er van uit dat beperkingsmogelijkheden van vrijheidsrechten inhouden, "dat de overheid onder zekere kwalificaties (bepaalde gevallen, bepaalde omstandigheden etc.) op legitieme wijze handelingen mag verrichten, welke haar in het algemeen door het vrijheidsrecht zijn verboden. ${ }^{4 \pi}$ Andere beperkingsmethoden als interpretatie en omschrijving van de reikwijdte van grondrechten of van de uitzonderingen daarop kunnen hier derhalve niet onder gebracht worden.

\subsubsection{Algemene en bijzondere beperkingen}

De eerste vormen van beperking van grondrechten waar Burkens op ingaat zijn de algemene en bijzondere beperkingen. In de Proeve zijn deze beperkingsvormen reeds aan de orde gekomen. Daarin wordt onder algemene beperkingen verstaan díe beperkingen die "zijn te vinden in de rechtsregels die zich niet speciaal richten op de uitoefening van een grondrecht, maar die door hun algemene werking ook de omvang van een grondrecht kunnen beïnvloeden." Bijzondere beperkingen zijn volgens de Proeve "beperkingen die voortvloeien uit regels die naar aard of strekking in het bijzonder op de uitoefening van een grondrecht betrekking hebben."

Ter ondersteuning van de aanvaardbaarheid van algemene beperkingen wordt in de Proeve verwezen naar hetgeen de Staatscommissie Van Schaik voordien heeft opgemerkt ten aanzien van artikel 181, namelijk dat de gegarandeerde vrijheid geen vrijbrief geeft om in strijd met strafrechtelijke normen te handelen. Aan de strafbaarheid van beledigende of lasterlijke uitspraken doet niet af, dat die uitspraken gedaan zijn tijdens het belijden van godsdienstige meningen. Het is volgens deze Staatscommissie niet nodig hiervoor uitdrukkelijke beperkingen aan het desbetreffende grondrecht te verbinden; bovendien zou daarmee de indruk gewekt kunnen worden, "dat de strafwet in de gedachtengang van de grondwetgever de vrijheid van belijdenis ongedaan zou kunnen maken." ${ }^{50}$ Ook volgens de Proeve wordt het niet nodig geacht om aan algemene beperkingen een grondwettelijke basis te geven; "zij zijn, naar algemeen wordt aanvaard, geoorloofd en met de geest van de grondrechten in overeenstemming. "\$1

M.C. Burkens, Beperking van grondrechten, p. 2. Burkens beperkt zich tevens in zijn onderzoek tot de in de Grondwet opgenomen klassieke grondrechten.

49 Proeve van een nieuwe grondwet, p. 53.

50 Eindrapport van de Staatscommissie tol herziening van de Grondwet, pp. 77-78.

51 Proeve van een nieuwe grondwet, p. 53. Zie ook het Tweede rapport van de Staatscommissie Cals/Donner (Staatscommissie van advies inzake de Grondwet en de Kieswet), pp. $45-46$. 
Volgens Burkens kleven aan de algemene beperkingen - zoals hierboven gedefinieerd - diverse bezwaren.

Allereerst zou het volgens Burkens van de gehanteerde wetgevingstechniek kunnen afhangen, of een bepaalde beperking van een grondrecht toelaatbaar is. Is een rechtsregel zodanig geformuleerd, dat het rechtstreeks op de beperking van het desbetreffende grondrecht is gericht, dan is sprake van een bijzondere beperking en moet de rechtsregel voldoen aan de voorwaarden van de beperkingsclausule die aan het grondrecht is verbonden. Wordt de rechtsregel zo geformuleerd, dat een bepaalde vorm van uitoefening van dat grondrecht deel uitmaaki van een samenstel van activiteiten, dat door de rechtsregel wordt bestreken, dan is het rechtens niet relevant dat uit deze rechtsregel de beperking van de uitoefening van dit grondrecht voortvloeit. De mogelijkheid bestaat hierbij volgens Burkens, dat een tot wetgeving bevoegd orgaan te kwader trouw een grondrecht beperkt, door rechtsregels "die de facto meer in het bijzonder op de uitoefening van het grondrecht zijn gericht en buiten dat toepassingsgebied niet of nauwelijks van betekenis zouden zijn" als algemeen geldende rechtsregels te formuleren. Op deze wijze zouden de voorwaarden van een eventueel bestaande bijzondere beperking kunnen worden omzeild, dan wel een grondrecht worden beperkt dat in het geheel niet van een beperkingsmogelijkheid is voorzien. Een extra bezwaar hierbij is volgens Burkens, dat elk overheidsorgaan, dat een regelgevende bevoegdheid heeft, bevoegd is op deze wijze de uitoefening van grondrechten te beperken. ${ }^{52}$

Voorts huldigt Burkens in zijn proefschrift de opvatting, dat wanneer men overeenkomstig de Proeve en het tweede rapport van de commissie Cals/Donner zou kiezen voor de leer van de algemene beperkingen, deze leer ook toegepast zou moeten worden ten aanzien van de in de Europese Conventie gegarandeerde rechten. Aan de strikte toepassing van de Conventie zou iedere betekenis worden ontnomen, indien naast de in het verdrag voorziene bijzondere beperkingen, ook algemene beperkingen zouden worden toegelaten."3 Alhoewel met deze laatste opmerking ingestemd kan worden, klopt mijns inziens de redenering niet dat, als men voor de leer van de algemene beperkingen kiest ten aanzien van de Grondwet, deze leer ook toegepast zou moeten worden ten aanzien van de Conventie. Wat ten aanzien van de Grondwet is toegestaan (algemene beperkingen), behoeft nog niet elders te worden toegelaten. Zoals reeds in paragraaf 2.4.1 is besproken, is bij de opstelling van de Conventie gekozen voor nauwkeurig in het verdrag gedefinieerde rechten én beperkingen en 
is de opneming van een (wel in eerdere ontwerpen, met name dat van de Raadgevende Vergadering, opgenomen) algemene beperkingsclausule afgewezen. Het verdrag staat zowel wat betreft de tekst, de geest van het verdrag en de totstandkomingsgeschiedenis geen algemene beperkingen, in de, onder andere, door de Proeve gegeven betekenis toe, althans voorzover zij niet zijn terug te voeren tot de in het verdrag voorziene beperkingsmogelijkheden. Het zou derhalve volstrekt in strijd met het verdrag zijn, indien een verdragsstaat de leer van de algemene beperkingen buiten de beperkingsclausules om zou gaan toepassen op de Conventiebepalingen!

Volgens Burkens kan ook aan de jurisprudentie geen argument vóór de leer van de algemene beperkingen worden ontleend. Dit zou enerzijds komen doordat de problematiek met betrekking tot deze leer in de rechtspraak nooit aan de orde is gekomen en anderzijds door de interpretatieve techniek die de Hoge Raad hanteert in relevante gevallen. Dat de problematiek nooit aan de orde zou zijn gekomen, is volgens Burkens te

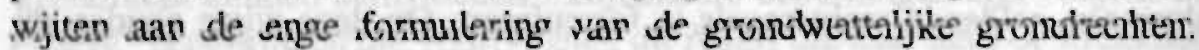
Hierdoor zou er nagenoeg geen grondslag zijn voor handelingen die in strijd zouden kunnen zijn met de algemeen in de samenleving geldende rechtsregels. Het enige grondrecht, dat voor problemen zou kunnen zorgen, zou de belijdenis-vrijheid zijn. Door onder meer de behoedzaamheid van de Hoge Raad waarmee meningsuitingen buiten de sfeer van de belijdenisvrijheid worden gehouden, is de rechter echter nog niet genoopt geweest om over de toelaatbaarheid van algemene beperkingen een oordeel uit te spreken. ${ }^{54}$

Ook door middel van een andere interpretatieve techniek heeft de rechter de algemene beperkingen buiten de deur weten te houden. Dit is met name gebeurd ten aanzien van de vrijheid van drukpers. Deze vrijheid heeft de rechter onderscheiden in een kernrecht - het recht van een ieder om zonder voorafgaand verlof van de overheid door de drukpers gedachten of gevoelens te openbaren - en een connex recht - het recht van een ieder om. zonder voorafgaand verlof van de overheid, door verspreiden, openlijk tentoonstellen of door enig ander middel de inhoud van gedrukte of geschreven stukken of afbeeldingen waarin gedachten en gevoelens zijn geopenbaard, aan het publiek in het openbaar bekend te maken (het verspreidingsrecht). Alleen het kernrecht valt onder de bescherming van artikel 7 Grondwet en de clausulering betreft slechts een repressief toezicht. Het connexe recht kan door materiële wetgeving worden beperkt. 
echter zonder dat het gebruik van een bepaald - zelfstandig verspreidingsmiddel in het algemeen wordt verboden of van een voorafgaand verlof van de overheid afhankelijk wordt gesteld. Ten aanzien van het connexe verspreidingsrecht is dus anders dan ten aanzien van het kernrecht wel (preventieve) beperking mogelijk. Het gaat hier echter niet om algemene beperkingen, omdat het hier beperkingen betreft, die niet zien op een grondwettelijk gepositiveerd grondrecht, maar op een specifiek stuk rechtersrecht. ${ }^{55}$

Een ander geval waarin de Hoge Raad volgens Burkens via interpretatie de leer van de algemene beperkingen heeft ontweken, betreft een zaak met betrekking tot de uit de AOW voortvloeiende volksverzekering tegen geldelijke gevolgen van ouderdom. Het ging hier om een belanghebbende met gemoedsbezwaren tegen deze verzekering, die een beroep deed op artikel 9 ECRM. Volgens de Hoge Raad bestrijkt artikel 9 niet de AOW. omdat deze verdragsbepaling ziet op de vrijheid van gedachte, geweten en godsdienst (inclusief de vrijheid om van godsdienst of overtuiging te veranderen en zijn godsdienst of overtuiging tot uiting te brengen door eredienst, onderricht, beoefening en inachtneming van godsdienstige gebruiken). Artikel 9 betekent niet, "dat het een ieder zou vrijstaan zich te onttrekken aan een wettelijke regeling, ook indien deze op het tot uiting brengen van een godsdienst of overtuiging in enigerlei vorm geen betrekking heeft, door op grond van aan zijn godsdienstige opvattingen of overtuigingen ontleende bezwaren de nietigheid of ongeldigheid daarvan te zijnen aanzien in te roepen." ${ }^{56}$

Tenslotte gaat Burkens in op de vraag, of in de toekomst een erkenning in de rechtspraak van algemene beperkingen aanbeveling zou verdienen. Burkens meent van niet. Opnieuw met behulp van de in de jurisprudentic ten aanzien van artikel $7 \mathrm{Gw}$ aangebracht onderscheiding tussen de vrijheid van drukpers en het verspreidingsrecht, voert Burkens aan, dat erkenning van algemene beperkingen met zich mee zou brengen, dat lagere wetgevers zich ook zouden kunnen richten tegen meningsuitingen van een bepaalde inhoud. Zo zou de gemeenteraad op grond van artikel 168 (oud, het

M.C. Burkens, Beperking van grondrechten, pp. 30-32.

56 M.C. Burkens, Beperking van grondrechten, pp. 32-34. Het betreft hier HR 13 april 1960, NJ 1960, 436. Burkens verwijst ook naar HR 30 mei 1967. NJ 1968, 64 met noot van Van Eck. Overigens geeft Burkens toe, dat er twijfel kan bestaan aan de juistheid van de interpretatie van de Hoge Raad van het desbetreffende verdragsartikel. (p. 34) De annotator bij het arrest van 13 april 1960 meent, dat het hier gaat om een wet, die in strijd is met de "inachtneming van godsdienstige gebruiken". Daarom zou toetsing van deze wet aan lid 2 van artike! 9 ECRM (met name aan de grond "gezondheid of zedelijkheid") geboden zijn. 
huidige artikel 149) gemeentewet, die de raad de bevoegdheid verleent verordeningen uit te vaardigen, onder andere, in het belang van de zedelijkheid, een zodanige algemene regeling tot stand kunnen brengen, dat tevens de verspreiding van drukwerk van onzedelijk geachte inhoud zou kunnen worden verboden.

Volgens Burkens schuilt de moeilijkheid van deze redenering in de belijdenisvrijheid, waarbij nauwelijks een onderscheid gemaakt kan worden tussen de inhoud van de belijdenis en de vorm waarin die belijdenis wordt geuit. Ten aanzien van de belijdenisvrijheid zou de erkenning van algemene beperkingen onvermijdelijk zijn bij het (toen) geldende artikel $181 \mathrm{Gw}$, indien men deze vrijheid wil binden aan normen van lagere wetgevers. Burkens acht het daarom wenselijk de redactie van dit grondwetsartikel te wijzigen en af te stemmen op die van artikel $7 \mathrm{Gw}$. Op deze wijze zou het aan de jurisprudentie kunnen worden overgelaten om de belijdenisvrijheid nader te concretiseren en uit te werken. ${ }^{57}$

Op grond van het bovenstaande komt Burkens in zijn proefschrift tot een afwijzing van de leer van de algemene beperkingen. Op min of meer dezelfde gronden wordt in de Memorie van Toelichting bij wetsvoorstel 13872 inzake de klassieke grondrechten de leer van de algemene beperkingen afgewezen. Hierbij moeten echter wel een aantal kanttekeningen worden gemaakt. Ten eerste wordt in de Memorie van Toelichting een andere definitie van algemene en bijzondere beperkingen gehanteerd dan in de Proeve: in de Memorie van Toelichting staat dat "onder deze zogenaamde algemene beperkingen worden verstaan die beperkingen, welke niet, zoals de zogenaamde bijzondere beperkingen, met het oog op een bepaald grondrecht zijn vastgesteld, niet speciaal op een bepaald grondrecht zijn gericht, maar die veroorzaakt worden doordat een geheel buiten de sfeer van een grondrecht gelegen regeling als neveneffect heeft dat de uitoefening van het grondrecht beperkingen ondergaat." Ten tweede berust de afwijzing van algemene beperkingen op een ander, formeel onderscheid, namelijk dat tussen "geschreven" en "ongeschreven" beperkingen. Het onderscheid tussen algemene en bijzondere beperkingen kan volgens de Memorie van Toelichting worden gemaakt "onafhankelijk van de vraag of de bevoegdheid tot het vaststellen van beperkingen wel of niet in de Grondwet is neergelegd. Ook de beperkingen, welke tot een grondwetsartikel herleidbaar zijn, kan men derhalve onderscheiden in bijzondere en algemene." Bij de afwijzing van de leer van algemene 
beperkingen gaat men uit van niet in de Grondwet verankerde beperkingen. ${ }^{58}$ Hoewel in eerste instantie ruimte lijkt te zijn opengelaten voor algemene beperkingen, zolang zij maar tot een grondwetsartikel, bijvoorbeeld een beperkingsclausule, herleidbaar zijn, kan dit - althans in lagere wetgeving - niet, op grond van de overwegingen in de kamerstukken ten aanzien van de delegatieterminologie. ${ }^{59}$ Vooralsnog lijkt, mijns inziens, alleen artikel 15 lid $4 \mathrm{Gw}$ een basis voor algemene beperkingen - afkomstig van lagere wetgevers - te bieden. Ter beantwoording van kamervragen $^{\omega 0}$ treft men de volgende overwegingen in de Memorie van Antwoord aan:

"Organen met regelgevende bevoegdheden komen in ons land in grote getale voor... Veelal berusten die bevoegdheden op wetsbepalingen, welke een algemene takomschrijving voor die organen inhouden. Wanneer nu zou moeten worden aangenomen, dat een dergelijke takomschrijving reeds uit hoofde van haar algemeenheid delegatie van grondrechten beperkende bevoegdheid impliceert, zouden al deze organen bevoegd zijn in de uitvoering van hun taak inbreuk op grondrechten te maken in al die gevallen waarin de Grondwet in beginsel delegatie toestaat. Dit zou niet in overeenstemming zijn met het beoogde waarborgkarakter van de grondrechten en gaat ons dan ook te ver.

Wanneer de wetgever in enig geval beperkingsbevoegdheden aan een ander orgaan wil overdragen, dient dit bewust en na afweging van belangen te geschieden en moet de wet daarvan blijk geven. Welke wet dat is doet niet ter zake. Delegatiebepalingen kunnen in beginsel in elke wet voorkomen, mits uit de wet met voldoende duidelijkheid kan worden afgeleid, dat de wetgever bewust een beperkingsbevoegaiheid heeft willen toekennen en ten aanzien van welk grondrecht hij dat heeft

Memorie van Toelichting bij wetsvoorstel 13872, Verklaring dat er grond bestaat .... Tweede Kamer, in: Algehele grondwetsherziening, deel la Grondrechten. pp. 2022(20). Bij veel auteurs, waaronder met name Korimann. Donner, Koekkoek en Konijnenbelt, en in de praktijk blijkt veel kritiek op deze afwijzing van ongeschreven algemene beperkingen te bestaan. Zoals gezegd aan het begin van deze paragraaf, zal deze kritiek aan het eind van dit hoofdstuk besproken worden.

59 Op de terminologie zelf, zal in het kader van de bespreking van de competentievoorschriften worden teruggekomen.

60 Vragen van de KVP, ARP en CHU in het Voorlopig Verslag bij wetsvoorstel 13872. Verklaring dat er grond bestaat .... Tweede Kamer, in: Algehele grondwetsherziening, deell Ia Grondrechten, p. 139. 
gewild. Deze eis hebben wij met de woorden "specifieke wetsbepaling" aangeduid. ${ }^{\text {61 }}$

De overweging, dat de delegerende formele wet uitdrukkelijk moet aangeven ten aanzien van welk grondrecht een beperkingsbevoegdheid wordt gedelegeerd, impliceert een bijzondere beperking, omdat het te beperken grondrecht specifiek moet worden aangewezen. Hieraan doet niet af, dat de lagere regeling - waaruit de beperkingen voortvloeien - een onderwerp in zijn algemeenheid kan regelen en daarbij beperkingen van een grondrecht mee kan brengen. Dit maakt de beperking nog niet tot een algemene beperking, aangezien er in het geval uit de regeling een grondrechtenbeperking voortvloeit, "een delegatiebevoegdheid in een specifieke wetsbepaling aanwijsbaar moet zijn" waarop dat gedeelte van de regeling berust. ${ }^{62}$ De beperkingen in de lagere regelingen dienen derhalve betrekking te hebben op bepáálde grondrechten.

Rest nog de vraag of de op de Grondwet berustende formeel-wettelijke grondrechtsbeperkingen algemeen kunnen zijn. De kamerstukken scheppen hierover niet veel duidelijkheid. Naar mijn mening zijn formeel-wettelijke algemene beperkingen niet per se uitgesloten, zolang maar - net als bij bijzondere beperkingen - uit de desbetreffende wet zelf duidelijk wordt hoever de grondrechtsbeperking gaat. ${ }^{63}$ In deze richting gaat de overweging van de regering in het kader van de horizontale werking van grondrechten in het Nader Rapport, dat de hierna nog nader te bespreken beperkingsclausule "behoudens ieders verantwoordelijkheid volgens de wet" - die geen delegatie toestaat - onder meer ziet op artikel 1401 oudBW (het huidige artikel 6: $162 \mathrm{BW}$ ). Dit artikel inzake de onrechtmatige daad ziet niet op de beperking van een specifiek grondrecht en bevat derhalve geen bijzondere beperking, terwijl de beperking van een grondrecht wel een (onbedoeld) gevolg kan zijn van deze wetsbepaling (algemene beperking). Aan de voorwaarde dat de wet zelf nauwkeurig moet aangeven hoe ver de grondrechtsbeperking gaat, is mijns inziens

61 Memorie van Antwoord bij wetsvoorstel 13872, Verkiaring dat er grond bestaat ..., Tweede Kamer, in: Algehele grondwetsherziening, deel la Grondrechten, p. 182; cursief van mij, $C S$.

62 Memorie van Antwoord bij wetsvoorstel 13872, Verklaring dat er grond bestaat .... Tweede Kamer, in: Aigehele grondwetsherziening, deel la Grondrechten, p. 182.

63 Memorie van Toelichting bij wetsvoorstel 13872, Verklaring dat er grond bestaat .... Tweede Kamer, in: Aigehele grondwetsherziening, deel la Grondrechten, p. 23. 
echter niet voldaan. Eenduidigheid kan de grondwetgever op dit punt niet bepaald verweten worden. ${ }^{\text {G }}$

Concluderend kan worden gesteld, dat de grondwetgever een voorkeur, zij het niet expliciet, heeft gehad voor bijzondere beperkingen. Weliswaar zijn door de afwijzing van niet tot de Grondwet herleidbare beperkingen, op de Grondwet gebaseerde algemene beperkingen niet uitdrukkelijk uitgesloten, maar vanwege hetgeen in verband met de delegatieterminologie naar voren is gebracht, beperkt de mogelijkheid tot het stellen van algemene beperkingen zich tot de formele wetgever. Beperkingen van lagere wetgevers moeten kunnen worden gebaseerd op een specifieke wetsbepaling.

Met de voorkeur voor bijzondere beperkingen is men er echter nog niet. De formele wetgever moet, zoals gezegd, nog angeven hoe ver de grondrechtsbeperking gaat. De formele wetgever moet hierbij blijven binnen de omlijning die in de Grondwet is aangebracht. De grondwetgever heeft hiermee het gevaar van uitholling van de grondrechten willen keren. De overheid zou op grond van een onbegrensde beperkingsclausule handelingen kunnen verrichten of regelingen tot stand kunnen brengen, die lijnrecht indruisen tegen het desbetreffende grondrecht. Zoals Burkens opmerkt, zou "een algemeen gestelde clausulering van een grondrecht ... slechts iets van het desbetreffende recht in stand laten, voor zover een onaantastbaar kernrecht zou worden aangenomen en uit dien hoofde de beperkingsmogelijkheden begrensd zouden zijn." ${ }^{\text {ss }}$ Voor de gewenste nadere omlijning van de (bijzondere) beperkingsclausules noemt Burkens diverse mogelijkheden:

- koppeling van beperkingsbevoegdheden aan competentievoorschriften: hierbij worden beperkingsbevoegdheden - bij uitsluiting van andere overheidsinstanties - aan een bepaald overheidsorgaan toegekend.

- koppeling van beperkingsbevoegdheden aan procedurevoorschriften: hierbij wordt de toelaatbaarheid van beperkingen afhankelijk gesteld van bepaalde te volgen procedures.

64 Ook op andere punten overigens niet. In de loop van de behandeling van wetsvoorstel 13872 wordt de afwijzing van "ongeschreven", niet tot de Grondwet herleidbare beperkingen nogal eens - onterecht - vereenzelvigd met de afwijzing van de "leer der algemene beperkingen". Zie over de omvang van de grondrechtenbeperkingen verder onder Competentievoarschriften.

M.C. Burkens, Beperking van grondrechten, p. 40. Op het kernrecht wordt later nog. teruggekomen. 
- koppeling van beperkingsbevoegdheden aan doelcriteria: hierbij wordt de toelaatbaarheid van een beperking afhankelijk gesteld van een bepaald te behartigen belang.

- koppeling van beperkingsbevoegdheden aan bepaalde algemene gedragscodes. Een voorbeeld hiervan is de voorwaarde van het noodzakelijk zijn van een beperking in een democratische samenleving in de artikelen 8 tot en met 11 van de Europese Conventie.

- koppeling van beperkingsbevoegdheden aan het bestaan van een bepaalde uitzonderingstoestand. ${ }^{66}$

De genoemde mogelijkheden om beperkingsclausules nader te omlijnen zullen hierna worden besproken.

\subsubsection{Competentievoorschriften}

Aan welk overheidsorgaan een beperkingsbevoegdheid is toegekend, kan worden opgemaakt uit de in de beperkingsclausule gebezigde terminologie. Van groot belang is hierbij de kwestie van de delegatie. In navolging van het voorstel van de Staatscommissie Van Schaik en latere voorstellen voor de herziening van de Grondwet, wordt in de Grondwet ten aanzien van delegatie een vaste terminologie gehanteerd. Bij gebruik van enigerlei vorm van het werkwoord "regelen", de zelfstandige naamwoorden "regels" en "regeling" of de term "bij of krachtens" is delegatie toegestaan. Ontbreken deze woorden, dan is delegatie niet toegestaan, de wetgever mag dan geen regelgevende bevoegdheid aan een ander orgaan overdragen. Ook mag de wetgever geen gebruik maken van zodanig vage formuleringen, dat hij "de hem opgedragen taak in feite aan een lager orgaan overlaat." De wet zal derhalve zelf moeten aangeven hoever de grondrechtenbeperking gaat. Op deze wijze acht de grondwetgever bijvoorbeeld een vergunningenstelsel dat de uitoefening van een grondrecht beperkt, alleen geoorloofd, indien "de wet zelf nauwkeurig aangeeft in welke gevallen de vergunning moet worden verleend of geweigerd. ${ }^{67}$

Een voorbeeld van een competentiebepaling, waarbij delegatie van de geattribueerde bevoegdheid niet is toegestaan is de zinsnede "behoudens ieders verantwoordelijkheid volgens de wet". Deze formulering stamt af van het al bestaande artikel 7 en betekent dat door de wetgever repressief toezicht kan worden gesteld op uitoefening van de in dat artikel gegarandeerde vrijheid; handhaving van de desbetreffende wetgeving berust bij de rechter. Bij de desbetreffende wetgeving moet niet, zoals dat 
aanvankelijk wel het geval was, alleen gedacht worden aan het burgerlijk recht of het strafrecht. De essentie is volgens de Memorie van Toelichting, dat "de wetgever, van deze beperkingsbevoegdheid gebruik makende, ervoor moet zorg dragen, dat in het concrete geval, waarin een beperking zich effectueert, uiteindelijk een rechtsgang naar een rechterlijk orgaan openstaat."

Op de hierboven beschreven delegatie-terminologie zijn in de Grondwet enkele uitzonderingen aangebracht. In artikel 104 Grondwet worden de termen "uit kracht van een wet" zodanig uitgelegd, dat grote terughoudendheid bij de delegatie moet worden betracht. ${ }^{69}$ Ook in afwijking met eerder besproken delegatie-terminologie is de interpretatie van de woorden "De wet regelt ..." in artikel 107 Grondwet. Deze formulering in artikel 107 betekent dat delegatie is toegestaan, echter alleen in uitzonderingsgevallen met betrekking tot detailpunten. ${ }^{70}$ In deze gevallen heeft de grondwetgever het derhalve niet aan de wetgever overgelaten te bepalen in hoeverre een bevoegdheid mag worden gedelegeerd. " Verder is de delegatie-terminologie in de nieuwe Grondwet niet van toepassing op het onderwijsartikel (artikel 23), omdat het voorstel tot herziening van dit artikel niet door de Tweede Kamer werd aanvaard. ${ }^{72}$ Voorts kan uit de Memorie van Antwoord bij het wetsvoorstel met betrekking tot de provincies en gemeenten afgeleid worden, dat ook daarin afgeweken wordt van de hierboven beschreven delegatie-terminologie. De hieruit voortvloeiende delegatie-terminologie in hoofdstuk 7 van de Grondwet 1983, brengt in tegenstelling tot de ten aanzien van de rest van de Grondwet gehanteerde terminologie met zich mee, dat lagere organen de vrijheid hebben om de inhoud van de te stellen regels of de te treffen maatregelen geheel of grotendeels naar eigen inzicht te bepalen. "Is die vrijheid er niet, dan is er geen sprake van gedelegeerde bevoegdheid maar alleen van min of meer gebonden uitvoering. "7s

Idem, p. 18.

69 Memorie van Toelichting bij wetsvoorstel 15575 met betrekking tot verandering in de Grondwet van bepalingen inzake de belastingen, zitting 1978-1979, nr. 3, in: Algehele grondwetsherziening, dee! Vc Wetgeving en bestuur, pp. 253-254.

70 Memorie van Antwoord bij wetsvoorstel 15046, nr. 7. in: Algehele grondwetsherziening, deel Vd Wetgeving en bestuur, p. 24.

71 Zie verder t.a.v. de delegatie-problematiek: C.A.J.M. Kortmann. De grondwetsherzieningen 1983 en 1987. pp. 25-30 en A.W. Heringa en T. Zwart, De Nederlandse Grondwet, pp. 6-8.

72 Zie hierboven p. 93 en Algehele grondwetsherziening, deel Ic Grondrechten.

73 Memorie van Antwoord bij wetsvoorstel 13990, zitting 1976-1977, nr. 6. in: Algehele grondwetsherziening, deel VIIa Provincies, gemeenten, waterschappen en andere openbare lichamen, pp. 67-69. Zie ook het Voorlopig Verslag, nr. 5, op pp. 
Overigens kunnen competentiebepalingen, die een beperkingsbevoegdheid aan de formele wetgever toekennen van invloed zijn op de bevoegdheden van andere organen. Als voorbeeld noemt de Memorie van Toelichting bij wetsvoorstel 13872 de bevoegdheden van de gemeenten inzake de beperking van het recht op betoging. Nu de bevoegdheid van beperking van dit recht in eerste instantie is toegekend aan de formele wetgever (met delegatie-mogelijkheid), kunnen gemeenten slechts op grond van een. formele wet en niet krachtens hun algemene autonome bevoegdheid van artikel 168 oud- gemeentewet tot het stellen van beperkingen overgaan. ${ }^{34}$

Kijken we naar de Grondwet, zoals die sinds de herziening van 1983 luidt, dan treffen we in de grondrechtenbepalingen, onder andere, de volgende competentievoorschriften aan:

1.a "behoudens bij de wet gestelde/te bepalen (beperkingen en) uitzonderingen" (artikelen 4, 12 lid 2, 54 lid 1) of b. "behoudens bij of krachtens de wet te stellen beperkingen" (artikelen 10 lid 1, 11);

2. "benhoudens ieders verantwoordefijkheid volgens de wet" (artikelen 6 lid 1,7 leden 1 en 3,9 lid 1$) ;^{* s}$

3. " de wet regelt" (artikelen 2 leden 1 en 2, 117 lid 4), "de wet kan regels stellen" (artikelen 6 lid 2, 9 lid 2), "de wet stelt regels" (artikelen 7 lid 2, 10 leden 2 en 3, 18 lid 2, 19 lid 2, 20 lid 2)

4. "bij de wet kan dit recht worden beperkt..." (artikel 8);

5.a. "gevallen bij de wet bepaald" (artikelen 13 leden 1 en 2, 117 lid 3, 121) of b. "gevallen bij of krachtens de wet bepaald" (artikelen 12 lid 1. 14 lid 3,15 lid $1^{76}$

46-47.

74 Memorie van Toelichting bij wetsvoorstel 13872, Verklaring dat er grond bestaat .... Tweede Kamer, in: Algehele grondwetsherziening, deel Ia Grondrechten, p. 23. Zo ook Rb. Roermond 3 januari 1995, NJCM-Bulletin 20-4 (1995), pp. $431-438$ met noot J.M.E. Derks. Dat de Memorie van Toelichting op het punt van de zelfstandige regelingsbevoegdheid van lagere organen toch niet zo duidelijk is als hier lijkt te worden gesuggereerd, zal hieronder blijken.

75 Zie ten aanzien van deze beperkingsclausule: $\boldsymbol{A}$. K. Koekkoek en W. Konijnenbelt, Het raam van hoofdstuk 1 van de herziene Grondwet, pp. 29-32.

76 In andere formuleringen:

1.a. "behoudens in de gevallen bij de wet bepaald" (artikel 2 lid 4) of b. "behoudens de beperkingen bij of krachtens de wet gesteld" (artikel 19 lid 3);

3.a. "de wet stelt voorwaarden" (artikel 23 lid 7) of b. "de wet kan ... regelen" (artikel 7 lid 3, laatste zin), "een bij de wet te regelen recht" (artikel 20 lid 3), "een en ander bij wet te regelen" (artikel 23 lid 2), "bij de wet geregeld" (artikel 23 leden 3 en 5), "bij de wet te stellen regels" (artikelen 23 lid 4, 110); 
In de zojuist aangehaalde competentievoorschriften wordt steeds gebruik gemaakt van de term "wet". Dat wil zeggen, dat de in die voorschriften opgenomen bevoegdheid om beperkingen, uitzonderingen of voorwaarden aan de uitoefening van grondrechten te verbinden of om grenzen of voorwaarden aan beperkingen op grondrechten te stellen, aan de formele wetgever is verleend. In een aantal gevallen staat het de formele wetgever daarbij vrij om deze bevoegdheid te delegeren."

Uitzonderingen op deze competentieverdeling zijn, bijvoorbeeld, te vinden in artikelen 2 lid 3 en 117 lid 1 van de Grondwet. In artikel 2 lid 3 staat dat uitlevering slechts krachtens verdrag kan plaatsvinden en artikel 117 lid 1 bepaalt dat de benoeming van de met rechtspraak belaste leden van de rechterlijke macht en de procureur-generaal bij de Hoge Raad bij koninklijk besluit geschiedt. Voorts zijn in de artikelen 19 lid 1, 20 lid 1, 21 en 22 Grondwet bevoegdheden toegekend aan de "overheid".

Bepérkingen op grondrechten kunnen overigens ook vit de Grondwet zelf voortvloeien. Zo bepaalde het Gerechtshof Den Haag, dat één van de beperkingen op het recht op eerbiediging van zijn persoonlijke levenssfeer (artikelen $10 \mathrm{Gw}$ ) - waarop door de wet beperkingen mogen worden gesteld - gebaseerd kan worden op artikel $110 \mathrm{Gw}$. Dit artikel "schrijft voor dat de overheid bij de uitoefening van haar taak volgens regels bij de wet te stellen "openbaarheid" betracht. Deze verplichting heeft vooral in de Wet openbaarheid van bestuur gestalte gekregen. "7"

Dat met het begrip "wet" in de Grondwet de formele wet bedoeld wordt, blijkt niet uit een zodanige definitie in de Grondwet of in de Memorie van Toelichting, maar meer uit de toelichting op de toekenning van delegatiebevoegdheden aan de wetgever. Hierin staat onder meer, dat in de Grondwet "geen onderscheid is gemaakt naar de mate waarin de formele wetgever de hem in eerste aanleg opgedragen taak of toegekende bevoegdheid mag overdragen". Of: "Zo zal, wanneer de Grondwet het beperken van een grondrecht alleen bij formele wet toestaat, de wet zelf moeten aangeven hoever de grondrechtsbeperking gaat." 79 De Memorie

5.a. "bij de wet gegeven" (artikel 2 lid 3), "bij de wet aangewezen" (artikelen 13 lid 2. 23 lid 2, 54 lid 2a, 117 lid 3), "bij de wet te bepalen..." (artikelen 15 lid 2, tweede zin, 117 lid 2), "bij de wet te stellen voorwaarden" (artikel 23 lid 7), "bij de wet worden de voorwalarden genoemd" (artikel 99) of b. "bij of krachtens de wet ... aangewezen" (artikel 12 lid 1), "een en ander naar bij of krachtens de wet te stellen voorschriften" (artikel 14 lid 1).

77 Namelijk, in geval van de formuleringen aangeduid met "b" (1.b; 3.b en 5.b).

78 Gerechtshof 's-Gravenhage 5 november 1987, NJ 1988, 1010.

79. Memorie van Toelichting bij wetsvoorstel 13872, Verklaring dat er grond bestaat ....,

Tweede Kamer, in: Algehele grondwetsherziening, deel la Grondrechten, pp. 22-23. 
van Antwoord is nog duidelijker: "In antwoord op opmerkingen ... wijzen wij erop, dat wij op het standpunt staan, dat het beperken van grondrechten niet buiten de formele wet om dient te geschieden..." ${ }^{80}$ Tenslotte kan nog worden gewezen op artikel 81 Grondwet, waarin staat dat de vaststelling van wetten geschiedt door de regering en StatenGeneraal gezamenlijk. Artikel 81 bevat derhalve het formele wetsbegrip. In artikel 89 , waar het gaat om algemene maatregelen van bestuur en andere vanwege het Rijk vastgestelde algemeen verbindende voorschriften (lid 4) wordt daarentegen géen gebruik gemaakt van het begrip wet, alhoewel het hier gaat om materiële wetgeving."

Op grond van het voorgaande zou men derhalve kunnen concluderen, dat in de veelvuldig voorkomende competentievoorschriften in hoofdstuk I van de Grondwet, de daarin opgenomen bevoegdheden - behoudens de genoemde uitzonderingen - aan de formele wetgever worden toegekend, eventueel met delegatiemogelijkheid.

Echter, in de Memorie van Toelichting is een onduidelijkheid geschapen, die ook in de doctrine en jurisprudentie kennelijk nog niet tot klaarheid is gebracht. Het gaat om de volgende overweging in de Memorie van Toelichting: "Daarentegen laat een opdracht aan de wetgever om regels te stellen omtrent het verlenen van rechtsbijstand aan minder-draagkrachtigen (artikel 1.17, lid 2 van het wetsvoorstel inzake de sociale grondrechten ${ }^{82}$ ) of omtrent de bescherming van de persoonlijke levenssfeer in verband met het vastleggen van persoonsgegevens (artikel 1.10 lid 2 yan het onderhavige wetsontwerp ${ }^{3}$ ) bestaande bevoegdheden van lagere organen om op dit terrein regelend op te treden onverlet, mits deze daarbij niet met een hogere regeling in strijd komen. " ${ }^{\text {st }}$ Aan de ene kant blijkt derhalve uit de delegatie-terminologie, dat het in bepalingen met dergelijke formuleringen (als onder punt 3. weergegeven), gaat om bevoegdheidstoekenning aan de formele wetgever met delegatie-mogelijkheid. Dit impliceert, dat de delegerende formele wet aangeeft welke ruimte de lagere organen - waaraan gedelegeerd is - nog hebben om regelend op te treden. Anderzijds blijkt uit de geciteerde passage uit de Memorie van Toelichting, dat er in het geheel geen formeel-wettelijke basis nodig is voor de

80 Memorie van Antwoord bij wetsvoorstel 13872, Verklaring dat er grond bestaat .... Tweede Kamer, in: Algehele grondwetsherziening, deel Ia Grondrechten, p. 183.

81 Zie verder de rechtspraktijk aan het einde van deze paragraaf, met name de in noot 93 genoemde jurisprudentie.

82 Artikel 18 lid 2 Grondwet 1983.

83 Artikel 10 lid 2 Grondwet 1983.

84 Memorie van Toelichting bij wetsvoorstel 13872, Verklaring dat er grond bestaat.... Tweede Kamer, in: Algehele grondwetsherziening, deel Ia Grondrechten, p. 23. 
uitoefening van de zelfstandige verordeningsbevoegdheid van de lagere organen, zolang er maar geen strijd bestaat met hogere regelingen. Het is ten aanzien van de hier bedoelde competentievoorschriften derhalve niet duidelijk aan wie nu eigenlijk de competentie wordt toegekend. In de Memorie van Toelichting geeft de regering dan ook aan, dat het niet de bedoeling is een terminologie in te voeren die voor alle gevallen grondwettelijk vastlegt of er in bepaald geval nog enige zelfstandige regelingsbevoegdheid voor lagere organen resteert. De bedoeling is, dat middels interpretatie van de desbetreffende bepalingen de in zich wijzigende inzichten op dit vlak tot hun recht kunnen komen. ${ }^{\text {ss }}$ Op het voorgaande maakt de Memorie van Toelichting vervolgens weer een uitzondering voor "die categorie van gevallen waarin aan de burgers een subjectief recht wordt toegekend." Als in die gevallen geen exclusieve beperkingsbevoegdheid zou worden toegekend zou de waarborg van die rechten uitgehold worden.

De toekenning van beperkingsbevoegdheden door middel van competentievoorschriften leidt op grond van de in de Memorie van Toelichting gegeven motivering, tot de volgende indeling:

In de gevallen waarin "elke beperkingsbevoegdheid ontbreekt (artikelen $1.1,1.3$ en $1.5^{86}$ ) of wanneer deze uitsluitend aan de formele wetgever is voorbehouden (artikelen 1.6 lid 1, 1.7 leden 1 en 3 eerste zin, 1.8, 1.9 lid $1^{57}$ ) [kan] aan een lager orgaan geen bevoegdheid ... toekomen inbreuk op het recht te maken. In de gevallen, waarin aan de formele wetgever de bevoegdheid is verleend het recht te beperken met inbegrip van de mogelijkheid van delegatie van de beperkingsbevoegdheid (artikelen 1.6 lid $2,1.7$, lid 3 tweede zin, 1.9 lid 2, 1.10 lid $1^{8 s}$ ), mogen lagere organen slechts krachtens uitdrukkelijke delegatie, dat wil zeggen op grond van een specifieke wetsbepaling inbreuk op het desbetreffende recht maken." Zou men deze overweging voortzetten, dan zou uit de voorgaande opsomming volgen, dat (toen) ten aanzien van alle overige competentievoorschriften nog géén uitspraak gedaan zou kunnen worden over de zelfstandige regelingsbevoegdheid van lagere organen.

85 Idem, pp. 23-24.

86 Respectievelijk de artikelen 1, 3 en 5 Grondwet 1983.

87 Respectievelijk de artikelen 6 lid 1,7 leden I en 3 eerste zin. 8 en 9 lid 1 Grondwet 1983.

88. Respectievelijk de artikelen 6 lid 2, 7 lid 3 tweede zin, 9 lid 2 en 10 lid 1 Grondwet 1983.

89 Memorie van Toelichting bij wetsvoorstel 13872, Verklaring dat er grond bestaat .... Tweede Kamer, in: Algehele grondwetsherziening, deel la Grondrechten, p. 24. 
Mijns inziens zouden de artikelen 16, 17, 18 lid 1, 23 lid 5 (wat betreft de vrijheid van richting) en 114 ook in het rijtje van rechten opgenomen kunnen worden waarbij elke beperkingsbevoegdheid ontbreekt. Tevens lijken de artikelen 2 lid 4, 4, 12 lid 2, 13 leden 1 en 2, 15 lid 2, 54 lid 1 en 117 leden 2 en 3 opgenomen te kunnen worden onder de bepalingen waarin de verleende beperkingsbevoegdheid uitsluitend aan de formele wetgever is toegekend. Voorts bevatten de artikelen 11, 12 lid 1, 14 lid 1, 15 lid 1 en 19 lid 3 beperkingsclausules die duiden op de toekenning van een bevoegdheid aan de formele wetgever mét de mogelijkheid van delegatie.

Wat betreft de resterende grondrechtenbepalingen: een deel daarvan bevat een uitdrukkelijke opdracht aan de wetgever om een bepaalde materie te regelen, zoals de artikelen 2 leden 1,2 , en 3 (laatste zin), 10 leden 2 en 3, 18 lid 2, 19 lid 2, 20 leden 2 en 3, 23 leden 2, 3, 4 en 7 en 117 lid $4 .^{90}$ Andere bepalingen verklaren een bepaald onderwerp tot "zorg der overheid", waaronder de artikelen 19 lid 1, 20 lid 1, 21, 22 en 23 lid 1. De eerste categorie artikelen lijkt erop te duiden dat er tenminste een verplichting voor de formele wetgever bestaat om de desbetreffende materie te regelen. De grondwet geeft niet aan, hoever de wetgever daarbij dient te gaan. De laatste groep bepalingen bevat niet een dergelijke verplichting tot wetgeving voor de formele wetgever. Wat betreft de autonome bevoegdheden van lagere wetgevers lijkt tussen beide soorten bepalingen niet veel verschil te bestaan. In beide gevallen bestaat hiertegen grondwettelijk gezien geen bezwaar, vooropgesteld natuurlijk, dat de lagere wetgeving niet in strijd is met eventueel tot stand gebrachte hogere regelingen. Juist zolang (nog) geen formele wetgeving op de aangegeven terreinen bestaat, valt het alleen maar toe te juichen als lagere wetgevers wèl tot regeling overgaan. Het is een andere kwestie of het ook wenselijk is dat regeling van de bedoelde onderwerpen op lager niveau plaatsvindt, ter aanvulling of in plaats van (tweede categorie bepalingen) formele wetgeving. Dan doet zich immers de mogelijkheid voor dat plaatselijke verschillen optreden in de uitwerking van de bedoelde grondrechten. Daarom zou er naar mijn mening bij de beoordeling van de vraag of er - naast een formele wet - nog ruimte bestaat voor lagere regelingen op grond van zelfstandige regelingsbevoegdheden, een onderscheid gemaakt moeten worden tussen regelingen als a.m.v.b.'s en regelingen afkomstig van gemeenten en provincies. Voor zover lokale regelingen werkelijk nodig zijn om op lokale ornstandigheden te kunnen inspelen bestaat er geen

90 Koekkoek en Konijnenbelt spreken van "grondrechten die nadere wettelijke 'beschermingsregels' nodig hebben". A.K. Koekkoek en W. Konijnenbelt, Het raam, van hoofdstuk 1 van de herziene Grondwet, p. 39. 
bezwaar tegen gemeentelijke/provinciale regelingen. Koekkoek en Konijnenbelt wijzen er terecht op dat indien, bijvoorbeeld, ten behoeve van leden van minderheidsgroepen in de gemeente of provincie extra voorzieningen worden getroffen, de (autonome) provinciale of gemeentelijke regeling alleen maar neerkomt op een nog sterker handelen in de geest van de desbetreffende grondrechtenbepaling." Afgezien van het inspelen op lokale omstandigheden, lijkt mij echter regeling op centraal niveau toch de voorkeur te verdienen om te veel lokale differentiatie te vermijden. ${ }^{92}$

In de rechtspraktijk, kunnen competentievoorschriften niet gerekend worden tot de juridische vraagstukken die hoog in de belangstelling staan.

Overeenkomstig de hierboven weergegeven opvatting van de regering in de Memorie van Toelichting, is in de rechtspraak bevestigd, dat met het woord wet in zowel artikel 6 lid 1 als in artikel 6 lid 2 gedoeld wordt op de wet in formele zin..$^{93}$

Voorts is er in een aantal gevallen een uitspraak gedaan over het al dan niet aanwezig zijn van de door het desbetreffende grondrecht geëiste formeel-wettelijke basis voor een bepaalde regeling of maatregel. ${ }^{94}$

Verder zijn er op grond van diverse grondrechtenbepalingen formele wetten tot stand gekomen (al dan niet ter vervanging van reeds bestaande wetgeving), zoals de Rijkswet op het Nederlanderschap (artikel 2 lid 1 $\mathrm{Gw}$ ), de Wet Openbare Manifestaties (artikelen 6 en $9 \mathrm{Gw}$ ) en de Wet Persoonsregistraties (artikel 10 leden 2 en 3). De Algemene wet gelijke behandeling (artikel $1 \mathrm{Gw}$ ) is op 1 september 1994 in werking getreden. Vele andere wetten hebben wijzigingen ondergaan.

91 A.K. Koekkoek en W. Konijnenbelt, Het raam van hoofdstuk 1 van de herziene Grondwet, p. 39.

92 Zie verder: A.W. Heringa, Sociale grondrechten, pp. 86-88.

93 Pres.Rb. 's-Hertogenbosch 25 juni 1985. KG 85, 217. En bijvoorbeeld: HR 5 juni 1987, AB 1988, 276 (verwijzend naar artikel 1401 BW). Voorts recentelijk: Rb. Roermond 3 januari 1995, NJCM-Bulletin 20-4 (1995), pp. 431-438 met noot J.M.E. Derks.

94 Bijvoorbeeld t.a.v. artikel $10 \mathrm{Gw}$ : artikel 24.1 Erkenningsregeling vrijwillige plaatsing jeugdhulpverlening (verstrekken van gegevens over cliënten door een erkende instelling aan ambtenaren t.b.v. controle of de instelling een plaatsingsbeleid voert overeenkomstig de subsidieregeling) mist een formeel-wettelijke basis, Vz.ARRS 30 juni 1988, KG 1988, 349; t.a.v. artikel $11 \mathrm{Gw}$ : dwangbehandeling was niet geregeld in de Krankzinnigenwet, Gerechtshof Arnhem 12 juli 1988, KG 1988 , 338 ; binnentreden door curator in woning/bedrijf tegen de wil van de gefailleerden teneinde zorg te dragen voor de bewaring van de boedel en het algemeen faillissementsbeslag te effectueren kan gebaseerd worden op de Faillissementswet, Gerechtshof Arnhem 16 september 1985, KG 1985, 403. 


\subsubsection{Procedurevoorschriften}

De Memorie van Toelichting bij wetsvoorstel 13872 geeft slechts één voorbeeld van een procedurevoorschrift: de bepaling op grond van artikel 1.11 lid 2 waarin wordt bepaald, dat van het binnentreden in een woning tegen de wil van de bewoner een schriftelijk verslag moet worden verstrekt. ${ }^{95}$ Overigens wordt niets ten aanzien van procedurevoorschriften opgemerkt. ${ }^{96}$ Ook in de literatuur wordt weinig op procedurevoorschriften ingegaan.

Burkens' bespreking van procedurevoorschriften beperkt zich tot de overweging, dat het binden van beperkingsmogelijkheden aan procedurevoorschriften impliceert, dat de desbetreffende procedure "door een bepaaldelijk aangewezen instantie gevolgd moet worden." Voorts zouden procedurevoorschriften de waarborg in zich houden tegen een lichtvaardig gebruik van de beperkingsbevoegdheid. Bovendien vergroten zij de voorzienbaarheid van de uitoefening van beperkingsbevoegdheden."

Andere voorbeelden van procedurevoorschriften dan dat in het reeds genoemde artikel 12 lid 2 Grondwet 1983 zijn opgenomen in: - artikel 13 lid 1: inbreuk op het briefgeheim mag alleen geschieden op last van de rechter;

- artikel 13 lid 2: inbreuk op het telefoon- en telegraafgeheim mag alleen plaatsvinden door of met machtiging van hen die daartoe bij de wet zijn aangewezen.

\subsubsection{Doelcriteria}

De hier besproken beperkingsmethode houdt in, "dat in een grondrechtartikel na de omschrijving van het recht een aantal beleidsdoeleinden wordt opgesomd ten behoeve waarvan op het grondrecht inbreuk mag worden gemaakt. ${ }^{\text {"98 }}$

95 Voorts zijn voorafgaande legitimatie en mededeling van het doel van het binnentreden vereist. In het huidige artikel 12 lid $2 \mathrm{Gw}$ kunnen op dit latste voorschrift bij de wet uitzonderingen worden gesteld. Van vóór de toevoeging van deze mogelijkheid tot beperkingen op dit procedurevoorschrift stammen onder meer de volgende uitspraken: Rb. Assen 16 augustus 1983, NJ 1984, 318; AA 33 (1984) 6. p. 324 e.v. met noot Kortmann en Rb. Zutphen 22 december 1983, NJ 1984, 319.

96 Memorie van Toelichting bij wetsvoorstel 13872, Verklaring dat er grond bestaat.... Tweede Kamer, in: Algehele grondwetsherziening, deel Ia Grondrechten, p. 17. M.C. Burkens, Beperking van grondrechten, p. 93.

98 Memorie van Toelichting bij wetsvoorstel 13872, Verklaring dat er grond bestaat.... Tweede Kamer, in: Algehele grondwetsherziening, deel Ia Grondrechten, p. 17. 
Burkens laat zich in algemene zin positief uit over de bruikbaarheid van deze beperkingsmethode. Hij is wel van mening, dat de mate waarin doelcriteria houvast bieden bij de toepassing van beperkingsmogelijkheden en bij de toetsing daarvan door de rechter, afhankelijk is van de gespecificeerdheid van de doelcriteria. In dit opzicht schortte er weil het een en ander aan de grondrechtenbepalingen in de toenmalige Grondwet; de ontwerpen van de Proeve en de Staatscommissie Cals/Donner brengen hierin geen verbetering, aldus Burkens. Daarbij doelt hij met name op de criteria "openbare orde" en "algemeen belang"100, die voor meerdere interpretaties vatbaar zijn. Volgens Burkens zou het "de voorkeur verdienen om hetzij reële - dat wil zeggen nauwkeurig gespecificeerde doelcriteria in de Grondwet op te nemen, hetzij deze criteria maar helemaal te laten vervallen. In het laatste geval wordt het manco in de bescherming althans zichtbaar; dan kan wellicht op andere wijze voor compensatie worden gezorgd. "101

In de Memorie van Toelichting bij wetsvoorstel 13872 wordt met name als voordeel van deze beperkingsmethode gezien, dat in het grondrechtartikel wordt aangegeven "welke belangen een rechtvaardiging voor het aanbrengen van beperkingen opleveren." Met name voor de beantwoording van de vraag of een bepaalde inbreuk op een grondrecht is toegestaan kan dan een aanknopingspunt in het geschreven recht gevonden worden.

Ook in de Memorie van Toelichting worden echter de bezwaren onderkend, die een gebruik van uitsluitend doelcriteria met zich mee zou brengen. Grondrechten hebben een zodanig ruim toepassingsgebied, dat de realisering van de meeste beleidsdoeleinden wel hier en daar een belemmering van een grondrecht met zich mee zou brengen. Vanuit een goed functionerend bestuur is het echter wenselijk, dat vele van dergelijke belemmeringen mogelijk zijn. Het is echter ondoenlijk, al deze belemmeringen door middel van doelcriteria in de tekst van de: Grondwet op te nemen. In dat geval zou men moeten overgaan tot opsomming van praktisch alle beleidsdoeleinden van enige betekenis in het desbetreffende grondwetsartikel. De "lengte van de opsomming, de vaagheid van sommige beleidsdoeleinden en het feit, dat een eenmaal genoemd

99 Aan de hand van een aantal voorbeelden laat Burkens zien, dat in de Nederlandse rechtsorde aan het begrip "openbare orde" vele betekenissen toe te kennen zijn en derhalve dat dit begrip weinig onderscheidend vermogen heeft. Het begrip is te flexibel en zou slechts zijn grenzen vinden in de bepalingen van de Europese Conventie. Zie M.C. Burkens, Beperking van grondrechten, pp. 58-74(61 en 69).

100 M.C. Burkens, Beperking van grondrechten, pp. 74-75.

101 M.C. Burkens, Beperking van grondrechten, pp. 57-87(87). 
doelcriterium elke inbreuk, ook de zeer ingrijpende, geoorloofd doet zijn zolang die inbreuk maar geschiedt ten behoeve van het genoemde beleidsdoel", zou tot uitholling van het desbetreffende grondrecht leiden. Ook zou onduidelijk zijn, welke overheidsorganen tot het stellen van beperkingen bevoegd zijn.

Op grond van de genoemde overwegingen is de regering tot de conclusie gekomen, dat de methode van de doelcriteria "in beginsel aanvaardbaar is doch dat het in vele gevallen ongewenst zal zijn de beperkingsbevoegdheden uitsluitend door middel van deze methode te regelen." 102

Grondwettelijke bepalingen waarin aan de beperking van het daarin gegarandeerde grondrecht een doelcriterium is verbonden zijn de artikelen 6 lid 2, 7 lid 3, laatste zin, 8, 9 lid 2, 10 leden 2 en 3, en 14 lid 1. De gestelde doelen zijn: de bescherming van de gezondheid en de goede zeden, het belang van het verkeer en de openbare orde, de bestrijding of voorkoming van wanordelijkheden, het algemeen belang, en het vastleggen

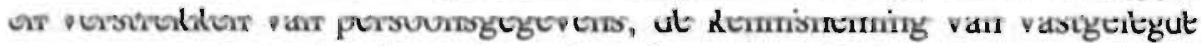
gegevens en het gebruik en de verbetering van zodanige gegevens.

Wat betreft de betekenis van die criteria moet worden opgemerkt, dat deze in de praktijk vaak niet worden gedefinieerd. Vaak worden de criteria toegepast, zonder dat eerst wordt vastgesteld wat ze inhouden. Aan het bovengenoemde bezwaar van de regering tegen doelcriteria, dat sommige daarvan zo vaag zijn, is in de praktijk derhalve nauwelijks tegemoet gekomen. Hierna zal slechts in beperkte mate kunnen worden aangegeven, wat onder de desbetreffende begrippen moet worden verstaan.

Ten aanzien van het doelcriterium openbare orde in artikel 8 Grondwet merkt de regering in de Memorie van Antwoord bij het wetsvoorstel inzake verboden rechtspersonen het volgende op. Aan de wetgever wordt veel ruimte overgelaten voor beperking van het recht van vereniging, niet alleen door de vage grenzen van het begrip openbare orde, maar ook doordat de beperking gerechtvaardigd wordt door al hetgeen in het belang van de openbare orde is. Uit de wetsgeschiedenis meent de regering te kunnen afleiden, dat het begrip beperkter is dan "strijd met de wet" en "aantasting van andermans rechten". Hierin zou de rechter, "die toch al weinig geneigd blijkt aan inbreuken op grondrechten een ruime uitleg te geven" een stimulans moeten vinden "om het begrip openbare orde en goede zeden in een beperkte betekenis op te vatten." Alleen handelingen die in strijd 
met de algemeen aanvaarde grondvesten van ons rechtsstelsel worden verricht, zouden het verbod van een vereniging of andere rechtspersonen kunnen rechtvaardigen. Hieronder vallen volgens de regering: ongerechtvaardigde aantasting van de vrijheid van anderen of van de menselijke waardigheid; gebruik van geweld of bedreiging daarmee tegen het openbaar gezag of tegen mensen met andere opvattingen; rassendiscriminatie en andere verboden discriminatie; het heulen met een mogendheid waarvan te verwachten valt dat zij een geboden kans om ons volk te onderdrukken zou grijpen; het weerstreven van onherroepelijke rechterlijke uitspraken of onrechtmatige benadeling van anderen als middel om het bestaan van de rechtspersoon te rekken; het stelselmatig niet afdragen van premies en frauderen; uitlatingen zoals het aanzetten tot haat en uitingen die verboden discriminatie inhouden of een mensonterend streven zoals het in de literatuur gegeven voorbeeld van een pleidooi om het doden van bepaalde bevolkingsgroepen straffeloos te maken. Volgens de regering hebben deze voorbeelden met elkaar gemeen, dat "zij een aantasting inhouden van de als wezenlijk ervaren beginselen van ons

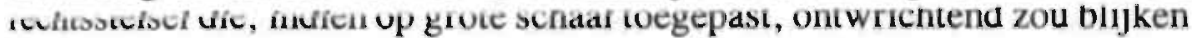
voor de samenleving. ${ }^{\text {"103 }}$

Hoewel uit het voorgaande blijkt, dat het bij openbare orde gaat om een bijzonder ruim begrip, is het volgens de regering niet alomvattend zoals het begrip in het algemeen belang en "zal het niet licht tot een verbod van politieke of culturele activiteiten leiden, mits deze activiteiten niet crimineel of anderszins ontoelaatbaar zijn." ${ }^{104}$ Een voorbeeld uit de rechtspraak is de uitspraak van de Afdeling Rechtspraak van 23 januari 1986, waarin werd bepaald, dat "bezwaren uit hoofde van de openbare orde ... zich ook [kunnen] voordoen, indien de naam [van de politieke groepering, in casu de Nederlandse Volksunie] waarvan registratie [ten behoeve de gemeenteraadsverkiezingen te Den Haag] wordt gevraagd is verbonden met een groepering die haar overtuigingen en opvattingen uitdraagt of heeft uitgedragen op een wijze die onmiskenbaar in strijd is met de openbare orde of goede zeden. ${ }^{\text {10s }}$

103 De zin: "Ik zie niet goed welke andersoortige voorbeelden van handelingen in strijd met de openbare orde zouden zijn te geven dan de (genoemde, CS) voorbeelden" lijkt erop te duiden dat beoogd is een uitputtende opsomming te geven. Memorie van Antwoord bij wetsvoorstel 17476 inzake verboden rechtspersonen, zitting 1984-1985. nr. 5 , p. 3.

104 Memorie van Antwoord bij wetsvoorstel 13872, Verklaring dat er grond bestaat..... Tweede Kamer, in: Algehele grondwetsherziening, deel la Grondrechten, p. 200. 
In het kader van de Wet Openbare Manifestaties werd ten aanzien van de zinsnede "... onthouden zich van gedragingen die het functioneren van de desbetreffende instelling aantasten" in artikel 9 WOM opgemerkt, dat deze formulering ruimer is dan de term "ter bestrijding van wanordelijkheden" in artikel 6 en 9 Grondwet. Niet ieder ongewenst gedrag of samenstel van gedragingen dat het functioneren van de betrokken instelling aantast kan als "wanordelijkheden" worden aangemerkt. Hierin ligt het verschil met de term "in het belang van de openbare orde". ${ }^{106}$

Met betrekking tot de criteria bescherming van de gezondheid, in het belang van het verkeer en ter bestrijding of voorkoming van wanordelijkheden in artikel 9 Grondwet heeft de Voorzitter van de Afdeling Rechtspraak uitgesproken, dat "de omstandigheid dat een bepaalde demonstratie bij het publiek irritaties opwekt of tegendemonstraties uitlokt ..." onvoldoende is "om de demonstratie op grond van [de Wet Openbare Manifestaties] te verbieden". Het ging hier om een verbod van een demonstratie op grond van artikel 5 (WOM) in verband met artıkeí $\bar{Z}$ van die wet, dat dezelfđ̃e doeĺcriteria noemt als artikel 9 Grondwet. De doorslaggevende factor in deze zaak was, dat het. beschikbare politiepersoneel onvoldoende was "om het redelijkerwijs te voorziene grootscheepse wanordelijk gebeuren ter plaatse in de hand te kunnen houden." 107

Ten aanzien van het begrip goede zeden in artikel 7 lid 3 Grondwet merkt. de regering in de Memorie van Toelichting bij wetsvoorstel $13872 \mathrm{op}$, dat dit begrip ruim moet worden opgevat, "zodat onder de bescherming van de goede zeden ook valt de bescherming van de zedelijke ontwikkeling van deze jeugdigen" (personen jonger dan 16 jaar, CS). ${ }^{108}$

Zoals gezegd, heeft de praktijk niet tegemoet kunnen komen aan het bezwaā van vaagheid van sommige doelcriteria. Het bezwaar van de regering, dat in geval van zelfstandig gebruik van doelcriteria niet duidelijk zou zijn welke overheidsorganen tot het stellen van beperkingen bevoegd

106 De aangehaalde zinsnede in artikel 9 WOM was dan ook niet gebaseerd op de tweede leden van artikel 6 en 9 . Grondwet, maar op de in de eerste leden vervatte formule "behoudens. ieders verantwoordelijkheid volgens de wet". Memorie van Antwoord bij wetsvoorstel 19427, WOM, Eerste Kamer (met verwijzing naar de Memorie van Toelichting).

107 Vz.ARRS 21 maart 1989, AB 1989, 498 met noot A.E. Schilder onder AB 1989, 499; KG 1989, 158.

108 Memorie van Toelichting bij wetsvoorstel 13872, Verklaring dat er grond bestaat .... Tweede Kamer, in: Algehele grondwetsherziening, deel la Grondrechten, p. 36 
zijn, is blijkens de vorige paragraaf weggenomen door het gebruik van competentievoorschriften. Nu de lengte van de opsomming van doelcriteria in de grondrechtenbepalingen ook wel meevalt, behoeft mijns inziens nu alleen nog bespreking het bezwaar "dat een eenmaal genoemd doelcriterium elke inbreuk, ook de zeer ingrijpende, geoorloofd doet zijn zolang die inbreuk maar geschiedt ten behoeve van het genoemde beleidsdoel", wat tot uitholling van het desbetreffende grondrecht zou leiden. Mijns inziens kan aan dit bezwaar - voor zover dit al niet op andere wijze is gebeurd - tegemoet gekomen worden door het gebruik van gedragscodes. Deze zullen in de nu volgende paragraaf besproken worden.

\subsubsection{Gedragscodes}

Onder een gedragscode kan worden verstaan de voorwaarde, dat een redelijke afweging plaatsvindt van de belangen ten behoeve waarvan een grondrecht wordt beperkt en de belangen die het desbetreffende grondrecht beoogt te garanderen. Volgens Akkermans c.s. is het verschil met de eerder besproken procedurevoorschriften hier in gelegen, dat bij procedurevoorschriften de toelaatbaarheid van beperkingen afhankelijk is gesteld van de inachtneming van een of meer formele vereisten. Bij gedragscodes moeten inhoudelijke gedragsnormen worden nageleefd. Gedragscodes kunnen van doelcriteria worden onderscheiden, daar doelcriteria aangeven in welk belang een grondrechtenbeperking mag geschieden en gedragscodes aangeven in hoeverre een de beperking van een grondrecht daadwerkelijk noodzakelijk moet worden geacht. ${ }^{109}$

Burkens noemt als voorbeeld van een gedragscode waaraan de beperking van een vrijheid wordt gebonden, de voorwaarde van de "noodzakelijkheid in een democratische samenleving" van een bepaalde inbreuk op die desbetreffende vrijheid (artikelen 8-11 ECRM). Volgens Burkens betekent deze voorwaarde voor de wetgever niet meer dan een verbod van willekeur, omdat de door de wetgever genomen maatregelen per definitie voorzieningen zijn, welke geacht kunnen worden noodzakelijk in een democratische samenleving te zijn; de wetgever is immers zelf de exponent. van de democratische samenleving, omdat hij is voortgekomen uit verkiezingen. Rechterlijke toetsing van een genomen maatregel aan het 
criterium van "noodzakelijkheid in een democratische samenleving" zou volgens Burkens dan ook nauwelijks mogelijk zijn. ${ }^{110}$

In de bestaande grondwet is in de beperkingsclausules geen met het "noodzakelijkheids"-criterium vergelijkbare gedragscode te vinden. Volgens Burkens zou echter het grondwettelijk gegarandeerde gelijkheidsbeginsel als een gedragscode opgevat kunnen worden. De norm van de gelijke behandeling van gelijke gevallen zou zowel voor de wetgeving (in materiële zin) als voor de wetstoepassing gelden en zou daarmee het gehele terrein van de grondrechtenbeperking bestrijken. "'

Op grond van het bovenstaande kan worden verwezen naar wat in het hoofdstuk ten aanzien van de Europese Conventie werd besproken bij de "grenzen van de beperkingsbevoegdheden". Ook daar kwam naar voren, dat het discriminatie-verbod grenzen stelt aan de beperking van grondrechten. ${ }^{112}$

Aldaar stonden ook nog andere bepalingen vermeld, die grenzen stelden aan de geboden beperkingsmogelijkheden in de Conventie: het verbod op het verder beperken van de gegarandeerde rechten dan de Conventie toestaat (artikel IT ECRM) en het verbod van detournement de pouvoir (artikel 18 ECRM). Soortgelijke bepalingen zijn niet in de Grondwet terug te vinden. Artikel 17 ECRM komt alleen ter sprake in verband met de aantasting van grondrechten door de uitoefening van grondrechten (misbruik van recht). De regering beantwoordt de vraag of een artikel als artikel 17 ECRM ook in de Grondwet moet worden opgenomen, ontkennend. Betwijfeld wordt, of een dergelijk artikel een maatschappelijke of politieke ontwikkeling naar een politieke orde, waarin de vrijheid van meningsuiting verregaand wordt beperkt en waarin alleen de aanhangers van het heersende politieke bewind hun rechten kunnen uitoefenen, kan tegenhouden. Volgens de regering bieden de opgenomen beperkingsclausules voldoende mogelijkheden om bepaalde maatregelen treffen, indien de omstandigheden daar ooit toe mochten nopen. ${ }^{13}$ Bepalingen terzake van het verbod op het verder beperken van grondrechten dan de Grondwet toestaat en terzake van het verbod van détournement de pouvoir als begrenzingen van de

110 M.C. Burkens, Beperking van grondrechten, pp. 87-90.

Zoals in het vorige hoofdstuk uit de bespreking van de Europese jurisprudentie ten aanzien van deze voorwaarde blijkt, is deze opvatting van Burkens inmiddels sterk verouderd. Zo varieert de mate van toetsing van recht tot recht en van beperkingsgrond tot beperkingsgrond en is in het kader van die toetsing een heel assortiment van criteria ontwikkeld. Zie hiervoor, pp. 23-29.

111 M.C. Burkens, Beperking van grondrechten, pp. 90-91.

112 Zie hiervoor, paragraaf 2.4.5.

113 Memorie van Toelichting bij wetsvoorstel 13872, Verklaring dat er grond bestaat .... Tweede Kamer, in: Algehele grondwetsherziening, deel Ia Grondrechten, p. 8. 
beperkingsmogelijkheden - als gedragscodes - komen gedurende de totstandkoming van de grondwetsherziening 1983, niet ter sprake. ${ }^{114}$

\subsubsection{Uitzonderingstoestanden ${ }^{115}$}

Uit de Memorie van Toelichting bij wetsvoorstel 15681 met betrekking tot verandering in de Grondwet van de bepalingen inzake uitzonderingstoestanden kan worden afgeleid, dat onder de term "uitzonderingstoestanden" in de Grondwet moet worden verstaan de "situaties waarbij van het overigens door de Grondwet bepaalde mag worden afgeweken binnen door de Grondwet zelf aangegeven grenzen"."16 Deze bevoegdheid tot afwijking wordt gegeven in artikel $103 \mathrm{Gw}$. Verschillende vragen kunnen bij de kwestie van de afwijking van grondwetsbepalingen rijzen. In het navolgende zal ik mij beperken tot díe vragen, die relevant zijn voor de afwijking van grondwetsbepalingen die grondrechten garanderen: Wie kan uitzonderingstoestanden in het leven roepen, in welke situaties en onder welke voorwaarden; wie is bevoegd van grondrechten af te wijken, is delegatie daarbij toegestaan, van welke grondrechten kan worden afgeweken etc.?

Uitzonderingstoestanden kunnen ingevolge artikel 103 lid $1 \mathrm{Gw}$ worden afgekondigd door middel van Koninklijk Besluit. Volgens de Memorie van Toelichting wordt hiermee uitdrukking gegeven aan de opvatting, dat de afkondiging van een uitzonderingstoestand een regeringszaak is. Andere organen zijn terzake dus onbevoegd. ${ }^{117}$ Dat betekent niet, dat er voor het parlement geen rol is weggelegd. Allereerst bestaat er de normaal geldende politieke verantwoordelijkheid van de regering. En verder moet de StatenGeneraal in verenigde vergadering ingevolge lid 3 van artikel $103 \mathrm{Gw}$ terstond na de afkondiging van een uitzonderingstoestand beslissen over het voortduren daarvan. Dit gebeurt voorts telkens wanneer de Staten-Generaal dit nodig acht zolang de uitzonderingstoestand voortduurt. Hiermee wordt volgens de regering gewaarborgd, "dat de interpretatie van de

114 Of er ondanks het ontbreken van expliciete gedragscodes in de Grondwet toch niet sprake is van het impliciet toepassen van gedragscodes in de praktijk, zal in verband met de redelijke wetstoepassing en algemene beperkingen ter sprake komen in het laatste hoofdstuk.

115. Vanwege de sterk versnipperde regeling van het staatsnoodrecht, zullen slechts enkele van die regelingen ter sprake komen.

116. Memorie van Toelichting bij wetsvoorstel 15681 met betrekking tot verandering in de Grondwet van de bepalingen inzake uitzonderingstoestanden, Tweede Kamer, in: Algehele Grondwetsherziening, deel Vc, p. 163.

117 Idem, in: Algehele Grondwetsherziening, deel Vc, p. 168 
omstandigheden, welke tot de afkondiging van een uitzonderingstoestand hebben geleid niet alleen aan de regering blijft voorbehouden." Het parlement beschikt hiermee over de mogelijkheid "om aan de duur van een uitzonderingstoestand een termijn te stellen". Een uitzonderingstoestand kan echter niet met terugwerkende kracht ongedaan gemaakt worden. ${ }^{118}$ Of de Staten-Generaal bevoegd is een uitzonderingstoestand te beëindigen wordt uit de tekst van artikel $103 \mathrm{Gw}$ niet duidelijk. Alhoewel de Memorie van Toelichting in die richting lijkt te wijzen ${ }^{119}$, zijn diverse auteurs de mening toegedaan dat een dergelijk bevoegdheid moet worden afgewezen. Zo zou vanwege het feit, dat een uitzonderingstoestand alleen per KB kan worden íngesteld moeten worden afgeleid, dat een zodanige toestand ook alleen per $\mathrm{KB}$ kan worden beëindigd. ${ }^{120}$ Bovendien spreekt artikel 103 lid 3 alleen van "zolang zij niet bij koninklijk besluit is opgeheven" en - wat betreft de Staten-Generaal - van "beslissen omtrent het voortduren". ${ }^{121}$ Voorts zou een beëindigingsbevoegdheid van het parlement ongewenst zijn, omdat indien de regering van mening zou zijn dat de uitzonderingstoestand moet worden gehandhaafd, de regering een in haar ogen noodzakelijk middel wondt ontmomen. De Staten-Generaal zouden het hier moeten doen met het ter verantwoording roepen van de regering. ${ }^{122}$

Voor het geoorloofd afkondigen van een uitzonderingstoestand moet sprake zijn van buitengewone of uitzonderlijke omstandigheden. Het in de normale situatie geldende rechtsregime kan onder die omstandigheden niet zonder meer functioneren. De voor normale omstandigheden voorziene mogelijkheden ter beperking van grondrechten kunnen onder deze omstandigheden ontoereikend zijn. Voor uitzonderingssituaties is in artikel 103 lid $2 \mathrm{Gw}$ de mogelijkheid geopend om grondrechten te beperken, waar dat onder normale omstandigheden niet mogelijk zou zijn. ${ }^{123}$ De onder de Grondwet 1972 toegelaten uitzonderingstoestanden werden nog bij nam genoemd: "staat van beleg". "staat van oorlog" (beiden artikel 202 lid 1 Gw 1972) en "oorlogsgevaar" (artikel 201 lid 4 Gw 1972). Deze termen

118 Idem, in: Algehele Grondwetsherziening, deel Vc. pp. 166-167.

119 Memorie van Toelichting bij wetswoorstel 15681 met. betrekking tot verandering in de Grondwet van de bepalingen inzake uitzonderingstoestanden, Tweede Kamer, in: Algehele Grondwetsherziening, dee! Vc, p. 167: "De bevoegdheid van de StatenGeneraal, om ... een uitzonderingstoestand te beëindigen lijkt de beste waarborg dat de normale verhoudingen zo snel mogelijk worden hersteld."

120 Kortmann spreekt van "parallélie des formes", C.A.J.M. Kortmann, De Grondwetsherzieningen 1983 en 1987, p. 291.

121 C.A.J.M. Kortmann, De Grondwetsherzieningen 1983 en 1987, p.291.

122 Th.J. Clarenbeek, Uitzonderingstoestanden in de nieuwe: Grondwet, p. 1017.

123 P.W.C. Akkermans, C.J. Bax en L.F.M. Verhey, Grondrechten, Grondrechten en grondrechtsbescherming in Nederland, pp. 161-162. Zie hierna. 
zijn in 1983 uit de Grondwet geschrapt. Volgens de Memorie van Toelichting bij wetsvoorstel 15681 wordt het begrip "uitzonderingstoestand" als volgt begrensd. Ten eerste moet een uitzonderingstoestand als zodanig door de wet worden aangewezen. Ten tweede moet de uitzonderingstoestand worden ingeroepen met het oog op een bepaald doel: de handhaving van de uitwendige of inwendige veiligheid. Voorbeelden van wetten waarin uitzonderingstoestanden worden vermeld zijn de Oorlogswet voor Nederland (OWN) en de Wet buitengewone bevoegdheden burgerlijk gezag (Wet bbbg). In artikel 1 OWN worden de "in staat van oorlog" en de "in staat van beleg" -verklaring genoemd en in artikel 1 Wet bbbg de "toestand van verhoogde waakzaamheid" en de "burgerlijke uitzonderingstoestand". ${ }^{124.125}$ De wetten die uitvoering geven aan artikel 103 lid $1 \mathrm{Gw}$ moeten aangeven in welke gevallen ter handhaving van de in of uitwendige veiligheid een uitzonderingstoestand kan worden ingesteld. Artikel 1 OWN beperkt zich tot de vage omschrijving, dat "buitengewone omstandigheden zulks noodzakelijk maken voor de uitvoering van de militaire taak ter handhaving van de uit- of inwendige veiligheid". In artikel 1 Wet bbbg gaat het om het "geval van de rechtsorde en het volksbestaan bedreigende oproerige beweging, onlusten of soortgelijke stoornissen van de openbare orde of van ernstige vrees voor het ontstaan daarvan".

Zoals in artikel 103 lid $1 \mathrm{Gw}$ staat, moeten de gevolgen van de afkondiging van een uitzonderingstoestand bij wet geregeld worden. Hieruit kan worden afgeleid, dat delegatie is toegestaan. De formulering van lid 2 van dit artikel ("Daarbij kan worden afgeweken ...") lijkt erop

124 Zie voor een niet-uitputtende lijst van wetten waarin in uitzonderingstoestanden is voorzien: Algehele Grondwetsherziening, deel Vc, Bijlage bij Nota naar aanleiding van het Eindverslag, p, 215.

125 Inmiddels is door de regering een wetsvoorstel ingediend die de bestaande weigeving inzake uitzonderingstoestanden zal moeten vervangen: de Coördinatiewet uitzonderingstoestanden (18 september 1992, Stcrt. 1992, 181). Op grond van deze tot stand te brengen wet zal volgens het voorstel van de regering het bestaande stelsel van buitengewone uitzonderingstoestanden worden vervangen door de beperkte en algemene noodtoestand. Hierdoor komen de hiervoor genoemde uitzonderingstoestanden in de OWN en de Wet bbbg te vervallen. Zie de Memorie van Toelichting bij wetsvoorstel 23790 , Coördinatiewet uitzonderingstoestanden, Tweede Kamer, pp. 12, de Memorie van Toelichting bij wetsvoorstel 23791, Invoeringswet Coördinatiewet uitzonderingstoestanden, Tweede Kamer, p. 1, de Memorie van Toelichting bij wetsvoorstel 23788 , inzake de hernieuwde vaststelling van de OWN ter aanpassing aan de Grondwet en aan de Coördinatiewet uitzonderingstoestanden, Tweede Kamer, pp. 1-3 en de Memorie van Toelichting bij wetsvoorstel 23789 , inzake de hernieuwde vaststelling van de Wbbbg ter aanpassing aan de Grondwet en aan de Coôrdinatiewet uitzonderingstoestanden, Tweede Kamer, pp. 1-5. 
te wijzen, dat de in dit lid voorziene afwijkingsmogelijkheden van bepaalde grondwetsbepalingen door de regering worden beschouwd als de in lid 1 bedoelde gevolgen van de afgekondigde uitzonderingstoestand. De afwijkingsmogelijkheden zullen in dat geval ook gedelegeerd kunnen worden. ${ }^{126}$

Wat betreft de mogelijkheid van afwijking van grondrechtenbepalingen in de Grondwet, beperkt artikel 103 lid $2 \mathrm{Gw}$ zich tot een opsomming van grondwetsbepalingen waarvan kan (dus niet: moet) worden afgeweken. Het uitgangspunt van de Grondwet is derhalve, dat in principe afwijking van de grondwettelijke grondrechten ongeoorloofd is, behalve voor wat betreft de in lid 2 genoemde bepalingen. ${ }^{127}$ Het betreft hier het recht om buiten gebouwen en besloten plaatsen zijn godsdienst of levensovertuiging te belijden (artikel 6), de vrijheid van meningsuiting (artikel 7), het recht tot vereniging (artikel 8), het recht tot vergadering en betoging (artikel 9), de bescherming van de woning (artikel 12 lid 2), het brief-, telefoon- en telegraafgeheim (artikel 13) en het in artikel 113 lid 1 en lid 3 geregelde. De mogelijkheid tot afwijking van artikel 113 leden 1 en 3 zijn pas naderhand per (tweede) Nota van wijzigingen aan het wetsvoorștel 15681 toegevoegd teneinde de mobiele krijgsraden, die ingevolge het militaire (straf)procesrecht met rechtspraak kunnen worden belast, van een grondwettelijke basis voor de berechting van strafbare feiten en de oplegging van vrijheidsstraffen te voorzien. Deze afwijkingsmogelijkheid is volgens de regering nodig omdat deze krijgsraden niet beschouwd kunnen worden als organen behorende tot de rechterlijke macht. De met rechtspraak belaste leden van de krijgsraden behoeven voorts niet voor het leven te worden benoemd en kunnen "onder bepaalde omstandigheden worden aangesteld door een lager gezag dan de Kroon." ${ }^{28}$ Van de bevoegdheid tot afwijking van de grondwettelijke grondrechten is in diverse wetten gebruik gemaakt. Vergaande inbreuken op de genoemde rechten zijn, onder andere, gelegen in de bevoegdheid tot inbeslagneming enz. van post- en andere stukken en afluistering van berichten (artikel 45 OWN; artikel 19 Wet bbbg), en tot beperking van het verspreiden enz, van

126 C. Riezebos, Artikel 103 Grondwet, p. 927.

127 Memorie van Toelichting bij wetsvoorstel 15681 met betrekking tot verandering in de Grondwet van de bepalingen inzake uitzonderingstoestanden, Tweede Kamer, in: Aigehele Grondwetsherziening, deel Vc, p. 166.

128 Tweede Nota van wijzigingen bij wetsvoorstel 15681 met betrekking tot verandering in de Grondwet van de bepalingen inzake uitzonderingstoestanden, Tweede Kamer. in: Algehele Grondwetsherziening, deel Vc, p. 216. Zie ten aanzien van het niet onder de afwijkingsmogelijkheden opgenomen artikel 15 lid 2 en artikel 17: pp. 169170 en Th.J. Clarenbeek, Uitzonderingstoestanden in de nieuwe Grondwet, pp. 1017 1018. 
geschriften of afbeeldingen (artikel 49 OWN; artikel 18 Wet bbbg), in het verbod van vergaderen enz. zonder vergunning (artikel $50 \mathrm{OWN}$; artikel 20 Wet bbbg), en in de bevoegdheid tot huiszoeking (artikel 54 OWN; artikel 22 Wet bbbg). ${ }^{129}$

Echter, ook worden in deze noodwetten mogelijkheden geschapen voor het maken van inbreuken op niet in artikel 103 lid $2 \mathrm{Gw}$ genoemde grondrechten. Zo maken artikel 53 OWN en artikel 21 Wet bbbg onderzoek aan kleding en lichaam mogelijk. In het tweede lid van artikel 21 Wet bbbg wordt aan de Minister van Binnenlandse Zaken opgedragen de uitoefening van de in het eerste lid gegeven bevoegdheid nader te regelen; hiermee lijkt de op het - in artikel $11 \mathrm{Gw}$ gegarandeerde - recht van een ieder op onaantastbaarheid van zijn lichaam gemaakte inbreuk te worden gedekt door de clausule in deze grondwetsbepaling die "bij of krachtens de wet" te stellen beperkingen toestaat. Hiervoor geldt dan wel de voorwaarde dat de desbetreffende ministeriële regeling uitdrukkelijk de omvang van de op artikel 11 Grondwet toegestane beperking aangeeft. Is aan die voorwaarde voldaan dan is opneming van artikel $11 \mathrm{Gw}$ in artikel 103 lid $2 \mathrm{Gw}$, wat betreft artikel $21 \mathrm{Wbbbg}$, derhalve overbodig. ${ }^{130}$ In artikel 53 OWN wordt, echter, geen nadere regeling van de daarin voorziene bevoegdheid tot onderzoek aan kleding en lichaam aan de lagere wetgever opgedragen en deze bepaling geeft zelf ook niet aan hoe ver de beperking op artikel 11 Grondwet (naar het hierin gegarandeerde grondrecht wordt in het geheel niet verwezen) mag gaan. Artikel 53 OWN is derhalve niet in overeenstemming met de Grondwet. In het wetsvoorstel ter aanpassing van de OWN aan de Grondwet en aan de Coördinatiewet uitzonderingstoestanden is dan ook de opneming van een bepaling in de OWN voorzien, teneinde deze onverenigbaarheid met artikel 11 Grondwet op te heffen. ${ }^{131}$

In overeenstemming met artikel 14 lid $1 \mathrm{Gw}$, bepaalt de Onteigeningswet, dat onteigening moet plaatsvinden middels een minnelijke

129 Ingevolge de voorgestelde Coördinatiewet uitzonderingstoestanden en de overige in noot 125 genoemde wetsvoorstellen, zal er alleen van grondrechten afgeweken kunnen worden in het geval van "algemene noodtoestand". Afwijking van de in artikel 103 Grondwet genoemde grondiechten zall alleen mogelijk zijn als het. voortbestaan van de vrije samenleving in het geding is. Zie de Memorie van Toelichting bij wetsvoorstel 23790 , Coördinatiewet uitzonderingstoestanden, Tweede Kamer, p. 2.

130 Impliciet: C. Riezebos, Artikel 103 Grondwet, p. 928.

131 Memorie van Toelichting bij wetsvoorstel 23788, inzake de hernieuwde vaststelling van de Oorlogswet voor Nederland ter aanpassing aan de Grondwet en aan de Coôrdinatiewet uitzonderingstoestanden, Tweede Kamer, p. 19. (artikel 38). Zie ook p. 6 en p. 10 ten aanzien van het voorgestelde artikel 8 OWN (geweldgebruik). 
overeenkomst (artikel 17), dan wel door middel van een onteigeningsprocedure voor de arrondissementsrechtbank (artikel 18). In de dagvaarding moet het bedrag, dat als schadeloosstelling wordt aangeboden, worden vermeld (artikel 22) en in het vonnis wordt naast de uitspraak over de onteigening, ook de schadeloosstelling vastgesteld (artikel 37). In geval van oorlog, brand of watersnood kan wanneer dit volstrekt noodzakelijk geacht wordt, inbezitneming ogenblikkelijk plaatsvinden (artikel 73 lid 1). De eigendom van het onteigende "gaat onmiddellijk op degene over, in wiens naam de inbezitneming is geschied" (artikel 73 lid 5). Artikel 74 bepaalt voorts, dat zodra dit na de onteigening mogelijk is, degene die de onteigening bevolen heeft, "aan de onteigenden geregtelijk eene schadevergoeding doen aanbieden". De aldus in geval van oorlog, brand of watersnood geschiede onteigening is derhalve niet in overeenstemming met artikel 14 lid $1 \mathrm{Gw}$ omdat vooraf geen schadeloosstelling is verzekerd. Toch is het niet nodig geweest om artikel 14 lid 1 in artikel 103 lid $2 \mathrm{Gw}$ op te nemen, omdat in lid 2 van artikel 14 Gw een beperking op lid 1 is aangebracht voor het geval van "nood". Lid 2 van artikel $14 \mathrm{Gw}$ dekt derhalve de voor het geval van oorlog enz. vastgestelde regeling (artikel 73 e.v. Onteigeningswet) van onteigening. ${ }^{13}$

Oorspronkelijk werd ook een inbreuk toegestaan op artikel $15 \mathrm{Gw}$ in de artikelen $57 \mathrm{OWN}$ en 24 Wet bbbg waarin de bevoegdheid wordt verschaft om iemand op basis van vermoedens te laten interneren of in bewaring te stellen. Oorspronkelijk bestond alleen de mogelijkheid om hiertegen bezwaar in te dienen bij de rechtbank, die hierover advies moest uitbrengen aan respectievelijk de Minister van Defensie en de Minister van Binnenlandse Zaken. In verband met de strijdigheid van deze artikelen met artikel 15 lid $2 \mathrm{Gw}$ was een additioneel artikel opgenomen waarin de wetgever vijf jaar de tijd kreeg om de desbetreffende bepalingen aan artikel 15 lid $2 \mathrm{Gw}$ aan te passen. Dit is inmiddels geschied. ${ }^{133}$

Tot nu toe is, zoals aangekondigd aan het eind van paragraaf 3.2.2, ingegaan op mogelijkheden ter nadere omlijning van de clausules waarin

132 Zoals hierboven al werd opgemerkt, werden de begrippen "staat van oorlog", "staat van beleg" en "oorlogsgevaar" in de artikelen 201 en 202 Gw 1972 in 1983 uit de Grondwet geschrapt. In artikel $103 \mathrm{Gw}$ kwam daar de algemene term "uitzonderingstoestanden" voor in de plaats. Hetzelfde is gebeurd met het oude onteigeningsartikel, artikel 165 lid 3 Gw 1972: de begrippen "oorlog", "oorlogsgevaar", "oproer", "brand" en "watersnood" zijn vervangen door het algemene begrip "nood" in artikel 14 lid 2 Gw 1983.

133 Wijziging van artikel $57 \mathrm{OWN}$ en artikel 24 Wet bbbg en toevoeging van artikelen $57 \mathrm{a}-57 \mathrm{~d}$ OWN en artikelen $24 \mathrm{a}-24 \mathrm{~g}$ bij Wet van 11 februari 1988, Stb. 36. 
bijzondere beperkingen op grondrechten kunnen worden vervat. In de volgende paragraaf zal ingegaan worden op een andere wijze waarop mogelijkheden tot beperking van grondrechten begrensd kunnen worden, namelijk via het onderscheid tussen kernrechten en connexe rechten.

\subsubsection{Kernrechten en connexe rechten}

Zoals al in de paragraaf over de algemene en bijzondere beperkingen (par. 3.2.2) vermeld werd, heeft de Hoge Raad door middel van het hanteren van een bepaalde interpretatieve techniek een uitspraak over de al dan niet toelaatbaarheid van algemene beperkingen weten te ontwijken. Bedoeld wordt het onderscheiden van kernrechten en connexe rechten. In de desbetreffende paragraaf wordt dit onderscheid geïllustreerd aan de hand van de jurisprudentie ten aanzien van artikel 7 lid 1 Grondwet. ${ }^{134}$ Het door artikel 7 lid 1 bestreken openbaringsrecht is volgens deze jurisprudentie het kernrecht; het verspreidingsrecht is het in het rechtersrecht ontwikkelde - voor het openbaringsrecht onmisbare maar daaraan ondergeschikte - connexe recht, dat niet tot het "wezen" van de drukpersvrijheid behoort. In deze redenering vallen twee benaderingen van de kernrechtgedachte samen. Volgens de formele benadering verstaat men onder een kernrecht een verdragsrechtelijk of grondwettelijk gegarandeerd recht en onder een connex recht een in het rechtersrecht ontwikkeld recht, dat aan het kernrecht verbonden is. In de materiële benadering bestaan er "graduele verschillen in belangrijkheid of "wezenlijkheid" van elementen van dit recht". ${ }^{135}$ Verschil van mening kan bestaan over de vraag of er ten aanzien van elk grondrecht in algemene zin een onderverdeling kan worden gemaakt tussen "wezenlijke" en "perifere" elementen, dan wel het van de omstandigheden van het geval afhangt of een bepaald element tot de kern van het desbetreffende recht hoort. Gaat men uit van de laatstgenoemde opvatting, dan kan in het concrete geval een afweging gemaakt worden tussen de waarden en belangen ten behoeve waarvan een grondrechtenbeperking plaatsvindt en "datgene wat van het grondrecht door die

134. Zie hierboven, p. 97. Voorbeelden van recentere (dan de daar genoemde) rechterlijke: uitspraken ten aanzien van artikel $7 \mathrm{Gw}$ en de kernrechtgedachte (vaak impliciet): (voor inwerkingtreding van de herziene Grondwet:) HR 2 maart 1982, NJ 1984, 133 en (na de inwerkingtreding:) HR 28 juni 1983, NJ 1984, 64; DD 1983, 453; HR 21 januari 1986, NJ 1986, 441 met nooll Th.W. van Veen, AB 1986, 572 met noot E.A. Alkema; Vz.ARRS 10 augustus 1989, KG 1989. 341, De Gemeentestem no. 6889. nr. 4. Zie verder: F.H. Kistenkas, De verspreidingsjurisprudentie in perspectief.

135 M.C. Burkens, Beperking van grondrechten, p. 141; zie ook P.W.C. Akkermans, C.J. Bax en L.F.M. Verhey, Grondrechten, Grondrechten en grondrechtsbescherming in Nederland, p. 157. 
beperking verloren gaat. Weegt dit laatste zwaarder dan het eerste, dan is sprake van aantasting van de kern. ${ }^{136}$ Deze casuïstische benadering biedt mijns inziens te veel ruimte voor arbitraire vaststellingen van wat wel en wat niet tot de kern van een grondrecht moet worden gerekend. Met Burkens kan worden ingestemd, dat aldus de beslissing over wanneer sprake is van de kern van een grondrecht "ingebed [kan] zijn in de normale afweging van het pro en contra van een inbreuk op een grondrecht en aldus [kan] resulteren in een beleidsvrijheid van wetgever en besturende overheid tot het maken van inbreuk."137 Bovendien zou uit de kernrechtgedachte niet duidelijk worden welk overheidsorgaan bevoegd is om grondrechten te beperken. Hierdoor zou in feite ieder overheidsorgaan inbreuk op een grondrecht kunnen maken zolang daarbij maar niet de kern van dit recht aangetast wordt. Ook zou niet duidelijk zijn, in hoeverre er nog ruimte zou bestaan voor extra beperkingsmogelijkheden naast de in de grondrechtbepalingen opgenomen beperkingsclausules. ${ }^{138}$

De kernrechtgedachte zou in de casuïstische benadering ook voordelen kunnen bieden boven beperkingsmogelijkheden als doelcriteria en algemene beperkingen; sommige elementen van een grondrecht zijn van groter gewicht dan andere onderdelen en op deze minder zwaar wegende elementen kunnen dan ook meer beperkingen worden aangebracht dan op fundamentelere onderdelen. $\mathrm{Bij}$ de beoordeling van de toelaatbaarheid van een grondrechtenbeperking wordt derhalve rekening gehouden met "het gewicht van datgene wat er van het grondrecht wordt weggenomen". Toch kunnen deze voordelen volgens de regering (in de Memorie van Toelichting bij wetsvoorstel 13872) niet opwegen tegen de genoemde nadelen. Daarom acht zij de kernrechtgedachte als zelfstandigé beperkingsgrond niet aanvaardbaar, alhoewel er "in bepaalde opzichten" wellicht een rol voor is weggelegd. ${ }^{139}$ Welke rol dit zou kunnen zijn, geeft de regering echter niet aan. Een suggestie wordt wèl gedaan door enkele fracties in de Tweede Kamer in het Voorlopig Verslag. Hierin stellen zij vast, dat de kernrechtgedachte niet als zelfstandige beperkingsgrond in aanmerking komt, omdat het begrip kernrecht fungeert

136 Memorie van Toelichting bij wetsvoorstel 13872. Verklaring dat er grond bestaat .... Tweede Kamer, in: Algehele Grondwetsherziening, deel Ia Grondrechten, p. 19.

137 M.C. Burkens, Algemene leerstukiken van grondrechten naar Nederlands constitutioneel recht, p. 96.

138 Memorie van Toelichting bij wetsvoorstel 13872, Verklaring dat er grond bestaat .... Tweede Kamer, in: Algehele Grondwetsherziening, deel la Grondrechten, p. 19.

139 Memorie van Toelichting bij wetsvoorstel 13872, Verklaring dat er grond bestaat .... Tweede Kamer, in: Algehele Grondwetsherziening, deel Ia, p. 19. 
als beperking van beperkingsbevoegdheden. Dit doet weer sterk denken aan de hierboven besproken gedragscodes. ${ }^{140}$

Overigens blijken zowel de grondwetgever als de wetgever impliciet de kernrechtgedachte wèl als zelfstandige beperkingsgrond te hebben toegepast. In artikel 6 heeft de grondwetgever een onderscheid gemaakt tussen het belijden van godsdienst binnen en buiten gebouwen en besloten plaatsen. Ten aanzien van het belijden binnen gebouwen en besloten plaatsen is alleen repressief toezicht mogelijk (lid 1), ten aanzien van het belijden erbuiten kunnen ook preventieve maatregelen worden genomen (lid 2). Hieruit zou kunnen worden afgeleid dat de belijdenis van geloof of overtuiging binnen gebouwen en besloten plaatsen een essentiëler element is van de godsdienstvrijheid dan de belijdenis erbuiten.

Wat betreft artikel 10 Grondwet kan erop worden gewezen, dat - naast de in lid 1 vervatte garantie van de persoonlijke levenssfeer - in leden 2 en 3 extra beschermingsverplichtingen aan de wetgever zijn opgelegd met betrekking tot persoonsgegevens. Dit lijkt erop te duiden dat de bescherming van de persoonlijke levenssfeer op dit vlak essentiëler geacht wordt.

Voorts heeft de grondwetgever in artikel 7 lid 4 Grondwet handelsreclame van de bescherming van vrijheid van meningsuiting uitgesioten. Kennelijk zijn dit soort uitingen minder wezenlijk dan andere, wel beschermde uitingen. Dit stemt overigens overeen met de jurisprudentie naar aanleiding van artikel 10 ECRM, alhoewel de kernrechtgedachte in het kader van de Conventie nooit aan de orde gesteld is. In het vorige hoofdstuk zagen we al, dat de Staten een grotere beoordelingsvrijheid lijken te hebben ten aanzien van de noodzakelijkheid van beperkingen op de vrijheid van meningsuiting, indien het gaat om handelsreclame (die wèl door artikel 10 ECRM bestreken wordt). De overigens zo voor de democratie essentieel geachte vrijheid van meningsuiting, lijkt op het gebied van handelsreclame minder zware eisen aan de Staat te stellen. ${ }^{141}$

140. Voorlopig Verslag bij wetsvoorstei 13872, Verklaring dat er grond bestaat .... Tweede Kamer, in: Algehele grondwetsherziening, deel la Grondrechten, p= 135 (derde alinea). De desbetreffende overweging van de kamerfracties werd overigens naar voren gebracht in het kader van hun kritiek op de afwijzing van de leer van de algemene beperkingen. Zie m.b.t. gedragscodes pp. 22-23 hierboven en verder het laatste hoofdstuk (voor zoweil algemene beperkingen, gedragscodes en kernrecht, en met name de combinatie van deze begrippen).

141 Zie o.a. EHRM 20 november 1989, Case of Markt Intern Verlag GmbH and Klaus Beermann, $\$ \S 33,37$, pp. 20,21 . Zie verder noot 184 van hoofdstuk 2, p. 78. 
Tenslotte kan een voorbeeld gegeven worden uit de Wet Gelijke Behandeling van mannen en vrouwen. Het gelijkheidsbeginsel lijkt bij de toelating tot het onderwijs en de toegang tot beroepsactiviteiten minder essentieel te zijn wanneer het (onder andere) gaat om een onderwijsinstelling of werkgever met een godsdienstige grondslag. In die gevallen mag er namelijk een uitzondering gemaakt worden op het gelijkheidsbeginsel (artikel 4 lid 3 respectievelijk artikel 5 lid 3 sub a WGB $\mathrm{m} / \mathrm{v}$ ).

\subsubsection{De beperkingssystematiek in de Grondwet, ingedeeld op de wijze die ten aanzien van de Europese Conventie is gehanteerd}

Zouden we de beperkingsmethoden - die in de Grondwet zijn gebruikt indelen op de wijze waarop de beperkingsmethoden in de Conventie in het vorige hoofdstuk zijn ingedeeld, dan komt die indeling er als volgt uit te zien $^{\text {in2 }}$ :

Beperking van rechten en vrijheden in vredestijd en tijden van rust (vergelijk par. 2.4.2)

Beperkingsclausules waarin de toegekende beperkingsbevoegdheid aan bepaalde voorwaarden is gekoppeld:

- aan competentievoorschriften;

- aan procedurevoorschriften;

- aan doelcriteria;

- of een combinatie van bovenstaande voorwaarden. ${ }^{193}$

Inhoudelijke omschrijving op zodanige wijze, dat in die omschrijving de beperkingsmogelijkheden besloten liggen:

Duidelijke voorbeelden van deze categorie beperkingsmogelijkheden zijn de bepalingen, waarin een recht specifiek aan "Nederlanders" wordt toegekend. Gedoeld wordt op de artikelen 3, 4 en 54 lid 1 (eerste zin), 19 lid 3 en 20 lid $3 \mathrm{Gw}$.

142 Vanwege de grote verschillen in aard, strekking en formulering tussen de grondwettelijke en de Conventie-bepalingen, kan een indeling van de grondwettelijke: beperkingsmethoden in het schema van beperkingsmethoden in de Conventie niet zonder voorbehoud gemaakt worden.

143 Zie voor een overzicht van de artikelen waar het hier om draait, bij de paragrafen die aan deze onderwerpen zijn gewijd. 
Verder staat in artikel 20 lid 3 dat het moet gaan om Nederlanders "die niet in het bestaan kunnen voorzien".

Ook artikel 23 zou wellicht in deze categorie kunnen worden ondergebracht. In artikel 7 lid 3 wordt verlof nader gekwalificeerd als "verlof ... wegens de inhoud daarvan". Voorts gaat het in artikel 15 lid 2 om de persoon "aan wie anders dan op rechterlijk bevel zijn vrijheid is ontnomen" en in artikel 15 lid 3 om een persoon "aan wie met het oog daarop [bedoeld is berechting, $C S$ ] zijn vrijheid is ontnomen".

Inhoudelijke omschrijving waarbij bepaalde gevallen of situaties van grondwettelijke bescherming zijn uitgesloten:

Een duidelijk voorbeeld hiervan is artikel 7 lid 4 waarin handelsreclame van de voorgaande bepalingen omtrent de vrijheid van meningsuiting in de leden 1 tot en met 3 wordt uitgesloten. Van degene aan wie rechtmatig zijn vrijheid is ontnomen, kan op grond van artikel 15 lid 4 de uitoefening van grondrechten worden beperkt "voor zover deze zich niet met de vrijheidsontneming verdraagt." Tenslotte kan ook artikel 54 lid 2 tot deze categorie gerekend worden.

Grondwetsbepalingen die uitwerking van het recht aan de wetgever overlaten:

Hier gaat het met name om bepalingen waarin door middel van een competentievoorschrift de regeling van een bepaald recht aan een overheidsorgaan (praktisch altijd de formele wetgever) is opgedragen. Gedoeld wordt op de artikelen 2 leden 1, 2, 3 (laatste zin), 7 lid 2, 10 leden 2 en 3, 18 lid 2, 19 leden 1 en 2, 20 leden 1 en 2, 21, 23 leden 1, $3,4,5$, (6) en 7 (laatste zin), 99, 110, 116 en 117 . Voorts zou ook artikel 1 , eerste lid onder deze soort grondwetsbepalingen begrepen kunnen worden, alhoewel in dit artikel niet expliciet een opdracht aan een overheidsorgaan gegeven wordt.

Beperking van de rechten ten aanzien van specifieke groepen personen: Eventueel zou artikel 54 lid 1, laatste zin in deze categorie te plaatsen zijn. De groep personen waar het hier om gaat zijn "Nederlanders die geen ingezetenen zijn".

Verbod van misbruik van grondrechten:

Geen van de grondwetsbepalingen kan in deze categorie worden ingedeeld. 
Beperkingen in geval van oorlog of noodtoestand (vergelijk par. 2.4.3)

Artikel 103 Grondwet:

In artikel $103 \mathrm{Gw}$ wordt afwijking toegestaan van de artikelen 7, 8, 9, 12 lid 2, 13, 113 leden 1 en 3.

Beperkingen, alléén in geval van noodtoestand:

Hieronder valt de beperking op grond van artikel $103 \mathrm{Gw}$ op artikel 113 leden 1 en 2.

Rechten waarvan noch in tijden van oorlog/noodtoestand, noch in situaties van vrede en rust kan worden afgeweken (vergelijk par. 2.4.4)

Grondwetsbepalingen waarop geen beperkingen zijn toegestaan:

De artikelen die in deze groep thuishoren zijn de artikelen 2 lid 3 (eerste zin), 5, 16, 17, 18 lid 1, 23 lid 5 (vrijheid van richting) en 114.

De grenzen van de beperkingshevoegdheden (vergelijk par. 2.4.5)

Deze grenzen kunnen worden afgeleid uit artikel 1 tweede zin en wat betreft het onderwijsartikel uit artikel 23 leden 6 en 7 . Verder zouden als grenzen aan beperkingsbevoegdheden opgevat kunnen worden de artikelen 7 lid 2, laatste zin (bevoegdheid: eerste zin) en 12 lid 2 (bevoegdheid: lid 1).

In de Grondwet zijn geen artikelen opgenomen waarin een verbod wordt gesteld op détournement de pouvoir en op het verder beperken van een grondrecht dan de Grondwet toestaat. ${ }^{14}$

\subsubsection{Afwijking van de in de Grondwet verankerde beperkingssystematiek: redelijke wetsuitleg en redelijke wetstoepassing}

Hierboven is een beschrijving gegeven van de beperkingssystematiek, zoals die in de Grondwet van 1983 is neergelegd. Hierbij is nog niet aan de orde gesteld, dat in de Memorie van Toelichting ontsnappingsmogelijkheden zijn gecreëerd. Na vastgesteld te hebben, dat het desbetreffende wetsvoorstel (13872) tot doel heeft dwingend recht te scheppen, stelt de regering, dat in uitzonderingsgevallen afwijking van de vastgelegde beperkingssystematiek ontwikkeld zouden kunnen worden. Dit kan ten eerste het 
geval zijn, "wanneer de heersende rechtsovertuigingen zodanig evolueren dat bepaalde belemmeringen in de uitoefening van een grondrecht, zonder tot een beperkingsclausule herleidbaar te zijn, algemeen aanvaard worden. " Ten tweede kunnen in de praktijk rechtsinstellingen tot stand komen, die in strijd zijn met de letter van het desbetreffende grondrecht, doch op een bepaald moment in het rechtsbestel algemeen aanvaard worden. Ten derde wijst de regering erop, "dat niet alleen een grondrechtartikel op redelijke wijze moet worden uitgelegd, maar dat ook aan de redelijkheid grenzen kunnen worden ontleend waarbuiten een grondrecht geen toepassing meer behoort te vinden". Zou de intrekking of vernietiging van een overheidsmaatregel, die een grondrecht beperkt, leiden tot "flagrante strijd... met wat algemeen als redelijk wordt aangemerkt, dan zal zo'n maatregel niet licht ongrondwettig mogen worden geacht. "Een rol wordt hierbij toegedacht aan het proportionaliteitsvereiste en de maatschappelijke en persoonlijke belangen die in het geding zijn.

Het is overigens de vraag of bij de twee eerstgenoemde ontsnappingsmogelijkheden niet beter gesproken kan worden van "redelijke beperking van grondrechten", omdat het gaat om situaties waarin een beperking, een met een grondrecht strijdige belemmering of instelling, algemeen aanvaard wordt geacht. De term "redelijke wetsuitleg" zou dan kunnen worden gebruikt voor de situatie waarin een regeling ten aanzien van - bijvoorbeeld - een bepaalde gedraging geacht wordt het desbetreffende grondrecht niet te raken, de regeling valt per definitie buiten de reikwijdte van het grondrecht. Het grondrecht wordt dan restrictief uitgelegd en het gaat om een toetsing in abstracto, dit in tegenstelling tot de "redelijke wetstoepassing" waarbij de aanwending van de regeling in concreto op zijn grondwettigheid getoetst zou moeten worden. ${ }^{14}$

Bij het hanteren van de geboden ontsnappingsmogelijkheden moet er volgens de regering voor worden opgepast, dat men "niet in de sfeer van het freies Ermessen" terecht komt, "waarin de eerbiediging van een grondwettelijk grondrecht op voet van gelijkwaardigheid tegenover andere belangen wordt afgewogen: het gaat hier om het vinden van uiterste grenzen." ${ }^{146} \mathrm{De}$ regering benadrukt, dat de geboden ontsnappingsmogelijkheden alleen met grote terughoudendheid mogen worden

145 Vergelijk B.P. Vermeulen, Algemene beperkingen, redelijke vitleg en redelijke toepassing van grondrechten. pp. 78-85(84).

146 Memorie van Toelichting bij wetsvoorstel 13872, Verklaring dat er grond bestaat .... Tweede Kamer, in: Algehele Grondwetsherziening, deel la Grondrechter, pp. 21-22. Als voorbeeld noemt de regering hier het vereiste van een vergunning, dat aan drukkerijen op grond van de Hinderwet en de Woningwet wordt gesteld. 
toegepast, teneinde "het karakter van uitzondering en uiterste oplossing niet" te verliezen. ${ }^{147}$

\subsection{Kritiek op de beperkingssystematiek in de Grondwet}

Zoals in het voorgaande is besproken, is in de Grondwet een - in beginsel - strikte beperkingssystematiek neergelegd. We treffen in de grondrechtenbepalingen, onder andere, beperkingsclausules aan, waarin beperkingsbevoegdheden gekoppeld zijn aan competentievoorschriften, procedurevoorschriften en/of doelcriteria. Alhoewel de kernrechtgedachte niet door de regering wordt beschouwd als een zelfstandige beperkingsmethode, wordt het niet uitgesloten geacht, dat deze kernrechtgedachte behulpzaam zou kunnen zijn bij de interpretatie en toepassing van grondrechten. Uitdrukkelijk uitgesloten wordt de toepassing van de leer van de algemene, ongeschreven beperkingen en de opneming van gedragscodes in de beperkingsclausules.

Wat zien we echter in de praktijk? Er zijn diverse voorbeelden uit de jurisprudentie, die zeer sterk doen denken aan toepassing van de leer van de algemene beperkingen. Deze leer wordt in de jurisprudentie niet uitdrúkkelijk erkend; een uitspraak over de geoorioofdheid van algemene beperkingen wordt veelal omzeild door toepassing van een bepaalde vorm van interpretatie. Zo zien we in het kader van artikel 7 Grondwet, dat een op grond van de Hinderwet ingesteld vergunningenstelsel geoorloofd wordt geacht, omdat de regeling in de Hinderwet niet gericht is op, "noch tot effect heeft de verkoop van geschriften van meningsuiting te beletten, doch uitsluitend beoogt gevaar, schade of hinder van ernstige aard, welke daarbuiten van het onderwerpelijke bedrijf zijn te duchten, te ondervangen." ${ }^{\text {as }}$ Een andere methode is gelegen in een zodanig enge interpretatie van de reikwijdte van het desbetreffende recht, dat het niet nodig is om tot beperking van dat recht over te gaan. Zo is in een zaak waarin een verdachte, onder andere, vorderde dat het de Staat werd verboden het door hem afgestane bloed te gebruiken voor onderzoek volgens de DNA-fingerprintmethode, door de President van de Rechtbank Rotterdam afgewezen, omdat met de fingerprintmethode geen inbreuk op

147 Memorie van Toelichting bij wetsvoorstel 13872, Verklaring dat er grond bestaat.... Tweede Kamer, in: Algehele Grondwetsherziening, deel Ia Grondrechten, p. 22. Zie voor commentaar op de geboden ontsnappingsmogelijkheden in de paragraaf hierna.

148 HR 11 februari 1986, NJ 1986, 673, met noot Th. W. van Veen; het citat is afkomstig uit de conclusie van $A-G$ Meijers. 
de persoonlijke levenssfeer wordt gepleegd. ${ }^{149}$ Voorts worden de ontsnappingsmogelijkheden, die in de vorige paragraaf zijn besproken - redelijke wetsuitleg of redelijke wetstoepassing - regelmatig toegepast. Zo heeft de regering gesteld, dat het eisen van een bouwvergunning of het verbinden van brandveiligheidsvoorschriften aan het gebruik van een kerkgebouw, niet mogen worden uitgelegd als beperking van de vrijheid van godsdienstuitoefening. Redelijke grondwetsinterpretatie zou deze conclusie met zich meebrengen. ${ }^{150}$ De genoemde voorbeelden geven aan, dat het noodzakelijk is in te gaan op de in de praktijk en de (onder andere naar aanleiding daarvan tot stand gekomen) literatuur ontwikkelde beperkingsmogelijkheden, die niet passen in de bovenomschreven beperkingssystematiek. Op die literatuur wordt nu eerst ingegaan.

Een eerste punt van kritiek, dat we met name bij Kortmann aantreffen, heeft betrekking op de term "algemene beperkingen". Dit begrip zou verwarring scheppen, omdat in de Memorie van Toelichting bij wetsvoorstel 13872 alleen de algemene, ongeschreven (dat wil zeggen, niet tot de Grondwet terug te voeren) beperkingen worden afgewezen en beperkingen - bijzondere of algemene - aanvaard worden, zolang ze maar tot een grondwetsartikel herleidbaar zijn. Volgens Kortmann komt het regeringsontwerp terzake van beperkingen derhalve neer op een competentieregeling. Men zou daarom beter kunnen spreken van "niet op de grondwet berustende beperkingen". ${ }^{151}$

Naar de mening van Burkens moet aan het onderscheid, dat de regering makt tussen algemene en bijzondere beperkingen geen normatieve betekenis toegekend worden. Het onderscheid zou alleen dienen als motivering voor afwijzing van de leer van de algemene beperkingen. Volgens de regering zou de strekking van een beperking (op een grondrecht gericht of niet) niet van belang zijn voor wat betreft het standpunt, dat een beperking tot een grondwetsartikel herleidbaar moet zijn. Wel relevant zou de strekking van de beperking geweest zijn, indien de regering de leer van de algemene beperkingen had aanvaard. In dat geval zouden - volgens de interpretatie van de regering - bijzondere

149 Pres.Rb. Rotterdam 10 april 1989. KG 89, 196. Vergelijk: C.A.J. Kortmann, Algemene en bijzondere beperkingen van grondrechten, pp. 922-923.

150 Memorie van Toelichting bij wetsvoorstel 19427, Wet Openbare Manifestaties, Tweede Kamer, p. 6.

151 C.A.J.M. Kortmann, Algemene en bijzondere beperkingen van grondrechten, p. 922 en C.A.J.M. Kortmann, De grondwetsherzieningen 1983 en 1987, pp. 52-53. 
beperkingen altijd tot de desbetreffende clausule herleidbaar moeten zijn; voor algemene beperkingen zou dat niet gelden. ${ }^{152}$

Mijns inziens kan met deze opvatting van Burkens ingestemd worden. Het draait er bovendien ook niet zozeer om, of de term "algemene beperkingen" passend is, maar of de afwijzing van algemene, ongeschreven beperkingen terecht is of niet.

Hiermee komen we op het volgende punt van kritiek: door afwijzing van de mogelijkheid van algemene beperkingen zouden grondrechten verabsoluteerd worden en buiten de maatschappelijke context geplaatst worden waarin alle rechtsnormen moeten functioneren. Hierdoor zou het gevaar dreigen, dat "op min of meer verkapte wijze algemene beperkingen worden erkend doordat bij wege van restrictieve interpretatie van deze rechten (grondrechten, $C S$ ) wat Donner noemt "inherente grenzen" worden erkend. "153 Volgens Donner zou "een theorie [der inherente grenzen] even vaag ... moeten blijven als ... [de leer van de algemene beperkingen] verweten wordt."1s4 Ook Kortmann wijst erop, dat afwijzing van algemene, ongeschreven beperkingen kan leiden tot een enge interpretatie van grondrechten, "indien de rechter een maatschappelijk alleszins aanvaardbare regeling die niet op zo'n beperkingsclausule berust wil sauveren. "15s De rechter zal in een dergelijk geval tot de conclusie komen dat het desbetreffende grondrecht "de litigieuze kwestie niet bestrijkt. "156

Burkens is het met Donner en Kortmann eens, dat grondrechten deel uitmaken van de rechtsorde en in die context moeten worden geïnterpreteerd. Het verschil van mening is mijns inziens gelegen in de vraag, of de beperking van een grondrecht reeds moet geschieden bij de interpretatie van het grondrecht door middel van het vaststellen van inherente grenzen (Burkens) of pas bij de toepassing van het (inmiddels begrensde) recht (Donner, Kortmann). Een voorbeeld uit de praktijk (in casu, die van de wetgever), waarin inherente grenzen aan een recht gesteld worden, treffen we onder meer aan in de notitie Grondrecht van vrijheid van arbeidskeuze, waarin staat dat de begrenzingen die voortvloeien uit de

152 M.C. Burkens, Algemene leerstukken van grondrechten naar Nederlands constitutioneel recht, p. 119.

153 M.C. Burkens, Algemene leerstukken van grondrechten naar Nederlands constitutioneel recht, p. 120. Zie A.M. Donner, Grondrechten als constitutionele rechten, pp. 24-26.

154 A.M. Donner, Grondrechten als constitutionele rechten, p. 26. De tekst tussen de haken is roegevoegd door mij, $C S$.

155 C.A.J.M. Kortmann, De grondwetsherzieningen 1983 en 1987, p. 55.

156 C.A.J.M. Kortmann, De vrijheid van god'sdienst en levensovertuiging in de nieuwe Grondwet, pp. 55-67(57). 
heersende sociaal-economische situatie en uit beperkingen van algemene handelingsvrijheid "niet te beschouwen [zijn] als "beperkingen" van de vrijheid van arbeidskeuze waartoe artikel 19, derde lid, Grondwet, de mogelijkheid opent ... Het gaat hier om begrenzingen die het gebied markeren dat buiten de vrijheid van arbeidskeuze in de zin van de Grondwet valt." Regelingen die bijvoorbeeld de handelingsvrijheid beperken, zoals die met betrekking tot de verkeersveiligheid, bouwvergunningen en belastingen en dergelijke, staan in een te verwijderd verband met de vrije arbeidskeuze om als beperking van dat grondrecht te kunnen worden aangemerkt. ${ }^{157}$ Een voorbeeld uit de jurisprudentie is het al eerder behandelde AOW-arrest van de Hoge Raad. ${ }^{1 \text { ss }}$

Tenslotte wordt in de literatuur gesteld, dat de afwijzing van de leer van de algemene beperkingen zou leiden tot centralisatie. ${ }^{159}$ Doordat beperkingen herleidbaar moeten zijn tot beperkingsclausules en in deze clausules de beperkingsbevoegdheden grotendeels aan de formele wetgever zijn toegekend, blijft er weinig ruimte over voor de lagere organen om gebruik te maken van hun autonome regelingsbevoegdheden. Iedere gemeentelijke of provinciale verordening, die regels bevat met betrekking tot het verkeer, de openbare orde of landschapsbescherming (enz.) zal wel in enigermate een beperking van een grondrecht inhouden en moet derhalve een formeel-wettelijke grondslag hebben. De autonome bevoegdheden, die in de artikelen 168 (oud, het huidige artikel 149) Gemeentewet en 90 (oud, het huidige artikel 145) Provinciewet worden verleend, worden door deze competentieregeling in de grondrechtenbepalingen aangetast. Een oplossing hiervoor zou zijn dat de delegatiebepalingen in de formele wetgeving ruim worden geformuleerd. Dit is echter in strijd met de eis dat de formele wet nauwkeurig aangeeft

157 Notitie grondrecht van vrije arbeidskeuze (wetsvoorstell 19376), p.5. Dit voorbeeld wordt genoemd in M.C. Burkens, Algemene leerstukken van grondrechten naar Nederlands constitutioneel recht, p. 122.

158 Zie pagina 97, HR 13 april 1960, NJ 1960, 436 en het andere in noct 56 genoemde arrest van 30 mei 1967. Zie voorts HR 4 november 1969, NJ 1970, 127. Voor een bespreking van de aan de onderhavige kwestie verwante, maar niet gelijk te stellen "inherente beperking" (beperking van de reikwijdte van een recht op grond van het behoren tot een groep personen in een bepaalde hoedanigheid) verwijs ik naar de volgende hoofdstukken. Enkeie van de daar aan de orde komende bezwaren tegen inherente beperking kunnen ook relevant zijn voor de kwestie van het vaststellen van "inherente grenzen" die hier aan de orde is.

159 En daarmee tot de noodzaak van een "zeer uitgebreid en gecompliceerdi wetgevingsprogramma". Advies van de Raad van State bij wetsvoorstel 13872, Verklaring dat er grond bestaat .... Tweede Kamer, in: Algehele Grondwetsherziening, deel La Grondrechten, p. 60. 
hoever een grondrechtenbeperking mag gaan. ${ }^{160}$ Deze eis vloeit voort uit de grondwettelijke taak van de formele wetgever om in beginsel de afweging te maken tussen enerzijds het belang van de uitoefening van een grondrecht en andere belangen anderzijds. Omdat het hier een politieke taak betreft, wordt de formele wetgever de geschiktste instantie geacht en bestaat er weinig ruimte voor rechterlijke controle op beperkende maatregelen. Dit is onder meer een gevolg van het verbod op toetsing van formele wetten aan de Grondwet in artikel 120 Grondwet. ${ }^{161}$ Hoewel kan worden ingestemd met het overlaten van politieke keuzes aan de formele wetgever, moet wel worden opgemerkt, dat indien deze formele wetgever ondanks de eis van een nauwkeurige afbakening van grondrechtenbeperkingen overgat tot het formuleren van beperkingsmogelijkheden met ruime dan wel vage grenzen, dit tot uitholling van de grondrechten kan leiden. ${ }^{162}$ Gelet op dit gevaar van uitholling van de grondwettelijke grondrechten kan men zich mijns inziens dan ook niet beroepen op het argument, dat "de afwijzing van algemene beperkingen ... een principiële keuze [is], waarvan men ook de schaduwzijde zal moeten aanvaarden. "Veel meer hout snijdt het argument, dat de formele wetgever als centraal orgaan de aangewezen instantie is inzake grondrechtenbeperkingen met het oog op de "verzekering van rechtsgelijkheid en algemeenheid ten aanzien van wezenlijke aspecten van grondrechten." 163.164

160 C.A.J.M. Kortmann, De grondwetsherzieningen 1983 en 1987 , pp. 56-57; C.A.J.M. Kortmann, Algemene en bijzondere beperkingen van grondrechten, p. 922. Zie hiervoor, pp. 98-99.

161 M.C. Burkens, Algemene leerstukken van grondrechten naar Nederlands constitutioneel recht. p. 124.

162 Van bijvoorbeeld artikel 125a en verder Ambtenarenwet en artikel 1401 BW kan moeilijk gezegd worden, dat ze een adequate toepassing vormen van de beperkingsclausule "behoudens ieders verantwoordelijkheid volgens de wet" in artikel 7 Grondwet: ze geven de omvang van de toegestane beperking niet aar.

163 M.C. Burkens (Algemene leerstukken van grondrechten naar Nederlands constitutioneel recht, p. 124) vermeldt beide argumenten. Het laatste argument ontleent hij aan het betoog van Simons tijdens de gezamenlijke mondelinge behandeling van de wetsvoorstellen 13872 en 13873 in de Eerste Kamer, in: Algehele grondwetsherziening, deel Ib Grondrechten. p. 150.

164 Of de wetgever deze zware verantwoordelijkheid aankan en in praktijk het in hem gestelde vertrouwen waarmaakt is een andere kwestie. Zie hieromtrent het Themanummer Rechten, regels, realiteit - Wetgever en mensenrechtenbeleid. NJCMBulletin 19-5 (1994), met daarin diverse bijdragen waarin een kritisch standpunt wordt ingenomen ten aanzien van de vervulling door de wetgever van de hem toebedeelde, grondwettelijk taak. 
Hebben we hiermee een argument voor het overlaten van fundamentele politieke keuzes aan de formele wetgever, dan is daarmee nog niets gezegd over de eisen van de dagelijkse praktijk. Vaak is het nodig rekening te houden met lokale omstandigheden. Simons (Regeringscommissaris voor de Grondwetsherziening) verwoordde dienaangaande tijdens de plenaire behandeling in eerste lezing van wetsvoorstel 13872 in de Eerste Kamer, dat dit wetsvoorstel voldoende ruimte bood voor "voorzieningen in verband met de uitoefening van grondrechten omtrent belangen als het goede verloop van het verkeer, de bescherming van de gezondheid of de bestrijding en voorkoming van wanordelijkheden". ${ }^{16 s}$ Uit de bestuurlijke en rechterlijke praktijk blijkt echter het tegendeel. Op die praktijk zal nu ingegaan worden.

Allereerst is in de praktijk ruimschoots gebruik gemaakt van de in de vorige paragraaf besproken "ontsnappingsmogelijkheden".

In het begin van deze paragraaf werd al het voorbeeld gegeven, dat met betrekking tot de Wet Openbare Manifestaties (WOM) was vastgesteld, dat redelijke grondwetsinterpretatie meebrengt, dat bij het eisen van bouwvergunningen en het stellen van brandveiligheidsvoorschriften voor een kerkgebouw geen sprake is van beperking van de vrijheid van godsdienst. ${ }^{166}$

Verder is bijvoorbeeld in de Memorie van Antwoord bij de WOM ingegaan op het verschil, dat bestond tussen de Memorie van Toelichting bij deze wet en de bestaande jurisprudentie over de afbakening van het begrip "besloten plaatsen" in artikel 6 Grondwet en het door de regering gehanteerde begrip "niet-openbare plaatsen". Volgens de regering kan de wetgever in het onderhavige geval van de jurisprudentie afwijken, "nu daarbij alleszins recht wordt gedaan aan zin en strekking van de desbetreffende grondwetsbepaling. Binnen ons staatsbestel is immers de formele wetgever als hoogste orgaan geroepen aan grondwettelijke begrippen zo nodig een passende uitwerking te geven. Hij is daarbij - zolang hij blijft binnen de grenzen van een redelijke grondwetsinterpretatie - niet gebonden aan eventuele eerdere uitspraken

165 Gezamenlijke mondelinge behandeling van de wetsontwerpen 13872 en 13873 in de Eerste Kamer, in: Algehele grondwetsherziening, deef Jb Grondrechten, p. 150.

166 Memorie van Toelichting bij wetsvoorstel 19427, WOM, Tweede Kamer, p. 6. Verwezen wordt naar de yoorbeelden die de regering geeft met betrekking tot de Hinderwet en Woningwet in de Memorie van Toelichting bij wetsvoorstel 13872. Verklaring dat er grond bestaat .... Tweede Kamer, in: Algehele grondwetsherziening, deel la Grondrechten, p. 22, noot 8. 
van de HR ..." De regering is dan ook van mening, dat er geen sprake is van strijd met de strekking van artikel 6 Grondwet. ${ }^{167}$

Tenslotte wat betreft de ontsnappingsmogelijkheden: voordat bij de grondwetswijziging van 1987 de zinsnede "behoudens bij de wet gestelde uitzonderingen" aan artikel 12 lid 2 werd toegevoegd, waren ten aanzien van dit artikel reeds twee ministeriële circulaires uitgevaardigd. Deze circulaires machtigden ambtenaren in strijd met de procedurevoorschriften van artikel 12 lid 2 binnen te treden in een woning, indien sprake was van "omstandigheden, waarin een acute en ernstige bedreiging van de rechtsorde terstond optreden" gebood of indien "een bewoner in ernstige nood" verkeerde en terstond hulp moest worden geboden" (noodsituaties). ${ }^{168}$ Niet-naleving werd vervolgens toelaatbaar geacht indien dit noodzakelijk was "in het belang van de opsporing van misdrijven die een ernstig gevaar opleveren voor het leven of de gezondheid van personen. ${ }^{169}$ Volgens de regering was de "motivering van de grondwettigheid van het onvolledig (..) of het niet uitvoeren van de grondwettelijke verplichtingen in bedoelde gevallen ... dat men aan de desbetreffende grondwettelijke voorschriften in redelijkheid toch niet die absolute betekenis kon toekennen dat zij een beletsel zouden kunnen vormen voor de bescherming van de veiligheid van personen in noodsituaties of voor de bescherming van de samenleving tegen delicten waarmee de veiligheid en de gezondheid van personen kunnen zijn gemoeid."170.171 Volgens Vermeulen zijn de in de desbetreffende circulaires gelegen beperkingen op artikel 12 lid 2 niet te rechtvaardigen in de leer van de algemene - ongeschreven - beperkingen, omdat het hier bijzondere, specifiek op het desbetreffende grondrecht gerichte beperkingen betreft. Ze kunnen dan - aldus Vermeulen - a fortiori ook niet aangemerkt

167 Menorie van Antwoord bij wetsvoorstel 19427, WOM. Tweede Kamer.

168 Minister van Binnenlandse Zaken, Binnentredingsbepalingen in herziene Grondwet, Circulaire aan de ministers, provinciale en gemeentebesturen, 7 maart 1983, Stcrt. 1983, 57 (d.d. 22-03-1983).

169 Minister van Justitie, Binnentredingsbepalingen in herziene Grondwet, Circulaire aan de procureurs-generaal bij de gerechtshoven en de advocaat-fiscaal bij het Hoog Militair Gerechtshof, 18 april 1983, Stcrt. 1983, 77 (d.d. 21 april 1983).

170 Memorie van Toelichting bij de Wet van 3 juni 1987, houdende verandering in de Grondwet van bepalingen over het binnentreden in woningen, Stb. 87, 270 (wetsvoorstel 19013).

171 Zowel de literatuur als de rechtspraak zijn niet eenduidig wat betreft de grondwettigheid van de genoemde circulaires. Zie verder: C.A.J.M. Kortmann, De Grondwetsherzieningen 1983 en 1987, pp. 100-101 en T.M. Schalken, Het grijze domein van de politie, pp. 805-811(809-811). Schalken gaat onder meer in op de (on)aanvaardbaarheid van artikel 28 Politiewet ais wettelijke basis voor optreden in de gevallen, die door de genoemde circulaires worden bestreken. 
worden als redelijke uitleg/toepassing van de desbetreffende bepaling omdat deze ontsnappingsmogelijkheden in de optiek van de grondwetgever nog veel minder ruimte zouden bieden dan de leer van de algemene beperkingen. ${ }^{m}$ Vermeulen's redenering lijkt te duiden op een uitleg van de argumenten van de regering - tijdens de parlementaire behandeling van de wetsvoorstellen 13872 en 13873 naar voren gebracht door Simons ${ }^{173}$ die daar niet noodzakelijkerwijs uit voortvloeit. Het is waar, dat de regering door het afwijzen van de leer van algemene beperkingen en het voorzien in ontsnappingsmogelijkheden bij de wèl aanvaarde beperkingssystematiek minder ruimte heeft geboden voor beperkingen, die niet op een beperkingsclausule kunnen worden gebaseerd, dan wanneer de leer van de algemene beperkingen wèl was aanvaard. Dit betekent mijns inziens echter niet, dat geen redelijke wetsuitleg of redelijke wetstoepassing zou kunnen plaatsvinden in geval van beperkingen, die - anders dan algemene beperkingen - gericht zijn op een specifiek grondrecht. Wèl lijken de gegeven voorbeelden van gebruikmaking van de ontsnappingsmogelijkheden er mijns inziens op te wijzen, dat het met het uitzonderingskarakter van de ontsnappingsmogelijkheden niet zo nauw genomen wordt.

Behalve van de gebruikmaking van de bedoelde "ontsnappingsmogelijkheden" kent de praktijk ook andere voorbeelden waaruit blijkt dat de strikte beperkingssystematiek in de Grondwet niet voldoet. De jurisprudentie toont een aantal voorbeelden van zaken, waarin - alhoewel niet expliciet - algemene beperkingen lijken te worden aanvaard. Hiervoor werd al de uitspraak van de Hoge Raad ten aanzien van artikel $7 \mathrm{Gw}$ aangehaald ${ }^{174}$.

Een uitspraak van de Centrale Raad van Beroep uit 1989 betrof de weigering van de burgemeester van Zevenaar om aan een hoofdagent van de gemeentepolitie ontheffing te verlenen van het verbod een nevenbetrekking te aanvaarden op grond van artikel 91 lid 1 sub b en lid twee van het Ambtenarenreglement voor de gemeentepolitie (ARGP). De nevenfunctie bestond uit het verzorgen van rij-instructie bij een in de

172 B.P. Vermeulen, Algemene beperkingen, redelijke uitleg en redelijke toepassing van grondrechten, p. 81 .

173. Vermeulen verwijst naar het betoog van Simons tijdens de Gezamenlijke mondelinge behandeling van de wetsontwerpen 13872 en 13873 door de Tweede kamer. Zie: Algehele grondwetsherziening, deell Ia, pp. 428-429.

174 HR 11 februari 1986, NJ 1986, 673. In een recente uitspraak worden algemene beperkingen wèl expliciet aanvaard; in het desbetreffende geval was alleen geen sprake van algemene beperkingen. Zie Rb. Roermond 3 januari 1995, NJCM-Bulletin 20-4 (1995), pp. $431-438$ met noot J.M.E. Derks. 
gemeente Zevenaar gevestigde autorijschool. Volgens de burgemeester zou het vervullen van de onderhavige nevenfunctie met zich mee kunnen brengen dat de eiser zijn taak als hoofdagent niet of niet volledig objectief zou uitoefenen. De weigering van ontheffing betekende in dit geval een beperking van de vrijheid tot het geven van onderwijs (artikel 23 Grondwet), die echter niet gebaseerd kon worden op een wettelijke regeling (waartoe een beperking op dit recht herleidbaar moet zijn). De Raad ging vervolgens over tot de toepassing van een zelfstandige beperkingsnorm, die inhoud "dat de ambtenaar in de uitoefening van grondrechten niet zo ver mag gaan dat de goede vervulling van zijn functie of de goede functionering van de openbare dienst in ontoelaatbare mate wordt aangetast". Deze in een eerdere uitspraak - ten aanzien van andere grondrechten - ontwikkelde norm heeft er wel toe geleid, dat de wetgever in het ontbreken van een wettelijke basis voor een dergelijke grondrechtenbeperking heeft voorzien door opneming van artikel 125a en volgende in de Ambtenarenwet 1929 en artikel 12a en volgende in de Militaire Ambtenarenwet. Echter, de wetgever heeft welbewust de onderwijsvrijheid in artikel 125a en volgende Ambtenarenwet weggelaten. De Centrale Raad heeft om die reden de jurisprudentiële norm aangescherpt, door de term "in ontoelaatbare mate" te lezen als "in volstrekt ontoelaatbare mate". Omdat de Raad van oordeel was dat de verlening van de verzochte ontheffing niet zou leiden tot een volstrekt ontoelaatbare aantasting van het goede functioneren van de eiser als hoofdagent, werd het besluit tot weigering van de ontheffing in strijd met artikel 23 Grondwet geacht. De geciteerde zelfstandige beperkingsnorm is een voorbeeld van een ongeschreven, algemene beperking van artikel 23 Grondwet. . $^{75}$

Tenslotte verdient de noodverordeningsbevoegdheid van de burgemeester ingevolge de artikelen 175 en 176 (219 en 220 oud-) gemeentewet de aandacht. ${ }^{176}$ Bij de toepassing van deze bevoegdheid door de

175 CRvB 16 november 1989, nr. AW 1987/313, TAR 1990, 13 en NTOR 2 - 17 mei 1990, pp. 97-102, met noot van L.F.M. Verhey en B.P. Vermeulen. De annotatoren vragen zich af of in het onderhavige geval redelijke (grond)weisuitleg niet te prefereren zou zijn geweest boven een algemene beperking, omdat de mogelijkheid van redelijke wetsuitleg ook door de grondwetgever wordt voorgestaan. Bovendien menen zij, dat ten aanzien van artikel 23 Grondwet de toepassing van algemene beperkingen niet is uitgesloten, omdat dit artikel door de verwerping van wetsvoorstel 13874 niet is aangepast aan de beperkingssystematiek van de Grondwet 1983.

176 Zie voor overigens niet aangehaalde literatuur: C.A.J.M. Kortmann, Het einde van 219 en 220 gemeentewer?, p. 343: H.Ph.J.A.M. Hennekens, Behoudens ieders verantwoordelijkheid volgens de wet en de gemeentelijke verordeningsbevoegdheid. 
burgemeester moet vooral gedacht worden aan beperking van de vrijheid van godsdienst in artikel $6 \mathrm{Gw}$, de vrijheid van meningsuiting in artikel 7 $\mathrm{Gw}$, de vrijheid van vergadering en betoging in artikel $9 \mathrm{Gw}$ en de vrijheid van beweging (niet in de Grondwet gegarandeerd). De bedoelde noodverordeningen voldoen niet aan de clausule "behoudens ieders verantwoordelijkheid volgens de wet", omdat in deze clausule gedoeld wordt op een formele wet. Delegatie is op grond van deze clausule niet toegestaan. Maar zelfs al was dat wel het geval, dan nog kunnen de artikelen 175 en 176 gemeentewet niet als formeel-wettelijke basis voor de beperking van de genoemde grondwetsartikelen dienen, aangezien ze niet voldoen aan de eis, dat de delegerende (formele) wetsartikelen de omvang van de beperkingen nauwkeurig moeten aangeven. Dezelfde overweging geldt voor de beperkingsclausules in de artikelen 6 lid 2 en 9 lid 2, waarin delegatie van de daar voorziene beperkingsbevoegdheid wèl is toegestaan. Uit het voorgaande zou afgeleid kumnen worden dat noodverordeningen van de burgemeester op grond van de artikelen 175 en 176 gemeentewet de genoemde grondrechten niet mogen beperken.

De uitspraak van de Voorzitter van de Afdeling Rechtspraak van de Raad van State van 1 juni 1989 geeft echter aan, dat deze conclusie in de rechterlijke praktijk niet altijd getrokken wordt. Allereerst merkt de Voorzitter op, dat ingevolge artikel 9 lid 1 Grondwet het recht tot vergadering en betoging wordt erkend behoudens ieders verantwoordelijkheid volgens de wet. Daarna overweegt hij in welke gevallen de burgemeester op grond van artikel 219-oud gemeentewet bevoegd is bevelen ter handhaving van de openbare orde te geven en of hieraan in casu is voldaan. Hiermee lijkt de Voorzitter impliciet van het oordeel te zijn uitgegaan, dat artikel 219 aangemerkt kan worden als een wet in de zin van artikel 9 lid 1 Grondwet. ${ }^{\prime \prime}$ In de Memorie van

pp. 459-464; R.E. de Winter, Het ontwerp Wet Openbare Manifestaties en de grondwettelijke toedeling van bevoegdheden, pp. 1082-1085; en B.P. Vermeulen. Algemene beperkingen, redelijke uitleg en redelijke toepassing van grondrechten, pp. 80-81.

177 VZ.ARRS 1 juni 1989. AE 1989, 499 met noot A.E. Schilder, KG 1989. 272.

Zie ook het verbod van de Burgemeester van Dordrecht van 6 augustus 1990 tot het houden van een persconferentie door de Centrum Partij '86 en het Vlaams Blok, NJCM-Bulletin 15-6/7 (1990), pp. 743-744. Zie het advies van M.C. Burkens op dit verbod op pp. 744-747. Opmerking verdient hier dat de desbetreffende persconferentie in een woning plaats zou vinden. Volgens de jurisprudentie over de gemeentelijke verordeningsbevoegdheid mag niet getreden worden in de "bijzondere belangen der ingezetenen". De artikelen 10 en 12 Grondwet komen hier derhalve in het geding. Mijns inziens kan m.b.t. deze artikelen t.a.v. de bevoegdheid van de burgemeester op grond van de artikelen 219 en 220 gemeentewet dezelfde conclusie getrokken worden als m.b.t. de tweede leden van artikel 6 en 9 Grondwet. Zie verder Burkens 
Toelichting van het voorstel voor een nieuwe Gemeentewet merkt de regering ten aanzien van ontwerp-artikel 174 (het huidige artikel 175) op, dat dit artikel voldoet aan de beperkingsclausule van artikel 9 lid 1 Grondwet ("behoudens..."). In de Memorie van Antwoord stelt de regering, dat de wet voldoende specifiek is om aangemerkt te kunnen worden als een wet in de zin van artikel 9 lid 2 . Echter, om voldoende specifiek te kunnen zijn, zou het artikel exact moeten aangeven hoe en welke grondrechten door de burgemeester bij het gebruik van zijn noodverordeningsbevoegdheden zouden mogen worden beperkt. Dit is echter niet het geval. Mijns inziens is zowel bij grondrechtenbeperkende noodverordeningen op grond van oude als op grond van de huidige artikelen 175 en 176 gemeentewet sprake van strijd met de beperkingssystematiek in de Grondwet. Wèl lijkt hier sprake te zijn van algemene beperkingen! ${ }^{17 \pi}$

\section{Tenslotte}

In het bovenstaande komt naar voren, dat zowel de literatuur als de praktijk voldoende reden geven voor de conclusie, dat de strikte beperkingssystematiek in de Grondwet niet geheel voldoet. Het probleem van de discrepantie tussen de grondwettelijke systematiek en de eisen van de praktijk zal tot een aanvaardbare oplossing moeten worden gebracht. In het laatste hoofdstuk zal gepoogd worden hiertoe een aanzet te geven. Ook ten aanzien van het in de literatuur en praktijk niet of nauwelijks ter sprake gebrachte ontbreken van gedragscodes in de grondwettelijke grondrechtenbepalingen zullen daar suggesties worden gedaan.

Allereerst zal echter in de volgende hoofdstukken ingegaan worden op de afbakening van de reikwijdte van grondrechten. Daarbij zullen (in hoofdstuk 6) zo nu en dan opnieuw voorbeelden opduiken van gevallen waarin niet voldaan wordt aan de grondwettelijk neergelegde beperkingssystematiek.

dienaangaande.

$178 \mathrm{Vgl}$. A. Meijer, De burgemeester in nood(toestand), pp. 237-242(239-240) en p. 239 voor de tekst van de ontwerp-artikelen 174 en 175 Gemeentewet. 


\section{Afbakening van de rechten in de Europese Conventie door de Europese en nationale instanties; jurisprudentie naar aanleiding van artikel 8 ECRM}

\subsection{De rechtspraak met betrekking tot artikel 8 ECRM; inleiding}

Zoals in paragraaf 1.3.3 werd gesteld, heeft de rechter veelal een grote beoordelingsruimte bij de vaststelling van de reikwijdte van grondrechten. Vaste criteria zouden de rechter bij die vaststelling van groot nut kunnen zijn en zouden de justitiabele ook een indicatie kunnen geven van de haalbaarheid van eventuele claims op bescherming van individuele belangen. Uit het navolgende zal moeten blijken ò er inderdaad criteria ter afbakening van enkele mensenrechten zijn ontwikkeld en zo ja, wèlke criteria. Allereerst zal de rechtspraak naar aanleiding van artikel 8 ECRM worden besproken. De Straatsburgse en Nederlandse rechtspraak zullen in respectievelijk de paragrafen 4.2 en 4.3 aan de orde komen.

Artikel 8 ECRM luidt:

1. Everyone has the right to respect for his private and family life, his home and his correspondence.

2. There shall be no interference by a public authority with the exercise of this right except such as is in accordance with the law and is necessary in a democratic society in the interests of national security, public safety or the economic well-being of the country, for the prevention of disorder or crime, for the protection of health or morals, or for the protection of the rights and freedoms of others.

1. Een ieder heeft recht op respect voor zijn privé leven, zijn familie- en gezinsleven, zijn woning en zijn correspondentie.

2. Geen inmenging van enig openbaar gezag is toegestaan in de uitoefening van dit recht, dan voor zover bij de wet is voorzien en in een democratische samenleving noodzakelijk is in het belang van de nationale veiligheid, de openbare veiligheid of het economisch weizijn van het land, het voorkomen van wanordelijkheden en strafbare feiten, de bescherming van de gezondheid of de goede zeden, of voor de bescherming van de rechten en vrijheden van anderen. 


\title{
4.2 De rechtspraak van de Straatsburgse instanties met betrekking tot artikel 8 ECRM
}

\subsubsection{The right to respect for his private life}

Hoewel artikel 8 naast het recht op respect voor het privéleven, het recht op eerbiediging van achtereenvolgens, het gezins- of familieleven, de woning en de correspondentie noemt, kunnen deze rechten ook begrepen worden als onderdeel van het recht op respect voor het privéleven. Desondanks kan worden aangenomen, dat het recht op eerbiediging van het privéleven meer inhoudt dan deze componenten alleen. Zo omschrijft Resolutie 428(1970) van de Raadgevende Vergadering van de Raad van Europa het recht op privacy als volgt:

\begin{abstract}
"The right to privacy consists essentially in the right to live one's own life with a minimum of interference. It concerns private, family and home life, physical and moral integrity, honour and reputation, avoidance of being placed in a false light, non-revelation of irrelevant and embarrassing facts, unauthorised publication of private photographs, protection from disclosure of information given or received by the individual confidentially."
\end{abstract}

Voorts heeft de Commissie in verscheidene zaken het recht op privacy in artikel 8 in verband gebracht met artikel 10 . Het betreft hier klachten over "defamation". ${ }^{2}$ Verder kan het recht op privacy bescherming vinden met behulp van de beperkingsgronden "bescherming van de goede naam" en "om de verspreiding van vertrouwelijke mededelingen te voorkomen". (artikel 10 lid 2)

Soms besparen de Conmissie en het Hof zich de moeite om in moeilijke gevallen vast te stellen of een bepaalde kwestie valt onder het recht op eerbiediging van het gezins- of familieleven etc., door vast te stellen, dat deze kwestie door het recht op eerbiediging van het privéleven bestreken. wordt. Zo heeft de Commissie in haar ontvankelijkheidsbeslissing in de zaak Brüggemann and Scheuten bepaald, dat zwangerschap en de afbreking ervan deel uitmaken van het privéleven en ook onder omstandigheden, van het gezins- of familieleven. De Commissie is er echter niet toe overgegaan

I Council of Europe, Consultative Assembly. Twenty-First Ordinary Session (Third. Part), Texts Adopted (1970), in: Council of Europe, Collected Texts, p. 908(911). 2 Zie o.a. Besl.Comm. 10 juli 1986, zaak nr. 10871/84, Winer v. UK, pp. 169-170. 
om vast te stellen of en wanneer zich dergelijke omstandigheden voordoen en heeft zich geconcentreerd op de (bevestigend beantwoorde) vraag off sprake is van een kwestie die bestreken wordt door het recht op respect voor het privéleven. ${ }^{3}$ In eenı andere zaak acht de Cornmissie het niet nodig om vast te stellen of sprake is van gezinsleven in het gevall van het ontbreken van een wettelijke relatie tussen een pleegmoedier en haar pleegkind, omdat in dit geval zonder twijfel sprake is van een inmenging in haar privéleven. ${ }^{4}$

Ook wanneer wél vastgesteld is, dat geen sprake is van gezins- of familieleven, kan het privéleven van de klager nog in het geding zijn. In het geval van. een vader en zijn vriendin is (in de zaak $X$ and $Y y$. Switzerland) geen sprake van gezinsleven, omdat in dit geval geen sprake is van een gemeenschappelijke huishouding van de klagers en ze niet op permanente basis samenleven. Bovendien is klager $\mathbf{X}$ gehuwd en verblijf hij gewoonlijk bij zijn gezin. Volgens de Commissie kan de relatie tussen deze klagers alleen aangemerkt worden als privéleven. ${ }^{5}$ In de zaak $X$ and $Y$ v. the United Kingdom stelt de Commissie vast dat,

"Despite the modern evolution of attitudes towards homosexuality, the Commission finds that the applicants' relationship does not fall within the scope of the right to respect for family life ensured by Article 8 . ... The Commission finds that the applicants" relationship is a matter of their private life..."

Ook zonder dat er een verband gelegd wordt met andere verdragsrechten, zijn er uitspraken waarbij zonder meer wordt vastgesteld, dat een bepaald gedrag of belang al of niet binnen de reikwijdte van het recht op privéleven valt. Van enige afbakening van de reikwijdte aan de hand van criteria is in de volgende zaken geen sprake.

3 Besl.Comm. 19 mei 1976, zaak nr. 6959/75, Case of Brüggemann and Scheuten, p. 115.

4 Besl.Comm. 10 juli 1978, zaak nr. 8257/78, X v. Swirzerland, pp. 252-253.

5 Besl.Comm. 14 juli 1977, zaak nrs. 7289/75 en 7349/76, $X$ and $Y$ v. Switzerland, p. 74. Zie verder P. van Dijk en G.J.H. van Hoof, De europese conventie in theorie en praktijk, pp. 408-409, met name t.a.v. de eerbiediging van de eer en goede naam. en het verbod om vertrouwelijke informatie prijs te geven.

6 Besl.Comm. 3 mei !983, zaak nr. 9369/81, $X$ and $Y_{v}$. Switzerland, p. 221. Volgens van Dijk is in de rechtspraak van de Afdeling Rechtspraak van de Raad van State een ander standpunt ingenomen; hij wijst op, o.a., ARRS 5 oktober 1993, RO2.90.3066 (Gyabaah). P. van Dijk, Toelating en verblijf van vreemdelingen in Nederland, p. 15. Zie verder $T$. Loenen, Mensenrechtelijke aspecten van de leefvormenproblematiek I, pp. 217-218, 220. 
In de ontvankelijkheidsbeslissing in de zaak $1504 / 62^{7}$ wordt zonder dat daarvoor een criterium wordt aangelegd, bepaald dat het recht op het gebruik van de titel "architect" niet opgenomen is tussen de rechten gewaarborgd door de Conventie, en met name niet door artikel 8 . Hetzelfde gebeurt in de uitspraak van het Hof in de zaak Klass e.a., waarin het Hof stelt dat het begrip telefoongesprek weliswaar niet uitdrukkelijk genoemd wordt in lid 1 van artikel 8 , maar dat het wel gedekt wordt door de begrippen "private life" en "correspondence" waarnaar dit artikel verwijst. ${ }^{8}$

Met betrekking tot artikel 8 hebben de Commissie en het Hof voorts bepaald, dat het privéleven de fysieke en morele integriteit van de persoon omvat, inclusief zijn of haar seksleven. ${ }^{9}$ Wat betreft die integriteit: zelfs een kleine medische behandeling tegen de wil van de patiënt moet opgevat worden als een inbreuk op het recht op privacy. ${ }^{10}$ Niet verbazingwekkend is dan ook, dat een rectaal onderzoek bij een gedetineerde - voor en na het ontvangen van bezoek - wordt opgevat als een inmenging op diens privéleven."

Ook een bepaalde levensstij], met name die van een in een lidstaat levende minderheid kan binnen het bereik komen van het recht op eerbiediging van het privéleven, familie- en gezinsleven en de woning. Zo acht de Commissie het aannemelijk, dat het oprichten van een hydroelektrische centrale in een voornamelijk door Lappen bewoonde vallei, waar zij ook hun rendieren weiden, een inbreuk zou kunnen maken op hun

Besl,Comm. 12 decernber 1963, zaak ir. 1504/62, X v. Austria, (niet gepubliceerd).

8 EHRM 6. september 1978, Case of Klass and others, $\$ 41$, p. 21; zie tevens Besí.Comm. 13 december 1979, zaak nr. 8290/78, A, B, C and D v. FRG, p. 179; Rapp.Comm. 18 maart 1981, McVeigh e.a., \$236, p. 52; EHRM 2 augustus 1984. Malone Case, $\$ 64$, p. 30; EHRM 24 aprił 1990. Kruslin Case, §26, p. 20 en EHRM 15 juni 1992, Lüdi Case, $\$ 39$, p. 19 (impliciet). In laatstgenoemde zaak is tevens uitgesproken dat het gebruik van een under-cover agent, op zichzelf noch in combinatie met de telefoontap, het privéleven in de betekenis van artikel 8 beïnvloed had.

9. EHRM 26 maant 1985, $X$ and $Y$ v. the Netherlands, \$22, p. 11. Zie o.a. ook Besi.Comm. 30 september 1975, zaak nr. 5935/72, X v. FRG, p. 284, en EHRM 22. oktober 1981, Dudgeon Case, \$\$40-41, pp, 18-19 en EHRM 25 maart 1993, Case of Costello-Roberts v. UK, \$34, p. 60 .

10 Besl.Comm. 13 december 1979, zaak nr. 8278/78, X v. Austria, p. 154 en Besi.Comm. 10 december 1984, zaak nr. 10435/83, Acmanne and others v. Belgium, p. 255 .

11 Rapp.Comm. 15 mei 1980, McFeeley and others v. UK, $\$ 81$, p. 90. 
privéleven, nu die vallei gedeeltelijk onder water zal komen te staan. ${ }^{12}$ Ook wordt artikel 8 van toepassing geacht wanneer de kwaliteit van iemand's privéleven en de mate waarin hij het genot heeft van zijn woning in negatieve zin beïnvloed worden door geluidsoverlast, die veroorzaakt wordt door vliegtuigen die gebruik maken van de landingsbanen van een nabijgelegen vliegveld. ${ }^{13}$

In de zaak Gaskin stemt het Hof in met het oordeel van de Commissie, dat de gegevensbestanden, waarin onder andere gegevens over klager's jeugd en achtergrond zijn opgenomen, in verband staan met zijn privé- en gezinsleven. Vervolgens constateert het Hof dat de kwestie van de toegang van klager tot deze gegevensbestanden binnen het bereik van artikel 8 valt. ${ }^{14}$ Het Hof bepaait in deze zaak uitdrukkelijk, dat het met genoemde constatering geen oordeel heeft willen geven over de vraag, of uit artikel 8 lid 1 een algemeen recht op toegang tot persoonsgegevens kan worden afgeleid.

"The Court is not called upon to decide in abstracto on questions of general principle in this field but rather has to deal with the concrete case of Mr Gaskin's application. "15.16

12 Besl.Comm. 3 oktober 1983, zaak nrs. 9278/81 en 9415/81, G. and E. v. Norway. pp. 35-36. Overigens was een beroep op onder meer artikel 8 de enige mogelijkheid voor de klagers om te klagen over gebrek aan eerbiediging van hun levensstijl aangezien de Conventie geen garantie biedt voor specifieke rechten van minderheden. Voorts kan artikel 14 - in combinatie met een andere Conventie-bepaling, die rechten en vrijheden garandeert (zie par. 2.4.5.1) - worden ingeroepen: het verbod van discriminatie op grond van het behoren tot een nationale minderheid. (p. 114) Het inroepen van artikel 14. dient wel te gebeuren in combinatie met een ander verdragsartikel met het oog op het onzelfstandige karakter van artikel 14, zie hiervoor par. 2.4.5.1, pp. 114-115.

13 EHRM 21 februari 1990, Case of Powell and Rayner, \$40, p. 18. Vgl. EHRM 9 december 1994, Case of López. Ostra, \$51, p. .

14 EHRM 7 juli 1989, Gaskin Case, \$\$36-37, p. 15. Anders: Judge Walsh in zijn dissenting opinion (p. 26). Hij koppelt het inzagerecht los van het recht op privacy en acht niet artikel 8 maar artikel 10 van toepassing. Vgl. HR 2 december 1988. NI 1989, 752 met noot Ma. Zie ook de noot onder het arrest in de zaak Gaskin in NJ 1991, 659.

15 EHRM 7 juli 1989. Gaskin Case, \$\$36-37, p. 15; NJCM-Bulletin 15-2 (1990), pp. 206-217 met noot L.F.M. Verhey. Ook in de Leander Case gaat het Hof niet verder dan de constatering, dat het opslaan en het vrijgeven van informatie m.b.t. het privéleven van de klager, tezamen met de weigering om Leander in de gelegenheid te stellen de gegevens te weerleggen, een inmenging in Leander's recht op eerbiediging van zijn privéleven inhouden. EHRM 26 maart 1987, Leander Case. \$48, p. 22. Zie ook BesI.Comm. 11 december 1985, zaak nr. 10473/83, Lundvall 
Vanuit het oogpunt van reikwijdte-afbakening valt dit, mijns inziens, te betreuren, aangezien het Hof hier de mogelijkheid heeft laten liggen om. - met betrekking tot het recht op toegang tot persoonsgegevens toetsingscriteria te formuleren, aan de hand waarvan ook in andere zaken kan worden uitgemaakt of een geval betreffende toegang tot persoonsgegevens binnen het bereik van artikel 8 lid 1 valt. Het Hof beperkt zich tot een oordeel over het onderhavige geval en tot toetsing aan de hand van de omstandigheden van het desbetreffende geval, waardoor het geen lijn uitzet voor toekomstige zaken op dit terrein.

Tenslotte moet hier gewezen worden op de zaken Van Oosterwijck, Rees, Cossey en $B v$. France waarin het ging om verandering van de gegevens omtrent het geslacht van de klagers in het geboorteregister. Ook in deze gevallen is artikel 8 lid 1 van toepassing verklaard. ${ }^{17}$

In het voorgaande werd vooral aangegeven welke kwesties onder het recht op privéleven kunnen vallen. Enige afbakening door middel van algemene criteria van de reikwijdte van het recht op privéleven vond in de genoemde zaken niet plaats. In het navolgende zal vooral gekeken worden naar zaken waarin de grenzen van dit recht wél worden aangegeven en de criteria die daarbij zijn ontwikkeld. Hierbij moet wel worden aangetekend, dat het Hof zelf in zijn jurisprudentie ${ }^{18}$ al heeft aangegeven, dat het niet mogelijk,

v. Sweden, p. 130:

"... there is no provision in the Convention which as such expressly or implicitly prohibits the use of personal identity numbers. ... the Commission recalls that it has previously held that data protection is an issue which falts within the scope of Article $8 \ldots \mathrm{It}$ is therefore conceivable that the use of personal identity numbers as a way of storing data in different registers and the matching of such registers could raise an issue under Article 8 of the Convention."

Zie verder ten aanzien van persoonsgegevens: Besi.Comm. 9 september 1992, zaak nr. 16810/90, Reyntjens v. Belgium, NJCM-Bulletin 18-3 (1993), pp. 337-339 met noot $A$.W. Heringa. Deze zaak betreft de verplichting tot het dragen en op verzoek tonen van een identiteitskaart.

16 Zie ook par. 1.3.1, noot 16.

17 Rapp.Comm. 1 maart 1979, Van Oosterwijck Case, \$45-50, pp. 24-25; impliciet in EHRM 17 oktober 1986, Rees Case, \$35 e.v., p. 14 e.v.; EHRM 27 september 1990. Cossey Case, $\$ 36$ e.v., p. 15 e.v. en EHRM 25 maart 1992. Case of $B$ v. France, $\$ 44$ e.v., p. 47 e.v.. Zie verder met betrekking tot deze arresten de paragraaf ten aanzien van positieve verplichtingen (par, 4.4).

18 EHRM 16 december 1992. Niemietz Case, \$29, p. 33 en EHRM 25 maart 1993. Case of Costello-Roberts v. UK, \$36, p. 60. Zo ook Rapp.Comm. I maart 1979, Van Oosterwijck Case, \$51, p. 25. 
noch noodzakelijk is om te trachten een uitputtende definitie van het begrip "privéleven" te geven.

In haar beslissing in de zaak $\boldsymbol{X} v$. Iceland bepaalt de Commissie, dat het recht op respect voor het privéleven meer onvat dan het recht om te leven onder bescherming tegen ongewenste publiciteit. Volgens de Commissie omvat het ook tot in zekere mate het recht

"to establish and develop relationships with other human beings, especially in the emotional field, for the development and fulfilment of one's own personality".

Vervolgens gaat de Commissie ertoe over te bepalen in welke mate het recht op respect voor het privéleven dit recht omvat:

"The Commission cannot, however, accept that the protection afforded by Article 8 of the Convention extends to rellationships of the individual with his entire immediate surroundings, insofar as they do not involve human relationships and notwithstanding the desire of the individual to keep such relationship within the private sphere."

Om deze reden moet de in deze zaak aan de orde zijnde vraag, of de vrijheid van een individu om een hond te houden beschermd wordt onder de Conventie en met name of het houden van honden behoort tot het privéleven in de zin van artikel 8 , negatief beantwoord worden. Volgens de Commissie is het feit, dat al sinds mensenheugenis de hond een nauwe band heeft met de mens, niet voldoende om het houden van een hond te brengen in de sfeer van het privéleven van de eigenaar omdat

"the keeping of dogs by the very nature of that animal necessarily (is) associated with certain interferences with the life of others and even with the public life." 19.20 "

19 Besl.Comm. 18 mei 1976, zaak nr. 6825/74, X v. Iceland, pp. 86-87. Vgl. HR 19 september 1990. BNB 1990/320 met noot G.J. van Leijenhorst: de Raad bevestigt een uitspraak van het Gerechtshof 's-Gravenhage van 17 mei 1989 waarin het heffen van hondenbelasting niet in strijd met artikel 8 wordt geacht. De A-G bij de Hoge Raad verwijst in zijn conclusie expliciet naar de zojuist genoemde uitspraak in $X v$. Iceland. Zie verder ook Besl.Comm. 5 mei 1981, zaak nr. 9101/80, X v. FRG, niet gepubliceerd, ten aanzien van het voeren van duiven: het betreft een handeling op de openbare weg die beperkt is met het oog op het openbaar belang. "It therefore falls clearly outside the scope of Article 8 of the Convention.... 
In de zaak Brüggemann en Scheuten wordt ook deze redenering gevolgd. Volgens de Commissie heeft het privêleven een zodanig bereik, dat het voor de individu een sfeer waarborgt waarbinnen hij vrijelijk de "development and fulfilment" van zijn persoonlijkheid kan nastreven. Hiertoe moet hij de mogelijkheid hebben relaties van diverse aard, waaronder seksuele, met andere personen aan te gaan. Inmenging in dit recht moet een rechtvaardiging vinden in het licht van lid 2 van artikel 8.

Echter, aidus de Commissie, er zijn grenzen aan de persoonlijke sfeer. Niet elke wetgeving met een "immediate or remote" effect op de mogelijkheid van een individu om zijn persoonlijkheid te ontplooien, kan beschouwd worden als een inmenging in het privéleven in de zin van artikel 8. Overeenkomstig eerdere jurisprudentie ${ }^{21}$, wordt

"the claim to respect for private life ... automatically reduced to the extent that the individual himself brings his private life into contact with public life or into close connection with other protected interests. "22

In een ander geval overweegt de Commissie, dat de weigering van de autoriteiten am al de gegevens van de klager in de gevangenichestanden te wijzigen zodat deze alleen zijn nieuwe (gewijzigde) naam bevatten, een kwestie is

"which relates not to the right to respect for private life under Article 8 of the Convention, but is a question relating to the public administration of prisons. Therefore this complaint falls outside the scope of Article 8."23.

Ook wat betreft het gebruik van namen, stelt het Hof in de zaak Burgharz vast - na te hebben geconstateerd dat de Conventie geen expliciete bepalingen bevat met betrekking tot namen - dat de naam van een persoon. zijn of haar privé- of gezinsleven betreft, aangezien het een middel van persoonlijke identificatie is en de persoon met een familie verbindt. Dat de maatschappij en de staat er belang bij hebben dat het gebruik van namen

20 In Rapp.Comm. I maart 1979, Van Oosterwijck Case, wordt voor wat betreft de: ontvankelijkheidsvraag expliciet verwezen naar de in de vorige noot genoemde zaak $X$ v. Iceland. \$\$51-52, pp. 25-26.

21 Bedoeld wordi Besı.Comm. 18 mei 1976, zaak nr. 6825/74, X v Iceland.

22 Rapp.Comm. 12 juli 1977, Case of Brüggemann and Scheuten, \$§55-56, p. 115; Zie ook: Rapp.Comm. 13 maart 1980, Dudgeon Case, \$87, pp. 33-34.

23 Besl.Comm. 10 december 1985, zaak nr. 11046/84, Lant v. UK, p. 237. 
wordt gereguleerd is niet voldoende om de kwestie van de naam van een persoon buiten de reikwijdte van het privé- en gezinsleven te doen vallen, aangezien deze 'publiekrechtelijke aspecten ${ }^{24}$ verenigbaar zijn met de interpretatie van privéleven, inhoudende dat het in zekere mate het recht omvat relaties met andere mensen aan te gaan en te ontwikkelen - ongeacht of dit in een professionele, zakelijke of andere context plaatsvindt. ${ }^{25}$

Voorts bepaalt het Hof in de zaak Niemietz dat het begrip "privéleven" een te beperkte betekenis zou krijgen indien het beperkt wordt tot een zogenaamde "inner circle", waarbinnen het individu zijn eigen leven op zijn eigen wijze kan leiden en de buitenwereld daarvan geheel uit te sluiten. Opnieuw verwijst het Hof hier naar de hiervoor geciteerde uitleg van "private life" dat het in zekere mate ook het recht om relaties met andere mensen aan te gaan en te ontwikkelen, omvat. ${ }^{26}$

Tenslotte is in de zaak Costello-Roberts uitgesproken - onder verwijzing naar de Belgische Taal-zaak ${ }^{27}$ - dat maatregelen in het kader van het onderwijs, onder omstandigheden, van invloed kunnen zijn op het recht op eerbiediging van het privéleven. Volgens het Hof levert, echter, niet iedere daad of maatregel - waarvan wordt aangenomen dat dit de fysieke of morele integriteit van een persoon aantast-noodzakelijkerwijs een inmenging in het privéleven op. In deze zaak gaat het om lijfstraffen op een particuliere school ("independent school"). Bij toetsing aan artikel 3 komt het Hof tot de conclusie dat de lijfstraffen niet ernstig genoeg waren voor toepasselijkheid van deze bepaling. Het Hof is van opvatting dat de bescherming die artikel 8 met betrekking tot tuchtstraffen biedt (aan iemand's fysieke of morele integriteit) ruimer zou kunnen zijn dan die wordt geboden door artikel 3. Echter, het Hof meent - het doel en de strekking van de Conventie in aanmerking nemende en in gedachten houdend dat het naar school sturen van een kind altijd wel enige inmenging in het privéleven van het kind met zich brengt - dat de lijfstraffen waarover werd geklaagd, de fysieke of morele integriteit van klager niet

24 Niet geheel duidelijk is waar het Hof met het gebruik van de woorden "public law aspects" naar verwijst. Vermoedelijk doelt het Hof op het maatschappelijk belang en het belang van de staat.

25 EHRM 22 februari 1994, Burgharz Case, 824, p. 28. Zo ook EHRM 25 november 1994, Stjerna Case, $\$ 37$.

26 EHRM 16 december 1992, Niemietz Case, \$29, p. 33.

27 EHRM 23 juli 1968, Belgian Linguïstic Case, \$7. p. 33. 
in voldoende mate aantastten "to bring it within the scope of the prohibition contained in Article 8." 28

In deze zaak zien we opnieuw dat iets wat onder het openbare leven valt - het naar school gaan/sturen. van een kind - in verband kan staan met het privéleven van dat kind, ja, zelfs een inmenging in het recht op respect voor het privéleven kan opleveren. Dit verband zal volgens het Hof altijd wel in enige mate aanwezig zijn. Ook hier zal derhalve voor de vraag of artikel 8 van toepassing is, uitgemaakt moeten worden in hoevérre een maatregel op het terrein van het onderwijs in verband staat met iemands privéleven. In het onderhavige geval worden de lijfstraffen niet ernstig genoeg bevonden om het binnen de reikwijdte van het verbod in artikel 8 te doen vallen. Deze laatste zin is wat duister. Bedoelt het Hof hiermee, dat artikel 8 niet van toepassing is, dat geen sprake is van een inmenging in klager's privéleven of dat de inmenging in dit geval niet verboden is omdat er een rechtvaardiging voor deze inmenging bestaat? Aangezien het Hof eerder heeft aangegeven dat niet iedere daad of maatregel - waarvan wordt aangenomen dat dit de fysieke of morele integriteit van een persoon aantast - noodzakelijkerwijs een inmenging in het privéleven oplevert en zijn overwegingen ten aanzien van artikel 8 beëindigt met de conclusie dat artikel 8 niet geschonden is (en níet dat artikel 8 niet van toepassing is), neem ik aan dat bedoeld wordt dat de lijfstraffen de fysieke of morele integriteit niet voldoende aantastten om te kunnen spreken van een inmenging op klager's recht op respect voor zijn privéleven. Is dat het geval, dan kan worden geconcludeerd dat in geval van lijfstraffen op particuliere scholen, zoals in deze zaak, het verband tussen de - onder het openbare leven vallende - maatregel en het privéleven zodanig nauw is (de fysieke of morele integriteit van de persoon wordt aangetast), dat artikel 8 van toepassing is. ${ }^{29}$

Het uit deze zaken af te leiden criterium, dat de reikwijdte van het recht op respect voor het privéleven begrensd wordt door de mate waarin dit privéleven in verband staat met het openbare leven (of andersom gezien de zojuist besproken zaak Costello-Roberts), zou men het openbaarheidscriterium kunnen noemen. Vanzelfsprekend is een dergelijk criterium zinloos als men het privéleven zonder meer afbakent door de vaststelling dat het privéleven alleen datgene omvat wat niet tot het openbare leven

28 EHRM 25 maart 1993, Case of Costello-Roberts v. UK, \$36, pp. 60-61; NJCMBulletin 18-5 (1993), pp. 572-578 met noot M.L. van Emmerik.

29 Mijns inziens had het Hof beter, net als de Commissie, kunnen concluderen dat sprake was van een inmenging, om vervolgens die inbreuk, te toetsen aan artikel \& lid 2. Zie Rapp.Comm. 8 oktober 1991, Case of Costello-Roberts v. UK, \$51, p. 72. 
behoort. Zoals echter uit de hierboven besproken jurisprudentie blijkt is veeleer sprake van een glijdende schaal tussen privéleven en de publieke sfeer, dan van een scherpe scheiding van beide sferen. Het is afhankelijk van de afweging in de concrete casus aan welke kant van die schaal men zich bevindt. Het openbaarheidscriterium kan derhalve een nuttige functie vervullen bij de bepaling of een bepaalde kwestie door het privéleven bestreken wordt of niet.

Wellicht zou uit de ontvankelijkheidsbeslissing van de Commissie in de zaak $X$ v. United Kingdom nog een ander criterium afgeleid kunnen worden. In deze zaak gaat het om een gedetineerde, die een mensenrechten-organisatie in het Verenigd Koninkrijk heeft verzocht zijn medisch dossier te onderzoeken. Het doel van deze organisatie is om campagne te voeren teneinde de publieke opinie te beïnvloeden over medische behandelingen in gevangenissen. Wanneer de voorzitter van deze organisatie, Mr A., de gedetineerde (de klager in deze zaak) met het oog op dit onderzoek wil bezoeken wordt dit bezoek door de gevangenisautoriteiten niet toegestaan.

De Commissie beschouwt het als een essentieel onderdeel van zowel het privéleven als van de rehabilitatie van gedetineerden, dat ter vergemakkelijking van hun reïntegratie in de samenleving na hun vrijlating, hun contact met de buitenwereld zoveel mogelijk in stand blijft. Het doel van het bezoek van Mr A. is echter om medische dossiers te bespreken; daarmee is het doel van Mr A.'s bezoek aan de klager én het doel van zijn organisatie volgens de Commissie van een openbaar karakter en maakt daarom geen deel uit van klager's privéleven. Verwezen wordt naar de bovengenoemde uitspraak in de zaak $X v$ Iceland, dat het privéleven het recht omvat om relaties met andere personen aan te gaan en te ontwikkelen, met name ter vervulling van de eigen persoonlijkheid. Het bezoek van $\mathrm{Mr} \mathrm{A}$. is er volgens de Commissie niet op gericht om de persoonlijke relatie tussen klager en $\mathrm{Mr} \mathrm{A}$ te onderhouden. ${ }^{30}$

Uit deze uitspraak zou men kunnen afleiden, dat ook een grens aan het recht op privéleven gesteld kan worden aan de hand van het doel van het aangaan van relaties met andere personen: dit doel moet bestaan in de ontwikkeling en vervulling van de persoonlijkheid. Dit zogenaamde doelcriterium zou kunnen dienen als een verfijning van het openbaarheidscriterium. De uitkomst van een toets aan het doelcriterium zou doorslaggevend kunnen zijn voor de vaststelling van de mate waarin een 
bepaalde kwestie in verband staat met het openbare leven (zoals bij toetsing aan het openbaarheids-criterium).

Het bestaan van een soort doelcriterium wordt ondersteund door de uitspraak in de zaak $F v$. Switzerland. In deze zaak bevestigt de Commissie, dat ter ontwikkeling en vervulling van de persoonlijkheid

"The choice of affirming and assuming one's sexual identity consequently comes under the protection of Article 8 para. 1 of the Convention ..."

Wanneer de Staat regels opstelt of toepast met betrekking tot het gedrag van een persoon in dit opzicht, dan is sprake van inmenging in die persoon's privéleven. Deze zaak betreft echter iemand, die op professionele basis - tegen betaling - seksuele relaties aangaat. De klaagster zoekt bovendien contact met haar partners via een "gespecialiseerd" tijdschrift. De Commissie bepaalt vervolgens, dat seksuele relaties - die kunnen worden aangemerkt als prostitutie - niet tot de sfeer van het privéleven worden gerekend."

Gezien de arresten van het Hof in de zaken Chappell, Huvig en Niemietz mag hieruit echter niet de conclusie getrokken worden, dat voor het bestaan van privéleven het aangaan van relaties niet (uitsluitend) gericht mag zijn op economisch gewin. In het arrest in de zaak Chappell gaat het om een huiszoeking die gericht was tegen bepaalde bedrijfsactiviteiten, wat voor het Hof echter geen reden is om de toepasselijkheid van artikel 8 ("private life") uit te sluiten. ${ }^{32}$ In de zaak Huvig bepaalt het Hof dat sprake is van een inmenging in klager's recht op respect voor zijn privéleven ondanks dat de bestreden telefoontaps betrekking hadden op telefoongesprekken met zowel een zakelijke als een privé- inhoud. ${ }^{33}$ In de zaak Niemietz spreekt het Hof dan ook uit dat

"There appears ... to be no reason of principle why this understanding of the notion of 'private life' should be taken to exclude activities of a professional or business nature since it is, after all, in the course of their working lives that the majority of people have a significant, if not the greatest, opportunity of developing relationships with the outside world."

31 Besl.Comm. 10 maart 1988, zaak nr. 11680/85, F v. Switzerland, pp. 180-181. Deze zaak moet men overigens niet verwarren met de gelijknamige zaak die heeft geleid tot EHRM 18 decenber 1987, F v. Switzerland.

32 EHRM 30 maart 1989. Chappell Case. $\$ 26$ en \$51, pp. 12-13 en 21-22.

33 EHRM 24 april 1990, Huvig Case, §8 en \$25, pp. 41 en 52. 
Deze opvatting wordt volgens het Hof ondersteund door het feit dat het niet altijd mogelijk is te onderscheiden tussen de activiteiten van een individu die deel uitmaken van zijn professionele of bedrijfsactiviteiten en activiteiten die daar niet toe behoren. Hieruit trekt het Hof de conclusie, dat "especially in the case of a person exercising a liberal profession, his work in that context may form part and parcel of his life to such a degree that it becomes impossible to know in what capacity he is acting at a given moment of time." Ook zou het onthouden van bescherming van artikel 8 op grond van het feit dat de bestreden overheidsmaatregel alleen gericht was op klager's professionele activiteiten een ongelijke behandeling betekenen ten opzichte van personen wier professionele en nietprofessionele activiteiten zo verstrengeld zijn, dat het onmogelijk is deze van elkaar te onderscheiden. ${ }^{4}$

Het is dan ook niet duidelijk waarom wel het aangaan van seksuele relaties met het doel zich te prostitueren, van het recht op respect op privéleven wordt uitgezonderd. Dit valt immers ook als een professionele activiteit aan te merken. Wellicht kan de verklaring worden gezocht in de omstandigheid dat voormelde ontvankelijkheidsbeslissing in de zaak $F v$. Switzerland afkomstig was van de Commissie en dateert van vóor eerdergenoemde uitspraken van het Hof in de zaken Chappell, Huvig en Niemietz. Het is, mijns inziens, ook niet ondenkbaar dat morele bezwaren van de Commissieleden tegen prostitutie hier een rol hebben gespeeld.

\section{Conclusie}

Ten aanzien van het recht op privéleven in artikel 8 ECRM kan worden geconcludeerd, dat de reikwijdte in hoofdzaak begrensd wordt door de mate waarin dit privéleven in verband staat met het openbare leven, al dan niet in de vorm van rechten van anderen dan wel de openbare orde. Eerder heb ik dit het openbaarheidscriterium genoemd. We kunnen zien dat dit criterium grote overeenkomsten vertoont met enkele van de beperkingsgronden genoemd in het $2^{i}$ lid van artikel 8 , zoals de voorkoming van wanordelijkheden (wat ziet op de openbare orde, zie paragraaf 2.4.2.1. pp. 65-67) en de bescherming van de rechten van anderen.

Het laatstbesproken, zogenaamde doelcriterium - waarbij het doel van het aangaan van relaties met andere personen als maatstaf dient voor de begrenzing van het privéleven - is nog zo zelden toegepast, dat het twijfelachtig is of hier gesproken kan worden van een vast criterium. De 
hiervoor besproken ontvankelijkheidsbeslissingen in de zaken $X v, U K$ en $F v$. Switzerland, die de toepassing van dit criterium laten zien, tonen mijns inziens aan, dat het wellicht een bruikbaar criterium zou kunnen zijn. ${ }^{35}$ Wèl moet daaraan worden toegevoegd, dat het onderzoeken van het doel met het oog waarop men relaties met anderen aangaat ook een zeker risico in zich bergt. De reden waarom men relaties met andere personen aangaat is immers ook een privé-aangelegenheid die gerespecteerd dient te worden. Voorzichtigheid is hier derhalve geboden.

Overigens is het interessant te kunnen constateren, dat het openbaarheidscriterium noch het doelcriterium gericht zijn op een ruimtelijke afbakening van het privéleven. Beide criteria zien, terecht, op een inhoudelijke, niet-formele begrenzing van dit begrip. Een ruimtelijke afbakening van het privéleven zou mijns inziens, onaanvaardbare consequenties kunnen hebben. Zou men, bijvoorbeeld, het privéleven ruimtelijk beperken tot de woning, dan zou dat tot gevolg hebben dat gedragingen die in hoge mate in verband staan met het openbare leven tot de privésfeer worden gerekend. Hierbij kan men denken aan strafbare feiten die binnenshuis kunnen plaatsvinden, zoals incest. ${ }^{36}$ Anderzijds zouden gedragingen die buiten de woning plaatsvinden automatisch de bescherming van artikel 8 moeten ontberen. Men denke bij dit laatste, bijvoorbeeld, aan het ontvangen van bezoek in een gevangenis. Bovendien zou een ruimtelijke begrenzing van het privéleven tot de woning tot gevolg hebben dat het recht op eerbiediging van de woning zodanig met het recht op eerbiediging van het privéleven zou samensnelten, dat het bestaan van het huisrecht los van het privéleven weinig zin zou hebben. Dit lijkt mij gezien de formulering van artikel 8 ECRM niet de bedoeling. Het Hof wijst er in de zaak Niemietz dan ook - naar mijn mening terecht - op, dat het feit dat artikel 8 ook professionele of zakelijke activiteiten (en gebouwen) beschermt, de Staten niet hoeft te hinderen aangezien zij het

35 Zie respectievelijk de noten 30 en 31 . Wat betreft laatstgenoemde zaak doet daaraan niet af dat prostitutie wellicht op grond van de arresten van het Hof in o.a. de zaak Niemietz niet meer van de reikwijdte van artikel 8 kan worden uitgesloten op de grond dat het doel van het aangaan van seksuele relaties met andere mensen gelegen is in de betaling die daar tegenover staat en een professioneel karakter draagt.

36 Een dergelijke redenering ten aanzien van het recht op eerbiediging van het familieof gezinsleven is te vinden in de conclusie van de AG bij HR 3-10-1989, NJ 1990. 443: de regel dat sprake is van family life tussen vader en kind indien sprake is van biologisch vaderschap, lijdt uitzondering wanneer de verwekking van het kind door middel van incest heeft plaatsgevonden. (Inmiddels, is bovengenoemde regel in de latere rechtspraak van de HR ook gewijzigd: HR. 10 november 1989, NJ 1990,628.) Zie hierna par. 4.3.2.1. 
recht behouden een inbreuk op de eerbiediging van die activiteiten en gebouwen te maken voorzover dat gerechtvaardigd is op grond van het tweede lid van artikel 8 . Dit recht tot het maken van een inbreuk onder lid 2, zal waarschijnlijk een ruimere reikwijdte hebben wanneer professionele activiteiten of gebouwen in het geding zijn dan in andere gevallen."

De uitspraak van het Hof van Justitie van de Europese Gemeenschappen in de zaak Hoechst, dat de door artikel 8 ECRM "geboden bescherming ... gericht [is] op de ontplooiing van de persoonlijke vrijheid van de mens en ... zich derhalve niet [kan] uitstrekken tot bedrijfslokalen" is dan ook, zeker voorzover deze overweging geen betrekking heeft op de onschendbaarheid van de woning, gezien het voorgaande onjuist. ${ }^{3 .}$

Tenslotte moet worden opgemerkt, dat in het merendeel van de uitspraken van de Commissie en het Hof helaas geen gebruik wordt gemaakt van vaste criteria. In veel gevallen wordt wel vastgesteld, dat een bepaalde kwestie al dan niet onder het recht op privéleven valt, maar niet in hoeverre en waarom. De grens van het recht op eerbiediging van het privéleven wordt veelal niet aangegeven. Enerzijds bergt dit het gevaar in zich, dat op een enigszins willekeurige wijze beslist wordt of een kwestie binnen het bereik van het recht op privacy valt en biedt de rechtspraak voor de justitiabele niet zoveel houvast als wat betreft dit recht wenselijk kan worden geacht. Anderzijds biedt het een mate van flexibiliteit, die met het oog op de dynamisch-evolutieve toepassing van de Conventie in de steeds veranderende en de zich, met name technologisch, ontwịkelende samenleving noodzakelijk is.

\subsubsection{The right to respect for his family life}

Anders dan bij het recht op eerbiediging van het privéleven, is voor de afbakening van het recht op respect voor het gezinsleven een veel groter aantal toetsingscriteria ontwikkeld.

37 Vergelijk par. 2.4.2.1, pp. $80-81,86$.

38 Arrest van 21 september 1989, Hoechtst, Jurisprudentie van het Hof van Justitie, 1989, band III, pp. 2919-2935, rechtsoverweging 18 (p. 2924). Eensluidend: de arresten van 17 oktober 1989, Dow Benelux $N$. V., Jur. Hof van Justitie, 1989, band IV., pp. 3150-3163, rechtsoverweging 29 (p. 3157) en Dow Chemical !bérica e.a., Jur. Hof van Justitie, 1989, band IV, pp. 3181-3197, rechtsoverweging 15 (p. 3185). Zie: I.G.F. Cath, Hebben ondernemingen recht op bescherming van de privésfeer? De zaken Hoechst en Chappell vergeleken, pp. 28-54(35 en 46).

Zie voor een bespreking van het recht op respect voor de woning, par, 4.2.3. 
De vaststelling of sprake is van "family life" is eenvoudig bij de relatie tussen een moeder en haar kind:

"... the fact of birth, i.e. the existence of a biological bond between mother and child, creates family life within the meaning of Article $8^{\prime \prime 39}$

Voor overige relaties is de kwestie gecompliceerder. Volgens het Hof in de zaak Marckx omvat het gezinsleven tenminste de banden tussen "near relatives", zoals die tussen grootouders en kleinkinderen, "since such relatives may play a considerable part in family life". ${ }^{0}$

De betekenis van het woord "relatives" lijkt duidelijk: bloedverwanten. Dit is echter een erg ruim begrip; ouders, broers en zusters vallen eronder, maar ook ooms, achternichten en dergelijke. Of sprake is van gezinsleven is dus afhankelijk van het woord "near" ofwel naaste. Wanneer is iemand echter een naaste bloedverwant? Volgens het Hof in de Marckx-zaak zijn dat onder andere grootouders ten opzichte van hun kleinkinderen. Maar geldt dat altijd en bovendien, wie omvat de categorie "naaste biloedverwant" nog meer? En is het bestaan van gezinsieven beperkt tor naaste bloedverwanten of kan dit gezinsleven ook bestaan tussen bijvoorbeeld niet-bloedverwante "gezins"leden? Door het gebruik van de term "tenminste" (at least) lijkt het Hof aan te geven, dat het gezinsleven niet beperkt hoeft te blijven tot de banden tussen naaste bloedverwanten."

Uit de Marckx-zaak kan men enkele conclusies trekken.

Ten eerste maakt het Hof in navolging van de Commissie geen onderscheid tussen wettige en onwettige verwantschap. Een dergelijk. onderscheid zou volgens het Hof niet in overeensternming zijn met het woord "everyone" in artikel $8 .{ }^{22}$ Dit wordt bevestigd door artikel 14 dat

39 Rapp.Comm. 10 december 1977. Marckx Case, \$\$69-71, p. 44.

40 EHRM 13 juli 1979, Marckx Case, \$45, p. 21; Besl.Comm. 10 maart 1981, zaak nt. 8924/80, X $v$ Switzerland. p. 185.

41 Hierbij valt te denken aan [a] de relatie tussen pleegouders en -kinderen, tussen adoptieouders en -kinderen en tussen stiefouders en -kinderen en [b] aan buitenechtelijke relaties, waaronder wellicht ook de relaties tussen verschillende leden van een woongemeenschap begrepen kunnen worden.

$42 \quad$ Vgl. art. I van de Conventie: "The High Contracting Parties shall secure to $\ell$ veryone within their jurisdiction the rights and freedoms defined in Section I of this Convention." Volgens de Commissie laat de formulering van artikel 1 niet toe dat er onderscheid gemaakt wordt tussen verschillende categorieăn personen "... 10 the extent of finding the Convention applicable in one case but not in the other:" 
discriminatie verbiedt onder andere op grond van geboorte. ${ }^{3}$ Het discriminatieverbod, dat zowel in het woord "everyone" gelegen is als in artikel 14, kan derhalve als maatstaf gehanteerd worden bij de bepaling van de reikwijdte van het begrip gezinsleven." Men zou deze maatstaf het non-discriminatie-criterium kunnen noemen. Het is echter vanzelfsprekend, dat dit niet alleen geldt voor het begrip gezinsleven.

Overigens dient men dit gebruik van het discriminatie-verbod van artikel 14 als toetsingscriterium voor de vaststelling van de reikwijdte van een grondrecht niet te verwarren met het discriminatie-verbod als criterium voor de toetsing van de uitoefening van een grondrecht. In het laatste geval is immers al geconstateerd dat het desbetreffende grondrecht van toepassing is en dat het ingeroepen belang dus binnen de reikwijdte van het grondrecht valt!

Ten tweede blijkt uit de Marckx-zaak, dat in ieder geval vereist is dat degenen die het recht op eerbiediging van het gezinsleven inroepen "play a considerable part in family life" ${ }^{45}$ Deze eis is in overeenstemming met de invulling die wordt gegeven aan het al eerder door de Commissie ontwikkelde criterium "required link":

Het is voor het vaststellen van het bestaan van "family life" niet voldoende dat er sprake is van een bloedverwantschap tussen de betrokken personen, maar ook moet aangetoond worden

"whether it [is] in fact possible to point to such a link as can be considered to establish family life within the meaning of Article 8" ${ }^{46}$

Rapp.Comm. 19 juli 1974, Case of Engel a.o., \$61, p. 59. Zie ook EHRM 18 december 1986. Case of Johnston a.o., \$55(b), p. 25.

43 EHRM 13 juli 1979, Marckx Case, \$31, pp. 14-15; zie ook Besl.Comm. 29 september 1975, zaak nr. 6833/74, Marckx v. Belgium, Yearbook XVIII, p. 270. D \& R 3. p. 133 en Besl.Comm. 2 oktober 1979, zaak nr. 8344/78, X v. UK, nie! gepubliceerd en Besl.Comm. 13 juli 1979, zaak nr. 8615/79, $X$ v. UK, niet gepubliceerd.

44 Men denke hierbij met name aan de relaties geneemd in noot 41 onder a. Op deze wijze zouden wellicht ook relaties tussen niet bleedverwanten onder gezinsleven gevat kunnen worden.

45 Zie het citaat behorend bij noot 40. Zie verder P. van Dijk en G.J.H. van Hoof, De europese conventie in theorie en praktijk, p. 420.

46 Besl.Comm. 14 mei 1986, zaak nr. 11418/85, Jolie, Jolie and Lebrun v. Belgium. p. 256. waarin wordt verwezen naar Besl.Comm. 29 september 1975, zaak nr. 6833/74, Marckx v. Belgium, pp. 248 e.v.. De eerste zaak waarin ik het "link"vereiste ben tegengekomen is Besl.Comm., zaak nr. 2991/66 en 2992/66, Khan and Singh v. UK, p. 500 . Zie verder, onder andere, Besl.Comm. 19 juli 1968, zaak nr. 
Voor het bestaan van een dergelijke "link" is onder andere van belang of

"there is (no) common household of the applicants" en of "they do (not) permanently live together" ${ }^{\text {47 }}$;

en in het geval dat het een andere relatie betreft dan die tussen twee levenspartners, de leeftijd en de mate van zelfstandigheid van de betrokkenen. In een zaak tegen het Verenigd Koninkrijk heeft de Commissie bepaald, dat in geval van andere relaties - dan die tussen "cohabiting dependents", zoals ouders en de van hen afhankelijke minderjarige kinderen - bijvoorbeeld die tussen volwassenen, bewijs geleverd moet worden van het bestaan van "further elements of dependency, involving more than the normal, emotional ties. ${ }^{48}$

Met betrekking tot het aspect van het op permanente basis samenwonen moet nog worden opgemerkt, dat dit niet een vereíste is voor het bestaan. van "family life". Het is slechts een van de factoren - alhoewel een belangrijke - die tezamen met de omstandigheden van het geval in ogenschouw genomen moeten worden bij het vaststellen van het al dan niet bestaan van "family life". ${ }^{49}$ Het gaat hierbij om factoren aan de hand waarvan kan worden aangetoond dat sprake is van voldoende mate van duurzaamheid van een relatie. ${ }^{50}$

Dat het samenleven voor het bestaan van "family life" niet per se vereist is, blijkt ook uit de volgende gevallen.

3110/67, X v. FRG, Yearbook XI, p. 518, Coll. 27, p. 91; BesI.Comm. 28 februari 1977, zaak nr. 7768/77, X v. FRG, niet gepubliceerd: Besl.Comm. 10 juli 1978. zaak nr. 8257/78, $X$ v Switzer!and, p. 252.

Voorzover mij bekend, heeft het Hof zich nooit expliciet over het "required link"criterium uitgelaten. Dit komt waarschijnlijk omdat de meeste zaken waarin dit criterium wordt toegepast, op grond van dit criterium niet-ontvankelijk verklaard worden en dus nooit bij het Hof terecht komen.

47 Wordt hieraan niet voldaan, dan is het overigens niet uitgesloten dat er nog wel sprake is van "private life" in de zin van art. 8 ECRM. Besl.Comm. 14 juli 1977, zaken nrs. $7289 / 75$ en 7349/76, $X$ and $Y$ v. Switzerland, pp. 74-75; zie verder o.a. Besl.Comm. 19 juli 1968, zaak nr. 3110/67, X v. FRG.

48 Besl.Comm. 14 juli 1982, zaak nr. 9492/ 81, Family $\boldsymbol{X}$. v. UK, p. 234. Zie ook: Besl.Comm. 8 februari 1972, zaak nr. 5269/71, X and $Y v$. UK, p. 574; Besl.Comm. 5 december 1979, zaak nr. 8157/78, $X$ and others $v$. UK, niet gepubliceerd en Besl.Comm. 10 december 1984, zaak nr. 10375/83, $S$ and $S$ v. UK, p. 198.

49 Besl.Comm. 9 maart 1988, zaak nr. 12402/86, Price v. UK, p. 234 en Besl.Comm. 14 juli 1988, zaak nr. 12763/87, Lawlor v. UK, p. 228. 
In gevallen waarin het bestaande gezinsleven in de zin van "samenleven" is beëindigd door echtscheiding, kan het wenselijk zijn en moet het mogelijk zijn, dat het contact tussen de ouder - die niet de voogdij over het kind heeft - en het kind wordt voortgezet. Uit artikel 8 vioeit voort, dat dit contact aan hen niet wordt ontzegd, tenzij er zwaarwegende redenen, zoals opgesomd in lid 2 van artikel 8 , aanwezig zijn die een dergelijke inbreuk rechtvaardigen. ${ }^{51}$

Bovendien verhindert het niet-samenleven volgens het Hof in de zaak $B_{\text {Berrehab }}{ }^{52}$ niet dat er sprake kan zijn van gezinsleven, in een relatie tussen ouders en minderjarige kinderen. Verwijzend naar de zaak Abdulaziz, Cabales en Balkandali ${ }^{33}$, moet volgens het Hof een relatie tussen echtgenoten

"created $\ldots$ by a lawful and genuine marriage $\ldots$ be regarded as "family life". It follows from the concept of family on which Article 8 is based that a child born of such a union is ipso jure part of that relationship; hence, from the moment of the child's birth and by the very fact of it, there exists between him and his parents a bond amounting to 'family life', even if the parents are not then living together.

"Subsequent events, of course, may break that tie, but this was not so in the instant case. ${ }^{154.55}$

51 Rapp.Comm. 8 maari 1982, Hendriks Case, §§95-96, pp. 14-15. Zie verder Besl.Comm. 20 december 1957, zaak nr. 172/56, Xv vweden, p. 217; Besl.Comm. 12 december 1977, zaak nr. 7911/77, X v. Sweden, p. 193; Besl.Comm. 13 maart 1980 , zaak nir. 8427/78, $\boldsymbol{X} v$. Netherlands, p. 225; en verder o.a. Besi.Comm. 14 december 1972, zaak nr. 5608/72, X v. UK, pp. 68-69.

52 EHRM 21 juni 1988, Berrehab Case, \$21, p. 14.

53 EHRM 28 mei 1985. Abdulaziz, Cabales en Balkandali, §62, p. 32.

54 EHRM 21 juni 1988, Berrehab Case, \$21, p. 14. Zie ook EHRM 23 september 1994, Hokkanen Case, §54.

55 Alkema maakt ten aanzien van deze laatsie zinsnede het bezwaar, dat het bestaan van gezinsleven op deze manier afhankelijk wordt gesteld van feitelijke omstandigheden. Hij vraagt zich af, of het niet beter was geweest om dergelijke feitelijkheden pas te betrekken in de toetsing in het kader van artikel 8 lid 2. Volgens Alkema suggereert het arrest in de zaak Berrehab anders dan het arrest in EHRM 24 maart 1988, Olsson Case (no.l) "dat feiten èn het bestaan van gezinsleven mede bepalen èn de beperking ervan kunnen rechtvaardigen." E.A. Alkema, annotatie bij de zaak Berrehab, §3, NJ $1988,746$.

Op zich valt er wel wat te zeggen voor deze opmerking van Alkema, omdat men zich inderdaad kan afvragen waarom niet altijd de weg van lid 2 gevolgd kan worden in geval van feiten, die aanleiding zouden kunnen geven tot een inperking van het recht op gezinsleven. Aan de andere kant is de overweging van het Hof ook weer niet zo uitzonderlijk, want het bestaan van gezinsleven wordt van wel meer feiten afhankelijk 
Naar aanleiding van deze uitspraak in de zaak Berrehab moeten onder meer de volgende punten overwogen worden.

Ten eerste lijkt de conclusie gerechtvaardigd dat het bestaan van gezinsleven, niet alleen meer als vanzelfsprekend aangenomen behoeft te worden in de relatie tussen een moeder en haar kind, zoals aan het begin van deze paragraaf naar voren werd gebracht, maar ook in de relatie tussen een vader en zijn kind, indien dit kind is geboren tijdens het huwelijk tussen beide ouders. In het zojuist aangehaalde citaat wordt immers gesproken van "parents". Toetsing aan het criterium "required link" lijkt hier niet meer noodzakelijk. ${ }^{56}$

Ten tweede, kan men zich afvragen, of het hierboven genoemde nondiscriminatie-criterium - dat het discriminatieverbod als maatstaf hanteert bij de afbakening van het begrip gezinsleven - net als in het geval van een ongehuwde moeder en haar onwettig kind, met zich mee kan brengen, dat ook met betrekking tot de relatie tussen een vader en zijn onwettig kind gesproken kan worden van gezinsleven. Hoewel de begrippen discriminatie of gelijke behandeling in deze zaken niet gevallen zijn, wijzen een aantal uitspraken van de Commissie en Hof in deze richting. Een zaak uit 1977 betreft een gehuwde man die met zijn gezin in München woont en zijn vriendin die met hun gezamenlijke kinderen in Liechtenstein woont. De vraag is of er tussen de man en zijn onwettige kinderen een relatie bestaat die kan worden aangemerkt als "family life" in de zin van artikel 8. Volgens de Commissie valt de relatie tussen een vader en zijn onwettige kinderen altijd onder het begrip "family life"!' In de uitspraak van 1987 in de zaak Jonsson $v$. Sweden is sprake van gezinsleven in die zin dat de ongehuwde ouders samen hebben geleefd. Dit samenleven is tot een einde gekomen vóór de geboorte van het kind. Onder deze omstandigheden en verder omdat geen twijfel bestaat over het vaderschap van de klager, accepteert de Commissie dat de afwijzing door de nationale rechterlijke instanties van het verzoek van de klager om een omgangsregeling een inmenging in zijn recht op eerbiediging van zijn gezins- en familieleven

gesteld. al was het alteen maar het bestaan van een huwelijk of een gelijksoortige relatie, of de geboorte van het kind.

Zie verder: I.J. Bolten, Mensen en staten. De grote woorden in de Berrehab-zaak. pp. 209-212 en de noot onder dit arrest in Rechtspraak Vreemdelingenrecht 1988. it. 17.

56 Het Hof betrok het feit dat Berrehab zijn dochter vaak en regelmatig zag alleen in zijn beschouwing omtrent de vraag of het familie- of gezinsleven al dan niet naderhand verbroken was.

57 Besl.Comm. 14 juli 1977, zaak nrs. $7289 / 75$ en 7349/76, $X$ and $Y$ v. Switzerland. p. 74 . 
betekent. ${ }^{58}$ Deze redenering vinden we ook terug in meer recente rechtspraak van het Hof. In de zaken Keegan (verwijzend naar Johnston a.o. ${ }^{57}$ ) en Kroon stelt het Hof vast dat het begrip "family" niet beperkt is tot op het huwelijk gebaseerde relaties maar ook de facto relaties kan omvatten indien de partijen ongehuwd samenwonen. Wordt een kind uit een dergelijke relatie geboren, dan makt het ipso jure deel uit van dat gezinsverband vanaf het moment van geboorte en door het enkele feit ervan. In de zaak Keegan voegt het Hof daar aan toe, dat er derhalve een als "family life" aan te merken betrekking tussen dat kind en zijn ouders bestaat, zelfs als op het moment van de geboorte de ouders niet langer samenleven of als hun relatie is verbroken. Hierin verschilt een relatie van ongehuwd samenwonenden niet met die van gehuwden in een vergelijkbare situatie. $^{60}$

Afgezien van het feit dat de zaak Berrehab een met uitzetting bedreigde vreemdeling betrof en dat Berrehab anders dan Jonsson, Keegan en de partner van mevrouw Kroon met de moeder van zijn kind gehuwd was geweest, zijn de casus én de uitkomsten in deze zaken vergelijkbaar. De hiervoor geciteerde zin in de zaak Berrehab ten aanzien van een relatie tussen echtgenoten die ontstaan is "by a lawful and genuine marriage" is voorts ontleend aan een passage uit de zaak Abdulaziz a.o. die het bestaan van gezinsleven tussen ongehuwde partners niet uitsluit:

"Whatever else the word 'family' may mean, it must at any rate include the relationship that arises from a lawful and genuine marriage ..." 61

Uit het bovenstaande volgt, dat de relatie tussen een vader en zijn onwettige kinderen als familie- of gezinsleven moet worden aangemerkt indien die kinderen geboren zijn uit een met het huwelijk vergelijkbare relatie. ${ }^{62}$ De opvatting van de Commissie in de genoemde zaak uit 1977 ,

58 Besl.Comm. 7 december 1987, zaak nr. 12495/86, Jonsson v. Sweden, pp. 192-193.

59 EHRM 18 december 1986. Case of Johnston and others.

60 EHRM 26 mei 1994, Keegan Case. \$\$\$\$44-45, pp. 17-18. Bij de laatste overweging in $\$ 44$ wordt verwezen naar EHRM 21 juni 1988, Berrehab Case, \$2.1, p. 14. Zie ook de annotatie van $M$. de Bruijn-Lückers bij het arrest in de zaak Keegan, in: NJCM-Bulletin 20-1 (1995). pp. 40-44, met name de punten 3 en 4. Zie voorts EHRM 27 oktober 1994. Case of Kroon a.o., \$30, pp. 55-56.

$61 \quad Z$ ie noot 53.

62 Hierbij wordt er dan vanuit gegaan, dat een huwelijk doorgaans impliceert dat de echtelieden op permanente basis samenwonen. Zo is bijvoorbeeld in het Nederlandse recht in artikel 1:83 BW de verplichting tot samenwoning voor echtgenoten vastgelegd. 
dat de relatie tussen een vader en zijn onwettige: kinderen altijd onder het begrip "family life" valt, lijkt mij op grond van deze rechtspraak van het Hof dan ook niet langer houdbaar. $\mathrm{Er}$ is mij overigens geen recente rechtspraak bekend waarin uitspraak wordt gedaan over de vraag of, indien uit een relatie - waarbij de ongehuwde ouders niet samenwonen en nooit hebben samengewoond - kinderen zijn geboren, de relatie tussen de vader en die onwettige kinderen zonder meer als "family life" moet worden aangemerkt. Mijns inziens kan ten aanzien van dit soort relaties tussen vaders en hun onwettige kinderen het criterium "required link" nog onverkort van toepassing verklaard worden; de positie van de ongehuwde vader ten opzichte van zijn onwettige kind is toch niet gelijk te stellen aan die van de ongehuwde moeder, wier relatie met haar kind immers reeds voortspruit uit de zwangerschap en de geboorte van het kind. Een uitspraak van de Straatsburgse instanties, hierover zou welkom zijn. ${ }^{63}$

Eerder bleek al uit een citaat uit het arrest in de zaak Berrehab, dat het bestaan van "family life" door latere gebeurtenissen of omstandigheden tot een eind kan komen. Vervolgens werd geconstateerd, dat het beëindigen van het samenleven van de betrokkenen niet per se tot een verbreking van het familie- of gezinsiever hoeft te ieviuen.

Een gebeurtenis waardoor het samenleven kan worden beëindigd is de uithuisplaatsing van kinderen en de ontzetting uit de ouderlijke macht/voogdij van de ouders. Uit de jurisprudentie blijkt, dat ook dit soort gevallen niet per definitie een einde van het familie- of gezinsleven in de zin van artikel 8 betekent. In de arresten van 8 juli 1987, Cases of $W, B$ and $R v$. UK, bepaalt het Hof, dat

"The exercise of parental rights ( $\mathrm{R} v \mathrm{UK}$ ) and the mutual enjoyment by parent and child of each other's company constitutes a fundamental element of family life. Furthermore, the natural family relationship is not terminated by reason of the fact that the child is taken into public care."

Vergelijk de annotatie van Steenbergen bij het Berrehab arrest: volgens haar zullen er strengere eisen gesteld worden aan de feitelijke band tussen ouder en kind naarmate er minder duideiijke familierechtelijke elementen zijn die gezinsleven doen ontstaan. $\mathrm{Zij}$ geeft bovendien nog een ander argument waarom huwelijk niet als noodzakelijke voorwaarde voor gezinsleven kan zijn: het zou een onderscheid tussen natuurlijke en wettige kinderen introduceren. J.D.M. Steenbergen. NJCM-Bulletin 13-6 (1988), p. 579 e.v.. Zie, ten aanzien van de positie van de ongehuwde vader ten opzichte van zijn kind in vergelijking met die van de ongehuwde moeder, ook: T. Loenen, Mensenrechtelijke aspecten van de leefvormenproblematiek I, pp. 223 (onderaan)-224 . 
De beslissing van de autoriteiten om klager's contact met het kind te beperken en te beëindigen, is dan ook een inmenging in het gezinsleven, die zijn rechtvaardiging moet vinden op grond van artikel 8 lid $2 .{ }^{64}$

In paragraaf 2.4.2.1 kwam bovendien al naar voren dat de hiervoor bedoelde beslissing inzake het contact van een ouder met een uithuisgeplaatst kind, tot stand moet zijn gekomen in een besluitvormingsprocedure die bepaalde waarborgen biedt. ${ }^{65}$ Ten einde aan het vereiste van noodzakelijkheid in een democratische samenleving in lid 2 te kunnen voldoen, moet een beslissing inzake - een het gezinsleven beperkende maatregel genomen zijn op grond van een procedure die een aan het recht op familie- en gezinsleven inherent en accessoir, procedureel recht in acht neemt. Dit betekent, onder andere, dat de natuurlijke ouders de gelegenheid wordt geboden hun opvattingen en belangen kenbaar te maken en dat deze opvattingen en belangen ook in overweging genomen worden. Bovendien dient de procedure niet dermate lang te duren dat het enkele verloop van tijd tot een bepaalde uitkomst van de procedure noopt. ${ }^{66}$

Deze opneming van een procedureel element - zowel ten aanzien van de vorm als de duur van de procedure waarin beslist wordt over een kwestie, die beheerst wordt door artikel 8 lid 1 - binnen de reikwijdte van het recht op respect voor het gezinsleven is een aanzienlijke uitbreiding van dit grondrecht. Het betekent in feite, dat bij de bepaling van de reikwijdte van dit recht, ook elementen van een ander artikel van de ECRM, namelijk artikel 6 (fair trial), een rol kunnen spelen. ${ }^{67}$ Dit verschijnsel zagen we al

64 EHRM 8 juli 1987, Case of $W$ v. $U K, 8859$, p. 27; EHRM 8 juli 1987. Case of $B$ v. UK. $\$ 60$, pp. 71-72 en EHRM 8 juli 1987, Case of $R$, UK, $\$ 64$, p. 117; zo ook EHRM 24. maart 1988, Olsson Case (no. 1), \$59, p. 29; EHRM 22 juni 1989, Eriksson Case, \$58, p. 24; EHRM 25 februari 1992, Case of Margareta and Roger Andersson, $\$ \$ 72-73$, p. 25; EHRM 22 april 1992, Rieme Case, $\$ \$ 54-56$, p. 68 en. in het geval waarin het gaat om een verbroken relatie, EHRM 26 mei 1994, Keegan Case, $\$ 50$, p. 19.

65 Zie pp. 82-84.

66 EHRM 8 juli 1987, Case of Wv. UK, $\$ \$ 61-65$, pp. 27-29; EHRM 8 juli 1987, Case of $B$ v. $U K, \S \S 62-65$, pp. 72-74; EHRM 8 juli 1987, Case of $R$ v. $U K, \$ \$ 66-70$, pp. 117-119. Zie voorts EHRM 8 juli 1987, Case of $H$ v. UK, $\$ \$ 87-90$, pp. 63-64.

67 Het verschil tussen de procedurele garanties in artikel 6 en artikel 8 is er in gelegen, dat artikel 6(1) "affords a procedural safeguard, namely the 'right to a court' in the determination of one's 'civil rights and obligations' ...; whereas not only does the. procedural requirement inherent in Article 8 cover administrative procedures as well. as judicial proceedings, but it is ancillary to the wider purpose of ensuring proper respect for, inter alia, family life." Artikel 6(1) bevat derhalve een zelfstandige waarborg, terwijl die in artikel 8 inherent en ondergeschikt (accessoir) is aan het recht op respect voor, o.a., het familie- en gezinsleven. Bovendien gaat het in artikel 
eerder ten aanzien van het discriminatieverbod van artikel 14. Alleen in het geval van genoemde procedurele elementen gaat het niet zozeer om een criterium, dat bij vaststelling van de reikwijdte wordt gehanteerd, zoals wel geldt voor het discriminatieverbod, maar om elementen die zelf bínnen die reikwijdte vallen. ${ }^{68}$ De werkelijke criteria die het Hof hanteert in de zaken $W, B$ and $R v U K$ zijn de specifieke omstandigheden van het geval en met name de ernstige aard van de te nemen beslissingen. Dit soort criteria wisselen dus van geval tot geval en kunnen dus in het algemeen geen houvast bieden voor de begrenzing van de reikwijdte van grondrechten.

Overigens moet nog vermeld worden, dat het bij toepassing van artikel 8 moet gaan om een reeds bestaand gezinsleven:

\section{"(Article 8) presupposes the existence of a family". ${ }^{69}$ "(Article 8) does}

6(1) om het recht op toegang tot een rechter ("right to a court") met betrekking tot de vaststelling van burgerlijke rechten en verplichtingen, terwijl de procedurele waarborg in artikel 8 ook administratieve procedures omvat. EHRM 24 februari 1995. McMichael Case, $\$ 91$.

68 Een dergelijke interpretatie van een grondrecht, waarbij een specifiek grondrecht elementen kan bevatten van een ander specifiek grondrecht, treffen we ook al aan in de uitspraak van het Hof in de Belgische Taalzaken, waarin maatregelen op het gebied van het onderwijs, die hoofdzakelijk getoetst dienen te worden aan artikel 2 van Protocol I ECRM, ook het recht op eerbiediging van het privé- en gezinsleven kunnen beinvloeden of dit zelfs kunnen inperken.

"... As the Court has already emphasised, the convention must be read as a whole. Consequently a matter specifically dealt with by one of its provisions may also, in some of its aspects, be regulated by other provisions of the Convention."

EHRM 23 juli 1968, Belgian Linguistic Case, \$7, p. 33 en het rapport in dezelfde zaak. Rapp.Comm. 24 juni 1965, Belgian Linguistic Case, \$388, p. 291; zie ook Rapp.Comm. 21 maart 1975, Kjeldsen, Busk Madsen and Pedersen, $\$ 169$, p. 48 en Rapp.Comm. 1 maart 1979, Van Oosterwijck, \$45, p. 24.

69 EHRM 13 juni 1979, Marckx Case, \$31, p. 14. Zie opnieuw EHRM 28 mei 1985, Case of Abdulaziz, Cabales and Balkandali $\$ \$ 62-63$, pp. 32-33, waarin het Hof vaststelt dat

"... this does not mean that all intended family life falls entirely outside its ambit. Whatever else the word 'family' may mean, it must at any rate include the relationship that arises from a lawful and genuine marriage ... even if a family life ... has not yet been fully established." (cursivering, CS) 
not oblige a State to grant a foreign citizen entry to its territory for the purpose of establishing a new family relationship there. "70

De laatstgeciteerde zaak betrof de adoptie van een buitenlands kind. Uit deze uitspraak valt een criterium te destilleren, dat men een "eigen schuld"-criterium zou kunnen noemen: de Commissie stelt vast, dat

"Article 8 does not oblige the State to take positive action to restore family life when it has been upset through the actions of the persons concerned ..." $" 11$

In dit desbetreffende geval was geen sprake van eigen schuld, omdat om adoptie was verzocht (waardoor het gezinsleven van de moeder en haar kind werd verstoord), zonder de toestemming van de moeder van het kind.

Dit criterium blijkt ook van toepassing te zijn op gevallen waarin het gaat om de uitzetting of uitlevering van of de weigering van toelating of verblijfsvergunning aan vreemdelingen. In principe is het het soevereine recht van een Staat om deze materie te regelen. Echter, dit recht is in zoverre beperkt - wanneer een Staat partij is bij de ECRM - dat de Staat moet blijven binnen de grenzen van zijn verplichtingen op grond van de ECRM, zo ook binnen de grenzen van artikel $8 .^{72}$ In de praktijk wordt aan de Staat echter een ruime vrijheid gelaten. De Commissie heeft onder meer geoordeeld, dat

"... qu'il y a lieu de souligner, notamment, en ce qui concerne plus particulièrement le droit au respect de la vie familiale, ..., que, puisque la requérante pourrait, si elle le voulait, quitter la République Fédérale d'Allemagne et suivre son mari." 73

"believed themselves to be married and that they genuinely wished to cohabit and lead a normal family life."

70 Besl.Comm. 30 mei 1974, zaak nr. 5416/72, X v. Austria, p. 88; Bes!.Comm. 15 december 1977 , zaak nr. 7229/75, $X$ and $Y$ v. UK. pp. 33-34.

71 Besl.Comm. 30 mei 1974, zaak nr. 5416/72, X v. Austria. Zie Besl.Comm. 19 december 1974, zaak nr. 6577/74, X v. FRG, p. 92 en Besl.Comm. 11 juli 1977, zaak. nr. 762,6/76, $X$ v. UK, p. 166.

72 Besl.Comm. 30 juni 1959, zaak nr. 434/58, X v. Sweden, pp. 372-374.

73 Besl.Comm. 16 juli 1965, zaak nr. 2535/65, X v. FRG, p. 30; zie onder vele andere ook Besl.Comm. 15 december 1967, zaak nr. 3325/67, X, Y, Z, V and $W v . U K$, Yearbook X, p. 536, Coll. 25, pp. 12i-122 en Besl.Comm. 8 februari 1972, zaak. nr. 5269/71, $X$ and $\boldsymbol{Y}$ v. UK, Yearbook. XV, p. 564, Coll. 39, p. 107. Zie ook EHRM 28 mei 1985, Case of Abdulaziz, Cabales and Balkandali, §68, p. 34: 
"This principle applies also where one of the two persons concerned is a national of the country ordering the expulsion of the other person. " ${ }^{74}$

Wanneer het gezinsleven derhalve is verstoord als gevolg van de vrije keuze van de wèl in het desbetreffende land (ver)blijvende partner/gezinsleden (namelijk om de partner niet naar een ander land te volgen), dan is de Staat daarvoor niet verantwoordelijk te stellen en kan artikel 8 niet worden ingeroepen. Met nadruk moet er wel op gewezen worden dat het moet gaan om een vrije keuze, het gezamenlijk verblijf in een ander land moet mogelijk zijn en bovendien behoeft de mogelijkheid van een legaal verblijf niet ten aanzien van ieder willekeurig land onderzocht te worden.

"If the only legal residence which they can find is in a country unconnected with either of them, the exclusion from residence in the 'home' country of one of them might constitute a violation of Article 8." 75

\section{De Commissie onderzoekt derhalve}

"the practicality and reasonableness of the close members of family concerned accompanying or following the applicant.

A further factor to be considered is the links which the deportee and the other members of the family have with the destination country and in particular whether there are further members of family or relatives there. ${ }^{176}$

"In the present case, the applicants have not shown that there were: obstacles to establishing family life in their own or their husbands' home countries or that there were special reasons why that could not be expected of them. ... There: was accordingly no 'lack of respect' for family life."

74 Besl.Comm. 19 mei 1977, zaak nr. 7816/77, $X$ and $Y$ v. FRG. pp. 220-221. Met "This principle" wordt gedoeld op de voorgaande. geciteerde overweging van de Commissie uit Besl.Comm. 16 juli 1965, zaak nr. 2535/65, X v. FRG.

75 Besl.Comm. 3 oktober 1972, zaak nrs. 5445/72 en 5446/72, $X$ and $Y v_{\text {. }}$ UK. p. 146.

76 Besl.Comm. 8 december 1981, zaak nr. 9478/81, $X$ v. FRG. pp. 243-246 met een verwijzing naar Besl.Comm. 8 februari 1972, zaak nr. 5269/71, $X$ and $Y$ v. UK, Yearbook 15, p. 574.

Er vindt derhalve een belangenafweging plaats tussen de met het toelatings- en uitwijzingsbeleid van de aangeklaagde staat gediende belangen en de voor betrokkenen aan herstel van de gezinseenheid in het buitenland verbonden nadelen. Zie verder P. van Dijk en G.J.H. van Hoof, De europese conventie in theorie en praktijk. pp. 336-338. 
De kwestie van de toelating en uitzetting van vreemdelingen brengt ook nog een ander probleem in verband met de bescherming van het familieen gezinsleven naar voren. Het staat buiten kijf, dat er binnen de diverse culturen die Europa. rijk is verschillen kunnen bestaan over de vraag wat moet worden verstaan onder "family life". Dit geldt nog sterker voor immigranten uit niet-Europese landen. De vraag is, onder andere, of de relaties tussen een man en zijn vrouwen en kinderen in geval van bigame of polygame huwelijken ook beschermd worden door artikel 8 . In haar ontvankelijkheidsbeslissing in de zaak $X v$. the Netherlands heeft de Commissie ten eerste geconcludeerd, dat er geen sprake is van familie- of gezinsleven in de zin van artikel 8 , omdat de zoon in kwestie op dat moment 26 jaar oud is, tussen 1966 en 1980 en na 1985 niet bij zijn vader gewoond heeft, en er geen financiële of andere afhankelijkheid tussen vader en zoon bestaat. Vervolgens bepaalt de Commissie ten aanzien van een klacht onder artikel 14 in verband met artikel 8 dat

"When considering immigration on the basis of family ties, a Contracting State cannot be required under the Convention to give full recognition to polygamous marriages which are in conflict with their own ordre public. This does not mean, however, that there is no right to respect for the family life of a father and his children born by different wives in a polygamous marriage."

Vervolgens gaat de Commissie in op het Nederlandse toelatingsbeleid, volgens welk het aan een in Nederland verblijvende man alleen wordt toegestaan één van zijn vrouwen - naar eigen keuze - en de kinderen van die vrouw naar Nederland te laten komen. Volgens de Commissie zou deze beleidsregel tot problemen kunnen leiden met betrekking tot de minderjarige kinderen, die een man heeft bij een andere echtgenote. In de onderhavige zaak doet zich dat geval niet voor omdat - zoals gezegd - de betrokken zoon 26 jaar oud is. De Commissie gaat derhalve niet op de mogelijke problemen in. ${ }^{7}$

Uit deze uitspraak zou men de volgende conclusie kunnen trekken. Allereerst sluit de Commissie niet uit dat althans enige erkenning van polygame huwelijken geboden is. Deze erkenning zou dan met name moeten bestaan in de bescherming van het familie- en gezinsleven van de kinderen uit deze huwelijken. Deze gevolgtrekking is mijns inziens gerechtvaardigd, omdat het familie- en gezinsleven van deze kinderen toch 
ook gerespecteerd zal moeten worden wanneer polygame huwelijken níet erkend worden, want het maken van onderscheid tussen wettige en onwettige kinderen is niet toegestaan. ${ }^{78} \mathrm{Bij}$ de vraag of er sprake is van een als familie- of gezinsleven te kenmerken relatie tussen een vader en zijn kinderen bij een andere echtgenote dan de echtgenote met wie hij in een verdragsstaat samenleeft, zal met name de mate waarin de vader met deze kinderen contacten onderhoudt en waarin hij de kinderen financieel steunt een rol spelen (de "required link"-toets).

Uit de uitspraak in de zaak $X v$. the Netherlands wordt helaas niet duidelijk wat de Commissie bedoelt met de constatering dat van verdragsstaten niet geëist kan worden dat ze polygame huwelijken volledig erkennen. Mijns inziens wijst dit of zou dit moeten wijzen op de mogelijkheid om het recht op eerbiediging van het familie- of gezinsleven op grond van het tweede lid van artikel 8 te beperken en niet op een beperktere uitleg van het recht op eerbiediging van het gezinsleven in geval van polygame huwelijken. De jurisprudentie is op dit punt niet duidelijk en het is dan ook wenselijk dat de Straatsburgse organen zich uitspreken over de uitleg van het begrip "family life" met betrekking tot polygame huwelijken, wanneer de gelegenheid daartoe zich voordoet.

Voorbeelden van gevallen waarin zich verschil in opvatting tussen verschillende culturen kunnen voordoen over de uitleg van de term "family life" zijn ook te vinden in zaken omtrent de toelating/uitzetting van (groot)ouders of volwassen kinderen van vreemdelingen. Tot nu toe hebben de Straatsburgse instanties er geen blijk van gegeven rekening te houden met andere culturele opvatting omtrent het familie- en gezinsleven. $^{79}$

Wèl heeft de Commissie erkend, dat het recht op eerbiediging van het familie- en gezinsleven de rechten en keuzes van ouders omvat ten aanzien van de opvoeding van hun kinderen. De opvoeding van kinderen wordt als een hoofdbestanddeel van het gezinsleven aangemerkt. In een uitspraak van 1982 heeft de Commissie bepaald, dat dit recht van de ouders om de opvoeding van de kinderen zelf te bepalen niet zover gaat, dat de staat zich ervan zou moeten onthouden wetten aan te nemen die

78 Zie hierboven m.b.t. de zaak Marckx en het door mij genoemde "non-discriminatie"criterium. Men denke voorts ook aan de eeĩder besproken uitspraak Besl.Comm. 14 juli 1977, zaak nrs. 7289/75 en 7349/76, $X$ and $Y v$. Switzerland, p. 74 .

79 Zie o.a. de al wat oudere uitspraken in de volgende zaken: Besl.Comm. 15 juli 1967. zaken nrs. 2991/66 en 2992/66, Khan and Singh v. UK, p. 500 ten aanzien van klager's in India woonachtige vader; Besl.Comm. 14 december 1972, zaak nr. $5532 / 72, X$ v, UK, p. 121 t.a.v. klager's in India levende moeder, broer en zus. 
are to encourage a positive review of the punishment of children by their parents, to discourage abuse and prevent excesses which could properly be described as violence against children. " 80

In deze zaak gaat het om een amendement op de "Code of Parenthood" waarin geen sancties zijn opgenomen en dat geen direct of indirect effect heeft op de interpretatie van het $Z$ weedse strafrecht. De praktische effecten van het amendement op het gezinsleven van de klagers zijn volgens de Commissie zeer onduidelijk. Volgens de Commissie is er dan ook geen sprake van een inmenging in het gezinsleven in de zin van artikel 8.

Verder is de Commissie van mening, dat de reikwijdte van het Zweedse recht op het gebied van "assault and molestation" een normale maatregel is tegen geweld. Voorts is volgens de Commissie de uitbreiding van de toepassing van deze wetgeving op "ordinary physical chastisement of children" door hun ouders bedoeld om mogelijk zwakke en kwetsbare leden van de samenleving te beschermen. Ook om deze redenen is er geen sprake van inmenging in het gezinsleven van de klagers."

De voorlopige conclusie die uit dit overzicht van de jurisprudentie ten aanzien van het recht op eerbiediging van het gezinsleven kan worden getrokken, is dat de reikwijdte van dit recht veelal tot in detail is afgebakend. In tegenstelling tot de jurisprudentie ten aanzien van het recht op eerbiediging van het privéleven zijn ten behoeve van de afbakening van het familie- of gezinsleven diverse criteria ontwikkeld. Dit geldt zowel voor de vraag, welke relaties (tussen welke personen) door het begrip gezinsleven gedekt worden alswel de vraag in welke situaties dit het geval is.

Ten aanzien van de eerste vraag zijn mijns inziens de belangrijkste criteria het "required link"-criterium en het "non-discriminatie"-criterium. Het "required link"-criterium wordt met name toegepast in gevallen waarin het niet de relatie tussen enerzijds de moeder en/of de - wettige of met de moeder samenwonende - vader en anderzijds de kinderen betreft. Het "required link"-criterium houdt in dat er sprake moet zijn van "further elements of dependency, involving more than the normal, emotional ties." Hierbij wordt met name gekeken naar het al dan niet voeren van een gemeenschappelijke huishouding door, of het op permanente basis

80 Besl.Comm. 13 mei 1982, zaak nr. 8811/79, Seven individuals v. Sweden, pp. $110-$ 114.

81 Idem, p. 114. 
samenwonen, de leeftijd of de mate van zelfstandigheid van de betrokkenen.

Bij het non-discriminatie-criterium wordt het discriminatieverbod als maatstaf gehanteerd bij de afbakening van het begrip gezinsleven. Dit betekent, dat bij de vaststelling of er een als "family life" te kenmerken band tussen bepaalde personen bestaat, geen discriminatie mag plaatsvinden op grond van een bepaalde hoedanigheid van die personen. Een uitzondering hierop lijkt te moeten worden gemaakt voor het onderscheid tussen hetero- en homoseksuelen. ${ }^{82}$ Zoals al in paragraaf 4.2.1 bleek uit een daar aangehaald ontvankelijkheidsbeslissing vallen relaties tussen homoseksuelen niet onder het recht op respect voor het familie- of gezinsleven, maar kunnen vallen onder het recht op respect voor het privéleven. ${ }^{35}$

Het opmerkelijke van dit "non-discriminatie"-criterium is dat het een grote overeenkomst vertoont met de werking van artikel 14 in geval van toepassing van de in de ECRM opgenomen rechten. Bij de afbakening van. het in het geding zijnde recht betreft het verbod van discriminatie de bepaling van de personen aan wie het grondrecht bescherming biedt, op wie de grondrechtsbepaling wordt toegepast. In het geval van toepassing van een recht betreft het verbod van discriminatie die toepassing zelf, de mate waarin en de wijze waarop de grondrechtsbepaling wordt toegepast.

Ten aanzien van de vraag in welke situaties bepaalde relaties door het begrip gezinsleven gedekt worden acht ik het criterium dat ik het "eigen schuld"-criterium heb genoemd het belangrijkst. Toepassing van dit criterium komt erop neer, dat nagegaan wordt of een eventuele verbreking van de als "family life" te kenmerken relatie het gevolg is van de vrije keuze van de betrokkene(n). Een vrije keuze impliceert dat deze verbreking voorkomen zou kunnen worden door een alternatieve keuze. Is de verbreking van het gezinsleven het gevolg van de vrije keuze van de betrokkene, dan kan deze geen beroep doen op artikel 8 lid 1 .

Evenals de hantering van het voornoemde "non-discriminatie"-criterium behoeft de gelding van dit criterium zich niet te beperken tot het recht op eerbiediging van het gezinsleven of zelfs tot artikel 8 ECRM. 


\subsubsection{The right to respect for his home}

Uit de beslissingen van de Commissie in de zaken 530/59 en 1216/61 valt op te maken, dat onder "home" (of "woning") verstaan moeten worden iemands "principal residence" (of "hoofdverblijfplaats"). Is hiervan sprake, dan wordt het recht van die persoon op de eerbiediging van die woning in principe beschermd door het huisrecht ingevolge artikel 8 lid 1 ECRM. De Commissie is echter wel van mening, dat het begrip "home"

"is a precise concept which may not be arbitrarily extended ..." ${ }^{84}$

Het begrip "home" omvat derhalve het hoofdverblijf van een persoon, mar het begrip "home" mag niet zover opgerekt worden, dat elke plaats waarin iemand zich permanent ophoudt daaronder valt; een nader criterium is nodig voor de afbakening van het begrip "home". Een dergelijk criterium lijkt te worden verschaft in de uitspraak van het Hof in de zaak Gillow.

In deze zaak is er volgens het Hof geen reden om te twijfelen aan de stellingen van de klagers, dat hoewel zij 19 jaar niet op Guernsey verbleven, zij wel de eigendom hadden behouden van hun huis "Whiteknights", waarin zij wilden terugkeren; en dat

"they lived in the property with a view to taking up permanent residence once the negotiations with the Housing Authority about their residential status had been concluded ..."

Deze stellingen worden, aldus het Hof, gesteund door het feit dat de klagers in 1956 voor zij naar Guernsey verhuisden hun huis in Lancashire hadden verkocht en dat zij tijdens hun 19 jaar durende afwezigheid "had not established any other home elsewhere in the United Kingdom." Ondanks hun langdurige afwezigheid hadden de klagers onder deze omstandigheden

84 Zie o.a. Besl.Comm. 4 januari 1960, zaak nr. 530/59, X v. FRG, p. 192 en Besl.Connn. 28 maart 1963, zaak nr. 1216/61, X v. FRG, p. 6. In deze zaken besloot de Commissie, dat de maatregelen waarover geklaagd werd, gerechtvaardigd waren op grond van lid 2 van artikel 8 . Er lijkt derhalve stilzwijgend te zijn aangenomen, dat lid 1 van toepassing was, aldus ook Besl.Comm. 30 mei 1974, zaak nr. $5488 / 72, X$ v. Belgium , pp. 224-226. 
"retained sufficient continuing links with 'Whiteknights' for it to be considered their 'home', for the purposes of Article 8 of the Convention ..."

Uit deze uitspraak kan derhalve het criterium afgeleid worden, dat voor het bestaan van "home" noodzakelijk is, dat er "sufficient continuing links" bestaan met de desbetreffende woning. Aanwijzing voor het bestaan van dergelijke "links" is, of sprake is van eigendom van het desbetreffende huis, of van een (beoogde) "permanent residence" en of de betrokkenen "have established any other home" of te wel, of sprake is van "principal residence".

Het genoemde "sufficient continuing links"-criterium doet overigens sterk denken aan de criteria "required link" - die tussen de betrokken personen bijv. een vader en zijn onwettige kind moet bestaan - en "link with destination country" - van (de familieleden van) een persoon die dreigt te worden uitgezet uit een land - die worden gehanteerd bij de vaststelling of sprake is van "gezinsleven". ${ }^{66}$

Iliv se suitgnnaak vas de Commisnie in to Ead Wiggins kam woruln geconcludeerd, dat wanneer het vestigen van het recht op eerbiediging van de woning (door in een huis te gaan wonen) aan een voorwaarde gebonden wordt, het naderhand niet meer voldoen aan deze voorwaarde niet aan de betrokken persoon kan worden tegengeworpen, wanneer redelijkerwijze niet was te verwachten, dat na verloop van tijd niet meer aan deze voorwaarde voldaan kon worden.

In casu ging het om de voorwaarde, dat klager deel uitmaakte van het huishouden van zijn echtgenote. $\mathrm{Na}$ hun echtscheiding bleef klager alleen in de desbetreffende woning (die zijn eigendom was) wonen. Volgens de Commissie bleef de woning zijn "home", ook na de echtscheiding. Het feit dat zijn vrouw hun gemeenschappelijke huishouding verliet, gaf geen aanleiding tot veranderingen in dit opzicht. ${ }^{87}$

85. EHRM 24 november 1986, Gillow Case, \$46, p. 19. Het Hof lijkt het begrip "continuing link" over te nemen uit het rapport van de Commissie. Rapp.Comm. 3 oktober 1984, Gillow Case, $\$ 114$, p. 33. De eigendom van het huis was volgens de Commissie een, bewijs van het bestaan van een dergelijke link, maar werd verder $0 . a$. aangetoond door het feit dat de klagers hun meubilair in het huis hadden achtergelaten.

86 Zie hierboven par. 4.2.2 op respectievelijk p. 213 en p. 222.

87 Besl.Comm. 8 februari 1978, zaak nr. 7456/76, Wiggins $v$. UK, p. 44. 
Er lijkt, opnieuw, enige gelijkenis bestaan met de eerdervermelde rechtspraak inzake het recht op eerbiediging van het gezinsleven, in dit geval met betrekking tot het omgangsrecht tussen ouder en kind.

Daarin werd uitgesproken, dat indien het bestaande gezinsleven in de zin van "samenleven" is beëindigd en dus niet meer voldaan wordt aan de voorwaarde van het voldoen aan het criterium "required link" (common household, permanently living together), het toch wenselijk is en het mogelijk moet zijn, dat het contact tussen ouder en kind wordt voortgezet. Uitzonderingen hierop moeten worden gerechtvaardigd op grond van artikel 8 lid $2 .^{88}$ Ook hier kan men er wel vanuit gaan, dat dit na verloop van tijd niet voldoen aan de voorwaarde van "required link" niet redelijkerwijs te verwachten mag zijn.

Maar, er bestaat ook een belangrijk verschil tussen de uitspraak inzake het huisrecht in de zaak Wiggins en de jurisprudentie ten aanzien van het recht op eerbiediging van het gezinsleven:

de voorwaarde van het bestaan van een "required link" bij het recht op gezinsleven is een voorwaarde, die in het algemeen wordt gesteld door de Europese Commissie en het Europese Hof voor de Rechten van de Mens, terwijl de voorwaarde met betrekking tot het huisrecht in de zojuist genoemde zaak, voor dit specifieke geval werd gesteld door een overheidsorgaan, de "Housing Authority". De voorwaarde dat men deel moet uitmaken van het huishouden van de echtgenoot wil er sprake kunnen zijn van een "home" wordt niet door de Straatsburgse instanties gesteld. Daarom zal men moeilijk kunnen concluderen, dat de genoemde voorwaarde uit de zaak Wiggins zelf een criterium voor het afbakenen van het begrip "home" vormt. ${ }^{89}$ Wel zou het wellicht in het algemeen mogelijk kunnen zijn, dat voor de interpretatie van het begrip "home" van belang kan zijn dat wanneer eens aan een door een Staat gestelde voorwaarde voor hebben van het recht op eerbiediging van de woning is voldaan, het naderhand niet meer voldoen aan deze voorwaarde niet per definitie het bestaan van een "home" teniet doet.

88 Rapp.Comm. 8 maart 1982, Hendriks Case, §§95-96, pp. 14-15 en pagina 215.

89 Dit geldt des te meer nu de uitspraak in de zaak Wiggins op zichzelf staat en niet als precedent heeft gediend voor volgende zaken met betrekking tot het huisrecht. Desondanks wordt deze beslissing besproken, ten eerste omdat het ontbreken van soortgelijke uitspraken niet per definitie het gevolg is van veranderde opvattingen bij Commissie of Hof, maar eerder van het ontbreken van zaken met een soortgelijke casus en ten tweede vanwege de overeenkomsten met het "required link"-criterium dat wordt gebruikt ter afbakening van het recht op respect voor het gezinsleven. 
Naar aanleiding van de zaak Wiggins (met betrekking tot een geval van echtscheiding) kan men zich afvragen of het huisrecht ook door artikel 8 beschermd blijft als "home" van degene die het huis blijft bewonen, na het overlijden van de partner.

De enige - mij bekende - uitspraak hierover is gedaan door de Commissie in haar ontvankelijkheidsbeslissing in de zaak $S v$. United Kingdom. In deze zaak is artikel 30 van de Housing Act 1980 in het geding, voorzover dit bepaalt dat het (onder bepaalde voorwaarden) mogelijk is om de overleden huurder van een woning op te volgen als huurder. Een van de voorwaarden is dat de gegadigde met de oorspronkelijke huurder gehuwd was, met hem of haar als man en vrouw samenleefde, dan wel tot het gezin van de oorspronkelijke huurder behoorde. Door de nationale instanties in deze zaak was beslist dat de klaagster geen beroep kon doen op artikel 30 van de Housing Act, omdat zij met de oorspronkelijke huurster een lesbische relatie had en derhalve niet aan de voorwaarden van artikel 30 voldeed.

De Commissie constateert in haar uitspraak van 14 mei 1986, dat de klaagster het huis - dat oorspronkelijk door haar partner werd gehuurd zonder rechtstitel bewoont. Volgens de Commissie heeft de klaagster vanaf de dood van haar partner geen recht meer om in de woning te verblijven onder het geldende recht en zijn de plaatselijke autoriteiten gerechtigd het bezit van de woning terug te vorderen. Op grond hiervan oordeelt de Commissie dat het huis niet langer kan worden beschouwd ais "home" voor de klaagster in de zin van artikel $8 .{ }^{\circ}$

Van doorslaggevende betekenis is derhalve het bestaan van een geldige rechtstitel. Deze redenering van de Commissie komt in wezen neer op een cirkelredenering: de klacht onder artikel 8 ECRM dat de klaagster onder de Housing Act haar overleden partner niet als huurster kan opvolgen (de Housing Act verschaft haar geen rechtstitel) is niet-ontvankelijk wegens het ontbreken van een rechtstitel.

Ook ten opzichte van de zaken Gillow en Wiggins wekt deze zaak enige bevreemding. In deze zaken vormde de rechtstitel waaronder de klagers in het huis verbleven (het eigendomsrecht) slechts éen van de elementen op grond waarvan werd beslist dat sprake was van "home" in de zin van artikel 8. In haar rapport in de zaak Gillow stelt de Commissie juist uitdrukkelijk vast dat "ownership of a property is not in itself sufficient to establish it as one's home"." Zou dit dan ook niet ten aanzien van huur

90 De vraag of het huurcontract "may or may not have permitted long-term visitors" wordt door de Commissie niet onderzocht. Besl.Comm. 14 mei 1986, zaak nr. $11716 / 85$. s $v . U K$, p. 278.

91 Rapp.Comm. 3 oktober 1984, Gillow Case, $\$ 114$ e.v.. p. 33. 
gelden? Klaagster $S$. in $S v$. United Kingdom had 3 jaar lang haar permanent verblijf in de woning en had niet elders een woning ("home"). In die periode voerde zij een gemeenschappelijke huishouding met haar partner in die woning. Mijns inziens kan op grond van deze feitelijke omstandigheden moeilijk volgehouden worden dat de woning waar klaagster in die drie jaar woonde niet haar "home" was en evenmin dat de woning door het overlijden van de partner van $\mathrm{S}$ ophield haar "home" te zijn (vergelijk de zaak Wiggins). Dit geldt des te meer nu de Housing Act het wel aan de partner van een overleden huurder in al dan niet huwelijkse man-vrouwrelatie toestaat de partner als huurder op te volgen. ${ }^{92}$

De hiervoor al besproken uitspraak van het Hof in de zaak Gillow is van later datum dan de beslissing van de Commissie in de zaak $S \nu$. United Kingdom. Wellicht had de zaak $S$ een andere uitkomst gehad wanneer het begrip "home" was getoetst aan de criteria uit de zaak Gillow: vermoedelijk zou dan de bestreden Britse wetgeving getoetst zijn aan artikel 8 lid 2 ECRM. Dit zou ook overeenkomen met de uitkomst van de zak Gillow in het rapport van de Commissie en van de ontvankelijkheidsbeslissing in de zaak Wiggins, die beiden van vóor de uitspraak in de zaak $S$ v. United Kingdom stammen.

Overigens blijkt uit de zaak Chappell, dat het er volgens de Commissie niet toe doet of een huis behalve als woning ("home") ook gedeeltelijk dienst doet als bedrijfspand. Het feit dat de advocaten van de tegenpartij van Chappell in een civiele procedure op grond van een zogenaamde "Anton Piller order" onaangekondigd toegang konden zoeken tot het pand, daar alle documenten en ander materiaal konden onderzoeken en in beslag nemen en het feit dat deze bevoegdheden op grond van de "Anton Piller order" uitgeoefend werden op hetzelfde moment dat de politie uitvoering gaf aan een huiszoekingsbevel, betekende volgens de Commissie een

92 De opvatting van de Commissie ten aanzien van de klacht van $\mathbf{S}$ onder artikel 14 dat het verschil in behandeling tussen partners in gemengde relaties enerzijds en partners in homoseksuele relaties anderzijds objectief en redelijk gerechtvaardigd kan worden omdat de bescherming van het gezin word beoogd door de desbetreffende wetgeving - heeft naar mijn mening betrekking op de toepassing en wel met name de beperking van het recht op eerbiediging van de woning. Het gaat hier derhalve niet om de afbakening van het begrip "home". Besl.Comm. 14 mei 1986, zaak nr. $11716 / 85, S$ v. UK, p. 279. 
inmenging in klager's recht op eerbiediging van zijn woning (en zijn privéleven)..$^{93}$

Ook in de zaak Niemietz spreekt het Hof uit, dat het woord "home" ook, bijvoorbeeld, iemand's kantoor ("a professional person's office") kan omvatten. ${ }^{96}$ Dit leidt het Hof af uit het feit dat het woord "domicile" in de Franse tekst van het verdrag een ruimere reikwijdte heeft dan het woord "home". Hierdoor is het gerechtvaardigd dat artikel 8 zó wordt geïnterpreteerd dat de bescherming van deze bepaling zich ook uitstrekt tot bedrijfsgebouwen. Vergelijkbaar met de redenering van het Hof met betrekking tot het recht op privéleven, is het niet altijd mogelijk om een onderscheid te maken tussen verschillende soorten activiteiten. Sommige activiteiten die verband houden met een beroep of bedrijf kunnen zeker ook uitgeoefend worden vanuit iemand's privéwoning en andere activiteiten die niet betrekking hebben op iemand's beroep of bedrijf, kunnen ook uitgeoefend worden in een kantoor of bedrijfsgebouw. Het Hof meent dan ook, dat net als bij een enge interpretatie van het recht op respect voor het privéleven, een enge interpretatie van de woorden "home" en "domicile" een ongelijke behandeling teweeg zou kunnen brengen tussen personen bij wie wèl en personen bij wie niet de professionele en niet-professionele activiteiten verstrengeld zijn in een mate dat het onmogelijk is ze van elkaar te onderscheiden. Een dergelijke interpretatie van de begrippen "private life" en "home" die ook professionele of bedrijfsactiviteiten of gebouwen bestrijkt, is volgens het Hof ook in overeenstemming met "the essential object and purpose of Article 8, namely to protect the individual against arbitrary interference by the public authorities. "ss

Op grond van deze uitspraken in de zaken Chappell en Niemietz kan geconcludeerd worden, dat aan de aard van de activiteiten die een gebouw ontplooid worden geen doelcriterium ontleend kan worden voor de afbakening van het begrip "home".

Behalve het betwisten van het genot van een woning (Gillow en Wiggins) en het betreden van een woning tegen de wil van de bewoner in verband

93 Rapp.Comm. 14 oktober 1987, Chappell Case, $\$ \$ 96-99(99)$, pp. 29-30. Voor het Hof erkent de Britse regering deze opvatting van de Commissie. Het Hof ziet geen reden om hierin van mening te verschillen met de Britse regering. EHRM 30 maart 1989. Chappell Case, §51, pp. 21-22.

94 EHRM 16 december 1992, Niemietz Case, $\$ \$ 30-31$, p. 34. Zie hiervoor al de bespreking van de overwegingen van Hof ten aanzien het recht op respect voor het privêleven (par. 4.2.1, pp. 208-209).

95 Het Hof verwijst hierbij naar EHRM 13 juni 1979, Marckx Case, §31, p. 15. 
met een huiszoeking (Chappell en Niemietz ${ }^{96}$ ) zijn ook de onteigening ${ }^{97}$ of de verplichte verkoop ${ }^{98}$ aan de Staat van een woning en de gedwongen ontruiming van een woning ${ }^{\circ}$ als inmenging op het recht op eerbiediging van de woning erkend. Daarentegen valt de bevoegdheid van een huurdersvereniging om namens de huurders te onderhandelen over het huurbedrag voor zijn woning, buiten de reikwijdte van artikel 8 lid $1 .{ }^{100}$

Naar aanleiding van deze bespreking van het recht op eerbiediging van de woning kan worden geconcludeerd, dat het criterium dat bij de afbakening van dit recht het meest bruikbaar is, het door het Hof in de zaak Gillow gehanteerde "sufficient continuing links"-criterium is. Aan de hand van dit criterium kan worden vastgesteld of sprake is van een "home" in de zin van artikel 8 lid 1 ECRM. Aanwijzing voor het bestaan van "sufficient continuing links" met betrekking tot een huis is, of sprake is van eigendom van het desbetreffende huis, of van een (beoogde) "permanent residence" en of de betrokkenen "have established any other home" oftewel, of sprake is van "principal residence".

Dit geldt in de eerste plaats voor woningen, maar zou blijkens de zaken Chappell en Niemietz ook voor bedrijfspanden kunnen gelden. Mijns inziens zal echter de vraag of sprake is van een "principal residence" ten aanzien van bedrijfspanden niet kunnen gelden als een aanwijzing voor het bestaan van "sufficient continuing links", aangezien voor de uitoefening van een beroep of bedrijf niet uitgesloten kan worden dat de in dat kader te verrichten activiteiten plaatsvinden in meerdere gebouwen, tenzij ervan uitgegaan wordt dat iemand in het kader van zijn beroep of bedrijf meerdere "principal residences" kan hebben. Of iemand permanent zijn beroeps- of bedrijfsactiviteiten in of vanuit een gebouw uitoefent (vergelijkbaar met "permanent residence") is naar mijn mening een bruikbaarder handvat voor het vaststellen van een "sufficient continuing links" met een pand.

96 Zo ook EHRM 25 februari 1993, Funke Case, $\$ \$ 47-48$ e.v., p. 22 e.v. en EHRM 25 februari 1993, Crémieux Case, \$28 en \$§31 e.v., p. 59 e.v. waarin door de Franse regering werd aanvaard dat sprake was van een inmenging in klager's recht op respect voor zijn privéleven en zijn woning (Funke) of inmenging in dit laatste recht door de Commissie werd geconstateerd (Crémieux). In deze zaken werd derhalve het recht op respect voor zijn woning niet afgebakend en werd direct overgegaan tot toetsing aan artike! 8 lid 2 .

97 Besl.Comm. 3 maart 1982, zaak nr. 9261/81, X v. United Kingdom, p. 183.

98 Besl.Comm. 18 oktober 1985, zaak nr. 10825/84, R. and W. Howard v. United Kingdom, p. 204.

99 Besl.Comm. 3 mei 1983, zaak nr. 9327/81, X v. the Netherlands, pp. 187-188.

100 EHRM 22 juni 1989, Langborger Case, \$\$38-39, p. 17. 
Ook acht ik de uitspraak in de - in het begin van deze paragraaf vermelde ontvankelijkheidsbeslissingen, dat het begrip "home" een "precise concept" is, door de latere uitspraken achterhaald. Het begrip "home" is mijns inziens helemaal niet meer zo nauwkeurig te definiëren en heeft een ruime reikwijdte.

Overigens moet worden opgemerkt dat de Nederlandse vertaling van het woord "home" met "woning" gezien de bovenstaande bespreking onvoldoende de lading van het begrip "home" dekt. Het woord woning heeft immers ook de betekenis van "huis". Mijns inziens geeft het woord "thuis" nog het best weer wat met het woord "home" bedoeld wordt, althans voor zover het niet gaat om beroeps- of bedrijfsactiviteiten. Wat betreft de laatste soort activiteiten lijkt "home" steeds ruimere betekenis te krijgen. Omdat de officiële vertaling van artikel 8 lid $1 \mathrm{nu}$ eenmaal het woord "woning" gebruikt, heb ik me daar bij de bespreking van het recht op eerbiediging van de "woning" maar aan gehouden.

\subsubsection{The right to respect for his correspondence}

Allereerst kan men zich bij dit recht de vraag stellen, wat moet worden

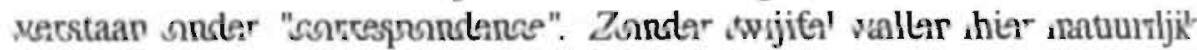
brieven onder. In de zaak Golder spreekt het Hof namelijk van "any message, such as a letter ... which would have been a piece of correspondence within the meaning of paragraph 1 of Article $8 \ldots$. . .101 Onder brieven kunnen ook zakelijke documenten begrepen worden die aan een ander worden toegezonden. ${ }^{102}$ Ten aanzien van brieven die materiaal bevatten dat bestemd is voor publikatie, heeft de Commissie in haar rapport in de zaak Silver and others overwogen dat deze "generally fall

101 Zie EHRM 21 februari 1975, Golder Case, §43, p. 20. Zie ook EHRM 25 maart 1983, Silver a.o, \$84, pp. 32 e.v.; EHRM 27 aprill 1988, Case of Boyle and Rice, $\$ 50$, p. 22 (in deze zaak gaf de regering schending van artikel 8 toe) en EHRM 24 september 1992, Herczegfalvy Case, \$87, p. 27 (waarin door de Oostenrij̄kse regering een inmenging in klager's recht op respect voor zijn correspondentie wordt toegegeven). Of, impliciet, met betrekking tot het openen en lezen door de gevangenissautoriteiten van brieven gericht aan of afkomstig van de advocaat en de Commissie van klager EHRM 25 maart 1992, Campbell Case, $\$ \$ 30,33$, pp. 15-16. In deze zaak werd ook verwezen naar de "European Agreement relating to persons participating in proceedings of the European Commission and Court of Human. Rights" van 5 mei 1969, waaraan ook het Verenigd Koninkrijk gebonden was vanaf. 1971. Zie voorts EHRM 26 februari 1993, Messina Case, $\$ \$ 30-31$, p. 104 (eveneens impliciet).

102 Impliciet in Besl.Comm. 12 oktober 1983, zaak nr. 9614/81, G, S and $M$ v. Austria. p. 122 . 
within the scope of Article 8 (1)". ${ }^{103}$ In welke gevallen hierop een uitzondering gemaakt kan worden (het woord "generally" suggereert de mogelijkheid van uitzonderingen), vermeldt deze uitspraak niet.

Voorts vallen, zoals al werd geconstateerd in paragraaf 4.2.1, telefoongesprekken onder de bescherming van het recht op respect voor de correspondentie. ${ }^{104}$

In een ontvankelijkheidsbeslissing uit 1982 gaat het om een klacht betreffende een strafrechtelijke veroordeling wegens het - in strijd met de toenmalige Belgische wetgeving - gebruikmaken van de 27 Mhz-band, door middel van particuliere radio-ontvangers en ten behoeve van "private communications between individuals". In deze zaak komt de vraag aan de orde of particuliere radio-ontvangers de bescherming van artikel 8 lid 1 genieten. Volgens de Commissie betreft het probleem in deze zaak de communicatiemiddelen die het contact mogelijk maken dat tot stand gekomen is tussen mensen die van het zelfde medium gebruik maken. Daarom "lijkt" dit probleem te vallen onder het recht op eerbiediging van de correspondentie. Vervolgens concludeert de Commissie dat

"the transmission of information or ideas via the technical medium used by the applicants constitutes a transmission of information or ideas that might be regarded as being carried out by correspondence within the meaning of Article 8..."

Hoewel de Commissie er in deze zaak derhalve toe geneigd is particuliere radio-ontvangers te rekenen tot het begrip "correspondence", is de Commissie allerminst stellig in haar opvatting gezien de termen "appears" (lijkt) en "might be". De Commissie neemt vervolgens niet de moeite (ook niet in het kader van artikel 10 ECRM) om de vraag te beantwoorden met betrekking tot het bestaan, en zoja, de reikwijdte van een recht op toegang tot bestaande technologie als radio, televisie en andere uitingsvormen ("forms of expression"), inclusief het gebruik van particuliere ontvangers. De Commissie beslecht de zaak onder artikel 8 lid $2 .^{105}$

103 Rapp.Comm. 11 oktober 1980, Silver and others, \$\$272-273, p. 72.

104 EHRM 6 september 1978, Case of Klass a.o., $\$ 41$, p. 21; zie voor eensluidende uitspraken noot 8. In EHRM 25 februari 1992, Case of Margareta and Roger Andersson, bepaalt het Hof, dat telefoongesprekken tussen gezins- of familieleden vallen onder zowel het recht op respect voor het gezinsleven als het recht op respect voor de correspondentie. $\$ 72$, p. 25.

105 Besl.Comm. 13 mei 1982, zaak nr. 8962/80, X and Y v. Belgium, p. 124. 
In de zaak Niemietz, ten slotte, gaat het om een bevel tot huiszoeking en tot inbeslagneming van documenten (in klager's advocatenkantoor) ten aanzien waarvan geen nadere kwalificatie of beperking was aangebracht. ${ }^{106}$ Volgens het Hof moeten deze overheidsmaatregelen noodzakelijkerwijs betrekking gehad hebben op "correspondence" en materiaal dat als zodanig kan worden beschouwd met het oog op het doel van artikel 8. Het Hof merkt vervolgens op, dat het in dit verband voldoende is te constateren dat deze verdragsbepaling anders dan ter aanzien van het woord "life", geen bijvoeglijk naamwoord gebruikt om hei begrip "correspondence" nader te kwalificeren. Het Hof wijst erop, dat het in eerdere zaken heeft geoordeeld in de context van correspondentie in de vorm van telefoongesprekken, dat een dergelijke kwalificatie ook niet aangebracht moet worden. ${ }^{107}$ Het Hof voert ook aan, dat in zaken met betrekking tot correspondentie met een advocaat het Hof niet eens de mogelijkheid van het niet-toepasselijk zijn van artikel 8 , op de grond dat de correspondentie van professionele aard was, heeft geopperd. ${ }^{108}$

Al met al, lijkt vooral na de laatstgenoemde uitspraak in de zaak Niemietz, het begrip "correspondence" enorm ruim te moeten worden uitgelegd. Een duideljik sriterium ter afhakening van dit begrip komt wit de rechtspraak niet naar voren.

\subsection{De rechtspraak van de Nederlandse rechterlijke instanties met betrekking tot artikel 8 ECRM}

In deze paragraaf zal worden onderzocht hoe de Nederlandse rechter de rechten die in artikel 8 ECRM worden gegarandeerd, afbakent. Gebruikt de Nederlandse rechterlijke macht dezelfde criteria als de Straatsburgse instanties of ontwikkelt zij eigen criteria? En als dit laatste het geval is, doet de rechter dit dan aan de hand van de Straatsburgse jurisprudentie of doet hij dit zelfstandig? Ter beantwoording van deze vragen zullen in de volgende sub-paragrafen achtereenvolgens het recht op respect voor het privéleven, het recht op respect voor het familie- en gezinsleven, het recht op respect voor de woning en het recht op respect voor de correspondentie besproken worden.

106 EHIRM 16 december 1992, Niemietz Case, \$32, pp. 34-35.

107 Het Hof verwij̣st hier naar EHRM 24 april 1990. Huvig Case, \$\$8, 25, pp. 41, 52.

108 Het Hof verwijst hier naar EHRM 20 juni 1988. Case of Schönenberger and Durmaz. \$24, p. 13 en EHRM 25 maart 1992. Campbell Case, $\$ 30$ e.v.. pp. 15-16. 


\subsubsection{Het recht op respect voor het privéleven}

In deze paragraaf zal de interpretatie van het recht op respect voor het privé-leven worden besproken, zoals dit in artikel 8 ECRM wordt gegarandeerd. Zoals hierna zal blijken, wordt deze interpretatie in de jurisprudentie van de Nederlandse rechterlijke instanties soms mede gegeven in het kader van de interpretatie van onder meer artikel 10 Grondwet. De jurisprudentie naar aanleiding van artikel 10 Grondwet zal hier echter alleen aan de orde komen voorzover die voor de uitleg van artikel 8 ECRM van belang is. De overige rechtspraak ten aanzien van artikel $10 \mathrm{zal}$ in een afzonderlijke paragraaf worden behandeld.

In 1986 moet de Hoge Raad onder meer de klacht van een verdachte beoordelen, of het Openbaar Ministerie niet-ontvankelijk had moeten worden verklaard omdat de aanhouding van de verdachte volgde op het onrechtmatig schaduwen van de verdachte door de politie. ${ }^{109}$ Dit schaduwen is volgens de verdachte onrechtmatig omdat het in strijd is met zijn recht op respect voor zijn privéleven. Volgens de verdachte hebben de rechtbank en het gerechtshof ten onrechte geen rekening gehouden met het bepaalde in artikel 8 ECRM. Volgens de Hoge Raad treft deze klacht van verdachte geen doel omdat de verbalisanten zich beperkten tot "waarneming van hetgeen in het openbaar geschiedde." Deze uitspraak van de strafkamer van de Hoge Raad komt in feite neer op de zeer ongenuanceerde uitspraak, dat alles wat in het openbaar plaatsvindt niet tot het privéleven kan behoren. ${ }^{10}$ Dit zou kunnen duiden op een ruimtelijke afgrenzing van het onderhavige recht als men alles wat niet in de woning plaatsvindt bestempelt als iets wat in het openbaar geschiedt. De uitspraak van de strafkamer geeft hierover geen uitsluitsel.

De civiele kamer komt in 1987 tot een geheel andere uitspraak. In de Edamse bijstandszaak" $k^{\prime \prime}$ gaat het om een vrouw die bijstand heeft genoten op grond van de Algemene Bijstandswet. Eind 1983 wordt haar uitkering ingetrokken op grond van gegevens die door haar buurman zijn verstrekt. Deze buurman is de adjunct-directeur van de Gemeentelijke Sociale Dienst (GSD) en heeft de desbetreffende gegevens verzameld door zijn buurvrouw van 1978 tot 1983 regelmatig te bespieden. Bij de beoordeling of de

109 HR 14 oktober 1986, NJ 1988, 511.

110 De geciteerde reden voor het afwijzen van het beroep op artikel 8 , noch de overige overwegingen omtrent dit deel van het cassatiemiddel wijzen erop dat de Hoge Raad hier impliciet (en zeker al niet expliciet) aan het tweede lid van artikel 8 toetst.

11 HR 9 januari 1987, NJ 1987, 928, met noot F.H. van der Burg. 
gedragingen van de buurman onrechtmatig zijn, gaat de Hoge Raad na of deze gedragingen een inbreuk opleveren op het recht op eerbiediging van de persoonlijke levenssfeer van de vrouw. Dit recht, aldus de Hoge Raad, wordt "naar zijin inhoud mede ... bepaald door art. 8 EVRM ...". Voor de begrenzing van het recht op eerbiediging van de persoonlijke levenssfeer zoekt de Hoge Raad steun bij diverse documenten. De hierna opgenomen passages uit deze documenten, worden door de Hoge Raad expliciet in zijn overwegingen betrokken.

Allereerst verwijst de Hoge Raad naar de Memorie van Toelichting van het toen nog niet in werking getreden artikel 10 Grondwet, dat volgens de Hoge Raad voortbouwt op onder meer artikel 8. Volgens de Memorie van Toelichting laat het onderhavige recht "zich niet ruimtelijk begrenzen bijv. tot het huis waarin men leeft en dat een inbreuk op dit recht door het vastleggen en doorgeven van gegevens, verkregen door gewone zintuiglijke waarnemingen, niet uitgesloten is. "112

De MvT verwijst voorts naar Resolutie 428 (1970) van de Raadgevende Vergadering van de Raad van Europa waarin wordt uitgesproken dat het recht op privacy het recht omvat om "zijn eigen leven te leiden met zo weinig mogelijk inmenging van buitenaf". "13 Ook besteedt de MvT aandacht aan de Memorie van Toelichting bij wetsvoorstel 9419 inzake de bescherming tegen het met een technisch hulpmiddel afluisteren en opnemen van gesprekken: hierin wordt onder persoonlijke levenssfeer verstaan "de reeks situaties waarin de mens ... onbevangen zich zelf wil zijn". 114

Vervolgens acht de regering volgens de MvT "de aard en de mate van intimiteit van hetgeen omtrent een ander wordt waargenomen, vastgelegd of aan anderen doorgegeven" van belang voor het bepalen van de grens van het recht op eerbiediging van de persoonlijke levenssfeer.

Volgens de Hoge Raad wijzen ook de algemene beschouwingen van de Staatscommissie bescherming persoonlijke levenssfeer in verband met persoonsregistraties, in "de hier aangeduide richting". "rs

De Hoge Raad komt op grond van deze overwegingen en de feiten van deze zaak tot de conclusie dat de verweerder in cassatie (de

112 Memorie van Toelichting bij wetsvoorstel 13872, Verklaring dat er grond bestaat,..., Tweede Kamer, in: Algehele grondwetsherziening, deel Ia Grondrechten, pp. 3942(40) geciteerd in r.o. 4.4, tweede alinea.

113 Council of Europe, Consultative Assembly. Twenty-First Ordinary Session (Third Part), Texts Adopted (1970), in: Council of Europe, Collected Texts, p. 908(911).

114 Kamerstukken II, 1967-1968, wetsvoorstel 9419, nr. 3 (Memorie van Toelichting), geciteerd in r.o. 4.4, derde alinea.

115 Eindrapport van 1976, pp. 20-24, aangehaald maar niet geciteerd in r.o. 4.4, vierde alinea. 
buurman/adjunct-directeur van de GSD) een inbreuk gemaakt heeft op het recht van eiseres (de buurvrouw) op eerbiediging van haar persoonlijke levenssfeer. ${ }^{116}$

De bovenstaande uitspraak van de strafkamer zou wellicht zo begrepen kunnen worden (althans het is niet uit te sluiten) dat bedoeld wordt het recht op eerbiediging van de persoonlijke levenssfeer ruimtelijk te begrenzen. De civiele kamer komt daarentegen - in navolging van de regering in wetsvoorstel 13872 - tot het oordeel dat het recht op eerbiediging van de persoonlijke levenssfeer niet ruimtelijk begrensd kan worden en dat wanneer bepaalde gegevens die door gewone zintuiglijke waarnemingen zijn verkregen, worden vastgelegd en doorgegeven, dit een inbreuk. op dit recht kan opleveren. Dit sluit niet uit, dat het kan gaan om gegevens over gedragingen die in het openbaar hebben plaatsgevonden.

De vraag kan derhalve worden gesteld, of ten gevolge van deze eventuele tegenstelling in de opvattingen van de strafkamer en de civiele kamer van de Hoge Raad een andere uitleg van artikel 8 moet worden gegeven al naar gelang het gaat om een strafzaak dan wel een civiele zaak. Bij een bevestigende beantwoording van die vraag zou immers de reikwijdte van het recht op respect voor het privéleven afhankelijk zijn van de aard van de zaak in kwestie.

Een uitspraak van de strafkamer in 1991 geeft hierover uitsluitsel. In deze zaak $^{117}$ gaat het om de inbeslagname van videobanden bij RTLVéronique van een demonstratie. RTL-V voert onder meer tegen deze inbeslagname aan, dat hiermee inbreuk gemaakt wordt op de privacy van de gefilmde demonstranten. De Hoge Raad wijst deze klacht af omdat "de filmopnamen slechts betrekking hadden op hetgeen in het openbaar geschiedde, terwijl niet is vastgesteld of aangevoerd dat de opnamen betrekking hadden op situaties waarin, naar moest worden aangenomen, de betrokkenen onbevangen zichzelf wilden zijn." Hierbij wordt kennelijk aangesloten bij de eerder aangehaalde Memorie van Toelichting bij wetsvoorstel 9419 inzake de bescherming tegen het met een technisch hulpmiddel afluisteren en opnemen van gesprekken. ${ }^{118}$

116 Zonder tot een uitvoerige motivering als in de Edamse bijstandszaak, komt de Hoge Raad ook in zịnn uitspraak van 20 maart 1992 tot de conclusie dat een onderzoek op grond van artikel $5 \mathrm{a}$ ABW naar de situatie van samenwonenden een inmenging vormt in de persoonlijke levenssfeer van betrokkene, indien dit onderzoek zich titstrekt tot de vraag of tussen deze personen een lesbische verhouding bestaat. HR 20 maart 1992, NJ 1994, 240 met noot E.A. Alkema.

117 HR 19 februari 1991, NJ 1992, 50, met noot G.J.M. Corstens.

118 Zie noot 114. 
Op grond van deze uitspraak is het voor afwijzing van een beroep op het recht op privacy derhalve niet meer voldoende dat de waargenomen gedragingen in het openbaar hebben plaatsgevonden, maar moet er ook worden vastgesteld of de desbetreffende gedragingen uiting geven aan de wens van de betrokkenen om onbevangen zich zelf te zijn. Hoe stel je de aanwezigheid van een dergelijke wens echter vast? Een dergelijke wens van betrokkenen "om onbevangen zichzelf te zijn" is een innerlijke beweegreden die zowel moeilijk bewijsbaar als moeilijk weerlegbaar is. ${ }^{\text {.19 }}$ Zoals hierna zal blijken kan hiervoor de oplossing gezocht worden bij de civielrechtelijke jurisprudentie inzake het vastleggen van gegevens op geluids-, foto- of film-materiaal en het gebruik daarvan. Deze jurisprudentie zal nu besproken worden.

In een zaak van 16 oktober 1987 gaat het om de bewijskracht van een geluidsband waarop zonder toestemming of medeweten van de gesprekspartner een telefoongesprek is vastgelegd door de tegenpartij in het geding. ${ }^{120}$ Voor de beantwoording van de vraag of hiermee een inbreuk gemaakt wordt op het recht op eerbiediging van de persoonlijke levenssfeer van die gesprekspartner wordt door de Hoge Raad opnieuw verwezen naar de Memorie van Toelichting bij wetsvoorstel 13872 . Hierin wordt vastgesteld, dat "sommige terreinen van het menselijk leven ... een zo intiem karakter [hebben], dat elke ongewenste waarneming ervan een ongeoorloofde aantasting van de privacy inhoudt. Op andere gebieden is gewone zintuiglijke waarneming toegelaten, maar is de vastlegging ervan een ongeoorloofde aantasting. Ook is mogelijk, dat niet de vastlegging maar slechts de publikatie van het geregistreerde ongeoorloofd is. " Groot

119 Slechts zelden zal zich de situatie voordoen, dat betrokkene van tevoren al heeft kunnen aangeven of hij een bepaalde overheidsmaatregel al dan niet als inmenging in zijn privéleven beschouwd. Een voorbeeld hiervan biedt de casus in HR 29 maart 1994, NJ 1994, 537 waarin een advocaat (tevens directeur van een bepaalde vennootschap en "protector van de trusts") klaagt over inbeslagneming van bepaalde dossiers die hij niet in zijn hoedanigheid van advocaat onder zich had. Deze inbeslagneming werd niet in strijd met artikel 8 geoordeeld, omdat de inbeslagneming was toegespitst op dossiers die in overleg met klager waren geselecteerd en door hem waren afgestaan, in het bijzijn van de Deken van de Nederlandse Orde van Advocaten. Mijns inziens had de Hoge Raad hier ook kunnen uitspreken dat het recht op eerbiediging van het privéleven (en correspondentie) van de advocaat net in het geding was. Zie ook HR 19 juni 1992, NJ 1993, 487 met noot MMM.

120 HR 16 oktober 1987, NJ 1988, 850, met noot E.A. Alkema. 
gewicht wordt toegekend aan de "aard en de mate van intimiteit van hetgeen omtrent een ander wordt waargenomen of gepubliceerd. ${ }^{121}$

Vervolgens komt de Hoge Raad tot de slotsom dat "het enkele zonder toestemming van de gesprekspartner op een geluidsband vastleggen van een telefoongesprek nog geen inbreuk op het recht op eerbiediging van de persoonlijke levenssfeer oplevert, maar dat daarvoor bijkomende omstandigheden vereist zijn." (Welke bijkomende onstandigheden dit zijn, laat de Hoge Raad in het midden; het betreft hier een in het zakelijk verkeer tussen twee directeuren van bedrijven gevoerd telefoongesprek met een geheel zakelijke inhoud, waardoor "in elk geval" geen sprake is van een inbreuk op het onderhavige recht.) Voorts concludeert de Hoge Raad, dat het "in haar algemeenheid" onjuist is te stellen, dat "openbaarmaking van een (als zodanig rechtens niet ongeoorloofde) vastlegging van een telefoongesprek die heeft plaatsgevonden zonder toestemming en/of medeweten van de gesprekspartner, 'te allen tijde' inbreuk maakt op het recht op eerbiediging van de persoonlijke levenssfeer." De openbaarmaking van de in het geding zijnde vastlegging aan de rechter in een civiele rechtszaak, waarvan in deze procedure sprake was, maakt volgens de Hoge Raad geen inbreuk op het recht op eerbiediging van de persoonlijke levenssfeer.

Het criterium, dat voor de vaststelling of de waarneming, de vastlegging of het gebruik van een dergelijke vastlegging van gegevens omtrent gedragingen van personen een inbreuk maakt op de persoonlijke levenssfeer van die personen is derhalve de "aard en de mate van intimiteit van hetgeen omtrent een ander wordt waargenomen". Dit criterium is ook in andere zaken gehanteerd.

Bijvoorbeeld, in een zaak van 1 juli 1988 gaat het om een foto van eiseres, die innig gearmd met een vriend in het Vondelpark wandelt. ${ }^{12}$ De foto wordt een jaar later - wanneer de relatie van het paar inmiddels is beëindigd - zonder toestemming van eiseres in een tijdschrift gepubliceerd. Eiseres meent, dat de openbaarmaking van de foto een

121 Memorie van Toelichting bij wetsvoorstel 13872, Verklaring dat er grond bestaat ..., Tweede Kamer, in: Algehele grondwetsherziening, deel Ia Grondrechten, p. 41. Overigens kan het voor de openbaarmaking van gegevens ook van belang zijn met. welk doel de desbetreffende gegevens mogen worden verzameld. Overheidsorganen moeten "zich er in beginsel van ... onthouden om persoonlijke gegevens met betrekking tot de burgers, welke gegevens zij in het kader van de uitoefening van een overheidstaak hebben verkregen, openbaar te maken yoor een ander doel dan waarvoor zij die gegevens mochten verzamelen. Handelen in strijd met dat recht is onrechtmatig." Pres.Rb. Groningen 7 oktober 1987, NI 1987, 455.

122. HR 1 juli 1988, NJ 1988, 1000 met noot $L W H$. 
onrechtmatige daad oplevert. Volgens de Hoge Raad vloeit uit het recht van een ieder op eerbiediging van zijn persoonlijke levenssfeer - dat naar zijn inhoud mede door artikel 8 ECRM wordt bepaald - voort, dat "indien de openbaarmaking van een portret op dit recht inbreuk maakt, in beginsel sprake is van een redelijk belang van de geportretteerde als bedoeld in art. 21 Aw dat zich tegen die openbaarmaking verzet."123 De Hoge Raad noemt vervolgens als criterium voor de beoordeling of sprake is van een inbreuk op de persoonlijke levenssfeer, de feitelijke omstandigheden, met name de aard en mate van intimiteit waarin de geportretteerde is afgebeeld. Ook het karakter van de foto en de context van de publikatie kunnen van belang zijn voor de vraag of sprake is van een inbreuk. ${ }^{124}$

Met betrekking tot dit criterium van de (al dan niet) intieme aard van de in het geding zijnde informatie, merkt Dommering in zijn annotatie bij het arrest in de Edamse bijstandszaak op, dat dit invoeren van een inhoudelijk kenmerk het recht op privacy een moeilijk te bepalen dynamische inhoud geeft. Deze annotator wijst op de voorbeelden van de beveiliging van de werkplaats respectievelijk een supermarkt door middel van een videocircuit. De geoorloofdheid van een videocircuit in een supermarkt en de ongeoorloofdheid ervan op de werkplek kan men omschrijven in termen van de inhoud van het recht (het rustig onbespied kunnen werken is "privé", winkelen is "openbaar"), maar ook in termen van de toegestane beperkingen op dit recht. ${ }^{i 2}$ In het eerste geval gaat het om afbakening

123 Artikel 21 Auteurswet 1912: Is een portret vervaardigd zonder daartoe strekkende opdracht, den maker door of vanwege den geportretteerde, of te diens behoeve, gegeven, dan is openbaarmaking daarvan door degene, wie het auteursrecht daarop toekomt, niet geoorloofd, voor zover een redelijk belang van den geportretteerde of, na zijn overlijden, van een zijner nabestaanden zich tegen de openbaarmaking verzet. Zie ten aanzien van dit artikel in verband met de persoonlijke levenssfeer o.a.: S. Gerbrandy, Kort commentaar op de Auteurswet 1912, pp. 272-280.

124 Vergelijk HR 21 januari 1994, NJ 1994, 473 waarin de Raad (in r.o. 3.5) spreekt van een "in het kader van een perspublikatie en zonder daartoe strekkende opdracht van de geportretteerde vervaardigd portret [dat] buiten diens toestemming openbaar wordi gemaakt onder zodanige omstandigheden dat deze openbaarmaking een inbreuk vormt op zijn recht op eerbiediging van zijn persoonlijke levenssfeer ...". Welke de omstandigheden zijn die de publikatie van de bedoelde foto een inbreuk doen zijn, vermeldi de Hoge Raad niet. Een aanwijzing levert r.o. 3.6 waarin de HR spreekt van klager's "belang om 'alleen te worden gelaten'."

125 E.J. Dommering, annotatie bij HR 9 januari 1987, in: Computerrecht, 1987/2, pp. 110-115(114). Dommering verwijst hier waarschijnlijk naar Pres.Rb. Roermond 12 september 1985, KG 1985, 299, NJCM-Bulletin 11-1 (1986), pp. 74-79 met noot Tj. Gerbranda, pp. 77-79, waarin is uitgesproken, dat "Toezicht door de werkgever op de werknemer in een werksituatie ... niet als inbreuk op de privacy beschouwd [wordt] zolang dit toezicht door een daartoe aangestelde functionaris in persoonlijk 
van de reikwijdte van het recht, in het tweede geval om toepassing van beperkingsbevoegdheden.

Verhey merkt in zijn annotatie bij hetzelfde arrest terecht op, dat de regering in de Memorie van Toelichting bij wetsvoorstel 13872 naar "de aard en intimiteit van hetgeen omtrent een ander wordt waargenomen" verwijst in het licht van de beoordeling of een inbreuk op de persoonlijke levenssfeer geoorloofd of ongeoorloofd is. Dit betekent, dat dit criterium in de visie van de regering - een rol speelt bij de beperking van het onderhavige recht en niet bij de vaststelling van de reikwijdte van het recht. ${ }^{126}$

De Hoge Raad hanteert dit criterium daarentegen wèl bij de afbakening van de reikwijdte van het recht op eerbiediging van de persoonlijke levenssfeer. Dommering spreekt in dit kader van de objectief dynamische inhoud van het recht; dit wil volgens hem zeggen dat "telkens aan de hand van geobjectiveerde omstandigheden moet worden vastgesteld of het individu in een privé of een openbare maatschappelijke rol wordt beoordeeld", derhalve of het recht op respect voor het privéleven hier van toepassing is of niet. Daarnaast wil Dommering het formele kenmerk - dat het individu met rust moet worden gelaten - bepalend doen zijn voor de inhoud van het recht. In dit geval spreekt Dommering van de subjectief dynamische inhoud van het recht: het individu moet zelf de grenzen van zijn privacy - de hoeveelheid rust die hij wenst - bepalen. ${ }^{127}$ Daarmee komen we weer terug bij het criterium "de reeks van situaties waarin de mens ... onbevangen zichzelf wil zijn". Deze wens van de individu om onbevangen zichzelf te zijn stemt overeen met de subjectief dynamische inhoud van het recht op privacy zoals Dommering die heeft beschreven.

Nog steeds rest ons het hierboven gesignaleerde probleem, dat een dergelijk subjectief criterium zowel moeilijk bewijsbaar als moeilijk weerlegbaar is. Mijns inziens kan het bestaan van een innerlijke beweegreden (de subjectief dynamische inhoud), afgeleid worden uit de objectief dynamische inhoud: geven de aard en de mate van de intimiteit

contact wordt uitgeoefend." Toezicht d.m.v. een TV-çircuit stelt de werknemers bloot aanı eenzijdige, niet ogenblikketijk kenbare en ongecontroleerde waarneming door degene die achter de monitoren zit. Door dit ontbreken van menselijk contact kan dit toezicht niet vergeleken worden met de eerstgenoemde vorm van toezicht. Volgens de President moet er in dit geding vanuit worden gegaan "dat van "reëel ervaren inbreuk op privacy" sprake is: "De bescherming van de persoonlijke levenssfeer strekt zich uit tot de werkplaats...". De President gaat overigens niet in op artikel 8 ECRM.

126. L.F.M. Verhey, annotatie bij HR 9 januari 1987, in: NJCM-Bulletin 12-4 (1987), pp. 298-305(302).

127 Dommering, annotatie bij HR 9 januari 1987, p. 114. 
van een bepaalde gedraging van een persoon ertoe aanleiding aan te nemen dat sprake is van een gedraging die in de persoonlijke levenssfeer van die persoon valt, dan zal het doorgaans ook de wens van die persoon zijn om bij die gedraging onbevangen zich zelf te zijn, om daarbij met rust gelaten te worden. Dit kan eventueel anders zijn als die gedraging gezien de aard en mate van intimiteit daarvan in het algemeen tot de privésfeer zal worden gerekend, maar daarbuiten valt op grond van de concrete omstandigheden en de achtergrond van de persoon. Of andersom: indien een gedraging in het algemeen niet tot de privésfeer wordt gerekend, maar gezien de omstandigheden en achtergrond van de betrokken personen wèl door het recht op privacy wordt beschermd. Zie bijvoorbeeld de bovengenoemde zaak waarin eiseres bezwaar makt tegen de publikatie van een foto waarop zij te zien is in een innig omarming met haar (inmiddels ex-) vriend. Hierin bepaalt de Hoge Raad, dat de vraag of eiseres een redelijk belang heeft dat zich tegen openbaarmaking van de foto verzet (artikel 21 Auteurswet), beoordeeld moet worden "in het licht van haar concrete omstandigheden en haar achtergrond en dat daarbij niet relevant is of dezelfde bezwaren zich bij anderen zouden voordoen."

Overigens is het op grond van een overweging van de Hoge Raad in het arrest met betrekking tot de filmopnamen van een demonstratie, raadzaam dat degene die zich op het recht op privacy beroept, zèlf feiten aandraagt waaruit kan worden afgeleid dat de in het geding zijnde gedraging van deze persoon uiting gaf aan de wens onbevangen zichzelf te zijn. De Hoge Raad overwoog namelijk dat "de filmopnamen slechts betrekking hadden op hetgeen in het openbaar geschiedde, terwijl niet is vastgesteld of aangevoerd dat de opnamen betrekking hadden op situaties waarin, naar moest worden aangenomen, de betrokkenen onbevangen zichzelf wilden zijn. "!2s

Ter aanvulling volgt nog een opmerking over het commentaai van Overkleeft-Verburg ${ }^{129}$ dat definities als "het recht zijn eigen leven te leiden met zo weinig mogelijk inmenging van buitenaf" en "de reeks van situaties waarin de mens ... onbevangen zichzelf wil zijn" ondeugdelijk zijn als definities van het grondrecht op eerbiediging van de persoonlijke levenssfeer. Ze zouden de indruk wekken dat het grondrecht zelf vereenzelvigd wordt met de uitkomst van het afwegingsproces. Voorgaand commentaar motiveert Overkleeft-Verburg onder meer door te stellen dat de genoemde omschrijvingen niet een in beginsel absolute aanspraak tot uitdrukking brengen, maar een relatieve, waarin de beperkingsgrondslag 
in het recht zelf is geïncorporeerd. Een dergelijke "ingebouwde" beperkingsbevoegdheid is volgens Overkleeft-Verburg in strijd met de grondrechtssystematiek van onze Grondwet omdat deze een uitdrukkelijk onderscheid makt "tussen de inhoud van het recht zelf en de daarop noodzakelijk geachte beperking, waarbij de belangenafweging in beginsel aan de formele wetgever is voorbehouden. Gaat men uit van een relatieve aanspraak, dan zou van een dubbele beperking sprake kunnen zijn. "130

Hoewel het juist is dat de reikwijdte (inhoud) van een recht enerzijds en de beperking van het recht anderzijds van elkaar onderscheiden dienen te worden gaat Overkleeft-Verburg er mijns inziens aan voorbij, dat praktisch iedere interpretatie - met name wanneer het een onduidelijk begrip betreft de uitkomst is van een afwegingsproces, een rechterlijk afwegingsproces. Dit is pas anders, als een recht zo duidelijk is, dat voor zijn toepassing geen verdere interpretatie nodig is. Zoals al vaker in dit boek is geconstateerd, is dit bij vrijwel geen enkel grondrecht het geval. Zeker de inhoud van het recht op respect voor het privéleven is uitermate vaag. Een rechterlijk afwegingsproces teneinde dit recht af te bakenen is daarom onontbeerlijk. Daarbij lijkt de jurisprudentie erop te wijzen, dat de rechter het onderhavige recht niet restrictief interpreteert: meestal worden klachten inzake schending van het recht op respect voor het privéleven afgedaan door middel van een belangenafweging in het kader van een oordeel over de (on)geoorloofdheid van een inbreuk op dat privéleven. Dit gebeurt dan ofwel aan de hand van artikel 8 lid 2 ECRM, ofwel - in veel gevallen - in het kader van een onrechtmatige daadsactie op grond van artikel 1401 oudBW (artikel 6: $162 \mathrm{BW}$ ). ${ }^{131}$

130 G. Overkleeft-Verburg. Wetgever en privacy, pp. 70-71.

131 Voorbeeldern: impliciet de conclusie van de AG bij HR 21 maart 1989. NJ 1989, 864 (afluisteren "opengebleven" telefoonverbinding) met noot Th.W. van Veen; HR 15 september 1989, NJ 1990, 322 (wijziging geboorteakte wegens transsexualiteit ouder) met noot E.A.A. Luijten en E.A. Alkema; Rb. Utrecht 10 januari 1990. NJ 1990, 624 (vordering tot vernietiging medisch dossier): Pres.Rb. Amsterdam 11 juni 1991. KG 1991. 242 (vordering tot ondergaan van AIDS-test door verkrachter), met noot $A$. Sas, in: NJCM-Bulletin 16-6 (1991), p. 560 e.v., vernietigd in hoger beroep. Gerechtshof Amsterdam 5 maart 1992. KG 1992, 126, met noot L.F.M. Verhey, in: NJCM-Bulletin 17-6 (1992) pp. 643-645; Gerechtshof 's-Hertogerbosch 18 september 1991. NJ 1991, 796 (inzagerecht afstammingsgegevens), met noot $F$. Kuitenbrouwer, in: Computerrecht 1992/2, p. 73 e.v. en L.F.M. Verhey, in: NJCMBulletin 17-2 (1992), pp. 156-161: HR 12 juni 1992, NJ 1992, 589 (informatierecht ouder tegen nadrukkelijke wens minderjarigen). Zie verder: L.F.M. Verhey, Horizontale werking van grondrechten, in het bijzonder van het recht op privacy. diss. Utrecht 1992, W.E.J. Tjeenk Willink: Zwolle 1992. 
De voorgaande bespreking zag voornamelijk ${ }^{132}$ op de waarneming en vastlegging van gegevens of gedragingen van natuurlijke personen en de gebruikmaking en openbaarmaking van dergelijke vastgelegde gegevens. In dit kader passen ook kwesties als de wijziging, de vernietiging of de inzage van gegevens omtrent een persoon. Voorts kan gedacht worden aan zaken met betrekking tot, bijvoorbeeld, het publiceren of verstrekken van gegevens omtrent rechtspersonen. Zo komt de Hoge Raad in een arrest van 15 december 1992 tot de uitspraak dat in het desbetreffende geval het Gerechtshof terecht het beroep op artikel 8 had verworpen, omdat de - bestreden - in artikel 394 van boek 2 BW opgenomen plicht van de daar bedoelde rechtspersonen tot het openbaarmaken van de jaarrekening zich slechts uitstrekt tot gegevens met betrekking tot de door de rechtspersoon gedreven onderneming, die niet onder de bescherming van artikel 8 lid 1 ECRM vallen. ${ }^{13}$ Anders dan het Gerechtshof bepaalt de Hoge Raad nít dat rechtspersonen in het geheel geen bescherming van artikel 8 toekomt. Dit is gezien de uitspraak van het Europese Hof in de zaak Niemietz terecht. ${ }^{14}$ Als gegevens in een jaarrekening met betrekking tot een door een rechtspersoon gedreven onderneming niet onder artikel 8 vallen, welke gegevens vallen hier dan wel onder? De rechtspraak geeft hierover geen uitsluitsel. Een criterimin voor de afóakening van hé recít op privacy dat rechtspersonen aan artikel 8 kunnen ontlenen, heb ik in de jurisprudentie niet kunnen ontdekken. Een arrest van de Hoge Raad van 12 februari 1993 betreft het inwinnen van inlichtingen omtrent de inkomsten van betrokkene op de voet van artikel $84 \mathrm{~d}$ lid 1 (oud) ABW - die de werkgever of de opdrachtgever van degene te wiens behoeve bijstand wordt verleend, desgevraagd aan burgemeester en wethouders verplicht waren te verstrekken. ${ }^{135}$ Dit inwinnen van inlichtingen levert volgens de Hoge Raad geen inbreuk op op artikel 8 voor zover het, zoals in het onderhavige geval, gaat om inlichtingen over bedrijfsmatig verworven inkomsten waarvan de betrokkene ingevolge artikel 30 lid 2 ABW eigener beweging mededeling had behoren te doen. In verband met artikel $84 \mathrm{~d}$ lid 3 (oud) AWB, dat volgens de Raad als doel en strekking had dat het uit een. oogpunt van openheid van bestuur niet aangaat dat de overheid achter iemands rug om inlichtingen over zijn inkomsten inwint, overweegt de. Raad echter dat "[o]nder bijzondere omstandigheden ... het inwinnen van zulke inlichtingen immers wèl inbreuk op het in art. 8 EVRM beschermde

132 Voonamelijk, doch niet uitsluitend: denk o.a. aan het cerdergenoemde schaduwarrest HR 14 oktober 1986, NJ 1988, 511.

133 HR 15 december 1992, NJ 1993, 550 met noot AHJS.

134 Zie hierboven de paragrafen 4.2.1 en 4.2.3.

135 HR 12 februari 1993, NJ 1993, 599, met noten van E.A. Alkema en HJS. 
recht [kan] opleveren en wanneer hij vooraf van het voornemen van de overheid in kennis wordt gesteld, kan betrokkene de overheid op deze bijzondere omstandigheden wijzen ...". Welke deze bijzondere omstandigheden kunnen zijn vermeld de Hoge Raad in deze uitspraak echter niet. De Raad stelt slechts vast dat het moet gaan om "zodanige (door betrokkene te stellen en, zonodig, aannemelijk te maken) omstandigheden dat het oordeel is gewettigd dat, zou de overheid deze hebben gekend, zij zich van het geven van uitvoering aan haar voornemen tot het inwinnen van inlichtingen had behoren te onthouden omdat dat inwinnen niet 'noodzakelijk' in de zin van art. 8 lid 2 EVRM kan worden beschouwd." 136

Hoewel de hiervoor behandelde, zogenaamde "informationele privacy" in de Nederlandse rechtspraak de boventoon voert, zijn ook andere aspecten van het recht op respect voor het privéleven onder artikel 8 ECRM door de Nederlandse rechter aan oordeel onderworpen. ${ }^{137}$ Men denke bijvoorbeeld aan de invulling die iemand aan zijn privéleven wenst te geven. Navolgende uitspraken geven geen criteria voor de afbakening van het recht op respect voor het privéleven, maar worden wèl vermeld, omdat het naar mijn mening interessant is om te zien wat er zoal onder dit recht valt.

In een zaak van 19 oktober 1990 ging het om de wens van verzoekster om met haar vriendin in het huwelijk te kunnen treden. ${ }^{138}$ De vraag is of de onmogelijkheid voor twee partners van hetzelfde geslacht om met elkaar in het huwelijk te treden een schending van het recht op respect voor het privéleven in de zin van artikel 8 ECRM en van het recht om te huwen op grond van artikel 12 ECRM oplevert. Volgens de Hoge Raad is de wettelijke regeling van het huwelijk niet in strijd met artikel 12 omdat dit betrekking heeft op het traditionele huwelijk tussen personen van verschillend geslacht. De Hoge Raad verwijst hierbij naar de uitspraak van

136 Zie de noot van Alkema onder dit arrest.

137 Zie ten aanzien van het begrip privacy, waaronder de informationele privacy: $L . F . M$. Verhey, Horizontale werking van grondrechten, pp. 192-198. Zie verder ten aanzien van de Nederlandse rechtspraak inzake het inzagerecht met betrekking tot privacygevoelige gegevens de annotatie E.I. Dommering bij EHRM 7 juli 1989. Gaskin Case, NJ 1991, 659, \$4 e.v..

138 HR 19 oktober 1990, NJ 1992, 129, met noten van E.A.A. Luijiten en E.A. Alkema, en met noot $L$. Mulder in: Tijdschrift voor Bestuurswetenschappen en Publielkrecht 1991. p.307-312; vervolg op Rb. Rotterdam 5 december 1988 en Gerechtshof 'sGravenhage 2 juni 1989, NJ 1989, 871 ; zie o.a. ook: $A$. Woltjer, Huwelijksperikelen: een heterosexueel voorrecht?, pp. 352-354. 
het Europese Hof voor de Rechten van de Mens in de zaak Rees. ${ }^{19}$ Aangezien artikel 12 niet voorziet in een recht van personen van gelijk geslacht om met elkaar in het huwelijk te treden, kan volgens de Hoge Raad "niet worden aangenomen dat het niet toekennen van dat recht in een nationale wet een door het verdrag verboden inmenging in het privé-leven of gezinsleven van de betrokkenen oplevert." Het door artikel 8 ECRM gegarandeerde privéleven en of gezinsleven vindt derhalve zijn afbakening in artikel 12 ECRM. Ik wil hierbij de nadruk leggen op de schuingedrukte woorden "een door het verdrag verboden inmenging". Deze formulering lijkt er mijns inziens op te duiden, dat de Hoge Raad het recht op privéleven in casu wel van toepassing acht en tevens van mening is, dat sprake is van een inmenging op dat privéleven. Het is volgens de Hoge Raad alleen niet een "verboden inmenging". Het al dan niet verboden zijn van de inmenging is hier alleen niet beoordeeld in het licht van artikel 8 lid 2 maar aan de hand van artikel 12. Wat men hiervan ook moge denken, feit blijft dat dit soort gevallen binnen de reikwijdte van artikel 8 lid 1 valt. ${ }^{100}$

Ook de lichamelijke en geestelijke integriteit van een persoon worden door artikel 8 ECRM beschermd. Zo blijkt uit een arrest van 1987, dat de verplichting tot het ondergaan van een bloedproef door iemand die werd verdacht van het rijden onder invloed een inmenging is op het recht op privéleven. ${ }^{141}$ Deze inmenging wordt gerechtvaardigd geacht op grond van artikel 8 lid 2. Een soortgelijke uitspraak - zij het minder uitdrukkelijk - is door de arrondissementsrechtbank Zutphen gedaan ten aanzien van de observatie van een verdachte (die daaraan weigerde mee te werken) in het Pieter Baan Centrum te Utrecht. ${ }^{192}$ Het Gerechtshof 'sHertogenbosch heeft voorts uitgesproken, dat een DNA-onderzoek bij een vaderschapsactie wat betreft de inbreuk op de privacy "niet wezenlijk verschilt van de inbreuk door reeds langer toegepaste bloedonderzoekstechnieken. "13 Ook hieruit zou men kunnen afleiden dat

139 EHRM 17 okiober 1986, Rees Case, NJ 1987, 945, met noot E.A. Alkema.

140 AG Moltmaker gaat in zijn conclusie (\$5.1) bij dit arrest nog verder: "Op zichzelf zie ik geen principiële bezwaren tegen het opnemen van het recht om te huwen onder het recht op gezinsleven".

141 HR 20 oktober 1987. NJ 1988, 447, met noot A.C. 't Hart.

142 Rb. Zutphen 3 april 1992, NJ 1993, 260.

143 Gerechtshof 's-Hertogenbosch 1 oktober 1990 en 7 mei 1991, NJ 1992, 53. Zie verder: HR 20 september 1976. NJ 1977. 28 (het dragen van een bromfietshelm); HR 23 december 1983, NJ 1985, 170 (psychiatrisch onderzoek in het kader van artikel 66 Faillissementswet). 
het recht op respect van het privéleven kennelijk van toepassing wordt geacht.

Een zelfde conclusie is mogelijk met betrekking tot een uitspraak van 27 van de arrondissementsrechtbank Dordrecht. De rechtbank beperkt zich ertoe te bepalen dat een nieuw (door de werkgever vastgesteld) arbeidsreglement waarin bepalingen zijn opgenomen op grond waarvan een werknemer verplicht kan worden een geneeskundig onderzoek (zij het niet zonder zijn toestemming) en visitatie (onderzoek aan kleding, bagage en vervoermiddel in daartoe door de werkgever aangewezen gesloten ruimten of op het terrein van de werkgever) te ondergaan, niet in strijd is met artikel 8 ECRM (en artikel 17 IVBPR en de artikelen 10 en 11 Grondwet). ${ }^{14}$

Het nemen van vingerafdrukken van een vreemdelinge ten behoeve van een onderzoek naar haar identiteit en het verspreiden van die vingerafdrukken levert volgens de Hoge Raad ook een inmenging op in haar recht op respect van haar privéleven. Deze inmenging moet gerechtvaardigd worden op grond van het tweede lid van artikel 8, aldus de Hoge Raad. Ook het nemen van vingerafdrukken en het verspreiden daarvan valt derhalve binnen de reikwijdte van het recht op respect voor het privéleven. ${ }^{145}$

Overigens lijkt de Hoge Raad een recht op vrijheid van artsenkeuze op grond van artikel 8 lid 1 te erkennen. Het Gerechtshof te Arnhem had een inbreuk op dit recht toelaatbaar geacht op grond van artikel 8 lid 2 en de Hoge Raad acht dit geen onjuiste rechtsopvatting. ${ }^{146}$

Tenslotte kan nog vermeld worden, dat de wettelijke onderhoudsplicht van de man, die - naar achteraf is gebleken - gebaseerd is op een fictieve juridische bloedverwantschap en niet op een biologisch bloedverwantschap binnen de werking van artikel 8 ECRM valt. Volgens de rechtbank zou

144 Rb. Dordrecht 27 mei 1992, NJ 1993, 128.

145 HR 19 februari 1993, NJ 1993, 624 met noot van A.H.J. Swart. De Hoge Raad stelde bij de toetsing aan artikel 8 lid 2 overigens zware eisen aan de motivering en de afweging in het kader van het proportionaliteitsvereiste. Dit hield verband met het feit dat het ging om een inmenging in het privéleven die voortvloeide uit niet of nauwelijks nader in het Vreemdelingenbesluit en de Vreemdelingencirculaire genormeerde bevoegdheden van in casu ambtenaren, belast met de grensbewaking of met het toezicht op vreemdelingen. Zie hieromtrent en wat betreft de verspreiding van vingerafdrukken de annotatie bij dit arrest.

146 HR 20 oktober 1987, NJ 1988, 447, met noot A.C. 't Hart. Zie hieromtrent met name de annotatie bij dit arrest. 
handhaving van de onderhoudsverplichting van de man een inbreuk opleveren op zijn privéleven. ${ }^{147}$

Wanneer we het voorgaande samenvatten dan ontstaat het volgende beeld van de afbakening van het recht op respect voor het privéleven. Voorzover de rechtspraak niet betreft de waarneming en vastlegging van gegevens of gedragingen van personen en de gebruikmaking en openbaarmaking van dergelijke vastgelegde gegevens, is sprake van een casuïstische toepassing van artikel 8 ECRM. Van een gestructureerde afbakening van het recht op respect voor het privéleven is geen sprake. In de rechtspraak ten aanzien van de waarneming en vastlegging van gegevens of gedragingen van personen en het gebruik daarvan hanteert de Hoge Raad zowel objectieve als subjectieve criteria voor de begrenzing van de privésfeer. Het objectieve criterium ziet op de gedraging die in het geding is. Gekeken wordt naar de aard en de mate van intimiteit van de gedragingen. Wordt een bepaalde gedraging waargenomen, vastgelegd en/of openbaargemaakt, dan moet vervolgens worden vastgesteld of sprake is van een inbreuk op het recht op privacy, die moet worden gerechtvaardigd op grond van artikel 8 lid 2 ECRM (of artikel 10 lid $1 \mathrm{Gw}$, "behoudens ... beperkingen"). Bij deze toetsing moet worden gekeken naar "bijkomende omstandigheden" (HR 16 oktober 1987), het karakter van de vastlegging op geluids-, foto- of filmmateriaal en de context van de openbaarmaking (HR 1 juli 1988).

De subjectieve criteria zien meer op de (innerlijke) wens van degene om wiens gedraging het gaat, om met rust te worden gelaten. Het gaat hier om de gehanteerde criteria "het recht zijn eigen leven leiden met zo weinig mogelijke inmenging van buitenaf" (HR 9 januari 1987) en "de reeks situaties waarin ... de mens onbevangen zichzelf wil zijn" (HR 9 januari 1987 en 19 februari 1991). Ook hier zal rekening gehouden moeten worden met de concrete omstandigheden en de achtergrond van degene wiens gedraging in het geding is en zijn de opvattingen van anderen niet relevant. (HR 1 juli 1988)

Mijns inziens bieden de in de rechtspraak gehanteerde (en veelal door parlementaire stukken aangereikte) criteria genoeg houvast om bruikbaar te zijn voor de afbakening van het recht op respect voor het privéleven. Anderzijds zijn ze nog dermate abstract, dat een flexibele uitleg van dit recht mogelijk is. Dit voorkomt een starre, niet aan maatschappelijke opvattingen en feitelijke omstandigheden aan te passen interpretatie. 


\subsection{2 \\ Het recht op respect voor het familie- of gezinsleven}

Het recht op respect voor het familie- en gezinsleven in artikel 8 ECRM is een recht dat geregeld ingeroepen wordt in zaken met betrekking tot het omgangsrecht, het ouderlijk gezag over minderjarige kinderen en erkenning door de vader van onwettige kinderen.

4.3.2.1

Omgangsrecht ten aanzien van wettige en onwettige kinderen: biologisch ouderschap

Vooral in zaken waarin verzocht wordt om een omgangsregeling speelt artikel 8 een grote rol. Tot 1985 is deze rol grotendeels beperkt tot zaken waarin het een omgangsregeling na echtscheiding betreft. Zo heeft de Hoge Raad herhaaldelijk uitgesproken, dat het omgangsrecht dat voor de ouderniet-voogd uit artikel 8 voortvloeit, in bijzondere omstandigheden moet wijken voor het belang van het kind of voor zijn recht op privé- leven of gezinsleven (eveneens ontleend aan artikel 8 lid 1). Een afweging van de in het geding zijnde belangen - in het kader van artikel 8 lid 2 - geeft hier de doorslag. ${ }^{148}$ In deze zaken wordt een afbakening van het recht op respect voor het familie- of gezinsleven niet gegeven. Het bestaan van "family life" wordt verondersteld.

In zaken betreffende de beëindiging van de samenwoning van ongehuwde ouders gaat artikel 8 met betrekking tot het omgangsrecht pas in 1985 een rol spelen. Voor die tijd gold de regel, dat artikel 1: 161 lid 5 (oud) $\mathrm{BW}^{149}$ analoog kan worden toegepast in situaties die - wat betreft de gezinsband - gelijkenis vertonen met de in dat artikel geregelde omgang na echtscheiding zoals het geval dat omgang wordt verzocht tussen een vader en zijn (onwettige,) erkende kinderen. Een verzoek om omgang tussen een

148 HR 2 mei 1980, NJ 1980. 537. met noot E.A. Alkema: HR 25 september 1981, 13 november 1981. 19 maart 1982. 16 april 1982. 7 mei 1982 en 25 juni 1982, NJ 1982, 557-562, met noot E.A. Alkema.

149 Artikel 1: 161 lid 5 (oud)BW luidde: De rechter kan op vordering onderscheidenlijk verzoek van beide ouders of van één van hen een regeling treffen inzake de omgang tussen het kind en de ouder die niet met het gezag over het kind is of zal worden belast. $\mathrm{Bij}$ ontbreken van een zodanige voorziening in het echtscheidingsvonnis of in de latere beschikking, bedoeld in het eerste lid, kan deze alsnog door de kinderrechter worden getroffen. 
vader en zijn onwettige, niet-erkende kinderen was volgens deze rechtspraak echter niet-ontvankelijk. ${ }^{150}$

Op 22 februari 1985 komt de Hoge Raad tot een heroverweging van deze jurisprudentie. ${ }^{15 i}$ Volgens de Hoge Raad vloeit uit het in artikel 8 voor "een ieder" neergelegde recht op eerbiediging van zijn gezinsleven voort,

"dat een ieder van wie op grond van de omstandigheden van het geval moet worden aangenomen dat hij tot een kind in zodanige betrekking staat of heeft gestaan dat hij met dit kind een 'gezinsleven' in de zin van deze verdragsbepaling heeft, in beginsel, wanneer het kind niet met hem samenwoont, gerechtigd is met het kind regelmatig omgang of althans contact te hebben. Daarbij is het in het licht van art. 14 Verdrag onverschillig of de betrekking tot het kind berust op wettig ouderschap, op erkenning, op biologisch ouderschap of op een andere relatie die voor de toepassing van art. 8 met de voorgaande op één lijn kan worden gesteld."

In deze zaak ging het om een verzoek om een omgangsregeling tussen een vader en zijn (onwettige,) niet-erkende kind. Op grond van de hierboven

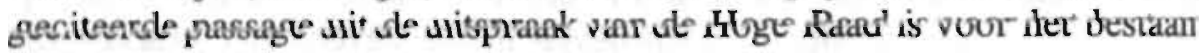
van "family life" in de zin van artikel 8 het biologisch vaderschap van de verzoeker voldoende. ${ }^{152}$ Dit blijkt ook uit de hier niet geciteerde overweging van de Hoge Raad, waarin deze vaststelt, dat de bijzondere kenmerken van de als gezinsleven aan te merken betrekking, zoals de aard van het ouderschap of die van een eventuele verwantschap en de tijdsduur van de samenleving en/of verzorging, bepalend kunnen zijn voor de inhoud van de vast te stellen omgangsregeling. Dit betekent mijns inziens dat de genoemde bijzondere kenmerken van de betrekking niet relevant zijn voor de vraag of sprake is van "family life". Die vraag wordt namelijk alleen gesteld on de ontvankelijkheid van het verzoek om een omgangsregeling vast te stellen. Pas nadat tot ontvankelijkheid is geconcludeerd, zal de inhoud van de eventueel vast te stellen omgangsregeling aan de orde komen. Ik spreek hier van een "eventueel" vast te stellen omgangsregeling,

150 HR 26 mei 1977, NJ 1978, 417; HR 4 november 1977, NJ 1978, 418, met noot E.A.A. Luijten: HR 10 december 1982, NJ 1983, 411 met noot E.A.A. Luijten. Zie ook HR 1 juli 1983, NJ 1984, 128: in de conclusie van A-G Ten Kate bij dit arrest wordt artikel 8 ECRM wel in de overwegingen betrokken. De $A_{-}-G$ ziet in de term "gezinsband" "een schakel naar het recht op eerbiediging van het 'privéleven' en het. "gezinsleven", zoals gewaarborgd in art. 8 ...".

151 HR 22 februari 1985, NJ 1986, 3 met noten van E.A.A. Luijien en E.A. Alkema.

152 Dit wordt bevestigd in o.a. HR 10 mei 1985, NJ 1986, 5 met noot W.H. H. Zie verder HR 15 juli 1985, NJ 1986, 6 en HR 16 mei 1986, NJ 1986, 627. 
omdat ook nog moet worden beoordeeld of er sprake is van één of meer van de in artikel 8 lid 2 genoemde omstandigheden, zoals de belangen van het kind, op grond waarvan het recht op eerbiediging van het gezinsleven van de verzoeker kan worden beperkt door het verzoek af te wijzen. ${ }^{153}$

Tot slot moeten aan het eind van deze sub-paragraaf nog twee zaken met betrekking tot het omgangsrecht besproken worden. In de eerste zaak, van 3 oktober 1989, gaat het om een incestpleger, die is veroordeeld tot een onvoorwaardelijke én een voorwaardelijke gevangenisstraf. ${ }^{154}$ Hierbij is hem de voorwaarde opgelegd, dat hij gedurende de proeftijd geen contact zal opnemen met zijn dochter (het slachtoffer) en haar - door hem verwekte - kind. Volgens de verdachte is deze voorwaarde in strijd met ittikel 8 ECRM. De Hoge Raad doet geen uitspraak over de vraag of ussen de verdachte en het kind dat hij bij zijn dochter heeft verwekt 'gezinsleven" in de zin van artikel 8 kan bestaan. De Hoge Raad oordeelt, lat

"ook indien ervan wordt uitgegaan dat van 'gezinsleven' ... reeds sprake is indien de betrekking tussen vader en kind berust op biologisch ouderschap, kunnen de rechten op eerbiediging van hun privé- en gezinsleven die het kind en zijn moeder aan het eerste lid van art. 8 EVRM ontlenen een bijzondere voorwaarde als de onderhavige rechtvaardigen."

De Hoge Raad doet deze zaak dus af onder artikel 8 lid 2, daarmee toepasselijkheid van artikel 8 veronderstellend, alhoewel de zinsnede "ook indien ervan wordt uitgegaan dat ..." twijfel hieromtrent bij de Hoge Raad suggereert. Ook al is in deze casus sprake van biologisch vaderschap, wat gezien de hiervoor besproken jurisprudentie voldoende is voor het bestaan van "gezinsleven" in de zin van artikel 8 , valt deze uitspraak mijns inziens te betreuren. Uit de volgende, hier kort aan te halen, zaken wordt duidelijk waarom het te rechtvaardigen zou zijn geweest indien de Hoge Raad op de

153 Zie noot 148. Zie bijv. ook HR 17 juni 1988. NJ 1988. 956 waarin het bestaan van "gezinsleven" wordt aangenomen op grond van de erkenning van de man. Het verzoek om een omgangsregeling is derhalve ontvankelijk. maar wordt toch afgewezen omdat de man niet de biologische vader van het kind is en met het kind nimmer heeft samengewoond noch het heeft verzorgd. De betrekking die de man met het kind heeft, is daarom van dien aard dat de rechten die de moeder en het kind aan artikel 8 kunnen ontlenen van zwaarder gewicht worden geacht dan het recht dat voor de man uit die bepaling voortvloeit.

154 HR 3 oktober 1989, NJ 1990, 443, met noot G.E. Mulder. 
regel, dat uit het biologisch vaderschap het bestaan van "gezinsleven" voortvloeit, een uitzondering had gemaakt.

In de (in de volgende sub-paragraaf uitgebreider te bespreken) zaak van 5 december 1986 betreft het een verzoek om omgang van een vrouw ten opzichte van een kind dat in onderling overleg is verwekt bij haar vriendin tijdens hun samenleving, maar dat is geboren nadat die samenleving is beëindigd. De Hoge Raad oordeelt in deze zaak, dat "een als 'gezinsleven' ... aan te merken betrekking tot een kind ... niet [kan] worden gevestigd door een overeenkomst als in het onderhavige geval tussen partijen gesloten. "155

De beschikking van het Gerechtshof Amsterdam met betrekking tot het verzoek van een spermadonor om omgang met het met zijn zaad verwekte kind is eensluidend. In deze beschikking is het Gerechtshof uitgegaan van het ten processe vaststaande oordeel van de kinderrechter, "dat door donorschap geen gezinsleven als bedoeld in art. 8 eerste lid EVRM ontstaat" en dat het "niet past bij overeenkomt te beschikken over bevoegdheden en verplichtingen de persoonlijke levenssfeer en familiebanden betreffende. Overeenkomsten over een kind zijn nietig. "156

Wamneer de Hoge Raad - avals in deze twee zaken - van oordeel is dat "gezinsleven" niet gevestigd kan worden bij overeenkomst, dan zou dit helemaal moeten gelden voor een misdrijf. Bij een overeenkomst kan nog gezegd worden dat er sprake is van instemming van beide partijen - de moeder en de sociale of biologische ouder van het kind - bij het ontstaan van een relatie tussen de sociale of biologische ouder en het kind, die al dan niet als "gezinsleven" kan worden aangemerkt. In het geval van een misdrijf ontbreekt die wil, sterker nog, zal vaak het tegenovergestelde gewenst worden door één van de betrokkenen partijen (de moeder van het kind).

De A-G merkt, naar mijn mening terecht, op in zijn conclusie bij de onderhávige zaak, dat

"de ... regel dat van gezinsleven in de zin van art. 8 lid 1 EVRM ... reeds sprake is indien de betrekking berust op biologisch ouderschap ... uitzondering [lijdt] in het geval waarin de sexuele gemeenschap, die de betrekking tussen de verwekker en het kind heeft doen ontstaan,

155 Zie noot 161 .

156 Rb.(kinderrechter) Utrecht 8 november 1988 en 14 december 1988, NJ 1989, 237 en in hoger beroep Gerechtshof Amsterdam 17 april 1989, NJ 1989,692. Bevestigd in HR 26 januari 1990. NJ 1990, 630, Nemesis $1990,89$. p. 94. Zie voor deze laatste uitspraak par. 4.3.2.3. 
door de verwekker met geweld of onder bedreiging met geweld of door gebruikmaking van het in art. $249 \mathrm{Sr}$ bedoelde gezag of overwicht van de vrouw is afgedwongen.

In zo een geval is immers de biologische band geforceerd door inbreuk op de geestelijke en lichamelijke integriteit van de vrouw." 157

De laatste zaak die ik hier nog wil bespreken is de beschikking van het Gerechtshof te 's-Gravenhage van 11 oktober 1985. In deze zaak was een man in zijn verzoek om een omgangsregeling door de kinderrechter nietontvankelijk verklaard. De man had na zijn echtscheiding de voogdij over zjn kind gekregen, maar werd hieruit ontheven in verband met zijn invaliditeit. Het kind werd vervolgens in een pleeggezin geplaatst. De verzoeker stelde, dat in deze situatie het omgangsrecht (artikel 1: 161 lid 5 (oud)BW), gelet op de familierechtelijke betrekking tussen hem en het kind en het recht op gezinsleven in artikel 8 ECRM analoog zou moeten worden toegepast. Volgens de kinderrechter ging deze stelling niet op "in een geval als het onderhavige, waarin door middel van de maatregel van outheffing door het openbaar gezag in aanzienlijke mate inbreuk is gemaakt op voormelde rechten, zulks ter bescherming van de rechten en belangen van een minderjarige."

Het Gerechtshof is het hiermee niet eens. Het stond van het begin af aan vast dat de vader vanwege zijn invaliditeit niet in staat zou zijn zelf de verzorging en opvoeding van zijn zoon op zich te nemen. Daarom werd het kind uithuisgeplaatst in het kader van een ondertoezichtstelling en vervolgens werd de vader uit de voogdij ontheven ten gunste van een vereniging (Kinderzorg). Wat betreft de contacten tussen vader en zoon "speelde het feit van de ontheffing als zodanig geen rol". Het Gerechtshof is van oordeel dat onder deze omstandigheden tussen de vader en de zoon "sprake is gebleven van een 'family life' als bedoeld in voormeld artikel." 158

Zoals hierna zal worden vermeld, heeft de Hoge Raad in een uitspraak van 10 november 1989 uitgesproken (in navolging van het arrest van het Europese Hof in de zaak Berrehab), dat een als "family life" aan te merken relatie tussen de biologische vader en zijn kind door latere gebeurtenissen

157 Zie noot 154. Vergelijk ook de conclusie van de A-G bij het in par. 4.3.2.2 te bespreken arrest (omgangsrecht van pleegouders) HR 6 november 1987 NJ 1988, 829: "Indien het kind onrechtmatig in het gezin van de pleegouders verblijft, dat wil zeggen tegen de wil van degenen die het gezag uitoefenen ... zullen de pleegouders naar het mij voorkomt in het algemeen geen rechten aan art. 8 EVRM kunnen ontlenen."

158 Rb.(kinderrechter) Rotterdam 29 mei 1985; Gerechtshof 's-Gravenhage 11 oktober 1985, NJ 1987, 454. 
dit karakter kan verliezen. Alhoewel deze uitspraak van het Gerechtshof 's-Gravenhage van 1985 is, derhalve van vóór de uitspraak van 10 november 1989, kan deze beschikking mijns inziens als voorbeeld genomen worden voor een geval waarin het bestaande "family life" níet op grond van latere gebeurtenissen is verbroken.

Kortom, iedere vorm van ouderschap lijkt op grond van de uitspraak van 22 februari 1985 van de Hoge Raad binnen de reikwijdte van het recht op respect voor het gezinsleven te vallen. De grens van dit recht wat betreft andere relaties is gelegen in het criterium "... of op een andere relatie die voor de toepassing van art. 8 met de voorgaande op één lijn kan worden gesteld." Mijns inziens had op de regel dat ouderschap voldoende is voor het bestaan van "gezinsleven" een uitzondering gemaakt dienen te worden ingeval het kind is verwekt door middel van een misdrijf, analoog aan de situatie waarin de verwekking van een kind het gevolg is van een overeenkomst. ${ }^{159}$ Voorts blijkt uit de uitspraak van het Gerechtshof 'sGravenhage van 11 oktober 1985, dat een als "family life" aan te merken betrekking tussen een ouder en zijn kind verbroken kan worden, maar dat dit geval zich niet voordoet door de enkele uithuisplaatsing in het kader van een ondertoezichtstelling van het kind en de ontheffing uit de voogdij van de ouder ten gunste van een vereniging.

4.3.2.2

Omgangsrecht bij andersoortige relaties met betrekking tot kinderen: niet-biologisch ouderschap

De in de vorige sub-paragraaf genoemde zaak van 22 februari 1985 ziet met name op de betrekking tot het kind op grond van wettig ouderschap, arkenning, biologisch ouderschap of een andere relatie die voor de toepassing van artikel 8 met de voorgaande op één lijn kan worden gesteld. ${ }^{160}$ Hieruit blijkt, dat de in dit arrest gegeven regel inzake het omgangsrecht niet opgaat voor andersoortige relaties met betrekking tot kinderen, relaties die voortvloeien uit niet-biologisch ouderschap. Welke zijn deze relaties die niet "voor de toepassing van art. 8" met de gegeven voorbeelden "op één lijn ... (kunnen) worden gesteld"? Wat houdt dit criterium in? De uitspraak van de Hoge Raad van 22 februari 1985 geeft hierover geen uitsluitsel, noch over de in het (in de vorige sub-paragraaf

159 Naar de huidige stand van zaken zal een dergelijke uitspraak als in HR 3 oktober 1989. NJ 1990, 443 niet meer gedaan kunnen worden in verband met de in par. 4.3.2.3 te bespreken beschikking HR i0 november 1989. NJ 1990. 628, waarbij de eerdere rechtspraak is herzien.

160 Zie het eerder op p. 252 opgenomen cital uit die zaak. 
opgenomen) citaat uit die zaak genoemde "omstandigheden van het geval" waaruit zou kunnen worden afgeleid "... dat hij tot een kind in zodanige betrekking staat of heeft gestaan dat hij met dit kind een 'gezinsleven' in de zin van deze verdragsbepaling heeft ...".

Uit de jurisprudentie van na deze uitspraak van 1985, blijkt dat in geval van niet-biologisch ouderschap andere eisen voor het bestaan van "family life" gelden dan voor de reeds besproken gevallen.

Zo blijkt uit de reeds aangehaalde zaak van 5 december 1986, waarin een rrouw een omgangsregeling verzoekt ten opzichte van een kind dat in onderling overleg is verwekt bij haar vriendin dat het bestaan van 'gezinsleven" door de Hoge Raad wordt getoetst aan de hand van de feitelijke omstandigheden van het geval. ${ }^{161}$ De Hoge Raad motiveert niet waarom in dit geval (anders dan in geval van biologisch ouderschap) aan feitelijke omstandigheden wordt getoetst.

De A-G gaat in de conclusie bij deze zaak uitvoerig in op, onder andere, de volgende uit het arrest van 22 februari 1985 afgeleide vragen: of de relatie tussen de vrouw en haar vriendin op éen lijn kan worden gesteld $a$. met een huwelijk, $b$. met een man/ vrouwrelatie buiten het huwelijk, waarbij de man de biologische vader is van het na het verbreken van de relatie geboren kind, waarbij de vader het kind wel zou willen maar niet zou kunnen erkennen; en of sprake is van $c$. sociaal ouderschap, waaronder pleegouderschap, "gezinsleven" in de zin van artikel 8 is. Volgens de A-G moeten de vragen a en b ontkennend, maar vraag c bevestigend beantwoord worden. Door de vragen a en $b$ negatief te. beantwoorden kan de in HR 22 februari 1985 ontwikkelde regel dat, in de in die zaak genoemde gevallen zonder meer sprake is van "family life", niet opgaan. Dit blijkt ook uit de volgende overweging van de A-G. In deze zaak is er geen sprake van "gezinsleven" omdat het kind geboren is na de beëindiging van de relatie tussen de verzoekster en de moeder van het kind en de verzoekster niet heeft bijgedragen aan de feitelijke opvoeding en verzorging van het kind. Van sociaal ouderschap en daarmee van "gezinsleven" in de zin van artikel 8 is dus volgens de A-G alleen sprake, indien bepaalde feitelijke omstandigheden zich voordoen, namelijk het bijgedragen hebben in de opvoeding en verzorging van het kind.

161 HR 5 december 1986, NJ 1987, 957 met noot E.A. Alkema. Volgens Alkema hangt het bestaan van een gezinsrelatie af van de feitelijke omstandigheden zodra bloedverwantschap tussen een ouder en een minderjarige ontbreekt. Mijns inziens geldt dit ook in sommige gevallen van bloedverwantschap, zoals het geval van een spermadonor. Vergelijk de in par. 4.3.2.1 genoemde zaak en noot 156. 
Dit wordt bevestigd in een uitspraak van de Hoge Raad van 6 november 1987, waarin het oordeel van het Gerechtshof, dat sprake is van gezinsleven niet onjuist wordt geacht. Het Gerechtshof had vastgesteld dat de minderjarige feitelijk ruim drie jaren onafgebroken in het gezin van appellante (de pleegmoeder) was verzorgd en opgevoed, waarvan twee jaren uit hoofde van ondertoezichtstelling. Uiteindelijk kwam het Gerechtshof tot het oordeel, dat dit verblijf van de minderjarige in het gezin van appellante "van zodanige aard is geweest, dat aangenomen moet worden dat tussen beiden zulke betrekkingen zijn ontstaan, dat kan worden gesproken van 'family life' in de zin van art. 8 lid 1 EVRM, welk effectief gezinsleven in beginsel moet worden beschermd". Volgens de Hoge Raad maakt het voor het bestaan van "family life" niet uit dat het kind gedurende een periode van twee jaar op grond van een ondertoezichtstelling in het pleeggezin verbleef. ${ }^{162}$ De feitelijke verzorging en opvoeding in het pleeggezin (het effectief gezinsleven) was hier derhalve doorslaggevend voor het bestaan van "gezinsleven" in de zin van artikel 8 lid 1 ECRM.

In een zaak van 20 november 1987 gaat de Hoge Raad, niet in op de vraag of er is een woangroep relaties (sociaal oulerschap) kumen ontstaan tussen de volwassenen en de kinderen, welke als gezinsleven in de zin van artikel 8 kunnen worden aangemerkt. De Hoge Raad stelt slechts vast, dat het Gerechtshof terecht de gevraagde omgangsregeling heeft geweigerd op grond van het welzijn van het kind. De A-G acht het in beginsel, althans voor wat betreft de volwassenen die zich in het bijzonder met de opvoeding en verzorging van een bepaald kind hebben beziggehouden, zeer wel mogelijk, dat er in een woongroep als "family life" aan te merken betrekkingen ontstaan. Volgens de A-G moet de vraag of dit in concreto voor een bepaalde volwassene geldt door de feitelijke rechter beoordeeld worden en zal dit oordeel moeten berusten op een waardering van de gegeven omstandigheden. ${ }^{163}$

Anders dan in de vorige drie zaken gaat het in de uitspraak van 15 mei 1987 niet om een omgangsregeling die verzocht is door een sociaal ouder, maar door een grootouder. In dit arrest stelt de Hoge Raad voor het eerst expliciet vast, dat er anders dan in de gevallen waar het arrest van 22

162 HR 6 november 1987. NJ 1988. 829 met noot E.A. Alkema.

163 HR 20 november 1987. NJ 1988. 281. In casu had het Gerechtshof te Amsterdam inderdaad op grond van de feiten en omstandigheden fde verzciekers hadden o.a. bijgedragen in verzorging en de opvoeding van het kind) geconcludeerd, dat sprake was van gezinsleven in de zin van artikel 8 . 
fabruari 1985 op ziet, in dit geval strengere eisen moeten worden gesteld vor het bestaan van "gezinsleven". Volgens de Hoge Raad gaat het om de vraag "of uit de gestelde feiten voortvloeit dat tussen grootmoeder en keinkind een zo nauwe persoonlijke betrekking bestaat dat voor een onderzoek naar de eventuele gerechtvaardigdheid van een omgangsregeling paats is". De eis van samenwoning in gezinsverband en "daadwerkelijke z)rg van de grootmoeder voor het kleinkind in een met gezinsleven gelijk te stellen situatie" die het Gerechtshof gesteld had, vond de Hoge Raad echter een te strenge maatstaf. ${ }^{164}$ Deze uitspraak is, wat betreft de eisen de moeten worden gesteld voor het bestaan van "gezinsleven", door de Hoge Raad nog eens bevestigd in een arrest van 25 juni 1993. ${ }^{165}$

Voorts wordt in zaak waarin een tante om een omgangsregeling verzoekt met haar minderjarige nicht hetzelfde criterium toegepast. De tante is vertegenwoordigster van de (Hindoestaanse) familie van de vader (die naar Suriname is uitgezet) van de minderjarige en heeft nog nooit contact met htt kind gehad. De rechtbank onderzoekt bij de beoordeling van het verzoek of door de tante voldoende concrete feitelijke omstandigheden zijn aangevoerd voor het bestaan van gezinsleven tussen haar en haar nicht. Het gat daarbij volgens de rechtbank om "omstandigheden waaruit voort kan viloeien dat tussen betrokkenen een zo nauwe persoonlijke betrekking bestaat dat voor een onderzoek naar de eventuele gerechtvaardigdheid van een omgangsregeling plaats is." De rechtbank komt tot een negatieve oordeel en het verzoek wordt afgewezen. In hoger beroep en in cassatie wordt deze uitspraak bevestigd. ${ }^{166}$

Samenvattend blijkt derhalve uit de bovenstaande rechtspraak ten aanzien van het omgangsrecht tussen personen - niet zijnde de biologische of wettige ouders - en minderjarige kinderen, dat voor het bestaan van gezinsleven noodzakelijk is dat voldoende concrete feitelijke omstandigheden worden gesteld, waaruit voort kan vloeien dat tussen betrokken een nauwe persoonlijke betrekking bestaat. Voorbeelden van dergelijke omstandigheden zijn het feitelijk bijgedragen hebben in de opvoeding en verzorging van het kind. Een aanwijzing voor het tegenovergestelde zou kunnen zijn dat er nooit contact is geweest tussen betrokkenen.

164 HR 15 mei 1987, NJ 1988, 654 met noot E.A. Alkema.

165 HR 25 juni 1993, NJ 1993, 628.

166 HR 2 oktober 1992, NJ 1992, 768, waarin de beschikking van de kinderrechter van de Rb. 's-Gravenhage van 21 augustus 1991 en de beschikking van het Gerechtshof 's-Gravenhage in hoger beroep van 29 november 1991 zijn weergegeven. 
4.3 .2 .3

Het omgangsrecht na de beschikking van de Hoge Raad van 10 november 1989

Op 10 november 1989 komt de Hoge Raad tot herziening van zijn eerdere rechtspraak. ${ }^{167}$ Bij deze herziening baseert de Hoge Raad zich op de uitspraak van het Europese Hof van 21 juni 1988 in de zaak Berrehab. ${ }^{168}$ Uit deze uitspraak vloeit volgens de Hoge Raad voort, dat het bestaan van "family life" afhangt van de aard van de relatie tussen de ouders van het kind. Deze relatie moet een wettig huwelijk zijn of een relatie die daarmee op één lijn kan worden gesteld. De enkele geboorte van een kind uit een dergelijke relatie doet de als "family life" aan te merken betrekking ontstaan tussen dat kind en zijn beide ouders. Dit is ook het geval als de geboorte plaatsvindt nadat de samenleving tussen de ouders definitief is verbroken. ${ }^{169}$

167 HR 10 november 1989, NJ 1990, 628 met noten van E.A.A. Luijten en E.A. Alkema; NJCM-Bulletin 15-5 (1990), pp. 581-588 met noot J. van der Velde.

168 EHRM 21 juni 1988, Berrehab Case, \$21, p. 14. Zie parr. 4.2.2, p. 215.

169 Vergelijk HR 8 februari 1991, NJ 1992, 21 (met noot E.A.A. Luijten onder HR 7 juni 1991. NJ 1992, 25), waarin het gaat om een kind dat is geboren ná de echtscheiding van de ouders, maar waarbij de vader op grond van artikel 1:197 tweede zin BW in familierechtelijke betrekking tot het kind staat. De man hoeft derhalve geen bijkomende omstandigheden te stellen waaruit voortvloeit dat er tussen hem en het kind een als "family life" aan te merken band bestaat. Opmerkelijk in deze zaak is overigens, dat de Hoge Raad - na de constatering dat een kind en zijn niet met het ouderlijk gezag belaste ouder op grond van artikel 1: 161a lid $1 \mathrm{BW}$ recht op omgang met elkaar hebben - uitspreekt dat de medewerking die de met het gezag beklede ouder daartoe in het algemeen met het oog op dat omgangsrecht zal moeten verienen, met zich zal brengen dat hij de andere ouder informeert over belangrijke feiten en omstandigheden met betrekking tot het kind. Op grond hiervan acht de Raad het dan ook niet uitgesloten, dat een rechter ingeval hij een verzoek tot het treffen van een omgangsregeling niet toewijsbaar acht.

"wel - indien zich geen gronden overeenkomstig die welke in art. 161a lid 3 (nieuw) zijn vermeld daartegen verzetten - een regeling vaststelt die daartoe beperkt blijft dat de met het gezag beklede ouder verplicht is de andere ouder in de door de rechter te bepalen omvang en vorm - inlichtingen betreffende het kind te geven. Een dergelijke verplichting - die de uitoefening van het gezag door de daarmede beklede ouder niet beperkt - is immers aan te merken als een minder vergaande dan die welke evengenoemde ouder verplicht eraan mede te werken dat de andere ouder zijn ongangsrecht uitoefent, en door de aanvaarding ervan wordt voorkomen dat de band tussen het kind en de andere ouder in ernstiger mate wordt verbroken dan wordt gerechtvaardigd door de gronden die zich tegen het treffen van een omgangsregeling verzetten." 
Volgens de Hoge Raad kan het ook niet worden uitgesloten, dat "uit na de geboorte van het kind ontstane omstandigheden ... [voortvloeit] dat tussen de vader en het kind zich een zo nauwe persoonlijke betrekking vormt dat deze als 'vie familiale/family life' moet worden beschouwd."

Voorts kan een als "family life" aan te merken relatie tussen de biologische vader en zijn kind door latere gebeurtenissen dit karakter verliezen.

Het bovenstaande brengt mee, dat de verzoeker van een omgangsregeling die slechts de biologische vader van zijn kind is (hij heeft het kind niet erkend), bijkomende omstandigheden moet stellen waaruit voortvloeit dat er tussen hem en het kind een als "family life" aan te merken betrekking bestaat.

In latere zaken zijn deze overwegingen van de Hoge Raad herhaaldelijk toegepast. Zo moet een spermadonor aantonen dat op grond van bijkomende omstandigheden (de feitelijke contacten tussen hem en het met zijn zaad verwekte kind) een dusdanige band tussen hem en het kind is ontstaan, dat sprake is van een als "family life" aan te merken betrekking. Het gerechtshof had echter in zijn uitspraak - waarvan cassatie werd verzocht - geoordeeld, dat deze feitelijke contacten een te summier karakter hadden om in combinatie met het donorschap tot "vie familiale/family life" te besluiten. Volgens de Hoge Raad geeft dit oordeel van het Gerechtshof geen blijk van een onjuiste rechtsopvatting. ${ }^{170}$

Een arrest van de Hoge Raad van 22 oktober 1993 betreft de relatie van een vader tot zijn, door hem erkende, minderjarige dochter ${ }^{171}$ Het kind is geboren uit een relatie van de vader met de moeder van het kind met wie de vader heeft samengewoond. Deze samenleving van de ouders is voor de geboorte van het kind beëindigd. Een verzoek van de vader om een omgangsregeling van de vader was afgewezen vanwege deze beëindiging van de samenleving van de ouders. Uit de uitspraak van de Hoge Raad komen een aantal punten naar voren.

Ten eerste is het Gerechtshof er in deze zaak veronderstellenderwijs van uitgegaan dat "de enkele erkenning door de vader" genoeg is voor het bestaan van "family life". De Hoge Raad wijst deze opvatting in zijn

Zie ook: HR 8 februari 1991, NJ 1992, 22; HR 5 april 1991, NJ 1992, 24 en HR 12 juni 1992, NJ 1992, 589 (impliciet).

170 HR 26 januari 1990, NJ 1990, 630, Nemesis 1990, 89, p. 94; vervolg op Rb.(kinderrechter) Utrecht, 8 november en 14 december 1988. NJ 1989, 237 en Gerechtshof Amsterdam 17 april 1989, NJ 1989, 692.

171 HR 22 oktober 1993. NJ 1994, 153 met noot WH-S. 
algemeenheid af, voor zover hieruit wordt afgeleid dat het voor het ontstaan van een dergelijke betrekking niet voldoende is dat het kind is geboren uit ouders die, zoals in deze zaak, al geruime tijd met elkaar samenleefden. De Hoge Raad bepaalt, opnieuw, dat indien een kind wordt geboren uit een relatie die in voldoende mate met die van een huwelijk op één lijn gesteld kan worden, aangenomen moet worden dat de enkele geboorte tussen dat kind en zijn beide ouders een als "gezinsleven" als bedoeld in artikel 8 aan te merken betrekking doet ontstaan, "ook als die geboorte plaatsvindt nadat de samenleving tussen de ouders definitief is verbroken". Erkenning van het kind door de vader is derhalve geen noodzakelijke voorwaarde, biologisch vaderschap is in dergelijke omstandigheden voldoende. in $^{17}$

Ten tweede meent de Raad in verband met de rechtsgevolgen die door de wet aan de erkenning van een kind worden verbonden, dat "er geen goede grond (is) om aan te nemen dat - anders dan tussen een vader en diens uit een huwelijk geboren wettige kind - tussen het kind en degeen die het heeft erkend, niet in beginsel een als 'vie familiale/family life' te kwalificeren betrekking zou bestaan." Erkenning is dus in beginsel voldoende voor het bestaan van "gezinsleven". Ik neem aan dat hiermee bedoeld wordt, dat de erkenning van een kind grond geeft voor het vermoeden dat sprake is van een relatie die op éen lijn kan worden gesteld met het huwelijk. Uit de omstandigheden van het geval zou dan kunnen blijken dat dit niet het geval is.

Ten derde acht de Hoge Raad het onvoldoende voor de conclusie dat een eenmaal bestaand "gezinsleven" nadien is verbroken, dat de ouders voor de geboorte van het kind hun relatie definitief hebben beëindigd en de vader zijn kind daarna maar één maal heeft gezien. Volgens de Hoge Raad is het voor het kunnen trekken van die conclusie noodzakelijk dat de

172 Zie bijvoorbeeld HR 24 april 1992, NJ 1992, 478: het gerechtshof had in deze zaak geoordeeld dat door het feit dat de vader zijn kind na de geboorte zeven weken lang dagelijks in het ziekenhuis bezocht, niet een zodanig nauwe persoonlijke band tussen hen was ontstaan, dat deze kan worden aangemerkt als "family life". Volgens de Hoge Raad ging het Gerechtshof er kennelijk van uit dat deze relatie niet in voldoende mate met die van een huwelijk op een lijn te stellen was om haar als "gezinsleven" te kunnen beschouwen. Volgens de HR noopten de feitelijke contacten tussen de vader en het kind niet tot een ander oordeel. In deze zaak speelt derhalve: voor het bestaan van "gezinsleven" géén rol, dat de vader het kind niet had erkend. Overigens hadden de ouders van het kind wèl voor de geboorte - met onderbrekingen - samengewoond (de relatie was een dag voor de geboorte verbroken en daarmee ook de samenleving), doch kennelijk was dit voor het Gerechtshof onvoldoende reden om de relatie van de ouders met een huwelijk op én lijn te stellen. Zo ook HR 17 december 1993, NJ 1994, 360. 
omstandigheid dat de vader het kind sinds de geboorte slechts één keer heeft gezien in samenhang met andere, zwaarwegende feiten en omstandigheden wordt beoordeeld. Dat de ouders uitelkaar zijn gegaan vocr de geboorte van het kind is volgens de Raad niet een dergelijke zwarwegende omstandigheid. Welke die zwaarwegende omstandigheden dan wel kunnen zijn, vermeldt deze uitspraak van de Hoge Raad niet. ${ }^{173}$

Eventueel valt een dergelijke omstandigheid wel af te leiden uit een arrest van de Hoge Raad van 17 december $1993^{174}$. Het Gerechtshof Amsterdam had, in navolging van de kinderrechter geoordeeld, dat de relaie van de ouders van het kind niet op één lijn gesteld kon worden met eenhuwelijk, waardoor de enkele geboorte van het kind uit die relatie niet voldoende was voor het bestaan van "family life". Zo er al sprake van een dergelijke betrekking tussen de biologische (niet-erkennende) vader en het kind was, dan vloeide dit voort uit het zeer kortstondig samenwonen van de cuders. Het gerechtshof, dat gezien deze formulering kennelijk al niet ovetuigd was van het bestaan van "family life" tussen de vader en het kind, besliste vervolgens dat ook indien aangenomen wordt dat er sprake was van "gezinsleven", dat dit in ieder geval op het moment van de beslissing niet (meer) het geval was. Daarbij wees het gerechtshof op de omstandigheid dat in de periode tussen het einde van de samenwoning en het tijdstip waarop het gerechtshof besliste, er slechts enkele malen contact tussen de vader en zijn kind was geweest, wat niet aan de moeder, maar aan hem zelf is te wijten zou zijn. Dit gold volgens het gerechtshof ook voor het effect van zijn gewelddadig optreden op de betrekkingen tussen hem en zijn kind - er werd naar aanleiding daarvan twee keer een straatverbod aan hem opgelegd. De Hoge Raad meent dat de gedachtengang van het gerechtshof niet blijk geeft van een onjuiste rechtsopvatting. Ook is die niet onbegrijpelijk.

Hieruit zou afgeleid kunnen worden, dat het enkele uitelkaar gaan van de ouders en het daarna plaatsvinden van slechts een gering aantal contacten waarschijnlijk op zichzelf niet een zwaarwegend feit oplevert op grond waarvan bestaand "family life" verbroken moet worden geacht. Het feit dat dit geringe contact echter het gevolg is van gewelddadig optreden van de vader zou wellicht wèl een zodanig zwaarwegende omstandigheid opleveren.

173 Zo ook al eerder HR 11 juni 1993, NJ 1993, 560. Zie over, onder andere, deze uitspraak: $P$. Vlaardingerbroek, De 'Blote' verwekker en het omgangsrecht, pp. 223226.

174 HR 17 december 1993, NJ 1994, 360. De gegevens over de inhoud van de beschikking van het Gerechtshof Amsterdam in deze zaak zijn, bij gebrek aan de tekst van deze beschikking, ontleend aan de uitspraak van de Hoge Raad. 
Bij de voorgaande bespreking van het omgangsrecht in relaties met betrekking tot kinderen die niet voortvloeien uit wettig of onwettig (al dan niet uitsluitend biologisch) ouderschap ${ }^{175}$ zijn zowel uitspraken aan de orde gekomen van vóór de beschikking van de Hoge Raad van 10 november 1989 als van daarna. In deze uitspraken zien we dat voor het bestaan van "family life" concrete, feitelijke omstandigheden gesteld moeten worden; sprake moet zijn van een nauwe persoonlijke band tussen betrokkenen. Veelal zal het bij de bedoelde omstandigheden gaan om regelmatige contacten tussen de verzoeker van een omgangsregeling en het kind en/of een feitelijke bijdrage aan de opvoeding en verzorging van het kind gedurende een bepaalde periode. Anders dan de regel die de beschikking van 22 februari 1985 geeft voor het geval dat een betrekking tot het kind berust op wettig ouderschap, op erkenning, op biologisch ouderschap, is hier het enkele bestaan van bijvoorbeeld pleegouderschap of het zijn van grootouder niet voldoende.

De uitspraak van november 1989 heeft in zoverre een verandering teweeggebracht in de jurisprudentie ten aanzien van het bestaan van "gezinsleven" tussen personen die niet de ouders van een kind zijn enerzijds en het betrokken kind anderzijds, dat aan de hand van de

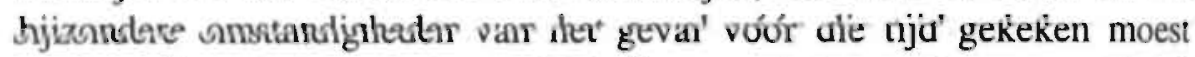
worden of sprake was van een relatie die voor de toepassing van artikel 8 op één lijn kon worden gesteld met een betrekking op grond van wettig ouderschap, erkenning of biologisch ouderschap. Ná de uitspraak van 10 november 1989 moet aan de hand van de omstandigheden worden beoordeeld of sprake is van een betrekking tussen personen die met een wettig huwelijk op één lijn kan worden gesteld. Uit de jurisprudentie blijkt vooralsnog niet, dat aan de aan te voeren bijzondere omstandigheden nu zwaardere eisen gesteld worden.

Welbeschouwd, brengt de uitspraak van de Hoge Raad van 10 november 1989 dan ook alleen verandering in de positie van de biologische (nieterkennende) vader, die nu voor het bestaan van "family life" bijkomende omstandigheden moet stellen. Ten aanzien van alle andere betrekkingen ten opzichte van kinderen die zijn geboren uit relaties die niet op één lijn te stellen zijn met het huwelijk, eiste de jurisprudentie al het bestaan van 
dergelijke omstandigheden. ${ }^{176}$ Deze jurisprudentie werd in feite in de besclikking van 10 november 1989 slechts bevestigd.

Sanenvattend, geeft de beschikking van 10 november 1989 een bruikbare intenretatie van het begrip "family life", die bovendien alle mogelijke relaties met betrekking tot kinderen dekt.

Het uit deze uitspraak te destilleren criterium voor de afbakening van het begri "familie- of gezinsleven"/"family life" bestaat uit de volgende elementen:

a. er moet sprake zijn van een huwelijk (I) tussen de ouders of een daarnee op één lijn te stellen relatie (II) waaruit het kind is geboren of b. val gebeurtenissen of omstandigheden ná de geboorte van het kind waartit een als "family life" aan te merken betrekking is ontstaan én c. deals "family life" te beschouwen band is niet verbroken door latere gebeurtenissen.

\subsubsection{Erkenning en "family life"}

De vigende categorie binnen het personen- en familierecht waarin artikel 8 een grote rol speelt is het recht met betrekking tot de erkenning van onwettige kinderen. De wetsbepaling die hier voornamelijk in het geding is, is artikel 1: 224 , eerste lid, aanhef en onder d BW. Dit artikel bevat als grond voor de nietigheid van de erkenning van een kind, het ontbreken van de toestemming van de moeder. De vragen, die in de rechtspraak aan de orde komen zijn, of het weigeren van de toestemming door de moeder in strijd is met het recht op respect voor het familie- en gezinsleven van de vader en zo ja, onder welke voorwaarden dit het geval is. Hoewel de ten aanzien van deze vragen gevormde jurisprudentie op zich zeer interessant is, biedt deze rechtspraak slechts zelden aanknopingspunten voor de afbakening van het recht op respect voor het familie- en gezinsleven in

176 Ik wijs er nogmaals op dat Hoge Raad 22 oktober 1993. NJ 1994. 153 doet vermoeden, dat door de Raad wordt aangenomen dat ingeval van erkenning van een kind door de vader, sprake is van het bestaan van een relatie die op één lijn gesteld kan worden met het huwelijk.

Een uitzondering op de hier besproken regel dat ingeval van louter biologisch vaderschap bijkomende omstandigheden moeten worden gesteld is Gerechtshof Amsterdam 19 januari 1995, NJCM-Bulletin 20-5 (1995), pp. 585-590 met noot $T$. Loenen. Mijns inziens wordt in deze zaak het "family life" veel te ver opgerekt. Deze uitspraak is wellicht verklaarbaar op grond van het feit dat de ongangsregeling. door het kind werd verzocht. 
artikel 8 ECRM. Het bestaan van "gezinsleven" wordt in deze zaken veelal zonder motivering verondersteld. ${ }^{1 m}$

In twee zaken van 18 mei 1990 bevestigt de Hoge Raad het oordeel van het Gerechtshof in deze zaken, dat sprake is van "gezinsleven" tussen de man die erkenning van zijn kinderen wenst en die kinderen op grond van de omstandigheden,

- dat hij de biologische vader van die kinderen is,

- dat hij met de kinderen heeft samengewoond en tijdens die samenwoning betrokken was bij de verzorging en opvoeding van de kinderen en

- dat na verbreking van de relatie met de moeder en beëindiging van de samenwoning regelmatig contact tussen de man en de kinderen is blijven bestaan op grond van een in onderling overleg tot stand gekomen omgangsregeling. ${ }^{178}$

Met deze overweging voldoen deze uitspraken derhalve aan het criterium dat met betrekking tot het omgangsrecht is ontwikkeld in de uitspraak van de Hoge Raad van 10 november 1989. ${ }^{179}$ Dat dit ook de bedoeling is blijkt uit de uitspraak van de Hoge Raad van 22 februari 1991. Hierin gaat het om het verzoek van een vader de rechtbank te gelasten een erkenningsakte op te maken, nu hij het kind wenst te erkennen, doch de

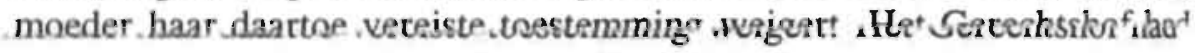
in hoger beroep dit verzoek niet-ontvankelijk verklaard, omdat het het enkele feit van het biologisch vaderschap niet toereikend achtte voor het bestaan van "family life". De aard en de omvang van de contacten tussen de vader en het kind vond het Gerechtshof van een te summier karakter om tot een ander oordeel te komen. Volgens de Hoge Raad heeft het Gerechtshof hiermee terecht - in overeenstemming met de beschikking van 10 november 1989 - voor het aanvaarden van een als "family life" aan te merken betrekking meer dan het enkele biologische vaderschap geëist.

"Weliswaar betrof dit oordeel (van 10 november 1989, CS) een verzoek van de biologische vader tot het treffen van een omgangsregeling met zijn kind, maar er bestaat ... geen grond om met betrekking tot een verzoek als het onderhavige anders te oordelen, gezien de ingrijpende consequenties die erkenning van een natuurlijk

177 Zie bijvoorbeeld HR 8 april 1988, NJ 1989, 170 met noot E.A.A. Luiten; HR 10 november 1989, NJ 1990, 450 met noot E.A.A. Luijten; HR 21 december 1990, NJ 1991, 741 met noten van E.A.A. Luijten en E.A. Alkema; HR 8 november 1991, NJ 1992, 440; Gerechtshof Amsterdam 21 december 1992, NJ 1994, 131 en Gerechtshof 's-Hertogenbosch 2 september 1993, NJ 1994, 283.

178 HR 18 mei 1990, NJ 1991, 374 en 375 met noten E.A.A. Luijten en E.A. Alkema. Impliciet in HR 20 december 1991, NJ 1992, 598 met noot E.A.A. Luijten.

179 Zie hierboven par. 4.3.2.3 en noot 167. 
kird door zijn verwekker meebrengt voor de tussen hen bestaande berekking."

Mijs inziens is deze uitspraak gelukkig te noemen, omdat hierdoor althans wat jetreft het omgangsrecht en de erkenning uniformiteit bestaat ten aanzen van de uitleg van het begrip "family life". Deze rechtspraak is tevers bevestigd in latere uitspraken. ${ }^{181}$

\section{3...5 Ouderlijk gezag en "family life"}

In dejurisprudentie ten aanzien van het ouderlijk gezag over kinderen ${ }^{182}$ in he geval de ouders niet of niet meer met elkaar gehuwd zijn, doet zich hetzefde verschijnsel voor als bij de erkenning van onwettige kinderen. De HogeRaad stapt vaak over de vraag van het bestaan van "family life" heen en gat onmiddellijk over tot de vaststelling, dat ouderlijke macht behoort tot dedoor artikel 8 beschermde rechten welke uit het "gezinsleven" tussen oudes en kinderen voor elk hunner voortvloeit. Vervolgens stelt de Hoge Raadeen aantal voorwaarden voor het bekleden van de ouders met de gezanenlijke ouderlijke macht, zoals het hebben van familierechtelijke betrekkingen met de betrokken kinderen. ${ }^{183}$ Volgens de Hoge Raad is deze voorwaarde een inmenging in het "gezinsleven" die gerechtvaardigd is onder lid 2 van artikel 8 . Uit het voorgaande blijkt derhalve, dat het

180 HR 22 februari 1991, NJ 1991, 376 met noot E.A.A. Luijten. Overigens vernietigt de HR de beschikking van het Gerechtshof wegens gebrek aan motivering van het oordeel dat de aard en de omvang van de contacten tussen de vader met het kind voor het bestaan van "family life" een te summier karakter hadden.

181 Vrijwel gelijke voorwaarden voor het bestaan van "family life" worden, bijvoorbeeld, gesteld in zaken met betrekking tot erkenning, in gevallen waarin de vader zijn kind niet kan erkennen, omdat het is geboren binnen de in artikel 1: 198 lid 1 BW genoemde termijn van 306 dagen na ontbinding van het huwelijk van de moeder met een andere man (zodat de moeder diens vaderschap moet ontkennen) en geen huwelijk tussen de moeder en de biologische vader plaats kan/zal vinden zoals deze wetsbepaling eist (artikel 1: 198 lid 3 BW). Zie Rb. Amsterdam 14 januari 1992, NJ 1992, 401 en HR 17 september 1993. NJ 1994. 373 met noot WH-S en E.A. Alkema.

182 HR 4 mei 1984, NJ 1985, 510; HR 21 maart 1986, NJ 1986, 585-588; HR 24 februari 1989. NJ 1989, 742; al deze beschikkingen met noten van E.A. Alkema en E.A.A. Luijten.

183 De andere voorwaarden zijn: a. tot de uitoefening van het gezag over het kind bevoegd zijn; b. beide ouders wensen met de ouderlijke macht bekleed te worden; c. er is een goede onderlinge verstandhouding tussen de ouders; $d$. het belang van het kind verzet zich niet tegen het uitoefenen van de ouderlijke macht door de ouders. 
bestaan van "family life" tussen de betrokken ouders en kinderen verondersteld wordt.

In een uitspraak van 23 maart 1990 geeft de Hoge Raad wel een criterium voor de afbakening van het begrip "gezinsleven". ${ }^{124}$ Deze zaak betreft niet het worden bekleed met de ouderlijke macht zelf, doch een ondertoezichtstelling en uithuisplaatsing van een kind, wat grote invloed heeft op de uitoefening van de ouderlijke macht door de ouders. In het geding is de mogelijkheid van het instellen van beroep tegen de beslissing van de Utrechtse kinderrechter om het kind slechts tijdelijk bij de grootouders onder te brengen totdat een geschikt opvanggezin is gevonden, terwijl het kind voorheen al drie en een half jaar in het kader van een ondertoezichtstelling en uithuisplaatsing (en ook na afloop daarvan), bij de grootouders heeft gewoond. De grootmoeder ging tegen de beslissing van de kinderrechter in beroep bij het Gerechtshof Amsterdam maar is daarin niet-ontvankelijk verklaard, omdat beroep slechts voor de ouders openstond. Deze mogelijkheid om beroep in te stellen dient, indien deze bepaling van toepassing is, te worden getoetst aan artikel $8 .{ }^{1 \text { tos }}$ Wat betreft de toepasselijkheid van artikel 8 overweegt de Hoge Raad, dat sprake is van een als "family life" aan te merken samenlevingsverband tussen de grootmoeder en het kind, op grond van de omstandigheden dat het kind drie en een half jaar lang deel uitgemaakt heeft van het gezin van de grootouders en de grootmoeder gedurende die periode de dagelijkse zorg voor het kind heeft gehad. In een (tussen)beschikking van het Haagse Gerechtshof van 7 december 1990 - die de zaak ten gronde betreft - wordt deze opvatting van de Hoge Raad herhaald en wordt hieraan toegevoegd dat er (op dat moment) geen feiten en omstandigheden zijn gebleken of aannemelijk geworden, waaruit moet worden geconcludeerd dat het bestaande gezinsleven door latere gebeurtenissen (dat wil zeggen gebeurtenissen na genoemde beslissing van de kinderrechter, het ijkpunt van de Hoge Raad) is opgehouden te bestaan. ${ }^{186}$ Criteria voor het bestaan van "gezinsleven" zijn op grond van deze zaak derhalve het samenleven in gezinsverband gedurende een bepaalde periode gedurende welke de

184 HR 23 maart 1990, NJ 1991, 150 met noot E.A.A. Luijten.

185 Vergelijk de hespreking in de paragrafen 2.4.2.1 en 4.2.2 van de procedurele eisen die volgens de Straatsburgse jurisprudentie uit artikel 8 voortvloeien, de uitspraken EHRM 8 juli 1987. Case of $W v$. UK, $\$ \$ 60$ (c), 61-65, pp. 27-29; EHRM 8 juli 1987. Case of $B$ v. UK, $\$ \$ 61$ (c), 62-65, pp. 72-74; EHRM 8 juli 1987, Case of $R$ v. $U K, \$ \$ 65(\mathrm{c}), 66-70$, pp. 117-119 en EHRM 8 juli 1987, Case of $H v$. UK. $\$ \$ 87-$ 90, pp. 63-64.

186 Gerechtshof 's-Gravenhage 7 december en 26 april 1991. NJ 1992. 102. Het gerechtshof verwijst hierbij naar EHRM 21 juni 1988, Berrehab Case. NJ 1988, 746 en HR 10 november 1989, NJ 1990, 628. 
(groot)ouder de dagelijkse zorg voor het kind heeft gehad en het eventueel bestaan van feiten of omstandigheden op grond waarvan gezinsleven kan zijn opgehouden te bestaan.

Een beschikking van de Hoge Raad van 19 november 1993 betreft een soortgelijke casus. ${ }^{187}$ Het verschil met de vorige zaak is erin gelegen dat de grootouders nog niet de dagelijkse zorg voor het kind hebben gedragen en het kind niet met hen in gezinsverband heeft samengeleefd. Het cassatiemiddel voert dan ook aan, dat artikel 8 alleen van toepassing is indien sprake is van een "nauwe persoonlijke betrekking" tussen de grootouders en het kind en niet het nastreven daarvan. De Hoge Raad overweegt hieromtrent, dat plaatsing van een minderjarige in een pleeggezin niet alleen de voortzetting van een effectief gezinsleven raakt (dat door verzorging van het kind door de grootouders is ontstaan) doch ook verhindert dat de grootouders uitvoering kunnen geven aan hun verlangen om een gezinsleven met hun kleinkind tot stand te brengen. Vervolgens wijst de Raad op de uitspraak van het Europese Hof in de zaak Marckx, waarin is uitgesproken dat de band tussen naaste bloedverwanten als grootouders en kleinkinderen in beginsel in aanmerking komt voor bescherming onder artikel $8 .^{188}$ In hoeverre bovendien feitelijke omstandigheden dienen te worden vastgesteld - teneinde de bescherming van artikel 8 te kunnen genieten -, zo vervolgt de Hoge Raad, "wordt van geval tot geval bepaald door de context waarin dat beroep wordt gedaan." Mijns inziens is dit juist.

Zowel uit de Europese als de hiervoor besproken Nederlandse rechtspraak blijkt, dat samenleving in gezinsverband en daadwerkelijke verzorging van kinderen, niet een conditio sine qua non zijn voor het bestaan van "family life". Zoals al bleek bij de bespreking van de rechtspraak inzake het omgangsrecht, kan door gebeurtenissen na de geboorte van een kind "gezinsleven" ontstaan als dit al niet bestaat door de geboorte van een kind uit een relatie die op één lijn is te stellen met een huwelijk. Deze situatie doet zich per definitie voor bij grootouders: de band tussen grootouders en kleinkind kan pas tot stand komen na de geboorte van het kind; de enkele bloedverwantschap tussen grootouders en kleinkind is niet voldoende voor het bestaan van "gezinsleven". De bedoelde latere gebeurtenissen hoeven niet per se te bestaan uit samenleving met het kind, het kan - bijvoorbeeld - ook ontstaan door regelmatige contacten met het kind. Van de omstandigheden van het concrete geval hangt af of dergelijke gebeurtenissen genoeg zijn voor het ontstaan van "family life".

188 Zie EHRM 13 juli 1979, Marckx Case, \$45, p. 21 en hierboven p. 212. 
In de onderhavige zaak lijkt de Hoge Raad overigens niet al te zware eisen te stellen aan de feitelijke omstandigheden van de zaak: in deze zaak waarin het noodzakelijk was dat de verzorging en opvoeding van het kind aan anderen dan de ouders wordt toevertrouwd, gaat het om grootouders die hebben aangegeven hun kleinkind in hun eigen gezin te willen opnemen en zelf op te willen voeden en verzorgen. Het rekening houden met deze wens acht de Hoge Raad een belang waarmee rekening dient te worden gehouden bij de beslissing omtrent de plaatsing van het kind in een pleeggezin, kortom de Hoge Raad acht het een belang dat onder bescherming van artikel 8 valt. Over feitelijke contacten tussen de grootouders en het kind vermeldt de uitspraak niets. Het tonen van zorg voor de kleinkinderen en de wens hen in hun gezin op te nemen en op te voeden is in dit geval kennelijk voldoende.

Overigens wijst de Hoge Raad er ook nog op dat het voor de beslissing relevant is, dat deze mogelijk een onomkeerbaar karakter heeft. Wordt het kind in een pleeggezin geplaatst dan is het mogelijk, dat na verloop van tijd het besluit hiertoe niet meer kan worden teruggedraaid, omdat dat in strijd zou zijn met de belangen van de minderjarige, die doorslaggevend zijn. ${ }^{189}$

Tensiotte verüient nog bespreking de uitspraak van de Hoge Raad van 15 april 1994. ${ }^{\infty}$ Deze zaak - die meermalen de aandacht van de pers heeft gekregen - draait om het kind Amber, dat door haar tante vanuit Brazilië naar Nederland is gebracht om daar te worden opgenomen in een pleeggezin. Het doel daarvan (tijdelijke verzorging of adoptie) is een twistpunt tussen de moeder (eiseres tot cassatie) en de pleegouders. In het geding is de eis van de moeder tot afgifte van het kind. In verband hiermee overweegt de Hoge Raad, dat tussen de moeder en het kind een als "gezinsleven" in de zin van artikel 8 aan te merken betrekking bestaat door het enkele feit van de geboorte van het kind uit de moeder. De Raad vervolgt daarop met de constatering dat een wezenlijk onderdeel van het recht op respect voor het gezinsleven is, het recht van de moeder en het kind op verzorging en opvoeding van het kind door de moeder en op het wederzijds genot van elkaars gezelschap. ${ }^{\text {(9i }}$ Indien hun dit zou worden belet, zou er sprake zijn van een inmenging in dit recht die

189 De HR verwijst hierbij naar EHRM 28 mei 1985. Case of Abdulaziz, Cabales and Balkandali, $\$ 62$, p. 32, N] 1988, 187 en EHRM 8 juli 1987. Case of Wv. UK, $3 \$ 52-64$, p. 28 e.v.

190 HR 15 april 1994, NJ 1994, 576.

191 De A-G noemt ook nog het recht van de moeder op uitoefening van het ouderlijk gezag over het kind (punt 14 van de conclusie bij dit arrest). 
gerechtvaardigd moet worden op grond van het tweede lid van artikel 8 . Het criterium van de Hoge Raad, dat door het enkele feit van de geboorte "family life" tussen een moeder en haar kind ontstaat, is in volledige overeenstemming met de Europese jurisprudentie, met name de uitspraak in de zaak Marckx, waarnaar de Raad dan ook terecht verwijst. ${ }^{192}$

Samenvattend blijkt uit de jurisprudentie in verband met het ouderlijk gezag, dat er diverse criteria worden gegeven voor het bestaan van het "familie- en gezinsleven". Tussen een moeder en haar kind bestaat "family life" op grond van de enkele geboorte van het kind (HR 15 april 1994). De band tussen andere naaste bloedverwanten zoals grootouders en kleinkinderen komt in beginsel ook in aanmerking voor bescherming onder artikel 8. In hoeverre feitelijke omstandigheden dienen te worden vastgesteld - teneinde de bescherming van artikel 8 te kunnen genieten - "wordt van geval tot geval bepaald door de context waarin dat beroep wordt gedaan." (HR 19 november 1993) Deze feitelijke omstandigheden kunnen bestaan uit het samenleven in gezinsverband gedurende een bepaalde periode gedurende welke de (groot)ouder de dagelijkse zorg voor het kind heeft gehad (HR 23 maart 1990) doch dit is geen noodzakelijke voorwaarde voor het bestaan van "gezinsleven" in de zin van artikel 8 . Ook andere feitelijke omstandigheden kunnen leiden tot de conclusie dat er van een dergelijke betrekking tussen (groot)ouders en kinderen sprake is (HR 19 november 1993). Uit feiten of omstandigheden zou bovendien kunnen worden afgeleid dat het gezinsleven is opgehouden te bestaan (HR 23 maart 1990). De hier besproken jurisprudentie biedt derhalve dezelfde criteria voor de afbakening van het "familie- en gezinsleven" in artikel 8, als de hiervoor reeds besproken Nederlandse en Europese uitspraken.

192 EHRM 13 juli 1979. Marckx Case. Zie ook de conclusie van de A-G bij HR 13 december 199!, NJ 1992, 575 (punt 3.3). 
AFBAKENING: JURISPRUDENTIE NAAR AANLEIDING VAN ART. 8 ECRM 272

4.3.2.6 "Family life" en de toelating of uitzetting van vreemdelingen ${ }^{193}$

De eerste zaak die in dit kader besproken zal worden is de uitspraak van de Hoge Raad van 12 december 1986 in de zaak Öncü..$^{194}$ Deze zaak betreft een Turkse jongen die geadopteerd was door zijn eveneens Turkse oom (Öncü), die al tien jaar legaal in Nederland verbleef. De jongen was op zijn dertiende jaar naar Nederland gekomen om in het gezin van zijn oom opgenomen te worden.

Vanaf zijn geboorte was de jongen eerst drie jaar door zijn wettige moeder verzorgd; daarna vier jaar door de echtgenote van Öncü, terwijl Öncï zelf naar Nederland was vertrokken; vervolgens na het vertrek van Öncü's echtgenote naar Nederland werd de jongen 5 jaar lang door zijn wettige moeder verzorgd terwijl Öncü en zijn vrouw hem jaarlijks voor langere tijd bezochten en in zijn onderhoud voorzagen en tenslotte tot zijn vertrek naar Nederland (ongeveer een jaar later in 1981) werd hij verzorgd door zijn grootmoeder van moederszijde. In 1981 is de jongen naar Turks recht geadopteerd, zoals al bij zijn geboorte was afgesproken tussen zijn wettige ouders en Öncü en zijn echtgenote. Na de komst van de jongen naar Nederland heeft Öncü voor hem een vergunning tot verblijf aangevraagd. Dit verzoek is zowel in eerste instantie als bij de herziening afgewezen en beroep is ingesteld bij de Afdeling Rechtspraak van de Raad van State. In de onderhavige zaak gaat het om de vraag of de Staat zich van uitzetting van de jongen, hangende dit beroep, zal dienen te onthouden.

Allereerst stelt de Hoge Raad vast, onder verwijzing naar de uitspraak van het Europese Hof in de zaak Abdulaziz, Cabales en Balkandali ${ }^{18}$, dat hoewel een vreemdeling aan het ECRM niet zonder meer het recht van toegang tot of verblijf in een bepaalde Verdragsstaat kan ontlenen, "moet het door de Verdragsstaat ter zake gevoerde beleid in overeenstemming zijn met zijn uit dat verdrag voortvloeiende verplichtingen en kan zulk

193. Zie uitgebrid hierover $\boldsymbol{P}$. van Dijk. Toelating en verblijf van vreemdelingen in Nederland, pp. 6-33. Dit artikel is een "must" voor wie een compleet beeld zoek van de rechtspraak van de Afdeling Rechtspraak over dit onderwerp angezien een enorme hoeveelheid angepubliceerde uitspraken in dit artikel is veiwerkt. In mijn onderzoek moet ik mij noodzakelijkerwijs beperken tot gepubliceerde uitspraken (uitzonderingen daar gelaten); ik meen, echter, uit het artikel van Van Dijk te moeten concluderen dat de uit de ongepubliceerde uitspraken blijkende praktijk met de door mij (ook in voorgaande paragrafen) beschreven praktijk overeenstemt.

194. HR 12 december 1986. NJ 1988. 188 met noot E.A. Alkema.

195 EHRM 28 mei 1985, Case of Abdulaziz, Cabales and Balkandali. 
beleid raken aan het in voormelde verdragsbepaling (artikel $8, C S$ ) aan een ieder gewaarborgde recht op eerbiediging van zijn gezinsleven."

Volgens de Hoge Raad laten de vermelde feiten en omstandigheden geen andere conclusie toe dan dat er tussen de jongen en zijn adoptiefouders een als "gezinsleven" aan te merken betrekking bestaat, vanaf het moment dat hij in 1971 "metterdaad" aan de zorg van Öncü en zijn vrouw is toevertrouwd. Hieraan doet volgens de Hoge Raad niet af, dat Öncu zijn vrouw en de jongen in 1971 in Turkije achterliet en naar Nederland vertrok. Wijzend op de uitspraak van de Europese Commissie in de zaak Berrehab ${ }^{1 \%}$, meent de Hoge Raad, "dat voor het bestaan van een als 'gezinsleven' aan te merken betrekking 'samenwonen' niet steeds onontbeerlijk is." Voorts bepaalt de Hoge Raad, dat

"... art. 8 EVRM mede beschermt tegen 'inmenging' die het daadwerkelijk hervatten van in feite onderbroken 'gezinsleven' bernoeilijkt of verhindert."

De Hoge Raad gaat dan ook over tot de vraag of de "inmenging" waarvan hier sprake was, gerechtvaardigd was onder artikel 8 lid 2 .

We zien in deze zaak, dat voor het bestaan van "family life" tussen de adoptief-ouders en de jongen de feitelijke omstandigheden van doorslaggevende betekenis zijn. Was het een gewoon geval van adoptiefouders en -kinderen geweest, dat wil zeggen Nederlandse en in Nederland woonachtige adoptief-ouders en -kinderen, dan was volgens de hierboven besproken uitspraak van 22 februari 1985 (inzake het omgangsrecht) ook zonder gestelde feitelijke omstandigheden sprake geweest van "family life". Het gaat immers om een wettig kind. De bijzondere omstandigheden van dit geval, het gaat om de toelating van een buitenlands kind tot Nederland teneinde te worden opgenomen in het gezin van zijn reeds in Nederland verblijvende adoptief-ouders, nopen hier tot een toetsing aan feitelijke omstandigheden. In de eerste plaats is de omstandigheid dat de jongen in Turkije is achtergebleven, nadat eerst zijn (latere) adoptief-vader en later ook diens echtgenote naar Nederland waren vertrokken, van groot belang. De feitelijke omstandigheden, het verzorgen van de jongen door Öncü's vrouw van 1971 tot 1975 leiden tot de conclusie dat "family life" in 1971 is ontstaan. De vraag is echter, of dit "family life" na het vertrek van

196 Besl.Comm. \& maart 1986, zaak nr. 10730/84, Berrehab en Koster v. Nederland, p. 196 e.v. en Rechtspraak Vreemdelingenrecht 1985, nr. 107: zie ook het ten tijde van de beslissing van de HR in de zaak Öncü nog niet gewezen arrest EHRM 21 juri 1988. Berrehab Case en hierboven op p. 215. 
Öncü's echtgenote is blijven bestaan. De adoptie in 1981 zelf en de geregelde contacten en de bijdragen in het levensonderhoud van de jongen, leiden ertoe dat de Hoge Raad oordeelt dat het "family life" is blijven voortduren, ook na het vertrek van Öncüs vrouw naar Nederland, zich hierbij baserend op de stelling dat voor het bestaan van "family life" samenwoning niet altijd noodzakelijk is. Ten tweede is de jongen in 1981 geadopteerd en zou uit dien hoofde "family life" zijn ontstaan als dat niet al had bestaan. Wat betreft de situatie na 1981 spelen de feitelijke omstandigheden derhalve opnieuw een rol bij de beantwoording van de vraag of de als "family life" aan te merken band tussen de adoptief-ouders en de jongen al dan niet is verbroken.

Een zaak van 1987 betreft een vreemdeling (Garti) die opkomt tegen zijn dreigende uitzetting. ${ }^{197}$ Het gaat om een buitenlandse man, aan wie tijdens zijn huwelijk een vergunning was verleend tot verblijf bij zijn echtgenote (een voorwaardelijke verblijfsvergunning). Uit dat huwelijk is een kind geboren. Naderhand werd het huwelijk beëindigd, op grond waarvan eiser's recht op verblijf verviel. Zijn aanvraag van een zelfstandige verblijfsvergunning is in twee instanties afgewezen en de onderhavige procedure betreft een verbod tot uitzetting hangende zijn beroep tegen die afwrijzing ủij đe Afúeiling Rechtspraak. Volgens de Hoge Raad had de man tijdens zijn huwelijk een als "family life" aan te merken betrekking met zijn kind. "Noch de verbreking van de samenleving, noch de echtscheiding hebben aan deze betrekking een einde gemaakt." Dat de man sinds de verbreking van de samenleving intensief contact met zijn kind heeft, wordt er door de Hoge Raad slechts ten overvloede aan toegevoegd.

Doordat de uitzetting van de man de voortzetting van zijn contact met zijn kind onmogelijk maakt, moet de uitzetting volgens de Hoge Raad worden aangemerkt als een inmenging in zowel het recht van de man als van zijn kind op eerbiediging van zijn gezinsleven.

De verschillen tussen de zaak Öncü en deze zaak zijn vooral toe te schrijven aan het feit, dat het in de zaak Öncü gaat om de toelating van een vreemdeling en in de laatste zaak (Garti) om de uitzetting van een vreemdeling. In de eerste zaak gaat het daarom om het kunnen hervatten van het effectief (feitelijk) gezinsleven en in de tweede zaak om het kunnen voortzetten ervan. Het verschil in overwegingen in deze zaken ten anzien

197 HR 18 december 1987, NJ 1988, 844 met noot A.H.J. Swart. Opmerkelijk is dat het Europese Hof in EHRM 21 juni 1988. Berrehab Case, \$16, p. 12 naar dit arrest var de Hoge Raad in de zaak Carti verwijst. Swart meent, dat dit de indruk wekt dat het arrest van de Hoge Raad het Europese Hof tot model heeft gediend. 
van het bestaan van "family life" in de zin van artikel 8 is erin gelegen, dat in de eerste zaak eerst nog moet worden vastgesteld of er al van "family life" sprake was voordat Öncü en zijn echtgenote naar Nederland waren vertrokken. In de zaak Garti vloeit het bestaan van "family life" direct voort uit het feit dat het kind geboren was uit het huwelijk van Garti en de moeder van het kind. De overeenkomst in de overwegingen in beide zaken is, dat de Hoge Raad in beide zaken moet nagaan of het bestaande "family life" al dan niet is verbroken en tot de conclusie komt dat dat niet het geval is. Deze laatste overwegingen zijn hoofdzakelijk gebaseerd op de uitspraak van de Europese Commissie in de zaak Berrehab, waarmee de zaak Garti zeer grote overeenkomsten vertoont.

In de zaak Öncu komt ook nog de vraag aan de orde, of van beide in Nederland gevestigde adoptief-ouders "in redelijkheid" gevergd kan worden, dat zij hun geadopteerde zoon naar Turkije volgen teneinde hem (aldaar) in hun gezin te kunnen opvoeden. Deze vraag wordt in de zaak Öncü onder lid 2 behandeld.

Hetzelfde gebeurt in een zaak van 26 september 1991, waarin de minderjarige, Nederlandse kinderen van een vreemdelinge een verblijfstitel vorderen voor hun Surinaamse moeder nadat een titel van verblijf in het kader van gezinshereniging aan haar was geweigerd. De kinderen worden voor de keuze gesteld hun moeder, die niet voor toelating in het kader van gezinshereniging in aanmerking komt, naar Suriname te volgen dan wel hier op te groeien zonder haar. Volgens het Gerechtshof 's-Gravenhage is er sprake van een inbreuk op het gezinsleven van de moeder en haar kinderen, wanneer de kinderen ervoor zouden kiezen om verder in Nederland, zonder hun moeder op te groeien. Deze inbreuk, aldus het Gerechtshof, is onder de gegeven omstandigheden echter gerechtvaardigd door het belang van de Staat de openbare orde en het economisch welzijn van Nederland te beschermen (lid 2). ${ }^{198}$

Een soortgelijke beslissing neemt de Afdeling rechtspraak van de Raad van State op 4 maart 1992. ${ }^{199} \mathrm{Na}$ de constatering dat er sprake is van

198 Gerechtshof 's-Gravenhage 26 september 1991, NJ 1992, 347.

199 ARRS 4 maart 1992 (zaak Bhattoe), AB 1992, 632 met noot $R$. Fernhout onder nr. 634. Zo ook ARRS 1 mei 1992, AB 1992, 633 met noot $R$. Fernhout onder AB 1992, 634 en implicieter HR 8 mei 1992, NJ 1992, 708 met noot $A H J S$; AB 1992, $634 \mathrm{met}$ noot $R$. Fernhout en eerder al ARRS 17 april 1991 (zaak Steinmetz, RO2.88.2462), ontleend aan de conclusie van A-G Mok bij het hiervoor genoemde HR 8 mei 1992. Om redenen die duidelijk zullen worden wanneer de uitspraak van de Afdeling Rechtspraak van 8 april 1991 zal worden besproken, dient hier vermeld te worden dat het in deze zaken gaat om voortgezet verblijf en niet om een eerste toelating. 
AFBAKENING: JURISPRUDENTIE NAAR AANLEIDING VAN ART. 8 ECRM 276

"familie- en gezinsleven" tussen appellante (de moeder) en haar (Nederlandse) kind moet onderzocht worden of het besluit van de Staatssecretaris van Justitie om aan de moeder geen zelfstandige vergunning tot verblijf in Nederland toe te staan (voorheen had ze ten vergunning tot verblijf bij haar echtgenoot, maar ze is inmiddels van hem gescheiden), een inmenging betekent in de uitoefening van het recht op respect voor dit familie- en gezinsleven. Vervolgens wordt de mening van de Staatssecretaris van Justitie weergegeven, inhoudende dat geen sprake is van een zodanige inmenging omdat van haar kind, gelet op de leeftijd daarvan, in redelijkheid kan worden gevergd dat het appellante volgt naar haar land van herkomst (Suriname). ${ }^{200}$ De Afdeling rechtspraak is het hiermee niet eens. Het besluit vormt wel degelijk een inmenging in her recht op respect voor het familie- en gezinsleven van appellante en haar kind. Om die reden dient deze inmenging te worden gerechtvaardigd op grond van artikel 8 , tweede lid.

Zoals in de in paragraaf 4.1 .2 besproken rechtspraak naar voren kwam, heeft de Europese Commissie de praktijk ontwikkeld, dat deze keuzemogelijkheid, om de personen - waarmee men gezinsleven heeft - te volgen naar het land van herkomst, als criterium geldt voor de toepasselijkheid van artikel 8 . Het gaat in die Europese uitspraken namelijk om de vraag of het gezinsleven is verbroken ten gevolge van de vrije keuze van betrokkene om zijn of haar partner of gezinsleden te volgen naar een ander land. Dit heb ik eerder het "eigen schuld"-criterium genoemd ${ }^{201}$ In deze Nederlandse zaken wordt voor een andere benadering gekozen en komt de keuzemogelijkheid pas aan de orde onder lid 2 en geldt derhalve niet als criterium voor de afbakening van lid $1 .{ }^{32}$

200 Dit standpunt van de Staatssecretaris kan wellicht verklaard worden op grond van het feit, dat de Afdeling Rechtspraak in eerdere rechtspraak dezelfde redenering volgde: ARRS 8 mei 1989 (zaak Feyereisen), RV 1989, 93 en ARRS 16 oktober 1989 (zaak Augustin, nr. RO2.97.1013), ontleend aan de conclusie van A-G Mok bij HR 8 mei 1992 (NJ 1992, 708; AB 1992, 634) die beide uitspraken bespreekt.

201 Zie pp. 221-222. Anders en meer overeenkomstig de Nederlandse rechtspraak lijkt te zijn Besl.Comm. 30 november 1994, zaak nr. 22791/93, Maikoe and Baboelalv. the Netherlands, zeer kort samengevat in: M.J.T.M. Vijghen, Rapporten en ontvankelijkheidsbeslissingen van de Europese Commissie voor de Rechten van de Mens in Nederlandse zaken, NJCM-Bulletin 20-5 (1995), p. 644-654(649).

202 Afwijkend in deze reeks zaken is ARRS 13 april 1992, AB 1992. 631 met noot A.H.J. Swart onder AB 1992, 634. Hierin onderzoekt de Afdeling, na constatering dat geen sprake is van een "inmenging", of sprake is van een positieve verpliching om uitoefening van het gezinsleven in Nederland mogelijk te maken. Met Swart - in zijn annotatie onder AB 1992,634 - ben ik het eens dat deze constructie vrij gekunsteld aandoet. De casus in deze zaak verschilt, mijns inziens te weinig van die in noot 199 genoemde zaken om een andere redenering te rechtvaardigen. 
Het zogenaamde "eigen schuld"-criterium lijkt overigens, in een andere gedaante, op te duiken in de nu te bespreken beschikking van 8 april 1991 van de Afdeling Rechtspraak van de Raad van State. ${ }^{203}$ De feiten en onstandigheden in deze zaak houden in, dat er een groot tijdsverloop (tien jaar) heeft plaatsgevonden tussen het vertrek van de moeder van appellante naar Nederland en het in het geding zijnde verzoek van appellante om een verblijfsvergunning; voorts is appellante sinds het vertrek van haar moeder duurzaam opgenomen in het gezin van haar grootouders. Hierdoor is volgens de Afdeling de "feitelijke gezinsband" (deze formulering lijkt te duiden op het effectief gezinsleven) tussen appellante en haar moeder verbroken. Tenslotte is de moeder van appellante pas sinds 1987 (eerste contact) enkele keren teruggegaan naar El Salvador om haar dochter te bezoeken. De Afdeling Rechtspraak ziet in deze feiten en omstandigheden 'geen grond om aan te nemen dat tussen appellante en haar moeder familie- of gezinsleven is komen te ontbreken. De beslissing ... om aan appellante een verblijfsvergunning te weigeren vormt evenwel geen inmenging in het recht op respect voor haar familie-of gezinsleven. " Deze beslissing belet volgens de Afdeling "immers niet de voortzetting van het familie- of gezinsleven tussen appellante en haar moeder in de vorm die dit lad aangenomen op het tijdstip dat appellante naar Nederland vertrok" (dat wil derhalve zeggen, dat de moeder haar zo nu en dan in El Salvador opzocht). De eerste conclusie die uit deze uitspraak kan worden getrokken is, dat de Afdeling er blijkbaar van uit gaat dat - wanneer een eerder hestaande (feitelijke) gezinsband in het land van herkomst is verbroken door het vrijwillige vertrek van de ouder naar Nederland en pas na lange tijd (kennelijk verwijtbaar) een bepaalde mate van contact wordt hersteld de bestaande, als "gezinsleven" aan te merken betrekking, niet is verbroken. Er is echter geen sprake van een inmenging in het "family life"

Vermoedelijk volgt de Afdeling in deze zaak de weg van de positieve verplichtingen, omdat in deze zaak niet puur (zoals in de andere zaken genoemd in noot 199) sprake is van de intrekking van een voorwaardelijke verblijfsvergunning en/of de weigering van een zelfstandige verblijfsvergunning (om het verblijf na echischeiding te kunnen voortzetten). In deze zaak gaat het om de weigering van de Staatssecretaris om intrekking van de aan appellante verleende vergunning tot verblijf achterwege te laten onder gelijktijdige wijziging van de aan deze vergunning verbonden beperking, teneinde het uitoefenen van het familie- en gezinsleven in een andere gezinssamenstelling in Nederland mogelijk te maken. Zie hierna, voor uitspraken waarin de toetsing aan eventuele positieve verplichtingen meer op zijn plaats lijkt, omdat het gaat om (een eerste) toelating van een vreemdeling.

203 ARRS 8 april 1991, AB 1991, 624 met noot $R$. Fernhout. Zo ook: ARRS 14 februari 1991, NJCM-Bulletin 17-2 (1992), pp. 163-164 met noot $N$. Albayrak (pp. 165-167) en ARRS 14 april 1991, AB 1991, 625 met noot $R$. Fernhout. 
wanneer de Nederlandse autoriteiten onder de genoemde omstandigheden aan het achtergebleven kind geen verblijfsvergunning verstrekken. Het zogenaamde "eigen schuld"-criterium (de verwijtbaarheid van de gebrekkige contacten) speelt hier derhalve een rol bij afweging die word verricht in het kader van de vaststelling of sprake is van een inmenging in het familie- of gezinsleven en niet al bij de vraag of sprake is van familieof gezinsleven. ${ }^{204}$

Enigszins curieus is de overweging, die de Afdeling op de voormelde overwegingen doet volgen: "Hetgeen appellante ... heeft aangevoerd omtrent haar persoonlijke feiten en omstandigheden wettigt niet de gevolgtrekking dat verweerder ... anderszins tekort heeft gedaan aan het recht van appellante op respect voor haar familie- of gezinsleven door haar een vergunning tot verblijf te weigeren." Het woord "anderszins" suggereert, dat ook op een andere wijze dan door middel van een "inmenging" een schending van het recht op respect voor het familie- ef gezinsleven plaats kan vinden. De tweede eventueel uit deze uitspraak af te leiden conclusie is derhalve, dat hoewel de Afdeling hierover niets expliciet bepaalt, deze overweging lijkt te duiden op de in de Straatsburgse rechtspraak uit artikel 8 afgeleide positieve verplichtingen. Onder omstandigheden is het namelijk mogelijk, dat - ook wanneer geen sprake is van een inmenging - het niet-verlenen van een verblijfstitel kan leiden tot een gebrek aan "respect" voor het gezinsleven in de zin van artikel 8. De positieve verplichting bestaat er in een dergelijk geval uit dat de overheid wel een verblijfstitel verstrekt. Blijkens de laatste, hiervoor geciteerde, overweging is in het onderhavige geval van dergelijke omstandigheden geen sprake. ${ }^{20 s}$

204 Zie ook punt 4 van de annotatie bij deze uitspraak. De jurisprudentie van de Europese Commissie waarvan de annotator onder punt 3 verwijst (zonder bepaalde zaken nader aan te duiden), is overigens in par. 4.2.2 slechts besproken voor zover deze relevant is voor de afbakening van het recht op respect voor het familie- en gezinsleven.

205 Zie hierover ook punt 5 van de noot van Fernhout onder deze uitspraak. Een voorbeeld van een uitspraak van het Europese Hof in dit kader is EHRM 28 mei 1985, Case of Abdulaziz. Cabales and Balkandali, $\$ 67$, p. 33, waarnaar ook de annotator verwijst. De indruk dat de Afdeling Rechtspraak in de laststgeciteerde overweging inderdaad doelt op een eventuele positieve verplichting wordt versterk door het feit dat in de (in noot 203) genoemde en vrijwel gelijkluidende uitsprak ARRS 14 april 1991, AB 1991,625 nog een zin op deze overweging volgr: "Aan hel bepaalde in art. 8 eerste lid EVRM kan appellant daarom ook geen aanspraak op een verguming tot verbliff ontlenen. "Overigens ontbreekt in de bedoelde overweging in deze laatste uitspraak het woordje "anderszins". Zie ook ARRS 14 februari 1991. NJCM-Bulletin 17-2 (1992), pp. 163-164 en Vz.ARRS 14 februari 1991. NJCM Bulletin 17-2 (1992), pp. 164-165 met noot $N$. Albayrak (pp. 165-167). Zie verder 
Opvallend in de behandelde rechtspraak van de Afdeling Rechtspraak is, dat in de eerder besproken zaken (en de in de noten genoende, soortgelijke uitspraken) waarin het ging om een voortgezet verblijf, de intrekking van een voorwaardelijke verblijfstitel en/of de weigering van een zelfstandige verblijfsvergunning aangemerkt wordt als een inmenging in het bestaande "family life". Gaat het daarentegen om een eerste welating, dan levert de weigering van een verblijfstitel in de behandelde zaken géén inmenging op in het (niet verbroken geachte) gezinsleven en gaat de Afdeling Rechtspraak over tot de toetsing of desondanks toch sprake is van omstandigheden op grond waarvan tot een schending van het recht op respect voor het familie- en gezinsleven moet worden geconcludeerd. Een dergelijk verschil in benadering heb ik in de - minder talrijke - uitspraken van de Hoge Raad c.q. feitenrechters in uitzettingszaken vooralsnog niet kunnen waarnemen. Zo werd in de zaak Öncü. waarin het ook ging om een eerste toelating. geconstateerd dat ook daar het effectief gezinsleven verbroken was, maar niet de als "family life" aan e merken betrekking en vervolgens dat sprake was van een inmenging. Of cok sprake was van een positieve verplichting op grond van artikel 8 werd in deze zaak niet onderzocht (ook niet impliciet). Een gevolgtrekking dat er derhalve een verschil bestaat tussen de rechtspraak van de Afdeling Rechtspraak en de gewone rechter wil ik hieruit echter niet trekken, aangezien er naar mijn mening te weinig uitspraken van de Hoge Raad zijn die hierop duiden en het verschil ook gelegen kan zijn in de (waardering van de) feitelijke omstandigheden van het geval.

Zoals ook al aan het eind van paragraaf 4.2.2 gebeurde, zal ook hier ingegaan worden op het begrip "family life" in gevallen die mensen uit andere culturen betreffen, waarin doorgaans andere opvattingen over instituties als familie en gezin bestaan dan bij ons. ${ }^{2 . w_{1}}$

De kwestie die hier allereerst kort aan de orde zal komen is die van het al dan niet bestaan van "family life" in het geval van een met uitzetting bedreigde ouder met een niet-Nederlandse nationaliteit ten opzichte van zijn volwassen (Nederlandse) kind.

De President van de Rechtbank te 's-Gravenhage doet op 25 januari 1991 uitspraak in een zaak van een Chinese vrouw die, teneinde de beslissing op een klacht bij de Europese Commissie tegen de afwijzing van een verzoek om een verblijfsvergunning, in Nederland te kunnen afwachten, haar uitzetting probeert te voorkomen. $\mathrm{Zij}$ voert onder meer aan dat haar

P. van Dijk, Toelating en verblijf van vreemdelingen in Nederland, pp. 23-26.

206 Zie hierover M.L.C.C. de Bruijn-Lückers, Het familierecht van vreemdelingen, pp. 
uitzetting is strijd met het recht op "family life" zou zijn, dat zij met haar volwassen zoon en schoondochter onderhoudt.

De rechtbank-president refereert in zijn uitspraak aan de jurisprudentie van de Europese Commissie met betrekking tot "family life" tussen ouders en volwassen kinderen. Van "family life" is op grond van die jurisprudentie sprake indien het gaat om een afhankelijkheids-relatie die meer omvat dan de "normal emotional ties." 2077 Belangrijke begrippen zijn hierbij volgens de President de "financiële ondersteuning die is of wordt geboden en de mate van contact die men met elkaar heeft onderhouden". Ook wordt van belang geacht of het achtergebleven familielid zich in het land van herkomst zelfstandig kan handhaven, "contacten onderhoudt met andere naaste verwanten aldaar, terwijl ook nog andere omstandigheden een rol kunnen spelen." Op grond van de feiten van de zaak komt de President tot de vaststelling dat in casu sprake is van een afhankelijkheidsrelatie die meer omvat dan "normal emotional ties", Geconcludeerd wordt dat "naar de maatstaven van de Europese Commissie sprake is van 'family life' in de zin van art. 8 EVRM, aangezien er zichi ten aanzien van eiseres bijzondere omstandigheden voordoen". ${ }^{208} \mathrm{De}$ voorgenomen uitzetting van eiseres vormt volgens de President een inmenging in haar "family life". ${ }^{209}$

Wanneer deze uitspraak exemplarisch is voor alle rechtspraak in dit soort zaken, dan ziet het er naar uit dat in zaken met betrekking tot het bestaan van "family life" tussen ouders en hun volwassen kinderen de interpretatie van dit begrip die door de Europese instanties wordt gegeven, zal worden gevolgd. ${ }^{210}$

Een uitspraak van de Hoge Raad van 28 mei 1993 betreft de relatie tussen een vreemdeling en zijn in Nederland wonende zuster en haar kinderen." Het verzoek van de man om toelating als vluchteling dan wel verlening van een verblijfsvergunning was afgewezen. In kort geding had hij gevorderd dat het de Staat zou worden verboden hem hangende de herzieningsprocedure uit te zetten. Deze vordering werd afgewezen en in hoger

207 Alhoewel de President in zijn uitspraak niet bepaalde uitspraken van de Europese Commissie noemt, gaat het hier waarschijnlijk om Besl.Comm. 14 juli 1982, zak nr. 9492/81, Family $X v$. UK, p. 234 en de andere uitspraken, die hierboven worden genoemd in noot 48.

208 Vermoedelijk wordt hier gedoeld op het feit dat eiseres zich gezien haar leeftijd nict zelfstandig in Hong Kong zal kunnen handhaven. Ze heeft eí geen woning, geet werk en geen familie om op terug te vallen.

209 Pres.Rb. 's-Gravenhage 25 januari 1991, KG 1991, 71.

210 Zie hierboven met name p. 214 en pp. 223-224.

211 HR 28 mei 1993, NJ 1993, 625 met noot A.H.J. Swart. 
beroep deed hij een beroep op artikel 8, dat echter door het Haagse Gerechtshof werd verworpen. Wat betreft de gezinsrelatie van de man ten opzichte van zijn neven en nichten, bepaalt de Hoge Raad dat artikel 8 geen steun geeft voor het standpunt, dat bij een graad van bloedverwantschap zoals die tussen een oom en zijn neven en nichten bestaat, het enkele voornemen om het gezinsleven te gaan uitoefenen reeds door artikel 8 beschermd wordt. Dit is naar mijn mening in overeenstemming met de eerder besproken Europese en Nederlandse rechtspraak. Voor het bestaan van "family life" tussen een niet-ouder en kinderen dienen feiten en omstandigheden gesteld te worden waaruit een nauwe persoonlijke betrekking tussen betrokkenen blijkt. Dergelijke feiten en omstandigheden zijn in de onderhavige zaak niet aangevoerd.

Het gerechtshof was in zijn beslissing ook nog ingegaan op de vraag of zich niet zodanige feiten of omstandigheden voordeden waardoor op de Staatssecretaris een uit artikel 8 voortvloeiende verplichting kwam te rusten om de man een verblijfsvergunning te verstrekken teneinde het hem mogelijk te maken zijn recht op respect voor zijn gezinsleven in Nederland uit te oefenen. $\mathrm{Na}$ afweging van de belangen van de man tegen het openbare belang, werd aan dit laatste een zwaarder gewicht toegekend. De Hoge Raad spreekt zich in cassatie niet uit over de vraag of uit artikel 8 een dergelijke (positieve) verplichting kan voortvloeien. De Raad stelt naar aanleiding van de klacht van de man dat het gerechtshof in de bedoelde belangenafweging ten onrechte niet de belangen van zijn zuster en haar kinderen had meegewogen, slechts vast dat het gerechtshof hiertoe niet verplicht was en dat de man op die belangen niet met zoveel woorden een beroep had gedaan.

Deze overweging van de Raad lijkt te suggereren, dat de Hoge Raad niet afwijst dat - althans in geval het gaat om de verlening van, bijvoorbeeld, een verblijfsvergunning - uit het recht op respect voor het familie- en gezinsleven een positieve verplichting kan voortvloeien tot het verstrekken van een dergelijke verblijfstitel. Meer kan, mijns inziens, ten aanzien van dergelijke positieve verplichtingen uit deze uitspraak niet worden afgeleid.

Tenslotte dient hier ook nog ingegaan te worden op het bestaan van "family life" in het geval van (kinderen uit) polygame huwelijken. Zoals reeds werd vermeld in paragraaf 4.2.2.2, wordt in Nederland de beleidsregel gehanteerd, volgens welke het aan een in Nederland verblijvende man alleen wordt toegestaan één van zijn vrouwen - naar eigen keuze - en de kinderen van die vrouw naar Nederland te laten 
AFBAKENING: JURISPRUDENTIE NAAR AANLEIDING VAN ART. 8 ECRM 282

komen. In een zaak van 1980 gaat het om de dochter van in Nederland verblijvende man en zijn eerste, in Marokko verblijvende vrouw. Deze man wenst zijn dochter in het gezin dat hij met zijn tweede vrouw in Nederland heeft, op te nemen. Aan de dochter wordt een vergunning tot verblijf - vanwege de hiervoor genoemde beleidsregel - geweigerd. De Afdeling Rechtspraak doet op 28 februari 1980 uitspraak in het beroep (na een fictieve beslissing in herziening) dat tegen deze weigering is ingesteld. Volgens de Afdeling kan in deze zaak "reeds hierom geen sprake zijn van schending van artikel $8 \ldots$ (ECRM) omdat het gezinsleven welks bescherming dit artikel beoogt, te dezen niet in het geding is. "Impliciet bepaalt de Afdeling hier derhalve, dat in dit geval geen sprake is van "family life" tussen de dochter en haar vader (en diens tweede echtgenote). Op welke gronden de Afdeling tot deze opvatting komt is echter niet duidelijk. ${ }^{213}$

Tot een andere uitspraak komt de Afdeling Rechtspraak in 1989. Volgens de Afdeling hebben de kinderen van appellant (de in Nederland verblijvende vader) en zijn eerste, in Marokko verblijvende (inmiddels ex-) vrouw, nimmer behoord tot het gezin dat hij hier te lande met zijn tweede echtgenote heeft gevormd. Dat hij zijn kinderen jaarlijks in Marokko heeft bezocht en regelmatig geld naar Marokko heeft overgemaakt ter voorziening in hun levensonderhoud leidt niet tot een andere conclusie. Wel zijn er volgens de Afdeling voldoende aanknopingspunten voor het oordeel dat appellant en zijn kinderen "geboren uit het rechtsgeldig en werkelijk huwelijk tussen appellant en zijn eerste echtgenote (dat naderhand is ontbonden, $C S$ ), in een zodanige betrekking tot elkaar zijn blijven staan dat sprake is van gezinsleven in de zin van art. 8". De beslissing om de kinderen een verblijfsvergunning te weigeren vormt een inmenging in de uitoefening van dit recht op gezinsleven, die zal moten worden gerechtvaardigd onder lid 2 van artikel $8 .{ }^{2 / 4}$

Deze laatste uitspraak stemt naar mijn mening overeen met de uitspraken van de Europese Commissie in dit kader. ${ }^{215}$ Zoals hieromtrent in

213 ARRS 28 februari 1980, Vreemdelingenrecht Jurisprudentie D13-52. p. 301 e.v..

214 ARRS 24 april 1989, AB 1990, 300 met noot H.J. Simon en B.M.J. van der Meulen. Zie ook ARRS 3 juli 1990. NJCM-Bulletin 16-5 (1991), pp. 430-436 met noot $S . W . E$. Rutten, waarin uitgegaan wordt van het bestaan van gezinsleven (dit was ook. het standpunt van verweerder, de Staatssecretaris van Justitie).

215 Zie p. 144 en Besl.Comm. 5 oktober 1987, zaak nr. 12139/86, $X$ v. the Netherlands, RV 1987, 93 met noot AHJS. In haar noot onder ARRS 3 juli 1990; NJCM-Bulletin 16-5 (1991), pp. 430-436 stelt Rutten dat uit bovengenoemde ontvankelijkheidsbeslis. sing (zie het citaat daaruit op p. 223) ook kan worden afgeleid dat in een geldig polygaam huwelijk in beginsel sprake is van gezinsleven mer álle echtgenotes (in verband met de rechtspraak dat als sprake is van een geldig huwelijk. in beginsel 
paragraaf 4.2.2 werd gesteld zou bij de vraag of er sprake is van een als familie- of gezinsleven te kenmerken relatie tussen een vader en zijn kinderen bij een andere echtgenote dan de echtgenote met wie hij in een verdragsstaat samenleeft, met name de mate waarin de vader met deze kinderen contacten onderhoudt en waarin hij ze financieel onderhoudt een rol spelen. We zien dat de Afdeling Rechtspraak in de onderhavige zaak inderdaad tot een dergelijke toetsing overgaat. Gezien die contacten en de bijdragen in het levensonderhoud van de kinderen oordeelt de Afdeling in casu dat in als "gezinsleven" aan te merken betrekking zijn blijven staan, dat derhalve het "family life" niet is verbroken.

De rechtspraak ten aanzien van het recht op familie- en gezinsleven in verband met de toelating of uitzetting van vreemdelingen overziende, kunnen de volgende conclusies getrokken worden. Evenals in de rechtspraak, besproken in de vorige sub-paragrafen, duidt de onderhavige jurisprudentie erop dat ook hier van het bestaan van "family life" uitgegaan kan worden in geval van kinderen geboren uit een wettig huwelijk, zelfs als dit een polygaam huwelijk is (ARRS 24 april 1989), dan wel wanneer sprake is van anderszins wettige kinderen (Öncü). In andere gevallen dient aan de hand van feiten en omstandigheden te worden nagegaan of sprake is van een als "family life" aan te merken betrekking (bijvoorbeeld, in de zaak Öncü de periode voorafgaand aan de adoptie of HR 28 mei 1993). In geval van een relatie tussen ouders en hun volwassen kinderen dient, in navolging van de Europese Commissie, te worden onderzocht of sprake is van een afhankelijkheidsrelatie die meer omvat dan "normal emotional ties" (Rb 's-Gravenhage 25 januari 1991). Voorts dient aan de hand van feitelijke omstandigheden, in geval van verbreking van het feitelijk of effectief gezinsleven, te worden vastgesteld of de als "family life" aan te merken band is blijven voortduren (o.a. Öncü, Garti, ARRS 8 april 1991,

sprake is van gezinsleven tussen de echtgenoten, zie EHRM 21 juni 1988, Berrehab Case, $\$ 21$, p. 14). Deze conclusie volgt m. i. niet uit deze beslissing die alleen ziet op uit polygame huwelijken geboren kinderen. Uit de rechtspraak van de ARRS zou een dergelijke gevolgtrekking wellicht wel gemaakt kunnen worden. Zie $P$. van Dijk, Toelating en verblijf van vreemdelingen in Nederland, p. 13: "Dat een zogenaamd 'polygaam huwelijk' naar Nederlands recht niet kan worden gesloten en dat naar Nederlands vreemdelingenbeleid in beginsel slechts een van de huwelijksrelaties en de daaruit geboren kinderen voor gezinshereniging in aanmerking, komen, betekent niet dat er met de andere huwelijkspartner(s) en de uit die relatie(s) geboren kinderen geen familie- en gezinsleven zou bestaan." Van Dijk haalt hierbij 3 uitspraken van de afdeling rechtspraak aan: ARRS 19 januari 1990, RO2.87.2500 (Nouha); ARRS 25 mei 1992, RO2.90.4061 (El Rheddar) en ARRS 15 september 1993, RO2.91.3010 (Mokiern). 
AFBAKENING: JURISPRUDENTIE NAAR AANLEIDING VAN ART. 8 ECRM 284

ARRS 24 april 1989). Wordt aan de hand van de voorgaande overwegingen vastgesteld dat sprake is van familie- of gezinsleven in de zin van artikel 8 , dan dient te worden nagegaan of sprake is van een inmenging die moet worden gerechtvaardigd op grond van het tweede lid van deze verdragsbepaling. De rechtspraak ten aanzien van de toelating en uitzetting van vreemdelingen stemt wat betreft de criteria voor de afbakening van het recht op respect voor het familie- en gezinsleven derhalve overeen met de in de voorgaande sub-paragrafen behandelde jurisprudentie. In een aantal uitspraken vindt echter, na de constatering dai van een "inmenging" geen sprake is, nog een belangenafweging plaats die lijkt te suggereren, dat uit artikel 8 volgens de Nederlandse rechter onder omstandigheden ook een positieve verplichting kan voortvloeien om an een vreemdeling een verblijfstitel te verstrekken. Dergelijke overwegingen die lijken te duiden op een erkenning van positieve verplichtingen op grond. van artikel 8 , ben ik in de eerder besproken jurisprudentie niet tegengekomen.

\subsubsection{Het recht op respect voor de woning}

Ten aanzien van het recht op respect voor de woning heb ik slechts twee uitspraken in verband met artikel 8 gevonden en dan nog zonder dat in die uitspraken van enige afbakening van het huisrecht sprake is.

De eerste uitspraak is een arrest van de Hoge Raad van 29 september 1992 waarin het gaat om de doorzoeking van de auto en woning van een verdachte. De Raad oordeelt dat de bevoegdheid tot huiszoeking op grond van artikel $111 \mathrm{~Sv}$ mede de bevoegdheid omvat tot het doen van onderzoek in voorwerpen die zich al dan niet afgesloten bevinden op de plaats waar de huiszoeking plaatsvindt. Het zou interessant geweest zijn indien de Hoge Raad ook zou hebben overwogen of de bescherming van de woning door artikel 8 ECRM zich ook uitstrekt tot een auto die zich op het erf van het desbetreffende huis bevindt. Zover komt het in deze zaak niet. De klacht in verband met artikel 8 beperkt zich tot een bij de aanvang van de huiszoeking gegeven bevel dat niemand zich tijdens de huiszoeking uit de woning zou mogen verwijderen of van de telefoon gebruik zou mogen maken. Het Gerechtshof had hieromtrent geoordeeld dat het hier ging om "een tijdelijke, met het oog op een richtige huiszoeking te treffen, ordemaatregel, die op geen enkele wijze geacht kan worden inbreuk te maken op de in art. 8 EVRM gewaarborgde rechten." Volgens de Hoge Raad moet deze overweging aldus uitgelegd worden dat deze ordemaatregel in overeenstemming met het tweede lid van artikel 8 ("... in accordance .. prevention of disorder or crime ...") was. De Raad motiveert dit oordeel niet. Als de bedoelde overweging inderdaad de 
betekenis moet worden toegekend die de Hoge Raad daaraan geeft, dan nog ontbreekt in deze uitspraak de vaststelling dat er inderdaad sprake was van een inmenging op het - in het eerste lid van artikel 8 gegarandeerde recht op respect voor de woning.

De tweede uitspraak is van 22 april 1994. Het gaat in deze zaak om een door de Ontvanger der Rijksbelastingen opgelegd bodembeslag op roerende goederen (welke volgens huwelijkse voorwaarden eigendom waren) van eiseres voor verhaal van belastingschulden van haar echtgenoot. Het Gerechtshof 's-Hertogenbosch had overwogen dat de in artikel 8 gegarandeerde rechten niet de strekking hebben de rechthebbende te beschermen tegen verhaal op roerende goederen, ook niet indien deze worden gebruikt "in het kader van diens privé- c.q. gezinsleven c.q. ter meubilering van diens woning". Volgens het gerechtshof is artikel 8 derhalve niet van toepassing. De Hoge Raad spreekt zich hierover niet uit. De Raad overweegt slechts dat voor zover het bodembeslag op de roerende zaken van eiseres, die zich in de echtelijke woning bevinden, aangemerkt kan worden als een "inmenging" in de uitoefening van haar recht op respect voor haar privéleven, deze inmenging in elk geval op grond van artikel 8 lid 2 is toegestaan.

Kortom, ten aanzien van het recht op respect voor de woning in het algemeen zijn al zeer weinig uitspraken voor handen. Met betrekking tot de afbakening van dit recht heb ik in het geheel geen uitspraak aangetroffen.

\subsubsection{Het recht op respect voor de correspondentie}

Ten aanzien van het recht op respect voor de correspondentie is er ook niet al te veel jurisprudentie met betrekking tot artikel 8 ECRM. Ik heb slechts én uitspraak gevonden waarin het daadwerkelijk om een briefwisseling (het sturen van briefkaarten) gaat. Het Gerechtshof Amsterdam overweegt omtrent het onderhavige recht alleen dat weliswaar een ieder het recht heeft op, onder andere, zijn briefwisseling, maar dat het mogelijk is dit recht te beperken indien dat nodig is ter bescherming van de rechten en vrijheden van anderen. Op deze beperkingsmogelijkheid wordt vervolgens ingegaan. ${ }^{216}$ De toepasselijkheid van artikel 8 lijkt mij hier niet aan twijfel onderhevig, dus het ontbreken van enige overweging hieromtrent kan, mijns inziens, het gerechtshof niet kwalijk genomen worden. 
Een uitspraak van de Hoge Raad van 29 maart 1994 betreft de inbeslagneming van dossiers bij een advocaat. ${ }^{217}$ Volgens de rechtbank was geen sprake van strijd met artikel 8 , omdat het ging om de inbeslagneming van dossiers, die in overleg met klager (de advocaat) zijn geselecteerd en door klager zelf zijn afgestaan in aanwezigheid van de Deken. De Hoge Raad meent dat dit oordeel geen blijk geeft van een onjuiste rechtsopvatting omtrent artikel 8 . Ook hier is dus opnieuw geen sprake van de afbakening van het onderhavige recht, alhoewel het - naar mijn mening - niet vanzelfsprekend is dat dossiers van een advocaat onder de term "correspondentie" vallen. Overigens stemt een dergelijke uitleg wel overeen met de Straatsburgse jurisprudentie. ${ }^{218}$

Het merendeel van de weinige uitspraken met betrekking tot het recht op respect voor de correspondentie betreft het afluisteren en/of het opnemen van telefoongesprekken. Aan artikel 8 worden in deze uitspraken echter weinig overwegingen gewijd.

Een uitspraak van de Hoge Raad waarin wèl expliciet de toepasselijkheid van artikel 8 aan de orde komt, is gedaan op 10 april 1979. ${ }^{2.9}$ In deze zaak is cassatie in het belang der wet ingesteld tegen een beschikking van de Rechter-Commissaris bij de rechtbank te Amsterdam van 27 november 19T6. Volgens deze beschikking werd het aan een opsporingsambtenaar van de rijkspolitie toegestaan de telefoongesprekken gevoerd met of vanuit bepaalde telefoonnummers af te luisteren en op te nemen. De desbetreffende telefoonaansluitingen stonden op naam van een advocaat, die hiervan gebruik maakte in de uitoefening van zijn beroep. Hierdoor konden door een ieder over de voormelde telefoonaansluitingen met een ander te voeren gesprekken worden afgeluisterd, derhalve ongeacht de personen tussen wie deze gesprekken worden gevoerd.

217 HR 29 maart 1994, NJ 1994, 537.

218 Zie EHRM 16 december 1992, Niemietz Case, \$32, pp. 34-35 en hiervoor par. 4.2.4. Zie bovendien hiervoor par. 4.3.1 inzake het recht op respect voor het. privéleven waar deze uitspraak van de Hoge Raad ook wordt genoemd.

219 HR 10 april 1979. NJ 1979, 374 met noot Th.W. van Veen. Zie ook, zonder overwegingen van de Hoge Raad ten aanzien van artikel 8: HR 9 juni 1992. NJ 1992,776 , waarin het weliswaar ook ging om een telefoonaansluiting van een zogenaamde "geheimhouder" (d.w.z. iemand die geheimhoudingsplicht heeft), maar dan wel een privé-alansluiting met een "geheim" nummer, zodat het niet werd beschouwd als een als een telefoonaansluiting, die door de verdachte in de uitoefening van zijn beroep (als reclasseringsambtenaar) werd gebezigd. Volgens HR 29 juni 1993. NJ 1993, 692 geldt de onbevoegdheid van de rechter-commissaris om op grond van $125 \mathrm{~g} \mathrm{~Sv}$ de telefoonaansluiting van een advocaat, die deze in de uitoefening van zijn beroep gebruikt, niet in het geval de advocaat zèlf de verdachte is. De HR komt echter niet op grond van artikel 8 ECRM tot deze conclusie. 
Je Hoge Raad stelt vast, dat onder de begrippen "vie privée" en "correspondence" in artikel 8 lid 1 ook telefoongesprekken begrepen zijn. Hierdoor was er "te dezen een inmenging van enig openbaar gezag met jetrekking tot de uitoefening van een in die bepaling bedoeld recht ...".

De Hoge Raad verwijst in deze zaak, anders dan de Procureur-Generaal die het cassatieberoep instelde, niet naar de zaak Klass ${ }^{220}$ van het Europese Hof. De door de Hoge Raad gehanteerde formulering stemt echter zodanig met die van het Europese Hof overeen, dat de zaak Klass de Hoge Raad bij deze uitspraak vermoedelijk wel voor ogen zal hebben gestaan.

Het geringe aantal uitspraken dat ik met betrekking tot het recht op respect voor de correspondentie heb gevonden, laat zien dat van enige afbakening van dit recht niet sprake is. Slechts in één uitspraak wordt expliciet vastgesteld dat het desbetreffende communicatiemiddel (telefoon) onder het begrip "correspondentie" valt. Overigens wordt kennelijk wèl toepasselijkheid van artikel 8 aangenomen ten aanzien van briefkaarten en dossiers.

Aan het eind van deze derde paragraaf van hoofdstuk 4 zou het op zijn plaats zijn de Europese en Nederlandse rechtspraak met betrekking tot de afbakening van artikel 8, eerste lid, eens naast elkaar te zetten. Echter, de Europese rechtspraak - met name ten aanzien van artikel 8 - rechtvaardigt een afzonderlijke bespreking van een bijzonder soort verplichtingen die uit de Conventie kunnen voortvloeien: positieve verplichtingen. Deze zullen derhalve, voordat tot een evaluatie van de rechtspraak inzake artikel 8 wordt overgegaan (in par. 4.5), eerst besproken worden.

\subsection{Positieve verplichtingen}

Zoals aan het eind van de vorige paragraaf werd aangegeven, geeft de Europese rechtspraak ertoe aanleiding, dat afzonderlijk - zij het niet al te uitgebreid $^{221}$ - ingegaan moet worden op positieve verplichtingen die uit

220 EHRM 6 september 1978, Case of Klass a.o., \$41, p. 21; zie prar. 4.2.1, p. 200 en par. 4.2 .4 , p. 235.

221 Voor een uitgebreide behandeling van de kwestie van positieve verplichtingen verwijs ik naar C.J. Forder, Legal protection under Article 8 ECHR: Marck及 and beyond en C.J. Forder, Positieve verplichtingen in het kader van. het Europees Verdrag tot Bescherming van de Rechten van de Mens en de Fundamentele V rijheden. Zie verder R. Lawson, Positieve verplichtingen onder het EVRM: opkomst en ondergang van 
de verdrags- en grondwetsartikelen kunnen voortvloeien. Er is een aantal redenen hiervoor te geven. In paragraaf 1.3.4 werd aangegeven, dat in het onderhavige hoofdstuk met name gekeken zal worden naar de reikwijdteafbakening van het in artikel 8 beschermde recht: "het recht op respect voor ...". In de tot nu toe besproken rechtspraak ging het voornamelijk om bescherming van de in artikel 8 lid 1 genoemde belangen "privéleven", "familie- en gezinsleven", "woning" en "correspondentie" tegen overheidsbemoeienis. Het "respect voor" deze belangen houdt in de zojuist bedoelde betekenis in, dat een ieder recht heeft op het genot van deze belangen zonder inmenging van de zijde van de overheid. Mengt de overheid zich desondanks toch in deze belangen, dan is in principe sprake van een schending van het in artikel 8 lid 1 gegarandeerde recht. Het tweede lid van deze bepaling bevat hierop echter een uitzondering, namelijk indien de desbetreffende overheidsinmenging in overeenstemming is met de in dit tweede lid genoemde criteria; in dat geval is de inmenging gerechtvaardigd en is géén sprake van een schending van artikel 8. In het kader van de afbakening van de reikwijdte van het recht op "respect voor ..." was het derhalve tot nu toe voldoende om de grenzen vast te stellen van de begrippen "privéleven", "familie- en gezinsleven", "woning" en "correspondentie", omdat daarmee dan duidelijk zou zijn met welke belangen de overheid zich niet zonder rechtvaardiging in de zin van het tweede lid zou mogen inlaten. In welke gevallen er sprake is van een dergelijke inmenging komt, namelijk, pas aan de orde in het kader van lid 2 , de beperkingsclausule. Zoals incidenteel al in de vorige paragrafen is gebleken, is het echter mogelijk dat - ook indien geen sprake is van een inmenging in het in artikel 8 lid 1 beschermde recht - deze verdragsbepaling toch kan zijn geschonden. Deze situatie kan zich voordoen in het geval van een op de overheid rustende verplichting om actie te ondernemen ter bescherming van de in artikel 8 gegarandeerde belangen. Zoals uit de hierna te bespreken jurisprudentie zal blijken, kan het op grond van artikel 8 lid 1 verschuldigde "respect" een dergelijk overheidsoptreden vereisen. Om te kunnen bepalen of een dergelijke situatie zich voordoet, is het nodig om - net als in de vorige paragrafen de reikwijdte van het in het eerste lid van artikel 8 gegarandeerde recht

de 'fair balance'-iest, pp. 558-573. Zie voorts Th.A. van Baarda. Oordeelsvorming in casus van botsende grondrechten, pp. 64-66 voor een vijital gradaties in hel onderscheid tussen negatieve en positieve verplichtingen: 1) een "obligation to recognize or to respect", 2) een "obligation to protect". 3) een "obligation to promote". 4) een "obligation to ensure" en 5) de verplichting van de staat om ervoor te zorgen dat iedereen van zijn rechten gebruik makt. Hierop zal ik verder niet ingaan, omdat de Straatsburgse rechtspraak daartoe onvoldoende aanleiding geeft. 
vast te stellen. In dit geval gaat het echter om het bepalen van de grenzen van het begrip "respect". Waarom het in geval van positieve verplichtingen rodig is dit begrip "respect" af te bakenen en niet in het geval van regatieve verplichtingen, zal hierna blijken uit het verschil in de rol die het tweede lid ten aanzien van beide soorten verplichtingen vervult. Om niet al te veel een voorschot op de navolgende bespreking te willen nemen, beperk ik me hier tot de verklaring van dit verschil, door te wijzen op het begrip "inmenging" in lid 2, dat enkel zou kunnen wijzen op overheidsoptreden en niet op het nalaten daarvan, dat zou moeten worden gerechtvaardigd. Dit heeft tot gevolg dat volgens de rechtspraak het tweede lid niet op positieve verplichtingen kan worden toegepast met als consequentie, dat de gehele toetsing - derhalve met betrekking tot de reikwijdte en (inherente) beperking - van positieve verplichtingen binnen het eerste lid, dus in het kader van het begrip "respect", plaatsvindt. ${ }^{22}$

De bespreking van de positieve verplichtingen zal plaatsvinden aan de hand van de Straatsburgse rechtspraak ten aanzien van artikel 8 ECRM. Positieve verplichtingen kunnen echter ook worden afgeleid uit andere verdragsbepalingen, zoals de artikelen 6 en 11 van de Conventie en artikel 2 van het Eerste Protocol. ${ }^{223}$ Aan het eind van deze paragraaf zal summier op deze artikelen ingegaan worden. De positieve verplichtingen in verband met het recht op toegang tot de rechter op grond van artikel 6 lid 1. zullen afzonderlijk worden behandeld in paragraaf 5.1.3. In dit kader zal bovendien slechts zeer kort op de grondwettelijke grondrechten ingegaan worden, omdat het aantal uitspraken naar aanleiding van de in dit boek behandelde grondwettelijke grondrechten hieromtrent zeer schaars is.

Bekend is, dat klassieke rechten dienen ter vrijwaring van de burger van overheidsinmenging (negatieve verplichting). In de uitspraak van het Europese Hof voor de Rechten van de Mens in de Belgische Taalzaken zegt het Hof ten aanzien van artikel 8 ECRM zelfs, dat dit artikel bovenal een verplichting voor de Staat bevat om af te zien van actief optreden. Het bevat geen uitdrukkelijke garantie van het recht om door de wet beschermd te worden tegen inbreuken op het privéleven. ${ }^{224}$

Uit bestudering van de rechtspraak blijkt echter, dat soms ook een actief overheidsoptreden vereist is; het grondrecht omvat een positieve

222 Zie hierna de bespreking van de overwegingen uit EHRM 17 oktober 1986, Rees Case, $\$ 37$, p. 15 voorafgaand aan noot 232 op p. 293.

223 Zie uitgebreider dienaangaande: $C . J$. Forder, Positieve verplichtingen in het kader van het EVRM, pp. 614-616.

224 EHRM 23 juli 1968, Belgian Linguïstic Case, \$7, p. 33. 
verplichting voor de overheid. Een inbreuk op een zodanig grondrech bestaat niet uit een overheidsoptreden, maar uit het nalaten van actief overheidsoptreden.

De Commissie drukte het in haar "Opinion" met betrekking tot de zaak Van Oosterwijck aldus uit, dat de verplichting die voor de Staat uit artikel 8 voortvloeit vooral een verplichting is om af te zien van actief handelen, maar dat er echter gevallen zijn, waarin de Staat ertoe overgegaan is om een bepaalde situatie te regelen, wettelijke gevolgen te verbinden aan bepaalde feiten of documenten; laat de Staat in een dergelijk geval na om rekening te houden met latere veranderingen in die feiten of documenten, dan zou dit onder bepaalde omstandigheden tot een inbreuk kunnen leiden op het recht op respect voor het privé-leven wanneer geen nieuwe positieve handeling van die Staat plaatsvindt. In casu werd sexeverandering toegestaan, maar werd niet voorzien in de mogelijkheid om het geboortenregister overeenkomstig te wijzigen, waardoor op zijn geboortebewijs en een aantal administratieve lijsten soms de aanduiding "vrouw" voorkwam, wat niet overeenkwam met zijn mannelijke verschijning. Volgens de Commissie levert de hiermee gepaard gaande weigering om klager's sexuele identiteit, het essentiële element van zijn persoonlijkheid, te erkennen weliswaar geen inmenging op in klager's uitoefening van zijn recht op respect voor zijn privéleven, maar wel een "veritable failure to recognise the respect due to his private life within the meaning of Article 8 (1)". ${ }^{22 s}$

Hieruit kan men afleiden, dat ook indien geen sprake is van een inmenging in de uitoefening van het recht op respect voor het privéleven, toch sprake kan zijn van een schending van artikel 8 wanneer een Staat het "respect" dat hij aan het privéleven verschuldigd is, aan betrokkene

225 Rapp.Comm. I maart 1979, Van Oosterwijck Case, \$45-52, pp. 24-26. Zie bijvoorbeeld ook EHRM 17 oktober 1986, Rees Case, $\$ 35$, p. 14, waarin op grond van het feit dat het Hof de enkele weigering om - naar aanleiding van de geslachtsverandering die klaagster had ondergaan - het geboortenregister te veranderen of om geboortebewijzen uit te geven waarvan de inhoud en aard verschillen van het geboortenregister, niet als inmengingen (op de in artikel 8 vervatte negatieve verplichting) beschouwt, het noodzakelijk geacht wordt om het bestaan en de reikwijdte van positieve verplichtingen te bepalen. Zo ook EHRM 27 september 1990. Cossey Case, §36, p. 15. 
onthoudt. ${ }^{226}$ Deze conclusie wordt bevestigd in de zaak Marckx, waarin het Hof overweegt dat,

"the object of the Article $(8, C S)$ is 'essentially' that of protecting the individual against arbitrary interference ... it does not merely compel the State to abstain from such interference: in addition to this primarily negative undertaking, there may be positive obligations inherent in an effective 'respect' for private or family life. "227

Uit latere jurisprudentie blijkt dat dit kan worden beschouwd als een standaard-formulering van het Hof. ${ }^{228}$

In de zaak Marckx beslist het Hof voorts dat

"when the State determines in its domestic legal system the régime applicable to certain family ties, ... it must act in a manner calculated to allow those concerned to lead a normal family life."

Eerbiediging van het gezinsleven in artikel 8 betekent met name, aldus het Hof, dat in de nationale wetgeving wettelijke waarborgen moeten worden opgenomen (positieve verplichting) die de integratie van het kind in het gezin vanaf de geboorte mogelijk maken. De Staat heeft hierbij de keuze

226 Zie voor een, eventueel, andere grondslag voor positieve verplichtingen (dan het begrip "respect" in het eerste lid van de artikelen 8-11) EHRM 18 januari 1978, Case of Ireland $v$. the United Kingdom, $\$ 239$, p. 91 :

"The Convention does not merely oblige the higher authorities of the Contracting States to respect for their own part the rights and freedoms it embodies; as is shown by Article 14 and the English text of Article 1 ("shall secure"), the Convention also has the consequence that, in order to secure the enjoyment of those rights and freedoms, those authorities must prevent or remedy any breach at subordinate levels."

Zie ook Besı.Comm. 16 oktober 1986, $N$ v. Sweden, p. 175.

227 EHRM 13 juni 1979, Marckx Case, \$31, p. 15. Het eerste gedeelte van het citaat ontleent het Hof aan EHRM 23 juli 1968, Belgian Linguïstic Case, §7. p. 33.

228 Zie 0.a. EHRM 26 maart 1985. Case of $X$ and $Y v$. the Netherlands, 823, p. 11; EHRM 28 mei 1985, Case of Abdulaziz, Cabales and Balkandali, §67, p. 33; EHRM 18 december 1986, Case of Johnston a.o., \$55(c), p. 25; EHRM 7 juli 1989, Gaskin Case, §38, pp. 15-16; EHRM 26 mei 1994, Keegan Case, 849, p. 19; EHRM 27 oktober 1994. Case of Kroon and others, \$31, p. 56; EHRM 25 november 1994. Stjerna Case, \$38; en Besl.Comm. 15 maar 1984, B, $R$ and $J v$. the Federal Republic of Germany, \$4, pp. 139-141 en Besl.Comm. 13 oktober 1986, $Z$ and $E v$. Austria, §6, p. 76. 
uit diverse middelen, maar een wet die niet aan dit vereiste kan voldoen, schendt art. 8 lid 1 "without there being any call to examine it under para. 2."

Uit deze laatste overweging blijkt het Hof onder andere, zonder deze term uitdrukkelijk te noemen, aan de Staat een beoordelingsvrijheid toe te kennen bij de keuze voor de wijze waarop de Staat een effectief respect voor het gezinsleven wenst te realiseren.

Hoe kan echter de al dan niet geslaagde realisering van dit "effectief respect" getoetst worden door het Hof? Voor toetsing zijn criteria nodig. Derhalve zal moeten worden nagegaan wanneer sprake is van een "effectief respect" voor het gegarandeerde recht. Ten aanzien van het begrip "respect" stelt het Hof in de zaak Abdulaziz, Cabales en Balkandali vast dat het begrip "respect" geen duidelijk begrip is. Aan welke voorwaarden voldaan moet zijn, wil men kunnen spreken van een effectief "respect" voor het desbetreffende recht, verschilt volgens het Hof van geval tot geval. Het Hof bepaalt dan ook - dit keer uitdrukkelijk - dat aan de Verdragsstaten een ruime beoordelingsvrijheid ("margin of appreciation") toekomt bij de vaststelling van de maatregelen die nodig zijn teneinde hun verdragsverplichtingen na te leven. Hierbij zal een Staat, aldus het Hof, rekening dienen te houden met de behoeften en middelen van de samenleving en van individuen. ${ }^{230}$

Voorgaande overwegingen suggereren dat de Staat de behoeften en middelen van de samenleving enerzijds en die van individuen anderzijds tegen elkaar dient af te wegen. Dit wordt bevestigd in de uitspraak in de zaak Rees waarin het Hof vaststelt dat, bij de bepaling of er sprake is van een positieve verplichting, een eerlijke afweging ("fair balance") moet plaatsvinden tussen het algemene belang van de gemeenschap en de belangen van de individu, "the search for which balance is inherent in the whole of the Convention."

229 EHRM 13 juni 1979, Marckx Case, \$31, p. 15. Zie ook EHRM 18 december 1986. Case of Johnston a.o. $\$ 72$. p. 29 en Besl.Comm. 17 november 1983, zaak ar. 9276/81, Cv. the United Kingdom, \$1, pp. 19-20.

230 EHRM 28 mei 1985, Case of Abdulaziz. Cabales and Balkandali, $\$ 67$. pp. 33-34. Zo ook EHRM 17 oktober 1986, Rees Case, \$35. p. 14: EHRM 18 december 1986. Johnston a.0., $\$ 55$ (c), p. 25; EHRM 27 september 1990, Cossey Case, \$37, p. 15 en EHRM 25 maart 1992. Case of $B v$. France, $\$ \$ 44$ en $63, p p, 47,53-54$.

231 EHRM 17 oktober 1986, Rees Case. $\$ 37$. p. 15. Het Hof verwijsi hierbij naar overwegingen in EHRM 23 september 1982. Case of Sporrong and Lönnroth. $\$ 69$. p. 26 en EHRM 21 februari 1986, Case of James and others. \$50. p. 34 die echter betrekking hadden op een afweging in het kader van artikel 1 (eerste lid, tweede zin 
In laatstgenoemde zaak beslist het Hof voorts, dat bij deze belangenafweging de doeleinden, die worden genoemd in lid 2 van artikel 8 een zekere rol kunnen spelen, alhoewel deze bepaling slechts verwijst nar inmengingen ("interferences") in het recht dat wordt beschermd door het eerste lid - met andere woorden, betrekking heeft op negatieve verplichtingen. ${ }^{232.233}$

In het arrest van 21 februari 1990 in de zaak Powell and Rayner, gaat het Hof verder door te overwegen dat

"Whether the present case be analysed in terms of a positive duty on the State to take reasonable and appropriate measures to secure the applicant's rights under paragraph 1 of Article 8 or in terms of an

van het Eerste Protocol. Zie ook Besi.Comm. 16 oktober 1986, Nv. Sweden, p. 175 waarin het ging om een horizontale verhouding die afweging van enerzijds het bestaan van een positieve verplichting t.b.v. klager en anderzijds het recht op vrijheid van meningsuiting van een andere particulier, vereiste. Zie voorts EHRM 18 december 1986, Case of Johnston a.o., $\$ \$ 72$ en 77, pp. 29 en 31 ; EHRM 7 juli 1989, Gaskin Case. §42. p. 17 (zie bij dit arrest ook de interessante noot van EJD: NJ 1991. 659); EHRM 27 september 1990, Cossey Case, 837, p. 15 en EHRM 25 maart 1992. Case of $B$ v. France. $\$ 44$, p. 47.

232 EHRM 17 oktober 1986, Rees Case, §37, p. 15; zo ook EHRM 18 december 1986, Case of Johnston a.o., §72, pp. 29-30 en EHRM 7 juli 1989, Gaskin Case, \$42, p. 17.

233 Ontbreekt een procedure, waarin een onafhankelijk orgaan de bedoelde belangenafweging kan maken, dan is sprake van een schending van artikel 8. In de zaak Gaskin was het voor beantwoording van de vraag of de Staat verplicht was klager toegang te geven tot gegevensbestanden waarin gegevens over met name klager's jeugd waren opgenomen, noodzakelijk dat een afweging, door een onafhankeiijk orgaan, plaatsvond tussen het belang van kiager van đie gegevens kennis te kunnen nemen. en de - voor de mogelijkheid een zodanig gegevensbestand op te zetten noodzakelijke - vertrouwelijkheid ten aanzien van de verschaffers van de in die bestanden op te nemen gegevens. Het Hof vond het niet in overeenstemming met het principe van proportionaliteit, dat in een, systeem, waarin het mogelijk was aan de verschaffers van informatie om toestemming te vragen de desbetreffende informatie vrij te geven, niet voorzien was in een procedure, waarin de bedoelde afweging plaats kon vinden, in het geval dat een groep personen niet bereikbaar was, de gevraagde toestemming zou weigeren dan wel in het geheel niet zou reageren; derhalve achtte het Hof artikel 8 geschonden. EHRM 7 juli 1989. Gaskin Case, \$49. p. 20. Zie hiervoor de paragrafen 2.4.2.1 en 4.2.2 voor dit uitbreiden van de reikwijdte van artikel 8 lid 1 met een procedureel element in EHRM 8 juli 1987, Case of $W v, U K, \S \S 60$ (c), 6165, pp. 27-29; EHRM 8 juli 1987, Case of $B$ v. UK, $\$ \S 61$ (c), 62-65. pp. 72-74; EHRM 8 juli 1987, Case of $R v$. UK, $\$ \$ 65$ (c), 66-70, pp. 117-119 en EHRM. 8 juli 1987. Case of $H v . U K, \$ \$ 87-90$, pp. 63-64. 
'interference by a public authority' to be justified in accordance with paragraph 2, the applicable principles are broadly similar. ${ }^{23 \mathrm{~A}}$

Met deze laatste zinsnede wordt gedoeld op de eerlijke afweging ("fair balance") tussen de betrokken belangen van de individu en de gemeenschap als geheel die in beide gevallen moet plaatsvinden en het feit dat in de context van beide soorten verplichtingen de Staat een zekere beoordelingsvrijheid geniet. ${ }^{235}$

Deze overwegingen worden in de zaak López Ostra vrijwel geheel overgenomen en bovendien wordt in deze uitspraak nog eens de overweging uit de zaak Rees herhaald, dat bij de bedoelde. belangenafweging ook in geval van positieve verplichtingen de in het tweede lid van artikel 8 genoemde doeleinden een zekere relevantie kunnen hebben. ${ }^{236}$

In de zaak Keegan formuleert het Hof het hiervoor geciteerde, in de zaak Powel and Rayner geformuleerde uitgangspunt, aldus, dat de grenzen tussen positieve en negatieve overheidsverplichtingen op grond van artikel 8 zich niet lenen voor nauwkeurige definiëring ("precise definition"), maar dat de toepasselijke beginselen niettemin hetzelfde zijn. Dit laatste is opvallend omdat het Hof nu spreekt van "similar" in plaats van "broadly similar"! ${ }^{37}$

De stand van zaken ten aanzien van positieve verplichtingen kan op grond van de bovenstaande rechtspraak aldus worden weergegeven. Howel artikel 8 hoofdzakelijk gericht is op de bescherming van het privéleven, het familie- en gezinsleven, de woning en de correspondentie tegen overheidsoptreden (negatieve verplichting), is dit niet de enige betekenis die aan het begrip "respect voor" in het eerste lid van deze bepaling toekomt. Effectief "respect" voor de beschermde belangen van de burger

234 EHRM 21 februari 1990, Case of Powell and Rayner, \$41. p. 18. Zo ook EHRM 9 december 1994, Case of López Ostra, $\$ 51$.

235 Zo ook EHRM 26 mei 1994. Keegan Case, §50, p. 19; EHRM 27 oktober 1994. Case of Kroon a.e.. \$31. p. 56 en EHRM 25 november 1994, Stjerna Case, \$38.

236. EHRM 9 december 1994, López Ostra Case, $\$ 51$.

237 EHRM 26 mei 1994, Keegan Case. \$49, p. 19. Zo ook EHRM 27 oktober 1994. Case of Kroon a.o. \$31, p. 56 en EHRM 25 november 1994, Stjerna Case, \$38. In de zaak Keegan vindt het Hof het overigens niet noodzakelijk om afzonderlijk het bestaan van positieve verplichtingen te toetsen, omdat volgens het Hof de (positieve en negatieve) verplichtingen - die uit artikel 8 voortvloeien - nauw met elkas verstrengeld zijn en het de inbreuk op de negatieve verplichting in kwestie alleen toegestaan acht indien voldaan is an de voorwaarden in het tweede lid. ( $(51)$ 
kan volgens de rechtspraak ook met zich meebrengen, dat de Staat wetgeving tot stand moet brengen of andere maatregelen treffen (positieve verplichting, o.a. Marckx, Keegan, Kroon en Stjerna). Omdat niet duidelijk is wat in de context van positieve verplichtingen exact onder "respect" verstaan moet worden - de betekenis van dit begrip is niet duidelijk - dient ter vaststelling van het bestaan en de reikwijdte van een eventuele positieve verplichting een eerlijke belangenafweging plaats te vinden tussen het individuele belang en het algemeen belang (o.a. Abdulaziz, Rees, Cossey en $B$ v. France). Omdat positieve en negatieve verplichtingen niet scherp van elkaar te onderscheiden zijn, is de toetsing die plaatsvindt aan vergelijkbare principes gebonden als in het geval van negatieve verplichtingen (o.a. Powell and Rayner, Keegan, Kroon, Stjerna en López Ostra). Dit houdt in, dat Staten een zekere beoordelingsruimte bezitten bij de vaststelling van de wijze waarop zij hun verdragsverplichtingen naleven en dat bij de bedoelde belangenafweging de in lid 2 genoemde doeleinden een rol kunnen spelen (o.a. Rees, Johnston, Gaskin en López Ostra).

De vraag is nu hoe het Hof in concreto een keuze makt tussen toetsing aan positieve of aan negatieve verplichtingen. Een tweede vraag is wat de consequenties van een dergelijke keuze zijn.

Bij de beantwoording van de eerste vraag stuiten we direct op problemen. In een aantal gevallen blijkt het mogelijk de overheidsverplichting op grond van artikel 8 zowel positief als negatief te formuleren. Deze situatie kan zich op twee manieren voordoen. Een eerste voorbeeld biedt de zaak Abdulaziz, Cabales en Balkandali. Aan de echtgenoten van klaagsters werd toelating tot het Verenigd Koninkrijk geweigerd. De vrouwen klaagden erover dat hun hierdoor hereniging met hun echtgenoten werd ontzegd, wat een schending van hun recht op respect voor hun familie- en gezinsleven zou opleveren. Het Hof bepaalt dat op de Britse autoriteiten geen verplichting rustte om de echtgenoten toe te laten, onder meer omdat klaagsters ook met hun man in hun land van herkomst familie- en gezinsleven konden hebben (geen inbreuk op positieve verplichting). In plaats daarvan had het Hof echter ook kunnen onderzoeken of de weigering de mannen toe te laten en hun geen verblijfstitel te verschaffen, een inmenging opleverde in het recht van klaagsters op respect voor hun gezinsleven (inbreuk op negatieve verplichting). De samenleving van klaagsters met hun echtgenoten werd door deze weigering immers verhinderd. Dit komt, mijns inziens, ook meer overeen met de inhoud van de klacht waaromtrent het Hof had bepaald, dat 
AFBAKENING: JURISPRUDENTIE NAAR AANLEIDING VAN ART. 8 ECRM 296

"(t)he applicants are not the husbands but the wives, and they are complaining not of being refused leave to enter or remain in the United Kingdom but, as persons lawfully settled in that country, of being deprived (Mrs. Cabales), or threatened with deprivation (Mrs. Abdulaziz and Mrs. Balkandali), of the society of their spouses there. "238

Deze zaak biedt derhalve een voorbeeld van een geval waarin de aanspraak die klaagsters maken op respect voor hun familie- en gezinsleven, dezelfde inhoud heeft, of deze aanspraak nu geformuleerd is als positieve verplichting dan wel als negatieve. ${ }^{239}$ Het gaat in beide gevallen om een beweerde schending van artikel 8 doordat de echtgenoten van klaagsters niet worden toegelaten tot het Verenigd Koninkrijk. De keuze van het Hof voor toetsing van de positieve verplichting (en niet van de negatieve verplichting) van de Staat behoefde in dit geval, naar mijn mening, meer motivering.

Een tweede voorbeeld van een situatie waarin het mogelijk lijkt de overheidsverplichting op grond van artikel 8 zowel positief als negatief te formuleren, is de volgende. Soms kan het nodig zijn dat de overheid ter bescherming van iemands rechten maatregelen treft, in een situatie die is ontstaan als gevolg van eerder overheidsoptreden. Een voorbeeld hiervan biedt de zaak López Ostra. Geklaagd werd over schending van het recht op respect voor de woning, het privéleven en het familie- en gezinsleven van klaagster ten gevolge van de milieuvervuiling die werd veroorzaakt door een particulier afvalverwerkingsbedrijf dat met toestemming en subsidie van de gemeentelijke autoriteiten op gemeentegrond was gebouwd. Een procedure ter toetsing van de rechtmatigheid van de bouw en het functioneren van de installatie was sinds 1991 aanhangig bij de Spanse Hoge Raad en had gedurende de procedure bij het Hof nog niet tot een uitkomst geleid. Het Hof onderzoekt in deze zaak of op de Spanse autoriteiten de verplichting rustté om actie te ondernemen ter beèindiging van de overlast. De procedure die klaagster's zuster in Spanje had gevoerd resulteerde weliswar in een beslissing tot tijdelijke sluiting van de installatie, maar deze beslissing (en andere, vergelijkbare besluiten van rechters) werd door het hiertegen, door de gemeente, ingestelde beroep

238 BHRM 28 mei 1985, Case of Abdulaziz. Cabales and Balkandali, §60, p. 31. Vgl. ook punt 3 van de noot van L.F.M. Verhey bij EHRM 7 juli 1989, Gaskin Case. NJCM-Bulletin 15-2 (1990), p. 216. Zie verder de dissenting opinion van rechter Martens bij EHRM 27 september 1990, Cossey Case, \$3.4, p. 26 t.a.v. EHRM 17 oktober 1986, Rees Case.

239 Zie C.J. Forder, Positieve verplichtingen in het kader van het EVRM, p. 619. 
geschorst of anderszins niet uitgevoerd. Uiteindelijk komt het Hof tot de conclusie dat - ondanks de beleidsvrijheid die de Spaanse autoriteiten terzake hadden - geen sprake is geweest van een eerlijke afweging van de in het geding zijnde belangen: het economisch welzijn van de gemeente en klaagster's effectieve genot van haar recht op respect voor haar woning, en haar privéleven en familie- en gezinsleven. Het Hof kiest derhalve voor een onderzoek naar het schenden van een positieve verplichting door de Spaanse overheid. Het was echter ook denkbaar geweest, dat het Hof had onderzocht of de situatie die tot het ondernemen van actie aanleiding gaf, zélf een inmenging in het recht op respect voor klaagster's woning en haar privé- en gezinsleven opleverde. Deze situatie was immers mede het gevolg van het verlenen van toestemming en het verstrekken van subsidie voor de bouw van de afvalverwerkings-installatie door de gemeente. De inmenging had derhalve kunnen worden afgeleid, niet uit het nemen van overheidsmaatregelen zelf, maar uit het bestaan van een - mede door de overheid geschapen - situatie op grond waarvan bepaalde overheidsmaatregelen genomen hadden moeten worden. ${ }^{240}$

Dit soort gevallen geeft aan, dat het niet altijd eenvoudig zal zijn te motiveren waarom in een bepaald geval nu juist de nakoming door de overheid van een positieve verplichting beoordeeld wordt en niet de naleving van een negatieve verplichting en omgekeerd. ${ }^{24 !}$ In de jurisprudentie terzake komt men veelal geen uitgebreidere motivering tegen dan dat het in casu gaat om een klacht dat de overheid bepaalde maatregelen niet, ontoereikend of op de verkeerde wijze genomen heeft. In zaken waarin de situatie duidelijk is, lijkt dit mij geen probleem, maar in zaken met een casuspositie als in, bijvoorbeeld de zaken Abdulaziz, Cabales en Balkandali en López Ostra ligt dit anders. In dat geval zal de keuze voor toetsing aan positieve of negatieve verplichtingen beter

240 Vergelijkbaar is het geval waarin de inmenging niet had behoeven te worden afgeleid uit het nemen van overheidsmaatregelen, maar reeds uit het bestaan van wetgeving op grond waarvan bepaalde overheidsmaatregelen genomen (hadden) kunnen of moeten worden. Zie J. de Boer, Art. 8 EVRM. Algemeen, pp. 52-53. C.J. Forder (Positieve verplichtingen in het kader van het EVRM, p. 622) geeft hierbij als voorbeeld de casus in de zaak Abdulaziz a.o., waarin hell de in het Verenigd Koninkrijk bestaande immigratie-wetgeving was, die verhinderde dat klaagsters hun potentiële familie- en gezinsleven in echt "family life" om te zetten. Deze wetgeving vormde op zichzelf reeds een inmenging in de zin van artikel 8.

241 Zie ook het voorbeeld van de Boer omtrent ouderlijke macht: ingeval van ontneming (niet-continuering) van de ouderiijke macht aan ouders na een echtscheiding gaat het om een inbreuk op een negatieve verplichting; bij een weigering om ongehuwde ouders met de ouderlijke macht te bekleden gaat het echter om een inbreuk op een positieve: verplichting. Art. 8 EVRM. Algemeen, p. 24. 
gemotiveerd moeten worden en zal voor de uitkomst van die keuze medebepalend kunnen zijn, ten eerste vanzelfsprekend de inhoud van de klacht en ten tweede, de consequenties die een dergelijke keuze met zich brengt. Daarmee komen we op de tweede, hierboven gestelde vraag.

Als tweede vraag, werd hierboven aan de orde gesteld, welke consequenties zijn verbonden aan een keuze voor toetsing aan positieve verplichtingen in vergelijking met toetsing aan negatieve verplichtingen.

Zoals eerder werd aangegeven, blijkt uit de rechtspraak dat bij de vaststelling of sprake is van een positieve verplichting en wat die verplichting in het concrete geval inhoudt ${ }^{242}$, een eerlijke afweging moet plaatsvinden tussen het individuele en het algemeen belang. Staten hebben een zekere beleidsvrijheid bij de vaststelling van de wijze waarop zij hun verdragsverplichtingen naleven. Bovendien kunnen bij de te verrichten belangenafweging de doeleinden, die worden genoemd in het tweede lid van artikel 8, een zekere relevantie hebben.

Kijken we naar de uitspraken van het Hof, dan blijkt dit in praktijk te betekenen, dat de toetsing van het bestaan en, met name, van de reikwijdte van positieve verplichtingen in concreto, zich geheel binnen het eerste lid van artikel 8 voltrekt, namelijk op grond van het begrip "respect". Dit wil zeggen dat een vermenging plaatsvindt van de vaststelling van (het bestaan en) de reikwijdte van de positieve verplichting van de overheid in abstracto en van de beperkingen die daarop in het concrete geval mogen worden gemaakt. ${ }^{243}$ Deze vermenging kan niet alleen verwarring zaaien omtrent de reikwijdte van het recht op respect voor het privéleven, het familie- en gezinsleven, de woning en de correspondentie en daarmee omtrent de kans van slagen van een beroep op dit recht, maar zou ook kunnen leiden tot het gevaar, dat de beperkingen in onvoldoende mate als uitzonderingen zullen worden beschouwd. Dit gevaar wordt nog versterkt, door de grote

242 Het Hof spreekt hier van de reikwijdte van de positieve verplichting.

243 Reikwijdte van een positieve verplichting in abstracto: de inhoud van de positieve verplichting dic voor de overheid in het algemeen uit de vâdragsbepaling voortvlocit: reikwijdte van een positieve verplichting in concreto: de inhoud van dezt abstracte verplichting nader uitgewerkt voor het concrete geval, dat wil zeggen nadat enerzijds het belang van de individu bij nakoming van de abstracte verplichting (in zijn volle omvang) is afgewogen tegen de belangen van de Staat om daarop met het oog op een bepaald doel, bijvoorbeeld het economisch welzijn van het land, een uitzondering op te maken. 
beoordelingsvrijheid die aan de Staat wordt toegekend bij het te voeren beleid naar aanleiding van artikel $8 .^{244}$

Juist wanneer een Staat een ruime beleidsvrijheid heeft bij de keuze van de middelen ter nakoming van zijn verplichtingen ingevolge artikel 8 lid 1 (en in het algemeen de ECRM), is het noodzakelijk dat de uitoefening van deze beleidsvrijheid expliciet getoetst kan worden aan de garanties van lid 2. Een illustratie hiervan biedt een voorbeeld dat kan worden ontleend aen Forder. ${ }^{245}$

Uit de hierboven geciteerde passage uit de Marckx-zaak ${ }^{246}$ kan men afleiden, dat artikel 8 lid 1 de Staat verplicht te voorzien in een wettelijke erkenning van de relatie tussen een ongehuwde moeder en haar kind, zonder welke erkenning het bestaan van gezinsleven tussen beide - en derhalve naleving van artikel 8 - niet mogelijk is. Op dezelfde wijze zou artikel 8 lid 1 de Staat kunnen verplichten tot het aannemen van een wettelijk instrument waarop het omgangsrecht van de gescheiden ouder - die niet de voogdij over zijn of haar kind heeft - met dat kind, zou kunnen worden gebaseerd. Op dit omgangsrecht zou dan onder omstandigheden een uitzondering op grond van lid 2 van artikel 8 gemaakt kannen worden met het oog op bijvoorbeeld de belangen van het kind. ${ }^{247}$ Het voorgaande geeft aan, dat de uitspraak in de Marckx zaak niet per definitie uitsluit, dat artikel 8 lid 2 op positieve verplichtingen wordt toegepast. Forder suggereert het bestaan van basisvoorwaarden (zoals de wettelijke erkenning van de relatie tussen - in dit geval - een ongehuwde moeder en haar kind) voor de garantie van negatieve verplichtingen (zoals het respect voor het gezinsleven). ${ }^{248}$ Afwijking van deze basisvoorwaarden zou niet onder lid 2 kunnen worden toegestaan: deze

244 De vermenging van de vaststelling van de reikwijdte van een recht en de daarop aan te brengen beperkingen is overigens een verschijnse! wat zich nie! alleen voordoet bij de toetsing van het Hof aan positieve verplichtingen, maar is juist een nadeel wat zich in het algemeen dreigt voor te doen bij het fenomeen "inherente beperkingen" ("implied limitations"). Vergelijk $\$ 1$ van de Concurring opinion van Judge Bernhardt bij EHRM 28 mei 1985. Case of Abdulaziz a.o., p. 47. die om die reden pleit voor het toepassen van het tweede lid van artikel 8. De jurisprudentie van het Hof naar aanleiding van het recht op toegang tot de rechter ex artikel 6 lid 1 ECRM laat echter zien, dat deze vermenging in geval van inherente beperkingen te vermijden is. Zie hiervoor paragraaf 5.1.3.

245 Vergelijk: C.J. Forder, Legal protection under Article 8 ECHR: Marckx and beyond, pp. 179-180.

246 Bedoeld wordt de passage voorafgaand aan noot 229 op pp. 293-294.

247 Dit is de praktijk zoals die in de Nederlandse rechtspraak op dit punt is ontwikkeld! Zie hiervoor de paragrafen 4.3.2.1 en 4.3.2.3.

248 C.J. Forder, Legal protection under Article 8: Marckx and beyond, pp. 179-180 spreekt van "core rights". 
afwijking zou zonder meer een schending van artikel 8 opleveren. De beperking van een relatie tussen bijvoorbeeld moeder/vader en kind in het individuele geval zou volgens Forder wél aan lid 2 getoetst kunnen worden. $\mathrm{Zij}$ sluit de rol van lid 2 bij de beperking van positieve verplichtingen, die gericht zijn op de uitoefening van het recht op gezinsleven (zoals het omgangsrecht) mijns inziens terecht niet uit. ${ }^{26}$

Zoals hiervoor is gebleken heeft het Hof deze betekenis in de zaak Rees en latere zaken echter niet aan de uitspraak in de zaak Marckx toegekend.

Bij wijze van conclusie, kan de praktijk van het Europese Hof met betrekking tot positieve verplichtingen op grond van artikel 8 als volgt worden samengevat. Uit de rechtspraak blijkt niet hoe het Hof in het concrete geval een keuze maakt tussen toetsing aan positieve of aan negatieve verplichtingen. Een duidelijke motivering omtrent deze keuze ontbreekt doorgaans. Dit valt te betreuren in zaken waarin de toetsing aan positieve verplichtingen niet overduidelijk voor de hand ligt. Niet in elk van de genoemde zaken van het Hof werd door de klager(s) uitdrukkelijk een beroep gedaan op het gebrek van de overheid om bepaalde maatregelen te nemen. Veelal wordt de Staat in algemene termen schending van artikel 8 verweten. Maar zelfs als wel gewezen wordt op het nalaten van bepaalde overńeidsmaatregelen, dan nog wil dat niet zeggen dat het toetsen aan positieve verplichtingen de aangewezen weg is om de klacht te behandelen. Hiervoor is getracht aan te geven, dat overheidsverplichtingen op grond van artikel 8 en de aanspraken die burgers daaraan menen te kunnen ontlenen, veelal als zowel een positieve verplichting als een negatieve verplichting geformuleerd kunnen worden. Wellicht zou daarom het Hof, ook uit eigener beweging (derhalve wanneer de klager wèl wijst op de nietnaleving van een positieve overheidsverplichting) moeten kijken of het mogelijk is de klacht te behandelen aan de hand van een toetsing aan een negatieve verplichting, en alleen wanneer er geen twijfel over bestaat dat uitsluitend een positief te formuleren overheidsverplichting in het geding is, de klacht ook als zodanig te behandelen. De reden die voor deze, mijns inziens, voorkeur voor toetsing aan negatieve verplichtingen (waar

249 C.J. Forder. Legal protection under Article 8: Marckx and beyond, pp. 179-180. Ook een voorkeur voor kwalificering van de klacht in de desbetreffende zaken als een klacht over schending van een negatieve verplichting en toetsing van do inmenging aan lid 2 hebben: annotator EJD bij EHRM 7 juli 1989. Gaskin Case, \$2 (laatste 3 alinea's), NJ 1991, 659, p. 2765 linker kolom; en rechter Martens in zijp dissenting opinion bij EHRM 27 september 1990, Cossey Case, §§3.4-3.5, pp. 26-27 mede ten aanzien van, onder andere, de zaak Rees (overigens meent Martens dat de kern van de klacht in laatstgenoemde zaak een andere is dan die geformuleerd is door het Hof). 
mogelijk) gegeven kan worden, valt naar mijn mening af te leiden uit de consequenties die - blijkens de jurisprudentie - uit de wijze van toetsen van psitieve verplichtingen voortvloeien.

Deze consequenties bestaan in de praktijk van het Hof hierin, dat geen azonderlijke vaststelling plaatsvindt van het bestaan en de reikwijdte van en positieve verplichiting in een bepaald soort zaken. In tegendeel, wordt dor het Hof meestal in het geheel niet aangegeven of er wellicht in het agemeen, dus in abstracto, een verplichting tot het nemen van een bepaald sort maatregelen in globaal aangeduide situaties bestaat. Slechts een enkele keer wordt zeer vaag een bepaalde overheidsverplichting genoemd, vaarvan echter nog op zo veel uiteenlopende wijzen uitvoering kan worden ggeven, dat de rechtzoekende nog geen enkel idee heeft wat voor anspraken op overheidsoptreden hij hieruit af kan leiden. Een voorbeeld van het laatste biedt, zoals gezegd, de verplichting die werd geformuleerd in de zaak Marckx en is herhaald in een aantal andere zaken, dat in de rationale wetgeving wettelijke waarborgen moeten worden opgenomen (ositieve verplichting) die de integratie van het kind in het gezin vanaf de geboorte mogelijk. maken. Dat er een verplichting tot het nemen van naatregelen bestaat voor de Staat blijkt hier wel uit, maar niet tot wat voor soort aanspraken dit kan leiden. Niet blijkt, derhalve, of de verplichting dwingt tot, bijvoorbeeld, het tot stand brengen van wetgeving die - in het algemeen - een recht geeft op de mogelijkheid om als onwettig kind van je natuurlijke moeder of je grootouders van moederszijde te erven, een recht op omgang tussen niet met het ouderlijk gezag belaste ouders en hun kinderen en dergelijke; wetgeving derhalve, aan de hand waarvan dan in het concrete geval getoetst kan worden welke uitwerking deze verplichting moet krijgen.

In de meeste zaken wordt niet eerst het bestaan en de inhoud van een algemene, abstracte verplichting vastgesteld en daarna in het concrete geval bekeken of een uitzondering op deze verplichting op grond van lid 2 gerechtvaardigd is. In die zaken wordt direct voor het concrete geval bepaald, of de overheid verplicht is tot het nemen van specifieke maatregelen zodat de reikwijdte-afbakening van de verplichting en de daarop aan te brengen beperkingen als het ware samenvallen. Er is derhalve sprake van slechts één toetsing, in plaats van twee. Deze toetsing betreft een belangenafweging van het individuele belang tegen het algemeen belang, waarbij de Staat een doorgaans ruime beleidsvrijheid geniet en de criteria van artikel 8 lid 2 (met name de doelcriteria) een rol kunnen spelen. Deze wijze van toetsen is vanuit het oogpunt van rechtszekerheid onbevredigend: uit de rechtspraak kunnen geen maatstaven afgeleid worden aan de hand waarvan in algemene zin aanspraken op 
AFBAKENING: JURISPRUDENTIE NAAR AANLEIDING VAN ART. 8 ECRM 302

(actief) overheidsoptreden op grond van artikel 8 kunnen worden vastgesteld. ${ }^{250}$

Het is derhalve wenselijk, dat er een andere constructie gezocht wordt voor de vaststelling van het bestaan en de reikwijdte van een, uit artikel 8 lid 1 voortvloeiende, positieve overheidsverplichting. Een constructie die in elk geval leidt tot een gescheiden vaststelling van de reikwijdte van de uit artikel 8 voortvloeiende positieve verplichting enerzijds en de daarop in het concrete geval te maken uitzonderingen anderzijds. Dat dit niet eenvoudig is, mede gezien het uitgangspunt dat de rechter niet een wetgevende rol kan gaan vervullen, staat buiten kijf. In het laatste hoofdstuk van dit boek zal getracht worden een mogelijk alternatief voor de huidige toetsingsmethode van positieve verplichtingen aan te dragen.

De voorgaande bespreking van positieve verplichtingen is met name bedoeld om aan te duiden, dat de rechten waaraan doorgaans het karakter van een negatieve overheidsverplichting wordt toegekend (de "klassieke" grondrechten) ook positieve verplichtingen kunnen inhouden. Wanneer derhalve een behandeling plaatsvindt van de afbakening van het in artikel 8 lid 1 vervatte recht, dan betekent dit dat niet alleen gekeken wordt naar de anwikkeling var oriteris shor rohters ten behoeve van de begrenzing van de begrippen "privéleven", "familie- of gezinsleven". "woning" en "correspondentie", maar ook van het in lid 1 genoemde begrip "respect" voor zover dit ziet op positieve verplichtingen. Dat is in deze paragraaf gebeurd.

De bespreking biedt, zoals in het begin van de paragraaf is aangekondigd, geen compleet beeld. Er vloeien ook positieve verplichtingen voort uit andere artikelen dan artikel 8 ECRM. Zo bepaalde het Hof bijvoorbeeld ten aanzien van artikel 6 ECRM in de zaak Airey, dat er een effectief rechtsmiddel beschikbaar moest zijn voor de vaststelling van een burgerlijk recht ("civil right"); op grond hiervan zou een staat in sommige gevallen gehouden kunnen zijn om rechtshulp te verschaffen. ${ }^{3 /}$

250 Zie ook de kritiek van Bellekom dat het Hof zich - door de beperkingsgronden in het tweede lid slechts beperkte betekenis toe te kennen en de Siaten een grote beleidsvijiheid te geven - slechts een marginale rol toebedeelt en zich deels de mogelijkheid ontneemt om met betrekking tot positieve verplichtingen een voortrekkersrol te vervulien in verband met toekomstige rechtsontwikkelingen. Th.L. Bellekom, Het Hof voor de Rechten van de Mens en de beperkingsclausules van het EVRM. p. 67. Zik voorts C.J. Forder, Positieve verplichtingen in het kader van het EVRM, pp. 635637 ten aanzien van EHRM 25 maart 1992. Case of Bi v. France en $\$ 10$ (Conclusie).

251 EHRM 9 oktober 1979, Airey Case, $\$ \$ 25$ en 26. pp. 14-16. Zie o.a. ook (implicit) EHRM 8 juli 1987 , Case of $O$ v. $U K, \S 63$, pp. 27-28. 
0ok met betrekking tot artikel 11 van de Conventie ${ }^{25}$ en artikel $2^{253}$ van tet Eerste Protocol heeft het Hof het bestaan van positieve verplichtingen tan de Staat vastgesteld.

Wat betreft de grondwettelijke grondrechten: ten aanzien van de veelal as klassiek betitelde grondrechten - in de artikelen 1 tot en met 17 - moet vorden opgemerkt, dat sommige van deze bepalingen ook sociale componenten bevatten, derhalve tot overheidsoptreden verplichten. In het rorige hoofdstukken zagen we al, dat diverse artikelen bepalingen bevatten, die de overheid verplichten een bepaalde materie te regelen. 0mgekeerd bevatten sommige "sociale grondrechten" (artikelen 18-23 Gw) ook klassieke componenten, zoals de artikelen 19 lid 3 (vrije arbeidskeuze) en 20 lid 2 (recht op bijstand). Derhalve omvatten ook verschillende grondwettelijke grondrechten positieve verplichtingen. ${ }^{254}$ Kortmann wijst in dit verband onder meer op het subsidiëren van de noodlijdende pers (artikel 7 Grondwet), het uit artikel 2 lid 4 Grondwet (het recht om het land te verlaten) afleiden van een plicht tot het verschaffen van een paspoort of ander reisdocument en - met betrekking tot artikel 9 - het ter beschikking stellen van vergaderruimten. ${ }^{25 s}$

\subsection{Evaluatie; een vergelijking van de criteria van de Nederlandse met de Straatsburgse instanties voor de afbakening van artikel 8 lid 1 ECRM}

$\mathrm{Na}$ de behandeling in de voorgaande paragrafen van de Nederlandse jurisprudentie met betrekking tot artikel $8 \mathrm{ECRM}$ is het noodzakelijk te komen tot een beantwoording van de in paragraaf 4.3 gestelde vragen. Deze vragen luiden: Gebruikt de Nederlandse rechterlijke macht dezelfde criteria als de Straatsburgse instanties of ontwikkelt zij eigen criteria? in

252 Zie EHRM 21 juni 1988, Case of Platform Ärzte für das Leben, \$̧\$31-32 (zie ook $\$ \$ 34$ en 36), p. 12.

253 Zie EHRM 25 februari 1988. Case of Camphell and Cosans v. UK, \$37(a), pp.17. 19(17). Forder leidt ook een positieve verplichting op grond van artikel 3 van het Eerste Protocol af uit EHRM 2 maart 1987, Case of Mathieu-Mohin and Clerfayt, $\$ 52$, p. 23. Zie C.J. Forder, Positieve verplichtingen in het kader van het EVRM, p. 616. Mijns inziens gaat het hier meer om grenzen die aan de bevoegdheid om voorwaarden aan het kiesrecht te verbinden worden gesteld. Deze grenzen doen sterk denken aan de voorwaarden die worden gesteld aan de impliciete beperkingen op het recht op toegang tot de rechter, die in paragraaf 5.1.3.1 zullen worden behandeld.

254 Dit zal duidelijker naar voren komen bij de bespreking van de jurisprudentie naar aanleiding van de interpretatie van de grondwettelijke grondrechten.

255 C.A.J.M. Kortmann, Grondrechten in de nieuwe grondwet, p. 238. 
AFBAKENING: JURISPRUDENTIE NAAR AANLEIDING VAN ART. 8 ECRM 304

als dit laatste het geval is, doet de rechter dit dan aan de hand van de Straatsburgse jurisprudentie of doet hij dit zelfstandig?

\section{Private life/privéleven}

Bij de behandeling van de Nederlandse jurisprudentie inzake het recht op privéleven kwam naar voren, dat in de rechtspraak die niet betrekking heeft op de waarneming, vastlegging, gebruikmaking en openbaarmaking van persoonsgegevens artikel 8 slechts casuïstisch wordt toegepast. Vaste criteria zijn op dit gebied niet ontwikkeld, noch wordt aansluiting gezocht bij de in Straatsburg ontwikkelde criteria.

Wat betreft de rechtspraak inzake het waarnemen en vastleggen van gegevens of gedragingen van personen en het gebruikmaken en openbaren van dergelijke gegevens geeft de Nederlandse jurisprudentie het volgende beeld. Twee soorten criteria kunnen in deze jurisprudentie worden onderscheiden, die eerder objectieve en subjectieve criteria zijn genoemd. ${ }^{36}$

Objectieve criteria hebben betrekking op de gedraging die in het geding is. Aan de hand van de aard en de mate van intimiteit van de gedraging kan worden vastgesteld of die gedraging behoort tot het privéleven van de persoon om wiens gedraging het gaat. Is dit het geval, dan zal vervolgens moeten worden vastgesteld of sprake is van een inbreuk op dit privéleven. Deze vaststelling gebeurt aan de hand van bijkomende omstandigheden, het karakter van de vastlegging van de desbetreffende gegevens op geluids-, foto- of filmmateriaal en de context van de openbaarmaking.

Subjectieve criteria betreffen de innerlijke wens van de persoon om wiens gegevens of gedraging het gaat om met rust te worden gelaten. Voorbeelden van subjectieve criteria zijn "het recht om zijn eigen leven te leiden met zo weinig mogelijk inmenging van buitenaf" en "de reeks van situaties waarin ... de mens onbevangen zich zelf wil zijn". Ook hier spelen concrete omstandigheden en de achtergrond van de betrokken persoon een rol en zijn de opvattingen van anderen omtrent het "privégehalte" van een gedraging niet relevant. Overigens zullen objectieve en subjectieve criteria elkaar vaak aanvullen. Zo zal bijvoorbeeld aangenomen kunnen worden dat wanneer een omhelzing (een gedraging van intieme aard) in het openbaar, maar wel in een achteraf-steegje plaatsvind (objectieve criteria), het de wens van de betrokkenen zal zijn om onbevangen zichzelf te kunnen zijn (subjectief criterium). Omhelzen ze 
elkaar echter, terwijl ze deelnemen aan een demonstratie (in de aard waarvan het besloten ligt dat die demonstratie gezien zal (moeten) worden), dan kan daaruit worden afgeleid, dat bij de betrokkenen niet die wil aanwezig was om onbevangen zichzelf te kunnen zijn.

Bij de bespreking van de Straatsburgse jurisprudentie werd als hoofdcriterium het "openbaarheids" "-criteriumonderscheiden. Dit criterium houdt in, dat het privékarakter van een gedraging of situatie afhangt van de mate waarin deze gedraging of situatie in verband staat met het openbare leven, het openbaar belang of de belangen van andere personen. ${ }^{27}$ Dit criterium is objectief van karakter. Hieraan moet wel worden toegevoegd, dat juist ten aanzien van het waarnemen en vastleggen van gegevens of gedragingen van personen en het gebruikmaken en openbaren van dergelijke gegevens geen criteria zijn ontwikkeld voor de vaststelling of sprake is van "private life". Zo komt het Hof bijvoorbeeld in de zaak Gaskin niet verder dan de constatering dat de gegevensbestanden, die in deze zaak in het geding waren, in verband staan met Gaskins privé- en gezinsleven. ${ }^{258}$

Het is waarschijnlijk, dat bij de hantering van het "openbaarheids"criterium door de Straatsburgse instanties ook gekeken zal worden naar de aard en de mate van intimiteit van de gedragingen of situaties die in het geding zijn. Vermoedelijk zal daarbij ook rekening gehouden worden met de omstandigheden en de context van het geval, al blijkt dit niet uit de besproken Straatsburgse zaken. Hieruit kan geconcludeerd worden, dat in de Nederlandse rechtspraak het Straatsburgse "openbaarheids"-criterium niet wordt toegepast, maar dat de ontwikkelde objectieve criteria, die hierboven werden omschreven, wèl met het "openbaarheids"-criterium in overeenstemming zijn. De Nederlandse objectieve criteria zijn gedetailleerder en worden vaker explicíet toegepast.

Een ander criterium met betrekking tot de bescherming van het privéleven dat eventueel uit een aantal uitspraken van de Commissie zou kunnen worden afgeleid, is het zogenaamde "doel"-criterium. Uit de Straatsburgse rechtspraak blijkt, dat het privéleven onder andere inhoudt dat men relaties met andere personen moet kunnen aangaan met het oog op de ontwikkeling en de vervulling van de persoonlijkheid. Wanneer een gedraging van een persoon bestaat uit het aangaan van relaties met andere personen, maar gericht is op iets anders dan de ontwikkeling en de vervulling van de 
persoonlijkheid, dan zou deze gedraging buiten de privésfeer kunnen vallen. ${ }^{29}$ Professionele of beroepsactiviteiten kunnen echter op grond van de rechtspraak van het Hof onder het recht op privéleven vallen. Volgens het Hof hebben de meeste mensen namelijk de grootste kans om relaties met de buitenwereld aan te gaan gedurende hun werkzame leven. ${ }^{20}$ of hier ook sprake is van het aangaan van relaties met andere personen met het oog op de ontwikkeling en de vervulling van de persoonlijkheid is niet duidelijk. Het is de vraag of en in welke situaties er nog gedragingen overblijven die op grond van het doelcriterium buiten de sfeer van het privéleven vallen. Dat dit doelcriterium derhalve nog enige onderscheidende werking (tussen gevallen die wèl en die niet onder het privéleven vallen) toekomt meen ik daarom te moeten ontkennen. Dit komt echter niet doordat het op zichzelf als criterium niet zou kunnen voldoen, maar doordat het doel van het aangaan van relaties met andere personen niet (langer) in de rechtspraak lijkt te worden geëxpliciteerd. ${ }^{261}$

Bovengenoemd doelcriterium is overwegend subjectief van aard. Dat een gedraging op een bepaald doel gericht wordt is afhankelijk van de (innerlijke) wens van degene om wiens gedraging het gaat. Wel zal deze wens zich vaak moeten manifesteren in objectief waarneembare gedragingen wil deze wens kenbaar zijn voor anderen.

Het hierboven ten aanzien van de Nederlandse rechtspraak omschreven subjectieve criterium geeft ook de innerlijke wens van een persoon ten aanzien van een bepaalde gedraging aan, namelijk het onbevangen zichzelf willen zijn of het met rust gelaten willen worden of het zijn eigen leven leiden zonder inmenging van buitenaf. De gedraging moet op deze wens zijn gericht en dat moet volgens de Nederlandse rechtspraak blijken uit de concrete omstandigheden en de achtergrond van de betrokken persoon.

Het verschil tussen de Straatsburgse en de Nederlandse praktijk is hier derhalve gelegen in de omschrijving van het doel, waarin de essentie van het recht op respect voor het privéleven is gelegen. In de Straatsburgse rechtspraak is dat doel, zoals gezegd het aangaan van relaties met andere personen ten einde de eigen persoonlijkheid te ontwikkelen en te vervullen; in de Nederlandse rechtspraak gaat het om het onbevangen zich zelf willen zijn, het zijn eigen leven willen leiden zonder inmenging van buitenaf. Mijns inziens geven noch de Straatsburgse, noch de Nederlandse rechtspraak aanleiding tot een principiële keuze voor de ene of de andere

259 Besl.Comm. 8 oktober 1982, zaak nr. $9054 / 80, X v, U K$ : Besl.Comm. 10 masr 1988, zaak nr. 11680/85, F v. Switzerland en hierboven, pp. 207-208.

260 EHRM 16 december 1992, Niemietz Case, \$29, p. 33.

261 Zie opnieuw EHRM 16 december 1992, Niemietz Case, \$29, p. 33. 
omschrijving van de essentie van het privéleven en daarmee voor de omschrijving van het doel waarop een gedraging gericht moet zijn wil die de bescherming van artikel 8 lid 1 ECRM genieten. Ze lijken eerder in elkaars verlengde te liggen: immers, iemand zal niet onbevangen zich zelf kunnen zijn indien hij niet zonder overheidsbemoeienis relaties met andere personen kan aanknopen en andersom zal iemand niet in staat zijn vrijelijk zijn persoonlijkheid te ontwikkelen en te vervullen wanneer hij niet zonder ongewenste inmenging van anderen zijn eigen leven kan leiden.

Deze vergelijking van de Europese en Nederlandse rechtspraak met betrekking tot het recht op respect voor het privéleven leidt mij tot de conclusie, dat de Nederlandse rechter niet de Straatsburgse criteria hanteert maar eigen criteria ontwikkelt. Deze criteria worden aan velerlei documenten ontleend, waaronder de Memories van Toelichting bij artikel 10 Grondwet en bij wetsvoorstel 9419 inzake de bescherming tegen het met een technisch hulpmiddel afluisteren en opnemen van gesprekken, en Resolutie 428 van de Raadgevende Vergadering van de Raad van Europa ${ }^{262}$ De in de Nederlandse rechtspraak ontwikkelde criteria zijn echter niet in strijd met de Straatsburgse criteria, maar kunnen hierop een nuttige aanvulling vormen.

\section{Family life/familie- of gezinsleven}

Met betrekking tot de bescherming van het familie- of gezinsleven is de beschikking van de Hoge Raad van 10 november $1989^{263}$ de meest toonaangevende. Deze beschikking heeft betrekking op het omgangsrecht, maar kan ook op andere gebieden een rol spelen, zoals met betrekking tot de erkenning van kinderen of het ouderlijk gezag. Uit deze beschikking van 10 november 1989 volgt dat voor het bestaan van "family life" er sprake moet zijn van:

a. een huwelijk tussen de ouders of een daarmee in voldoende mate op één lijn te stellen relatie waaruit het kind is geboren, of

b. gebeurtenissen of omstandigheden ná de geboorte van het kind waaruit een als "family life" aan te merken betrekking tussen de vader en het kind is ontstaan, én

c. de als "family life" te beschouwen band niet is verbroken door latere gebeurtenissen. 
Bij deze uitspraak heeft de uitspraak van het Europese Hof voor de Rechten van de Mens in de zaak Berrehab ${ }^{264}$ een doorslaggevende rol gespeeld. "Deze uitspraak van het Europese Hof noopt inderdaad tot heroverweging van de ... vermelde rechtspraak ${ }^{265} .$. ", aldus de Hoge Raad. ${ }^{266}$ De onder $a$ vermelde voorwaarde ontleent de Hoge Raad aan de overweging uit de zaak Berrehab, waarin het Europese Hof bepaald, dat "(i)t follows from the concept of family on which Article 8 is based that a child born of such a union is ipso jure part of that relationship". Met het woord "relationship" wordt in de eerste plaats gedoeld op een wettig huwelijk. In paragraaf 4.2 .2 is bovendien overwogen, dat de Berrehabzaak niet uitsluit, dat ook tussen een vader en zijn onwettige kinderen een als "family life" aan te merken band kan bestaan indien die kinderen geboren zijn uit een met het huwelijk vergelijkbare relatie. ${ }^{267}$

Ten aanzien van de voorwaarde b constateert de Hoge Raad in de beschikking van 10 november 1989 , dat "(i)n het licht van die uitspraak (dat is de uitspraak in de zaak Berrehab, CS) is er voorts geen reden om uit te sluiten dat ..." in de omstandigheden genoemd in voorwaarde b sprake kan zijn van "family life".

De voorwaarde $b$ is in de zaak van 10 november 1989 toegesneden op de relatie vader-kind, maar uit de behandeling van de rechtspraak ${ }^{20}$ in andersoortige relaties met betrekking tot kinderen blijkt, dat deze voorwaarde ook voor deze andere relaties opgaat. Ook ten aanzien van bijvoorbeeld pleegouders wordt de voorwaarde gesteld dat feitelijke omstandigheden worden gesteld, waaruit blijkt dat een als "family life" aan te merken band tussen hen en het kind is ontstaan. Hiermee geeft de Hoge Raad een interpretatie aan de uitspraak in de zaak Berrehab, die strookt met de interpretatie van de Europese Commissie van het begrip "family life". Bij de bespreking van de jurisprudentie van de Commissie zagen we dat volgens de Commissie een bloedverwantschap tussen de betrokken personen niet voldoende is voor het bestaan van "family life" maar dat ook aan de hand van de feitelijke omstandigheden van het geval moet worden

264 EHRM 21 juni 1988, Berrehab Case.

265 Hiermee wordt verwezen naar de hierboven in de noten 151 en 152 vermelde rechtspraak.

266 Zie paragraaf 4.3 .2 .3 , p. 260 e.v.

267 Zie op pp. 216-217, EHRM 26 mei 1994, Keegan Case, \$\$44-45, pp. 17-18, EHRM 27 oktober 1994, Case of Kroon a.o., \$30, pp. 55-56 en de verwijzing naar EHRM 28 mei 1985, Case of Abdulaziz, Cabales and Balkandali. Zie voorts Besl.Comm. 7 december 1987, zaak nr. 12495/86, Jonsson v. Sweden.

268 Zie paragraaf 4.3 .2 .2 , pp. $256-259$. 
aangetoond "whether it [is] in fact possible to point to such a link as can be considered to establish family life within the meaning of Article 8 ." ${ }^{269}$

Ook voorwaarde $c$ is direct ontleend aan de zaak Berrehab, waarin het Europese Hof ten aanzien van het bestaan van "family life" vaststelde dat "subsequent events, of course, may break that tie ...". Deze voorwaarde speelt overigens ook een belangrijke rol in de besproken uitspraken ten aanzien van de toelating of uitzetting van vreemdelingen. ${ }^{270}$

In een uitspraak van 8 april $1991^{271}$ komt naar voren, dat de Afdeling Rechtspraak van de Raad van State van oordeel is dat de weigering van een verblijfsvergunning aan appellante geen inmenging vormt in haar gezinsleven wanneer het eerder bestaande effectief gezinsleven (dus niet de als "family life" aan te merken band!) is verbroken door het vertrek van de ouder naar Nederland met achterlating van het kind (appellante) in het land van herkomst en het naderhand weer tot stand gekomen contact in de huidige vorm (in de zin dat de moeder appellante zo nu en dan in El Salvador komt opzoeken) kan worden voortgezet. Eerder werd geconstateerd dat hier een soort "eigen schuld"-criterium een rol lijkt te spelen bij de vraag of sprake is van een inmenging, omdat het kennelijk verwijtbaar was dat het contact verbroken was geweest en het effectief gezinsleven daarna slechts een beperkte vorm had aangenomen.

We zagen bij de bespreking van de Europese jurisprudentie ook de hantering van een "eigen schuld"-criterium alleen dan niet bij de vraag of sprake is van een inmenging, maar bij de vraag of sprake is van familieof gezinsleven. Het ging hierbij ook om een andere casuspositie, namelijk die met betrekking tot de keuzemogelijkheid die men kan hebben, om de personen - waarmee men gezinsleven heeft - te volgen naar het land van herkomst in het geval dat deze personen niet tot een land worden toegelaten of een land worden uitgezet." In de Nederlandse rechtspraak blijkt deze keuzemogelijkheid pas bij de toetsing aan lid 2 van artikel 8 een rol te spelen. Op dit punt bestaat er dus ook een verschil met de Europese jurisprudentie.

Aan het eind van paragraaf 4.3.2.6 zagen we tenslotte nog dat met betrekking tot het bestaan van gezinsleven tussen ouders en volwassen kinderen en het bestaan van een dergelijke band tussen een vader en zijn

269 Besl.Comm. 14 mei 1986, zaak nr. 11418/85. Jolie, Jolie and Lehrun v. Belgium en de overige in noot 46 genoemde zaken. Zie p. 213 (e.v.).

270 Zie paragraaf 4.3.2.6.

271 ARRS 8 april 1991, NJ 1991, 624; zie hierboven, p. 277.

272 Zie pp. 221-222. 
kinderen uit een polygame huwelijk geen verschil in benadering bestaat tussen de Europese en Nederlandse instanties.

Al met al kan gezegd worden, dat de Nederlandse rechter - zoals in de beschikking van 10 november 1989 (NJ 1990, 628) - criteria heeft ontwikkeld die zeer sterk lijken op de criteria die door de Europese instanties zijn ontwikkeld althans daarop zijn geënt. Over het algemeen blijkt de Europese jurisprudentie in de Nederlandse rechtspraak inzake het personen- en familierecht een grote rol te spelen waar het de interpretatie en toepassing van artikel 8 ECRM betreft.

\section{Home/woning}

In paragraaf 4.3 .3 is gebleken, dat de zeldzame uitspraken van Nederlandse rechterlijke instanties die ik omtrent het recht op respect voor de woning heb gevonden, geen afbakening van dit recht laten zien. Een vergelijking van afbakeningscriteria (met de Straatsburgse rechtspraak terzake) is derhalve niet mogelijk.

\section{Correspondence/correspondentie}

Uit een in paragraaf 4.3 .4 besproken $\mathrm{zaak}^{233}$ inzake telefoontaps werd geconeludeerd, dat de door de Hoge Raad in die zaak gehanteerde formulering zodanig met die van het Europese Hof in de zaak Klass overeenstemt, dat de Hoge Raad deze Europese uitspraak vermoedelijk wel als leidraad zal hebben genomen. Overigens lijkt in de rechtspraak naar aanleiding van het recht op respect voor de woning de toepasselijkheid van dit recht stilzwijgend te zijn aangenomen. Dit geldt ook van andere middelen dan het in de bedoelde zaak gehanteerde communicatiemiddel (telefoon), zoals dossiers en briefkaarten.

\section{Positieve verplichtingen}

Hierboven is in paragraaf 4.4 gebleken, dat in de Straatsburgse rechtspraak het "concept" van de positieve verplichtingen veelvuldig is behandeld. Alhoewel de kern van de overheidsverplichtingen op grond van artikel 8 is gelegen in negatieve, op overheidsonthouding gerichte verplichtingen, kunnen onder omstandigheden ook positieve, tot overheidsoptreden dwingende verplichtingen uit het recht op respect voor het privéleven, het 
fmilie- en gezinsleven, de woning en de correspondentie voortvloeien. Het Hof laat het bestaan en, met name, de inhoud van positieve rerplichtingen afhangen van de uitkomst van een afweging van het individuele tegen het algemeen belang. Hierbij heeft de Staat een ruime teleidsvrijheid en spelen (vrijwel) dezelfde beginselen een rol als bij de betsing aan negatieve verplichtingen, zoals de beperkinsgronden genoemd in het tweede lid van artikel 8. Anders dan bij de toetsing aan negatieve verplichtingen, speelt de gehele toetsing van positieve verplichtingen zich a binnen het eerste lid. Dat betekent in praktijk, dat een vermenging flaatsvindt van de afbakening van de reikwijdte van de positieve terplichting met de beperkingen daarop, doordat in feite het bestaan en de inhoud van de positieve verplichting in het concrete geval worden agewogen. Dit alles gebeurt in het kader van de notie "respect" in lid $1 .{ }^{274}$

In een klein aantal uitspraken van Nederlandse rechterlijke instanties ${ }^{275}$ n vreemdelingenzaken vindt na de constatering dat de weigering van een terblijfstitel geen "inmenging" oplevert, nog een belangenafweging plaats cie erop lijkt te wijzen, dat uit artikel 8 volgens de Nederlandse rechter ender omstandigheden een positieve verplichting kan voortvloeien om aan ten vreemdeling een verblijfstitel te verstrekken. Dergelijke overwegingen die lijken te duiden op een erkenning van positieve verplichtingen op grond van artikel 8 . Nergens in de behandelde Nederlandse rechtspraak wordt dit echter met zoveel woorden bevestigd.

Het concept van de positieve verplichtingen is derhalve in de Nederlandse rechtspraak ten aanzien van artikel 8 veel minder ontwikkeld dan de Straatsburgse.

274 Nogmaals ter verduidelijking: ook de negatieve verplichting dat de overheid zich van bemoeienis met het "privéleven", het "familie- en gezinsleven", de "woning" en de "correspondentie" dient te onthouden, vloeit ook voort uit het begrip "respect". De reikwijdte-afbakening hiervan ("wanneer is sprake van overheidsbemoeienis in de genoemde belangen") geschiedt echter niet onder lid 1, maar in het kader van de afbakening van het begrip "inmenging" in lid 2 . Omdat het in dit hoofdstuk ging om de afbakening van het in het eerste lid van artikel 8 , is de interpretatie van het begrip "inmenging" niet uitdrukkelijk aan de orde gekomen, maar slechts waar dat naar mijn mening nodig was ter verduidelijking van de inhoud van de begrippen "privéleven", "familie- en gezinsleven", "woning" en "correspondentie".

275 ARRS 8 april 1991, AB 1991, 624 met noot $R$. Fernhout; ARRS 14 april 1991. AB 1991. 625 met noot $R$. Fernhout; HR 28 mei 1993, NJ 1993, 625 met noot A.H.J. Swart (zie met name de hierin aangehaalde uitspraak van het Gerechtshof in deze zaak). 


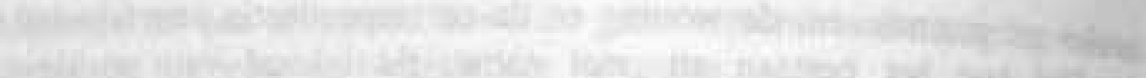

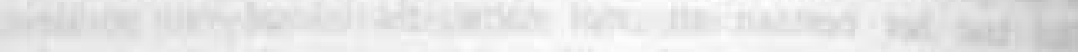

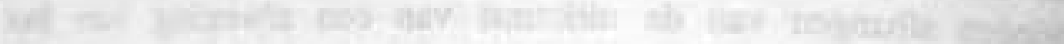

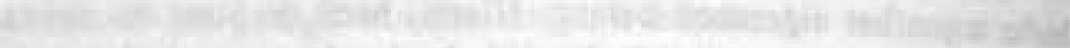

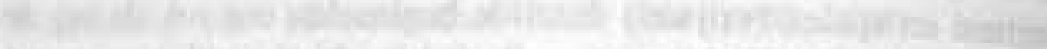

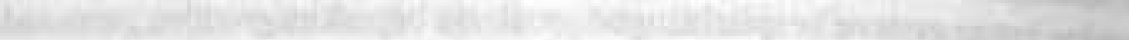
-

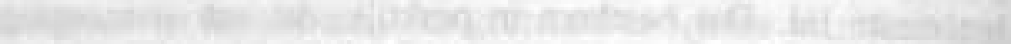

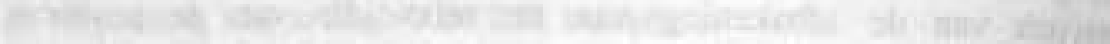

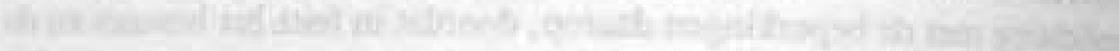

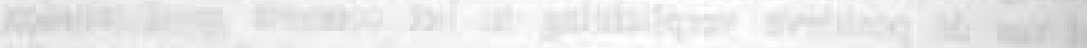

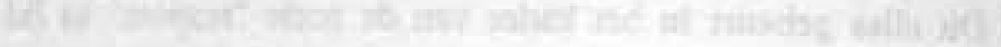

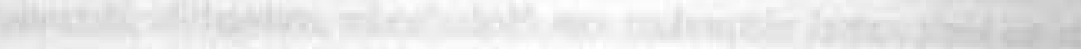

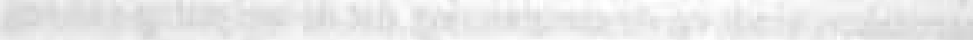

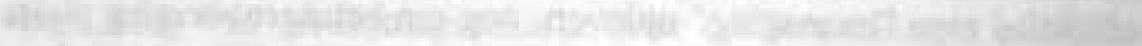

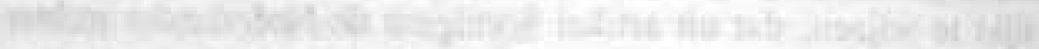

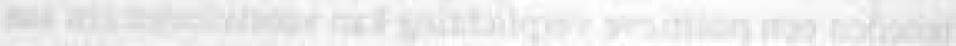
4.

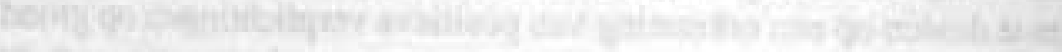

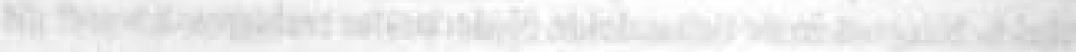

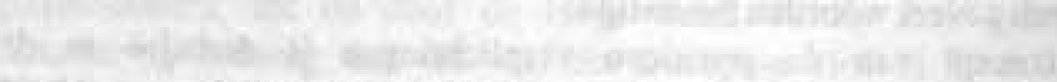

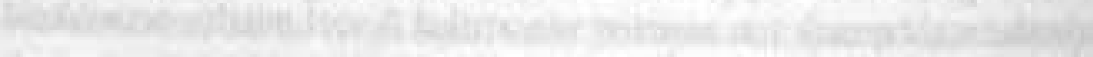

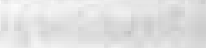

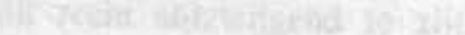
(4)

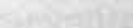

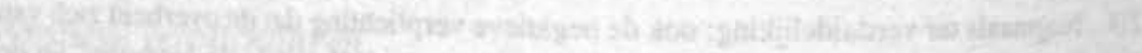

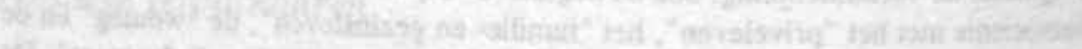

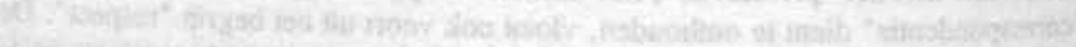

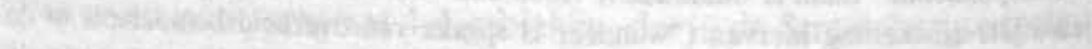

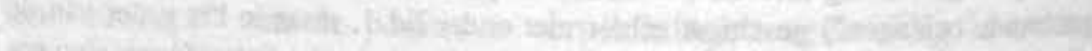

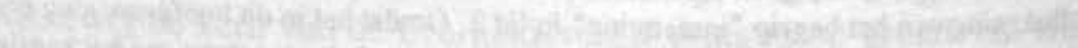

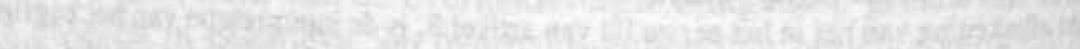

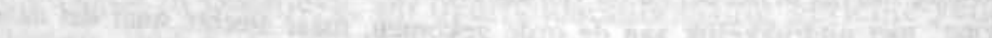

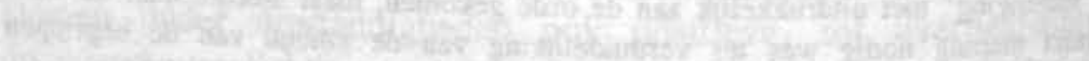

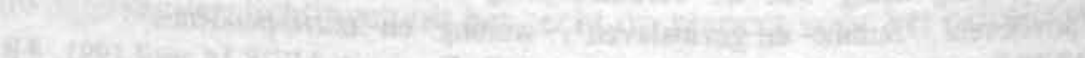

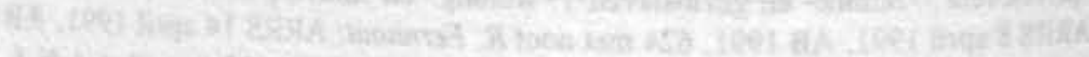

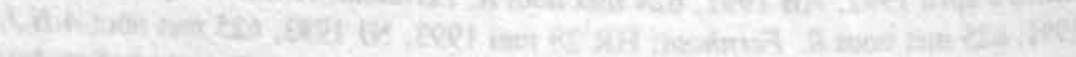

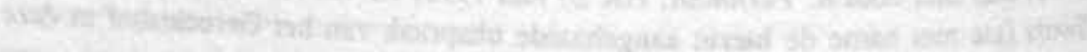




\section{Afbakening van de rechten in de Europese Conventie door de Europese en nationale instanties; jurisprudentie naar aanleiding van artikel 6 lid 1 ECRM}

\subsection{De rechtspraak van de Straatsburgse instanties met betrekking tot artikel 6 lid 1 (eerste zin) ECRM}

Aan het eind van paragraaf 1.3.4 werd reeds aangegeven, dat voor een onderzoek naar de jurisprudentie naar aanleiding van artikel 6 lid 1 (eerste zin) ECRM was gekozen omdat het - in tegenstelling tot artikel 8 ECRM niet voorzien is van een beperkingsbevoegdheid of -clausule. Hieraan werd toegevoegd, dat in de omschrijving van het in dit artikel vervatte recht wel een beperkingsmogelijkheid besloten ligt. Gedoeld werd hier op begrippen als "civil rights and obligations", "criminal charge", "reasonable time" en "independent and impartial tribunal".

Zoals uit de navolgende bespreking zal blijken, is dit artikel nog op grond van enkele andere overwegingen (omtrent inherente beperkingen, afstand van recht en positieve verplichtingen) interessant, zowel vanuit het oogpunt van vaststelling van de reikwijdte van het recht als op grond van de kwestie van de beperking van het recht. Vanwege de enorme hoeveelheid onderwerpen die bij een volledige bespreking van artikel 6 lid 1 (eerste zin) aan de orde zou moeten komen, is om praktische redenen gekozen voor één bepaald onderwerp in het kader van dit artikel, dat vanuit afbakenings- en beperkingsoogpunt het interessantst is: het recht op toegang tot de rechter, "the right to access to court". Een andere reden waarom dit aspect van artikel 6 lid 1 wordt behandeld is, dat men aan de procedurele waarborgen van artikel 6 niets heeft als men niet eens in staat is een procedure te beginnen. Ofwel, in de termen van het Hof:

"The fair, public and expeditious characteristics of judicial proceedings are of no value at all if there are no judicial proceedings. "2

Ten aanzien van dit recht op "access to court" zal worden nagegaan, of de Europese en Nederlandse instanties bij de vaststelling van de reikwijdte criteria hebben ontwikkeld en zo ja, welke criteria dat zijn. Andere aspecten van artikel 6, waaronder de voorwaarde voor de toepasselijkheid van dit artikel, namelijk dat sprake moet zijn van de "determination" van 


\section{AFBAKENING: JURISPRUDENTIE NAAR AANLEIDING VAN ART. 6 ECRM}

"civil rights and obligations" of "any criminal charge against him", zullen buiten beschouwing blijven. ${ }^{3}$

Hieronder zal allereerst het recht op "access to court" nader worden geintroduceerd. Vervolgens zal ingegaan worden op de grondslag van het recht op "access to court". De grondslag van dit recht zal immers mede bepalend zijn voor de inhoud en de reikwijdte ervan. Vervolgens zal die reikwijdte van het recht op "access" aan de orde komen. Tenslotte zal worden onderzocht wat moet worden verstaan onder "court".

\section{Artikel 6 lid 1 ECRM luidt:}

In the determination of his civil rights and obligations or of any criminal charge against him, everyone is entitled to a fair and public hearing within a reasonable time by an independent and impartial tribunal established by law. Judgment shall be pronounced publicly but the press and public may be excluded from all or part of the trial in the interests of morals, public order or national security in a democratic society, where the interests of juveniles or the protection of the private life of the parties so require. or to the extent strictlv necessay in the opinion of the court in special circumstances where publicity would prejudice the interests of justice.

3 Zie voor een bespreking van de begrippen "burgerlijke rechten en verplichtingen" en "strafvervolging" het proefschrift van M.L.W.M. Viering. Het toepassingsgebied van artikel 6 EVRM, respectievelijk pp. 51-144 en pp. 145-196.

4 Zoals uit het voorgaande reeds duidelijk zal zijn geworden, vindt het onderzoek plaats met het oog op het al dan niet bestaan van criteria voor de afbakening van het recht op "access to court". Voor een uitgebreidere behandeling van het recht op toegang tot de rechter verwijs ik naar: A.F.M. Brenninkmeijer, De toegang tot de rechter. Een onderzoek naar de betekenis van onathankelijke rechtspraak in een democratische rechtsstaat. diss. Tilburg (KUB) 1987, W.E.J. Tjeenk Willink: Zwolle 1987.

Bij het vaststellen van zijn burgerlijke rechten en verplichtingen of bij het bepalen van de gegrondheid van een tegen hem ingestelde vervolging heeft een ieder recht op een eerlijke en openbare behandeling van zijn zaak, binnen een redelijke termijo. door een onafhankelijk en onpartijdig gerecht dat bij de wet is ingesteld. De uitspraak moet in het openbaar worden gewezen maar de toegang tor de rechtszas kan aan de pers en het publiek worden ontzegd, gedurende de gehele terechtziting of een deel daarvan, in het belang van de goede zeden, van de openbare orde of nationale veiligheid in een democratische samenleving. wanneer de belangen vat minderjarigen of de bescherming van het privé leven van procespartijen dit eisen of. in die mate als door de rechter onder bijzondere omstandigheden strikt noodzakelijk wordt geoordeeld, wanneer de openbaarheid de belangen van een behoorlije rechtspleging zou schaden. 


\subsection{The right to access to court; introductie}

Ip het eerste gezicht lijkt artikel 6 lid 1 de burger alleen procedurele granties te bieden in het geval van een "determination" van "civil rights ad obligations" of een "criminal charge against him". Het artikel vermeldt spliciet dat sprake moet zijn van een "fair and public hearing", die plaats loet vinden "within a reasonable time" ten overstaan van een independent and impartial tribunal". Het in artikel 6 verschafte recht vordt veelal aangeduid als het recht op "fair trial". Dat "fair trial" echter 1eer omvat dan de zojuist genoemde procedurele garanties bleek al uit het ipport van de Commissie in de, een strafzaak betreffende, zaak Nielsen. ${ }^{s}$ la te hebben geconstateerd, dat artikel 6 het begrip "fair trial" niet efinieert, overwoog de Commissie:

"Para. 3 of the Article enumerates certain specific rights which constitute essential elements of that general notion ('fair trial', CS), and para. 2 may be considered to add another element. The words 'minimum rights', however, clearly indicate that the six rights specifically enumerated in para. 3 are not exhaustive, and that a trial may not conform to the general standard of a 'fair trial', even if the minimum rights guaranteed by para. 3 - and also the right set forth in para. 2 - have been respected."

In een geval waarin geen sprake was van een schending van artikel 6 lid 3 , zou de vraag of de procedure voldoet aan de in het eerste lid neergelegde waarborg, volgens de Commissie moeten worden beslist op grond van "a consideration of the trial as a whole, and not on the basis of an isolated consideration of one particular aspect of the trial or one particular incident." Hieruit blijkt, en dit wordt bevestigd door de latere jurisprudentie van de Commissie en het Hof, dat de waarborg van een "fair trial" meer inhoudt dan de som van de diverse expliciet in artikel 6 opgenomen procedurele garanties. ${ }^{6}$ Een voorbeeld van een garantie die uit artikel 6 voortvloeit, alhoewel het daarin niet expliciet wordt genoemd, is

5 Rapp.Comm. 15 maart 1961, Nielsen Case, §52, p. 550. Zie ook o.a.: Rapp.Comm. 23 november 1962. Ofner and Hopfinger, \$46. p. 696; Rapp.Comm. 28 maart 1963. Pataki and Dunshirn, §36. p. 730; Rapp.Comm. 30 maart 1963, zaak nr. 788/60. Austria v. Italy (Pfunders). pp. 790-792; en recenter Rapp.Comm. 12 juli 1984, Can Case, \$48, p. 15 en EHRM 27 februari 1980. Deweer Case, \$56, p. 30; EHRM 13 mei 1980. Artico Case, \$32, p. 15 en EHRM 25 april 1983. Pakelli Case, \$42. p. 19.

6 Zo ook: $\boldsymbol{H}$. Heubel, Der "fair trial" - ein Grundsatz des Strafverfahrens?, pp. 35-36. 


\section{AFBAKENING: JURISPRUDENTIE NAAR AANLEIDING VAN ART. 6 ECRM}

het beginsel van de "equality of arms". In haar rapport in de zaak Ofner and Hopfinger stelde de Commissie, dat dit beginsel een inherent element is van een "fair trial". Volgens de Commissie

"it is beyond doubt that ... the wider (dan lid $3, C S$ ) and general provision for a fair trial, contained in para. 1 of Article 6, embodies the notion of 'equality of arms'."

Een andere garantie die uit artikel 6 voortvloeit is het recht op toegang tot de rechter ofwel "the right to access to court". In de zaak Golder bepaalde het Hof dat

" ... Article $6 \$ 1$ secures to everyone the right to have any claim relating to his civil rights and obligations brought before a court or tribunal. In this way the Article embodies the 'right to a court', of which the right of access, that is the right to institute proceedings before courts in civil matters, constitutes one aspect only. To this are added the guarantees laid down by Article $6 \S 1$ as regards both the organisation and composition of the court, and the conduct of the proceedings. In sum, the whole makes up the right to a fair hearing."

Zoals in het begin van deze paragraaf werd gesteld, lijkt artikel 6 lid I alleen procedurele garanties te verschaffen. Waarop baseert het Hof dan het bestaan van een recht op "access to court"? In de volgende paragraaf zal deze vraag worden behandeld.

\subsubsection{De grondslag van het recht op "access to court"}

Er is slechts één zaak in de gehele jurisprudentie van de Commissie en het Hof. waarin de grondslag van het recht op "access to court" uitgebreid onderzocht wordt. Deze uitspraak heeft dan ook als precedent gediend voor de gehele daarop volgende rechtspraak van Commissie en Hof ten aanzien van dit recht. Bedoeld wordt de zaak Golder. ${ }^{9}$ Zowel de Commissie als het

7 Rapp.Comm. 23 november 1962. Ofner and Hopfinger, \$46, p. 696; zie ook Rapp.Comm. 28 maart 1963, Pataki, \$36, pp. 730. 732 en Rapp. Comm. 12 december 1981. Pakelli Case, $\$ 91$, p. 28 en Rapp.Comm. 14 december 1981. Jespers Case, \$55. pp. 71-72.

8 EHRM 21 februari 1975. Golder Case, \$36, p. 18. Zie samenvattend EHRM 21 september 1994, Fayed Case, $\$ 65$, p. 49.

9 Rapp.Comm. I juni 1973, Golder Case, \$41-73, pp. 32-45; EHRM 21 februari 1975, Golder Case, \$26-36, pp. 12-18. 
Hof hebben in deze zaak eerst uitgebreid aandacht besteed aan de te lanteren interpretatie-methoden. ${ }^{10}$ Vervolgens hebben zij aan de hand van (eze methoden de vraag onderzocht of artikel 6 lid 1 het recht op toegang $\mathrm{bt}$ de rechter garandeert. Bij de beantwoording van deze vraag heeft een antal beginselen een rol gespeeld, die beschouwd kunnen worden als de tasis ofwel de grondslag van het recht op "access to court".

De casus in de zaak Golder betreft de weigering van de minister van tinnenlandse zaken van het Verenigd Koninkrijk om aan de gedetineerde Golder toe te staan een advocaat te raadplegen in verband met een eventueel door hem in te stellen rechtszaak tegen één van de cipiers in de gevangenis waar hij gedetineerd was. De vraag die vervolgens rijst, is of loor deze weigering het recht van Golder op een "fair trial" op grond van urtikel 6 lid 1 ECRM is geschonden. Voor de beantwoording van deze iraag is het allereerst noodzakelijk vast te stellen of artikel 6 het recht op 'access to court", op toegang tot de rechter, omvat.

h eerste instantie rechtvaardigt de Commissie de interpretatie dat er een recht op "access to court" uit artikel $6 \$ 1$ voortvloeit op basis van zowel de Franstalige" als de Engelstalige tekst van dit artikel. De formulering uit de Franse tekst, "Toute personne a droit à ce que sa cause soit entendue", wijst er volgens de Commissie op, dat een beperking van

10 Alleen met betrekking tot de vraag of er in de zaak Golder al dan niet sprake is van een extensieve interpretatie van artikel 6 ECRM zal - aan het eind van deze paragraaf - op de in deze zaak gehanteerde interpretatie-methoden worden ingegaan. Overigens wordt hier slechts vermeld, dat zowel Commissie als Hof in de zaak Golder eerst getracht hebben via een uitleg van de tekst zelf tot een interpretatie van artikel 6 te komen (grammaticale interpretatie); vervolgens hebben zij artikel 6 geïnterpreteerd aan de hand van de context van de Conventie in het algemeen en dit artikel in het bijzonder en aan de hand van het voorwerp en doel van dit artikel en het verdrag. Op grond van de aan de hand van deze interpretatie-methoden bereikte uitleg van artikel $6 \mathrm{kwamen}$ de Commissie en het Hof tot de hierna te bespreken conclusie. Een interpretatie met behulp van secundaire bronnen, zoals de travaux préparatoires, werd overbodig geacht. Zie par. 1.3.2 voor een algemene beschouwing over deze en andere interpretatie-methoden. Zie voorts voor een bespreking van de interpretatie-methoden in verband met de Conventie in het algemeen en artikel 6 in het bijzonder: $P$. Lemmens, Geschillen over burgerlijke rechten en verplichtingen, pp. 9-20.

11 De Franse tekst van artikel 6 lid 1 (eerste zin) luidt:

"Toute personne a droit à ce que sa cause soit entendue équitablement, publiquement et dans un délai raisonnable, par un tribunal indépendant et impartial, établi par la loi, qui décidera, soit des contestations sur ses droits et obligations de caractère civil. soit du bien-fondé de toute accusation en matière pénale dirigée contre elle." 
artikel 6 (1) tot procedures die al gestart zijn niet beoogd is. De Franstalige tekst zou juist suggereren, "in effect, that everyone is entitled to a hearing of his claim, wherever there is a dispute as to his civil rights and obligations." De Engelstalige tekst is volgens de Commissie minder duidelijk, maar ook hier ziet de Commissie geen reden om de woorden "In the determination of.." alleen uit te leggen als "in the judicial process." Volgens de Commissie "it is just as natural to take this phrase to mean "wherever his civil rights and obligations are being determined'". ${ }^{2}$

De Commissie meent dan ook, dat lezing van zowel de Frans- als Engelstalige tekst de interpretatie rechtvaardigt dat er een "right of access to the courts ..." bestaat "... combined, of course, with the requirements of Article $6(1)$ concerning the judicial procedure."

De Commissie vervolgt deze overweging met de constatering dat deze laatstgenoemde - procedurele eisen alleen niet voldoende zijn om de volle raison d'être van artikel $6(1)$ vast te stellen. De procedurele eisen van artikel 6 "simply represent elementary guarantees exactly such as distinguish judicial procedures from other ways of determining the legal position of the individual."

Daarna merkt de Commissie op, dat deze vereisten gecombineerd met de toegang tot de rechter de essentie van de rule of law vormen. ${ }^{13}$ Deze verwijzing naar de rule of law wordt duidelijk bij de interpretatie van artikel 6 (1) aan de hand van de context van de bepaling en het verdrag.

Allereerst gaat de Commissie in op de directe context van artikel $6(1)$. Hierbij komt zij tot de vaststelling dat de eisen van een "fair and public hearing" "confirm the idea of the rule of law". Volgens de Commissie kan men de idee van de rule of law niet scheiden van de idee van de toegang tot de rechter en de garanties die rechterlijke procedures binnen het bereik van artikel 6 (dat wil zeggen, in geval van een "determination of his civil rights and obligations or of any criminal charge against him") bieden bij de vaststelling van een persoon's rechtspositie.

Ook de, ruimere, context van de Conventie zelf "nowhere else offers a. similar basis for meeting this requirement of the idea of the rule of law which, according to its Preamble, is one of the main objects and purposes of the Convention. "Om die reden vindt de Commissie het begrijpelijk om in de gehele contexi van de Conventie een bevestiging te zien van de waarborging van de "justiciability of civil rights and obligations" door een recht op "access to courts". i4 
Nast de tekst van artikel 6 lid 1 biedt derhalve ook de idee van de rule of low een grondslag voor het bestaan van een recht op "access to court".

De Commissie is van opvatting dat door het bestaan van een recht op "iccess to court" af te leiden uit artikel 6 lid 1. geen extensieve betekenis an dit artikel wordt gegeven in de zin dat een interpretatie gegeven wordt "zoing beyond the ordinary meaning with due regard to context and pirposen. ${ }^{n}$

Ook het Hof komt op grond van de interpretatie van de tekst van artikel 6 lid 1 tot de conclusie, dat zowel de Engelstalige als de Franstalige formulering in artikel 6 lid 1 "imply the right to have the determination of dsputes relating to civil rights and obligations made by a court or 'tribunal'." Volgens het Hof is het juist dat het Franse woord "cause" een "procès qui se plaide" kan betekenen. ${ }^{16}$ Maar volgens het Hof is dit niet de enige gebruikelijke betekenis van dit woord: "it serves also to indicate by extension 'l'ensemble des intérêts à soutenir, à faire prévaloir'."17 Verder bestaat, aldus het Hof, een "contestation" (in het Engels vertaald as "claim") in het algemeen voordat de rechterlijke procedure wordt gestart en ziet de zinsnede "tribunal indépendant et impartial établi par la loi" meer op de organisatie dan op het functioneren, meer op instituties dan op procedures.

Ten aanzien van de Engelstalige zinsnede "in the determination of his civil rights and obligations" bevestigt het Hof de opvatting van de Commissie dat het hierbij niet noodzakelijkerwijs gaat om reeds danhangige gedingen. De zinsnede kan ook opgevat worden als een synoniem voor "wherever his civil rights and obligations are being determined." 18

Wat betreft de context van artikel 6 lid 1 overweegt het Hof het volgende. Hoewel het Hof van mening is dat, anders dan de Commissie stelde, de rule of law niet in de Preambule is opgenomen als "object and purpose" van de Conventie, verwijst de Preambule wèl naar de rule of law als één van de kenmerken van het gemeenschappelijk erfgoed van de Lid-Staten van de Raad van Europa. Het Hof is het met de Commissie eens dat het

15 Rapp.Comm. 1 juni 1973, Golder Case, §57, pp. 39-40.

16 Het arrest bevat hier een verwijzing naar: Littré, Dictionnaire de la langue française, tome 1, p. 509, $5^{\circ}$.

17 Hier verwijst het Hof naar: Paul Robert, Dictionnaire alphabétique et analogique de la langue française, tome 1, p. $666,11-2^{\circ}$.

18 EHRM 21 februari 1975, Golder Case, \$32, pp. 14-15. 
verkeerd zou zijn in deze verwijzing niet meer dan louter een "min of meer retorische verwijzing" te zien, die irrelevant is voor de interpretatie van de Conventie. De Verdragsstaten besloten volgens het Hof "de eerste stappen te doen voor de collectieve handhaving van sommige der in de Universele Verklaring vermelde rechten" (laatste alinea van de Preambule) vanwege hun "profound belief in the rule of law". Het Hof vindt dan ook dat het zowel natuurlijk als in overeenstemming met het beginsel van de goede trouw (artikel 31(1) Weens Verdragenverdrag) is, "to bear in mind this widely proclaimed consideration when interpreting the terms of Article $6 \$ 1$ according to their context and in the light of the object and purpose of the Convention." Dit geldt des te meer nu het beginsel van de rule of law ook in de Preambule en artikel 3 van het Statuut van de Raad van Europa is terug te vinden. Het Hof concludeert vervolgens dat "in civil matters one can scarcely conceive of the rule of law without there being a possibility of having access to the courts." 19

Naast de tekst, context en voorwerp en doel van het verdrag, noemt artikel 31 lid 3 (c) Weens Verdragenverdrag ook als interpretatie-maatstaf "any relevant rules of international law applicable in the relations between the parties". Volgens het Hof vallen hier "general principles of law" en met name "general principles of law recognized by civilized nations" (artikel $38 \$ 1$ (c) Statuut van het Internationaal Gerechtshof) onder. Ten aanzien van het recht op "access to court" overweegt het Hof vervolgens dat "(t)he principle whereby a civil claim must be capable of being submitted to a judge ranks as one of the universally 'recognised' fundamental principles of law; the same is true of the principle of international law which forbids the denial of justice. Article $6 \$ 1$ must be read in the light of these principles."

Zou artikel 6 lid 1 zo worden uitgelegd, dat het alleen betrekking heeft op rechterlijke procedures die al gestart zijn, dan zou een verdragsstaat zonder artikel 6 te schenden gerechten kunnen opheffen, hun jurisdictie ten aanzien van bepaalde soorten burgerlijke procedures kunnen wegnemen en die aan, van de regering afhankelijke, organen kunnen toevertrouwen. Een dergelijke uitleg, die het gevaar van willekeur in zich bergt, zou volgens het Hof ernstige gevolgen kunnen hebben, die in strijd zijn met de voornoemde beginselen. ${ }^{20}$ EHRM 1 juii 1961, Lawless Case, p. 52 en EHRM 17 januari 1970, Delcourt Case. 
Uiteindelijk komt het Hof tot de vaststelling dat "the right of access constitutes an element which is inherent in the right stated by Article 6 \$1." Evenals de Commissie, voegt het Hof hieraan toe, dat deze vaststelling niet het gevolg is van een extensieve interpretatie die de Verdragsstaten nieuwe verplichtingen oplegt. Volgens het Hof is de conclusie gebaseerd op de formulering van de eerste zin van artikel 6 lid 1 zelf, gelezen in de context van deze bepaling en met het oog op het voorwerp en het doel van de Conventie, een rechtsscheppend verdrag ${ }^{21}$ en in het licht van "general principles of law."22

Overigens bestaat over de vraag of hier nu wel of niet sprake is van (te) extensieve interpretatie geen eensgezindheid. De rechters Verdross, Zekia en Fitzmaurice tonen zich in hun "separate opinions" een groot tegenstander van de door de meerderheid van het Hof gegeven interpretatie. ${ }^{23}$ Zo merkt rechter Verdross op dat hij het niet toelaatbaar acht

"to extend, by means of an interpretation depending on clues, the framework of the clearly stated rights and freedoms. Considerations of legal certainty too make this conclusion mandatory. ${ }^{24}$

Rechter Fitzmaurice geeft diverse argumenten tegen het afleiden van het recht op toegang tot de rechter als een aan het recht op een fair trial inherent recht. Een aantal van die argumenten zullen hier kort aan de orde komen. Volgens Fitzmaurice moeten de rechten in de Conventie die de Verdragsstaten op grond van artikel 1 van het verdrag moeten garanderen, in het verdrag gedefinieerd worden. ${ }^{25}$ Wat voor uitleg men ook geeft aan het woord "definition" in artikel 1, volgens Fitzmaurice betekent dit dat het recht toch op zijn minst in de Conventie genoemd moet worden en dat is met het recht op toegang niet het geval. Dit geldt volgens hem des te meer nu "the very notion of a right of access to the courts is itself an ambiguous one ...". Bovendien kan volgens Fitzmaurice een verdrag, dat de uitkomst is van een onderhandelingsproces en beperkt moet worden tot dat wat is overeengekomen, niet zo geconstrueerd worden dat het meer

21 Het Hof verwijst hier naar EHRM 27 juni 1968, Wemhoff Case, §8, p. 23.

22 EHRM 21 februari 1975. Golder Case, \$36, p. 18.

23 Separate opinions van Judge Verdross, Judge Zekia en Judge Sir Gerald Fitzmaurice bij EHRM 21 februari 1975, Golder Case, respectievelijk pp. 24-25. pp. 26-31 en pp. 32-63.

24 Separate opinion van Judge Verdross, zie noot 23, p. 24.

25 Vergelijk de separate opinion van Judge Verdross, zie noot 23, p. 24. 
garanties biedt dan het bevat "or than is necessarily to be inferred from what it contains." Het woord "necessarily" brengt volgens hem mee, dat "an inference or implication can only be regarded as a 'necessary' one if the provision cannot operate, or will not function, without it." Dit is volgens hem met betrekking tot het recht op toegang tot de rechter niet het geval. Voorts acht Fitzmaurice het ook niet de taak van de verdragsorganen om een eventueel gebrek in de verdragsbescherming aan te vullen. Dit behoort tot de competentie van de verdragspartijen. De meeste andere bezwaren van Fitzmaurice komen er voornamelijk op neer dat het afleiden van een recht op toegang tot de rechter uit artikel 6 lid 1 , niet in overeenstemming is met de wil van de verdragspartijen bij de opstelling van het verdrag. ${ }^{26}$ Fitzmaurice vindt een restrictieve of "a cautious and conservative" interpretatie te rechtvaardigen met name ten aanzien van bepalingen waarvan de betekenis onzeker is en waar "extensive constructions" zouden kunnen leiden tot verdragsverplichtingen die de Staten

"had not really meant to assume, or would not have understood themselves to be assuming. ... Any serious doubt must therefore be resolved in favour of, rather than against, the government concerned "2?

Mijns inziens ontkennen al deze argumenten het speciale karakter van de Conventie. Zoals reeds in paragraaf 1.3 .2 bij de bespreking van de interpretatie-methoden werd vermeld, heeft de Commissie in de zaak Golder gesteld dat dit karakter bij de interpretatie aan de hand van de internationale interpretatie-regels in het Weens Verdragenverdrag in het oog gehouden moet worden. De Commissie heeft daaraan toegevoegd, dat de Conventie voorziet in een stelsel van internationale rechtspraak, dat tot doel heeft een objectieve interpretatie van de Conventiebepalingen tot stand te brengen "and not to interpret the Convention by reference to what may have been the understanding of one Party at the time of its ratification. ${ }^{\text {ng }}$ Ik kan dan ook instemmen met Pelloux wanneer hij schrijft dat

"... on peut s'étonner, avec tout le respect dû à un jurisconsulte de sa notoriété, de l'insistance et de l'ingéniosité avec lesquelles Sir Gerald Fitzmaurice a combattu la thèse de la majorité. Nous avons été frappé de le voir affirmer une conception purement volontariste du droit

28 Rapp.Comm. 1 juni 1973, Golder Case, \$44, pp. 33-34. 
international et une extrême méfiance à l'égard de toute initiative du alégislateur judiciaire»." 29

Verder is een restrictieve interpretatie als voorgestaan door Fitzmaurice ook niet verenigbaar met de opvatting van het Hof in de zaak Wemhoff dat het noodzakelijk is "to seek the interpretation that is most appropriate in order to realise the aim and achieve the object of the treaty, not that which would restrict to the greatest possible degree the obligations undertaken by the Parties." ${ }^{30}$ Pelloux merkt terecht op ten aanzien van de door Fitzmaurice voorgestane restrictieve interpretatie:

"Nous avons été encore plus surpris de le voir affirmer que le caractère spécial de la Convention, le fait qu'elle pénètre "en profondeur dans quelques-uns des secteurs les plus jalousement gardés de la compétence nationale ou du domaine réservé des gouvernements» pourrait même justifier une interprétation quelque peu restrictive. Cette remarque mérite d'autant plus d'être relevée que, souvent au contraire, les juristes ont tiré argument du caractère spécial de la Convention, du fait qu'elle régit des Etats liés par une véritable communauté de civilisation morale et juridique, pour appuyer une interprétation quelque peu constructive et hardie. ${ }^{131}$

Mijns inziens geldt voorts ook wat het Hof in de zaak Marckx heeft uitgedrukt, namelijk dat "this Convention must be interpreted in the light of present-day conditions. "32 Op grond van een dergelijke dynamischevolutieve interpretatie kan het recht op "access" uit het recht op een eerlijke en openbare behandeling van zijn zaak in artikel 6 lid 1, afgeleid worden, dat wel - in de termen van artikel 1 van de Conventie - is "defined in Section 1 of this Convention." Anders dan Fitzmaurice meent, ben ik het met het Hof eens dat dit recht op "access" wel noodzakelijkerwijs uit artikel 6 voortvloeit, omdat dit artikel bij een andere opvatting geen functie meer zou hebben als Verdragsstaten - om aan hun verdragsverplichtingen te ontkomen - "could ... do away with its courts,

29 R. Pelloux, L'affaire Golder devant la Cour Européenne des Droits de l'Homme, p. 339.

30 EHRM 27 juni 1968. Wemhoff Case, $\$ 8$, p. 23.

31 Pelloux, L'affaire Golder devant la Cour Européenne, p. 339.

32 EHRM 13 juni 1979. Marckx Case, §41. p. 19. Zie verder noot 52 van paragraaf 1.3 .2 (p. 23). 
or take away their jurisdiction to determine certain classes of civil actions and entrust it to organs dependent on the Government. ${ }^{33}$

Men zou extensieve interpretatie kunnen definiëren als de betekenis die aan een bepaling wordt toegekend, die niet overeenkomt met de letterlijke tekst van een wets- of verdragsbepaling of de oorspronkelijke bedoeling van de wetgever/verdragspartijen, maar wel in overeenstemming is met de strekking van die bepaling en de daaraan ten grondslag liggende gedachten en beginselen (wellicht hier samen te vatten als de "object en purpose" van de bepaling). Er vindt derhalve een uitbreiding van de (tekstuele en wetshistorische) betekenis van de bepaling plaats aan de hand van de strekking van de bepaling en de beginselen waarop die bepaling is gebaseerd. Op deze wijze wordt de reikwijdte van de desbetreffende bepaling uitgebreid. Bij deze definitie van het begrip "extensieve interpretatie" is er bij het afleiden van het recht op toegang tot de rechter uit artikel 6 lid 1 sprake van extensieve interpretatie. Zowel tekstueel (het recht wordt niet letterlijk genoemd) als wetshistorisch (de verdragsopstellers beoogden het recht niet te beschermen) kan het recht op toegang tot de rechter niet uit artikel 6 worden afgeleid. Dit kan wel indien men afgaat op de grammaticale uitleg en de "shiest" san "pupssee" vanket verdrag. Het Hof komt vermoedelijk tot de conclusie dat geen sprake is van extensieve interpretatie omdat het én niet uitgaat van de letterlijke tekst van artikel 6 (1), maar deze (taalkundig) interpreteert (grammaticale interpretatie-methode) én reeds de interpretatie aan de hand van "object and purpose" van het verdrag als uitgangspunt neemt. Dit laatste lijkt mij terecht, omdat "object and purpose" van het verdrag bij de hantering van de teleologische interpretatie-methode in aanmerking genomen wordt. Deze interpretatie-methode brengt niet met zich dat het toepassingsgebied van artikel 6 lid 1 bij erkenning van het recht op "access" wordt uitgebreid. maar dat het (aan de hand van hedendaagse rechtsopvattingen) nader wordt gedefinieerd. Mijns inziens verdient deze opvatting van het Hof de voorkeur boven de mening dat sprake is van extensieve interpretatie, alhoewel het voor de praktijk geen verschil maakt.

Tot de opvatting dat wel sprake is van extensieve interpretatie komen onder meer Wiarda ${ }^{34}$ en Van Dijk ${ }^{35}$. Wiarda geeft onder meer het

33 EHRM 21 februari 1975, Golder Case, \$35, p. 17.

34 G.J. Wiarda. Extensieve en restrictieve verdragstoepassing door het Europese Hof voor de rechten van de mens; een middenkoers?, pp. 371-385.

35 P. van Dijk. The interpretation of "civil rights and obligations" by the European Court of Human Rights - one more step to take, pp. 131-143 en P. van Dijk en G.J.H. van Hoof. De europese conventie in theorie en praktijk. p. 329. 
afeiden van het recht op "access to court" uit artikel 6 als voorbeeld van ef extensieve verdragsuitleg. Volgens hem heeft de formulering van dit arikel tot vele interpretatieproblemen geleid, die "bijna steeds in een exensieve zin zijn opgelost. Niet onwaarschijnlijk is dat het artikel dardoor een veel grotere reikwijdte heeft gekregen dan die waarop men bi de redactie verdacht is geweest. "36 Deze opvatting wil overigens niet zegen, dat deze auteurs het niet eens zijn met de erkenning van het recht of "access to court". Volgens van Dijk is er geen reden om op de bslissing - dat uit artikel 6 een "right to a court" voortvloeit - terug te kmen, omdat het is gebaseerd op "the ordinary meaning to be given to [frticle $6 \$ 1$ ] in [its] context and in the light of its object and purpose, wich overrides the fact that its legal history may point in a somewhat diferent direction." 37

Jf er nu wel of niet sprake is van extensieve interpretatie, de erkenning van het recht op "access to court" behoort inmiddels tot de vaste jurisprudentie van de Commissie en het Hof. Op de reikwijdte van dit reht zal in de volgende paragraaf worden ingegaan.

\subsection{De reikwijdte van het recht op "access to court"}

\subsubsection{Beperkingen}

In de zaak Golder heeft de Commissie overwogen, dat de nauwkeurige definitie van een recht, inclusief de beschrijving van de aard, reikwijdte en inhoud van dit recht, uitdrukkelijk of impliciet de beperkingen op dat recht zal aangeven. Om die reden is het volgens de Commissie onmogelijk een scheiding aan te brengen tussen de vraag of artikel 6 een recht op toegang tot de rechter bevat en de vraag of er impliciete of inherente beperkingen op dit recht zijn. Mijns inziens geldt dit ook voor de vraag of er expliciete beperkingen op dit recht zijn opgenomen in de Conventie. ${ }^{38}$ Een bespreking van de reikwijdte van het recht op "access to court" betekent derhalve onvermijdelijk een behandeling van de mogelijkheden tot beperking van dit recht.

G.J. Wiarda, Extensieve en restrictieve verdragstoepassing door het Europese Hof voor de rechten van de mens; een middenkoers?, p. 374. Zie ook p. 384: "Extensief in de zin dat het Hof in menig geval door interpretatie naar 'object' en 'purpose' het toepassingsgebied van bepaalde artikelen ruimer en de betekenis daarvan groter heeft gemaakt dan wellicht aanvankelijk was voorzien; ...".

38 Rapp.Comm. 1 juni 1973, Golder Case, §88, p. 50. 
Hierbij moet worden aangetekend, dat een restrictieve interpretatie van dit recht niet op haar plaats is. Het Hof heeft in de zaak Delcourt bepaald, dat

"(i)n a democratic society within the meaning of the Convention, the right to a fair administration of justice holds such a prominent place that a restrictive interpretation of Article 6 (1) would not correspond to the aim and the purpose of that provision. ${ }^{39}$

Dat er inderdaad beperkingen op het recht op "access to court" mogelijk zijn, volgt reeds uit de constatering van het Hof in de zaak Golder, dat dit recht niet absoluut is. ${ }^{40}$

Een voorbeeld van expliciet in de Conventie opgenomen beperkingen is volgens de Commissie de term "civil rights and obligations"." Naar mijn mening geldt dan hetzelfde voor de termen "determination" en "criminal charge". In paragraaf 5.1 (pp. 313-314) zagen we reeds dat indien geen sprake is van de "determination" van "civil rights and obligations" of "any criminal charge against him", artikel 6 (1) niet van toepassing is. In artikel 6 (1) zijn derhalve expliciet beperkingen op de door deze bepaling omvatte rechten voorzien in de voorwaarden voor toepasselijkheid van dit artikel. Mijns inziens moet hier nog wel opgemerkt worden, dat de genoemde voorwaarden niet beschouwd kunnen worden als beperkingen "pur sang", omdat ze geen beperking vormen op de uitoefening van het recht, maar slechts op de toepasselijkheid. Met de toepasselijkheids-voorwaarden in artikel 6 lid 1 wordt wel een voorbeeld gegeven van een verband tussen de vaststelling van de reikwijdte van het recht en de beperking van de uitoefening van dat recht, dat in hoofdstuk 1 als uitgangspunt werd genoemd. ${ }^{42}$

Overigens betekent het garanderen van een recht op "access" alleen dat de individu het recht heeft een geschil omtrent het bestaan van een (burgerlijk) recht aan de rechter voor te leggen. Het is echter aan de

39 EHRM 17 januari 1970, Delcourt Case, \$25, p. 15. Het Hof verwijst in deze passage naar EHRM 27 juni 1968, Wemhoff Case, §8, p. 23. Zie ook EHRM 26 oktober 1984, De Cubber Case, \$30. p. 16.

40 EHRM 21 februari 1975, Golder Case, \$38, p. 18. Zie ook EHRM 28 mei 1985, Ashingdane Case, \$57, p. 24: EHRM 27 augustus 1991. Case of Philis v. Greece. $\$ 59$, p. 20 en EHRM 16 december 1992, Case of de Geouffre de la Pradel, \$28. p. 41 en Rapp.Comm. 5 oktober 1978, Deweer Case, $\$ 58$, p. 28 en Rapp.Comm.

12 mei 1982, Case of Campbell and Fell, \$148, p. 76.

41 Rapp.Comm. 1 juni 1973, Golder Case, §58, p. 40.

42 Zie paragraaf 1.1, p. 6 en paragraaf́ 2.4 .2 .2 , pp. $92-94$. 
nationale instanties, zoals wetgever en rechter, om vast te stellen of de burger een dergelijk recht ook kan inroepen en wat de reikwijdte en inhoud van het desbetreffende recht is.$^{43}$ Of zoals het Hof het uitdrukt:

"... that Article $6 \$ 1$ extends only to 'contestations' (disputes) over (civil) 'rights and obligations' which can be said, at least on arguable grounds, to be recognised under domestic law; it does not in itself guarantee any particular content for (civil) 'rights and obligations' in the substantive law of the Contracting States."44

Staat eenmaal vast, dat artikel 6 (1) van toepassing is en dat er sprake is van een recht op toegang tot de rechter, dan rijst de vraag of de mate waarin iemand onder het nationale recht een recht op "access" heeft voldoende is in het licht van artikel 6 .

Volgens de Commissie - in haar rapport in de zaak Golder - betekent een recht op "access" niet dat een gerecht altijd een uitspraak ten gronde moet doen in een zaak. Immuniteit, verjaring en dergelijke kunnen hieraan in de weg staan. Het betekent evenmin, dat rechters zich niet onbevoegd kunnen verklaren (ratione materiae of ratione loci), of dat de uitoefening van het recht op toegang onvoorwaardelijk moet zijn. ${ }^{45}$

"... Article 6 (1) ... does not necessarily guarantee or require that all cases are decided on their merits. If an impartial tribunal, the court, decided that it does not have jurisdiction in a case or that for other reasons, e.g. procedural defects, limitation periods, etc., the claim cannot be decided on its merits, then the plaintiff has received a fair hearing 'in the determination' ... of his case. "46

De uitoefening van een recht moet volgens de Commissie altijd onderworpen zijn aan formele - procedurele en administratieve voorwaarden in zaken waarin het noodzakelijk is zich tot overheidsorganen, zoals rechterlijke instanties, te wenden voor de bescherming of handhaving van dat recht. De Commissie noemt hier naast tijdslimieten en zekerheidsstelling voor kosten etc. ook "triviale" vereisten

43 Zie, bijvoorbeeld, Rapp.Comm. 12 mei 1983, Ashingdane Case, \$91, p. 41 en Rapp.Comm. 7 maart 1984, Case of Lithgow a.o., §474, p. 122.

4 EHRM 8 juli 1986, Case of Lithgow and others, §192, p. 70. Zie ook EHRM 21 september 1994, Fayed Case, \$65, p. 49.

45 Rapp.Comm. 1 juni 1973, Golder Case, §58, p. 40.

46 Rapp.Comm. 1 juni 1973, Golder Case, §94, p. 52. 
als kantooruren, het gebruik van bepaalde formulieren en dergelijke. Volgens de Commissie is het theoretisch moeilijk om een onderscheid te maken tussen een recht en de uitoefening ervan. Toch meent de Commissie dat het in dit geval wenselijk is een onderscheid te maken tussen de formele vereisten voor de uitoefening van het recht en de substantiële beperking van of inmenging in het recht zelf. In de speciale context van detentie, waar het in de zaak Golder om gaat, is dit onderscheid van een aanzienlijk praktisch belang. De Commissie is van mening, dat "the proper administration of order in prison requires rules governing the exercise of prisoners' rights ...". Om die reden moeten het recht om een advocaat te raadplegen voor juridisch advies en het recht om een procedure te starten volgens de Commissie geregeld worden. Indien echter een dergelijke regeling "amounts to interference with the substance of the right concerned, it seems necessary to find a basis in the Convention for such limitation. ${ }^{\text {47 }}$

Voordat verder op deze - de "substance" rakende - regelingen van het recht ingegaan zal worden, zal eerst aandacht besteed worden aan de formele, aan de uitoefening van het recht op "access to courts" gestelde beperkingen.

Met betrekking tot de jurisdictie van rechterlijke instanties bepaalt de Commissie in de zaak Kaplan onder verwijzing naar de zaak Golder, dat "the jurisdiction of the courts cannot be removed altogether or limited beyond a certain point." ${ }^{48}$ In de zaak Ashingdane voegt de Commissie daaraan toe dat

"A real threat to the rule of law could emerge if a State were arbitrarily to remove the jurisdiction of civil courts to determine certain classes of civil action. ${ }^{149}$

De vraag is derhalve of in casu de beperkingen op het recht van de klager op toegang tot de rechter willekeurig zijn. In deze zaak gaat het om een psychiatrische patiënt die een klacht voor de rechter wil brengen wegens "breach of a statutory duty to provide appropriate hospital care for his mental state of health." Voor het aanhangig maken van een dergelijke klacht heeft een patiënt echter toestemming nodig van de "High Court" en de klacht moet gericht zijn tegen "acts done negligently or in bad faith." 
Aan geen van beide voorwaarden is in de onderhavige zaak voldaan. Ashingdane heeft zelfs verzuimd toestemming te vragen en had deze volgens de rechterlijke instanties waarvoor zijn zaak diende ook niet gekregen.

Uiteindelijk komt de Commissie in deze zaak tot de conclusie dat de in het geding zijnde beperkingen op de toegang tot de rechter (de voorwaarden voor het aanhangig maken van de onderhavige klacht) in het nationale recht, niet willekeurig of onredelijk waren. ${ }^{50}$

Een vergelijkbare redenering wordt gevolgd in het rapport van de Commissie in de zaak Lithgow. Het gaat hier om het recht op schadevergoeding aan de individuele aandeelhouders van een genationaliseerde onderneming. Op grond van bepaalde criteria ("base value", "appropriate deductions", "conversion date") wordt het schadevergoedingsbedrag vastgesteld in verhouding tot het individuele aandeel in de onderneming. De vaststelling van de schadevergoeding geschiedt op collectieve basis. De criteria op grond waarvan dat gebeurt, worden in onderlinge overeenstemming vastgesteld tussen de "Secretary of State" (de minister van industrie) en de "Stockholders' Representative" of bij gebreke van overeensternming door middel van arbitrage tussen deze partijen. De individuele aandeelhouder kan zijn zaak niet aan arbitrage of rechterlijke beoordeling onderwerpen. Wel kan hij de Stockholders' Representative voor de rechter dagen in geval zijn taak onrechtmatig uitoefent. Daarvan is in deze zaak geen sprake.

Volgens de Commissie zijn deze beperkingen op de rechten van de individuele aandeelhouder geenszins arbitrair

"... being justified by the obvious need in circumstances of this kind to avoid a multiplicity of individual claims, which could lead to the same shares being valued differently in different cases. ${ }^{\text {5l }}$

Tot slot kan in dit verband nog gewezen worden op het stellen van tijdslimieten aan het recht op toegang tot de rechter. Een zaak uit 1969 betreft de klacht, dat een verzoek om schadevergoeding ter compensatie van in de tweede wereldoorlog ondergane leed en verloren eigendommen is 
AFBAKENING: JURISPRUDENTIE NAAR AANLEIDING VAN ART. 6 ECRM

afgewezen, omdat het verzoek te laat werd ingediend. ${ }^{52}$ De Commissie overweegt in deze zaak dat

"... in any system of distribution, it was reasonable for the Government to impose a strict time-limit which had the result of excluding any claimants who attempted to register their claims subsequently;"

Ook na overweging van de argumenten van de klager waarom hij de tijdslimiet niet in acht kon nemen, komt de Commissie tot de conclusie, dat de (nationale) beslissing dat zijn verzoek te laat werd ingediend "cannot ... be considered to have caused him an injustice in violation of his rights under Article 6 of the Convention."

De bovenstaande uitspraken samenvattend, is in de jurisprudentie van de Commissie een criterium te onderscheiden om vast te stellen, of de mate waarin iemand - in verband met de jurisdictie van de rechterlijke instanties - recht heeft op toegang tot de rechter, voldoende is in het licht van artikel 6 (1): het willekeur-criterium of redelijkheid-criterium. Dit criterium kan blijkens de uitspraak van de Commissie in de zaak Ashingdane afgeleid worden uit het veel ruimere en vagere criterium van de "rule of law".

Ook het Hof hanteert in de zaak Ashingdane voor de beoordeling of de mate van toegang onder het nationale recht voldoende is om een "right to a court" aan de individu te verzekeren, als maatstaf de "rule of law in a democratic society". ${ }^{33}$ Echter, een behandeling van de beperking van het recht op "access" in verband met de jurisdictie van rechterlijke instanties als zijnde formele beperkingen - afzonderlijk van de beperkingen die de "substance" van het recht raken (materiële beperkingen), komt uit de rechtspraak van het Hof niet naar voren..$^{34}$ De rechtspraak van het Hof komt erop neer dat iedere formele beperking als een materiële beperking wordt opgevat. Om die reden zal hier verder ingegaan worden op deze laatste soort beperkingen.

52 Besl.Comm. 17 mei 1969, zaak nr. 3332/67, X v. UK. p. 9. Zo ook Besi.Comm. 26 mei 1970, zaak ur. 4045/69, X v. FRG, p. 36 en Besl.Comm. 3 oktober 1983, zaak nr. 9960/82, X v. Switzeriand, (niet gepubliceerd). Impliciet tijken tijdslimieten te worden aanvaard in EHRM 16 december 1992. Hennings Case, $\$ 26$, p. 11.

53 EHRM 28 mei 1985, Ashingdane Case, $\$ 57$, p. 24. Het Hof verwijst naar EHRM 21 februari 1975, Golder Case, \$\$34-35, pp. 16-18 en Rapp.Comm. 12 mei 1983. Ashingdane Case, $\$ 92$, p. 41.

54 Zie, bijvoorbeeld, EHRM 8 jull 1986, Case of Lithgow a.o.. \$\$194-197, pp. 71-72. 
Volgens de Commissie in haar rapport in de zaak Golder, kan uit het arrest van het Hof in de Vagrancy-zaken een aanwijzingss gevonden worden voor de conclusie, dat de Conventie geen ruimte biedt voor inherente beperkingen op de rechten die het verdrag garandeert. Een verdere argumentatie geeft de Commissie hier niet. Zij vervolgt met de overweging, dat of de Conventie nu wel of niet inherente beperkingen toestaat, de Commissie er geen kan ontdekken die van toepassing is op de onderhavige zaak. Toen de Commissie eerder in haar rapport de conclusie trok dat artikel 6(1) een recht op "access to the courts" omvat, heeft de Cornmissie reeds de reikwijdte van dit recht overwogen, zo niet al volledig gedefinieerd en beschreven. Volgens de Commissie is er geen rechtvaardiging voor een beperking zoals die door de Britse regering beoogd wordt. Artikel 6(1), aldus de Commissie, bevat geen met artikel 8 lid 2 vergelijkbare voorziening. Was het de bedoeling van de opstellers van het verdrag geweest de reikwijdte van artikel 6(1) op andere wijzen te beperken (dan die waarin expliciet is voorzien), dan hadden zij dit uitdrukkelijk gedaan: "one would naturally expect that they would have written such other limitations expressly into the Article as well."

Ook op grond van de praktijk in de andere Verdragsstaten dan het Verenigd K.oninkrijk komt de Commissie niet tot een ander standpunt. Bovendien, als een beperking op het bereik van artikel 6(1) impliciet zou zijn, dan zou het nodig zijn de reikwijdte van deze beperking vast te stellen. De Commissie verwijst bovendien naar artikel 18 van de Conventie, dat eist dat beperkingen "shall not be applied for any purpose other than those for which they have been prescribed". Volgens de Commissie betekent dit dat niet alleen de reikwijdte maar ook het doel van de impliciete beperking bepaald moet worden. als men tot de conclusie komt dat er een dergelijke impliciete beperking bestaat. ${ }^{56}$

De positie van de gedetineerde, die voor het consulteren van een raadsman en het starten van een civiele procedure toestemming dient te vragen, is volgens de Commissie - in afwijking van het standpunt van de Britse regering - niet vergelijkbaar met die van personen die een vorm van imrnuniteit genieten, personen die ervan beschuldigd worden misbruik van recht te maken, kinderen, krankzinnigen en failliet verklaarden.

55 De Commissie verwijst hier naar $\$ \$ 9$ 1-93 van EHRM 18 juni 1971, De Wilde, Ooms and Versyp cases ("Vagrancy Cases"), pp. 45-46. De door de Commissie bedoelde aanwijzing heb ik niet aangetroffen (ook geen impliciete aanwijzing). Het Hof doet in deze passages niet meer dan de bestreden maatregelen toetsen aan artikel 8 lid 2 . 
In geval van personen die immuniteit genieten gaat het om bescherming van een eventuele tegenpartij in een civiele procedure. De rechter dient zich in een dergelijke zaak onbevoegd te verklaren, niet omdat er geen toegang tot de réchter zou zijn, maar omdat de tégenpartij niet toegankelijk is, dat wil zeggen niet voor de rechter gedaagd kan worden. Daarom is volgens de Commissie een jurisdictionele beperking als deze voor het geval van inherente beperkingen niet relevant. ${ }^{57}$

Wat betreft de persoon die beschuldigd wordt van misbruik van recht: of deze beschuldiging terecht is wordt door de rechter vastgesteld in een "acceptable form of judicial proceedings". Is de beschuldiging onterecht, dan kan de persoon verder procederen. ${ }^{58}$

Ten aanzien van kinderen, krankzinnigen en faillietverklaarden constateert de Commissie, dat ze dezelfde rechten hebben als andere leden van de gemeenschap, maar kunnen deze rechten niet zelf uitoefenen. Namens hen treedt een wettig vertegenwoordiger of curator op.

Geen van deze voorgaande gevallen is vergelijkbaar met de situatie van een gedetineerde. Het geval, dat de gedetineerde vooraf toestemming moet vragen voor het raadplegen van een advocaat of voor het starten van een procedure, ook indien die gericht is tegen het bestuur en zijn ambtenaren, is in strijd met het adagium dat een persoon geen rechter in zijn eigen zaak mag zijn. De Commissie vindt hiervoor dan ook geen rechtvaardiging in artikel 6 (1) en sluit uit dat een dergelijke beperking op het recht op toegang tot de rechter impliciet kan zijn. ${ }^{59}$

De Commissie meent voorts, dat aanvaarding van het begrip "inherente beperkingen" ten aanzien van artikel 6 (1) de rechten die door dit artikel gewaarborgd worden onzeker ("uncertain") en wellicht vatbaar voor willekeurige definiëring ("open to arbitrary definition") zou maken. De Commissie wijst er hierbij op dat het begrip "inherente beperkingen" "... seems rather loose as an independent concept $t^{\prime}$. Wanneer dit begrip wordt toegepast op gedetineerden, dan wordt daarbij doorgaans gedoeld op het feit dat bepaalde beperkingen op hun vrijheid, beweging, communicatie etc. in dit begrip beschouwd worden als "inherente kenmerken" van hun. situatie. Volgens de Commissie zijn echter de opvattingen over deze

57 Rapp.Comm. I juni 1973, Golder Case, \$93-94, p. 52. De Commissie doelt hier vermoedelijk op het eerder besproken onderscheid tussen formele beperkingen op de uitoefening van het recht op "access" waaronder jurisdictionele beperkingen vallen en anderzijds de materiële beperkingen op het recht, waar het bij inherente beperkingen om gaat.

58 Rapp.Comm. I juni 1973, Golder Case, \$95, p. 52.

59 Rapp.Comm. 1 juni 1973, Golder Case, \$95-96, p. 53. 
"inherente kenmerken" constant aan wijzigingen onderhevig en daarom is deze uitdrukking misleidend. De Commissie meent, dat beperkingen ten aanzien van de detentie meer te doen hebben met dat wat ten alle tijde beschouwd wordt als wenselijk en redelijk dan met enig "inherent kenmerk". 60

Met name de legitieme noodzaak om de goede orde in gevangenissen te handhaven en de begrijpelijke wens om, bijvoorbeeld, gevangenisbewaarders te beschermen tegen misbruik van rechtsmiddelen tegen hen, zijn volgens de Commissie onvoldoende om de onderhavige aan gedetineerden gestelde beperkingen te rechtvaardigen. Het ontmoedigen van als misbruik aan te merken gerechtelijke procedures zal op andere wijzen dienen te geschieden dan door het weigeren van rechtsbijstand of van het vervolgens instellen van juridische procedures. ${ }^{61}$

De Commissie komt uiteindelijk tot de slotsom, dat artikel 6 (1) geen inherente beperkingen bevat op het recht van (veroordeelde) gedetineerden om procedures aanhangig te maken en voor dit doel onbeperkt toegang tot een raadsman te hebben. Wel erkent de Commissie, dat er andere beperkingen op de uitoefening van het recht op "access to courts" zijn, die noodzakelijkerwijs voortvloeien uit het feit van de detentie in combinatie met administratieve noodzaak. Zulke beperkingen, zoals de beperking van de mogelijkheid tot het raadplegen van een raadsman tot bepaalde bezoekuren of het in persoon verschijnen van een gevangene voor de rechter, "are the result of normal prison administration". ${ }^{62}$

Uit dit rapport in de zaak Golder valt op te maken, dat de Commissie niet erg welwillend staat tegenover het toestaan van inherente beperkingen. Echter, het argument dat indien de opstellers van het verdrag de reikwijdte van artikel 6(1) op andere wijzen hadden willen beperken dan ze uitdrukkelijk gedaan hebben, ze dergelijke andere beperkingen ook wel uitdrukkelijk in artikel 6 zouden hebben opgenomen, is mijns inziens niet erg sterk. Immers, uit artikel 6(1) heeft de Commissie ook een impliciet recht afgeleid. De Commissie had dan even goed kunnen redeneren, dat als het de bedoeling van de opstellers van het verdrag was geweest, dat artikel $6(1)$ het recht op toegang tot de rechter omvat, ze dit recht wel uitdrukkelijk in deze bepaling hadden opgenomen. Dat heeft de Commissie nu echter niet gedaan. 


\section{AFBAKENING: JURISPRUDENTIE NAAR AANLEIDING VAN ART. 6 ECRM}

Terecht merkt de Commissie op, dat indien impliciete beperkingen op het recht op "access" worden toegestaan, dat dan ook de reikwijdte en het doel van de beperkingen moeten worden vastgesteld. Dit stemt overeen met de wijze van toetsing aan expliciete rechten en beperkingen.

In dit concrete geval, komt de Commissie tot de conclusie, dat geen sprake is van een gerechtvaardigde, inherente beperking op het recht op "access" van de gedetineerde Golder. Praktische, op grond van de administratieve noodzaak gestelde beperkingen zoals het beperken van het raadplegen van een advocaat tot bepaalde bezoekuren, beschouwt de Commissie niet als inherente, de "substance" van het recht rakende beperkingen, maar als formele beperkingen op de uitoefening van het recht.

Het Hof gaat in de zaak Golder veel minder uitgebreid in op de kwestie van de inherente beperkingen. Het Hof stelt vast ten aanzien van het recht op toegang tot de rechter, dat

"As this is a right which the Convention sets forth ... without, in the narrower sense of the term, defining, there is room, apart from the bounds delimiting the very content of any right. for limitations permitted by implication. ${ }^{\text {"63 }}$

Ter ondersteuning van deze overweging maakt het Hof een vergelijking met de overwegingen ten aanzien van artikel 2 van het Eerste Protocol bij de Conventie, in de Belgische Taal-zaak. Daarin bepaalde het Hof:

"The right to education ... by its very nature calls for regulation by the State, regulation which may vary in time and place according to the needs and rescurces of the community and of individuals. It goes without saying that such regulation must never injure the substance of the right to education nor conflict with other rights enshrined in the Convention. ${ }^{n s t}$

Het Hof voegt hieraan toe, dat deze overwegingen unt de Belgische Taalzaak des te meer gelden ten aanzien van een recht dat, anders dan het recht op onderwijs, niet in uitdrukkelijke bewoordingen in de Conventie wordt genoemd. ${ }^{\text {s5 }}$ Deze opvatting heeft het 1 fof in latere zaken bevestigd. ${ }^{\text {to }}$ 
Lit het arrest in de zaak Winterwerp blijkt, dat de mogelijkheden tot beperking van het recht op toegang tot de rechter ook ten aanzien van psychiatrische patiënten niet onbeperkt zijn. De klacht van de in een iurichting opgenomen klager betreft het feit, dat hij in de procedures ten anzien van zijn verzoeken om ontslag uit de inrichting niet was gehoord en ook was in die procedures zijn klacht omtrent zijn (on)vermogen om zijn eigen goederen te beheren niet aan de orde gekomen. Het Hof oordeelt - verwijzend naar de uitspraak in de zaak Golder, dat

"mental illness may render legitimate certain limitations upon the exercise of the 'right to a court', it cannot warrant the total absence of that right as embodied in Article $6 \S 1 .{ }^{.67}$

I de zaak Ashingdane gaat het, zoals eerder vermeld werd, ook om een Kacht van een psychiatrisch patiënt. In deze zaak gaat het erom, dat de Kacht van Ashingdane over de behandeling die hij in een psychiatrisch ziekenhuis onderging in de nationale procedure niet-ontvankelijk werd verklaard, omdat hij geen toestemming had van de "High Court" voor het voeren van een dergelijke procedure. Mijns inziens blijkt uit de - hierna t: bespreken - uitspraak van het Hof, dat ten aanzien van (de beperking van) het recht op toegang van psychiatrische patiënten geen andere maatstaven behoeven te worden aangelegd. dan in geval van "gewone" justitiabelen. De door het Hof ontwikkelde criteria bieden voldoende ruimte om met de geestelijke vermogens van de klager rekening te houden.

Zoals eerder werd opgemerkt heeft het Hof in de zaak Ashingdane onder verwijzing naar de zaak Golder bepaald, dat vastgesteld moet worden of ${ }^{*}$

"the degree of access afforded under the national legislation was sufficient to secure the individual's 'right to a court', having regard to the rule of law in a democratic society."

Vervolgens bevestigt het Hof dat het recht op "access" niet absoluut is en inherente beperkingen zijn toegestaan aangezien regeling van dit recht door de Staat noodzakelijk kan zijn. Hier voegt het Hof aan toe, dat de Staat bij

66 Zie bijvoorbeeld EHRM 27 februari 1980, Deweer Case, waar het Hof in $\$ 49$ (p. $25)$ vaststelt, dat " $(t)$ he 'right to a court' ... is no more absolute in criminal than in civil matters. It is subject to implied limitations ..." Zie EHRM 28 mei 1985 , Ashingdane Case, §57, p. 24; EHRM 8 juli 1986, Case of Lithgow a.o., $\$ 194$ (a), p. 71 en EHRM 27 augustus 1991, Case of Philis v. Greece. \$59. pp. 20-21. Zie voorts Rapp.Comm. 12 mei 1982, Case of Campbell and Fell. \$1 148. p. 76.

67 EHRM 24 oktober 1979, Winterwerp Case, §75, p. 29. 
het vaststellen van een dergelijke regeling van een recht op toegang tot de rechter een zekere beoordelingsvrijheid heeft.

"Whilst the final decision as to observance of the Convention's requirements rests with the Court, it is no part of the Court's function to substitute for the assessment of the national authorities any other assessment of what might be the best policy in this field."

Waar de uiterste grens van deze beoordelingsvrijheid van de Staat ligt blijkt uit de daaropvolgende overweging van het Hof:

"Nonetheless, the limitations applied must not restrict or reduce the access left to the individual in such a way or to such an extent that the very essence of the right is impaired. Furthermore, a limitation will not be compatible with Article $6 \$ 1$ if it does not pursue a legitimate aim and if there is not a reasonable relationship of proportionality between the means employed and the aim sought to be achieved."

Het Hof stelt in de zaak Ashingdane derhalve enigszins andere eisen an de beoordelingsvrijheid van de Staat, dan in de zaak Golder en de daarop volgende zaken. Spreekt het Hof in de zaak Golder, in navolging van de Belgische Taal-zaak van het niet mogen schaden van de "substance of the right", in de zaak Ashingdane verbiedt het Hof een zodanige beperking van het recht op "access" dat "the very essence of the right is impaired". De "very essence of the right" ofwel de kern van het recht is mijns inziens een beperkter begrip dan de "substance of the right", de materie van het recht. Hiermee lijkt het Hof in de zaak Ashingdane de beoordelingsvrijheid van de Staat te verrumen. Dit is echter niet het geval, gezien het feit, dat het Hof een extra voorwaarde aan die beoordelingsvribheid stelt, die in eerdere zaken nog niet gesteld werd. De beperking moet een legitiem doel nastreven en er moet sprake zijn van een "reasonable relationship of proportionality" ussen de beperking en het daarmee nagestreefde doel.

In de zaak de Geouffie de la Pradel, tenslotte, gaat het on een tijdslimiet die in de Franse wetgeving is gesteld aan de toegang tot de Conseil d'État

68 EHRM 28 mei 1985, Ashingdane Case. \$57, pp. 24-25. Evenzo EuRM 8 juli 1986. Case of Lithgow a.0., 8194, p. 71: EHRM 27 augustus 1991, Philis v. Greece, \$59. pp. 20-21: EHRM 16 december 1992, Case of de Geouffre de la Pradel, \$28, p. 41 en EHRM 21 september 1994, Fayed Case. $\$ 581$ en 65, pp. 55 en 49-50. In hel arrest in de zaak de Geouffre de la Pradel herhaalt het Hof alleen de eerste zin var het citaat ait de zaak Ashingdane. 
met betrekking tot het instellen van beroep tegen bepaalde administratieve besluiten. Het Hof ziet zich voor de vraag gesteld, of de beroepsprocedure in kwestie en met name de wijze van berekening van de aan deze procedure gestelde tijdslimiet voldoende zijn om een effectief "right to a court" te verzekeren. In casu gaat het om de aanwijzing van gebied. waarvan een deel in eigendom van de klager is, als zijnde van "outstanding beauty", wat betekent dat het als natuurmonument beschermd wordt. Het Hof acht de wetgeving inzake natuurbehoud tezamen met de jurisprudentie ten aanzien van de classificatie van administratieve handelingen uitermate complex. Wat betreft de door klager gevolgde procedure, die twee en half jaar in beslag nam, zou een dergelijke complexiteit zeer waarschijnlijk leiden tot rechtsonzekerheid ten aanzien van de exacte aard van het desbetreffende aanwijzingsbesluit en de wijze van berekening van de tijdslimiet voor het instellen van beroep tegen dit besluit.

\section{Volgens het Hof}

"... the applicant was entitled to expect a coherent system that would achieve a fair balance between the authorities' interests and his own; in particular, he should have had a clear, practical and effective opportunity to challenge an administrative act that was a direct interference with his right of property."

Omdat het wettelijk systeem onvoldoende coherent en duidelijk is en met het oog op de omstandigheden van het geval, komt het Hof uiteindelijk tot de conclusie, dat de klager geen praktisch, effectief recht op toegang tot de Conseil d'État heeft gehad. Artikel 6 lid 1 is derhalve geschonden. ${ }^{69}$

Deze uitspraak geeft een verdere uitwerking van de eerder besproken jurisprudentie. Uit die uitspraken kan worden afgeleid dat de Staat de uitoefening van het recht op toegang tot de rechter kan reguleren, mits hierbij maar niet de kern van het recht wordt aangetast en er een legitieme reden voor beperking van het recht bestaat evenals proportionaliteit tussen de beperking en het daarmee nagestreefde doel. In deze uitspraak bepaalt het Hof, dat de desbetreffende regeling van het recht op toegang tot de rechter ook coherent en duidelijk ("coherent and clear") moet zijn. Bovendien moet de regeling een eerlijke afweging ("fair balance") bewerkstelligen tussen de openbare belangen en de belangen van de burger

69 EHRM 16 december 1992, Case of de Geouffre de la Pradel, \$\$29, 32-35. pp. 4143. Vergelijk EHRM 21 september 1994, Fayed Case, $\$ 65$, p. 50: "These principles reflect the process, inherent in the Court's task under the Convention, of striking a fair balance between the demands of the general interest of the community and the requirements of the protection of the individual's fundamental rights." 
op wie de regeling wordt toegepast. Verder moet de regeling hem een "clear, practical and effective opportunity" bieden om een (administratief) besluit, waarop artikel 6 van toepassing is, bij de rechter aan te vechten. Hiermee wordt derhalve opnieuw een grens gesteld aan de beoordelingsvrijheid van de Staat bij het regelen van het recht op toegang tot de rechter.

Overigens moet ten aanzien van de rechtspraak van het Hof nog opgemerkt worden, dat het Hof zich in zaken waaraan een individuele klacht ten grondslag ligt bij zijn beoordeling van de klacht zoveel mogelijk beperkt tot de voorliggende zaak, zonder overigens de algemene context van de zaak uit het oog te verliezen. ${ }^{70}$ Hiertoe moet het Hof, volgens het arrest in de zaak Philis, "examine the provisions in question to the extent to which the impediment to the individual's right of access was in fact the result of their application. "73

Onderwerpen we de hierboven beschreven jurisprudentie aan een nadere beschouwing, dan kan het volgende worden opgemerkt.

De Commissie makt een onderscheid tussen formele beperkingen op de uitoefening van het recht op "access" en beperkingen die een inbreuk maken op de "substance" van het recht, hier materiele beperkingen genoemul. De eerste soort beperkingen betreft onder meer het voldoen aan voorwaarden as tijdslimieten (ratione temporis) of voorafgande loestemming van een bevoegde instantie dan wel een collectief recht (bijvoorbeeld van een groep aandeelhouders in de zaak Lithgow) in plaats van een individueel recht op access (ratione personae). Deze formele beperkingen mogen niet arbitrair of onredelik zijn. De vraag of inherente beperkingen toegestaan zijn komt in dit soort zaken niet aan de orde.

Overigens wat betref de voorwaarde van voorafgaande toestemming van een bevoegde instante legt de Commissie kennelijk verschillende maatstaven an. In de zaak Ashingdane ging het om een in een inrichting opgenomen psychiatrische patiẻnt die toestemming nodig had om een civiele procedure te staten. In het rapport in deze zak kom de kwestie van de inherente beperkingen niet aan de orde. Dit is anders in de zaken Golder en Campbell and Fell waarin het ging on gedetineerden die voorafgaande toestemning nodig hadden. In deze zaken gaat de Commissie wel in op de vraag of inherente beperkingen toegestaan zijn. Vit de rapporten van de Commissie blikt niet, dat er op dit vlak een principiel

70 EHRM 28 mei 1985, Ashingdane Case, \$59, p. 25. Zie pok. EHRM 21 februari 1975. Golder Case, \$39, p. 19. Zie ook noot 16 in paragraaf 1.3.1. p. 12.

71 EHRM 27 augustus 1991, Philis Case, \$61, p. 21. 
verschil bestaat tussen (in inrichtingen opgenomen) psychiatrische patiënten enerzijds en gedetineerden anderzijds. Dit geldt des te meer nu de rechtvaardiging voor de vereiste toestemming in beide gevallen de zelfde is: het voorkomen van ongefundeerde rechterlijke procedures.

Wat betreft de "materiële" beperkingen: de Commissie is in de zaak Golder nog wat terughoudend ten aanzien van het toestaan van inherente beperkingen, maar volgt naderhand de praktijk van het Hof terzake.

Het Hof maakt geen onderscheid tussen formele en materiële beperkingen op het recht op "access to court". Volgens het Hof zijn inherente beperkingen toegestaan. Voor de goede orde dient hier opgemerkt te worden dat het Hof hier spreekt van "limitations by implication". Ook komt in de rechtspraak de term "implied limitations" voor. Bij bestudering van deze rechtspraak is niet gebleken, dat het met deze verschillende formuleringen ook inhoudelijke verschillen beoogd zijn.

De grenzen van de (inherente) beperkingen lagen aanvankelijk in de vraag of er sprake was van beperkingen die "injure the substance of the right" of "conflict with other rights enshrined in the Convention" (Belgische Taalzaak, Golder). Sinds de zaak Ashingdane is het criterium of sprake is van beperkingen die "restrict or reduce the access left to the individual in such a way or to such an extent that the very essence of the right is impaired." Bovendien moet de beperking gericht zijn op een legitiem doel en moet sprake zijn van een redelijke verhouding van proportionaliteit tussen de beperking en dit daarmee beoogde doel. De verwijzing aan het begin van de relevante overwegingen in de zaak Ashingdane naar de rule of law doet vermoeden dat de idee van de rule of law aan de basis van de zojuist genoemde criteria ligt.

Voorts moet, volgens de uitspraak van het Hof in de zaak de Geouffre de la Pradel, de regeling waarin de beperking is vervat duidelijk en coherent zijn en een eerlijke afweging van openbare en individuele belangen garanderen. Het recht op "access to court" moet "clear, practical and effective" zijn.

Juist het ontbreken van het onderscheid tussen formele en materiële beperkingen maakt de jurisprudentie van het Hof veel overzichtelijker en hanteerbaarder. Het onderscheid is ook niet noodzakelijk. Immers, indien een formele beperking (bijvoorbeeld een tijdslimiet voor het instellen van een procedure), in de zin van de praktijk van de Commissie, geen beperking vormt van de "substance" van het recht, dan zal zeker geen sprake zijn van een beperking die de kern ("the very essence") van het recht op "access" aantast. De door de Commissie gehanteerde criteria 
AFBAKENING: JURISPRUDENTIE NAAR AANLEIDING VAN ART. 6 ECRM

terzake van formele beperkingen, het willekeurs- en het redelijkheidscriterium, passen ook goed in de door het Hof ontwikkelde criteria. Indien een tijdslimiet op een onredelijke of willekeurige manier wordt toegepast wordt toegepast, dan zal het daardoor beperken van het recht op "access" vermoedelijk een inbreuk maken op de kern van dit recht of zal de proportionaliteit tussen doel en middel ontbreken.

Al met al vertoont de jurisprudentie ten aanzien van de beperking van het recht op access op bepaalde punten grote overeenkomsten met de beperkingsclausules in de tweede leden van de artikelen 8 tot en met 11 van de Conventie." Ook daar geniet de Staat een zekere "margin of appreciation" ten aanzien waarvan een aantal maatstaven zijn ontwikkeld. aan de hand waarvan moet worden beoordeeld of de Staat op een juiste wijze van die beoordelingsvrijheid gebruik heeft gemaakt. Zo zijn de eisen dat de beperking gericht moet zijn op een legitiem doel en dat sprake moet zijn van proportionaliteit tussen het middel (de beperking) en dat legitieme doel, voorbeelden van maatstaven die ook ten aanzien van de bedoelde beperkingsclausules worden gehanteerd. ${ }^{73}$ Voorts dienen de (openbare) belangen van de overheid enerzijds en de individuele belangen van de

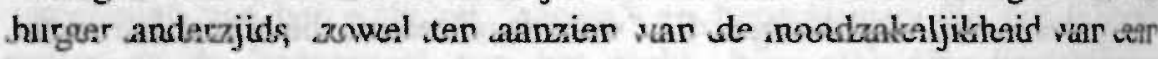
beperking op grond van een beperkingsclausule als met betrekking tot de regeling van het "access to court", tegen elkaar te worden afgewogen.

Alhoewel de rechtspraak niet expliciet eist, dat beperkingen op het recht op "access to court" vervat moeten zijn in een wet, kan eventueel de vaststelling van het Hof dat dit recht "calls for regulation by the State" wel als een aanwijzing in deze richting worden beschouwd. Immers, ook het begrip wet ("law") in de tweede leden van de artikelen 8 tot en met 11 heeft volgens de jurisprudentie de betekenis van een materiële wet.

72 Zie paragraaf 2.4.2.1, pp. 55-92. Vergelijk ook $J$. van der Velde, Beroepstermijn en het recht op toegang tot de rechter, pp. 330-336.

73 Zo ook het Hon In de zaak Fayed overweegt het Hof naar aanleiding van het standpunt van de Britse regering dat artikel 6, lid 1 niet van toepassing was, maar hooguit één of enkele van de "substantive rights", zoals artikel 8: "It is not always an easy matter to trace the dividing line between procedural and substantive limitations of a given entitlement under domestic law.... In the present case the Court does not consider it necessary to settle the question of the precise nature of the defence of privilege for the purposes of Article $6 \$ 1$, since it is devoid of significan$c e$ in the particular circumstances. If the Court were to treat the facts underlying the complaints declared admissible by the Commission as raising a substantive, rather than a procedural, complaint going to the right to respect for private life under Article 8 of the Convention ... the same central issues of legitimate aim and proportionality as under Article $6 \$ 1$ would be posed. "EHRM 21 september 1994, Fayed Case, 867 , pp. 50-51. 
Eovendien lijkt de overweging van het Hof in de zaak de Geouffre de la Fradel, dat een regeling van het recht op toegang tot de rechter "clear and cherent" moet zijn, op de eisen van "accessability" en "foreseeability" ten anzien van het begrip "wet" in de beperkingsclausules.

Tot slot kan ten aanzien van de reikwijdte van het recht op "access to curt" het volgende worden geconcludeerd. Aan het begin van deze paragraaf werd geconstateerd, dat sprake was van een verbondenheid of onscheidbaarheid van de vraag naar de reikwijdte van het recht op "access" en de beperkingen op dit recht. Dientengevolge, dienen de criteria die zijn ontwikkeld ter afbakening van de mogelijkheden tot (inherente) beperking van het onderhavige recht ook ter begrenzing van de reikwijdte van het recht op "access" zelf.

In het bovenstaande ging het om in de nationale wetgeving neergelegde beperking op het recht op "access", derhalve om beperkingen waarvoor de Staat verantwoordelijkheid draagt. Er bestaat echter ook de mogelijkheid dat een beperking van het recht op "access" voor rekening van de individu ksmt. Het onderwerp "afstand van recht" of "waiver" zal hieronder kort aan de orde gesteld worden.

\subsubsection{Afstand van recht}

Indien een individu door middel van een bepaald gedrag (een expliciete wilsuiting, een handelen of een nalaten) te kennen heeft gegeven afstand te doen van een bepaald recht, dan kan hij naderhand geen beroep meer doen op dit recht. Door afstand te doen van zijn recht heeft de individu zelf een beperking aangebracht op zijn mogelijkheden tot uitoefening van dit recht. ${ }^{74}$ Wanneer is sprake van een rechtsgeldige afstand van recht? Ten aanzien van de rechten van een klager onder artikel 6 lid 1, heeft de Commissie geoordeeld dat de geldigheid van de afstand van deze rechten niet uitsluitend beoordeeld moet worden aan de hand van het nationale recht van de desbetreffende Staat:

"In order to be effective for Convention purposes, a waiver of procedural rights requires minimum guarantees commensurate to its importance." 75

74 Vergelijk het in par. 4.2 .2 (pp. 221 e.v.) genoemde "eigen schuld"-criterium.

75 Rapp.Comm. 11 oktober 1990, Case of Pfeifer and Plankl, \$74, p. 26. Deze opvatting wordt bevestigd door de uitspraak van het Hof in deze zaak, EHRM 25 februari 1992, Case of Pfeifer and Plankl, \$37, pp. 16-17. 
Zelfs al zou de afstand naar nationaal recht geldig zijn, dan nog zal er met het oog op de Conventie geen gevolg aan verbonden mogen worden als niet aan deze minimum garanties voldaan is.

Hetzelfde zou mijns inziens moeten gelden voor niet-procedurele rechten, zoals het hier in het geding zijnde recht op toegang tot de rechter. Ook de afstand van dit recht dient met bepaalde minimum garanties te zijn omgeven.

Uit het navolgende zal blijken in hoeverre de rechtspraak van de Commissie en het Hof aangeeft, welke deze garanties zijn. ${ }^{76}$

Reeds in een ontvankelijkheidsbeslissing van 1962 heeft de Commissie uitgesproken, dat het ondertekenen van een clausule waarin - in geval van een geschil - dit geschil zal worden onderworpen aan arbitrage, opgevat moet worden als een gedeeltelijk afstand doen van de uitoefening van de rechten die gegarandeerd worden door artikel $6 \$ 1$. Volgens de Commissie is er niets in de tekst van dit artikel, noch van enig ander artikel van de Conventie, dat een dergelijke uitdrukkelijke afstand verbiedt. Onder omstandigheden kan echter een arbitrage-clausule wèl in strijd met de Conventie blijken te zijn:

"Que la clause compromissoire litigieuse aurait pu, toutefois, se révéler contraire à la Convention si $\mathrm{X}$. ne l'avait signée que sous la contrainte $m 77$

Deze beslissing wordt bevestigd door de Commissie en het Hof in de zaak Deweer ${ }^{78}$ Had de hiervoor besproken zaak uit 1962 betrekking op een arbitrage-clausule in een contract, de zaak Deweer betreft een schikking die aan een strafrechtelijke procedure in de weg staat. Door een dergelijke schikking te aanvaarden deed Deweer afstand van zijn recht om zijn zaak door een rechter te laten behandelen. De Commissie en het Hof zijn van mening dat ook in strafzaken een schikking, zoals het betalen van etn boete, in beginsel niet in strijd is met de Conventie. Het Hof voegt hier echter aan toe dat het enkele feit dat een individu voorafgand an een rechterlijke procedure een schikking overeenkomt met de vervolgende instanties, onvoldoende is om het recht op een "court" te verliezen. Daarvoor wordt in een democratische samenleving te veel belang gehecht

76 In de zaak waaruit bovenstaand citaat afkomklig is, de zaak Pfeifer and Plankl, geven noch de Commissie, noch het Tof an welle de betoelde minimum garanties zijp.

77 Best.Comm. 5 maant 1962, zaak 琵. 1197/61, X v. FRG, p. 13.

78 Rapp.Comm. 5 oktober 1978, Deweer Case, \$854-59, pp. 27-28 en EHRM 27 februari 1980, Deweer Case. $349-54$, pp. $25-29$. 
an dit recht. Wanneer, op het gebied van de openbare orde van een maatregel of beslissing beweerd wordt dat die in strijd is met artikel 6, dan moet deze maatregel of beslissing aan een uitermate zorgvuldige heroverweging onderworpen worden.

Afwezigheid van dwang bij het aanvaarden van een schikking is een van de voorwaarden waaraan in ieder geval voldaan moet worden; volgens het Hof is dit "dictated by an international instrument founded on freedom and the rule of law."

Volgens de Commissie had de klager echter geen vrije keuze omdat de autoriteiten, die hem voorstelden een bepaalde boete te betalen, tegelijkertijd dreigden - binnen 48 uur en voor onbepaalde tijd - zijn winkel te sluiten, als hij dit voorstel niet accepteerde. Omdat de beslissing van Deweer, om met het voorstel in te stemmen, was genomen onder de dreiging van aanzienlijke schade, was deze beslissing het gevolg van een keuze die onder dwang gemaakt werd. ${ }^{80}$

Het Hof wijst erop, dat het vooruitzicht om voor de rechter te moeten verschijnen zeker een bereidheid tot een schikking kan oproepen aan de kant van vele verdachten van een strafbaar feit; de dwang die van dit vooruitzicht uitgaat is geenszins onverenigbaar met de Conventie: zolang de vereisten van artikel 6 en 7 in acht genomen worden, laat de Conventie de verdragstaten vrij om "gedrag, dat niet bestaat uit de normale uitoefening van iemands rechten", als een strafbaar feit aan te wijzen en te vervolgen. In de onderhavige zaak was de klager waarschijnlijk weinig bevreesd voor strafrechtelijke vervolging aangezien het niet onwaarschijnlijk was dat de procedure zou eindigen in een vrijspraak. De dwang waarover Deweer klaagde was dan ook gelegen in de maatregel tot sluiting van zijn winkel. Tengevolge van deze maatregel zou Deweer grote schade leiden. De aangeboden schikking om dit gevaar af te wenden, betekende voor klager een aanzienlijk minder kwaad. ${ }^{81}$ Volgens het Hof was Deweer's afstand van een eerlijk proces, dat door alle garanties omgeven was die door de Conventie vereist worden, onder dwang aangetast ("tainted"). Er was derhalve sprake van schending van artikel 6 $\S 1.82$ 
Interessant is hier overigens de volgende overweging van het Hof:

"... in the area of human rights he who can do more cannot necessarily do less. The Convention permits under certain conditions some very serious forms of treatment, such as the death penalty (Article $2 \$ 1$, second sentence), whilst at the same time prohibiting others which by comparison can be regarded as rather mild, for example 'unlawful' detention for a brief period (Article $5 \$ 1$ ) or the expulsion of a national (Article $3 \$ 1$ of Protocol No. 4). The fact that it is possible to inflict on a person one of the first-mentioned forms of treatment cannot authorise his being subjected to one of the second-mentioned, even if he agrees or acquiesces ..." ${ }^{\text {83 }}$

Kennelijk is deze overweging van het Hof bedoeld als antwoord op de stelling van de Belgische regering, dat de schikking aan de klager een mildere, meer flexibele en minder belastende oplossing bood dan de sluiting van zijn winkel. Het Hof lijkt hier te bedoelen, dat zelfs als het zou zijn toegestaan om - met alle schade voor klager van dien - de winkel van Deweer te sluiten totdat een rechterlijke uitspraak in zijn zaak zou zijn verkregen, dat nog niet betekent dat daarmee de door Deweer als alternatief te betalen boete ook toelaatbaar is, ook al stemt Deweer hierin toe.

In de zaak Pfeifer and Plankl gaat het om rechters die volgens het nationale recht onbevoegd waren in de onderhavige zaak recht te spreken. ${ }^{84}$ De rechters verzuimden echter zich van de zaak te verschonen. Eén van deze rechters, de voorzitter van het gerecht, nam in tegendeel juist stappen om hun deelneming aan de procedure te verzekeren, ondanks hun onbevoegdheid. Om dit te bereiken zette hij de klager er toe aan, afstand te doen van zijn recht op een rechtsmiddel dat anders voor hem open zou hebben gestaan.

De Commissie acht het in deze zaak niet nodig om te onderzoeken of te veel druk op de klager was uitgeoefend of dat hij misleid was over de juridische situatie. De Commissie acht het voldoende te constateren dat de klager in moeilijke psychologische situatie was toen hij voor de voorzittende rechter moest verschijnen - zonder de assistentie van zijn raadsman - en onmiddellijk een antwoord moest geven op de suggestie van deze rechter tot afstand van zijn recht. Onder deze specifieke omstandigheden van het geval waaronder de klager afstand deed, meent de

84 Rapp.Comm. 11 oktober 1990 , Case of Pfeifer and Plankl, $\$ \$ 75-80$, pp. $26-27$. 
Commissie ten aanzien van de afstand dat "it cannot be held to be effective for the purposes of the Convention."

De Commissie sluit hierbij niet uit, dat een verklaring van afstand door de klager in het bijzijn van zijn advocaat ten overstaan van een rechter die niet zelf onbevoegd was, wel als bindend zou kunnen worden beschouwd met het oog op het verdragsrecht.

Het Hof bevestigt de conclusie van de Commissie in deze zaak en stelt dat zelfs al zou een verdachte afstand kunnen doen van de desbetreffende rechten, de omstandigheden van de klager's beslissing ontnamen deze afstand - bezien vanuit Conventie-standpunt - van iedere geldigheid. Voor het Hof maakt het feit dat de klager had verklaard het niet noodzakelijk te vinden dat zijn advocaat aanwezig was, voor deze conclusie geen verschil."

Het standpunt van de Commissie en het Hof in de zaak Pfeifer and Plankl valt wellicht te verklaren aan de hand van de uitspraak van het Hof in de zaak Le Compte, Van Leuven and De Meyere. In deze zaak gaat het om een door de klagers al dan niet gedane afstand van het recht op een openbare behandeling van hun zaak. Het Hof bepaalt hieromtrent, dat noch de letter noch de geest van artikel 6 (1) "would have prevented them from waiving this right of their own free will, whether expressly or tacitly ..." ${ }^{86}$ Het Hof zou derhalve in de zaak Pfeifer and Plankl kunnen bedoelen, dat ook in het geval dat er geen sprake is van een dwang tot het doen van afstand (en derhalve van het ontbreken van de "vrije" wil hiertoe van de klager), dit nog niet wil zeggen dat de afstand geldig is. De afstand moet ook in overeenstemming zijn met de vrije "wil" van de betrokken persoon. De beslissing van het Hof in de zaak Pfeifer and Plankl zou er dan op neerkomen, dat onder de omstandigheden van dit geval de klager zijn wil ten aanzien van de afstand niet of onvoldoende heeft kunnen bepalen en dat daarom de afstand niet geldig is.

Omdat het moeilijk kan zijn vast te stellen wat de wil van een persoon is ten aanzien van de afstand van recht, kan worden ingestemd met nog een andere een voorwaarde die het Hof aan het afstand doen van verdragsrechten heeft gesteld. Volgens het Hof moet de afstand van een

86 EHRM 23 juni 1981, Case of Le Compte, Van Leuven and De Meyere, \$59, p. 25.

Zie ook EHRM 10 februari 1983, Case of Albert and Le Compte, \$35, p. 19 en EHRM 24 juni 1993, Schuler-Zgraggen Case, §58, p. 19. 
door de Conventie gegarandeerd recht - voor zover deze afstand is toegestaan -

"... be established in an unequivocal manner." ${ }^{\text {n }}$

Uit de zaak Neumeister blijkt ten aanzien van het recht op schadevergoeding onder artikel 50 van de Conventie, dat wanneer de klager afstand van dit recht aanbiedt in ruil voor gratie, nog niet aan deze voorwaarde voldaan is ${ }^{8 *}$

Ook is van een op onmiskenbare, ondubbelzinnige wijze ("in an unequivocal manner") gedane afstand van recht, volgens het Hof in de zaak Oberschlick, geen sprake wanneer verdachten zich er pas na een rechtszitting van bewust worden dat de rechters in deze zaak zich ex officio van de zaak hadden moeten verschonen. $\mathrm{Zij}$ hadden derhalve tijdens de rechtszitting, op deze grond, nog geen bezwaren tegen deze rechters kunnen uiten. Of wèl van een - stilzwijgende - afstand sprake was geweest indien de verdachten zich wel van de onbevoegdheid van de rechters bewust waren geweest, laat het Hof in het midden. ${ }^{89}$

Toch is - in het algemeen - voor een geldige afstand van recht kennelijk niet noodzakelijk, dat een dergelijke afstand uitdrukkelijk wordt uitgesproken of op schrift wordt gesteld. In de eerder genoemde zaak $L e$ Compte, Van Leuven and De Meyere spreekt het Hof namelijk van "waiving this right of their own free will, whether expressly or tacity $\ldots .{ }^{\prime}{ }^{90}$ Een stizwijgende afstand kan volgens het Hof derhalve wel, zolang deze maar onmiskenbaar ("unequivocal") is.

87 EHRM 23 mei 199:, Oberschlick Case, \$51, D. 23; Zie 0.a. EHRM 7 mei 1974, Neumeister Case fartikel 501, \$36, p. 16; EHRM 10 februari 1983. Case of Abert and Le Compte, 35, f. 19; EHRM 12 februari 1985. Colozza Case, \$28, pp. 14-15; EIRM 6 december 1988, Case of Barberd, Messegué and Jabardo, 882, p. 35; EHKM 25 februari 1992, Pfeifer and Plank, 837, p. 16; en EHRM 24 juni 1993, Schuler-Zgraggen, 58 . p. 19. Zie ten aanzien van de afstand van het recht om bij de behanteling van zin zaak aanwezig te zin in verband met verstek-zaken, de annotatie wan CFR bij het arrest in de zak Colozza, in: A A 35 (1986) 4. p. 309$315(312-315)$.

88 ENRM 7 mei 1974, Neumeister Case (artikel 50), \$36, p. 6.

89 EHRM 23 mei 1991, Oberschlick Case, \$51, 0. 24. Vgl. ook EHRM 19 december 1989. Brozicek Case, 345 , p. 19, waanut - in verband mel de vraag of afstand van recht is gedaan - blijki. dat klager op de hoogte moet zijn van het bestaan van zijn recht.

90 EHDM 23 jun 1981, Case of Le Compte, Van Leuven and De Meyere. \$59, p. 25. De beweerde afstand van rechl in deze zaak betreft de openbaarheids-garantie van artimel 6 ind 1 . 
Tot slot blijkt uit een klein aantal uitspraken dat het doen van afstand van recht niet in strijd mag zijn met "any important public interest". ${ }^{11}$ Wat hieronder moet worden verstaan wordt vooralsnog niet duidelijk uit deze arresten. Door het Hof wordt slechts geconstateerd dat in dit concrete geval een dergelijk openbaar belang niet in het geding was.

Samenvattend kunnen we stellen dat van een - vanuit het oogpunt van de Conventie - rechtsgeldige afstand van het recht op "access to court" sprake is indien de beslissing tot afstand niet onder dwang tot stand is gekomen, in overeenstemming met de vrije wil van de betrokkene is en op een onmiskenbare manier kenbaar is gemaakt, uitdrukkelijk of stilzwijgend. Hierbij is van dwang ook sprake indien in ruil voor de afstand van de desbetreffende rechten een schikking, bijvoorbeeld een boete, wordt aangeboden die de betrokken persoon minder schade toebrengt dan de maatregelen die bij afwijzing van die schikking getroffen zouden worden.

In het voorgaande ging het om begrenzing van het recht op toegang tot de rechter door middel van beperkingen op dit recht door overheidsmaatregelen of wetgeving om de gang van de burger naar de rechter te verhinderen, al dan niet na afstand van de burger van dit recht. Hierna zal bekeken worden of het recht op toegang tot de rechter zover reikt, dat de overheid ook verplicht kan worden tot het treffen van maatregelen of het tot stand brengen van wetgeving om het recht van de burger om zijn zaak aan een rechter voor te leggen te bevorderen. Gedoeld wordt op positieve verplichtingen op grond van artikel 6 lid 1 .

\subsubsection{Positieve verplichtingen ${ }^{92}$}

Hoewel volgens de vaste jurisprudentie van de Commissie ${ }^{93}$ de Conventie geen recht op gratis rechtsbijstand garandeert, bepaalt de Commissie in 1975, dat onder bepaalde omstandigheden door de hoge kosten van een procedure artikel 6 (1) in het geding kan komen, dat aan een ieder het

91 EHRM 21 februari 1990, Case of Hdkansson and Sturesson, §66, p. 20 en EHRM 24 juni 1993, Schuler-Zgraggen Case, §58, p. 19.

92 Zie paragraaf 4.4 voor een bespreking van positieve verplichtingen in verband met artikel 8 .

93 Zie, bijvoorbeeld, Besl.Comm. 20 juli 1957, zaak nr. 265/57, X v. FRG, pp. 192 194; Besl.Comm. 28 september 1956, zaak nr. 180/56, X v FRG, pp. 236-237; Besl.Comm. 8 april 1967, zaak nr. 2942/66, X v. FRG, p. 61; Besl.Comm., zaak nr. $2857 / 66, X$ v. FRG, p. 15; Besl.Comm. 16 maart 1975, zaak nr. 6202/73, $X$ and $Y$ v. the Netherlands, $\$ 2$, p. 71 en Besl.Comm. 10 december 1975, zaak nr. 6958/75, X v. Switzerland, p. 157. 
recht op toegang tot de rechter en het recht op een "fair trial" toekent." Deze opvatting bevestigt de Commissie in haar rapport in de zaak Airey." De Commissie constateert in deze zaak dat de toegang van Airey tot de "High Court" niet belemmerd werd door enige wetsbepaling maar doordat Airey niet in de financiële positie verkeerde om de hoge kosten te betalen die een scheidingsprocedure met zich brengt. Vervolgens overweegt de Commissie dat het recht op "access to court" niet slechts een algemeen recht is dat door economische en andere obstakels ineffectief gemaakt kan worden. De Commissie wijst op de uitspraak van het Hof in de zaak Golder, dat "(h)indrance in fact can contravene the Convention just like a legal impediment" ${ }^{\prime *}$. Artikel 6, zo meent de Commissie, "must rather be understood to impose an obligation on the State to secure proper access by removing such obstacles". Hieraan wordt toegevoegd, dat de reikwijdte van deze verplichting niet tot in detail kan worden afgebakend in verband met specifieke omstandigheden. De Commissie wijst voorts op het werk onder auspiciën van de Raad van Europa met betrekking tot maatregelen ter bevordering van "access to justice"."

De Commissie overweegt, dat onder de omstandigheden van dit geval "the applicant has been denied effective access to the competent court to purcule what is, in fant, the only' adequate romedly' consuentad' with the regulation of her family life, because of the high costs involved in the proceedings."

Belangrijk zijn vervolgens de consequenties die de Commissie aan deze conclusie verbindt. Volgens de Commissie leidt deze conclusie niet tot het vereiste dat automatisch in deze of andere burgerlike zaken gratis rechtsbijstand moet worden toegekend. De Commissie bliff bij het eerder genoemde standpunt dat de Conventie "does not guarantee the right to legal aid as such". Bovendien was een belangrijk kenmerk in de onderhavige zaak dat de klaagster geen toegang tot de "High Court" had. Volgens de Commissie kan op meer manieren, waarvan zij enkele voorbeelden noemt, aan deze klacht tegemoet gekomen worden.

94. Besl.Comm. 16 maart 1975, zaak nr. 6202/73, $X$ and $Y v$, the Netherlands, p. $11 \mathrm{en}$ Besl.Comm. 10 december 1975 , zaak nr. $6958 / 75, X$ v. Swizzerland, p. 157.

95 Rapp.Comm. 9 mant 1978, Airey Case, $\$ \$ 71-80$, pp. $31-34$.

96 EHRM 21 februari 1975 , Golder Case, $\$ 26, \mathrm{p} .13$.

97 De Commissie doelt met zame op Resolution (78)8 on legal aid and advice, aangenomen dost het Comité van Ministers op 2 mart 1978, gepubliceenlin: $H$. Miehsler and H. Petrold, European Convention on Human kights, Texts and Documents, Vol. II, Carl Ileymanns Verlag KG: Köln etc. 1982, Resolutions and Recommendations of the Committee of Ministers. op. 198-207. 
Het Hof bevestigt de uitspraak van de Commissie. ${ }^{98}$ Volgens het Hof

' $(t)$ he Convention is intended to guarantee not rights that are theoretical or illusory but rights that are practical and effective".

Volgens het Hof geldt dit des te meer voor het recht op "access to the courts" vanwege de prominente plaats die het recht op een "fair trial" in een democratische samenleving inneemt.

Vanwege de hoge kosten van een procedure voor de "High Court" en de complexe problemen die een scheidings-procedure met zich kan brengen, acht het Hof het hoogst onwaarschijnlijk dat iemand in een positie als klaagster effectief zijn of haar eigen zaak kan verdedigen. De mogelijkheid om in persoon voor de "High Court" te verschijnen biedt de klaagster dan ook niet een effectief recht op toegang tot de rechter.

In verband met het verweer van de lerse regering - dat het beweerde ontbreken van toegang tot de rechter niet het gevolg is van overheidshandelen, maar van de persoonlijke omstandigheden van Airey waarvoor Ierland niet verantwoordelijk gehouden kan worden - verwijst ook het Hof naar de overweging uit de zaak Golder, dat feitelijke belemmeringen evenzeer in strijd met de Conventie kunnen zijn als wettelijke obstakels. Hieraan voegt het Hof toe, dat

"fulfilment of a duty under the Convention on occasion necessitates some positive action on the part of the State; in such circumstances, the State cannot simply remain passive and 'there is ... no room to distinguish between acts and omissions'. The obligation to secure an effective right of access to the courts falls into this category of duty." 99

98 EHRM 9 oktober 1979, Airey Case, §§22-26, pp. 12-16. Zo ook EHRM 13 mei 1980. Artico Case, $\$ 33$, p. 16 en herhaald in Rapp.Comm. 14 juli 1982, zaak nr. 8966/80, Goddi Case, §56, p. 23 en Rapp.Comm. 5 mei 1983, zaken nrs. 9024/80 en 9317/81, Case of Colozza and Rubinat, \$122, p. 31.

99 EHRM 9 oktober 1979 , Airey Case. $\$ 25$, p. 14. Bij het citaat in deze overweging verwijst het Hof naar EHRM 13 juni 1979, Marckx Case, \$31, p. 15 en EHRM 10 maart 1972, De Wilde, Ooms and Versyp cases ("Vagrancy Cases"), \$22, p. 10. Zie verder, i.v.m. artikel 6 lid 3(c), $\$ 36$ van EHRM 13 mei 1980, Artico Case, p. 18:

"... it was for the competent ... authorities to take steps to ensure that the applicant enjoyed effectively the right to which they had recognised he was entitled." 
Ook het Hof overweegt voorts dat de conclusie in deze zaak - dat de mogelijkheid voor Airey om in persoon voor de "High Court" te verschijnen haar geen effectief recht op toegang tot de rechter biedt - niet voor alle zaken met betrekking tot "civil rights and obligations" of voor iedere betrokkene bij een dergelijke zaak hoeft te gelden. Veel zal afhangen van de specifieke omstandigheden. Bovendien, laat de garantie in artikel 6(1) van een effectief recht op toegang tot de rechter aan de Staten "a free choice of the means to be used towards this end". ${ }^{100}$ Het is niet de taak van het Hof om aan te geven welke middelen moeten worden aangewend. Een Staat hoeft derhalve niet in elke zaak met betrekking tot de vaststelling van een burgerlijk recht gratis rechtsbijstand te bieden. Wel kan artikel 6 lid 1 - ondanks het ontbreken van een verplichting, voor burgerlijke zaken, als in lid 3(c) is opgenomen voor strafzaken $^{101}$ - de Staat dwingen te voorzien in de assistentie van een raadsman. Dit kan het geval zijn wanneer die assistentie onmisbaar is voor een effectief recht op "access", ofwel omdat procesvertegenwoordiging door het nationale recht is voorgeschreven, ofwel vanwege de complexiteit van de procedure of de zaak. ${ }^{102}$

100 EHRM 9 oktober 1979, Airey Case, \$26, p. 15. Vgl. \$30 van EHRM 12 februari 1985, Colozza Case, p. 15: "The Contracting States enjoy a wide discretion as regards the choice of the means calculated to ensure that their legal systems are in compliance with the requirements of Article $6 \$ 1$ in this field."

101 Artikel 6 lid 3 aanhef en onder (c) luidt:

"Everyone charged with a criminal offence has the following minimum rights: ... to defend himself in person or through legal assistance of his own choosing or if he has not sufficient means to pay for legal assistance, $t$ be given it free when the interests of justice so require:"

Overigens ben ik het met Alkema eens, dat deze uitspraak in de zaak Airey ten aanzien van civiele zaken ook van belang kan zijn voor strafzaken in het geval dat een Verdragsstas een worbehoud bij artikel 6 lid 3 (c) heefi gemakt. Alkema voert aan, dat cen verdachte weliswar in een strafproces formeel steeds wegang tot do rechter heeft, mas bat zijn positie zonder rechtshulp zo zwak kan zijn. "dat zijn recht on woor cen rechter te verschijnen illusoir wordt." Zie de annotalie van E.A. Alkema bij EHRM 9 oktober 1979. Case of Airey $\%$. Ireland, in: N] 1980, 376. In dergelyke gevallen zal cen voorbehoud met betrekking tot artikel 6 id 3 (c) deels zijn betekenis vertiezen.

102 Vergelijk \$30 van EHRM 12 februari 1985. Colozza Case. Pp. 15-16:

"The Cours' task is not to indicate those means (to ensure ... compliance with ... Article $651, \mathrm{CS}) \ldots$ but to determine whether the result called for by the Convention has been achieved. For this to be so, the resources available under domestic law must be shown to be effective ..." 
Dit laatste punt, dat artikel 6 (1) Staten niet verplicht to het verstrekken van gratis rechtsbijstand aan een ieder die in een civielrechtelijke procedure betrokken is, wordt nader uitgewerkt in een ontvankelijkheidsbeslissing van 10 juli 1980. In deze zaak constateert de Commissie, dat waar een staat een stelsel van rechtsbijstand opstelt teneinde te voorzien in een toegang tot de rechter, een dergelijk stelsel alleen effectief kan werken - gezien de beperkte middelen van de Staat met behulp van een mechanisme, dat zaken selecteert die juridisch zouden moeten worden bijgestaan. Dergelijke beperkingen op de beschikbaarheid van gratis rechtsbijstand eisen vaak dat een financiële bijdrage wordt geleverd of dat de zaak een redelijke kans op succes biedt.

Volgens de Commissie eist artikel 6 (1) niet dat rechtsbijstand in iedere zaak, onafhankelijk van de aard van de aanspraak en het ondersteunend bewijs, wordt verleend. Indien een individu gratis rechtsbijstand wordt geweigerd omdat de voorgestelde civielrechtelijke eis of onvoldoende gefundeerd is ofwel als "frivolous or vexatious" wordt aangemerkt, dan ligt de last op die individu om zijn recht op "access to court" op een andere manier te verzekeren, zoals bijvoorbeeld door de zaak zelf aan te brengen of bijstand van een andere bron te zoeken. De Commissie is derhalve van mening dat

"... where a prisoner has been refused legal aid on the basis that his claim lacks reasonable prospects of succes such a situation would not normally constitute a denial of access to court unless it could be shown that the decision of the administrative authority was arbitrary. ${ }^{103}$

Een nabeschouwing van de hierboven besproken jurisprudentie leert, dat uit artikel 6 lid 1 positieve verplichtingen voor de Staat kunnen voortvloeien, om een effectief recht op toegang tot de rechter te garanderen. Omdat feitelijke belemmeringen van de uitoefening van dit recht, zoals economische obstakels, evenzeer in strijd zijn met de Conventie als wettelijke belemmeringen, dient de Staat onder omstandigheden actie te ondernemen om deze belemmeringen op te heffen. De reikwijdte van deze positieve verplichting voor de Staat wordt in de rechtspraak van de Commissie en het Hof niet nauwkeurig gedefinieerd, maar wel worden enkele aanwijzingen voor de afbakening van deze

In deze zaak ging het om manieren om de verblijfplaats van de klager te achterhalen teneinde hem te kunnen berechten.

Vergelijk met betrekking tot artikel 6 lid 3 (c) ook EHRM 24 mei 1991, Quaranta Case, $\$ \$ 27,30,32-35$, pp. 16-17.

103 Besl.Comm. 10 juli 1980 , zaak nr. $8185 / 78, X$ v. UK, $\$ \$ 12-17$, p. 101. 
verplichting gegeven. Allereerst kan worden opgemerkt dat het vaak van de omstandigheden van het geval zal afhangen of een positieve verplichting tot het bevorderen van de toegang tot de rechter op de Staat rust. De Staat is niet verplicht aan een ieder die in een rechtsgeding betrokken is, gratis rechtsbijstand te (doen) verlenen. Zo rust deze verplichting niet op de Staat indien wordt vastgesteld dat het beroep dat op de rechter gedaan wordt een "redelijke" kans op succes mist. Deze vaststelling mag echter niet willekeurig tot stand gekomen zijn. Voorts heeft Staat een zekere beoordelingsvrijheid bij de keuze van de methoden om het recht op toegang tot de rechter te verzekeren. Het bieden van gratis rechtsbijstand is slechts één van die methoden. Het gaat er uiteindelijk altijd om, zowel bij de beoordeling of er een positieve verplichting op de Staat rust als bij de beslissing over de reikwijdte en de inhoud van die verplichting, dat het recht op "access to court" effectief moet zijn.

Bij het in deze paragraaf besproken onderzoek naar criteria voor de afbakening van de reikwijdte van het recht op "access to court" lag de nadruk op het aspect van de "access". De begrenzing van de reikwijdte van het recht op "access to court" kan hier echter niet toe beperkt blijven. Ook zal moeten worden vastgesteld, wat in dit kader verstaan moet worden onder "court". Hierover gaat de volgende paragraaf.

\subsubsection{De betekenis van de term "court" in het recht op "access to court"}

\subsubsection{Introductie}

Op grond van de vorige paragraaf wisten we al dat artikel 6 lid 1 bepaalde procedurele garanties biedt voor procedures ten aanzien van de "determination" van "civil rights and obligations" en "any criminal charge against him". Ook bleek dat artikel 6 een recht op "access to court" garandeert voor een ieder die een dergelijke procedure wil starten. De vraag is nu, of het begrip "court" hier dezelfde betekenis heeft als het begrip "independent and impartial tribunal established by law" in artikel 6 lid 1. Deze vraag is van belang, omdat indien het (procedurele) vereistedat een procedure moet plaatsvinden voor een "independent and impartial tribunal etc." - geschonden is, in geval van een positieve beantwoording van deze vraag ook het recht op "access to court" is geschonden.

De eerste aanwijzing voor de conclusie dat het begrip "court" inderdaad hetzelfde betekent als het begrip "independent and impartial tribunal established by law", is te vinden in de overweging van het Hof in de zaak. Golder, waarin het stelt, dat 
"Article $6 \$ 1$ secures to everyone the right to have any claim relating to his civil rights and obligations brought before a court or tribunal."

Door te spreken van "court or tribunal", lijkt het Hof deze termen aan elkaar gelijk te stellen. Voorts spreekt het Hof in de zaak Le Compte, Van Leuven and De Meyere in verband met "the right to court" onder artikel 6 lid 1, van een procedure "before 'tribunals' meeting the Article's various recuirements". ${ }^{105}$ Volgens het Hof in de zaak Neumeister, betekent het woord "court" in artikel 5 lid 4 dat

'the authority called upon to decide ... must possess a judicial character, that is to say be independent both of the executive and of the parties to the case; ... ${ }^{106}$

In dit verband kan, wat betreft de functie van een rechter, ook nog verwezen worden naar de uitspraak van het Hof in de zaak Sunday Times, warin het met betrekking tot de termen "authority of the judiciary" in artikel 10 lid 2 aangaf dat

"the courts are, and are accepted by the public at large as being, the proper forum for the ascertainment of legal rights and obligations and the settlement of disputes relative thereto; further, that the public at large have respect for and confidence in the courts' capacity to fulfil that function." 107

De kenmerken die het Hof noemt - "judicial character" en "independent" (Neumeister) en "ascertainment of legal rights and obligations and the settlement of disputes" (Sunday Times) - zijn, zoals we hierna zullen zien, ook vereisten die gesteld worden aan een "tribunal" in de zin van artikel 6 lid 1. Ook spreekt het Hof in de zaak Lithgow met betrekking tot het recht op "access to courts" van "access to an independent tribunal" ${ }^{108}$ Overigens meent de Commissie dat artikel 6 lid 1 niet vereist dat iedere

104 EHRM 21 februari 1975, Golder Case, §36, p. 18.

105 EHRM 23 juni 1981, Case of Le Compte, Van Leuven and De Meyere, \$51(a), p. 23.

106. EHRM 27 juni 1968, Neumeister Case, $\$ 24$, p. 44; zie ook EHRM 18 juni 1971, De Wilde, Ooms and Versyp cases ("Vagrancy Cases"), $\$ \$ 76$ and 78, pp. 41-42 en EHRM 5 november 1981, Case of $X$ v. UK, §53, p. 23.

107 EHRM 26 april 1979. The Sunday Times Case (no. 1), \$55. p. 34.

108 EHRM 8 juli 1986. Case of Lithgow and others, $\$ 193$, p. 71. Vergelijk $\$ 92$ van Rapp.Comm. 6 oktober 1985. Case of $H$ v. Belgium, p. 61: " ... access to a tribunal meeting the requirements of that provision (artikel $6(1), C S$ ) ...". 
beslissing met betrekking tot "civil rights and obligations" genomen moet worden door een orgaan dat door het nationale recht als een "court" beschreven wordt, zolang dit orgaan "may be considered as a tribunal within the meaning of Article 6, paragraph 1 of the Convention" ${ }^{109} \mathrm{Niel}$ de kwalificatie in het nationale recht is derhalve doorslaggevend, maar de kwalificatie die de Conventie aan een orgaan geeft.

Op grond van deze overwegingen kan er dan ook vanuit gegaan worden dat de term "court" in het recht op "access to court" dezelfde betekenis heeft als het begrip "independent and impartial tribunal established by law". Voor de bepaling van de reikwijdte van het recht op "access to court" is derhalve ook van belang de reikwijdte van het procedurele vereiste van een procedure voor een "independent and impartial tribunal etc." na te gaan. ${ }^{110}$ In het navolgende zal eerst de betekenis van het begrip "tribunal" onderzocht worden, vervolgens wordt nagegaan wat verstaan wordt onder "established by law" en voorts worden de termen "independent" en "impartial" onder de loep genomen.

Voordat hier echter toe overgegaan wordt, dienen de volgende twee punten nog vermeld te worden.

Ten eerste bepaalt het Hof in de zaak Le Compte, Van Leuven and De Meyere, dat

"(w)hilst Article $6 \$ 1$ embodies the 'right to a court', it nevertheless does not oblige the Contracting States to submit 'contestations' ... to a procedure conducted at each of its stages before "tribunals" meeting the Article's various requirements. Demands of flexibility and efficiency, which are fully compatible with the protection of human rights, may justify the prior intervention of administrative or professional bodies and, a fortiori, of judicial bodies which do not satisfy the said requirements in every respect; the legal tradition of many member States of the Council of Europe may be invoked in support of such a system."

109 Besl.Comm. 12 oktober 1982, zaken nrs. $8588 / 79$ en 8589/79, Bramelid and Malmström v. Sweden, pp. 84-85.

110 Dit blijkt impliciet, bijvoorbeeld, uit de wijze van toetsen door het Hof in EHRM 28 juni 1990, Obermeier Case, \$\$66-70, pp. 21-23.

111 EHRM 23 juni 1981 , Case of Le Compte, Van Leuven and De Meyere, $\$ 51$ (a), p. 23. Zie 0.a. ook EHRM 21 februari 1984, Öztürk Case. \$56, pp. 21-22 en Rapp.Comm. 3 juli 1985, Case of Enl and others, \$77, p. 23. 
In latere uitspraken wordt aan deze overweging toegevoegd, dat Staten weliswaar de vrijheid hebben zelf te bepalen of zaken waarop artikel 6 lid 1 van toepassing is, worden beoordeeld door administratieve, "professionele" of rechterlijke organen; maar hierbij dient de Staat dan wèl één van de volgende systemen te volgen: ofwel de betreffende organen voldoen zelf aan de vereisten van artikel 6 lid 1, ofwel - wanneer dit niet het geval is - zijn hun beslissingen vatbaar voor beroep bij "a judicial body that has full jurisdiction and does provide the guarantees of Article 6 $\S 1^{\prime \prime} .112$

Indien het gerecht in eerste instantie wel aan de vereisten van artikel 6 lid 1 voldoet, dan dient hierbij nog het volgende aangetekend te worden. Hoewel de Conventie niet voorziet in een recht op hoger beroep of cassatie, dienen - indien het nationale recht toch in de mogelijkheid tot hoger beroep of cassatie voorziet, de procedurele vereisten van artikel 6 zowel in deze hogere instanties als in eerste instantie gerespecteerd te worden. ${ }^{113}$ Onterecht is mijns inziens dan ook de - ongemotiveerde opvatting van zowel Alkema als Brenninkmeijer, dat de waarborgen van artikel 6 in civiele procedures, anders dan in strafzaken, alleen in de hoogste instantie behoeven te worden gerespecteerd. ${ }^{114}$ Van Dijk had al eerder dezelfde opvatting verkondigd, daarbij uitgaand van het verschil tussen civiele en strafzaken. Dat verschil kwam er volgens hem - simpel weergegeven - op het volgende neer. In civiele procedures gaat het initiatief tot procederen van de eisende partij uit, die dan ook voor de eerbiediging van de garanties van artikel 6 in die procedure moet opkomen. In strafzaken is het niet de verdachte die tot het voeren van een proces over gaat. Dat gebeurt pas na de eerste instantie, wanneer de

112 EHRM 10 februari 1983, Albert and Le Compte, $\$ 29$, p. 16 (cursivering, CS). Zie ook o.a. EHRM 26 oktober 1984, De Cubber Case, \$31, p. 17: EHRM 21 september 1993, Zumtobel Case, $\$ 29$, p. en EHRM 25 november 1994. Ortenberg Case, \$31, pp. $49-50$ en Rapp.Comm. 3 juli 1985, Case of Ettl and others, \$78, p. 23 en Rapp.Comm. 6 oktober 1985, H v. Belgium, \$92, pp. 61-62. Zie met name ten aanzien van het hebben van de volle jurisdictie: EHRM 23 september 1982, Sporrong and Lönnroth, §86, p. 31.

113 EHRM 26 oktober 1984 , De Cubber Case, $\$ 32$, p. 18. Zie ook de rechtspraak waarnaar in deze uitspraak verwezen wordt: EHRM 17 januari 1970, Delcourl Case, $\$ 25$, p. 14 (onderaan) en EHRM 22 februari 1984, Sutter Case, \$28, p. 13. Zie voorts Rapp.Comm. 3 juli 1985, Case of Ettl and others, \$\$88-89, pp. 25-26 en de rechtspraak waarnaar de Commissie in dit verband verwijst.

114 Annotatie van E.A. Alkema bij EHRM 26 oktober 1984, De Cubber Case, punt 6, NJ 1988, 744; A.F.M. Brenninkmeijer, De toegang tot de rechter, p. 43. 
verdachte in hoger beroep gaat. ${ }^{11}$ Dit verschil zou betekenen dat de civiele procespartij als voordeel boven de verdachte zou hebben, dat hij tijdens de eerste instantie de mogelijkheid zou hebben eventuele gebreken aan de eerbiediging van artikel 6 in die procedure nog aan te kaarten. Deze mogelijkheid lijkt mij illusoir gezien het feit dat het probleem er hier juist in schuilt dat deze eerste instantie niet aan artikel 6 voldoet. Naar mijn mening dienen dan ook zowel in civiele als in strafzaken de eerste en de hogere instanties aan de eisen van artikel 6 te voldoen. Voor beide soorten procedures geldt, dat een andere opvatting in strijd zou zijn met

$" .$. the intention underlying the creation of several levels of courts, namely to reinforce the protection afforded to litigants. "116

Overigens moet ten aanzien van cassatie-procedures opgemerkt worden, dat de wijze waarop artikel 6 wordt toegepast op cassatie-procedures volgens het Hof "must ... clearly depend on the special features of such proceedings." 117 Deze overweging is ook van belang met oog op het nu te bespreken tweede punt.

Het tweede, nunt dat hier ng vermeld mat wordar heaf botrkkking or de rechterlijke toetsing. In de zaak Le Compte, Van Leuven and De Meyere heeft het Hof vastgesteld, dat zowel in burgelijke als in strafzaken, artikel 6 lid 1 geen onderscheid maakt tussen feitelijke kwesties en kwesties ten aanzien van het recht. Beiden zijn even cruciaal voor de uitkomst van burgelijke procedures. Daarom concludeert het Hof dat

"the 'right to a court' and the right to a judicial determination of the dispute cover questions of fact just as much as questions of law."

In de zaak Albert and Le Compte spreekt het Hof bovendien van "full jurisdiction"."

$115 P$. van Dijk, De op Nederland rustende internationale verplichtingen ter zake van een behoorlijke rechtspraak, pp. 122,91-93. Nota bene: dit preadvies is geschreven voordat het Hof het arrest van 26 oktober 1984 in de zaak De Cubber had gewezen.

116 EHRM 26 oktober, De Cubber Case, \$32, p. 18. Zo ook $J$. van der Velde, Het "vrije spel der rechterlijke krachten", p. 89 en P. van Dijk en G.J.H. van Hoof, De europese conventie in theorie en praktijk, p. 340.

117 EHRM 17 januari 1970, Delcourt Case, \$26, p. 15.

118 EHRM 23 juni 1981, Case of Le Compte, Van Leuven and De Meyere, \$51(b), p. 23. Zie o.3. ook EHRM 10 februari 1983, Albert and Le Compte. \$29, p. 16 en Rapp.Comm. 3 juli 1985. Case of Etll a.o., 878, p. 23.

119 EHRM 10 februari 1983, Albert and Le Compte, $\$ 29$, p. 16. 
Worden derhalve in een procedure niet zowell feitelijke als rechtskwesties aaneen rechterlijke beoordeling onderworpen, dan is in die procedure niet aan de vereisten van artikel 6 lid 1 voldaan. In Nederland mogen in een cassatie-procedure alleen rechtsvragen aan de orde worden gesteld. In zowel de zaak Le Compte, Van Leuven and De Meyere als in de zaak Albert and Le Compte heeft het Hof geoordeeld dat een behandeling die in feitelijke instantie niet voldoet aan artikel 6, niet kan worden gecorrigeerd door een behandeling in cassatie die wel aan artikel 6 volioet. Dat komt, aldus het Hof, doordat het Belgische Cour de cassation "shill not take cognisance of the merits of cases". ${ }^{120}$ Dit betekent mijns inziens dat ofwel een procedure in feitelijke instantie aan artikel 6 moet voldoen, dan wel na de constatering door de cassatie-rechter dat artikel 6 geschonden is, deze rechter ofwel toch zelf tot een waardering van de feiten moet overgaan of moet terugverwijzen naar een feitelijke instantie die wèl aan artikel 6 voldoet. Deze laatste mogelijkheid is in de Necerland'se rechtsorde de meest aangewezen weg.

Betekenen de overwegingen van het Hof dat "the 'right to a court' and the right to a judicial determination of the dispute cover questions of fact just as much as questions of law" en dat sprake moet zijn van een rechterlijk orgaan "that has full jurisdiction" dat de rechter ook ten aanzien van bestuurshandelingen tot een volledige toetsing overgaat? ${ }^{121}$ Ook ten aanzien van bestuurshandelingen geldt mijns inziens dat de toetsing betrekking moet hebben op zowel feitelijke als rechtskwesties. Met Frowein kan ik stellen dat het juist is "daß eine Überprüfung von Verwaltungsentscheidungen, die an die von der Verwaltung festgestellten Tatsachen umfassend gebunden ist, nach Art. 6 Abs. 1 EMRK nicht ausreichen kann." ${ }^{122}$ Aan de andere kant beschikken bestuursorganen bij hun besluiten veelal een beoordelingsmarge. In de zaak Ashingdane oordeelt het Hof ten aanzien van de in het geding zijnde wetgeving, dat

"(e)ven assuming that a right is conferred on the individual citizen ..., the legal obligation thereby created, being couched in rather general terms, leaves a wide discretion to the Minister and would, by its very

120 EHRM 23 juni 1981, Le Compte, Van Leuven and De Meyere, \$60, p. 26: EHRM 10 tebruari 1983. Albert and Le Compte. \$36. p. 19.

121 Zie hieronder noot 202 voor een begripsbepaling ten aanzien van de hier te noemen vormen van inetsing.

122 J.A. Frowein. Die Überprüfungshefugnis im Rahmen von Art. 6 Abs. 1 EMRK, p. 148 
nature and quite apart from section 141 of the 1959 Act, not be amenable to full judicial control by the national courts. ${ }^{123}$

Indien er met betrekking tot bestuurshandelingen, waarbij het bestur een beoordelingsvrijheid heeft, vanuit gegaan moet worden dat geen plaats is voor een volledige toetsing, hoever kan die toetsing dan wèl gaan? Het arrest van het Hof in de zaak Belilos lijkt erop te wijzen, dat toetsing aan een willekeur-criterium onvoldoende is. ${ }^{124}$ Ook kan een rechter niet volstaan met een toetsing op procedurele onregelmatigheden en het overschrijden van de beoordelingsvrijheid door het desbetreffende bestuursorgaan. Het Hof bepaalt in de zaak Obermeier, dat "such a limited review cannot be considered to be an effective judicial review under Article $6 \$ 1 . " 125$ Wat een dergelijke "effective judicial review" inhoudt, stelt het Hof niet vast. Van der Velde merkt dienaangaande op dat "de jurisprudentie ... langzamerhand ... richting volledige rechtmatigheidstoetsing [opschuift]. "126

Kan men derhalve op grond van de zaak Ashingdane concluderen dat inzake bestuurshandelingen de rechter zich zal dienen te beperken tot een rechtmatigheidstoetsing; ten aanzien van deze rechtmatigheidstoetsing lijk de jurisprudentie erop te duiden, dat een (marginale) toetsing aan de hand van alleen algemene beginselen, zoals het willekeur-criterium, onvoldoende is. ${ }^{127}$ Met het oog op een "effectieve" rechtsbescherming lijkt het mij gerechtvaardigd om uit te gaan van een volledige rechtmatigheidstoetsing (derhalve ook toetsing aan algemeen verbindende voorschriften).

\subsubsection{Tribunal ${ }^{128}$}

In navolging van de hiervoor besproken, in de zaak Neumeister gegeven, betekenis van het begrip "court" in artikel 5 lid 4, geeft het Hof in de zaak Ringeisen dezelfde betekenis aan het woord "tribunal" in artikel 6 lid 1 . De in deze zaak te beoordelen "Regional Commission" is volgens het Hof een "tribunal" omdat

123 EHRM 28 mei 1985. Ashingdane Case, $\$ 59$, p. 25 . Zie ook ten aanzien van dit arrest P. Lemmens, De Raad van State en Art. 6, lid 1, EVRM, p. 642.

124 EHRM 29 april 1988, Betilos Case, \$72, p. 32.

125 EHRM 28 juni 1990, Obermeier Case, $\$ 70$, p. 23.

126 Van der Velde. Het "vrije spel der rechterlijke krachten", p. 101.

127 Anders: $P$. Lemmens, Geschillen over burgerlijke rechten en verplichtingen, pp. 280283.

128 Zie ten anzien van het begrip "tribunal" in de Conventie: $\boldsymbol{J}$. Velu. La notion de "tribunal" et les notions avoisinantes dans la Convention de sauvegarde des droits de I'homme ef des libertés fondamentales, pp. 1287-1315. 
it is independent of the executive and also of the parties, its members are appointed for a term of five years and the proceedings before it afford the necessary guarantees. "129

Volgens deze uitspraak zijn derhalve de onafhankelijkheid van het bestuur en van de betrokken partijen, de duur van de periode waarvoor de leden van het orgaan benoemd zijn en procedurele garanties voorwaarden voor het bestaan van een "tribunal" in de zin van artikel 6 lid 1. Deze opvatting wordt door het Hof bevestigd in de zaak Le Compte, Van Leuven and De Meyere, waarin het Hof bepaalt dat het uitoefenen van juridische functies voor het bestaan van een "tribunal" niet volstaat. ${ }^{130}$ Volgens het Hof mag de term "tribunal" alleen gebruikt worden als voldaan is aan een aantal verdere vereisten, zoals - opnieuw -

$" . .$. independence of the executive and of the parties to the case, duration of its members' term of office, guarantees afforded by its procedure - several of which appear in the text of Article $6 \$ 1$ itself." ${ }^{13 !}$

In andere zaken noemt het Hof ook nog de onpartijdigheid van het orgaan als vereiste. ${ }^{132}$ Op grond van deze vereisten komt het Hof in de zaak

129 EHRM 16 juli 1971, Ringeisen Case, \$95, p. 39. Het Hof verwijst hier o.a. naar EHRM 27 juni 1968, Neumeister Case, §78, p. 44.

130 Velu spreekt ten aanzien van het uitoefenen van juridische functies als voorwaarde voor het bestaan van een "tribunal" van een "critère matériel": "L'autorité doit être juridiquement apte à prendre des décisions obligatoires s'analysant en des actes juridictionnels par leur contenu, ce qui implique notamment qu'elle puisse dire pour droit si l'acte ou l'abstention à l'origine du litige est conforme ou non à la légalité."

J. Velu, La notion de "tribunal" et les notions avoisinantes dans la Convention, p. 1301.

131 EHRM 23 juni 1981, Le Compte, Van Leuven and De Meyere, \$55, p. 24. Zie verder EHRM 24 november 1994, Beaumartin Case, §38, p. 63 ("Only an institution that has full jurisdiction and satisfies a number of requirements, such as independence of the executive and also of the parties, merits the designation 'tribunal' within the meaning of Article $6 \$ 1$.") en Rapp.Comm. 6 oktober 1985, Case of $H v$. Belgium, $\$ 95$, p. 62.

132 EHRM 23 oktober 1985, Benthem Case, \$43, p. 18; EHRM 29 april 1988, Belilos Case, \$64, p. 29 en EHRM 27 augustus 1991, Demicoli Case, §39, p. 18. Deze vereisten van onafhankelijkheid en onpartijdigheid brengt Velu onder de term "critères organiques". Andere organieke vereisten zijn volgens Velu, de voorwaarde dat de rechterlijke instantie "doit être établi par la loi" en "doit être légalement compétent". Ten aanzien van dit laatste vereiste stelt hij: "... bien que le texte de l'article $6 \$ 1$ er, ... ne le dise pas explicitement, il nous paraît que le tribunal, devant être établi par la loi, doit aussi être légalement compétent: les personnes relevant de 
Benthem tot de conclusie, dat artikel 6 lid 1 geschonden is. Het Koninklijk Besluit van de Kroon in deze zaak was volgens het Hof een administratief besluit, dat afkomstig was van een minister die daarover verantwoording schuldig was aan het parlement. Bovendien was deze minister hiërarchisch de superieur van de inspecteur voor de volksgezondheid die het beroep in deze zaak had ingesteld en van de Directeur-Generaal die verantwoordelijk was voor het technische rapport waarop het Koninklijk Besluit was gebaseerd. Tenslotte was het Koninklijk Besluit in kwestie ook niet vatbaar voor herziening door een rechterlijk orgaan als vereist door artikel 6 lid 1. ${ }^{13}$ Zonder deze conclusie uitdrukkelijk te formuleren, lijkt het Hof hiermee te zeggen, dat de Kroon geen "tribunal" in de zin van artikel 6 lid 1 is.

Wat betreft het uitoefenen van een juridische functie als voorwaarde voor het bestaan van een "tribunal", constateert de Commissie in de Sramek. zaak dat het essentiële kenmerk van een "tribunal" is, dat

"... its decisions should not be primarily left to its discretion, but should be arrived at in orderly proceedings conducted on the basis of the rule of law. ${ }^{134}$

Het Hof bevestigt dit in dezelfde zaak Sramek, en bepaalt ten aanzien van de onder beoordeling staande "Regional Authority" (die in het nationale recht niet als "court" wordt gekwalificeerd):

"For the purposes of Article 6, however, it comes within the concept of a 'tribunal' in the substantive sense of this expression: its function is to determine matters within its competence on the basis of rules of law, following proceedings conducted in a prescribed manner. ${ }^{n 13}$

la juridiction des Etats contractants ont droit à leur juge naturel: elles ne peuvent être distraites, contre leur gré, du juge que la loi leur assigne." Met betrelking tot de procedurele waarborgen in de zinsnede uit bovengenoemde arresten "guarantees afforded by its procedure - several of which appear in the text of Article $6 \$ 1$ itself spreekt Vetu van "critères formels". J. Velu, La notion de "tribuna!" et les notions avoisinantes dans la Convention, pp. 1301-1302 respectievelijk pp. 1303-1306.

133 EHRM 23 oktober 1985 , Benthem Case, \$43, p. 18.

134 Rapp,Comm. 8 december 1982, Sramek Case, \$71. p. 31.

135 EHRM 22 oktober 1984, Sramek Case, \$36, p. 17. Zie ook EHRM 18 oktober 1984 , De Cubber Case, $\$ 32$ (impliciet), p. 18; EHRM 30 november 1987, H v. Belgium, $\$ 50$, p. 34; EHRM 29 april 1988 . Belilos Case, \$64, p. 29 en EHRM 27 augusus 1991, Demicoli Case, \$39, p. 18. 
Of oals het Hof het uitdrukt in de Benthem-zaak:

".. a power of decision is inherent in the very notion of 'tribunal' uthin the meaning of the Convention."

In eze zaak komt het Hof dan ook tot de conclusie dat de procedure voor de sfdeling Geschillen van Bestuur van de Raad van State niet voorziet in de 'determination by a tribunal of the matters in dispute", omdat de Afeling alleen een advies opstelt, dat voor de Kroon niet bindend is. ${ }^{136}$

Teslotte blijkt ook uit de rechtspraak van het Hof dat wanneer een Staat bij de nakoming van zijn verdragsverplichtingen - waarondei het garnderen van het recht op "access to court" - de Staat de vrijheid heeft te kezen tussen verschillende methoden die hiervoor ter beschikking staan. Ditgeldt ook voor het opzetten van organen voor de beslissing van door artiel 6 bestreken rechtsgedingen.

"hus, in Article $5 \S 4$ the word 'court' is not necessarily to be uderstood as signifying a court of law of the classic kind, integrated wthin the standard judicial machinery of the country. "137

Deze overweging uit de zaak $X v$. United Kingdom is herhaald ten aanzien van de term "tribunal" in artikel 6 lid $1 .{ }^{138}$ De betekenis van deze overweging is, dat Staten ook organen mogen opzetten die niet behoren tot wat in Nederland wel de "gewone rechterlijke macht" wordt genoemd, dat wil zeggen de burgerlijke en strafrechter. Een Staat is bevoegd ten aanzien

136 EHRM 23 oktober 1985, Benthem Case, $\$ 40$, p. 17. Het Hof verwijst hier naar EHRM 22 mei 1984. Case of de Jong, Baljet and van den Brink, \$48, pp. 23-24. Zoals bekend betekent deze beslissing in de Benthem-zaak het einde voor het Kroonberoep. Zie voor een dergelijke uitspraak ten aan zien van het College van Beroep voor het Bedrijfsleven (CBB) EHRM 19 april 1994, Van de Hurk Case, §45, p. 16.

De voorwaarde voor het bestaan van een "tribunal" dat het desbetreffende orgaan een bindende beslissing geeft, brengt Velu onder het criterium "de l'autorité de la chose jugée". J. Velu, La notion de "tribunal" et les notions avoisinantes dans la Convention, p. 1306.

137 EHRM 5 november 1981, $X$ v. UK, §53, p. 23.

138 EHRM 28 juni 1984, Case of Campbell and Fell, §76, p. 39; en EHRM 8 juli 1986, Lithgow a.o., \$201, p. 73. 


\section{AFBAKENING: JURISPRUDENTIE NAAR AANLEIDING VAN ART. 6 ECRM}

van een beperkt aantal specifieke kwesties een orgaan in te stellen, op voorwaarde dat dit orgaan aan de voorwaarden van artikel 6 voldoet. ${ }^{19}$

Samenvattend kan het begrip "tribunal" in artikel 6 lid 1 als volgt afgebakend worden. Het moet gaan om een orgaan dat een juridisch bindende beslissing geeft die niet tot stand gekomen is op grond van de discretie van het desbetreffende orgaan, maar die is genomen in een voorgeschreven procedure en met inachtneming van de rule of law. Met het oog op deze laatste toevoeging kan met name gewezen worden op de vereisten van onafhankelijkheid en onpartijdigheid, de duur van de benoeming van de leden van het orgaan en een met garanties omgeven procedure. Zoals ook het Hof aangeeft is een aantal van deze vereisten, zoals de onafhankelijkheid en onpartijdigheid van de rechter, expliciet in artikel 6 lid 1 opgenomen. Deze vereisten zijn derhalve meer dan procedurele vereisten alleen. Ze zijn voorwaarden voor het bestaan van een "tribunal" in de zin van artikel 6 lid 1 en daarmee voor het bestaan van een recht op "access to court".

Het begrip "tribunal" heeft gezien de zojuist beschreven criteria een inhoudelijke ("substantive") betekenis. Het gaat er derhalve niet om of een orgaan in het nationale recht al dan niet een "tribunal" genoemd word."

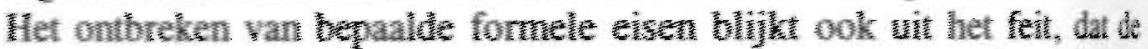

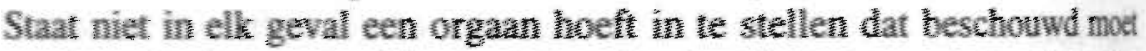

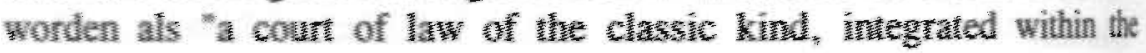

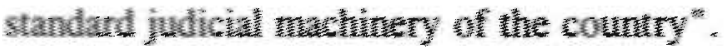

\subsubsection{Estabished by law}

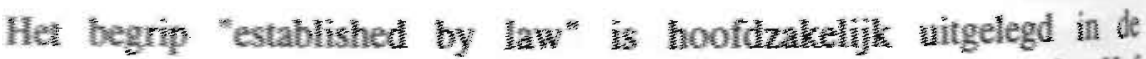

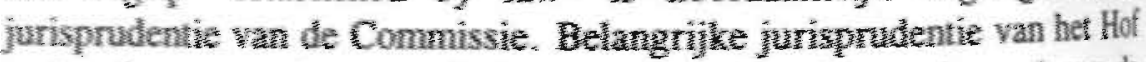

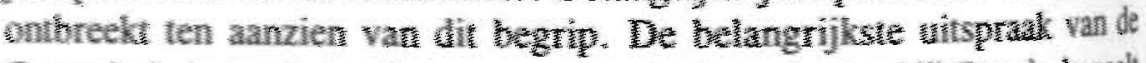

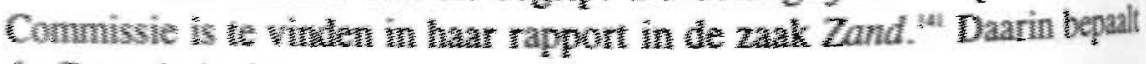
de Commissie dat

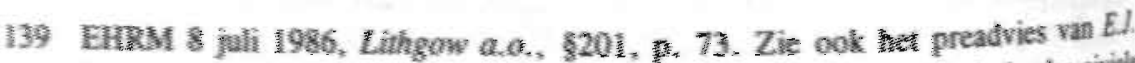
Domsnering, He grondrecht op behoorlijke rechtsprask it het Nederlandse civik recht, ne. 211-212.

140 Zie 365 van "manicipal authorities" er "advinistrative atuthorities": "... such terms do not appear

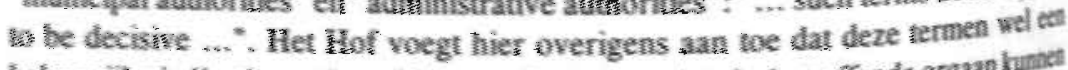
belamgrijke indicatie met betrekking tot de ankt wan het desbetreffende organ kunth seven.

141 Rapp.Comm. 2 oktober 1978, Zand Case, \$861-73, p. 80. 
"... the term 'a tribunal established by law' in Article 6 (1) envisages the whole organizational set-up of the courts, including not only the matters coming within the jurisdiction of a certain category of courts, but also the establishment of the individual courts and the determination of their local jurisdiction."

Dit betekent derhalve, dat de gehele organisatorische structuur en de jurisdictie van zowel een bepaalde soort rechterlijke instantie als van het individuele gerecht bij wet moet zijn geregeld.

Volgens de Commissie vereisen het voorwerp en doel van de term "established by law" in artikel 6 lid 1, dat de juridische organisatie in een democratische samenleving niet afhankelijk is van de discretie van het bestuur ("the Executive"), maar geregeld is in een van het parlement afkomstige wet. ${ }^{142}$ Dit betekent echter niet dat delegatie zonder meer onaanvaardbaar is ten aanzien van de rechterlijke organisatie. De formele wet hoeft niet elk detail op dit terrein te regelen,

$"$ ".. if the legislature establishes at least the organizational framework for the judicial organization."

Voor de wettigheid ("lawfulness") van een gerecht is het noodzakelijk dat de instelling van rechterlijke organen bij gedelegeerde wetgeving en de beoordelingsvrijheid van een minister (of in het algemeen, het bestuur) daarbij, in overeenstemming is met de interne (formele) wetgeving van de desbetreffende Staat, inclusief de relevante bepalingen in de Constitutie. ${ }^{143}$.

In de zaak Le Compte, Van Leuven and De Meyere gaat het om provinciale en beroepsraden, organen van de "Medical Association". Deze "Medical Association" is ingesteld bij formele wet en gereorganiseerd bij een Koninklijk Besluit dat op weer een andere formele wet is gebaseerd. De samenstelling, jurisdictie en procedure van de provinciale en beroepsraden worden beheerst door deze wetgeving. Na te hebben geconstateerd dat het hier om delegatie van wetgeving gaat, stelt de Commissie vast dat

142 Rapp.Comm. 12 oktober 1978, Zand Case, $\$ \$ 68-69$. p. 80. Zie ook Rapp.Comm. 13 mei 1981, Piersack Case, $\$ \$ 47-48$, p. 23 en Besl.Comm. 18 december 1980. zaken nrs. 8603/79, 8722/79, 8723/79 en 8729/79, Crociani, Palmiotti, Tanassi and Lefebvre d'Ovidio v. Italy, §§8-9, pp. 219-220.

143 Rapp.Comm. 12 oktober 1978 , Zand Case, $\S \$ 69,71$, p. 80 
"... the instruments issued by the executive on this authority must be considered as complying with the concept of "law" within the meaning of the Convention."

Op grond van deze overweging komt de Commissie tot de conclusie dat de provinciale en beroepsraden "established by law" zijn. Deze overweging en met name de verwijzing naar het concept "law" in de betekenis van de Conventie duidt erop, dat de Commissie het begrip "law" in artike 6 110 1 een betekenis geef die overeenkomt met het begrip "law" in de wweede leden van de artikelen 8 tot en met 11 van de Conventie. In paragraaf 2.4.2.1 (pp. 59-60) zagen we dat het begrip "law" aldaar de betekenis van "materiele wet" heeft. De Commissie geeft door middel van de zojuist geciteerde overweging aan, ook het begrip "law" in artikel 6 lid t een materiele betekenis te geven door ook een Koninklik Besluit als "law" te bestempelen. Omdat het hier gaat om gedelegeerde wetgeving, het Koninklijk Besluit is op een formele wet gebaseerd, kan waarschijnijk wel worden aangenomen, dat het begrip "Law" duidt op een materiele wet, die te herleiden is tot een formele wet.

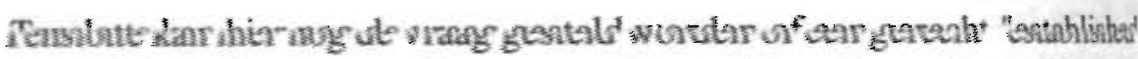

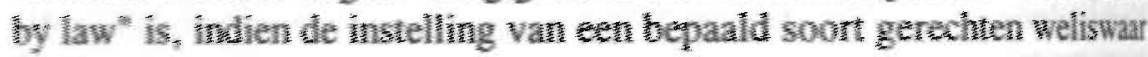
bij) wet geregeld is; maar deze regeling me is cugeleefd. In en

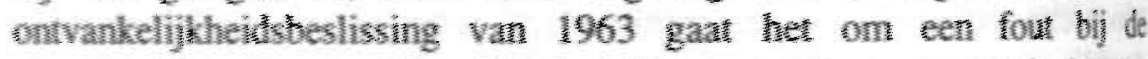
samenstelling van sen jury. De instelling un "jury courts" is in cast geregeld bi] wet.

Volgens de Commissie is de samenstellngs van de jury etn administratieve kwestie die âs zodanig niet de "establishment" van hat gerecht betreft. Fen dusdanige auministratieve fout kan allen in aanmerking genomen worden in zoverre deze fout "caused such prejudice to the Applicant as to amoun in a denial of justice". Wiervan zou sprake zijn als le toelating van bepaalde juryleden op enige wijze isvlod zou hebben op de nitkonst van de procedure. In het ondertavige geval is hiervan geen sprake en aerhalve is artikel 6 in dit opzicht niet geschonden ${ }^{\text {ses }}$

De Commissie verkondigt in huar rapport in de zak Pfeifer and Plank - waarin het gaat on rechers ate zich vanwege hun vettelijle

144 Rapp Comm. 14 december 1979. Case of Le Compte. Van Leusen and De Moyer. 575. pp. 39-40. Zonder nadere twelichting zijn deze nverwegingen bevestigd it Rapp. Comm. 14 december 1981, Albent and Le Compte, \$\$873-74, pr. 38-39.

145 Besl. Comm. 23 juh 1963, zaak ur. 1476162. X n. Antria, p. 42. 
onbevoegdheid hadden moeten verschonen, maar dat niet gedaan hebben een andere opvatting. Volgens de Commissie,

"(i)n principle, a court cannot be regarded as being 'established by law' if, in a particular case, the provisions as to its lawful composition have not been complied with."

Om deze reden en omdat de door de Staat ingeroepen afstand van recht door de klager, niet geldig wordt geacht, is de garantie van een "tribunal established by law" ten aanzien van de klager niet nageleefd. ${ }^{146}$

Mijns inziens is het verschil tussen een jury-gerecht en een gerecht waarin rechters zitting hebben hier van geen betekenis. Beide soort gerechten worden geacht zaken volgens de wet en volgens voorgeschreven procedures te beoordelen. De wettelijke regelingen ten aanzien van de samenstelling van rechterlijke organen dienen derhalve ook in het individuele geval te worden nageleefd. Wordt hierbij een fout gemaakt, dan is in dat geval geen sprake van een gerecht dat "established by law" is.

Kortom komt de betekenis van het begrip "established by law" op het volgende neer. Het begrip ziet op de gehele organisatorische structuur ("organizational set-up"), inclusief de instelling, jurisdictie en samenstelling, van zowel een categorie rechterlijke instanties als het individuele gerecht. Deze organisatorische structuur moet bij wet geregeld zijn, wat inhoudt dat de structuur moet zijn neergelegd in een formele wet of een materiële wet, die op een formele wet is gebaseerd (delegatie). Fouten in de naleving van de wettelijke regels betekenen, ook in het individuele geval, dat het vereiste "established by law" niet is nageleefd.

\subsubsection{Independent ${ }^{147}$}

De eerste betekenis die er aan de term "independent" is gegeven, kan worden gevonden in de uitspraak van het Hof in de zaak Ringeisen. Hierin

146 Rapp.Comm. 11 oktober 1990, Case of Pfeifer and Plankl, $\$ \S 63-80(6,3,80)$, pp. 25 27. Vergelijk Besl.Comm. 18 december 1980, Crociani a.o., $\$ 9$ (eerste alinea), p. 220.

$147 \mathrm{Vgl}$. Recommendation No. R(94) 12 of the Committee of Ministers to Member States on the Independence, Efficiency and Role of Judges, 13 October 1994, in: NJCMBulletin 20-5 (1995), pp. 620-623. 
AFBAKENING: JURISPRUDENTIE NAAR AANLEIDING VAN ART. 6 ECRM

spreekt het Hof van "independent of the executive and also of the parties". ${ }^{148}$

In de zaak Zand gaat de Commissie in op het aspect van "independence of the executive". In deze zaak gaat het om beoordelingsvrijheid van de Minister van Justitie in Oostenrijk om een "Labour Court" in te stellen. Op grond van de relevante wetgeving dient een dergelijk gerecht naar behoefte ("according to need") ingesteld te worden. Volgens de Commissie betekent. dit de objectieve behoefte voor het bestaan van een "Labour Court" op een bepaalde plaats. Naar de mening van de Commissie gaat het hier om een begrip dat willekeurige beslissingen van de minister uitsluit. Zelfs al zou de ruime beoordelingsvrijheid de minister de gelegenheid bieden irrelevante overwegingen ("extraneous considerations") in zijn beslissing te betrekken, dan is deze enkele mogelijkheid volgens de Commissie onvoldoende om te concluderen dat de onafhankelijkheid van de "Labour Courts" in het algemeen beïnvloed is. Aan de hand van individuele zaken zal aangetoond moeten worden dat de praktijk in dit soort zaken als geheel onbevredigend is of dat tenminste de instelling van een bepaald gerecht beïnvloed is door onjuiste motieven. Dezelfde redenering geldt ten aanzien van de benoeming van de voorzitters ("Presiding Judges") van deze gerechten. $^{149}$

Wat betreft het ontslag van "Presiding Judges" overweegt de Commissie, dat

"... according to the principles of the rule of law in democratic states which is the common heritage of the European countries, the irremovability of judges during their term of office, whether it be for a limited period of time or for lifetime, is a necessary corollary of their independence from the Administration and thus included in the guarantees of Article 6 (1) of the Convention."150

Overigens betekent de onafhankelijkheid van de rechter, volgens de Commissie in de zaak Sutter, niet dat hij voor het leven benoemd zou

148 EHRM 16 juli i97!, Ringeisen Case, \$95, p. 39. Zie ook EHRM 28 juni 1984, Case of Campbell and Fell. \$78, p. 39 en Rapp.Comm. 12 oktober 197\$, Zand Case, \$74, p. 81; Rapp.Comm. 13 mei 1981, Piersack Case, \$51, p. 24; Rapp.Conm. 12 mel 1982. Case of Camphell and Fell, \$137, p. 73; Rapp.Comm. 12 december 1983, Case of Bramelid and Malmström, \$36, pp. 39-40 en Rapp.Comm. 7 mart 1984, Case of Lithgow a.0., \$\$460-463, pp. $118-119$.

149 Rapp.Conm. 12 oktober 1978 , Zand Case, $\$ \$ 77-78$, pp. $81-82$.

150 Rapp.Comm. 12 oktober 1978. Zand Case, $\$ 80$, p. 82. 
moeten worden ${ }^{151}$ of dat "he should be irrennovable in law, i.e. that he cannot be given other duties without his consent." Maar het is essentieel dat de rechter een zekere stabiliteit geniet, zelfs al is dit slechts voor een bepaalde periode, en dat hij niet aan enige autoriteit onderworpen is bij de uitoefening van zijn functie als rechter. In deze zaak zijn de rechters van de desbetreffende militaire gerechten ("Divisional Court" en "military Court of Cassation") weliswaar zelf militairen die in hun respectieve "units" aan de autoriteit van superieuren zijn onderworpen, in hun functie van rechter zijn zij aan niemand verantwoording schuldig over de wijze waarop zij recht spreken. Onder meer om deze reden kwam de Commissie tot de conclusie dat er geen reden tot twijfel bestond aan de onafhankelijkheid van de beide rechterlijke organen. ${ }^{152}$ Dat de rechtspraak in dit opzicht veranderd is, geven de uitspraken in, onder andere, de zaken Campbell and Fell, Sramek en Ertle and others aan.

In de zaak Campbell and Fell gaat het om een "Board of Visitors". Dit is een orgaan, dat zowel rechtsprekende als toezichthoudende functies uitoefent. De "Board" is wettelijk verplicht onafhankelijk van de partijen en onpartijdig te functioneren. Onafhankelijkheid van het bestuur vereist volgens de Commissie meer dan dat:

"To be truly 'independent' the 'tribunal' must be independent from the Executive in its functions and as an institution. Such independence forms an additional practical guarantee that the tribunal will act fairly and objectively and ensures that justice is seen to be done."

Volgens de Commissie voldoet de "Board of Visitors" niet aan de eis van institutionele onafhankelijkheid ten aanzien van het gevangenisbestuur. De leden van de "Board" worden voor beperkte perioden benoemd door de Minister van Binnenlandse Zaken, die de leiding heeft over het gevangenisbestuur. Voorts komt de "Board" vanwege zijn toezichthoudende functies dagelijks in contact met de gevangenisleiding. $\mathrm{Om}$ die redenen is niet aan de eis van onafhankelijkheid voldaan. ${ }^{153}$

Het Hof komt in deze zaak tot een andere conclusie. Volgens de uitspraak van het Hof staat met het feit dat de Minister de leden van de "Board" benoemt niet vast dat hierdoor de leden van de "Board" niet onafhankelijk

151 De Commissie verwijst hier naar Besl.Comm. 2 oktober 1975, zaak nr. 6859/74, $X$ v. Belgium, p. 139, waarin dit impliciet zou zijn uitgesproken.

152 Besl.Comm. I maart 1979, zaak nr. 8209/78, Sutter v. Switzerland, \$2, p. 174.

153 Rapp.Comm. 12 mei 1982, Case of Campbell and Fell, $\$ 137$, pp. 73-74. 
zijn van het bestuur. Zou men wèl tot deze conclusie komen, dan zouden rechters die door of op advies van een minister zijn benoemd, die verantwoordelijk is "in the field of the administration of the courts", ook niet onafhankelijk zijn. Bovendien kan het Ministerie van Binnenlandse Zaken dan wel richtlijnen voor de "Boards" uitvaardigen voor de uitoefening van hun functies, zij staan niet onder de instructies van de Minister in hun rechtsprekende rol. ${ }^{154}$ Deze laatste redeneerwijze word: ook gevolgd in de uitspraak van het Hof in de zaak Sramek. Hierin acht het Hof het feit dat de leden van het desbetreffende rechtsprekende orgaan door de "Land"-regering worden benoemd onvoldoende reden tot twijfel aan de onafhankelijkheid van deze leden, omdat

"they are appointed to sit in an individual capacity and the law prohibits their being given instructions by the executive" ${ }^{155}$

Het Hof vervolgt in de zaak Campbell and Fell met de overweging, dat de leden van de "Board of Visitors" wel voor een relatief korte periode worden benoemd, maar de reden daarvoor is begrijpelijk: de leden worden niet voor hun werkzaamheden betaald.

Wat betreft het ontbreken van regels ten aanzien van de overplaatsing en de onafzetbaatheid ("irremovability") van de leden van de "Board" bepaalt het Hof het volgende. Alhoewel de Minister het ontslag van een lid zou kunnen eisen, zal dit slechts in zeer uitzonderlijke omstandigheden gebeuren en het bestaan van deze mogelijkheid kan volgens het Hof in geen enkel opzicht beschouwd worden als een bedreiging van de onafhankelikheid van de leden van de "Board" bij de uitoefening van hun rechtsprekende functies.

"It is true that the irremovability of judges by the executive during their tern of office must in general be considered as a corollary of their independence ... However, the absence of a formal recognition of this irremovability in the law does not in itself imply lack of independence provided that it is recognised in fact and that the other necessary guarantees are present."

Ten aanzien van het feit, dat de "Board" in de uitoefening van de toezichthoudende functies regelmatig in contact komt met het

154 EHRM 28 juni 1984, Case of Campbell and Fell, \$79, p. 40.

155 EHRM 22 oktober 1984, Sramek Case, $\$ 38$, p. 18. Zie ook Rapp.Comm. 3 juli 1985, Case of Ettl a.o., $\$ 92$, p. 26.

156 EHRM 28 juni 1984, Case of Campbell and Fell, $\$ 80$, p. 40. 
gevagenispersoneel - evenals met de gedetineerden - doet het Hof de volende uitspraak. Dat de gedetineerden de indruk kunnen hebben dat de "Bords" nauw verbonden zijn met het bestuur en de gevagenisadministratie is een zwaarwegende factor, met name in verband methet belang in de context van artikel 6 van de grondregel

\section{"jstice must not only be done: it must also be seen to be done". ${ }^{15}$}

Hetsestaan van dergelijke gevoelens bij de gedetineerden is echter volgens het Hof onvoldoende voor de conclusie dat er een gebrek aan onahankelijkheid bij de "Board" bestaat.

"his requirement of Article 6 (onafhankelijkheid, $C S$ ) would not be saisfied if prisoners were reasonably entitled, on account of the frquent contacts between a Board and the authorities, to think that the fomer was dependent on the latter; "158

HetHof meent dat louter het bestaan van deze contacten, dat ook bestaat met de gedetineerden zelf, een dergelijke indruk niet zal kunnen ‘ceshvaardigen. ${ }^{159}$

Een aanwijzing van wat het Hof verstaat onder het zijn van "reasonably entitled ... to think that the former (het lid van een rechterlijk orgaan) was dependent on the latter (het bestuur of één van de partijen)" zou kunnen worden afgeleid uit de uitspraak van het Hof in de zaak Sramek. In deze zaak wordt - onder verwijzing naar onder meer de zaak Campbell and Fell, vermoedelijk in verband met de genoemde grondregel "justice must not only be done ... etc." - door het Hof bepaald dat bij de vaststelling of een rechterlijke instantie als onafhankelijk beschouwd kan worden,

"appearances may also be of importance".

157 EHRM 28 juni 1984, Case of Campbell and Fell, §81, p. 41. Dit adagium, dat afkomstig is uit het angel-saksische recht, wordt het voor het eerst aangehaald in het arrest in de zaak Delcourt. Volgens het Hof drukt dit adagium een idee uit dat door artikel 6 lid 1 bestreken wordt. EHRM 17 januari 1970, Delcourt Case, §31, p. 17.

158 EHRM 28 juni 1984, Case of Campbell and Fell, $\$ 81$, p. 41. Het Hof verwijst na deze overweging naar EHRM 1 oktober 1982, Piersack Case, $\S 30$, p. 15, alhoewel de desbetreffende passage uit de zaak Piersack betrekking heeft op de onpartijdigheid van het in het geding zijnde gerecht.

159 EHRM 28 juni 1984, Case of Campbell and Fell, §81, pp. 40-41. 
Wanneer onder de leden van een "tribunal" een persoon (in dit geval een ambtenaar) is die zich - wat betreft zijn taak en de organisatie van de dienst waarbinnen hij werkzaam is - in een ondergeschikte positie bevind? tegenover één van de partijen, dan

"... litigants may entertain a legitimate doubt about that person's independence. Such a situation seriously affects the confidence which the courts must inspire in a democratic society. ${ }^{\text {th6s }}$

Wanneer er geen sprake is van ondergeschiktheid van een lid van een rechterlijk orgaan aan (de vertegenwoordiger van) én van de partijen, noch van uitoefening van de functies binnen dit orgaan onder instructie van die partil, dan is dit op zich nog niet genoeg om de volledige onathankelijkheid en onpartijdigheid van het orgaan te verzekeren. Volgens de Commissie in de zaak Ettle and others vereist volledige onafhankelijkheid ook

"a sufficient organisational separation from the executive branch".

Een "tribunal" moet voor de individu zonder enige juridische scholing als

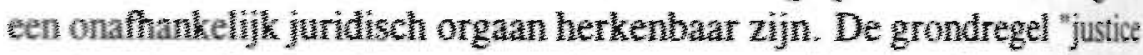

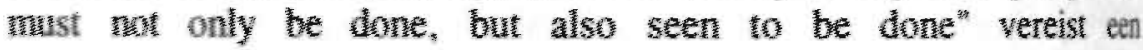

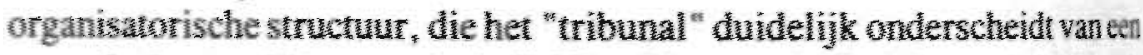

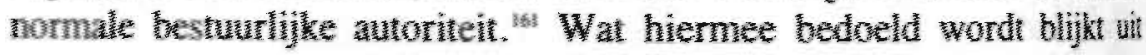
veruere overwegingen van de Commissic.

In le zaak Ettle is het merended wan de leden van het rechtsprekende orgaan in wvestie anbutenaar. Deze ambenaren staan in de witoefening van

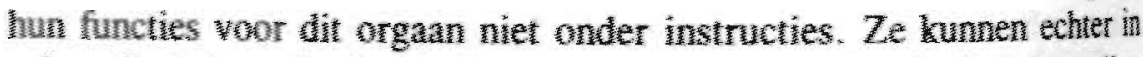

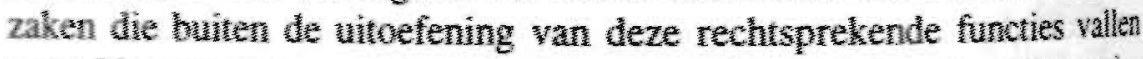

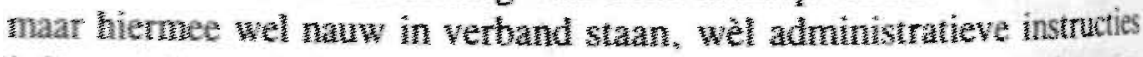

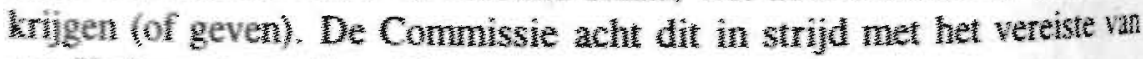
een "wivependent tribunal".

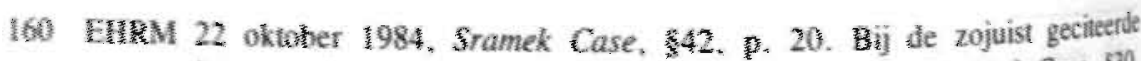

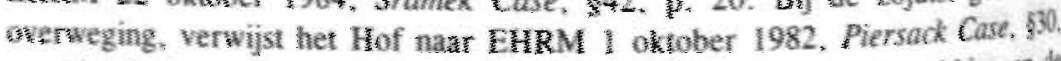
pp. I4t-15. In de zaach Piersack heeft deze overweging ecliter hetrekking op de onpartijdighed vatu de rechter.

161 Raph, Comm. 3 jull 1985, Case of EHl a. a, 395, 5.27 , Vergelij conclusie 11 in De onafhankelijke zechter, Rapport van een werkgroep van de afdeling rechterlike organisatie van de Nederlandse Vereniging voor Rechuspraak, in: Trema" Specil - '79-2 - Nederlandse Vereniging voor Rechtspraak: "s-Gravenhage 1979. p. 30: De zittende en staande magistratuut meeten als van elkaat gescheiden organen voor de burger 20 dudidelijk mogelijk herkenbaar zijn ..." 
Volgens de Commissie bestaat zelfs meer reden tot twijfel aan de onafhankelijkheid van het betreffende "tribunal", indien al deze ambtenaren deel uit maken van hetzelfde bestuurlijke orgaan of zelfs van hetzelfde onderdeel daarvan. Hierdoor wordt het aannemelijk dat ze al om deze reden dezelfde standpunten zullen innemen. Ook is het onaanvaardbaar dat er een hiërarchische verhouding bestaat tussen de individuele leden van het gerecht onderling. Zelfs al is een hiërarchische structuur beperkt tot zaken die buiten de bevoegdheid van het "tribunal" vallen, dan kan het niet worden uitgesloten dat die structuur ook het gedrag binnen het "tribunal" beïnvloedt. ${ }^{162}$

Verder heeft de Commissie - in verband met de grondregel "justice must not only be done; it must also be seen to be done" - in de zaak Bramelid and Malmström bepaald, dat het niet voldoende is dat de arbiters, in de in die zaak in het geding zijnde "Arbitration Board", in feite onafhankelijk zijn. Hun onafhankelijkheid

\section{"must be seen by all to be incontrovertible."}

In deze zaak tegen Zweden ligt het probleem niet bij de onafhankelijkheid van het bestuur, maar bij de onafhankelijkheid van de partijen bij de zaak (niet zijnde het bestuur). Volgens de Commissie bestaat er tussen de partijen niet altijd gelijkheid wat betreft de relatie die zij hebben met de arbiters die zij zelf hebben benoemd. In deze zaak had een groep minderheids-aandeelhouders, waaronder de klagers, geen praktische mogelijkheid om tot overeenstemming te komen over de keuze van een arbiter. Omdat volgens de wet de keuze van een arbiter moet steunen op een unanieme beslissing, waren zij genoodzaakt hun arbiter te láten benoemen. Hierdoor konden bij die benoeming de verschillende voorkeuren van de afzonderlijke aandeelhouders niet in aanmerking genomen worden. De tegenpartij, een machtige onderneming, kon dit wèl. Een accountant werd benoemd die zoals vele accountants door ondernemingen wel ingehuurd wordt om daarbij veelal de belangen van deze ondernemingen te behartigen. Naar de mening van de Commissie is deze onevenwichtigheid tussen de partijen niet opgeheven door de keuze van de derde arbiter. ${ }^{164}$

162 Rapp.Comm. 3 juli 1985. Case of Etll a.o., \$99, p. 28. Zie ook EHRM 29 april 1988. Belilos Case, $\$ \$ 66-67$. pp. 29-30.

163 Rapp.Comm. 12 december 1983, Case of Bramelid and Malmstriom. $\$ 35$, p. 39.

164 Rapp.Comm. 12 december 1983, Case of Bramelid and Malmström, $\$ 37-38$, p. 40. 
De voorgaande overwegingen tonen volgens de Commissie het belang aan van "pre-established courts to which are appointed judges who are totally unconnected with the case they are to hear." Het woord "tribunal" in artikel 6 duidt op dit soort gerechten. Weliswaar acht de Commissie uitzonderingen in specifieke procedures mogelijk, maar dan moet er wel een strikte garantie van gelijkheid tussen de partijen zijn wat betreft de invloed die zij uitoefenen op de samenstelling van het gerecht. . $^{\text {ts }}$

Aan de onafhankelijkheid van de rechter van het bestuur en van de partijen in een zaak, voegt de rechter in een zaak tegen Italië de onafhankelijkheid van de wetgevende macht, het parlement, toe. Deze toevoeging valt te verklaren uit het feit, dat het hier gaat om de vervolging van personen voor misdrijven, die gerelateerd zijn aan ambtsmisdrijven van ministers en derhalve aan dezelfde procedure onderworpen kunnen worden als deze ambtsmisdrijven. De rol van het parlement is in casu om de aanklacht tegen de klagers vast te stellen ("determining the charge"). De beslissing van het parlement ten aanzien van de aanklacht is derhalve van belang voor de jurisdictie van het Constitutionele Hof dat op de aanklacht zal moeten beslissen. Volgens de Commissie zijn de - toegevoegde - rechters van het Constitutionele Hof, waarvan de onafhankelijkheid wordt betwist, niet ondergeschikt aan enige autoriteit en kunnen zij hun taak uitoefenen zonder inmenging van het bestuur of het parlement. Bovendien zijn zij benoemd voor een vastgestelde periode, zijn de bepalingen voor de onverenigbaarheid van (neven)functies ("ineligibility") in de wet vastgelegd, kunnen zij voor opvattingen die zij bij de uitoefening van hun taak hebben geuit niet vervolgd worden en behoeven tegen hen ingestelde procedures de toestemming van Constitutionele Hof zelf. ${ }^{166}$

Samenvattend kan men uit deze uitspraken van het Hof en de Commissie afleiden dat voor de betekenis van het begrip "independent" de standaardformulering "independent of the executive and also of the parties" wordt gebruikt. Deze formulering is voorts verder in de jurisprudentie uitgewerkt. Hierin kan men de volgende aspecten van de betekenis van het begrip "independent" onderscheiden.

Het eerste aspect ziet op de benoeming van leden van rechterlijke organen door het bestuur, bijvoorbeeld een minister. Impliciet blijkt uit het

165 Rapp.Comm. 12 december 1983, Case of Bramelid and Malmström, \$39, p. 40. Vergelijk EHRM 8 juli 1986, Case of Lithgow a.o., \$202, p. 73: " ... criteria for the selection of members of the Tribunal were worked out jointly".

166 Besl.Comm. 18 december 1980, Crociani a.o. \$10, pp. 220-221. 
arrest van het Hof in de zaak Campbell and Fell dat dit is toegestaan, ondanks het vereiste van onafhankelijkheid van het bestuur.

Wat betreft het geval dat een minister, of in het algemeen het bestuur, bij de instelling van een gerecht of de samenstelling van een bepaald gerecht beoordelingsvrijheid heeft: teneinde te kunnen vaststellen of de onafhankelijkheid van de gerechten of de individuele rechters in het algemeen in het geding is, moet aan de hand van individuele zaken worden vastgesteld dat de praktijk in dit soort zaken als geheel onbevredigend is of dat tenminste de instelling van een bepaald gerecht of de benoeming van een bepaalde rechter beïnvloed is door onjuiste motieven. (Zand)

Voorts is de onafzetbaarheid ("irremovability") van rechters "a necessary corollary of their independence from the Administration". Dit betekent niet dat de rechter geen andere taken toebedeeld kan krijgen, maar wel dat hij niet aan enige autoriteit onderworpen is bij de uitoefening van zijn rechtsprekende functie. (zaken Zand en Sutter) Het feit dat onafzetbaarheid niet formeel erkend is in de wet betekent op zich niet een gebrek aan onafhankelijkheid indien de onafzetbaarheid feitelijk, in de praktijk, wel erkend wordt en aan de overige noodzakelijke voorwaarden wel voldaan is. (Campbell and Fell)

Alhoewel in de rechtspraak de benoeming voor een bepaalde vaste periode niet uitdrukkelijk als vereiste voor onafhankelijkheid van de rechter wordt genoemd, wordt dit vaak wel in de beoordeling van de onafhankelijkheid betrokken. (zaken Campbell and Fell, Sramek, Ettle a.o., Crociani a.o.)

Artikel 6 ziet bij uitstek op rechterlijke instanties die zijn ingesteld en samengesteld los van de zaken die zij moeten beoordelen. Gaat het bij uitzondering om rechterlijke instanties waarvan de instelling en samenstelling met betrekking tot een bepaalde zaak moet plaatsvinden, bijvoorbeeld bij arbitrage, dan geldt de voorwaarde dat er een strikte garantie van gelijkheid tussen de partijen moet zijn wat betreft de invloed die zij uitoefenen op de samenstelling van de desbetreffende instantie. (Bramelid and Malmström)

Een grote rol is in de rechtspraak van de Commissie en het Hof weggelegd voor de grondregel "justice must not only be done, but also be seen to be done". Deze grondregel brengt ten aanzien van de onafhankelijkheid van de rechter met zich, dat niet aan dit vereiste is voldaan indien men redelijkerwijs mag denken ("reasonably entitled ... to think") dat het rechterlijk orgaan in kwestie afhankelijk is van het bestuur of één van de partijen. (Campbell and Fell) Ofwel "appearances may also be of importance". Zo is twijfel aan de onafhankelijkheid van een gerecht of een 
lid daarvan gelegitimeerd indien dit lid zich - qua taak en wat betreft de organisatie van de dienst waarbinnen hij werkzaam is - in een ondergeschikte positie tegenover één van de partijen bevindt. (Srameḱ) Maar ook wanneer geen sprake is van ondergeschiktheid aan of het ontvangen van instructies van - één van de partijen - door een lid van het rechterlijke orgaan, dan is dit nog geen voldoende garantie voor de volledige onafhankelijkheid van het orgaan. Volgens de Commissie dient sprake te zijn van een voldoende organisatorische scheiding tussen het "tribunal" en het bestuur $c . q$. de partijen bij een zaak. Van een voldoende organisatorische scheiding is geen sprake, indien de leden van het gerecht (of één of enkele daarvan) weliswaar in de uitoefening van hun rechtsprekende taak niet onder instructie of in hiërarchisch ondergeschikte positie staan van het bestuur of de partijen, maar wel ten aanzien van andere, nauw hiermee verbonden - functies. Ook is een hiërarchische verhouding (buiten het rechterlijk orgaan) tussen de leden van dit orgaan onderling niet acceptabel. (Ettle a.o.)

Indien de vaststelling van de aanklacht tegen een persoon en daarmee de bevoegdheid van een rechterlijk orgaan in een bepaalde zaak is overgelaten aan het parlement, zoals bij bepaalde ambtsmisdrijven, dan dient het orgaan in kwestie ook onafhankelijk van het parlement te zijn. (Crociani a.o.)

In een aantal van de eerder besproken zaken worden de onafhankelijkheid en de onpartijdigheid van de rechter tegelijk behandeld. Ook wordt met betrekking tot de onafhankelijkheid een aantal keren gebruik gemaakt van redeneringen die eerder waren gehanteerd in het kader van de onpartijdigheid. Dit geeft al aan dat de onafhankelijkheid en de onpartijdigheid van de rechter twee begrippen zijn, die nauw met elkaar in verband staan. Sterker nog, in haar rapport in de zaak Bramelid and Malmström constateert de Commissie dat

"... there is a functional relationship between independence and impartiality, the former being essentially a precondition of the latter. ${ }^{\text {167 }}$

167 Rapp.Cornm. 12 december 1983, Case of Bramelid and Malmström, §33, p. 39. Het Hof heeft ook in een aantal uitspraken aangegeven dat het het moeilijk of onnodig vindt on de kwesties van de onafhankelijkheid en onpartijdigheid afzonderlijk te onderzoeken. Zie EHRM 25 november 1993, Holm Case, $\$ 30$, p. 14 en EHRM 22. september 1994, Debled Case, \$36, p. 43. 
Dit zou betekenen, dat in het geval het onafhankelijkheidsvereiste niet vervuld wordt, ook aan de eis van onpartijdigheid van de rechter niet voldaan kan worden.

Hoe dan ook, in het navolgende zal op de onpartijdigheid ingegaan worden.

\subsubsection{Impartial}

Ten aanzien van de garantie van de onpartijdigheid van de rechter heeft de Commissie in de zaak Piersack bepaald, dat de inhoud en de reikwijdte van deze waarborg onafhankelijk van het nationale recht kan worden gedefinieerd. ${ }^{168}$ Het nationale recht is derhalve niet beslissend voor de betekenis van het begrip "impartial".

Voorts moet, voordat overgegaan wordt tot de behandeling van het begrip "impartial", gewezen worden op het feit, dat het Hof ten aanzien van de onderhavige waarborg herhaaldelijk heeft uitgesproken, dat het de relevante nationale wetgeving en praktijk niet in abstracto toetst, maar vaststelt of de toepassing daarvan in het specifieke geval een schending van artikel 6 oplevert. ${ }^{169}$

In de zaak Le Compte, Van Leuven and De Meyere gaat het om de samenstelling van een beroepsraad ("Appeals Council"), een orgaan van de "Medical Association". Dit orgaan bestaat uit evenveel artsen als rechters en één van de rechters heeft een beslissende stem in geval van staking van de stemmen ("casting vote"). De Commissie meent dat de deelname van artsen in de beroepsraad niet noodzakelijkerwijs betekent dat dit orgaan partijdig is wanneer een disciplinaire klacht tegen een arts beoordeeld wordt. Echter, in dit geval betreft de klacht het gedrag van de klagers, dat ingegeven is door hun verzet tegen de "Medical Association" in het algemeen en de verplichting tot lidmaatschap van deze organisatie in het bijzonder. De medische leden van de "Appeals Council" hadden derhalve belangen die nauw verwant waren aan die van één van de partijen bij die procedure: de "Medical Association". In verband met de grondregel "justice must not only be done, it must also be seen to be done" komt de Commissie tot de constatering, dat in een dergelijk geval niet automatisch gesteld kan worden dat de "Appeals Council" onpartijdig is. De

168 Rapp.Comm. 13 mei 1981, Piersack Case, \$49, p. 24.

169 EHRM 24 mei 1989, Hauschildt Case, \$45, p. 21. Zo ook EHRM 27 augustus 1991, Demicoli Case, §39, p. 18; EHRM 25 juni 1992, Thorgeir Thorgeirson Case, §48, p. 23; EHRM 24 februari 1993, Fey Case, \$27, p. 12 en EHRM 26 februari 1993, Padovani Case, §24, p. 20. 
Commissie vervolgt met de opmerking dat de vertegenwoordiging van één van de partijen in de procedure in het orgaan dat de voorliggende zaak moet beslissen, niet altijd wijst op partijdigheid. In geval van een arhitrage-instantie benoemen de partijen vaak hun vertegenwoordigers in deze instantie. Echter, om te kunnen spreken van een "independent tribunal"

"... the different interests involved must be equally represented in that organ".

$\mathrm{Nu}$ de medische leden van de "Appeals Council" in de specifieke omstandigheden van deze zaak geacht moet worden een ongunstige visie ten aanzien van de klagers te hebben en aangezien de juridische leden als neutraal beschouwd moeten worden,

"the composition of the appeal council seems, as a whole, to be partial and unfavourable to the applicants."

Om die reden is, volgens de Commissie, de "Appeals Council" geen "impartial tribunal". ${ }^{10}$

Het Hof is het niet met de uitspraak van de Commissie eens. Volgens het Hof biedt de aanwezigheid van rechters - de helft van het aantal leden van de "Appeals Council" - waarvan één beschikt over een "casting vote", een zekere garantie ("a definite assurance") van onpartijdigheid."

In haar rapport in de zaak Albert and Le Compte spreekt de Commissie haar twijfels uit over deze uitspraak van het Hof. Zij wijst in dit verband opnieuw op de grondregel "justice must not only be done, it must also be seen to be done". De Commissie vult dit aan met een andere grondregel: "A judge must be impartial. It is also his duty to give no one any reason to doubt his impartiality". " $\mathrm{Zij}$ voegt hier echter aan toe, dat Le Compte

170 Rapp.Comm. 14 december 1979. Case of Le Compte, Van Leuven and De Meyere, $\$ \$ 78-80$, p. 41.

171. EHRM 23 juni 1981, Le Compte, Van Leuven and De Meyere, \$58, p. 25. Ook de wijze van verkiezing van de medische leden van de "Áppeals Council" - door de "Provincial Council", ook een orgaan van de "Medical Association, uit antsen die geen lid zijn van deze provinciale raad - "cannot suffice to bear out a charge of bias".

172 De Commissie ontleent dit adagium aan W. Ganshof van der Meersch, Réflexions sur l'art de juger et l'exercice de la fonction judiciaire, in: Journal des tribunaux, jaargang 1973, pp. 509 e.v.. 
weliswaar zijn bezwaren heeft geuit ten aanzien van de beroepsraad in zijn geheel, maar

"did not specifically challenge the members individually on the ground of bias."

De Commissie is van mening, dat zelfs wanneer bepaalde twijfel bestaat an een rechterlijk orgaan als geheel, er bij afwezigheid van specifieke klachten tegen individuele leden van dit orgaan, geen reden is voor de conclusie dat de leden van dit orgaan persoonlijk bevooroordeeld zijn. ${ }^{173}$ Deze opvatting van de Commissie steunt op de uitspraak van het Hof in de zaak Le Compte, Van Leuven and De Meyere, dat

"... the personal impartiality of each member must be presumed until there is proof to the contrary. "174

Een belangrijke zaak in de jurisprudentie met betrekking tot het begrip "impartial" is de zaak Piersack. In deze zaak gaat het om het feit, dat de officier van justitie in dit geval een ondergeschikte was van Mr.A., een "senior deputy public prosecutor", die later als President optrad van het Assize Court dat de zaak van de klager moest beoordelen.

Het Hof bepaalt in deze zaak, dat "(w)hilst impartiality normally denotes absence of prejudice and bias, its existence or otherwise can, notably under Article $6 \S 1$ of the Convention, be tested in various ways."

De eerste methode waarop het Hof doelt is de zogenaamde "subjective approach", waarbij gepoogd wordt de persoonlijke overtuiging van een bepaalde rechter in een bepaalde zaak te verifiëren. De tweede methode is de "objective approach, waarbij wordt vastgesteld of deze rechter voldoende garanties bood om enige legitieme twijfel in dit opzicht uit te sluiten. ${ }^{175}$

173 Rapp.Comm. 14 december 1981, Case of Albert and Le Compte, \$75, pp. 39-40.

174 EHRM 23 juni 1981, Le Compte, Van Leuven and De Meyere, \$58, p. 25. Zie ook EHRM 28 juni 1984, Case of Campbell and Fell, §84, p. 41; EHRM 26 oktober 1984, De Cubber Case. \$25, p. 14; EHRM 24 mei 1989, Hauschildt Case, \$47, p. 21; EHRM 25 juni 1992, Thorgeir Thorgeirson Case, \$50, p. 23; EHRM 26 februari 1993, Padovani Case, §26, p. 20 en EHRM 22 september 1994, Debled Case, \$37, p. 43 en Rapp.Comm. 5 juli 1983, De Cubber Case, \$63, p. 22 en Rapp.Comm. 12 december 1983, Case of Bramelid and Malmström, $\$ 34$, p. 39.

175 EHRM 1 oktober 1982, Piersack Case, \$30, p. 14. Zie ook EHRM 26 oktober 1984 , De Cubber Case, \$24. pp. 13-14: EHRM 24 mei 1989. Hauschildt Case. §46, p. 21; EHRM 27 augustus 1991, Demicoli Case, §40, p. 18; EHRM 25 juni 1992, Thorgeir Thorgeirson Case, $\$ 49$, p. 23; EHRM 24 februari 1993, Fey Case, §28, p. 12; 
In deze zaak wordt de persoonlijke onpartijdigheid van de President van het "Assize Court" niet door de klager in twijfel getrokken en het Hof gaat er dan ook van uit dat "personal impartiality is to be presumed until there is proof to the contrary". Maar volgens het Hof kan men zich niet beperken tot een zuiver subjectieve test. Op dit terrein "even appearances may be of a certain importance." Het Hof bevestigt dan ook de opvatting van het Belgische Hof van Cassatie, dat elke rechter ten aanzien van wie er een legitieme reden is om te vrezen voor een gebrek aan onpartijdigheid, zich terug moet trekken.

"What is at stake is the confidence which the courts must inspire in the public in a democratic society. "i76

Wanneer is nu sprake van een legitieme reden om te vrezen voor een gebrek aan onpartijdigheid? In dit opzicht moet volgens het Hof ook rekening gehouden worden met kwesties van interne organisatie. Indien een persoon, na een positie te hebben gehad bij het openbaar ministerie waarvan de aard is dat hij in de uitoefening van zijn taken een bepaalde zaak moet behandelen, later in dezelfde zaak rechter is, dan is men gerechtigd te vrezen dat hij niet voldoende garanties voor onpartijdigheid biedt. Het is hierbij niet van belang of de klager zich van al deze feiten op het relevante tijdstip bewust was of niet. Ook is het niet noodzakelijk de exacte omvang van de rol van betreffende rechter vast te stellen. Het is volgens het Hof voldoende, dat

"the impartiality of the 'tribunal' which had to determine the merits of the charge was capable of appearing open to doubt. "in

EHRM 26 februari 1993, Padowani Case, $\$ 25$, p. 20 en EHRM 22 april 1994, Case of Saraiva de Carvalho, \$33, p. 38 en Rapp.Comm. 5 juli 1983, De Cubber Case, \$62. p. 22 en Rapp.Comn. 11 december 1990. Thorgeir Thorgeirson Case, \$57, p. 35 .

176 EHRM I oktober 1982. Piersack Case, \$30(a), p. 14. Zie ook EHRM 28 juni 1984 , Case of Campbell and Fell, \$85. p. 41: EHRM 26 oktober 1984, De Cubber Case, \$26, p. 14: EHRM 24 mei 1989. Hauschildt Case, \$48. p. 21; EHRM 25 juni 1992. Thorgeir Thorgeirson Case, \$\$50-51, p. 23 en EHRM 22 april 1992, Case of Saraiva de Carvalho, $\$ 35$, p. 38 en Rapp.Comm. 5 juli 1983, De Cubber Case, $\$ 64$, p. 22 en Rapp.Comm. 11 decenber 1990. Thorgeir Thorgeirson Case, \$57, p. 35. In de De Cubber zaak breidt het Hof dit laatste citaat uit met: "... and above all, as far as criminal proceedings are concerned, in the accused. "Zo ook EHRM 24 februari 1993, Fey Case, $\$ 30$, p. 12 en EHRM 26 februari 1993, Padovani Case, $\$ 27$, p. 20.

177 EHRM I okiober 1982. Piersack Case. $\$ \$ 30$ (d)-31, pp. 15-16. Zie ook EHRM 10 februari 1983, Case of Albert and Le Compte. \$32. pp. 17-18 en EHRM 29 april 1988, Belilos Case, $\$ 67$, p. 30. 
In de De Cubber-zaak gaat het om het feit, dat de functies van "investigating judge" en "trial judge" door dezelfde persoon in éen bepaalde zaak werden uitgeoefend. Hoewel de onderzoeksrechter onafhankelijk van het Openbaar Ministerie opereerde en geen mening over de schuldvraag uitsprak, is dit volgens het Hof niet beslissend voor de vraag of sprake was van onpartijdigheid. Er zijn verschillende factoren die op het tegendeel wijzen.

Zo zijn de wettelijke verschillen tussen officieren van justitie ("judicial officers") in het Openbaar Ministerie en de onderzoeksrechters minder duidelijk dan ze aanvankelijk leken. Zo heeft een onderzoeksrechter vergaande bevoegdheden zoals in casu het bevelen van de arrestatie van de klager. Welke maatregelen de onderzoeksrechter verder nog genomen heeft blijkt niet uit de zaak, maar volgens het Hof moeten ze - gezien de complexiteit van de zaak en de duur van het vooronderzoek - zeer uitgebreid zijn geweest. Voorts is het vooronderzoek naar Belgisch recht geheim en vindt niet plaats in de aanwezigheid van de partijen. Volgens het Hof is het begrijpelijk, dat de verdachte zich ongemakkelijk voelt ("feel some unease") indien hij de onderzoeksrechter die zijn bewaring heeft bevolen en die hem meermalen tijdens het vooronderzoek heeft verhoord, in het gerecht dat zijn zaak moet beoordelen terugziet.

Bovendien zal de onderzoeksrechter vanwege de verschillende methoden van onderzoek die hij tijdens het vooronderzoek heeft aangewend, anders dan zijn collega's al voor de zitting een tamelijk gedetailleerde kennis hebben van de dossier die hij heeft aangelegd.

"Consequently, it is quite conceivable that he might, in the eyes of the accused, appear, firstly, to be in a position enabling him to play a crucial role in the trial court and, secondly, even to have a pre-formed opinion which is liable to weigh heavily in the balance at the moment of the decision." 178

Op grond van deze en andere overwegingen komt het Hof tot de conclusie dat de desbetreffende rechterlijke instantie

"... was capable of appearing to the applicant to be open to doubt. Although the Court itself has no reason to doubt the impartiality of the member of the judiciary who had conducted the preliminary investigation, it recognises, having regard to the various factors 
AFBAKENING: JURISPRUDENTIE NAAR AANLEIDING VAN ART. 6 ECRM

discussed above, that his presence on the bench provided grounds for some legitimate misgivings on the applicant's part."

Het Hof voegt hier nog aan toe, dat een restrictieve interpretatie van article $6 \$ 1$, met name ten aanzien van het fundamentele beginsel van onpartijdigheid, niet in overeenstemming met het voorwerp en doel van deze bepaling zou zijn,

$"$ "... bearing in mind the prominent place which the right to a fair trial holds in a democratic society within the meaning of the Convention." 179

Overigens zijn de overwegingen uit de zaken Piersack en De Cubber ten aanzien van de objectieve test - dat het gaat om "the confidence which the courts in a democratic society must inspire in the public and above all, as far as criminal proceedings are concerned, in the accused" en dat elke rechter ten aanzien van wie er een legitieme reden tot vrees bestaat dat hij niet onpartijdig is, zich terug moet trekken - door het Hof in de Hauschildt-zaak enigszins ingeperkt. Wanneer er in een bepaalde zaak een legitieme reden is om te vrezen dat een bepaalde rechter niet onpartijdig is, is het standpunt van de verdachte belangrijk maar niet beslissend. Wél beslissend is of deze vrees objectief gerechtvaardigd is. ${ }^{180}$

In deze zaak gaat het om rechters die al in een eerder stadium van de procedure in deze zaak betrokken zijn geweest en al diverse beslissingen ten aanzien van de klager hebben genomen in de fase die aan het onderzoek ter terechtzitting vooraf gaat ("at a pre-trial stage"). Dit soort situaties kan volgens Hof tot grieven aan de zijde van de verdachte leiden met betrekking tot de onpartijdigheid van de rechter. Deze grieven zijn begrijpelijk, maar kunnen desalniettemin niet noodzakelijkerwijs als objectief gerechtvaardigd beschouwd worden. Of ze dit zijn hangt af van de specifieke omstandigheden van het geval. ${ }^{\text {is: }}$

In dit geval kenmerkte de rol van de rechters, tijdens fase voorafgaand aan het onderzoek ter terechtzitting, zich als een rol van een onafhankelijke

179 EHRM 26 oktoher 1984. De Cubber Case. $\$ 30$, p. 16.

180 EHRM 24 mei 1989. Hauschild Case. \$48, p. 21. Zie ook EHRM 25 juni 1992. Thorgeir Thorgeirson Case, \$51, p. 23: EHRM 24 februari 1993. Fey Case. \$30. p. 12; EHRM 26 februari 1993. Padovani Case, \$27, p. 20; EHRM 24 augusus 1993. Nortier Case \$33, p. 15 en EHRM 22 april 1994. Case of Saraiva de Carvalho, $\$ 35$, p. 38 en Rapp.Comm. 11 december 1990, Thorgeir Thorgeirson Case, $\$ 57$, p. 35.

181 EHRM 24 mei 1989, Hauschild Case, \$49, p. 21. 
rechter die niet verantwoordelijk is voor de voorbereiding van de zaak voor de terechtzitting of voor de beslissing of de verdachte berecht moet worden. De beslissingen in kwestie betroffen onder andere verzoeken van de politie tot verlenging van de bewaring en tot eenzame opsluiting, die de klager kon betwisten. De verhoren naar aanleiding van deze verzoeken werden in het openbaar gehouden. De aard van de functies die derhalve door de rechters werden uitgeoefend voordat het onderzoek ter terechtzitting aanving, waren daarom anders dan in de gevallen van Piersack en De Cubber. Het Hof komt dan ook tot de conclusie dat

"... the mere fact that a trial judge or an appeal judge, in a system like the Danish, has also made pre-trial decisions in the case, including those concerning detention on remand, cannot be held as in itself justifying fears as to his impartiality. "182

Het Hof voegt hier nog wel aan toe, dat speciale omstandigheden in een zaak tot een andere conclusie kunnen leiden. ${ }^{183}$ Dit is in de zaak Hauschild het geval. De verschillen tussen de beslissingen die de rechters in de fase voor het onderzoek ter terechtzitting moesten geven en de beslissingen die tijdens dit onderzoek werden genomen, zijn namelijk vaag. In het eerste geval moest de rechter namelijk vaststellen of er een hoge mate van duidelijkheid bestond ten aanzien van de schuld. Uiteindelijk komt het Hof dan ook tot de conclusie, dat onder de omstandigheden van het geval de onpartijdigheid van de desbetreffende rechterlijke orgaan "was capable of appearing to be open to doubt and that the applicant's fears in this respect can be considered objectively justified. "184

Gaat het in de zaak Hauschildt om een rechtsstelsel "where investigation and prosecution are exclusively the domain of the police and the prosecution", ook in stelsels "of an inquisitorial character", zoals het Oostenrijkse hebben de voorgaande overwegingen volgens het Hof in de zaak Fey enige relevantie. Onder verwijzing naar, onder meer, de zaak $D e$ Cubber stelt het Hof in de zaak Fey vast dat

182 EHRM 24 mei 1989, Hauschildt Case. \$50, p. 22. Zo ook o.a. EHRM 24 februari 1993, Fey Case, $\$ 30$, p. 12.

183 Zo ook EHRM 22 april 1994, Care of Saraiva de Carvalho, \$39, p. 39.

184 EHRM 24 mei 1989, Hauschildt Case, \$\$51-52, pp. 22-23. Zie ook EHRM 27 augustus 1991, Demicoli Case, $\$ 41$, p. 18. 
382 AFBAKENING: JURISPRUDENTIE NAAR AANLEIDING VAN ART. 6 ECRM

"What matters is the extent and nature of the pre-trial measures taken by the judge." ${ }^{\text {Iss }}$

In deze zaak gaat het om een verzoek om rechtshulp van het "Landesgericht" van Innsbruck aan het "Bezirksgericht" van Zell am Ziller teneinde een getuige te doen ondervragen. Dezelfde rechter die naar aanleiding van dit verzoek de betrokken getuige ondervraagt, doet uiteindelijk ook uitspraak ten aanzien van de schuld van verdachte, nadat de zaak - om redenen van jurisdictie - is verwezen naar laatstgenoend "Bezirksgericht". De enige andere beslissing die deze rechter in de zaak heeft genomen, voorafgaande aan de terechtzitting, is die met betrekking tot de vaststelling van de datum van de hoorzitting. Aangaande de reikwijdte en aard van de beslissingen van de betrokken rechter overweegt het Hof dat de ondervraging niet inhield dat de rechter ten tijde van het vooronderzoek de merites van de beschuldigingen tegen klager zou moeten onderzoeken; ook daadwerkelijk heeft de rechter dit niet gedaan en er is ook geen aanwijzing dat het ten tijde van de ondervraging reeds voorzienbaar was dat deze rechter naderhand de zaak zou berechten. Ook uit de beslissing inzake de vaststelling van de datum van de hoorzitting bleek geen overtuiging aan de zijde van de rechter "that there was a likelihood that he was guilty". Volgens het Hof was de betrokken rechter pas in de positie om zich een mening te vormen aangaande klager's schuld nadat deze hoorzitting was aangevangen.

"It does not appear that the various measures which she had taken prior to the trial were such as could have led her to reach a preconceived view on the merits. "186

Het Hof concludeert ten aanzien van de "extent and nature of the pre-trial measures" dat deze dan ook duidelijk te onderscheiden zijn van die in de zaak De Cubber omdat in die zaak één van de rechters als onderzoeksrechter uitgebreid onderzoek in de zaak had verricht, waaronder het verscheidene malen verhoren van de verdachte. In de zaak Fey was dit niet het geval. ${ }^{187}$

185 EHRM 24 februari 1993, Fey Case, \$30, p. 12. Zie ook EHRM 24 augustus 1993. Nortier Case. \$33, p. 15 en EHRM 22 april 1994. Case of Saraiva de Carvalho, \$3. p. 38.

186 EHRM 24 februari 1993, Fey Case, \$34, p. 13.

187 EHRM 24 februari 1993, Fey Case, \$35, pp. 13-14. 
Soortgelijke overwegingen als in de zaak Fey zijn ook terug te vinden in de zaak Nortier. In deze zaak gaat het om een kinderrechter die, onder andere, beslissingen heeft genomen met betrekking tot de voorlopige hechtenis van de verdachte. Van zijn bevoegdheden ten aanzien van het gerechtelijk vooronderzoek maakt deze rechter geen ander gebruik dan het bevelen van een psychiatrisch onderzoek van de verdachte. De reikwijdte en de aard van deze beslissingen zijn zodanig, dat de vragen die de betrokken rechter "had to answer ... were not the same as those which were decisive for his final judgment". ${ }^{188}$

Dat onder bepaalde omstandigheden de subjectieve test geheel achterwege gelaten kan worden blijkt uit de zaak Pfeifer and Plankl. Zoals al eerder is aangegeven, betreft het hier rechters die zich vanwege hun eerdere rol als onderzoeksrechter ingevolge het nationale recht van de deze zaak hadden moeten verschonen. Volgens de Commissie is de objectieve test onder meer terug te vinden in de desbetreffende nationale wetsbepalingen die een rechter uitsluiten van het uitoefenen van bepaalde functies: "they manifest the law-makers' 'concern to make ... courts free of any legitimate suspicion of partiality'." Treden rechters ondanks hun diskwalificatie door het nationale recht toch op, dan ontbreekt hun onpartijdigheid in de zin van artikel 6 lid 1. Volgens de Commissie

"(i)t is irrelevant in this context whether, subjectively, the two judges concerned actually had pre-formed opinions concerning the case as the first applicant claims. "189

Deze uitspraak is door het Hof bevestigd. Volgens het Hof betekent nietnaleving van de desbetreffende wetgeving, dat

"... Mr Pfeifer was tried by a court whose impartiality was recognised by national law itself to be open to doubt. In this respect, it is unnecessary to define the precise role played by the judges in question during the investigative stage. "190

188 EHRM 24 augustus 1993, Nortier Case, \$35, p. 16. Vergelijk EHRM 22 april 1994, Case of Saraiva de Carvalho, $\$ 39$, p. 39.

189 Rapp.Comm. 11 oktober 1990, Case of Pfeifer and Plankl, §§83-85, pp. 27-28.

190 EHRM 25 februari 1992, Case of Pfeifer and Plankl, §36, p. 16. Zo ook EHRM 23 mei 1991, Oberschlick Case, §50, p. 23. 
Ervan uitgaande dat het begrip "impartial tribunal" ziet op de afwezigheid van "prejudice and bias" bij (de leden van) de desbetreffende rechterlijke instantie (Piersack), toont de jurisprudentie met betrekking tot dit begrip, samengevat, het volgende beeld.

Evenals bij de onafhankelijkheid van de rechter, wordt door de Commissie ook ten aanzien van de onpartijdigheid gesteld, dat indien de partijen in het rechterlijk orgaan in kwestie zijn vertegenwoordigd of invloed hebben op de samenstelling van het orgaan, zoals bij arbitrage, de verschillende belangen van de partijen gelijkelijk in dit orgaan moeten zijn vertegenwoordigd. (Le Compte e.a.)

Echter, bij twijfel aan de onpartijdigheid van een rechterlijke instantie, moet de klager bewijs ten aanzien van de partijdigheid van de individuele leden aandragen, want de persoonlijke onpartijdigheid van de rechter wordi verondersteld totdat er bewijs is van het tegendeel. (Le Compte e. a.; Alben and Le Compte) Het gaat hier om wat in de zaak Piersack de subjectieve benadering of test genoemd wordt, die het Hof omschrijft als het verifiëren van de persoonlijke overtuiging van een bepaalde rechter in een bepaalde zaak. Daarnaast staat de objectieve benadering, volgens welke vastgesteld wordt of de betrokken rechter voldoende garanties biedt om enige twijfel aan zijn onpartijdigheid uit te sluiten.

Net als ten aanzien van de onafhankelijkheid, stelt het Hof ook ten aanzien van de onpartijdigheid dat "even appearances may be of a certain importance". In verband daarmee kan opnieuw verwezen worden naar de grondregel "justice must not only be done, it must also be seen to be done". De schijn kan derhalve een rol spelen. Volgens de jurisprudentie kan hier met name de interne organisatie van het rechterlijk bedrijf van belang zijn. (Piersack, De Cubber)

Wanneer ten aanzien van een bepaalde rechter een legitieme reden bestaat om een gebrek aan onpartijdigheid te vrezen, dan moet hij zich van een zaak terugtrekken. Dit komt omdat in een democratische samenleving de rechterlijke instanties een zeker vertrouwen van het publiek en in strafzaken met name van verdachten moeten genieten ("the confidence the courts must inspire in the public ... and in the accused ..."). (Piersack. De Cubber) Bij de vraag of er een legitieme reden is om een gebrek aan onpartijdigheid bij een rechter te vrezen is het standpunt van de verdachte weliswaar belangrijk. maar niet beslissend. De vrees moet objectief gerechtvaardigd zijn. Of dit zo is hangt af van de specifieke omstandigheden van het geval. (Hauschildt)

De jurisprudentie lijkt erop te wijzen dat een vrees objectief gerechtvaardigd zal kunnen zijn, indien een bepaalde rechter eerder in de procedure betrokken is geweest in een functie die niet met waarborgen zoals onafhankelijkheid, onpartijdigheid en openbaarheid is ongeven. 
Bovendien lijkt een rol te spelen of de betrokken rechter in die eerdere functie moest beslissen over punten die overeenkomen met kwesties waarover hij als rechter moet oordelen, zoals de schuldvraag. (Hauschildt, Demicoli)

Tenslotte kan de subjectieve test achterwege blijven wanneer reeds volgens de objectieve test blijkt, dat een bepaalde rechter reeds door de nationale wetgeving is uitgesloten om over een bepaalde zaak te oordelen. De nationale wetgeving geeft dan zelf reeds aan dat in dat geval (legitieme) twijfel bestaat aan de onpartijdigheid van deze rechter. Of de betrokken rechter werkelijk bevooroordeeld is ten aanzien van de desbetreffende zaak is niet van belang. (Pfeifer and Plankl)

De voorgaande paragrafen bevatten een bespreking van de Straatsburgse rechtspraak ten aanzien van het recht op "access to court", zowel wat betreft de "access" als met betrekking tot het begrip "court". In de navolgende paragrafen komt de Nederlandse jurisprudentie ten aanzien van dit recht aan de orde. Daarna zal in paragraaf 6.3 de Straatsburgse en Nederlandse jurisprudentie ten aanzien van het recht op "access to court" geêvalueerd worden.

\subsection{De rechtspraak van de Nederlandse rechterlijke instanties met betrekking tot artikel 6 lid 1 (eerste zin) ECRM}

De Nederlandse rechtspraak met betrekking tot het uit artikel 6 lid 1 ECRM afgeleide recht op toegang tot de rechter zal in deze paragraaf besproken worden. ${ }^{191}$ Bekeken zal worden of de Nederlandse rechterlijke instanties criteria ontwikkeld hebben ter afbakening van dit recht en zo ja, of deze criteria overeenstemmen met de criteria die in Straatsburg zijn geformuleerd.

Zoals in het navolgende zal blijken, is de rechtspraak ten aanzien van het recht op toegang zeer verbrokkeld. Met name ten aanzien van de grondslag van het recht op toegang ontbreken rechterlijke uitspraken. Toch zal getracht worden zoveel mogelijk de volgorde van behandeling van het recht op toegang tot de rechter aan te houden, die ook bij de bespreking van de Straatsburgse rechtspraak gevolgd werd. Dat wil zeggen, dat - bij

191 Een aantal van de te bespreken uitspraken betreft wetgeving die inmiddels vervalien is of rechtsgangen die niet meer bestaan, al dan niet tengevolge van de inwerkingtreding van de Algemene Wet Bestuursrecht op 1 januari 1994. Aangezien het hier gaat on de interpretatie van artikel 6 ECRM en niet zozeer om een beoordeling van de zojuist bedoelde wetgeving of rechtsgangen, blijft deze rechtspraak relevant. 
gebrek aan rechtspraak ten aanzien van de basis van het recht op toegang eerst $\mathrm{zal}$ worden ingegaan op de reikwijdte van het recht aan de hand van de beperkingsmogelijkheden, afstand van recht en positieve verplichtingen. Vervolgens zal worden ingegaan op het begrip "rechter", dat wil zeggen "een onafhankelijk en onpartijdig gerecht dat bij de wet is ingesteld".

\subsubsection{De reikwijdte van het recht op toegang}

\subsubsection{Beperkingen}

\section{Beperkingen gesteld aan de rechtsmacht van de rechter}

In een arrest van de Hoge Raad van 14 april 1980 gaat het om een verdachte van een verkeersovertreding, die door de kantonrechter was veroordeeld tot een boete van 50 gulden zonder dat hem overeenkomstig artikel 311 lid 4 Wetboek van Strafvordering (Sv) het recht was gelaten om als laatste het woord te voeren. ${ }^{192}$ Op grond van de artikelen 44 en 101 Wet op de Rechterlijke Organisatie (Ro) is het voor de verdachte niet mogelijk om tegen dit vonnis van de kantonrechter in hoger beroep of in cassatie te gaan. Dit levert volgens hem een schending van het in artikel 6 ECRM neergelegde recht op "fair trial" op. De Hoge Raad wijst het beroep op artikel 6 af. Volgens de Hoge Raad bevat de Conventie geen "voor rechtstreekse toepassing door de rechter vatbare bepaling ... waarbij aan de rechterlijke macht der onderscheiden verdragsstaten een grotere rechtsmacht wordt verleend dan de nationale wet haar toekent ...". Dit is juist. Ondanks het ontbreken van een verplichting in de Conventie tot het instellen van hoger beroep en cassatie-procedures, worden in de artikelen 44 en 101 Ro mogelijkheden tot hoger beroep en cassatie geopend. Echter, deze mogelijkheden zijn tot een aantal soorten zaken en cassatie-gronden beperkt. De jurisdictie van de beroeps-instanties en de Hoge Raad in cassatie is derhalve begrensd. Zoals we zagen bij de bespreking van de uitspraken van de Europese Commissie ten aanzien van de jurisdictie van rechterlijke instanties, betekent het recht op toegang niet dat altijd een uitspraak over de merites van de zaak moet worden gedaan, noch dat rechters zich niet onbevoegd kunnen verklaren of dat de uitoefening van het recht op toegang onvoorwaardelijk moet zijn. ${ }^{193}$ Volgens de Europese jurisprudentie mag de beperking van de rechtsmacht van een gerecht niet de kern van het recht op toegang tot de rechter aantasten, moet zij gericht

192 HR 14 april 1980. NJ 1981, 401 met noot Th.W. van Veen.

193 Zie p. 327, en Rapp.Comm. 1 juni 1973, Golder Case. $\$ 58$, p. 40. 
zijn op een legitiem doel en moet er sprake zijn van een redelijke mate van proportionaliteit tussen de beperking en het beoogde doel. Bovendien moet de regeling waarin de beperking is vervat coherent en duidelijk zijn. Alhoewel de beperking van de rechtsmacht van de hoger beroeps- en cassatie-instanties in de artikelen 44 en 101 Ro mijns inziens met deze criteria in overeenstemming is, stelt de Hoge Raad in de onderhavige zaak geen vergelijkbare criteria vast. De Hoge Raad beperkt zich tot de vaststelling dat op grond van de Conventie aan de rechterlijke macht geen grotere rechtsmacht wordt verleend dan haar door de nationale wet is toegekend.

Hoewel de vraag of artikel 6 de rechter verplicht zijn uitspraken te motiveren in de Straatsburgse jurisprudentie alleen aan de orde is gekomen in verband met het recht op een "fair hearing" ${ }^{\text {"194 }}$, zal er hier toch kort op ingegaan worden. In een uitspraak van de Hoge Raad van 1989 gaat het namelijk om de toegang tot de rechter in hoger beroep vanwege het schenden van de motiveringsplicht. ${ }^{195}$ Deze zaak betreft een beschikking van de kantonrechter om een arbeidsovereenkomst te ontbinden, waartegen geen hoger beroep openstaat. Volgens de Hoge Raad kan het hoger beroep toch ontvankelijk zijn op grond van een klacht betreffende verzuim van essentiële vormen bij de totstandkoming van de beschikking, maar alleen in het geval dat "aan die klacht ten grondslag ligt dat een zo fundamenteel rechtsbeginsel is veronachtzaamd dat van een eerlijke en onpartijdige behandeling van de zaak niet meer kan worden gesproken." Volgens de Hoge Raad is hiervan geen sprake in het geval van een klacht dat de motiveringsplicht is geschonden. ${ }^{1 \%}$ De Hoge Raad meent dat artikel 6 niet tot een ander opvatting noopt en bepaalt dat de Rechtbank terecht het hoger beroep niet-ontvankelijk heeft verklaard.

De uitkomst van deze zaak is mijns inziens juist. Artikel 6 verplicht staten niet tot het openen van de mogelijkheid van hoger beroep. Dit is in navolging van de Straatsburgse instanties, herhaaldelijk door de

194 Zie o.a. Besl.Comm. 17 januari 1963, zaak nr. 1035/61, X v. FRG, p. 18; Besl.Comm. 2 april 1973, zaak nr. 5460/72, Firestone Tire and Rubber Co. v. UK, pp. 107-109; Besl.Comm. 2 oktober 1979, zaak nr. 8512/79, $X$ v. UK, niet gepubliceerd; Besl.Comm. 16 juli 1981, zaak nr. 8769/79, $X$ v. FRG, p. 241; en Besl.Comm. 18 mei 1984, zaak nr. 9982/82, X v. Belgium, niet gepubliceerd.

195 HR 3 juli 1989 , NJ 1989, 857.

196 De Hoge Raad baseert zich hierbij op HR 4 maan 1988, NJ 1989, 4. Zie ook HR 25 maart 1988, NJ 1989, 3, met noot WHH. Het voorgaande citaat is, al dan niet in dezelfde formulering, ook terug te vinden in HR 24 april 1992, NJ 1992, $672 \mathrm{met}$ noot $P A S$ en HR 8 januari 1993 , NJ 1993, 558 met noot $H J S$. 
Nederlandse rechters uitgesproken. ${ }^{197}$ De eerste instantie dient echter wel aan de eisen van artikel 6 te voldoen. Volgens de in noot 193 genoemde jurisprudentie vloeit uit het recht op een "fair hearing" een motiveringsplicht voort. Deze plicht is echter niet absoluut: de rechter hoeft geen redenen te geven voor de verwerping van alle punten van verweer. De Commissie heeft uitgesproken, dat de mate waarin op de rechter een motiveringsplicht rust, afhangt van de aard en de complexiteit van de desbetreffende zaak. ${ }^{198}$ In de onderhavige zaak betreft de klacht van schending van de motiveringsplicht - blijkens de uitspraken van de Rechtbank en de Hoge Raad - de veroordeling in de kosten van de procedure. Wellicht is dit een punt waarin minder strengere eisen aan de motivering kunnen worden gesteld. Mocht er desondanks geconcludeerd worden dat in eerste instantie sprake is geweest van een schending van artikel 6, dan moet dit - ter voorkoming van een klacht in Straatsburg kunnen worden gecorrigeerd. Daarom zou het raadzaam zijn hoger beroep toch toe te laten. ${ }^{199}$

In een uitspraak van de Afdeling Rechtspraak van de Raad van State van 29 juli 1980 gaat het om de vraag of de beperking van de bevoegdheid van de Raad van State op grond van artikel 34 lid 1, aanhef en onder b (-oud) Vreemdelingenwet verenigbaar is met, onder andere, artikel 6 lid 1 ECRM ${ }^{200}$ Volgens het tot 1 januari 194 geldende artikel 34 lid 1 is het beroep op de Afdeling Rechtspraak van de Raad van State, in het geval dat op een verzoek om herziening in overeenstemming met het advies van de Adviescommissie voor Vreemdelingenzaken geheel of ten dele afwijzend is beslist, beperkt tot diegene die op de dag waarop die beschikking wordt genomen sinds een jaar zijn hoofdverblijf in Nederland heeft. Volgens de Raad van State is deze beperking op de beroepsmogelijkheid bij de Afdeling Rechtspraak in overeenstemming met artikel 6 lid 1 ECRM.

197 Vergelijk de eerder besproken uitspraak van de Hoge Raad van 14 april 1980, N 1981, 401 met noot Th.W. van Veen en zie verder de zojuist genoemue uitspraak HR 24 april 1992: HR 18 november 1992, NJ 1993, 174; HR 3 mei 1989. NJ 1991, 167 met noot E.A. Alkema en in verband met "het gesloten systeem van rechtsmiddelen tegen rechterlijke beslissingen": Rb. Zutphen 14 december 1989. NJ 1991, 90; HR: 1 februari 1991, NJ 1991. 413 met noot Th.W. van Veen.

198 Zie Besi.Comm. 2 oktober 1979, zaak nr. 8512/79, X v. UK, niet gepubliceerd.

100 Vergelijk in dit verband ook de afwijzing van een beroep op (o.a.) arikel 6 in HR 26 januari 1990. NJ 1992, 602 met noot E.A. Alkema (m.n. punt 4. $2^{\circ}$ alinea).

200 ARRS 29 juli 1980, RV 1980, 46 met noot redactie: NJCM-Bulletin, jaargang 5-6 (1980), pp. 368-373 met noot A.H.J. Swart. Artikel 34(-oud) Vreendelingenwet is vervallen bij wet van 23 december 1993, Stb. 1993, 707 (inwerkingtreding 1 januari 1994). 
omdat er toch een beroepsgang op een onafhankelijke en onpartijdige rechter openstaat, namelijk de burgerlijke rechter. ${ }^{201}$

Zoals echter al bleek uit de bespreking van de jurisprudentie van de Europese Commissie ten aanzien van beperkingen op de rechtsmacht van gerechten, mogen deze beperkingen niet onredelijk of willekeurig zijn. Zouden deze beperkingen wel onredelijk of willekeurig zijn dan zou, in de termen van het Europese Hof, sprake kunnen zijn van het ontbreken van een legitiem doel van de beperking en zou derhalve artikel 6 geschonden zijn. Van onredelijkheid en willekeur zal sprake kunnen zijn indien er tussen de wèl - voor de van beroep op de Raad van State uitgesloten groep justitiabelen - openstaande beroepsgang op de burgerlijke rechter (een in principe onafhankelijk en onpartijdig gerecht) en het beroep op de Raad van State een voor de justitiabele nadelig verschil bestaat en hiervoor onvoldoende rechtvaardiging is. Swart wijst hierbij onder meer op het feit dat de administratieve rechter anders dan de burgerlijke, niet lijdelijk is. Bovendien zou volgens hem sprake kunnen zijn van verschillen in omvang van de rechtmatigheidstoetsing ${ }^{202}$ van overheidsbeslissingen. Maar zelfs al zouden de administratieve en burgerlijke rechter dezelfde toetsingsnormen hanteren, dan nog, aldus Swart, maakt de speciale deskundigheid van de administratieve rechter hem "tot de aangewezen instantie". ${ }^{203}$ Volgens Swart zijn de redenen die ten grondslag lagen aan deze ongelijke behandeling van rechtzoekenden die wèl en die niet aan de voorwaarden van artikel 34 lid 1 (b) (-oud) Vreemdelingenwet voldeden, niet steekhoudend. Welke deze redenen waren, vermeldt hij helaas niet, maar mocht hij gelijk hebben, dan kan de beperking van de rechtsmacht van de Raad van State in artikel 34 (-oud) Vreemdelingenwet willekeurig

201 Zo ook, eveneens door A.H.J. Swart geannoteerd, Gerechtshof 's-Gravenhage 16 april 1980, NJCM-Bulletin 5-6 (1980), pp. 368-373. Vergelijk het Schellen-en deuropenersarrest van de Hoge Raad van 22 februari 1957, NJ 1957, 310.

202 Om verwarring in terminologie te voorkomen geef ik hier aan wat ik - in dit onderzoek - onder bepaalde gebruikte termen versta:

volledige toetsing: doelmatigheids- èn rechtmatigheidstoetsing;

marginale toetsing: alleen rechtmatigheidstoetsing;

- doelmatigheidstoetsing: toetsing aan doelmatigheids/beleidsaspecten; in administratieve procedures waarin het gaat om opgelegde sancties, wordt in dit onderzoek ook wel gesproken van inhoudelijke toetsing: hierbij worden de feiten opnieuw door de rechter vastgesteld en wordt o.a. getoetst aan beginselen van straftoemeting;

- rechtmatigheidstoetsing: toetsing aan de wet en algemene beginselen van behoorlijk bestuur.

203 Annotatie bij Gerechtshof 's-Gravenhage 16 april 1980, NJCM-Bulletin 5-6, en ARRS 29 juli 1980, RV 1980, 46, p. 371. 
genoemd worden en ontbrak een legitiem doel voor die beperking. In dat geval was er sprake van schending van artikel 6 ECRM.

Tot een vergelijkbare uitspraak als in de vorige zaak, komt de Vooritter van de Afdeling Rechtspraak van de Raad van State op 10 mei 1988. Op grond van artikel 30c lid 1(c) van de herziene Wet op de Kansspelen kan de gemeenteraad een verordening vaststellen waaraan de burgemeester de bevoegdheid kan ontlenen om vergunningen te verlenen voor het "aanwezig hebben" van speelautomaten. Op grond van artikel V van de Wet van 13 november 1985 (Stb. 600) expireren vergunningen die verleend zijn op basis van de oude Wet op de Kansspelen uiterlijk 24 maanden na inwerkingtreding van deze wet. De gemeenteraad van Hoogeveen besluit van de bevoegdheid om een verordening als bedoeld in artikel 30c lid 1(c) herziene Wet op de Kansspelen geen gebruik te maken. Daardoor is de burgemeester onbevoegd om aan appellant een vergunning, om speelautomaten te houden, te verlenen en zal de oude vergunning van appellant expireren op 1 januari 1988. Appellant wenst tegen het besluit van de gemeenteraad in beroep te gaan bij de Afdeling Rechtspraak van de Raad van State. De Voorzitter van de Afdeling Rechtspraak oordeelt dat het besluit van de gemeenteraad om geen verordening op grond van artikel 30c lid 1(c) herziene Wet op de Kansspelen uit te vaardigen, evenzeer een besluit van algemene strekking is als een besluit om wèl een dergelijke verordening vast te stellen. Dit is niet anders nu dit besluit voor appellant het gevolg heeft dat zijn oude vergunning zal verlopen en hem geen nieuwe vergunning zal kunnen worden verleend. Het feit, dat het hier derhalve gaat om een besluit van algemene strekking, heeft volgens de Voorzitter tot gevolg, dat de Afdeling Rechtspraak op grond van artikel 7 juncto 2 lid 2(a) Wet Arob niet bevoegd is van het beroep van appellant kennis te nemen. ${ }^{205} \mathrm{De}$ Voorzitter voegt hier echter aan toe, dat "indien appellant meent dat de door hem gewraakte beslissing van verweerder een onrechtmatige aantasting betekent van zijn burgerlijke rechten, hij ter zake een vordering kan instellen bij de burgerlijke rechter ...". Dit betekent dat in deze rechtsgang naar de burgerlijke rechter een beroep gedaan zal moeten worden op de onrechtmatigheid van het besluit van de

204 Vz. ARRS 10 mei 1988, AB 1989, 86 met noot J.H.vd V.

205 De Wet Arob, evenals de hierop gebaseerde rechtsgang naar de Afdeling Rechtspraak van de Raad van State zijn vervallen bij de Wet van 16 december 1993 (voltooing eerste fase herziening rechterlijke organisatie) Stb. 1993, 650, inwerkingtreding . januari 1994. 
gemeenteraad. In het midden latend of dit nu zo'n gelukkige uitkomst is $^{26}$, kan ook weer in deze zaak opgemerkt worden dat geen uitspraak gedaan wordt over de reikwijdte van het recht op toegang tot de rechter en de beperkingen daarop. Men kan uit deze en de hiervoor besproken zaak opmaken, dat de (Voorzitter van de) Afdeling Rechtspraak van oordeel is dat het recht op toegang tot de rechter niet inhoudt dat een beroepsgang openstaat bij een bepaalde rechter, maar dat het erom gaat dát er beroep op een onafhankelijke en onpartijdige rechter mogelijk is. Dit is mijns inziens juist. Echter, er is in deze zaken wel sprake van een beperking van het recht op toegang voorzover de keuze van de nationale wetgever voor een bepaalde rechter een beperking ten aanzien van de toetsingsmogelijkheden en daarmee van een effectieve rechterlijke controle met zich brengt. Hierop is in deze twee uitspraken niet ingegaan.

\section{Beperkingen ten aanzien van de persoon/personen die toegang tot de rechter zoekt/zoeken}

In een uitspraak in kort geding van de President van de Amsterdamse Rechtbank van 18 juni 1987, gaat het om een ontruimingszaak waarin een aantal verweerders anoniem is gedagvaard.$^{207}$ De verweerders voeren in deze zaak aan, dat de dagvaarding alleen gericht kan zijn tot díe personen die op het moment van het uitbrengen van de dagvaarding in het desbetreffende pand verbleven. Volgens hen kan de dagvaarding niet personen betreffen die voorheen op het adres hebben verbleven dan wel personen die daar nog zullen verblijven. Zij baseren dit verweer op de grond, dat wanneer de dagvaarding wel betrekking op deze laatste personen zou hebben, het vonnis zou werken tegen personen die geen partij bij de onderhavige procedure zijn geweest. Zij achten dit in strijd met het "recht op een burgerlijk proces" in artikel 6 ECRM.

De President verwerpt dit verweer op de grond, dat "de strekking van de anonieme dagvaarding is om de collectiviteit van bewoners in rechte te betrekken, niet individuele bewoners. " Het vonnis dat uit de procedure kan

206 R.M. van Male meent - zonder dit overigens te motiveren - in zijn annotatie bij College van Beroep voor het Bedrijfsleven 31 maart 1988, AB 1988, 567, in een soortgelijke zaak. dat hiermee "bepaald niet de meest efficiënte oplossing" wordt geboden. Zie ook de noot van J.H. van der Veen bij de hier besproken beslissing. AB 1989, 86 en de daarin genoemde literatuur. Zie overigens het gewijzigde art. 30v Wet op de Kansspelen (Wet van 16 december 1993 (voltooiing eerste fase herziening rechterlijke organisatie) Stb. 1993, 650), dat bepaait dat tegen een op grond van de paragrafen 2 (hierin staat art. 30c), 3 of 4 van dezt titel genomen besluit belanghebbende beroep kan instellen bij het College van Beroep voor het Bedrijfsleven.

207 Pres.Rb. Amsterdam 18 juni 1987, KG 1987. 277 
voortvloeien kan dan tegen deze collectiviteit ten uitvoer gelegd worden. De collectiviteit kan zich, volgens de President, hiertegen in rechte verweren. Vervolgens concludeert de President, dat het dagvaarden van een collectiviteit met een wisselend bestand aan leden gebaseerd is op de wet - verwezen wordt naar de artikel 4 en 5 Wetboek van Burgerlijke Rechtsvordering (Rv) - en geen strijd oplevert "met enige direct toepasselijke verdragsbepaling".

Op zich zelf is het niet in strijd met artikel 6 om het recht op toegang tot de rechter in een bepaald geval alleen toe te kennen aan een collectiviteit. De uitspraken van de Commissie en het Hof in de zaak Lithgow - warin het recht op toegang tot de rechter was voorbehouden aan een collectiviteit van minderheids-aandeelhouders, vertegenwoordigd door een "Stockholders' Representative" - zijn hiervan sprekende voorbeelden." Het verschil met de zaak Lithgow is er echter in gelegen dat in die zaak de individuele aandeelhouder de "Stockholders' Representative" nog voor de rechter kon dagen wegens het onrechtmatig uitoefenen van zijn taak.

Anders dan de Rechtbank-President, ziet het Gerechtshof Amsterdam in hoger beroep nog wel een individueel recht op toegang tot de rechter voor de nieuwe bewoners van het desbetreffende pand, wanneer deze zonder in de ontruimingsprocedure betrokken te zijn geweest, uit de woning dreigen te worden gezet. ${ }^{\alpha r}$ Volgens het Gerechtshof kunnen de nieuwe bewoners nog wel opkomen in een executiegeschil "waarin hun aanspraken volledig tot hun recht kunnen komen, zodat geen strijd bestaat met art. 6 EVRM". Of hier inderdaad sprake zal zijn van het volledig tot hun recht komen van de aanspraken onder artikel 6 van deze nieuwe bewoners, is de vraag. In een executiegeschil zouden dan volledig alle punten, die ook in de oorspronkelijke ontruimingsprocedure aan de orde zijn gesteld worden, moeten worden getoetst. Hoe het ook zij, ik denk dat voor deze beperking van het recht op individuele toegang van bewoners van kraakpanden, die na het uitbrengen van de dagvaarding het pand hebben betrokken, voldoende rechtvaardiging bestaat. Het lijkt mij onrechtvaardig voor de eigenaar van het te ontruimen pand en niet in overeenstemming met de rechtszekerheid, wanneer deze eigenaar steeds opnieuw tegen "nieuwe" bewoners van kraakpanden een ontruimingsprocedure zou moeten voeren. Op die manier zouden krakers continu de ontruiming van het pand kunnen frustreren.

208. Rapp.Comm. 7 maart 1984, Case of Lithgow a.o., \$476, pp. 122-123 en EHRM 8 juli 1986, Case of Lithgow a.o.. \$196, p. 71: zie voorts pp. 3291 e.v...

209 Gerechtshof Amsterdam 9 juli 1987. KGK 1987, 1079: KG 1987, p. 808. Zie ook: Pres.Rb. Amsterdam 25 februari 1988. KG 1988, 128. 


\section{Beperking door middel van tijdslimieten}

Een uitspraak van de Hoge Raad van 22 juni 1988 betreft de beperking van de toegang tot de rechter door middel van het stellen van tijdslimieten. In casu gaat het om overschrijding van de termijn voor bezwaar en beroep door een belastingplichtige aan wie een verhoging is opgelegd ${ }^{210}$ In deze zaak oordeelt de Hoge Raad dat het recht op toegang tot de rechter niet gewaarborgd is, indien de belastingplichtige stelt dat de termijnoverschrijding is te wijten aan een hem niet toe te rekenen omstandigheid, terwijl ten aanzien van die stelling in rechte geen zekerheid verkregen kan worden en die onzekerheid toch voor zijn risico wordt gebracht. Het is, aldus de Hoge Raad, in een dergelijk geval mogelijk dat de belastingplichtige "als gevolg van een hem niet toe te rekenen omstandigheid verstoken blijft van zijn recht om het opleggen van de verhoging aan het oordeel van de rechter te onderwerpen." De conclusie van de Hoge Raad is dat de regel volgens welke een na afloop van de gestelde termijn ingediend bezwaar of beroep niet-ontvankelijk is, buiten toepassing moet worden gelaten indien de betrokken belastingplichtige aanvoert dat, en op welke grond, de termijnoverschrijding niet aan hem is toe te rekenen. Volgens de Hoge Raad kan de niet-ontvankelijkheid slechts worden uitgesproken indien bewezen kan worden dat die stelling onjuist is.

Hoewel de Hoge Raad niet in algemene zin aangeeft dat het stellen van termijnen aan het indienen van bezwaar of beroep een legitieme beperking vormt op de toegang tot de rechter, impliceert deze zaak dat wèl, omdat de Raad grenzen stelt aan de mogelijkheid om overschrijding van die termijnen aan de rechtzoekende tegen te werpen. Dit komt neer op een beperking van een beperking op het recht op toegang tot de rechter. Het criterium voor de vaststelling of termijnoverschrijding de belastingplichtige kan worden tegengeworpen is, of de onjuistheid kan worden bewezen van de stelling dat die overschrijding de belastingplichtige niet toegerekend kan

210 HR 22 juni 1988, NJ 1988, 955 met noot Th.W. van Veen; BNB 1988/292 met noot J.P. Scheltens. Zie voor de toepasselijkheid van artikel 6 op dit soort belastingzaken HR 19 juni 1985, NJ 1986, 104; BNB 1986/29 met noot J.P. Scheltens; Weekblad FED 1985, 644 met noot Ch.J. Langereis en HR 26 oktober 1988, BNB 1989/16 met noot J.P. Scheltens. Zie voorts G.J.M. Corstens en P.M. Frielink, De Hoge Raad en de fiscale boete: twee maal in de pas, een maal uit de pas, p. 223; J.W. Ilsink, De gevolgen van de eerste tranche van de Algemene Wet Bestuursrecht voor de fiscale beroepsprocedure, pp. 899-901; J.J.M. Hertoghs, De AWB en de rechtspositie van de contribuabele, pp. 904-905 en M.W.C. Feteris, Belastingen en mensenrechten, p. 756 . 
worden. Dit veronderstelt overigens wel, dat de belastingplichtige dit heeft aangevoerd.

Door middel van voormeld criterium stelt de Hoge Raad een zeer enge grens aan de mogelijkheid om termijnoverschrijding als beperking op het recht op toegang aan te wenden. Immers, alleen wanneer wordt bewezen dat termijnoverschrijding aan de belastingplichtige kan worden toegerekend, wordt diens beroep of bezwaar niet-ontvankelijk verklaard. Terecht merkt Scheltens hierover op, dat het uitgangspunt van de presumptio innocentiae in een procedure voor een onafhankelijke rechter niet mag worden gefrustreerd door bijvoorbeeld fouten van de PTT of andere derden voor risico van de belastingplichtige te brengen, waardoor zijn recht op beroep op een rechter verloren zou gaan. ${ }^{m}$

Overigens is het opmerkelijk dat de civiele kamer van de Hoge Raad, wellicht verklaarbaar uit het verschil in aard van de in het geding zijnde zaken, veel strenger is bij termijnoverschrijding. In een uitspraak van 17 november 1989 wordt de appellant niet-ontvankelijk verklaard wegens overschrijding van de beroepstermijn in artikel 910 lid $4 \mathrm{Rv}$, ondanks het feit dat sprake was van een cumulatie van formele fouten bij de rechtbank (de rechter heeft, onder meer, na verhoor niet conform artikel 909 lid 3 Rv medegedeeld wanneer de uitspraak zou plaatsvinden). ${ }^{232}$ Volgens de hoge Raad biedt artikel $910 \mathrm{Rv}$ geen aanknopingspunt om in een dergelijk geval de termijn van hoger beroep pas in te laten gaan op het tijdstip waarop de partij die hoger beroep wil instellen met (de inhoud van) de beschikking bekend is of bekend kan zijn. Daar wordt dan nog, op zichzelf juist, aan toe gevoegd dat artikel 6 ECRM (net als artikel 14 IVBPR) niet

21 Zie de annotate vun Sheltens bij dit arrest, BNB 1988/202, pp. 1921-1922. De onschuldprosumptie in artikel 6 lid 2 ECRM is hier van toepassing. omdat het in geval van fiscale boetes gaat om strafvervokging in de zin van arikel 6 lid 1 ECRM. Op de fiscale boete wordt verder nog ingegaan in par, 5.2.2.1. Zie in verband met de onschuldpresumptic ca.v. de bewijslastverdeling HR 15 juli 1988 , BNB 1988/270, FED 1988/706; HR 20 december 1989. BNB 1990/102 met noot $F$. Ploeger; HR 17 januari 1990, BNB 1990/193 met noot J.P. Scheltens; HR 10 juni 1992, BNB 1992/274 (artikelen 18 en 21 AWR): HR 11 okwober 1989, BNB 1990/87 met nool J.P. Scheltens (artikel 16 Wet MB 1966) en HR 15 juli 1993, NJ 1994, 177 met noot $C$ (artikel 5 WAHV). vgl. EHRM 7 oktober 1988. Salabiaku Case; ta.v. het gebruik van vermoedens HR 18 november 1992 , BNB $1993 / 40$ net noot $P$. $J$. Wattel; ta.V. omkering van de bewijslast indien tevens een strafvervolging is ingesteld HR 11 december 1991. BNB 1992/243 met noot J.P. Scheltens. Zie ook M. Viering en J. Fleuren, Onschuldpresumptie en recht op hoger beroep: twee grenzen aan eenvoudige afdoening, pp. 461-464.

212 HR 17 november 1989, NJ 1990, 496 mei noot JBMV. Deze uitspraak stemt overeen met eerdere arresten van de Hoge Rạd, wạaronder HR 13 oktober 1989, NJ 1990. 412; zie voor een overzicht van deze jurisprudentie de conclusie van A-G Leiten. 
een recht op hoger beroep toekent. De annotator merkt, mijns inziens echter terecht op, dat "(D)e praktische consequentie is dat de advocaat niet alleen de door hein zelf in acht te nemen termijnen en formaliteiten zal moeten bewaken, maar ook die van de rechter en de griffie. Dat is in een volle advocatenpraktijk een forse lastenverzwaring, waarover men niet licht mag denken."

Overigens heeft de Hoge Raad in een uitspraak 16 oktober 1991 een nadere afbakening gegeven aan het in de uitspraak van 22 juni 1988 geformuleerde criterium. ${ }^{213}$ Dit laatstbedoelde criterium gaat alleen op voor gevallen waarin een belastingplichtige stelt dat hij het hem toegezonden aanslagbiljet niet heeft ontvangen en daardoor niet tijdig bezwaar heeft kunnen maken. Het criterium is niet van toepassing, aldus de Hoge Raad, wanneer de belastingplichtige stelt dat zijn gemachtigde tijdig zijn beroepsschrift per post heeft verzonden, maar dat het ais gevolg van omstandigheden die hem niet kunnen worden toegerekend, niet op tijd op de griffie van het Hof is binnengekomen. Desondanks komt de Hoge Raad tot de conclusie - echter niet op grond van artikel 6 ECRM - dat het feit dat het beroepsschrift te laat is binnengekomen "kennelijk te wijten [is] aan een in de sfeer van de PTT liggende omstandigheid van zodanig abnormale aard, dat deze niet aan belanghebbende kan worden toegerekend." Het effect is beide gevallen echter hetzelfde, namelijk in beide gevallen moet niet-ontvankelijkverklaring van het beroep achterwege blijven.

Tenslotte moet ten aanzien van de door de Hoge Raad in het arrest van 22 juni 1988 gegeven regel met betrekking tot termijnoverschrijding nog het volgende worden opgemerkt. Ilsink en Hertoghs wijzen erop dat dit arrest als basis heeft gediend voor artikel 6.2.5 van het wetsvoorstel voor de Algemene Wet Bestuursrecht (het huidige artikel 6:11 AWB). Volgens Hertoghs geldt hierdoor de in het arrest geformuleerde regel inzake termijnoverschrijding in geval van beroep of bezwaar tegen een opgelegde verhoging vanaf de inwerkingtreding van de AWB voor termijnoverschrijding bij beroep of bezwaar in het gehéle bestuursrecht. ${ }^{2 / 4}$ Met andere woorden, deze aan artikel 6 ECRM ontleende regel in verband met de toegang tot de rechter geldt via artikel 6:11 AWB ook voor de toegang tot de rechter in zaken waarop artikel 6 niet van toepassing is!

213 HR 16 oktober 1991, BNB 1991/343 met noot G.J. van Leijenhorst.

214 J.W. Ilsink, De gevolgen van de eerste tranche van de Algemene Wet Bestuursrecht voor de fiscale beroepsprocedure, pp. 899-900; J.J.M. Hertoghs, De AWB en de rechtspositie van de contribuabele, p. 905. 


\section{Overige}

In de zaak waarop de beschikking van de Hoge Raad van 24 oktober 1989 betrekking heeft, gaat het om een aanvrage tot herziening van een uitspraak van het Gerechtshof Leeuwarden. Het Gerechtshof had de aanvrager op 22 april 1986 veroordeeld tot een gevangenisstraf onder aftrek van zijn voorarrest, zonder dat aanvrager op de terechtzitting van 8 april 1986 aanwezig had kunnen zijn. Reden hiervoor was, dat aanvrager inmiddels als ongewenst verklaarde vreemdeling was uitgezet naar Marokko. De aanvrager meent dat de Staat artikel 6 ECRM heeft geschonden door aan de ene kant aanvrager uit te zetten naar Marokko en aan de andere kant de strafvervolging tegen aanvrager voort te zetten. Het gerechtshof had volgens de aanvrager, het Openbaar Ministerie in zijn vervolging niet-ontvankelijk moeten verklaren indien het op de hoogte was geweest van de voormelde omstandigheid.

Volgens de Hoge Raad is geen sprake van schending van "enig" in artikel 6 genoemd recht, nu de aanvrager tijdens eerdere zittingen wel aanwezig was geweest, daardoor tegen hem geen verstek was verleend en mitsdien zijn raadsvrouwe op de zitting van 8 april 1986 ondanks zijn afwezigheid zijn verdediging kon voeren. De aanvrage tot herziening word vervolgens door de Hoge Raad niet-ontvankelijk verklaard.

De Hoge Raad vermeldt niet welke rechten op grond van artikel 6 hier in het geding zijn. Mijns inziens zijn dat het recht op toegang tot de rechter en het recht om in persoon ter terechtzitting aanwezig te zijn. In wezen worden deze twee rechten in deze zaak aan elkaar gekoppeld, ook al onderscheidt de Hoge Raad deze rechten niet expliciet. De Hoge Raad concludeert, dat de aanvrager - doordat hij ondanks zijn afwezigheid zijn verdediging kon doen voeren omdat geen verstek tegen hem was verleendniet verstoken was van enig in artikel 6 gegarandeerd recht. Hiermee zegt de Hoge Raad eigenlijk, dat de aanvrager ofwel onder de gegeven omstandigheden geen recht erop had om in persoon op de terechiziting anwezig te zijn (beperking van de uitoefening van het recht) ofwel dat dit recht is gerespecteerd door zijn verdediging te laten voeren door zijn raadsvrouwe (beperking van de reikwijdte van het recht). Wat hiervan ook zij, hieruit vloeit in de redenering van de Hoge Raad voort, dat ook het recht van aanvrager op toegang tot de rechter niet is geschonden. Deze laatste gevolgtrekking lijkt mij juist. Wat betreft het recht om in persoon op de terechtzitting aanwezig te zijn: het lijkt mij, zonder al te diep hierop in te gaan, dat gekozen moet worden voor de gesuggereerde beperking van de uitoefening van het recht. De beperking van de reikwijdte van het recht om aanwezig te zijn op de terechtzitting tot gevallen waarin geen sprake is van vertegenwoordiging door een raadsman (of -vrouw) lijkt mij niet 
wenselijk en ook niet in overeenstemming met de Straatsburgse rechtspraak terzake, omdat de persoonlijke hoedanigheid van een verdachte in een strafzaak een grote rol kan spelen en daarom de aanwezigheid van een verdachte ondanks vertegenwoordiging door een raadsman, cruciaal kan zijn. ${ }^{215}$ Beperking van de uitoefening van dit recht lijkt mij daarom in casu verkieslijker, omdat ondanks de afwezigheid van de aanvrager op de zitting van 8 april 1986 het Gerechtshof toch rekening had kunnen houden met de hoedanigheden van de aanvrager, omdat hij op eerdere zittingen wel aanwezig was geweest.

In al de hiervoor besproken zaken, gaat het om het recht op toegang tot de rechter in verband met de bevoegdheid van de desbetreffende rechteriijke instanties. Alhoewel deze zaken interessant zijn voor een beschouwing over hoe de Nederlandse rechter het onderhavige recht toepast, worden in deze uitspraken - uitgezonderd die ten aanzien van termijnoverschrijding in verband met beroep of bezwaar tegen een opgelegde belastingverhoging geen criteria ontwikkeld of gehanteerd voor de afbakening van het recht op toegang. In die zin is de besproken rechtspraak teleurstellend te noemen. Het in de behandelde belastingzaak ontwikkelde criterium (of de onjuistheid kan worden bewezen van de stelling dat de termijnoverschrijding de belastingplichtige niet toegerekend kan worden) is dermate op het bestuursrecht toegesneden, dat daarmee geen handvat aangereikt wordt voor de afbakening van het recht op toegang in gevallen buiten dit rechtsgebied. Dit blijkt ook uit de strengere houding van de civiele kamer van de Hoge Raad.

In het navolgende wordt ingegaan op het aspect van de positieve verplichting die uit artikel 6 voortvloeit ten aanzien van het recht op

215 Hieraan mag overigens niet de conclusie verbonden worden dat de aanwezigheid van een verdachte mag worden afgedwongen door bij zijn afwezigheid te weigeren zijn raadsman namens hem het woord te laten voeren. In EHRM 22 september 1994. Lala Case, §33, p. 13 en EHRM 22 september 1994, Pelladoah Case, §40, pp. 3435 is uitgesproken dat

"... it is also of crucial importance for the fairness of the criminal justice system that the accused be adequately defended, both at first instance and on appeal, the more so if, as is the case under Netherlands law, no objection may be filed against a default judgment given on appeal.

In the Court's view that latter interest prevails. Consequently, the fact that the defendant, in spite of having been properly summoned, does not appear, cannot - even in the absence of an excuse - justify depriving him of his right under Article $6 \S 3$ of the Convention to be defended by counsel. ..." 
toegang. Het gaat hier om de verzekering van een effectief recht op toegang.

Verzekering van een effectief recht op toegang tot de rechter

In een uitspraak van de President van de Rechtbank van Amsterdam van 26 januari 1984, gaat het om een geschil tussen de Stichting Rechtshulp Amsterdam en enkele van haar medewerkers omtrent de hantering van wettelijke regels met betrekking tot de eigen bijdrage van cliënten aan wie een advocaat wordt toegevoegd. ${ }^{216}$ Volgens de betrokken medewerkers is het. in strijd met artikel 6 ECRM dat in alle gevallen een eigen bijdrage moet worden opgelegd. De Rechtbank-President oordeelt anders. Volgens de President staat de regeling van gedeeltelijk kosteloze rechtshulp niet op gespannen voet met het in artikel 6 gegarandeerde recht op "vrije toegang van de burger tot de rechter". De President bepaalt, dat

"het voor eigen rekening laten van een eigen bijdrage van $f 50,-\ldots$ niet [kan worden] gezien ... als het opwerpen van een onaanvaardbare belemmering voor de toegang tot de rechter."

In het hedendaagse stelsel van sociale zekerheid en sociale voorzieningen is een dergelijk bedrag een aanzienlijke uitgave voor hen die tot de lagste inkomensgroepen behoren, maar deze uitgave - zo vervolgt de President -

"is voor de burger, die een zekere prioriteit aan het verkrijgen van rechtshulp toekent, niet onmogelijk."

De medewerkers van de Stichting Rechtshulp Amsterdam worden vervolgens in het ongelijk gesteld.

Voor de vaststelling of sprake is van een voldoende verzekering van een effectief recht op toegang hanteert de President hier het criterium of de eigen bijdrage geen onaanvaardbare belemmering voor de toegang tot de rechter vormt. Bij de bespreking van de Straatsburgse rechtspraak ten aanzien van de garantie van de effectieve toegang tot de rechter bleek, dat de Staat niet verplicht is om in elk geval gratis rechtsbijstand te verschaffen. ${ }^{217}$ Op zich is het derhalve juist, dat een eigen bijdrage geen 
onaanvaardbare belemmering voor de toegang tot de rechter hoeft te zijn. Ik ben echter van opvatting, dat de President rekening had dienen te houden met de omstandigheden van het geval, waaronder de financiële omstandigheden van de rechtzoekende. Dit vloeit mijns inziens voort uit de uitspraak van het Europese Hof in de zaak Airey, waarin - nadat was geconstateerd dat de conclusies met betrekking tot het geval van Airey niet voor alle zaken hoeven te gelden - werd bepaald dat "much must depend on the particular circumstances. "218 De Rechtbank-President houdt geen rekening met die specifieke omstandigheden en acht een eigen bijdrage "voor de burger, die een zekere prioriteit aan het verkrijgen van rechtshulp toekent, niet onmogelijk". Met deze redenering ben ik het niet eens. Moet men dan veronderstellen dat een ieder die betrokken raakt in een gerechtelijke procedure "een zekere prioriteit aan het verkrijgen van rechtshulp toekent"? Het stellen van prioriteiten impliceert een keuze. Er valt echter weinig te kiezen als men onvoldoende financiële middelen heeft. Moet men in het geval dat iemand onvoldoende geld heeft voor een procedure dan maar concluderen dat die persoon geen prioriteit toekent aan het verkrijgen van rechtshulp? Die conclusie zou, mijns inziens, in strijd zijn met de besproken Europese jurisprudentie inzake artikel 6. Naar mijn mening zal er altijd rekening gehouden moeten worden met de specifieke omstandigheden van het geval.

Dit geldt des te meer nu in de op 1 januari 1994 in werking getreden Wet op de Rechtsbijstand ${ }^{219}$ en de daarop gebaseerde algemene maatregelen van bestuur een aanzienlijke hogere eigen bijdrage van de rechtzoekende geëist wordt. ${ }^{220}$

Naast het heffen van een eigen bijdrage voor rechtshulp, bestaat er nog een drempel voor de effectieve toegang tot de rechter: de mogelijkheid voor de tegenpartij in een geding om op grond van artikel $152 \mathrm{Rv}$ te verzoeken dat de eisende partij, indien dit een vreemdeling is, vooraf zekerheid stelt voor de kosten van de procedure, voor het geval deze vreemdeling in de kosten zou worden veroordeeld. In een zaak van 10 maart 1981 bepaalt de Rechtbank Haarlem, dat toepassing van artikel $152 \mathrm{Rv}$ met zich zou kunnen brengen, dat de effectieve toegang tot de rechter niet is

218 EHRM 9 oktober 1979, Airey Case, §26, p. 15. Zie hierboven p. 350.

219 Wet van 23 december 1993, Stb. 775 .

220 Zie hierover mijn bijdrage "Het recht op rechtsbijstand in verband met het recht op toegang tot de rechter onder artikel 6 EVRM" en het NJCM-commentaar bij het Wetsvoorstel inzake regelen omtrent de door de overheid gefinancierde rechtshijstand, pp. 203-205. 
verzekerd. ${ }^{22 !}$ Dit zou volgens de Rechtbank het geval zijn, "indien de financiële omstandigheden van de vreemdeling het stellen van de verlangde zekerheid niet zouden toelaten. "In dat geval dient artikel $152 \mathrm{Rv}$, aldus de Rechtbank, buiten toepassing te blijven. In deze zaak was dat het geval. $^{m}$

Met het Hof van Justitie Nederlandse Antillen en Aruba ben ik van mening dat de hier besproken drempel in de toegang tot de rechter toelaatbaar en gerechtvaardigd is. ${ }^{223}$ Anders dan dit Hof doet, vind ik echter dat in overeenstemming met de uitspraak van de Rechtbank Haarlem gekeken moet worden naar de specifieke omstandigheden van het geval. De in het algemeen aanvaardbare drempel in de toegang tot de rechter kan immers in het individuele geval te hoog zijn. Aangezien in artikel 6 ECRM gaat om een effectieve toegang tot de rechter zal in een dergelijk geval een verzoek om zekerheidstelling afgewezen moeten worden.

Een dergelijke afwijzing wordt in een vonnis van het Kantongerecht Amsterdam van 25 maart 1992 uitgesproken. Na een overweging die vergelijkbaar is met die van de Haarlemse rechtbank, stelt de kantonrechter vast dat de omstandigheid dat eiser kosteloos procedeert met (slechts) een eigen bijdrage van $f 50$, het standpunt ondersteunt dat in dit geval de eis van het stellen van reële zekerheid zich niet verdraagt met artikel 6 lid 1. 224

221 Rb. Haarlem 10 maart 1981, NJ 1981, 451; NYIL, 1982, pp. 337-338. Zo ook: Kg. Dordrecht 14 april 1983, Praktijkgids 1984, 2068 met noot I.W. Soek.

222 Impliciet vindt in de uitsprask van het Gerechtshof 's-Gravenhage 3 februari 1984. NI 1985, 504 een zelfde toetsing (met een ander resultaat) plaats: "De ... opvatting, dat genoemde verdragen (waaronder artikel 6 ECRM, CS) ... a an wewijzing vain de incidentele vordering (verzoek om zekerheidstelling. $C S$ ) in de weg starn, gaat-te meer nu niet is gebleken dat door het stellen van zekerheid van Sagoe (incidenteel verweerster, CS) de sffectieve toegang tot de rechter niet verzekerd zou zijn - te ver en komt in feite neer op de buitengebruikstelling van art. $152 \mathrm{Rv}$. ".

223 Hof van Justitie Ned. Antillen en Aruba 28 oktober 1986. NJ 1983, 532. Het Hof van Justitie vindt de in artikel $152 \mathrm{Rv}$ neergelegde drempel in de toegang tot de rechter "alleszins toelaatbaar en gerechtvaardigd" vanwege het beginsel in het burgerijk procesrecht, dat de verliezende partij als regel de kosten van de procedure zal hebben te dragen. Aangezien het niet of moeilijk zal zijn op een vreemdeling jeze kosten te verhalen, omdat vonnissen (bij het ontbreken van een verdrag dat dat mogelijk makt) niet buiten de landsgrenzen ten uitvoer kunnen worden getegd, is zekerheidstelling vaak de enige verhaalsmogelijkheid.

$224 \mathrm{Ktg}$. Amsterdam 25 maart 1992, NJ 1992, 435. In tegenstelling tot deze uitspraak is HR 11 februari 1992. NJ 1992.692 met een lezenswaardige conclusie van A-G Meijers en noot $C$. omtrent zekerheidsstelling op grond van artikel 11 hid 1 WAHV) onvoldoende gemotiveerd. 
Uit deze jurisprudentie blijkt derhalve, dat de grens van de beoordelingsvrijheid van de staat bij de nakoming van de positieve verplichting tot verzekering van het recht op toegang tot de rechter gelegen is in de effectiviteit van de toegang. Een criterium dat bij de toetsing in aanmerking genomen moet worden is dat van de omstandigheden van het geval. Hoewel dit criterium uiterst handzaam is voor de rechter, biedt het echter geen enkele houvast voor de rechtzoekende. In de rechtspraak moet worden uitgemaakt wat voor omstandigheden hier een aanwijzing kunnen opleveren voor het in het gedrang komen van de effectiviteit van de toegang tot de rechter. In zijn uitspraak van 25 maart 1992 noemt de Amsterdamse kantonrechter er, met betrekking tot de toelaatbaarheid van het eisen van zekerheidstelling, één: het kosteloos procederen met een eigen bijdrage van (slechts) $f 50 .{ }^{225}$

Ten aanzien van een andere belemmering van het recht op toegang, de verplichting tot het betalen van griffierechten heb ik slechts enkele rechterlijke uitspraken gevonden, die het vermelden waard zijn. In een uitspraak van 17 juni 1992 bepaalt de Hoge Raad, dat niet iedere heffing van griffierecht in strijd is met het recht op toegang tot de rechter in artikel 6. lid 1. ${ }^{226}$ Hiervan is slechts sprake indien het bedrag aan griffierecht "een wezenlijke belemmering van de toegang tot de rechter vormt." Vervolgens constateert de Hoge Raad, dat van de rechten die op grond van artikel 5 Wet administratieve rechtspraak belastingzaken (WARB) worden geheven niet gezegd kan worden dat zij de toegang tot de rechter wezenlijk belemmeren. De Hoge Raad voegt daar de opmerking aan toe, dat het mogelijk is dat de voorzitter van het betrokken rechterlijk college het griffierecht vermindert in zaken van gering financieel belang, alsmede aan natuurlijke personen die als on- en minvermogend moeten worden aangemerkt. Mijns inziens is deze uitspraak in zoverre juist, dat voor griffierechten inderdaad hetzelfde geldt als voor de eigen bijdrage en zekerheidstelling: het heffen van griffierechten is op zichzelf, in abstracto, in overeenstemming met artikel 6 lid 1 ECRM. Mijn bezwaar tegen deze uitspraak van de Hoge Raad is echter, dat de beoordeling van het bedrag dat op grond van artikel 5 WARB wordt geheven, door de Hoge Raad wordt gemaakt zonder rekening te houden met de specifieke omstandigheden van het geval, derhalve ook in abstracto. Voorts betreft

225 Zoals ik hierboven heb betoogd kan een eigen bijdrage van $f 50$ onder omstandigheden ook al een te grote belemmering van het recht op toegang zijn. Uit het woordje "slechts" in de overweging van de kantonrechter mag mijns inziens dan ook niet afgeleid worden, dat dit bedrag altijd aanvaardbaar is.

226 HR 17 juni 1992, BNB 1992/277. 
de mogelijke vermindering door de voorzitter van het desbetreffende college (op grond van artikel 5, derde en vierde lid, WARB) van hel griffierecht vaststaande bedragen, waardoor ook niet rekening gehouden kan worden met de specifieke omstandigheden waarin de betrokken rechtzoekende verkeert. Zoals ik hiervoor al aanvoerde ten aanzien van de eigen bijdrage en de zekerheidstelling, zal voor de beoordeling van de verenigbaarheid met artikel 6 , gelet moeten worden op de specifieke (financiële) omstandigheden van het geval. Aan deze voorwaarde word: voldaan in de uitspraak van de President van de Rechtbank Assen van 21 maart 1994. Volgens de President speelt - voor de vraag of een rechtzoekende (in casu een rechtspersoon) niet-ontvankelijk verklaard moet worden in haar beroep (in kort geding), nu deze slechts de helft van het verschuldigde griffierecht $(f 400)$ heeft voldaan - een doorslaggevende rol dat

"verzoeksters feitelijke financiële situatie een verhindering voor betaling van $f 400$ aan de griffier vormde toen zij haar verzoek deed en dat op grond van de hiervoor geschetste situatie en het spoedeisende karakter van het verzoek, ... niet van haar verlangd mocht worden die betaling feitelijk mogelijk te doen zijn, omdat daarmee het recht op een snelle toegang tot een oordeelsvorming van de president feitelijk onmogelijk was. Dit nu is een met art. 6, eerste lid, EVRM strijdig gevolg." 227

Cruciaal is derhalve in deze uitspraak, dat gekeken wordt naar de feitelijke financiële situatie van verzoekster. Mijns inziens is deze uitspraak, gezien de Straatsburgse jurisprudentie, dan ook juist. ${ }^{228}$

De rechtspraak ten aanzien van het recht op "toegang" tot de rechter overziende, moet geconcludeerd worden dat het aantal uitspraken waarin een criterium voor de afbakening van dit recht geformuleerd is, minimaal is. ${ }^{229}$ De besproken zaken betreffen ofwel de beperking van de toegang in verband met de bevoegdheid van de rechter ofwel de verplichting van de staat om een effectief recht op toegang te verzekeren. Zaken ten aanzien

227 Pres.Rb. Assen 21 maart 1994, FED 1994, nr. 399, pp. 1769-1771 met noot M.W.C. Feteris; NJCM-Bulletin 20-1 (1995), pp. 28-3! met noot $N$. Verheij (met name de punten 2 en 3 ).

228 Zie hieromtrent opnieuw mijn bijdrage "Het recht op rechtsbijstand in verband met het recht op toegang tot de rechter onder artikel 6 EVRM", pp. 121 en 126-128.

229 Geringe afbakening van een recht hoeft overigens niet (uitsluitend) te wijten te zijp aan de rechter, maar kan wellicht ook voortvloeien uit door de partijen in het geding aangedragen grieven of cassatiemiddelen. 
van inherente beperking van het recht op toegang heb ik niet kunnen vinden. Hetzelfde geldt voor uitspraken ten aanzien van het doen van afstand van het recht op toegang tot de rechter. ${ }^{230}$

In zijn preadvies van 1991 voor de Nederlandse Juristen-Vereniging noemt Brenninkmeijer als uitgangspunt in een democratische rechtsstaat, dat een ieder die in redelijkheid kan menen in zijn of haar rechten geschonden te zijn, effectief toegang tot de rechter behoort te hebben. Volgens hem behoren de organisatie van de rechtspleging en de inrichting van het procesrecht in het teken te staan van de realisatie van dit uitgangspunt. ${ }^{231}$ Mijns inziens zou de rechter tot de verwezenlijking van het door Brenninkmeijer geformuleerde uitgangspunt kunnen bijdragen door het recht op toegang tot de rechter duidelijker af te bakenen dan in de hierboven besproken zaken is gebeurd. De rechter zou hiertoe, bijvoorbeeld, nauwer aan kunnen sluiten bij de in Straatsburg ontwikkelde criteria. Geven de aangevoerde grieven of cassatiemiddelen hiertoe niet direct aanleiding, dan zou dit, met name bij de hogere rechters, wellicht ambtshalve kunnen gebeuren. Alleen dan zal de inhoud van dit recht komen vast te staan en kan worden vastgesteld in hoeverre het genoemde uitgangspunt is gerealiseerd.

In de volgende paragraaf zal ingegaan worden op de betekenis van het begrip "rechter". Omdat hier de behandelwijze van de Europese jurisprudentie gevolgd zal worden, zal ik dan ook ingaan op de Nederlandse rechtspraak ten aanzien van het vereiste in artikel 6 van "een onafhankelijk en onpartijdig gerecht dat bij de wet is ingesteld".

230 In het NJCM-commentaar op het rapport van de Commissie Moons, p. 368, worden een aantal zaken (o.a. HR 2 juli 1990, NJ 1990, 692 met noot Th.W. van Veen en HR 2 oktober 1990, NJ 1991, 130 met noot $C$ ) genoemd waarin het zou gaan om afstand van recht. Zo men deze uitspraken inderdaad aldus moet begrijpen, afstand van recht wordt niet expliciet genoemd, dan voldoet de toetsing de toetsing van die afstand niet aan de in de Straatsburgse rechtspraak ontwikkelde criteria. Zie paragraaf 5.1.3.2. Omdat het hier uitspraken betreft waarin niet het recht op toegang tot de rechter in het geding is, zal niet verder op deze zaken ingegaan worden.

231 A.F.M. Brenninkmeijer, Het procesrecht als proces, pp. 12-20, met name pp. 14-15. 


\subsubsection{Toegang tot "een onafhankelijk en onpartijdig gerecht dat bij de wet is ingesteld"}

5.2 .2 .1

Introductie; verplichtingen voor de staat in geval van beslissingen genomen door niet onafhankelijke en onpartijdige, administratieve organen

In jurisprudentie heb ik geen zaken aangetroffen, waarin is uitgesproken dat - wanneer het recht op toegang tot de rechter aan de orde is - met het woord "rechter" gedoeld wordt op het in artikel 6 genoemde onafhankelijke en onpartijdige gerecht dat bij wet is ingesteld. Omdat dit uitgangspunt wèl uit de Europese jurisprudentie kan worden afgeleid, zal hiervan uitgegaan worden.

Voordat op de onafhankelijkheid en de onpartijdigheid van de rechter zal worden ingegaan, zal eerst een ander onderwerp behandeld worden, namelijk de rechterlijke toetsing ten aanzien van administratieve boetes en andere administratieve besluiten. Reden voor de behandeling van dit onderwerp is wat betreft de administratieve boetes, dat zowel in het geval van fiscale boetes als boetes opgelegd op grond van de Wet auministratieve handhaving verkeersvoorschriften (WAHV, ook wel de Wet Mulder genoemd) er pas een weg naar de rechter openstaat nádat de boete is opgelegd. ${ }^{232}$ In het kader van de AWR en de WMRB worden de sancties in eerste instantie opgelegd door de belastinginspecteur ${ }^{233}$, en op grond van de WAHV geschiedt dit door bij algemene maatregel van bestuur aangewezen ambtenaren (artikel 3 WAHV). Tegen een opgelegde fiscale boete kan een bezwaarschrift worden ingediend bij de belastinginspecteur (artikel 23 AWR), tegen een sanctie op grond van de WAHV kan beroep worden ingesteld bij de officier van justitie (artikel 6 WAHV). Doet de betrokkene dat niet, dan wordt de beschikking waarbij de boete is opgelegd

232. Boetes op grond van, bijvoorbeeld de artikelen 18 en 21 Algemene wet rijksbelastingen (AWR) kunnen alleen worden opgelegd als bij de desbetreffende wetsovertreding sprake is van opzet of grove schuld van de belastingplichtige, terwijl op grond van de artikelen 16 Wet op de motorrijtuigenbelasting 1966 (WMRB) of artikel 5 WAHV boetes opgelegd kunnen worden op grond van een vermoeden dat door degene aan wie de sanctie is opgelegd de wetsovertreding is begaan (een soort risico-aansprakelijkheid).

233 Wetsvoorstel 23470, "Wijziging van de Algemene Wet inzake rijksbelastingen en de Invorderingswet 1990 in verband met de herziening van het stelsel van Administratieve boeten en van het fiscale strafrecht", kamerstuknr. 23470 , introduceert de boeteinspecteur. Zie over dit wetsvoorstel Ch.J. Langereis, Herziening van het stelsel vant administratieve boeten en van het fiscale strafrecht, pp. 60-69. 
definitief en zal betaald moeten worden. Tegen de beslissing van de belastinginspecteur op het bezwaarschrift staat beroep open op (de belastingkamer van) het gerechtshof (artikel 26 AWR juncto artikel 1 Wet administratieve rechtspraak belastingzaken, WARB), tegen de beslissing van de officier van justitie op het ingestelde beroep kan in beroep gegaan worden bij de kantonrechter (artikel 9 WAHV).

Uit de rechtspraak kan worden afgeleid, dat belastinggeschillen op zichzelf niet onder het toepassingsgebied van artikel 6 ECRM vallen, maar wèl indien ze vergezeld gaan van een opgelegde verhoging, oftewel een fiscale boete. Zowel fiscale boetes als boetes op grond van de WAHV worden beschouwd als "criminal charges" in de zin van artikel 6 ECRM ${ }^{24}$ In beide gevallen is artikel 6 ECRM van toepassing en zal er toegang moeten zijn tot een rechterlijke instantie die voldoet aan de aan strafprocedures verbonden waarborgen.

Ook andere administratieve besluiten dan administratieve boetes, zoals bijvoorbeeld in Kroonberoep gedane uitspraken ${ }^{235}$, worden eerst genomen door administratieve organen, die niet voldoen aan de vereisten van artikel 6 ECRM. Hier van belang zijn, met name, die besluiten die "civil rights and obligations" betreffen. In deze gevallen zal er, net als bij administratieve boetes, toegang moeten zijn tot een rechterlijke instantie die de garanties biedt van artikel 6 lid 1 ECRM.

Zoals bleek in paragraaf 5.1.4.1 is het op grond van de Straatsburgse jurisprudentie toegestaan bepaalde zaken waarop artikel 6 van toepassing is, te laten beoordelen door administratieve organen. In verband met het recht op toegang tot de rechter werd hier wèl de voorwaarde aan gesteld dat, ofwel deze organen zélf aan de vereisten van artikel 6 voldoen (met betrekking tot de administratieve boetes niet alleen lid 1, maar ook de

234 Zie EHRM 21 februari 1984, Öztürk Case, \$49, p. 18; EHRM 25 augustus 1987, Lutz Case, §55, p. 23; EHRM 29 april 1988, Belilos Case, §68, p. 30 en EHRM 24 februari 1994, Bendenoun Case, $\$ 47$, p. 20. Zie voor Nederlandse uitspraken: HR 19 juni 1985, BNB 1986/29 (artikel 16 Wet MB, artikelen 18 en 21 AWR); HR 15 juli 1988, BNB 1988/270, HR 22 juni 1988, BNB 1988/292 en HR 26 oktober 1988. BNB 1989/16; HR 7 september 1988, BNB 1988/298 (artikel 22 AWR); HR 3 mei 1989, BNB 1989/256, NJ 1991, 167; en HR 24 januari 1990, BNB 1990/287 (artikel 9(3) AWR). Zie voorts impliciet HR 15 juli 1993, NJ 1994, 177, expliciet in Ktg. Utrecht 28 september 1992 waartegen het beroep in cassatie was ingesteld (artikel 5 WAHV) en HR 9 november 1993, NJ 1994, 199.

235 Ik zal me hierbij vanwege de voorhanden zijnde jurisprudentie beperken tot de besluiten waarbij de Kroon betrokken is, zij het dat die jurisprudentie gedateerd is vanwege de herziening van de rechterlijke organisatie en de invoering van de Algemene Wet Bestuursrecht. Deze jurisprudentie geeft echter wel inzicht in de uitleg die de Nederlandse rechter aan artikel 6 ECRM geeft. 
leden 2 en 3 omdat het - anders dan in bedoelde jurisprudentie - een "criminal charge" betreft), ofwel tegen hun beslissingen beroep openstaat bij "a judicial body that has full jurisdiction and does provide the guarantees of Article $6 \$ 1 \ldots$ (en opnieuw lid 2 en lid 3). ${ }^{236}$ Van zowel de fiscale boete als de Wet Mulder-boete kan gezegd worden dat zij worden opgelegd door administratieve organen die niet aan de vereisten van artikel 6 voldoen, omdat de belastinginspecteur en de in de WAHV bedoelde ambtenaren niet onafhankelijk en onpartijdig (en al helemaal geen rechter) zijn. Hetzelfde kan gezegd worden van (opnieuw) de belastinginspecteur en de officier van justitie waarbij respectievelijk een bezwaarschrift moet worden ingediend en beroep moet worden ingesteld. Ook gaat deze constatering op voor de Kroon en andere administratieve organen. Er zal derhalve na procedures bij deze administratieve instanties beroep moeten openstaan op "a judicial body that has full jurisdiction and does provide the guarantees of Article $6 . . . "$.

Verder is in de Straatsburgse jurisprudentie ook uitgesproken, dat "the "right to a court" and the right to a judicial determination of the dispute cover questions of fact just as much as questions of law." Dit geldt voor zowel burgerlijke als strafzaken en betekent, mijns inziens, dat een volledige toetsing van de beslissing waartegen het beroep is gericht, plaatsvindt. ${ }^{237}$ Wat betreft de administratieve boetes betekent dit, dat de rechterlijke beoordeling niet beperkt mag worden door het bestuursoordeel, bijvoorbeeld, door de toetsing van dit oordeel te beperken tot een toetsing aan de algemene beginselen van behoorlijk bestuur. Zou dit anders zijn, dan kan niet ieder aspect van het oordeel van een niet-onafhankelijk orgaan ten aanzien van een "criminal charge" heroverwogen worden, door een rechterlijke instantie die de waarborgen van artikel 6 ECRM biedt. ${ }^{238}$ Omdat de keuze voor het opleggen van administratieve sancties en het volgen van administratieve procedures in plaats van het instellen van strafvervolgingen en het volgen van strafrechtelijke procedures veelal

236 EHRM 10 februari 1983, Albert and Le Compte, $\$ 29, p .16$ en de overige in noot 112 genoemde jurisprudentie.

237 EHRM 23 juni 1981, Le Compte, Van Leuven and De Meyere, \$51(b), p. 23 en de overige jurisprudentie genoemd in noot 118 . Zie, nogmaals, voor de omschrijving van de door mij gehanteerde begrippen volledige en marginale toetsing. noot 202.

238 Zie $\boldsymbol{C}$. Houps en $\boldsymbol{P}$. Wattel, Enige grondrechtelijke aspecten van de rechterlijke beoordeling van fiscale boeten, p. 584. Zie dit artikel voor een completere behandeling van de toetsing door de rechter van de oplegging van de fiscale boete in verband met artikel 6 ECRM. 
gebaseerd is op pragmatische overwegingen ${ }^{29}$ en niet op overwegingen die erop neerkomen dat deze sancties principieel in het bestuursrecht thuishoren, is er mijns inziens geen reden, om anders dan in zaken die tot het traditionele terrein van het burgerlijk recht of het strafrecht horen, de rechterlijke toetsing te beperken tot een marginale toetsing. Dit betekent, mijns inziens, dat - tevens in overeenstemming met de onschuldpresumptie van artikel 6 lid 2 - "de betrokkene niet als "verdachte" maar eerder als eisende partij ... [wordt] behandeld", wanneer deze in beroep bij de rechter gaat. ${ }^{200}$ Daarbij zal de rechter zelfstandig onderzoek moeten kunnen doen naar de gegrondheid van de beschuldiging van overtreding van een wettelijk voorschrift en zelf moeten kunnen oordelen over de al dan niet op te leggen sanctie. Daarbij zal de rechter, aldus ook Houps en Wattel, ook zelfstandig aan beginselen van straftoemeting moeten kunnen toetsen. ${ }^{24}$ Dit kan worden afgeleid uit de overweging in de uitspraak van het Europese Hof in de zaak Le Compte, Van Leuven and De Meyere, dat de rechter zelfstandig moet onderzoeken "whether the sanction is proportionate to the fault". ${ }^{242}$

Wat betreft de administratieve besluiten, van met name de Kroon, waarbij burgerlijke rechten en verplichtingen in het geding zijn: uit de Straatsburgse jurisprudentie kan worden afgeleid, dat er weliswaar bij bestuurshandelingen, waarbij het bestuur over een beoordelingsvrijheid beschikt, geen plaats is voor een volledige toetsing van het besluit, maar de rechtmatigheid kan wel in al zijn aspecten aan een rechterlijke beoordeling onderworpen worden. Dat beroep openstaat bij "a judicial body that has full jurisdiction and does provide the guarantees of Article $6 \S 1$..." en voorts dat "the 'right to a court' and the right to a judicial determination of the dispute cover questions of fact just as much as questions of law" wil hier derhalve zeggen een "full jurisdiction" ten

239 M.W.C. Feteris, Fiscale administratieve sancties en het recht op een behoorlijk proces, pp. 33-34. Anita den Hartog, Artikel 6 EVRM: Grenzen aan het streven de straf eerder op de daad te doen volgen, pp. 268-269 noemt, onder meer, als redenen voor de overbrenging van een aantal verkeersdelicten naar de administratieve sfeer in de WAHV, het streven naar een effectievere bestrijding van de overtreding van verkeersvoorschriften door de daaraan verbonden sanctie eerder op de daad te doen volgen en het verminderen van de politiële en justitiële werklast.

240 E.A. Alkema, Het arrest-Öztürk en de vereenvoudigde afdoening van (verkeers-) overtredingen, p. 243.

241 Vergelijk $C$. Houps en $P$. Wattel, Enige grondrechtelijke aspecten van de rechterlijke beoordeling van fiscale boeten, p. 585 .

242 EHRM 23 juni 1981, Le Compte, Van Leuven and De Meyere, §51(a), p. 23. 
aanzien van de rechtmatigheid. Alleen toetsing aan het willekeurcriterium lijkt op grond van deze rechtspraak onvoldoende te zijn. ${ }^{243}$

De vraag is derhalve of de procedures voor respectievelijk (de belastingkamer van) het gerechtshof, de kantonrechter (WAHV) en de burgerlijke rechter (in verband met het Kroonberoep) aan de genoemde voorwaarden voldoen. Er vanuit gaande dat deze instanties kunnen worden beschouwd als "judicial bodies" die, althans in beginsel, onafhankelijk en onpartijdig zijn, gaat het hier - in verband met de reikwijdte van het recht op toegang tot de rechter - met name om de vraag of deze rechterlijke organen "full jurisdiction" dan wel (ten aanzien van het Kroonberoep) een bevoegdheid tot "volledige" rechtmatigheidstoetsing hebben. Vanzelfsprekend zal ook aan de andere vereisten van artikel 6 ECRM voldaan moeten worden, maar om praktische redenen zal op die eisen niet ingegaan worden.

\section{Fiscale en andere administratieve boetes}

De Hoge Raad bepaalt in zijn uitspraak van 19 juni $1985^{24}$, dat indien de rechter tot het oordeel komt dat een te hoge verhqging is spgetegr, de rechter zelfstandig een kwijtscheldingsbesluit moet nemen. Dit houdt volgens de Hoge Raad in, dat de belastingadministratie, zelfs bij voorlegging van de zaak aan de rechter, invloed blijft houden op de hoogte van het bedrag van de verhoging. Daarbij is de belastingadministratie gebonden aan, voor de belastingplichtige kenbare, vaste regels, waarvan de toepassing door de rechter wordt getoetst. De rechter is vervolgens bevoegd de verhoging te verminderen,

"... indien die regels leiden tot een verhoging welke bij afweging van de betrokken belangen in redelijkheid niet kon worden opgelegd, of anderszins in strijd is met enig beginsel van behoorlijk bestuur ..." ${ }^{245}$

Zoals moge blijken uit het voorgaande, gaat deze toetsing aan de algemene beginselen van behoorlijk bestuur mij niet ver genoeg, want er vindt

243 Zie hierboven pp. 233-234 en EHRM 28 mei 1985, Ashingdane Case, §59, p. 25; EHRM 29 april 1988, Belilos Case, \$72, p. 32 en EHRM 28 juni 1990, Obermeier Case, $\$ 70$, pp. 22-23. 
- onder meer - geen zelfstandige afweging plaats van de hoogte van de op te leggen sanctie aan de hand van beginselen van straftoemeting. ${ }^{246}$

Uit de bespreking van de uitspraak van 23 november 1983, waarin de Hoge Raad ook deze mening lijkt te zijn toegedaan, blijkt het verschil tussen marginale en volledige toetsing in dit soort zaken, ${ }^{247}$ Alhoewel artikel 6 in deze zaak niet ingeroepen, noch toegepast is, kan deze uitspraak toch een licht werpen op de rechterlijke toetsing in verband met het recht op toegang tot de rechter. De zaak betreft het cassatie-beroep van de Staatssecretaris van Financiën tegen een uitspraak van het Gerechtshof Amsterdam, waarin het Gerechtshof tot het oordeel kwam, dat de belastinginspecteur ten onrechte de opgelegde verhoging (volgens het Gerechtshof terecht vastgesteld op $100 \%$ ) slechts tot $50 \%$ van het nagevorderde bedrag heeft kwijtgescholden (op grond van artikel 18 AWR). Het Gerechtshof stelde vast dat door opzet of grove schuld van de belastingplichtige te weinig belasting was geheven. Echter, op grond van een afweging van de betrokken belangen had, aldus het Gerechtshof, de belastinginspecteur in redelijkheid niet tot zijn beslissing kunnen komen. Het Gerechtshof stelde vervolgens zelfstandig het percentage van de kwijtschelding vast op $85 \%$. De Staatssecretaris doet in cassatie beroep op de algemene beginselen van behoorlijk bestuur. De Hoge Raad merkt hierover op, dat

"... de rechter die ... na gegrondbevinding van het tegen een kwijtscheldingsbesluit van de Inspecteur ingestelde beroep, zelfstandig bepaalt in welke mate de opgelegde verhoging voor kwijtschelding in aanmerking komt niet een - door bedoelde beginselen beheerste bestuurstaak vervult, maar een rechterlijke taak, op de uitoefening waarvan niet die beginselen van toepassing zijn."

De annotator bij deze zaak merkt over deze overweging op, dat de staatssecretaris zijns inziens op het standpunt stond, dat de belastingrechter zich in principe aan de Leidraad (vermoedelijk wordt de "Leidraad

246 Zie verder de noot van Ch.J. Langereis bij dit arrest. in: Weekblad FED 1985, 644. Deze conclusie geldt vanzelfsprekend alleen de zaken met betrekking tot administratieve sancties. derhalve zaken die vallen onder "determination ... of any criminal charge"; de toetsing aan algemene heginselen van hehoorlijk bestuur in zuiver bestuurlijke zaken blijfi hierdoor onverlet.

247 HR 23 november 1988, AB 1989, 120 met noot F.H. van der Burg; BNB 1989/29 met noot J.P. Scheltens. Zie over dit arrest ook $C$. Houps en $P$. Wattel, Enige grondrechtelijke aspecten van de rechterlijke beoordeling van fiscale boeten. $p$. 584 e.v.. 
administratieve boeten 1971" of de "Leidraad administratieve boeten 1984" bedoeld) heeft dienen te houden, tenzij uitdrukkelijk wordt aangegeven dat en waarom de rechter de toepassing van de Leidraad onredelijk acht. De annotator acht dit een pleitbare stelling, maar voegt hieraan toe dat indien men "de belastingrechter, die zelfstandig de strafmaat bepaalt, als een strafrechter [ziet], dan gaat deze stelling niet op." ${ }^{248}$ Ook al zijn met betrekking tot administratieve boetes straf(proces)rechtelijke regels niet van toepassing ${ }^{299}$, de taak en werkwijze (waaronder de wijze van toetsing) van de belastingrechter ten aanzien van de fiscale boete moeten mijns inziens gezien het strafkarakter ervan - wèl vergeleken worden met die van de strafrechter. Bijloos leidt mijns inziens dan ook terecht uit de geciteerde overweging van de Hoge Raad af, dat de rechterlijke toetsing van de fiscale boete in de praktijk volledig in plaats van marginaal is. ${ }^{250}$ Deze conclusie wordt naar mijn mening versterkt door de - niet in cassatie bestreden - overweging van het Gerechtshof "dat door opzet of grove schuld van belanghebbende te weinig belasting is geheven, omdat belanghebbende begrepen moet hebben dat ...". Het Gerechtshof doet daarbij zelfstandig een uitspraak over de schuldvraag. Daarmee wordt tevens recht gedaan aan de onschuldpresumptie van artikel 6 lid 2 !

Is ten aanzien van fiscale en andere administratieve boetes (zoals die in het kader van de Wet Administratiefrechtelijke handhaving verkeersvoorschriften) sprake van een toetsing die voldoet aan de hierna te noemen voorwaarden, dan heeft de rechtzoekende aan wie de boete is opgelegd toegang tot een rechter die voldoet aan de vereisten van artikel 6 (ervan uitgaande dat de onafhankelijkheid en onpartijdigheid van de rechter en dergelijke niet ter discussie staan). De bedoelde voorwaarden zijn:

1) de rechter gaat na of de beslissing van het administratieve orgaan niet in strijd is met de wet, 2) de feiten worden vastgesteld, 3) een oordeel wordt gevormd van de overtreding, de op te leggen sanctie en het verband tussen beide, zodat - in de termen van de Raad van State - de rechter "zich ... een zodanig breed oordeel ten gronde vormt, dat hij bij betwisting van

248 AB 1989. 120 onder punt 4. Nota bene: volgens latere rechtspraak (o.a. HR 28 maart 1990, BNB 1990/194) werden de genoemde leidraden beschouwd als "recht" in de zin van artikel 99 (2) RO, en diende de rechter derhalve wel aan deze leidraden te toetsen! Zie F.J.P.M. de Haas, Het opleggen en kwijtschelden van verhogingen bij het heffen van belasting, p. 104. Inmiddels zijn deze leidraden vervangen door het Voorschrift administratieve boeten 1993 (VAB 1993), Regeling van 28 september 1992. Stcrt. 193, zoals gewijzigd bij Regeling van 7 juli 1993, Stcrt. 131.

249 Zie 0.a. HR 7 september 1988, BNB 1988/298; HR 11 oktober 1989 (r.o. 4.6), BNB 1990/87 en HR 31 januari 1990, BNB 1990/93.

250 A.W.M. Bijloos, Administratieve boeten en art. 6 EVRM in Nederland, p. 23. 
de grond van de sanctie of de zwaarte daarvan de verantwoordelijkheid voor het al dan niet bevestigen van de strafoplegging ten volle kan dragen". ${ }^{251}$ Alhoewel, de Hoge Raad dergelijke criteria in de uitspraak van 23 november 1989 niet heeft geformuleerd, wordt in deze uitspraak mijns inziens wel aan deze voorwaarden voldaan. Voor de rechtszekerheid is het wenselijk, dat de Hoge Raad ook expliciet aangeeft, dat in geval van toetsing van een beslissing van een administratief orgaan waarbij een administratieve sanctie wordt opgelegd (of een dergelijke oplegging in beroep wordt gehandhaafd), uit artikel 6 voortvloeit, dat ter garantie van het recht op toegang tot de rechter een dergelijke toetsing volledig dient te zijn.

Hoewel niet erg duidelijk, gaat de uitspraak van de Hoge Raad van 20 december 1989 in die richting. ${ }^{252}$ In deze zaak voert de belanghebbende aan dat de in artikel 27 lid 2 AWR opgenomen regeling met betrekking tot het beroep tegen een kwijtscheldingsbesluit wat betreft "major offences" in strijd is met artikel 6 ECRM, omdat deze regeling de belastingplichtige niet de mogelijkheid biedt dit besluit aan volledige rechterlijke toetsing te onderwerpen. ${ }^{253}$ De Hoge Raad acht dit betoog onjuist. Volgens de Hoge Raad maakt de hoogte van de opgelegde verhoging (derhalve in de termen van het Europese Hof in de zaak Öztürk: het zijn van "minor offence" of "major offence") voor de verenigbaarheid van de beroepsregeling met artikel 6 niets uit. Ten aanzien van de in artikel 27 lid 2 AWR opgenomen beroepsgronden bepaalt de Hoge Raad, dat deze

251 Zie het preadvies van Bijloos, Administratieve boeten en art. 6 EVRM in-Nederland, pp. 25-26. De verwijzing naar de Raad van State, ontleend aan genoemd preadvies, betreft het advies van de Raad van State over de wijziging van de Wet individuele huursubsidie, Kamerstukken II 21032 , B, p. 3 linker kolom. Zie tevens het preadvies van Bijloos voor een vollediger bespreking van administratieve sancties (ook andere dan de hier genoemde) in verband met artikel 6.

252 HR 20 december 1989, BNB 1990/102 met noot F. Ploeger.

253 Het inmiddels bij wet van 23 december 1993 (Stb. 690) vervallen artikel 27 lid 2 AWR luidde:

Het beroep kan worden ingesteld ter zake dat de inspecteur:

a. van de bevoegdheid tot het geheel of gedeeltelijk niet verlenen van kwijtschelding kennelijk tot een ander doel gebruik heeft gemaakt dan tot de doeleinden, waartoe die bevoegdheid gegeven is;

b. bij afweging van de betrokken belangen niet in redelijkheid tot het besluit heeft kunnen komen;

c. anderszins heeft besloten in strijd met enig in het algemeen rechtsbewustzijn levend beginsel van behoorlijk bestuur. 
"... de rechter ruime mogelijkheden bieden tot inhoudelijke toetsing van het besluit inzake kwijtschelding ..."

Zo steit, aldus de Hoge Raad, de grond onder b de rechter in staat "te onderzoeken of, gelet op alle naar zijn oordeel in aanmerking komende omstandigheden van het gegeven geval, de inspecteur in redelijkheid tot het besluit heeft kunnen komen". De c-grond biedt de rechter bovendien de mogelijkheid om te beoordelen of "de verhoging ... niet als onevenredig is aan te merken in verhouding tot de gedraging op grond waarvan zijn is opgelegd".

Op het eerste gezicht lijkt de Hoge Raad hier te zijn teruggekeerd naar een toetsing door de rechter aan algemene beginselen van behoorlijk bestuur, derhalve naar marginale toetsing. Nauwkeuriger lezing van de geciteerde overweging, met name van de termen "inhoudelijke toetsing" wijst erop, dat de Hoge Raad ondanks de toetsing aan algemene beginselen van behoorlijk bestuur toch een volledige toetsing noodzakelijk acht. Hiermee wordt mijns inziens het begrip "algemene beginselen van behoorlijk bestuur" opgerekt, in die zin dat in zaken van strafrechtelijke aard, namelijk die met betrekking tot administratieve sancties, de algemene beginselen een meer inhoudelijke betekenis krijgen die de rechter tot een volledige toetsing noopt. ${ }^{254}$ Vermoedelijk ziet de Hoge Raad zich tot deze - in mijn visie - "kunstgreep" genoodzaakt, omdat hij anders - gezien de eerder besproken uitspraak van 23 november 1988 - artikel 27 lid 2 AWR wegens strijd met artikel 6 ECRM buiten toepassing had moeten verklaren. Hoewel deze uitspraak wat betreft de eerbiediging van artikel 6 valt toe te juichen, verdient deze uitspraak niet bepaald een schoonheidsprijs. Op grond van de huidige wetgeving zal een dergelijke kunstgreep door de rechter niet meer nodig zijn, nu artikel 27 AWR vervallen is. Hierdoor kan de rechter voortaan een opgelegde boete volledig en zelfstandig toetsen. ${ }^{2 s s}$

De conclusie die ik uit de hierboven besproken jurisprudentie ten aanzien van fiscale boetes afleid, is dat het recht op toegang tot de rechter in

254 Vergelijk Wattel over deze uitspraak van de Hoge Raad (in zijn annotatie onder HR 18 november 1992, BNB 1993/40): "Forneel toetst de belastingrechter dus weliswaar nog steeds het besiuit van de inspecteur (aan de beginselen van behoorlijk bestuur), maar feitelijk beoordeelt hij mijns inziens direct, net als de strafrechter, het gedrag van de belastingplichtige/beboete."

255. Zie Ch.J. Langereis, Herziening van het stelsel van administratieve boeten en van het fiscale strafrecht, p. 69. 
artikel 6 de rechter noopt tot een volledige toetsing van de bestreden administratieve, maar van strafrechtelijke aard zijnde - beslissing, zij het impliciet. Uit de rechtspraak inzake fiscale of andere administratieve boetes - er is te weinig rechtspraak naar aanleiding van de WAHV, om ook maar enige conclusie te kunnen trekken omtrent de rechterlijke toetsing van de oplegging van boetes op grond van deze wet - biijkt niet van enige nadere, expliciete, afbakening van het recht op toegang tot de rechter. ${ }^{256}$

\section{Andere administratieve besluiten, zoals in Kroonberoep genomen}

De hier te behandelen uitspraken betreffen volgens de rechter besluiten die gevat moeten worden onder de term "determination of ... civil rights and obligations" in artikel 6. In al deze uitspraken wordt in navolging van het arrest van het Europese Hof in de zaak Benthem geconcludeerd, dat het Kroonberoep niet voldoet aan artikel 6. Reden hiervoor is dat de Kroon geen onafhankelijk en onpartijdig gerecht in de zin van artikel 6 is. $^{237}$ Vanzelfsprekend stammen de Koninklijke Besluiten (KB's) in deze zaken van voor de inwerkingtreding van de Tijdelijke Wet Kroongeschillen (TWK) op 1 januari 1988. ${ }^{288}$ Het belang van de uitspraken in deze zaken

256 Zie voor de bespreking van de fiscale boete in verband met de overige vereisten die artikel 6 ECRM stelt, M.W.C. Feteris, Fiscale administratieve sancties en het recht op een behoorlijk proces. Zie voor een verdergaande bespreking van de administratieve boete op grond van de WAHV in verband met artikel 6 ECRM in het algemeen en het recht op toegang tot de rechter in het bijzonder: A. den Hartog, Artikel 6 EVRM: grenzen aan het streven ..., pp. 268-297 en L.L.J. Rogier, De Wet Mulder, Artikelsgewijs commentaar op de Wet administratiefrechtelijke handhaving verkeersvoorschriften, pp. 43-48, 75-83 en 87-91.

257 O.a.: Gerechtshof Amsterdam 17 februari 1986, KG 1986, 138: HR 6 februari 1987 (ARAL-arrest), NJ 1988, 926 met noot $M$. Scheltema; AB 1987, 272 met noot F.H. van der Burg; Bouwrecht 1987, pp. 520-533 met noot N.S.J. Koeman (pp. 531-533); De Gemeentestem 1988, pp. 88-91 met noot L.J.A. Damen (pp. 90-91); HR 25 mei 1988, NJ 1988, 927; Bouwrecht 1987, p. 761; HR 25 mei 1988, NJ 1988, 928 met noot $M$. Scheltema en de noot van E.A. Alkema onder NJ 1988, 930; in verband met HR 25 mei 1988, NJ 1988, 928: Vz.ARRS 28 april 1987, Bouwrecht 1987, pp. 600601 en HR 25 mei 1988, NJ 1988, 930 met noot E.A. Alkema.

258 Wet van 18 juni 1987 , Stb. 317 ; deze wet is inmiddels vervallen door de inwerkingtreding op 1 januari 1994 van de Wet van 16 december 1993, Stb. 650: Wijzigingswet wet op de rechterlijke organisatie enz. (voltooiing eerste fase herziening rechterlijke organisatie), 4 Wijziging van bijzondere wetten in verband met de te treffen definitieve voorzieningen in kroongeschillen. Sinds de inwerkingtreding van de TWK wordt een beroep op de burgerlijke rechter in verband met het ontbreken van de onafhankelijkheid van de Kroon (op grond van de uitspraak in de Benthemzaak) niet-ontvankelijk verklaard wegens het openstaan van beroep op de Afdeling geschillen van bestuur van de Raad van State: anticiperend HR 28 april 1989, NJ 
is gelegen in de gevolgen die worden verbonden aan het niet-voldoen aan, met name, het vereiste van onafhankelijkheid. De vraag die in het navolgende opnieuw centraal gesteld wordt, is of de burgerlijke rechter in dit soort zaken een bevoegdheid tot "volledige" rechtmatigheidstoetsing heeft, dat wil zeggen of de rechter de rechtmatigheid in al zijn aspecten (derhaive niet alleen toetsing aan het willekeurcriterium) aan een rechterlijke beoordeling kan onderwerpen.

In een uitspraak van de Hoge Raad van 6 februari $1987^{259}$ gaat het om een besluit van de gemeente tot sluiting van een LPG-installatie op grond van de Hinderwet, dat door de Kroon is vernietigd. De gemeente is, terwijl het beroep tegen het besluit tot sluiting bij de Kroon aanhangig was, overgegaan tot feitelijke sluiting van de LPG-installatie. De eigenaar heeft tengevolge van die sluiting schade geleden en vordert schadevergoeding van de gemeente wegens onrechtmatige daad. De rechtbank wijst de vordering af, het Gerechtshof wijst in hoger beroep de vordering toe onder vernietiging van het rechtbankvonnis. In cassatie voert de gemeente aan, dat het Gerechtshof zich ten onrechte aan het oordeel van de Kroon in administratief beroep gebonden acht, omdat dit niet een rechterlijk oordeel is. De gemeente wijst hierbij op artikel 6 ECRM.

De Hoge Raad gaat er in zijn oordeel van uit, dat de administratiefrechtelijke beroepsgang bij de Kroon een naar intern Nederlands recht met voldoende waarborgen omklede rechtsgang is. Aan het oordeel van de Kroon komt dan ook in beginsel - in een geding voor de burgerlijke rechter - formele rechtskracht toe, wat betekent dat de burgerlijke rechter dit oordeel als juist dient te aanvaarden. En uitzondering op dit beginsel wordt volgens de Hoge Raad gemaakt, indien de "houder van de vergunning of degene die de inrichting drijft" zich erop beroept, dat de Kroon niet als een rechterlijke instantie in de zin van artikel 6 ECRM kan worden beschouwd. De burgerlijke rechter dient dan het door de Kroon besliste punt (het gaat om een rechtmatigheidsoordeel) "ten volle zelfstandig te beoordelen". In deze zaak wordt echter niet door de houder van de vergunning, maar door de gemeente een beroep op artikel 6 gedaan. Volgens de Hoge Raad komt de gemeente een dergelijk beroep niet toe. De rechtsongelijkheid (tussen enerzijds de houder van de vergunning indien die zich op artikel 6 zou beroepen en anderzijds de gemeente) die hierdoor ontstaat kan volgens de Hoge Raad worden aanvaard omdat "zij ligt besloten in de strekking van genoemd verdrag bescherming van de burger tegen de overheid - met welke strekking niet 
zou stroken de overheid, wanneer in de administratiefrechtelijke rechtsgang een voor haar ongunstige uitspraak is gevallen, bevoegd te achten de zaak ten nadele van de burger weer op losse schroeven te zetten door ter zake een nieuw, zelfstandig oordeel van de burgerlijke rechter te verlangen."

Deze zaak roept twee vragen op. Allereerst kan men zich afvragen of het gerechtvaardigd is dat de Hoge Raad de zogenaamde formele rechtskracht van de beslissing van de Kroon in stand laat indien het beroep tegen deze beslissing wordt ingesteld door een overheidsorgaan dan wel indien artikel 6 ECRM op de desbetreffende beslissing niet van toepassing is (omdat, bijvoorbeeld, geen sprake is van "civil rights and obligations").

Ten tweede, geldt de overweging van de Hoge Raad dat de rechter "het door de Kroon reeds besliste punt van geschil ten volle zelfstandig [heeft] te beoordelen" ook indien het gaat om een beslissing van de Kroon op doelmatigheidsgronden dan wel indien het niet duidelijk is of het gaat om een doelmatigheids- of rechtmatigheidsoordeel?

Ten aanzien van de eerste vraag wil ik kort zijn. De uitsluiting van het beroep van overheidsorganen op artikel 6 lijkt op het eerste gezicht acceptabel. Volgens de Hoge Raad is de rechtsbescherming die de Conventie biedt voorbehouden aan burgers. Wat betreft de gelding van grondrechten in het algemeen (vooral van vrijheidsrechten) en de eisen van onafhankelijkheid en onpartijdigheid in het bijzonder kan ik me hier wel in vinden, omdat ondanks de mogelijkheid dat een overheidsorgaan als privaatrechtelijke partij aan het rechtsverkeer deelneemt, tóch een publiekrechtelijk orgaan (zij het een rechtspersoon) blijft en derhalve niet volledig gelijkgesteld kan worden met de burger. ${ }^{260}$ Toch sluiten sommige rechten, naar mijn mening, niet per definitie uit dat zij door overheidsorganen ingeroepen kunnen worden. Mogelijke voorbeelden hiervan zouden kunnen zijn de eisen op grond van artikel 6 ten aanzien van de motiveringsplicht of het vereiste van een behandeling van de zaak binnen een redelijke termijn. Enige voorzichtigheid bij het niet laten gelden van mensenrechten voor overheidsorganen, is derhalve geboden. Het argument van de Hoge Raad, dat beroep van overheidsorganen op artikel 6 vanwege de rechtszekerheid van de burger moet worden afgewezen, is mijns inziens dan ook overtuigender.

260 Anders in HR 22 januari 1993, AB 1993, 198 (Rost van Tonningen) met noot F.H. van der Burg. Zie ook W. Hins. Uitingsvrijheid voor de Staat?!. p. 37 en met name de. mijns inziens terechte, kritiek van C.A.J.M. Kortmann, Vrijheid van meningsuiting voor de regering?. pp. 333-334 en L.F.M. Verhey, Vrijheid van meningsuiting voor de regering?, pp. $410-417$. 
Over het aanvaarden van de formele rechtskracht van uitspraken van de Kroon over besluiten waarop artikel 6 ECRM niet van toepassing is, ben ik niet onverdeeld positief. Weliswaar hebben de verdragsopstellers bewust ervoor gekozen het toepassingsgebied van artikel 6 te beperken ${ }^{261}$, maar het gevolg hiervan is wel dat er een onderscheid gemaakt wordt tussen Kroon-uitspraken waarop artikel 6 wèl en waarop artikel 6 nìet van toepassing is, en waarin derhalve respectievelijk niet en wel sprake is van formele rechtskracht. Het gevolg hiervan is weer dat in het eerste geval wel een rechtsgang naar de burgerlijke rechter openstaat en in het laatste geval niet. ${ }^{262.263}$ Van Maarseveen merkt in het NJB van 1987, mijns inziens terecht, op: "Een rechtsgang is op zichzelf wel of niet voldoende van waarborgen voorzien, dat kan niet afhangen van de aard van het geschil." ${ }^{264}$ Dit zou met zich mee moeten brengen, dat het Kroonberoep in geen enkel geval meer beschouwd kan worden als een met voldoende waarborgen omgeven rechtsgang en dat alle geschillen - waarbij eerst K.roonberoep openstond - door een onpartijdige en onafhankelijke rechter beoordeeld dienen te worden. Wèl zou - al naar gelang het soort geschil een onderscheid aangebracht kunnen worden in de aard en de mate van de toetsing. Daarover gaat de tweede vraag, die nu besproken zal worden: dient de rechter een door de Kroon reeds beslist geschilpunt volledig en zelfstandig te toetsen, ook indien het een beslissing betreft die door de Kroon op doelmatigheidsgronden is gebaseerd of indien niet duidelijk is of het gaat om een doelmatigheids- of rechtmatigheidsoordeel?

In zijn annotatie bij het Benthem-arrest merkt Hirsch Ballin op dat rechtspraak door een orgaan dat - in de termen van het arrest van het Europese Hof in de zaak Le Compte, Van Leuven and De Meyere - "has füll jurisdiction", volledige beoordeling van de feiten en het recht omvat, maar ook niet meer dan dat. Volgens hem is het niet met het karakter van

261 Zie M.L.W.M. Viering, Het toepassingsgebied van artikel 6 EVRM, pp. 44-49.

262 Zie HR 12 december 1986, NJ 1987, 381 met noot MS; HR 18 december 1987, NJ 1989. 527 met noot MS, AB 1988, 569 met noot FHvdB, De Gemeentestem 1988, nr. 6858 , p. 279 met noot L.J.A. Damen. Bouwrecht 1988, p. 367 en HR 28 april 1989, NJ 1990, 213 met noot $M S$.

263 Zie ook artikel 1 lid 2 Tijdelijke Wet Kroongeschillen, dat een aantal geschillen - onder meer betreffende besluiten van algemene strekking - uitzonderde van de rechtsgang naar de (onafhankelijke) Afdeling voor geschillen van bestuur van de Raad van State.

264 H. van Maarseveen, Kroongeschil en burgerlijke rechter, p. 140. Vgl. Koeman in zijn annotatie (in Bouwrecht 1987, pp. 531-533) bij HR 6 februari 1987, NJ 1988, 926, die opmerkt dat de waarborgen die een beroepsprocedure binnen het bestuur omgeven deze procedure nog niet tot een rechterlijke procedure maken. (punt 4) 
rechtspraak te verenigen "om aan het geschillenbeslechtend orgaan de bevoegdheid te geven zelf op grond van andere beleidsinzichten wijziging te brengen in de beslissing. " Hij wijst derhalve doelmatigheidstoetsing door de rechter af. Naar zijn mening zou het desbetreffende orgaan dan een niet-verantwoordelijk bestuursorgaan worden, hetgeen onverenigbaar met ons constitutionele recht zou zijn. Wèl acht hij het aanvaardbaar, dat aan een rechterlijk orgaan de bevoegdheid wordt toegekend om in de zaak te voorzien, dat wil zeggen een beslissing te nemen die het vernietigde besluit vervangt. ${ }^{265}$

De hierboven besproken uitspraak van 6 februari 1987 stemt hiermee overeen. De vernietiging van het desbetreffende gemeentebesluit werd door de Kroon gebaseerd op een rechtmatigheidsoverweging. De Hoge Raad oordeelt dat de rechter een dergelijk punt "ten volle [heeft] te beoordelen".

Twee uitspraken van de Hoge Raad van 25 mei 1988 verdienen in dit kader eveneens bespreking. In de eerste $z^{2} \mathbf{k}^{266}$ gaat het om een besluit van de Kroon op grond van artikel $72 \mathrm{a}$ jo. 64 jo. 14 , eerste lid Onteigeningswet (Ow) waarbij een gedeelte van een perceel, toebehorend aan eiser tot cassatie ter onteigening (door de gemeente Boxtel) wordt aangewezen. De gemeente vordert voor de Rechtbank ${ }^{267}$ dat de onteigening vervroegd wordt uitgesproken. De Rechtbank is van oordeel dat het desbetreffende onteigeningsbesluit van de Kroon in strijd met artikel 6 gegeven is, nu hiertegen geen beroep op een onafhankelijke en onpartijdige rechter openstaat. De Rechtbank acht het in dit verband daarom volstrekt onvoldoende, dat hij op grond van artikel 25 Onteigeningswet slechts aan enkele strikt formele vereisten mag en moet toetsen. Indien men wetswijziging niet kan afwachten ziet de Rechtbank met betrekking tot beroep tegen een onteigeningsbesluit twee mogelijkheden: het via artikel 94 Grondwet op grond van artikel 6 ECRM alsnog toelaten van beroep (1) bij de onteigeningsrechter (de Rechtbank) dan wel (2) bij de administratieve rechter, met name de Afdeling Rechtspraak van de Raad van State.

265 EHRM 23 oktober 1985, Benthem Case, AB 1986, 1, punt 9(e). Vergelijk M. Scheltema, Een nieuwe uitdaging voor de administratieve rechtspraak?, pp. 42-44, 46-49.

266 HR 25 mei 1988, NJ 1988, 928 met noot $M$. Scheltema.

267 Op grond van artikel 17 Ow tracht de onteigenende partij hetgeen door de Kroon ter onteigening is aangewezen, te verkrijgen bij minnelijke overeenkomst. Lukt dit niet, dan kan de onteigenende partij op grond van art. 18 Ow voor de rechtbank vorderen, dat deze de onteigening uitspreekt en het bedrag van de schadeloosstelling vaststelt. Art. $54 \mathrm{f}$ Ow regelt de vordering tot vervroegde uitspraak over de onteigening. 
De Rechtbank acht zich echter niet voldoende toegerust om een inhoudelijk oordeel te geven over bestuursbeslissingen. De Rechtbank ziet voor zichzelf als burgerlijke rechter derhalve geen taak weggelegd. Daarom stelt de Rechtbank vervolgens de verweerder in eerste instantie - in een tussenvonnis van 30 januari 1987 - in de gelegenheid de zaak aan de Afdeling Rechtspraak voor te leggen.

In haar beschikking van 28 april 1987 acht de Afdeling zich niet bevoegd om zich over het onteigeningsbesluit uit te spreken. ${ }^{268}$ Volgens de Afdeling kan de belanghebbende zich tot de burgerlijke rechter wenden ten aanzien van wie geen wettelijke beperkingen gelden als vervat in artikel 5 , aanhef en onder a, Wet Arob. Hier voegt de Afdeling aan toe, dat voorzover de Onteigeningswet aan de burgerlijke rechter beperkingen stelt bij de toetsing van de rechtmatigheid van het KB, deze rechter op grond van artikel 6 ECRM deze beperkende voorschriften ingevolge artikel 94 Grondwet (Gr.w.) buiten toepassing moet laten. Dit stelt de burgerlijke rechter in staat een inhoudelijke toetsing van het onteigeningsbesluit uit te voeren, indien hij meent dat dit door artikel 6 vereist wordt.

Kennelijk vindt de Rechtbank - in zijn eindvonnis van 2 oktober 1987 dat een inhoudelijke toetsing niet door artikel 6 vereist wordt: de Rechtbank oordeelt dat nu er een $\mathrm{KB}$ voorligt, waarvan de uitvoerbaarheid niet is geschorst, de Rechtbank zonder nadere toetsing van dat besluit hieraan uitvoering behoort te geven.

Tegen dit oordeel stelt belanghebbende beroep in cassatie in. De Hoge Raad bevestigt dat de Kroon niet kan worden beschouwd als een onafhankelijke en onpartijdige rechterlijke instantie in de zin van artikel 6 ECRM. Nu er noch beroep op de Afdeling Rechtspraak, noch op enige andere administratieve rechter openstaat,

"dient de tot het uitspreken van de onteigening geroepen rechter op grond van art. 6 van genoemd Verdrag in verband met art. 94 Gr.w., ook buiten de hem bij de Onteigeningswet opgedragen taak, de bezwaren tegen het $\mathrm{KB}$ te onderzoeken."

De toetsing door de onteigeningsrechter dient zich volgens de Hoge Raad wat betreft de afweging van de bij het besluit betrokken belangen, te beperken tot een toetsing op willekeur.

In een andere uitspraak van 25 mei 1988, ook met betrekking tot een onteigening, gaat het om een onteigeningsbesluit van de gemeenteraad dat 
bij $\mathrm{KB}$ is goedgekeurd. ${ }^{20}$ In deze zaak komt de Hoge Raad tot een soortgelijk oordeel als in de hiervoor besproken zaak. Volgens de Hoge Raad, mag de onteigeningsrechter - daar vaststaat dat de gemeenteraad noch de Kroon bij hun besluitvorming aan belanghebbende de rechtsbescherming bieden waarop hij op grond van de Conventie recht heeft - niet overgaan tot het uitspreken van de onteigening voordat hij

"zich van de - bestreden - rechtmatigheid van het besluit tot onteigening [heeft] ... vergewist."

Ten aanzien van bezwaren die zich richten tegen het bestemmingsplan dat tot de desbetreffende onteigening aanleiding geeft, overweegt de Hoge Raad het volgende. De toetsing van het al dan niet aanwezig zijn van een noodzaak, in het belang van een goede ruimtelijke ordening, tot de in het plan gegeven bestemmingen en voorschriften (artikel 10 Wet op de Ruimtelijke Ordening, WRO) evenals de toetsing in het kader van de vraag of er reden bestond tot de in artikel $11 \mathrm{WRO}^{270}$ bedoelde uitwerking of wijziging van het bestemmingsplan, dient zich te beperken tot - opnieuw een toetsing op willekeur.

Op grond van bovenstaande zaken kan worden geconcludeerd - ter beantwoording van de hierboven gestelde, tweede vraag ${ }^{271}$ - dat de Hoge Raad van opvatting is dat de rechter zich bij de toetsing van bestuursbesluiten dient te beperken tot een toetsing aan het willekeurcriterium voor zover het beleidsaspecten betreft (zoals een afweging van bij een besluit betrokken belangen, noodzakelijkheid van gegeven voorschriften of genomen maatregelen). Daar bij dit soort besluiten beleidsaspecten veelal een grote rol zullen spelen, lijkt mij een marginale toetsing aanvaardbaar. ${ }^{2 n}$ Echter, de Straatsburgse rechtspraak

269 HR 25 mei 1988, NJ 1988, 930 met noot E.A. Alkema.

270 Artikel 11 WRO is gewijzigd bij wet van 16 december 1993, Stb. 650, Wijzigingswet wet op de rechterlijke organisatie enz. (voltooiing eerste fase herziening rechterlijke organisatie), inwerkingtreding 1 januari 1994. In, onder andere, lid 6 van deze bepaling is het Kroonberoep vervangen door het beroep op de Afdeling bestuursrechtspraak van de Raad van State.

271 Deze vraag hield in of de rechter een door de Kroon reeds beslist geschilpunt volledig en zelfstandig te toetsen, ook indien het een beslissing betreft die door de Kroon op doelmatigheidsgronden is gebaseerd of indien niet duidelijk is of het gaat om een doelmatigheids- of rechtmatigheidsoordeel.

272 Vgl. de annotaties bij deze arresten. Zie verder Rb. Den Haag 6 juli 1988, NJCMBulletin 14-2 (1989), pp. 181-192 met noot G. Heerma van Voss en besproken door C.E.M. van den Boon, Een rechterlijke toetsing van de ontslagbeschikking van de 
lijkt meer te eisen dan een toetsing aan het willekeurcriterium. De rechtmatigheidstoetsing dient een toetsing aan alle criteria van rechtmatigheid te zijn, derhalve dient, bijvoorbeeld, ook toetsing aan het evenredigheidsbeginsel plaats te vinden.

De Nederlandse rechtspraak lijkt, gezien bovenstaande uitspraken ten aanzien van de toetsing door de burgerlijke rechter van bepaalde administratieve besluiten (niet zijnde administratieve boetes), een iets beperktere reikwijdte te geven aan het recht op toegang tot de rechter, door deze rechter beperktere toetsingsmogelijkheden toe te kennen ten aanzien van deze administratieve besluiten dan waartoe de Straatsburgse rechtspraak de staat lijkt te verplichten.

Wat betreft het recht op toegang tot de onafhankelijke en onpartijdige rechter heeft de bovenstaande rechtspraak grotendeels haar betekenis verloren door invoering - zoals eerder vermeld - van de Tijdelijke Wet Kroongeschillen (TWK) op 1 januari $1988 .{ }^{273}$ Ingevolge deze wet konden de onder deze wet vallende geschillen onderworpen worden aan het oordeel van de Afdeling voor geschillen van bestuur van de Raad van State. ${ }^{274}$ Alleen ten aanzien van de in artikel 1 lid 2 van die wet uitgesloten geschillen - voor zover onder het bereik van artikel 6 ECRM vallend - bleef deze rechtspraak nog van belang. ${ }^{273}$ Inmiddels is op 1 januari 1994 de Algemene wet bestuursrecht (AWB, eerste en tweede tranche) in werking getreden. Afgewacht zal moeten worden, hoe administratieve beslissingen waarop artikel 6 ECRM van toepassing is, getoetst gaan worden op grond van deze wet. ${ }^{276}$ In elk geval staat tegen de meeste - niet alle - administratieve besluiten beroep open op de administratieve kamer van de rechtbank en hoger beroep op de Afdeling

273 Zie noot 258

274 Zie echter B. van der Meulen en P.J.M. Koning in hun annotatie bij Rapp.Comm. 10 december 1992, zaak nr. 16034/90. Van de Hurk $v$. the Netherlands: "... waarom wordt zo vanzelfsprekend gevonden dat de rechtsprekende afdelingen van de Raad van State onaantastbaar zijn?" Zij wijzen onder meer op het feit dat de Raad van State één van de vaste onderdelen van de wetgevende macht is, zonder wiens advies geen voorstel wet of algemene maatregel van bestuur kan worden. Bovendien, aldus de annotatoren, heeft de Raad van State taken in de sfeer van de uitvoerende macht. Ten aanzien van de (on)afhankelijkheid van de afdelingen van de Raad van State verwijs ik naar EHRM 28 september 1995, Procola v. Licxembourg. \$45.

275 Zo ook Koeman in zijn annotatie (in Bouwrecht 1987, pp. 531-533) bij HR 6 februari 1987. NJ 1988, 926, punt 6.p. 533.

276 Op het moment waarop ik het jurisprudentie-onderzoek heb afgesloten, 1 januari 1995, waren mij nog geen uitspraken van de Afdeling Besfuursrechtspraak bekend waarin het recht op toegang tot de rechter aan de orde komt. 
Bestuursrechtspraak. van de Raad van State, welke beicle in beginsel kunnen worden beschouwd als onafhankelijke en onpartijdige instanties.

Over de onafhankelijkheid en onpartijdigheid van rechterlijke instanties in de zin van artikel 6 gaat de volgende paragraaf.

5.2 .2 .2

Een onafhankelijk en onpartijdig gerecht dat bij de wet is ingesteld

\section{Een ... gerecht dat bij de wet is ingesteld}

Uitspraken over wat volgens de Nedeillandse rechterlijke instanties moet worden verstaan onder een "gerecht" in de zin van artikel 6 lid 1 ECRM heb ik niet gevonden. Wèl heb ik éen uitspraak aangetroffen waarin een uitspraak gedaan wordt over wat moet worden verstaan onder het woord "wet" in de zinsnede "dat bij de wet is ingesteld". In de uitspraak van de Hoge Raad van 20 decennber 1991 gaat het om de tussenkomst door de president van de rechtbank op grond van artikel 34 Besluit vergoiedingen. rechtsbijstand (Moduulbesluit) in een geschil tussen een rechtshulpverlener en de griffier, omtrent de wijze van vaststelling van vergoedingen door de rechter aan toegevoegde advocaten, procureurs en gerechtsdeurwaarders. Artikel 34 Moduulbesluit is gebaseerd op artikel 25 lid 4 Wet rechtsbijstand on- en minvermogenden (WROM) ${ }^{2 \pi}$ waarin is bepaald dat bij algemene maatregel van bestuur nadere regels kunnen worden gesteld omtrent de vaststelling van de vergoedingen door de rechter. Appellant heeft in deze zaak aangevoerd dat hier geen sprake is van een procedure bij een (rechterlijke) instantie welke bij de wet is ingesteld. De Hoge Raad overweegt hieromtrent:

"De omstandigheid dat de ter zake bevoegde rechter niet in een formele wet is aangewezen maar in een algemene maatregel van bestuur die op de wet berust, brengt niet mee dat niet is voldaan aan de in art. 6 gestelde eis dat de rechterlijke instantie is 'established by law'/"etabli par la loi'." 278

Deze uitspraak is in overeenstemming met de Europese rechtspraak. In paragraaf 5.1.4.3 bleek dat het begrip "established by law" inhoudt dat de hele organisatorische structuur van zowel een categorie rechterlijke instanties als een individueel gerecht moet zijn geregeld in een formele wet 
of in een materiële wet, die op een formele wet is gebaseerd. Bovenstaande uitspraak is met deze Straatsburgse jurisprudentie in overeenstemming, omdat het hier gaat om een rechter waarvan een deel van zijn bevoegdheid is verleend bij een algemene maatregel van bestuur (het Moduulbesluit) die berust op een formele wet (de WROM) en waarvan overigens de organisatorische structuur bij wet is geregeld (zoals de Wet op de Rechterlijke Organisatie).

\section{Onafhankelijk en onpartijdig}

De eerste zaken die uitdrukkelijk gewijd zijn aan de onafhankelijkheid en onpartijdigheid van een gerecht, betreffen de Krijgsraad en het Hoog Militair Gerechtshof (HMG) ${ }^{279}$ Al deze zaken hebben dezelfde uitkomst: beide (militair)rechterlijke organen kunnen worden beschouwd als onafhankelijke en onpartijdige gerechten in de zin van artikel 6. De - op wetgeving berustende - argumenten voor deze conclusie zijn volgens de Hoge Raad:

a- dat de President van de Krijgsraad, evenals zijn plaatsvervanger voor het leven worden benoemd en de leden voor onbepaalde tijd, gedurende welke zij onafzetbaar zijn;

b. dat de President van het HMG en het andere rechtsgeleerde lid raadsheren zijn in het Gerechtshof 's-Gravenhage;

c- dat aan de militaire leden van het HMG, wanneer zij de leeftijd van zeventig jaar hebben bereikt, met ingang van het daarop volgende kalenderjaar ontslag wordt verleend;

d- dat de militaire leden geen plaats binnen de militaire hiërarchie vervullen;

e- dat deze militaire leden worden bezoldigd door de minister van Justitie (derhalve niet door de minister van defensie!);

f- dat de President en de leden van de Krijgsraad en het HMG voordat zij in functie treden, moeten zweren of beloven zich oprecht eerlijk en onpartijdig te zullen gedragen;

g-dat zij met betrekking tot hun beslissingen aan niemand gehoorzaamheid of verantwoording verschuldigd zijn.

279 HR 6 januari 1981, NJ 1981, 515 met noot G.E. Mulder, MRT 1981, pp. 535-553 met naschrift W.H. Vermeer; HR 9 september 1986, NJ 1987, 259 met noot A.C. 't Hart; HR 22 december 1987, DD 88.171 (1988, p.486); HR 9 februari 1988, NJ 1989, 109; HR 17 mei 1988, NJ 1989, 230. 
Bovendien oordeelt de Hoge Raad in de uitspraak van 6 januari $1981^{280}$, dat de stelling dat een gerecht waarvan niet-juristen mede deel uitmaken niet een "competent court" in de zin van artikel 5 lid 1(a) ECRM zou zijn, geen steun vindt in het Verdrag. Mijns inziens zal de Hoge Raad - gezien het enkele maanden later gewezen arrest van het Eliropese Hof in de zaken Le Compte, Van Leuven and De Meyere en het arrest in de zaak Albert and Le Compte - dezelfde conclusie moeten trekken ten aanzien van een "independent and impartial tribunal" in de zin van artikel 6. Anders dan in deze uitspraken van de Hoge Raad, is het echter wel wenselijk bij een toetsing aan artikel 6 dat de Hoge Raad ingaat op de omstandigheid, dat het organiek dezelfde commandant is die de vervolging gelast en die de militaire leden van de Krijgsraad benoemt. In latere zaken is deze omstandigheid voor zover mij bekend niet meer aangevoerd. Was dit wel het geval geweest, dan had hier met name getoetst moeten worden aan de eis die de Europese Commissie ten aanzien van onafhankelijkheid stelt, namelijk dat sprake moet zijn van "a sufficient organisational separation from the executive branch"281 en het adagium "justice must not only be done, but also seen to be done" dat een vast begrip in de Europese rechtspraak is. ${ }^{232}$ Desondanks kan mijns inziens het eindoordeel van de Hoge Raad juist geacht worden, omdat weliswaar vóór de benoeming van de militaire leden, deze onder het gezag van de desbetreffende commandant vallen, maar ná die benoeming de bovenstaande garanties (a $\mathrm{t} / \mathrm{m} \mathrm{g}$ ) voor onafhankelijkheid en onpartijdigheid van het gerecht gelden.

De Hoge Raad maakt in de bovenstaande zaken niet uitdrukkelijk een onderscheid tussen onafhankelijkheid enerzijds en onpartijdigheid anderzijds. Bekijken we de in de rechtspraak aangevoerde argumenten voor het oordeel dat sprake is van een onafhankelijk en onpartijdig gerecht, dan kunnen de gronden $\mathrm{a}, \mathrm{b}, \mathrm{c}$, e en $\mathrm{g}$ gezien worden als voorwaarden voor onafhankelijkheid en de gronden $d$ en $f$ als vereisten voor onpartijdigheid. De criteria voor onafhankelijkheid zien meer op de benoeming, onafzetbaarheid, ontslag, bezoldiging en het ontbreken van een verantwoordingsplicht, terwijl de overige criteria dienen ter voorkoming van vooringenomenheid en partijdigheid. Zoals ik echter constateerde bij de bespreking van de Europese rechtspraak over deze begrippen, bestaat

280 Zie noot 279.

281 Rapp.Comm. 3 juli 1985, Case of Ettle a.o., §95, p. 27.

282 Zie o.a. EHRM 17 januari 1970, Delcourt Case, \$31, p. 17. Zie ook EHRM 28 juni 1984, Case of Campbell and Fell, §81, pp. 40-41; EHRM 22 oktober 1984. Sramek Case, §42, p. 20 en EHRM 29 april 1988, Belilos Case, §66-67, pp. 29-30 en hierboven pp. 240-241. 
er een nauwe relatie tussen beide en heeft met name de (on)afhankelijkheid van een orgaan invloed op de (on)partijdigheid ervan. ${ }^{283}$

De overige gevonden uitspraken betreffen alle de onpartijdigheid van de rechter. Daarbij heb ik overigens slechts één uitspraak aangetroffen waarin ook een verwijzing is te vinden naar de subjectieve benadering/test van de (on)partijdigheid van de rechter, naast een objectieve test als in de hierna te bespreken uitspraken. De Hoge Raad overweegt in een uitspraak van 30 november 1990": "Volgens vaste rechtspraak van het Europese Hof voor de rechten van de mens gaat het bij onpartijdigheid in de zin van deze verdragsbepaling niet alleen om de persoonlijke instelling van de betrokken rechter (subjectieve benadering, $C S$ ): mede op grond van de voor het ambt van rechter geldende benoembaarheidseisen en de gehanteerde selectiecriteria moet tot op bewijs van het tegendeel worden aangenomen dat de rechter zich bij zijn taakvervulling los weet te maken van eventuele vooringenomenheid." De bewijslast van een persoonlijke bevooroordeeldheid van de rechter ligt derhalve volgens de Hoge Raad op de rechtzoekende. Dit is in overeenstemming met de Europese rechtspraak, waarin - zoals besproken in paragraaf 5.1.4.5 - is uitgesproken dat "... the personal impartiality of each member must be presumed until there is proof to the contrary". ${ }^{285}$ De Raad vervolgt met de objectieve benadering: "Van een gebrek aan onpartijdigheid kan echter, geheel afgezien van de persoonlijke instelling van de betrokken rechter, ook sprake zijn indien bepaalde feiten of omstandigheden grond geven te vrezen dat het een rechter in die omstandigheden aan onpartijdigheid ontbreekt." De Hoge Raad concludeert vervolgens dat een rechter zich een dergelijk geval van een heslissing van de hoofdzaak zal moeten onthouden, omdat rechtzoekenden in het rechterlijk apparaat vertrouwen moeten kunnen stellen en onder omstandigheden rekening gehouden zal moeten worden met de uiterlijke schijn. Dit stemt overeen met de uitspraak van het Europese Hof dat "(w)hat is at stake is the confidence which the courts must inspire in the public in a democratic society" en dat "even appearances may be of a certain importance". ${ }^{2 a 6}$ De vraag is nu, in

283 Zie hierboven pp. 374-375.

284 HR 30 november 1990, NJ 1992, 94 met noot HJS onder Ktg. 's-Hertogenbosch 31 juli 1990. NJ 1992, 95.

285 Zie EHRM 23 juni 1981. Case of Le Compte, Van Leuven and De Meyere, $\$ 58$. p. 25. Zie ook de overige arresten genoemd in noot 174.

286 EHRM 1 oktober 1982. Piersack Case, $\$ 30($ a), p. 14 en de overige in noot 176 genoemde rechtspraak. 
hoeverre de Nederlandse rechtspraak ten aanzien van de onpartijdigheid van de rechter nog meer met de Straatsburgse overeenkomt. ${ }^{23}$

Allereerst zal hier ingegaan worden op de uitspraak van de Hoge Raad van 15 maart $1988 .^{\text {as }}$ In deze zaak gaat het om een raadsheer van het Gerechtshof 's-Hertogenbosch die eerder in de zaak is opgetreden als rechter-commissaris. De betrokken raadsheer heeft als rechter-commissaris bij de Rechtbank Maastricht de bewaring van de verdachte bevolen, maar heeft geen gerechtelijk vooronderzoek verricht. Het Gerechtshof overwoog hieromtrent, dat het onderzoek in deze zaak (met de betrokken raadsheer) kon worden voortgezet omdat deze raadsheer "geen onderzoek heeft verricht in deze zaak." De raadsheer was volgens het Gerechtshof als rechter-commissaris slechts bij het verhoor van de verdachte ten behoeve van de inbewaringstelling aanwezig geweest en heeft daarop de bewaring van verdachte bevolen. Volgens de Hoge Raad bedoelde het Gerechtshof hiermee, dat door de verrichtingen van de betrokken raadsheer als rechtercommissaris in deze zaak "de rechterlijke onpartijdigheid bij de behandeling ter terechtzitting in hoger beroep niet in gevaar werd gebracht." Het cassatieberoep wordt vervolgens verworpen.

Zoals in paragraaf 5.1.4.5 uit de Europese rechtspraak werd afgeleid, is functie-cumulatie van rechters op zichzelf nog niet genoeg om te kunnen spreken van een objectief gerechtvaardigde vrees dat aan de onpartijdigheid van een rechter gebreken kleven. Het hangt van de specifieke omstandigheden van het geval af, of hiervan sprake is. Dergelijke omstandigheden doen zich, bijvoorbeeld, voor wanneer een bepaalde rechter eerder in de procedure betrokken is geweest in een functie die niet met waarborgen zoals onafhankelijkheid, onpartijdigheid en openbaarheid is omgeven. Ook kan een rol spelen dat de betrokken rechter in die eerdere functie moest beslissen over punten die overeenkomen met kwesties waarover hij als rechter moet oordelen, zoals de schuldvraag. Ter voorkoming van de hier bedoelde "objectief gerechtvaardigde vrees" voor gebreken aan de rechterlijke onpartijdigheid kan artikel $268 \mathrm{~Sv}$ uitkomst bieden $^{289}$, dat bepaalt dat de rechter die als rechter-commissaris enig

287 Zie hieromtrent, bijvoorbeeld, ook M.S. Groenhuijsen. (On)partijdige rechtspraak?, De Nederlandse strafrechtspleging na Hauschildt, pp. 57-60.

288 HR 15 maart 1988. NJ 1988, 847 met noot Th.W. van Veen.

289 Zie HR 27 november 1990, NJ 1991, 220 met noot Th.W. van Veen: "Art. 268 Sv strekt ertoe te voorkomen dat een rechter-commissaris, ten aanzien van wie de vrees zou kunnen bestaan dat hij op grond van zijn in de zaak reeds verrichte onderzoek niet meer geheel onbevangen staat tegenover de tot de verdachte gerichte beschuldiging, meewerkt aan het onderzoek ter terechtzitting omtrent de gegrondheid van die beschuldiging en aan de op de grondslag van dat onderzoek te geven uitspraak. "HR 
onderzoek in de zaak verricht heeft, niet aan het onderzoek op de terechtzitting deel mag nemen. Echter, zoals ook het Gerechtshof in deze zaak constateerde, is dit artikel in hoger beroep op grond van artikel 415 Sv niet van toepassing. Toch leek het Gerechtshof, en ook de Hoge Raad, aan artikel $268 \mathrm{~Sv}$ te toetsen, oordelend dat geen strijd met de eis van onpartijdigheid aanwezig is omdat de betrokken raadsheer als rechtercommissaris "geen onderzoek in deze zaak had verricht." Kennelijk wordt hier de term "onderzoek" uitgelegd als "gerechtelijk vooronderzoek", want de rechter-commissaris zal voorafgaande aan de bewaring toch altijd nog enige onderzoekshandelingen verrichten. Klaarblijkelijk acht de Hoge Raad dit soort onderzoekshandelingen onvoldoende voor de conclusie dat de desbetreffende raadsheer partijdig zou (kunnen) zijn. Myjer constateert mijns inziens echter terecht, dat bij een verhoor - door de rechtercommissaris - gedane verklaringen een belangrijke rol kunnen blijven spelen in het verdere onderzoek. ${ }^{290}$ Daarom meen ik dat het door het Gerechtshof en de Hoge Raad in de hierboven besproken zaak geformuleerde standpunt niet veralgemeend zou moeten worden. Overeenkomstig de Europese rechtspraak zou per geval onderzocht moeten worden in hoeverre de rechter-commissaris onderzoekswerkzaamheden heeft verricht die van invloed zouden kunnen zijn op zijn (on)bevangenheid ten aanzien van de schuldvraag op het moment dat de zaak ter terechtzitting wordt onderzocht en beoordeeld.

Hetzelfde commentaar zou kunnen worden geleverd ten aanzien van de rol van de kinderrechter. De Kinderrechter bij de rechtbank Rotterdam ${ }^{291}$ oordeelt op 15 augustus 1991 dat een rechter niet onpartijdig is, die 1) als kinderrechter was belast met de behandeling van de civiele ondertoezichtstelling van de verdachte; 2) als rechter-commissaris de vordering tot inbewaringstelling behandelde; 3) als kinderrechter in de raadkamer betrokken was bij de behandeling van de vordering tot gevangenhouding en 4) de verlenging daarvan. Ten aanzien van 1) is de kinderrechter van mening dat deze taak van geheel andere aard is dan de beoordeling van een strafzaak. Met betrekking tot het tweede en derde punt stelt de kinderrechter, dat bij een beslissing over inbewaringstelling en

30 juni 1992, NJ 1993, 194 met noot Sch. voegt daar aan toe: "Nu het ter terechtzitting gevoerde verweer zich beperkte tot een beroep op schending van art. $268 \mathrm{~Sv}$ behoefde het hof niet uitdrukkelijk te overwegen dat te dezen aan de eis van berechting door een "impartial tribunal" ... was voldaan. Het Gerechtshof was wel gehouden dit punt ambtshalve te onderzoeken."

290 Vgl. E. Myjer, Een nietige rechter-commissaris in kinderstrafzaken?, p. 59. Zie ook G.J.M. Corstens, De onpartijdige strafrechter, pp. 178-182.

291 Rb.(kinderrechter) Rotterdam 15 augustus 1991, NJ 1991, 847. Deze uitspraak is in hoger beroep bevestigd. 
gevangenhouding geoordeeld wordt of er ernstige bezwaren tegen verdachte bestaan, waarmee de rechter wel aangeeft dat zich niet het geval voordoet dat redelijkerwijs niet te verwachten is, dat de rechter die ten gronde over de zaak moet oordelen, bewezen zal achten dat verdachte het feit heeft begaan. Hiermee geeft de rechter echter niet te kennen "dat zij als rechter in de hoofdzaak, tot de conclusie zal komen dat de verdachte het feit heeft begaan. Veeleer gaat het om de beslissing of er bij de gegeven stand van zaken op het eerste oog voldoende ernstige bezwaren bestaan voor de verdenking." Wat betreft punt 4 , stelt de kinderrechter vast dat hierbij de ernst van het feit waarop de vervolging betrekking heeft, wordt gewogen en dat niet vooruitgelopen wordt op een mogelijke bewezenverklaring. De kinderrechter stelt derhalve in zijn algemeenheid dat een kinderrechter die als rechter-commissaris respectievelijk als kinderrechter in de raadkamer oordeelt over respectievelijk de inbewaringstelling en de gevangenhouding van een verdachte (en de verlenging daarvan) niet onpartijdig is. Naar eventueel aanwezige bijzondere omstandigheden van het geval wordt niet gekeken, wat juist bij deze rechter wenselijk is, aangezien de vermenging van taken van de kinderrechter voor velen een grote zorg is met het oog op de rechterlijke onpartijdigheid. ${ }^{202}$ Het is namelijk mogelijk dat de kinderrechter in verschillende hoedanigheden en in verschillende stadia aan een procedure deel kan nemen. ${ }^{293}$ Doordat de kinderrechter in een procedure diverse

292 Zie E. Myjer, Een nietige rechter-commissaris in kinderstrafzaken; $T . M$. Schalken, Jeugdstrafrecht russen welzijn en de eis van een behoorlijke rechtspleging (Artikel 6 Europees Verdrag), pp. 245-249 en M.L.C.C. De Bruijn-Lïckers, Het jeugdstrafprocesrecht en de "De Cubber-case", pp. 569-573.

293 Onder meer de volgende rollen kunnen door de kinderrechter in de procedure worden vervuld:

rol van de kinderrechter bij de vervolging:

- bij een onvoorwaardelijk sepot dient de Officier van Justitie (OvJ) het gevoelen van de kinderrechter in te winnen (493 lid $1 \mathrm{~Sv}$ );

- bij een voorwaardelijk sepot behoeft de OvJ de machtiging van de kinderrechter (493 lid 2 Sv);

- bij vervolging tegen het advies van de kinderbescherming in, moet eerst overleg met de kinderrechter plaatsvinden alvorens de zaak aanhangig gemaakt kan worden (499 Sv);

vervolging vindt in eerste aanleg voor de kinderrechter plaats (500 lid $1 \mathrm{~Sv}$ ); verwijzing naar de meervoudige kamer kan alleen met toestemming van de kinderrechter (500 lid $2 \mathrm{~Sv}$ ), terwijl die kinderrechter in het laatste geval verplicht deelneemt aan het onderzoek ter terechtzitting (500e Sv). 
functies vervult en daarbij uitgebreide bevoegdheden heeft, komt het zeer vaak voor, dat de kinderrechter over zijn eigen beslissingen een oordee] zal moeten vellen dan wel een beslissing in een zaak zal moeten maken op grond gegevens die hij zelf in het vooronderzoek heeft verzameld. Ten aanzien van de kinderrechter kan derhalve met recht betwijfeld worden of hij onbevangen staat tegenover een zaak die hij moet beoordelen. Ofwel in de termen van de Straatsburgse rechtspraak: er zou sprake kunnen zijn van een objectief gerechtvaardigde vrees dat aan de onpartijdigheid van een kinderrechter gebreken kleven.

Door de zogenaamde Commissie Anneveldt is - zonder dat artikel 6 in haar overwegingen werd betrokken - wijziging van het jeugdstrafprocesrecht bepleit omdat de positie van de kinderrechter zich niet verdraagt met de onafhankelijkheid van de rechterlijke macht. ${ }^{29}$ Ook diverse auteurs hebben zich in deze zin uitgelaten. ${ }^{295}$ Men zou hierbij onder andere kunnen denken aan het wegnemen van de uitzonderingen op de artikelen 21 lid 4, 168 en 268 Sv en aan het schrappen van de rol van de kinderrechter bij beslissingen ten aanzien van de vervolging. In wetsvoorstel 21327 inzake de wijziging van het Wetboek van Strafrecht, het Wetboek van Strafvordering en andere wetten in verband met de

rol van de kinderrechter bij het gerechtelijk vooronderzoek:

- in afwijking van artikel 170 lid $1 \mathrm{~Sv}$ treedt de kinderrechter op als rechter= commissaris (494 Sv) en verricht het gerechtelijk vooronderzoek (496 Sv).

rol van de kinderrechter bij de voorlopige hechtenis:

- de kinderrechter treedt op als rechter-commissaris (494 Sv) en beslist in die hoedanigheid over toepassing van voorlopige hechtenis (bewaring: $63 \mathrm{~Sv}$ );

de kinderrechter treedt in afwijking van artikel 21 lid $2 \mathrm{~Sv}$ op als raadkamer en beslist als zodanig over de gevangenhouding (derhalve daarbij oordelend over zijn eigen bevel tot bewaring als rechter-commissaris, 65 lid $1 \mathrm{~Sv}$ ), over de verlenging daarvan ( 66 lid $3 \mathrm{~Sv}$ ) en over de opheffing van de voorlopige hechtenis (69 Sv).

\section{rol van de kinderrechter bij het onderzoek ter terechtzitting:}

- de kinderrechter neemt, ook indien hij enig onderzoek in de zaak heeft verricht. aan het onderzoek ter terechtzitting deel omdat artikel $268 \mathrm{~Sv}$ niet van toepassing is verklaard $(500 \mathrm{~d} \mathrm{~Sv})$.

294 Rapport van de Commissie herziening strafrecht voor jeugdigen (Commissie Anneveldt), eindrapport "Sanctierecht voor jeugdigen", Den Haag 1982, p. 22 e.v..

295 Zie opnieuw E. Myjer, Een nietige rechter-commissaris in kinderstrafzaken, p. 60; T.M. Schalken, Jeugdstrafrecht russen welzijn en de eis van een behoorlijke rechtspleging, pp. 248-249 en M.L.C.C. De Bruijn-Lückers, Het jeugdstrafprocesrecht en de "De Cubber-case", p. 573. 
herziening van het strafrecht voor jeugdigen worden dit soort wijzigingen inderdaad voorgesteld. ${ }^{206}$

In verschillende andere uitspraken lijkt inderdaad van geval tot geval bekeken te worden of er sprake is van rechterlijke onpartijdigheid. Zo overweegt de Hoge Raad in een uitspraak. van 14 mei 1991: "De enkele betrokkenheid van een rechter bij beslissingen over de voorlopige hechtenis van de verdachte tast in het algemeen zijn onpartijdigheid in de zin van de door het middel bedoelde verdragsbepalingen niet aan. Bijzondere omstandigheden die in dit geval tot een ander oordeel hadden moeten leiden blijken niet uit de stukken van het geding. "20n Of in een uitspraak van 26 mei 1992: "Bij de beoordeling van een beroep op het ontbreken van onpartijdigheid van de rechter in de zin van art. 6 eerste lid EVRM dient voorop te staan dat een rechter uit hoofde van zijn aanstelling moet worden vermoed onpartijdig te zijn, tenzij zich uitzonderlijke omstandigheden voordoen die zwaarwegende aanwijzingen opleveren voor het oordeel dat een rechter jegens de verdachte een vooringenomenheid koestert, althans dat bij de verdachte dienaangaande bestaande vrees objectief gerechtvaardigd is. "29s

Wat zijn nu volgens de Nederlandse rechters voorbeelden van dergelijke bijzondere omstandigheden of uitzonderlijke omstandigheden die zwaarwegende aanwijzingen (etc.) opleveren? In de zaak van 14 mei 1991 wordt slechts vastgesteld dat het feit dat twee van de rechters die het vonnis van de rechtbank hebben gewezen tevoren over de voorlopige

296 Zie voor de op dit moment meest recente tekst van de voorgestelde wijzigingen het Tweede nader gewijzigd voorstel van wet, vergaderjaar 1993-1994, Eerste Kamer, nr. 78. Zie ook: J.W. Fokkens, Het nieuwe jeugdstrafprocesrecht, pp. 224-226; A.T. Vos, Een wankel evenwicht tussen rechtsbescherming en pedagogische aanpak, pp. 227-232; het commentaar van de Studiekring Familie- en Jeugdrechtspraak van de Nederlandse Vereniging voor Rechtspraak op de Memorie van Antwoord en het gewijzigd wetsvoorstel 21327, in: FJR, afl. 10 (1992), pp. 233-238 en E. Myjer, De onpartijdige kinderrechter, annotatie bij EHRM 24 augustus 1993, Nortier Case, pp. $989-990$.

297 HR 14 mei 1991, NJ 1991, 695 met noot 't Hart; eerder al in soortgelijke zin: HR 26 februari 1991, NJ 1991, 509 met noot Th.W. van Veen. Zo ook HR 13 oktober 1992, NJ 1993, 142 en HR 29 juni 1993, NJ 1993, 692 met noot 't Hart.

298 HR 26 mei 1992, NJ 1992, 676 met noot 't Hart; zie ook E. Myjer, Strafrecht en Mensenrechten, NJCM-Bulletin 17-5 (1992), pp. 519-521. Overigens ging het in deze zaak om een rechter die eerder over medeverdachten oordeelde en niet om functie-cumulatie in een zaak tegen dezelfde verdachte. Zie voor hetzelfde citaat ook HR 16 juni 1992, NJ 1992, 819; HR 30 juni 1992, NJ 1993, 194 met noot Sch.; HR 29 september 1992, NJ 1993, 58 met noot Kn. en HR 18 januari 1994, FED 1994, 437 met noot M.W.C. Feteris. 
hechtenis hebben geoordeeld, níet een bijzondere omstandigheid oplevert. In de zaak van 30 juni 1992 bepaalt de Hoge Raad dat het feit, dat betrokken rechter in een soortgelijke zaak tegen de verdachte een getuige heeft gehoord die ook in de onderhavige zaak is opgetreden, niet de bedoelde zwaarwegende omstandigheden oplevert. ${ }^{299}$

Een uitspraak van de Hoge Raad van 13 november 1990 betreft een kinderrechter, die eerst als rechter-commissaris is opgetreden en naderhand als president van de meervoudige kamer de zaak heeft behandeld. ${ }^{300}$ De Hoge Raad overweegt ten eerste dat aan het onpartijdigheids-vereiste niet is voldaan "indien de verdachte redelijkerwijze in de gegeven omstandigheden reden kan hebben gehad te vrezen dat een van de aan het onderzoek ter terechtzitting deelnemende rechters de vereiste onpartijdigheid miste." Vervolgens stelt de Raad vast, dat moet worden aangenomen dat dit het geval is indien "een van die rechters voordien, hetzij als rechter-commissaris in het kader van een gerechtelijk vooronderzoek dan wel anderszins gedurende het voorbereidend onderzoek, met dezelfde zaak bemoeiingen heeft gehad die gericht waren op het verzamelen van bewijsmateriaal."

In een uitspraak van de: Hoge Raad van 18 januari 1994 komt de Raad tot het oordeel dat sprake is van een omstandigheid op grond waarvan moet worden geconcludeerd dat niet is voldaan aan het vereiste van onpartijdigheid. Deze omstandigheid is, dat de rechter die als voorzitter van het Gerechtshof Amsterdam verzoeker tot cassatie bij verstek heeft veroordeeld, na terugverwijzing door de Hoge Raad (naar aanleiding van een tegen die veroordeling met succes ingesteld cassatieberoep), opnieuw als voorzitter van het Gerechtshof deel uitmaakt. ${ }^{30 r}$

Uit de bovenstaande rechtspraak blijkt, dat de bijzondere of zwaarwegende omstandigheden die leiden tot de conclusie dat sprake is van een objectief gerechtvaardigde vrees dat aan de onpartijdigheid van een rechter gebreken kleven, niet gauw aanwezig worden geacht.

Tot slot moet hier nog worden vermeld dat, volgens de Hoge Raad in een uitspraak van 30 november 1990 , "(w)raking ... het middel is dat pp. ten dienste staat om het hun ingevolge onder meer art. 6 EVRM toekomende

299 Zie noot 298. Zie ook Rb. Leeuwarden 20 september 1993, NJ 1994, 327, waarin de rechtbank nog een aantal omstandigheden noemt die níet beschouwd kunnen worden als de hierbedoelde bijzondere omstandigheden.

300 HR 13 november 1990, NJ 1991, 219 met noot Th.W. van Veen; BNB 1991/134; FED 1991, 246.

301 HR 18 januari 1994, FED 1994, 437. 
recht op een onpartijdige rechter af te dwingen. "302 In deze zaak is door de Hoge Raad uitgesproken, dat artikel $30 \mathrm{Rv}$ - waarin limitatief een aantal wrakingsgronden worden opgesomd - niet meer zodanig kan worden uitgelegd dat de in die bepaling genoemde gevallen, waarin wraking kan worden toegewezen, als uitputtend moeten worden beschouwd. Uit de rechtsontwikkeling sinds de totstandkoming van artikel $30 \mathrm{Rv}$ en uit artikel 6 ECRM kan worden afgeleid dat ook op andere gronden een verzoek om wraking kan worden toegewezen. Eenzelfde redenering geldt indien een regeling met betrekking tot wraking van rechters ten aanzien van een bepaald soort zaken geheel ontbreekt. Dit is het geval in de zaak waarop de uitspraak van de Hoge Raad van 20 februari 1991 betrekking heeft. ${ }^{\text {jos }}$ Deze zaak betreft een opgelegde fiscale boete en de desbetreffende wet is de Wet administratieve rechtspraak belastingzaken (WARB). De Hoge Raad vernietigt in deze zaak een beslissing van het Gerechtshof Arnhem omtrent een verzoek om wraking van de voorzitter van de meervoudige belastingkamer: deze rechter heeft namelijk deelgenomen aan de beraadslaging over het verzoek om wraking en heeft meebeslist over dit verzoek. De voorzitter had volgens de Hoge Raad zich van de behandeling van het verzoek tot wraking moeten onthouden totdat de meervoudige kamer hierover een beslissing zou hebben genomen. Dit vloeit, aldus de Raad, voort uit de eisen van een behoorlijke rechtspleging die meebrengen dat een rechter wiens wraking is voorgesteld op grond van feiten en omstandigheden die het vormen van een onpartijdig oordeel zouden kunnen belemmeren, niet medewerkt aan de beslissing daarover. Voorzover het gaat om een belastingaanslag waarin een verhoging (fiscale boete) is begrepen vindt dit steun in artikel 6 ECRM omdat het dan gaat om een "determination of ... any criminal charge against him ...".

Bezien we de schaarse rechtspraak ten aanzien van de onafhankelijkheid en onpartijdigheid van de rechter, dan kan geconstateerd worden dat de Hoge Raad ten aanzien van de Krijgsraad en het Hoog Militair Gerechtshof voldoende garanties in de wet aanwezig acht voor de conclusie dat deze instanties onafhankelijk en onpartijdig zijn. Deze garanties zien op de benoeming, onafzetbaarheid, ontslag, bezoldiging en het ontbreken van een verantwoordingsplicht, en dienen ter voorkoming van vooringenomenheid en partijdigheid. De Hoge Raad formuleert niet in algemene zin criteria waaraan een rechterlijk orgaan moet voldoen, wil sprake zijn van

302 HR 30 november 1990, NJ 1992, 94; zie ook Rb. Arnhem 22 maart 1990, NJ 1990. 671 .

303 HR 20 februari 1991, NJ 1991, 463 met noot $M S$. 
verenigbaarheid met artikel 6 , maar de rechtspraak ten aanzien van de Krijgsraad en het HMG geeft daartoe wel ruimschoots aanwijzingen.

Ten aanzien van de partijdigheid kan uit de rechtspraak worden afgeleid, dat de Hoge Raad gevaar voor de rechterlijke onpartijdigheid aanwezig acht, indien een rechter in een eerder stadium van de procedure bepaalde onderzoekswerkzaamheden heeft verricht. ${ }^{304}$ Dit vloeit behalve uit artikel 6 ECRM, ook voort uit artikel $268 \mathrm{~Sv}$. Onder deze "onderzoekswerkzaamheden" valt in het algemeen niet de taak van de rechter-commissaris ten aanzien van de voorlopige hechtenis. Functiecumulatie is op zichzelf niet genoeg om te concluderen tot partijdigheid van een rechter. Er zal sprake moeten zijn van bijzondere of zwaarwegende omstandigheden die twijfel ten aanzien van de onpartijdigheid doen rijzen. Van een dergelijke omstandigheid is sprake indien een rechter hetzij als rechter-commissaris in het kader van een gerechtelijk vooronderzoek dan wel anderszins gedurende het voorbereidend onderzoek, met dezelfde zaak bemoeiingen heeft gehad die gericht waren op het verzamelen van bewijsmateriaal. In dat geval kan de verdachte redelijkerwijze reden hebben gehad te vrezen dat een van de aan het onderzoek ter terechtzitting deelnemende rechters de vereiste onpartijdigheid miste.

Al met al is de Straatsburgse rechtspraak geleidelijk aan tot de Hoge Raad doorgedrongen. De criteria zoals die door het Europese Hof in de zaken Piersack, De Cubber, Hauschildt en Demicoli zijn ontwikkeld om vast te stellen of sprake is van een onpartijdige rechter, behoren nu - meestal in een gelijkluidende formulering of in een formulering van soortgelijke strekking - tot de vaste rechtspraak van de Hoge Raad.

Beschouwen we tot slot de Nederlandse jurisprudentie ten aanzien van artikel 6 ECRM, dan kan ik niet anders dan tot de slotsom komen, dat het aantal zaken waarin door de Nederlandse rechter criteria - voor de afbakening van het recht op toegang tot een (onafhankelijke, onpartijdige en bij wet ingesteld) gerecht - worden geformuleerd of daarvoor aanknopingspunten worden geboden, helaas (voor degene die naar dat soort criteria op zoek is) nog niet al te groot is. Met name de rechtspraak ten aanzien van de (on)partijdigheid van de rechter toont echter aan dat de Hoge Raad zich wel degelijk - en in steeds grotere mate - met de

304 Dit gevaar wordt, bijvoorbeeld, niet aanwezig geacht in het geval dat de ProcureurGeneraal bij een gerechtshof "de ruimte waarin zich de leden van het Hof tijdens een onderbreking van het onderzoek ter terechtzitting bevinden (heefi betreden)" met het doel de leden van het gerechtshof enige brieven van de raadslieden in de onderhavige en andere zaken te overhandigen. HR 22 juni 1993, NJ 1994, 498 met noot $C$. 
Straatsburgse rechtspraak rekening houdt en veelal de criteria van het Europese Hof overneemt. Het is te hopen dat een dergelijke ontwikkeling zich ook ten aanzien van de andere onderdelen van het recht op toegang tot een onafhankelijk en onpartijdig bij de wet ingesteld gerecht, voor zal doen.

In de volgende paragraaf zal de Europese en Nederlandse rechtspraak waarin wèl criteria voor de afbakening van het recht op toegang tot een (onafhankelijke, onpartijdige en bij wet ingesteld) gerecht zijn ontwikkeld of toegepast, worden geëvalueerd.

\subsection{Evaluatie; een vergelijking van de criteria van de Nederlandse met de Straatsburgse instanties voor de afbakening van het recht op toegang tot de rechter onder artikel 6 lid 1 ECRM}

$\mathrm{Na}$ de behandeling in de vorige paragrafen van zowel de Straatsburgse als de Nederlandse jurisprudentie ten aanzien van het recht op "access to court" onder artikel 6 lid 1, is het noodzakelijk de balans op te maken ten behoeve van de beantwoording van de in paragraaf 5.2 gestelde vraag, of de Nederlandse rechterlijke instanties criteria voor de afbakening van dit recht hebben ontwikkeld en zoja, of deze criteria overeenstemmen met de door de Straatsburgse organen ontwikkelde criteria.

Bestudering van de rechtspraak naar aanleiding van het recht op toegang tot de rechter wees uit, dat een uitspraak over de reikwijdte van dit recht alleen gedaan kan worden wanneer daarbij ook de reikwijdte van de beperkingsmogelijkheden in aanmerking genomen wordt. Het recht op toegang tot de rechter wordt namelijk niet in artikel 6 lid 1 letterlijk toegekend, maar wordt uit de eerste zin van deze bepaling impliciet afgeleid. Aangezien geen enkel recht absoluut is ${ }^{305}$, moeten er derhalve ook beperkingen op het recht op toegang tot de rechter bestaan. De eerste zin van artikel 6 (1) bevat echter - afgezien van de expliciet opgenomen voorwaarden voor toepasselijkheid van deze bepaling ("In the determination of his civil rights and obligations or of any criminal charge against him ...") - geen uitdrukkelijke beperkingsmogelijkheden op de in deze bepaling vervatte rechten. Beperkingen op het recht op "access to court" moeten derhalve - evenals het recht zelf - impliciet of inherent zijn. 
De bespreking van de reikwijdte van het recht op toegang tot de rechter bracht voorts aan het licht, dat het de Staat niet alleen de verplichting oplegt zich te onthouden van ongeoorloofde beperkingen op de toegang tot de rechter maar ook een verplichting tot het verzekeren van een effectief recht op toegang. Naast een negatieve verplichting omhelst het recht op "access" derhalve een positieve verplichting voor de Staat. Voor de vaststelling van de reikwijdte van het recht op toegang moesten om die reden de grenzen van beide - uit dit recht voor de Staat voortvloeiende soorten verplichtingen worden onderzocht.

Verder werd ingegaan op de rol van de rechtzoekende zelf of de reikwijdte van zijn recht op toegang door middel van "afstand van recht". In dit verband is het met name van belang tot welke grens een Verdragsstaat een beroep kan doen op een gedane afstand van recht. Dit betreft de vraag wanneer een gedane afstand van recht rechtsgeldig is.

Tot slot is voor de reikwijdte van het recht op "access to court" ook van belang wat moet worden verstaan onder "court". In paragraaf 5.1.4.1 werd beargumenteerd, dat bij het recht op "access to court" uitgegaan moet worden van het recht op toegang tot een "independent and impartial tribunal established by law". Voor de afbakening van het recht op "access to court" is het derhalve van belang na te gaan wat de reikwijdte is van de garantie van "onafhankelijkheid" en "onpartijdigheid" van een "gerecht dat bij wet is ingesteld".

In paragraaf 5.1.2 kwam naar voren dat volgens het Europese Hof het recht op "access to court" gefundeerd moet worden op de tekst van artikel 6 lid 1 zèlf, gelezen in de context van deze bepaling en met het oog op het voorwerp en doel van de Conventie en in het licht van "general principles of law". Van groot gewicht is het beginsel van de "rule of law". Maar niet alleen bij de fundering van het recht op "access to court" is dit beginsel belangrijk, ook ten aanzien van de afbakening van dit recht speelt de "rule of law" een grote rol. Als criterium voor de reikwijdte-bepaling van het recht op toegang is de rule of law natuurlijk uitermate vaag. We zien dan ook in de Europese jurisprudentie, dat aan de hand van dit beginsel van de rule of law een antal nauwkeuriger criteria is ontwikkeld.

Zo zien we in de rechtspraak van de Commissie dat het willekeurcriterium is geformuleerd ten einde een arbitraire beperking van het recht op toegang te voorkomen. Zo oordeelt de Commissie in de Ashingdane-zaak dat 
"[a] real threat to the rule of law could emerge if a State were arbitrarily to remove the jurisdiction of civil courts to determine certain classes of civil action. ${ }^{306}$

\section{Ook het Hof bepaalt dat}

"[i]t must still be established that the degree of access afforded under the national legislation was sufficient to secure the individual's 'right to a court", having regard to the rule of law in a democratic society. "307

Vervolgens geeft het Hof aan dat de Staat het - niet absolute - recht op toegang mag reguleren en daarbij een beoordelingsvrijheid heeft. Het Hof stelt echter ook de grenzen van die beleidsmarge van de Staat vast. De beperkingen op het recht op "access" mogen de kern van dit recht niet aantasten, moeten een legitiem doel nastreven en moet sprake zijn van een redelijke proportionaliteit tussen de beperking en het daarmee nagestreefde doel. ${ }^{108}$ Het bovenstaand citaat geeft mijns inziens aan dat deze criteria als nadere invulingen van de "rule of law" kunnen worden gezien. Datzelfde zal vermoedelijk ook gelden voor de andere criteria die, in andere zaken, ter afgrenzing van de beoordelingsvrijheid van de Staat bij de beperking van het recht op toegang - zijn geformuleerd, zoals de voorwaarde dat de regeling waarin de beperking is opgenomen duidelijk en coherent moet zijn en een eerlijke afweging van openbare en individuele belangen moet garanderen en dat het recht op toegang "clear, practical and effective" moet zijn. ${ }^{309}$

Ook ten aanzien van de rechtsgeldigheid van een gedane afstand van het recht op toegang tot de rechter speelt de rule of law een cruciale rol. Volgens het Hof vloeit uit een internationaal instrument dat gebaseerd is op "freedom and the rule of law", zoals de Conventie, voort, dat bij het aanvaarden van een schikking (waarbij afstand van recht op toegang tot de rechter wordt gedaan) geen sprake mag zijn van dwang." ${ }^{31 \prime}$ Deze voorwaarde voor de rechtsgeldigheid van een afstand van recht lijkt te

306 Rapp.Comm. 12 mei 1983, Ashingdane Case, $\$ 92$, p. 41.

307 EHRM 28 mei 1985, Ashingdane Case, §57, p. 24.

308 EHRM 28 mei 1985, Ashingdane Case, \$57, pp. 24-25. Zie noot 68 voor gelijkluidende uitspraken.

309 Zie pp. 338-341 voor een korte samenvatting van de Europese jurisprudentie ten aanzien van beperkingen op het recht op toegang tot de rechter.

310 EHRM 27 februari 1980, Deweer Case, \$49, pp. 25 e.v.. 
worden uitgebreid in latere uitspraken. Uit deze zaken blijkt dat de afstand van recht door de rechtzoekende uit vrije wil gedaan moet zijn, ofwel uitdrukkelijk, ofwel stilzwijgend. ${ }^{31}$ Dit is mijns inziens meer dan de afwezigheid van dwang (negatieve wil): de afstand van recht moet in overeenstemming zijn met de (positieve) wil van de betrokken persoon. Deze wil moet voorts op een onmiskenbare, ondubbelzinnige wijze blijken." ${ }^{312}$

In de zaak Airey stellen Commissie en Hof een ondergrens aan het recht op "access to court": dit recht moet namelijk effectief zijn. Hieruit leiden de Europese organen af, dat ten einde een effectief recht op toegang te verzekeren, de Staat verplicht kan zijn rechtsbijstand te verschaffen. Van de specifieke omstandigheden zal afhangen hoever deze verplichting reikt. De Staat heeft beleidsvrijheid bij de keuze van de middelen waarmee hij een effectief recht op toegang wil bereiken. ${ }^{313}$ Niet in alle gevallen behoeft derhalve gratis rechtsbijstand worden verschaft. Naar mijn mening dient ook dit criterium van "effectiviteit" van het recht uit de rule of law te worden afgeleid. Het recht op toegang is zoals geconstateerd werd, gebaseerd op onder meer de rule of law en indien dit recht illusoir ineffectief - zou zijn, dan is dit in strijd met de rule of law.

Dat het gerecht in de zin van het recht op "access to court" een instantie moet zijn, die onafhankelijk, onpartijdig en bij wet ingesteld is, kan ook worden gebaseerd op de rule of law. De Commissie bepaalt in de Sramekzaak, dat het een essentieel kenmerk van een "tribunal" is, dat

"... its decisions should not be primarily left to its discretion, but should be arrived at in orderly proceedings conducted on the basis of the rule of law. "314

De eisen die het Hof stelt aan een "tribunal" betreffen de onafhankelijkheid en onpartijdigheid van het orgaan en (andere) procedurele waarborgen, waarvan er verschillende in artikel 6 zijn vervat. ${ }^{315}$ Gezien het

311 Zie o.a. EHRM 23 juni 1981, Case of Le Compte, Van Leuven and De Meyere, $\$ 59$, p. 25 .

312 Zie o.a. EHRM 23 mei 1991, Oberschlick Case, \$51, p. 23.

313 EHRM 9 oktober 1979, Airey Case, \$§22-26, pp. 12-16.

314 Rapp. Comm. 8 december 1982, Sramek Case, \$71, p. 31. Deze opvatting van de Commissie wordt bevestigd door het Hof in EHRM 22 oktober 1984. Sramek Case, §36, p. 17.

315 Zie 0.a. EHRM 23 juni 1981, Le Compte, Van Leuven and De Meyere, \$55, p. 24. 
bovenstaand citaat kunnen deze eisen ook worden gebaseerd op de rule of law. Dit beginsel speelt derhalve ook een rol bij de afbakening van de genoemde procedure-eisen. We zien dit onder andere bij de onafzetbaarheid van de rechter als voorwaarde voor zijn onafhankelijkheid, ten aanzien waarvan de Commissie vaststelt, dat

$"$... according tot the principles of the rule of law in democratic states ... the irremovability of judges during their term of office .... is a necessary corollary of their independence from the Administration and thus included in the guarantees of Article 6 (1) of the Convention. "316

Hoewel de andere criteria ${ }^{317}$, die ter afgrenzing van de vereisten die aan een "court" - in de zin van "access to court" - worden gesteld, niet uitdrukkelijk worden afgeleid uit de rule of law, kan mijns inziens worden angenomen dat dit wel impliciet het geval is, aangezien de rule of law tevens de basis is voor de bedoelde vereisten (onafhankelijkheid, onpartijdigheid etc.).

Kortom: uit de Straatsburgse jurisprudentie kan worden afgeleid dat het recht op "access to court" gebaseerd kan worden op, onder meer, de rule of law en dat dit beginsel ook dient ter afbakening van de verplichtingen (negatieve en positieve) die voor de Staat uit dit recht van de burger voortvloeien. Het beginsel van de rule of law is echter een dermate vaag afbakeningscriterium, dat in de rechterlijke praktijk op basis van dit beginsel concretere criteria zijn geformuleerd, die de rechter meer houvast geven bij de interpretatie en toepassing van het recht op "access to court" in een concreet geval. Zoals aan het eind van de bespreking van de

316 Rapp.Comm. 12 oktober 1978, Zand Case, $\$ 80$, p. 82.

317 Met andere criteria wordt, onder meer, gedoeld op: de duur en wijze van benoeming van een rechter, de bezoldiging en het ontslag van een rechter, een voldoende organisatorische scheiding tussen het gerecht en het bestuur of één van de partijen bij de zaak, de leden van het gerecht staan in hun rechtsprekende taak niet onder instructie of in een hiërarchisch ondergeschikte positie van het bestuur of de partijen (criteria t.a.v. de onafhankelijkheid); de persoonlijke overtuiging van een bepaalde rechter in een bepaalde zaak (subjectieve test), de garanties die een bepaalde rechter biedt om enige twijfel aan zijn onpartijdigheid uit te sluiten (objectieve test): aanwezigheid van een objectief gerechtvaardigde vrees: een bepaalde rechter is eerder in de procedure betrokken geweest in een functie die niet met waarborgen zoals onafhankelijkheid etc. is omgeven en/of moest in die eerdere functie beslissen over punten die overeenkomen met kwesties waarover hij als rechter moet oordelen, zoals de schuldvraag (criteria t.a.v. de onpartijdigheid). Zie respectievelijk de paragrafen 5.1.4.4, pp. 365-375 (samenvatting pp. 372-375) en 5.1.4.5, pp. 375-385 (samenvatting pp. 384-385). 
Europese jurisprudentie ten aanzien van beperkingen op het recht op "access" in paragraaf 5.1.3.1 (pp. 340-341) werd geconstateerd, vertonen de criteria met betrekking tot de aan deze beperkingen gestelde grenzen grote overeenkomsten met de criteria die zijn ontwikkeld ten aanzien van de beperkingsclausules in de tweede leden van de artikelen 8 tot en met 11 vain de Conventie.

De Nederlandse jurisprudentie geeft een aanmerkelijk minder helder beeld. Over de basis van het recht op toegang tot de rechter is niets in de rechtspraak terug te vinden, hetzelfde geldt voor overwegingen ten aanzien van inherente beperkingen, afstand van recht en de betekenis van het begrip "court" in "access to court". In de jurisprudentie ten aanzien van beperkingen op het recht op toegang tot de rechter - voornarnelijk betrekking hebbend op de rechterlijke competentie - worden nauwelijks criteria ter afbakening van het recht op toegang geformuleerd of toegepast.

Alleen ten aanzien van termijnoverschrijding in verband met beroep of bezwaar tegen een opgelegde fiscale boete is een criterium ontwikkeld aan de hand waarvan kan worden vastgesteld of de termijnoverschrijding de rechtzoekende kan worden tegengeworpen en daarmee zijn toegang tot de rechter kan wordeo geblokkeerd. Het gaat hierhji sw de vraag af se termijnoverschrijding de belastingplichtige kan worden aangerekend of niet. Hiermee wordt een grens gesteld aan de mijns inziens legitieme en met de Europese jurisprudentie ${ }^{3 / 8}$ verenigbare beperking (het stellen van tijdslimieten) op de toegang tot de rechter. Het hierboven weergegeven criterium geeft naar mijn mening uitdrukking aan het door het Europese Hof aan een beperking gestelde eis van proportionaliteit tussen de beperking en het daarmee nagestreefde doel. Hoewel er op geen enkele wijze in deze zaak verwezen wordt naar de Europese jurisprudentie, is het geformuleerde criterium hiermee derhalve wel in overeenstemming. Het criterium is echter - zoals geconstateerd in paragraaf 5.2.1.1 - dermate casuïstisch, dat het in gevallen buiten het bestuursrecht geen dienst kan doen.

Uit de schaarse Nederlandse rechtspraak ten aanzien van het verzekeren van een effectief recht op toegang tot de rechter blijkt het volgende. In de enige zaak ten aanzien van het recht op rechtsbijstand in verband met artikel 6 , hanteerde de rechter als criterium voor de vaststelling of sprake is van een voldoende verzekering van een effectief recht op toegang, of de 
eigen bijdrage geen onaanvaardbare belemmering voor de toegang vormt. ${ }^{39}$ De rechter kijkt echter alleen naar de hoogte van het bedrag en houdt geen rekening met de specifieke (financiële) omstandigheden van die rechtzoekende. Op zich is het in overeenstemming met de Europese jurisprudentie om de vraag of sprake is van een onaanvaardbare belemmering van de toegang tot de rechter, als criterium te hanteren voor de afbakening van een effectief recht op toegang te hanteren. Nadere invulling van dit criterium op grond van de zaak Airey zou echter met zich brengen, dat rekening wordt gehouden met de specifieke omstandigheden van het geval. Dat gebeurt in de bedoelde Nederlandse zaak niet. Anders is dit in een aantal zaken ten aanzien van de mogelijkheid voor de tegenpartij in een geding om van de eisende partij te vorderen dat deze vooraf zekerheid stelt voor de kosten van de procedure ${ }^{320}$ en in één zaak met betrekking tot de betaling van griffierechten. ${ }^{31}$ Zoals echter al eerder is geconstateerd, is een criterium volgens welk rekening gehouden wordt met de specifieke omstandigheden van het geval, zeer handzaam voor de rechter, maar biedt nauwelijks houvast voor de rechtzoekende.

Ten aanzien van het vereiste van onafhankelijkheid van de rechter zijn in de Nederlandse rechtspraak geen expliciete criteria ontwikkeld of toegepast. Wel zijn in de rechtspraak ten aanzien van de Krijgsraad en het Hoog Militair Gerechtshof aanwijzingen te vinden met betrekking tot de voorwaarden waaraan een onafhankelijk (en onpartijdig) gerecht moet voldoen. ${ }^{322}$ Wat betreft de onpartijdigheid van de rechter is een toenemende invloed van de Straatsburgse rechtspraak op die van de Nederlandse rechterlijke instanties merkbaar. De criteria die ten aanzien van de onpartijdigheid van de rechter worden gehanteerd, vertonen steeds grotere overeenkomsten met de in Straatsburg ontwikkelde criteria. ${ }^{323}$

De Nederlandse rechtspraak - ten aanzien van het recht op toegang tot een onafhankelijk en onpartijdig, bij de wet ingesteld gerecht - overziende, is wat betreft de formulering en toepassing van afbakeningscriteria teleurstellend te noemen. De benadering van de Nederlandse rechterlijke instanties is zeer casuïstisch. Grotendeels is de Nederlandse jurisprudentic wèl in overeenstemming met de Europese, maar naar de uitspraken van de Straatsburgse organen wordt slechts mondjesmaat verwezen. Mijns inziens

319 Pres.Rb. Amsterdam 26 januari 1984, KG 1984, 111.

320 Zie de in noten 221,222 en 224 genoemde zaken.

321 Pres.Rb. Assen 21 maart 1994, FED 1994, nr. 399, pp. 1769-1771.

322 Zie de in noot 279 genoemde uitspraken.

323 Zie noot 317 en p. 437. 
440 AFBAKENING: JURISPRUDENTIE NAAR AANLEIDING VAN ART, 6 ECRM

zou het de rechtszekerheid bevorderen, wanneer de Nederlandse rechter die in verband met het recht op toegang tot de rechter moet toetsen aan artikel 6 ECRM, duidelijk de reikwijdte van dit recht zou aangeven, alvorens tot toepassing ervan over te gaan. De Europese rechtspraak is naar mijn mening voldoende uitgewerkt om de Nederlandse rechter hierbij tot richtsnoer te dienen. 


\section{Afbakening van de rechten in de Grondwet van 1983; jurisprudentie naar aanleiding van de artikelen 1, 6 lid 1, 7 leden 1 en 3 en artikel 9 lid 1 Grondwet}

In de voorgaande hoofdstukken werd de afbakening van enkele verdragsrechtelijke rechten onder de loep genomen. In dit hoofdstuk zal onderzocht worden of de rechterlijke instanties bij de interpretatie van de grondrechten die zijn opgenomen in hoofdstuk I van de Grondwet (1983), criteria hebben ontwikkeld ter afbakening van deze rechten. Gaat de rechter anders te werk bij de interpretatie van grondwettelijke grondrechten dan bij de verdragsrechtelijke rechten of is de wijze van afbakening van de rechten vergelijkbaar? Om de omvang van het in dit hoofdstuk te verrichten jurisprudentieonderzoek niet al te veel te laten uitdijen, is voor het onderzoek van een beperkt aantal grondwetsartikelen gekozen. Het eerste artikel dat onderzocht zal worden is artikel 1 Grondwet in paragraaf 6.1. Dit artikel is uitgekozen, omdat het niet voorzien is van een beperkingsclausule. Bovendien kan het in dit artikel vervatte discriminatieverbod, zoals in paragraaf 3.2.6 (onder het kopje gedragscodes) is gesteld, ook als grens voor de beperkingsbevoegdheid van de staat ten aanzien van andere rechten gehanteerd worden. Daarna zullen de rechten die zijn opgenomen in de eerste leden van de artikelen 6, 7 en 9 en het derde lid van artikel 7 in paragraaf 6.2 onder de loep genomen worden, omdat deze rechten voorzien zijn van dezelfde beperkingsclausule, luidende "behoudens ieders verantwoordelijkheid volgens de wet". Enerzijds kan dan bekeken worden of er een verschil bestaat tussen de reikwijdteafbakening van een recht zonder beperkingsclausule (artikel 1) en van rechten met deze specifieke beperkingsclausule, anderzijds kan binnen deze groep artikelen onderzocht worden of er verschillen in de wijze van begrenzing van de rechten bestaan ondanks dat ze voorzien zijn van dezelfde beperkingsclausule.'

Aangezien het hier gaat om de rechterlijke afbakening van de grondrechten zoals die zijn opgenomen in de Grondwet, zal slechts waar dat nodig is aandacht besteed worden aan de wetgeving, die op basis van deze grondwettelijke grondrechten tot stand is gekomen dan wel is gewijzigd. Dit zal met name het geval zijn waar er onvoldoende jurisprudentie voorhanden is om conclusies te kunnen trekken met

1 Dit wil, overigens, niet zeggen dat uit een onderzoek in te stellen naar rechten die weer van andere beperkingsmogelijkheden zijn voorzien, zoals bijvoorbeeld de artikelen 8 en 10 tot en met 13 Grondwet, geen interessante resultaten te verwachten zouden zijn. 
betrekking tot de vaststelling van de reikwijdte van het desbetreffende recht. Opnieuw zal aan het eind van de bespreking van deze jurisprudentie een evaluatie volgen.

\subsection{De rechtspraak met betrekking tot artikel 1 Grondwet}

Artikel 1 van de Grondwet luidt:

Allen die zich in Nederland bevinden, worden in gelijke gevallen gelijk behandeld. Discriminatie wegens godsdienst, levensovertuiging, politieke gezindheid, ras, geslacht of op welke grond dan ook, is niet toegestaan.

Bezien we de rechtspraak naar aanleiding van artikel 1 dan kan geconstateerd worden dat er weliswaar een ruime hoeveelheid uitspraken voor handen is waarin dit artikel wordt ingeroepen dan wel toegepast, maar slechts een beperkt aantal uitspraken met betrekking tot de afbakening van het in dit artikel opgenomen gelijkheidsbeginsel en discriminatieverbod. De relevante uitspraken zullen hieronder worden besproken. De behandeling van de reikwijdte-afbakening van artikel $1 \mathrm{zal}$ als volgt plaatsvinden. Eerst zal ingegaan worden op de gelijkheid van gevallen, voorts op de ongelijke behandeling van die gevallen - die gerechtvaardigd moet worden - en daarna de behandeling van ongelijke gevallen. Voorts zal de werking van het gelijkheidsbeginsel behandeld worden in verband met het afwijken van vast overheidsbeleid en verschillen in beslissingen over dezelfde materie door verschillende overheidsorganen. Tenslotte zal kort aandacht besteed worden an een meer dogmatische benadering van de toetsing aan het gelijkheidsbeginsel, zoals verwoord door Timmermans. ${ }^{2}$ Deze benadering geeft een voorbeeld van een wijze van toetsen die een nadrukkelijkere vaststelling van de reikwijdte van het gelijkheidsbeginsel inhoudt. Hierna volgt de bespreking van het discriminatie-verbod. Achtereenvolgens komen daarbij aan bod: de pejoratieve betekenis van het discriminatie-verbod, de zwaarte van de toetsing en verschillen tussen non-discriminatiegronden daarbij. Kort zal stilgestaan worden bij het onderwerp indirect onderscheid, daarna zal het verschil tussen de termen onderscheid en discriminatie besproken worden; ook het voorstel dat heeft geleid tot de Algemene wet gelijke behandeling komt daarbij aan de orde. Voorts wordt de jurisprudentie in verband met 
het verschil tussen het gelijkheidsbeginsel en het discriminatie-verbod behandeld. Tot slot zullen de afzonderlijke non-discriminatiegronden aan bod komen. Aan het einde van deze paragraaf zal getracht worden in hoofdlijnen aan te geven hoe de rechterlijke afbakening van artikel 1 Grondwet vornn heeft gekregen.

\subsubsection{Gelijke gevallen}

Ten aanzien van de gelijkheid van gevallen wordt er in de kamerstukken betreffende de grondwetsherziening in $1983^{3}$ en in de literatuur' terecht op gewezen, dat geen enkel geval volkomen gelijk of ongelijk aan een ander geval is. Wanneer het recht een kwestie regelt, abstraheert het van bepaalde niet relevant geachte verschillen, waardoor bepaalde gevallen als gelijk beschouwd kunnen worden. Ongelijk zijn dan gevallen die van elkaar afwijken op grond van een wèl relevant geacht verschil. Niet relevant geachte overeenkomsten tussen die gevallen doen dan niet ter zake.' Om gevallen met elkaar te kunnen vergelijken - Timmermans spreekt van een vergelijkbaarheidstoets ${ }^{6}$ - dient een differentiatie-criterium gekozen te worden. Hoe algemener dit differentiatie-criterium is, hoe groter de groep gevallen is die aan elkaar gelijk zijn. Aan de hand van het criterium "mens" kunnen bijvoorbeeld veel meer gevallen aan elkaar gelijk gesteld worden dan op grond van het criterium "eigenaar van een vakantiehuisje in de Algarve".?

Het differentiatie-criterium wordt gekozen op grond van de doelstelling van de in het geding zijnde regeling, het differentiatie-doel. De wetgever is vrij in de keuze van een differentiatie-doel maar dit doel moet wel

3 Nader rapport bij wetsvoorstel 13872, Verklaring dat er grond bestaat ..., Tweede Kamer, in: Algehele grondwetsherziening, deel Ia Grondrechten, p. 85.

4 Zie o.a. M.C. Burkens, Gelijke behandeling, pp. 58-65; G.J.H. van Hoof en A.Ph. Jaspers, Over gelijkheid: enige aspecten van rechterlijke toetsing aan het gelijkheidsbeginsel, pp. 143-145.

5 Zie noot 4. Zie ook P.W.C. Akkermans, Artikel 1 Grondwet, pp. 43-44: "Het gaat hierbij om (on)gelijke gevallen en (on)gelijke behandeling vanuit bepaalde gezichtspunten. Heel wel denkbaar is dat categorieën personen in vele opzichten ongelijk zijn, maar dat zij vanuit sommige gezichtspunten zo in de termen van 'gelijke gevallen' te beschrijven zijn dat daarbij dan gelijke behandeling geboden is." Zo ook (van voor de grondwetsherziening): 1.P. Asscher-Vonk, Wat is discriminatie?, p. 635 linker kolom, bovenaan. Zie verder Th.A. van Baarda, Oordeelsvorming in casus van botsende grondrechten, pp. 214-218.

6 C.W.A. Timmermans, Verboden discriminatie of (geboden) differentiatie, pp. 432 433. Zie verderop in paragraaf 6.1.4.

7 M.C. Burkens, Gelijke behandeling, pp. 59-60; G.J.H. van Hoof en A.Ph. Jaspers, Over gelijkheid, p. 143. 
zakelijk verantwoord zijn, anders is er sprake van willekeur. ${ }^{8}$ Van Hoof en Jaspers voegen hier terecht aan toe dat bij toepassing van een differentiatie-criterium het differentiatie-doel dient te worden geëxpliciteerd.' Zonder de vermelding van het differentiatie-doel van een regeling kan de aanvaardbaarheid van een differentiatie-criterium moeilijk of niet getoetst worden.

Een goed voorbeeld van een zaak waarin de gelijkheid van gevallen getoetst wordt treffen we aan in de uitspraak van de Rechtbank Zwolle van 21 mei $1985 .{ }^{10}$ Het gaat in deze zaak om de vraag of een huwelijk volgens zigeunertraditie met een huwelijk in de zin van artikel 1947 lid 1 BW (oud, vervallen met ingang van 1 april 1988) gelijk moet worden gesteld. Volgens de rechtbank is een dergelijk zigeunerhuwelijk niet zonder meer gelijk te stellen met een concubinaat of een burgerlijk huwelijk. De rechtbank is van oordeel dat dit huwelijk als een bijzondere samenlevingsvorm op zijn merites moet worden beoordeeld en acht het doorslaggevend of de partners in een dergelijke samenlevingsvorm volgens hun eigen normen en waarden met elkaar de "hoogste graad van lotsverbondenheid zijn aangegaan" en of die lotsverbondenheid in hun eigen kring als samenlevingsvorm volledig erkend wordt. De rechtbank overweegt vervolgens dat

"[u]itgaande van de bedoeling die de wetgever met artikel 1947 lid 1 BW heeft gehad, te weten het uitsluiten in een civiele procedure van getuigenissen van personen die al te zeer met (de belangen van) een procespartij moeten worden vereenzelvigd, zulks vooral ook met het oog op de vereiste scherpte in de bewijsvoering in civiele zaken, en gelet op het ... ontwikkelde criterium, ... de Rb van oordeel [is] dat het huwelijk volgens zigeunertraditie te dezen met een huwelijk in de zin van vorenbedoelde wetsbepaling moet worden gelijkgesteld."

In deze zaak vergelijkt de rechtbank het voorliggende geval met andere gevallen aan de hand van het differentiatie-criterium "huwelijk volgens zigeunertraditie" met betrekking tot de doelstelling van de in het geding zijnde wetsbepaling. De rechtbank komt tot de conclusie dat in dit geval

8 M.C. Burkens, Gelijke behandeling, p. 60. Zie ook het Nader rapport bij wetsvoorstel 13872, Tweede Kamer, in: Algehele grondwetsherziening, deel la Grondrechten, p. 85.

9 G.J.H. van Hoof en A.Ph. Jaspers, Over gelijkheid, p. 144.

10 Rb. Zwolle 21 mei 1985, NJ 1986, 116. 
sprake is van gelijke gevallen. Dat betekent dat in dit geval het bedoelde differentiatie-criterium niet gebruikt mag worden."

De hiervoor besproken zaak betreft de relatering van een differentiatiecriterium aan een differentiatie-doel, ter bepaling van (on)gelijkheid van gevallen. De navolgende uitspraak geeft een voorbeeld met betrekking tot de vraag welke punten, waarin gevallen van elkaar afwijken, relevant zijn voor de vaststelling of sprake is van (on)gelijke gevallen die (on)gelijk behandeld moeten worden. In een uitspraak in kort geding van 11 mei 1994 wordt om schorsing gevraagd van een besluit waarbij de erkenning van een automobielbedrijf (verleend op grond van artikel $9 g$ Wegenverkeerswet, WVW) om Algemene Periodieke Keuringen (APK) te verrichten tijdelijk wordt ingetrokken (sanctie op grond van artikel 9i lid 2 sub a WVW). ${ }^{12}$ Eiseres voert aan dat de Minister van Verkeer en Waterstaat bij de oplegging van de sanctie ten onrechte geen rekening heeft gehouden met het verschil in gevolgen dat oplegging van een dergelijke sanctie met zich brengt, al naar gelang het een grote dan wel een kleine APK keuringsinstantie betreft. Het sanctie-beleid van de Minister is er slechts op gericht om in gevallen waarin dezelfde overtreding is begaan, een even zware sanctie op te leggen. De rechtbank-president bepaalt dat dit onvoldoende is. Volgens de president voldoet verweerders sanctiebeleid niet omdat het niet rekening houdt met de economische gevolgen van de oplegging van de sanctie voor de erkenninghouder, waardoor "gelijke overtredingen ongelijk gesanctioneerd (worden) en ... het beleid derhalve ook in strijd (is) met het gelijkheidsbeginsel".

Het differentiatie-doel is hier - zo neem ik aan - gelegen in de gelijke bestraffing van gelijke overtredingen. Om dezelfde (even zware) sanctie op te kunnen leggen (dit wil zeggen, de gevallen gelijk te behandelen), dienen volgens deze uitspraak derhalve niet alleen de overtredingen gelijk te zijn, maar ook de gevolgen van de op te leggen sanctie. Met andere woorden, relevant voor de bepaling van gelijkheid van de gevallen is zowel de aard van de overtreding als de ernst van de gevolgen van een bepaalde op te

11 In het overzicht van Tj. Gerbranda en M.Kroes (Grondrechten evaluatie-onderzoek, Documentatierapport - 1, pp. 184-199) staan diverse voorbeelden van zaken waarin, in meer of mindere mate gemotiveerd de (on)gelijkheid van gevallen wordt getoetst.

12 Pres. Rb. Rotterdam 11 mei 1994, KG 1994, 248. Zie voorts o.a. CRvB 14 maart 1991, TAR 1991, 105 met noot G.L. Coolen waarin de verschillen tussen beroepsmilitairen en dienstplichtigen in het algemeen voldoende zijn om te concluderen tot ongelijke gevallen, echter wanneer de vrijheid van godsdienst in het geding is blijken deze verschillen niet relevant (genoeg) te zijn, dan is in beginsel sprake van gelijke gevallen; Pres.Rb. Haarlem 4 juli 1994, KG 1994, 322 (geen toetsing aan art. $1 \mathrm{Gw}$ ) waarin, zij het impliciet, blijkt dat geen sprake is van gelijke gevallen. 
leggen sanctie naar aanleiding van die overtreding. In casu, ging het wèl om dezelfde overtreding, maar waren de gevolgen van een bepaalde sanctie voor grote en kleine keuringsinstanties niet dezelfde en diende derhalve niet een even zware sanctie opgelegd te worden. Het waren ongelijke gevallen en deze dienden dan ook ongelijk behandeld te worden. De Minister had ongelijke gevallen gelijk behandeld. Dit had als gevolg dat voor dezelfde overtreding verhoudingsgewijs een zwaardere sanctie werd opgelegd. Om die reden spreekt de President in bovenstaand citaat van het ongelijk sanctioneren van gelijke overtredingen.

Overigens kan zich de situatie voordoen, dat aanvankelijk bepaalde gevallen niet als gelijk werden beschouwd, maar dat in die opvatting verandering is opgetreden ten gevolge van maatschappelijke ontwikkelingen. Het is dan aan de rechter te bepalen, vanaf wanneer sprake is van gelijke gevallen en derhalve vanaf wanneer die gevallen gelijk behandeld moeten worden. De toepasselijkheid van het gelijkheidsbeginsel wordt derhalve voor de desbetreffende gevallen in tijd begrensd. Een voorbeeld van een dergelijke situatie doet zich voor in een aantal uitspraken van de Centrale Raad van Beroep van 13 november 1986. ${ }^{13}$ Het gat hier om de vraag of bepaalde voor gehuwde militairen getroffen voorzieningen mogen worden onthouden aan een ongehuwde militair die met een partner samenwoont. Alhoewel de ambtenarenrechter naar de opvatting van de Raad niet de plaats van de wet- of regelgever of van het bestuur mag gaan innemen, moet hij besluiten omtrent de genoemde voorzieningen wel toetsen aan bindende normen van geschreven en ongeschreven recht. Hierbij moeten tevens de heersende rechtsovertuiging - en de ontwikkelingen daarin - betrokken worden. In verband met het gelijkheidsbeginsel stelt de Raad vast, dat een dusdanige rechtsontwikkeling heeft plaatsgevonden, dat met betrekking tot de bedoelde voorzieningen gehuwden en ongehuwd, op basis van op basis van een notarieel samenlevingscontract in een gemeenschappelijke huishouding samenwonenden niet meer als ongelijke gevallen kunnen worden beschouwd. Aan deze ongehuwd samenwonenden mogen de aan gehuwde militairen verschafte voorzieningen niet meer worden onthouden. De Raad vervolgt zijn uitspraak met de volgende overweging: 
"De Raad onderkent dat het noemen van een exact tijdstip waarop de rechtsontwikkeling op dit terrein het vorenbedoelde stadium heeft bereikt, enigszins arbitrair aandoet. In het kader van de afdoening van deze en soortgelijke zaken is het stellen van een datum evenwel onvermijdelijk. De Raad heeft gemeend dit tijdstip te moeten stellen op 1 januari 1985."14

Uit dit citaat blijkt, dat de Raad een datum prikt waarop de rechtsontwikkeling het punt bereikt heeft waarop ten aanzien van de in het geding zijnde regelingen gehuwden en op grond van een notarieel samenlevingscontract samenwonenden als gelijke gevallen kunnen worden beschouwd en derhalve gelijk behandeld dienen te worden.

\subsubsection{Ongelijke behandeling van gelijke gevallen}

Wordt geconcludeerd tot het bestaan van gelijke gevallen, dan moeten die volgens artikel 1 Grondwet gelijk behandeld worden. De tekst van artikel 1 Grondwet bevat geen uitzonderingsmogelijkheden, maar uit de rechtspraak en literatuur blijkt er wel een uitzonderingsmogelijkheid te bestaan: indien sprake is van een objecrieve en redelijke rechtvaardiging ${ }^{15}$ van een ongelijke behandeling van gelijke gevallen, dan is geen sprake van schending van het gelijkheidsbeginsel. Het gaat hier om een "geïmpliceerde begrenzing" van de reikwijdte van het gelijkheidsbeginsel; dat wil mijns inziens zeggen dat de grens van het gelijkheidsbeginsel uit zijn eigen aard voortvloeit. ${ }^{16}$ Akkermans spreekt van een objectiveerbare rechtvaardigingsgrond, wat betekent dat "de middelen, gekozen voor het bereiken van een (geoorloofd) doel, adequaat moeten zijn, in deze zin dat zijn niet alleen geschikt zijn om het doel te bereiken, maar ook noodzakelijk, en dat zij daarom gekozen worden". ${ }^{17}$

14 CRvB 13 november 1986, nr. MAW 1985/41, zie noot 13.

15 De termen "objectieve" en "redelijke" worden vooral gebezigd in de Europese (communautaire) rechtspraak, maar zoals onderstaande uitspraak van de Voorzitter van de Afdeling rechtspraak van 6 november 1987 (KG 1988, 65) laat zien, worden ze ook wel in het nationale recht gebruikt. Zo ook o.a. Pres.Rb. 's-Gravenhage 25 mei 1994, TAR 1994, 166. En zie ten aanzien van art. 26 IVBPR o.a. HR 30 september 1992, NJ 1994, 495 met noot E.A. Alkema.

16 De term "geïmpliceerde begrenzing" ontleen ik aan de Memorie van Antwoord bij wetsvoorstel 22014, Algemene wet gelijke behandeling. Tweede Kamer, punt 7.2, p. 37.

17 P.W.C. Akkermans, Artikel 1 Grondwet, p. 44. Zie ook de zeer lezenswaardige noot van Olde Kalter bij CRvB 25 maart 1993. TAR 1993, 99: "In hoofdzaak komt de jurisprudentie echter op het volgende neer: het onderscheid moet gericht zijn op een 
In de uitspraak van de Voorzitter van de Afdeling Rechtspraak van de Raad van State van 6 november 1987 gaat het om de vraag of de voorwaarden die in artikel 18 lid 1 , aanhef en onder b Woonwagenwet worden gesteld aan de verlening van een vergunning tot het bewonen van een woonwagen ingevolge artikel 14 van die wet, in overeenstemming is met onder meer artikel 1 Grondwet, artikel 14 ECRM en artikel 26 IVBPR. ${ }^{18}$ Volgens de Voorzitter kan het stellen van de desbetreffende eisen worden aangemerkt als "een objectief en redelijkerwijs te rechtvaardigen middel, dat past bij het ... doel dat met deze wet is beoogd." Volgens de Voorzitter betekent het stellen van deze eisen geen ongerechtvaardigd verschil in behandeling (tussen de in artikel 18 lid 1 , onder b Woonwagenwet aangeduide personen en andere woonwagenbewoners, $C S$ ) in de zin van artikel 14 ECRM en kan om dezelfde reden het beroep op artikel 1 Grondwet worden verworpen. $\mathrm{Er}$ is derhalve geen sprake van schending van het gelijkheidsbeginsel in artikel 1 indien gelijke gevallen niet gelijk behandeld worden en de ongelijke behandeling objectief en redelijkerwijs gerechtvaardigd kan worden.

Tot een vergelijkbare uitspraak ten aanzien van het beginsel van nondiscriminatie in artikel 1 komt de Voorzitter in de uitspraak van 28 september 1989 waarin het gaat om gewetensbezwaarden die vóór 1 maart 1989 zijn begonnen met de vervulling van de gewone vervangende dienst en gewetensbezwaarden die daar na die datum mee zijn gestart. ${ }^{19}$ De

redelijk doel ('objectief zijn); het moet, gelet op de beschikbare middelen, in de juiste verhouding staan tot dat doel (proportionaliteit), terwijl het doel niet met middelen kan worden bereikt die de rechtzoekende minder belasten (subsidiariteit), De Centrale Raad van Beroep concludeert in deze zaak ook dat de toepassing van het leeftijdscriterium geen "deugdelijk en geschikt middel" is om te bereiken dat de functie warnaar appellant had gesolliciteerd voor langere tijd door eenzelfde persoon. wordt vervuld. Zo ook t.a.v. art. 26 IVBPR de conclusie van A-G Moltmaker voor HR 8 juli 1988, BNB 1988, 302 met noot Scheltens.

18 Vz.ARRS 6 november 1987, KG 1988,65. Een klacht onder artikel 14 ECRM tegen een vergelijkbare uitspraak van de Afdeling Rechtspraak (ARRS 2 januari 1986, AB 1986, 443) is door de Commissie niet-ontvankelijk verklaard. In Besl.Comm. 25 februari 1991. Beckers v. the Netherlands, NJCM-Bulletin 17-2 (1992), p. 188, oordeelt de Commissie eveneens dat "... this difference in treatment has an objective and reasonable justification ... There is no indication. in the circumstances of the present case, of a lack of proportionality between ... and the means employed ..."

19 Vz.ARRS 28 september 1989. KG 1990, 28. Op het feit - dat in deze zaak ten aanzien van het discriminatieverbod dezelfde maatstaf wordt aangelegd als in de hiervoor besproken uitspraak van de Vz.ARRS van 6 november 1987, KG 1988, 65 met betrekking tot het gelijkheidsbeginsel - wordt later nog ingegaan. Dit geldt ook voor de vraag of hier wel terecht het non-discriminatiebeginsel wordt toegepast in 


\section{laatste groep krijgt op grond van de Interim-Regeling openbaar} vervoerkaart tewerkgestelden een Defensie Openbaar Vervoerkaart (DOVkaart) terwijl de eerste groep met een declaratie-systeem genoegen moet nemen. Vanwege mogelijke capaciteitsproblemen bij het openbaar vervoer is de regeling gefaseerd, lichtingsgewijs ingevoerd per 1 maart 1989 en daarbij de eerste helft van 1989 ook nog experimenteel. De Voorzitter meent dat gefaseerde invoering van de DOV-kaart met een experimentee! karakter "redelijkerwijs noodzakelijk is" om bepaalde ontwikkelingen die zich in de praktijk zouden kunnen voordoen het hoofd te kunnen bieden. Om die reden acht hij het verschil in behandeling tussen beide categorieën gewetensbezwaarden zakelijk en objectief gerechtvaardigd. Daarbij acht hij nog van belang dat de rechtspositie van erkende gewetensbezwaarden die vóór 1 maart 1989 met hun vervangende dienst zijn begonnen door de regeling niet wordt aangetast. Het gemaakte onderscheid is volgens de Voorzitter niet in strijd met het in artikel 1 Grondwet geformuleerde beginsel van non-discriminatie.

Wat betreft de toetsing aan het gelijkheidsbeginsel: een uitspraak van de Afdeling Rechtspraak van 1 augustus 1983 duidt erop, dat een zwaardere toetsing aan dit beginsel plaatsvindt wanneer tevens een ander grondrecht en met name de vrijheid van godsdienst en levensovertuiging, in het geding is. Dat wil zeggen dat er in een dergelijk geval zwaarderwegende gronden moeten worden aangevoerd om een ongelijke behandeling van gelijke gevallen te rechtvaardigen. ${ }^{20}$ Het gaat in deze zaak om de subsidiëring van godsdienstig en levensbeschouwelijk onderwijs. Reeds sinds 1957 subsidieert de gemeente Haarlem de vereniging tot verspreiding van bijbelkennis. In 1981 verzoekt de Stichting voor Humanistisch Vormingsonderwijs om eenzelfde subsidie van de gemeente. De

plaats van het gelijkheidsbeginsel. Zie paragraaf 6.1.7.

20 ARRS 1 augustus 1983, AB 1984, 532 met noot B.J. van der Net; NJCM-Bulletin 9-2 (1984), pp. 156-166 met noot J.E. Goldschmidt; zie ook A.W. Heringa, Het discriminatieverbod als sociaal grondrecht, pp. 204-205. Vergelijk verder CRvB 14 maan 1991, TAR 1991, 105 met noot G.L. Coolen: volgens de Raad zijn dienstplichtigen en beroepsmilitairen groepen die binnen de krijgsmacht onderscheiden dienen te worden en die naar hun aard verschillen, waardoor zonder schending van het gelijkheidsbeginsel uiteenlopende rechtspositionele rechten en plichten kunnengelden. Gaat het echter om een zwaarwegend grondrecht als de vrijheid van godsdienst en levensovertuiging, dan mogen aan de ene groep ter uitoefening van dit grondrecht verleende faciliteiten niet aan de andere groep onthouden worden "tenzij op duidelijk in het oog springende gronden kan worden gemotiveerd dat sprake van ongelijke gevallen is". Omdat de vrijheid van godsdienst hier in het geding is, is sprake van gelijke gevallen die gelijk behandeld moeten worden, terwijl anders van ongelijke gevallen sprake zou zijn geweest. Zie hieromtrent punt 4 van de noot. 
gemeenteraad wijst dit verzoek om verschillende redenen af. Eén van de redenen voor afwijzing is, dat volgens de gemeente het gelijkheidsbeginsel niet met zich kan brengen dat bij subsidieverlening aan één bepaalde instelling, aan een onbeperkt aantal gelijksoortige instellingen als de vereniging ook subsidie zou moeten verleend - gezien onder meer de beperkte financiële middelen van de gemeente. De Afdeling begrijpt dit verweer, in verband met wat de gemeente overigens heeft aangevoerd, aldus, dat geen sprake is van gelijke gevallen, indien zoals in dit geval, een bepaalde instelling (de vereniging) reeds een aantal jaren subsidie ontvangt en het in verband met de beperkte financiële middelen niet wenselijk wordt geacht meer geld voor de subsidiëring van soortgelijke instellingen, beschikbaar te stellen. Dit zou vermindering van de subsidie aan de vereniging tot gevolg hebben en daarmee afbreuk doen aan de positie die deze zich daarmee heeft verworven. Op zich zelf acht de Afdeling een dergelijke stellingname van de gemeente redelijk. Echter in dit geval gaat het om een verzoek aan de gemeente om subsidie ten behoeve van het levensbeschouwelijk vormingsonderwijs, terwijl die gemeente het godsdienstonderwijs reeds van financiële ondersteuning voorziet. De Afdeling is van opvatting, dat de overheid zich dient te onthouden van de continuering - anders dan op grond van een overgangsregeling - van een beleid dat bepaalde godsdienstige of levensbeschouwelijke stromingen bevoordeelt. Volgens de Afdeling dient

"[a]an het beginsel dat gelijke gevallen gelijk behandeld moeten worden .... als het gaat om behandeling van godsdienstige of levensbeschouwelijke stromingen, bijzondere betekenis te worden gehecht."

Deze overweging brengt volgens de Afdeling met zich, dat de gemeente zo spoedig als dit onder de gegeven omstandigheden redelijkerwijs mogelijk zou zijn, naar aanleiding van het subsidieverzoek van de Stichting, maatregelen had moeten treffen met het oog op het verschaffen van een aan het godsdienstonderwijs gelijkwaardige positie aan het door de Stichting gewenste onderwijs. De bestreden beslissing wordt uiteindelijk vernietigd op grond van schending van het motiveringsbeginsel.

In verband met deze zaak wil ik op twee dingen wijzen. Allereerst lijkt de Afdeling de door de gemeente aangevoerde gronden voor afwijzing van het subsidieverzoek (het reeds sinds jaren subsidiëren van de vereniging, de beperkte financiële middelen van de gemeente) in het algemeen te aanvaarden als redelijke rechtvaardiging voor de ongelijke behandeling van gelijke gevallen. Alleen nu ook de vrijheid van godsdienst en levensovertuiging (artikel 6 Grondwet) in het geding is, is dit niet zonder 
meer het geval. Met deze termen "zonder meer" kom ik op het tweede punt waarop ik de aandacht wil vestigen.

Door te overwegen "dat de overheid zich [dient] te onthouden van een beleid dat een ... bevoordeling van bepaalde godsdienstige of levensbeschouwelijke stromingen anders dan bij wege van overgangsmaatregel continueert", stelt de Afdeling een beperking in de tijd aan de gelding van het gelijkheidsbeginsel. Voor de hiervoor weergegeven opvatting van de Afdeling dat de door de gemeente aangevoerde gronden voor afwijzing van het subsidieverzoek in het algemeen een redelijke rechtvaardiging voor ongelijke behandeling vormen, maar dat dit in het geval de vrijheid van godsdienst en levensovertuiging in het geding komt niet zonder meer het geval is, moet dan ook als volgt worden uitgelegd. Indien de ongelijke behandeling ook op gespannen voet staat met de vrijheid van godsdienst etc. kunnen de aangevoerde gronden slechts gedurende een bepaalde overgangstermijn een redelijke rechtvaardiging voor de ongelijke behandeling vormen.

Principieel bezien lijkt mij deze uitspraak onjuist, er is immers vanaf het moment van de bestreden beslissing sprake van ongelijke behandeling van ongelijke gevallen. Dat neemt niet weg dat de rechter daaraan om pragmatische redenen niet onmiddellijk, maar op termijn consequenties kan verbinden.

\subsubsection{Ongelijke gevallen, ongelijke behandeling}

Tot zover de ongelijke behandeling van gelijke gevallen. Komt men tot de conclusie dat sprake is van ongelijke gevallen, dan betekent dit, dat deze ongelijke gevallen ongelijk behandeld moeten worden. ${ }^{21}$ In een uitspraak

21 Bij de parlementaire behandeling van het wetsvoorstel (13872) tor herziening van de Grondwet bestond nog twijfel over dit standpunt aangezien de regering in de Memorie van Antwoord bij dit wetsvoorstel had gesteld, dat "ongelijke gevallen ongelijk mogen (hetgeen niet altijd een moeten inhoudt) worden behandeld." Memorie van Antwoord bij wetsvoorstel 13872. Verklaring dat er grond bestaat ..., Tweede Kamer, in: Algehele grondwetsherziening, deel Ia Grondrechten, p. 184. (Cursivering, CS) Naar aanleiding van een kamervraag hierover (Gezamenlijke mondelinge behandeling van de wetsontwerpen 13872 en 13873 door de Tweede Kamer, in: Algehele grondwetsherziening, deel Ia Grondrechten, p. 436) heeft de Minister van Binnenlandse Zaken, De Gaay Fortman, geantwoord dat indien zich in de kring van ongelijke gevallen gelijke trekken vertonen, opnieuw het beginsel moet gelden dat gelijke gevallen gelijk behandeld moeten worden. De minister benadrukt dat bij de behandeling van ongelijke gevallen niet gediscrimineerd mag worden. (Gezamenlijke mondelinge behandeling ..., idem, p. 442) Dit komt mijns inziens op hetzelfde neer als het hier beschreven standpunt dat ongelijke gevallen ongelijk behandeld moeten worden naar de mate van hun ongelijkheid. 
van het College van Beroep Studiefinanciering van 3 maart 1989 gaat het om toepassing van de hardheidsclausule in artikel 131 Wet op de studiefinanciering. ${ }^{22}$ Dit artikel verleent de Minister van Onderwijs en Wetenschappen de bevoegdheid om "voor bepaalde gevallen of groepen van gevallen tegemoet te komen aan onbillijkheden van overwegende aard die zich bij de toepassing van deze wet (de WSF, CS) mochten voordoen." In het beleid dat naar aanleiding van de hardheidsclausule is ontwikkeld, zijn ten aanzien van studenten jonger dan 21 jaar andere beleidslijnen geformuleerd dan met betrekking tot studenten van 21 jaar of ouder. In het geval van studenten van 21 jaar en ouder geldt als criterium voor de toepassing van de hardheidsclausule dat er al dan niet een band tussen de studerende en zijn ouders bestaat. Het bestaan van een dergelijke band wordt verondersteld indien de ouders (een deel van) de ouderlijke bijdrage betalen. In het geval van de studerende van onder de 21 jaar doet die band er niet toe. Criterium is dan slechts of er sprake is van alimentatie die door de civiele rechter vanwege de draagkracht van de ouder op nihil is vastgesteld dan wel niet inbaar is (volledige weigerachtigheid). Dit wil zeggen, dat de hardheidsclausule niet kan worden toegepast als sprake is van partiële weigerachtigheid, waarbij wel alimentatie, maar geen ouderlijke bijdrage wordt betaald. Het College stelt, mijns inziens terecht, vast dat het betalen van alimentatie niets zegt over de aard van de ouderkind relatie.

Het College bepaalt verderop in deze uitspraak, onder verwijzing naar eerdere uitspraken, dat

"het algemeen beginsel van behoorlijk bestuur dat eist dat gelijke gevallen gelijk moeten worden behandeld en ongelijke gevallen ongelijk naar de mate van hun ongelijkheid ...". ${ }^{23}$

Bij de uitoefening van zijn bestuursbevoegdheid geniet de Minister, volgens het College, beleidsvrijheid, waarbij hij wel de algemene beginselen van behoorlijk bestuur in acht dient te nemen. De Minister kan kiezen voor een beleid waarbij de mogelijkheid voor alle studerenden om de toekenning van een aanvullende beurs en het inkomen van de ouders te ontkoppelen kan worden beperkt "tot die uitzonderingscategorieën waarvoor onverkorte toepassing van het beginsel van ouderafhankelijkheid in de WSF te zeer in strijd zou komen met de maatschappelijke realiteit en dan zou kunnen leiden tot een onbillijkheid van overwegende aard." 
Anders dan dit criterium leidt het hierboven beschreven beleid van de Minister, waarbij onderscheid gemaakt wordt tussen twee categorieën studenten - enerzijds die van jonger dan 21 jaar, anderzijds die van 21 jaar en ouder - tot schending van het gelijkheidsbeginsel in die zin, dat ongelijke gevallen niet ongelijk worden behandeld naar de mate van hun ongelijkheid. Deze conclusie van het College van Beroep kan aldus verklaard worden dat het beleid van de Minister eraan voorbij gaat dat ook in het geval van studerenden van jonger dan 21 jaar de maatschappelijke realiteit hierin kan bestaan, dat de band tussen de ouders en de studerende geheel is afgesneden (ongeacht het betalen van alimentatie).

In de bovenstaande zaak wordt artikel 1 Grondwet niet ingeroepen noch toegepast, maar wordt het gelijkheidsbeginsel als algemeen beginsel van behoorlijk bestuur aangevoerd. Mijns inziens maakt dit voor de reikwijdte van het gelijkheidsbeginsel niet uit. ${ }^{24}$

\subsubsection{Commentaar op de toetsing aan het gelijkheidsbeginsel}

Hiervoor werd besproken hoe in de rechtspraktijk de toetsing aan het gelijkheidsbeginsel plaatsvindt. Er bestaat ook een meer dogmatische benadering van de toetsing aan het gelijkheidsbeginsel. Zo onderscheidt Timmermans een vergelijkbaarheidstoets en een rechtvaardigingstoets. ${ }^{25}$ Kort weergegeven zien die toetsen er aldus uit:

vergelijkbaarheidstoets:

* Is er met het oog op de vergelijking van gevallen sprake van een factor (een differentiatie-criterium) die "gelet op het toepassingsgebied èn de doelstellingen van de maatregel of de regeling relevant (kan) worden geacht"? Met andere woorden: is er sprake van een differentiatie-criterium dat relevant is met het oog op een differentiatie-doel, nog eens anders geformuleerd: rechtvaardigt het differentiatie-doel een differentiatie op grond van een bepaald criterium?

* zo ja, dan is in het geval dat aan de hand van dat criterium onderscheid gemaakt wordt met het oog op dat differentiatie-doel,

24 Zie 0.a. punt 5 van de annotatie van F.H. van der Burg bij HR 27 maan 1987, AB 1987, 273: "Waar er een norm is van grondwettelijk niveau, bestaat er geen behoefte aan ongeschreven beginselrecht."

25 C.W.A. Timmermans, Verboden discriminatie of (geboden) differentiatie, pp. 432442. Timmermans neemt in zijn bijdrage het Europese, communautaire recht als uitgangspunt. Zie voorts G.J.H. van Hoof en A.Ph. Jaspers, Over gelijkheid, pp. 143-147 en 155-162. 
sprake van ongelijke gevallen. Deze ongelijke gevallen moeten ongelijk behandeld worden naar de mate van hun ongelijkheid;

* zo nee, dan mag aan de hand van dat criterium geen onderscheid gemaakt worden omdat sprake is van gelijke gevallen. Deze gelijke gevallen moeten gelijk behandeld worden.

\section{rechtvaardigingstoets:}

* worden gelijke gevallen ongelijk behandeld of ongelijke gevallen gelijk behandeld, dan moet deze afwijking van het gelijkheidsbeginsel gerechtvaardigd worden. Deze rechtvaardiging moet objectief en redelijk dan wel voldoende zijn.

Op het eerste gezicht valt het verschil met de toetsing die in het algemeen in de rechtspraktijk plaatsvindt niet op. Bekijken we bovenstaand overzicht nader dan kan men constateren, dat daarin drie toetsingsmomenten zijn terug te vinden en in de praktijk maar twee.

(1) Volgens de dogmatische benadering toetst men eerst of er een differentiatie-doel is dat het maken van onderscheid aan de hand van een bepaald differentiatie-criterium rechtvaardigt. (2) Daarna toetst men aan de hand van dit differentiatie-criterium of er sprake is van gelijke dan wel ongelijke gevallen. (3) Vervolgens, indien gelijke gevallen ongelijk behandeld worden of ongelijke gevallen gelijk, wordt getoetst of daarvoor een rechtvaardiging te vinden is.

In de rechtspraktijk vallen de eerste en de derde toets meestal samen. ${ }^{26}$ Vastgesteld wordt of sprake is van gelijke of ongelijke gevallen, doorgaans zonder dat daarbij een differentiatie-doel wordt geexpliciteerd. Daarna, indien gelijke gevallen ongelijk worden behandeld of ongelijke gevallen gelijk, wordt daarvoor een rechtvaardiging gezocht veelal aan de hand van het differentiatie-doel! Dit valt over het algemeen niet op, omdat men de toetsing riet expliciet in toetsingsmomenten verdeelt. Toch biedt de volgende uitspraak een goed voorbeeld van de onduidelijkheid die een. dergelijke toetsing in de praktijk met zich zou kunnen brengen. In de uitspraak van de Hoge Raad van 23 november 1984 gaat het om de beslissing een vreemdeling niet in Nederland toe te laten voor verblijf bij zijn - hier op grond van een verblijfsvergunning verblijvende - echtgenote. 
In deze zaak wordt een beroep gedaan op artikel 26 IVBPR. ${ }^{27} \mathrm{De}$ betrokken vreemdeling voert een ongelijke behandeling met andere groepen vreemdelingen aan. Hij vergelijkt zijn positie met die van een evenmin nog tot Nederland toegelaten vreemdeling die zijn aanspraak baseert op zijn huwelijk met een hier woonachtige Nederlander of vreemdeling met een vestigingsvergunning. De Hoge Raad bevestigt het oordeel van het Gerechtshof Amsterdam ${ }^{2 s}$ dat "voor dit door betrokkene gewraakte verschil, in verband met hetgeen de Staat heeft aangevoerd omtrent het algemeen belang, het onderling verschil in status tussen de door betrokkene genoemde groepen een objectieve en redelijke rechtvaardiging vormt. "Uit deze overweging blijkt, dat op grond van de vergelijkbaarheidstoets gekomen had kunnen worden tot de conclusie dat het geval van de betrokken vreemdeling niet gelijk is aan die van de andere - door hem ter vergelijking aangevoerde - gevallen van vreemdelingen vanwege "het onderling verschil in status". Echter, volgens deze uitspraak kan op grond van de rechtvaardigingstoets gekomen worden tot het oordeel, dat ongelijke behandeling van het geval van appellant en de gevallen van de andere bedoelde groepen vreemdelingen objectief en redelijk gerechtvaardigd is. $"[\mathrm{H}]$ et onderling verschil in status" is in dit geval aangevoerd als objectieve en redelijke rechtvaardiging. Deze laatste conclusie kan echter alleen bereikt worden indien men uitgaat van het bestaan van gelijke gevallen. In deze uitspraak laat de Hoge Raad dat in het midden.

27 HR 23 november 1984, NJ 1985, 604; zie G.J.H. van Hoof en A.Ph. Jaspers, Over gelijkheid, p. 159. Vergelijkbare kritiek op de toetsing van de Hoge Raad kan worden geleverd naar aanleiding van HR 22 april 1994, NJ 1994, 560, met noot E.A. Alkema, waarin het ging op een bodembeslag in verband met een belastingschuld van de echtgenoot van eiseres. Ook op de eigendommen van eiseres was beslag gelegd, maar niet op goederen van andere derden die in de woning aanwezig waren. Het gerechtshof lijkt het beroep op het gelijkheidsbeginsel af te wijzen, omdat geen sprake is van gelijke gevallen die gelijk behandeld behoeven te worden: de verhouding tussen eiseres en haar echtgenoot valt niet op één lijn te stellen met die tussen de echtgenoot en andere derden. (r.o. 4.6) De HR voert de moeilijkheid van het vaststellen van de eigendom van zaken in de gemeenschappelijke woning van echtgenoten of samenwonenden aan als "voldoende rechtvaardiging om hen anders te behandelen dan andere derden tussen wie geen vergelijkbare band bestaat". (r.o. 3.5) De Raad lijkt hier derhalve een verschil in behandeling te willen rechtvaardigen ondanks dat er geen sprake is van een "vergelijkbare band", wat mijns inziens wil zeggen dat - net als het gerechtshof lijkt te hebben bedoeld - geen sprake is van "gelijke gevallen" en dus een ongelijke behandeling niet gerechtvaardigd had behoeven te worden. 
Strikt genomen is de dogmatische benadering vanuit het oogpunt van de reikwijdte-afbakening van het gelijkheidsbeginsel correcter. Eerst zou men moeten toetsen aan het uitgangspunt: gelijke gevallen moeten gelijk behandeld worden (en ongelijke gevallen dienen ongelijk behandeld te worden) en pas daarna aan de uitzondering daarop. De rechtvaardiging van ongelijke behandeling van gelijke gevallen en van gelijke behandeling van ongelijke gevallen is immers een impliciete beperking op dat uitgangspunt. Impliciet, want deze beperking is niet uitdrukkelijk in artikel 1 Grondwet opgenomen. In de praktijk werkt dat niet zo. Ik denk dat dit niet bezwaarlijk is zolang het resultaat van de toetsing aan artikel 1 Grondwet in zijn geheel bevredigend is. Alleen in zaken zoals de zojuist aangehaalde uitspraak van de Hoge Raad werkt het achterwege laten van een expliciete, afzonderlijke toetsing van het differentiatie-criterium (stap 1 in bovenstaand overzicht) nogal verwarrend, aangezien laatstbedoelde toetsing zou hebben aangetoond dat het ging om ongelijke gevallen en dat het derhalve voor het Gerechtshof Amsterdam helemaal niet nodig was de rechtvaardiging van de ongelijke behandeling te onderzoeken.

\subsubsection{De reikwijdte van het gelijkheidsbeginsel in het overheidsbeleid en ten aanzien van besluiten van verschillende overheidsorganen}

Zoals in de eerder besproken zaken naar voren kwam, kan van het gelijkheidsbeginsel worden afgeweken op redelijke en objectieve gronden. Er zijn een aantal uitspraken waarin dit wordt bevestigd ten aanzien van het al dan niet afwijken van een door de overheid gevoerd beleid. In deze uitspraken wordt artikel 1 Grondwet weliswaar niet ingeroepen of toegepast, maar ze zijn dermate interessant dat ik ze toch wil bespreken. Allereerst moet voorop gesteld worden dat de overheid moet beslissen overeenkomstig het vaste beleid dat gevoerd wordt. Zoals de President van de Rechtbank te Den Haag op 18 april 1986 terecht oordeelt, dat wanneer een overheidsorgaan afwijkt van het vaste beleid bij wijze van "Einzelfallbarmhartigheid", een dergelijke beslissing de maatstaf zal gaan vormen in vergelijkbare gevallen. ${ }^{29}$ In dat geval vormt zich als het ware een nieuw vast beleid ten aanzien van de desbetreffende gevallen. Wanneer mag dan wel van het vaste beleid worden afgeweken?

In de uitspraak van het Gerechtshof 's-Gravenhage van 26 juni 1986 gaat het om de beslissing van de staatssecretaris van Sociale Zaken en Werkgelegenheid om aan de betrokkene ontheffing van de 
verzekeringsplicht - op grond van de sociale verzekeringswetgeving - te weigeren. ${ }^{.0}$ Volgens het Gerechtshof is een dergelijke weigering van de gevraagde ontheffing onrechtmatig indien de Staat in redelijkheid niet tot dit besluit had kunnen komen. Bij zijn beslissing dient de rechter rekening te houden met diverse factoren, waaronder het gelijkheidsbeginsel, maar ook het beleid dat de Staat voert. Het Gerechtshof stelt vast, dat gelijksoortige gevallen niet automatisch hetzelfde behandeld behoeven te worden. De Staat mag op goede gronden van een eerder gevoerd beleid afwijken."

Deze opvatting van het Gerechtshof wordt bevestigd in een andere zaak. In een uitspraak van de Hoge Raad van 27 maart 1987 gaat het om de weigering van de gemeente Amsterdam aan een B.V. een vergunning te verlenen tot bestemmingswijziging van een bepaald pand. ${ }^{12}$ Voorheen voerde de gemeente een beleid krachtens welk in gevallen als onderhavige een vergunning tot bestemmingswijziging werd verleend. Nog voordat de betrokken B.V. de hier gevraagde vergunning aanvroeg, wijzigde de gemeente echter haar beleid. Bij een beroep op het gelijkheidsbeginsel kan, aldus de Hoge Raad, niet verwezen worden naar soortgelijke gevallen (waarin wel een vergunning is verleend) die stammen van vóór de beleidswijziging van de gemeente met betrekking tot de verlening van de onderhavige vergunningen.

Wat betreft een geval van ná de beleidswijziging waarnaar de B.V. verwees: volgens de Hoge Raad is geen sprake van "een rechtens relevante strijd met het gelijkheidsbeginsel" indien zich enkel de omstandigheid voordoet dat de gemeente in een losstaand geval - zonder dat daar voldoende grond voor was - een uitzondering heeft gemaakt op haar vaste beleid, "ook al zou die uitzondering niet zijn terug te voeren op een vergissing aan de zijde van de gemeente."

Uit deze laatste twee zaken kan men afleiden, dat men op grond van het gelijkheidsbeginsel alleen van een vast beleid af kan wijken indien daarvoor een redelijke, voldoende grond voor aangevoerd kan worden. In het opzichzelfstaande geval, waarnaar in de laatstgenoemde zaak verwezen werd, was afgeweken van het gevoerde beleid terwijl daarvoor geen voldoende grond voor aangevoerd kon worden. Op grond daarvan zou men moeten concluderen dat in dát geval het gelijkheidsbeginsel geschonden

30 Gerechtshof 's-Gravenhage 26 juni 1986, RSV 1987, 39.

31 Vgl. CRvB 5 april 1983, RSV 1983, 146: in deze zaak wordt het bestaan van een "redelijke grond" niet gesteld en ook is daarvan niet gebleken. Daarom wordt een afwijking van het "bestendig gebruik" in verband met het gelijkheidsbeginsel niet geaccepteerd.

32 HR 27 maart 1987, AB 1987, 273. 
werd. Hieruit is te verklaren dat het geval waarop deze uitspraak betrekking had, niet gelijk behandeld werd met dit losstaande geval maar overeenkomstig het vaste beleid beslist werd.

De geciteerde zinsnede - dat geen sprake is van strijd met het gelijkheidsbeginsel wanneer een beroep op een losstaand geval, waarin een uitzondering gemaakt werd op het vaste beleid van de gemeente, wordt afgewezen ook al is die uitzondering niet terug te voeren op een vergissing van de gemeente - kan als volgt uitgelegd worden. Volgens vaste jurisprudentie kan een beroep op het gelijkheidsbeginsel er niet toe leiden dat een overheidsorgaan een met de wet strijdige beslissing herhaalt. In een uitspraak van de Afdeling Rechtspraak van de Raad van State van 26 juli 1983 gaat het om de weigering van Gedeputeerde Staten van Gelderland goedkeuring te verlenen aan het besluit van de gemeente Duiven tot wijziging van het plaatselijke bestemmingsplan. ${ }^{33}$ Bij hun beroep op het gelijkheidsbeginsel wijzen appellanten op een soortgelijk besluit tot wijziging van het bestemmingsplan van de gemeente Duiven dat door Gedeputeerde Staten van Gelderland wèl is goedgekeurd. Volgens Gedeputeerde Staten is dit besluit juridisch gezien niet juist. De Afdeling Rechtspraak overweegt hieromtrent onder meer, dat

"een - mogelijk terecht - beroep op het gelijkheidsbeginsel er niet toe kan leiden dat het overheidsorgaan op grond daarvan zou kunnen worden gedwongen - nogmaals - een foutieve, namelijk met de wet strijdige beslissing te nemen."

Ook in een uitspraak van 14 februari 1984 bepaalt de Centrale Raad van Beroep, dat het gelijkheidsbeginsel niet met zich brengt dat een bepaald geval gelijk aan een ander geval behandeld dient te worden indien in dit andere geval de beslissing het gevolg was van een administratieve fout. ${ }^{3}$ Een nuancering op dit standpunt wordt aangebracht in een uitspraak van de President van de Haagse Rechtbank van 14 mei 1992, betreffende een gevorderd verbod tot uitzetting hangende de behandeling van het beroep bij de Affdeling Rechtspraak van de Raad van State tegen de weigering van een verblijfsvergunning aan appellant's zoon. ${ }^{35}$ Aan een dochter van appellant (het vergelijkbare geval) was bij vergissing in afwijking van het geldende toelatingsbeleid ${ }^{36}$ een verblijfsvergunning verleend. Hoewel de

33 ARRS 26 juli 1983, AB 1983, 587 met noot Crince le Roy.

34 CRvB 14 februari 1984, RSV 1984, 112; zo ook o.a. CRvB 23 mei 1985, TAR 1985, 173.

35 Pres.Rb. 's-Gravenhage 14 mei 1992, KG 1992, 271.

36 Dit is het in de paragrafen 4.2.2 en 4.3.2.6 besproken "polygamie-beleid". 
President het eens is met het standpunt dat het gelijkheidsbeginsel er niet toe kan leiden dat in ieder afzonderlijk geval een eenmaal gemaakte fout dient te worden herhaald, kan dit in het onderhavige geval slechts gelden indien de ten aanzien van eerderbedoelde dochter genomen beslissing "kennelijk onjuist was of dat door gedaagde destijds aan eiser kenbaar was gemaakt, dat er sprake was geweest van een vergissing"., ${ }^{37}$ Omdat de President deze nuancering duidelijk toespitst op het in het geding zijnde geval, kan aan deze uitspraak - mijns inziens - vooralsnog geen verdergaande gevolgtrekking verbonden worden dan dat het onder omstandigheden nodig kan blijken te zijn dat - indien bij de uitvoering van het overheidsbeleid een vergissing wordt gemaakt - deze fout aan betrokkene(n) kenbaar moet zijn gemaakt of dat de desbetreffende beslissing kennelijk onjuist moet zijn.

Ten aanzien van het gelijkheidsbeginsel in verband met het overheidsbeleid kan worden geconcludeerd, dat een overheidsbeslissing in overeenstemming met het vast beleid moet worden genomen. Afwijking van het vaste beleid kan alleen indien sprake is van een redelijke of voldoende grond voor die afwijking. Is in een vergelijkbaar geval een uitzondering op het vaste beleid gemaakt, dan kan en moet in verband met het gelijkheidsbeginsel alleen een zelfde uitzondering op het beleid gemaakt worden indien de uitzondering - in het geval waarnaar wordt verwezen niet strijdig met de wet is genomen of het gevolg is geweest van een administratieve fout (tenzij zich omstandigheden voordoen waarin de vergissing kenbaar moet zijn gemaakt). Aan de uitzondering in het vergelijkbare geval moet een voldoende grond ten grondslag hebben gelegen. In geval van wets- of beleidswijziging kan overigens alleen verwvezen worden naar vergelijkbare gevallen van ná die wijziging. ${ }^{3 s}$

Een ander soort uitzonderingen op het gelijkheidsbeginsel betreft de overheidsorganen die de desbetreffende beslissingen nemen. Aan de ene kant is bij Koninklijk Besluit van 23 januari 1985 vastgesteld, dat een bepaald raadsbesluit (ten aanzien van de eenmalige uitkering) van de gemeente Muiden zich niet verdraagt met het gevoerde rijksbeleid ter

37 Cursivering van mij, $C S$.

38 Vgl. HR 27 maart 1987, AB 1987, 273: "Het hof miskent in dit oordeel vooreerst ... dat het voorheen gevoerde vaste beleid in beginsel niet relevant meer is, nu ... dit beleid reeds was gewijzigd ...". Welke betekenis aan de woorden "in beginsel" moet worden gehecht, blijkt uit deze uitspraak niet. 
zake. $^{39}$ Als gevolg van het ontwikkelde gemeentebeleid wordt de structurele inkomenspositie van de zogenaamde echte minima afhankelijk gesteld van lokale besluitvorming. Dit leidt volgens de Kroon tot een ongelijke inkomensverdeling binnen de categorie van de echte minima en (derhalve, $C S$ ) tot ongelijke behandeling van de tot deze categorie behorende personen. ${ }^{20}$

Aan de andere kant wordt in diverse latere uitspraken het bestaan van verschillen in beleid, tussen verschillende bestuursorganen op een zelfde niveau, wèl toegelaten. Een uitspraak van de Afdeling Rechtspraak van de Raad van State van 23 juni 1986 betreft de verlening van een vergunning tot exploitatie van een cafébedrijf, waaraan door de deelgemeente Kralingen op grond van de Verordening op inrichtingen van vermakelijkheden Rotterdam een voorwaarde is verbonden die het sluitingsuur van het bij het café behorende terras op een vroeger tijdstip stelt dan dat van de caféruimte zelf. ${ }^{41}$ De betrokkene beroept zich vergeefs op het gelijkheidsbeginsel, enerzijds omdat in de deelgemeente Kralingen geen andere vergunningen op grond van de Verordening zijn verleend. Anderzijds zijn de cafés waarnaar eiser verwijst en waaraan in de vergunning geen voorwaarden zijn gesteld ten aanzien van de sluitingstijd van het terras, gelegen buiten het grondgebied van de deelgemeente Kralingen. Volgens de Afdeling vloeit hieruit voort dat de deelgemeente Kralingen niet verplicht is om ook - net als bij die andere cafés - bij de verlening van de vergunning van betrokkene een dergelijke voorwaarde achterwege te laten.

In de uitspraak van de Centrale Raad van Beroep van 12 mei 1987 gaat het om het beleid van de Bedrijfsvereniging voor de Metaalnijverheid (de Nieuwe Algemene BV) met betrekking tot "werken met behoud van uitkering". ${ }^{42}$ In casu heeft de Bedrijfsvereniging beslist dat betrokkene niet werkloos in de zin van de Werkloosheidswet (WW) zou zijn en aan hem geen buitenwettelijke uitkering zou worden toegekend indien en voor zover

39 KB 23 januari 1985 (gemeente Muiden), Stb. 92, AB 1986, 118 met noot B.J. van. der Net onder KB 13 november 1985, nr. 18, AB 1986, 119.

40 Op grond van dit (spontane vernietigings-)KB van 23 januari 1985 hebben Gedeputeerde Staten van Noord-Holland hun goedkeuring, volgens de Kroon terecht. onthouden aan de uit het vernietigde besluit voortvloeiende suppletoire begrotingspost. Zie KB 13 november 1985, nr. 18, AB 1986, 119 met noot. B.J. van der Net. In dit $\mathrm{KB}$ wordt het beroep, dat de gemeente Muiden tegen de weigering van bedoelde goedkeuring door GS hebben ingesteld, door de Kroon ongegrond verklaard.

41 ARRS 23 juni 1986, AB 1987, 17 met noot J.H. van der Veen.

42 CRvB 12 mei 1987, RSV 1987, 234. Artikel I Grondwet wordt in deze zaak niet ingeroepen of toegepast. 
hij de onbetaalde arbeid in kwestie zou gaan verrichten. Eiser klaagt er onder meer over dat de Bedrijfsvereniging hieromtrent een ander standpunt inneemt dan andere bedrijfsverenigingen. Volgens de Raad kan aan het enkele feit dat twee bedrijfsverenigingen een verschillend standpunt innemen ten aanzien van de onderhavige kwestie niet tot de conclusie leiden dat de bedrijfsvereniging die geen toestemming verleent tot het werken met behoud van uitkering om die reden enig algemeen beginsel van behoorlijk bestuur - waaronder het gelijkheidsbeginsel - schendt. De Raad komt tot dit oordeel ondanks dat de Raad van mening is dat de duidelijkheid en de rechtszekerheid ermee gebaat zou zijn indien door alle bedrijfsverenigingen op dit terrein een zo groot mogelijke uniformiteit in hun beleid zou worden nagestreefd. ${ }^{43}$

Volgens van der Veen ${ }^{4}$ is het inherent aan decentralisatie dat een gedecentraliseerd bestuursorgaan - wanneer het gebruikmaakt van de bevoegdheid tot het vaststellen van beschikkingen voor een bepaald territoriaal of functioneel gebied - niet verweten kan worden het gelijkheidsbeginsel te schenden met een beroep op gelijke gevallen die onder bevoegdheid van een ander bestuursorgaan over een ander gebied vallen. Volgens hem ligt het voor de hand dat er in dit soort gevallen acht geslagen zal worden op wat er door andere bestuursorganen ter zake wordt beslist. Maar wat dan als dit niet gebeurt? "Naarmate een wederzijdse afstemming van beleid waar deze niet kan worden gemist, beter gestalte krijgt, zal er minder aanleiding zijn voor ingrijpen van "hoger" gezag, bijvoorbeeld via verdere regelgeving", aldus van der Veen. Wellicht zou men het dan ook kunnen omdraaien, zodat in gevallen waarin onderlinge afstemming van beleid waar deze niet kan worden gemist nog geen gestalte heeft gekregen, aanleiding bestaat voor ingrepen van bovenaf. In dat geval draait het om de vraag wanneer wederzijdse afstemming van beleid niet kan worden gemist en welke maatregelen dan van bovenaf kunnen worden genomen. Wat betreft het laatste geeft van der Veen voorbeelden als het zogenaamde spontane vernietigingsrecht (op grond van artikel 268 Gemeentewet) en de aanwijzing.

Overigens doet zich in deze zaken de situatie voor, dat niet duidelijk is of hier - doordat het gaat om besluiten van verschillende bestuursorganen nu sprake is van ongelijke gevallen die ongelijk behandeld (moeten)

43 Zie verder CRvB 11 mei 1984, RSV 1984, 234: in deze zaak warin artikel 1 Grondwet niet wordt ingeroepen of toegepast gaat het om een experiment ter verbetering van de uitvoeringspraktijk naar aanleiding van enkele bepalingen in ue A.AW en de WAO, dat beperkt is tot enkele regin's.

4 Zie zijn annotatie bij ARRS 23 juni 1986, AB 1987, 17. punt 1. 
worden of om gelijke gevallen die gerechtvaardigd ongelijk behandeld worden. De omstandigheid dat de desbetreffende besluiten door verschillende organen worden genomen kan zowel als argument voor de conclusie dat geen sprake is van gelijke gevallen, als bij wijze van rechtvaardigingsgrond voor de ongelijke behandeling van gelijke gevallen, gebruikt worden. De Afdeling Rechtspraak en de Centrale Raad van Beroep geven hierover in de hierboven besproken zaken geen duidelijkheid.

\subsubsection{Het discriminatieverbod; de pejoratieve betekenis van het verbod}

Tot nu toe is alleen het gelijkheidsbeginsel besproken. In de tweede zin van artikel 1 is echter een discriminatie-verbod opgenomen. In het begin. van paragraaf 6.1 werd de vraag gesteld wat het verschil is tussen het gelijkheidsbeginsel en het discriminatie-verbod. Op deze vraag zal nu ingegaan worden.

Het is opmerkelijk, dat in een aantal van de hierboven besproken zaken voor de vaststelling van het al dan niet bestaan van een schending van het gelijkheidsbeginsel dan wel het non-discriminatiebeginsel, hetzelfde criterium wordt gehanteerd: de ongelijke respectievelijk gelijke (al dan niet discriminerende) behandeling van gelijke respectievelijk ongelijke gevallen is (niet) objectief en redelijkerwijs of zakelijk gerechtvaardigd te achten. ${ }^{\text {"s }}$ Het aanleggen van de dezelfde maatstaf ten aanzien van het gelijkheidsbeginsel en het non-discriminatiebeginsel zou kunnen duiden op de opvatting, dat de beginselen twee verschillende formuleringen van hetzelfde principe zijn. $A-G M o k$ lijkt in zijn conclusie bij de uitspraak van 12 oktober 1984 deze opvatting te huldigen. ${ }^{46}$ Volgens de A-G is discriminatie de keerzijde van het gelijkheidsbeginsel. Hij meent, dat er sprake is van discriminatie indien er in gevallen die gelijk behandeld zouden moeten worden geen gelijke behandeling plaatsvindt. Hij voegt hier aan toe, dat er ook een ander begrip discriminatie is, waarvan sprake is indien iemand "een ander zodanig behandelt dat hij die ander duidelijk maakt dat hij bepaalde aspecten van zijn mens-zijn als onvolwaardig beschouwt." Deze betekenis van het begrip discriminatie ontleent hij aan de opvatting van De Gaay Fortman, de Minister van Binnenlandse Zaken ten tijde van de behandeling in de Tweede Kamer van het ontwerp ten

45 Vz.ARRS 6 november 1987, KG 1988, 65 en Vz.ARRS 28 september 1989, KG 1990, 28.

46 HR 12 oktober 1984. NJ 1985, 230 met noot $G$. In de uitspraak van de Hoge Raad kwam artikel 1 niet aan de orde. 
behoeve van de herziening van de Grondwet in $1983 .{ }^{47}$ De annotator bij deze zaak spreekt met betrekking tot de laatste omschrijving van discriminatie van een behandeling van de ander die voor deze diffamerend is. Hij stelt, dat indien er in de wet of een verdrag sprake is van discriminatie in het algemeen, het eerstgenoemde, ruime begrip discriminatie bedoeld wordt. Volgens dit begrip wordt discriminatie gelijkgesteld aan (ongeoorloofde) ongelijke behandeling in gelijke gevallen. De annotator stelt ook, dat in burgerrechtelijke verhoudingen volgens hem discriminatie slechts dan ongeoorloofd is indien "de ongelijkheid van behandeling diffamerend is voor de persoon die tot een bepaalde groep behoort."

Mijns inziens wordt in deze opvattingen van de A-G en de annotator onterecht het begrip discriminatie gelijkgesteld met het begrip (ongeoorloofde) ongelijke behandeling. In dat geval zou het discriminatieverbod niets aan het gelijkheidsbeginsel toevoegen en dat is uitdrukkelijk niet de bedoeling geweest van de grondwetgever. ${ }^{48}$ In de ontstaansgeschiedenis is het verschil in betekenis tussen het gelijkheidsbeginsel en het discriminatie-verbod onder meer tot uitdrukking gebracht in het verbinden van een pejoratieve betekenis aan het begrip "discriminatie". ${ }^{49}$ Voorts is het van belang dat de term "discriminatie" ziet op wat Burkens noemt "persoonsgebonden groepsattributen". Het gaat hierbij om bepaalde essentiële persoonlijke eigenschappen die een persoon bezit, waardoor hij of zij tot een bepaalde groep mensen behoort (groepsattribuut) en waarvan hij of zij zich (persoonsgebonden:) ò in het geheel niet kan ontdoen omdat ze aangeboren zijn (zoals geslacht of ras),

47 Gezamenlijke mondelinge behandeling van de wetsontwerpen 13872 en 13873 door de Tweede Kamer, in: Algehele grondwetsherziening, deel Ia Grondrechten, p. 442. Zie ook pp. 443-444, 448-449.

48 Zie o.a. Minister De Gaay Fortman tijdens de gezamenlijke mondelinge behandeling van de wetsontwerpen 13872 en 13873 door de Tweede Kamer, in: Algehele grondwetsherziening, deel la Grondrechten, p. 444(r.k.): "Ik herhaal, dat men niet kan volstaan met het gelijk behandelen van gelijke gevallen. (Ondat het discriminatic artikel verdergaat, moet het opgenomen worden."

$49 \mathrm{Vgl}$. de Memorie van Antwoord bij wetsvoorstel 20239, Aanvulling van het Wetboek van Strafrecht met enkele bepalingen tot het tegengaan van discriminatie op grond van ras, godsdienst, levensovertuiging, geslacht of hetero- of homoseksuele gerichtheid, Tweede Kamer, p. 12: Bij de definitic van discriminatic in artikel 90 quater $\mathrm{Sr}$ is de wederrechtelijkheid volgens de regering "ingehouwd". Zit voorts de Memorie van Antwoord bij het zelfde wetsvoorstel, Eerste Kamer, p. 2: "De in artikel 90 quater $\mathrm{Sr}$ gegeven definitie (van discriminatie, CS) kan dus niet als neutraal worden beschouwd. Het gaat om ongerechtvaardigd onderscheid. .. Gerechtvaardigd onderscheid is geen discriminatie." Dit wetsvoorstel is tot wet geworden bij Wet van 14 november 1991 , Stb. 623 (en in werking getreden op 1 fehruari 1992). 
òf hij of zij kan zich er niet van ontdoen zonder daarmee schade toe te brengen aan de eigen persoonlijkheid en/of geestelijke integriteit (zoals godsdienst, levensovertuiging of politieke gezindheid). ${ }^{50}$ In dit verband betekent het discriminatieverbod mijns inziens, dat uit deze "persoonsgebonden groepsattributen" geen eigenschappen mogen worden afgeleid op basis waarvan men concludeert tot ongelijkheid van de in het geding zijnde gevallen. Aan kenmerken als ras, geslacht, overtuiging en dergelijke, mogen - behoudens in enkele uitzonderingsgevallen - geen differentiatie-criteria worden ontleend. Zoals Biesheuvel terecht stelt, werpt het gebruik van één van de genoemde gronden als selectiecriterium al op voorhand een verdenking van discriminatie op degene die het onderscheid makk. .1 $^{1}$ Kortom, uitgangspunt is dat op grond van de genoemde nondiscriminatiegronden niet geconcludeerd mag worden tot het bestaan van ongelijke gevallen. Het desondanks toch onderscheid maken op grond van één van deze gronden is verdacht. ${ }^{52}$ In de volgende sub-paragraaf zal kort (nogmaals) worden aangegeven wat in de praktijk het verschil tussen het gelijkheidsbeginsel en het discriminatieverbod betekent voor de toetsing van gemaakt onderscheid. Vervolgens zal in de daaropvolgende subparagraaf worden ingegaan op de verschillen in (zwaarte van de) toetsing aan het discriminatieverbod, die voortvloeien uit een verschil in de mate van "verdachtheid" van de non-discriminatiegronden in artikel 1.

50 M.C. Burkens, Gelijke behandeling, p. 63: Het zijn eigenschappen die "in nauwe relatie staan tot de persoonlijkheid en de mogelijkheid (in zich bergen, $C S$ ) tot presentatie als persoon van de leden van de groep." Zie ook Old Kalter in zijn annotatie bij CRvB 25 maart 1993. TAR 1993, 99 volgens wie het verbod van discriminatie niet van toepassing is op allerlei 'toevallige' differentiatiecriteria (autobezitter of hondenbezitter) maar betrekking heeft op "menselijke karakteristieken: eigenschappen of kenmerken die in sterke mate mensen maken tot wie zij zijn".

51 M.B.W. Biesheuvel, Tien gedachten over discriminatie en recht, p. 216. Zie opnieuw Olde Kalter in zijn noot bij CRvB 25 maart 1993. TAR 1993, 99: "Het verbod van Jiscriminatie heeft ... tot doel bescherming te bieden ten aanzien van die menselijke karakteristieken die aangegrepen kunnen worden om een groep van mensen ongerechtvaardigd achter te stellen."

52 Mijns inziens geldt dat voor de met zoveel woorden in artikel 1 genoemde gronden, maar ook voor gronden die volgens vasie rechtspraak kunnen worden ondergebracht onder de ook in artikel 1 opgenomen zinsnede "op welke grond dan ook". Zie verder Olde Kalter in zijn noot bij CRvB 25 maart 1993. TAR 1993, 99: "Indien een differentiatiecriterium tot non-discriminatie grond wordt bestempeld, heeft dat tot gevolg dat onderscheid op die grond 'verdacht' is." 


\subsubsection{De jurisprudentie en het verschil tussen het gelijkheidsbeginsel en het discriminatie-verbod}

Uit het bovenstaande kan worden afgeleid, waaruit het verschil tussen het gelijkheidsbeginsel en het discriminatie-verbod bestaat. $\mathrm{Bij}$ het gelijkheidsbeginsel dient allereerst te worden vastgesteld of sprake is van gelijke gevallen of niet. In het kader van het discriminatie-verbod is een dergelijke vaststelling niet nodig. Het gaat hierbij namelijk om bepaalde min of meer "verdachte" criteria. Op grond van deze criteria mag niet geconcludeerd worden dat sprake is van ongelijke gevallen, omdat gelijkheid van de gevallen bij deze criteria uitgangspunt is. ${ }^{35}$ Ongelijke behandeling van gelijke gevallen (het maken van onderscheid) moet zowel bij het gelijkheidsbeginsel als bij het discriminatie-verbod gerechtvaardigd worden, maar de toetsing van deze rechtvaardiging is zwaarder in geval van onderscheid op de verdachte non-discriminatiegronden dan bij niet verdachte criteria in het kader van het gelijkheidsbeginsel.

Het geschetste verschil in betekenis tussen het gelijkheidsbeginsel en het discriminatie-verbod komt in de jurisprudentie niet of nauwelijks naar voren. De volgende uitspraken illustreren dat.

In de eerder behandelde uitspraak van 4 juli 1989 van de Rechtbank Maastricht gaat het om het verschil in behandeling in de APV Heerlen van prostitué(e)s en prostituanten..$^{54}$ Omtrent het alleen strafbaar stellen in die APV van prostitué(e)s en derhalve niet van prostituanten, oordeelt de Maastrichtse rechtbank (in hoger beroep), dat

"[e]en zo vergaand ongelijke behandeling ... in strijd [is] met het gelijkheidsbeginsel zoals uitgedrukt in art. $1 \mathrm{Gr} . w$. , tenzij er een redelijke grond voor deze ongelijke behandeling is."

Tot zover is deze overweging mijns inziens terecht. Echter verderop in de uitspraak bepaalt de rechtbank dat de gemeenteraad van Heerlen in redelijkheid niet - ter bestrijding van de overlast door straatprostitutie - de keuze had kunnen maken om alleen de prostitué(e) strafbaar te stellen,

53 In de termen van Timmermans (Verboden discriminatie of (geboden) differentiatie): er behoeft bij onderscheid op grond van de verdachte non-discriminatiegronden geen vergelijkbaarheidstoets plaats te vinden, alleen een rechtvaardigingstoets. Zie paragraaf 6.1.4.

54 Rb. Maastricht 4 juli 1989. AB 1989, 423. 
"... daar een dergelijke eenzijdige strafbaarstelling noodzakelijkerwijze en voorzienbaar leidt tot een met art. $1 \mathrm{Gr}$.w. strijdig opsporings- en vervolgingsbeleid door vergaande - en ongegronde - discriminatie van de prostitué(e) tegenover de klant."

Terecht vraagt Kroes zich af of er dan ook gegronde vormen van discriminatie kunnen bestaan. Op grond van de pejoratieve betekenis die de grondwetgever aan het begrip "discriminatie" heeft gegeven, moet die vraag mijns inziens ontkennend beantwoord worden. Met Kroes ben ik van mening dat de Rechtbank beter tot een niet te rechtvaardigen ongelijke behandeling en derhalve tot schending van het gelijkheidsbeginsel had kunnen concluderen. ${ }^{55}$ In cassatie toetst de Hoge Raad inderdaad aan het gelijkheidsbeginsel, zonder overigens iets over de onterechte toepassing van het discriminatieverbod door de rechtbank op te merken. ${ }^{56}$ De Hoge Raad vernietigt het vonnis van de rechtbank omdat de Raad bij de belangenafweging in het kader van de willekeurtoetsing tot een andere conclusie komt. ${ }^{57}$ De Hoge Raad bepaalt, dat het tippelverbod in de APV Heerlen, ook al is het slechts gericht tot één bepaalde groep personen, op zichzelf een geschikt en redelijk middel ter bevordering van het nagestreefde doel kan zijn. De Hoge Raad oordeelt daarop dat de eenzijdige strafbedreiging op het tippelverbod niet in strijd is met het gelijkheidsbeginsel in artikel 1 "op de enkele grond dat niet een overeenkomstig verbod is gericht tot een andere groep van personen die eveneens tot de te bestrijden overlast kan bijdragen."

Ten slotte kan ook nog gewezen worden op de reeds in paragraaf 6.1.2 besproken uitspraak van de Voorzitter van de Afdeling Rechtspraak van 28 september 1989 waarin het gaat om gewetensbezwaarden waarvan de gewone vervangende dienst is aangevangen vóór 1 maart 1989 en gewetensbezwaarden die na die datum zijn begonnen. ${ }^{58}$ De laatste groep krijgt op grond van de Interim-Regeling openbaar vervoerkaart tewerkgestelden een Defensie Openbaar Vervoerkaart (DOV-kaart) terwijl de eerste groep reiskosten moet declareren. Vanwege mogelijke capaciteitsproblemen bij het openbaar vervoer is de regeling gefaseerd,

55 Tj. Gerbranda en M. Kroes, Grondrechten evaluatie-onderzoek, Eindrapport, pp. 247-248.

56 HR 6 november 1990, NJ 1991, 218 met noot ' $t$ Hart: AB 1991, 109 met noot $F . H$. van der Burg. Zie voorts R.E. de Winter, Het Heerlens tippelverbod: de Hoge Raad als feitenrechter, p. 1681.

57 Zie hieromtrent punt 5 van de noot van 't Hart, NJ 1991, 218.

58 Vz.ARRS 28 september 1989, KG 1990, 28. 
lichtingsgewijs ingevoerd per 1 maart 1989 en daarbij de eerste helft van 1989 ook nog experimenteel. De Voorzitter is van oordeel dat gefaseerde invoering van de DOV-kaart met een experimenteel karakter "redelijkerwijs noodzakelijk is" om op bepaalde ontwikkelingen die zich in de praktijk zouden kunnen voordoen te kunnen inspelen. Om die reden acht hij het verschi! in behandeling tussen beide categorieën gewetensbezwaarden zakelijk en objectief gerechtvaardigd. Van belang is ook dat de rechtspositie van erkende gewetensbezwaarden die vóor 1 maart 1989 met hun vervangende dienst zijn begonnen door de regeling niet wordt aangetast. De Voorzitter meent dat het gemaakte onderscheid niet in strijd is met het in artikel 1 Grondwet geformuleerde beginsel van nondiscriminatie.

Ook hier wordt onterecht gesproken van het non-discriminatiebeginsel. Het in deze zaak gemaakte onderscheid gebeurt niet op grond van een verdacht criterium. Het differentiatie-criterium is gelegen in de aanvangsdatum van de vervangende dienst voor gewetensbezwaarden militaire dienst. De Voorzitter had hier (expliciet) moeten toetsen aan het gelijkheidsbeginsel.

\subsubsection{Zwaarte van de toetsing en verschillen tussen non- discriminatiegronden}

Hier zal ingegaan worden op hoe de toetsing aan verschillende nondiscriminatiegronden plaats zou kunnen vinden, waarbij ervan uitgegaan wordt dat niet alle gronden even zwaar wegen. Deze bespreking zal in de eerste plaats geschieden aan de hand van de Amerikaans rechtspraktijk die door de Boer kort is behandeld. ${ }^{59}$ Daarna zal aandacht besteed worden aan recente Nederlandse jurisprudentie over dit onderwerp.

In de jurisprudentie van het Amerikaanse Supreme Court zijn volgens de Boer drie benaderingen te onderscheiden:

1.) de "strict scrutiny-test", waarbij zowel doel als middelen inhoudelijk worden beoordeeld. Het doel van het onderscheid moet een "compelling state interest" zijn en de middelen (de ongelijke behandeling) moeten vour de realisering van dat doel "necessary" zijn. Deze toets vindt plaats als het gaat om een "suspect classification" (ras) of om "an impact on fundamental rights or interests" (zoals "voting" of "criminal appeals");

2.) de "heightened scrutiny-test", waarbij het gaat om "important governmental objectives" (in plaats van "compelling state interest") en de ongelijke behandeling moet "closely and substantially related" (in plaats 
van "necessary", zoals bij 1 of "rationally related", zoals bij 3) zijn. Deze: toets zou worden gehanteerd bij de toetsing van onderscheid naar gesiacht; 3.) de "minimum-scrutiny-test" of "rational relation-test", waarbij vooral op de middelen gelet wordt. De Staat heeft grote beoordelingsvrijheid en er vindt vooral een (marginale) willekeurtoetsing plaats. Het gaat erom, dat sprake is van een redelijk verband tussen doel en middelen.

Ook ten aanzien van de terreinen waarop het onderscheid wordt gemaakt (bijvoorbeeld onderwijs, arbeid, politieke rechten, het genot van een aantal mensenrechten, het openbare leven) bestaat een onderscheid in meer en minder verdachte gebieden. Volgens de Boer is het ene gebied suspecter dan het andere, met name, doordat de betrokkene op het ene terrein een. afhankelijker positie inneemt dan op het andere. Hij geeft hierbij het voorbeeld dat het erger is als vrouw te worden gediscrimineerd bij het verkrijgen van huisvesting of werk dan wanneer zij in een bepaald administratief systeem wordt gedwongen zich met de naam van haar echtgenoot te laten registreren. Ook is het volgens de Boer van belang wie het onderscheid maakt (overheid, privé-persoon, kerk, monopolist etc.).

De conclusie zou kunnen zijn dat hoe verdachter ("suspecter") het differentiatie-criterium is, en hoe fundamenteler het gebied waarop het onderscheid wordt gemaakt, hoe strenger zal moeten worden getoetst. Kan een gemaakt onderscheid deze toets niet doorstaan, dan is sprake van discriminatie. ${ }^{60}$

Vraag is nu, welke benadering de Nederlandse rechterlijke instanties aanwenden bij de toetsing aan het discriminatieverbod in artikel 1. Daartoe behandel ik een tweetal uitspraken inzake discriminatie naar leeftijd. ${ }^{6}$

De eerste uitspraak is die van de Centrale Raad van Beroep van 4 november 1993 die betrekking heeft op het ontslag van een hoogleraar wegens het bereiken van de pensioengerechtigde leeftijd. ${ }^{22}$ Eiser acht dit ontslag in strijd met het verbod van discriminatie op grond van leeftijd.

Ter beantwoording van de vraag of sprake is van discriminatie, onderzoekt de Raad of voor het gemaakte onderscheid redelijke en objectieve gronden aangevoerd kunnen worden. De Ratad overweegt dat het

60 Zie, kort, met name ten aanzien van een zwaarte-verschil in toetsing tussen de diverse non-discriminatiegronden onderling: A.W. Heringa, Onderscheid en discriminatie, pp. 12-14.

6l. Soortgelijke uitspraken naar aanleiding van onderscheid op andere - in artikel 1 uitdrukkelijke genoemde of onder de termen "op welke grond dan ook" te brengen gronden heb ik niet gevonden.

62 CRvB 4 november 1993, AB 1994, 213 met noot $H H$; TAR 1994, 6. 
hier niet gaat om één van de differentiatiecriteria, welke in artikel 1 (en ook artikel 26 IVBPR) met zoveel woorden zijn vermeld maar om discriminatie "op welke grond ook". Hoewel de Raad aan dit verschil geen al te grote betekenis wil toekennen en "een te ver reikende stelligheid op dit punt" afwijst, ligt hierin volgens de Raad toch enig waardeverschil besloten. Dit verschil komt tot uitdrukking in de toetsing van het concrete geval, namelijk bij de toetsing aan welke eisen moet worden voldaan wil het gewraakte onderscheid redelijk en objectief gerechtvaardigd kunnen zijn en bij de eisen die aan partijen worden gesteld met betrekking tot de motivering van hun stellingen. Wel meent de Raad dat het hier gaat om graduele verschillen.

In geval van direct onderscheid op grond van één van de expliciet genoemde non-discriminatiegronden moet de motivering van dat onderscheid aan vrij zware eisen voldoen en een grote overtuigingskracht hebben om het onderscheid te kunnen rechtvaardigen. Daartegenover stelt de Raad het onderscheid dat in vele rechtspositionele regelingen wordt gemaakt. Dat onderscheid wordt veelal gebaseerd op de meest uiteenlopende beleidsnormen en -doelen. Bij het gebruikmaken van dergelijke differentiatie-criteria zal meestal sprake zijn van beleidskeuzen waarbij een "nog marginalere toetsing dan gebruikelijk" zal moeten uitwijzen of aan het onderscheid redelijke en objectieve gronden ten grondslag liggen. In dit laatste geval is het meer aan de ambtenaar om de aanwezigheid van discriminatie, derhalve de afwezigheid van redelijke en objectieve gronden hard te maken, terwijl in het geval van onderscheid op grond van de in artikel 1 met name genoemde "suspecte" criteria het administratief orgaan de afwezigheid van discriminatie en daarmee de aanwezigheid van redelijke en objectieve grond zal moeten aantonen.

In het onderhavige geval gaat het om een rechtspositionele regeling (ontslagregeling) waarin onderscheid gemaakt wordt op grond van leeftijd, een differentiatie-criterium dat niet behoort "tot de in artikel $1 \ldots$ met name genoemde en bij voorbaat suspecte differentiatiecriteria". Bij de toetsing door de Centrale Raad speelt een rol dat leeftijd één van de criteria is die algemeen in wet- en regelgeving worden gehanteerd. In dit geval wordt het leeftijdscriterium gebruikt om het begin en het einde van de deelname aan het arbeidsproces aan te geven. Bij dit laatste, het vaststellen van de pensioengerechtigde leeftijd, hebben volgens de Raad inzichten en wenselijkheden van verschillende aard een rol gespeeld. Behalve dat de 65-jarige leeftijd de gemiddelde leeftijd is waarop ook de sociale verzekeringswetgeving geënt is, is het - aldus de Raad - ook een compromis tussen het (individuele) verlangen naar een periode van een arbeidsvrij inkomen en het verlangen naar een voortzetting van de beroepsuitoefening. De Raad overweegt uiteindelijk: 
"Aan eiser kan worden toegegeven, dat op de verschillende argumenten, die ter onderbouwing van dit systeem worden aangevoerd, bij afzonderlijke analyse het een en ander kan worden afgedongen, maar dat de figuur van het leeftijdspensioen met zijn mede historisch bepaalde ontstaans- en bestaansgronden een redelijke en objectieve grondslag als bovenbedoeld zou ontberen, is de raad niet gebleken en deze stelling wordt naar 's raads oordeel ook niet gedragen door de thans heersende rechtsovertuiging."

In een tweede uitspraak van de Centrale Raad van Beroep, ook van 4 november 1993, gaat het om het hanteren van een leeftijdscriterium in verband met aanspraken op een overlijdensuitkering op grond van artikel 102 lid 2 ARAR. ${ }^{63}$ Overlijdt een ambtenaar, dan wordt bij het ontbreken van een weduwe of weduwnaar van wie de overledene niet duurzaam gescheiden leefde, een uitkering gedaan aan de minderjarige kinderen van overledene; zijn er geen minderjarige kinderen, dan wordt de uitkering gedaan aan meerderjarige kinderen indien voldaan is aan de voorwaarde dat overledene van hen de kostwinner was. Deze kostwinner-eis wordt niet gesteld ten aanzien van minderjarige kinderen. Volgens de (meerderjarige) eiseressen, ten aanzien van wie niet aan deze voorwaarde was voldaan, is de kostwinnerseis in strijd met het discriminatieverbod. Ten aanzien van het onderscheid naar leeftijd citeert de Raad de hiervoor besproken overwegingen uit de eerder behandelde uitspraak van 4 november 1993 (ontslag hoogleraar) en gaat de Raad opnieuw over tot een toetsing van het gemaakte onderscheid. Tevens kenmerkt de Raad, ook hier, de vaststelling van het leeftijdscriterium op 18 jaar als een compromis, waarbij een afweging is gemaakt tussen een aantal maatschappelijke en individuele factoren. De conclusie van de Raad luidt hier als volgt:

"Gelet op het vorenoverwogene en mede in aanmerking genomen dat in tal van regelingen het minderjarig dan wel meerderjarig zijn een rol speelt, kan naar 's Raads oordeel niet worden gesteld dat voor de in geding zijnde regeling geen redelijke en objectieve gronden zijn aan te voeren.

Uit deze twee uitspraken van de Centrale Raad van Beroep kunnen de volgende conclusies getrokken worden ten aanzien van de zwaarte van de toetsing aan de verschillende non-discriminatiegronden. 
Gaat het om onderscheid op één van de in artikel 1 uitdrukkelijk genoemde gronden dan is het onderscheid bij voorbaat verdacht. Dat wil zeggen dat sprake is van de verdenking van discriminatie. Er is pas géén sprake van discriminatie wanneer degene die het onderscheid maakt overtuigend kan antonen, dat het onderscheid objectief en redelijk gerechtvaardigd is. Op deze partij ligt een zware motiveringsplicht. ${ }^{\circ}$

Is sprake van onderscheid op grond van een niet in artikel 1 genoemd criterium $^{65}$ op een terrein waarin veelal grote vrijheid bestaat bij het maken van beleidskeuzen, dan ligt het meer op de weg van degene die een beroep doet op het discriminatieverbod om an te tonen dat er geen objectieve en. redelijke gronden zijn aan te voeren voor het gemaakte onderscheid en dus sprake is van discriminatie. Onderscheid op deze gronden is derhalve niet bij voorbaat verdacht. In dit geval zal ook sprake zijn van "een marginalere toetsing dan gebruikelijk" - waarmee met de term gebruikelijk vermoedelijk gedoeld wordt op de toetsing van een onderscheid gebaseerd op één van de uitdrukkelijk in artikel 1 genoemde criteria - en behoeft slechts te worden beoordeeld of de gemaakte beleidskeuze "binnen redelijkheidsgrenzen" ligt. Aangezien het volgens de Centrale Raad van Beroep gaat om graduele verschillen, veronderstel ik dat het hier gaat om de twee uitersten van een glijdende schaal.

De bovenstaande uitspraken suggereren dat het in de daar aan de orde zijnde casus gaat om een onderscheid dat ergens tussen deze uitersten in ligt, zij het dichterbij het onderscheid waarbij de zwaarste motiveringsplicht rust op degene die zich op het discriminatieverbod beroept. Het gaat in de casus om een niet in artikel $1 \mathrm{Gw}$ genoemd differentiatie-criterium (leeftijd), om een terrein waarop degene die het onderscheid maakt een zekere beleidsvrijheid geniet en het gehanteerde leeftijdscriterium vrij gangbaar is in de desbetreffende soort wetgeving.

64 Zie ook Olde Kalter in zijn noot bij CRvB 25 maart 1993, TAR 1993, 99, waarin hij aan de eerder in noot 52 geciteerde overweging - dat wanneer een differentiatiecriterium tot non-discriminatiegrond wordt bestempeld, dat tot gevolg heeft dat onderscheid op die grond 'verdacht' is - toevoegt, dat de "bewijslast omtrent de gerechtvaardigdheid van het onderscheid ... als het ware (wordt) omgekeerd".

65 Wat betreft dit differentiatie-criterium: de Raad spreekt hier van "de meest uiteenlopende beleidsnormen en -doelen (die) als onderscheidend criteriumn worden gehanteerd". Het lijkt mij dat dit een wat ongelukkige formulering is. Wellicht bedoelt de Raad hier te zeggen dat het onderscheidend criterium met het oog op de meest uiteenlopende beleidsnormen en -doelen worden gehanteerd? In dat geval vormen de desbetreffende beleidsnormen en -doelen de - met het gebruik van het differentiatie-criterium beoogde - differentiatie-doelen. 
Dat het gebruik van het leeftijdscriterium, als niet in artikel $1 \mathrm{Gw}$ genoemd criterium, niet per definitie dicht bij deze uiterste zijde van de glijdende schaal ligt, is op te maken uit een reeds eerder in 1993 door de Centrale Raad besliste zaak. ${ }^{66}$ In die zaak ging het om het gebruik van het leeftijdscriterium van 55 jaar in een interne sollicitatieprocedure binnen de Rijksdienst voor het Wegverkeer. Ten aanzien van de redenen die door gedaagde (de Minister van Verkeer en Waterstaat) zijn aangevoerd, oordeelt de Centrale Raad van Beroep dat deze redenen de Raad niet overtuigen van de gerechtvaardigdheid van het onderscheid en derhalve niet kunnen worden beschouwd als redelijke en objectieve gronden "temeer nu zij op geen enkele wijze zijn geconcretiseerd en/of nader onderbouwd". Uit deze uitspraak blijkt, en voorgaand citaat illustreert dat, dat op degene die het onderscheid maakt in deze zaak de plicht rust de redenen voor het onderscheid adequaat te motiveren. Het enkele geven van redenen voor het onderscheid is niet voldoende.

Kortom, de toetsing is het zwaarst in het geval van de uitdrukkelijk in artikel 1 genoemde differentiatie-criteria. De motiveringsplicht rust hier hoofdzakelijk bij degene die onderscheid maakt. Of het terrein (zoals onderwijs, arbeid, etc.) waarop het onderscheid gemaakt wordt en de mate van beleidsvrijheid van degene die het onderscheid maakt hierbij verschil uitmaken, kan uit de besproken uitspraken niet worden afgeleid. Omdat onderscheid op deze gronden bij voorbaat verdacht is, maakt het vermoedelijk niet uit op welk terrein en met welke mate van beleidsvrijheid onderscheid gemaakt wordt. Dit laatste is wel het geval bij non-discriminatiegronden die vallen onder de zinsnede "op welke grond dan ook". Hier is de toetsing lichter en rust de motiveringsplicht meer op degene die zich gediscrimineerd voelt, al naar gelang degene die het onderscheid maakt een grotere beleidsvrijheid toekomt. Naast de mate van beleidsvrijheid die een instantie heeft die onderscheid maakt, lijkt ook de vraag in hoeverre het desbetreffende leeftijdscriterium in de toepasselijke categorie van regelgeving gangbaar is, van invloed te zijn op de verdeling van de "motiveringslast". ${ }^{67}$ Of een non-discriminatiegrond die volgens vaste jurisprudentie onder de zinsnede "op welke grond dan ook" valt bij

66 CRvB 25 maart 1993, TAR 1993, 99 met noot C.J.G. Olde Kalter. Vgl. Rb. Zutphen 11 mei 1995, NJCM-Bulletin 20-5 (1995), pp. 598-605 met noot G. Heerma van Voss.

67 In de twee uitspraken van 4 novernber 1993 ging het om gangbare leeftijdscriteria ( 65 jaar in verband met pensioengerechtigdheid en 18 jaar met betrekking tot aan onderhoudsverplichtingen tussen ouder en kind gerelateerde sociale wetgeving), in de uitspraak van 25 maart 1993 niet (55 jaar en sollicitatie naar een leidinggevende functie). 
voorbaat verdacht is (wat - nogmaals - betekent dat degene die onderscheid makt afwezigheid van discriminatie moet aantonen), hangt blijkbaar af van de context waarin het onderscheid gemaakt wordt. ${ }^{*}$

\subsubsection{Indirect onderscheid}

Alhoewel het bij indirect onderscheid gaat om een op zichzelf neutraal differentiatie-criterium, is dit onderscheid - ondanks dat het criterium geschikt is met het oog op het na te streven differentiatiedoel - niet toegestaan indien gebruik van dit criterium leidt tot een onderscheid op grond van een verdacht criterium. Op grond van de hantering van een neutraal criterium wordt geconcludeerd tot ongelijkheid van de gevallen die ongelijk behandeld mogen worden, maar dit resulteert in de ongelijke behandeling van gevallen die als gelijke gevallen dienen te worden beschouwd. De ontstane ongelijke behandeling moet daarom objectief en redelijk gerechtvaardigd worden, anders is sprake van (indirecte) discriminatie. Men denke bijvoorbeeld aan het in de praktijk voorkomende geval, dat door werkgevers onderscheid gemaakt (in verband met ontslagen, loonsverhogingen en dergelijke) wordt tussen werknemers die full-time en werknemers die part-time werken. Het is een gegeven, dat het vooral vrouwen zijn die part-time werken. Een onderscheid gebaseerd op de omvang van het dienstverband (full-time of part-time) kan derhalve al gauw een onderscheid naar geslacht met zich brengen dat gerechtvaardigd moet worden, wil er geen sprake zijn van indirecte discriminatie. ${ }^{69}$

68 Volgens Olde Kalter (noot bij CRvB 25 maart 1993, TAR 1993, 99) betreft het hier, naast de uitdrukkelijk in artikel 1 genoemde en het criterium leeftijd, ook de nondiscriminatiegronden: seksuele gerichtheid, burgerlijke staat, nationaliteit, handicap en afkomst.

69 De rechtspraak ten aanzien van indirecte discriminatie brengt een speciale hewijsproblematiek met zich, die van belang zou kunnen zijn voor de reikwijdte van het begrip discriminatie (zie bijvoorbeeld CRvB 31 mei 1990, TAR 1990, 161). Aangezien de rechtspraak echter meestal niet artikel 1 Grondwet betreft, maar communautair recht, artikel 26 IVBPR, de Wet Gelijke Behandeling, bepalingen uit het WvSr of BW (artikel 1401-oud) zal op dit onderwerp - vanwege de omvang van het onderzoek die dat met zich zou brengen - niet verder ingegaan worden. Ik verwijs hiervoor naar onder meer: $T$. Loenen, AAW en deeltijdwerkers, noot bij RvB Groningen 10 april 1990, pp. 479-493 en K. Wentholt, Onderbroken loopbaan en indirecte discriminatie, noot bij Ktg. Zaandam 15 februari 1990, pp. 672-679: M.C. Burkens en H.R.B.M. Kummeling, Het bewijs van discriminatie, pp. 3-27; A.W. Heringa, Recente EG jurisprudentie gelijke behandeling man/vrouw, pp. 55-70; $G$. Heerma van Voss, Indirecte discriminatie in sociale zekerheid vastgesteld, noot bij CRvB 23 juni 1992, pp. 292-298. Wel betrekking op artikel 1 Grondwet hebben de hieronder bij de non-discriminatiegronden nog te bespreken zaken: Gerechtshof 


\subsubsection{Verschil tussen de termen onderscheid en discriminatie; de Algemene wet gelijke behandeling ${ }^{70}$}

Voor zover dat nog niet uit het bovenstaande duidelijk is geworden - moet erop gewezen worden dat de termen onderscheid en discriminatie niet door elkaar gebruikt kunnen worden. Er is pas sprake van discriminatie als het gemaakte onderscheid niet gerechtvaardigd kan worden. Discriminatie is verboden onderscheid, onderscheid zelf is niet per definitie verboden." Zie hieromtrent ook een publikatie van het Landelijk Bureau Racismebestrijding. Ten aanzien van indirecte discriminatie en indirect onderscheid wordt opgemerkt dat deze begrippen vaak onterecht als synoniemen worden gebruikt. Juridische gezien is er een groot verschil tussen beide termen: "indirecte discriminatie is discriminatie en dus verboden. Het constateren van indirect onderscheid daarentegen levert in eerste instantie een vermoeden van discriminatie op. Kan dat vermoeden niet worden weerlegd op objectief te rechtvaardigen gronden, dan is er sprake van indirecte discriminatie met het bekende gevolg: verbod. " Daar op volgt de opmerking dat indirect onderscheid mogelijk objectief te rechtvaardigen is, maar indirecte discriminatie nimmer. ${ }^{2}$

Steun voor deze opvatting kan tevens gevonden worden in de Algemene wet gelijke behandeling. In deze wet zien we dat de wetgever zich bedient van de term "onderscheid" en niet van de term "discriminatie". Er is volgens de regering sprake van discriminatie in geval van een door deze wet verboden onderscheid. ${ }^{33}$ Onderscheid op de door de wet bestreken

Amsterdam 6 september 1990 (direct onderscheid naar nationaliteit als indirecte discriminatic naar ras), LBR-Bulletin 1990, nr. 6, pp. 27-32 met noot Pattipawae; Tijdschrift voor Consumentenrecht 1990, pp. 396-399, in cassatie: HR 13 december 1991, NJCM-Bulletin 17-5 (1991), pp. 522-528, punt 3: LBR-Bulletin. 1992, nr. 1, pp. 12-21 met noot $P$. Rodrigues: HR 20 maart 1992. NJ 1992. 495 (indirecte discriminatie naar nationaliteit) met noot PAS: Rb. Rotterdam 27 juli 1990 , Migrantenrecht 1990, 10. pp. 143-149; Pres.Rb. Amsterdam 13 september 1984, KG 1984, 280 (indirecte discriminatie naar hetero- of homoseksuele gerichtheid).

70 Wet van 2 maart 1994. Stb. 230, in werking getreden per 1 september 1994. Zie voor een bespreking van de totstandkoming van deze wet Th.A. van Baarda, Oordeelsvorming in casus van botsende grondrechten, pp. 131-170.

71 Het heeft derhalve absoluut geen zin om te spreken van verboden of ongerechrvardigde discriminatie, zoals wel in de literatuur gebeurd (zie bijvoorbeeld de titel van de bijdrage van C.W.A. Timmermans: "Verboden discriminatie of (geboden) differentiatie").

72 Landelijk Bureau Racismebestrijding, Met recht rassendiscriminatie bestrijden, p. 10.

73 Memorie van Antwoord bij wetswoorstel 22014. Algemene wet gelijke behandeling. Tweede Kamer, punt 5.3. 
terreinen (zie de artikelen 5 tot en met 7) op grond van de in de wet genoemde criteria - godsdienst, levensovertuiging, politieke gezindheid, ras, geslacht, nationaliteit ${ }^{4}$, hetero- of homoseksuele gerichtheid en burgerlijke staat - is volgens de regering bij voorbaat verdacht. ${ }^{75}$ Volgens de artikelen 2 en 3 van de wet zijn bepaalde uitzonderingen op het verbod van onderscheid (let wel: niet op het verbod van discriminatie!) toegestaan. Zo is indirect onderscheid niet verboden in geval van een objectieve rechtvaardiging. Voorts gelden ten aanzien van diverse nondiscriminatiegronden een aantal uitzonderingen, zoals in geval van voorkeursbehandeling ${ }^{76}$ van vrouwen of personen behorende tot een

74 De non-discriminatiegrond "nationaliteit" is ingevoegd bij de Zesde nota van wijziging, wetsvoorstel 22014, Algemene wet gelijke behandeling. Tweede Kamer.

75 Memorie van Antwoord bij wetsvoorstel 22014, A.lgemene wet gelijke behandeling. Tweede Kamer, punt 4.1, vierde alinea.

76. Een aardige uitspraak inzake de voorkeursbehandeling van etnische minderheden is Nat. Ombudsman 3 november 1989, AB 1989, 564. Uit deze uitspraak volgt dat positieve actie, opgevat als tijdelijke maatregelen die een bepaalde groep personen met bepaalde groepskkenmerken bevoorđelen ter bestrijding van een bestaande achterstand van die groep, niet in strijd is met artikel 1 Grondwet alhoewel positieve actie een achterstelling van andere groepen inhoudt. In dit soort gevallen is het maken van onderscheid gerechtvaardigd met het oog op het wegwerken van een bestaande achterstand. De Ombudsman hanteert naast het bestaan van een achterstand voorts een aantal andere criteria: de Ombudsman acht van belang de betekenis die. volgens algemeen aanvaarde maatschappelijke opvattingen terzake, moet worden gehecht aan een bestaande ongelijkheid en welke urgentie aan de bestrijding daarvan toekomt. Voorts spelen de belangen van derden een rol: in dit geval is van belang dat de niet bevoorrechte groep personen niet categorisch wordt uitgesloten van een bepaalde functie (hetzelfde zou bijvoorbeeld kunnen gelden voor bepaalde woonruimte) en de tijdelijkheid van de maatregel. Een dergelijke benadering van het fenomeen positieve actie of voorkeursbehandeling strookt mijns inziens ook met de opvatting van de regering en de Raad van State (Nader rapport bij wetsvoorstel 22014, Algemene wet gelijke behandeling, Tweede Kamer, punt 6, p. 11) ten aanzien van de uitzondering op het verbod van onderscheid in geval van een voorkeursbehandeling in artikel 2 lid 3 wetsvoorstel Algemene wet gelijke behandeling, dat er sprake moet zijn van evenredigheid tussen de ongelijke behandeling en het beoogde doel: het wegwerken van een bepaalde achterstand. Het voorgestelde artikel 2 lid 3 AWGB spreekt van een "redelijke verhouding ... tot dat doel" (het opheffen van feitelijke ongelijkheden). Overigens heeft de regering uitgesproken de nadere invulling van deze uitzonderingsgrond aan de rechtspraak en de uitvoeringspraktijk over te laten. Deze uitspraak van de Ombudsman zou daarvoor mijns inziens een goede leidraad kunnen zijn. Ook kan verwezen worden naar de jurisprudentie van de Commissie Gelijke Behandeling. Zie verder Vz.ARRS 15 oktober 1993, AB 1994, 178 waar in de Voorzitter bepaalt dat het voeren van een voorkeursbeleid - dat gericht is op de beëindiging van een achterstandssituatie van bepaalde groepen in de samenleving op zichzelf niet in strijd behoefi te zijn met artikel 1, maar dat dan de gerechtvaardigdheid van dit voorkeursbeleid wel moet worden aangetoond aan de hand van een 
bepaalde etnische of culturele minderheidsgroep en gevallen waarin het geslacht of het ras van een persoon bepalend is. De structuur van de wet brengt met zich, dat in geval van direct onderscheid op één van de in de wet genoemde non-discriminatiegronden bij voorbaat de verdenking rijst dat voor dat onderscheid geen rechtvaardiging bestaat. Volgens de regering wordt het bestaan van een rechtvaardigingsgrond als een uitzonderlijke situatie gezien. Wie zich bij het maken van een dergelijk onderscheid kan beroepen op een van de voorziene uitzonderingsgevallen, valt niet onder het verbod. ${ }^{n}$

\subsubsection{De non-discriminatiegronden}

Ten slotte zal worden ingegaan op de non-discriminatiegronden in artikel 1 Grondwet. Onderzocht zal worden wat de reikwijdte van deze gronden is. Omdat vrijwel geen criteria ter afbakening van de nondiscriminatiegronden in de jurisprudentie te vinden zijn, zal deze bespreking vooral betrekking hebben op wat er onder de bedoelde begrippen valt, zonder de grenzen van de non-discriminatiegronden aan te kunnen geven.

Met betrekking tot de term "ras" is tijdens de parlementaire behandeling ten aanzien van artikel 1 door de regering de opvatting verkondigd, dat het niet de bedoeling is in de wetgeving te introduceren dat het begrip "ras" geïnterpreteerd moet worden naar de verworvenheden van de wetenschap. Dat betekent dat wanneer men spreekt over "ras", niet alleen bedoeld wordt de wetenschappelijke betekenis van dit begrip (waarbij met ras gedoeld wordt op "etnisch verschillen") maar ook de uitleg naar spraakgebruik, zodat men bij discriminatie van bijvoorbeeld een Surinamer

grondige en toereikende motivering.

77 Vgl. de Memorie van Antwoord bij wetsvoorstel 20239, Aanvulling van het Wetboek van Strafrecht met enkele bepalingen tot het tegengaan van discriminatie .... Tweede Kamer, p. 4: Het hegrip discriminatie wordt omschreven in artikel 90quater Sr. De term onderscheid omvat direct en indirect onderscheid. "Direct onderscheid is behoudens in de wet limitatief opgesomde uitzonderingen altijd verboden, indirect onderscheid is verboden, tenzij het objectief gerechtvaardigd is. ... dat indirect onderscheid niet alteen onderscheid is dat direct onderscheid tot gevolg heeft, doch ook onderscheid dat direct onderscheid redelijkerwijs tot gevolg kan hebben, waarmee ik bedoelde dat het gevolg redelijkerwijs valt te voorzien." 
Creool, Chinees, Hindoestaan, Indiaan, Libanees, etc. - ook kan spreken van discriminatie naar ras. ${ }^{78}$

Ten aanzien van het begrip "ras" bestaat een vaste jurisprudentie, echter niet naar aanleiding van artikel 1 Grondwet maar op grond van de artikelen 137 c-e Wetboek van Strafrecht $(\mathrm{Sr}$ ). Toch is deze jurisprudentie belangrijk voor de interpretatie van het begrip "ras" in artikel 1 Grondwet, omdat de bedoelde strafwetgeving kan worden beschouwd als een uitwerking van het grondwettelijke discriminatieverbod. In een uitspraak van de Rechtbank Zwolle van 6 februari 1986 wordt het begrip "ras" in artikel $137 \mathrm{~d} \mathrm{Sr}$ uitgelegd "naar de kennelijke strekking van de in artikel 1 Internationaal Verdrag van New York van 7 maart 1966 inzake de uitbanning van alle vormen van rassendiscriminatie (IVRD) gegeven opsomming, waarin naast 'ras' ook worden genoemd: huidskleur, afkomst of nationale of etnische afstamming. ${ }^{\text {"79 }}$ Volgens de Hoge Raad doet hier niets aan af, dat het begrip "ras" in artikel 137c Sr door deze interpretatie een ruimere strekking heeft dan deze term in het normale spraakgebruik heeft. Op grond van de uitspraak van de Hoge Raad van 1 juli 1986 valt onderscheid naar nationaliteit in etnische (en niet in staatkundige) zin ook onder het begrip "ras": het kan begrepen worden als onderscheid naar "ras" in de zin van "nationale afstamming". ${ }^{00}$

Met betrekking tot de andere, uitdrukkelijk genoemde nondiscriminatiegronden: onder artikel 1 is mij geen rechtspraak bekend waarin de betekenis en reikwijdte van deze non-discriminatiegronden worden onderzocht. ${ }^{81}$ Ook de kamerstukken met betrekking tot het voorstel dat heeft geleid tot de Algemene wet gelijke behandeling kunnen hier maar beperkt houvast bieden. Ten aanzien van de non-

78 Gezamenlijke mondelinge behandeling van de wetsontwerpen 13872 en 13873 door de Tweede Kamer, in: Algehele grondwetsherziening, deel la Grondrechten, p. 444. (kamervragen op pp. 437 en 439).

79 Rb. Zwolle 6 februari 1986, NJ 1986, 454. De Rechtbank verwijst naar HR 15 juni 1976, NJ 1976, 551. Zie voorts HR 11 maart 1986, NJ 1986. 613 met noot $A . C$. ' $t$ Hart (t.a.v. artikel 137c Sr) en Rb. Leeuwarden 8 juli 1987. NJ 1988, 144 (t.a.v. artikel 137e Sr). Zo ook de Memorie van Toelichting bij wetsvoorstel 22014, AWGB, Tweede Kamer, Artikelsgewijze toelichting bij artikel 1, p. 13. Zie voorts voor andere uitspraken waarin deze discriminatiegrond wordt toegepast $T$ j. Gerbranda en $M$. Kroes, Grondrechten evaluatie-onderzoek, Documentatierapport - 1, pp. 227-243(227-230).

80 HR 1 juli 1986, NJ 1987, 217.

81 Vanzelfsprekend wil dit niet zeggen, dat deze discriminatie-gronden in de rechterlijke praktijk niet zijn toegepast. Voor deze rechtspraak verwijs ik naar $T j$. Gerbranda en M. Kroes, Documentatierapport - 1, pp. 221-226 (godsdienst en levensovertuiging), 226-227 (politieke gezindheid) en 243-266 (geslacht). 
discriminatiegrond "geslacht" wordt in de Memorie van Toelichting opgemerkt dat sprake is van direct onderscheid indien onderscheid gemaakt wordt op grond van zwangerschap, bevalling en moederschap. ${ }^{82}$ De nondiscriminatiegronden "godsdienst", "levensovertuiging" en "politieke gezindheid" worden ook in deze kamerstukken niet toegelicht. Anders is dit in de kamerstukken ten aanzien van artikel 1 Grondwet 1983 met betrekking tot het begrip "politieke gezindheid". In de stukken en tijdens de parlementaire behandeling van artikel 1 is veelvuldig gesproken over de reikwijdte van het discriminatieverbod op deze grond. Hierbij gaat het met name om de gevallen waarin iemands politieke gezindheid wel een rol kan spelen, derhalve de uitzonderingen op het verbod van onderscheid op deze grond. Het betreft hier onder meer de samenstelling van colleges van advies en bijstand. Daarbij moet niet alleen gelet worden op specialistische kennis, aldus de regering, maar ook op een evenwichtige samenstelling naar politieke overtuiging. Bovendien kunnen bij benoemingen geschiktheidseisen worden gesteld, wat met zich kan brengen dat de politieke gezindheid van een kandidaat mee gewogen wordt, "in dier voege, dat die politieke gezindheid mede bepalend is voor de beoordeling van de geschiktheid van een bepaalde kandidaat voor een bepaalde functie. "83 Naderhand wordt dit verder toegelicht. In de Memorie van Antwoord stelt de regering dat het door deze uitzondering mogelijk is aan kandidaten voor bijvoorbeeld het burgemeestersambt de voorwaarde te stellen "dat zij onder alle omstandigheden hun functie in overeenstemming met de eisen van een democratische rechtsstaat zullen vervullen." Of een kandidaat aan deze voorwaarde voldoet, zal moeten worden afgeleid uit zijn gedragingen en andere relevante gegevens, waaronder eventueel ook zijn politieke gezindheid. De regering benadrukt dat het hierbij steeds gaat on de geschiktheid van een concreet persoon voor een concrete functie." In de Nota naar aanleiding van het eindverslag wordt hieraan ter verduidelijking van de noodzaak van de geschetste uitzondering op het verbod van onderscheid naar politieke gezindheid toegevoegd, dat er in Nederland personen zijn met een gezindheid die gericht is op de vervanging van onze rechtsstaat door een dictatoriaal regime. Dergelijke personen kunnen volgens de regering niet aan de gestelde

82 Memorie van Toelichting bij artikel 1 van wetsvoorstel 22014, AWGB, Tweede Kameri, p. 13.

83 Memorie van Toelichting bij wetsvoorstel 13872, Verklaring dat er grond bestaat .... Tweede Kamer, in: Algehele grondwetsherziening. deel Ia Grondrechten, p. 25.

84 Memorie van Antwoord bij wetsvoorstel 13872, Verklaring dat er grond bestaat .... Tweede Kamer, in: Algehele grandwetsherziening, deel la Grondrechten, pp. 186187. 
geschiktheidseisen voldoen. ${ }^{\text {s5 }}$ In principe is het derhalve op grond van artikel 1 Grondwet verboden onderscheid te maken op grond van een persoon's politieke gezindheid. Dit kan echter uitzondering leiden bij de samenstelling van bepaalde commissies en raden met het oog op een evenwichtige politieke samenstelling van deze organen. Ook kan wel onderscheid op grond van politieke gezindheid gemaakt worden indien het gaat om de vervulling van een bepaalde vertrouwensfunctie. Van de kandidaat mag verwacht worden dat hij de functie onder alle omstandigheden in overeenstemming met de eisen van een democratische rechtsstaat kan vervullen. Van personen met bepaalde politieke overtuigingen, onder meer die gezindten die een dictatoriaal regime nastreven, wordt bij voorbaat verwacht dat zij niet aan deze geschiktheidseisen zullen kunnen voldoen. Wel zal met de individuele capaciteiten van de kandidaat rekening gehouden moeten worden, want het gaat om de geschiktheid van een bepaalde persoon voor een bepaalde functie. Ten tijde van de grondwetsherziening werd bij deze politieke gezindten waarvan bij voorbaat vermoed werd dat zij ongeschikt waren voor bepaalde functies, bijvoorbeeld het burgemeestersambt, in de eerste plaats gedacht aan communisten. ${ }^{86}$ In deze tijd, na het einde van de koude oorlog, is hier minder aanleiding voor en zal vermoedelijk men het oog hebben op alle extremistische groeperingen - links én rechts - in de samenleving. ${ }^{87}$

85 Nota naar aanleiding van het eindverslag bij wetsvoorstel 13872, Verklaring dat er grond bestaat .... Tweede Kamer, in: Algehele grondwetsherziening, deel Ia Grondrechten, p. 222. Zie verder de gezamenlijke mondelinge behandeling van de wetsontwerpen 13872 en 13873 door de Tweede Kamer, in: Algehele grondwetsherziening, deel la Grondrechten, pp. 444-445 en ten aanzien van het vragen naar de politieke gezindheid (en godsdienst) van een kandidaat voor een vertrouwensfunctie, p. 446: hiernaar mag gevraagd worden indien dat relevant is en degene die ernaar vraagt moet die relevantie aantonen en bewijzen dat het eventueel gemaakte onderscheid niet discriminerend is. Kamervragen op pp. 372, 436, 438-439, en 441 .

$86 \mathrm{Vgl}$. de gezamenlijke mondelinge behandeling van de wetsontwerpen 13872 en 13873 door de Tweede Kamer, in: Algehele grondwetsherziening, deel la Grondrechten, pp. 441 en 447.

87 Men kan zich hier overigens afvragen, of het wellicht niet gewenster is dergelijke groeperingen zelf te verbieden in plaats van alleen de leidende figuren van die bewegingen uit bepaalde functies te weren. Komt men tot de conclusie, zoals destijds kennelijk met betrekking tot de CPN (Communistische Partij Nederland), dat een bepaalde politieke partij niet verboden kan worden en kan deelnemen aan verkiezingen voor vertegenwoordigende organen, dan lijkt mij weinig reden voor het uitsluiten van leden en aanhangers van die partijen van bepaalde functies. Die discussie past echter niet in het kader van dit onderzoek en laat ik aan anderen over. 
Wat betreft de interpretatie van "godsdienst" en "levensovertuiging": wellicht kan de interpretatie van artikel 6 hier uitkomst bieden. ${ }^{\text {s8 }}$

Vervolgens moet ingegaan worden op de non-discriminatiegronden die onder de termen "op welke grond dan ook" in artikel 1 Grondwet gebracht kunnen worden. Oorspronkelijk stonden in het wetsvoorstel tot herziening van de Grondwet bij het discriminatieverbod in artikel 1 alleen de gronden godsdienst, levensovertuiging, politieke gezindheid, ras en geslacht vermeld. Reden voor de opname van deze gronden was dat men deze in de toenmalige situatie te lande "relevant" achtte. Andere kenmerken zoals nationale of andere afkomst, eigendom, arbeid, geboorte en andere status hadden volgens de regering in ons land een minder grote actualiteit. Ten aanzien van de toevoeging van leeftijd in zijn algemeenheid, burgerlijke. staat en persoonlijke kenmerken in zijn algemeenheid (als voorbeeld noemt de regering geestelijke en lichamelijke bekwaamheden) was de regering van opvatting dat het onvermijdelijk zou blijven in tal van gevallen op deze gronden rechten en plichten te differentiëren. Onderscheid op gronden als homofilie en nationaliteit zou volgens de regering getoetst kunnen worden aan het gelijkheidsbeginsel. Juist het noemen van bepaalde kenmerken in de tweede zin van artikel $\mathbf{J}$ beschouwde de regering als de kracht van het discriminatieverbod. ${ }^{89}$ Toevoeging van andere non-discriminatiegronden werd niet zinvol geacht. ${ }^{\circ}$ Deze argumenten werden bij de parlementaire behandeling van het wetsvoorstel tegengesproken. Zo werd onder meer aangevoerd, dat "de Grondwet niet primair op de actualiteit gericht dient te zijn, maar een aantal principiële uitgangspunten registreert. ${ }^{n 9 !}$ Ook werd de keuze van kenmerken arbitrair geacht, omdat er altijd wel mogelijkheden tot discriminatie te vinden zouden zijn waarin niet voorzien is. ${ }^{92}$ Als argument tegen de limitatieve opsomming van non-

Zie paragraaf 6.2.1.1.

89. Memorie van Antwoord bij wetsvoorstel 13872, Verklaring dat er grond bestaat ..., Tweede Kamer, in: Algehele grondwetsherziening, deel Ia Grondrechten, pp. 185186.

90 Nota naar aanleiding van het eindverslag bij wetsvoorstel 13872. Verklaring dat er grond bestaat .... Tweede Kamer, in: Algehele grondwetsherziening, deel la Grondrechten, p. 222.

91 Kamerlid Huijsen, Gezamenlijke mondelinge behandeling van de wetsontwerpen 13872 en 13873 door de Tweede Kamer, in: Algehele grondwetsherziening, deel la Grondrechten, p. 39!.

92 Respectievelijk de kamerleden Huijsen, Kappeyne van de Coppello, Bakker en Roethof. Gezamenlijke mondelinge behandeling van de wetsontwerpen 13872 en 13873 etc., in: Algehele grondwetsherziening, deel Ia Grondrechten, respectievelijk pp. 391-392, 436,437 en $439-440$. 
discriminatiegronden werd voorts gewezen op diverse mensenrechtenverdragen waarin een non-discriminatieverbod is opgenomen met nietlimitatieve opsomming van gronden (bijvoorbeeld artikel 26 IVBPR). ${ }^{93}$ Door het kamerlid Bakker werd een amendement ingediend, waarin werd voorgesteld aan de genoemde non-discriminatiegronden de formulering "op welke grond dan ook" toe te voegen. ${ }^{\text {" }}$ Dit amendement werd naderhand door de regering overgenomen. ${ }^{95}$

Welke non-discriminatiegronden omvatten de termen "op welke grond dan ook"? Tijdens de behandeling van het voorgestelde artikell 1 Grondwet kwamen met name de gronden "seksuele geaardheid" en "nationaliteit" ter sprake. Over de reikwijdte van het discriminatieverbod in verband met deze gronden wordt uit de kamerstukken echter niett veel duidelijk. Alleen wat betreft de grond "nationaliteit" wordt erop gewezen, dat rekening gehouden moet worden met de bestaande situatie dat er in de wereld verschillende staten zijn, wat rechtvaardigt dat er een aantal verschillen in rechten tussen vreemdelingen en eigen staatsburgers bestaan, zoals met betrekking tot het kiesrecht en het recht op bijstand. ${ }^{\%}$ Ook wordt niet bij voorbaat uitgesloten dat in het kader van de internationale samenwerking voordeelregelingen (EG) met betrekking tot bepaalde nationaliteiten bestaan." Om meer inzicht te krijgen in de betekenis van de nondiscriminatiegronden die zouden kunnen vallen onder de formulering "op welke grond dan ook" in artikel 1 Grondwet, zal hier opnieuw - waar nodig - gekeken worden naar de parlementaire stukken ten aanzien van, met name, de Algemene wet gelijke behandeling.

Met betrekking tot de grond "hetero- of homoseksuele gerichtheid" wordt in de Memorie van Toelichting bij het wetsvoorstel AWGB opgemerkt dat het woord "gerichtheid" ziet op iemands gerichtheid in seksuele en

93 Kamerlid Roethof, Gezamenlijke mondelinge behandeling van de wetsontwerpen 13872 en 13873 etc., in: Algehele grondwetsherziening, deel la Grondrechten, p. 440 .

94 Amendement van het lid Bakker bij wetsvoorstel 13872, Verklaring dat er grond bestaat .... Tweede Kamer, in: Algehele grondwetsherziening, deel Ia Grondrechten, p. 231.

95 Gezamenlijke mondelinge behandeling van de wetsontwerpen 13872 en 13873 door de Tweede Kamer, in: Algehele grondwetsherziening, deel Ia Grondrechten, p. 448.

96 Zie 0.a. het Nader rapport bij wetsvoorstel 13872, Verklaring dat er grond bestaat .... Tweede Kamer, in: Algehele grondwetsherziening, deel la Grondrechten, p. 86.

97 Memorie van Antwoord bij wetsvoorstel 13872, Verklaring dat er grond bestaat ...., Tweede Kamer, in: Algehele grondwetsherziening, deel Ia Grondrechten, p. 185. Zie ook de gezamenlijke mondelinge behandeling van de wetsontwerpen door de Tweede Kamer, idem, pp. 440-441. 
liefdesgevoelens, -uitingen en relaties. ${ }^{97}$ In de Memorie van Antwoord bij wetsvoorstel 20239 wordt ten aanzien van de term "gerichtheid" in het te wijzigen artikel 90quater Sr vermeld, dat voor deze term is gekozen, "omdat het niet alleen gat om de geaardheid, maar ook om de wijze waarop die geaardheid zich openbaart." ${ }^{19}$ Ook biseksualiteit kan volgens de Nota naar aanleiding van het eindverslag bij de voorgestelde AWGB onder deze non-discriminatiegrond gebracht worden. ${ }^{100}$ Ten aanzien van andere gevallen van discriminatie op grond van seksuele gerichtheid benadrukt de regering, dat nu deze niet geregeld worden door de voorgestelde AWGB, dit niet wil zeggen dat discriminatie in deze gevallen toegestaan is. De rechter moet, aldus de Memorie van Antwoord, in een hem voorgelegd geval aan de hand van het geldende recht over de rechtmatigheid van het gemaakte onderscheid een oordeel vellen ${ }^{101}$ Een voorbeeld, van de schaarse jurisprudentie waarin op de betekenis van de non-discriminatiegrond "hetero- of homoseksuele gerichtheid" wordt ingegaan, is de uitspraak van het Gerechtshof Amsterdam van 10 december 1987. ${ }^{102}$ Deze zaak betreft een vordering van, onder andere, de Nederlandse Vereniging tot Integratie van Homoseksualiteit COC naar aanleiding van uitlatingen van Kardinaal Simonis, dat volgens de leer van de Rooms-Katholieke Kerk homofielle gedragingen ongeoorloofd zjjin. Ten aanzien van artikel 1 Grondwet bepaalt het Gerechtshof dat in het discriminatieverbod sexuele gerichtheid niet uitdrukkelijk wordt genoemd, "doch wel is inbegrepen". De desbetreffende uitlatingen van de Kardinaal

98 Memorie van Toelichting bij ar. I van wetsvoorstel 22014, AWGB, Tweede Kamer, p. 13. In de Memorie van Antwoord wordt het aldus geformuleerd, dat het begrip "gerichtheid" naast gevoelens en voorkeuren ook concrete uitingen omvat, p. 21.

99 Memorie van Antwoord bij wetsvoorstel 20239. Aanvulling van het Wetboek van Strafrecht met enkele bepalingen tot het tegengaan van discriminatie ..., Tweede Kamer, p. 19.

100 Nota naar aanleiding van het eindverslag bij wetsvoorstel 22014. AWGB. Tweede Kamer, punt 4.9 .

101 Memorie van Antwoord bij wetsvoorstel 22014, AWGB. Tweede Kamer, punt 4.5. $\mathrm{Vgl}$. de Nota naar aanleiding van het eindverslag bij wetsvoorstel 20239, Aanvulling van het Wietboek van Strafrecht met enkele bepalingen tot het tegengaan van discriminatie .... Tweede Kamer, p. 8. Zie voor een uitspraak t.a.v. de hoogte van een uitkering van een man waarin de transseksualiteit van zijn partner een rol speelt: KB 10 januari 1986, nr. 76, Jurisprudentie ABW 1986, 154. In deze zaak gaat het niet om een beroep op het discriminatie-verbod. Betrokkene voert ongelijkheid van zijn relatie met een gezinsrelatie aan teneinde toekenning van een hogere uitkering te bewerkstelligen. De Kroon accepteert dit beroep. wat echter niet leidt tot de toekenning van de gevraagde (hogere) uitkering.

102 Gerechtshof Amsterdam 10 december 1987, NJCM-Bulletin 14-3 (1989), pp. 312-317 met noot C. Waaldijk, pp. 324-331. Hoger beroep van Pres.Rb. Utrecht 5 maart 1987, idem, pp. 305-312. 
kunnen derhalve aan het discriminatieverbod worden getoetst. Interessanter en wellicht meer illustratief voor hoe deze grond zou kunnen worden toegepast is de uitspraak van de President van de Rechtbank Amsterdam van 13 september $1984 .{ }^{103}$ Het gaat in deze zaak onder meer om de vraag of de toepassing van de beleidsregel - dat samenlevende partners, van wie één van beiden de Nederlandse nationaliteit heeft, over passende huisvesting moet beschikken - strijdig is met het discriminatieverbod in onder andere artikel 1 Grondwet. Hoewel de Vreemdelingencirculaire onderscheid makt tussen gehuwd en ongehuwd samenwonenden is dit onderscheid in casu volgens de President niet relevant. Van belang is hier de vraag of het aanvaardbaar is dat er géén onderscheid gemaakt wordt tussen heteroseksuele en homoseksuele samenwonenden. Deze gevallen zijn, aldus de President, niet gelijk omdat heteroseksuele partners in het algemeen wel met elkaar kunnen trouwen, maar homoseksuele partners in het geheel niet. Dit verschil acht de President in het onderhavige geval relevant vanwege het in het beleid gemaakte onderscheid tussen gehuwden en samenwonenden. Om die reden meent de President dat deze twee categorieën samenwonenden niet altijd gelijk behandeld dienen te worden. Onverkorte toepassing van de hierboven weergegeven beleidsregel dat samenwonende partners over passende huisvesting moeten beschikken kan dan ook in strijd komen met het discriminatieverbod in artikel 1 Grondwet. Op deze wijze zouden homoseksuele partners worden achtergesteld bij huwelijkspartners met wie zij volgens de President overigens op één lijn kunnen worden gesteld. In deze zaak is volgens de President het gemaakte onderscheid naar burgerlijke staat niet aan de orde. De kern van de uitspraak is er in gelegen dat laatstgenoemd onderscheid kan leiden tot een gelijke behandeling van één van de onderscheiden groepen - de ongehuwd samenwonenden - die niet in overeenstemming is met de binnen deze groep bestaande verschillen. Zoals ongelijke behandeling moet plaatsvinden naar de mate van ongelijkheid, moet blijkens deze uitspraak gelijke behandeling van gevallen alleen plaatsvinden naar de mate van hun gelijkheid. De gevallen van homoseksuele samenwonenden zijn dermate verschillend van die van heteroseksuele samenwonenden (de eersten kunnen niet, de anderen kunnen in het algemeen wel trouwen) dat homoseksuele samenlevende partners met gehuwden moeten worden gelijkgesteld. Het verschil tussen gehuwden en ongehuwden weegt hier kennelijk niet op tegen het verschil

103 Pres.Rb. Amsterdam 13 september 1984, KG 1984, 2801. Tegen deze zaak is hoger beroep ingesteld. Van de uitkomst van deze hoger beroepszaak ben ik niet op de. hoogte. Zie ook: Pres.Rb. 's-Gravenhage 3 mei 1986, KG 1986, 248. In deze zaak: draait het wel om het onderscheid tussen huwelijkse relaties en homoseksuele relaties. 
tussen homoseksuele en heteroseksuele samenwonenden. Toepassing van de genoemde beleidsregel komt in feite neer op indirecte discriminatie naar (hetero- of homoseksuele) gerichtheid, omdat het gemaakte onderscheid naar burgerlijke staat niet leidt tot een onderscheid naar seksuele gerichtheid waar dit wel zou moeten worden gemaakt.

Het criterium "burgerlijke staat" ziet volgens de Memorie van Toelichting op de huwelijkse staat. Het maken van onderscheid op grond van het al dan niet gehuwd zijn is op grond van dit wetsvoorstel niet toegestaan. Ook het maken van onderscheid tussen wettige, natuurlijke en adoptiefkinderen valt onder deze non-discriminatiegrond. Tevens kan het onderscheiden op grond van de leef- of woonsituatie onder omstandigheden opgevat worden als een vorm van indirect onderscheid op grond van burgerlijke staat. ${ }^{\text {in }}$ Opnieuw moet ik opmerken dat mij geen rechterlijke uitspraken bekend zijn waarin expliciet op de reikwijdte van dit non-discriminatiecriterium wordt ingegaan. Veel uitspraken waarin wel dit differentiatie-criterium wordt toegepast, betreffen het gelijkheidsbeginsel. Gaat het in deze zaken om het discriminatieverbod, dan beperkt de toetsing zich veelal tot artikel 26 IVBPR. $^{105}$

Uit de rechtspraak kan worden opgemaakt, dat onder de termen "op welke grond dan ook" tevens de non-discriminatiegrond "nationaliteit" begrepen kan worden, hoewel dit voor zover mij bekend niet expliciet door de rechter is uitgesproken. In de praktijk blijkt de rechter bij toetsing aan artikel 1 het begrip "nationaliteit" als non-discriminatiegrond toe te passen. In een uitspraak van de Rechtbank Haarlem van 28 juni 1988 gaat het om een reisbureau dat bij de verkoop van vliegtickets onderscheid gemaakt heeft tussen personen van Turkse nationaliteit en andere personen. ${ }^{106} \mathrm{Het}$ gaat hier om een achterstelling van Turkse gastarbeiders doordat aan hen een bepaald soort tickets niet verkocht worden die het bureau wel aan andere personen verkoopt. De Rechtbank stelt eerst vast dat het maken van onderscheid naar nationaliteit op zichzelf niet verboden is, tenzij het verschil in feite resulteert in een verschil wegens ras $c . q$. etnische afkomst of een dergelijk verschil beoogt. ${ }^{107}$ Door de handelswijze van het

104 Memorie van Toelichting bij artikel 1 van wetsvoorstel 22014, AWGB, Tweede Kamer, Artikelsgewijze toelichting.

105 Zie voor een overzicht van deze zaken Tj. Gerbranda en M. Kroes, Grondrechren evaluatie-onderzoek, Documentatie-rapport - 1. pp. 283-292.

106 Rb. Haarlem 28 juni 1988, AB 1989. 213; NJCM-Bulletin 14-1 (1989), pp. 43-51 met noot $\boldsymbol{P}$. Minderhoud.

107 Vgl. HR I juli 1986. NJ 1987, 217. 
reisbureau wordt een deel van een minderheidsgroep van buitenlandse afkomst categorisch achtergesteld. Om die reden is er sprake van een verschil in behandeling naar ras dat is strijd is met artikel 429quater $\mathrm{Sr}$, artikel 1 Grondwet, artikel 1 IVRD en artikel 26 IVBPR. Hier voegt de rechtbank de in dit kader belangrijke overweging aan toe, dat

"het feit, dat zowel in de Grondwet als in de internationale verdragen aan staten de bevoegdheid is gegeven onderscheid naar nationaliteit te maken, ... betrekking [heeft] op andere dan de hierbedoelde situatie en in dit geval niet mee[brengt] dat aan particulieren dit recht ook toekomt."

Deze uitspraak geeft aan dat het in beginsel aan staten is toegestaan onderscheid op grond van nationaliteit te maken, maar dat deze bevoegdheid niet onbeperkt is. Onderscheid naar nationaliteit is niet toegestaan indien dit neerkomt op een onderscheid naar ras. Er kan sprake zijn van onderscheid naar ras indien dit met het onderscheid naar nationaliteit wordt beoogd of er het feitelijk gevolg van is. Voorts is de bevoegdheid tot onderscheid naar nationaliteit gezien de zinsnede "betrekking ... [heeft] op andere dan de hierbedoelde situatie ..." niet op iedere situatie van toepassing. De rechtbank geeft niet aan op welke situaties de bevoegdheid van de staat om op grond van nationaliteit onderscheid te maken van toepassing is en op welke situaties niet. De rechtbank bepaalt slechts dat die bevoegdheid niet geldt voor de in het geding zijnde situatie. Tenslotte geeft deze uitspraak ook aan dat de bevoegdheid om onderscheid op grond van nationaliteit te maken "in dit geval niet mee[brengt] dat aan particulieren dit recht ook toekomt". Of dit in andere gevallen wel zo is en welke gevallen dat zijn, blijkt niet uit deze uitspraak.

De uitspraak van de Rechtbank is hoofdzakelijk gebaseerd op het bestaan van onderscheid naar nationaliteit in etnische zin. De overwegingen van de Rechtbank laten in het midden of het gaat om een vorm van direct of indirect onderscheid naar ras. De Rechtbank onderzoekt of er redelijke gronden zijn die het verboden karakter aan het gernaakte onderscheid kunnen ontnemen (en acht deze gronden niet aanwezig). Dit kan volgens Minderhoud verklaard worden uit zowel het zoeken naar een objectieve rechtvaardiging van een indirect onderscheid als uit het feit dat het gaat om een belangenafweging in het kader van de beoordeling of sprake is van een 
onrechtmatige daad. ${ }^{108}$ Naar mijn mening is alleen het laatste mogelijk. Het gaat hier niet om een indirect onderscheid omdat nationaliteit in etnische zin niet opgevat kan worden als een toelaatbaar (want neutraal) differentiatie-criterium, waarvan het gebruik resulteert in een onderscheid op grond van een verdacht criterium. Nationaliteit in etnische zin is zelf al een verdacht criterium.

In hoger beroep gaat het Gerechtshof Amsterdam uit van indirecte discriminatie naar ras. ${ }^{109}$ Het Gerechtshof oordeelt dat het maken van onderscheid naar nationaliteit in juridisch-politieke (staatkundige) zin niet onverenigbaar is met onder andere artikel 1 Grondwet. ${ }^{110}$ De toelaatbaarheid van het maken van een dergelijk onderscheid vindt volgens het Gerechtshof

"in ieder geval zijn grens ... waar dit onderscheid er feitelijk toe leidt dat aan het publiek aangeboden diensten (of goederen) slechts in zeer beperkte mate toegankelijk zijn voor personen van een bepaalde etnische afkomst, met als gevolg dat het overgrote deel van deze personen in zoverre bij het overige publiek wordt achtergesteld."

Deze overweging komt erop neer, dat direct onderscheid naar nationaliteit in staatkundige zin niet toegestaan is voor zover dit resulteert in een (indirect) onderscheid naar nationaliteit in etnische zin, derhalve naar ras. Dat aan het gewraakte onderscheid geen bedoeling om naar ras te discrimineren ten grondslag lag is volgens het Gerechtshof niet relevant. De Hoge Raad is het in zijn uitspraak van 13 december 1991 tot zover met het Gerechtshof eens."' De uitspraken van het Gerechtshof en de Hoge Raad verschillen hierin, dat de Hoge Raad anders dan het Gerechtshof van

108 Annotatie bij HR 13 december 1991, NJCM-Bulletin 17-5 (1991), pp. 522-528, punt 3 (abusievelijk staat boven deze annotatie 13 november 1991 als datum van het arrest); LBR-Bulletin, 1992, nr. 1, pp. 12-21 met noot P. Rodrigues.

109 Gerechtshof Amsterdam 6 september 1990. LBR-Bulletin 1990, nr. 6, pp. 27-32 met noot Pattipawae; Tijdschrift voor Consumentenrecht 1990, pp. 396-399.

110 Terecht merken Minderhoud en Rodrigues op, dat het nog maar de vraag is of het onderscheid tussen Turkse gastarbeiders ("Turkish migrant workers") in de Turkse luchtvaartvoorschriften opgevat kan worden als onderscheid naar nationaliteit in staatkundige zin. De Turkse voorschriften spreken niet van "Turkish nationals" of "Turkish citizens". Annotaties bij HR 13 december 1991, zie noot 108. Een beter voorbeeld van onderscheid naar nationaliteit in staatkundige zin biedt o.a. Ktg. Nijmegen 10 september 1986, RV 1986, 78 met noot ACP; Rechtspraak Rassendiscriminatie $1986,131$.

111 HR 13 december 1991, NJCM-Bulletin 17-5 (1991), pp. 522-528; LBR-Bulletin, 1992, nr. 1, pp. 12-21. Zie ook de Nota naar aanleiding van het eindverslag bij wetsvoorstel 22014, AWGB, Tweede Kamer. punt 4.8. 
oordeel is dat er een objectieve rechtvaardigingsgrond voor het gemaakte (indirecte) onderscheid aanwezig is (de Turkse luchtvaartvoorschriften die aan het gemaakte onderscheid ten grondslag lagen) en er geen bijkomende omstandigheden zijn gesteld, zoals een ongerechtvaardigde ongelijke behandeling bij het controleren welke nationaliteit gegadigden voor de vliegtickets hebben. De Hoge Raad is van opvatting dat er geen sprake van discriminatie naar ras.

In een arrest van 20 maart 1992 bevestigt de Hoge Raad een vonnis van de Rechtbank Rotterdam van 27 juli 1990. ${ }^{112}$ In deze zaak gaat het om het collectief ontslag door Nedlloyd rederijdiensten B.V. van 222 werknemers, dat volgens eisers - 119 ontslagen buitenlandse werknemers - in strijd met het non-discriminatiebeginsel in onder meer artikel 1 Grondwet is genomen. De beweerde discriminatie heeft betrekking op de selectiecriteria, niet op de ontslaggrond. De selectie-criteria bestaan hierin, dat werknemers die niet beschikken over het certificaat "geïntegreerd gezel" voor ontslag in aanmerking komen. Op zichzelf beschouwt de Rechtbank deze certificaats-eis als een objectief en redelijk criterium voor ontslag. Dit wil echter niet zeggen, dat dit criterium ook in het onderhavige geval objectief en redelijk is. Reden voor het feit dat betrokkenen niet over het certificaat "geïntegreerd gezel" beschikken is dat Nedlloyd hen niet in de gelegenheid heeft gesteld het certificaat te behalen. De hiervoor door Nedlloyd aangevoerde gronden acht de Rechtbank niet redelijk of objectief. Eén van die redenen was dat de betrokken werknemers niet voldeden aan de taal-eis. Deze reden acht de Rechtbank niet redelijk of objectief omdat niet is gesteld, noch is gebleken dat de taaleis onderdeel uitmaakt van de profielschets voor een geïntegreerd gezel. Nu Nedlloyd ook geen andere feiten of gronden heeft aangevoerd op grond waarvan zij eisers op redelijke en objectieve gronden - anders dan haar Nederlandse werknemers - de gelegenheid tot het behalen van het desbetreffende certificaat kon onthouden, kan de Rechtbank het certificaats-criterium ten aanzien van eisers niet aanmerken als een redelijk en objectief selectiecriterium. Op grond hiervan concludeert de Rechtbank dat sprake is van indirecte discriminatie. Het hanteren door Nedlloyd van het op zichzelf neutrale certificaatscriterium heeft als feitelijk gevolg dat uitsluitend werknemers van niet-Nederlandse afkomst zijn ontslagen. Hiervoor zijn geen redelijke en objectieve gronden aanwezig. De Rechtbank is van oordeel, dat

112 HR 20 maart 1992, NJ 1992, 495 met noot PAS; Rb Rotterdam 27 juli 1990, Migrantenrecht 1990,10, pp.143-149. 
"het enkele feit, dat in de Grondwet en in internationale verdragen aan Staten de bevoegdheid wordt gegeven onderscheid te maken naar nationaliteit, niet zonder meer meebrengt, dat deze bevoegdheid ook particulieren als Nedlloyd toekomt."

\section{Hier voegt de Rechtbank aan toe:}

"Maar zelfs indien wordt aangenomen, dat het onderscheid maken naar nationaliteit op zichzelf ook voor particulieren niet verboden is, dan nog kan Nedlloyd daarop slechts met succes een beroep doen, wanneer zij voor dat onderscheid objectief redelijke gronden had. Zoals hiervoor werd overwogen, was dat in casu niet het geval."

Deze laatste overweging lijkt de rechtbank als overweging ten overvloede op te nemen, voor het geval de Hoge Raad tot het oordeel zou komen, dat het aan particulieren wèl toegestaan is onderscheid naar nationaliteit te maken. Deze overwegingen komen echter in het arrest van de Hoge Raad niet meer ter sprake.

Het differentiatie-criterium "nationaliteit" komt in dit rechtbank-vonnis slechts in staatkundige zin aan de orde en wel bij wijze van indirect onderscheid. Door het ontbreken van objectieve en redelijke gronden voor dit onderscheid is sprake van discriminatie. Het vonnis lijkt erop te wijzen, dat het aanwezig zijn van dergelijke gronden alleen relevant is in geval van indirect onderscheid naar nationaliteit door particulieren, omdat "in de Grondwet en in internationale verdragen aan Staten de bevoegdheid wordt gegeven onderscheid te maken naar nationaliteit". Direct onderscheid naar nationaliteit komt in deze zaak niet aan de orde.

Op grond van deze uitspraken ${ }^{13}$ is duidelijk, dat onderscheid naar nationaliteit in etnische zin niet geoorloofd is. We zagen dit reeds bij de bespreking van de non-discriminatiegrond "ras". "Wa War het hier om gaat is, of "nationaliteit" op zichzelf - derhalve los van de grond "ras" - een verdacht criterium is. De vraag is derhalve of "nationaliteit" ook een verboden onderscheidingscriterium is wanneer het gebruik ervan geen onderscheid naar ras oplevert. Uit de hierboven besproken uitspraken

113 Zie voor andere uitspraken waarin de discriminatiegrond "nationaliteit" een rol speelt in $T$ j. Gerbranda en $M$. Kroes. Grondrechten evaluatie-onderzoek. Documentatierapport - 1, pp. 266-275.

114 Zie ook de Memorie van Antwoord bij wetsvoorstel 22014, AWGB. Tweede Kamer, punt 4.4 en de Nota naar aanleiding van het eindverslag bij wetsvoorstel 22014 . AWGB. Tweede Kamer, punt 4.8. 
blijkt, dat onderscheid naar nationaliteit (in staatkundige zin) niet in strijd is met artikel 1 Grondwet. De uitspraken van de Rechtbank Haarlem en de Rechtbank Rotterdam suggereren dat dit alleen opgaat voor onderscheid dat door de staat gemaakt wordt. Dit wordt bevestigd door de Zesde nota van wijziging bij het wetsvoorstel inzake de Algemene wet gelijke behandeling, waarin de grond "nationaliteit" als non-discriminatiegrond wordt toegevoegd aan artikel 1 van dat voorstel. ${ }^{\text {is }}$ Volgens de toelichting is de overtuiging gegroeid dat burgers die onderling onderscheid maken op grond van nationaliteit, "in feite ontoelaatbaar discrimineren". Onderscheid naar nationaliteit door burgers onderling is volgens de regering bij voorbaat verdacht. De regering acht dit onderscheid slechts in uitzonderlijke gevallen gerechtvaardigd, zoals bij het samenstellen van teams voor internationale sportwedstrijden ${ }^{16}$ en in het internationaal privaatrecht (echtscheiding, afstamming, huwelijksvermogensrecht en bij het vaststellen van de personele gevolgen van het huwelijk). Anderzijds is volgens de toelichting onderscheid naar nationaliteit door staten in beginsel gerechtvaardigd. Verwezen wordt naar artikel 1 leden 2 en 3 van het Internationaal Verdrag inzake de uitbanning van alle vormen van rassendiscriminatie. In dit gerechtvaardigd onderscheid naar nationaliteit door staten, evenals de uitzonderlijke gevallen van toelaatbaar onderscheid naar nationaliteit door burgers, wordt voorzien in de uitzonderingsbepalingen in artikel 2 lid 5 van het wetsvoorstel. ${ }^{117}$

In de diverse kamerstukken naar aanleiding van het wetsvoorstel voor een Algemene wet gelijke behandeling zijn nog twee non-discriminatiegronden ter sprake gekomen, die niet als bij voorbaat verdachte differentiatiecriteria worden beschouwd. Het gaat om de gronden "leeftijd" en "handicap". In de Nederlandse samenleving en wetgeving worden herhaaldelijk leeftijdscriteria gehanteerd - zowel in verticale als in horizontale verhoudingen - zonder dat sprake is van discriminatie van de betrokken personen. De regering noemt als voorbeelden, de leeftijd als criterium voor handelingsbekwaamheid (de minderjarigheidsgrens) of als grens voor de leerplicht of voor bepaalde voorzieningen zoals het algemeen ouderdomspensioen. Vaak ook hangen leeftijdscriteria onderling samen. De minderjarigheidsgrens is bijvoorbeeld direct bepalend voor een aantal andere rechten, waaronder het kiesrecht. Ook in het ouderenbeleid worden

115 Zie noot 74.

$116 \mathrm{Vgl}$. Pres.Rb. Amsterdam 22 augustus 1985, KG 1985, 267.

117 Zie voor een overzicht van 1990 van de jurisprudentie naar aanleiding van de discriminatiegrond "nationaliteit": Landelijk Bureau Racismebestrijding, Met recht rassendiscriminatiebestrijden, pp. 3-7. 
leeftijdscriteria toegepast. Dit alles neemt niet weg dat de regering van. mening is dat discriminatie van ouderen moet worden tegengegaan. "I" Datzelfde geldt voor de achterstelling van gehandicapten. Volgens de regering is het gehandicaptenbeleid van het kabinet gericht op het bevorderen van een volwaardige deelname van gehandicapten in onze samenleving. Het criterium "handicap" wordt, onder andere, gehanteerd om te onderzoeken welke extra voorzieningen en beleidsmaatregelen. hiervoor noodzakelijk zijn. ${ }^{19}$ Ook wordt aan de hand van dit criterium. bepaald of iemand behoort tot de doelgroep van het door de overheid gevoerde gehandicaptenbeleid. Overigens erkent de regering dat het moeilijk is een definitie te geven van het begrip "handicap". Er zijn vele vormen van lichamelijke dan wel geestelijke invaliditeit en in verschillende gradaties. ${ }^{120}$

De regering meent, dat de Algemene wet gelijke behandeling zich niet leent voor de opneming van de gronden "leeftijd" en "handicap" ais nondiscriminatiegronden, omdat dan een categorisch verbod van het maken van onderscheid op deze gronden bewerkstelligd zou worden, behoudens de in de wet opgenomen uitzonderingen. Het opnemen van deze criteria in de wet vereist volgens de regering een compleet beeld van de gevallen waarin onderscheid op deze gronden gerechtvaardigd is. Bij de structuur van de wet zou dit er op neerkornen, dat alle uitzonderingsgevallen in de wet zouden moeten worden opgenomen. Om die reden past het opnemen van deze gronden niet in de wet. Het enkel verbieden van ongerechtvaardigd onderscheid op deze gronden zal, volgens de regering, daarentegen niet bijdragen aan een vergroting van de rechtszekerheid en zal in het normale rechtsverkeer van weinig praktische waarde zijn ${ }^{121}$ Wel heeft de regering het van belang geacht een onderzoek in te stellen ten einde inzicht te krijgen in de situaties waarin leeftijdscriteria worden gehanteerd. De bedoeling van dit onderzoek is dat duidelijkheid wordt verschaft over in welke gevallen het gebruik van het leeftijdscriterium knelpunten kan opleveren, die door middel van wetgeving moeten worden

118. Memorie van Toelichting bij wetsvoorstel 22014, AWGB, Tweede Kamer, punt 4.1, pp. 16-17.

119 Memorie van Toelichting bij wetsvoorstel 22014, AWGB, Tweede Kamer, punt 4.1, p. 17.

120 Nota naar aanleiding van het eindverslag bij wetsvoorstel 2201.4, AWGB, Tweede Kamer, punt 4.3, pp. 8-9.

121 Memorie van Antwoord bij wetsvoorstel 22014, AWGB, Tweede Kamer, punt 4.1, pp. 17-18 en Nota naar aanleiding van het eindverslag, Tweede Kamer, punten 4.3 en 4.4 , pp. 8-9. 
opgelost. Dit onderzoek is in 1991 gestart. ${ }^{12}$ in de door de Tweede Kamer aangenomen motie van de leden Kalsbeek en Krajenbrink is voorgesteld een dergelijk onderzoek ook te verrichten met betrekking tot de discriminatie van gehandicapten. ${ }^{123}$ Overigens betekent de nietopneming van de non-discriminatiegronden "leeftijd" en "handicap" niet, dat daarmee al het onderscheid op deze gronden is toegestaan. De regering heeft herhaaldelijk opgemerkt, dat de wet niet een uitputtende uitwerking van artikel 1 Grondwet beoogt te geven. "De rechter kan in voorkomende gevallen beoordelen of een niet door dit wetsvoorstel verboden onderscheid strijd oplevert met artikel 1 Grondwet." Artikel 1 Grondwet is volgens de regering onverkort en rechtstreeks van toepassing voor de overheid en ook in rechtsverhoudingen tussen burgers onderling kan het doorwerken. ${ }^{124}$ Inmiddels is in diverse rechterlijke uitspraken aanvaard, dat het discriminatieverbod in artikel 1 ook ziet op discriminatie naar leeftijd. ${ }^{123.126}$

122 Memorie van Antwoord bij wetsvoorstel 22014, AWGB, Tweede Kamer, punt 4.1, p. 17 en Nota naar aanleiding van het eindverslag, AWGB, Tweede Kamer, punt 4.1, pp. 6-7.

123 Motie van de leden Kalsbeek en Krajenbrink bij wetsvoorstel 22014, AWGB, Tweede Kamer.

124 Zie o.a. de Nota naar aanleiding van het eindverslag bij wetsvoorstel 22014, AWGB, Tweede Kamer, punt 4.3, p. 8. Vgl. de Nota naar aanleiding van het eindverslag bij wetsvoorstel 20239. Aanvulling van het Wetboek van Strafrecht met enkele bepalingen tot het tegengaan van discriminatie .... Tweede Kamer, p. 5: "... betekent het niet verbieden van onderscheid op andere gronden dan genoemd in het wetsvoorstel niet, dat op die gronden wel zou mogen worden gediscrimineerd."

125 Zie voor een toetsing aan de grond "leeftijd" onder artikel 26 IVBPR: HR 6 juni 1990, NJB, afl. 29 (1990), nr. 10. pp. 1176-1177. In deze zaak gaat het om toetsing van een wet (artikel $44 \mathrm{~m}$ Wet van 9 februari 1984, Stb. 27) aan het discriminatieverbod. I.v.m. het toetsingsverbod in artikel $120 \mathrm{Gw}$. kan niet aan artikel $1 \mathrm{Gw}$. getoetst worden. Toetsing aan artikel 1 Grondwet vind wèl plaats in RvB Roermond 29 augustus 1990. NJCM-Bulletin 16-4 (1991) met noot I.P. Asscher-Vonk, pp. 309. 316; CRvB 25 maart 1993, TAR 1993, 99; ARRS 31 augustus 1993, AB 1994, 14: CRvB 4 november 1993. AB 1994, 213, TAR 1994, 6 en TAR 1994, 4 (zie ook par. 6.1.8); Pres.Rb. 's-Gravenhage 25 mei 1994, TAR 1994, 166. Onderscheid naar leeftijd kan soms ook indirecte discriminatie naar geslacht opleveren, zie I.P. Asscher-Vonk, Overzicht oordelen Commissie gelijke behandeling, p. 684

126. Zie met betrekking tot de grond "gehandicapte", Pres.Rb. 's-Gravenhage 5 juni 1985. KG 1985, 196. punt 3, alinea 3-5 (artikel I Gw. niet ingeroepen of toegepast). Hoewel de grond "taal" niet expliciet als non-discriminatiegrond - vallende onder de formulering "op welke grond dan ook" - wordt aangemerkt, is toch interessant de uitspraak van ARRS 20 juni 1990, NJB, afl. 32 (1990), nr. 4, pp. 1287-1289 (weigering GS Firiesland van toezending van de Nederlandse vertaling van een in de Friese taal gestelde nota). 


\subsubsection{Conclusies ten aanzien van de afbakening van artikel 1 Grondwet}

Ter afsluiting van deze paragraaf over artikel 1 Grondwet moet ik constateren, dat voor een onderzoek naar de reikwijdte van de in dit artikel neergelegde beginselen van gelijke behandeling en non-discriminatie erg weinig jurisprudentie voor handen is. Ik heb zoveel mogelijk geprobeerd aan de hand van de wèl aanwezige jurisprudentie, literatuur en kamerstukken naar aanleiding van artikel 1 Grondwet, de Algemene wet gelijke behandeling en enkele gewijzigde of toegevoegde bepalingen van het Wetboek van Strafrecht, een beeld te vormen van de afbakening van artikel 1 Grondwet. Toekomstige jurisprudentie zal moeten uitwijzen of het aldus ontstane beeld juist is.

Hier zal ik tot slot trachten in hoofdlijnen aan te geven hoe de rechterlijke afbakening van artikel 1 Grondwet tot nu toe vorm heeft gekregen.

Allereerst met betrekking tot de vaststelling van de (on)gelijkheid van gevallen: in de praktijk blijken rechterlijke instanties slechts zelden expliciet aan te geven op welke gronden geconcludeerd wordt tot het bestaan van geljike of ongelijike gevallen. ${ }^{127}$ Een juiste toetsing aan artikel 1 vindt mijns inziens plaats, indien uitdrukkelijk wordt aangegeven welk differentiatie-criterium bij het maken van onderscheid wordt gehanteerd. Idealiter zou hierbij moeten worden onderzocht of dat differentiatiecriterium noodzakelijk is met het oog op een bepaald differentiatie-doel, maar in de rechtspraak gebeurt dat vrijwel nooit expliciet. Meestal wordt slechts volstaan met het geven van de conclusie van de (vergelijkbaarheids)toetsing. Luidt die conclusie dat sprake is van gelijke gevallen dan moeten die gevallen gelijk behandeld worden, is sprake van ongelijke gevallen dan moeten ze ongelijk behandeld worden, in de mate van hun ongelijkheid. ${ }^{\text {la }}$ Ook komt het geregeld voor dat de rechter zelfs in zijn geheel over deze kwestie heen stapt en meteen overgaat tot de toetsing van de rechtvaardiging van een (on)gelijke behandeling.

Deze toetsing van de (on)gelijkheid van gevallen is alleen van belang voor het gelijkheidsbeginsel. Het verbod van discriminatie impliceert namelijk dat de gelijkheid van bepaalde gevallen als uitgangspunt wordt genomen en onderscheid op non-discriminatiegronden niet gemaakt mag worden. In de rechtspraak zal dan ook nooit in verband met het discriminatie-verbod een toetsing van de gelijkheid van de desbetreffende gevallen plaatsvinden.

128 CBS 3 maart 1989, AB 1990, 182 met noot A.F.M. Brenninkmeijer; Nat. Ombudsman 3 november 1989, AB 1989, 564. 
Dit wil niet zeggen dat het gelijkheidsbeginsel en het discriminatieverbod nooit door elkaar gehaald worden. Soms vindt een toetsing aan het gelijkheidsbeginsel plaats onder het mom van het discriminatieverbod, hoewel geen sprake is van "verdachte" differentiatie-criteria. ${ }^{129}$

Ten tweede blijkt uit zowel rechtspraak, kamerstukken als literatuur een impliciete beperking op het gelijkheidsbeginsel (let wel: niet op het discriminatie-verbod!). De reikwijdte van het gelijkheidsbeginsel hangt hierdoor mede af van de mate waarin dit beginsel beperkt kan worden. Deze impliciete beperking houdt in, dat geen sprake is van schending van het gelijkheidsbeginsel indien de ongelijke behandeling van gelijke gevallen en de gelijke behandeling van ongelijke gevallen gerechtvaardigd kan worden. Deze rechtvaardiging moet volgens de rechtspraak objectief en redelijk zijn. ${ }^{130}$ Betreft de ongelijke behandeling gevallen die gelijk hadden moeten worden behandeld omdat onderscheid op een verdacht, non-discriminatiecriterium niet is toegestaan, dan moet een zwaardere rechtvaardigingstoets plaatsvinden dan bij onderscheid op grond van "gewone", niet-verdachte criteria het geval is. Kan dit onderscheid niet gerechtvaardigd worden, dan is sprake van discriminatie en daarmee van schending van het discriminatie-verbod. Op het discriminatie-verbod is geen beperking toegestaan. De rechtvaardiging van gemaakt onderscheid is in het kader van het gelijkheidsbeginsel aan te merken als een impliciete beperking; in verband met het discriminatie-verbod moet de rechtvaardigingstoets gezien worden als een element van de toetsing of van discriminatie sprake is, derhalve als onderdeel van de definitie van discriminatie. ${ }^{131}$ Zoals gezegd, de rechtvaardiging in het kader van het discriminatieverbod dient zwaarder te zijn dan die in verband met het

129 Een voorbeeld hiervan is de besproken uitspraak Vz.ARRS 28 september 1989, KG 1990, 28.

130 Zie bijvoorbeeld Vz.ARRS 6 november 1987, KG 1988, 65 en opnieuw Vz.A.RRS 28 september 1989, KG 1990, 28.

131 Het gelijkheidsbeginsel omvat het beginsel dat geiijke gevallen gelijk behandeld moeten worden en ongelijke gevallen ongelijk behandeld moeten worden. De gelijkheid van de gevallen dient te worden vastgesteld door toetsing van de relevantie van het gehanteerde differentiatie-criterium. Bij ongelijke behandeling van gelijke gevallen of gelijke behandeling van ongelijke gevallen wordt het gelijkheidsbeginsel geschonden, tenzij de ongelijke behandeling van gelijke gevallen of de gelijke behandeling van ongelijke gevallen objectief en redelijk gerechtvaardigd kan worden. Het discriminatieverbod omvat eveneens het beginsel dat gelijke gevallen gelijk behandeld moeten worden. De gelijkheid van een aantal gevallen hoeft echter niet te worden vastgesteld, maar wordt verondersteld. Een aantal differentiatie-criteria is namelijk bij voorbaat verdacht. Wordt in deze gevallen toch ongelijk behandeld dan is sprake van discriminatie, tenzij de ongelijke behandeling objectief en redelijk gerechtvaardigd kan worden. 
gelijkheidsbeginsel. Een uitzondering is wellicht het volgende geval. Uit de rechtspraak blijkt dat (ook) bij rechtvaardiging in verband met het gelijkheidsbeginsel een zwaardere toetsing moet plaatsvinden als een ander grondrecht in het geding is. ${ }^{132}$ Wat betreft de toetsing aan de verschillende non-discriminatiegronden die ten aanzien van het discriminatieverbod zijn opgenomen: volgens enkele uitspraken dient degene die onderscheid op de uitdrukkelijk in artikel 1 genoemde gronden maakt daarvoor overtuigend en adequaat gemotiveerd een rechtvaardiging aan te voeren, aangezien onderscheid op deze gronden bij voorbaat de verdenking van discriminatie doet rijzen. ${ }^{133}$ Bij gronden die worden aanvaard als non-discriminatiegronden vallende onder de zinsnede "op welke grond dan ook" is sprake van een andere verdeling van de motiveringsplicht. In dat geval lijkt op grond van de bedoelde uitsprakeri de motiveringsplicht steeds meer te verschuiven naar de zijde van degene die zich op het discriminatieverbod beroept, naarmate degene die het onderscheid maakt meer vrijheid heeft bij de te maken beleidskeuzen. In dat geval wordt het onderscheid op een dergelijke grond steeds minder "verdacht". Ook naarmate een bepaald onderscheid in de wet- en regelgeving meer gangbaar is, zal op degene die zich gediscrimineerd voelt steeds meer de last rusten om aan te tonen dat sprake is van discriminatie, derhalve dat voor het gemaakte onderscheid geen objectieve en redelijke rechtvaardiging bestaat.

In verband met het gelijkheidsbeginsel werd speciaal gekeken naar de toepassing ervan in het overheidsbeleid. Het gelijkheidsbeginsel blijkt dan in te houden dat beslissingen moeten worden genomen overeenkomstig het geldende vaste beleid. ${ }^{134}$ Onder omstandigheden kan echter op goede, voldoende gronden van het gelijkheidsbeginsel worden afgeweken. ${ }^{15}$ Hiermee worden de bovenstaande bevindingen over de reikwijdte van het gelijkheidsbeginsel bevestigd: uitzonderingen op dit beginsel zijn mogelijk, indien gerechtvaardigd. Deze conclusie is belangrijk omdat in vergelijkbare gevallen dan ook een uitzondering op het vaste beleid gemaakt moet worden. Gevallen waarin ongerechtvaardigd, dus in strijd met het gelijkheidsbeginsel een uitzondering is gemaakt op het vaste beleid - bijvoorbeeld in geval van een vergissing - mogen niet dienen als

132 ARRS 1 augustus 1983, AB 1984, 532 met noot B.J. van der Net; NJCM-Bulletin 9-2 (1984), pp, 156-166 met noot J.E. Goldschmidt.

133 CRvB 4 november 1993, AB 1994, 213, TAR 1994, 6 en CRvB 4 november 1993, TAR 1994, 4.

134. Pres.Rb. 's-Gravenhage 18 april 1986, KG 1986, 222.

135 Zie CRvB 5 april 1983, RSV 1983, 146; Gerechtshof 's-Gravenhage 26 juni 1986. RSV 1987, 39. 
"vergelijkbare gevallen" voor nieuwe, mogelijke afwijkingen van dit beleid. Overigens gaat het hier alleen om een verplichting voor het bestuur om volgens eigen vast beleid te beslissen. Verschillen in beleid tussen verschillende bestuursorganen is blijkens de rechtspraak toegestaan, ook al schept dit ongelijkheden tussen burgers die onder het beleid van verschillende bestuursorganen vallen. ${ }^{136}$ Wel blijkt uit een uitspraak dat de duidelijkheid en de rechtszekerheid ermee gebaat zou zijn indien bestuursorganen een zo groot mogelijke uniformiteit in hun beleid zouden nastreven. ${ }^{137}$ Bovendien kan uit een KB van 23 januari $1985^{138}$ afgeleid worden dat lagere bestuursorganen niet een eigen beleid zullen kunnen voeren wanneer op het desbetreffende terrein al sprake is van een rijksbeleid dat niet doorkruist mag worden, juist met het oog op de gelijke behandeling van bepaalde categorieën personen. Hierdoor zullen onderlinge verschillen op deze terreinen tussen verschillende lagere organen zich niet gauw voordoen. Andere uitspraken die dit bevestigen heb ik niet gevonden.

Het begrip discriminatie is in verband met artikel 1 Grondwet voor zover mij bekend in de rechtspraak niet gedefinieerd. Dit is anders voor wat betreft de discriminatie-grond "ras": volgens vaste rechtspraak moet de term "ras" in de artikelen 137c-e WvSr - en daarmee mijns inziens ook het begrip "ras" in artikel 1 Grondwet - uitgelegd worden "naar de kennelijke strekking van de in artikel 1 Internationaal Verdrag van New York van 7 maart 1966 inzake de uitbanning van alle vormen van rassendiscriminatie (IVRD) gegeven opsomming, waarin naast 'ras' ook worden genoemd: huidskleur, afkomst of nationale of etnische afstamming. "139 Onderscheid naar "nationaliteit in etnische zin" kan volgens de rechtspraak ook discriminatie naar "ras" in de zin van "etnische afstamming" opleveren. ${ }^{140}$ Jurisprudentie waarin de betekenis en reikwijdte van de andere, uitdrukkelijk in artikel 1 genoemde non-discriminatiegronden wordt onderzocht, is mij niet bekend. De inhoud van de begrippen "godsdienst", "levensovertuiging", "politieke gezindheid", en "geslacht" werd in de bovenstaande bespreking vastgesteld aan de hand van voornamelijk de kamerstukken met betrekking tot de Algemene wet gelijke behandeling. Uit

136 Zie CRvB 11 mei 1984, RSV 1984, 234; ARRS 23 juni 1986, AB 1987, 17 met noot J.H. van der Veen; CRvB 12 mei 1987, RSV 1987, 234.

137 CRvB 11 mei 1984, RSV 1984, 234; CRvB 12 mei 1987, RSV 1987. 234.

138 KB 23 januari 1985 (gemeente Muiden). Stb. 92, AB 1986, 118 met noot. B.J. van der Net onder KB 13 november 1985, nr. 18, AB 1986, 119.

139 O.a. HR 15 juni 1976, NJ 1976, 551; Rb. Zwolle 6 februari 1986, NJ 1986, 454; HR 11 maari 1986, NJ 1986, 613 met noot A.C. ' $t$ Hart; Rb. Leeuwarden 8 juli 1987, NJ 1988, 144.

140 HR I juli 1986, NJ 1987, 217. 
de rechtspraak blijkt welke non-discriminatiegronden ten minste onder de woorden "of op welke grond dan ook" (kunnen) vallen: "hetero- of homoseksuele gerichtheid", "burgerlijke staat", "nationaliteit", "leeftijd" en "handicap". Een interpretatie van deze begrippen wordt in de rechtspraak echter amper gegeven. Ten aanzien van het begrip "nationaliteit" zou uit enkele uitspraken afgeleid kunnen worden, dat hieronder niet alleen "nationaliteit in etnische zin" maar ook "nationaliteit in staatkundige zin" kan worden begrepen. Volgens deze uitspraken en de kamerstukken naar aanleiding van de AWGB is onderscheid naar "nationaliteit in staatkundige zin" alleen dan, in beginsel, niet toelaatbaar indien het gemaakt wordt door burgers. ${ }^{\text {|41 }}$

\subsection{De rechtspraak met betrekking tot de artikelen 6 lid 1, 7 leden 1 en 3, en 9 lid 1 Grondwet}

In deze paragraaf zal de afbakening van de grondwettelijke rechten die voorzien zijn van de beperkingsclausule "behoudens ieders verantwoordelijkheid volgens de wet" onder de loep genomen worden. Het gaat hier derhalve om een onderzoek naar de criteria voor vaststelling van de reikwijdte van de artikelen 6 lid 1, 7 leden 1 en 3 en artikel 9 lid 1.

\subsubsection{Artikel 6 lid 1}

Artikel 6 luidt als volgt:

1. Ieder heeft het recht zijn godsdienst of levensovertuiging, individueel of in gemeenschap met anderen. vrij te belijden, behoudens ieders verantwoordelijkheid volgens de wet.

2. De wet kan ter zake van de uitoefening van dit recht buiten gebouwen en besloten plaatsen regels stellen ter bescherming van de gezondheid, in het belang van het verkeer en ter bestrijding of voorkoming van wanordelijkheden.

In het navolgende zullen achtereenvolgens het begrip "godsdienst", het begrip "levensovertuiging" en de nevenschikking van de vrijheid van godsdienst en de vrijheid van levensovertuiging worden besproken.

141 Rb. Haarlem 28 juni 1988, AB 1989, 213: NJCM-Bulletin 14-1 (1989), pp. 43-51 met noot $P$. Minderhoud; Rb. Rotterdam 27 juli 1990, Migrantenrecht 1990,10 , pp. 143-149 en de Zesde nota van wijziging, wetsvoorstel 22014. Algemene wet gelijke behandeling, Tweede Kamer. 
Vervolgens zal het begrip "belijden" worden onderzocht en de vraag, wie er een beroep kan doen op de vrijheid van godsdienst en levensovertuiging in artikel 6. Daarna wordt de reikwijdte van de onderhavige bepaling in zijn geheel behandeld en voorts de inspanningsverplichting die rust op degene die het onderhavige recht uitoefent. Ten slotte zal worden ingegaan op het feit dat er voor de overheid ruimte overblijft om een beleid te voeren en om voorschriften uit te voeren, die in enige mate indruisen tegen de vrijheid van godsdienst of levensovertuiging, maar waarbij toch geen gebruik gemaakt wordt van de in artikel 6 voorziene beperkingsmogelijkheden.

\subsubsection{1}

\section{Het begrip "godsdienst"}

De allereerste vraag die opkomt bij het lezen van dit artikel is, wat moet worden verstaan onder "godsdienst" en "levensovertuiging". Voor zover mij bekend bestaat er geen wettelijke definitie van deze begrippen en dit lijkt mij in het licht van de vrijheid van godsdienst en levensovertuiging ook juist. Toch is voor de toepassing van dit grondrecht wel enige interpretatie van deze begrippen noodzakelijk teneinde te voorkomen dat dit recht te pas en te onpas zou kunnen worden ingeroepen. In de jurisprudentie heb ik slechts één uitspraak aangetroffen waarin het begrip "godsdienst" expliciet wordt geïnterpreteerd. Het gaat om de uitspraak van het Gerechtshof 's-Gravenhage van 13 december 1984, bevestigd door de Hoge Raad op 31 oktober 1986. ${ }^{142}$ In deze zaak gaat het om een kort geding, aangespannen door de Kloosterorde der Zusters van Sint Walburga (onderdeel van de Kerk van Satan) waarin deze vordert de staat te veroordelen om zich te onthouden van regelmatige routinematige politiecontroles zonder dat van een ernstig vermoeden van misdrijf sprake is. Aan de orde is de vraag of de termen "godsdienst" en "godsdienstoefening" in artikel 123 aanhef en lid $2 \mathrm{~Sv}$ - inhoudende dat het door het wetboek van strafvordering toegelaten betreden van plaatsen, anders dan bij ontdekking op heterdaad, niet plaatsvindt "in lokalen voor godsdienst bestemd, gedurende de godsdienstoefening" - juist zijn uitgelegd. Allereerst moet, in verband met de ontvankelijkheid van de vordering, worden nagegaan of de Kerk van Satan kan worden gezien als een kerkgenootschap en of de kloosterorde moet worden beschouwd als een zelfstandig onderdeel van een kerkgenootschap. Voor het zijn van een kerkgenootschap wordt - nu geen sprake is van een christelijke of joodse 
kerkgenootschap waar artikel 2 lid 1 boek $2 \mathrm{BW}^{143}$ met name het oog op heeft - de eis gesteld dat het gaat om godsdienst en dat de aanhangers een gestructureerde organisatie hebben. Het Gerechtshof meent dat beide voorhands onvoldoende zijn komen vast te staan. Volgens het Gerechtshof kan Sint Walburga ook niet als zelfstandig onderdeel van een kerkgenootschap worden beschouwd wegens de aard van haar activiteiten. Op grond van de processen-verbaal van de politie - waaruit blijkt dat in het klooster van eiseres seksuele shows plaatsvinden die tegen betaling kunnen worden bezocht, pornofilms worden vertoond en alcohol rijkelijk wordt ingenomen - komt het Gerechtshof tot de conclusie dat de activiteiten van Sint Walburga zich niet van die van een gewone sexclub onderscheiden

"en noch bij de betalende bezoekers noch bij de door Sint Walburga als 'zusters' aangeduide optredende vrouwen ... enigerlei religieuze ervaring [is] waar te nemen."

Een beroep van eiseres op een lange traditie van satanisme, vruchtbaarheidscultus, zwarte magie en zwarte misvieringen, heksendom en dergelijke mag niet baten. Hoewel het feit dat eiseres op de zojuist weergegeven gronden niet als zelfstandig onderdeel van een kerkgenootschap kan worden beschouwd, leidt dit niet tot nietontvankelijkheid omdat het Gerechtshof haar beschouwt als een vereniging met beperkte rechtsbevoegdheid. De vordering van eiseres wordt echter afgewezen. Volgens het Gerechtshof kan een beroep op artikel 123 Sv niet slagen, omdat de activiteiten van eiseres - zoals het eerder overwoog - "het karakter van een sexinrichting hebben en niet van godsdienstoefening". Ook kan het "klooster" niet worden aangemerkt als een lokaal "bestemd voor de godsdienst". De Hoge Raad gaat akkoord met deze uitspraak ("... heeft het Gerechtshof geen blijk gegeven van een onjuiste rechtsopvatting. ") en verwerpt het cassatieberoep.

Het Gerechtshof oordeelt in deze zaak derhalve dat men kan spreken van een kerkgenootschap in de zin van artikel 2 lid 1 boek 2 BW indien sprake is van godsdienst en van een gestructureerde organisatie ${ }^{14}$. Hoewel het Gerechtshof niet uitdrukkelijk aangeeft wat moet worden verstaan onder godsdienst, moeten de overwegingen van het Gerechtshof ten aanzien van de beoordeling of sprake is van een zelfstandig onderdeel van een

143 Artikel 2: 2 lid 1 BW luidt: "Kerkgenootschappen alsmede hun zelfstandige onderdelen en lichamen warin zij zijn verenigd, bezitten rechtspersoonlijkheid:"

144 Wat betreft het begrip "gestructureerde organisatie" spreekt het Gerechtshof van het ontbreken van toezicht op de activiteiten en firanciën van de "kloosterorde" door de Kerk van Satan. Op dit punt zal niet verder ingegaan worden. 
kerkgenootschap mijns inziens wel in dit licht bekeken worden. Het eerste van de hierna te noemen criteria wordt immers ook door het Gerechtshof gebruikt bij de interpretatie van het begrip "godsdienstoefening" in artikel 123 lid 2 Sv en zoals de A-G terecht in zijn zeer lezenswaardige conclusie bij het arrest van de Hoge Raad opmerkt: "Van een 'godsdienstoefening' kan slechts worden gesproken waar het gaat om 'godsdienst'"las. De criteria die het Gerechtshof in dit kader hanteert zijn: 1, de aard van de ontplooide activiteiten en 2 . het niet waarneembaar zijn van enigerlei religieuze ervaring bij de bezoekers van eiseres, noch bij de als "zusters" aangeduide vrouwen.

Dat een rechter zich op glad ijs begeeft zodra hij zich gaat bezighouden met de interpretatie van begrippen als "godsdienst" en "godsdienstoefening" moge duidelijk zijn. Zoals de A-G in bovenstaande zaak opmerkte mag er niet uit het feit, dat de rechter wetsbepalingen moet toepassen waarin dit soort termen zijn opgenomen, afgeleid worden dat vanwege de autoriteiten een toetsing van een beweerde geloofsovertuiging plaats mag vinden. ${ }^{146}$ Aan de andere kant kan het ook weer niet zo zijn dat iedereen zich naar willekeur op zijn godsdienstvrijheid kan beroepen en overal het etiketje "godsdienst" op kan plakken teneinde aan bepaalde wettelijke plichten of verantwoordelijkheden te ontkomen. ${ }^{147}$ In de zaak van de Zusters van Sint Walburga hanteert het Gerechtshof schijnbaar puur feitelijke criteria. Zo is het eerstgenoemde criterium, met betrekking tot de aard van de activiteiten van de "kloosterorde", volgens de A-G een feitelijke vaststelling, omdat het berust op de waardering van de concrete feiten en omstandigheden van het geval. Het ging om activiteiten die - uiterlijk - zich niet onderscheidden van die van een sexclub. Dit argument gaat eraan voorbij dat activiteiten ingegeven kunnen worden door innerlijke beweegredenen. Overtuigender is in dit opzicht mijns inziens het tweede criterium, dat enige religieuze ervaring bij de bezoekers van eiseres, of bij de als "zusters" aangeduide vrouwen niet waarneembaar is. En zelfs dat criterium is dubieus aangezien dat soort waarnemingen ook moeilijk objectief te doen zijn. We leven immers in een door de christelijke cultuur beheerste maatschappij, die van grote invioed is op de wijze waarop we de dingen waarnemen. Hoeft dit omtrent de waarneming

145 Conclusie A-G Franx bij HR 31 oktober 1986, NJ 1987, 173, punt 4.

146 Conclusie A-G Franx bij HR 31 oktober 1986, NJ 1987, 173, punt 11, alinea 4.

147 Vergelijk hieromtrent de overwegingen van de regering om de gewetensvrijheid niet in de Grondwet op te nemen. Zo werd opgemerkt dat "(g)een enkele rechtsstaat evenwel kan toestaan, dat de burger zich met een beroep op het eigen individueel geweten aan legaal tot stand gekomen verplichtingen onttrekt." Memorie van Antwoord bij wetsvoorstel 13872, Verklaring dat er grond bestaat .... Tweede Kamer, in: Algehele grondwetsherziening, deel la Grondrechten, p. 173. 
van religieuze ervaring en activiteiten van mensen van aanverwante godsdiensten als de islam en het jodendom wellicht nog geen problemen op te leveren, dit zal anders zijn ten aanzien van godsdiensten die verder van het christendom afstaan. Ik vraag me af of de A-G hiermee rekening gehouden heeft wanneer hij stelt dat de rechter "(d)e gevolgtrekking dat van een serieuze godsdienstoefening geen sprake is, ... in het concrete geval reeds [kan doen] steunen enkel en alleen op de uiterlijke vorm van de activiteiten die als 'godsdienstoefening' wordt gepresenteerd. "148 Daar komt nog bij, wat annotator van Veen terecht opmerkt, dat het denkbaar is dat men de uiterlijke vormen van een godsdienstoefening kan nabootsen zonder dat er van een godsdienstoefening sprake is. ${ }^{149}$ Met het oog op deze interpretatie-problematiek met betrekking tot de vrijheid van godsdienst en levensovertuiging zullen nog een aantal uitspraken besproken worden.

Een uitspraak van het Gerechtshof Arnhem van 11 juli 1984 betreft de wijze van eedaflegging ingevolge artikel 1 Eedswet $1911 .^{150}$ De vraag is of betrokkene aan zijn godsdienstige gezindheid de plicht ontleende om de eed op een bepaalde - van de in de wet afwijkende - wijze af te leggen. Een dergelijke plicht heeft volgens het Gerechtshof een in hoge mate subjectieve inhoud, die bepaald wordt door de godsdienstige opvattingen van degene die de eed moet afleggen. Hiermee verdraagt zich geen toetsing door de rechter

"die verder gaat dan een summier onderzoek ter beantwoording van de vraag of het bestaan van zulke plicht hem aannemelijk voorkomt."

Doorslaggevend is derhalve volgens het Gerechtshof, of het bestaan van een op grond van de godsdienst gebaseerde plicht aannemelijk is geworden.

De Centrale Raad van Beroep spreekt zich op 4 juni 1986 uit over de weigering van een werkloosheidsuitkering op basis van de Werkloosheidswet naar aanleiding van het ontslag van betrokkene. ${ }^{131}$ Betrokkene - die behoort tot de punkbeweging - is ontslagen omdat zij zich niet wenst te houden aan de normen die haar werkgever ten aanzien van het uiterlijk en de kleding van zijn werknemers stelt. Omtrent de

148 Conclusie A-G Franx bij HR 31 oktober 1986, NJ 1987. 173, punt 11, alinea 6.

149 Zie noot 142.

150 Gerechtshof Arnhem 11 juli 1984. NJ 1985, 536.

151 CRvB 4 juni 1986, RSV 1987, 16. 
levensovertuiging van betrokkene stelt de Raad vast dat hij er niet van overtuigd is

"dat de in de punkbeweging gebruikelijke wijze van gekleed gaan en het dragen van andere uiterlijke kenmerken ... zodanig essentieel zijn voor ... het deelnemerschap van die beweging, dat het afstand moeten doen van die kentekenen en het zich voegen naar de gangbare normen, haar om fundamentele redenen van cultureel-maatschappelijke, religieuze of andere aard in een ernstig gewetensconflict zou brengen."

Ten aanzien van haar beroep op haar persoonlijke vrijheid - waarschijnlijk wordt gedoeld op de vrijheid van levensovertuiging - merkt de Raad op dat het zich uit oogpunt van gelijke rechtsbedeling eerder moet laten leiden door objectieve maatstaven dan door de subjectieve beleving van de betrokkene van inbreuken op die vrijheid.

Mijns inziens geeft de Raad hier onterecht een inhoudelijk oordeel over wat wel en wat niet als essentieel moet worden beschouwd voor betrokkene's levensovertuiging. De Raad denkt te kunnen oordelen of het gedwongen afstand doen van uiterlijke kentekenen die zeer kenmerkend zijn voor de punkbeweging, betrokkene in een ernstig gewetensconflict kunnen brengen. Naar mijn mening gaat de Raad hier te ver. Dan zou de Raad ook kunnen stellen dat het dragen van hoofddoekjes voor islamitische vrouwen niet essentieel is voor hun geloofsbeleving of het dragen van tulbanden door Sikhs. De Raad zegt zich te laten leiden door objectieve maatstaven eerder dan door de subjectieve maatstaven van betrokkene. Welke zijn dan die objectieve maatstaven? Uit gangbare kledingnormen kan toch niet worden afgeleid dat punkkleding niet essentiee! is voor de levensovertuiging van de punkbeweging! Ik wil hier niet betogen dat iedere werkgever welke kleding- of haardracht dan ook die afwijkt van de gangbare, zal moeten dulden, maar een oplossing in het bovenstaande geval had ook gevonden kunnen worden door middel van een belangenafweging in het kader van de beperkingsclausule (bijvoorbeeld aan de hand van artikel 7A: 1639p lid 2 sub 10 BW). Het impliciete oordeel van de Raad dat hier geen sprake is van een inbreuk op de vrijheid van levensovertuiging van betrokkene wordt mijns inziens te snel geveld.

Een uitspraak van de Rechtbank Breda van 11 juni 1987 betreft een conflict binnen de Noodgemeente Breda van de Noodgemeente Protestantse Molukse Kerk in Nederland. ${ }^{132}$ Binnen deze gemeente speelde een aantal 
conflicten omtrent het fungeren van de predikant en de al dan niet afsplitsing van een deel van de leden van de gemeente. Deze leden eisen in reconventie dat gedaagden zullen worden veroordeeld om een Algemene Kerkvergadering volgens de kerkelijke reglementen te houden. De rechtbank bepaalt dat hij deze vordering niet kan toewijzen, omdat de burgerlijke rechter niet bevoegd is in deze intern-kerkelijke aangelegenheid dwingend in te grijpen.

In een uitspraak van dezelfde rechtbank van 30 oktober 1987 gaat het om een conflict binnen de Molukse Evangelische Kerk (GIM) in Tilburg over het gebruiksrecht van een kerkgebouw. ${ }^{153}$ De rechtbank bepaalt als burgerlijke rechter bevoegd te zijn van dit geschil kennis te nemen omdat het een geschil betreft over een burgerlijk recht. De rechtbank bedoelt kennelijk hiermee te zeggen, dat niet het onderliggende geschil over de toelating van gemeenteleden tot het Avondmaal - dat tot een afscheiding binnen de gemeente Tilburg van de kerk heeft geleid - in het geding is, maar slechts het conflict omtrent gebruiksrecht van de kerk dat van dat geschil een uitvloeisel is. De vordering kan volgens de rechtbank niet worden afgewezen op grond van het door gedaagden aangevoerde argument dat toewijzing van de vordering tot het medegebruik van een kerkgebouw het ontstaan van schisma's binnen de kerk zou stimuleren. De rechtbank acht het niet aan de civiele rechter "om aan een op grond van principiële bezwaren afgescheiden groepering rechten te onthouden, om de leden daarvan aldus indirect te dwingen, of zelfs maar te beïnvloeden, om anders dan uit vrije wil tot de kerk waarvan zij zich heeft afgescheiden terug te keren." Ook uit deze overweging blijkt, dat de rechter zich niet bevoegd. acht zich door argumenten te laten leiden die een inhoudelijke waardering met zich brengen over beginselen van godsdienstige aard, in casu de principiële motieven tot afscheiding van de eisers in het geding..$^{154}$

Met deze uitspraak strookt ook de uitspraak van de President van de Rechtbank Haarlem van 17 februari 1989 omtrent de vordering tot veroordeling van een gedaagde tot medewerking aan de totstandkoming van rabbinale echtscheiding. ${ }^{155}$ Ook hier acht de President zich niet

153 Rb. Breda 30 oktober 1987, KG 1987, 501. Zie tevens Gerechtshof's-Hertogenbosch 22. december 1989. KG 1990, 487. Ook in deze zaak weigert het Gerechtshof in te gaan op de "innerlijke waarcle" van de opvattingen van de partijen. Zie voorts KB 4 december 1984, Sib. 685, AB 1985, 163 met noot B.J. van der Net (scheiding van kerk en staat).

154 Vergelijk Gerechtshof Arnhem 29 mei 1987, AB 1988, 275: "Het is echter niet an de rechter in de beoordeling daarvan (een bepaalde bijbelexegese. CS) te treden. aangezien dat een aantasting zou betekenen van de grondwettelijk gegarandeerde vrijheid van geloofsverkondiging ...".

155 Pres. Rb. Haarlem 17 februari 1989, KG 1989, 134. 
bevoegd "zich een oordeel .. [aan te matigen] over een joods religieuze aangelegenheid die niet tot zijn competentie maar tot die van de rabbijn behoort ...". Daaraan voegt de President later toe, dat "(d)e burgerlijke rechter ... zich in het algemeen terughoudend [zal] opstellen in zaken van geloof, godsdienst en/of kerkelijke wetgeving." Op dit terrein begeeft de burgerlijke rechter zich echter niet, aldus de President, indien hij bij een onrechtmatig handelen overgaat tot de veroordeling tot medewerking aan een rabbinale echtscheiding.

Uit de bovenstaande zaken blijkt, dat de rechter zich in het algemeen verre meent te moeten houden van inhoudelijke oordelen over kwesties van godsdienstige of levensbeschouwelijke aard. Dit standpunt is terecht, maar de zaak van de Zusters van Sint Walburga geeft aan, dat het moeilijk is een grens te leggen tot waar de rechter mag gaan. Hoewel de uitkomst van deze zaak wellicht juist is, is de juridische redenering die tot die uitkomst heeft geleid onbevredigend. Ook de Hoge Raad lijkt er zo over te denken, gezien het feit dat hij de uitspraak van het Gerechtshof niet vernietigt. De zinsnede dat "... het Gerechtshof geen blijk [heeft] gegeven van een onjuiste rechtsopvatting" duidt er mijns inziens echter op, dat ook de Hoge Raad de interpretatie van het Gerechtshof niet erg sterk acht. Hier moet echter onmiddellijk aan toegevoegd worden, dat het erg moeilijk - zo niet onmogelijk - is een bevredigende afbakening van de begrippen "godsdienst" en "levensovertuiging" te geven. Zoals ik reeds aanvoerde bij de bespreking van het arrest inzake Sint Walburga, is het voor een rechter die functioneert in een hoofdzakelijk door het christendom beïnvloede maatschappij, vrijwel onmogelijk om een objectief oordeel te geven of in een bepaald geval sprake is van godsdienst of levensovertuiging, godsdienstige of levensbeschouwelijke activiteiten etc. Bij het afbakenen van deze begrippen zal de rechter zich daarom iedere keer weer ervan moeten vergewissen of hij zich niet te veel een inhoudelijk oordeel over iemands opvattingen of levenswijze aanmatigt. Zoals ik reeds opmerkte bij de bespreking van de uitspraak van 4 juni 1986, ging de Centrale Raad van Beroep in die zaak te ver. ${ }^{156}$

156 Zie voor formele criteria voor de vaststelling of sprake is van een afzonderlijke "richting" van een school (in verband met de bekostiging van het bijzonder onderwijs), waarbij de rechter zich ook van een inhoudelijke: beoordeling van de godsdienstige of levensbeschouwelijke grondslag van een schooi zal dienen te onthouden: AGvBRS 3 februari 1992, AB !992, 199; AGvBRS 10 november 1992. AB 1993, 88 met noot B.J. van der Net: A.GvBRS 10 november 1992. AB 1993, 522 met noot. B.J. van der Net; VZ.AGvBRS 14 juni 1993, A.B 1993, 458 met noot B.J. van der Net. 


\subsubsection{Het begrip "levensovertuiging" en de nevenschikking van de vrijheid van godsdienst en de vrijheid van levensovertuiging}

De genoemde zaak van de Centrale Raad van beroep van 4 juni 1986 betreft betrokkene's (beweerde, maar door de Raad ontkende) levensovertuiging. Uit de jurisprudentie wordt niet meer over dit begrip duidelijk. Kijken we echter naar de kamerstukken inzake de grondwetsherziening van 1983, dan treffen we de volgende overwegingen aan. Aanleiding voor deze overwegingen vormt de door de regering voorgestane opneming van de vrijheid van godsdienst en de vrijheid van levensovertuiging in één grondwetsartikel.

Als reden voor de opneming van deze vrijheden in één artikel noemt de regering in de Memorie van Toelichting, dat "de godsdienstige en levensbeschouwelijke overtuigingen in de praktijk tal van geleidelijke overgangen [blijken] te vertonen". Een afzonderlijke opneming van deze vrijheden in aparte artikelen zou kunnen leiden tot de netelige vraag of een bepaalde overtuiging tot de godsdienst dan wel tot de levensovertuiging moet worden gerekend. ${ }^{157}$ Door opneming van de vrijheid van godsdienst en de vrijheid van levensovertuiging in één artikel heeft men ook willen voorkomen, dat de vrijheid van levensovertuiging zich zo ver zou gaan uitstrekken dat het de vrijheid van meningsuiting zou gaan overlappen. Zoals Schneider het formuleert heeft men "(d)oor de interpretatie van de levensovertuiging te trekken naar die van godsdienst ... een maatschappelijke opvatting uitgesloten." De uiting van deze puur maatschappelijke opvatting geniet niet de bescherming van artikel 6 maar die van artikel 7 Grondwet. Ter onderscheiding van een maatschappelijke opvatting zou men - met Schneider -

"(d)e orde waartoe godsdienst en levensovertuiging behoren ... kunnen omschrijven als een "samenhangende levensbeschouwing, die de hele levensopvatting doortrekt ...". iss

In het Nader Rapport wordt geconstateerd, dat het woord "levensovertuiging" zo ruim kan worden opgevat, dat het ook de godsdienst omvat. De regering acht het echter niet noodzakelijk het woord

157 Memorie van Toelichting bij wetsvoorstel 13872, Verklaring dat er grond bestaat .... Tweede Kamer, in: Algehele grondwetsherziening, deel la Grondrechten, p. 29.

158 J.W. Schneider, De vrijheid van godsdienst en levensovertuiging, p. 161. Zie ook de Memorie van Antwoord bij wetsvoorstel 13872, Verklaring dat er grond bestaat .... Tweede Kamer, in: Algehele grondwetsherziening, deel Ia Grondrechten, p. 193. 
"levensovertuiging" zo ruim te interpreteren. Het woord "levensovertuiging" kan ook in beperkte zin begrepen worden, waardoor met de begrippen godsdienst en levensovertuiging "geheel eigen leefwerelden met een geheel eigen gevoelswaarde worden aangeduid". Het afzonderlijk opnemen van godsdienst en levensovertuiging verwoordt dit, volgens de regering, en "geeft op passende wijze uitdrukking aan de thans bestaande situatie waarin godsdienstige en ongodsdienstige overtuigingen naast elkaar voorkomen en aanspraak mogen maken op een gelijkwaardige rechtspositie. " 159

Hiermee komen we op de nevenschikking van de vrijheid van godsdienst en de vrijheid van levensovertuiging. Volgens de regering is deze nevenschikking slechts van staatsrechtelijke aard. Zou men - volgens de regering ten onrechte - er vanuit gaan dat godsdienst en levensovertuiging van gelijke aard zijn, dan miskent men volgens de regering de essentie van godsdienst en levensovertuiging, omdat men de wezensverschillen tussen beide uit het oog zou verliezen. Wanneer men echter erkent dat godsdienst en levensovertuiging zowel naar aard als naar gerichtheid elk een eigen karakter vertonen, mag dit niet van invloed zijn op "de waarborging van vrijheid, bescherming en staatsrechtelijke gelijkheid ...". 100 De nevenschikking komt ook naar voren uit de rechtspraak. Hierbij valt te wijzen op de al eerder in verband met artikel 1 Grondwet besproken uitspraak van de Afdeling Rechtspraak van de Raad van State van 1 augustus 1983. ${ }^{161}$ In die zaak gaat het om het besluit van de gemeenteraad van Haarlem subsidie aan de Stichting voor Humanistische Vormingsonderwijs te verlenen terwijl wel subsidie is toegekend aan de Haarlemse vereniging tot verspreiding van bijbelkennis. De Afdeling bepaalt in deze zaak dat de overheid geen beleid mag voeren dat de bevoordeling van een bepaalde godsdienstige of levensbeschouwelijke stroming, anders dan bij wege van een overgangsmaatregel, in stand houdt.

159 Nader rapport bij de Memorie van Teelichting bij wetsyoorstel 13872. Verklaring dat er grond bestaat .... Tweede Kamer, in: Algehele grondwetsherziening, deel la Grondrechten, p. 88.

160 Memorie van Toelichting bij wetsvoorstel 13872, Verklaring dat er grond bestaat .... Tweede Kamer, in: Algehele grondwetsherziening, deel Ia Grondrechten, p. 29. Zo ook de Memorie van Antwoord bij wetsvoorstel 13872, idem, p. 193. Vergelijk ook respectievelijk de Memorie van Toelichting, Memorie van Antwoord en de Nota naar aanleiding van het Eindverslag bij wetsvoorstel 21335 , Wetsvoorstel tot aanpassing aan de Grondwet van de giftenaftrek in de Wet op de inkomstenbelasting 1964 en van enige faarmee samenhangende bepalingen in andere wetten, Tweede Kamer.

161 ARRS I augustus 1983. AB 1984, 532 met noot B.J. van der Net; NICM-Bulletin 9-2 (1984), pp. 156-166 met noot J.E. Goldschunidi (pp. 164-166). Zie ook. bijvoorbeeld, ARRS 18 december 1986, AB 1987, 260. 
Hoewel de Afdeling zijn overwegingen vooral vastknoopt aan artikel 1 Grondwet, wijst zij ook expliciet op artikel 6 Grondwet. ${ }^{162}$ Deze uitspraak is in latere zaken bevestigd. ${ }^{163.164}$

\subsubsection{Het begrip "belijden"}

In het voorgaande kwamen diverse gedragingen aan de orde die werden ingegeven door de (beweerde) godsdienstige of levensbeschouwelijke opvattingen van betrokkenen: bepaalde uiterlijke kenmerken (punkkleding en -haardracht), een bepaalde wijze van eedaflegging, een rabbinale echtscheiding of het geven van een bepaald soort onderwijs. Dit soort gedragingen moeten, indien zij voortvloeien uit iemands (al dan niet godsdienstige) overtuiging, worden gewaarborgd door artikel 6 , omdat zij vormen van het "belijden" van een godsdienst of levensovertuiging zijn.

162 Zie p. 453 voor wat betreft de zinsnede "anders dan bij wege van overgangsmaatregel" .

163 ARRS 21 maart 1985, AB 1986, 16 met noot P.J.J. van Buuren; ARRS 12 maart 1987. AB 1987, 287 met noot I.C. van der Vlies. In deze laatste zaak behoeft geen gelijke behandeling plaats te vinden omdat geen sprake is van "gelijke gevallen". De Afdeling overweegt: "De Afd. sluit niet uit dat een instelling op een godsdienstige of levensbeschouwelijke grondslag een beroep zou kunnen doen op het gelijkheidsbeginsel wanneer een overheidsorgaan een of meer instellingen met een bepaalde godsdienstige of levensbeschouwelijke signatuur zou subsidiëren met uitsluiting van instellingen die uitgaan van andere onder de bevolking levende godsdienstige of levensbeschouwelijke signatuur. Daarvan is echter in het onderhavige geval gelet op het overkoepelende karakter van de Stichting Madi geen sprake."

Vergelijk ook AGvBRS 3 april 1992. AB 1992, 483 met noot AFMB (geen toetsing aan artikel $6 \mathrm{Gw}$. maar wat de annotator noemt een "met de grondrechten strakende wetsuitleg" van art. 15 eerste lid onder c Dienstplichtwet). Zie verder Tj. Gerbranda en M.Kroes, Grondrechten evaluatie-onderzock. Documentatierapport - 2, pp. 64-69.

164 Overigens mag uit deze zaak niet opgemaakt worden dat uit artikel 6 de (positieve) verplichting voor de Stat voortvloeit godsdienstige en levensheschouwelijke instellingen te subsidiëren. Fen (financiële) aanspraak zonder meer (waaronder bijvoorbeeld de gelijke hehandeling aan andere instellingen kan worden begrepen. met een beroep op artikel 1 Grondwet) kan uit deze bepaling niet worden afgeleid. Zie onder andere CRvB 14 maart 1991. TAR 1991. 105 met noot G.L. Coolen. Dit kan verklaard worden uit dezelfue scheiding russen kerk en staat, op grond waarvan het de rechter niet is toegestaan een inhoudelijk oordeel te geven over internkerkelijke of op overtuiging gebaseerde opvattingen. Zie over dit onderwerp, onder andere, B.P. Vermeulen. Artikel 6 Grondwel. Pp. 129-131; M.J. Bokma en H.P. Vonhögen, Artikel 6 en artikel 9 Grondwet: zwakke waarborgen, gebrekkige uitwerking, pp. 109-110: M.C. Burkens, J. Bokma, H.P. Vonhögen en W.L.J. Voogt, Actuele ontwikkelingen en problemen op het terrein van de gelding van grondwettelijke grondrechten, Pp. 297-300; M.M. den Boer. Artikel 6 Grondwet: vrijheid van godsdienst en levensovertuiging. pp. 123-124. 
In de Memorie van Toelichting bij het wetsvoorstel inzake de grondwetsherziening stelt de regering, dat het begrip "belijden" niet alleen ziet op het huldigen van de godsdienstige of levensbeschouwelijke overtuiging, maar ook op het zich daarnaar gedragen. ${ }^{\text {ts }}$ Dit belijden kan individueel of in groepsverband plaatsvinden en zowel binnen als buiten gebouwen en besloten plaatsen. ${ }^{166}$ Op het begrip "belijden" is voor zover ik weet in de jurisprudentie niet expliciet ingegaan. ${ }^{16}$ Een uitspraak die volgens enkele auteurs een indicatie geeft van de betekenis van het begrip "belijden" is de beslissing van de Afdeling Rechtspraak van de Raad van State van 7 april 1983. ${ }^{168}$ In deze zaak gaat het om een antroposofisch arts die vrijstelling verzoekt onder artikel 26 Wet betreffende verplichte deelneming in een pensioenregeling. Hij beroept zich in deze zaak op zijn vrijheid van levensovertuiging - vervat in artikel 9 lid 1 ECRM en artikel 18 lid 1 IVBPR (artikel 6 lid 1 Grondwet wordt niet ingeroepen). De Afdeling overweegt dienaangaande dat het aannemelijk is dat er een verband bestaat tussen de levensovertuiging van de arts en zijn afwijzing van de voor de pensioenverplichtingen noodzakelijke vaststelling van zijn bruto-beroepsinkomen. Echter, hieruit volgt volgens de Afdeling niet dat

"die afwijzing op zichzelf een gedraging oplevert waardoor appellant naar objectieve maatstaven een directe uitdrukking geeft aan zijn godsdienst of levensovertuiging in de zin van voornoemde Verdragsartikelen."

165 Vgl. J.W. Schneider. De vrijheid van godsdienst en levensovertuiging. p. 160: "Diit laatste (het zich ernaar gedragen. CS) element strekt zich verder uit dan alleen maar bezig zijn met godsdienstbeoefening. het betreft maatschappelijk gedrag."

166 Memorie van Toelichting bij wetsvoorstel 13872, Verklaring dat er grond bestaat...., Tweede Kamer, in: Algehele grondwetsherziening, deel la Grondrechten, p. 29.

167 Het begrip is wel in de literatuur besproken: zie 0.a. M.M. den Boer, Artikel 6 Grondwet. pp. 113-116; C.A.J.M. Kortmann, De vrijheid van godsdienst en levensovertuiging in de nieuwe Grondwet, pp.61-65; G.J.M. van Wissen, Grondrechten, pp. 101-104. Deze auteurs onderscheiden een forum internum, de innerlijke overtuiging (of privésfeer), die een absolute bescherming geniet waardoor ook geen dwang mag worden uitgeoefend op het belijden van een overtuiging of op het veranderen van overtuiging: en een forum externum, de externe sfeer, waarop wel beperkingen zijn toegestaan. Zie ook Th.A. van Baarda, Oordeelsvorming in casus van botsende grondrechten, pp. 66-67. Van Wissen onderscheidt tussen deze sferen in nog een derde schil: deze schil "betreft het verrichten van godsdienstige handelingen of rituelen, alleen of met anderen." (p. 102)

168 ARRS 7 april 1983, AB 1983, 430 met noot P.J. Boon. Zie M.M. den Boer, Artikel 6 Grondwet: vrijheid van godsdienst en levensovertuiging; G.J.M. van Wissen, Grondrechten, pp. 102-103. 
Zoals ik al eerder opmerkte bij de hierboven besproken jurisprudentie en waar ook Boon in zijn annotatie bij deze uitspraak op wijst, is dat "objectieve maatstaven" niet bestaan. Den Boer merkt naar aanleiding van deze constatering op, dat volgens hem "(e)en redelijk oordeel over het verband tussen de beleden overtuiging en de gedraging " een hanteerbaarder criterium is. Volgens den Boer moet het gaan om "een gedraging waardoor de rechtsgenoot in redelijkheid een rechtstreekse uitdrukking geeft aan de geloofs- of levensovertuiging en om het zwaarwegende belang dat aan de naleving van de overtuiging moet worden gehecht." Naar zijn mening kunnen onder "gedraging" ook maatschappelijk georiënteerde handelingen vallen. ${ }^{169}$ Ook dit oordeel over de redelijkheid van het oordeel of er een verband bestaat tussen overtuiging en gedraging impliceert een oordeel dat onvermijdelijk beïnvloed wordt door de overheersende cultureel-religieuze traditie van de samenleving, maar het wekt althans niet de schijn van objectiviteit. De toetsing aan de eis dat het moet gaan om een "zwaarwegend belang" dat aan de naleving van de overtuiging moet worden gehecht, zou naar mijn mening moeten kunnen voorkomen dat de onderhavige vrijheid overloopt in een recht dat ook de gewetensvrijheid omvat, die nu juist door de grondwetgever bewust niet in de herziene Grondwet is opgenomen. ${ }^{100}$ Overigens moet ik er hier voor de duidelijkheid op wijzen, dat het door den Boer voorgestelde criterium ziet op de reikwijdte van de vrijheid van godsdienst en levensovertuiging. Dit betekent dat het "zwaarwegende belang" van de naleving van de overtuiging hier een rol speelt bij de afbakening van deze vrijheid en met name van het begrip "belijden". Ditzelfde zwaarwegende belang zou echter

169 M.M. den Boer (Artikel 6 Grondwet, p. 115) lijkt dit criterium te hebben ontleend aan de Memorie van Antwoord bij wetsvoorstel 19427. Wet openbare manifestaties, Eerste Kamer, p. 4. waarin staat dat het moet gaan om "op de godsdienst of levensovertuiging gebaseerd gedrag. althans voorzover dat in redelijkheid rechtstreeks uitdrukking geeft aan die overtuiging."

170 Memorie van Toelichting bij wetsvoorstel 13872. Verklaring dat er grond bestaat.... Tweede Kamer, in: Algehele grondwetsherziening, deel Ia Grondrechten, p. 31; zie voor de motivering hiervan de Memorie van Antwoord bij hetzelfde wetsvoorstel. Tweede Kamer, idem: pp. 173-174. Zo zou een gegarandeerde gewetensvrijheid. onder andere, de vrijheid moeten verschaffen zich naar bepaalde eigen normen te gedragen. De regering acht het echter onaanvaardbaar dat een burger zich met een beroep op het eigen individueel geweten aan wettelijke verplichtingen zou kunnen onttrekken. De gewetensvrijheid zou daarom voorzien moeten worden van zeer uitgebreide beperkingsclausules. Dit acht de regering weinig zinvol en het zou afbreuk kunnen doen aan andere grondrechten. 
ook een rol kunnen spelen bij de beperking van de onderhavige vrijheid. ${ }^{171}$ Vooralsnog zullen we het echter moeten doen met het criterium dat in de uitspraak van de Afdeling van 7 april 1983 is gehanteerd.

Ten aanzien van het begrip een "ieder" in artikel 6 wil ik kort opmerken dat hieronder zowel de individu als groepen begrepen kunnen worden. Dit leidt ik allereerst af uit de zinsnede in artikel 6 "individueel of in gemeenschap met anderen". Het zou onlogisch zijn als de individu wel "in gemeenschap met anderen" zijn overtuiging mag belijden, maar dit niet met die groep als groep zou mogen doen. De in dit hoofdstuk besproken jurisprudentie wijst erop - hoewel het begrip "ieder" daarin niet wordt geïnterpreteerd - dat inderdaad onder "ieder" individuen èn groepen begrepen worden. In de bedoelde zaken wordt door zowel individuen als groepen een beroep op de vrijheid van godsdienst of levensovertuiging gedaan, die ofwel wordt gehonoreerd ofwel wordt afgewezen, maar dan niet op de grond dat de rechtzoekende niet onder het begrip "ieder" begrepen kan worden. Men denke in geval van groepen aan Kerken, andere organisaties die zich op een overtuiging baseren of organisaties waarin aanhangers van een bepaalde overtuiging samenwerken. ${ }^{17}$ Bovendien mag in verband met artikel 1 Grondwet bij de waarborg van de vrijheid van godsdienst en levensovertuiging in principe geen onderscheid gemaakt worden tussen Nederlanders en vreemdelingen. ${ }^{173}$

171 Ofwel in verticale verhoudingen als gedragscode. d.w.z. indien bij de beperking bijvoorbeeld rekening wordt gehouden met de noodzakelijkheid van de inbreuk op het recht, waarbij de proportionaliteit tussen beperking en inbreuk wordt getoetst aan de hand van een belangenafweging (individueel belang versus algemeen belang): ofwel bij horizontale verhoudingen als belang dat moet worden afgewogen tegen het belang van degene die gebaat is bij een beperking van de vrijheid. Zie de paragrafen 3.2.6 en 7.5.2.

172 Uitgebreider: M.M. den Boer. Artikel 6 Grondwet, p. 116. Zie ook S.C. den Dekkervan Bijsterveld, De verhouding tussen kerk en staat in het ticht van de grondrechten, pp. 50-51, 58-59.

173 Zie echter hierna met betrekking tot de toelating van imams. Zie voorts $M . M$. den Boer, Artikel 6 Grondwet, pp. 116-117 ten aanzien van de gelding van artikel 6 voor minderjarigen. 


\subsubsection{De reikwijdte van het recht in zijn geheel}

$\mathrm{Nu}$ is het, na de afzonderlijke behandeling van de diverse begrippen in artikel 6 lid 1, natuurlijk de vraag hoe de reikwijdte van het in deze bepaling opgenomen recht in zijn geheel moet worden afgebakend. Dit zal blijken uit de hierna te bespreken rechterlijke uitspraken. Allereerst zullen hier de zogenaamde Goeree-zaken worden besproken. ${ }^{74}$ De eerste zaken gaan om uitspraken van het echtpaar Goeree in hun gospel-blad Evan die erop neerkomen dat de Joden de Jodenvervolging tijdens de Tweede Wereldoorlog aan zichzelf te wijten hebben onder meer omdat zij "hun verlosser [hebben] vermoord". Deze uitlatingen van de Goeree's worden door velen als discriminerend en beledigend ervaren. Als gevolg daarvan zijn zowel een civiele (kort geding) procedure als een strafprocedure gevoerd. In kort geding wordt gevorderd dat het de Goeree's wordt verboden de desbetreffende afleveringen van hun gospelblad verder te verspreiden. In eerste instantie wordt de vordering toegewezen en het echtpaar Goeree gaat in hoger beroep alwaar zij een beroep doen op artikel 6 lid 1 en artikel 7 lid 1 (vrijheid van meningsuiting) Grondwet. Het Gerechtshof Arnhem erkent in zijn uitspraak van 29 september 1986 dat het recht hen toekomt om hun godsdienstige opvattingen in woord en geschrift te verkondigen ook al staan de meeste kerken afwijzend tegenover die opvattingen. Deze vrijheid van appellanten wordt, aldus het Gerechtshof, beperkt door ieders verantwoordelijkheid volgens de wet. Dit brengt voor hen mee,

174 Pres.Rb. Zwolle 13 september 1985, AB 1986, 236 met noot P.J. Boon; Gerechtshof Arnhem 29 september 1986, AB 1987, 199; HR 5 juni 1987. NJ 1988, 702 met noot E.A. Alkema, AB 1988. 276 met noot J.A. Hofman en B.M.J. van der Meulen (kort geding-procedure wegens belediging van joden); Rb. Zwolle 9 oktober 1986. Migrantentecht 1986, p. 275 e.v.; Gerechtshof Arnhem 29 mei 1987, NJ 1987, 816. AB 1988, 275 met noot J.A. Hofman en B.M.J. van der Meulen onder AB 1988, 276. AA 1988. p. 119 e.v. met noot S.A.M. Stolwijk; HR 18 oktober 1988. NJ 1989. 476 met noot GEM: na verwijzing Gerechtshof Leeuwarden 16 maart 1989. NJ 1989. 810 (strafprocedure wegens (dezelfde) belediging van joden), alle voorgaande zaken ook in: NJCM-Bulletin 14-3 (1989), pp. 296-304 met noot M.M. den Boer;

Pres.Rb. Zwolle 6 mei 1987, KG 1987, 236; Gerechtshof Arnhem 9 februari 1988, beiden uitspraken in: NJCM-Bulletin 14-3 (1989), pp. 317-331 met noot $C$. Waaldijk; HR 2 februari 1990, NJ 1990, 289 met noot E.A. Alkema (kort geding-procedure wegens belediging van homoseksuelen).

Zie voorts B.P. Vermeulen, De Goerees en de Kardinaal, ofwel: vrijheid van godsdiensi versus discriminatieverbod, pp. 258-278. 
"dat zij genoemd evangelie niet op voor anderen nodeloos kwetsende of grievende wijze mogen verkondigen en zich jegens hun dusdoende niet aan een onrechtmatige daad mogen schuldig maken."

Vervolgens komt het Gerechtshof op grond van de omstandigheden van het geval, namelijk al hetgeen Joden gedurende de Tweede Wereldoorlog is angedaan en de gevoelens van nabestaanden en overlevenden van die oorlog die zich het lot van de Joodse slachtoffers aantrekken, tot de conclusie dat de desbetreffende uitlatingen van het echtpaar Goeree een onrechtmatige daad opleveren omdat zij "onnodig grievend, kwetsend en denigrerend [zijn] en (in)druisen ... tegen de zorgvuldigheid, welke in het maatschappelijk verkeer betaamt ...". Het Gerechtshof bepaalt dan ook dat appellanten aldus

"bij het belijden van hun godsdienstige overtuiging en appellant sub 3 bij het door de drukpers openbaren daarvan, hun verantwoordelijkheid volgens de wet - art. 1401 Boek 4 BW - verzaakt (hebben) en kunnen zij daarvoor aansprakelijk worden gesteld."

Volgens de Hoge Raad - in zijn uitspraak van 5 juni $1987^{175}$ - heeft het Gerechtshof terecht geoordeeld dat artikel 1401 BW beperkingen kan stellen aan de wijze waarop gebruik gemaakt wordt van de in artikel 6 Grondwet gegarandeerde vrijheid van een ieder tot het belijden van zijn godsdienst. Ook bepaalt de Hoge Raad dat het Gerechtshof "zonder schending van enige rechtsregel" tot zijn conclusie - dat de Goeree's onrechtmatig hebben gehandeld - heeft kunnen komen.

De bovenstaande - door het Gerechtshof gedane - uitspraak wordt in een ander geval, ook een kort geding tegen het echtpaar Goeree, nader uitgewerkt. Het gaat opnieuw om uitlatingen van de Goeree's in hun blad Evan, dit keer over homoseksualiteit in Nederland, homoseksuelen in het algemeen en tevens in verband met de ziekte AIDS. Ook in deze zaak stelt de Zwolse Rechtbank-President vast, dat het echtpaar Goeree een beroep kan doen op de vrijheid van godsdienst, ook al worden hun opvattingen niet gedeeld door anderen of zijn ze in strijd met hetgeen maatschappelijk min of meer aanvaard wordt. ${ }^{176}$ Dit geldt ook, indien velen zich aan deze opvattingen storen of pijnlijk getroffen worden. Voor een verbodsaktie op dit soort uitingen is geen plaats indien ze zijn terug te voeren tot "bronnen, 
die de oorsprong zijn van hun geloofsovertuiging". Het wordt anders, aldus de President,

"indien en voor zover de Goerees verweten kan worden dat zij zijn getreden buiten de grenzen van dat wat als geloofsverkondiging kan gelden of dat zij zich bij die geloofsverkondiging op nodeloos kwetsende en grievende wijze en met veronachtzaming van de zorgvuldigheid, die hen in het maatschappelijk verkeer jegens hun medemensen betaamt, hebben geuit."

De President verwijst hierbij naar de beperkingsclausule in onder meer artikel 6 lid 1 Grondwet. In casu is volgens de President sprake van uitlatingen die niet vallen binnen het bereik van de vrijheid van godsdienst. Reden hiervoor is dat ongenuanceerd en ongemotiveerd - en tegen beter weten in onjuist en misleidend - een verband wordt gelegd tussen homoseksualiteit en de ziekte AIDS. ${ }^{17.178}$

Dergelijke buiten de vrijheid van godsdienst en levensovertuiging vallende uitlatingen zijn onrechtmatig jegens een homoseksueel, omdat zij "kwetsend, grievend en jegens hem hoogst onzorgvuldig" zijn. Immers, tegen beter weten in en onder het mom van geloofsverkondiging wordt met betrekking tot een ernstige aangelegenheid als AIDS een onjuiste voorstelling van zaken gegeven, die homoseksuelen in een kwaad daglicht stelt. Het nadeel en de schade die homoseksuelen aldus leiden is aan de schuld van de Goerees te wijten, aldus de President.

Wat betreft de overige bestreden uitlatingen - die erop neer komen dat de ziekte AIDS voor homofielen Gods straf is voor hun zonden - heeft de President het volgende overwogen. Hoewel dit soort uitlatingen voor velen onaanvaardbaar zullen zijn, zijn ze niet onrechtmatig, "zolang zij (degenen die de uitlating doen, $(S)$ bij het uiten daarvan niet nodeloos grievend en kwetsend, dan wel onzorgvuldig te werk gaan." Doen zij deze uitlatingen los van de eerder onrechtmatig (want ongenuanceerd en ongemotiveerd) geachte uitlating omtrent het beweerde verband tussen AIDS en homoseksualiteit, dan "blijven zij binnen het kader van de grondwettelijk

177 Op grond van de vaststelling dat een groot deel van de AIDS-slachtoffers homoseksuele mannen zijn, wordt de onjuiste stelling geponeerd dat homoseksualiteit van mannen onverbiddelijk tot AIDS-hesmetting leidt.

178 Op grond hiervan meen ik. dat Vermeulen onterecht uit deze overwegingen van de President afleidt, dat deze van oordeel zou zijn dat geen sprake meer is van geloofsverkondiging - en daarmee van toepasselijkheid van de godsdienstvrijheid omdat de opvattingen van de Goerees niet zouden zijn terug te voeren "tot de bron die de oorsprong is van de geloofsovertuiging van de Goerees, de Bijbe!". B.P. Vermeulen, De Goerees en de Kardinaal, pp. 262-263. 
beschermde vrijheid van godsdienst(uiting). Het verkondigen van die opvatting in dat kader moge voor homoseksuelen ... pijnlijk zijn, doch dat is de pijn die in onze hogergeschetste veelvormige democratische samenleving omwille van de vrijheid verdragen moet worden."

Het Gerechtshof Arnhem bekrachtigt deze uitspraak op 9 februari 1988. ${ }^{179}$ Het Hof hanteert min of meer dezelfde argumenten als de President. Echter, daarna overweegt het Hof, dat de desbetreffende passages "ook voor zover deze wel als geloofsverkondiging moeten worden beschouwd, mede gezien hun kenbare onjuistheid en tot discriminatie uitnodigende karakter, onrechtmatig jegens homoseksuelen" zijn.

Ook de Hoge Raad bepaalt in zijn uitspraak van 2 februari 1990, dat bepaalde beperkingen op de vrijheid zijn godsdienstige opvattingen tot uiting te brengen op grond van artikel 6 lid 1 zijn toegestaan. ${ }^{100}$ Volgens de Hoge Raad behoort de bescherming die artikel 1401 BW biedt tegen beledigende, onnodig grievende en tot discriminatie uitnodigende uitlatingen, tot de op grond van artike! 6 lid 1 toegelaten beperkingen.

Uit deze rechtspraak komt het volgende naar voren met betrekking tot de reikwijdte van de vrijheid van godsdienst ${ }^{181}$ : uitingen die ongenuanceerd, ongemotiveerd - en tegen beter weten in onjuist en misleidend - gedaan worden, in dit geval omdat onterecht een verband wordt gelegd tussen homoseksualiteit en de ziekte AIDS, vallen buiten het kader van de vrijheid van godsdienst. Uitlatingen die niet op deze wijze op kennelijke onjuistheden zijn gebaseerd en die een uitdrukking van iemands geloofsovertuiging vormen, vallen binnen het kader van de godsdienstvrijheid, ook wanneer ze in strijd zijn met wat algemeen aanvaard wordt en zelfs wanneer ze pijnlijk zijn voor een bepaalde groep personen. $^{182}$ Reden hiervoor is dat men dit soort uitingen in een "hogergeschetste veelvormige democratische samenleving" moet verdragen vanwege deze godsdienstvrijheid.

179 Gerechtshof Arnhem 9 februari 1988. NJCM-Bulletin 14-3 (1989), pp. 317-331.

180 HR 2 februari 1990, NJ 1990, 289.

181 Zie voor vergelijkbare uitspraken: Pres.Rb. Utrecht, 5 maart 1987 en Gerechtshof Amsterdam 10 december 1987, beiden in: NJCM-Bulletin 14-3 (1989), pp. 305-312 resp. 312-317 met noot C. Waaldijk (pp. 324-331).

182 Vgl. Pres.Rb. Amsterdam 22 september 1988, KG 1988, 423 ten aanxien van de film "The last temptation of Christ": "Deze in de Grondwet en verdragen verankerde vrijheid van godsdienst en meningsuiting brengt mee dat niemand het uitdragen van een visie op de figuur van Jezus Christus die afwijkt van de eigen geloofsovertuiging mag verhinderen. Dit is slechts anders wanneer bij het uitdragen van die visie de grenzen gesteld in het strafrecht zouden worden overschreden of anderszins onrechtmatig zou worden gehandeld." 
Het verschil tussen wèl en niet door de godsdienstvrijheid beschermde uitingen blijkt uit de criteria die worden aangelegd voor de beoordeling van de (on)rechtmatigheid van die uitingen. Uitlatingen die buiten de reikwijdte van de godsdienstvrijheid vallen zijn onrechtmatig indien zij kwetsend, grievend en jegens hem hoogst onzorgvuldig zijn. Uitingen die wel door artikel 6 lid 1 bestreken worden, zijn onrechtmatig indien zij onnodig/nodeloos grievend, kwetsend en denigrerend zijn en indruisen tegen de zorgvuldigheid, welke in het maatschappelijk verkeer betaamt. In het arrest van de Hoge Raad van 2 februari 1990 wordt - in navolging van het Hof - daarenboven nog het tot discriminatie uitnodigende karakter als argument voor de onrechtmatigheid van de desbetreffende uitlating genoemd. Overigens wordt hierbij door het Hof in zijn uitspraak van 29 september 1986 en de Hoge Raad in zowel het arrest van 5 juni 1987 als dat van 2 februari 1990 vastgesteld, dat met het begrip "wet" in de beperkingsclausule "behoudens ieders verantwoordelijkheid volgens de wet" onder meer gedoeld wordt op artikel $1401 \mathrm{BW}$. In hoofdstuk $3^{183}$ wordt hieromtrent reeds betoogd dat het twijfelachtig is of deze interpretatie in overeenstemming is met de in de Grondwet neergelegde beperkingssystematiek. Artikel 1401 (het huidige artikel 6: 162) BW voldoet strikt genomen niet aan de eisen die aan het begrip "wet" in de beperkingsclausule "behoudens ieders verantwoordelijkheid volgens de wet"- alhoewel het wel een formele wet is. De in deze beperkingsclausule bedoelde wet dient volgens de Memorie van Toelichting bij het wetsvoorstel inzake de grondwetsherziening de omvang van de beperking op de desbetreffende grondrechten nauwkeurig aan te geven, en dat is in artikel 1401/6: $162 \mathrm{BW}$ niet het geval. De Hoge Raad keurt in deze zaken derhalve impliciet goed, dat op grond van een algemene beperkingsbevoegdheid de in artikel 6 lid 1 vervatte godsdienstvrijheid wordt beperkt. ${ }^{184}$

In de strafzaken ten aanzien van het echtpaar Goeree ligt de afbakeningskwestie eenvoudiger: de "wet" waarop de beperkingsclausule in artikel 6 lid 1 doelt is in deze zaak artikel 137e Sr. ${ }^{\text {Iss }}$ Het Gerechtshof Arnhem constateert, dat het niet mag treden in de uitleg die de Goerees aan een Bijbeltekst geven, ook al wijkt die af van de door de Raad van Kerken

183 Zie paragraaf 3.2.2.

184 Zie hieromtrent verder hiervoor paragraaf 3.2 en tevens de annotatie van Alkema bij HR 2 februari 1990, NJ 1990, 289.

185 Rb. Zwolle 9 oktober 1986, Migrantenrecht 1986, p. 275 e.v.: Gerechtshof Arnhem 29 mei 1987, NJ 1987, 816; HR 18 oktober 1988, NJ 1989, 476 en Gerechtshof Leeuwarden 16 maart 1989, NJ 1989, 810. 
of door rabbijnen geautoriseerde exegese. Dit zou anders een aantasting van hun vrijheid van "geloofsverkondiging" opleveren. Het Gerechtshof vervolgt deze overweging, door te bepalen dat de grenzen van deze vrijheid worden overschreden indien de desbetreffende geloofsverkondiging plaatsvindt "op een wijze die als beledigend, derhalve als nodeloos grievend en kwetsend ... moet worden gekwalificeerd. " Hiermee geeft het Gerechtshof een omschrijving van belediging wegens ras en/of godsdienst die overeenkomt met het criterium voor onrechtmatigheid in de besproken kort geding-procedures. Het vervolg van de zaak, ook in cassatie, draait voorts om de beoordeling of inderdaad van belediging sprake is en de daartoe aangelegde criteria. Hierop zal niet verder ingegaan worden. Hoewel artikel 137e Sr niet expliciet een beperking maakt op het in artikel 6 lid 1 neergelegde recht en eerder is geformuleerd als een uitwerking van het discriminatie-verbod, is het mijns inziens voldoende specifiek om als een "wet" in de zin van deze bepaling te worden aangemerkt. Het gaat immers in artikel 137e $\mathrm{Sr}$ om uitlatingen "anders dan ten behoeve van zakelijke berichtgeving". Bij dit soort uitlatingen komt men dan al gauw uit bij artikel 6, 7 en 9 Grondwet. Ook is de omvang van de beperking op de in deze bepalingen vervatte rechten - gezien de strekking van de artikelen 137c Sr en volgende, naar mijn mening voldoende begrensd. In de strafzaken tegen het echtpaar Goeree bestaat geen twijfel ten aanzien van de toepasselijkheid van artikel 6 (en 7) Grondwet op de bestreden uitlatingen.

\subsubsection{Inspanningsverplichting bij uitoefening van het onderhavige recht}

Overigens betekent het verbod tot het doen van onrechtmatige uit!atingen of andere gedragingen bij het uitoefenen van de vrijheid van godsdienst en levensovertuiging niet alleen, dat men zich van bepaalde uitlatingen of gedragingen heeft te onthouden. Op de betrokkene rust ook een zekere inspanningsverplichting, om de schade die uit de uiteefening van zijn overtuiging voortvloeit te beperken. Zo kan het voorkomen, dat men op geloofsgronden bepaalde werkzaamheden niet wil verrichten. Volgens de Centrale Raad van Beroep dient men in dat geval alles in het werk te stellen om uit die principiële gronden voortvloeiende werkloosheid te voorkomen, dan wel zich van ander werk te verzekeren. ${ }^{186}$ In een uitspraak van 30 maart 1984 gaat het om het wegblijven van het werk op 
een islamitische feestdag - nadat de door haar gevraagde snipperdag was geweigerd - door een werkneemster, naar aanleiding waarvan zij op staande voet is ontslagen. ${ }^{187}$ De Hoge Raad stelt vast dat in ons recht geen onderscheid gemaakt mag worden tussen verschillende godsdiensten in die zin dat de wens van een werknemer om een snipperdag op te nemen voor het vieren van een godsdienstige feestdag "verschillend wordt gewaardeerd naar gelang van zijn godsdienst". Dat betekent niet dat een snipperdag alleen mag worden geweigerd onder omstandigheden waaronder ook van werknemers mag worden geëist dat zij op algemeen erkende christelijke feestdagen werken. Deze laatste dagen worden in de samenleving beschouwd als algemeen aanvaarde vrije dagen, dat wil zeggen als dagen waarop niet behoeft te worden gewerkt, ongeacht het geloof van de werknemer. Voor het al dan niet verlenen van een snipperdag voor de viering van een religieuze feestdag behoeft een nietchristelijke feestdag derhalve niet gelijkgesteld te worden aan een algemeen erkende christelijke feestdag. De Hoge Raad voegt hier aan toe, dat

"in de regel de aanwezigheid op het werk in redelijkheid niet [zal] kunnen worden verlangd van een werknemer die tijdig tevoren, onder opgaaf van redenen, toestemming voor het opnemen van een snipperdag heeft gevraagd voor de viering van een voor hem belangrijke godsdienstige feestdag."

Dit lijdt uitzondering indien de afwezigheid van betrokkene ernstige schade zou berokkenen aan de gang van zaken in het bedrijf van de werkgever. Of hiervan sprake is zal afhangen van de omstandigheden van het geval.

Deze uitspraak betekent, dat de vrijheid van godsdienst meebrengt dat men dit recht mag uitoefenen door een snipperdag op te nemen voor de viering van een religieuze feestdag, echter onder de voorwaarde dat men hiervoor tijdig tevoren, onder opgaaf van redenen, toestemming vraagt. Slechts bij wijze van hoge uitzondering - in geval van ernstige schade voor de gang van zaken in het bedrijf - zal deze snipperdag geweigerd mogen worden. Enige schade voor het bedrijf wordt kennelijk aanvaardbaar geacht. ${ }^{\text {ig }}$ De uitspraak van de Hoge Raad lijkt er voorts op te duiden, dat het niet van belang is of de bedoelde religieuze feestdag in het algemeen door de aanhangers van de desbetreffende religie als belangrijk wordt beschouwd. Het gaat erom of het een voor de werknemer belangrijke

187 HR 30 maart 1984, AB 1984, 366 met noot F.H. van der Burg; NJ 1985, 350 met noot E.A. Alkema; NJCM-Bulletin 9-3 (1984), pp. 253-258 met noot M.B.W. Biesheuvei (pp. 256-258).

188 Zo ook Biesheuvel in zijn annotatie. NJCM-Bulletin 9-3 (1984), pp. 256-258. 
godsdienstige feestdag betreft. Dit voorkomt mijns inziens terecht dat de rechter inhoudelijk een oordeel moet gaan vellen over het belang van een bepaalde feestdag voor de aanhangers van een bepaalde religie. ${ }^{159}$

De President van de Rechtbank. Arnhem heeft voorts op 24 februari 1989 een uitspraak gedaan waarin aan de uitoefening van de godsdienstvrijheid (in casu het uitspreken van een gebed tijdens een kerkdiensi) de voorwaarde wordt gesteld dat de persoonlijke levenssfeer wordi gerespecteerd van de persoon voor wie hardop wordt gebeden omdat hij te kennen heeft gegeven zich als dooplid van de desbetreffende kerk te willen uitschrijven. ${ }^{190}$ Het standpunt van eiser dat "uitschrijving als dooplid voor [hem] ... niet betekent dat er ook automatisch een breuk mett God en zijn gebod op volgt ..." had ook in de kerkdienst kenbaar gemaaki moeten worden ter beperking van de ernst van de inbreuk op zijn persooniijke levenssfeer. Het nalaten hiervan is bepalend geweest voor de mate van negatieve gevoelens die bij de kerkgangers zijn gewekt ten aanzien van betrokkene en daarmee voor de ernst van de inbreuk op zijn persoonlijke levenssfeer. De President geeft hiermee geen oordeel over de juistheid van het standpunt van eiser, hiertoe is de President niet bevoegd en bovendien zou het dan gaan om een botsing van de vrijheid van godsdienst van de kerk enerzijds en eiser anderzijds. In deze zaak gaat het om een botsing van de vrijheid van godsdienst van de kerk met het recht op bescherming van de persoonlijke levenssfeer van de eiser. De President bakent door middel van de genoemde voorwaarde de reikwijdte van deze rechten ten opzichte van elkaar af. ${ }^{191}$

\subsubsection{Beleidsvrijheid van de overheid}

Overigens betekent de waarborg van de vrijheid van godsdienst niet, dat er voor de overheid geen ruimte overblijft een beleid te voeren, dat in

$189 \mathrm{Vgl}$. de annotatie van Alkema, punt 1, eerste alinea, NJ 1985, 350. Zie ook B.P. Vermeulen, Artikel 6 Grondwet, pp. 115-116.

190 Pres.Rb. Arnhem 24 februari 1989, KG 1989, 114.

191 Op grond van het bovenstaande is mijns inziens dan ook de stelling van Vermeulen onjuist, dat in deze zaak de President zijn boekje te buiten gaat. Hij suggereert dat de President een stellingname inneemt ten aanzien yan het al dan niet ontstaan van een breuk met God en zijn geboden tengevolge van uitschrijving uit het doopregister door van de predikant te eisen dat eiser's standpunt te vermelden in een rectificatie. Dit is, zoals ik aangevoerd heb, niet het geval. B.P. Vermeulen. Artikel 6 Grondwet, p. 135 en aldaar noot 181 . Zie voorts voor een beperking van de godsdienstvrijheid door de vrijheid van inrichting van het onderwijs: Gerechtshof 's-Hertogenbosch 5 september 1989, RV 1989, 96 met noot B.P. Vermeulen; KG 1989, 394; NJCMBulletin 15-5 (1990), pp. 589-594 met noot $R$. de Winter en NI 1990, 377. 
enige mate indruist tegen die vrijheid, zonder dat sprake is van toepassing van de beperkingsclausules. Hetzelfde geldt voor het uitvoeren van voorschriften. In de navolgende zaken gaat het om het toelatingsbeleid voor vreemdelingen voor wat betreft imams. Een uitspraak van de President van de Haagse Rechtbank van 9 februari 1983 betreft de weigering van een verblijfsvergunning aan een imam. ${ }^{192}$ Reden voor deze weigering is, dat de imam geen machtiging tot voorlopig verblijf heeft gevraagd voor zijn vertrek naar Nederland. De aanvraag van een machtiging tot voorlopig verblijf geeft de autoriteiten (Ministerie van Justitie) de gelegenheid vragen te onderzoeken betreffende het aantal imams dat er in Nederland werkzaam dienen te zijn, de voorziening in het levensonderhoud van de aan te trekken imam, de aanwezigheid van passende huisvesting en met het oog op de openbare orde of nationale veiligheid: de kans dat de door een bepaalde groepering aangetrokken en aanvaardbaar geachte imam de politieke en interreligieuze tegenstellingen tussen verschillende Islamitische groeperingen zal opwekken of aanwakkeren. De President acht dit beleid waarin een machtiging tot voorlopig verblijf een - zij het niet absolute - voorwaarde vormt voor de verlening van een verblijfsvergunning, gerechtvaardigd ondanks het feit, dat volgens vaste jurisprudentie het ontbreken van een machtiging tot voorlopig verblijf onvoldoende gronden oplevert voor de weigering van een verblijfsvergunning. ${ }^{193}$ Volgens de Rechtbank-President impliceert deze praktijk niet dat de eis van een m.v.v. in het geheel geen betekenis meer zou moeten worden toegekend. Integendeel, de autoriteiten doen niets anders dan gebruik maken van de hen ten dienste staande rechtmatige middelen. Hoewel een ingrijpen in het godsdienstige en geestelijk leven van de in Nederland levende islamieten niet beoogd is, heeft de Minister er een gerechtvaardigd belang bij, dat "niet anderen ... bepalen wie voor imain hier te lande in aanmerking komen. "De President meent dat uit een oogpunt van algemeen belang de overheid enige controle op de situatie moet hebben vanwege geconstateerde "verschillen van politieke, religieuze en culturele aard ... binnen groeperingen van in Nederland woonachtige vreendelingen van dezelfde nationaliteit en/of tussen verschillende Islamitische groeperingen ...". Het feit dat het beslissen over de verlening

192 Pres. Rb. 's-Gravenhage 9 februari 1983, KG 1983, 102.

193. Zie 0.a. ARRS 10 december 1981, AB 1982. 244. De President onderkent overigens. dat aan de in het beleid voor het verlenen van een verblijfsvergunning gestelde eis, dat met de aanwezigheid van de vreemdeling een wezenlijik Nederlands belang wordt gediend, ingeval van een imam voldaan kan zijn met het oog op het "welbevinden van de hier te lande legaal verblijvende vreemdelingen van Islamitische geloofsovertuiging". 
van een machtiging tot voorlopig verblijf - met betrekking tot functionarissen in het godsdienstig en geestelijk leven - in feite de enige mogelijkheid voor de Staat is om zijn bevoegdheden onder de Vreemdelingenwet uit te oefenen, brengt mee dat aan dit vereiste van een machtiging tot voorlopig verblijf "ook ten aanzien van imams strikt de hand dient te worden gehouden." Daarbij komt nog, dat "(g)eenszins is ... gebleken dat imams de toegang tot Nederland zal worden geweigerd." De President concludeert dan ook dat geen sprake is van strijd met de vrijheid van godsdienst.

Vergelijkbaar met deze uitspraak is de beslissing van de Afdeling Rechtspraak van 2 juli 1984. ${ }^{194}$ De Afdeling volgt een soortgelijke redenering als de Rechtbank-President, met deze uitzondering, dat de Afdeling het aanvaardbaar acht dat in het onderzoek naar aanleiding van het verzoek om een machtiging tot voorlopig verblijf ook "de aanvaardbaarheid van de voorgedragen vreemdeling om bij de desbetreffende islamitische gemeenschap als imam werkzaam te zijn" nagegaan wordt. Hiertegen is terecht kritiek geuit. ${ }^{199}$ De Afdeling staat hier immers toe, dat de autoriteiten een inhoudelijk oordeel uitspreken over een intern-" kerkelijke" aangelegenheid, waarvan in de hiervoor besproken rechtspraak juist werd geoordeeld dat dit oordeel aan de overheid niet toekomt. Overigens lijkt de constatering, dat eventuele uitzetting van een imam in verband met zijn bijzondere positie in de islamitische gemeenschap meer commotie teweeg zal brengen dan die van een willekeurig lid van de desbetreffende gemeenschap, in deze uitspraak als hoofdargument gebruikt te worden voor afwijking van de genoemde vaste jurisprudentie (dat het ontbreken van een machtiging tot voorlopig verblijf onvoldoende gronden oplevert voor de weigering van een verblijfsvergunning). ${ }^{196}$

Een aantal andere zaken waaruit duidelijk wordt dat de: vrijheid vervat in artikel 6 Grondwet niet met zich brengt dat er voor de overheid geen ruimte overblijft om - zonder gebruikmaking van de beperkingsclausules een beleid te voeren, dat in enige mate indruist tegen die vrijheid, betreft het gebruik van panden als moskee in strijd met het desbetreffende

194. ARRS 2 jüli 1984, AB 1985, 273 met noot $R$. Fernhout en J.A. Hofman; RV 1984, 37 met noot C.A. Groenendijk; AA 1985, 488 met noot P.W.C. Akkermans.

195 Zie de annotatie van Fernhout en Hofman, AB 1985 "273, punt 2 en S.C. den Dekker-van Bijsterveld, De toelating van imams, p. 1092. Overigens stamt dit - inmiddels geschrapte - criterium uit een circulaire.

196 Zie hieromtrent punt 1 van de annotatie van R. Fernhout en J.A. Hofman, AB 1985, 273. 
bestemmingsplan. In een uitspraak van 20 juni 1985 stelt de Voorzitter van de Afdeling Rechtspraak van de Raad van State vast, dat de Stichting Islamitisch Centrum Helmond in strijd met het bestemmingsplan een pand als gebedsruimte gebruikt en ook niet in aanmerking komt voor een vrijstelling van de toepasselijke voorschriften. ${ }^{197}$ Toch heeft de Voorzitter - in verband met de bijzondere omstandigheden van het geval - bezwaren tegen het besluit van B en W van Helmond waarbij de Stichting, onder aanzegging van politiedwang, wordt opgedragen het gebruik van het pand als gebedsruimte te staken. Volgens de Voorzitter staat tegenover het belang bij handhaving van het plaatselijke bestemmingsplan het belang van de betrokken godsdienstige groepering bij het kunnen voldoen aan hun dagelijkse godsdienstige verplichtingen. Onmiddellijke effectuering van het genoemde besluit van B en W heeft tot direct gevolg "dat deze groep de mogelijkheid wordt ontnomen haar godsdienstige plichten te vervullen". Voorts neemt de Voorzitter de mate van overlast veroorzaakt door het gebruik van het pand als gebedsruimte in aanmerking. Uiteindelijk komt de Voorzitter tot de conclusie, dat ondanks dat het met het bestemmingsplan strijdige gebruik van het pand niet licht opgevat mag worden, uitvoering van het bestreden besluit thans voor de Stichting "onevenredig nadeel oplevert in verhouding tot de met zodanige uitvoering te dienen belangen."

Uit deze zaak kan men afleiden, dat met een gebruiksbepaling, behorende bij een bestemmingsplan, strijdig gebruik van een pand vermoedelijk niet excuseerbaar is met een beroep op de godsdienstvrijheid. Ik schrijf hier "vermoedelijk" omdat artikel 6 Grondwet in deze zaak niet wordt genoemd. Zou dit wel het geval zijn, dan speelt de vraag of de formele wet waarop het bestemmingsplan is gebaseerd, artikel 10 Wet op de Ruimtelijke Ordening, wel voldoende nauwkeurig de omvang van de beperking op de in artikel 6 lid 1 Grondwet gegarandeerde vrijheid aangeeft. Mijns inziens is dit niet het geval en moet de onderhavige beperking op de vrijheid van godsdienst en levensovertuiging dan ook opgevat worden als een - strikt genomen - niet toegelaten algemene beperking. Immers, het gaat hier om een bepaling die niet is gericht op de beperking van een specifiek grondrecht, maar een dergelijke beperking wel tot gevolg heeft.

De uitspraak van de President van de Rechtbank 's-Hertogenbosch van 25 juni 1985 ( 5 dagen later!) geeft wél aan in hoeverre de gebruiksbepaling behorende bij het desbetreffende bestemmingsplan van de gemeente Eindhoven in overeenstemming met artikel 6 Grondwet is. ${ }^{194}$ Het gaat in 
deze zaak om een eis in kort geding dat het de verweerder (Stichting Islamitisch Centrum Eindhoven) wordt verboden een bepaald pand te gebruiken voor het houden van gebedsdiensten. Deze eis wordt onder meer gebaseerd op de bedoelde gebruiksbepaling. De President bepaalt, na te hebben vastgesteld dat het woord "wet" in artikel 6 lid 1 ziet op een formele wet, dat de in het geding zijnde gebruiksbepaling

"vermag - gelet op het bepaalde in art. 6 Gr.w. - dat gebruik dan ook niet onmogelijk maken."

Hierna concludeert de President dat de vordering "als zijnde in strijd met voormelde gebruiksbepaling dient te worden afgewezen." De gebruiksbepaling wordt door de President in deze zaak zodanig uitgelegd, dat deze geen beperking op de vrijheid van godsdienst en levensovertuiging inhoudt die gebruik van een pand als gebedsruimte "onmogelijk maakt". De President kleedt deze overweging kennelijk in als een afbakening van de reikwijdte van de onderhavige vrijheid, omdat juist daarvoor door de President is geconcludeerd dat artikel 6 lid 1 voor beperking van die vrijheid een formele wet eist (wat de gebruiksbepaling niet is). Deze overweging impliceert een restrictieve uitleg van artikel 6 lid 1 met betrekking tot het gebruik van panden voor gebedsdiensten. Dit gebruik mag slechts niet "onmogelijk" gemaakt worden. Daaruit zou kunnen worden afgeleid, dat aan dat gebruik derhalve wel allerhande voorwaarden gesteld mogen worden. Deze gevolgtrekking lijkt mij onjuist, omdat dit soort voorwaarden niet gedekt worden door de beperkingsclausule in artikel 6 lid 1. De overweging van de President dat het gebruik van een pand als gebedsruimte niet onmogelijk gemaakt mag worden is dan ook, naar mijn mening, te restrictief geformuleerd.

In de uitspraak van 16 februari 1989 van de Voorzitter van de Afdeling Rechtspraak is een met die uit de voorgaande zaak vergelijkbare overweging te vinden. ${ }^{199}$ De casus stemt overeen met die van de uitspraak

199 Vz.ARRS 16 februari 1989, AB 1990, 9 met noot P.J. Boon; tB/S 1989. nr. 20 met noot M.C.B.; AA 1990. pp. $398-402$ met noot P.W.C. Akkermans; De Gerneentestem, no. 6883, nr. 11, pp.359-360 met naschrift J.M.H.F. Teunissen. Vergelijkbaar is Vz.ARRS 17 augustus 1990, AB 1991, 44 met noot P.J. Boon; De Gemeentestem, no. 6913, nr. 3 met noot $B$ (verzoek om schorsing van beslissing over bezwaar tegen vergunning waarbij slechts beperkt ontheffing is verleend van het verbod tot het in werking hebben van een geluidsapparaat "op zodanige wijze dat geluidshinder wordt veroorzaakt" - in casu - het ten gehore brengen van versterkte muziek). Zie ook Vz.ARRS 17 oktober 1985, AB 1986. 288 voor een zaak waarin de Voorzitter tot het oordeel kwam dat onmiddellijke effectuering van het besluit (aanschrijving politiedwang tot staken van bouwwerkzaamheden i.v.m. inrichting van een. 
van 25 juni 1985. Het gaat om het gebruik van een pand voor kerkelijke activiteiten dat in strijd is met de voorschriften van het toepasselijke bestemmingsplan. Ook in dit geval wordt schorsing gevraagd van het besluit waarin politiedwang wordt aangezegd wanneer verzoekster (Evangelie gemeente "De Deur" te Arnhem) de desbetreffende activiteiten in het pand niet staakt. Verzoekster doet een beroep op de godsdienstvrijheid. Allereerst overweegt de Voorzitter dat verweerders (B en W van Arnhem) nu het gaat om de uitoefening van een grondrecht, "bij hun besluitvorming een grote mate van zorgvuldigheid in acht dienden te nemen." In casu hadden zij hieraan voldaan. Anders dan in de - in de vorige sub-paragraaf besproken - zaken waarin het ging het om een inspanningsverplichting tot het beperken van de schade door uitoefening van de vrijheid van godsdienst en levensovertuiging, die rust op degene die die vrijheid wenst uit te oefenen, gaat het er hier om bij de bepérking van de onderhavige vrijheid ook bij de inbreuk "een grote mate van zorgvuldigheid in acht ... te nemen."

In deze zaak wordt opnieuw artikel 6 Grondwet niet toegepast, maar vindt een belangenafweging in het kader van artikel 107-oud Wet op de Raad van State plaats. De Voorzitter overweegt hieromtrent dat

\begin{abstract}
"het feit dat sprake is van de uitoefening van een grondrecht niet met zich [brengt] dat de voorschriften van het bestemmingsplan hun betekenis zouden verliezen. Die voorschriften hebben immers niet tot gevolg, dat kerkelijke activiteiten nergens in het plangebied zijn toegestaan."
\end{abstract}

Ik wijs hier op de overweging, dat handhaving van de voorschriften niet tot gevolg heeft, "dat kerkelijke activiteiten nergens in het plangebied zijn toegestaan. "Evenals de overweging van de Rechtbank-President van 'sHertogenbosch geeft deze formulering blijk van een restrictieve afbakening van de vrijheid van godsdienst. Nei als bij de formulering dat het gebruik van een pand als gebedsruimte niet onmogelijk gemaakt mag worden, laat de onderhavige overweging de mogelijkheid open, dat er aan kerkelijke activiteiten zware voorwaarden kunnen worden gesteld zolang deze maar "ergens" in het plangebied zijn toegestaan.

In de annotaties naar aanleiding van deze uitspraak zijn de meningen verdeeld over de vraag of in deze beslissing nu wel of niet sprake is van aanvaarding van de mogelijkheid van algemene beperkingen. Volgens Boon en Teunissen is dit wel het geval, volgens Burkens en Akkermans niet. 
Akkermans is van opvatting dat sprake is van één van de door de grondwetgever ten aanzien van de beperkingssystematiek voorziene ontsnappingsmogelijkheden, namelijk dat intrekking of vernietiging van een overheidsmaatregel "in flagrante strijd zou zijn met wat algemeen als redelijk wordt aangemerkt." Welk plakkertje je er in dit geval opplakt, doet er volgens mij niet zo toe. Het bestreden besluit is gebaseerd op een gebruiksbepaling, die niet gericht is op de beperking van een specifiek. grondrecht, maar wel een beperking van de godsdienstvrijheid tot gevolg kan hebben. In die zin is de gebruiksbepaling een algemene beperking op de godsdienstvrijheid, die zonder meer in strijd is met de beperkingssystematiek. ${ }^{200.201}$ Maar door middel van toepassing van de aangehaalde ontsnappingsmogelijkheid kan in dit geval de algemene beperking in stand blijven: de voorschriften (in casu gaat het om de gebruiksbepaling) van het bestemmingsplan verliezen hun betekenis niet door uitoefening van de godsdienstvrijheid, om met de Voorzitter te spreken. Welke van de hier geopperde wegen (Boon en Teunissen: erkenning algemene beperkingen, Burkens en Akkermans: toepassing van de grondwettelijke ontsnappingsmogelijkheid of mijn optie: allebei) de Voorzitter heeft gevolgd blijkt niet uit de uitspraak. Vermoedelijk is de Voorzitter hier met opzet in het vage gebleven omdat de opvattingen omtrent algemene beperkingen nogal uiteenlopen. Voor het overige omtrent deze materie verwijs ik naar hoofdstuk 3 alwaar ik de grondwettelijke beperkingssystematiek heb besproken. ${ }^{202}$

Ik wil aan deze beschouwingen slechts toevoegen, dat formuleringen als die in de uitspraak van de Rechtbank-President van 's-Hertogenbosch van 25 juni 1985 (dat door toepassing van de desbetreffende gebruiksbepaling het gebruik van een pand als gebedsruimte niet onmogelijk gemaakt mag worden) en die in de onderhavige zaak (dat handhaving van de voorschriften niet tot gevolg heeft, "dat kerkelijke activiteiten nergens in het plangebied zijn toegestaan. ") grote overeenkomsten vertonen met de

200 Vgl. de annotatie van P.J. Boon onder Vz.ARRS 17 augustus 1990, AB 1991, 44. met name punt 2.

201 De opvatting van Vermeulen dat er in dit soort gevallen in het geheel geen sprake is yan bepérking van de onderhavige vrijheid doordat het grendrecht redelijk wordt uitgelegd, is mijns inziens slechts ten dele juist. Zie B.P. Vermeulen, Artikel 6 Grondwet, pp. 116-118 en hiervoor hoofdstuk 3, noot 142. Ook restrictieve uitleg is naar mijn mening een (oneigenlijke?) methode om de titoefening van een grondrecht te beperken. Zie verder hoofdstuk, 3 .

202 Men denke ter vergelijking met de rechterlijke overwegingen hiervoor ten aanzien van de voorschriften bij bestemmingsplannen ook aan het in hoofdstuk drie gegeven voorbeeld van brandveiligheidsvoorschriften. Zie ook B.P. Vermeulen, Algemene beperkingen, redelijke uitleg en redelijke toepassing van grondrechten, p. 84 . 
standaardformulering in het kader van artikel 7 lid 1 dat er een "gebruik van enige betekenis" over moet blijven bij het beperken van het verspreidingsrecht. Ik verwijs hiervoor naar de bespreking van artikel 7 Grondwet hierna. ${ }^{203}$

De laatste uitspraak die ik hier wil bespreken is een beslissing van de Afdeling Rechtspraak van 16 juni $1993 .^{204}$ In het geding is het besluit van $\mathrm{B}$ en W van Amersfoort om aan appellante (opnieuw Evangelie gemeente "De Deur") geen ontheffing te verlenen van het in artikel 15 lid 1 Geluidshinderverordening van de gemeente Amersfoort opgenomen verbod om in de open lucht een geluidapparaat en dergelijke in werking te hebben op een zodanige wijze, dat voor een omwonende of overigens voor de omgeving geluidshinder veroorzaakt wordt. De ontheffingsmogelijkheid staat in het tweede lid. Ten aanzien van het door appellante ingestelde beroep (tegen ongegrondverklaring van haar bezwaarschrift tegen voornoemd besluit van B en W) overweeg de Afdeling als volgt. Voormeld verbod in de Amersfoortse Geluidshinderverordening in samenhang met de in het tweede lid van artikel 15 opgenomen ontheffingsmogelijkheid is op zichzelf niet in strijd met artikel $6 \mathrm{Gw}$. Een redelijke uitleg van deze grondwetsbepaling brengt volgens de Afdeling met zich mee, dat degenen die het hierin vervatte grondrecht uitoefenen "daarbij onderworpen zijn aan de bepalingen die in algemene zin zijn gesteld ter voorkoming of beperking van geluidshinder". B en W zullen er voorts voor moeten waken, wanneer het gaat om ontheffing met betrekking tot het gebruik van geluidsversterkende apparatuur bij het belijden van godsdienst of levensovertuiging, dat het ontheffingsbeleid op grond van artikel 15 tweede lid van de verordening niet gaat functioneren als een grondrechtenbeperking. Volgens de Afdeling mag het gebruik van geluidsapparatuur bij het belijden van godsdienst of levensovertuiging niet sterker aan banden worden gelegd dan strikt noodzakelijk is te achten voor het voorkomen of beperken van geluidshinder. Bij de beoordeling van deze noodzakelijkheid zal het gebruik van geluidsversterkende apparatuur dat in de gemeente Amersfoort in andere gevallen wordt geaccepteerd mede een rol spelen.

Uit deze overwegingen kan het volgende worden afgeleid. Het verbod in artikel 15 van de verordening wordt niet opgevat als een beperking van de vrijheid van godsdienst en levensovertuiging zolang het gebruik van geluidsapparatuur bij het belijden van godsdienst of levensovertuiging niet

203 Zie voorts de annotatie van Teunissen. De Gemeentestem, no. 6883, nr. 11, pp. 359360 en de annotatie van $B$ onder Vz.ARRS 17 augustus 1990, De Gemeentestem, no. $6913, \mathrm{nr}, 3$.

204 ARRS 16 juni 1993, AB i994, 424 met noot van C. Riezebos. 
sterker aan banden gelegd wordt dan strikt noodzakelijk is met het oog op het voorkomen of beperken van geluidshinder. Strikt noodzakelijke beperkingen op het gebruik van geluidsversterkende apparaten zijn in overeenstemming met een redelijke uitleg van artikel $6 \mathrm{Gw}$. Als bij de bedoelde, strikt noodzakelijke beperkingen op het gebruik van geluidsapparatuur geen sprake is van een beperking van de (uitoefening van de) godsdienstvrijheid, dan kan deze opvatting van de Afdeling - mijns inziens - niets anders betekenen dan dat het verbod in de geluidshinderverordening in zoverre niet binnen de reikwijdte van de godsdienstvrijheid valt, het raakt de godsdienstvrijheid niet; er is derhalve sprake van een restrictieve uitleg van de godsdienstvrijheid. Dit is naar mijn mening slechts te verdedigen als de Afdeling hiermee beoogt uit te spreken dat weliswaar het belijden van godsdienst of levensovertuiging door artikel 6 beschermd wordt doch dat het gebruik van geluidsapparatuur daarbij geen element van het belijden is. Is dit niet de bedoeling van de Afdeling geweest en behoort het gebruik van geluidsapparatuur ten behoeve van het belijden van godsdienst of levensovertuiging wèl tot het "belijden", dan kan er geen twijfel over bestaan dat de godsdienstvrijheid in casu van toepassing is (en het verbod in de verordening derhalve binnen de reikwijdte van artikel $6 \mathrm{komt}$ ) en is sprake van een ongrondwettige, algemene beperking van dit grondrecht. Immers, de verbodsbepaling is niet op de beperking van de vrijheid van godsdienst of levensovertuiging gericht, maar kan dit wel tot gevolg hebben en is niet gebaseerd op een specifieke formele wetsbepaling (vermoedelijk het huidige 149 gemeentewet). Artikel 6 lid $2 \mathrm{Gw}$ zal daarom niet als basis voor het onderhavige verbod dienst kunnen doen. In dat geval kan de onderhavige verbodsbepaling alleen grondwettig worden geacht indien sprake is van een redelijke toepassing van het grondrecht. ${ }^{205}$ Hoewel de Afdeling deze in de beperkingssystematiek van de Grondwet ingebouwde ontsnappingsmogelijkheid niet expliciet toepast, bieden de overwegingen hiertoe voldoende aanknopingspunten. Het zou in flagrante strijd met wat in het algemeen als redelijk wordt beschouwd, zijn indien de verbodsbepaling vernietigd of ingetrokken zou moeten worden als gevolg van de toepassing van artikel $6 \mathrm{Gw}$. Of het verbod in concreto, dat wil zeggen het niet verlenen van ontheffing in het concrete geval, grondwettig wordt geacht, hangt ervan af of de beperking van de vrijheid van godsdienst of levensovertuiging in het zich voordoende geval strikt noodzakelijk is met het oog op het voorkomen of beperken van geluidshinder. Dit zou erop kunnen duiden dat volgens de Afdeling een

205 Vergelijk B.P. Vermeulen, Algemene beperking, redelijke uitleg en redelijke toepassing van grondrechten, pp. 84-85. 
belangenafweging plaats moet vinden. Mijns inziens, zou er ook sprake moeten zijn van een proportionaliteits- en subsidiariteitstoetsing en zou ook nagegaan moeten worden of er in dit geval nog voldoende mogelijkheden overblijven voor het belijden van de godsdienst of levensovertuiging. ${ }^{20}$

Zoals gezegd, de Afdeling past deze ten aanzien van de grondwettelijke beperkingssystematiek voorziene ontsnappingsmogelijkheid niet expliciet toe. Naar mijn mening zou dat echter veel overtuigende geweest zijn dan de wèl door de Afdeling expliciet toegepaste methode van redelijke wetsuitleg, met name omdat de Afdeling niet strikt noodzakelijke beperkingen op het gebruik van geluidsapparatuur als grondrechtenbeperking beschouwt en hiervan logischerwijs pas sprake kan zijn als het onderhavige grondrecht van toepassing wordt geacht ten aanzien van het gebruik van dergelijke apparaten ten behoeve van het belijden van godsdienst en levensovertuiging.

Tot slot wil ik hier nog even terugkomen op de uitspraak van de Voorzitter van de Afdeling Rechtspraak van 20 juni 1985. Bij het besluit strekkende tot staking van dit gebruik - al dan niet onder bedreiging van politiedwang - moet volgens de Voorzitter rekening worden gehouden met de bijzondere omstandigheden van het geval, zoals enerzijds de mate van overlast die het gebruik als gebedsruimte voor de omgeving met zich brengt en anderzijds de mate waarin de betrokken religieuze groepering nog aan haar godsdienstige plichten kan voldoen bij (onmiddellijke) effectuering van dat besluit. Hierbij mag effectuering van het besluit geen onevenredig nadeel aan het belang van de groepering toebrengen. ${ }^{207}$ De Voorzitter moest deze belangenafweging toen maken op grond van artikel 80 -oud Wet op de Raad van State (Rus). In de uitspraak van 16 februari 1989 moet de Voorzitter dezelfde afweging maken op grond van artikel 107-oud Rus. Deze overwegingen doen sterk denken aan de in het ECRM terug te vinden "gedragscode" in de beperkingsclausules van de artikelen 8 tot en met 11, volgens welke een beperking "noodzakelijk in een

206 Oftewel. is de beperking van de godsdienstvrijheid evenredig aan het daarmee nagestreefde doel van voorkoming en beperking van geluidshinder (proportionaliteit) en is die beperking met het oog op die beperking noodzakelijk voor het bereiken van dit doel of kan dit doel ook worden verwezenlijkt met behulp van andere, voor de in het geding zijnde grondrecht minder belastende. middelen (subsidiariteit)? Zie ook de punten 3 en 5 van de noot van Riezebos bij deze uitspraak.

207 Overigens acht de Voorzitter het passender dat bij de behandeling van het bezwaarschrift van de Stichting (tegen de weigering van een vrijstelling van de desbetreffende gebruiksbepaling in het bestemmingsplan) een weging van alle belangen plaatsvindt. Uit de annotatie valt op te maken dat het bezwaar ongegrond is verklaard. Vz.ARRS 20 juni 1985. KG 1985, 281: RV 1985. 118 met noot Bo. 
democratische samenleving" moet zijn. Ook hierbij moet - volgens de Straatsburgse organen - het proportionaliteitsbeginsel in acht genomen worden. Artikel 80-oud respectievelijk artikel 107-oud Wet op de Raad van. State vervullen hier als het ware de rol van gedragscode. Een dergelijke gedragscode kan bij bijzondere beperkingen reeds voorkomen dat door toepassing van de beperkingsclausule het desbetreffende grondrecht illusoir wordt. Bij algemene beperkingen is deze rol nog essentiëler: het gevaar voor uitholling van grondrechten - dat bij de grondwetsherziening werd aangevoerd als argument tegen algemene beperkingen - kan eveneens door middel van een dergelijke gedragscode worden beteugeld. ${ }^{20}$

\subsubsection{Conclusies ten aanzien van de afbakening}

Wat betreft de afbakening van het begrip godsdienst heb ik slechts één uitspraak gevonden waarin deze term wordt geïnterpreteerd, namelijk de beslissing van het Gerechtshof 's-Gravenhage van 13 december 1984, die is bevestigd door de Hoge Raad op 31 oktober 1986 (Zusters van Sint Walburga). ${ }^{209}$ Het Gerechtshof geeft niet uitdrukkelijk aan wat moet worden verstaan onder godsdienst, maar geeft een uitleg van het begrip "godsdienstoefening" in artikel 123 lid 2 Sv. De criteria die het Gerechtshof hanteert zijn: 1. de aard van de ontplooide activiteiten en 2. het (niet) waarneembaar zijn van enigerlei religieuze ervaring bij de betrokkenen. Het Gerechtshof hanteert schijnbaar puur feitelijke criteria. Echter, met betrekking tot het eerste criterium moet in dat opzicht worden opgemerkt dat activiteiten ingegeven kunnen worden door innerlijke beweegredenen. Deze zijn niet minder relevant voor de vaststelling van de aard van de activiteiten dan de uiterlijke kant van de activiteiten. En wat betreft het tweede criterium: dit soort waarneiningen zijn moeilijk objectief te doen. We leven immers in een door de christelijke cultuur beheerste maatschappij, die van grote invloed is op de wijze waarop we de dingen waarnemen. Hoeft dit omtrent de waarneming van religieuze ervaring en acciviteiten van mensen van aanverwante godsdiensten als de islam en het jodendom wellicht nog geen problemen op te leveren, dit zal anders zijn ten aanzien van godsdiensten die verder van het christendom afstaan.

Dat een rechter zich op glad ijs begeeft zodra hij zich gaat bezighouden met de interpretatie van begrippen als "godsdienst" en "godsdienstoefening" is duidelijk. Aan de ene kant mag uit het feit, dat de rechter wetsbepalingen moet toepassen waarin dit soort termen zijn 
opgenomen, niet afgeleid worden dat vanwege de autoriteiten een toetsing van een beweerde geloofsovertuiging plaats mag vinden. Uit verschillende behandelde zaken ${ }^{20}$ is af te leiden, dat de rechter zich in het algemeen verre dient te houden van inhoudelijke oordelen over kwesties van godsdienstige of levensbeschouwelijke aard. Dit standpunt is naar mijn mening juist, maar uit de uitspraak inzake de Zusters van Sint Walburga blijkt, dat het moeilijk is een grens te leggen tot waar de rechter mag gaan. Aan de andere kant kan ook weer niet zo zijn dat iedereen zich naar willekeur op zijn godsdienstvrijheid kan beroepen en overal het etiketje "godsdienst" op kan plakken teneinde aan bepaalde wettelijke plichten of verantwoordelijkheden te ontkomen. De genoemde criteria kunnen derhalve wel bruikbaar zijn, maar men moet de zojuist herhaalde kanttekeningen bij dit soort criteria in gedachten houden.

Criteria voor de afbakening van het begrip levensovertuiging heb ik in de jurisprudentie niet aangetroffen. Hiervoor is men op de kamerstukken bij de grondwetsherziening en de literatuur aangewezen. Het was de bedoeling van de wetgever om overlappingen met de vrijheid van meningsuiting te voorkomen. Daartoe werden de vrijheid van godsdienst en de vrijheid van levensovertuiging in één artikel opgenomen. ${ }^{211}$ Door Schneider is hierover onder meer opgemerkt, dat men "(d)oor de interpretatie van de levensovertuiging te trekken naar die van godsdienst ... een maatschappelijke opvatting (heeft) uitgesloten." De uiting van deze puur maatschappelijke opvatting wordt niet beschermd door artikel 6 maar door artikel 7 Grondwet. En wat betreft godsdienst en levensovertuiging stelt hij dat men "(d)e orde waartoe godsdienst en levensovertuiging behoren ... " kan omschrijven als een "samenhangende levensbeschouwing, die de hele levensopvatting doortrekt ...". ${ }^{212}$. Hoewel ik het hiermee in algemene zin mee eens ben, dient hierbij wel in gedachte gehouden te worden, dat - juist omdat iemands godsdienst of levensovertuiging zijn "hele levensopvatting doortrekt" - ook de maatschappelijke opvatting van een persoon ingegeven kan zijn door diens godsdienst of levensovertuiging. Een duidelijke, strikte scheiding tussen uitingen die door artikel 6 enerzijds

210 Gerechtshof Arnhem 11 juli 1984, NJ 1985, 536; KB 4 december 1984. Stb. 685. AB 1985, 163 met noot B.J. van der Net; Rb. Breda 11 juni 1987, KG 1987, 265: Rb. Breda 30 oktober 1987, KG 1987, 501: Pres. Rb. Haarlem 17 februari 1989. KG 1989. 134: Gerechtshof 's-Hertogenbosch 22 december 1989, KG 1990, 487.

211 Memorie van Toelichting bij wetsvoorstel 13872, Verklaring dat er grond bestaat ..., Tweede Kamer, in: Algehele grondwetsherziening, deel Ia Grondrechten, p. 29.

212 J.W. Schneider, De vrijheid van godsdienst en levensovertuiging. p. 161. Zie ook de Memorie van Antwoord bij wetsvoorstel 13872. Verklaring dat er grond bestaat .... Tweede Kamer, in: Algehele grondwetsherziening, deel la Grondrechten, p. 193. 
en door artikel 7 anderzijds worden beschermd, zal naar mijn mening dan ook niet altijd mogelijk zijn.

Godsdienst en levensovertuiging dienen wel van elkaar te worden onderscheiden, omdat het gaat om "geheel eigen leefwerelden met een geheel eigen gevoelswaarde ...". Erkent men aldus dat godsdienst en levensovertuiging zowel naar aard als naar gerichtheid elk een eigen karakter vertonen, dan mag dit niet van invloed zijn op "de waarborging van vrijheid, bescherming en staatsrechtelijke gelijkheid ...". ${ }^{21}$ Deze nevenschikking van godsdienst en levensovertuiging komt ook naar voren uit de rechtspraak. ${ }^{214}$

Het begrip belijden is voor zover mij bekend niet expliciet in de jurisprudentie geïnterpreteerd. Er is een uitspraak die een aanwijzing kan inhouden voor de uitleg van de term "belijden". In een beslissing van 7 april $1983^{215}$ bepaalt de Afdeling Rechtspraak van de Raad van State dat het moet gaan om "een gedraging ... waardoor appellant naar objectieve maatstaven een directe uitdrukking geeft aan zijn godsdienst of levensovertuiging". Zoals al eerder is opgemerkt, is hett praktisch onmogelijk om te spreken van "objectieve" maatstaven omdat maatstaven onvermijdelijk beïnvloed worden door de overheersende cultureelreligieuze traditie van de samenleving. Naast deze ene rechterlijke uitspraak, geeft de Memorie van Toelichting bij het wetsvoorstel inzake de grondwetsherziening meer informatie over de betekenis van het begrip "belijden". Volgens de regering ziet het begrip "belijden" niet alleen op het huldigen van de godsdienstige of levensbeschouwelijke overtuiging. maar ook op het zich daarnaar gedragen. Dit belijden kan individueel of in groepsverband plaatsvinden en zowel binnen als buiten gebouwen en besloten plaatsen. ${ }^{216}$

213 Memorie van Toelichting bij wetsvoorstel 13872. Verklaring dat er grond bestaat .... Tweede Kamer, in: Algehele grondwetsherziening, deel la Grondrechten, p. 29. Zo ook de Memorie van Antwoord bij wetsvoorstel 13872, idem, p. 193. Vergelijk ook respectievelijk de Memorie van Toelichting. Memorie van Antwoord en de Nota naar aanleiding van het Eindverslag bij wetsvoorstel 21335. Wetsvoorstel tot aanpassing aan de Grondwet van de giftenaftrek in de Wet op de inkomstenbelasting $1964 \mathrm{en}$ van enige daarmee samenhangende bepalingen in andere wetten. Tweede Kamer.

214 ARRS 1 augustus 1983, AB 1984, 532 met noot B.J. van der Ner; NJCM-Bulletin 9.2 (1984), pp. 156-166 met noot J.E. Goldschmidt (pp. 164-166); ARRS 21 maart 1985, AB 1986, 16 met noot P.J.J. van Buuren: ARRS 18 december 1986, A. 1987, 260: ARRS 12 maart 1987, AB 1987. 287 met noot I.C. van der Vlies.

215 ARRS 7 april 1983, AB 1983, 430 met noot P.J. Boon. Zie M.M. den Boer, Artikel 6 Grondwet: vrijheid van godsdienst en levensovertuiging. G.J.M. van Wissen, Grondrechten, pp. 102-103.

216. Memorie van Tcelichting bij wetsvoorstel 13872, Verklaring dat er grond bestaat .... Tweede Kamer, in: Algehele grondwetsherziening, deel Ia Grondrechten, p. 29. 
In verband met het woord "ieder" in artikel 6 kan worden opgemerkt, dat zowel uit de jurisprudentie als uit met name artikel 1 Grondwet voortvloeit, dat de vrijheid van godsdienst en levensovertuiging aan een ieder - ongeacht zijn rechtsverhouding tot de overheid en of het nu individuen of groepen betreft - toekomt.

In een aantal uitspraken wordt de reikwijdte van de vrijheid van godsdienst en levensovertuiging in zijn geheel vastgesteld. ${ }^{217}$ Uit deze uitspraken blijkt het volgende. Uitingen die ongenuanceerd, ongemotiveerd - en tegen beter weten in onjuist en misleidend - gedaan worden, vallen buiten het kader van de vrijheid van godsdienst. Uitlatingen die niet op deze wijze op kennelijke onjuistheden zijn gebaseerd en die een uitdrukking van iemands geloofsovertuiging vormen, vallen binnen het kader van de godsdienstvrijheid, ook wanneer ze in strijd zijn met wat algemeen aanvaard wordt en zelfs wanneer ze pijnlijk zijn voor een bepaalde groep personen. Reden hiervoor is dat men dit soort uitingen in een "hogergeschetste veelvormige democratische samenleving" moet verdragen vanwege deze godsdienstvrijheid.

Voorts blijkt uit de jurisprudentie ${ }^{218}$ dat de vrijheid van godsdienst en levensovertuiging niet alleen met zich brengt, dat men zich van bepaalde uitlatingen of gedragingen heeft te onthouden. Op de betrokkene rust ook een zekere inspanningsverplichting, om de schade die uit de uitoefening van zijn overtuiging voortvloeit te beperken.

In de bovenstaande bespreking kwam ook naar voren dat uit een (niet al te groot) aantal rechterlijke uitspraken blijkt dat de waarborg van de vrijheid van godsdienst niet betekent, dat er voor de overheid geen ruimte overblijft een beleid te voeren, dat in enige mate indruist tegen die vrijheid en zonder dat gebruik gemaakt van de in artikel 6 voorziene beperkingsmogelijkheden. Hetzelfde geldt voor het uitvoeren van voorschriften. ${ }^{219}$ Dit blijkt onder meer uit de overweging van de Voorzitter van de Afdeling Rechtspraak van de Raad van State, dat "het feit dat sprake is van de uitoefening van een grondrecht niet rnet zich [brengt] dat de voorschriften van het bestemmingsplan hun betekenis zouden verliezen. Die voorschriften hebben immers niet tot gevolg, dat

217 Zie de uitspraken genoemd in noot 174.

218 HR 30 maart 1984, AB 1984, 366, met noot F.H. van der Burg: NJ 1985, 350, met noot E.A. Alkema; NJCM-Bulletin 9-3 (1984), pp. 253-258 met noot M.B.W. Biesheuve! (pp. 256-258): CRvB 17 april 1984, RSV 1984, 194: CRvB 17 april 1984, RSV 1984, 195: CRvB 7 augustus 1984, RSV 1985, 28; CRvB 23 april 1985. AB 1986, 37. RSV 1985. 218 en KB 22 oktober 1986. AB 1987, 194; Pres.Rb. Arnhem 24 februari 1989. KG 1989, 114.

219 Bij de meeste zaken gaat het hier om het gebruik van panden voor kerkelijke activiteiten of gebedsdiensten in strijd met het plaatselijke bestemmingsplan. 
kerkelijke activiteiten nergens in hel plangebied zijn toegestaan. "220 Een vergelijkbare formulering heb ik aangetroffen in een beslissing van de Rechtbank-President van 's-Hertogenbosch, namelijk dat de gebruiksbepaling behorende bij een bestemmingsplan geen beperking op de vrijheid van godsdienst en levensovertuiging mag inhouden die gebruik van een pand als gebedsruimte "onmogelijk maakt". ${ }^{21}$ Ten aanzien van dit soort overwegingen heb ik onder meer opgemerkt, dat het lijkt te gaan om algemene beperkingen, aangezien de gebruiksbepaling bij een bestemmingsplan niet een formele wet is als bedoeld in de beperkingsclausule "behoudens ieders verantwoordelijkheid volgens de wet" en niet specifiek gericht is op de beperking van de vrijheid van godsdienst en levensovertuiging maar deze beperking wel tot gevolg heeft. Door middel van redelijke grondwetstoepassing lijkt deze gebruiksbepaling te (kunnen) worden gesauveerd. Ook doet dit soort formuleringen sterk denken aan de hierna bij artikel 7 te behandelen voorwaarde voor beperking van het verspreidingsrecht, dat "gebruik van enige betekenis" van het verspreidingsmiddel moet overblijven.

Uit een andere, soortgelijke uitspraak ${ }^{22}$ blijkt, dat in dit soort zaken veelal een belangenafweging dient plaats te vinden. Enerzijds is er het belang van de autoriteiten bij handhaving van het plaatselijke bestemmingsplan, anderzijds het belang van de betrokken godsdienstige groepering bij het kunnen voldoen aan hun dagelijkse godsdienstige verplichtingen. Bij de beoordeling van een besluit van B en W - waarbij de gebruiker van het pand, onder aanzegging van politiedwang, wordt opgedragen het gebruik van het pand als gebedsruimte te staken - moet worden onderzocht of onmiddellijke effectuering van dit besluit tot direct gevolg heeft "dat deze groep de mogelijkheid wordt ontnomen haar godsdienstige plichten te vervullen". Ook dient de mate van overlast veroorzaakt door het gebruik van het pand als gebedsruimte in aanmerking genomen te worden en dient sprake te zijn van evenredigheid tussen doel (handhaving van het bestemmingsplan) en middel (beperking van de rechten van de godsdienstige groepering).

Andere zaken in verband met het voeren van een beleid dat in enige mate indruist tegen de vrijheid van godsdienst en levensovertuiging betreffen het

220 Vz.ARRS 16 februari 1989. AB 1990, 9 met noot P.J. Boon; tB/S 1989, nr. 20 met noot M.C.B.: AA 1990, pp. $398-402$ met noot P.W.C. Akkermans; De Gemeentestem, no. 6883, nr. 11. pp. 359-360 met naschrift J.M.H.F. Teunissen.

221 Pres.Rb. 's-Hertogenbosch 25 juni 1985. KG 1985, 217.

222 Vz.ARRS 20 juni 1985, KG 1985, 281: RV 1985. 118 met noot Bo. 
toelatingsbeleid voor vreemdelingen voor wat betreft imams. ${ }^{23} \mathrm{Het}$ betreft hier vooral het punt dat ook aan de toelating van imams de eis van een verleende machtiging voor voorlopig verblijf wordt gesteld. De hoofdreden dat deze eis door de rechter wordt aanvaard, is het feit dat het beslissen over de verlening van een machtiging tot voorlopig verblijf - met betrekking tot functionarissen in het godsdienstig en geestelijk leven - in feite de enige mogelijkheid voor de Staat is om zijn bevoegdheden onder de Vreemdelingenwet uit te oefenen. Bovendien is volgens de rechter van belang dat "(g)eenszins is ... gebleken dat imams de toegang tot Nederland zal worden geweigerd." Derhalve wordt - om met de woorden van de Rechtbank-President van 's-Hertogenbosch in bovenstaande zaak van 25 juni 1985 te spreken - de toelating van imams tot Nederland niet "onmogelijk gemaakt".

Mijns inziens is het voeren van een beleid en het handhaven van daarop toepasselijke voorschriften wanneer dat indruist tegen de vrijheid van godsdienst en levensovertuiging slechts in uitzonderingsgevallen aanvaardbaar. Het moet de overheid bij zijn beleid niet te gemakkelijk gemaakt worden grondrechten te ontkrachten alleen met een beroep op zijn beleid. Bij voorkeur dient er dan ook een formele wet aan de basis van dit met het grondrecht strijdige beleid te liggen. Algemene - niet tot een specifieke, formele wetsbepaling te herleiden - beperkingen zullen praktisch gezien niet altijd kunnen worden voorkomen. In elk geval dienen mijns inziens dan wel bij de redelijke grondwetstoepassing, met behulp waarvan de algemene beperking zullen moeten worden gesauveerd (zo niet, dan is sprake van schending van het grondrecht), strenge toetsingseisen dienen te gelden. In de bovenstaande zaak van 20 juni $1985^{224}$ zijn die eisen terug te vinden: een gedegen belangenafweging waarbij een evenredigheidstoetsing plaatsvindt.

\subsubsection{Artikel 7 leden 1 en 3 (eerste zin) Grondwet}

Artikel 7 luidt als volgt:

1. Niemand heeft voorafgaand verlof nodig om door de drukpers gedachten of gevoelens te openbaren, behoudens ieders verantwoordelijkheid volgens de wet.

223 Pres.Rb، 's-Gravenhage 9 februari 1983, KG 1983, 102; ARRS 2 juili 1984, AB 1985, 273 met noot R. Fernhout en J.A. Hofman; RV 1984, 37 met noot C.A. Groenendijk; AA 1985, 488 met noot P.W.C. Akkermans. Men bedenke dat het hier slechts 2 uitspraken betreft.

224 Vz.ARRS 20 juni 1985, KG 1985, 281: RV 1985, 118 met noot Bo. 
2. De wet stelt regels omirent radio en televisie. Er is geen voorafgaand toezicht op de inhoud van een radio- of televisieuitzending.

3. Voor het openbaren van gedachien of gevoelens door andere dan in de voorgaande leden genoemde middelen heeft niemand voorafgaand verlof nodig wegens de inhoud daarvan, behoudens ieders: verantwoordelijkheid volgens de wet. De wet kan het geven van vertoningen toegankelijk voor personen jonger dan zestien jaar regelen ter bescherming van de goede zeden.

4. De voorgaande leden zijn niet van toepassing op het maken van handelsreclame.

Zoals aangegeven in de inleiding van dit hoofdstuk zullen van artikel 7 mel name de leden 1 en 3 (eerste zin) onder de loep genomen worden. Omdan met het huidige artikel 7 lid 1 beoogd is de jurisprudentie van voor de grondwetsherziening in stand te houden, zal eerst aangegeven worden hoe de interpretatie van het in deze bepaling vervatte recht op het moment van de grondwetsherziening luidde. Hierna zal ingegaan worden op de afbakening van lid 3 door de grondwetgever. Daaropvolgend zal worden aangegeven hoe de rechtspraak met betrekking tot de reikwijdte van artikel 7 zal worden behandeld.

\subsubsection{1}

De afbakening van de reikwijdte van artikel 7 lid 1 bij de grondwetsherziening

De naar aanleiding van het oude artikel 7 gevormde jurisprudentie is bewust door de grondwetgever behouden door deze bepaling ongewijzigd op te nemen in het eerste lid van artikel 7 Grondwet 1983. Reden hiervocr is geweest dat de door de Hoge Raad aan dit artikel gegeven betekenis een belangrijke plaats is gaan innemen in de rechtspraktijk. Men achtte het onmogelijk de vele nuanceringen die het artikel in de jurisprudentie had gekregen in een grondwetsartikel weer te geven, en besloot daarom de bepaling ongewijzigd te laten. ${ }^{225}$ Welke is deze betekenis die artikel 7 (oud) - en daarmee artikel 7 Grondwet 1983 - in de rechtspraak heefit gekregen?

Een onderscheid wordt gemaakt tussen een openbarings- of uitingsrecht en een verspreidingsrecht. Het openbaringsrecht betreft de inhoud van het

225 Memorie van Toelichring bij wetsvoorstel 13872, Verklaring dat er grond bestaat ..., Tweede Kamer, in: Algehele grondwetsherziening, deel la Grondrechten, p. 32; Memorie van Anturoord bij hetzelfde wetsvoorstel, Tweede Kamer, idem, pp. 195 196. 
geopenbaarde en mag alleen achteraf beperkt worden op grond van een formele wet. Dit blijkt uit de beperkingsclausule "behoudens ieders verantwoordelijkheid volgens de wet". Naast dit "de geesteswereld betreffende" openbarings- of uitingsrecht, bestaat een verspreidingsrecht dat voor het openbaringsrecht onmisbaar wordt geacht maar wel daaraan ondergeschikt is. Dit in de rechtspraak erkende "recht van een ieder om door verspreiden, openlijk tentoonstellen of door enig ander middel de inhoud van gedrukte of geschreven stukken of afbeeldingen, waarin gedachten of gevoelens zijn geopenbaard, aan het publiek in het openbaar bekend te maken", kan ook door de lagere wetgever - naar tijd, plaats en wijze van verspreiden - beperkt worden. Deze beperkingen mogen echter niet zo ver gaan, "dat het gebruik van een bepaald middel van bekendmaking, dat naast andere middelen zelfstandige betekenis heeft en met het oog op die bekendmaking in een bepaalde behoefte kan voorzien, in het aigemeen zou worden verboden of van een voorafgaand verlof der overheid afhankelijk zou worden gesteld". Voorts moet er aan het verspreidingsmiddel gebruik van enige betekenis worden gelaten. ${ }^{26}$

De zaak waarin voor het eerst een onderscheid werd gemaakt tussen "openbaren" en "verspreiden" dateert van 7 november 1892. ${ }^{27}$ De bespreking van dit arrest van de Hoge Raad - inclusief zijn voorgeschiedenis en de commentaren erop-door de Winter in zijn dissertatie $^{22 s}$ doet vermoeden dat aanvankelijk de opvatting bestond dat onder de vrijheid van drukpers alleen het openbarings of -uitingsrecht begrepen werd. Zo zou de fixatie toentertijd op de bescherming van de "openbare orde" - in het licht waarvan allerlei (wettelijke) maatregelen ter regulering van de verspreiding van drukwerken tot stand konden worden gebracht - geen ruimte hebben geboden voor een verspreidingsrecht. Waarom de Hoge Raad in 1892 tot een ander standpunt overging is niet helemaal duidelijk $\mathrm{k}^{229}$ en wil ik hier in het midden laten. Van belang is. dat waarschijnlijk een recht in een grondwetsbepaling wordt gelezen, dat

226 Citaten uit zaken van vlak voor en na de grondwetswijziging: HR 2 maart 1982. NJ 1984, 133 met noot $J A B$ onder HR 5 april 1983, NJ 1984, 134 en HR 28 juni 1983, NJ 1984, 64. Zie ook de Memorie van Antwoord bij wetsvoorstel 13872, Verklaring dat er grond bestaat .... Tweede Kamer, in: Algehele grondwetsherziening, deel la Grondrechten, p. 196.

227 HR 7 november 1892, Weekblad van het Recht nr. 6259.

228 R.E. de Winter, De heersende leer. Honderd jaar verspreidingsjurisprudentie: 1892. 1992, dissertatie Maastricht 1993. Sdu: 1993. Hier is met name hoofdstuk 1 relevant.

229 Althans volgens R.E. de Winter, De heersende leer, hoofdstuk 1. Omdat ik zijn onderzoek niet nog eens over wil doen, verlaat ik mij hierbij op de bevindingen van de Winter. 
darin niet expliciet is geformuleerd en bovendien vermoedelijk niet door de toenmalige grondwetgever was beoogd. Duidde de uitspraak van 1892 erop, dat het in artikel 7 geformuleerde recht mede het verspreidingsrecht bestrijkt, sinds een arrest van 28 november 1950 is de hierboven geciteerde en in de Memorie van Toelichting overgenomen overweging geformuleerd, dat naast het in artikel 7 neergelegde, "de geesteswereld betreffende recht tevens, als tot het met dat recht beoogde doel onmisbaar doch aan dat recht ondergeschikt" het bestaan van een verspreidingsrecht door de rechter wordt aangenomen. In de literatuur is wel de discussie gevoerd of artikel 7 nu wel of niet het verspreidingsrecht "omvat". Brenninkmeijer lijkt uit het zojuist aangehaalde citaat - onder verwijzing naar Donner en Boukema - de conclusie te willen trekken dat het verspreidingsrecht niet (meer) rechtstreeks onder artikel 7 valt. Argument hiervoor zou zijn dat het verspreiden niet onder openbaren in artikel 7 zou vallen, "omdat anders beperkingen door de lagere wetgever uitgesloten zouden zijn". ${ }^{200}$ Hoewel het juist is, dat indien het verspreidingsrecht door het openbaringsrecht bestreken wordt beperkingen door de lagere wetgever onmogelijk zouden zijn, vloeit mijns inziens hieruit slechts voort dat het verspreidingsrecht niet "rechtstreeks" - in de zin van "letterlijk" onder artikel 7 valt, het valt er naar mijn mening wel "niet-rechtstreeks" onder. De formulering ".. als tot het met dat recht beoogde doel onmisbaar" lijkt mij erop te duiden dat het hier gaat om een van het openbaringsrecht te onderscheiden doch daaraan inherent recht. De termen "doch aan dat recht ondergeschikt" zouden dan kunnen betekenen dat het verspreidingsrecht in mindere mate beschermo wordt dan het openbaringsrecht. ${ }^{231}$ Mijns inziens gaat dan ook de conclusie te ver, dat in het arrest van 1950 het verspreidingsrecht van het openbaringsrecht is lósgekoppeld. ${ }^{232}$ Zou deze conclusie kloppen, dan zou er geen aanknopingspunt meer zijn voor de bescherming van het verspreidingsrecht onder artikel 7 en die is er blijkens de latere jurisprudentie duidelijk wel. Het verspreidingsrecht valt wel - alleen impliciet - onder artikel 7, maar wordt - zoals gezegd - in mindere mate door dat artikel 7 beschermd dan

230 A.F.M. Brenninkmeijer, Van drukpersvrijheid tot informatievrijheid, p. 180. Verwezen wordt naar A.M. Donner. Handboek van het Nederlandse staatsrecht, Zwolle 1977 , p. 480 en P.J. Boukema, Enkele aspecten van de vrijheid van meningsuiting in de Duitse Bondsrepubliek en in Nederland, Amsterdam 1966, p. 116 e.v..

231 Vgl. R.E. de Winter, De heersende leer, p. 111. Zie ook R.E. de Winter, idem, pp. 109-111. 113!, 138-141.

232 O.a. F.H. Kistenkas, Vrije straatcommunicatie, p. 13. Zo ook de door Kistenkas aangehaalde literatuur op pp. 28-29. Zie ook J.M. De Meij. Uitingsvrijheid, p. 102. 
het expliciet in die bepaling geformuleerde openbaringsrecht.$^{233}$ Overigens moet nog worden opgemerkt dat de beperkingen op het impliciete verspreidingsrecht per definitie ook impliciet zijn. De beperkingen op het verspreidingsrecht - hoe kan het ook anders - staan immers niet in artike] 7 geformuleerd.

Een vergelijking dringt zich hier op met het eerder behandelde recht op toegang tot de rechter in verband met artikel 6 lid 1 ECRM. Daarbij gaat het om een aan het expliciet in die bepaling geformuleerde recht op een "fair trial", waaraan het recht op toegang tot de rechter inherent is. Ook het recht op toegang tot de rechter kan aan impliciete beperkingen onderworpen worden. ${ }^{234}$

Samenvattend kan dan ook worden geconcludeerd dat vergelijkbaar met de jurisprudentie ten aanzien van artikel 6 ECRM - waaruit blijkt dat de reikwijdte van het recht op een "fair trial" afhangt van de reikwijdte van het aan dat recht inherente recht op toegang tot de rechter inclusief de (impliciete) beperkingen daarop ${ }^{235}$ - de rechtspraak sinds 1892 blijkt uit te gaan van een aan de drukpersvrijheid inherent - doch naar men vermoedt oorspronkelijk niet beoogd - recht op verspreiding. De reikwijdte van de vrijheid van drukpers hangt dan ook af van zowel de afbakening van het openbaringsrecht als van het verspreidingsrecht inclusief de daarop aangebrachte (impliciete) beperkingen.

233 Vgl. de discussie omtrent kernrechten en connexe rechten: het openbaringsrecht is het kernrecht, het verspreidingsrecht is het connexe recht. Anders dan Burkens beweert, geniet het connexe verspreidingsrecht mijns inziens wel bescherming van artikel 7. Zie M.C. Burkens, Beperking van grondrechten, pp. 30-32 en hiervoor paragraaf 3.2 .2 , pp. 152-153. De (eventueel preventieve) beperkingen op het verspreidingsrecht, die hierna nog aan de orde zullen komen, zijn - anders dan Burkens of Brenninkmeijer beweren - geen algemene beperkingen omdat ze specifiek op de beperking van het verspreidingsrecht gericht zijn en dus nít omdat het verspreidingsrecht niet grondwettelijk gepositiveerd is maar sprake is van rechtersrecht. Voor het algemene karakter van een beperking maakt het mijns inziens niet uit of het grondrecht waarop de beperking is gericht, grondwettelijk is gepositiveerd of niet. Zie Brenninkmeijer, Van drukpersvrijheid tot informatievrijheid, p. 180. 


\subsubsection{De reikwijdte van artikel 7 lid 3 volgens de grondwetgever}

Artikel 7 lid 3 is nieuw, voor 1983 stond het niet in de Grondwet. Zoals eerder is aangegeven, zal in dit onderzoek alleen gekeken worden naar de eerste zin van lid 3.

Het onderscheid tussen openbaren en verspreiden acht de grondwetgever niet voor elke uitingsvorm bruikbaar. Soms zal het openbaren en verspreiden van gedachten of gevoelens te zeer samenvallen en is het onderscheid niet reëel te noemen. De grondwetgever noemt als voorbeeld het spreken in het openbaar. De oplossing die de grondwetgever biedt is, in plaats van het onderscheid tussen openbaren en verspreiden, het onderscheid tussen de inhoud van het geopenbaarde en de vorm waarin de openbaring plaatsvindt. Zo is ten aanzien van de inhoud van het geopenbaarde geen preventieve censuur toegestaan, maar mag wel repressief opgetreden worden; in dat geval moet een rechtsgang naar de rechter openstaan. Dit is vergelijkbaar met de beperkingsmogelijkheid op het openbaringsrecht in lid $10^{236}$ In het Nader rapport merkt de regering op, dat het derde lid de mogeiijkheid tot het stellen van niet de inhoud betreffende voorschriften door de materiële wetgever omtrent bijvoorbeeld plaats, tijdstip en wijze van openbaarmaking, onverlet laat. Hieraan voegt de regering toe, dat "(v)anzelfsprekend ... door deze voorschriften het feitelijke functioneren van het recht niet volledig onmogelijk mag worden gemaakt." De regering geeft hierbij een toelichting die erop neerkomt dat zich ten aanzien van lid 3 een zelfde ontwikkeling kan voordoen als bij lid 1 , namelijk dat beperkingen ten aanzien van plaats, tijdstip en wijze van openbaarmaking - die niet de inhoud betreffen - niet zover mogen gaan "dat aan een middel van openbaarmaking, dat naast andere middelen zelfstandige betekenis heeft en met het oog op de openbaarmaking in een bepaalde behoefte kan voorzien, redelijkerwijze geen gebruik van enige betekenis wordt gelaten. ${ }^{237}$

Memorie van Toelichting bij wetsvoorstel 13872 , Verklaring dat er grond bestaat ..., Tweede Kamer, in: Algehele grondwetsherziening, deel Ia Grondrechten, pp. 35-36. 237 Nader rapport bij wetsvoorstel 13872, Verklaring dat er grond bestaat .... Tweede Kamer, in: Algehele grondwetsherziening, deel la Grondrechten, p. 91. 
Behandelplan ten aanzien van de rechtspraak met betrekking tot de reikwijdte van artikel 7 lid 1 en lid 3 eerste $z$ in

Op de vaststelling van de reikwijdte van de vrijheid van drukpers door de rechter zal in het navo!gende worden ingegaan. Hierbij zal zoveel mogelijk uitgegaan worden van de jurisprudentie van ná de inwerkingtreding van de herziene Grondwet in 1983. De volgende aspecten van de reikwijdte van artikel 7 leden 1 en 3 zullen worden besproken:

* Allereerst dient voor de toepasselijkheid van artikel 7 te worden vastgesteld wat moet worden verstaan onder gedachten en gevoelens;

* Omdat het openbarings- of uitingsrecht, het de inhoud betreffende recht in artikel 7 lid 1, slechts repressief beperkt mag worden is het van belang vast te stellen tot waar dit recht reikt. Wanneer is nog sprake van het openbaren van gedachten en gevoelens en wanneer spreekt men reeds van verspreiden?

* In lid 3 (eerste zin) gaat het om een onderscheid tussen de inhoud van het geopenbaarde en de vorm waarin dit geschiedt. De vraag is nu waar de grens tussen beide ligt. Hiertoe zal onderzocht dienen te worden wat moet worden verstaan onder de "inhoud" van te openbaren gedachten of gevoelens.

* Vanwege de opvatting in de rechtspraak dat beperkingen op het verspreidingsrecht niet zo ver mogen gaan, "dat het gebruik van een bepaald middel van bekendmaking, dat naast andere middelen zelfstandige betekenis heeft en met het oog op die bekendmaking in een bepaalde behoefte kan voorzien, in het algemeen zou worden verboden of van een voorafgaand verlof der overheid afhankelijk zou worden gesteld" kan men zich afvragen:

- wat moet worden verstaan onder een zelfstandig middel van. bekendmaking (dat met het oog op die bekendmaking in een bepaalde behoefte kan voorzien);

- wanneer men kan stellen dat een middel in het algemeen wordt verboden of

- van een voorafgaand verlof van de overheid afhankelijk wordt gesteld en - wanneer is nog sprake van gebruik van enige betekenis?

Omdat de reikwijdte-afbakening door de grondwetgever van lid 3, afgezien van het onderscheid tussen openbaren en verspreiden, ongeveer gelijkluidend is, dienen deze vragen ook beantwoord te worden voor een onderzoek naar de rechterlijke interpretatie van lid 3 . 
Voordat op deze punten ingegaan zal worden, nog een opmerking vooraf. In artikel 7 leden 1 en 3 staat dat "niemand" voorafgaand verlof nodig heeft voor het openbaren van gedachten en gevoelens via de daar bedoelde verspreidingsmiddelen. Dit impliceert dat de in deze leden gegarandeerde rechten aan iedereen toekomen. Deze opvatting is in overeenstemming met het in artikel 1 vervatte gelijkheidsbeginsel en het daarin eveneens opgenomen discriminatieverbod. Ook stemt dit uitgangspunt, dat de vrijheid van meningsuiting aan een ieder toekomt, overeen met het bij de grondwetsherziening ingenomen standpunt, "dat de grondwettelijke grondrechten voor een ieder gelden, ongeacht zijn verhouding tot de overheid ...". Personen in een bijzondere rechtsverhouding (zoals ambtenaren, militairen en gedetineerden) kunnen zich derhalve ook op artikel 7 beroepen. ${ }^{2 s}$ Dat wil echter niet zeggen dat de uitoefening van de vrijheid van meningsuiting voor een ieder dezelfde betekenis heeft. Zo zal er op personen in bepaalde functies een zwaardere verantwoordingsplicht rusten ten aanzien van door hen gedane uitingen; men denke hierbij aan ambtenaren, militairen en journalisten. Dit is echter een beperkings-kwestie: de verantwoording zal achteraf moeten geschieden. ${ }^{239}$ Ook zullen gedetineerden niet altijd in dezelfde mate hun vrijheid van meningsuiting kunnen uitoefenen gezien de beperkingsmogelijkheid die gelegen is in artikel 15 lid 4 Grondwet. ${ }^{240} \mathrm{Op}$ de beperking van dit recht zal niet verder worden ingegaan, orndat het hier gaat om de reikwijdte van het in artikel 7 vervatte recht. Daarover gaat het navolgende.

\subsubsection{Gedachten en gevoelens}

In het Nader rapport wordt door de regering verwezen naar het Advies van de Raad van State wanneer ingegaan wordt op de betekenis van de termen "gedachten of gevoelens". De Raad merkt in dat advies op dat onder het begrip gevoelens twee dingen begrepen kunnen worden: "mening" en "gemoedsbeweging". Het feit dat een bepaling spreekt over "gevoelens" kan volgens de Raad bovendien betekenen dat deze bepaling een ruimere

238 Memorie van Toelichting bij wetsvoorstel 13872. Verklaring dat er grond bestaat ..., Tweede Kamer, in: Algehele grondwetsherziening, deel La Grondrechten, p. 11.

239 Zie bijvoorbeeld CRvB 5 juni 1986, TAR 1986, 209; Rb. Alkmaar 25 november 1993, TAR 1994, 50 (ambtenaren) en Gerechtshof Amsterdam 3 december 1992 (r.o. 4.3), in: HR 21 januari 1994, NJ 1994, 473 (cassatieberoep verworpen) met noot DWFV (pers) en de in noot 323 aangehaalde jurisprudentie.

240 Zie uitgebreider ten aanzien van dit onderwerp J.M. de Meij, Uitingsvrijheid, pp. 51 69. Zie ook $S$. Zwemstra, Bescherming van uitingsrechten door administratieve rechters, pp. 175-372 (met name pp. 177-214). 
betekenis heeft dan een bepaling waarin alleen de vrijheid van meningsuiting wordt gegarandeerd. Zo kunnen andere dan verbale uitingen, zoals muziek, onder het begrip "gevoelens" gebracht worden. De Raad wijst er voorts op dat "niet slechts opinies, maar ook gemoedsbewegingen te uiten door symbolische handelingen, het openbaren van gedachten of gevoelens tot iets maakt, dat zich in velerlei vormen van gedraging voordoet." De regering stemt op dit punt met de Raad van State in. ${ }^{241}$

Met betrekking tot het geven van inlichtingen stelt de regering in de Memorie van Antwoord het volgende vast. De vrije stroom van informatie vormt een wezenlijk onderdeel van de vrijheid van drukpers. Deze vrijheid zou niet naar behoren kunnen functioneren wanneer het doorgeven van informatie buiten de reikwijdte van deze vrijheid zou vallen. Als voorbeeld van een gevolg hiervan noemt de regering dat een groot deel van een krant - namelijk dat deel waarin alleen informatie of inlichtingen worden verschaft en geen commentaren of opinies staan - de bescherming van artikel 7 zou moeten ontberen. Volgens de regering kan dat de bedoeling niet zijn en zij meent dan ook dat "het enkele feit, dat het openbaren van gedachten in het geven van inlichtingen bestaat, niet tot gevolg kan hebben dat artikel 7 Grondwet of het voorgestelde artikel 1.7 niet van toepassing zou zijn." De regering wijst echter wel op de mogelijkheid dat het geven van inlichtingen zo buiten de sfeer van artikel 7 gelegen is, dat het oneigenlijk zou zijn als dat artikel toch zou worden toegepast. Een voorbeeld hiervan is volgens de regering het verschaffen van informatie over de samenstelling van een produkt op de verpakking ervan. De regering geeft hierbij toe dat hier in principe een afbakeningsvraag speelt, maar door de werking van artikel 7 lid 4 meent zij dat deze vraag weinig moeilijkheden zal opleveren. ${ }^{22}$ In dit artikel 7 lid 4 staat dat de voorgaande leden niet van toepassing zijn op handelsreclame. Handelsreclame, ook voor zover daarbij gedachten of gevoelens worden

241 Advies van de Raad van State bij wetsvoorstel 13872, Verklaring dat er grond bestaat .... Tweede Kamer, in: Algehele grondwetsherziening. deel Ia Grondrechten. p. 65: Nader rapport bij wetsvoorstel 13872. idem, n. 90. Vgl. Pres, Rh. Groningen 26 mei 1994, KG 1994, 320, waarin - onder meer - wordt overwogen dat "met de vrijheid van meningsuiting een groot openbaar belang is gemoeid. De grenzen die zijn verbonden met deze vrijheid mogen niet te nauw getrokken worden. In principe moet men vrij zijn om gevoelens, gedachten en meningen te openbaren, ook als deze anderen ergeren of kwaadmaken. Dit klemt nog meer, wanneer het - zoals in dit geval - een literair werk betreft. De grenzen moeten dan nog ruimer zijn."

242 Memorie van Antwoord bij wetsvoorstel 13872. Verklaring dat er grond bestaat .... Tweede Kamer, in: Algehele grondwetsherziening, deel Ia Grondrechten, p. 194. Zie hieromtrent ook J.M. de Meij, Uitingsvrijheid, p. 98. 
geopenbaard, geniet niet de bescherming van artikel 7 leden 1 tot en met 3 en kan derhalve in het algemeen worden verboden of aan voorafgaand verlof worden gebonden, ook wegens de inhoud van de uiting. Dit betekent niet dat censuur geoorloofd is indien die censuur op het bij voorbaat afdwingen van een verbod op handelsreclame gericht is. Immers, in dergelijke gevallen zouden dan bijvoorbeeld uitingen die onder artikel 7 leden 1 tot en met 3 vallen toch van tevoren (inhoudelijk) gescreend kunnen worden op reclameboodschappen, wat deze leden nu juist verbieden. ${ }^{243}$

Wat moet worden verstaan onder handelsreclame? In de kamerstukken wordt een onderscheid gemaakt tussen enerzijds reclame voor commerciële doeleinden "in de ruime zin des woords", dat "elk aanbod van goederen en diensten omvat" en anderzijds propaganda voor ideële doeleinden. Alleen de eerste vorm van reclame valt volgens de regering onder "handelsreclame", maar toegegeven wordt dat de grens tussen beide niet scherp is. Aan de hand van de casuïstiek zou in de wetgeving en rechtspraak een scherpe lijn getrokken moeten worden. ${ }^{24}$ De rechtspraak die naderhand tot stand gekomen is, is echter allerminst duidelijk. In een uitspraak van 8 april 1988 (APV Bunschoten) maakt de Afdeling rechtspraak onderscheid tussen aan de ene kant reclame, waarin gedachten of gevoelens zijn geopenbaard, en aan de andere kant, reclame in de zin van artikel 7 lid $4 .^{245}$ Dit zou impliceren dat in handelsreclame nimmer gedachten en gevoelens worden geopenbaard. Een dergelijke opvatting wijkt af van de opvatting van de regering in het Nader rapport: "Naar onze mening zal niet licht door interpretatie van de term "openbaren van gedachten of gevoelens" een algehele uitzondering op die term voor commerciële reclameboodschappen, waarin gedachten of gevoelens kunnen zijn geopenbaard, tot stand worden gebracht". Om deze reden acht de regering de opname van het vierde lid in artikel 7 noodzakelijk. ${ }^{246}$ De regering was blijkens voorgaand citaat van opvatting dat in handelsreclame wèl gedachten en gevoelens kunnen zijn geopenbaard. Deze mening van de regering zou men ook kunnen lezen in de uitspraak van de Afdeling

243 HR 11 december 1987, NJ 1990, 73: NJCM-Bulletin 13-1 (1988), p. 121 (t.a.v. lid 2: voorafgaand toezicht op ondertitelde buitenlandse (v-programma's).

244 Memorie van Toelichting bij wetsvoorstel 13872, Verklaring dat er grond bestaat...., Tweede Kamer, in: Algehele grondwetsherziening, deel la Grondrechten, p. 38.

245 ARRS 8 april 1988, AB 1988, 357 met noot van J.H.vdV.; zie ook ARRS 10 april 1986, Weekoverzicht RvS/R.3.314/86, tB/S $1986 \mathrm{nr} .73$.

246 Nader rapport bij wetsvoorstel 13872, Verklaring dat er grond bestaat .... Tweede Kamer, in: Algehele grondwetsherziening, deel la Grondrechten, p. 94. Zie ook B.P. Vermeulen en J.J.A. Pelle, Artikel 7 Grondwet, pp. 151-152 en 189-190. Anders: F.H. Kistenkas, Vrije straatcommunicatie, p. 17. 
rechtspraak van 24 juni $1991 .^{247}$ Daarin wordt (eerst) vastgesteld dat het in het geding zijnde uithangbord "dient tot het openbaren van gedachten en gevoelens, als bedoeld in artikel 7 Grondwet en [vervolgens dat het ${ }^{20}$ ] niet betreft het maken van handelsreclame als bedoeld in het vierde lid van dat artikel. Deze opvatting licht de Afdeling niet toe. Waarom er in dit geval sprake is van de openbaring van "gedachten en gevoelens" en niet van "handelsreclame" wordt uit deze uitspraak derhalve niet duidelijk. ${ }^{29}$ Ook ten aanzien van het onderscheid tussen ideële reclame en reclame voor commerciële doeleinden, waarbij de laatste soort reclame onder handelsreclame begrepen zou moeten worden, brengt de jurisprudentie geen duidelijkheid. Er zijn mij geen uitspraken bekend waarin door de desbetreffende rechterlijke instantie beargumenteerd wordt waarom een bepaalde vorm van reclame wel of niet door artikel 7 lid 4 bestreken wordt. ${ }^{250}$

Al met al biedt artikel 7 lid 4, anders dan in de Memorie van Antwoord bij het wetsvoorstel inzake de grondwetsherziening wordt gesuggereerd, geen oplossing voor de afbakeningsvraag of een uiting - bestaande in het geven van al dan niet wervende informatie - nu wel de openbaring van gedachten of gevoelens behelst of niet. Ook in gevallen waarin de vraag of sprake is van handelsreclame niet speelt, is nog niet veel duidelijkheid geschapen over de betekenis van de termen "gedachten of gevoelens". Uit een KB van 5 juni 1986 blijkt dat vloeken daar in beginsel wel onder valt. Een vloekverbod in de gemeente Ermelo werd om die reden vernietigd wegens strijd met artikel 7 lid 3. ${ }^{251}$ Blijkens de Nota van toelichting op dit $\mathrm{KB}$ moest men tot een oordeel over de vraag of sprake is van het

247 ARRS 24 juni 1991 (APS Arnhem), AB 1992, 26 met noot P.J. Boon; De Gemeentestem no. 6930, nr. 3 met noot E. Brederveld.

248 Toevoeging door mij. $C S$.

249 Onterecht concludeert Boon mijns inziens, dat men de desbetreffende overweging nauwelijks anders kan lezen dan dat het uithangbord geen handelsreclame bevat "en ... dus (dient) tot het openbaren van gedachten of gevoelens als bedoeld in artikel 7 Grondwet." Annotatie bij ARRS 24 juni 1991, AB 1992, 26. Ook de. Winter wijst de conclusie van Boon af: R.E. de Winter, De heersende leer, pp. 255-266. Zie verder Vz.ARRS 3 november 1987 (Zandvoort), De Gemeentestem no. 6855, nr. 5 met noot $E$. Brederveld.

250 De in de noten 245 en 247 genoemde uitspraken gaan wel over reclame, maar waarom geen sprake is van "handelsreclame" wordt niet gemotiveerd. In Vz.A.RRS 3 november 1987, De Gemeentestem no. 6855, nr. 5 komt de Voorzitter zelfs niet aan die vraag toe.

251 KB 5 juni 1986, Stb. 337, AB 1986, 569 met noot B.J. van der Net. Zo ook KB 29 mei 1987, Stb. 365 (vloekverbod) en HR 10 november 1992, NJ 1993, 197 (verbod tot het in het openbaar iemand uitjouwen, naschreeuwen of met aanstootgevende taal lastig vallen). Vergelijk ook HR 9 februari 1993, NJ 1993, 646 (uitjouw-verbod). 
"openbaren van gedachten of gevoelens" komen via een "welhaast" grammaticale uitleg van dit begrip, waarbij de intenties of motieven van degene die zich uit geen rol spelen. Met de Winter kan worden ingestemd, wanneer hij opmerkt dat deze overweging niet duidelijk is. Bovendien geeft de Kroon hiermee aan welke interpretatiemethode moet worden gehanteerd en niet een criterium ter onderscheiding van gevallen die wel en gevallen die niet als "gedachten of gevoelens" kunnen worden aangemerkt. ${ }^{252}$

Concluderend kan worden gesteld, dat bij de grondwetsherziening de volgende aanzetten voor de reikwijdte-afbakening van het begrip "gedachten of gevoelens" zijn gegeven: "gevoelens" bestrijkt zowel "mening" als "gemoedsbeweging", de openbaring van "gedachten of gevoelens" kan zowel verbaal ais non-verbaal en kan, behoudens waar dat een oneigenlijke toepassing van artikel 7 teweeg zou brengen, het geven van inlichtingen betreffen. Dat - in het geval een bepaalde uiting zou leiden tot een oneigenlijke toepassing van artikel 7 - lid 4 moeilijkheden bij de afbakeningsvraag zou voorkomen, blijkt in de rechtspraktijk niet. Lid 4 filtert er niet nog eens gevallen uit die geen "gedachten of gevoelens" betreffen omdat bij handelsreclame kennelijk ook gedachten of gevoelens kunnen worden geopenbaard. Dit blijkt althans uit de kamerstukken ten aanzien van de artikel 7 en kan eventueel ook worden afgeleid uit een - in dit opzicht niet gemotiveerde - uitspraak van de Afdeling rechtspraak van 24 juni $1991^{253}$. Welke vormen van "openbaren van gedachten of gevoelens" verder bescherming van artikel 7 leden 1 tot en met 3 genieten is ook niet duidelijk. Handelsreclame wordt daarvan in lid 4 uitgesloten, maar de precieze betekenis van die term staat ook niet vast. Het zou moeten gaan om reclame voor commerciële doeleinden ter onderscheiding van ideële reclame, maar de grens tussen beide blijkt niet scherp te zijn. Dok overigens - dat wil zeggen buiten de gevallen van reclame - biedt de rechtspraak geen handvat(ten) voor de afbakening van het begrip "gedachten of gevoelens".

252 VgI. R.E. de Winter, De heersende leer, pp. 251-252 e.v.. Zie voorts HR 23 juni 1992. (wenskaarten), De Gemeentestem no. 6961, nr. 4; NJB, afl. 31 (1992), rechtspraak Hoge Raad (strafkamer), nr. 127 en daarover $R$.E. de Winter, idem, pp. 257-258.

253 ARRS 24 juni 1991, zie noot 247. 
De grens tussen het openbaringsrecht en het verspreidingsrecht in artikel 7 lid 1

Zoals aan het begin van paragraaf 6.2.2.1 werd vermeld, ziet het openbaringsrecht op de inhoud van de geopenbaarde gedachten of gevoelens; het betreft de "geesteswereld". Het verspreidingsrecht is het recht om die inhoud aan het publiek in het openbaar bekend te maken door het verspreiden, openlijk tentoonstellen en dergelijke van gedrukte of geschreven stukken of afbeeldingen. Het openbaringsrecht mag slechts repressief door de formele wetgever worden beperkt, terwijl het verspreidingsrecht - anders dan met betrekking tot de inhoud - ook preventief door de materiële wetgever aan beperkingen kan worden onderworpen, zolang het gebruik van een zelfstandig middel van bekendmaking niet in het algemeen wordt verboden of van voorafgaand verlof afhankelijk wordt gesteld. Daarom is het van belang vast te stellen wanneer nog sprake is van het "openbaren" van gedachten of gevoelens en wanneer van verspreiden moet worden gesproken.

Veel jurisprudentie die een licht op deze vraag zou kunnen werpen, heb ik niet aangetroffen. In een uitspraak van 13 september 1984 van het Gerechtshof Amsterdam gaat om een concept-nota van het Wetenschappelijk Bureau Centrumpartij waarvan de inhoud - die onrechtmatig wordt geacht - in de openbaarheid is gebracht door een aanvankelijk tot die beperkte kring behorend, maar naderhand daaruit getreden persoon. ${ }^{254}$ De strekking van de vordering (in kort geding) is dat wordt voorkomen dat de inhoud van bedoelde concept-nota (verder) in de openbaarheid wordt gebracht. Het Gerechtshof bepaalt dat "het ontwikkelen, koesteren en voor niet openbaar gebruik vastleggen van gedachten en gevoelens van welke inhoud dan ook" vrij is. Om dezelfde reden zou het verspreiden van het drukwerk waarin die inhoud is vastgelegd binnen een beperkte kring van personen ook vrij zijn. Echter. de vrijheid van meningsuiting, aldus het Gerechtshof, "sluit preventief optreden tegen een nog te verwachten publikatie van een wat de inhoud betreft met de wet strijdig geschrift door middel van een in k.g. te treffen voorlopige maatregel niet uit". Volgens het hof is er geen goede reden om het verbod voor de toekomst (op grond van artikel 1401 oud-BW) "beperkt te achten tot de gevallen, dat onrechtmatige publikatie reeds heeft plaatsgevonden." Een mogelijk slachtoffer van een dergelijke publikatie hoeft niet passief af te wachten totdat tot de publikatie wordt overgegaan. Toch is voor een dergelijke maatregel in dit geval geen grond, aldus hel 
Gerechtshof, nu niet aannemelijk is dat zal worden overgegaan tot publikatie van het concept-rapport zoals het thans luidt. Volgens verweerder is geen enkele stap ondernomen om tot publikatie over te gaan en verdere verspreiding wordt niet overwogen.

Uit deze uitspraak zou men kunnen afleiden, dat het ontwikkelen, koesteren en voor niet openbaar gebruik vastleggen van gedachten en gevoelens van welke inhoud dan ook, evenals het verspreiden van het gedrukte of geschreven stuk waarin die inhoud is vastgelegd binnen een beperkte kring van personen, niet beperkt kan worden, ook niet repressief. Deze gevallen dienen dan in elk geval nog onder het openbaringsrecht te vallen. Omdat het openbaringsrecht hooguit repressief beperkt mag worden, lijkt de overweging - dat preventief optreden tegen een te verwachten publikatie van een geschrift met een onrechtmatig geachte inhoud, niet is uitgesloten - erop te duiden, dat we in dat geval al ten aanzien van het openbaringsrecht spreken van een repressief optreden. De maatregel zou in die zin genomen worden nádat de inhoud van gedachten of gevoelens in het drukwerk zijn geopenbaard, maar vóórdat het drukwerk wordt verspreid. Alleen ten aanzien van het verspreidingsrecht is de maatregel dan preventief. Over het algemeen zal dit alleen mogelijk zijn indien het moment waarop de inhoud van gedachten of gevoelens wordt geopenbaard en het moment waarop die inhoud in een gedrukt of geschreven stuk wordt verspreid, te onderscheiden zijn en de inhoud van het geopenbaarde voor die tijd bekend is geworden. Die situatie zal zich vermoedelijk niet al te vaak voor doen. Preventieve controle op de verspreiding van stukken vanwege de inhoud daarvan, is immers niet toegestaan. In dit geval was het echter (vermoedelijk) mogelijk omdat de inhoud van het desbetreffende stuk reeds door anderen dan verweerders openbaar was gemaakt.

De uitspraken van de Hoge Raad van 17 november 1987 en 18 september 1989 met betrekking tot het Weekblad Bluf! lijken deze interpretatie te bevestigen. ${ }^{\text {2s }}$ In de eerste zaak beklaagt het Weekblad Bluf! zich over de inbeslagneming van een nog niet verspreide oplage van dit blad, de tweede zaak betreft het beroep tegen de toewijzing van de vordering van de Officier van Justitie tot onttrekking aan het verkeer van deze oplage. In deze oplage zouden gegevens worden gepubliceerd waarvan geheimhouding in de zin van artikel 98 e.v. $\mathrm{Sr}$ is geboden, te weten een kwartaaloverzicht van de BVD. Het Weekblad Bluf! was zelf geen verdachte van overtreding van deze artikelen uit het Wetboek van

255 HR 17 november 1987, NJ 1988. 394 met noot Th. W. van Veen; HR 18 september 1989. NJ 1990, 94 eveneens met noot Th.W. van Veen, NJCM-Bulletin 15-3 (1990), pp. $291-298$ met noot R.E. de Winter. 
Strafrecht. Desondanks worden zowel de inbeslagneming als de onttrekking aan het verkeer door de Hoge Raad beschouwd als middelen waarmee de door de artikelen 98 en 98a $\mathrm{Sr}$ te beschermen belangen kunnen worden veiliggesteld. De artikelen 98 en 98 a $\mathrm{Sr}$ bevatten volgens de uitspraak van de Hoge Raad van 1989 wettelijke voorschriften als bedoeld in artikel 7 leden 1 en 3 Grondwet ("behoudens ieders verantwoordelijkheid volgens de wet") en de toepassing van de middelen inbeslagneming en onttrekking aan het verkeer "kan niet worden gelijkgesteld met het onderwerpen aan de voorwaarde van "voorafgaand verlof"... ook al wordt als gevolg daarvan het desbetreffende drukwerk met de daarin neergelegde gedachten en gevoelens niet openbaar". ${ }^{256}$ In beide zaken wordt dan ook geen strijd met artikel 7 aanwezig geacht.

Ook in deze zaken gaat het om maatregelen die worden genomen voordat het gedrukte stuk kan worden verspreid en wel om inhoudelijke redenen. De verwijzing naar de beperkingsclausule in artikel 7 leden 1 en 3 duidt er mijns inziens op, dat de bestreden maatregelen worden gezien als een vorm van repressief toezicht op de openbaring van de inhoud van gedachten of gevoelens en niet als (preventieve) censuur. ${ }^{257}$ Dit impliceert dat op het moment dat de maatregelen worden genomen de openbaring van die inhoud reeds heeft plaatsgevonden. In dit geval waren de stukken wel al gedrukt en klaargemaakt voor verspreiding (bij een deel van de exemplaren zaten de verzendwikkels met de adressen van de abonnees er al omheen), maar nog niet verspreid. Kennelijk ligt de grens tussen openbaren en verspreiden tussen het moment waarop de inhoud van gedachten of gevoelens in een gedrukt of geschreven stuk is vastgelegd (dat wil zeggen nadat het is gedrukt of geschreven) en voordat het wordt verspreid. ${ }^{238}$

256 HR 18 september 1989, NJ 1990, 94. De overwegingen van de HR in het arrest van 1987 zijn nogal summier, maar afgezien van de laatstgeciteerde overweging. komt deze uitspraak op hetzelfde neer. Zie in deze zaak voorts EHRM 9 februari 1995 , Case of Vereniging Weekblad Bluf:, waarin het Hof een schending van artikel 10 ECRM vaststelde.

257 Vgl. de annotatie van van Veen: "Van preventieve censuur is geen sprake bij de inbeslagneming en onttrekking aan het verkeer van reeds gedrukte stukken, die gereed zijn voor verspreiding en waarvan het voorradig hebben om de inhoud van die stukken strafhaar is." Zie noot 255, punt 2. Zie ook P.J. Boon. Zonder voorafgaand verlof, p. $62 ; J . M$. de Meij, Uitingsvrijheid, p. 89 en R.E. de Winter in zijn annotatie, NJCM-Bulletin 15-3 (1990), p. 296.

258 Vergelijkbaar ten aanzien van het medium televisie (lid 2) is het onderscheid dat in Pres.Rb. Amsterdam 28 april 1994, KG 1994, 171 wordt gemaakt tussen het maken van opnamen in het kader van een vrije nieuwsgaring enerzijds en de openbaarma. king ervan anderzijds. Alleen tegen deze openbaarmaking was de vordering (verbod) van eiseres gericht. 
Welke rol de bedoeling tot het al dan niet verspreiden van het stuk speelt is niet geheel duidelijk. De zaak met betrekking tot de concept-nota van het Wetenschappelijk Bureau Centrumpartij zou een aanwijzing kunnen bevatten dat de aannemelijkheid van de bedoeling om tot publikatie (lees: verspreiding) over te gaan een rol bij de afbakening zou kunnen spelen, bijvoorbeeld dat de maatregelen pas mogen worden genomen indien de bedoeling tot verspreiden aannemelijk is geworden. Dit zou dan de matstaf kunnen zijn voor de beoordeling of het openbaringsrecht is "uitgewerkt", dat de openbaring is voltooid. In de Bluf!-zaken treffen we een soortgelijke overweging niet aan, maar deze uitspraken sluiten een dergelijke conclusie niet uit.

\subsubsection{Lid 3: de grens tussen inhoud en vorm van het geopenbaarde}

De regering merkt in het Nader rapport ten aanzien van het onderscheid tussen de inhoud van het geopenbaarde en de vorm ervan, op, dat niet elk aspect van het openbaren van gedachten of gevoelens dat door de grondrechtenpretendent als inhoudelijk wordt aangemerkt, dat ook daadwerkelijk is. Volgens de regering moet het begrip "inhoud" worden geobjectiveerd. Dit zal, aldus de regering weinig problemen opleveren bij verbale uitingen, maar er zijn gevallen waarin inhoud en vorm van een uiting nauw zijn verweven of zelfs samenvallen. Als voorbeeld wordt genoemd een toneelvoorstelling. "Niet alleen wàt wordt gezegd, maar ook hoe het wordt gezegd, met welke gebaren, in welke aankleding, met welke hulpmiddelen, al deze aspecten kunnen betrekking hebben op de inhoud van de geuite gedachten of gevoelens", aldus de regering. De Raad van State had als voorbeeld gegeven de geluidssterkte bij muzikale uitingen. De Raad was bang dat lid 3 te weinig bescherming zou bieden tegen everlast. ${ }^{259}$ Ten aanzien van dit voorbeeld merkt de regering op dat lid 3 "geen vrijbrief verschaft voor elke door musici gewenste geluidssterkte. Ook in deze gevallen zullen door redelijke uitleg van wat onder inhoud moet worden verstaan grenzen kunnen worden gesteld. " De regering voegt hieraan toe dat de beperkingsclausule "behoudens ieders verantwoordelijkheid volgens de wet" - ter kering van veroorzaakte overlast - uitkomst kan bieden in het geval de geluidssterkte in een bepaald geval tot de inhoud van de geopenbaarde gedachten of gevoelens moet

259 Advies van de Raad van State bij wetsyoorste! 13872, Verklaring dat er grond bestaat .... Tweede Kamer, in: Algehele grondwetsherziening, deel la Grondrechten, p. 65 . 
worden gerekend. ${ }^{260}$ Kortom, dan kan repressief opgetreden worden. Met de verwijzing naar de "redelijke uitleg" lijkt de regering hier te doelen op een restrictieve uitleg van het begrip "inhoud". Deze redenering, volgens welke de ene geluidssterkte wèl en de andere geluidssterkte niet meer onder de inhoud van de uiting valt, doet wat gekunsteld aan. Een betere methode om toch de geluidssterkte preventief aan banden te kunnen leggen, lijkt mij gelegen te zijn in één van de andere ontsnappingsmogelijkheden die zijn gecreëerd op de beperkingssystematiek, namelijk de redelijke wetstoepassing. Indien het in flagrante strijd zou zijn met wat in het algemeen redelijk wordt geacht, wanneer een muziekuitvoering (of andere openbaring van gedachte of gevoelens) niet preventief vanwege de geluidssterkte kan worden beperkt (bijvoorbeeld door middel van een verbod op een geluidssterkte boven een $\mathrm{x}$-aantal decibel of het stellen van voorwaarden), dan brengt redelijkheid met zich dat artikel 7 lid 3 in dit concrete geval ten aanzien van dit soort maatregelen geen bescherming kan bieden. Artikel 7 lid 3 blijft wel gelden omdat de geluidssterkte binnen de reikwijdte van het begrip "inhoud" valt, maar komt in concreto geen werking toe. ${ }^{261}$ Dat neemt mijns inziens niet weg, dat in een dergelijk geval de muziekuitvoering zelf - dus los van de geluidssterkte - wel bescherming geniet tegen preventief overheidsoptreden.

In de Memorie van Antwoord stelt de regering nogmaals vast, dat het begrip "inhoud" ziet op datgene wat geuit wordt en niet op de vraag wanneer, waar en hoe geuit wordt. Ook hier echter voegt de regering eraan toe, dat vooral bij artistieke uitingen de artistieke vormgeving in het algemeen tot de inhoud van het geopenbaarde zal behoren. ${ }^{262}$

Kortom, het begrip "inhoud" is een objectief begrip, wat wil zeggen dat het bestrijkt datgene wat "in het algemeen" tot de inhoud wordt gerekend. Normaal gesproken is dat datgene wat wordt geuit, en niet het tijdstip, de plaats en de wijze waarop de gedachten of gevoelens geuit worden. Maar bij artistieke uitingen kan de vormgeving ook onder het begrip "inhoud"

260 Nader rapport bij wetsvoorstel 13872, Verklaring dat er grond bestaat .... Tweede Kamer, in: Algehele grondwetsherziening. deel Ia Grondrechten, p. 90.

261 Bij redelijke wetstoepassing dient echter wel het proportionaliteitsbeginsel in acht genomen te worden en moet rekening gehouden worden met de maatschappelijke en persoonlijke belangen die in het geding zijn. Vgl. verder hoofdstuk 3, par. 3.2.10.

262 Memorie van Antwoord bij wetsvoorstel 13872. Verklaring dat er grond bestaat .... Tweede Kamer, in: Algehele grondwetsherziening, deel Ia Grondrechten, p. 199. 
vallen. ${ }^{26}$ Met een dergelijke verwijzing naar wat in het algerneen tot de inhoud wordt gerekend, reikt de grondwetgever een uitermate vaag criterium aan voor het afbakenen van de term "inhoud". De rechtspraak gaat amper op het begrip "inhoud" in. Weliswaar blijkt uit een uitspraak van de Afdeling Rechtspraak van 14 november 1985, dat "redelijke eisen van welstand" die aan reclame of ondersteunigsconstructies ten behoeve van reclame worden gesteld, geen ruimte bieden voor een inhoudelijke beoordeling van de te openbaren gedachten of gevoelens; hiermee biedt deze uitspraak echter geen houvast voor de afbakening van het begrip "inhoudelijke". ${ }^{264}$ Uitspraken waarin dat houvast wel geboden wordt zijn mij niet bekend.

\subsubsection{7}

Zelfstandig middel van bekendmaking

Ten aanzien van de omvang van de beperkingsbevoegdheid van de overheid met betrekking tot het verspreidingsrecht - of ten aanzien van lid 3 , de uitingsvorm - is het noodzakelijk te onderzoeken wat moet worden verstaan onder "een bepaald middel van bekendmaking dat naast andere middelen zelfstandige betekenis heeft en met het oog op die bekendmaking in een bepaalde behoefte kan voorzien". ${ }^{265}$ In de kamerstukken bij de grondwetsherziening was aangegeven welke middelen niet onder lid 1 vallen: bandopnamen, grammofoonplaten, video-tapes en filmrollen ${ }^{206}$, maar niet welke verspreidingsmiddelen wèl onder lid 1 of lid 3 vallen. Artikel 7 lid 1 kent alleen het begrip "drukpers". Vanzelfsprekend zijn dan ook boeken, tijdschriften, pamfletten en andere drukwerken als zelfstandige

263 Mijns inziens zal heuelfde dienen te gelden in het geval van de "symbolische handelingen" waarmee aan gedachten en gevoelens uiting wordt gegeven. Zit hierboven paragraaf 6.2 .2 .4 . p. 540 . Inhoud en vorm zijn bij dergelijke symbolische handelingen immers ook doorgaans niet te scheiden.

264 ARRS 14 november 1985, AB 1986, 458 net noot $\boldsymbol{P} . J . J$. van Butren. De. Afdeling makt hierbij geen onderscheid ussen artikel 7 lid 1 en lid 3 . Of bovendien deze conclusie van de Afdeling klopt, wordt mijns inziens terecht betwijfeld door A.W. Heringa in zijn annotatie onder HR 26 mei 1987, NJCM-Bulletin 12-8 (1987), p. 624. Hij merkt daarbij op, dat ook de kleur en vorm essentieel voor de inhoud van de uiting kunnen zijn.

265 Immers, het gebruik van een dergelijk zelfstandig verspireidingsmiddel mag niet in het algemeen worden verboden of van een voorafgaand verlof van de overheid afhankelijk worden gesteld.

266 Zie, onder andere, de Memorie van Toelichting bij wetsvoorsteí 13872, Veríklaring dat er grond bestaat .... Tweede Kamer, in: Algehele grondwetsherziening, deel la Grondrechten, p. 33. Overigens komt de regering tot die conclusie op grondl van de jurisprudentie. Volgens $R . E$. de Winter blijkt het echter helemaal niet uit de jurisprudentie. De heersende leer, p. 164. 
verspreidingsmiddelen aan te merken. Geschreven stukken liggen al minder voor de hand, maar zijn duidelijk als zelfstandige verspreidingsmiddelen te beschouwen. Maar hoe zit het met minder vanzelfsprekende middelen? Uit de "oude" jurisprudentie kenden we inmiddels ook de neon-letters. ${ }^{27}$ In een uitspraak van 24 januari 1967 kwam de Hoge Raad tot de conclusie dat het aanbrengen van een tekst in neonletters op een toren "op één lijn (moest) worden gesteld met het aanbrengen van gedrukte of geschreven stukken, nu dit als middel van bekendmaking in het maatschappelijk. verkeer dezelfde functie heeft als het aanbrengen van geschriften in eigenlijke zin". Het criterium is volgens de Hoge Raad in deze uitspraak kennelijk de functie die een middel in het maatschappelijk verkeer heeft. Is deze functie dezelfde als die van "geschriften in eigenlijke zin", dan gaat, het om een zelfstandig middel van bekendmaking in de zin van artikel 7 oud (en derhalve van artikel 7 lid 1). Een dergelijk criterium ben ik in de latere jurisprudentie, met name die van na 1983 niet meer tegengekomen. Dit geldt voor zowel artikel 7 lid 1 als lid 3. Wel geeft de jurisprudentie diverse voorbeelden van verspreidingsmiddelen die als een zelfstandig middel van bekendmaking zijn aanvaard:

- lid 3: videobanden ${ }^{265}$, geluidswagens ${ }^{269}$, mondelinge uitingen ${ }^{270}$ en - lid 1 en 3: het neerzetten van een marktkraampje voor het verspreiden van lectuur (lid 1) en het verstrekken van mondelinge informatie (lid $3)^{271}$.

Hier moet wel aan toegevoegd worden dat de jurisprudentie erg casuïstisch is ten gevolge van de verschillende formuleringen van al dan niet

267 HR 24 januari 1967, NJ 1967, 270 ("Nederland ontwapent") met noot W.F. Prins: zie R.E. de Winter. De heersende leer, pp. 141 e.v..

268 Vz.ARRS 9 maart 1984, KG 1984, 128, AB 1985, 192; zie R.E. de Winter. De heersende leer, pp. 243-244.

269 ARRS 19 januari 1987, AB 1988, 58 met noot P.J. Boon; zie R.E. de Winter. De heersende leer, pp. 217 e.v..

270 CRvB 3 januari 1985 NJB, afl. 8 (1985), nr. 6, p. 262; TAR 1985, nr. 59 en CRvB 5 juni 1986, TAR 1986, nr. 208; zie ook S. Zwemstra, Bescherming van uitingsrechten door administratieve rechters, pp. 205-2207.

271 Impliciet in ARRS 8 april 1988, AB 1989, 88. Wat betreft collectes: "het aanvaarden van geld of goederen voor een niet-commercieel doel ... 'bij', dat wil zeggen gelijktijdig of in samenhang met, het aanbieden van voorwerpen waaronder gedrukte stukken" wordt blijkens HR 26 mei 1987, NJ 1988, 1005; AB 1988, 106; NJCMBulletin 1987, p.607 e.v.. niet als zelfstandig middel angemerkt. (Vgl. ARRS 19 oktober 1978, tB/S III, p. 517) De Winter ziet hierin een "omgaan" van de HR ten opzichte van HR 27 juni 1978, NJ 1979, 59. R.E. de Winter, De heersende leer, pp. 246-248, zie ook pp. 167 e.v.. Zie voor een chronologisch overzicht van in de rechtspraak erkende zelfstandige verspreidingsmiddelen: $F . H$. Kistenkas, Vrje straatcommunicatie, pp. 32-33. 
zelfstandige verspreidingsmiddelen in de diverse (verbods)bepalingen in APV's ${ }^{m}$ Hoewel het juist met het oog op die verschillende formuleringen nuttig is dat de rechter voldoende beoordelingsvrijheid heeft bij zijn beslissing of een bepaald middel nu wel als een zelfstandig verspreidingsmiddel in de zin van artikel 7 leden 1 en 3 valt aan te merken, is het mijns inziens wel gewenst dat de rechter hierbij op zijn minst toetst aan de functie die een verspreidingsmiddel in het maatschappelijk verkeer vervult. In de zaken met betrekking tot de zojuist genoemde middelen wordt dat niet gedaan, althans niet kenbaar. ${ }^{23}$

\section{2 .2 .8}

Algemeen verbod

Eerder is al aangegeven dat volgens de oude jurisprudentie naar aanleiding van artikel 7 (oud) - welke opvatting door de grondwetgever is overgenomen ten aanzien van artikel 7 lid 1 - het beperken van het verspreiden van drukwerk via een bepaald zelfstandig middel van bekendmaking niet ertoe mag leiden dat het gebruik van dit middel in het algemeen wordt verboden. Ook met betrekking tot lid 3 van artikel 7 is aangegeven dat het feitelijk functioneren van het daarin opgenomen recht niet volledig onmogelijk mag worden gemaakt. Kortom, ook het gebruik van een zelfstandig middel van bekendmaking in de zin van lid 3 mag niet in het algemeen verboden worden. Wanneer is echter sprake van een algemeen verbod? De beantwoording van deze vraag lijkt mij niet problematisch. Het lijkt mij vanzelfsprekend dat hieronder een absoluut verbod van het gebruik van een bepaald verspreidingsmiddel verstaan moet worden. De Winter noemt een aantal voorbeelden uit de oude jurisprudentie, maar geeft ook aan dat absolute verboden zeldzaam zijn. ${ }^{27}$

272 Zie o.a. Vz.ARRS 3 november 1987. De Gemeentestem no. 6855, nr, 5 ; ARRS 8 april 1988, AB 1988, 357: Vz.ARRS 10 augustus 1989. KG 1989, 34i, De Gemeentestem no. 6889. nr. 4: Vz.ARRS 15 maart 1990. De Gemeentestem no. 6904, nr. 9 en Vz.ARRS 15 maart 1990, De Gemeentestem no. 6907, nr. 3. Zie voorts $R$.E. de Winter, De heersende leer. pp. 235-236.

273 Zie verder wat betreft het onderscheid tussen verspreidingsmiddelen in de zin van fid 1 en lid 3: P.J. Boon, Zonder voorafgaand verlof, pp. 35-38; J.M. de Meij, Uitingsvrijheid, pp. 189-190; S. Zwemstra, Bescherming van uitingsrechten door administratieve rechters, $\mathrm{pp}$. 353-354. Voorts is de afbakeningskwestie ten aanzien van lid 3 ook nog van groot belang in verband met de reikwijdte van artikel 9 . Zie daarover meer in paragraaf 6.2.3.

274. HR 31 mei 1939, NJ 1939, 769 (Heerenveen); zie R.E. de Winter. De heersende leer, pp. 89 e.v... Voorts HR 28 november 1950, respectievelijk NJ 1951, 137 (Tilburg), 138 (Sittard I) en 369 (Sittard II): zie R.E. de Winter, idem, pp. 106 e.v. ook voor een weergave van de in het geding zijnde bepalingen van de desbetreffende verordeningen. 
Of een bepaalde beperking néérkomt op een algemeen verbod is een andere vraag en komt nog aan de orde bij de bespreking van het "gebruik van enige betekenis".

\subsubsection{Voorafgaand verlof}

Allereerst dient hier de vraag besproken te worden wat bedoeld wordt mei de term "voorafgaand verlof". Opvallend is dat de grondwetgever deze term zelf nagenoeg niet gebruikt. Naar aanleiding van de beperkingen die op de vrijheid van meningsuiting mogen worden aangebracht, spreekt de regering in de diverse kamerstukken van respectievelijk "preventieve bemoeienis", "preventieve censuur" en "preventief toezicht". ${ }^{275}$ In de Memorie van Antwoord stelt de regering vast - nadat geconstateerd is dat, al naar gelang informatie binnenkomt ten behoeve van de drukpers, de omroep of overige middelen, respectievelijk het eerste, het tweede of het derde lid van artikel 7 van toepassing is - dat preventieve censuur verboden is. Onder lid 1 is volgens de regering bovendien elk preventief toezicht verboden en mogen overige beperkingen (kennelijk worden repressieve beperkingen bedoeld) alleen bij wet in formele zin gesteld worden. Is het tweede lid van toepassing, dan mag geen preventieve censuur plaatsvinden maar is de wetgever overigens vrij beperkingen te stellen. Tenslotte verbiedt het derde lid ook preventieve censuur, mogen beperkingen in verband met de inhoud slechts bij formele wet worden opgelegd en is de wetgever vrij overige beperkingen te stellen. ${ }^{276}$ Uit de voorgaande overwegingen van de regering lijkt dan ook voort te vloeien, dat met "voorafgaand verlof" gedoeld wordt op preventieve bemoeienis met de vrijheid van meningsuiting als overkoepelende term voor "preventieve censuur" - op te vatten als preventieve inmenging in de inhoud van de uiting - én "preventief toezicht" - uit te leggen als overige preventieve bemoeienis met de meningsuiting, dus niet betrekking

275 Zie respectievelijk de Memorie van Toelichting bij wetsvoorstel 13872 , Verklaring dat er grond bestaat .... Tweede Kamer, in: Algehele grondwetsherziening, deel la Grondrechten. p. 18 en p. 35: Memorie van Antwoord bij hetzelfde wetsvoorstel, Tweede Kamer, idem, p. 194. Vergelijk ook de vraag van het kamerlid Rothof tijdens de parlementaire behandeling van de voorstellen tot grondwetswijziging. inhoudende wat eigenlijk de bedoeling is nu in de Memorie van Toelichting, met name in verband met artikel 7 lid 3, gesproken wordt van zowel preventieve bemoeienis als preventieve censuur. Gezamenlijke mondelinge behandeting van de wetsontwerpen (13872 en 13873) door de Tweede Kamer, idem, p. 462, rechter kolom.

276 Memorie van Antwoord bij hetzelfde wetsvoorstel, idem, p. 194. 
hebbende op de inhoud. ${ }^{2 n}$ Deze ruime interpretatie van het begrip "voorafgaand verlof" zal hier verder als uitgangspunt genomen worden. Aangezien de hierna te bespreken uitspraken zien op "voorafgaand verlof" ten aanzien van de verspreiding (lid 1) van de uiting, zullen ze geen betrekking hebben op "preventieve censuur", doch slechts op andere vormen van preventieve (overheids)bemoeienis.

Welke betekenis moet nu worden gehecht aan de bij de grondwetsherziening ten aanzien van artikel 7 lid 1 verkondigde opvatting, dat beperkingen op het gebruik van een zelfstandig middel van bekendmaking niet zover zouden mogen gaan dat dat gebruik van voorafgaand verlof der overheid afhankelijk wordt gesteld? In 1948 kwam in een Koninklijk Besluit naar aanleiding van de Brunssumse leesbibliotheekbepaling nog een overweging voor waaruit zou kunnen worden afgeleid, dat de voorwaarde van voorafgaand verlof - bestaande in een vergunningenstelsel - wel toegestaan zou zijn indien er criteria in de bepaling waren geformuleerd die uitsloten dat bij de (niet-)verlening van de vergunning inhoudelijke overwegingen een rol zouden kunnen spelen. In casu was dat niet het geval waardoor de bepaling niet door de beugel kon. ${ }^{n}$ Dergelijke overwegingen treffen we in de latere jurisprudentie echter niet meer aan. Er zijn uitspraken waaruit zou kunnen worden afgeleid dat de verspreiding in het geheel niet van voorafgaand verlof afhankelijk mag worden gesteld. ${ }^{279}$ De rechtspraak is hieromtrent echter niet geheel eenduidig. In de bedoelde uitspraken gaat het om een algeheel verbod behoudens vergunning of ontheffing. Uit andere uitspraken lijkt de conclusie te kunnen worden getrokken dat de eis van voorafgaand verlof voor het gebruik van een zelfstandig verspreidingsmiddel geoorloofd is indien daarmee het gebruik niet in het algemeen - derhalve zonder

277 Zie ook B.P. Vermeulen en J.J.A. Pelle, Artikel 7 Grondwet, p. 149: "Met de zinsnede dat niemand voōrafgaand verlof nodig heeft ... wordt in de eerste plaats beoogd censuur, de verplichting om geschriften ter goedkeuring aan een overheidsambt voor te leggen alvorens ze te (doen) drukken, onvoorwaardelijk uit te sluiten. Ook alle andere preventieve maatregelen ter zake van het met de drukpers openbaren worden door het verbod van voorafgaand verlof getroffen." Zie voorts G.J.M. van Wissen. Grondrechten, p. 81.

278 KB 11 mei 1948, S. 184, AB 1948, 642; zie R.E. de Winter, De heersende leer, p. 103.

279 Uitspraken van na 1983: Vz.ARRS 3 november 1987, De Gemeentestem no. 6855, nr. 5; ARRS 8 april 1988, AB 1988, 357; Vz.ARRS 10 augustus 1989, KG 1989, 341, De Gemeentestem no. 6889, nr. 4; Vz.ARRS 15 maart 1990, De Gemeentestem no. 6904, nr. 9; Vz.ARRS 15 maart 1990, De Gemeentestem no. 6907, nr. 3; zie R.E. de Winter, De heersende leer, pp. 235 e.v.. 
uitzondering - van dat voorafgaand verlof afhankelijk wordt gesteld. ${ }^{20}$ Een voorbeeld hiervan is een bepaling in de Utrechtse APV, volgens welke het was verboden om zonder vergunning van Burgemeester en Wethouders op een onroerend goed afbeeldingen, letters e.d. aan te brengen of te hebben behoudens op door B. en W. daartoe aangewezen plaatsen of overeenkomstig bepaalde door B. en W. gestelde voorschriften die geen betrekking mogen hebben op de inhoud van de meningsuitingen of bekendmakingen. Zowel in een uitspraak van 24 juni 1980 als van 10 juni 1986 werd deze bepaling niet in strijd met artikel 7 lid 1 geacht. ${ }^{28 .}$ De desbetreffende uitzonderingen moeten dan echter wel "gebruik van enige betekenis" van het verspreidingsmiddel overlaten.

Mijns inziens zal het van deze laatste toetsing (of "gebruik van enige betekenis" overblijft) afhangen of een dergelijke opvatting over het toegestaan zijn van de eis van voorafgaande toestemming (indien die eis maar niet voor een gemeente in zijn geheel geldt), bevredigend is. Een vergunningen- of ontheffingsstelsel bergt nu eenmaal de mogelijkheid in zich dat bij de beslissing omtrent de verlening van die vergunning of ontheffing naar de inhoud van de te openbaren gedachten of gevoelens wordt gekeken. Zijn er - zowel juridisch als feitelijk - onvoldoende mogelijkheden om zonder voorafgaande toestemming zijn mening te uiten, dan is er nauwelijks verschil met artikel 7 lid $3 .{ }^{282}$ In een dergelijk geval dient men tot de conclusie te komen dat er geen gebruik van enige betekenis van het middel is overgebleven. ${ }^{283}$

Overigens dient hier - wellicht ten overvloede - te worden opgemerkt, dat het in artikel 7 gaat om voorafgaand verlof van de overheid. In diverse APV's staat een verbod om "wederrechtelijk" of om "zonder toestemming van de rechthebbende" te plakken. Dit soort bepalingen leveren geen

280 Zo ook B.P. Vermeulen en J.J.A Pelle, Artikel 7 Grondwet. p. 166. Vgl. A.F.M. Brenninkmeijer. Van drukpersvrijheid tot informatievrijheid, p. 181 en noot 66 en I.M. de Meij, De feitelijke mogelijkheid tot vrije meningsuiting. p. 17 r.k..

281 HR 24 juni 1980, NJ 1981, 659; HR 10 juni 1986. NJ 1987, 133. Zie R.E. de Winter. De heersende leer, respectievelijk p. 188 en p. 216 . Vergelijkbare uitspraken van voor 1983: ARRS 22 januari 1981, De Gemeentestem no. 6692, nr. 2: ARRS 28 april 1981. AB 1981, 480; HR 27 oktober 1981, NJ 1982, 103: R.E. de Winter. idem, pp. 191-192, 197-198.

282 Ten aanzien van lid 3 is het afhankelijk stellen van voorafgaand verlof van het gebruiken van een zelfstandig verspreidingsmiddel toegestaan. indien de inhoud van het geopenbaarde niet getoetst wordt. VgI. ARRS 19 januari 1987. AB 1988, 58; Vz.ARRS 17 augustus 1990, De Gemeentestem no. 6913, nr. 3; en zonder duidelijk onderscheid tussen lid 1 en lid 3: ARRS 8 april 1988, AB 1989, 88.

283 Dit was de uitkomst in ARRS 28 april 1981, AB 1981, 480 en HR 27 oktober 1981. NJ 1982, 103. 
schending van artikel $7 \mathrm{op}^{24}$, tenzij aannemelijk kan worden gemaakt dat er onvoldoende rechthebbenden in een gemeente zijn die hun toestemming voor het aanplakken geven om te kunnen stellen dat er gebruik van enige betekenis van dit verspreidingsmiddel overblijft. Daarover in de volgende sub-paragraaf meer.

In de praktijk hebben zich ook een aantal gevallen voorgedaan, waarin het strikt genomen niet ging om voorafgaand verlof, maar die er desondanks wel toe zouden kunnen leiden dat belanghebbenden van tevoren toestemming zullen vragen aan de betrokken autoriteiten om van een verspreidingsmiddel gebruik te mogen maken. Het gaat hier om bepalingen in APV's zoals die getoetst werd in een uitspraak van de Afdeling Rechtspraak van 14 november $1985{ }^{235}$ Het ging in deze zaak om een verbod om reclame of een ondersteuningsconstructie ten behoeve van reclame aan te brengen of te hebben, indien deze (achteraf, CS) naar het oordeel van B en W niet aan redelijke eisen van welstand voldoen. Mijns inziens stellen de Winter en de Meij terecht, dat men in praktijk eerst naar $B$ en W zal stappen om toestemming voor het aanbrengen van een reclamebord te krijgen, om te voorkomen dat men het achteraf weer weg zal moeten halen. Het effect is derhalve vergelijkbaar met voorafgaand verlof. ${ }^{266} \mathrm{Om}$ die reden zal het nodig zijn dit soort eisen ook aan het criterium, dat er gebruik van enige betekenis van het desbetreffende verspreidingsmiddel moet overblijven, te toetsen.

Ten slotte dient hier nog ingegaan te worden op een ander soort vergunning die we in de rechtspraak naar aanleiding van artikel 7 tegenkomen: de Hinderwetvergunning. Uit een aantal uitspraken blijkt dat het stellen van een vergunning ter ondervanging van "gevaar, schade of hinder van ernstige aard, welke daarbuiten van het onderwerpelijke bedrijf zijn te duchten" niet in strijd is met artikel 7 omdat "toepassing van de Hinderwet noch tot doel, noch tot effect heeft de verkoop van geschriften

284 Vgl. HR 17 oktober 1989. NJ 1990, 222, AB 1990. 318 met noot F.H. van der Burg. NJCM-Bulletin 15-4 (1990), pp. 444-450 met noot R.E. de Winter: " ... dat "voorafgaand verlof" in evengenoemd artikel (artikel $7 \mathrm{Gw}$., CS) betrekking heeft op voorafgaand verlof van de overheid".

285 ARRS 14 november 1985, AB 1986, 458; NJCM-Bulletin 1988, pp.126-127 met noot R.E. de Winter. Zo ook ARRS 20 augustus 1981, De Gemeentestem no. 6692 , ni. 3. Zie R.E. de Winter, De heersende leer, pp. 194-195, 233-234.

286 R.E. de Winter, De heersende leer, pp. 195, 235 en J.M. de Meij. Uitingsvrijheid, p. 108. Het feit, dát het hier niet om een vergunningenstelsel gaat, lijkt Boon te zijn ontgaan; zie P.J. Boon. Zonder voorafgaand verlof, p. 57. Hetzelfde geldt voor Heringa in zijn noot onder HR 26 mei 1987, NJCM-Bulletin 12-8 (1987), p. 624. 
van meningsuiting te beletten". ${ }^{287}$ Volgens de A-G, wiens motivering door de Hoge Raad in een uitspraak van 11 februari 1986 wordt overgenomen, is er alleen sprake van strijd met artikel 7 indien de betrokken autoriteiten misbruik maken van hun bevoegdheden "om een drukker te muilkorven". ${ }^{288}$ Ook de Voorzitter van de Afdeling voor geschillen van bestuur stelt dat de Hinderwet wel voorwaarden mag stellen aan de technische uitrusting van drukkerijen, maar dat de inhoud van het te drukken werk geen rol mag spelen. ${ }^{289}$

Ei zijn diverse verschillen aan te geven met de hiervoor behandelde zaken omtrent vergunningenstelsels. In het voorgaande werd geconstateerd, dat de rechtspraak erop lijkt te wijzen dat vergunningenstelsels hooguit zijn toegestaan - ten aanzien van de wijze, het tijdstip en de plaats van de verspreiding - indien het voorafgaand verlof (de bedoelde vergunning) voor het gebruik van een zelfstandig verspreidingsmiddel niet in het algemeen geëist wordt. Bij het stelsel van de Hinderwet, wordt wél - althañs voor wat betreft bepaalde zelfstandige verspreidingsmiddelen - in het algemeen een vergunning vereist van drukkerijen. Weliswaar geldt volgens het Hinderbesluit een grens van 1,5 kWatt elektromotorisch vermogen van de drukpersen, maar het drukken van een krant of tijdschrift - die als zelfstandige verspreidingsmiddelen kunnen worden beschouwd - is hiermee nog steeds in het geheel aan een vergunningenstelsel onderworpen, omdat daarvoor een vermogen van minder dan $1,5 \mathrm{kWatt}$ niet volstaat. ${ }^{200}$ Een ander verschil is hier, zoals blijkt uit de conclusie van de A-G bij de uitspraak van 11 februari 1986 (die op zijn beurt verwijst naar een $K B$ van 28 november 1980), dat "toepassing van de Hinderwet noch tot doel, noch tot effect heeft de verkoop van geschriften van meningsuiting te beletten". De vergunningen- of ontheffingsstelsels in de eerder besproken rechtspraak waren juist wel op beperking van het verspreidingsrecht gericht. Omdat de beperkingen die in de Hinderwet zijn gesteld op het uitoefenen van het drukkerij-bedrijf en daarmee op de verspreiding van drukwerk, daarop niet

287 Curieus is de afwijkende formulering in AGvBRS 20 november 1992, AB 1993, 241 met noot $I$. Sewandono: "dat de strekking van het Hinderbesluit en meer in het bijzonder het hiervan i.c. toepasselijke artikel 1 onder I sub a noch tot doel noch tot effect heeft het oprichten dan wel in werking hebben van drukkerijen te enen male te beletten, doch uitsluitend beoogt gevaar, schade of hinder, welke van de inrichting zijn te duchten, te ondervangen, zodat van strijd met artikel 7 Gr.w geen sprake is." (Cursivering, CS) Dit is de enige overweging t.a.v. artikel $7 \mathrm{Gw}$. Wat betreft de vrijheid van meningsuiting wordt de zaak verder behandeld onder artikel 10 ECRM, met name het tweede lid van die bepaling.

288 HR 11 februari 1986, NJ 1986, 673 met noot Th. W. van Veen.

289 Vz.AGvBRS 26 april 1991, De Gemeentestem no. 6931, nr. 7 met noot Brederveld.

$290 \mathrm{Vgl}$. R.E. de Winter, De heersende leer, p. 239. 
waren gericht maar juist in het algemeen op inrichtingen met een elektromotorisch vermogen van meer dan 1,5 kWatt, kan hier gesproken worden van algemene beperkingen. ${ }^{291}$ De bepalingen van de Hinderwet (en het Hinderbesluit) zijn immers niet specifiek gericht op de beperking van de door artikel 7 Grondwet beschermde vrijheid, maar kúnnen dit wél tot gevolg hebben. Dat is voldoende om te kunnen spreken van algemene beperkingen: een daadwerkelijk beperkend effect is daarvoor niet noodzakelijk. Overigens kan men betwijfelen of de uitspraak juist is dat de toepassing van de Hinderwet niet tot effect heeft de verkoop van geschriften te beletten. Ten aanzien van déze drukker had de toepassing van de Hinderwet immers wel dat effect. ${ }^{292}$

Zoals al eerder in paragraaf 3.2.10 (noot 146) is aangegeven, is juist deze afwijking (de Hinderwetvergunning) van de beperkingssystematiek in de kamerstukken bij de grondwetsherziening als voorbeeld aangevoerd voor het hanteren van de redelijke wetstoepassing. Uit een redelijke toepassing van artikel 7 zou in dit geval moeten voortvloeien, dat dit artikel in dit geval geen gelding meer heeft: ongrondwettigverklaring van het vergunningenstelsel in de Hinderwet zou buiten de grenzen van de redelijkheid liggen. Op deze wijze kan deze beperking op het verspreidingsrecht worden gesauveerd, maar dit doet er niet aan af dat het hier op zich wél gaat om een "voorafgaand verlof" dat zonder deze redelijke wetstoepassing, mijns inziens, in strijd zou zijn met de hiervoor besproken verspreidingsjurisprudentie, omdat een zelfstandig verspreidingsmiddel in zijn geheel van voorafgaand verlof afhankelijk wordt gesteld. ${ }^{293}$

291 Vgl. A.F.M. Brenninkmeijer, Van drukpersvrijheid tot informatievrijheid, p. 176; P.J. Boon, Zonder voorafgaand verlof, p. 58. Anders: J.M. de Meij, Uitingsvrijheid, p. 46 .

292 Zo ook J.M. de Meij, Uitingsvrijheid, p. 87. Overigens valt mijns inziens - gezien de (voorzichtige) conclusie aan het eind van paragraaf́ 6.2.2.5, namelijk dat de grens tussen het openbaringsrecht en het verspreidingsrecht getrokken zou kunnen worden tussen het moment waarop de inhoud van gedachten of gevoelens in een gedrukt stuk is vastgelegd en voordat het wordt verspreid - fe verdedigen dat het vereiste van een Hinderwetvergunning een beperking inhoudt van niet slechts het verspreidingsrecht, maar eerder nog van het openbaringsrecht. De vergunning dient immers voorafgaand aan het drukken te worden verleend. Deze beperking is, behoudens ontsnappingsmogelijkheid van de redelijke toepassing, niet slechts ongeoorloofd omdat het gaat om een algemene beperking door een lagere wetgever zonder basis in een specifieke, formele wetsbepaling, maar tevens omdat beperkingen ten aanzien van het openbaringsrecht slechts achteraf en bij formele wet mogen worden gesteld.

293 Zowel de rechterlijke instanties, de A-G, de annotatoren als de Winter gaan op deze materie van de algemene beperkingen en de redelijke wetstoepassing niet in. Soortgelijke kwesties doen zich voor in, bijvoorbeeld, KB 20 april 1989, AB 1989. 
Omdat de jurisprudentie naar aanleiding van het "voorafgaand verlof" niet geheel eenduidig is, is voorzichtigheid bij het trekken van conclusies geboden. Toch meen ik uit de rechtspraak te kunnen afleiden, dat het afhankelijk stellen van voorafgaand verlof van de overheid (dus niet van particuliere rechthebbenden) voor het gebruik van een zelfstandig verspreidingsmiddel via vergunningen- of ontheffingsstelseis in het algemeen niet is toegestaan. Dat wil zeggen dat het gebruik van een zelfstandig verspreidingsmiddel niet voor het gehele territoir van een gemeente aan voorafgaande toestemming mag worden gebonden of gedurende 24 uur per etmaal. Wel is het mijns inziens toegestaan voorafgaand verlof te eisen indien deze voorwaarde niet in het algemeen wordt gesteld, maar er bepaalde uitzonderingen gelden: bijvoorbeeld wordt ten aanzien van bepaalde delen van de bebouwde kom geen voorafgaande toestemming geëist, of worden in die delen waar dat wel wordt geëist toch nog vrije aanplak- of verspreidingsmogelijkheden gecreëerd. Of wordt de verspreiding op bepaalde uren van de dag wél zonder voorafgaand toestemming toegestaan. Deze uitzonderingen moeten dan wel nog gebruik van enige betekenis van het verspreidingsmiddel zonder voorafgaand verlof overlaten. Ook moet daar waar voorafgaand verlof van de overheid als voorwaarde voor het gebruik van een zelfstandig verspreidingsmiddel wordt gesteld, gebruik van enige betekenis van dat middel bestaan. Dat wil zeggen dat het aantal gevallen waarin een vergunning of ontheffing wordt verleend voldoende moeten zijn om van "gebruik van enige betekenis" te kunnen spreken.

In het voorgaande ging het om "voorafgaand verlof" in verband met artikel 7 lid 1. Ook in lid 3 wordt gesproken van "voorafgaand verlof". Evenals in lid 1 is. het niet toegestaan om een vergunning- of ontheffingsstelsel in te stellen dat ziet op de inhoud van de te openbaren gedachten of gevoelens (preventieve censuur). Anders dan bij lid 1 echter, is het in het algemeen afhankelijk stellen van voorafgaand verlof - ten aanzien van de wijze, plaats en tijd - van het gebruik van een zelfstandig verspreidingsmiddel in de zin van lid 3 wél toegestaan. ${ }^{24}$ Echter ook hier geldt, dat waar voorafgaand verlof van de overheid als voorwaarde voor het gebruik van een zelfstandig verspreidingsmiddel wordt gesteld, gebruik van enige

304, ten aanzien van voorschriften in de Wet Ruimtelijke Ordening en in Vz.ARRS 17 augustus 1990, De Gemeentestem no. 6913, nr. 3 met noot van Brederveld, ten aanzien van een bepaling in de APV Zwolle ter bestrijding van geluidshinder.

294 Zo ook o.a. B.P. Vermeulen en J.J.A. Pelle, Artikel 7 Grondwet, p. 185. VgI. J.M. de Meij, De feitelijke mogelijkheid tot vrije meningsuiting, p. 17 (r.k.). 
betekenis van dat middel moet overblijven. ${ }^{205}$ Over dat begrip gaat de volgende subparagraaf.

\subsubsection{Gebruik van enige betekenis}

Zoals in paragraaf 6.2.2.1 al bleek, had de Hoge Raad reeds in 1892 bepaald, dat het verspreiden van een gedrukt geschrift beperkt mag worden "zonder haar in het algemeen te verbieden". In paragraaf 6.2.2.8 stelde ik vast, dat onder een algemeen verbod - strikt genomen - een absoluut verbod moet worden verstaan, dat wil zeggen dat de verspreiding in het geheel onmogelijk wordt gemaakt. Daar werd er tevens op gewezen, dat de vraag of een bepaalde beperking néérkomt op een algemeen verbod iets anders is. Ook hieromtrent geeft de oude jurisprudentie ten aanzien van artikel 7 aan, dat ook een beperking op het verspreidingsrecht die het gebruik van een verspreidingsmiddel niet geheel beperkt, maar bijna geheel - zodat er onvoldoende gebruiksmogelijkheden van dat middel overblijven niet is toegestaan. De Hoge Raad formuleerde dit aldus, dat

"het recht tot gebruik van dit middel wel door den gemeenteraad of ... door B. en W. kan worden onderworpen aan voorschriften ... doch die beperkingen van dat middel nooit zover mogen gaan dat zij neerkomen op een in het algemeen verbieden; dat dit gevolge echter in het leven wordt geroepen door het aangevallen Besluit van B. en W., hetwelk ... van bedoeld verspreidingsmiddel geen gebruik van enige betekenis overlaat; $" 296$

Dit betekent derhalve, dat ook als in een bepaald geval geen sprake is van een algemeen verbod, een beperking toch in strijd met artikel 7 kan zijn omdat het neerkomt op een algemeen verbod aangezien het geen gebruik van enige betekenis van het desbetreffende verspreidingsmiddel overlaat. Het verspreidingsrecht wordt in een dergelijk geval illusoir. ${ }^{297}$ De geciteerde overweging is in latere zaken veelvuldig herhaald en heeft sindsdien aan betekenis gewonnen, doordat deze uitleg sinds de

295 Onjuist lijkt mij dan ook de opvatting van Brenninkmeijer, dat indien de rechter ten aanzien van lid 3 niet ieder algeheel vergunningenstelsel verbiedt, "iedere beperking die de vorm betreft, toelaatbaar is, ook al worden daardoor zelfstandige openbaringsmiddelen onbruikbaar gemaakt". Van drukpersvrijheid tot informatievrijheid, p. 182.

296 HR 17 maart 1953, NJ 1953, 389 (Nuth). Eerder was de formulering al te vinden in HR 10 juni 1952, NJ 1952, 688 (Deventer).

297 Zie J.J. van Riemsdijk Kreenen, Het venten van drukwerk op de openbare straat, diss. Leiden 1895, pp.34-35; ontleend aan R.E. de Winter. De heersende leer, p. 29 en p. 122 . 
grondwetswijziging van 1983 - zij het in een andere formulering - ook is gaan gelden voor artikel 7 lid $3 .{ }^{298}$

De wijze van vaststelling of er nog sprake is van gebruik van enige betekenis is een andere kwestie. Terwijl beperkingen naar tijd niet van de plaatselijke omstandigheden afhankelijk zijn, zijn beperkingen naar plaats dat wel. De Hoge Raad kan als cassatierechter niet treden in de beoordeling van de feitelijke omstandigheden ter plaatse. De beoordeling of beperkingen naar plaats van een bepaald verspreidingsmiddel nog gebruik van enige betekenis overlaten, zal de Hoge Raad dan ook aan de lagere instanties over moeten laten. Deze lagere instanties zijn dan ook verplicht om naar die (bijzondere) plaatselijke omstandigheden een onderzoek in te stellen. ${ }^{209}$ De vraag is alleen hoever die onderzoeksplicht gaat. Uit een vrij recente uitspraak van de Hoge Raad blijkt, dat de lagere rechter niet kan volstaan met een overweging als door de rechtbank Alkmaar is gehanteerd ten aanzien van een bepaling waarin het, onder andere, is verboden om een anders eigendom wederrechtelijk te beschrijven, bekrassen en dergelijke. De Alkmaarse rechtbank overwoog dat het een feit van algemene bekendheid is "dat derden minder geneigd zijn burgers in de gelegenheid te stellen om van hun onroerend goed gebruik te maken voor aankondigingen en mededelingen door middel van aanplakbiljetten naarmate de aankondiging of boodschap op het aanplakbiljet minder neutraal van aard is" en dat daarom geen mogelijkheid tot gebruik van enige betekenis van het middel overblijft. Uit deze overweging blijkt, aldus de Hoge Raad, dat de rechtbank kennelijk niet de mogelijkheid heeft onderzocht of derden bereid zijn tegen betaling beplakking van hun onroerend goed toe te staan. Niet zeker is, hoe de Hoge Raad zou hebben geoordeeld, indien de rechtbank ook had overwogen dat het een feit van algemene bekendheid is dat derden niet snel geneigd zijn hun onroerend goed voor beplakking beschikbaar te stellen in geval van minder neutrale uitingen, ook indien zij daarvoor geld zouden krijgen aangeboden. Had de rechter dan moeten onderzoeken, hoe deze neiging tot het geven van toestemming zich verhoudt tot de hoogte van het aangeboden bedrag? Het wachten is op verdere uitspraken van de Hoge

298 Zie hiervoor paragraaf 6.2.2.2. Vgl. voorts o.a. ARRS 19 januari 1987. AB 1988. 58. Zie ook B.P. Vermeulen en J.J.A. Pelle. Artikel 7 Grondwet. p. 187.

299 Zie, bijvoorbeeld. HR 28 juni 1983. NJ 1984, 64: "... Derhalve kan - behoudens het geval dat bijzondere plaatselijke omstandigheden zouden medebrengen dat het verbad in feite geen mogelijkheid tot gebruik van enige betekenis van het onderhavige middel van bekendmaking openlaat - niet worden gezegd, dat art. 9 in strijd is met ... art. 7 lid 1 Gr.w. ...". (Cursivering. CS)

Zie, o.a., ook HR 21 januari 1986, NJ 1986, 441 met noot Th.W. van Veen; AB 1986, 572: HR 26 januari 1993, NJ 1993, 534. 
Raad. In elk geval zal niet kunnen worden verstaan met een verwijzing naar een feit van algemene bekendheid, omdat dan niet de feitelijke omstandigheden ter plaatse worden onderzocht.

Wat betreft beperkingen naar tijd: dit zijn feiten van algemene bekendheid (tijd is immers niet van plaatselijke omstandigheden afhankelijk) waarover de Hoge Raad zich in principe wel zal kunnen uitlaten. Dit zal naar mijn mening anders zijn indien zich specifieke plaatselijke omstandigheden voordoen, bijvoorbeeld indien door bepaalde evenementen het belang van bepaalde tijdstippen voor de effectiviteit van het verspreidingsrecht anders is dan in het algemeen ten aanzien van die tijdstippen geldt. ${ }^{300}$

De rechtspraak naar aanleiding van bepalingen in APV's waarin "plakken" zonder toestemming ${ }^{301}$ van de rechthebbende wordt verboden is een goede illustratie van waartoe de terughoudendheid van de Hoge Raad bij de toetsing van beperkingen naar plaats aan het criterium "gebruik van enige betekenis" kan leiden. Bij vervolging wegens overtreding van het bedoelde verbod, zal de verdachte zich - indien het feit (aantoonbaar) is begaan - veelal verweren met een beroep op de rechtvaardigingsgrond, dat de desbetreffende verbodsbepaling in strijd is met artikel 7 en daarom onverbindend is. Dit zal dan gemotiveerd worden op de grond dat het verbod onvoldoende gebruik van het verspreidingsmiddel overlaat. Bij een beroep op een rechtvaardigingsgrond rust op de verdachte een "stelplicht": hij moet aannemelijk maken dat er onder het plakverbod onvoldoende plakmogelijkheden overblijven, dit verweer stavend met feiten. Vervolgens kan de rechter dit verweer niet verwerpen met een overweging dat de gestelde feiten niet wettig en overtuigend bewezen zijn of niet "gebleken" zijn. Op de verdachte rust immers geen bewijslast. De rechter moet de gestelde feiten derhalve onderzoeken, alhoewel de eventuele verwerping van het verweer niet hoeft te steunen op gebezigd bewijsmateriaal. Kan een verdachte van overtreding van het plakverbod niet aannemelijk maken dat er onvoldoende plakmogelijkheden zijn, dan behoeft de rechtbank de aanwezigheid van voldoende plakmogelijkheden niet verder na te gaan. Ook hoeft de rechter niet op het verweer in te gaan indien de verdachte geen feiten ter staving van dit verweer aanvoert. ${ }^{\text {kn }}$ Dit soort

300 Hierop zal ik niet nader ingaan, omdat ik geen jurisprudentie in die zin heb gevonden. Beperkingen naar de wijze van verspreiden betreffen de vraag of sprake is van een "zelfstandig middel van bekendmaking". Hiervoor verwijs ik naar paragraaf 6.2.2.7.

301 Soms wordt zelfs schriftelijke toestemming van de rechthebbende geëist. Dit vereiste is volgens de rechtspraak toegestaan. Zie o.a. HR 5 april 1983, NJ 1984, 134 met noot JAB; HR 23 juni 1987. NJ 1988, 222.

302. Vgl. H.G.M. Krabbe, Verweren in de zin van art. 358 derde lid Sv., pp. 171-191. 
verwerpingen van het verweer van de verdachte luiden, bijvoorbeeld, als volgt:

"... dat geenszins aannemelijk is geworden dat vrijwel alle eigenaren of huurders in de gemeente Tilburg hun toestemming zouden weigeren

dat al evenmin aannemelijk is geworden dat eventuele toestemming van huurders zou kunnen worden ontkracht door optreden van verhuurders; dit met name niet voor de situatie waarin de toegestane wijze van aanplakking verhuurders niet in hun belangen raakt;

dat de omstandigheid dat de gemeente weigert openbare aanplakborden te plaatsen en om toestemming te geven tot aanplakken van haar panden geen verandering brengt in deze waardering, aangezien, zoals vermeld, voldoende andere mogelijkheden openblijven." ${ }^{303}$

Wanneer de lagere rechter aldus vaststelt dat er voldoende plakmogelijkheden zijn, dan moet de cassatierechter dit oordeel eerbiedigen. ${ }^{304}$

Of er toestemming is verkregen tot het plakken op gebouwen waarvan de gemeente eigenaar is, is niet al te moeilijk vast te stellen: het gaat slechts om één rechthebbende, dus het al dan niet verkrijgen van toestemming is eenvoudig na te gaan. Ook indien een vergunning vereist is, is de (niet-)verlening daarvan snel vast te stellen. Maar ten aanzien van particuliere rechthebbenden is dit anders. Hoe maak je aannemelijk dat er onvoldoende plakmogelijkheden zijn bij een verbod om zonder

303 Zie het vonnis van de Rb. Breda van 4 oktober 1982, in: HR 28 juni 1983. NJ 1984. 65. Zoals uit een eerder weergegeven citaat blijkt, had de rechtbank Alkmaar hierover een tegengestelde opvatting. Zie in: HR 26 januari 1993, NJ 1993, 534 en hierboven.

304 Zie 0.a. HR 28 juni 1983. NJ 1984, 65; HR 10 juni 1986, NJ 1987, 133; HR 5 januari 1988. De Gemeentestem no. 6872, nr. 5 met naschrift Brederveld. NJCMBulletin 14-4 (1989), pp. 439-446 met noot R.E. de Winter; HR 17 oktober 1989, NJ 1990, 222, AB 1990, 318 met noot F.H. van der Burg. NJCM-Bulletin 154 (1990), pp. 444-450 met noot R.E. de Winter. Dit geldt overigens ook indien de lagere rechter tot een tegengesteld oordeel komt. Zo kon de Hoge Raad niet beoordelen of de opvatting van de rechtbank Alkmaar juist is - dat het een feit van algemene bekendheid is dat rechthebbende minder geneigd zullen zijn toestemming voor het beplakken e.d. van hun onroerend goed te geven in geval van een minder neutrale uiting. Het vonnis werd om andere redenen vernietigd, onder meer ondat de rechtbank niet zou hebben onderzocht of dit oordeel van de rechibsank anders zou zijn indien aan de rechthebbenden betaling zou worden geboden als tegenprestatie voor het laten beplakken van hun onroerend goed. Zie HR 26 januari 1993, NJ 1993, 534. 
toestemming van de particuliere rechthebbende te plakken? Het is ondoenlijk iedere rechthebbende afzonderlijk om toestemming te vragen. Toch kan dit - of althans een representatieve steekproef - van een plakker, blijkens de jurisprudentie, worden verwacht. Hoe anders maakt men aannemelijk, dat er onvoldoende plakmogelijkheden zijn? In een zaak ten aanzien van een Bussumse strafbepaling bieden twee getuige/deskundigen uitkomst die verklaren "geen particuliere rechthebbenden op onroerend goed in de gemeente Bussum te kennen die zouden toestaan dat op dat onroerend goed wordt geplakt." ${ }^{005}$ Hoe die getuige/deskundigen aan die wetenschap gekomen zijn, is mij onbekend. Wat dat betreft is een zaak van 8 februari 1985, duidelijker omdat een getuige zich hier baseert op een bestuursakkoord, waaruit blijkt dat de fracties binnen de Arnhemse gemeenteraad zelf al tot de conclusie zijn gekomen dat het nodig is om voldoende plaatsen beschikbaar te stellen waar "... bekendmakingen aan het publiek openbaar kunnen worden gemaakt ...". ${ }^{306}$

Toch blijft het onduidelijk hoe de rechtbanken in deze zaken tot de conclusie zijn gekomen dat er in deze gevallen geen gebruik van enige betekenis overblijft. De rechtbanken geven geen criterium voor de afbakening van dit begrip.

In een uitspraak van de Haarlemse rechtbank ${ }^{307}$ is wel een poging gedaan om het gebruik van enige betekenis nader te preciseren naar aanleiding van de overweging dat "de mogelijkheid om van het middel "plakken" gebruik te maken om gedachten en gevoelens te verspreiden, ook zonder voorafgaand verlof van die rechthebbenden (onverlet blijft)". De rechtbank oordeelt vervolgens dat

"in aanmerking genomen de omvang van de gemeente Haarlem, de "vrije" plakmogelijkheden in Haarlem, bezien naar aantal, oppervlakte en plaats ... zodanig onvoldoende zijn dat van enig reëel gebruik van het onderhavige middel van bekendmaking geen sprake kan zijn."

305 Rb. Amsterdam 18 april 1984, NJCM-Bulletin 10-1 (1985), pp. 57-64 met noot F.H. Kistenkas. Zie ook Rb. Arnhem 8 februari 1985, NJCM-Bulletin 10-4 (1985), p. 303. Overigens maakt het wederrechtelijke karakter in de hier in het geding zijnde strafbepalingen wèl deel uit van de delictsomschrijving. Niet duidelijk is of en zoja, hoe dat in deze zaken van belang is geweest voor het oordeel van de rechtbank dat er van de mogelijkheid tot plakken geen gebruik van enige betekenis overblijft.

306 Zie noot 305.

307 Rb. Haarlem, in: HR 5 januari 1988, De Gemeentestem no. 6872, nr. 5. Zie ook Kıg. Nijmegen 22 februari 1989, Praktijkgids 1989, nr. 3066, pp. 286-288. 
Het criterium dat er bij een verbod om zonder toestemming van de rechthebbende te plakken voldoende "vrije" plakmogelijkheden moeten zijn, is - ondanks dat dit oordeel van de Haarlemse rechtbank in cassatie in stand blijft - in de latere rechtspraak afgewezen. ${ }^{308}$ Dit doet er echter niet aan af, dat deze uitspraak wel een aantal nuttige handvatten biedt over hóe kan worden vastgesteld of er gebruik van enige betekenis overblijft: de omvang van de gemeente, het aantal mogelijkheden om van het verspreidingsmiddel gebruik te maken bezien naar aantal, oppervlakte en plaats. Bovendien moet het gebruik van het verspreidingsmiddel "reëel" zijn. De Meij stelt ten aanzien van dit begrip "reëel gebruik" dat dit een positievere benadering inhoudt dan het Nuth-criterium "gebruik van enige betekenis" omdat bij dit laatste begrip het aanplakken slechts een restpost is, terwijl bij de termen "reëel gebruik" de vrije aanplakmogelijkheden juist als uitgangspunt worden genomen. Op zich lijkt mij deze opvatting juist, maar voor de afbakening van de reikwijdte van artikel 7 biedt het begrip "reëel gebruik" niet meer houvast dan het Nuth-criterium, omdat het niet minder vaag is dan het laatstgenoemde criterium. ${ }^{309}$ Hoewel deze zaak - gezien de afwijzing van de maatstaf van de "vrije" plakmogelijkheden in latere uitspraken - geen soelaas biedt in zaken met betrekking tot een verbod om zonder toestemming van de rechthebbende te plakken, de verdachte moet immers nog steeds aannemelijk maken dat er onvoldoende mogelijkheden tot plakken op particulier onroerend goed zijn, biedt het wel inzicht in de wijze van toetsen door de rechter, indien de verdachte daar wel in slaagt. Ook kan het uitkomst bieden in zaken waarin het gaat om beperkingen op ander verspreidingsmiddelen. ${ }^{310} \mathrm{Met}$ name de verwijzing in deze zaak naar de oppervlakte en plaats van de plakmogelijkheden duidt ook op een kwalitatieve toetsing van de mogelijkheden tot gebruik van het verspreidingsmiddel." In dit opzicht zijn de uitspraken van de Middelburgse en Haagse rechtbank-presidenten inzake straatverboden bij abortusklinieken teleurstellend. ${ }^{32}$ In beide zaken gaat het om een groepje personen, dat via diverse - soms zelfs agressieve middelen tracht de werkzaamheden van de desbetreffende kliniek stil te leggen en patiënten van het ondergaan van een abortus te weerhouden.

308 Expliciet HR 17 oktober 1989. NJ 1990. 222. In deze richting wees ook eerder al HR 25 september 1989. NJCM-Bulletin 14-8 (1989), pp. 950-952 met noot R.E. de Winter, VgI. R.E. de Winter, De heersende leer, p. 232.

309 J.M. de Meij, De feitelijke mogelijkheid tot vrije meningsuiting, p. 17 (I.k.).

310 Over deze andere verspreidingsmiddelen is veel minder jurisprudentie. Het gros van de uitspraken betreft plakverboden.

311 Vgl. R.E. de Winter, De heersende leer, p. 213.

312 Pres.Rb. Middelburg 29 januari 1990. KG 1990, 81: Pres.Rb. 's-Gravenhage 14 december 1990, NJCM-Bulletin 16-2 (1991), pp. 128-134 met noot R.E. de Winter. 
Deze acties hebben een dusdanige weerslag op de psychische gesteldheid van de patiënten, dat zij soms niet in staat zijn daarna de ingreep te ondergaan. Bovendien is de gang van zaken in de desbetreffende kliniek verstoord. Eiseres, de Stichting voor Medisch Verantwoorde Zwangerschapsonderbreking (STIMEZO) acht de acties onrechtmatig en vordert in kort geding dat aan gedaagden (de actievoerders) een straatverbod wordt opgelegd. In beide zaken wordt de vordering toegewezen. Hoewel in beide zaken getoetst wordt aan de vrijheid van meningsuiting, wordt daarbij niet het criterium van het "gebruik van enige betekenis" gehanteerd; de gebruikte argumenten kunnen mijns inziens wel in het licht van dit criterium beschouwd worden. De Middelburgse President constateert "dat een verbod zich in de omgeving van de kliniek op te houden voor gedaagde op zichzelf (afgezien van de mogelijkheid op deze wijze bezoekers van de kliniek te beïnvloeden) geen hinderlijke beperking van hun vrijheid inhoudt." De Haagse President bepaalt hieromtrent dat met een dergelijk verbod "wellicht ... hiermee in de ogen van gedaagden het protest aan effectiviteit (zal) inboeten, maar van een wezenlijke aantasting van enig hen toekomend recht is geen sprake". Deze overwegingen zou men kunnen interpreteren in die zin dat volgens de betrokken Presidenten er "gebruik van enige betekenis" overblijft omdat ze hun acties wel elders kunnen voeren. Dit miskent mijns inziens dat het voeren van deze acties voor gedaagden juist bij die kliniek zeer wezenlijk zal zijn. Hun doel was immers het beïnvloeden van de patiënten van de kliniek en door het straatverbod wordt dat onmogelijk gemaakt. Het actievoeren op een andere plek zal de gedaagden in dit opzicht vermoedelijk niet veel soelaas bieden. ${ }^{313}$

Er valt naar mijn mening veel voor te zeggen in een dergelijk geval een kwalitatieve toetsing toe te passen: dan kan er rekening mee worden gehouden in welke mate het van belang is dat het gebruik van een verspreidingsmiddel op een bepaalde plaats (of een bepaald tijdstip) plaatsvindt. De rechtspraak biedt voor een dergelijk standpunt echter te weinig aanknopingspunten. ${ }^{314}$

313 Zie ook R.E. de Winter. De heersende leer, pp. 242-243. De Winter doet hier de suggestie om, in een geval als in de zojuist besproken zaken, het actievoeren op een bepaalde plaats als een zelfstandig verspreidingsmiddel aan te merken. In dat geval zouden de onderhavige straatverboden een algemeen verbod in houden, dat strijdig is met artikel 7. Zie wat betreft het preventieve karakter van het stratverbod, hierboven paragraaf 6.2.2.9.

314 In de STIMEZO-zaken had de President wellicht het beroep op artikel 7 kunnen afwijzen op de grond "misbruik van recht". Zie hierover paragraaf 7.2.6. 
Tot dus ver ging het om de interpretatie van het begrip "gebruik van enige betekenis" door de gewone rechter. De vraag is nu of de uitleg van dit begrip op dezelfde wijze door de administratieve rechter geschiedt. De uitspraken die ik hierover heb gevonden, betreffen allen lid 3 van artikel 7. ${ }^{315}$ Het toetsingscriterium dat in deze zaken gehanteerd wordt sluit aan op de maatstaf die reeds bij de grondwetsherziening werd genoemd: dat de beperkende voorschriften het feitelijk functioneren van het recht om door middel van zelfstandige verspreidingsmiddelen gedachten of gevoelens openbaar te maken, niet onmogelijk gemaakt mag worden. In een uitspraak van 19 januari 1987 wordt deze maatstaf gepreciseerd: ten aanzien van de feitelijke toepassing van een verbodsbepaling met ontheffingsmogelijkheid ter voorkoming van geluidshinder wordt de maatstaf aangelegd of het beleid of besluit "er ... op neer(komt) dat het gebruik van ... (het) middel van openbaarmaking van gedachten of gevoelens anders dan bij calamiteit onmogelijk wordt gemaakt." Deze formulering doet sterk denken aan die in het Nuth-arrest met betrekking tot het gebruik van enige betekenis.3.16 Niet uitgesloten kan daarom worden, dat de door de grondwetgever mogelijk geachte ontwikkeling ten aanzien van lid 3, dat - net als bij lid 1 - beperkingen niet zover mogen gaan "dat aan een (zelfstandig, CS) middel van openbaarmaking ... redelijkerwijze geen gebruik van enige betekenis wordt gelaten", zich inderdaad voordoet. ${ }^{317}$

Gezien het gegeven, dat de Afdeling rechtspraak - anders dan de Hoge Raad als cassatierechter - wel een feitelijke beoordeling van de voorgelegde zaken kan geven, is het niet verwonderlijk dat in de praktijk dan ook bij de toetsing aan artikel 7 op de concrete omstandigheden van het geval wordt gelet. De Afdeling rechtspraak (of zijn voorzitter) onderzoekt eerst de bestreden bepaling zelf op verenigbaarheid met artikel 7 en daarna afzonderlijk daarvan, de feitelijke toepassing van de bepaling. ${ }^{318}$ In deze uitspraken kan men lezen op welke feitelijke

315 ARRS 19 januari 1987, AB 1988, 58: ARRS 8 april 1988, AB 1989. 88; Vz.ARRS 17 augustus 1990, AB 1991, 44; ARRS 15 juli 1991. De Gemeentestem no. 6931, nr. 6.

316 HR 17 maart 1953, NJ 1953, 389: dat "... die beperkingen van dat middel nooit zover mogen gaan dat zij neerkomen op een in het algemeen verbieden ...". Zie hierboven in het begin van deze subparagraaf. Zie ook R.E. de Winter, De heersende leer, p. 218.

317 Nader rapport bij wetsvoorstel 13872. Verklaring dat er grond bestaat .... Tweede Kamer, in: Algehele grondwetsherziening, deel Ia Grondrechten, p. 91. Zie hierboven, pp. 3-4.

318 De Hoge Raad volgt deze stapsgewijze behandeling ook in HR 26 januari 1993, NJ 1993, 534. 
omstandigheden de Afdeling let. Echter, ook uit deze zaken kan men geen criteria afleiden ter nadere afbakening van het begrip "gebruik van enige betekenis" - of wat betreft lid 3 - van de termen "het niet onmogelijk maken van het feitelijk functioneren" van het verspreidingsmiddel.

In sommige zaken komt de Afdeling overigens niet aan deze feitelijke toetsing toe, omdat de beleidslijn - waarop de bestreden beslissing wordt gebaseerd - niet blijkt uit enig beleidsdocument of ander schriftelijk stuk. In deze gevallen wordt de weigering van de ontheffing gebaseerd op strijd met het motiveringsbeginsel. ${ }^{319}$

In tegenstelling tot de genoemde uitspraken van de (Voorzitter van de ) ARRS, blijkt uit een uitspraak van de Centrale Raad van Beroep van 12 november 1985 die ik omtrent het begrip "gebruik van enige betekenis" heb gevonden, nauwelijks dat op feitelijke omstandigheden is gelet. In deze zaak - waarin het gaat om het ophangen van een affiche voor het raam van een gerechtsgebouw door een aldaar werkzame ambtenaar - volstaat de Centrale Raad met de vaststelling dat "de bestreden beperking ... van het onderhavige verspreidingsmiddel ... binnen en vooral buiten het gerechtsgebouw vele gebruiksmogelijkheden onaangetast [laat]. " Kortmann en Hennekens merken over deze laatste vaststelling op dat "(e)en dergelijke verwijzing naar 'buiten' (neer)komt ... op een algehele 'plaatselijke' uitsluiting ..." Zou dit argument valide zijn, aldus deze annotatoren, dan zou een gemeentebestuur in het kader van een plakverbod een beroep kunnen doen op de vele "buiten de gemeente" gelegen plakmogelijkheden. Zij vragen zich mijns inziens dan ook terecht af hoe dit te rijmen is met de verspreidingsjurisprudentie. Gezien de bovenstaande behandeling van deze rechtspraak kan wellicht gesteld worden dat deze uitspraak níet met de verspreidingsjurisprudentie te rijmen valt. ${ }^{320}$

Samenvattend kan worden gesteld, dat in de rechtspraak geen nadere afbakening wordt gegeven van het begrip "gebruik van enig betekenis". Dit kan verklaard worden uit het feit dat de Hoge Raad slechts sporadisch

319 Vz.ARRS 17 augustus 1990, AB 1991, 44; ARRS 15 juli 1991, De Gemeentestem no, 6931, nr. 6.

320 Zie in dit verband ook $R$. de Winter, Verwijdering van vreemdelingen en spandoeken, p. 122 r.k..

CRvB 12 november 1985, AB 1986, 579 met noot C.A.J.M. Kortmann en H.Ph.J.A.M. Hennekens; NJCMI-Bulletin 11-2 (1986), pp. 157-163 met noot $F . H$. Kistenkas; reactie R.E. de Winter, in: NJCM-Bulletin 11-3 (1986), pp. 237-238; reactie daarop F.H. Kistenkas, in: NJCM-Bulletin 11-5 (1986), pp. 449-451. Zie voorts R.E. de Winter, De heersende leer, pp. 215-216 en S. Zwemstra, Bescherming van uitingsrechten door administratieve rechters, pp, 196-205. 
aan dit begrip toetst, omdat de toetsing van feitelijke omstandigheden tot de taken van de lagere (feiten-)rechters behoort, wier oordeel de Hoge Raad in cassatie heeft te eerbiedigen. De lagere rechters hebben het onderhavige begrip ook niet nader ingevuld. ${ }^{321}$ Ook wordt in deze uitspraken nauwelijks aangegeven op welke factoren gelet wordt bij de toetsing aan het begrip "gebruik van enige betekenis". Uitzondering hierop is de uitspraak van de Rechtbank Haarlem die een aantal voorbeelden biedt van hoe aan het onderhavige begrip zou kunnen worden getoetst: de rechtbank let in zijn beoordeling op de omvang van de gemeente, het aantal mogelijkheden om van het verspreidingsmiddel gebruik te maken bezien naar aantal, oppervlakte en plaats. Mij zijn geen uitspraken bekend waarin even expliciet aan feitelijke omstandigheden wordt getoetst. Naar mijn mening zouden deze factoren echter wel door de rechter in zijn oordeel moeten worden betrokken. Met name in geval van verboden, waarbij het aan de verdachte is om aannemelijk te maken dat er onvoldoende gebruiksmogelijkheden van het middel overblijven (in geval van een beroep op een rechtvaardigingsgrond) is het noodzakelijk dat de rechter expliciet toetst, omdat de verdachte toch al in een nadelige positie verkeert vanwege de op hem rustende "stelplicht". Anders dreigt het verspreidingsrecht te worden uitgehold. De mogelijkheden voor een verdachte om dit aannemelijk te maken zijn immers zeer beperkt. Een kwalitatieve toetsing is hier mijns inziens op zijn plaats. Een welwillende opstelling van de rechter lijkt mij met name gewenst nu - zoals in de rechtspraak (althans de administratieve) is geconstateerd - een grote mate van zorgvuldigheid betracht moet worden aangezien een grondrecht in het geding is..$^{32.323}$ Of een andere aanpak van de rechter bij de toetsing aan

321 Hierop bestaan een aantal uitzonderingen met als aanvoerder de Haarlemse rechtbank (zie in: HR 5 januari 1988. De Gemeentestem no. 6872, nr. 5). Zoals gezegd zijn deze uitspraken door latere jurisprudentie achterhaald.

322 Zie Vz.ARRS 17 augustus 1990, AB 1991. 44: "... dat, nu het hier de uitoefening van een grondrecht betreft, verweerders bij hun besluitvorming een grote mate van zorgvuldigheid in acht dienden te nemen." Mijns inziens dienen niet alleen B en W een grote mate van zorgvuldigheid in acht te nemen, maar ook de rechter.

323 Andersom dient ook bij de uitoefening van dit grondrecht de nodige zorgvuldigheid betracht worden in verband met de belangen van anderen: Gerechtshof Arnhem 25 juli 1989, KG 1989, 323 (persbericht politie m.b.t. strafrechtelijk onderzoek): Rh. Haarlem 12 april 1983, NJ 1987, 339; HR 4 maart 1988, NJ 1989, 361 met noot CJHB (i.v.m. persoonlijke levenssfeer van "public figures"); Gerechtshof Ansterdam 10 maart 1983, NJ 1984, 352: Pres.Rb. Amsterdam 6 februari 1986, KG 1986. 118 (uitlatingen tijdens verkiezingsstrijd); HR 24 juni 1983, NJ 1984. 801 met noot MS; HR 27 januari 1984. NJ 1984, 802 en 803 met noot CHJB; Pres.Rb. Amsterdam 18 oktober 1984. KG 1984, 320; Pres.Rb. Middelburg 5 december 1984, KG 1985, 18; HR 8 maart 1985, 1986, 437, waarin een uitleg van HR 24 juni 1983, met noot 
artikel 7 te verwachten valt, is echter gezien de consistentie in de bovenstaande uitspraken zeer twijfelachtig.

De Afdeling Rechtspraak toetst (in casu ten aanzien van lid 3), anders dan de Hoge Raad, wél de feitelijke omstandigheden. Uit de genoemde uitspraken valt echter geen leidraad voor andere zaken te ontlenen vanwege het casuïstische karakter van de toetsing in die zaken. De Afdeling Rechtspraak geeft ook geen nadere afbakening van het begrip "gebruik van enige betekenis".

\subsubsection{Samenvatting}

De voorgaande behandeling van de diverse onderdelen van artikel 7 leden 1 en 3 levert het volgende beeld op van de afbakening van de reikwijdte van het in deze leden gegarandeerde recht:

Het begrip gedachten of gevoelens wordt niet door middel van een criterium afgebakend. Uit de kamerstukken naar aanleiding van de grondwetsherziening blijkt wel dat volgens de regering onder "gevoelens" zowel opinies als gemoedsbewegingen verstaan kunnen worden. Bovendien wordt ook het geven van inlichtingen onder artikel 7 begrepen, in die zin, dat dit niet het geval is indien het geven van inlichtingen zo buiten de sfeer van het artikel gelegen kan zijn, dat het oneigenlijk zou zijn wanneer deze bepaling toch zou worden toegepast. Het voorbeeld dat de regering hier geeft is produktinformatie op de verpakking ervan. Overigens is niet duidelijk wat de regering onder "oneigenlijk" verstaat. Lid 4, dat handelsreclame van de bescherming van de voorgaande leden uitsluit, biedt geen uitweg uit eventuele afbakeningsproblemen, anders dan de grondwetgever suggereert. Uit de kamerstukken en een enkele uitspraak van de Afdeling Rechtspraak volgt namelijk dat ook in handelsreclame "gedachten of gevoelens" kunnen worden geopenbaard. Wat onder handelsreclame verstaan moet worden is everigens niet duidelijk: de in de Memorie van Toelichting voorgestelde grens tussen reclame voor cornmerciële doeleinden en ideële reclame is niet scherp te trekken. Kortom, het begrip "gedachten of gevoelens" heeft een groot bereik, maar een duidelijke afbakening komt niet uit de rechtspraak naar voren.

CHJB; Pres.Rb. Maastricht 1 april 1985, NJ 1985, 618; e.a. waarvan recentelijk Pres.Rb. Utrecht 16 april 1993, KG 1993.223 en HR 21 januari 1994, NJ 1994, 473 (beschuldigingen en andere openbaarmakingen in de pers). Zie voorts $\boldsymbol{R}$. Pagano, Recht op TV, Een onderzoek naar de toelating van televisie-camera's tot de openbare rechtszitting, dissertatie Rotterdam 1992, Gouda Quint bv: Arnhem 1992 (met name hoofdstukken 3 en 4). 
Waar - in het kader van lid 1 - de grens ligt tussen het openbaringsreci en het verspreidingsrecht kan slechts met grote voorzichtigheid uit d rechtspraak worden afgeleid, want het aantal uitspraken hieromtrent is zee gering. Uit een uitspraak van het Gerechtshof Amsterdam van 1984 zo men kunnen afleiden, dat het ontwikkelen, koesteren en voor niet openbaa gebruik vastleggen van gedachten en gevoelens van welke inhoud dan ook evenals het in beperkte kring van personen verspreiden van gedrukte 0 geschreven stukken waarin die inhoud is vastgelegd, niet beperkt ka worden, ook niet repressief. Hier zou men dan zeker nog moeten sprekes van het openbaringsrecht. In combinatie met twee uitspraken van de Hogi Raad in de Bluf!-zaken, zou de grens tussen openbaren en verspreider kunnen worden getrokken tussen het moment van het in druk of geschrif vastleggen van de inhoud van gedachten of gevoelens en eventueel het if beperkte kring verspreiden van die stukken enerzijds en het verspreider ervan (in niet-beperkte kring) anderzijds. Wellicht kan uit de uitspraak var het Gerechtshof Amsterdam nog afgeleid worden dat de bedoeling tot he verspreiden van de stukken als grens tussen het openbaringsrecht en he: verspreidingsrecht kan fungeren.

Een duidelijke grens tussen inhoud en vorm van het geopenbaarde in verbana met artikel 7 lid 3 valt uit de rechtspraak niet af te leiden. Volgens de kamerstukken bij de grondwetsherziening is het begrip "inhoud" een objectief begrip, wat wil zeggen dat het datgene bestrijkt wat "in het algemeen" tot de inhoud wordt gerekend. Normaal gesproken is dat datgene wat wordt geuit, en niet het tijdstip, de plaats en de wijze waarop de gedachten of gevoelens geuit worden. Maar bij artistieke uitingen kan de vormgeving ook onder het begrip "inhoud" vallen. Met een dergelijke verwijzing naar wat in het algemeen tot de inhoud wordt gerekend, reikt de grondwetgever een uitermate vaag criterium aan voor het afbakenen van de term "inhoud".

Uit de jurisprudentie kan geen duidelijk criterium worden afgeleid, voor de vaststelling of sprake is van een zelfstandig middel van bekendmaking in de zin van de leden 1 en 3 van artikel 7 . Het enige criterium dat ik ben tegengekomen, reeds in een uitspraak van 1967, betreft de functie die een middel in het maatschappelijk verkeer heeft. Dit criterium is uitermate vaag en kan de rechter maar beperkt richting geven bij de toetsing of een bepaald verspreidingsmiddel door lid 1 of lid 2 bestreken wordt.

Wat betreft het algemeen verbod: hieronder meen ik een absoluut verbod van het gebruik van een bepaald verspreidingsmiddel te moeten verstaan. Veel komen dit soort verboden niet voor. Veelal draait het om de vraag of een bepaalde beperking neerkomt op een algemeen verbod, derhalve of et nog sprake is van "gebruik van enige betekenis" van het desbetreffende verspreidingsmiddel. 
Ten aanzien van het voorafgaand verlof meen ik uit de rechtspraak te kunnen afleiden, dat het afhankelijk stellen van voorafgaand verlof van de overheid (dus niet van particuliere rechthebbenden) voor het gebruik van een zelfstandig verspreidingsmiddel via vergunningen- of ontheffingsstelsels in het algemeen - dat wil zeggen voor het gehele territoir van een gemeente of gedurende 24 uur per etmaal - niet is toegestaan. Wel is het naar mijn mening toegestaan voorafgaand verlof (toestemming) te eisen indien deze voorwaarde niet in het algemeen wordt gesteld, maar er bepaalde uitzonderingen gelden: bijvoorbeeld wordt ten anzien van bepaalde delen van de bebouwde kom geen voorafgaande toestemming geëist, of worden in die delen waar dat wel wordt geëist toch nog vrije aanplak- of verspreidingsmogelijkheden gecreëerd. Of wordt de verspreiding op bepaalde uren van de dag wél zonder voorafgaand verlof toegestaan. Deze uitzonderingen moeten dan wel nog gebruik van enige betekenis van het verspreidingsmiddel zonder voorafgaand verlof overlaten. Ook moet daar waar voorafgaand verlof van de overheid als voorwaarde voor het gebruik van een zelfstandig verspreidingsmiddel wordt gesteld, gebruik van enige betekenis van dat middel bestaan. Dat wil zeggen dat het aantal gevallen waarin een vergunning of ontheffing wordt verleend voldoende moeten zijn om van "gebruik van enige betekenis" te kunnen spreken.

Wanneer is er nu sprake van gebruik van enige betekenis? De jurisprudentie biedt voor de uitleg van dit begrip nauwelijks aanknopingspunten. De Hoge Raad kan zelf niet aan dit criterium toetsen omdat het gaat om een toetsing van feitelijke omstandigheden. Maar ook de lagere rechters geven nauwelijks aan op welke factoren gelet moet worden bij de toetsing aan het begrip "gebruik van enige betekenis". Een uitzondering hierop is de Rechtbank Haarlem die in een uitspraak een aantal voorbeelden biedt van hoe aan het onderhavige begrip zou kunnen worden getoetst: de rechtbank let in zijn beoordeling op de omvang van de gemeente, het aantal mogelijkheden om van het verspreidingsmiddel gebruik te maken bezien naar aantal, oppervlakte en plaats. Ik ken geen uitspraken waarin even expliciet aan feitelijke omstandigheden wordt getoetst. Ik ben van mening dat deze factoren wel door de rechter in zijn oordeel zouden moeten worden betrokken.

De Afdeling Rechtspraak toetst (in casu ten aanzien van lid 3), anders dan de Hoge Raad, wél de feitelijke omstandigheden. Uit de jurisprudentie van de Afdeling valt echter ook geen criterium voor andere zaken af te leiden vanwege het casuïstische karakter van de toetsing in die zaken. De Afdeling Rechtspraak geeft ook geen nadere afbakening van het begrip "gebruik van enige betekenis". 
Concluderend kan worden vastgesteld, dat in de rechtspraak naar aanleiding van artikel 7 lid 1 en lid 3 nauwelijks sprake is van een nadere afbakening van de in het geding zijnde recht. De criteria die in deze paragraaf zijn onderzocht, zijn in zekere zin al de uitkomst van de begrenzing van de vrijheid van meningsuiting in de jurisprudentie naar aanleiding van artikel 7-oud. Deze uitermate vage begrippen, die door de grondwetgever in 1983 zijn behouden ten aanzien van het huidige artikel 7 lid 1 en ook deels zijn overgenomen met betrekking tot lid 3, behoeven echter nadere invulling. Zoals gezegd, gebeurt dit in de jurisprudentie slechts sporadisch.

\subsubsection{Artikel 9 lid 1 Grondwet}

De rechten in artikel 9 Grondwet zijn als volgt geformuleerd:

1. Het recht tot vergadering en betoging wordt erkend, behoudens ieders verantwoordelijkheid volgens de wet.

2. De wet kan regels stellen ter bescherming van de gezondheid, in het belang van het verkeer en ter bestrijding of voorkoming van wanordelijkheden.

Ook ten aanzien van artikel 9 Grondwet geldt, dat er weinig jurisprudentie ten aanzien van deze bepaling beschikbaar is, met name met betrekking tot lid 1. Dit betekent dat ten aanzien van de afbakening van het in artikel 9 gegarandeerde recht in de jurisprudentie slechts voorzichtige conclusies zullen kunnen worden getrokken. Hiertoe zal allereerst ingegaan worden op de vraag aan wie het in artikel 9 geformuleerde recht toekomt. Daarna zal ingegaan worden op het begrip vergadering en de reikwijdte van het vergaderrecht en vervolgens op de term betoging en de reikwijdte van het betogingsrecht. Tenslotte zal ingegaan worden op een afwegingsvraagstuk dat cruciaal is in verband met het betogingsrecht: dat van de "hostile audience". Hoewel dit vraagstuk meestal geplaatst wordt in de context van lid 2 bij de beperking van het in het eerste lid gewaarborgde recht, met name in verband met de beperkingsgrond "ter bestrijding of voorkoming van wanordelijkheden", is deze materie ook van belang voor de reikwijdte van het in lid 1 opgenomen recht op betoging. Uit dit vraagstuk kan men namelijk een zorgplicht voor de overheid afleiden, die de reikwijdte van het betogingsrecht verruimt. 
6.2.3.1 Wie komt het recht op vergadering en betoging toe?

Anders dan bij de artikelen 1 ("Allen"), 6 ("Ieder") en 7 ("Niemand") kan uit de formulering van artikel 9 lid 1 zelf niet afgeleid worden aan wie het vergader- en betogingsrecht toekomt. Op grond van de geiding van het gelijkheidsbeginsel dient mijns inziens ervan te worden uitgegaan, dat het recht in principe aan een ieder toekomt. ${ }^{324}$ Dit wordt bevestigd in de Memorie van Toelichting, waarin - zoals reeds bij de bespreking van artikel 7 werd opgemerkt - het standpunt wordt ingenomen dat "dat de grondwettelijke grondrechten voor een ieder gelden, ongeacht zijn verhouding tot de overheid ...". Ook ten aanzien van artikel 6 geldt derhalve dat personen in een bijzondere rechtsverhouding (zoals ambtenaren, militairen en gedetineerden) een beroep op artikel 9 kunnen doen. ${ }^{325}$ Tevens meen ik dat, net als ik naar voren bracht ten aanzien van artikel 7, bij artikel 9 moet gelden dat op personen in bepaalde functies een zwaardere verantwoordingsplicht zal rusten bij de uitoefening van de in artikel 9 gewaarborgde rechten, met name het betogingsrecht. Dit geldt met name voor ambtenaren en militairen. ${ }^{126}$ Bovendien zullen de rechten in artikel 9 - niet in dezelfde mate als gewone burgers - kunnen worden uitgeoefend door gedetineerden. De mogelijkheid tot beperking van de rechten van gedetineerden is terug te voeren tot artikel 15 lid 4 Grondwet. ${ }^{327}$ Het gaat hier om - niet verder te bespreken beperkingskwesties.

Steun voor de opvatting dat de door artikel 9 beschermde rechten aan een ieder toekomen wordt bevestigd door een uitspraak van de President van de Haagse rechtbank van 9 juni 1987. ${ }^{328}$ In deze zaak gaat het om de weigering van het Congresgebouw om een zaal te verhuren aan de Stichting "Nederlands Zuid-Afrikaanse Werkgemeenschap" voor de viering

324 Zo ook C.A.J.M. Kortmann, De grondwetsherzieningen van 1983 en 1987, pp. 9091 .

325 Memorie van Toelichting bij wetsvoorstel 13872. Verklaring dat er grond bestaat .... Tweede Kamer, in: Algehele grondwetsherziening, deel Ia Grondrechten, p. 11.

326 Zie over dit onderwerp een artikel van voor de grondwetswijziging: J.A. Peters, De zaak Kalma en de vrijheid van meningsuiting, pp. 369-377. Zie voorts: artt. 33 en 34 Wet militair tuchtrecht (wet van 14, juni 1990, Stb. 1990, 367) en artikel 125a Ambtenarenwet.

327 Zie over dit onderwerp opnieuw een artikel van voor de grondwetswijziging: $M . B . W$. Biesheuvel en J.A. Peters, Rechten van gedetineerden: heeft de rechter een eigen cliêntèle?, pp. 1045-1054.

328 Pres.Rb. 's-Gravenhage 9 juni 1987. KG 1987, 268. Bevestigd in Gerechtshof 'sGravenhage 1 oktober 1992, NJCM-Bulletin 18-3 (1993) met noot $\boldsymbol{A}$.W. Heringa, pp. 299-302. 
van "Geloftedag". Bij de vordering in kort geding waarbij onder meer geëist wordt dat gedaagde wordt bevolen een zaal voor eiseres te reserveren, doet de Stichting (eiseres) een beroep op, onder andere, artikel 9 Grondwet. De President bepaalt ten aanzien van dit beroep, dat het er bij een beoordeling van het beroep niet toe doet of de Stichting schendingen van grondrechten in Zuid-Afrika toejuicht of goedpraat. "De Verdragen en de Grondwet maken geen onderscheid tussen burgers, ook niet naar hun opvattingen. Grondrechten heeft iedereen. Rechtsbescherming tegen inbreuken genieten in een dennocratische samenleving ook burgers met controversiële opvattingen. " Het wordt door de President bovendien niet van belang geacht dat in dit geval een beroep op artikel 9 gedaan wordt door een rechtspers.oon. Uit deze uitspraalk blijkt derhalve, dat de Haagse President van opvatting is dat, onder meer, het recht op vergadering aan een ieder toekomt. Andere uitspraken hieromitrent heb ik niet gevonden.

\subsubsection{Het begrip "vergadering" en de reikwijdte van het vergaderrecht}

Het begrip "vergadering" wordt noch in de toelichtende stukken bij de grondwetsherziening, noch in de rechtspraak nader gedefinieerd. In de Memorie van Toelichting wordt - nota bene bij de bespreking van de verenigingsvrijheid in artikel 8 - slechts ten aanzien van vergadering en betoging opgemerkt, dat het gaat om het daadwerkelijk bijeenkomen van een aantal mensen in beslotenheid of in het openbaar. ${ }^{329}$ Deze overweging duidt erop, dat het gaat om een recht dat slechts door meerdere personen (twee of meer) uitgeoefend kan worden. In je eentje kun je niet vergaderen of betogen; een vergadering is een collectief gebeuren. ${ }^{330}$ Bovendien kan een dergelijke bijeenkomst blijkens de Memorie van Toelichting zowel in beslotenheid als in het openbaar plaatsvinden. Terecht wordt door Akkermans hieromtrent opgemerkt, dat het gegeven de huidige

329 Memorie van Toelichting bij wetsvoorstel 13872, Verklaring dat er grond bestaat.... Tweede Kamer, in: Algehele grondwetsherziening, deel la Grondrechten, p. 38.

$330 \mathrm{Vgl}$. A.E. Schilder, Het recht tot vergadering en betoging. Pp. 25-27. Zo ook: de Memorie van Toelichting bij wetsvoorstel 19427. Wet Openbare Manifestaties (verder aangehaald als WOM), Tweede Kamer, p. 8 en de Mernorie van Antwoord bij hetzelfde wetsvoorstel, p. 13. De WOM (wet van 20 april 1988, Stb. 1988, 157) is op 27 april 1988 in werking getreden. Zie echter de volgende uitzondering die in de Memorie van Toelichting bij de WOM wordt gemaakt: "Daarom zijn onder de term 'manifestaties' ... alleen die individuele vormen van belijdenis begrepen, die een sterk publiekgericht karakter hebben ... en daardoor nauwe verwantschap vertonen met collectieve bijeenkomsten." 
technologische mogelijkheden niet noodzakelijk is dat deelnemers aan een vergadering fysiek bijeenkomen: vergaderingen via telefoon en andere communicatiemiddelen zijn ook mogelijk. ${ }^{331}$

Meer valt uit de toelichtende stukken bij de grondwetsherziening omtrent het vergaderrecht niet op te maken. Hiertoe zullen andere bronnen moeten worden geraadpleegd. Zo valt uit een wetsontwerp van 1850 - dat overigens nooit wet geworden is - op te maken dat "het recht der ingezetenen tot vergadering ... hun bevoegdheid (is) tot het beleggen en bijwonen van bijeenkomsten ter gemeenschappelijke beraadslaging of gemeenschappelijke handeling." In de Memorie van "Beantwoording" bij dit wetsontwerp wordt voorts opgemerkt dat "(b)ijeenkomsten van gezellig verkeer of ter bijwoning van openbare vermakelijkheden" niet onder dit recht vallen. ${ }^{332} \mathrm{Om}$ te kunnen spreken van een vergadering moet het doel van de bijeenkomst blijkens dit oude wetsontwerp derhalve zijn gelegen in "gemeenschappelijke beraadslaging of gemeenschappelijke handeling". Een zomaar bij elkaar komen van een groep personen voor de gezelligheid is in deze visie geen vergadering. Schilder merkt - mijns inziens terecht dienaangaande op, dat deze opvatting ook heden ten dage nog opgeld doet. Een - zij het vage - aanwijzing hiervoor bevat een uitspraak van de Afdeling Rechtspraak van 8 januari 1988. ${ }^{33}$ Tegen de sluiting van een bordeel werd een beroep gedaan op de artikelen 8 en 9 Grondwet. De Afdeling overwoog hieromtrent dat het in deze bepalingen gegarandeerde recht tot vereniging en vergadering "niet aan de orde (is) in een geval als het onderhavige waar het gaat om de vestiging van een inrichting." Niet ieder samenkomen valt derhalve onder artikel 9. De Afdeling geeft echter niet aan, wat wèl onder een vergadering moet worden verstaan.

Bij de grondwetsherziening van 1983 wordt over een bepaald doel van een bijeenkomst als voorwaarde voor het bestaan van een vergadering niets gezegd, maar uit de Memorie van Toelichting bij het wetsvoorstel voor de Wet Openbare Manifestaties blijkt dat de regering van opvatting is dat het moet gaan om "gemeenschappelijke beraadslaging, in de vorm van discussie en eventueel besluitvorming, over een bepaald onderwerp ... Doorgaans zal dit onderwerp ... van politieke of maatschappelijke aard zijn." De vergadering is volgens de regering vooral gericht op interne

331 P.W.C. Akkermans, Artikel 9 Grondwet, p. 210.

332 Ontleend aan A.E. Schilder. Het recht tot vergadering en betoging, p. 14, die op zijn beurt weer verwijst naar H.Y. IJzonides, Het recht van vergadering, dissertatie Utrecht 1938. p. 11 en pp. 30-31.

333 ARRS 8 januari 1988, AB 1988, 417. Vgl. ook een oude uitspraak besproken door Schilder: HR 7 maart 1871, Weekblad van het Recht 1871, 3386 en 3387. Zie voor deze uitspraak en de commentaren erop bij $A . E$. Schilder, Het recht tot vergadering en betoging, pp. 28-32. 
menings- en besluitvorming. ${ }^{34}$ Hiermee is de opvatting van Schilder in overeenstemming, dat de meningsuiting geen noodzakelijke voorwaarde voor het bestaan van een vergadering vormt. ${ }^{335}$ Hij gebruikt hier het voorbeeld van het organiseren van een bepaalde activiteit waarvan de technische aspecten onderwerp van bespreking, op de vergadering, vormen. Schilder is echter ook van mening, dat beraadslagingen niet vereist zijn voor het bestaan van een vergadering: hij wijst op een "zwijgende meeting". Mij ontgaat echter waarom hier nog sprake zou zijn van een vergadering; wellicht zou men eerder van een demonstratieve bijeenkomst moeten spreken, die onder het betogingsrecht zou kunnen vallen? Dit zou mijns inziens meer in overeenstemming zijn met het doelvereiste van een vergadering zoals dat in de Memorie van Toelichting bij de WOM is geformuleerd.

Schilder doet voorts nog een aantal bruikbare suggesties voor de afbakening van het recht tot vergadering. Volgens hem moet er tussen de deelnemers aan een vergadering een bepaalde, door hen beoogde, band bestaan. ${ }^{336}$ Mijns inziens doelt hij erop dat bij het samenkomen van een aantal "loslopende" personen, die niets met elkaar van doen hebben, geen sprake kan zijn van een vergadering. Wellicht ontstaat de beoogde band tussen de deelnemers aan een bijeenkomst uit een gemeenschappelijke interesse in het doel van de vergadering? Akkermans stelt dienaangaande dat de bedoelde band slechts een hele lichte kan zijn. Hij wijst erop dat degenen die op een voor belangstellenden toegankelijke vergadering op de publieke tribune plaatsnemen, zich onder omstandigheden ook op het vergaderrecht kunnen beroepen (bijvoorbeeld bij verstoring van de vergadering door derden). ${ }^{337}$

Voorts behoeft volgens Schilder de bijeenkomst niet per se van tevoren georganiseerd te zijn. Een vergadering kan zijns inziens ook ter plekke ontstaan. Hoe het ook zij, de rechtspraak geeft over al deze punten (het doelvereiste, de aard van het doel, de band tussen de deelnemers, voorafgaande organisatie e.d.) geen uitsluitsel.

334 Memorie van Toelichting bij wetswoorstel 19427. WOM. Tweede Kanter, p. 8. Zie ook P.W.C. Akkermans, Artikel 9 Grondwet, p. 211.

335 A.E. Schilder, het recht tot vergadering en betoging, p. 32 . Zo ook: P.J. Boon, Zonder voorafgaand verlof, p. 40 , noot 16 .

336 A.E. Schilder, Het recht tot vergadering en betoging, p. 32.

337 P.W.C. Akkermans, Artikel 9 Grondwet, p. 211. 
Interessante uitspraken ten aanzien van het recht tot vergadering zijn twee arresten van de Hoge Raad van 25 juni 1982. ${ }^{\text {ss }}$ In deze beslissingen wordt letterlijk uitgesproken, dat het verschaffen van vergaderruimte en andere vergaderfaciliteiten onderdeel van het vergaderrecht uitmaken, indien deze noodzakelijk zijn voor de uitoefening van dit recht. In deze zaken gaat het om een puur verticale rechtsverhouding tussen de overheid en personen in een bijzondere rechtspositie: gedetineerden. Zoals eerder gezegd komt aan gedetineerden ook het vergaderrecht toe, maar kan dit recht worden beperkt waar dit zich niet met de vrijheidsbeneming verdraagt. De Hoge Raad heeft bepaald, dat een besluit van de directeur van een Huis van Bewaring - waarbij een verzoek on dergelijke vergaderfaciliteiten wordt afgewezen - als een zodanige beperking valt aan te merken. Dit overweegt de Hoge Raad echter, nadat is overwogen, dat in cassatie mag worden aangenomen, dat de bedoelde faciliteiten "... in beginsel nodig zijn voor een doeltreffende uitoefening van het ook aan dezen (eiser, een vereniging van gedetineerden) toekomende ... 'recht tot vereniging en vergadering' (art. $9 \mathrm{Gw}$ ), zodat het gebruik mogen maken van die faciliteiten moet worden aangemerkt als een noodzakelijk element van dat grondrecht."

In deze zaak wordt derhalve bepaald dat het vergaderrecht in beginsel de verplichting voor de overheid omvat (het is een "noodzakelijk element") om bepaalde vergaderfaciliteiten ter beschikking te stellen ("het gebruik mogen maken van"), indien dat voor een doeltreffende uitoefening van het vergaderrecht nodig is. Hiermee is nog niets gezegd over de vraag of de overheid ook in andere situaties dan detentie, een verplichting heeft om vergaderfaciliteiten ter beschikking te stellen indien dit nodig is voor een doeltreffende uitoefening van het vergaderrecht, bijvoorbeeld in het geval een aantal mensen wil vergaderen en er in de desbetreffende gemeente geen (te huur zijnde) vergaderruimte voorhanden is. Voordat ik een poging tot beantwoording van deze vraag zal ondernemen, wil ik eerst de volgende uitspraak behandelen.

Het gaat om de al eerder aangehaalde uitspraak van de Haagse RechtbankPresident van 9 juni $1987 .{ }^{339}$ Uit deze uitspraak blijkt, dat soms uit artikel 9 Grondwet de - niet per se op de overheid rustende - verplichting tot verhuur van vergaderruimte kan voortvloeien. Het gaat in deze zaak om een weigering van het Congresgebouw om zaalruimte aan de Stichting

338 HR 25 juni 1982, A.B 1983, 37 met noot F.H. van der Burg; NI 1983, 295; HR 25 juni 1982, NJ 1983, 296 met noot E.A. Alkema. In deze zaken gaat het om artike! 9-oud Grondwet; desondanks acht ik ze ook voor het huidige artikel 9 relevant.

339 Pres.Rb. 's-Gravenhage 9 juni 1987, KG 1987, 268. 
"Nederlands Zuid-Afrikaanse Werkgemeenschap" te verhuren. Dertig procent van de aandelen van het Congresgebouw is in handen van de gemeente Den Haag, die ook vier van de acht zetels in de Raad van Commissarissen bezet, twee andere zetels zijn voor de Staat. Er is derhalve een grote invloed van de overheid op het bestuur van het Congresgebouw. In deze zaak wordt dan ook uitgegaan van de meest vergaande benaderingswijze van horizontale werking: de weigering van het Congresgebouw om een zaal aan de Stichting te verhuren wordt integraal aan de beperkingsclausule in, onder andere, artikel 9 lid 2 Grondwet getoetst. ${ }^{30}$ Geconcludeerd wordt dat de weigering van het Congresgebouw in strijd met artikel 9 Grondwet en derhalve onrechtmatig is. De vordering in kort geding - om het Congresgebouw te bevelen een zaal aan de Stichting te verhuren - wordt vervolgens toegewezen nadat is geconstateerd dat geen doelmatiger voorziening voor handen is.

De zware toetsing in deze zaak kan worden verklaard uit het feit dat er veel overheidsinvloed op het bestuur van het Congresgebouw is. ${ }^{\text {.n }}$ Vermoedelijk zal een steeds minder zware vorm van toetsing plaatsvinden naarmate de positie van de partijen gelijkwaardiger, dus horizontaler, is. Dan zal er minder gauw tot een schending van het vergaderrecht worden geconcludeerd en daarmee de verplichting tot verhuur van vergaderruimte minder gauw worden opgelegd..$^{342}$

Terugkomend op de eerder gestelde vraag of de overheid ook in andere situaties dan detentie, een verplichting heeft om vergaderfaciliteiten ter beschikking te stellen indien dit nodig is voor een doeltreffende uitoefening van het vergaderrecht: de uitspraak van de Haagse Rechtbank-President lijkt er op te wijzen, dat hoe meer invloed de overheid heeft op de ter beschikkingstelling van vergaderruimte, des te minder ruimte er bestaat om

340 Zie de Memorie van Toelichting bij wetsvoorstel 13872. Verklaring dat er grond bestaat .... Tweede Kamer, in: Algehele grondwetsherziening. deel la Grondrechten. pp. 15-16. Zie ook A.E. Schilder, Het recht tot vergadering en betoging. pp. 52-53.

341 Zie hieromtrent de uitspraak in hoger beroep: Gerechtshof 's-Gravenhage 1 oktober 1992. NJCM-Bulletin 18-3 (1993). pp. 299-302 en de annotatie bij deze uitspraak van A.W. Heringa.

342 Hierbij is van belang dat het verweer van het Congresgebouw wordt gebaseerd op mogelijke demonstraties buiten het gebouw tegen de vergadering van de Stichting. Hier speelt het vraagstuk van de "hostile audience" dat verderop in deze paragraaf nog aan de orde komt. Voorlopig wordt er hier mee volstaan, dat naarmate de overheidsinvloed op het bestuur van een verhuurder kleiner is, minder van een verhuurder verlangd kan worden op het vlak van de bescherming van het vergaderrecht van de huurder. Zie $A . E$. Schilder, Het recht tot vergadering en betoging, pp. 53-54. 
een verzoek om (de verhuur van) vergaderruimte te weigeren. Deze invloed van de overheid is logischerwijs het grootst wanneer de rechthebbenden in een afhankelijke positie verkeren, zoals in bijzondere rechtsverhoudingen. Maar ook buiten die gevallen kan er mijns inziens reden zijn een verplichting tot het ter beschikking stellen van vergaderruimte voor de overheid aan te nemen. Naar mijn mening zit - voor de beantwoording van de gestelde vraag - de crux in de termen "nodig zijn voor" (de uitoefening van het vergaderrecht) in de arresten van de Hoge Raad van 25 juni 1982. ${ }^{30}$ Hoe minder van dit soort vergaderruimte beschikbaar is, hoe moeilijker het voor verhuurders van zaalruimte wordt om een verzoek tot verhuur van die ruimte te weigeren. Dit geldt des te meer - de uitspraak van de Haagse President in acht nemend - wanneer de invloed van de overheid op het bestuur van die verhuurders groot is. Is in het geheel geen vergaderruimte - zoals hierboven bedoeld - aanwezig, dan zou wellicht op de overheid de verplichting kunnen rusten om aan deze situatie wat te veranderen. De jurisprudentie biedt hiervoor echter niet meer dan de in de zojuist behandelde rechtspraak gegeven aanknopingspunten.

\subsubsection{De term "betoging" en de reikwijdte van het betogingsrecht ${ }^{34}$}

Bij de bespreking van het vergaderrecht werd al opgemerkt dat in de Memorie van Toelichting ten aanzien van vergadering en betoging werd. gesteld dat het daarbij gaat om het daadwerkelijk bijeenkomen van een aantal mensen in beslotenheid of in het openbaar. Met betrekking tot het betogingsrecht werd door de regering daaraan toegevoegd, dat het gaat om het samenkomen van een aantal mensen bij voorkeur op de openbare weg. ${ }^{\text {.45 }}$ Verderop in de Memorie van Toelichting wordt de betoging omschreven als een middel "om, het liefst met zoveel mogelijk mensen,

343 Wellicht zouden deze woorder erop kunnen duiden dat er "gebruik van enige betekenis" van het vergaderrecht mogelijk moet zijn. Vgi. paragraaf 6.2.2.10 ten aanzien van artikel 7 .

344 Artikel 9 is met betrekking tot het recht tot betoging op 17 februari 1988 in werking getreden (additioneel artikel V Grondwet).

345 Betogingen op besloten plaatsen zullen mijns inziens tot de uitzonderingen behoren. Een voorbeeld van een dergelijke betoging zou wellicht kunnen zijn het bezetten van een niet voor een ieder toegankelijk pand. Of het gezamenlijk houden van een hongerstaking bij iemand thuis. Het lijkt mij voor het voldoen aan het hierna te vermelden doelvereiste van "in het openbaar uiting ... geven aan gevoelens of wensen op maatschappelijk en politiek gebied" wel noodzakelijk dat aan dergelijke acties ruchtbaarheid wordt gegeven. 
in het openbaar uiting te geven aan gevoelens of wensen op maatschappelijk en politiek gebied. " ${ }^{446}$ Tijdens de mondelinge behandeling van de wetsvoorstellen tot grondwetsherziening stelt de Minister van Binnenlandse Zaken vast dat het recht van betoging betekent dat "men het recht heeft om door het betogen uiting te geven aan zijn gevoelens." Het recht houdt volgens hem niet in dat men het recht heeft anderen in de uitoefening van beroep of bedrijf schade toe te brengen. De grens ligt volgens de Minister daar waar een betoging leidt "tot onaantastbare aantasting van de rechten van anderen". In het laatste geval zal sprake kunnen zijn van strafbare feiten. ${ }^{377}$ Hiermee bevestigt de Minister wat eerder al in de Memorie van Antwoord is vastgesteld ten aanzien van de reikwijdte van het betogingsrecht. Daar is als volgt aangegeven in welk geval er geen sprake meer is van een betoging: "... dat acties, waarvan de hoedanigheid van gemeenschappelijke meningsuiting op de achtergrond is geraakt en die het karakter hebben van dwangmaatregelen jegens de overheid of jegens derden, zoals dat bij blokkades van wegen en waterwegen het geval kan zijn, geen betogingen in de zin van het voorgestelde artikel 1.9 zijn." ${ }^{\text {un }}$ Schilder merkt - mijns inziens in verband met de door de regering in het hiervoor aangehaalde citaat gehanteerde term "dwangmaatregelen" terecht - op, dat blokkades in het algemeen een betoging zullen vormen en slechts buiten de reikwijdte van artikel 9 zullen vallen wanneer met die blokkades beoogd wordt "rechtstreeks een handeling of besluit ... af te dwingen." Wanneer is echter iets een dwangmaatregel? Schilder doet de suggestie dat in het geval dat het om een kort durende actie gaat, hieruit kan blijken dat het dwangelement niet op de voorgrond staat. Ook zou het volgens hem kunnen worden afgeleid uit het verband tussen de actie en het doel daarvan. Wanneer het dwangelement een middel is om het doel van de actie (bijvoorbeeld het

346 Memorie van Toelichting bij wetsvoorstel 13872, Verklaring dat er grond bestaat.... Tweede Kamer, in: Algehele grondwetsherziening, deel Ia Grondrechten, pp. 38-39. Herhaald in het Nader rapport bij wetsvoorstel 13872. Verklaring dat er grond hestaat .... Tweede Kamer, idem, p. 94 en in de Memorie van Antwoord bij hetzelfde wetsvoorstel. Tweede Kamer, p. 201. Zo ook in de Memorie van Toelichting bij wetsvoorstel 19427, WOM. Tweede Kamer. p. 8: " $\ldots$ bij de betoging gaat het om het uitdragen van gemeenschappelijk beleefde gedachten of wensen op politiek of maatschappelijk gebied."

347 Gezamenlijke mondelinge behandeling van de wetsontwerpen (13872 en 13873) door de Tweede Kamer, in: Algehele grondwetsherziening. deel Ia Grondrechten. p. 474 r.k..

348 Artikel 1.9 is het huidige artikel 9 Grondwet. CS. Memorie van Antwoord bij wetsvoorstel 13872. Verklaring dat er grond bestaat .... Tweede Kamer. in: Algehele grondwetsherziening. dee! Ia Grondrechten, pp. 201-202. Zie ook de Memorie van Toelichting bij wetsvoorstel 19427. WOM. Tweede Kamer, p. 8. 
krijgen van bekendheid van bepaalde standpunten) te bereiken en niet een doel op zich zelf, dan zou volgens Schilder geen sprake zijn van een niet door artikel 9 beschermde dwangmaatregel. Hij geeft echter ook terecht aan dat de grens tussen een beschermde betoging en een dwangmaatregel niet altijd scherp te trekken zal zijn..$^{39}$ Over deze kwestie zijn, voor zover mij bekend, geen duidelijke uitspraken door de rechter gedaan. Wel meen ik, dat het van belang is om - zoals Schilder ook doet - blokkades niet te snel van het betogingsrecht uit te sluiten. Wanneer blokkadeacties tot schade zouden leiden, dan kan hiertegen immers altijd nog op grond van de beperkingsclausules opgetreden worden.

Ook ten aanzien van de betoging meent Schilder tenslotte, dat sprake moet zijn van een beoogde onderlinge band tussen de deelnemers. Deze kan volgens hem daarin bestaan dat zij bij de betoging een gemeenschappelijk standpunt uitdragen. Ook de jurisprudentie van de Hoge Raad lijkt erop te wijzen dat een groepsverband voor het bestaan van een betoging vereist is. ${ }^{130}$

Wat voor bijeenkomsten zijn als betoging aan te merken? In de jurisprudentie zijn onder andere de volgende als betoging erkend: het rondlopen in capes waarop bepaalde leuzen zijn afgebeeld en waarbij pamfletten worden uitgedeeld ${ }^{131}$; een demonstratieve mars of optocht ${ }^{132}$; het opslaan van een tentenkamp ${ }^{35}$. Volgens de regering vallen Sinterklaasen carnavalsoptochten en bloemencorso's buiten de werkingssfeer van de WOM. Dit soort optochten verschillen naar hun aard van de optochten die vallen onder het begrip "manifestatie", dat in de wetsvoorstellen nog in artikel 1 , lid 1 van het ontwerp werd omschreven. Uitingen die tijdens dergelijke optochten worden gedaan kunnen volgens de regering wel onder de bescherming van artikel 7 Grondwet vallen. ${ }^{34}$ De regering lijkt door

349 Zo ook: C.A.J.M. Kortmann, De grondwetsherzieningen van 1983 en 1987, p. 92.

350 HR 17 fełruari 1981, NJ 1981, 299.

351 Idem.

352 HR 30 mei 1967. NJ 1968, 5: Vz.ARRS 27 mei 1982. AB 1983, 62 met noot J.H. v.d. V.: NJCM-Bulletin 8-2 (1983), pp. 141-146 met noot A. Kors; Ned.Gem. 1982, no. 31, pp. $\$ 147 / 148$ met noot M.A.C. van Egdom en J.M.H.F. Teunissen.

353 VZ.ARRS 27 mei 1982, AB 1983, 62 met noot J.H. v.d.V.. Schilder noemt nog andere voorbeelden: optochten anders dan door voetgangers, bijvoorbeeld fietsers, automobilisten of ruiters. Volgens hem is het niet relevant of de demonstranten zich voortbewegen of niet. Ook noemt hij demonstratieve handelingen anders dan optochten: het vormen van een menselijke ketting of het door een groep verbranden van een vlag. Zie A.E. Schilder. Het recht tot vergadering en betoging, p. 34.

354 Memorie van Toelichting bij wetsvoorstel 19427, WOM, Tweede Kamer, p. 8. Zo ook: de Memorie van Antwoord bij hetzelfde wetsvoorstel, idem, p. 13. 
deze verwijzing naar artikel 7 Grondwet erop te duiden, dat dit soort optochten niet alleen buiten de werkingssfeer van de WOM, maar ook buiten het bereik van artikel 6 en 9 Grondwet vallen. De argumentatie van de regering is summier en mijns inziens niet overtuigend. Verwezen wordt naar de aard van optochten die vallen onder het begrip "manifestatie". In de Memorie van Toelichting bij de WOM is het begrip betoging omschreven als "het uitdragen van gemeenschappelijk beleefde gedachten of wensen op politiek of maatschappelijk gebied." Sinterklaas en carnaval zijn van godsdienstige oorsprong en kunnen mijns inziens om die reden wel onder de deze omschrijving gebracht worden. De WOM is immers een wet die bepalingen bevat terzake van de uitoefening van onder andere de godsdienstvrijheid. Dit soort optochten vallen in dat geval ook niet buiten het bereik van artikel 6 Grondwet. Wat betreft bloemencorso's: kunst is algemeen aanvaard als een vorm van meningsuiting. Ik zie geen reden voor een andere opvatting ten aanzien van bloemencorso's. Wellicht kunnen dit soort meningsuitingen niet (althans meestal niet) gezien worden als "gedachten of wensen op politiek of maatschappelijk gebied". Het is mogelijk dat in dat geval geen sprake is van een demonstratie in de zin van de WOM; mijns inziens kan een bloemencorso echter wel een betoging zijn in de zin van artikel 9 Grondwet. Tijdens de mondelinge behandeling van de wetsvoorstellen tot grondwetsherziening hanteert de Minister van Binnenlandse Zaken namelijk een ruimere omschrijving van het recht van betoging: "het recht ... om door het betogen uiting te geven aan zijn gevoelens." Vanwege het collectieve aspect van een bloemencorso valt dit soort evenementen naar mijn mening beter onder artikel 9 Grondwet te brengen dan onder artikel 7 , zoals de regering voorstaat. ${ }^{355}$ Voor zover mij bekend zijn omtrent dit soort optochten geen rechterlijke uitspraken voor handen.

Overigens ten aanzien van de afbakening ten opzichte van artikel 7: het te koop aanbieden van (rotte) sinaasappelen waarmee demonstranten naar een kaart van Zuid-Afrika konden gooien valt onder artikel 9 en niet onder

355 Memorie van Toelichting bij wetsvoorstel 19427. WOM. Tweede Kamer. p. 8. Kortmann merkt hierover op dat de ontwerpers kennelijk geen verband (meer) zien tussen Sint Nicolaas, carnaval en godsdienst. De grondwetsherzieningen van 1983 en 1987, p. 92, noot 326. Zie ook: A.W. Heringa, Concept-voorstel van een wet openbare manifestaties, p. 158. 
artikel $7 .{ }^{136}$ Hetzelfde geldt voor het meevoeren van spandoeken "als onderdeel", "als wezenlijk element" van een betoging. ${ }^{357}$

Samenvattend: ook ten aanzien van het betogingsrecht geldt derhalve dat er sprake moet zijn van meerdere deelnemers. In de jurisprudentie is dit nooit expliciet uitgesproken, wel blijkt uit de schaarse jurisprudentie dat in bepaalde gevallen sprake is van een betoging en derhalve kennelijk het antal deelnemers daaraan voor de toepasselijkheid van artikel 9 voldoende is. ${ }^{\text {sa }}$ Hoeveel deelnemers er precies moeten zijn blijkt ook niet uit de kamerstukken, in de Memorie van Toelichting was slechts gesproken van "... het liefst met zoveel mogelijk mensen ...". In elk geval zal het, net als bij een vergadering, moeten gaan om minstens 2 deelnemers. ${ }^{159}$

Tussen de betogers moet een - beoogde - band bestaan. Ook de jurisprudentie lijkt hierop te wijzen. ${ }^{360}$

Voorts lijkt een betoging plaats te kunnen vinden op zowel besloten plaatsen als in het openbaar, alhoewel de regering voor het laatste een voorkeur uitspreekt ("bij voorkeur op de openbare weg"). In de rechtspraak is hierover, voor zover ik weet, nog geen uitspraak gedaan. Verder stelt de regering ten aanzien van het doel van de bijeenkomst een vereiste: het "in het openbaar uiting te geven aan gevoelens of wensen op maatschappelijk en politiek gebied". De jurisprudentie lijkt te bevestigen dat het moet gaan om de openbaring van gedachten en gevoelens. ${ }^{361}$ Geen sprake van een betoging is, indien een actie beoogt iets van de overheid of derden af te dwingen (het dwangelement is doel van de actie). Rechtspraak hierover heb ik niet aangetroffen.

356 HR 15 april 1975, NJ 1976, 23.

357 Memorie van Antwoord bij wetsvoorstel 13872, Verklaring dat er grond bestaat .... Tweede Kamer, in: Algehele grondwetsherziening, deel Ia Grondrechten, p. 198. Zie overigens ten aanzien van de verhouding tot andere grondrechten: P.W.C. Akkermans, Artikel 9 Grondwet, pp. 216-218 en A.E. Schilder, Het recht tot vergadering en betoging, pp. 58-60.

358 In HR. 11 mei 1976, NJ 1976, 540 gaat het bijvoorbeeld om 8 personen met sandwichborden. Volgens de HR is in dit geval sprake van een demonstratie. Uitspraken waarin het ging om een kleiner aantal deelnemers zijn mij niet bekend.

359 De opvatting is ook wel verkondigd dat ook sprake kan zijn van een eenmansdemonstratie (o.a. de Kantonrechter in de zojuist genoemde zaak en S.C. den Dekker-van Bijsterveld, Het voorstel van Wet openbare manifestaties, p. 218). Met Schilder meen ik echter dat dit soort acties buiten de reikwijdte van artikel 9 valt en door artikel 7 bestreken wordt. Zie A.E. Schilder, Het recht tot vergadering en betoging, p. 27. Zie wel hierboven noot 330 .

360 HR 17 februari 1981 , NJ 1981, 299.

361 HR 17 februari 1981. NJ 1981. 299. 
Tenslotte is als grens van het betogingsrecht aangegeven het punt waarop uitoefening van dit recht leidt "tot onaantastbare aantasting van de rechten van anderen". In dat geval zal, mijns inziens, moeten worden overgegaan tot toetsing aan de beperkingsmogelijkheden.

Tot slot kan hier nog worden opgemerkt, dat in de Memorie van Antwoord naar mijn mening terecht wordt aangegeven "dat vergaderingen en betogingen naar hun uiterlijke verschijningsvorm gelijksoortige fenomenen zijn en de overgang tussen beide dikwijls niet te achterhalen is. " 362 Dit zal naar mijn mening met name het geval zijn indien een vergadering de uiting van gedachten of gevoelens tot onderwerp heeft en in de openbaarheid plaatsvindt, dat wil zeggen vrij toegankelijk is.

\subsubsection{Een zorgplicht van de overheid in geval van een "hostile audience"}

De meeste van de schaarse uitspraken naar aanleiding van een beroep op artikel 9 Grondwet betreffen de vraag of een betoging kan worden verboden op grond van te verwachten ongeregeldheden van de zijde van tegenstanders van de betrokken betogers. Een bekende uitspraak is die van de Voorzitter van de Afdeling Rechtspraak van de Raad van State van 27 mei $1982{ }^{36}$ In deze zaak gaat het om de weigering van B en W van Amersfoort om een vergunning te verlenen aan de Vereniging Roze Front voor één van de drie door de Vereniging georganiseerde optochten en om een terrein beschikbaar te stellen voor het houden van een tentenkamp. De voornaamste weigeringsgrond is de vrees voor intolerant gedrag van derden. Alhoewel artikel 9 op dat moment nog niet in werking is getreden, wordt dit artikel wel in de beslissing van de Voorzitter betrokken. Volgens de Voorzitter moeten er zwaarwegende omstandigheden in het geding zijn om een betoging te kunnen beperken. Een dergelijke beperking kan er volgens de Voorzitter niet in gelegen zijn dat het onwettig gedrag van derden tegenover de deelnemers aan de betoging een verstoring van de openbare orde tot gevolg zal hebben. Hieraan doet niet af, aldus de Voorzitter, dat de onderhavige demonstraties een zware belasting voor het

362 Memorie van Antwoord bij wetsvoorstel 13872, Verklaring dat er grond bestaat .... Tweede Kamer, in: Algehele grondwetsherziening, deel la Grondrechten, p. 202.

363 Vz.ARRS 27 mei 1982, AB 1983, 62 met noot J.H. v.d.V.: NJCM-Bulletin 8-2 (1983), pp. 141-146 met noot A. Kors; Ned.Gem. 1982, no. 31, pp. \$147/148 met noot M.A.C. van Egdom en J.M.H.F. Teunissen. Zie ook: Vz.ARRS 30 mei 1983 , AB 1984, 85 met noot P.J. Boon; De Gemeentestem no. 6756, nr. 3 met noot J.M. Kan. 
politiekorps zullen betekenen en dat het verkeer in ernstige mate zal worden gehinderd. In latere uitspraken van de Voorzitter is deze beslissing verder uitgewerkt. In een uitspraak van 21 maart 1989 bevestigt de Voorzitter dat "(d)e omstandigheid dat een bepaalde demonstratie bij het publiek irritaties opwekt of tegendemonstraties uitlokt ... onvoldoende basis (is) om de demonstratie ... te verbieden. ${ }^{\text {"364 }}$ Er kan slechts grond voor een verbod van een demonstratie bestaan, indien "er gegronde vrees voor ongeregeldheden (bestaat) die niet kunnen worden voorkomen of bestreden door middel van door de overheid te treffen maatregelen". De Voorzitter ondersteunt deze overwegingen aan de hand van het volgende citaat uit de Memorie van Toelichting bij de Wet Openbare Manifestaties:

"In het tweede lid is tot uitdrukking gebracht, dat indien aan de gestelde aanmeldingseisen is voldaan, een manifestatie slechts in dwingende situaties preventief mag worden verboden: een van de in art. 2 genoemde belangen moet dat vorderen, dat wil zeggen het belang in kwestie moet in de gegeven situatie preponderant zijn en de situatie moet van dien aard zijn, dat niet met een lichtere maatregel - bijv. het stellen van voorschriften en beperkingen - kan worden volstaan. Te denken valt aan een aangekondigde ... betoging die naar redelijke verwachting gepaard zal gaan met wanordelijkheden op zodanige schaal, dat daaraan niet het hoofd kan worden geboden door het inzetten van voldoende politiepersoneel. "365

Bij de afweging of van een dergelijke situatie sprake is, stelt de Voorzitter vast, dat hoewel de oproep tot tegendemonstraties op zichzelf niet doorslaggevend mag zijn, dit wel een factor is die "in het geheel van de beoordeling" een rol speelt. Wèl doorslaggevend is het verweer van B en W dat "het beschikbare politiepersoneel, ook al wordt rekening gehouden met behulp van politiekorpsen uit de omliggende gemeenten, mede gelet op de door verzoekster beoogde lokaties in de gemeente, volstrekt onvoldoende is om het redelijkerwijs te voorziene grootscheeps wanordelijk gebeuren ter plaatse in de hand te kunnen houden." De

364 Vz.ARRS 21 maart 1989. AB 1989, 498 met noot A.E. Schilder onder AB 1989. 499. Zie ook Vz.ARRS 22 september 1987, AB 1988, 249 en Vz.ARRS 1 juni 1989. AB 1989, 499 met noot A.E. Schilder: KG 1989, 272.

365 Memorie van Toelichting bij wetsvoorstel i9427, WOM. Tweede Kamer, pp. 19-20. Toelichting bij artikel 4 (het huidige artikel 5 WOM). Onder "redelijke verwachting" moet blijkens de Memorie van Antwoord bij hetzelfde wetsvoorstel verstaan worden een "objectieve, op ervaringsregels berustende, verwachting." Het begrip "wanordelijkheden" moet volgens de regering mede worden bepaald door de plaats waar deze zich voordoen (pp. 17, 20). 
Voorzitter meent dan ook dat verweerder na afweging van de betrokken belangen in redelijkheid tot het bestreden besluit heeft kunnen komen.

Uit voorgaande zaken blijkt derhalve dat voor de gerechtvaardigde beperking van het betogingsrecht - het gaat hier om een beperking op grond van artikel 9 lid 2 Grondwet - sprake moet zijn van zwaarwegende omstandigheden. Intolerant gedrag of wanordelijkheden veroorzaakt door tegenstanders van de betoging rechtvaardigen op zich geen beperking van het betogingsrecht. Wèl kunnen de te verwachten wanordelijkheden meewegen in de beoordeling of de beperking van de betoging redelijk is in verband met de mogelijkheid om politiepersoneel in te zetten (ook uit naburige korpsen) en andere maatregelen te treffen om de tegenstanders van de betoging in het gareel te houden. Met name moet overwogen worden of ook met lichtere maatregelen dan een verbod aan de situatie tegemoet kan worden gekomen. Betogers moeten derhalve kunnen rekenen op een weloverwogen inschatting van de situatie (omvang van de te verwachten ongeregeldheden), een adequate politie-inzet om aan de wanordelijkheden het hoofd te bieden, waarbij zij zich eventueel aan bepaalde voorwaarden zullen moeten houden. Slechts wanneer redelijkerwijs - ook bij voìduende politic-ineet - de situatie niet in de hanu gehouden kan worden, mag het recht op betoging worden beperkt. Deze afweging van de situatie impliceert een evenredigheidstoetsing tussen doel (voorkoming van wanordelijkheden) en middel (beperking van het betogingsrecht): beperking van het betogingsrecht moet nodig zijn met het oog op de voorkoming van wanordelijkheden. Dit is slechts het geval indien men met lichtere maatregelen niet kan volstaan en voldoende politiebescherming geen soelaas kan bieden. ${ }^{365}$ Enerzijds is er hier expliciet sprake van een soort toetsing die met de toetsing aan de clausule "noodzakelijk in een democratische samenleving" in de tweede leden van de artikelen 8 tot en met 11 ECRM overeen lijkt te stemmen, anderzijds betekenen de eisen die de Voorzitter van de Afdeling Rechtspraak stelt, dat er een zorgplicht op de overheid rust om voldoende bescherming te bieden aan betogers, tegen wier demonstraties grote weerzin bestaat bij anderen. die tot actie zouden kunnen overgaan. Slechts wanneer dit redelijkerwijze onmogelijk is, kan tot beperking worden overgegaan. De reikwijdte van het betogingsrecht lijkt zich hiermee uit te strekken tot het punt waarop

366 Vgl. de Memorie van Toelichting bij wetsvoorstel 19427. WOM. Tweede Kamer. pp. 19-20 ten aanzien van artikel 4 lid 2 sub c (het huidige artikel 5 lid 2 sub c WOM). Zie ook Nationale Ombudsman 9 september 1993, AB 1994, 22 met noot PJS ten aanzien van het politieoptreden bij een landelijke jongerendemonstratie op 8 mei 1993 te 's-Gravenhage. 
overheidsbescherming niet meer redelijk geacht kan worden. Het betogingsrecht houdt aldus ook een positieve, zorg-verplichting voor de overheid in. In die zin, is er bij de kwestie van de "hostile audience" niet alleen sprake van een beperkingskwestie, maar ook van een afbakeningsvraag.

Dat deze zorgverplichting van de overheid niet alleen onder de reikwijdte van het betogingsrecht valt, maar ook onder het bereik van het vergaderrecht, lijkt - mijns inziens terecht - te worden voorgestaan door het NJCM in zijn commentaar op de ongeregeldheden die op 29 mei 1986 plaatsvonden naar aanleiding van een vergadering van de Centrumpartij en de Centrumdemocraten in Kedichem. ${ }^{367}$ De vergadering was van tevoren angemeld en toch waren op het moment dat de ongeregeldheden uitbraken, tengevolge van het gewelddadig optreden van een aantal demonstranten, slechts twee politieambtenaren ter plaatse. De vergadering moest vanwege deze situatie worden beëindigd. Het NJCM is van mening dat wanneer wanordelijkheden ten gevolge van een tegendemonstratie worden gevreesd, de lokale autoriteiten zullen moeten zorgen voor een adequate politiebescherming, zodat de betreffende vergadering of betoging - ook een controversièle - ongestoord doorgang kan vinden. Een verbod of ontbinding van de vergadering of betoging acht het NJCM een "ultimum remedium". Hiervan kan alleen sprake zijn indien "ook met een redelijke politie-inzet ernstige ongeregeldheden niet voorkomen kunnen worden." Hiertoe zou alleen overgegaan mogen worden als met een minder verstrekkend middel volstaan kan worden, dat het recht op betoging of vergadering onverlet laat. ${ }^{368}$ Naar mijn mening hanteert het NJCM terecht dezelfde maatstaven voor een vergadering als voor een betoging. Hiervoor werd uit de Memorie van Toelichting al het geciteerd "dat vergaderingen en betogingen naar hun uiterlijke verschijningsvorm gelijksoortige fenomenen zijn en de overgang tussen beide dikwijls niet te achterhalen is. " "

367 NJCM-commentaar op de gebeurtenissen te Kedichem (29-3-1986), NJCM-Bulletin 11-5 (1986), pp. 478-487.

368 Verwezen wordt naar J.A. Peters. De vrijheidl van demonstratie en de controversiële meningsuiting, in: Beeld van een Goede vriendschap, opstellen aangeboden aan Prof.mr. B. de Goede, red. F.D.A. Claessen e.a., Vuga: 's-Gravenhage 1980, pp. 171-199(194).

369 Memorie van Antwoord bij wetsvoorstel 13872, Verklaring dat er grond bestaat .... Tweede Kamer, in: Algehele grondwetsherziening, deell Ja Grondrechten, p. 202. 

het recht tot vergadering en betoging

Hoewel de beperking van de rechten in dit hoofdstuk in principe niet aan de orde komt, lijkt mij het - gezien de overeenkomsten met de interpretatie van artikel 7, waarbij impliciete beperkingen wel onder de reikwijdte begrepen werden - nuttig de volgende kanttekeningen bij de beperking van de in artikel 9 gegarandeerde rechten te plaatsen.

Allereerst blijkt de regering van opvatting te zijn dat een beperking van de onderhavige rechten door middel van een verbod behoudens ontheffing niet in overeenstemming met artikel 9 is, omdat deze bepaling het recht tot betoging (en vergadering) ten principale erkent. ${ }^{370}$

Voorts acht de regering het niet toegestaan, dat bemoeienis met de inhoud van de uitingen plaatsvindt. Deze bemoeienis is - "in het stelsel van de artikelen 6 en 9 van de Grondwet" - aan de formele wetgever voorbehouden en tevens dient preventieve censuur te worden uitgesloten. ${ }^{371} \mathrm{Om}$ die reden zijn artikel 3 lid 4 en artikel 4 lid 3 in de Wet Openbare Manifestaties opgenomen. Volgens de regering moet niet alleen daadwerkelijk preventieve censuur vermeden worden, maar ook de schijn ervan. ${ }^{372}$ Overigens staan deze bepalingen volgens de regering wel toe dat naar het doel of onderwerp van de manifestatie wordt gevraagd. Gegevens hierover kunnen volgens de regering, "mede in samenhang met de identiteit van de organiserende persoon of groepering, van essentieel belang zijn voor de beoordeling van de vraag, of en in welke mate zich wanordelijkheden zouden kunnen voordoen, en welke maatregelen in

370 Memorie van Toelichting bij wetsvoorstel 19427. WOM. Tweede Kamer, p. 10. Vgl. de Memorie van Antwoord bij hetzelfde wetsvoorstel, idem, p. 2.

371 Memorie van Toelichting bij wetsvoorstel 19427. WOM. Tweede Kamer, p. 18. Zie ook P.W.C. Akkermans, Artikel 9 Grondwet, p. 213, noot 25. Anders: C.A.J.M. Kortmann, De grondwetsherzieningen van 1983 en 1987, p. 91: "Zelfs een regeling houdende preventief toezicht op de inhoud van een vergadering is niet uitgesloten, mits de wet nauwkeurige voorschriften terzake bevat."

372 Artikel 3 lid 4 WOM (was artikel 3 lid 3 ontwerp) luidt: "Over de inhoud van hetgeen wordt beleden worden geen gegevens verlangd." Artikel 4 lid 3 WOM (was artikel 3 lid 3 ontwerp) luidt: "Over de inhoud van de te openbaren gedachten of gevoelens worden geen gegevens verlangd." Artikel 5 lid 3 WOM (was artikel 4 lid 3 WOM) luidt: "Een voorschrift, beperking of verbod kan geen betrekking hebben op de inhoud van hetgeen wordt beleden, onderscheidenlijk van de te openbaren gedachten of gevoelens." Vgl. ook de Memorie van Antwoord bij wetsvoorstel 19427, WOM, Tweede Kamer, p. 3. 
verband daarmee vereist zijn. ${ }^{\text {"3n }}$ Dit wijst op de hierboven behandelde zorgverplichting van de overheid. Naar mijn mening zal men wel bij het trekken van conclusies uit gegevens over doel en onderwerp van de manifestatie en de identiteit van de organisatoren voorzichtig moeten zijn, aangezien van bepaalde organisatoren en bij bepaalde onderwerpen van manifestaties veelal de inhoud van de manifestatie geen geheim meer zal zijn. $^{374}$

Ten aanzien van de tweede leden van artikel 6 en 9 Grondwet merkt de regering in de Memorie van Antwoord bij de WOM - in verband met de voorafgaande controle van de burgemeester in verband met artikel 4 ontwerp (het huidige artikel 5 WOM) - op, dat deze bepalingen zich noch naar de bewoordingen noch naar de strekking tegen een stelsel van voorafgaand verlof of voorafgaande kennisgeving verzetten, "mits de beslissing niet (mede) wordt bepaald door een oordeel over de (on)gewenstheid van inhoud of doelstelling van de manifestatie. "375

\subsubsection{Conclusie}

Naar aanleiding van het voorgaande kan worden gesteld, dat rechtspraak naar aanleiding van artikel 9 schaars is. Is er al rechtspraak omtrent artikel 9, dan betreft dit meestal de beperking op grond van het tweede lid in geval van wanordelijkheden tengevolge van het optreden van tegenstanders van de in het geding zijnde betoging. Uit deze uitspraken kan naar mijn mening, de conclusie getrokken worden dat de reikwijdte van de rechten in artikel 9 niet alleen negatieve onthoudingsverplichtingen van de overheid omvat, maar eveneens een (positieve) zorgverplichting voor de overheid inhoudt. Op grond van deze verplichting dient de overheid adequate politiebescherming te bieden aan personen die hun recht tot vergaderen of betogen wensen uit te oefenen tegen intolerant gedrag van derden. De grens ligt daar waar redelijkerwijs - ook bij voldoende politie-inzet - de situatie niet in de hand kan worden gehouden. In dat geval mag tot beperking van het in het geding zijnde recht worden overgegaan. Deze afweging van de situatie impliceert een evenredigheidstoetsing tussen doel (voorkoming van wanordelijkheden) en middel (beperking van het betogingsrecht): beperking van het betogingsrecht moet nodig zijn met het oog op de voorkoming van wanordelijkheden. Dit is slechts het geval

373 Zie de Memorie van Toelichting bij wetsvoorstel 19427, WOM, Tweede Kamer, pp. 19-20. Zo ook de Memorie van. Antwoord bij wetsvoorstel 19427, WOM, idem., p. 3.

374 Zie ook $A$. W. Heringa, Concept-voorstel van een wet openbare manifestaties, p. 160.

375 Memorie van Antwoord bij wetsvoorstel 19427, WOM. Tweede Kamer, p. 9. 
indien men met lichtere maatregelen niet kan volstaan en voldoende politiebescherming geen soelaas kan bieden.

Overigens is de hoeveelheid rechtspraak beperkt. Uit een uitspraak van de Haagse Rechtbank-President kan worden afgeleid, dat de in artikel 9 gegarandeerde rechten aan iedereen toekomen, ook aan mensen of organisaties met controversiële opvattingen. Dit wordt ondersteund door de kamerstukken bij de grondwetsherziening. ${ }^{376}$

Wat betreft het vergaderrecht is er een uitspraak waaruit de conclusie kan worden getrokken dat niet ieder samenkomen van mensen een vergadering genoemd kan worden. Dit impliceert een doelvereiste. Uit de rechtspraak blijkt niet wat dit doel zou kunnen zijn. Hiervoor moet men andere bronnen raadplegen, zoals de kamerstukken bij het wetsvoorstel voor de Wet Openbare Manifestaties. Hieruit blijkt dat de regering van mening is dat het moet gaan om "gemeenschappelijke beraadslaging, in de vorm van discussie en eventueel besluitvorming, over een bepaald onderwerp ... Doorgaans zal dit onderwerp ... van politieke of maatschappelijke aard zijn."

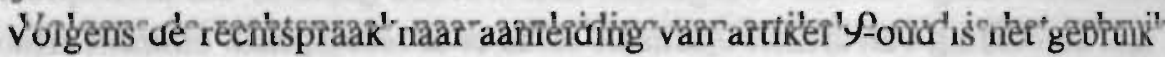
mogen maken van vergaderfaciliteiten een noodzakelijk element van het vergaderrecht, indien die faciliteiten "... in beginsel nodig zijn voor een doeltreffende uitoefening van het ... 'recht tot vereniging en vergadering' ". Deze uitspraken hebben betrekking op een verzoek om gebruik te mogen maken van vergaderfaciliteiten in een Huis van Bewaring door (een vereniging van) gedetineerden. De directeur van deze instelling mag dit recht tot het gebruiken van de vergaderfaciliteiten beperken indien het zich niet met de vrijheidsbeneming verdraagt. Niet zeker is of een dergelijk recht tot gebruikmaking van ofwel een plicht voor de overheid om

376 De vraag is alleen of de in de vorige alinea bedoelde rechterlijke praktijk met betrekking tot het geval van een "hostile audience" niet tot een andere conclusie noopt. Hoewel de door de betrokken rechterlijke instanties gehanteerde redenering op zich neutraal is ten aanzien van het soort opvattingen van personen die een vergadering of betoging wensen te houden, is het toch wel opvallend dat alle zaken waarin een verbod van een demonstratie of vergadering werd opgelegd. de Centrumpartij of de Centrumdemocraten betroffen; partijen met tamelijk controversiële opvattingen derhalve. Overigens hoeft dit niet te liggen aan een minder tolerante houding van de betrokken overheidsinstanties ten aanzien van deze parijen. Het kan ook komen doordat dit soort partijen meer weerstand in de samenleving oproepen en daardoor de kans op ernstige wanordelijkheden naar aanleiding van vergaderingen/betogingen van deze partijen, groter is. 
zodanige vergaderfaciliteiten ter beschikking te stellen, ook bestaat buiten de detentie-situatie.

Verder kan uit de eerder genoemde uitspraak van de President van de Haagse rechtbank. worden afgeleid, dat het weigeren van het verhuren van vergaderruirnte onder omstandigheden een schending van artikel 9 kan inhouden. Hierop kan een bevel tot het verhuren van een zodanige ruimte door de rechter worden gegeven. In een dergelijk geval omvat het vergaderrecht een verplichting voor zaalhouders om vergaderruimte te verhuren.

Overigens dient men het voor de afbakening van het vergaderrecht te stellen met kamerstukken en literatuur. De volgende standpunten kunnen hieruit worden afgeleid. Het gaat bij het vergaderrecht om een collectieve activiteit: het vergaderrecht komt individueel aan een ieder toe, maar kan slechts collectief door meerdere personen worden uitgeoefend. Tussen deze personen zal een beoogde band moeten bestaan, die wellicht zou kunnen voortkomen uit een gemeenschappelijke interesse in het doel van de vergadering. Voorts kan een vergadering zowel in beslotenheid, als in het openbaar plaatsvinden en behoeft niet van tevoren te zijn georganiseerd.

Voor het betogingsrecht geldt ongeveer hetzelfde. Voor het collectieve karakter van een betoging, evenals voor het bestaan van een beoogde band tussen de deelnemers aan een bijeenkomst - alvorens van een betoging te kunnen spreken - kan in de rechtspraak wellicht een aanwijzing worden gevonden. Voorts lijkt de jurisprudentie de opvatting in de kamerstukken en literatuur te bevestigen dat het moet gaan om de openbaring van gedachten en gevoelens. ${ }^{37}$ Hierin wijkt het betogingsrecht af van het vergaderrecht.

Geen rechterlijke uitspraken heb ik gevonden omtrent de volgende standpunten in kamerstukken en literatuur: dat een betoging zowel op besloten plaatsen als in het openbaar kan plaatsvinden (in de rechtspraak ben ik alleen het laatste soort betogingen tegen gekomen) en dat wanneer een actie beoogt iets van de overheid of derden af te dwingen (het dwangelement is doel van de actie) geen sprake is van een betoging. Voorts zal als grens van het betogingsrecht kunnen worden aangenomen het punt waarop uitoefening van dit recht leidt "tot onaantastbare aantasting van de rechten van anderen". In dat geval gaan de beperkingsmogelijkheden een rol spelen. 


\subsection{Evaluatie}

In de voorgaande paragrafen is de rechterlijke afbakening van de artikelen 1, 6 lid 1, 7 leden 1 en 3 en 9 lid 1 Grondwet onder de loep genomen. Aan het einde van elke paragraaf is samengevat hoe de reikwijdte van deze rechten afzonderlijk, door de rechter is begrensd. In deze paragraaf zullen de resultaten ten aanzien van de afzonderlijke grondrechten met elkaar vergeleken worden. Bekeken zal worden of er een lijn valt te ontdekken in de rechterlijke interpretatie van de artikelen 6 lid 1, 7 leden 1 en 3 en 9 lid 1 Grondwet, zijnde de artikelen in de Grondwet die vergezeld gaan van de beperkingsclausule "behoudens ieders verantwoordelijkheid volgens de wet". Daarna zal worden nagegaan of er verschillen of overeenkomsten zijn met de rechterlijke afbakening van artikel 1 Grondwet, een bepaling die niet voorzien is van een beperkingsclausule.

\subsubsection{Rechterlijke afbakening van de artikelen 6 lid 1, 7 leden 1 en 3 en 9 lid 1 Grondwet}

De vraag of er een lijn valt te ontdekken in de rechteriijke interpretatie van de artikelen 6 lid 1, 7 leden 1 en 3 en 9 lid 1 Grondwet moet mijns inziens bevestigend beantwoord worden. Dit blijkt uit het volgende.

Ten aanzien van alle drie bepalingen blijkt dat de hierin vervatte rechten door een ieder kunnen worden ingeroepen. Dit kan worden afgeleid uit de woorden "ieder" in artikel 6 lid 1 en "niemand" in artikel 7, maar tevens uit artikel 1 Grondwet dat ook bij de uitoefening van de grondwettelijke grondrechten in acht genomen moet worden.

Voorts blijkt dat de beperkingsclausule "behoudens ieders verantwoordelijkheid volgens de wet" bij de afbakening van deze rechten geen rol speelt, ondanks dat deze clausule in dezelfde zin is opgenomen als die waarin het recht zelf wordt geformuleerd. Hieruit zou men kunnen afleiden, dat de rechter voordat hij tot beperking overgaat, eerst los daarvan de reikwijdte vaststelt (zoals het mijns inziens ook zou moeten). Echter, zoals in het voorgaande naar voren kwam, is er wel een invloed van andere beperkingsmogelijkheden op de reikwijdte-afbakening waar te nemen.

Ten eerste heb ik bij de bespreking van artikel 6 geconstateerd, dat de vrijheid van godsdienst en levensovertuiging niet uitsluit, dat door de overheid een beleid gevoerd wordt dat in enige mate indruist tegen deze vrijheid, zonder dat van de voorziene beperkingsmogelijkheden gebruik wordt gemaakt. Men denke hierbij, onder meer, aan de overweging van de Voorzitter van de Afdeling Rechtspraak dat "het feit dat sprake is van de uitoefening van een grondrecht niet met zich [brengt] dat de 
voorschriften (van het bestemmingsplan) hun betekenis zouden verliezen." $^{\text {"37 }}$ Ik ben er in paragraaf 6.2 .1 .7 vanuit gegaan, dat hier sprake is van algemene beperkingen omdat de desbetreffende voorschriften niet gericht zijn op beperking van de vrijheid van godsdienst en levensovertuiging, maar die beperking wel tot gevolg hebben. Via redelijke wetstoepassing lijken die met de beperkingssystematiek strijdige (want niet op een specifieke, formele wetsbepaling gebaseerde) beperkingen te kunnen worden gesauveerd. Om in de termen van de grondwetgever te spreken: aan de redelijkheid kunnen grenzen worden ontleend waarbuiten een grondrecht geen toepassing meer behoort te vinden. Wel dient dan het proportionaliteitsvereiste in acht genomen te worden en moeten de maatschappelijke en persoonlijke belangen die in het geding zijn tegen elkaar worden afgewogen. ${ }^{379}$ Ik sprak hiervoor van "lijken", omdat in de bedoelde uitspraken niet expliciet van algemene beperkingen of redelijke wetstoepassing wordt gesproken. Ten tweede bestaat er ook een zeker verband tussen de reikwijdte van artikel 6 lid I en de beperking van het hierin vervatte recht, waar in de rechtspraak is bepaald dat op degene die de vrijheid van godsdienst of levensovertuiging uitoefent een zekere inspanningsverplichting rust om de schade die uit die uitoefening voortvloeit, zoveel mogelijk te beperken. Deze inspanningsverplichting kan immers een beperking van die uitoefening met zich brengen.

Ook bij de afbakening van artikel 7 blijken beperkingen een rol te spelen. Hier gaat het om de beperking van het impliciet door artikel 7 lid 1 gegarandeerde verspreidingsrecht; een beperking derhalve die noodzakelijkerwijs zelf ook impliciet is. Voor de omvang van de reikwijdte van het in artikel 7 lid 1 gegarandeerde recht dient zowel het bereik van het expliciet genoemde recht als van het impliciete recht, inclusief de impliciete beperkingen daarop, meegerekend te worden. Het in artikell 7 lid 1 gegarandeerde openbaringsrecht kan niet van voorafgaand verlof afhankelijk worden gesteld en slechts achteraf worden beperkt op grond van de beperkingsclausule "behoudens ieders verantwoordelijkheid volgens de wet". ${ }^{380}$ Het impliciete verspreidingsrecht, kan (ook door de lagere

378 Vz.ARRS 16 februari 1989. AB 1990, 9 met noot P.J. Boon: $\mathrm{B} / \mathrm{S} 1989$, nr. 20 met noot M.C.B.; AA 1990 , pp. 398-402 met noot P.W.C. Akkermans; De Gemeentestem, no. 6883, nr. 11, pp. 359-360 met naschrift J.M.H.F. Teunissen.

379 Memorie van Toelichting bij wetsvoorstel 13872, Verklaring dat er grond bestaat .... Tweede Kamer, in: Algehele grondwetsherziening, deel la Grondrechten, pp. 21-22.

380 Strikt genomen is het openbaringsrecht in lid 1 - evenals het recht in lid 3 om door andere middelen dan de in lid 1 en lid 2 genoemde, zijn gedachten en gevoelens te openbaren - ook niet expliciet geformuleerd: er staat niet dat een ieder het recht heeft om zonder voorafgaand verlof door de drukpers gedachten of gevoelens te. openbaren, behoudens ... . Alleen het ontbreken van een bepaalde beperkings- 
wetgever) - naar tijd, plaats en wijze van verspreiden - beperkt worden. Deze beperkingen mogen echter niet zo ver gaan, "dat het gebruik van een bepaald middel van bekendmaking, dat naast andere middelen zelfstandige betekenis heeft en met het oog op die bekendmaking in een bepaalde behoefte kan voorzien, in het algemeen zou worden verboden of van een voorafgaand verlof der overheid afhankelijk zou worden gesteld". Voorts moet er aan het verspreidingsmiddel gebruik van enige betekenis worden gelaten. ${ }^{381}$ Deze laatste zin kan worden gezien als een grens die aan de beperkingsbevoegdheid van de wetgever wordt gesteld. In de paragrafen 6.2.2.2 en 6.2.2.10 zagen we bovendien, dat deze grens ook wordt gesteld aan de beperkingen die, anders dan ten aanzien van de inhoud van het geopenbaarde, op de openbaring van gedachten en gevoelens door middel van verspreidingsmiddelen bedoeld in lid 3 van artikel 7 kunnen worden aangebracht.

Ten aanzien van de reikwijdte van artikel 9 lid 1 zou op grond van de rechtspraak kunnen worden gesteld, dat een deel ervan voortvloeit uit de toepassing van de beperkingsbevoegdheid in lid 2. Op grond van dit artikellid mag in het geval dat gevreesd moet worden dat een vergadering of betoging intolerant gedrag van derden oproept, alleen overgegaan worden tot een verbod van de vergadering of betoging, indien redelijkerwijs te verwachten is dat - bij voldoende politie-inzet - de situatie niet meer in de hand gehouden kan worden. Dit impliceert mijns inziens dat het recht in lid 1 een positieve verplichting inhoudt tot het verlenen van politiebescherming aan een groep personen die een vergadering of betoging wenst te houden.

Overigens is er nauwelijks of geen rechtspraak voor handen ten aanzien van de afbakening van de in de artikelen 6, 7 en 9 gegarandeerde rechten. Dit geldt voor zowel de afzonderlijke bewoordingen waarin het recht is geformuleerd als voor de rechten in hun geheel. Hierop bestaan enkele uitzonderingen, waarvan de voornaamste ${ }^{382}$ hier kort zullen worden herhaald.

bevoegdheid op dit openbaringsrecht staat expliciet vermeld, wat echter een recht waarop die beperking niet mag worden aangebracht, veronderstelt!

381 Citaten uit zaken van vlak na de grondwetswijziging: HR 2 maart 1982, NJ 1984, 133 met noot $J A B$ onder HR 5 april 1983. NJ 1984, 134 en HR 28 juni 1983, NJ 1984, 64. Zie ook de Memorie yan Antwoord bij wetsvoorstel 13872. Verklaring dal er grond bestaat .... Tweede Kamer, in: Algehele grondwetsherziening, deel la Grondrechten. p. 196.

382. Hieronder versta ik uitzonderingen waarin het èn gaat om meerdere uitspraken èn om uitspraken waarin een afbakenings-criterium wordt gehanteerd of ontwikkeld. 
Allereerst blijkt uit diverse uitspraken ten aanzien van godsdienstige uitlatingen dat ongenuanceerde, ongemotiveerde en - tegen beter weten in onjuiste en misleidende uitingen niet onder de vrijheid van godsdienst in artikel 6 lid 1 vallen. Overige godsdienstige uitlatingen vallen hier wèl onder, ook al zijn ze in strijd met wat algemeen aanvaard wordt of pijnlijk zijn voor een bepaalde groep personen. Hier wordt derhalve een grens gesteld aan de toepasselijkheid van artikel 6 lid 1 .

Voorts, ten aanzien van het afhankelijk stellen van voorafgaand verlof (in de zin van preventieve overheidsbemoeienis anders dan censuur) van de verspreiding van gedrukte of geschreven stukken onder artikel 7 lid 1: uit de jurisprudentie zou een criterium voor het toegestaan zijn van voorafgaand verlof kunnen worden afgeleid, namelijk dat voorafgaand verlof niet in het algemeen geëist mag worden. Een vergunningen- of ontheffingsstelsel mag, per zelfstandig verspreidingsmiddel, geen betrekking hebben op het gehele territoir van een gemeente of gelden gedurende 24 uur per etmaal. Het criterium dat een verlofstelsel niet algemeen mag zijn, is echter een negatief criterium. In hoeverre een verlofstelsel dan wèl mag, blijkt hier niet uit. Hiervoor dient het criterium dat er gebruik van enige betekenis van het middel moet overblijven, maar dat is in de rechtspraak niet nader geconcretiseerd. Aan het negatieve criterium hebben we dan ook niet meer dan dat het een algeheel verlofstelsel uitsluit.

\subsubsection{Vergelijking tussen de rechterlijke afbakening van enerzijds artikel 1 en anderzijds de artikelen 6, 7 en 9}

Dok ten aanzien van artike! 1 Grondwet, het wordt eentonig, is weinig rechtspraak te vinden waarin een criterium voor de afbakening wordt gegeven van het ge! ijkheidsbeginsel en het discriminatieverbod. In zoverre wijkt dit beeld niet af van dat van de artikelen 6,7 en 9.

Een tweede overeenkomst met de voornoemde artikelen is erin gelegen dat ook met betrekking tot het gelijkheidsbeginsel sprake is van een impliciete beperking. We zagen dit al eerder bij artikel 7 . Anders dan in artikel 7, ziet de impliciete beperking in artikel 1 wèl op een expliciet daarin geformuleerd recht, het gelijkheidsbeginsel. Zoals ik constateerde in paragraaf 6.1.2 houdt deze impliciete beperking in, dat pas sprake is van schending van artikel 1, indien een afwijking van het gelijkheidsbeginsel (dat wil zeggen, bij ongelijke behandeling van gelijke gevallen of gelijke behandeling van ongelijke gevallen) niet gerechtvaardigd kan worden. Blijkens de rechtspraak moet het gaan om een objectieve en redelijke dan wel voldoende rechtvaardiging. 
Een derde overeenkomst die uit de rechtspraak naar aanleiding van het gelijkheidsbeginsel blijkt, is dat overheidsbeleid tegen dit beginsel kan indruisen, in die zin dat er verschillen in beleid tussen verschillende overheidsorganen mag bestaan. We zagen eerder al dat overheidsbeleid ook in zekere mate - buiten de beperkingsclausules om - tegen de vrijheid van godsdienst en levensovertuiging kan indruisen. De ratio van de afwijking van deze rechten is echter verschillend. Bij artikel 6 blijkt afwijking van dit recht door een bepaald beleid te zijn toegestaan omdat het ondoenlijk is ten aanzien van ieder voorschrift te voorspellen of het al dan niet de uitoefening van een bepaald grondrecht op enigerlei wijze zal belemmeren. Een voorschrift kan immers een veelheid van onderwerpen beïnvloeden, waaronder de uitoefening van grondrechten. Ten aanzien van de in het geding zijnde voorschriften achtte de rechter het dan ook niet noodzakelijk dat de beperking van de vrijheid van godsdienst terug te voeren was op een specifieke, op die beperking gerichte, formele wet. Bij artikel 1 gaat het om de verschillen in beleid van verschillende bestuursorganen. De ratio is gelegen in essentie van decentralisatie: er kan worden ingespeeld op plaatselijke omstandigheden, die danig van elkaar kunnen afwijken.

Voor zover de beperkte hoeveelheid jurisprudentie - waarin de artikelen $6(1), 7(1$ en 3$)$ en $9(1)$ enerzijds en artikel 1 anderzijds worden afgebakend - dit toelaat, kan mijns inziens worden geconcludeerd dat geen noemenswaardige verschillen bestaan in de begrenzing van de reikwijdte van deze bepalingen. Men zou wellicht verwachten, maar dat is in dit hoofdstuk niet gebleken, dat een recht dat niet is voorzien van een beperkingsbevoegdheid (zoals artikel 1) nauwkeuriger zou worden afgebakend dan een recht met een dergelijke bevoegdheid (zoals de artikelen 6. 7 en 9). ${ }^{383}$ Immers, geen enkel recht is absoluut en van een recht zonder beperkingsmogelijkheid zal de reikwijdte ook altijd in enige mate begrensd moeten worden. Voor een dergelijk recht is dit de enige mogelijkheid om de uitoefening ervan te beperken. Zo zou men ook kunnen verwachten dat de rechter bij een grondrechtenbepaling zonder expliciete beperkingsmogelijkheid eerder impliciete beperkingen op het gegarandeerde recht aanbrengt, dan bij bepalingen met een beperkingsbevoegdheid. De rechtspraak naar aanleiding van artikel 7 laat echter zien, dat dit niet altijd opgaat. Wellicht zou dit anders geweest zijn. indien het verspreidingsrecht - het recht waarop de impliciete beperking onder artikel 7 lid 1 ziet - expliciet in artikel 7 lid 1 was geformuleerd.

383 Hiermee is niet gezegd, dat het voor een recht mét een beperkingsmogelijkheid minder noodzakelijk of gewenst is om nauwkeurig te worden afgebakend. 
Tot slot kan geconstateerd worden, dat in de jurisprudentie naar aanleiding van de onderzochte grondwettelijke grondrechten weliswaar slechts sporadisch afbakening van deze rechten plaatsvindt en weinig hanteerbare criteria zijn ontwikkeld, doch dat - voor zover ze deze criteria er zijn - ze wel in een aantal categorieën zijn onder te verdelen. Men denke hierbij aan criteria die zien op het verzekeren van het effectieve nut van het recht (onder andere, "gebruik van enig betekenis"), criteria die nopen tot een proportionaliteitstoetsing (bijvoorbeeld, in het kader van de toetsing van de positieve verplichting op grond van artikel 9 lid 1 Grondwet) en criteria die gericht zijn op de voorkoming van misbruik van rechten (zie artikel 6, de Goeree-zaken). Omdat dit soort categorieën criteria ook te onderscheiden zijn in de jurisprudentie met betrekking tot de Europese Conventie, zal hierop teruggekomen worden in het laatste hoofdstuk. 
and

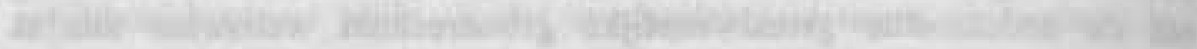

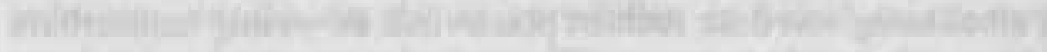

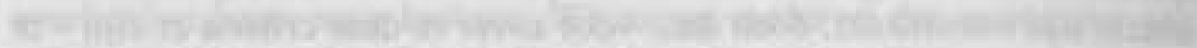
That The

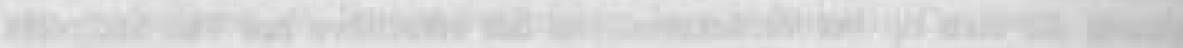

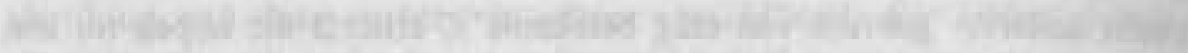

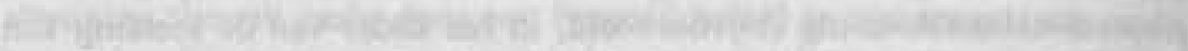

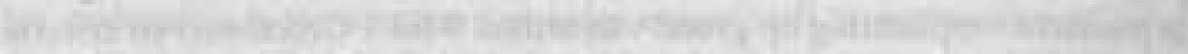

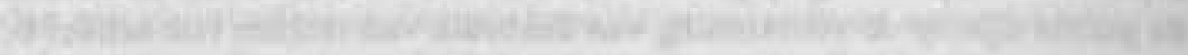

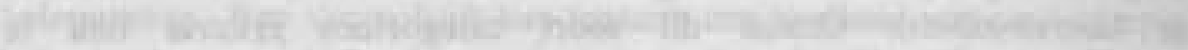

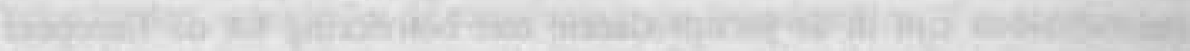

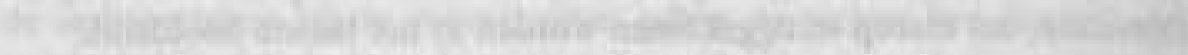

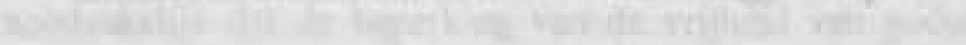

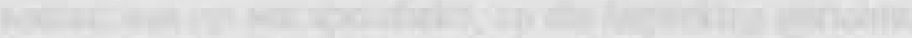

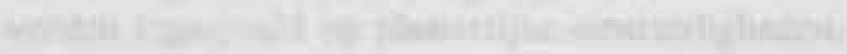

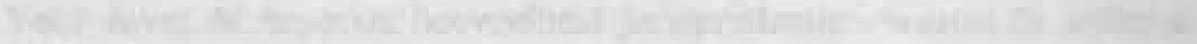

14.

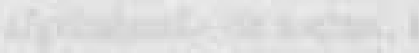

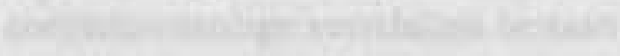

1

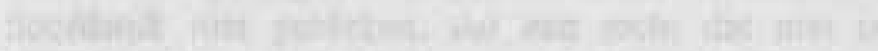

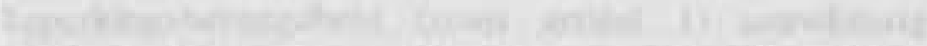

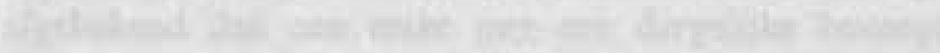

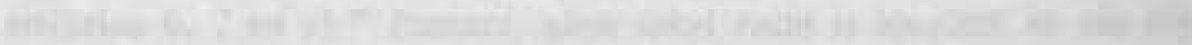

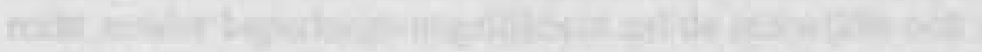

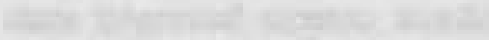

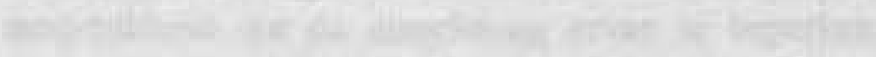

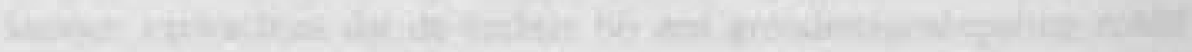

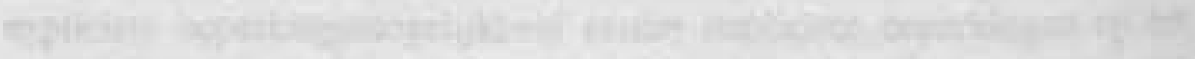
and

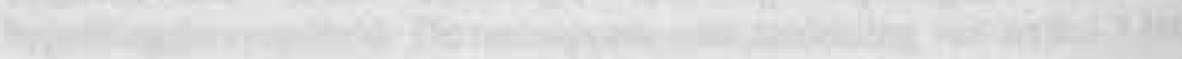

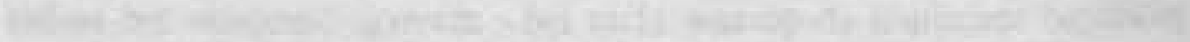

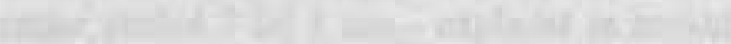




\section{Samenvatting en Conclusies}

\subsection{Inleiding}

In hoofdstuk 1 is een beschrijving gegeven van het onderwerp van dit proefschrift, te weten de vaststelling van de reikwijdte van mensenrechten door de rechter. Als uitgangspunt voor een onderzoek naar dit onderwerp is de volgende hoofdvraagstelling geformuleerd: "Op welke wijze stelt de rechter de reikwijdte van mensenrechten vast?". Ter behandeling en beantwoording van deze vraag is uitgegaan van twee stellingen. De eerste stelling luidt: "Er bestaat een verband tussen de vaststelling van de reikwijdte van mensenrechten en de beperking van de uitoefening van mensenrechten". Volgens de tweede stelling levert dit verband een spanning op tussen de oorspronkelijke bedoelingen van de opstellers van de Conventie en de grondwetgever bij de formulering van de rechten en daarbij behorende beperkingsmogelijkheden enerzijds en de rechterlijke praktijk anderzijds. In de daarop volgende twee hoofdstukken zijn die oorspronkelijke bedoelingen ten aanzien van de formulering van de mensenrechtenbepalingen behandeld in het kader van een bespreking van de totstandkoming van de Conventie en de fundering van de beperkingssystematiek in de Conventie (hoofdstuk 2) evenals het proces dat heeft geleid tot de herziening van de Grondwet in 1983 en de argumentatie achter de daarin vervatte beperkingssystematiek (hoofdstuk 3). In diezelfde hoofdstukken is ook de beperkingssystematiek van beide instrumenten zelf besproken. Vervolgens is in de hoofdstukken 4 tot en met 6 ingegaan op de reikwijdte-afbakening van mensenrechten. In hoofdstuk 4 vond een behandeling plaats van de Straatsburgse en Nederlandse jurisprudentie naar aanleiding van artikel 8 lid 1 ECRM. In hoofdstuk 5 is de vaststelling van de reikwijdte van artikel 6 lid 1 ECRM aan een onderzoek onderworpen, welk onderzoek is toegespitst op het recht op toegang tot een onafhankelijke en onpartijdige rechter in de zin van dit artikel. Tot slot is in hoofdstuk 6 de bepaling van de reikwijdte van enkele grondrechten in de Grondwet 1983 onder de loep genomen, namelijk de artikelen 1, 6(1), $7(1$ en 3$)$ en $9(1)$ Grondwet.

Het is de bedoeling van dit slot-hoofdstuk om de resultaten van het in de hoofdstukken 2 tot en met 6 beschreven onderzoek terug te koppelen naar de in hoofdstuk 1 geformuleerde hoofdvraag en stellingen. Hoe stelt de rechter de reikwijdte van mensenrechten vast? Stelt hij nauwkeurige of open criteria vast? En in verband met de eerste stelling: wat voor rol spelen de beperkingsmogelijkheden hierbij? In hoeverre zijn de twee bovengenoemde stellingen bewaarheid? En noodzaakt, met name in het geval de tweede stelling juist is gebleken, dit onderzoek tot een wijziging 
in de rechtspraktijk? Zijn er alternatieven voor de gevolgde praktijk voor handen? Op deze vragen zal hieronder ingegaan worden.

\subsection{Beantwoording van de hoofdvraag: hoe stelt de rechter de reikwijdte van mensenrechten vast?}

Allereerst moet hier worden opgemerkt, dat in zeer veel gevallen de rechterlijke instanties - met name de Nederlandse - over de vraag naar de reikwijdte van een recht heenstappen en onmiddellijk overgaan tot toetsing aan de in de ingeroepen verdrags- of Grondwetsbepaling voorziene (of daaruit afgeleide) beperkingsmogelijkheden. In paragraaf 7.4.2 zal hierop worden ingegaan en zullen mogelijke verklaringen hiervoor worden gegeven. Overigens meen ik, op grond van het in de voorgaande verrichte onderzoek, uit de gevallen waarin wèl tot (enige) reikwijdte-afbakening is overgegaan de volgende conclusies te kunnen trekken.

Uit de hierbedoelde rechtspraak blijkt, dat de criteria die de rechter hanteert voor de vaststelling van de reikwijdte van de onderzochte grondrechten, nu eens zeer concreet zijn dan weer vrij open. De concrete criteria zijn doorgaans toegespitst op de voorliggende casus. De open criteria kunnen veeleer als maatstaf voor verscheidene, soortgelijke zaken dienen maar bieden daarmee wel minder houvast voor de rechtzoekende die vooraf wil beoordelen of een beroep op het desbetreffende grondrecht een redelijke kans van slagen heeft. Het is niet mijn bedoeling alle gevonden criteria op deze plek te herhalen; ik verwijs hiervoor naar, met name, de samenvattingen die na iedere behandeling van een grondrecht zijn opgenomen en de evaluaties in de paragrafen 4.5, 5.3 en 6.3. De criteria die in de rechtspraak worden geformuleerd zijn in een beperkt aantal categorieën in te delen, die ik hieronder zal noemen. De reden hiervoor is, dat uit deze "basis-criteria" wellicht voor gevallen waarin nu nog geen toetsingsmaatstaven zijn geformuleerd, specifiekere criteria kunnen worden afgeleid. De nu te noemen "basis-criteria" hangen, overigens, nauw met elkaar samen.

\subsubsection{De "rule of law"}

Ten eerste zou ik hier willen wijzen op het beginsel van de rule of law. In de zaak Golder wordt dit beginsel reeds door het Hof genoemd als maatstaf die bij de interpretatie moet worden gehanteerd. In die zaak ging het om de interpretatie van artikel 6 van de Conventie, maar aangezien de rule of law in de Preambule van het verdrag wordt genoemd als één van de kenmerken van het gemeenschappelijk erfgoed van de Lid-Staten van 
de Raad van Europa en voorkomt in de Preambule en artikel 3 van het Statuut van de Raad van Europa, zal dit beginsel ook als toetsingsnorm ten aanzien van de interpretatie van andere rechten dienen te gelden. De uitspraak van het Hof in de zaak Golder sluit dit ook niet uit. De rechtspraak waarin de, hierna te noemen, criteria uit de rule of law worden afgeleid betreft echter uitsluitend artikel 6 ECRM.

Zoals is aangegeven aan het begin van paragraaf 5.1.3.1, omvat de vaststelling van de reikwijdte van het recht op toegang tot de rechter ook de bepaling van de omvang van de beperkingsmogelijkheden op dit recht, omdat het hier gaat om een impliciet in artikel 6 ECRM gegarandeerd recht en derhalve om, eveneens, impliciete beperkingen daarop (de zogenaamde "implied limitations"). Bij de behandeling van de rechtspraak naar aanleiding van deze beperkingen, blijken aan de rule of law verscheidene criteria te worden ontleend ter begrenzing van de beperkingsmogelijkheden. Zo kan op grond van een aantal rapporten van de Commissie het verbod van willekeur genoemd worden in verband met de afbakening van de beoordelingsvrijheid die aan de Staat toekomt bij het beperken van het recht op toegang tot de rechter (Ashingdane, Lithgow'). Ook het Hof neemt de rule of law in aanmerking bij de toetsing of de in het geding zijnde beperkingen op het recht op toegang zijn toegestaan. Het Hof formuleert hierbij als criteria dat de beperking niet de kern van het recht ("the very essence of the right") mag schaden, gericht moet zijn op een legitiem doel ("legitimate aim") en dat er sprake moet zijn van proportionaliteit ("a reasonable relationship op proportionality") tussen de beperking en het daarmee nagestreefde legitieme doel (o.a. Ashingdane, Lithgow, Philis, de Geouffre de la Pradel en Fayed'). De kern van het recht en het proportionaliteitsbeginsel zullen ook hieronder nog bij de andere criteria voor de afbakening van de reikwijdte van grondrechten zijn terug te vinden. Verder moet hier worden vermeld, dat op grond van de rule of law volgens het Hof alleen sprake is van een rechtsgeldige afstand van het recht op toegang tot de rechter wanneer deze afstand is gedaan zonder dwang (Deweer ${ }^{r}$ ). In andere uitspraken bepaalt het Hof dat een afstand van recht in overeenstemming met de vrije wil van de rechtzoekende moet zijn, die deze wil uitdrukkelijk of stilzwijgend en op ondubbelzinnige wijze heeft kenbaar gemaakt. (0.a. Le Compte, Van Leuven and De Meyere, Albert and Le Compte, Oberschlick, Pfeifer and

Rapp.Comm. 12 mei 1983, Ashingdane Case. 892, p. 41 en Rapp.Comm. 7 maari 1984, Case of Lithgow and others, \$476, pp. 122-123. Zie pp. 328-329.

2 Zie noot 68, p. 336.

3 EHRM 27 februari 1980, Deweer Case, \$49, p. 25-26. 
Plankl en Schuler-Zgraggen ${ }^{4}$ ). Hierbij heb ik geen verwijzing naar het beginsel van de rule of law aangetroffen, maar dit beginsel zal vermoedelijk wel aan deze uitspraken van het Hof ten grondslag hebben gelegen, gezien de verwijzing in de zaak Deweer. Tot slot: in paragraaf 5.1.4.1 is gebleken dat het recht op toegang tot de rechter een rechtsgang naar een rechterlijke instantie die is ingesteld bij wet en onafhankelijk en onpartijdig is, impliceert. Wil sprake zijn van een "tribunal" in de zin van artikel 6, dan moeten de procedures die voor dit gerecht worden gevoerd, voldoen aan de rule of law: "... its decisions should not be primarily left to its discretion, but should be arrived at in orderly proceedings conducted on the basis of the rule of law." Onder de vereisten waaraan procedures op grond van de rule of law moeten voldoen zijn de rechterlijke onafhankelijkheid en onpartijdigheid. Hoewel dit slechts in een enkel geval ${ }^{6}$ uitdrukkelijk is uitgesproken, kunnen op grond van het voorgaande de criteria die zijn ontwikkeld ter vaststelling van de onafhankelijkheid en onpartijdigheid van de rechter ook worden teruggevoerd tot de rule of law.

\subsubsection{Het effectieve nut van een grondrecht}

Uit verschillende Straatsburgse en Nederlandse uitspraken komt naar voren, dat de reikwijdte van een recht minimaal het "effectieve nut" dat een recht voor een justitiabele kan hebben, omvat. Deze minimum-norm treffen we voornamelijk aan bij de afbakening van rechten, waarbij de overheid vaak een ruime beleidsmarge toekomt. Dit geldt in de eerste plaats volgens de jurisprudentie voor rechten waaruit voor de overheid positieve verplichtingen kunnen voortvloeien. Ten tweede komen we deze "margin of appreciation" tegen bij de rechtvaardiging van op gegarandeerde rechten aangebrachte beperkingen, namelijk bij de vaststelling van de noodzaak van een beperking. Deze beoordelingsmarge is relevant voor de reikwijdte van een recht, in het geval de toepasselijke verdrags- of grondwetsbepaling naast het expliciet gegarandeerde recht, eveneens een impliciet recht beschermt. In dat geval dienen bij de reikwijdte-afbakening van dat recht tevens de - ook implicietebeperkingen in de beschouwing te worden betrokken. Met betrekking tot expliciet gegarandeerde rechten waaruit voor de overheid negatieve (onthoudings-)verplichtingen voortvloeien, bestaat geen beoordelingsruimte

$4 \quad Z$ ie de noten 86 en 87 in paragraaf 5.1.3.2. pp. 345-346.

5 Rapp.Comm. 8 december 1982, Sramek Case, \$71. p. 31, bevestigd door het Hof in EHRM 22 oktober 1984, Sramek Case, \$36, p. 17.

6 Namelijk in verband met de onafzetbaarheid van rechters, zie Rapp.Comm. 12 oktober 1978, zaak nr. 7360/76, Zand Case, §80, p. 82. 
voor de overheid om te bepalen of een recht van toepassing is. Dit oordeel is aan de rechter en deze hoeft de reikwijdte van een recht niet te beperken tot een minimum-kern, die slechts het effectieve nut van het desbetreffende recht bestrijkt. Zoals op verschillende plaatsen uit het onderzoek in de voorgaande hoofdstukken naar voren kwam, is juist de reikwijdte van een aantal rechten in de loop der tijd steeds ruimer geworden (en vaak evenredig daaraan de beperkingsmogelijkheden).

Voorbeelden uit de jurisprudentie, waarin het effectieve nut van het recht werd genoemd als afbakeningscriterium voor de reikwijdte van een recht, zijn de volgende. Ten eerste kan gewezen worden op de rechtspraak naar aanleiding van artikel 7 Grondwet volgens welke "gebruik van enige betekenis" moet overblijven van een zelfstandig middel van verspreiding van meningsuitingen, in het geval niet-inhoudelijke beperkingen op de verspreiding van die uitingen worden aangebracht (o.a. HR 17 maart 1953, Nuth; ARRS 19 januari $1987^{7}$ ). Vergelijkbaar hiermee is de overweging naar aanleiding van artikel 6 Grondwet dat een gebruiksbepaling behorende bij een bestemmingsplan geen beperking op de vrijheid van godsdienst en levensovertuiging mag inhouden die het gebruik van een pand als gebedsruimte "onmogelijk maakt" (Pres.Rb. 's-Hertogenbosch 25 juni 1985').

Verder zijn er de volgende voorbeelden van het gebruik van het "effet utile" als eriterium voor de afbakening van mensenrechten in het geval van positieve verplichtingen. Uit de jurisprudentie terzake van artikel 8 ECRM blijkt dat het ter verzekering van een effectief "respect" voor het familieof gezinsleven noodzakelijk kan zijn dat bepaalde overheids-maatregelen genomen worden (o.a. Van Oosterwijck, Marckx'). Zo zijn er, bijvoorbeeld, uitspraken van de Afdeling Rechtspraak van de Raad van State, dat uit artikel 8 ECRM in het geval van een eerste toelating van een vreemdeling (derhalve niet in het geval van voortgezet verblijf) een positieve verplichting voor de overheid kan bestaan om tot verlening van een verblijfsvergunning over te gaan (ARRS 8 april 1991 en ARRS 14 april $1991^{10}$ ). Uit artikel 6 ECRM vloeit (ingevolge de rule of law, zie hierboven) voort, dat het recht op toegang tot de rechter effectief dient te

7 Zie paragraaf 6.2.2.10, pp. 559-569 en HR 17 maart 1953. NJ 1953, 389 en ARRS 19 januari 1987, AB 1988, 58.

$8 \quad$ Pres.Rb. 's-Hertogenbosch 25 juni 1985, KG 1985, 217.

9 Rapp.Comm. I maart 1979, Van Oosterwijck Case, \$45-52, pp. 24-26; EHRM 13 juni 1979. Marckx Case, \$31, p.15. Zie ook de in noot 228 op p. 291 genoemde uitspraken.

10 ARRS 8 april 1991, AB 1991, 624 met noot R. Fernhout en ARRS 14 april 1991. AB 1991, 625 met noot $R$. Fernhout. 
zijn, waardoor het - al naar gelang de specifieke omstandigheden van het geval - noodzakelijk kan zijn rechtsbijstand aan een rechtzoekende te verlenen (Airey, Pres.Rb. Amsterdam 26 januari 1984"). Kenmerkend is de overweging uit het arrest in de zaak Airey dat

"(t)he Convention is intended to guarantee not rights that are theoretical or illusory but rights that are practical and effective".

Mijns inziens gaat deze uitspraak ook op voor in de Grondwet gegarandeerde rechten, inclusief de expliciet gegarandeerde rechten waaruit negatieve onthoudingsverplichtingen voor de overheid voortvloeien. Deze laatste toevoeging is relevant voor het geval de rechter neigingen mocht vertonen de reikwijdte van dergelijke rechten restrictief uit te leggen.

Een voorbeeld uit de jurisprudentie ten aanzien van een grondwettelijk gegarandeerd grondrecht is de rechtspraak naar aanleiding van artikel 9 Grondwet. Verschillende uitspraken impliceren een positieve verplichting op grond van het eerste lid van deze bepaling om politiebescherming te verlenen aan een groep personen die een vergadering of betoging wenst te houden in het geval van een "hostile audience". Slechts wanneer gevreesd moet worden dat een vergadering of betoging dermate intolerant gedrag van derden oproept, dat redelijkerwijs te verwachten is dat (bij voldoende politie-inzet) de situatie niet meer in de hand gehouden kan worden, mag een vergadering of betoging verboden worden (Vz.ARRS 21 maart $\left.1989^{12}\right)$. De voldoende politie-inzet is derhalve nodig om de effectieve uitoefening van het vergader- of betogingsrecht te verzekeren. Ook lijkt een tweetal uitspraken erop te wijzen dat artikel 9 onder omstandigheden kan vereisen dat vergaderruimten ter beschikking worden gesteld (twee uitspraken van de HR van 25 juni $\left.1982^{13}\right)$.

\subsubsection{Het proportionaliteitsbeginsel}

Het proportionaliteitsbeginsel komen we in de eerste plaats als afbakeningscriterium tegen bij toetsing aan de beperkingsclausules in de

11 EHRM 9 oktober 1979, Airey Case, \$22-26, pp. 12-16; Pres.Rb. Amsterdam 26 januari 1984, KG 1984, 111; zie o.a. ook EHRM 13 mei 1980. Artico Case. $\$ \$ 33$ en 36, pp. 16 en 18.

12 Vz.ARRS 21 maart 1989, AB 1989, 498 met noot A.E. Schilder onder AB 1989. 499: zie ook Vz.ARRS 22 september 1987, AB 1988, 249 en Vz.ARRS 1 juni 1989. KG 1989. 272.

13 HR 25 juni 1982, AB 1983, 37 met noot F.H. van der Burg. NJ 1983, 295 en HR 25 juni 1982, NJ 1983, 296 met noot E.A. Alkema. Vergelijk verder Pres.Rb. "sGravenhage 9 juni 1987, KG 1987, 268. 
artikelen 8 tot en met 11 ECRM. Aan het eind van paragraaf 5.1 .3 is geconstateerd dat de eisen die worden gesteld aan "implied limitations" die kunnen worden aangebracht op het recht op toegang tot de rechter op grond van artikel 6 ECRM, grote overeenkomsten vertonen met de beperkingsvoorwaarden die gelden ten aanzien voor beperkingen op de artikelen 8-11. Omdat, zoals eerder al herhaaldelijk is gezegd, het recht op toegang tot de rechter impliciet gegarandeerd wordt, behoort de toetsing van de beperkingen op dit recht tot de afbakening van de reikwijdte van het recht. Derhalve is het proportionaliteitsbeginsel, dat een afweging van het recht op toegang van een rechtzoekende tegen het met de beperking op dat recht nagestreefde legitieme doel impliceert, een criterium dat bij de afbakening van het recht op toegang een rol speelt (o.a. Ashingdane, Geouffre de la Pradel, Fayed). Zo overwoog het Hof in de zaak Ashingdane dat "a limitation will not be compatible with Article $6 \$ 1$ if it does not pursue a legitimate aim and if there is not a reasonable relationship of proportionality between the means employed and the aim sought to be achieved. "I4 In de uitspraak in de zaak de Geouffre de la Pradel bepaalde het Hof voorts dat "... the applicant was entitled to expect a coherent system that would achieve a fair balance between the authorities' interests and his own; ...". ${ }^{13}$ Tot slot oordeelde het Hof in de zaak Fayed, dat "(i)f the Court were to treat the facts underlying the complaints ... as raising a substantive, rather than a procedural, complaint going to the right to respect for private life under Article 8 of the Convention ... the same central issues of legitimate aim and proportionality as under Article $6 \$ 1$ would be posed."

Een dergelijke afweging tussen het door het grondrecht beschermde belang dat een justitiabele heeft en een door de overheid te beschermen algemeen belang treffen we ook aan bij de toetsing van de vraag of sprake is van (schending van) een positieve verplichting. Ook ten aanzien dit soort zaken is door het Hof uitgesproken dat de toetsing vergelijkbaar is met die in zaken betreffende negatieve verplichtingen (o.a. Rees, Powel and Rayner, Keegan en López Ostra). Zo merkt het Hof in de zaak Rees op. dat bij de vaststelling of er sprake is van een positieve verplichting, een eerlijke afweging plaats moet vinden tussen het algemene belang van de gemeenschap en de belangen van de individu. Reden hiervoor was dat een dergelijk onderzoek naar een dergelijk evenwicht tussen algemeen en

15 EHRM 16 december 1992, Case of de Geouffre de la Pradel, \$\$29, 32-35, pp. 4143.

EHRM 21 september 1994, Fayed Case, \$67, pp. 50-51. 
individueel belang inherent was "in the whole of the Convention. "1" Dat het proportionaliteitsbeginsel bij de afbakening van de rechten van de mens die zijn opgenomen in de Conventie, een grote rol speelt is, mijns inziens dan ook voor de hand liggend.

Bij de afbakening van de grondwettelijke grondrechten lijkt het proportionaliteitsbeginsel nauwelijks een rol te spelen. We zien in de rechtspraak het duidelijkst een afweging tussen het algemene belang en het individuele belang van degene die zich op een grondrecht beroept in zaken waarin het gaat om de uitoefening van het betogingsrecht en een daartegen gericht "hostile audience". Ook hier gaat het derhalve weer om een impliciet door artikel 9 lid 1 Grondwet bestreken recht waaruit voor de overheid een positieve verplichting voortvloeit. De reikwijdte van deze zorgplicht, inhoudende een adequate inzet van politie, wordt in het individuele geval vastgesteld aan de hand van een afweging tussen het doel van de zorgplicht - het voorkomen van door derden veroorzaakte wanordelijkheden - en het middel, beperking van het betogingsrecht.

Met betrekking tot andere grondwettelijke grondrechten heb ik de rechtspraak zelden toetsing aan het proportionaliteitsbeginsel kunnen vaststellen. Een uitzondering vormt, bijvoorbeeld, een uitspraak waarin het gaat om uitoefening van de vrijheid van godsdienst, maar waarin niet aan artikel 6 Grondwet wordt getoetst. Aan de orde is een met een gebruiksbepaling (behorende bij een bestemmingsplan) strijdig gebruik van een pand als gebedsruimte. ${ }^{\text {Is }}$ De onmiddellijke effectuering van het betwiste besluit tot aanzegging van politiedwang - teneinde dit gebruik als gebedsruimte te doen beëindigen - wordt door de Voorzitter van de Afdeling Rechtspraak ongeoorloofd geacht. De Voorzitter van de Afdeling Rechtspraak komt tot dit oordeel aan de hand van een afweging tussen de hoeveelheid overlast die het gebruik als gebedsruimte voor de omgeving met zich brengt enerzijds en de mate waarin de betrokken religieuze groepering nog aan haar godsdienstige verplichtingen kan voldoen bij (onmiddellijke) effectuering van het besluit anderzijds.

De reden waarom overigens nauwelijks een rol voor het proportionaliteitsbeginsel lijkt te zijn weggelegd, is wellicht de volgende. In het Europese recht wordt - zoals hierboven nogmaals is vermeld - het proportionaliteitsbeginsel afgeleid uit de expliciet in de beperkingsclausules van de artikelen 8-11 ECRM opgenomen gedragscode "noodzakelijk in een democratische samenleving" alsmede de "rule of law" (zie par. 7.2.1). Met deze gedragscode vergelijkbare beperkingsvoorwaarden worden ook toegepast bij impliciete beperkingen op een impliciet gegarandeerd recht, 
zoals het recht op toegang tot de rechter. In paragraaf 3.2 .6 is geconstateerd dat in de grondwettelijke beperkingssystematiek niet een vergelijkbare gedragscode is opgenomen. Hierdoor ontbreekt het de Nederlandse rechter aan een handvat in de grondwettelijke beperkingsclausules voor de toetsing aan het proportionaliteitsbeginsel wanneer het gaat om de beperking van expliciet gegarandeerde rechten, maar ook wanneer het de reikwijdte-afbakening van impliciet door de Grondwet beschermde rechten betreft.

\subsubsection{Het recht op een "fair trial"}

Dit criterium is het eerste van een aantal wat minder frequent gebruikte toetsingsmaatstaven. Strikt genomen is het recht op een "fair trial" geen criterium ter vaststelling van de grenzen van een recht. Toch meen ik dit recht hier op te moeten nemen, omdat ik het hier niet heb over het recht op een "fair trial" in de zin van artikel 6 ECRM, maar over een procedurele garantie die door het Hof is afgeleid uit artikel 8 ECRM. In de paragrafen 2.4.2.1 en 4.2.2 bleek dat bij toetsing aan artikel 8 , met name in gevallen van ondertoezichtstelling of uithuisplaatsing van een kind, de vraag relevant is of

"... having regard to the particular circumstances of the case and notably the serious nature of the decisions to be taken, the parents have been involved in the decision-making process, seen as a whole, to a degree sufficient to provide them with the requisite protection of their interests. If they have not, there will have been a failure to respect their family life and the interference resulting from the decision will not be capable of being regarded as 'necessary' within the meaning of Article $8 . " 19$

Eerder heb ik in paragraaf 7.2.2 het effectieve nut van een grondrecht als onderdeel van de kern van dat recht behandeld. In die paragraaf heb ik naar voren gebracht dat het "effectieve nut" voornamelijk een afbakeningscriterium zal zijn in gevallen waarin de overheid een

19 Zie EHRM 8 juli 1987. Case of W v. UK, 859, p. 27; EHRM 8 juli 1987, Case of $B$ v. UK. $\$ 60$, pp. 71-72; EHRM 8 juli 1987, Case of $R$ v. UK, $\$ 64$, p. 1!7; EHRM 24 maart 1988, Olsson Case (no. 1), \$59. p. 29: EHRM 22 juni 1989. Eriksson Case, \$58, p. 24; EHRM 25 februari 1992. Case of Margareta and Roger Andersson, \$\$72-73, p. 25; EHRM 22 april 1992, Rieme Case, 8\$54-56, p. 68; EHRM 26 mei 1994, Keegan Case. \$50, p. 19 en EHRM 24 februari 1995. McMichael Case, $\$ 87$. 
beoordelingsmarge toekomt ten aanzien van de reikwijdte van het recht. Ik heb toen ook aangevoerd dat die beoordelingsruimte niet bestaat in het geval van negatieve verplichtingen die uit een recht voortvloeien, omdat het uiteindelijk de rechter is die de reikwijdte van dat recht vaststelt (tenzij de verdragsopstellers of grondwetgever een recht nader afbakenen). Ook heb ik daaraan toegevoegd dat de rechter de reikwijdte van een aantal rechten in de loop der tijd steeds ruimer is gaan uitleggen, waardoor ze veel meer zijn gaan omvatten dan de kern van het effectieve nut van een recht. Het recht op een "fair trial" in verband met het recht op respect voor het familie- en gezinsleven in artikel 8 is daar een voorbeeld van. Het recht op een behoorlijke procesgang behoort zeker niet tot de kern van het recht dat artikel 8 beoogt te beschermen. Wel zou gesteld kunnen worden dat het recht op een "fair trial" onder artikel 8 als doel heeft om de kern van het recht op respect voor het familie- en gezinsleven te beschermen. ${ }^{20}$ Ik zou niet willen uitsluiten, dat een soortgelijke procedurele waarborg ook afgeleid zou kunnen worden uit andere verdragsrechtelijk of grondwettelijk gegarandeerde rechten. Een aanwijzing hiervoor is de in de Memorie van Toelichting bij het wetsvoorstel inzake de Algehele Grondwetsherziening omschreven essentie van de beperkingsclausule "behoudens ieders verantwoordelijkheid volgens de wet" in de artikelen 6 lid 1, 7 leden 1 en 3 en 9 lid 1 Grondwet: deze essentie is dat "de wetgever, van deze beperkingsbevoegdheid gebruik makende, ervoor moet zorg dragen, dat in het concrete geval, waarin een beperking zich effectueert, uiteindelijk een rechtsgang naar een rechterlijk orgaan openstaat. "21

\subsubsection{Het non-discriminatie-criterium}

Dit criterium ter afbakening van de reikwijdte van rechten van de mens heb ik afgeleid uit de uitspraak van het Hof in de zaak Marckx, waarin in verband met het recht op respect voor het familie- en gezinsleven is uitgesproken dat geen onderscheid tussen wettige en onwettige verwantschap mag worden gemaakt. "Het Hof verwees hierbij zowel naar

20 Hierin onderscheidt dit recht op een "fair trial" zich ook van het recht in artikel 6 dat tot doel heeft te voorzien in een procedurele waarborg. het recht op toegang tot de rechter, bij de vaststelling van iemand's burgerlijke rechten en verplichtingen. Zie EHRM 24 februari 1995. McMichael Case. \$91.

21 Memorie van Toelichting bij wetsvoorstel 13872. Verklaring dat er grond bestaat .... Tweede Kamer, in: Algehele grondwetsherziening, deel la Grondrechten. p. 18. In de rechtspraak is deze procedurele waarborg. voor zover mij bekend. nooit aan de orde gekomen.

22 EHRM 13 juli 1979. Marckx Case, \$31, pp. 14-15: zie ook EHRM 18 december 1986. Case of Johnston a.o., \$55(b). p. 25. 
de term "everyone" in artikel 8 als naar het discriminatie-verbod in artikel 14 ECRM. Naar mijn mening dient dit non-discriminatie-criterium evenzeer bij de afbakening van andere rechten van de mens gehanteerd te worden als bij het recht op respect voor het familie- en gezinsleven. Dit wordt alleen al ondersteund door het feit, dat in vele rechten in de Conventie en de Grondwet het desbetreffende recht aan een "ieder" is toegekend. Maar ook ten aanzien van rechten waarbij dat niet is gebeurd, dient mijns inziens het discriminatie-verbod in acht genomen te worden. Voorbeelden uit de Nederlandse rechtspraak kunnen, ter ondersteuning van dit standpunt, worden aangetroffen ten aanzien van artikel 6 Grondwet (ARRS 1 augustus 1983) ${ }^{23}$ en artikel 9 Grondwet. Met betrekking tot deze laatstgenoemde bepaling oordeelde de President van de Haagse rechtbank: "De Verdragen en de Grondwet maken geen onderscheid tussen burgers. ook niet naar hun opvattingen. Grondrechten heeft iedereen. ..." ${ }^{24}$

\subsubsection{Het verbod van misbruik van recht}

Zoals is uiteengezet in paragraaf 2.4.2.6, is in artikel 17 ECRM het verbod van misbruik van recht opgenomen. Uit de jurisprudentie van de Commissie kwamen twee benaderingswijzen naar voren. Bij de eerste wordt artikel 17 gehanteerd bij de vraag naar de toepasselijkheid van het door de klager ingeroepen recht. Gewezen werd op uitspraken waarin geconcludeerd werd dat de klacht - omdat sprake was van misbruik van het ingeroepen recht - niet kon worden gebaseerd op één van de Conventiebepalingen en daarom als onverenigbaar met de Conventie nietontvankelijk moest worden verklaard. ${ }^{25}$ Volgens de tweede benaderingswijze wordt aan artikel 17 getoetst bij de vraag of een op het ingeroepen recht gemaakte inbreuk gerechtvaardigd is. Bij deze methode is ruimte voor een meer inhoudelijke toetsing. Het desbetreffende recht wordt wel van toepassing geacht en ook wordt inbreuk daarop geconstateerd; de toetsing van de rechtvaardiging van die inbreuk vindt echter mede plaats aan de hand van artikel 17. Recentere jurisprudentie duidt erop dat de Commissie deze tweede benaderingswijze hanteert,

23 ARRS 1 augustus 1983. AB 1984. 532 met noot B.J. van der Net; NJCM-Bulletin 9-2 (1984), pp. 156 e.v. met noot J.E. Goldschmidt; zie voorts paragraaf 6.1.2. Vergelijk ook CRvB 14 maart 1991. TAR 1991, 105 met noot G.L. Cooten.

24 Pres.Rb. 's-Gravenhage 9 juni 1987. K.G 1987, 268. Deze uitspraak is bevestigd in hoger beroep. Gerechtshof 's-Gravenhage 1 oktober 1992. NJCM-Bulletin 18-3 (1993) met noot A.W. Heringa op pp. 299-302. Zie paragraaf 6.2.3.1.

25 Besl.Comm. 20 juli 1957, zaak nr. 250/57, Kommunistische Parlei Deutschland, p. 225 en Besl.Comm. 11 oktober 1979, zaken nis. 8348 en 8406/78, Glimmerveen en Hagenbeek, pp. 196-197. 
waarop dan - in het geval van geconstateerd misbruik van recht - de uitspraak volgt dat de klacht kennelijk ongegrond is. Er is derhalve wèl sprake van een inhoudelijke toetsing, maar niet door het Hof of het Comité van Ministers waartoe de tweede benaderingswijze oorspronkelijk leidde. Concluderend ten aanzien van artikel 17 ECRM kan gesteld worden, dat het verbod van misbruik van recht in de recentere jurisprudentie (zoals inherent is aan de tweede benaderingswijze) fungeert als beperkingsgrond en niet als criterium ter afbakening van de in de Conventie gegarandeerde rechten (zoals bij de eerste benaderingswijze).

In de Grondwet is - zo bleek ook in paragraaf 3.2.6 - geen met artikel 17 ECRM vergelijkbare bepaling opgenomen. In de Memorie van Toelichting bij het wetsvoorstel tot herziening van de Grondwet is daar door de regering als motivering voor gegeven, dat een dergelijke bepaling als vervat in artikel 17 ECRM een maatschappelijke of politieke ontwikkeling naar een politieke orde, waarin de vrijheid van meningsuiting verregaand wordt beperkt en waarin alleen de aanhangers van het heersende politieke bewind hun rechten kunnen uitoefenen, niet kan tegenhouden. Volgens de regering bieden de opgenomen beperkingsclausules voldoende mogelijkheden om bepaalde maatregelen treffen, indien de omstandigheden daar ooit toe mochten nopen. ${ }^{26}$ Allereerst kan hieromtrent worden opgemerkt dat het verbod van misbruik in artikel 17 ECRM op meer rechten ziet dan alleen de vrijheid van meningsuiting. Voorts ziet het eerste punt, betreffende de genoemde politieke ontwikkeling, op de in artikel 17 geformuleerde grens die gesteld wordt aan de beperkingsmogelijkheden van de Staat (verbod om een recht verder te beperken dan de Conventie toestaat, zie par. 2.4.5.2) en niet op een beperkingsbevoegdheid zelf, zoals bij misbruik van recht. Hiermee komen we op het laatste punt: ook de regering ziet blijkens de verwijzing naar de beperkingsclausules misbruik van recht in het licht van beperkingen op rechten en niet als kwestie van afbakening van die rechten.

Toch acht ik dit niet vanzelfsprekend. Moeten we een discriminerende uitlating van een notoire racist wel vatten onder de vrijheid van meningsuiting? Heeft een vereniging met democratie-ondermijnende doelstellingen wel vrijheid van vereniging? Heeft een verkrachter nog wel recht op onaantastbaarheid van zijn lichaam, als door zijn slachtoffer (wiens lichamelijke en geestelijke integriteit hij zelf op gruwelijke wijze heeft geschonden) gevorderd wordt dat hij een AIDS-test ondergaat? Komt aan een man die via incest bij zijn dochter een kind heeft verwekt, wel een beroep toe op het recht op respect voor familie- en gezinsleven wanneer 
hij om omgangsrecht met dat kind verzoekt? Natuurlijk moet niet te snel tot een ontkennende beantwoording van dit soort vragen worden overgegaan, maar toch zal er bij de toepasselijkheid van grondrechten een grens getrokken moeten worden en in dit soort gevallen acht ik het mogelijk dat die grens bereikt is. Wanneer, echter, zou misbruik van recht inderdaad tot de conclusie moeten leiden dat een grondrecht niet langer van toepassing is en niet meer kan worden ingeroepen? Een mogelijk antwoord op deze vraag biedt een uitspraak van de President van de Rechtbank Zwolle in één van de Goeree-zaken ten aanzien van artikel 6 Grondwet. ${ }^{27}$ De President was van oordeel dat de bestreden uitlatingen niet vielen binnen het bereik van de vrijheid van godsdienst omdat zij ongenuanceerd, ongemotiveerd en tegen beter weten in, onjuist en misleidend waren. Met name de verwijzing naar het "tegen beter weten in" onjuiste en misleidende uitlatingen doen, duidt op misbruik van de vrijheid om godsdienstige uitlatingen te doen. ${ }^{28}$ Voorbeelden van zaken waarin het verbod van misbruik van recht bij de afbakening een rol had kunnen spelen (maar dat niet deed omdat de zaak in het kader van de beperkingsmogelijkheden werd beoordeeld) zijn de zaken STIMEZO ${ }^{29}$. Mijns inziens hadden de Haagse en Middelburgse Rechtbank-presidenten in deze zaken, waarin het ging om acties van demonstranten bij abortusklinieken, tot niettoepasselijkheid van artikel 7 Grondwet kunnen concluderen als de acties dermate agressief en intimiderend waren geweest dat aan de patiënten geen vrije keuze meer werd gelaten om al dan niet een abortus te ondergaan. Het recht van de patiënten om vrijelijk over hun eigen lichaam te beschikken (de lichamelijk integriteit die door artikel 8 ECRM beschermd wordt, zie de paragrafen 4.2.1 en 4.3.1) werd door de acties wezenlijk ondermijnd en wellicht onmogelijk gemaakt. De omschrijving van de feiten in deze zaken lijken erop te wijzen dat patiënten soms, ten gevolge van de

27 Pres.Rb. Zwolle 6 mei 1987, KG 1987. 236. NJCM-Bulletin 14-3 (1989), pp. 317 e.v.. Deze uitspraak is in hoger instanties bevestigd. Zie verder paragraaf 6.2.1.5.

28 Vgl. ook de strafbaarstelling in Duitsland van de zogenaamde "Auschwitz-Luge". Volgens het Bundesverfassungsgericht geniet de ontkenning van de holocaust geen bescherming van de vrijheid van meningsuiting: "... Unter diesem Gesichtspunkt ist unrichtige Information kein schützenswertes Gut. Das BVerfG geht deswegen in ständiger Rechtsprechung davon aus, dass die bewusst oder erwiesen uwahre Tatsachenbehauptung nich vom Schutz der Meinungsfreiheit umfasst wird." BVerfG 13 april 1994, NJW 1994, 1779. Ontleend aan $R$. de Winter. De 'Auschwitz-Lüge' na 50 jaar: strafwaardig?, p. 655 . Die strafwaardigheid waar het artikel van de Winter voornamelijk over gaat is, mijns inziens, een geheel andere kwestie dan de vraag of uitingen waarin de holocaust ontkend wordt de bescherming van de vrijheid van meningsuiting toekomt.

29 Pres.Rb. Middelburg 29 januari 1990, KG 1990, 81: Pres.Rb. 's-Gravenhage 14 december 1990, NJCM-Bulletin 16-2 (1991), pp. 128-134 met noot R.E. de Winter. 
acties, van behandeling hebben afgezien en dat het functioneren van de kliniek werd verstoord. De Presidenten beoordeelden de toelaatbaarheid van de gevorderde straatverboden, echter, in het kader van de beperkingsmogelijkheden en bepaalden dat de verboden geen "hinderlijke beperking" van hun vrijheid van meningsuiting inhielden en geen "wezenlijke aantasting van enig hen toekomend recht" vormden. ${ }^{\text {00 }}$

Uit bovengenoemde zaken zou men wellicht kunnen afleiden in welke situaties (overtreding van) het verbod van misbruik van recht gehanteerd zou kunnen worden als criterium ter afbakening van de reikwijdte van een grondrecht. Allereerst kan gedacht worden aan de situatie dat bij de uiting van een discriminerende mening - die normaal gesproken wordt beschermd door de vrijheid van meningsuiting, de vrijheid van godsdienst of levensovertuiging of het betogingsrecht - die mening als zijnde "objectief juist" (aan de hand van al dan niet "wetenschappelijke" "bewijzen) gepresenteerd wordt. Het is mogelijk dat die zogenaamde bewijzen kennelijk onjuist zijn, bijvoorbeeld, doordat in wetenschappelijke kring de juistheid van die beweerdelijk objectieve gegevens, die aan de geuite mening ten grondslag liggen, zeer omstreden is of de onjuistheid ervan zelfs onbetwistbaar is vastgesteld. In dergelijke situaties is het uiten van de mening willens en wetens onjuist en misleidend. Met de President van de Rechtbank Zwolle in de zaak Goeree, acht ik het aanvaardbaar dat onder dit soort omstandigheden de uiting van de mening niet door de eerdergenoemde grondrechten wordt beschermd.

Op grond van de STIMEZO-zaken kan men zich vervolgens afvragen of ook wanneer het middel met behulp waarvan een bepaalde mening wordt geuit, per definitie uitermate agressief en intimiderend is tegenover een bepaalde groep personen wier rechten door die wijze van grondrechtsuitoefening worden geschonden, het verbod van misbruik van recht aan toepasselijkheid van de vrijheid van meningsuiting (of een van de andere uitingsrechten) in de weg staat. Mij lijkt het denkbaar dat wanneer een uitingsmethode bestaat uit het plegen van fysiek of psychisch geweld teneinde derden te overreden, deze methode als "zelfstandig middel van bekendmaking" - om de termen uit de jurisprudentie naar aanleiding van de artikel 7 Grondwet te gebruiken - in zijn geheel te verbieden, derhalve zonder dat er "gebruik van enige betekenis" van dit middel overblijft. Deze uitingsmethode zou dan de bescherming van het uitingsrecht geheel moeten ontberen. Alhoewel onbedoeld, is dit het uiteindelijk resultaat geweest in de zaken STIMEZO.

30 Op p. 565 heb ik aangegeven dat (en waarom) ik twijfel aan de juistheid van deze conclusies. 
Tot slot wil ik hier nog wijzen op de situatie - zoals in bovengenoemd geval van de incestpleger - dat een beweerde aanspraak op bescherming van een grondrecht voortvloeit uit een daad van geestelijk of lichamelijk geweld of andere ernstige vorm van schending van de fundamentele rechten van derden. Het verbod van misbruik van recht zou ook onder dergelijke omstandigheden aan toepasselijkheid van het ingeroepen grondrecht in de weg kunnen staan. Zoals ik reeds in paragraaf 4.3.2.1 heb opgemerkt, zou het niet mogelijk moeten zijn dat een grondrechtenaanspraak wordt gevestigd door middel van een misdrijf."

Mijns inziens dient, op grond van het voorgaande, het verbod van misbruik van recht gezien te worden als een mogelijk afbakeningscriterium, zij het dat het met voorzichtigheid dient te worden toegepast. Een klein aantal zaken van de Commissie en, met name, de procedure in één van de Goeree-zaken kunnen hierbij als voorbeeld genomen worden.

\subsubsection{De (subjectieve) keuze van het rechtssubject}

Tenslotte kan uit de jurisprudentie worden afgeleid, dat de toepasselijkheid van een grondrecht soms (mede) kan worden vastgesteld op grond van een subjectieve keuze ten aanzien van een bepaalde gedraging van het rechtssubject. Zo bleek in paragraaf 4.3.1 dat, naast objectieve criteria, de wensen of subjectieve beleving van een individuele burger relevant kunnen zijn voor de vraag of sprake is van privéleven. Gedoeld wordt op de criteria "het recht zijn eigen leven (te) leiden met zo weinig mogelijke inmenging van buitenaf" (HR 9 januari 1987, Edamse bijstandszaak ${ }^{32}$ ) en "de reeks situaties waarin ... de mens onbevangen zichzelf wil zijn" (HR 9 januari 1987 en 19 februari $199 \mathrm{I}^{33}$ ). Tevens bleek dat hierbij rekening gehouden moet worden met de concrete omstandigheden en de achtergiond van degene wiens gedraging in het geding is en doet er niet toe wat de opvattingen van anderen terzake zijn (HR 1 juli 1988).

Ook uit de Straatsburgse jurisprudentie naar aanleiding van artikel 8 ECRM kunnen subjectieve criteria worden afgeleid. Het gaat hier, ten eerste, orn het zogenaarnde "doelcriterium". Het privéleven houdt volgens, de uitspraken van, met name, de Commissie in dat men relaties met andere personen moet kunnen aangaan met het oog op de ontwikkeling en de vervulling van de persoonlijkheid. Of een gedraging op dit doel gericht wordt is afhankelijk van de (innerlijke) wens van degene om wiens 
gedraging het gaat. Deze wens zal zich dan wel op enigerlei wijze moeten manifesteren, echter in praktijk blijkt dit vaak niet zo te zijn. Het doel van het aangaan van relaties met andere personen wordt in de rechtspraak niet (langer) geëxpliciteerd (zie par. 4.2.1 en par. 4.5) en daardoor mist het doelcriterium in praktijk onderscheidende werking tussen gevallen die wèl en die niet onder het privéleven vallen. Zou dit wel gebeuren dan zou het doelcriterium wellicht een nuttige functie kunnen vervullen als afbakeningscriterium.

Ten tweede kan gedacht worden aan het in hoofdstuk 4 uit de rechtspraak naar aanleiding van artikel 8 ECRM afgeleide "eigen schuld"criterium. Toetsing aan dit criterium, in het geval dat een als gezinsleven aan te merken relatie is verstoord, houdt in dat een antwoord gegeven moet worden op de vraag of deze verbreking van het gezinsleven het gevolg is van de vrije keuze van de betrokkene(n). Hiervan is, onder meer, sprake indien een buitenlandse partner van iemand die zich in een Verdragsstaat bevindt niet tot die Verdragsstaat wordt toegelaten, terwijl het voor de partner die in de Verdragsstaat verblijft mogelijk is de partner naar een ander land te volgen. Voor de verbreking van het gezinsleven die het gevolg is van dit niet volgen van de partner naar een ander land kan de desbetreffende Verdragsstaat niet verantwoordelijk worden gesteld."

Voorts kan worden opgemerkt, dat wanneer rechtsgeldig (derhalve in overeenstemming met de eisen die daaraan op grond van de Conventie worden gesteld) afstand van recht gedaan wordt, dan is het niet van toepassing zijn van een Conventie-bepaling ook het gevolg van de eigen keuze van het rechtssubject. ${ }^{35}$

Tot slot: ik hoop met de voorgaande sub-paragrafen de hoofdvraag naar de wijze waarop de rechter de reikwijdte van de rechten van de mens vaststelt, voldoende te hebben beantwoord. Een aantal van de besproken punten zullen in de volgende paragrafen nog nader aan de orde worden gesteld. Na de conclusies in deze paragraaf ten aanzien van de hoofdvraag, kom ik nu toe aan de conclusies met betrekking tot de stellingen aan de hand waarvan ik het onderzoek heb verricht teneinde die hoofdvraag te kunnen beantwoorden. In de volgende paragraaf zal ik ingaan op de eerste stelling. 


\subsection{De eerste stelling: $\mathrm{Er}$ bestaat een verband tussen de vaststelling van de reikwijdte van mensenrechten en de beperking van de uitoefening van mensenrechten}

In hoofdstuk 2, waarin de beperkingssystematiek in de Europese Conventie is besproken, zijn al diverse voorbeelden van het verband tussen de vaststelling van de reikwijdte en de beperking van de uitoefening van mensenrechten naar voren gekomen. Bezien we de eerste aldaar besproken beperkingsmethode, de beperkingsclausules vervat in de artikelen 8-11 ECRM, artikel 2 Protocol IV ECRM en artikel 1 Protocol VII ECRM, dan blijkt het volgende. De beperkingsbevoegdheden van de Staat zijn gekoppeld aan een aantal voorwaarden: de beperking moet bij de wet zijn voorgeschreven of daarmee in overeenstemming zijn; de beperking moet noodzakelijk zijn in een democratische samenleving en de beperking moet dienen voor één of meer van de in de beperkingsclausule genoernde belangen. De voorwaarde "noodzakelijk in een democratische samenleving" is in de jurisprudentie nader uitgewerkt. Allereerst blijkt de Staat een grote beoordelingsvrijheid te hebben bij de gebruikmaking van de gegeven beperkingsbevoegdheid. Aan deze beoordelingsvrijheid is een aantal grenzen gesteld. Enkele van die grenzen zijn de volgende: de redenen die voor de beperking gegeven worden moeten relevant en voldoende ("relevant and sufficient") zijn en voortspruiten uit een "pressing social need". Voorts moet de beperking proportioneel zijn aan het nagestreefde legitieme doel ervan. Dit vloeit voort uit de beginselen waaraan voldaan moet zijn om te kunnen spreken van een democratische samenleving ("principles characterising a "democratic society"). Hoewel hiermee maatstaven zijn ontwikkeld aan de hand waarvan de beslissing van de Staat tot het aanbrengen van een beperking op de gegarandeerde rechten kan worden getoetst, staat hiermee de beoordelingsvrijheid van de Staat bij het nemen van die beslissing niet onomstotelijk vast. Wel blijkt echiter in de rechtspraak, dat het voor de omvang van die beleidsmarge van de Staat van belang kan zijn. welk gegarandeerd recht in het geding is. In hoofdstuk 2 werd gewezen op de uitspraak van het Hof in de zaak Dudgeon $n^{16}$, walarin werd uitgesproken dat niet alleen de aard van het doel van de beperking - de beperkingsgrond - de omvang van de beoordelingsvrijheid beïnvloedt. maar ook de aard van de desbetreffende activiteiten - dat wil zeggen de activiteiten waarvoor de bescherming van het onderhavige recht (in casu artikel 8 lid 1) wordt ingeroepen. De beleidsmarge van de Staat bij het beperken van een recht is kleiner 
naarmate het "a most intimate aspect of private life" betreft. In dat geval moeten de autoriteiten uitermate serieuze redenen aanvoeren wil een inbreuk op een recht legitiem kunnen zijn. Behalve ten aanzien van het recht op privéleven, is ook met betrekking tot de vrijheid van meningsuiting (artikel 10) uitgesproken dat de beoordelingsmarge van de Staat beperkt is. Dit is anders indien het gaat om de economische orde van de Staat, zoals bij het recht op eigendom in artikel 1 Protocol I ECRM. In dat geval is de beoordelingsvrijheid van de Staat ruimer. Ook binnen artikel 8 lid 1 - zo werd in hoofdstuk 2 geconstateerd - bestaan er verschillen in ornvang van de beleidsmarge van de Staat ten aanzien van de beperking van het recht op respect voor het privéleven enerzijds en het recht op respect voor de woning anderzijds. Met betrekking tot dit laatste recht is de beoordelingsruimte van de Staat ruimer dan ten aanzien van het recht op respect voor het privéleven.

Het verschil in beleidsmarge tussen, bijvoorbeeld, de vrijheid van meningsuiting en het recht op eigendom, kan blijkens de uitspraak van het Hof in de zaak Handyside afgeleid worden uit de eerdergenoemde beginselen die kenmerkend zijn voor een democratische samenleving. Van een dergelijke samenleving kan volgens het Hof geen sprake zijn zonder vrijheid van meningsuiting, omdat er in dat geval niet voldaan is aan de aan die democratische samenleving gestelde eisen van "pluralism, tolerance and broadmindedness". ${ }^{37}$ Voor de beoordeling van de mogelijkheid van de Staat om een bepaald recht te beperken speelt derhalve de aard van het: desbetreffende recht een rol.

De aard van de activiteiten of gedragingen, waarvoor de bescherming van een grondrecht wordt ingeroepen, kan vervolgens weer in verband staan met de reikwijdte van het recht, althans ingeval van verschillen in omvang van de beoordelingsmarge bij de beperking van rechten binnen éćn. verdragsbepaling. ${ }^{38}$ Gaat het om kritische, politieke uitlatingen, dan staan deze uitingen in nauwer verband met de kern van de vrijheid van meningsuiting in artikel 10 dan, bijvoorbeeld, commerciële uitingen. Ten. aanzien van de eerste soort uitingen zijn de gestelde eisen van "pluralism, tolerance and broadmindedness" meer aan de orde. Bij de eerste soort uitlatingen heeft de Staat dan ook een kleinere beoordelingsmarge ten aanzien van de beperking van de vrijheid van meningsuiting dan met betrekking tot de laatste. In het kader van artikel 8 kan als voorbeeld

37 EHRM 7 december 1976. Handyside Case, \$49. p. 23: NJ 1978, 236. Zo ook EHRM 24 mei 1988, Case of Müller a.o., p. 22. Zie par. 2.4.2.1. pp. 84-85.

38 Verschillen in beoordelingsvrijheid tussen de diverse verdragsbepalingen zijn, naar mijn mening, niet terug te voeren tot de reikwijdte van het recht. Het navolgende geldt derhalve niet voor deze verschillen in beoordelingsmarge. 
gegeven worden, dat de Staat een grotere beoordelingsvrijheid zal hebben bij de beperking van het recht op privéleven, wanneer het gaat om het onderhouden van zakelijke contacten dan in het geval van intieme (al dan niet seksuele) relaties. De ene gedraging - en dit is mijns inziens afhankelijk van de aard van die gedraging - ligt binnen de reikwijdte van de grondrechtsbepaling dichter bij de kern van het recht en derhalve verder van de uiterste grenzen van het recht, dan de andere gedraging. Hoe dichter een gedraging waarvoor de bescherrning van een grondrecht gezocht wordt, tot de kern van het recht behoort, des te minder beoordelingsvrijheid de Staat bij de beperking van het desbetreffende recht zal hebben. Hieruit valt te verklaren, dat wanneer een recht restrictief wordt uitgelegd door, bijvoorbeeld, de bescherming van het recht te beperken tot de kern van het recht, er weinig ruimte voor de Staat overblijft om dat recht te beperken. De beperkingsmogelijkheden van de Staat dienen dan derhalve ook restrictief te worden uitgellegd. Hier zien we derhalve het eerste voorbeeld van het verband tussen reikwijdte-afbakening en de beperking van mensenrechten.

Bekijken we vervolgens de tweede en derde methode van beperking die in hoofdstuk. 2 zijn besproken: ten eerste de inhoudelijke omschrijving van rechten en vrijheden waarbij een aantal elementen van het recht zijn beschreven, zodanig dat uit die omschrijving een beperking voortvloeit. Ten tweede de inhoudelijke omschrijving van rechten en vrijheden waarbij bepaalde gevallen of situaties van bescherming zijn uitgesloten. ${ }^{39} \mathrm{Bij}$ de laatstgenoemde methode is het strikt genomen mogelijk om de toetsingsmomenten van de reikwijdte-afbakening enerzijds en de beperking van het recht anderzijds te onderscheiden. Zo kan men met betrekking tot artikel 2 ECRM eerst de reikwijdte van het recht op leven afbakenen alvorens tot de conclusie te komen, dat in een bepaald geval sprake is van één van de omschreven uitzonderingssituaties, bijvoorbeeld dat sprake is van levensberoving ten gevolge van het onderdrukken van een oproer op opstand (artikel 2 lid 2 sub c). Of in de praktijk inderdaad eerst een reikwijdte-afbakening plaatsvindt indien men een beroep op het desbetreffende recht kan afdoen op grond van één van de voorziene uitzonderingsgevallen heb ik niet onderzocht, maar gezien de praktijk ten aanzien van de beperkingsclausules - waarbij ook vaak over de vraag naar de reikwijdte van het recht wordt heengestapt - is dit niet waarschijnlijk. Anders is de toetsing in geval van de tweede beperkingsmethode. De omschrijving van een recht aan de hand van de opsomming van een aantal 
elementen van dit recht fungeert als een beperking van het recht omdat dit zonder die omschrijving een ruimere afbakening "had kunnen hebben". Deze omschrijving betreft echter wel de reikwijdte van het recht. Er is derhalve slechts één toetsingsmoment, namelijk de vaststelling van de reikwijdte van het recht. In dit soort gevallen worden de toetsingscriteria echter niet alle door de rechter vastgesteld, maar zijn enkele al in de desbetreffende bepaling gegeven. Dit is een tweede voorbeeld van het bestaan van een verband tussen vaststelling van de reikwijdte van mensenrechten en de beperking van die rechten. Artikel 6 lid 1 ECRM is een bepaling die in deze categorie beperkingen valt. De omschrijving van het in artikel 6 vervatte recht op een "fair trial" door middel van de voorwaarden dat sprake moet zijn van "the determination of ... civil rights and obligations ...." of van "the determination of ... any criminal charge ...", beperkt de reikwijdte van het recht. Is niet aan deze voorwaarden voldaan, dan is artikel 6 niet van toepassing. Puur administratieve zaken worden op deze wijze van het in artikel 6 gegarandeerde recht uitgesloten, alhoewel in hoofdstuk 5 bleek, dat onder omstandigheden ook administratieve zaken onder artikel 6 kunnen vallen. ${ }^{* 0}$ Op deze voorvragen is in hoofdstuk 5 niet verder ingegaan. In hoofdstuk 5 wordt de interpretatie van een onderdeel van dit artikel onderzocht, te weten het recht op toegang tot een onafhankelijk en onpartijdige, bij wet ingestelde rechter.

Ook het discriminatie-verbod in artikel 14 ECRM en artikel 1 Grondwet en het gelijkheidsbeginsel in de laatstgenoemde bepaling vormen een (derde) voorbeeld van het verband tussen de reikwijdte-afbakening en beperking van mensenrechten. In hoofdstuk 2 en 3 heb ik laten zien, dat het discriminatieverbod (maar mijns inziens geldt hetzelfde voor het gelijkheidsbeginsel) een grens stelt aan de beperkingsbevoegdheid van de Staat." Een Staat mag bij het beperken van een recht niet discrimineren (of niet-discriminerend ongelijk behandelen in gelijke gevallen). Hetzelfde geldt echter voor de interpretatie van de reikwijdte van een recht. Bij de bepaling of op een bepaald grondrecht een beroep gedaan mag worden mag in beginsel niet gekeken worden naar wie dat beroep doet. Het verband tussen interpretatie en beperking van mensenrechten is er hier derhalve in gelegen, dat het gelijkheidsbeginsel en het discriminatie-verbod in beide gevallen in acht genomen dienen te worden.

Een kwestie die hier van belang is, is die van de inherente beperking. Inherente beperking werd eerder in hoofdstuk 1 (zie ook par. 1.1) 
omschreven als de inperking van de reikwijdte van een recht ten aanzien van een persoon of een groep van personen wegens een bepaalde eigenschap van die persoon of groep. ${ }^{42}$ Zo werd in de Golder-zaak door de regering als verweer op een klacht onder artikel 8 lid 1 (recht op respect voor de correspondentie) ter rechtvaardiging van de beperking op dit recht een beroep gedaan op het feit dat Golder gedetineerd was. Een dergelijke inherente beperking is door het Hof afgewezen op de grond dat de restrictieve formulering van artikel 8 lid 2 geen ruimte overlaat voor het concept "inherente beperkingen". De juridische status ("legal status") van het onderhavige recht verschilde in dit opzicht aanzienlijk van het recht op toegang tot de rechter. ${ }^{3}$ Uit de overwegingen van het Hof in de zaak Golder ten aanzien van dit recht op toegang in artikel 6 lid 1 ECRM blijkt, dat hierbij wel "implied limitations" zijn toegestaan. Dit vloeit voort uit het feit dat "this is a right which the Convention sets forth ... without, in the narrower sense of the term, defining ...". In In de zak Ashingdane overweegt het Hof ten aanzien van beperkingen op het recht op toegang dat "these are permitted by implication since the right of access "by its very nature calls for regulation by the State ...". . Volgens deze overwegingen vloeien "implied limitations" ofwel inherente beperkingen voort uit de aard van het recht. In het geval van het recht op toegang is die aard, het feit dat het recht niet expliciet in de Conventie is gedefinieerd en dat het noodzaakt tot regulering door de Staat. Dit is een ruimere omschrijving, dan de eerder gegeven definitie van inherente beperking, dat sprake is van een inperking van de reikwijdte van een recht ten aanzien van een persoon of een groep van personen wegens een bepaalde eigenschap van die persoon of groep. Inherente beperking betekent niet noodzakelijk dat de reikwijdte van het recht wordt beperkt op grond van een bepaalde eigenschap van een persoon of groep personen, alhoewel dit kennelijk wel vaak het geval is. Het Hof overweegt namelijk in de zaak Golder, dat de regering en de Commissie in die zaak gewezen hebben op diverse voorbeelden van reguleringen van het recht op toegang tot de rechter met betrekking tot minderjarigen en geestelijk gehandicapten. Het Hof voegt daaraan toe, dat regulering van dit recht ten aanzien van gedetineerden (waar Golder over klaagt) ook een voorbeeld is, echter komt dit soort regelgeving minder vaak voor en is zeer anders van aard. Dit betekent niet dat het Hof inherente beperking van het recht op toegang ten

43 EHRM 21 februari 1975, Golder Case, \$44, p. 21.

45 EHRM 28 mei 1985, Ashingdane Case, \$57, p. 24. Het Hof verwijst naar EHRM 23 juli 1968, Belgian Linguistic Case, 85. p. 32. 
aanzien van bepaalde categorieẻn personen toestaat (of afkeurt). Het Hof merkt slechts ten aanzien van dit soort regelgeving op, dat "(I)t is not the function of the Court to elaborate a general theory of the limitations admissible in the case of convicted prisoners, nor even to rule in abstracto on the compatibility of Rules ...". Het Hof doet derhalve geen uitspraak over de inherente beperking van het recht op toegang op grond van de aard van de betrokken groep - in casu gedetineerden - maar beperkt zich tot een beoordeling van het onderhavige geval. ${ }^{46}$ Enerzijds is de inherente beperking van rechten voorzien van een strikte beperkingsclausule uitgesloten en is die beperking bij andere rechten wel toegestaan. Anderzijds wordt over de toespitsing van beperking op specifieke groepen personen vanwege de aard van die personen of de groep in het algemeen geen uitspraak gedaan, maar wordt slechts de beperking in het individuele geval beoordeeld. Dit is naar mijn mening in overeenstemming met het gelijkheidsbeginsel en het discriminatieverbod die - zoals gezegd - bij de reikwijdte-afbakening in acht genomen moeten worden. In ieder voorliggend geval waarin een beperking van de reikwijdte van een recht wordt afgeleid uit een bepaalde eigenschap van een persoon of groep personen, zal dat voor het individuele geval gerechtvaardigd moeten worden en kan niet volstaan worden met een verwijzing naar de aard van de groep waartoe de betrokken persoon behoort. Er zal derhalve - om in de termen te spreken die ik bij de behandeling van artikel 1 Grondwet heb gebruikt ${ }^{47}$ - sprake moeten zijn van een objectieve en redelijke rechtvaardiging indien bij de afbakening van grondrechten onderscheid gemaakt wordt tussen verschillende groepen personen, net als bij de beperking van grondrechten.

Overigens is in hoofdstuk 6 op een aantal plaatsen ${ }^{48}$ gerefereerd aan het feit dat volgens de grondwetgever de grondwettelijke grondrechten "... voor een ieder gelden, ongeacht zijn verhouding tot de overheid ...". Dat wil zeggen dat personen in bijzondere rechtsverhoudingen in gelijke mate als andere personen een beroep op grondrechten kunnen doen, wat er overigens niet aan in de weg staat, dat deze grondrechten ten aanzien van deze personen verdergaand beperkt zouden kunnen worden. Enerzijds zullen gedetineerden van bepaalde grondrechten op grond van hun detentiesituatie niet hetzelfde gebruik van bepaalde grondrechten kunnen maken als mensen die zich vrij kunnen bewegen. Anderzijds zal op bepaalde groepen personen een zwaardere verantwoordingsplicht rusten bij het gebruikmaken van bepaalde grondrechten, zoals bij de vrijheid van

48 Zie, onder andere, de laatste alinea in par. 6.2.2.3 en in par. 6.2.3.1. 
meningsuiting en van betoging op ambtenaren, militairen en journalisten een zwaardere verantwoordingsplicht rust. Deze (grotere) beperkingsmogelijkheden nemen echter niet weg dat de grondrechten voor deze groepen personen onverkort gelden.

Een volgende, vierde voorbeeld van het verband tussen de vaststelling van de reikwijdte en de beperking van mensenrechten treffen we aan bij de behandeling van de beperkingssystematiek in de Grondwet 1983 in hoofdstuk $3^{49}$ en de interpretatie van de artikelen $6(1)$ en $7(1)$ Grondwet in hoofdstuk $6^{5 \circ}$. Daarbij wordt meermalen gewag gemaakt van het feit dat de rechter zich soms bedient van de in de Memorie van Toelichting geboden mogelijkheden om aan de beperkingssystematiek te ontsnappen, zoals redelijke wetsuitleg of -toepassing. Via die ontsnappingsmogelijkheden worden - in beginsel met de beperkingssystematiek strijdige - algemene beperkingen gesauveerd. Het verband tussen de reikwijdte-afbakening van het recht en de beperking daarop is hierin gelegen, dat een algemene beperking op een bepaalde vorm van uitoefening van een bepaald recht door de rechter wordt geaccepteerd, door middel van de constructie van redelijke wetsuitleg, die erop neerkomt dat in dit specifieke geval deze bepaalde vorm van uitoefening van dit bepaalde recht buiten de reikwijdte van het grondrecht valt. Deze bepaalde vorm van uitoefening van dit bepaalde recht wordt als het ware uit de reikwijdte van het grondrecht geïnterpreteerd. In andere gevallen wordt een algemene beperking niet ongrondwettig geoordeeld, doordat een bepaalde gedraging in het algemeen wel binnen de reikwijdte van het recht valt, maar desondanks niet door het grondrecht beschermd wordt. In het concrete geval lijkt deze gedraging derhalve niet onder het grondrecht te vallen. Hoe dit er in de praktijk uitziet, laten de gevonden voorbeelden zien.

In de rechtspraak ten aanzien van artikel 6 heb ik voorbeelden van zaken gevonden, waarin voorschriften behorende bij een bestemmingsplan - die niet gericht zijn op, maar wel tot gevolg hebben dat de vrijheid van godsdienst wordt beperkt (derhalve algemene beperkingen inhouden) - door de rechter worden geaccepteerd. onder meer omdat "het feit dat sprake is van de uitoefening van een grondrecht niet met zich [brengt] dat de voorschriften van het bestemmingsplan hun betekenis zouden verliezen. Die voorschriften hebben immers niet tot gevolg, dat kerkelijke activiteiten nergens in het plangebied zijn toegestaan" dan wel "het gebruik van een

50 Zie paragraaf 6.2 .1 .7 . pp. 517-527 en paragraaf 6.2 .2 .9 , pp. 555-557. 
pand als gebedsruimte "onmogelijk" maken. ${ }^{51}$ De zin "het feit dat sprake is van de uitoefening van een grondrecht niet met zich [brengt] dat de voorschriften van het bestemmingsplan hun betekenis zouden verliezen" doet denken aan de overweging in de kamerstukken bij de grondwetsherziening ${ }^{52}$ ten aanzien van redelijke grondwetstoepassing, dat in bepaalde gevallen intrekking of vernietiging van een overheidsmaatregel "in flagrante strijd zou zijn met wat algemeen als redelijk wordt aangemerkt." De grondwetgever meende dat in dergelijke gevallen "aan de redelijkheid grenzen kunnen worden ontleend waarbuiten een grondrecht geen toepassing meer behoort te vinden." Een dergelijk geval lijkt zich hier, gezien de in het geding zijnde uitspraken, voor te doen, overigens zonder dat de rechter expliciet spreekt van redelijke wetstoepassing (of algemene beperking). Ook lijkt de rechter in deze zaken niet te toetsen aan het proportionaliteitsvereiste, noch een afweging te maken tussen de maatschappelijke en individuele belangen, zoals de grondwetgever voorstond." Vergelijkbaar met de bovenbedoelde voorschriften bij bestemmingsplannen, zijn blijkens de Memorie van Toelichting bij de Wet Openbare Manifestaties, voorschriften waarin een bouwvergunning geëist wordt of brandveiligheidsvoorschriften voor kerkgebouwen. Volgens de regering zou redelijke grondwetsinterpretatie met zich brengen dat hierbij geen sprake is van beperking van de vrijheid van godsdienst..$^{54}$

Voorts zagen we bij de bespreking van de rechtspraak ${ }^{\text {ss }}$ ten aanzien van de interpretatie van artikel 7 dat ook de voorschriften in de Hinderwet en het Hinderbesluit, waarin een vergunning voor bepaalde inrichtingen wordt geëist, een algemene beperking op de vrijheid van meningsuiting inhouden indien deze voorschriften op drukkerijen van toepassing zijn. Bij de grondwetsherziening werd deze Hinderwetvergunning als voorbeeld genoemd van een geval waarin redelijke wetstoepassing uitkomst zou kunnen bieden (uit de beperkingssystematiek).

51 Vz.ARRS 16 februari 1989. AB 1990, 9 met noot P.J. Boon: tB/S 1989, nr. 20 met noot M.C.B.: AA 1990. pp. 398-402 met noot P.W.C. Akkermans: De Gemeentestem, no. 6883, nr. 11. pp. 359-360 met naschrift J.M.H.F. Teunissen: Pres.Rb. 'sHertogenbosch 25 juni 1985, KG 1985, 217.

52 Memorie van Toelichting bij wetsvoorstel 13872. Verklaring dat er grond bestaat .... Tweede Kamer, in: Algehele grondwetsherziening, deel Ia Grondrechten, pp. $21-22$.

53 In een andere uitspraak leek dit wel in enige mate te gebeuren: Vz.ARRS 20 juni 1985. KG 1985, 281: RV 1985, 118 met noot $B o$.

54 Memorie van Toelichting bij wetsvoorstel 19427, WOM. Tweede Kamer. p. 6.

55 HR 11 februari 1986, NJ 1986, 673 met noot Th.W. van Veen: Vz.AGvBRS 26 april 1991, De Gemeentestem no. 6931, nr. 7 met noot Brederveld. Zie p. 556-557. 
Een vijfde voorbeeld van het verband tussen de vaststelling van de reikwijdte en de beperking van de uitoefening van de rechten van de mens heb ik aangetroffen in de Europese rechtspraak ten aanzien van uit artikel 8 lid 1 voortvloeiende positieve overheidsverplichtingen. Uit deze rechtspraak blijkt, dat de beperkingsclausule in artikel 8 lid 2 van belang is bij de vaststelling van het bestaan en de reikwijdte van positieve verplichting op grond van lid 1. Dit blijkt uit de uitspraak van het Hof in de zaak Rees, waarin het Hof eveneens heeft bepaald, dat in geval van positieve verplichtingen de functie van lid 2 als beperkingsclausule is uitgesloten. ${ }^{56}$ De belangen genoemd in lid 2 spelen volgens deze uitspraak een rol bij de belangenafweging die plaats moet vinden tussen het algemene belangen van de gemeenschap en de belangen van de individu. Volgens het Hof in de uitspraak in de zaak Powell and Rayner makt het niet uit of deze afweging plaatsvindt in het kader van lid 1 of lid 2. De beginselen die moeten worden toegepast in het kader van de vaststelling van een positieve overheidsverplichting tot het nemen van redelijke en gepaste maatregelen ter bescherming van de rechten van een klager (op grond van lid 1) zijn nagenoeg dezelfde als de beginselen die van toepassing zijn bij de vraag of sprake is van gerechtvaardigde inbreuk door de overheid op het toepasselijke recht in de zin van lid $2 .{ }^{57}$ In hoofdstuk 4 heb ik hierover opgemerkt, dat hierdoor een vermenging plaatsvindt van de vaststelling van de reikwijdte van een positieve verplichting enerzijds en de beperking daarop anderzijds. Een dergelijke wijze van toetsen van positieve verplichtingen heeft het nadeel, dat de burger niet aan de hand van door de rechter vastgestelde criteria kan voorspellen in welke mate hij aanspraak kan maken op een bepaald overheidsoptreden. Dit komt de rechtszekerheid niet ten goede en verhoogt de kans op willekeur. Bovendien wordt een nalaten van dit overheidsoptreden - dit is een beperking op de overheidsverplichting - niet expliciet gerechtvaardigd, zoals bij een inbreuk op een negatieve (onthoudings)verplichting.

In de goede richting lijkt mij dan ook de rechtspraak naar aanleiding van het in hoofdstuk 6 besproken recht tot vergadering en betoging in artikel 9 Grondwet te gaan. ${ }^{58}$ Deze rechtspraak naar aanleiding van de beperkingsclausule in het tweede lid van deze bepaling houdt in dat een betoging pas in verband met intolerant of gewelddadig gedrag van derden, bijvoorbee!d in geval van een tegendemonstratie, verboden of anderszins beperkt mag worden, indien redelijkerwijs verwacht kan worden dat - ook bij voldoende politie-inzet - de situatie niet in de hand gehouden kan 
worden. Voordat tot beperking van het betogingsrecht (maar ook van het vergaderrecht ${ }^{59}$ ) kan worden overgegaan, dient eerst een evenredigheidstoetsing tussen doel en middel plaats te vinden; met name dient nagegaan te worden of ter voorkoming van de wanordelijkheden niet volstaan kan worden met een lichtere maatregel. Uit deze rechtspraak zou men kunnen afleiden, dat de in het eerste lid van artikel 9 Grondwet gegarandeerde rechten de positieve verplichting van de overheid omvatten, inhoudende dat de overheid adequate politiebescherming dient te bieden aan personen die hun recht tot vergaderen of betogen wensen uit te oefenen tegen eventuele (gewelddadige) acties van anderen. De reikwijdte van deze verplichting wordt in deze jurisprudentie afgebakend aan de hand van het criterium "adequaat" in "adequate politie-bescherming". Dit is een vaag criterium, dat echter recht doet aan de noodzaak maatregelen af te kunnen stemmen op de zich voordoende situatie, namelijk de omvang en plaats van en de reden tot de demonstratie evenals de omvang en aard van het gedrag van derden ten aanzien van de demonstratie. Beperking op deze verplichting kan slechts aangebracht worden indien redelijkerwijs verwacht kan worden dat men aan de situatie niet het hoofd zal kunnen bieden. De wijze van toetsing aan deze beperkingsmogelijkheid (onder andere evenredigheidstoetsing) doet denken aan de "gedragscode" in de tweede leden van de artikelen 8 tot en met 11 van de Conventie, dat beperkingen "noodzakelijk in een democratische samenleving" moeten zijn en gericht op een legitiem doel. ${ }^{\circ}$ Dit doel is in dit geval de voorkoming van wanordelijkheden.

Kortom, het hierboven niet zo positief gewaardeerde verband tussen de interpretatie van de uit Conventie-bepalingen (met name artikel 8) voortvloeiende verplichtingen tot actief overheidsoptreden en de beperkingen op die verplichtingen, behoeft niet te bestaan. Afbakening van deze verplichtingen aan de hand van de beperkingsclausules van deze bepalingen is mijns inziens niet gewenst, noch noodzakelijk. Hieronder in paragraaf 7.5.1 zal deze laatste gevolgtrekking gestaafd worden aan de hand van een ander mogelijk alternatief voor de hier bekritiseerde toetsing van positieve verplichtingen.

De rechtspraak van het Hof naar aanleiding van de vaststelling van de reikwijdte van het recht op privéleven in artikel 8 lid 1 ECRM biedt een zesde voorbeeld van een verband tussen reikwijdte-afbakening en beperking van mensenrechten. Hier is het verband gelegen in het feit dat "privéleven"

59 Vgl. het NJCM-commentaar op de gebeurtenissen te Kedichem (29-3-1986). NJCMBulletin 11-5 (1986), pp. 478-487.

60 Zie paragraaf 2.4 .2 .1 , pp. 74 e.v. en paragraaf 3.2 .6 . pp. 171-173. 
wordt begrensd door wat in hoofdstuk 4 een "openbaarheids"-criterium wordt genoemd. Dit criterium houdt het volgende in: uit de rechtspraak van de Straatsburgse instanties ten aanzien van het recht op privéleven blijkt, dat dit recht hoofdzakelijk begrensd wordt door de mate waarin het privéleven in verband staat met het openbare leven. Onder dit openbare leven worden verstaan de rechten van anderen dan wel de openbare orde. ${ }^{61}$ Doordat de rechten van anderen en de openbare orde tevens in artikel 8 lid 2 ECRM zijn opgenomen als doelcriteria voor de beperking van de in het eerste lid gegarandeerde rechten, kan het "openbaarheids"criterium gezien worden als een voorbeeld van het verband tussen de afbakening van de reikwijdte van een recht en de beperking daarop.

Het niet expliciet in artikel 6 lid 1 ECRM geformuleerde recht op toegang ontbeert, juist vanwege het ontbreken van een formulering van dit recht in deze bepaling, een expliciete beperkingsclausule. De beperking van het recht op toegang vindt derhalve plaats in het kader van de vaststelling van de reikwijdte van dit recht. Dit is het zevende voorbeeld van het bestaan van een verband tussen reikwijdte-afbakening en beperking. ${ }^{62}$ De grenzen die aan de beperkingsmogelijkheden van de Staat worden gesteld, zijn ook de grenzen van het bereik van het recht op toegang zélf. Welke zijn die grenzen? In paragraaf 5.1.3.1 bleek uit de bespreking van de jurisprudentie van het Hof, dat het eerste criterium is of sprake is van beperkingen die "restrict or reduce the access left to the individual in such a way or to such an extent that the very essence of the right is impaired." Ten tweede moet de beperking gericht zijn op een legitiem doel en dient er een "reasonable relationship of proportionality" te bestaan tussen de beperking en dat doel. Deze criteria lijken, blijkens de uitspraak van het Hof in de zaak Ashingdane, te worden afgeleid uit de idee van de rule of law. ${ }^{63}$ De regeling waarin de beperking op het recht op toegang is gebaseerd, moet voorts duidelijk en coherent zijn en een eerlijke afweging van openbare en individuele belangen garanderen. Het recht op "access to court" moet "clear, practical and effective" zijn." In paragraaf 5.1.3.1 werd naar aanleiding van deze criteria reeds opgemerkt, dat de jurisprudentic inzake de beperking van het recht op toegang tot de rechter grote overeenkomsten vertoont met die ten aanzien van de beperkingsclausules van de artikelen 8 tot en met 11 ECRM. Met name wordt gedoeld de criteria ter afgrenzing

61 Zie paragraaf 4.2.1.

62 Zie paragraaf 5.1 .3 , pp. 325 e.v..

63 EHRM 28 mei 1985, Ashingdane Case, \$57, pp. 24-25.

64 EHRM 16 december 1992, Case of de Geouffre de la Pradel, \$829, 32-35, pp. 41 43. 
van de beoordelingsvrijheid van de Staat: de beperking moet gericht zijn op een legitiem doel en sprake moet zijn van proportionaliteit tussen middel (de beperking) en dat legitieme doel en er moet een afweging van de overheidsbelangen tegen de individuele belangen van de burger plaatsvinden. Verder dienen de beperkingen op het recht op toegang te zijn opgenomen in regelingen die "clear and coherent" moeten zijn, wat weer lijkt op de eisen van "accessability" en "foreseeability" die gesteld worden aan de wettelijke regeling(en) waarin de beperkingen op de rechten in de artikelen 8 tot en met 11 zijn vervat.

Een vergelijkbaar verband tussen de vaststelling van de reikwijdte van een recht en de beperking ervan, treffen we aan met betrekking tot het gelijkheidsbeginsel in artikel 1 Grondwet en ten aanzien van de vrijheid van meningsuiting in artikel 7 lid 1 Grondwet. In paragraaf 6.1.2 bleek dat de reikwijdte van het gelijkheidsbeginsel, inhoudende dat allen in gelijke gevallen gelijk behandeld moeten worden, mede bepaald wordt door de reikwijdte van de op dit beginsel aangebrachte impliciete beperking. Deze houdt in dat geen sprake is van schending van het gelijkheidsbeginsel, indien de ongelijke behandeling van gelijke gevallen of de gelijke behandeling van ongelijke gevallen (objectief en redelijk) gerechtvaardigd kan worden, ${ }^{\text {s }}$

Bij artikel 7 gaat het om het impliciet door die bepaling gegarandeerde verspreidingsrecht, dat - noodzakelijkerwijs - aan impliciete beperkingen is gebonden. Naast het expliciete, de inhoud van geopenbaarde betreffende, openbaringsrecht waarborgt artikel 7 lid 1 tevens een voor dat recht onmisbaar, maar daaraan ondergeschikt verspreidingsrecht. De in artikel 7 lid 1 geformuleerde beperkingsclausule ("behoudens ieders verantwoordelijkheid volgens de wet") staat een beperking achteraf, op grond van een formele wet, toe op het openbaringsrecht. De impliciete beperking van het verspreidingsrecht houdt in, dat de wetgever (ook de lagere) beperkingen kan stellen naar tijd, plaats en wijze van verspreiden van stukken waarin gedachten of gevoelens zijn geopenbaard, voor zover "het gebruik van een bepaald middel van bekendmaking dat naast andere middelen zelfstandige betekenis heeft en met het oog op die bekendmaking in een bepaalde behoefte kan voorzien (niet) in het algemeen ... (wordt) verboden of van een voorafgaand verlof der overheid afhankelijk ... (wordt) gesteld. " ${ }^{66}$ De reikwijdte van het in artikel 7 lid 1 gewaarborgde recht wordt derhalve mede begrensd aan de hand van de impliciete beperkingsmogelijkheid op het impliciet door deze bepaling gegarandeerde verspreidingsrecht. 
In paragraaf 5.3 werd in de evaluatie van de afbakening van artikel 6 lid 1 ECRM al geconstateerd, dat het aantal uitspraken waarin het recht op toegang tot de rechter door de Nederlandse rechterlijke instanties wordt afgebakend, klein is. Ook in paragraaf 6.3 heb ik aangegeven, dat slechts in een beperkt aantal gevallen een afbakening van de artikelen 6 lid 1, 7 leden 1 en 3 en artikel 9 lid 1 Grondwet heeft plaatsgevonden. ${ }^{67}$ Indien de oorzaak hiervoor gezocht moet worden in de omstandigheid dat de rechter over de reikwijdte-afbakening heenstapt, teneinde de zaak af te doen aan de hand van de beperkingsmogelijkheden, dan kan dit gezien worden als een achtste voorbeeld (en tevens het laatste hier te noemen voorbeeld) van het verband tussen de vaststelling van de reikwijdte van mensenrechten (die in deze gevallen achterwege blijft) en beperking van de uitoefening van mensenrechten. ${ }^{68}$

Met de bovenstaande voorbeelden van het bestaan van een verband tussen de interpretatie van de reikwijdte van de in deze studie onderzochte mensenrechten en de beperking van die rechten, meen ik voldoende de juistheid van de eerste stelling te hebben aangetoond. In de volgende paragraaf zal blijken of dezelfde conclusie kan worden getrokken ten aanzien van de tweede stelling.

\subsection{De tweede stelling: Het verband tussen de interpretatie en de beperking van mensenrechten roept een spanning op tussen de argumentatie achter de formulering van de rechten en de beperkingsmogelijkheden enerzijds en de rechterlijke praktijk anderzijds}

Alvorens in te gaan op de vraag naar de juistheid van deze stelling, zal eerst nog eens kort herhaald worden wat de argumenten achter de formulering van de rechten en de beperkingsmogelijkheden in de Europese Conventie en de Grondwet 1983 waren.

Overeenkomstig de indeling van de eerste zes hoofdstukken, zullen ook in deze paragraaf de Conventie en de Grondwet afzonderlijk behandeld worden. 


\subsubsection{Conclusies ten aanzien van de tweede stelling met betrekking tot de Europese Conventie}

Zoals in hoofdstuk 2 is uiteengezet, is de formulering van de rechten en de beperkingsmogelijkheden de resultante van een intense discussie ten tijde van de opstelling van het verdrag tussen voorstanders van nauwkeurige definiëring van de rechten en beperkingsmogelijkheden enerzijds en tegenstanders daarvan anderzijds, die meer voelden voor een opsomming van mensenrechten - gecombineerd met een algemene beperkingsclausule - in navolging van de Universele Verklaring voor de Rechten van de Mens. Uiteindelijk zijn het de voorstanders van nauwkeurige definiëring geweest, die hun zin hebben gekregen, al is in beperkte mate aan de wensen van de tegenstanders tegemoetgekomen.

Gevolg van deze uiteindelijke keuze is, dat - althans dat was de bedoeling - de in de Conventie te garanderen rechten en vrijheden nauwkeurig, maar niet excessief gedetailleerd, zijn gedefinieerd. Hetzelfde geldt volgens deze opzet voor de beperkingen en uitzonderingen op deze rechten en vrijheden. Bij wijze van compromis zijn echter aan de rechten enkele algemene beginselen in het verdrag opgenomen ${ }^{69}$ Dientengevolge ziet de Conventie er in hoofdlijnen als volgt uit: de te beschermen rechten zijn opgenomen vergezeld van een op dat recht toegesneden beperkingsclausule (artikelen 8-11 ECRM, artikel 2 Protocol IV ECRM en artikel 1 Protocol VII ECRM), dan wel zijn aldus geformuleerd dat de beperkingsmogelijkheden in de omschrijving van het recht besloten liggen (artikel 4, tweede en derde lid en artikel 6, eerste en derde lid) ofwel bepaalde gevallen of situaties van bescherming zijn uitgesloten (artikel 2 en artikel 5 (recht op vrijheid van de persoon) ECRM en artikel 2 lid 2 Protocol VII EC.RM). Ook bevat de Conventie een aantal bepalingen waarvan de regeling van de uitoefening en beperking van een recht meer aan nationale instanties wordt overgelaten (Artikel 10 lid 1, laatste zin en artikel 12 ECRM); deze rechten worden de derhalve minder nauwkeurig gedefinieerd dan de overige rechten. Tenslotte zijn er nog drie afzonderlijke bepalingen die een beperking op de beschermde rechten inhouden, namelijk een bepaling die voorziet in de beperking van de gegarandeerde rechten in tijden van oorlog en andere noodtoestand (artikel 15 ECRM), een artikel inzake de beperking van politieke activiteiten van vreemdelingen (artikel 16 ECRM) en een bepaling inzake misbruik van recht (artikel 17 ECRM). Daarnaast zijn er een aantal bepalingen, die grenzen stellen aan het gebruik door de Staat van de 
beperkingsmogelijkheden, zoals het discriminatieverbod (artikel 14 ECRM), het verbod van het verder beperken van een recht dan de Conventie toestaat (artikel 17 ECRM) en het verbod van détournement de pouvoir ten aanzien van de beperkingsbevoegdheden van de Staat (artikel 18 ECRM). ${ }^{70}$

Wat waren nu de argumenten die aan de keuze voor nauwkeurige definiëring van de rechten en beperkingsmogelijkheden ten grondslag werden gelegd? In hoofdstuk 2 werd gewezen op, onder meer, de volgende punten. Men wilde een juridisch bindend document, waarin de rechten en de beperkingen op de rechten in gedetailleerde juridische normen moesten worden neergelegd, zodat de aard en de reikwijdte van de verdragsverplichtingen duidelijk zouden zijn voor de Staten die partij zouden worden bij het Verdrag. Bovendien zou nauwkeurige definiëring tegemoetkomen aan de in artikel 1 van het Statuut van de Raad van Europa geformuleerde doelstelling van een grotere eenheid tussen de Lid-Staten. ${ }^{7}$

In verband met de hier te behandelen - tweede - stelling, is het de vraag, of uit de rechtspraktijk van het Hof en de Commissie inderdaad blijkt, dat de aard en de reikwijdte van de verdragsverplichtingen duidelijk zijn voor de Verdragsstaten en dat een grotere eenheid tussen de Lid-Staten van de Raad van Europa is/wordt bewerkstelligd.

Om met het laatste punt te beginnen: door de omvangrijke jurisprudentie die inmiddels door het Hof tot stand is gebracht, waarin ten aanzien van de diverse verdragsbepalingen - zij het niet ten aanzien van alle bepalingen in gelijke mate - een lijn voor de interpretatie is uitgezet, die vanwege de precedentwerking die van de uitspraken uitgaat, voor alle Verdragsstaten geldt, kan men stellen dat de Conventie bijdraagt tot een grotere eenheid tussen de Lid-Staten van de Raad van Europa, althans wat betreft de mensenrechtenbescherming. Dit komt ook doordat de Lid-Staten van de Raad van Europa allemaal partij zijn of - vrij snel na toetreding tot de Raad - partij worden bij de Conventie. De relativering die men hier echter naar mijn mening moet aanbrengen, is dat naarmate een Staat bij de waarborging en beperking van verdragsrechten een grotere beoordelingsvrijheid ("margin of appreciation") heeft, de kans op eenheid in de bescherming van die rechten afneemt. ${ }^{n}$

70 Zie paragraaf 2.4.5.

$71 \quad$ Zie paragraaf 2.4 .

72 Zie voorts in dit verband ook ten aanzien van het ontwikkelen van Europese maatstaven, voor de interpretatie van de Conventie, door de Straatsburgse instanties, P. van Dijk en G.J.H. van Hoof, De europese conventie in theorie en praktijk, p. 662-664 en hierboven, paragraaf 2.4.2.1, pp. 88-89. 
Wat betreft de vraag, of uit de rechtspraktijk van het Hof en de Commissie inderdaad blijkt, dat de aard en de reikwijdte van de verdragsverplichtingen duidelijk zijn voor de Verdragsstaten zijn er diverse aanwijzingen dat dit maar tot op zekere hoogte het geval is. In abstracto is redelijk duidelijk uit de verdragsbepalingen af te leiden welke verplichtingen uit de Conventie voor de Verdragsstaten voortvloeien. De praktijk van de Straatsburgse instanties laat echter zien, dat hun taak uit meer bestaat dan uit het toetsen van individuele klachten aan de verdragsbepalingen. In de meeste gevallen is het noodzakelijk gebleken de reikwijdte van rechten nader af te bakenen. Hetzelfde geldt voor de reikwijdte van de beperkingsbevoegdheden van de Staten. Hierin verschilt de functie van met name het Hof niet van die van nationale rechterlijke instanties. In concreto dient het Hof (en tot op zekere hoogte ook de Commissie) de verdragsbepalingen derhalve nog nader te moeten definiëren. De vervulling van deze rechterlijke functie kan, indien dit goed gebeurt, bijdragen aan de verduidelijking van de aard en de reikwijdte van de verplichtingen die voor de Staten uit de Conventie voortvloeien en is derhalve nog in overeenstemming met de uitgangspunten bij de formulering van de rechten en beperkingsmogelijkheden in de Conventie. Spanning met de argumenten die aan deze formulering ten grondslag liggen treedt echter op, zodra de reikwijdte van de rechten niet nader wordt afgebakend of door middel van te vage criteria, of wanneer aan de Staten bij de beperking van de rechten een te grote "margin of appreciation" wordt gelaten. Het onderzoek dat in de voorgaande hoofdstukken is verricht, laat zien dat de rechter (met name de Nederlandse) regelmatig over de reikwijdte-vraag heenstapt en direct de zaak beslist aan de hand van de beperkingsmogelijkheden. Bovendien vindt ook in een bepaald sœon gevallen een onvoldoende afbakening van de reikwijdte van de rechten of beperkingsbevoegdheden plaats. Ik doel hiermee op een van de in paragraaf 7.3 gencemde voorbeelden van het bestaan van een verband tussen de interpretatie en beperking van mensenrechten: de vermenging van de vaststelling van de reikwijdte van een positieve verplichting, die uit artikel 8 ECRM voortvloeit, enerzijds en de beperking daarop anderzijds. In paragraaf 4.4 - en in het kort in paragraaf 7.3 - is aangegeven, hoe het Hof bij de toetsing van de naleving van uit artikel 8 ECRM voortvloeiende. positieve verplichtingen, de daarbij te maken belangenafweging tussen het algemeen belang en de belangen van het betrokken individu voltrekt aan de hand van de in artikel 8 lid 2 genoemde beperkingsdoeleinden. Bij die toetsing wordt niet eerst afzonderlijk de reikwijdte van de positieve verplichting vastgesteld op grond van lid 1 en daarna de rechtvaardiging onderzocht van de eventuele beperking, aan de hand van lid 2. De reikwijdte van de verdragsverplichtingen wordt op deze manier derhalve 
niet duidelijk voor de Verdragsstaten (noch voor de individuele rechtzoekende) en levert om die reden spanning op met de argumentatie achter de formulering van de rechten en beperkingsmogelijkheden in de Conventie.

De overige voorbeelden van het bestaan van een verband tussen interpretatie en beperking van mensenrechten - voor zover betrekking hebbend op de Conventie - lijken geen afbreuk te doen aan de duidelijkheid van de aard en de reikwijdte van de verdragsverplichtingen voor de Verdragsstaten.

De conclusie die dan ook ten aanzien van de tweede stelling, met betrekking tot de Europese Conventie, getrokken kan worden is, dat die stelling juist is voor zover het positieve verplichtingen betreft die voor de Verdragsstaten uit de Conventie-bepalingen voortvloeien en ten aanzien van de gevallen waarin de rechterlijke instanties een afbakening van de reikwijdte van het desbetreffende recht achterwege laten. Overigens is de juistheid van de tweede stelling, wat betreft de Conventie, niet aangetoond.

\subsubsection{Conclusies ten aanzien van de tweede stelling met betrekking tot de Grondwet}

Ook de kwestie van de formulering van de rechten en de beperkingsmogelijkheden in de Gróndwet is het onderwerp geweest van een uitvoerige discussie, een zeer langdurige zelfs. Kwam de Conventie in betrekkelijk korte tijd tot stand, voor de algehele herziening van de Grondwet is aanzienlijk meer tijd nodig geweest (1950-1983). Aan het wetsvoorstel tot de algehele grondwetsherziening ${ }^{3}$, waarin uitvoerig aandacht is besteed aan deze kwestie, vooral met betrekking tot de beperkingsmogelijkheden, zijn een rapport van de Staatscommissie Van Schaik, de Proeve tot grondwetswijziging, en rapporten van de Staatscommissie Cals/Donner voorafgegaan. Uiteindelijk resultaat van deze rapporten en de discussies die naar aanleiding van de grondwetsherziening tussen regering en Staten-Generaal hebben plaatsgevonden, is het volgende.

Hoofdstuk 1 van de Grondwet geeft een opsomming van te garanderen grondrechten, ten aanzien waarvan de volgende, in hoofdstuk 3 (par. 3.2) besproken beperkingssystematiek wordt gehanteerd. De belangrijkste beperkingsmogelijkheden zijn de beperkingsclausules, waarin de

73 Wetsvoorstel 13872, Verklaring dat er grond bestaat ..., in: Algehele grondwetsherziening, eerste lezing, deel Ia Grondrechten. 
bevoegdheid om de grondrechten te beperken, zijn gekoppeld aan competentievoorschriften, procedurevoorschriften of doelclausuleringen of een combinatie daarvan. Daarnaast kent ook de Grondwet als beperkingsmethoden de inhoudelijke omschrijving van het recht waarbij in die omschrijving de beperkingsmogelijkheden besloten liggen (onder andere de artikelen 3, 4 en 54 lid 1, 19 lid 3 en 20 lid 3), de inhoudelijke omschrijving van het recht waarbij bepaalde gevallen of situaties van grondwettelijke bescherming zijn uitgesloten (artikelen 7 lid 4, 15 lid 4 en 54 lid 2); voorts kent de Grondwet bepalingen die de uitwerking van het recht aan de wetgever of overheid is overgelaten (onder andere de artikelen 10 leden 2 en 3, 18 lid 2, 19 leden 1 en 2, 20 leden 1 en 2, 21, 23 leden $1,3,4,5$ en 7 , de artikelen 99,110,116 en 117) of die beperkingen van rechten ten aanzien van bepaalde groepen personen toestaan (artikel 54 lid 1. laatste zin). In situaties van oorlog of noodtoestand kan van bepaalde grondrechten worden afgeweken op grond van artikel 103 Grondwet. Bepalingen die grenzen stellen aan het gebruik dat van de beperkingsmogelijkheden kan worden gemaakt treffen we aan in artikel 1 , tweede zin en artikel 23 leden 6 en 7 ten aanzien van het onderwijsartikel, in artikel 7 lid 2 laatste zin ten aanzien van de eerste zin, en artikel 12 lid 2 ten aanzien van lid $1 .^{74}$

Terugkomende op de competentievoorschriften: deze komen er op neer, dat het vrijwel altijd de formele wetgever is, die bevoegd wordt verklaard het desbetreffende grondrecht te beperken eventueel met de mogelijkheid van delegatie.

Uitgangspunt in de Grondwet is, dat beperkingen van grondwettelijke grondrechten altijd tot de Grondwet herleidbaar moeten zijn, "ongeschreven" beperkingen zijn niet geoorloofd. Strikt genomen betekent dit dat de Grondwet zowel bijzondere als algemene beperkingen toestaat." De enige grondwetsbepaling die - althans wat betreft lagere wetgevers - die ruimte lijkt te bieden voor algemene beperkingen is naar mijn mening artikel 15 lid 4 . Ten aanzien van de andere grondwetsbepalingen bleek in hoofdstuk 3, dat de voorgaande stelling dat algemene beperkingen met een grondwettelijke basis niet zijn uitgesloten, hoogstens op kan gaan ten aanzien van de formele wetgever. Uit de toelichting in de kamerstukken

74 Zie paragraaf 3.2.9, pp. 182-184.

75 Ter herinnering: onder algemene beperkingen worden verstaan die beperkingen, die niet speciaal op een bepaald grondrecht zijn gericht, maar die veroorzaakt worden doordat een geheel buiten de sfeer van een grondrecht gelegen regeling als neveneffect heeft dat de uitoefening van het grondrecht beperkingen ondergat. Bijzondere beperkingen zijn dan juist wèl met het oog op een bepaald grondrecht vastgesteld. 
ten aanzien van de bevoegdheid tot delegatie blijkt, dat beperkingen door lagere wetgevers gebaseerd moeten zijn op een "specifieke wetsbepaling". inhoudende dat "uit de wet met voldoende duidelijkheid kan worden afgeleid, dat de wetgever bewust een beperkingsbevoegdheid heeft willen toekennen en ten aanzien van welk grondrecht hij dat heeft gewild." Lagere regelgeving, ook al is die algemeen geformuleerd, dient indien en voor zover deze een beperking van een grondrecht inhoudt, op een dergelijke specifieke wetsbepaling te berusten en is, mijns inziens, daarmee per definitie een bijzondere beperking. ${ }^{76}$

In de kamerstukken, met name de Memorie van Toelichting, wordt ook gewezen op mogelijkheden van de beperkingssystematiek in de Grondwet af te wijken via redelijke (grond)wetsuitleg en -toepassing. Redelijke wetsuitleg wil volgens de Memorie van Toelichting zeggen dat een met een grondrechtsbepaling strijdige overheidsmaatregel of -regel die ten gevolge van de ontwikkeling van de heersende rechtsovertuiging algemeen aanvaard wordt geacht, niet vanwege strijd met die grondrechtsbepaling of - in het algemeen - de beperkingssystematiek ongrondwettig verklaard wordt. In paragraaf 3.2.10 heb ik aangegeven dat redelijke grondwetsbeperking voor deze mogelijkheid tot afwijking van de beperkingssystematiek een inhoudelijk correctere term is. Het begrip redelijke wetsuitleg zou beter gebruikt kunnen worden voor gevallen waarin de beperkingssystematiek "omzeild" wordt door het desbetreffende grondrecht restrictief af te bakenen, waardoor het in het bewuste geval niet van toepassing is. Redelijke wetstoepassing betekent dat ook geen ongrondwettigverklaring plaatsvindt wanneer aan de redelijkheid grenzen ontleend kunnen worden waarbuiten een grondrecht geen toepassing meer behoort te vinden. Intrekking of vernietiging van de desbetreffende overheidsmaatregel zou in een dergelijk geval ongewenst zijn omdat dit zou leiden tot "flagrante strijd ... met wat algemeen als redelijk wordt aangemerkt". Wel moet rekening gehouden worden met de evenredigheid tussen doel (het door middel van de overheidsmaatregel of -regel voorkomen van die ongewenste uitoefening van het grondrecht) en het middel (de beperking van de toepassing van het grondrecht) ingevolge het proportionaliteitsvereiste dat volgens de grondwetgever in acht genomen moet worden. Een afweging tussen algemeen belang en individueel belang zal hierbij moeten plaatsvinden. ${ }^{n}$

76 Memorie van Antwoord bij wetsvoorstel 13872, Verklaring dat er grond bestaat .... Tweede Kamer, in: Algehele grondwetsherziening, deel Ia Grondrechten, p. 182.

77 Zie paragraaf 3.2 .10 , pp. 184-186. 
Welke argumenten van de grondwetgever liggen ten grondslag aan de formulering van de rechten en de genoemde beperkingssystematiek in de Grondwet? Het antwoord hierop kan worden afgeleid uit de volgende overwegingen van de regering in de Memorie van Toelichting bij het wetsvoorstel inzake de algehele grondwetsherziening.

In algemene zin wordt als verschil tussen nationale en internationale grondrechten aangeduid, dat internationale grondrechten ruim geformuleerd zijn met uitvoerige clausuleringen en dat nationale grondrechten zowel qua reikwijdte als wat betreft de beperkingsmogelijkheden "scherper omlijnd" zijn. Oorzaak hiervan is volgens de regering dat de internationale grondrechten flexibel moeten kunnen functioneren omdat de omstandigheden in de nationale staten sterk kunnen verschillen; pas bij toepassing van internationale rechten ontstaat een concretisering, waardoor gaandeweg een nadere afbakening van die rechten ontstaat. Nationale grondrechten daarentegen zijn veel meer toegesneden op een eenduidige toepassing in een bepaalde nationale rechtsorde. Bij een ruime formulering van deze rechten in combinatie met uitvoerige clausuleringen zouden deze rechten volgens de regering veel van hun betekenis verliezen. In de nationale rechtsorde zijn preciezere waarborgen nodig. Deze precisering dient volgens de regering "in de omschrijving van de rechten zelf worden gegeven". " Deze opvatting van de regering impliceert mijns inziens, dat het de bedoeling van de regering bij de grondwetsherziening is geweest, dat de tekst van de diverse grondrechtenbepalingen nauwkeurig de reikwijdte van het desbetreffende grondrecht omschrijft alsmede de mogelijkheid/mogelijkheden tot beperking van dat recht aangeeft. Vraag is derhalve of uit de rechterlijke praktijk blijkt of de reikwijdte en beperkingsmogelijkheden inderdaad zo nauwkeurig in de grondwetsbepalingen zijn vastgelegd en of de grondwettelijke grondrechten inderdaad de zojuist bedoelde "gepreciseerde waarborgen" bieden zoals de regering beweerde.

In hoofdstuk 6 (en herhaald in paragraaf 7.3: het vierde voorbeeld van het verband tussen de vaststelling van de reikwijdte en de beperking van mensenrechten) bleek bij de behandeling van de reikwijdte-afbakening door de rechter van een aantal grondwettelijke bepalingen, dat van de mogelijkheden om van de beperkingssystematiek af te wijken regelmatig gebruik gemaakt wordt, daarmee bedoeld of onbedoeld "ongeschreven" algemene beperkingen sauverend afkomstig van lagere regelgevers, die in strijd zijn met de beperkingssystematiek. Hieruit kan men afleiden, dat 
kennelijk de in de grondrechtenbepalingen geboden beperkingsmogelijkheden onvoldoende ruimte bieden voor - althans door de betrokken autoriteiten - gewenst geachte beperkingen op de uitoefening van bepaalde grondrechten in bepaalde situaties. Dit lijkt erop te wijzen, dat de beperkingsmogelijkheden die de Grondwet biedt, wellicht té restrictief geformuleerd zijn. De oplossing die hiervoor is gebruikt - zij het niet expliciet - namelijk de redelijke wetsuitleg of -toepassing, staat echter op gespannen voet met de bedoelingen van de grondwetgever. Ten eerste omdat het niet de bedoeling kan zijn via de achterdeur van de "ontsnappingsmogelijkheden" de afgewezen, "ongeschreven", algemene beperkingen binnen te halen. Reden waarom een ruime formulering van de grondrechten in combinatie met uitvoerige clausuleringen af te wijzen was juist omdat daardoor deze rechten volgens de regering veel van hun betekenis zouden verliezen. Dit is nu juist wat zou kunnen gebeuren wanneer bij wijze van redelijke wetsuitleg of -toepassing niet-toegestane beperkingsmethoden worden toegelaten. Dit geldt met name, omdat zoals reeds in hoofdstuk 6 is geconstateerd, de door de regering aan de redelijke wetstoepassing verbonden proportionaliteitstoets en belangenafweging in praktijk onvoldoende blijken plaats te vinden. In deze gevallen bieden de desbetreffende grondrechten, mijns inziens, niet de "gepreciseerde waarborgen" die de grondwetgever voorstond. Zodra de autoriteiten, wanneer zij dit wenselijk achten, via de achterdeur van de redelijke (restrictieve) wetsuitleg of redelijke wetstoepassing beperkingen op grondrechten kunnen aanbrengen die niet herleidbaar zijn tot de grondwetsbepalingen en daardoor in strijd zijn met de beperkingssystematiek, zijn die waarborgen - zo deze al niet zelf zijn aangetast - niet "gepreciseerd" meer; dan staat de reikwijdte van de waarborg niet meer vast. Hierdoor is sprake van spanning tussen deze rechterlijke praktijk en de bedoelingen van de grondwetgever.

Daar komt vervolgens nog bij, dat ook het regelmatig gebruik maken van de mogelijkheden tot afwijking van de beperkingssystematiek zélf (derhalve los van de niet-toegestane beperkingen die daarmee kunnen worden gesauveerd) spanning oplevert met de bedoelingen van de grondwetgever, omdat deze afwijkingsmogelijkheden slechts bedoeld zijn om in uitzonderingssituaties uitkomst te bieden en alleen terughoudend gehanteerd zouden mogen worden.

Ook andere in hoofdstuk 3 genoende voorbeelden van het ontwijken van de beperkingssystematiek kunnen mijns inziens de toets der kritiek niet doorstaan. Een dergelijk voorbeeld (dat overigens niet het verband tussen de reikwijdte-afbakening en de beperking van een grondrecht betreft) is de opvatting van de regering dat de artikelen 175 en 176 Gemeentewet 
moeten worden aangemerkt als specifieke wetsbepalingen op grond van de artikelen 6 lid 1 en 9 lid 1 Grondwet. Deze opvatting levert spanning met de bedoelingen van de grondwetgever op. Reden voor deze opvatting van de regering is, dat hierdoor het gebruik van de noodbevoegdheden van de burgemeester waarbij de in deze grondwetsbepalingen vastgelegde grondrechten worden beperkt, de door deze grondrechtenbepalingen vereiste formeelwettelijke basis heeft. Uit de artikelen 175 en 176 Gemeentewet kan echter niet "met voldoende duidelijkheid ... worden afgeleid, dat de wetgever bewust een beperkingsbevoegdheid heeft willen toekennen en ten aanzien van welk grondrecht hij dat heeft gewild" en deze bepalingen zijn in de betekenis die de grondwetgever aan dit begrip heeft gegeven dan ook géén "specifieke wetsbepalingen".

Overigens heb ik niet kunnen constateren dat de in paragraaf 7.3 genoemde voorbeelden van het bestaan van een verband tussen de interpretatie en beperking van mensenrechten spanning met de bedoelingen van de grondwetgever (1983) opleveren. Dat wil overigens niet zeggen, dat de genoemde voorbeelden geen kritische vragen doen rijzen. Zo betreft het, in paragraaf 7.3 genoemde, achtste voorbeeld een rechterlijke praktijk die mijns inziens niet correct is. Ik doel op de praktijk dat rechters over de vraag naar de reikwijdte van een recht heenstappen en de vraag naar de schending van het ingeroepen recht slechts afdoen aan de hand van de beperkingsmogelijkheid/heden bij dit recht. Zonder de taak van de rechter aan een onderzoek te hoeven onderwerpen, kan mijns inziens gesteld worden dat hiertoe wel behoort de vaststelling van de reikwijdte van een recht waarop de rechtzoekende een beroep doet teneinde vast te stellen of dit recht van toepassing is en tot hoever. Stapt de rechter over die vraag heen, dan doet hij het rechtszekerheidsbeginsel tekort. De rechtzoekende dient in enige mate houvast te hebben bij de vraag of hij met enige kans van slagen een beroep op een bepaald recht kan doen. Te dien einde dient de rechter de grenzen van dit recht, met behulp van - soms in verband met de aard van het recht, vage - criteria vast te stellen. Komt hij tot de conclusie dat het desbetreffende recht van toepassing is dan kan hij vervolgens vaststellen of sprake is van een inmenging in dit recht die al dan niet gerechtvaardigd kan worden met een beroep op een beperkingsmogelijkheid, waarvan dan ook de reikwijdte vastgesteld zal moeten worden.

Overigens kan men zich afvragen, waarom de Nederlandse rechterlijke instanties wèl duidelijke criteria hanteren bij de toetsing aan artikel 8

79 Memorie van Antwoord bij wetsvoorstel 13872. Verklaring dat er grond bestaat .... Tweede Kamer, in: Algehele grondwetsherziening, deel Ia Grondrechten. p. 182. 
ECRM en niet bij de afbakening van artikel 6 lid 1 ECRM en de onderzochte artikelen van de Grondwet.

Ten opzichte van artikel 6 ECRM kan men het wellicht verklaren uit de aard van het recht. ${ }^{.0}$ Artikel 8 stelt grenzen aan bestuursoptreden die de rechter nader uitwerkt, terwijl artikel 6 - althans voor zover het de onafhankelijkheid en onpartijdigheid van de rechter betreft - met name de rechter zèlf betreft. Daaraan kan worden toegevoegd dat het recht op toegang tot de rechter niet expliciet in artikel 6 lid 1 ECRM is opgenomen en de nationale rechter daarom wellicht minder bekend is met dit recht is of huiverig is eraan te toetsen. Gezien de ruime Europese rechtspraak die voorhanden is, die de rechter tot richtsnoer zou kunnen nemen, is dit nauwelijks een valide argument te noemen.

Een eerste verklaring van het verschil in afbakenen tussen artikel 8 ECRM enerzijds en de behandelde grondwettelijke grondrechten anderzijds, vloeit wellicht voort uit een bij de rechter bestaande opvatting, dat die nauwkeurigere afbakening uit het ECRM voortvloeit. Het risico bestaat hier (meer dan bij louter toetsing aan de Grondwet) dat een zaak aan de Straatsburgse organen voorgelegd zal worden, als de rechter geen bevredigende interpretatie van de desbetreffende verdragsbepaling geeft.

Een tweede verklaring voor de geringe afbakening - die de Nederlandse rechter van de behandelde grondwettelijke grondrechten geeft - kan mijns inziens worden gezocht in het feit dat indien een vermeende inbreuk op een grondrecht wordt gemaakt, deze terug te voeren is tot of gesanctioneerd wordt door een formele wet, die ingevolge het verbod van artikel 120 Grondwet niet aan de Grondwet getoetst mag worden. In dergelijke gevallen is men aangewezen op toetsing aan verdragen. Dit is dan ook op grote schaal gebeurd, met name in geval van vermeende schending van het discriminatieverbod. Men denke hierbij met name aan de toetsing van de verscheidene sociale verzekeringswetten. Dit verklaart voor het grootste deel waarom niet vaker aan artikel 1 wordt getoetst. ${ }^{81}$

Een derde verklaring kan erin zijn gelegen, dat ter uitwerking van de oude Grondwet zowel als de herziene Grondwet diverse implementatie-

80 Dit geldt ook in het algemeen: ten aanzien van het ene recht zal de rechter duidelijkere afbakeningscriteria kunnen vaststellen dan ten aanzien van andere rechten. De aard van een recht kan met zich meebrengen dat een rechter bijvoorbeeld niet een inhoudelijk oordeel kan geven, zoals bijvoorbeeld bleek bij de afbakening van het begrip "godsdienst". In dat geval kan de rechter slechts marginaal toetsen en zijn de te hanteren toetsingscriteria derhalve ook vaag.

81 Vergelijk, bijvoorbeeld, de in noot 69 van hoofdstuk 6 genoemde jurisprudentie en de in de daar aangehaalde literatuur behandelde rechtspraak. 
wetten tot stand zijn gekomen, waarin de grondwettelijke grondrechten - alsmede de beperkingen daarop - nader zijn uitgewerkt. Dit is al het geval voor wat betreft het werkingsgebied van de bestaande Wet gelijke behandeling mannen en vrouwen en de diverse strafbepalingen ter bestrijding van discriminatie in het Wetboek van Strafrecht en zal naar ik verwacht ook steeds meer gaan spelen voor de Wet Openbare Manifestaties (in verband met artikel 6 en 9). Ook zal vermoedelijk minder aan artikel 1 Grondwet getoetst gaan worden, nu de Algemene wet gelijke behandeling in werking is getreden.

Dit verklaart echter niet waarom, in de periode voorafgaande aan de inwerkingtreding van de zojuist genoemde wetgeving, deze grondrechten zo weinig werden ingeroepen of toegepast in zaken waarin deze grondrechten wel in het geding waren. Ten aanzien van artikel 9 en in iets mindere mate met betrekking tot artikel 6 Grondwet kan het geringe aantal uitspraken waarin een afbakening van de in deze bepalingen opgenomen rechten gegeven wordt, worden verklaard (vierde verklaring) uit het feit dat deze bepalingen maar mondjesmaat worden ingeroepen dan wel toegepast. Een uitgewerkte reikwijdte-afbakening kan men ten aanzien van deze artikelen dan ook nauwelijks verwachten.

Geven de geopperde (althans de derde en vierde) verklaringen aan waarom er wellicht weinig aan de artikelen 1, 6 en 9 wordt getoetst, voor artikel 7 gaan alleen de eerste en tweede verklaring (toetsing aan artikel 10 ECRM in plaats van aan dit grondwetsartikel) op en dan nog maar gedeeltelijk want juist artikel 7 Grondwet wordt wèl geregeld voor de rechter ingeroepen en door deze toegepast. Misschien is de volgende verklaring voor het ontbreken van een uitgebreide jurisprudentie waarin het in deze bepaling gegarandeerde recht wordt afgebakend, aannemelijker. Naar mijn mening ontbreekt een nadere ${ }^{82}$ afbakening van artikel 7 , omdat het merendeel der zaken betrekking heeft op plakverboden. Deze plakverboden zijn echter zo verschillend in de diverse Algemene Politie Verordeningen (APV) geformuleerd, dat de rechter genoodzaakt is tot een casuistische toetsing aan artikel 7.

De hiervoor gesuggereerde verklaringen voor het feit dat de nationale rechter wel het in artikel $8 \mathrm{ECRM}$ vervatte recht aan de hand van criteria afbakent, maar niet of nauwelijks de in artikel 6 ECRM en de artikelen 1 .

82 Ik spreek van een nadere afbakening omdat vele van de in paragraaf 6.2 .2 besproken kwesties, zoals het onderscheid openbaringsrecht-verspreidingsrecht, algemeen verbod, zelfstandig middel van bekendmaking en gebruik van enige betekenis, reeds criteria zijn ter nadere invulling van de vrijheid van meningsuiting in artikel 7. Deze begrippen zijn echter nog zo vaag. dat afbakening van ook deze begrippen noodzakelijk is voor de begrenzing van de reikwijdte van arrikel 7 . 
$6(1), 7(1$ en 3 ) en 9(1) Grondwet gegarandeerde rechten, zijn echter niet meer dan gissingen. Bovendien zal de mate waarin de rechter een recht begrenst wellicht ook afhankelijk zijn van de ingediende grieven (lagere rechter), de cassatiemiddelen (Hoge Raad) dan wel de inhoud van de ingediende klacht (Straatsburgse instanties).

Concluderend kan ten aanzien van de rechterlijke praktijk inzake de interpretatie en beperking van grondwettelijke grondrechten geconstateerd worden dat er een zekere spanning met de bedoelingen van de grondwetgever bestaat. Het betreft hier dan de rechterlijke praktijk waarbij regelmatig gebruik gemaakt wordt van de mogelijkheden tot afwijking van de beperkingssystematiek in de Grondwet, teneinde (onder meer) voorschriften die algemene beperkingen op grondrechten bevatten die niet herleidbaar zijn tot in de Grondwet voorziene beperkingsmogelijkheden, voor ongrondwettig-verklaring te behoeden. Hiermee kan vastgesteld worden dat ten aanzien van deze rechterlijke praktijk ook de juistheid van de tweede stelling - het verband tussen de interpretatie en de beperking van mensenrechten roept een spanning op tussen de argumentatie achter de formulering van de rechten en de beperkingsmogelijkheden enerzijds en de rechterlijke praktijk anderzijds - is aangetoond. Tot slot zal dan ook in de volgende paragraaf, zoals aangekondigd in paragraaf 7.1 , bekeken worden of er alternatieven zijn voor de rechterlijke praktijk voorzover die spanning met de bedoelingen van de verdragspartijen dan wel de grondwetgever oplevert.

\subsection{Mogelijke alternatieven voor de gevallen waarin de rechterlijke praktijk spanning met de bedoelingen van de verdragspartijen respectievelijk de grondwetgever oplevert}

Wanneer een onderzoeker constateert dat een bepaalde, in casu een rechterlijke, praktijk niet correct is, dan zal mijns inziens toch minstens een poging ondernomen moeten worden door deze onderzoeker om een alternatief voor deze rechterlijke praktijk aan te reiken, om aan te geven hoe het eventueel anders zou kunnen. Een dergelijke poging wil ik in deze laatste paragraaf ook doen. Achtereenvolgens zal ik in de volgende subparagrafen ingaan op de vraag hoe naar mijn mening de rechter de geconstateerde spanning tussen twee voorbeelden van het verband tussen de vaststelling van de reikwijdte en de beperking van de uitoefening van mensenrechten enerzijds en de bedoelingen van de verdragspartijen respectievelijk de grondwetgever anderzijds zou kunnen worden 
weggenomen. Ik pretendeer niet een sluitende oplossing te leveren, maar wil wel aanzet tot het vinden daarvan aanreiken.

\subsubsection{Een alternatief voor de toetsing van positieve verplichtingen onder de Conventie}

In paragraaf 7.4.1 is geconstateerd dat er een spanning bestaat tussen de toetsingspraktijk van het Hof ten aanzien van positieve verplichtingen van de overheid op grond van artikel 8 ECRM en de bedoelingen van de opstellers van het verdrag. Eén van de intenties van de verdragspartijen was dat de aard en de reikwijdte van de verdragsverplichtingen duidelijk zouden zijn voor de Verdragsstaten. De aard en de reikwijdte van de positieve verplichtingen die voor de Staat voortvloeien uit artikel 8 ECRM worden voor de Verdragsstaten niet duidelijk, nu het Hof bij de toetsing aan artikel 8 niet eerst afzonderlijk de reikwijdte van de positieve verplichtingen van de overheid vaststelt op grond van lid 1 en daarna de rechtvaardiging onderzoekt van de eventuele beperking, aan de hand van lid 2. In plaats daarvan voltrekt het Hof de bij die toetsing te maken belangenafweging tussen het algemeen belang en de belangen van het betrokken individu aan de hand van de in artikel 8 lid 2 genoemde beperkingsdoeleinden. ${ }^{83}$ Er vindt een vermenging plaats van de vaststelling van de reikwijdte van de positieve verplichting, die uit artikel 8 ECRM voortvloeit, enerzijds en de beperking daarop anderzijds. De vraag is nu of dit niet anders kan.

In paragraaf 5.1.3.3 bleek dat ook uit het recht op toegang tot de rechter, dat is afgeleid uit het recht op een "fair trial" in artikel 6 lid 1 ECRM, een positieve verplichting voor de overheid kan voortvloeien. ${ }^{84}$ Afhankelijk van de omstandigheden van het geval kan het soms noodzakelijk zijn dat de overheid actief optreedt ten einde aan de rechtzoekende een effectief recht op toegang tot de rechter te verzekeren. bijvoorbeeld door bepaalde - juridische of feitelijke - belemmeringen in de toegang tot de rechter weg te nemen. De overheid heeft een beoordelingsvrijheid bij de keuze van de middelen om dit recht op toegang te verzekeren, het betekent derhalve niet dat de overheid altijd gratis rechtsbijstand dient te verzekeren. Wèl kan artikel 6 lid 1 de Staat onder omstandigheden dwingen te voorzien in de bijstand door een raadsman, bijvoorbeeld wanneer die bijstand onmisbaar voor een effectief recht op toegang is. Dit is bijvoorbeeld het geval wanneer proces-

83 Zie EHRM 21 februari 1990, Case of Powell and Rayner, $\$ 41$, p. 18.

84 Zie ook C.J. Staal, Het recht op rechtsbijstand in verband met het recht op toegang tot de rechter onder artikel 6 EVRM, pp. 116-129. 
vertegenwoordiging volgens het nationale recht verplicht is of indien de desbetreffende zaak zeer complex is. Besluit een Staat zijn positieve verplichting na te komen door middel van het verstrekken van door de overheid gefinancierde rechtsbijstand, dan mogen daarop wèl weer beperkingen aangebracht worden, bijvoorbeeld het laten betalen van een eigen bijdrage door de rechtzoekende of het stellen van de voorwaarde dat de zaak een redelijke kans van slagen heeft. De grens die aan het stellen van dergelijke beperkingen wordt gesteld blijft echter, dat het recht op toegang tot de rechter effectief moet zijn.

Bij deze positieve verplichting gaat het om een verplichting die is gebaseerd op een recht (op toegang tot de rechter) dat niet expliciet in artikel 6 lid 1 is gegarandeerd. Het wel in artikel 6 lid 1 expliciet gewaarborgde recht is het recht op "fair trial". Artikel 6 lid 1 bevat geen beperkingsbevoegdheid voor de Staat, alleen een beperking ten aanzien van de toepasselijkheid van de bepaling. ${ }^{\text {ss }}$ Om die reden is het bij de door artikel 6 lid 1 beschermde rechten moeilijker, indien al mogelijk, om een scheiding aan te brengen tussen de vaststelling van de reikwijdte van het recht en de beperking ervan. ${ }^{86}$ Toch is het wel enigszins mogelijk om de reikwijdte-afbakening van de positieve verplichting van de Staat op grond van artikel 6 lid 1 te onderscheiden van de beperking van deze verplichting. De reikwijdte kan aldus worden begrensd: Er bestaat een positieve verplichting voor de overheid op het moment dat er voor een rechtzoekende een feitelijke of juridische belemmering bestaat voor het effectief uitoefenen van het recht op toegang tot de rechter. Het bestaan van de verplichting hangt derhalve af van de concrete omstandigheden van het geval. De overheid heeft in het algemeen een beoordelingsvrijheid bij de keuze van de middelen ter nakoming van deze verplichting; dit is slechts anders wanneer een bepaald middel onmisbaar is voor het effectief uitoefenen van het recht op toegang. Dit kan blijken uit objectieve gegevens. Zo kan uit de nationale wetgeving (= objectief gegeven) blijken dat procesvertegenwoordiging verplicht is en dat derhalve bijstand door een raadsman onmisbaar is. Bestaat er bij de rechtzoekende een - bijvoorbeeld financiële - belemmering voor het inroepen van de hulp van een raadsman, dan rust op de Staat de verplichting om voor de bijstand van een raadsman zorg te dragen. Hiermee is de reikwijdte van het recht op toegang vastgesteld voor dit geval. Vervolgens kan gekeken worden of beperkingen mogelijk zijn. Op grond van de jurisprudentie van het Hof

85 Zie hoofdstuk 2, paragraaf 2.4.2.2: Inhoudelijke omschrijving van rechten en vrijheden op zodanige wijze, dat in die omschrijving de beperkingsmogelijkheden besloten liggen.

86 Zie paragraaf 5.1.3.1, p. 325. 
kan aan de rechtzoekende betaling van een eigen bijdrage gevraagd worden en ook kan als eis gesteld worden dat de desbetreffende zaak waarvoor de bijstand van een raadsman gevraagd wordt, kans van slagen heeft. Aan deze beperkingsbevoegdheid van de Staat wordt de grens gesteld, dat deze beperking niet zover mag gaan dat het recht op toegang tot de rechter niet meer effectief kan worden uitgeoefend. Hiermee is de beperkingsmogelijkheid op de positieve overheidsverplichting vastgesteld.

De positieve verplichtingen die onder omstandigheden uit artikel 8 lid 1 kunnen worden afgeleid, zouden mijns inziens op dezelfde wijze moeten kunnen worden afgebakend. Ook volgens de jurisprudentie naar aanleiding van positieve verplichtingen op grond van artikel 8 , heeft de overheid een beoordelingsvrijheid bij de keuze van de middelen ter nakoming van de desbetreffende verplichting. Hier geldt dan mijns inziens opnieuw: indien een bepaald middel onmisbaar is voor het effectief uitoefenen van de in artikel 8 lid 1 gegarandeerde rechten, dient de overheid dat middel te kiezen. Dit kan dan weer blijken uit objectieve gegevens. Om de casus van de zaak Powell and Rayner er bij te halen, het ging hier om geluidsoverlast veroorzaakt door een vliegveld, dan zou het - bijvoorbeeld - zo kunnen zijn dat uit een objectief deskundigen-onderzoek blijkt dat alleen bij het reduceren van het geluidsniveau tot onder een bepaald aantal decibel nog een effectieve uitoefening van het recht op privéleven mogelijk is. De overheid zal dan een maatregel hiertoe dienen te treffen. De aldus afgebakende positieve verplichting kan dan eventueel beperkt worden, indien voldaan wordt aan de voorwaarden van het tweede lid. Een probleem bij de afbakening zou kunnen rijzen, wanneer er in het geheel geen objectieve gegevens zijn die wijzen op de noodzaak van het treffen van bepáálde maatregelen. Dan heeft de overheid een vrije keuze van middelen ter nakoming van de desbetreffende positieve verplichting. Dan nog, echter, zal de rechter een grens kunnen trekken tot waar de overheidsverplichting reikt. ${ }^{87}$ Wenst de overheid niet volledig aan die verplichting te voldoen, dan moet deze - uit een nalaten bestaande beperking - worden gerechtvaardigd op grond van artikel 8 lid 2 .

87 Dit is mijns inziens in overeenstemming met de teleologische(-sociologische) interpretatie-methode: onderzoek naar het maatschappelijk verkeer, waaruit zen regel wordt afgeleid, aan de hand waarvan een doelmatige inrichting van het maatschappelijk leven dient plaats te vinden. Is het de wetgever (of de "verdraggever"), die bij conflicterende belangen in het maatschappelijk leven, de beslissing neemt welk doelen (belangen) zullen worden nagestreefd; het is de rechter, die binnen de grenzen door de wetgever gesteld, die zal moeten nagaan hoe (volgens welke regel/maatstaven) deze doeleinden conform de maatschappelijke ontwikkelingen het best bereikt kunnen worden ( $\boldsymbol{P}$. Scholten, Algemeen Deel, p. 118-119). 
Hiermee komen we op een tweede probleem: anders dan in gevallen, waarbij de beperking bestaat uit een actief overheidsoptreden (bij negatieve verplichtingen), gaat het bij positieve verplichtingen om een beperking die een nalaten van overheidsoptreden inhoudt. Toch is toetsing van een dergelijke beperking aan het tweede lid van artikel 8 ECRM naar mijn mening niet onmogelijk."

Ten eerste de toetsing aan het wetsvereiste: de beperking moet voorzien zijn bij wet. In de jurisprudentie naar aanleiding van negatieve verplichtingen is dit vereiste aldus uitgelegd, dat het hier kan gaan om zowel formele als lagere wetgeving en zowel geschreven als ongeschreven recht. De voorwaarde die hieraan gesteld wordt is dat de wetgeving voldoende toegankelijk en voorzienbaar is. Ten aanzien van positieve verplichtingen kan men wellicht de eis stellen, dat indien het gaat om nietincidentele positieve maatregelen, deze maatregelen gebaseerd zijn op voldoende toegankelijke en voorzienbare regelingen. Bij incidentele maatregelen kan men op zijn minst de voorwaarde stellen dat de beslissing tot het nemen van deze maatregelen voldoende inzichtelijk is. Aan de hand van deze regelingen/beslissing kan men met voldoende zekerheid vaststellen wanneer en tot hoever de positieve maatregel zal worden genomen en daaruit zal men dan ook kunnen afleiden wanneer en tot hoever níet. De noodzaak tot het nemen van een uitdrukkelijke beslissing om een bepaalde maatregel níet te nemen zal - indien deze beslissing niet al genomen wordt op eigen initiatief van de betrokken overheidsorganen in elk geval genomen moeten worden indien vanuit de samenleving dan wel door individuele personen verzoeken tot het treffen van die maatregel aan die organen worden gedaan.

Vervolgens wat betreft de "noodzakelijkheid in een democratische samenleving": hieruit is in de jurisprudentie met name het vereiste van een "pressing social need" afgeleid, die de toetsing aan het proportionaliteitsvereiste met zich brengt. Bij negatieve verplichtingen wordt dan getoetst of gesproken kan worden van een evenredige verhouding tussen de beperking van het recht van betrokkene en het doel met het oog waarop die beperking plaatsvindt. Het gaat hier derhalve om de vraag of de beperking (de bestreden overheidsmaatregel) van het recht van betrokkene niet te ver gaat. Bij positieve maatregelen kan men omgekeerd de vraag stellen, of de overheidsmaatregel wel ver genoeg gaat, dat wil zeggen, komt de maatregel wel voldoende aan het door het grondrecht beschermde belang tegemoet. Het gaat hier derhalve, net als bij het recht op toegang tot de rechter, om de vraag of het in het geding zijnde 
recht wel effectief kan worden uitgeoefend. Zowel bij het wetsvereiste als bij het noodzakelijkheidsvereiste zien we, dat in geval van positieve verplichtingen de vraag of aan deze vereisten is voldaan als het ware spiegelbeeldig is aan die bij negatieve verplichtingen. Negatieve verplichting: staat de beperking op de verplichting in een voldoende toegankelijke en voorzienbare regeling, positieve verplichting: staat de verplichting zèlf in een voldoende toegankelijke en voorzienbare regeling (etc.).

Ten derde wat betreft de beperkingsgronden: net zoals bij negatieve verplichtingen een beperking (overheidsinmenging) gerechtvaardigd moet kunnen worden op grond van de in lid 2 van artikel 8 genoemde beperkingsgronden, moet ook een beperking op een positieve verplichting (een nalaten) gerechtvaardigd kunnen worden met een beroep op de bedoelde doelcriteria.

Op grond van het voorgaande, zou geconcludeerd kunnen worden dat ook in het geval een verdragsartikel (en mijns inziens eveneens een grondwetsbepaling) een mensenrecht garandeert dat naast negatieve (onthoudings)verplichtingen aan de nationale overheid positieve verplichtingen oplegt, een afzonderlijke reikwijdtebepaling en toetsing aan beperkingsmogelijkheden plaats kan vinden. Verschil bestaat alleen in de wijze van toetsing. De rechterlijke toetsing aan positieve verplichtingen zal marginaler zijn dan bij negatieve verplichtingen, omdat de overheid bij eerstgenoemde verplichtingen doorgaans een ruimere beoordelingsvrijheid zal hebben. Dit is slechts anders als, bijvoorbeeld objectieve gegevens de overheid tot een bepááld optreden verplichten. Bovendien zal bij positieve verplichting de toetsing aan de beperkingsclausules wellicht spiegelbeeldig (in de zin als hierboven uitgelegd) plaatsvinden. Op deze wijze zullen de aard en de reikwijdte van de verdragsverplichtingen duidelijker kunnen worden voor de Verdragsstaten, dan in de praktijk van het Hof, zoals geillustreerd door het arrest in de zaak Powell and Rayner, het geval was. Daarmee zou dan ook de spanning tussen de rechterlijke praktijk en de bedoelingen van de verdragspartijen bij de opstelling van de Conventie kunnen verminderen.

\subsubsection{Een alternatief voor de rechterlijke praktijk ten aanzien van ongeschreven, algemene beperkingen en andere niet toegestane beperkingsmethoden}

In de hoofdstukken 3 en 6 (en kort herhaald in paragraaf 7.3) is naar voren gekomen, dat er voorbeelden in de praktijk van de Nederlandse rechterlijke instanties zijn te vinden, waarin gemeentelijke algemene regelingen tot 
gevolg hebben dat onbedoeld bepaalde grondrechten worden beperkt. Alhoewel hier - volgens de definitie in de Memorie van Toelichting bij het wetsvoorstel dat tot de grondwetsherziening van 1983 heeft geleid - sprake is van algemene beperkingen, worden deze regelingen niet als zodanig door de betrokken instanties aangemerkt. Ondanks dat algemene, niet tot een grondwetsbepaling herleidbare, beperkingen door de grondwetgever zijn afgewezen, worden de bedoelde regelingen toch in stand gelaten, via de constructie van de redelijke wetsuitleg of -toepassing, zij het dat dit - opnieuw - niet expliciet door de rechterlijke instanties wordt uitgesproken. Ook andere dan algemene beperkingen, die niet in overeenstermming zijn met de grondwettelijke beperkingssystematiek - bijvoorbeeld bijzondere beperkingen in noodverordeningen van burgemeesters die niet tot een specifieke formele wetsbepaling zijn te herleiden - worden aldus in stand gelaten.

Bij redelijke wetsuitleg moet gedacht worden aan uitspraken als dat een bepaalde maatschappelijk algemeen aanvaarde maatregel of regeling die de uitoefening van een grondrecht raakt, in beginsel niet opgevat wordt als beperking van dit grondrecht. ${ }^{\text {" }}$ Redelijke wetstoepassing houdt in dat in het concrete geval moet worden beoordeeld of een maatregel die in strijd is met een bepaald grondrecht, toch zijn gelding behoudt. Er zal moeten worden vastgesteld of aan de redelijkheid grenzen ontleend kunnen waarbuiten het grondrecht geen toepassing meer behoort te vinden. De overheid heeft hierbij geen volledige beleidsvrijheid; er moet sprake zijn van een proportionaliteitstoets en een afweging van het individuele en het algemeen belang.

Op zich zijn er mijns inziens geen bezwaren tegen redelijke grondwetstoepassing, mits er maar in elk concreet geval getoetst wordt aan bepaalde materiële criteria zoals het proportionaliteitsbeginsel en het subsidiariteitsbeginsel. Daarnaast zal voldaan moeten worden aan de voorwaarde dat de kern van het recht, waaronder het effectieve nut van het recht, niet aangetast mag worden. ${ }^{\circ}$ Redelijke wetsuitleg stuit naar mijn mening op meer bezwaren omdat het het gevaar in zich bergt dat de reikwijdte van een grondrecht bij hantering van die methode te restrictief geïnterpreteerd wordt. En zelfs als - zoals Vermeulen doet" - bij redelijke

89 Zie o.a. B.P. Vermeulen, Wie bepaalt de reikwijdte van grondrechten?, p. 40. Deze omschrijving van Vermeulen wijkt wat af van die van de grondwetgever (zie paragraaf 3.2.10), maar is meer in overeenstemming met de praktijk.

90 Zie hiervoor de paragrafen 7.2.2 en 7.2.3. Vgl. B.P. Vermeulen, Algemene beperkingen, redelijke uitleg en redelijke toepassing van grondrechten, pp. 83-84. Vermeulen noemt daarnaast nog het onderscheid tussen inhoud en vorm van het grondrecht.

91 B.P. Vermeulen, Wie bepaalt de reikwijdte van grondrechten?, pp. 40-41. 
wetsuitleg wordt uitgegaan van een onderscheid tussen vorm en inhoud van de grondrechtsuitoefening, wat erop neerkomt dat de grondwettelijke grondrechten niet zover reiken, dat in het kader van die grondrechten te verrichten handelingen op ieder moment, overal en op elke wijze moeten kunnen plaatsvinden, dan nog bestaat het gevaar van restrictieve interpretatie. ${ }^{92}$ Ook al gebeurt dit in een concreet geval, de restrictieve interpretatie kan ook haar invloed hebben voor andere gevallen. Mijns inziens verdient het dan ook de voorkeur om dit risico te vermijden en de desbetreffende maatregel of regeling wèl als beperking van het ingeroepen grondrecht aan te merken en vervolgens aan een toetsing in het kader van de beperkingsmogelijkheden of redelijke grondwetstoepassing te onderwerpen.

De in paragraaf 7.4.2 geconstateerde spanning met de bedoelingen van de grondwetgever die hierdoor is ontstaan, bestaat hierin dat de bedoelde ontsnappingsmogelijkheden vaker gehanteerd worden dan de grondwetgever gezien het woord "uitzondering" voor ogen stond en tevens dat de door de grondwetgever aan deze ontsnappingsmogelijkheden gekoppelde proportionaliteitstoets en belangenafweging niet in alle gevallen

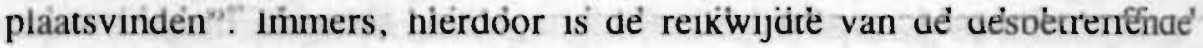
grondrechten en de daaraan gekoppelde beperkingsmogelijkheden niet meer omlijnd, gepreciseerd, zoals de grondwetgever voor ogen stond. Hierdoor dreigt mijns inziens uitholling van de desbetreffende grondrechten. Vraag is wat hieraan gedaan kan worden. Hiertoe zal eerst de vraag beantwoord moeten worden, waarom de rechter (en zoals in paragraaf 3.3 bleek ook de wetgever) herhaaldelijk van de ontsnappingsmogelijkheden gebruik makk - al dan niet in combinatie met algemene beperkingen - en waarom daarbij de vereiste toetsing niet plaatsvindt.

De reden waarom de grondwetgever er vanuit ging. dat de nationale grondrechten preciezere waarborgen moesten bevatten dan internationale

92 Vgl. B.P. Vermeulen, Algemene beperkingen, redelijke uitleg en redelijke toepassing van grondrechten, p. 83, noot 83: "Zo zal de redelijke uitleg meestal neerkomen op een restrictieve uitleg van het grondrecht, waardoor elke belangenafweging per definitie overbodig gemaakt wordt: de beperkende regeling wordt dan immers immuun gemaakt doordat zij geacht wordt buiten de werkingssfeer van het grondrecht te liggen." Verwezen wordt naar C.A.J.M. Kortmann. De Grondwetsherzieningen 1983 en 1987. p. 55.

93 Redelijke wetstoepassing heb ik in paragraaf 1.3 .2 (p. 18) een voorbeeld van toepassing van de teleologische of sociologische interpretatie-methode genoemd. Teleologische (-sociologische) interpretatie: zie noot 29. pp. 17-18. Deze interpretatiemethode vereist derhalve ook een degelijke belangenafweging door de rechter en daarvan is in de bedoelde praktijk zoals gezegd geen sprake. 
mensenrechten, was dat nationale grondrechten veel meer toegesneden zijn op een eenduidige toepassing in een bepaalde nationale rechtsorde. Volgens de regering zouden, bij een ruime formulering van deze rechten in combinatie met uitvoerige clausuleringen, de nationale grondrechten volgens de regering veel van hun betekenis verliezen. Internationale grondrechten daarentegen moeten flexibel kunnen functioneren omdat de omstandigheden in de nationale staten sterk kunnen verschillen; pas bij toepassing van internationale rechten ontstaat een concretisering, waardoor gaandeweg een nadere afbakening van die rechten ontstaat. Internationale grondrechten zijn daarom ruim geformuleerd met uitvoerige clausuleringen. De vraag waarom de rechter regelmatig van de ontsnappingsmogelijkheden gebruik maakt - al dan niet in combinatie met algemene beperkingen zou aldus beantwoord kunnen worden, dat de grondwettelijke beperkingsmogelijkheden wellicht té gepreciseerd, té scherp omlijnd zijn. De nationale grondrechten zouden meer toegesneden moeten zijn op een eenduidige toepassing in een bepaalde nationale rechtsorde, echter, in praktijk blijken de grenzen van de werkingssfeer van de grondrechten uitermate vaag en ruim te zijn. Een zekere flexibiliteit is voor het functioneren van grondrechten dan ook noodzakelijk. De grondwettelijke (beperkings)systematiek biedt die flexibiliteit niet. Hierdoor neemt de (lagere) wetgever waarschijnlijk zijn toevlucht tot niettoegestane beperkingsmethoden en zoekt de rechter zijn heil in redelijke wetsuitleg en -toepassing. "

De vraag waarom de rechter bij het gebruik van de bedoelde ontsnappingsmogelijkheden in het concrete geval onvoldoende overgaat tot, onder meer, een proportionaliteitstoetsing is minder makkelijker te beantwoorden. Wellicht is dit te wijten aan een te casusgerichte benadering van de rechter. onwetendheid of onvermogen? Hoe het ook zij, mijns inziens is verandering in de (rechterlijke) praktijk noodzakelijk; de vraag is alleen hoe.

94 Vgl. B.P. Vermeulen, Algemene beperkingen, redelijke uitleg en redelijke toepassing van grondrechten, p. 82. Vermeulen wijst ook op de maatschappelijke en technologische ontwikkelingen, de voortschrijdende levensbeschouwelijke pluriformiteit en individualisering van de samenleving en een toenemend overheidsingrijpen in het maatschappelijk ieven. 
Opheffing van het vereiste van een specifieke formele wetsbepaling en toevoeging van een expliciete toetsing aan het noodzakelijkheidsvereiste als gedragscode

Wanneer er, zoals in de hierboven gesuggereerde verklaring voor de huidige praktijk, inderdaad vanuit gegaan wordt dat de grondwettelijke beperkingssystematiek te rigide is, dan ligt het voor de hand om te onderzoeken of aan die beperkingssystematiek wat veranderd zou kunnen worden. Om te voorkomen dat de rechter in de toekomst ook nog zijn toevlucht zal moeten nemen tot de ontsnappingsmogelijkheden "redelijke wetsuitleg en -toepassing", zou allereerst kunnen worden overwogen om de eis van specificiteit die aan delegerende formele wetsbepalingen wordt gesteld, te laten vallen. Hierdoor kunnen ook algemene beperkingen en uitoefening van noodbevoegdheden door burgemeesters gebaseerd worden op formele wetsbepalingen die overigens voldoen aan de grondwettelijke beperkingsvoorschriften. Reden voor de eis van een specifieke wetsbepaling was, dat het niet in overeenstemming met het waarborgkarakter van de grondrechten zou zijn, indien alle organen met regelgevende bevoegdheden bevoegd zouden zijn "in de uitvoering van hun taak inbreuk op grondrechten te maken in al die gevallen waarin de Grondwet in beginsel delegatie toestaat." Om aan dit bezwaar tegernoet te komen zou in dit soort gevallen een zwaardere toetsing aan materiële criteria door de rechter dienen plaats te vinden in het concrete geval dat aan de rechter wordt voorgelegd. Bij de bespreking van de beperkingssystematiek kwam aan de orde het ontbreken van gedragscodes als voorschriften voor de beperking van grondrechten. Gedragscodes werden daar omschreven als voorwaarden, dat een redelijke afweging plaatsvindt van de belangen ten behoeve waarvan een grondrecht wordt beperkt en de belangen die het desbetreffende grondrecht beoogt te garanderen. Daaraan werd toegevoegd dat gedragscodes aangeven in hoeverre een beperking van een grondrecht daadwerkelijk noodzakelijk. moet worden geacht. ${ }^{95}$ De toetsing aan materiële criteria door de rechter zou wellicht bevorderd kunnen worden door de beperking van. grondrechten te koppelen aan een gedragscode, waarbij eventueel het criterium "noodzakelijkheid in een democratische samenleving" dat is opgenomen in onder meer de tweede leden van de artikelen 8 tot en met 11 ECRM (inclusief de interpretatie daarvan door de Straatsburgse instanties), als voorbeeld zou kunnen dienen. Toetsing aan deze 
gedragscode brengt met zich dat getoetst moet worden aan vragen als: is sprake van een dwingende maatschappelijke noodzaak tot de beperking ("pressing social need"), is de beperking proportioneel aan het daarmee nagestreefde doel en zijn de redenen die worden gegeven voor de beperking relevant en voldoende? ${ }^{\%}$ De beleidsvrijheid die de overheid bij het beperken van een grondrecht geniet, is bovendien afhankelijk van de aard van de in het geding zijnde activiteiten en van de aard van de beperkingsgrond waarop de overheid zich beroep ter rechtvaardiging van de beperking.

Hoe kan deze mogelijke oplossing gerealiseerd worden? Naar mijn mening is hiertoe grondwetsherziening níet de aangewezen weg, omdat dit te omslachtig en te tijdrovend zou zijn en bovendien niet noodzakelijk. Ten eerste behoeft de tekst van de Grondwet voor de gesuggereerde oplossing geen wijziging. De verandering betreft de interpretatie van de grondwetsbepalingen aangezien het vereiste van een specifieke wetsbepaling en de mogelijkheid van redelijke wetsuitleg/toepassing niet in de tekst van de Grondwet zelf zijn opgenomen, maar slechts in de toelichtende stukken. In paragraaf 1.3.2 is reeds naar voren gebracht dat, wanneer de documenten waarin de wetsgeschiedenis is neergelegd eveneens woorden of passages bevatten die voor nadere uitleg vatbaar zijn, of wanneer zij in het geheel geen duidelijkheid verschaffen omtrent de interpretatie van het desbetreffende grondrecht - hetzij omdat eventuele problemen omtrent de interpretatie over het hoofd zijn gezien, hetzij omdat de onduidelijkheden naderhand pas zijn gerezen bijvoorbeeld tengevolge van maatschappelijke ontwikkelingen - de rechter aansluiting zal moeten zoeken bij de teleologische interpretatiemethode. ${ }^{97}$ Vooral naarmate een wet ouder is, gaat van een wetshistorische interpretatie minder overtuigingskracht uit dan van andere interpretatiemethoden. Kortom, naar mijn mening zou de hierboven aangedragen (mogelijke) oplossing voor de spanning tussen de rechtspraktijk en de bedoelingen van de grondwetgever het best gerealiseerd kunnen worden via de teleologische interpretatiemethode.

Ten tweede ben ik van mening dat toetsing aan een gedragscode als het noodzakelijkheidsvereiste altijd plaats zou moeten vinden, ook onder de gangbare interpretatie van de grondrechten en beperkingsmogelijkheden. Een niet-noodzakelijke beperking, ook al is die in overeenstemming met alle beperkingsvoorschriften (competentie- en procedurevoorschriften, doelcriteria), is mijns inziens niet aanvaardbaar. De formele wetgever moet

97 M.M. den Boer, Grondwettelijke grondrechten geïnterpreteerd, p. 67. 
nu al aangeven welke grondrechten hij beperkt en de omvang van de beperking aangeven. Naar mijn mening moet de wetgever (de formele wetgever én vanzelfsprekend ook de lagere wetgever) ook de noodzaak van een beperking onderzoeken. Steun hiervoor kan worden gevonden in de zogenaamde Aanwijzingen voor de regelgeving. ${ }^{98}$ Hier zijn naar mijn mening, onder meer, de volgende aanwijzingen van belang":

1) Volgens aanwijzing 6 mag alleen tot het tot stand brengen van regelgeving besloten worden indien de noodzaak daarvan is komen vast te staan.

2) Voordat tot regelgeving wordt overgegaan zal op grond van aanwijzing 7 , onder meer, de na te streven doelstelling zo concreet en nauwkeurig mogelijk moeten worden vastgesteld (onderdeel b), moet onderzocht worden of voor het bereiken van die doelstelling wel overheidsinterventie noodzakelijk is (onderdeel c) en zullen eventuele alternatieven voor overheidsinterventie moeten worden overwogen (onderdeel d). Bij deze alternatieven kan het blijkens de toelichting op deze aanwijzing gaan om zowel instrumenten die door middel van wetgeving worden gecreëerd (bijvoorbeeld ge- en verboden of vergunningenstelsels) als om andere middelen, zoals feitelijk optreden van de overheid.

3) Een aantal aspecten dient volgens aanwijzing 9 bij de afweging van de verschillende mogelijkheden tot overheidsinterventie om een doelstelling te bereiken, te worden overwogen:

a. de mate waarin verwacht mag worden dat een regeling het beoogde doel zal helpen te vewezenlijken (effectiviteit);

b. de neveneffecten van een regeling en

c. de lasten van een regeling voor de overheid enerzijds en burgers, bedrijven en instellingen anderzijds. Onderdeel b houdt, onder andere, in dat afgewogen dient te worden in hoeverre onbedoelde neveneffecten de aanvaardbaarheid van de regeling negatief beïnvloeden. Volgens de toelichting kan negatieve beivloeding van de aanvaardbaarheid van de regeling een reden zijn om van de desbetreffende regeling af te zien.

4) Volgens aanwijzing 13, die voortbouwt op onderdeel c van aanwijzing 3. dienen de lasten voor burgers, bedrijven en instellingen bij de keuze voor een bepaalde regeling zo beperkt mogelijk te zijn. Volgens de toelichting kan wat betreft de gevolgen (de lasten) voor burgers gedacht

98 Vastgesteld bij Besluit van de Minister-President van 18 november 1992, Stcrt. 230 en in werking getreden op 1 januari 1993. Voor de tekst van de Aanwijzingen verwijs ik naar $C$. Borman, Aanwijzingen voor de regeigeving en andere voor de regelgeving relevante aanwijzingen. W.E.J. Tjeenk Willink: Zwolle 1993.

99 Zie ook C. Waaldijk, Motiveringsplichten van de wetgever, o.a. pp. 202-219 en 379 380. 
worden aan administratieve verplichtingen, de noodzaak to inschakeling van deskundigen, het vertragend effect van termijnen en nieuwe rechtstreekse financiële lasten die uit een regeling voortvloeien. Gezien de formulering van deze toelichting ("kan worden gedacht") lijkt het hier niet te gaan om een uitputtende opsomming van mogelijke lasten die voor de burger uit een regeling kunnen voortvloeien. Een beperking van grondrechten van burgers zou wellicht ook onder het begrip "lasten" kunnen worden gebracht.

5) Aanwijzing 15 houdt in dat de nadelige gevolgen van een regeling voor een of meer belanghebbenden mogen niet onevenredig zijn in verhouding tot de met de regeling te dienen doelen.

6) Op grond van aanwijzing 211 dient een wetsvoorstel te worden voorzien van een memorie van toelichting.

Op grond van aanwijzing 212 dient die toelichting, onder meer, de volgende punten aan de orde te stellen: de met de regeling nagestreefde doelstelling (vergelijk aanwijzing $7 b$ ), de te verwachten (neven)effecten (vergelijk aanwijzing 9b), de noodzaak van de overheidsinterventie (vergelijk aanwijzingen 6 en 9c), en de overwogen varianten (vergelijk aanwijzing 7d).

Uit bovenstaande aanwijzingen kan, met name als ze in onderling verband worden gelezen, worden afgeleid dat een wetgever moet nagaan welke voordelen (realisering van de doelstelling) en nadelen (bijvoorbeeld beperking van een grondrecht, al dan niet als beoogd of niet beoogd neveneffect) een door hem te formuleren regeling zal hebben, of de regeling voor het bereiken van de doelstelling wel strikt nodig is en of naleving van de norm opweegt tegen (evenredig is met) de daaraan voor de burger verbonden lasten (de beperking van een grondrecht) en eventuele varianten moet overwegen mede in verband met de voor- en nadelen van die varianten (subsidiariteit). ${ }^{100}$ Vinden dit soort overwegingen door de wetgever in abstracto plaats (althans, zouden plaats moeten vinden), de rechter zal de toetsing in concreto moeten voltrekken. Dergelijke overwegingen omtrent de noodzakelijkheid van een grondrechtenbeperking van de formele wetgever zal de rechter, indien getoetst moet worden aan een grondwettelijk grondrecht, niet kunnen toetsen zolang het toetsingsverbod van artikel 120 Grondwet gehandhaafd blijft. Bij lagere regelgeving kan een dergelijke toetsing mijns inziens wel plaatsvinden. De zwaarte van de toetsing aan het noodzakelijkheidsvereiste lijkt mij wel te verschillen al naar gelang men te maken heeft met beperkingen die wel of 
niet op een specifieke formele wetsbepaling berusten. In het eerste geval zou de rechter mijns inziens marginaler moeten toetsen, omdat de formele wetgever al een noodzakelijkheidsafweging heeft gemaakt of zou hebben moeten maken. Het is mijns inziens aan onze hoogste rechters, waaronder met name de Hoge Raad, en in enige mate ook de afdeling Bestuursrechtspraak van de Raad van State en de Centrale Raad van Beroep, een dergelijke toetsing aan het noodzakelijkheidsvereiste te realiseren, al dan niet naar het voorbeeld van de Straatsburgse instanties.

Louter toevoeging van een expliciete toetsing aan het noodzakelijkheidsvereiste als gedragscode in geval van redelijke wetstoepassing; afschaffen van redelijke wetsuitleg

Minder hoeft er aan de praktijk veranderd worden als men de eis van herleidbaarheid tot een specifieke formele wetsbepaling in stand laat en de mogelijkheid van redelijke wetstoepassing openlaat, maar dan wel onder de voorwaarde dat de toetsing aan materiële criteria gegarandeerd is, in de vorm van het noodzakelijkheidsvereiste als hierboven omschreven. In dit geval is de toepassing van de beperkingsmogelijkheden minder eenduidig (let wel: dit was het uitgangspunt dat ten grondslag lag aan de bedoeling van de grondwetgever dat de grondwettelijke grondrechten "gepreciseerde waarborgen" bieden!) dan bij de eerste door mij gesuggereerde oplossing, omdat nu beperkingen die wel en beperkingen die niet herleidbaar zijn tot een specifieke, formele wetsbepaling anders getoetst worden. Ligt de verandering van de praktijk louter in een garantie van toetsing bij redelijke wetsioepassing aan bepaalde materiële criteria, dan ligt hier opnieuw een taak voor de hoogste rechters in onze rechtsorde. Zij zullen in hun uitspraken de lijn moeten uitzetten volgens welke de lagere rechters beperkingen, die niet passen binnen de beperkingssystematiek in de Grondwet en die via redelijke wetstoepassing in stand gelaten moeten worden, getoetst moeten worden.

Overigens wil ik hier wel bepleiten dat niet meer getoetst wordt via de methode van de redelijke wetsuitleg. vanwege de hierboven reeds aangeduide risico dat een grondrecht restrictief uitgelegd zou kunnen worden. Zoals in paragraaf 7.4.2 is aangegeven levert ook restrictieve interpretatie spanning op met de bedoelingen van de grondwetgever. 


\subsection{Uitleiding}

In het voorgaande heb ik naar aanleiding van het onderzoek dat in de hoofdstukken 2 tot en met 6 is weergegeven, naar mijn mening een antwoord kunnen geven op de in hoofdstuk 1 geformuleerde hoofdvraagstelling en kunnen aantonen dat de - ter beantwoording van die hoofdvraag - geponeerde stellingen tot op zekere hoogte houdbaar zijn. Met name omdat de houdbaarheid van de tweede stelling impliceert dat de rechtspraktijk niet geheel strookt met de oorspronkelijke bedoelingen van de opstellers van de Europese Conventie en de Grondwet, zijn een aantal mogelijke oplossingen hiervoor aangedragen. Vanzelfsprekend gaat het hier om punten, die nog volop ter discussie staan, dan wel zouden moeten staan.

Afsluitend zou ik dan ook willen opmerken, dat dit onderzoek een weergave is van de stand van zaken met betrekking tot de interpretatie en beperking van mensenrechten, aan het einde van een periode van ruim 41 jaar nadat de Conventie voor Nederland in werking is getreden ( 31 augustus 1954) en bijna 13 jaar na de inwerkingtreding (17 februari 1983) van de herziene Grondwet van 1983, een periode waarin zich belangrijke ontwikkelingen in de mensenrechtenbescherming hebben voorgedaan. Echter, het door dit boek bestreken onderzoeksterrein is er één, dat voortdurend in ontwikkeling is. De gestage produktie van arresten van het Europese Hof, met daarin soms vernieuwende uitspraken of beslissingen op deels nog onontgonnen terrein, biedt daarvan duidelijke voorbeelden. 


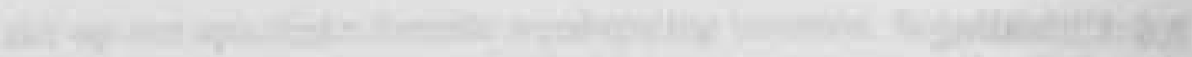

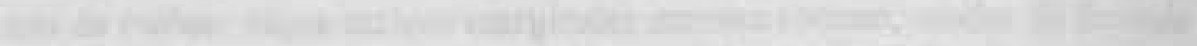

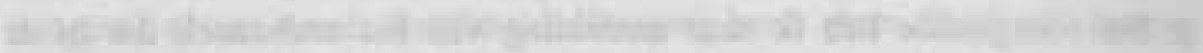

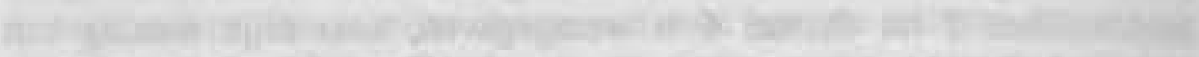

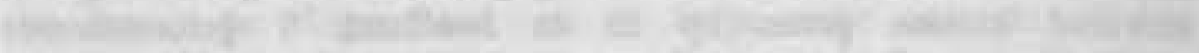

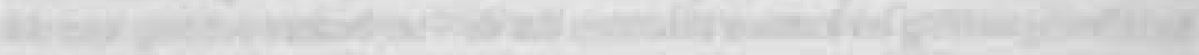
The

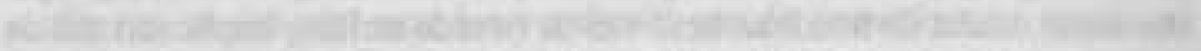

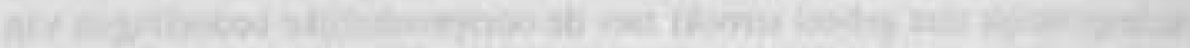

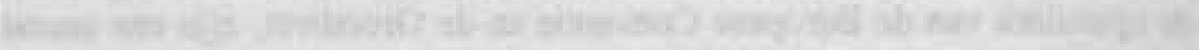

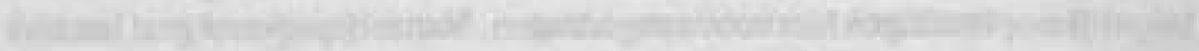

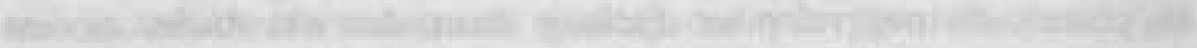

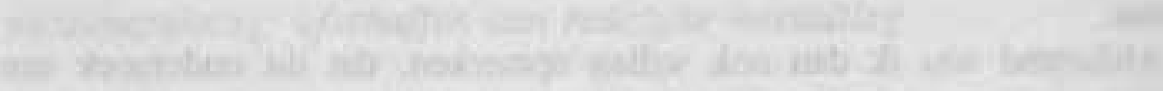

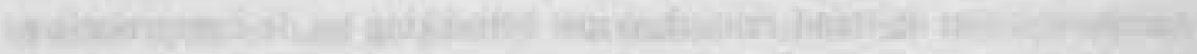

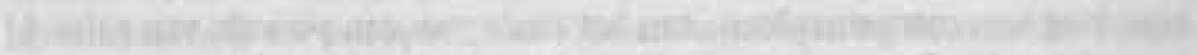

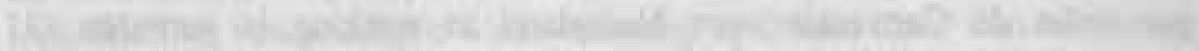

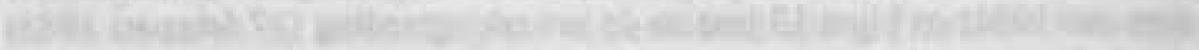

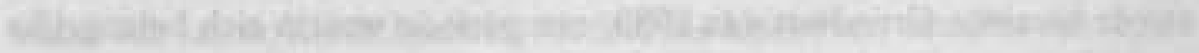

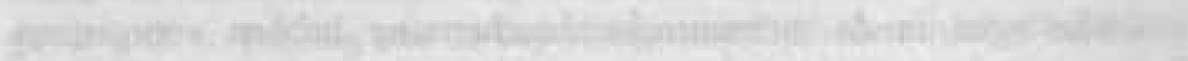

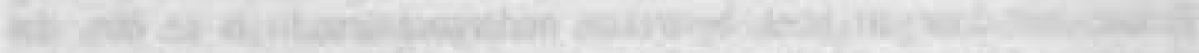

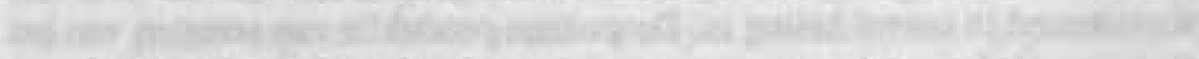

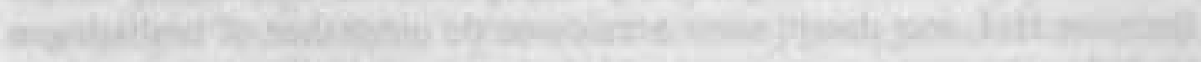

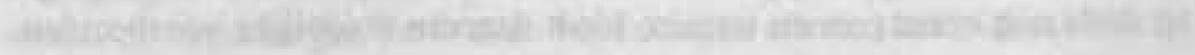

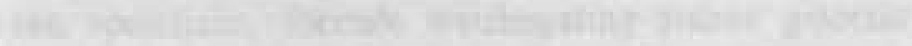




\section{Samenvatting}

In hoofdstuk $I$ wordt er allereerst op gewezen dat de rechten van de mens in een maatschappelijk kader functioneren waardoor de kans op een conflict tussen realisering van het doel van een recht en een ander beschermenswaardig belang groot is. Ter oplossing van dit conflict is in de Grondwet en de diverse mensenrechtenverdragen voorzien in mogelijkheden tot beperking van de in die instrumenten opgenomen rechten. Voorwaarde voor toepassing van die beperkingsmogelijkheden is echter dat het desbetreffende grondrecht van toepassing is. Of dit het geval is, is veelal niet direct uit de tekst van de bewuste Grondwets- of verdragsbepaling op te maken. Slechts in een beperkt aantal gevallen is het toepassingsbereik van een mensenrechtenbepaling expliciet aangegeven. Ten aanzien van de overige gevallen is soms een nadere aanduiding van de reikwijdte te vinden in ter uitvoering van de gegarandeerde grondrechten tot stand gebrachte wetgeving. In de meeste gevallen is de rechtzoekende echter aangewezen op de afbakening van het recht door de rechter. Ter bevordering van de rechtszekerheid en ter voorkoming van willekeur bij de toepassing van de rechten van de mens is het noodzakelijk dat de rechter het voor hem ingeroepen recht definieert. Zonder dat is een optimale bescherming van het recht niet mogelijk, omdat de rechtzoekende niet met zekerheid weet wanneer hem welk recht toekomt en de kans op een inbreuk op dat recht groter is, omdat de overheid en andere particuliere personen niet weten dat hun besluiten of gedragingen de uitoefening van een grondrecht belemmeren. De in dit onderzoek gestelde hoofdvraag luidt dan ook: "Op welke wijze stelt de rechter de reikwijdte van de rechten van de mens vast?".

Bij de behandeling en beantwoording van deze vraag wordt uitgegaan van een tweetal stellingen. De eerste stelling is als volgt geformuleerd: "Er bestaat een verband tussen de vaststelling van de reikwijdte van mensenrechten en de beperking van de uitoefening van die rechten". De tweede stelling is: "Tengevolge van het verband tussen de vaststelling van de reikwijdte en de beperking van de uitoefening van mensenrechten bestaat er een spanning tussen de rechterlijke praktijk ten aanzien van de reikwijdte-afbakening en beperking van mensenrechten enerzijds en de argumentatie die aan de beperkingssystematiek ten grondslag ligt anderzijds."

De doelstelling van dit proefschrift komt er samengevat op neer dat, door middel van een onderzoek naar zowel de fundering van de beperkingssystematiek van de Conventie en de Grondwet van 1983 als de rechtspraktijk naar aanleiding van enkele in deze instrumenten gewaarborgde rechten, getracht zal worden de gegrondheid van de 
hierboven weergegeven stellingen aan te tonen en tot een beantwoording van de geformuleerde hoofdvraagstelling te komen.

In hoofdstuk 2 wordt de beperkingssystematiek in de Europese Conventie behandeld. Na een inleiding in de historische context waarin de Conventie tot stand is gekomen en een bespreking van het totstandkomingsproces zelf, wordt in par. 2.4.1 ingegaan op de inhoudelijke fundering van de formulering van de rechten en de beperkingssystematiek in de Conventie. Het blijkt dat bij het opstellen van de Conventie - voor wat betreft de formulering - de discussie zich concentreerde op de vraag of de rechten en beperkingsmogelijkheden nauwkeurig gedefinieerd moesten worden dan wel een opsomming van rechten moest plaatsvinden in combinatie met een algemene beperkingsclausule, in navolging van de Universele Verklaring voor de Rechten van de Mens. Uiteindelijk is gekozen voor een nauwkeurige, doch niet excessief gedetailleerde formulering van de rechten en beperkingsmogelijkheden.

In par. 2.4.2 volgt een bespreking van de verschillende soorten beperkingsmogelijkheden in vredestijd en in tijden van rust. Bij de behandeling in par. 2.4.2.1 van de beperkingsmogelijkheden in de artikelen 8-11 ECRM en artikel 2 Protocol IV ECRM, wordt erop gewezen, dat de hier besproken beperkingsclausules alleen van toepassing zijn indien er sprake is van een "inmenging" ("interference") door de nationale autoriteiten in het desbetreffende gegarandeerde recht. Deze inmenging is alleen dan gerechtvaardigd op grond van de beperkingsclausules, als voldaan is aan een aantal voorwaarden: de inmenging moet zijn voorzien bij wet ("prescribed by law"/"in accordance with the law"), gericht zijn op een bepaald legitiem doel ("in the interest of ..." etc.) en noodzakelijk zijn in een democratische samenleving ("necessary in a democratic society"). Met name ten aanzien van deze laatste voorwaarde is een uitgebreide jurisprudentie tot stand gekomen. Bij de beoordeling of een beperking noodzakelijk is in een democratische samenleving heeft de Staat een beoordelingsmarge ("margin of appreciation"). Het Europese Hof heeft verschillende criteria ontwikkeld ter begrenzing van die beoordelingsmarge, waaronder het proportionaliteitsvereiste, de eis van subsidiariteit, het vereiste dat sprake moet zijn van een "pressing social need" en dat voldoende redenen ("relevant and sufficient reasons") ter rechtvaardiging van de beperking kunnen worden aangevoerd. Voorts blijkt de omvang van de beoordelingsmarge af te hangen van, onder meer, de aard van het recht dat de Staat wenst te beperken, de aard van de ingeroepen beperkingsgrond en de mate waarin er een uniforme Europese standaard bestaat voor de interpretatie van een verdragsrecht. Opvallend is voorts dat de beoordelingsvrijheid van de overheid kleiner is indien het gaat om beslissingen 
omtrent maatregelen die een inmenging vormen op een fundamenteel element van het familie- en gezinsleven van de betrokkene(n) - het wederzijds genot dat ouder(s) en kin(eren)van elkaars gezelschap kunnen hebben - en die een onomkeerbaar proces in gang kunnen zetten. In die gevallen dienen die maatregelen, ten einde noodzakelijk in een democratische samenleving te kunnen zijn, genomen te zijn in een met waarborgen omklede besluitvormingsprocedure. Het noodzakelijkheidsvereiste in het tweede lid van artikel 8 brengt in dit soort zaken met zich mee, dat het eerste lid van die bepaling mede een - aan het daarin beschermde recht accessoir - procedureel recht garandeert. Is dit accessoire recht niet gerespecteerd, dan is de genomen maatregel niet noodzakelijk in een democratische samenleving.

In par. 2.4.3 wordt ingegaan op beperkingen die mogelijk zijn in tijden van oorlog of noodtoestand. De grenzen van de beperkingsbevoegdheden worden in par. 2.4.5 besproken. Tot slot komt in par. 2.4.6 nog artikel 64 ECRM aan bod, in welke bepaling is voorzien in de mogelijkheid om voorbehouden bij specifieke verdragsbepalingen te maken. De bespreking van de beperkingsmogelijkheden, van de grenzen die daaraan worden gesteld en van voorbehouden gebeurt aan de hand van de rechterlijke praktijk.

In hoofdstuk 3 vindt een bespreking van de beperkingssystematiek in hoofdstuk I Grondwet (1983) plaats. Ingegaan wordt op de achtergronden van de herziening van de Grondwet in 1983 en met name van hoofdstuk I (par. 3.1), de inhoudelijke fundering van de in de Grondwet opgenomen beperkingssystematiek en de uitwerking daarvan in de rechtspraktijk.

Par. 3.2.10 bevat een bespreking van de mogelijkheden tot afwijking van de in de Grondwet verankerde beperkingssystematiek middels de redelijke wetsuitleg en redelijke wetstoepassing. Anders dan de uitleg die aan deze begrippen is gegeven in de eerder aangeduide Memorie van Toelichting bij het wetsvoorstel tot herziening van hoofdstuk I van de Grondwet, wordt in het vervolg van dit proefschrift uitgegaan van de volgende betekenissen. De term "redelijke wetsuitleg" wordt gebruikt ter aanduiding van een situatie waarin een grondrecht restrictief wordt geïnterpreteerd, waardoor een bepaalde gedraging per definitie buiten de reikwijdte van het grondrecht valt. In het geval van "redelijke wetstoepassing" is een bepaald grondrecht wèl van toepassing, doch leidt dit grondrecht in het concrete geval niet tot ongrondwettigheid van een bepaalde - dat grondrecht beperkende - overheidsmaatregel, omdat de intrekking of vernietiging van deze laatste zou leiden tot "flagrante strijd ... met wat algemeen als redelijk wordt aangemerkt". Bij de toepassing van deze mogelijkheden tot "ontsnapping" aan de beperkingssystematiek, zou het proportionaliteitsver- 
eiste en de afweging van maatschappelijke en persoonlijke belangen een rc moeten spelen. Bovendien zouden volgens de regering deze ontsnapping: mogelijkheden alleen terughoudend, dus als uitzondering, mogen worde toegepast.

In par. 3.3 wordt ingegaan op de kritiek die is geuit ten aanzien van d in de Grondwet 1983 neergelegde beperkingssystematiek. Uit deze kritie blijkt, onder meer, dat van de mogelijkheden tot afwijking van $c$ beperkingssystematiek - anders dan waar het beoogde uitzonderingskaraktt op lijkt te wijzen - ruimschoots gebruik is gemaakt. Zoals ook u hoofdstuk 7 zal blijken (zie hierna) lijken de "ontsnappingsmogelijkheder vooral uitkomst te bieden in gevallen waarin de beperking van ee grondrecht niet mogelijk is op grond van de voorziene beperkingsmogelijl heden. Het gaat hierbij opvallend vaak om beperkingen in lagere wetgt ving die, anders dan de Grondwet eist, niet kunnen worden teruggevoet op een specifieke wetsbepaling, dat wil zeggen een formele wetsbepalir waarin wordt aangegeven op welk recht een beperking mag worde aangebracht en tot hoever die beperking mag gaan. Een ander voorbeel is de noodverordeningsbevoegdheid van de burgemeester. Al met al blijt dat de strikte beperkingssystematiek in de Grondwet niet geheel voldoe

In hoofdstuk 4 wordt ingegaan op de vaststelling van de reikwijdte door zowel de Straatsburgse instanties (par. 4.2) als de nationale rechterlijke organen (par. 4.3) van de in artikel 8 lid 1 ECRM gegarandeerde rechten.

Uit de evaluatie van de behandelde rechtspraak in par. 4.5 blijkt het volgende. Bij de afbakening van het recht op privéleven is zowel door de Straatsburgse als de nationale instanties een klein aantal criteria ontwikkeld, zij het verschillende. Het belangrijkste "Straatsburgse" criterium is het "openbaarheids"-criterium: het privékarakter van een gedraging of situatie hangt af van de mate waarin deze gedraging of situatie in verband staat met het openbare leven, het openbaar belang of de belangen van andere personen. Opvallend is dat juist de bescherming van deze belangen weer een legitieme beperkingsgrond in de zin van het tweede lid van artikel 8 kan vormen. Eén van de soorten criteria in de Nederlandse rechtspraak - die hoofdzakelijk betrekking hebben op het waarnemen en vastleggen van gegevens of gedragingen van personen en op het gebruikmaken en openbaren van die gegevens - zijn de subjectieve criteria, die de innerlijke wens betreffen van de persoon om wiens gegevens of gedraging het gaat om met rust te worden gelaten. De (subjectieve) keuze van het rechtssubject kan derhalve doorslaggevend zijn voor de reikwijdte van het recht op respect voor het privéleven.

Ten aanzien van de vaststelling van de reikwijdte van het recht op respect voor het familie- en gezinsleven kan geconstateerd worden dat de 
Nederlandse rechtspraak duidelijk afgestemd is op de Straatsburgse. Toonaangevend zijn de uitspraken van het Europese Hof in de zaken Marckx, Abdulaziz, Cabales en Balkandali en Berrehab (en bevestigd in Keegan en Kroon) en een uitspraak van de Hoge Raad van 10 november 1989 (NJ 1990, 628). Uit deze rechtspraak kan het volgende worden afgeleid: de relatie tussen een moeder en haar kind zijn per definitie aan te merken als "family life". Hierbij maakt het geen enkel verschil of het kind wettig of onwettig is. Wel kan deze relatie naderhand worden verbroken. In andere gevallen moet worden vastgesteld "whether it [is] in fact possible to point to such a link as can be considered to establish family life within the meaning of Article 8". Dit is het zogenaamde "required link"-criterium, dat als volgt in de rechtspraak is ingevuld. Sprake moet zijn van "further elements of dependency, involving more than the normal, emotional ties". Is een kind geboren uit een huwelijk of uit een daarmee op één lijn te stellen relatie, dan is - zelfs wanneer die relatie op het moment van de geboorte al was verbroken - ook tussen vader een kind sprake van "family life", tenzij deze band door latere gebeurtenissen is verbroken. Ook hier is dus niet relevant of het kind wettig of onwettig is. In dit verband kan gesproken worden van een "non-discriminatie"criterium, omdat bij de afbakening van "family life" geen onderscheid gemaakt mag worden op grond van de (on)wettige status van het kind. In het geval van andere relaties tussen personen dan die welke op één lijn zijn te stellen met een huwelijk, dienen feitelijke omstandigheden aangedragen te worden waaruit blijkt dat een als "family life" aan te merken betrekking tussen de betrokkenen is ontstaan. Dit geldt voor puur biologische vaders als sperma-donors en voor groot- en pleegouders ten opzichte van minderjarige kinderen en voor alle relaties met meerderjarige kinderen.

Verder valt uit uitspraken van de Commissie nog een zogenaamd "eigen schuld"-criterium af te leiden. Dit houdt in dat, indien een als "family life" aan te merken relatie wordt verbroken ten gevolge van gedragingen van de rechtzoekende zelf, dit niet aan de Staat kan worden tegengeworpen.

Onderzoek naar de schaarse Europese rechtspraak ten aanzien van het recht op respect voor de woning levert één bruikbaar afbakeningscriterium op, het "sufficient continuing links"-criterium. Sprake is van een "home" indien er een voldoende band met het huis bestaat; een aanwijzing voor het bestaan hiervan is, of sprake is van eigendom van het desbetreffende pand, of van een (beoogde) "permanent residence" en of de betrokkenen "have established any other home". In het laatste geval gaat het erom of sprake is van een "principal residence". Het voorgaande geldt in eerste instantie voor woningen, maar zou gezien de rechtspraak (Chappell en Niemietz) ook voor bedrijfspanden kunnen gelden, met dien verstande dat - mijns inziens - in dat geval beter gesproken zou kunnen worden van het 
permanent in of vanuit een gebouw uitoefenen van beroeps- of bedrijfsactiviteiten. Bruikbare Nederlandse rechtspraak is er vooralsnog niet ten aanzien van dit recht.

Wat betreft het recht op respect voor de correspondentie: voor de afbakening van dit recht is geen duidelijk criterium in de rechtspraak te vinden. Wel wordt duidelijk dat het een ruime reikwijdte toekomt. In de zaak Niemietz wordt, bijvoorbeeld, zonder nadere kwalificatie gesproken van "documenten". Naast vanzelfsprekend brieven, vallen ook telefoongesprekken onder dit recht.

Alhoewel de kern van de overheidsverplichtingen op grond van artikel 8 is gelegen in negatieve, op overheidsonthouding gerichte verplichtingen, kunnen onder omstandigheden ook positieve, tot overheidsoptreden dwingende, verplichtingen uit het recht op respect voor het privéleven, het familie- en gezinsleven, de woning en de correspondentie voortvloeien. Hierover gaat par. 4.5. Het Hof laat het bestaan en, met name, de inhoud van positieve verplichtingen afhangen van de uitkomst van een afweging van het individuele tegen het algemeen belang. Hierbij heeft de Staat een ruime beleidsvrijheid en spelen (vrijwel) dezelfde beginselen een rol als bij de toetsing aan negatieve verplichtingen, zoals de beperkingsgronden genoemd in het tweede lid van artikel 8 . Anders dan bij de toetsing aan negatieve verplichtingen, speelt de gehele toetsing van positieve verplichtingen zich af binnen het eerste lid. Dat betekent in praktijk, dat een vermenging plaatsvindt van de afbakening van de reikwijdte van de positieve verplichting met de beperkingen daarop, doordat in feite het bestaan en de inhoud van de positieve verplichting in het concrete geval worden afgewogen tegen het algemeen belang. Dit alles gebeurt in het kader van de notie "respect" in lid 1.

In een klein aantal uitspraken van Nederlandse rechterlijke instanties in vreemdelingenzaken vindt na de constatering dat de weigering van een verblijfstitel geen "inmenging" oplevert, nog een belangenafweging plaats die erop lijkt te wijzen, dat uit artikel 8 volgens de Nederlandse rechter onder omstandigheden een positieve verplichting kan voortvloeien om aan een vreemdeling een verblijfstitel te verstrekken. Dergelijke overwegingen lijken te duiden op een erkenning van positieve verplichtingen op grond van artikel 8 . Nergens in de behandelde Nederlandse rechtspraak wordt dit echter met zoveel woorden bevestigd.

In hoofdstuk 5 gaat het om de afbakening van het recht op toegang tot de rechter dat impliciet door artikel 6 lid 1 (eerste zin) wordt beschermd. In par. 5.1.1 vindt een introductie op het recht op toegang tot de rechter plaats, welke in par. 5.1.2 wordt gevolgd door een onderzoek naar de grondslag van dit recht. Het beginsel van de rule of law, dat de 
voornaamste grondslag voor het onderhavige recht vormt, speelt een doorslaggevende rol bij de afbakening van het recht op toegang en ligt aan de basis van de in de navolgende paragrafen ontwikkelde afbakeningscriteria.

Paragraaf 5.1.3 omvat het onderzoek naar de reikwijdte van het recht op toegang tot de rechter. Omdat het recht op toegang een impliciet in artikel 6 gegarandeerd recht is, wordt ervan uitgegaan dat de reikwijdte van dit recht zowel het recht zelf als de - eveneens impliciete - beperkingen omvat. In par. 5.1.3.1 blijkt dat de belangrijkste grens die in de rechtspraak aan het recht op toegang wordt gesteld grote overeenkomsten vertoont met de beperkingsclausules in de tweede leden van de artikelen 8 tot en met 11. De beoordelingsvrijheid van de staat met betrekking tot de regeling van het recht op toegang tot de rechter vindt zijn grens in, onder meer, de eis dat op dit recht aangebrachte restricties niet de toegang tot de rechter mogen beperken op een wijze of in een mate dat de kern van dit recht wordt aangetast. Verder moet de desbetreffende beperking een legitiem doel nastreven, proportioneel zijn en de regeling van het recht moet coherent en duidelijk zijn en de rechtzoekende een "clear, practical and effective opportunity" bieden om een besluit waarop artikel 6 van toepassing is bij de rechter aan te vechten. Naast beperkingen door de overheid op het recht op toegang tot de rechter zijn ook beperkingen op de uitoefening van dit recht door de rechtzoekende zelf mogelijk, namelijk via afstand van recht. De interpretatie die in de rechterlijke praktijk aan dit onderwerp is gegeven is tevens van belang voor de afbakening van het recht op toegang.

Vervolgens blijkt in par. 5.1.3.3 het recht op toegang tot de rechter ook positieve verplichtingen voor de overheid te omvatten, bijvoorbeeld het voorzien in rechtsbijstand. De reikwijdte van deze verplichtingen hangt af van de specifieke omstandigheden van het geval, zoals de persoonlijke (financiële) omstandigheden van de rechtzoekende, de complexiteit van de zak en een al dan niet verplichte procesvertegenwoordiging. Het criteriunn voor afbakening van het recht op toegang dat uit de rechtspraak inzake positieve verplichtingen kan worden afgeleid is dat de uitoefening van dit recht effectief moet zijn.

In par. 5.1.4 wordt voorts de betekenis van het begrip "court" in het recht op "access to court" onderzocht. Het begrip "court" ziet op een onafhankelijk en onpartijdig gerecht dat bij de wet is ingesteld in de zin van artikel 6 lid 1. Op de eisen die in de rechtspraak onder artikel 6 aan een dergelijk gerecht worden gesteld wordt vervolgens ingegaan.

De rechtspraak van de Nederlandse rechterlijke instanties met betrekking tot het recht op toegang tot de rechter komt aan bod in par. 5.2. In deze uitspraken vindt zelden een afbakening van dit recht plaats. Slechts ten 
aanzien van de rechterlijke onpartijdigheid zijn criteria geformuleerd, die overigens zeer grote gelijkenis vertonen met de Straatsburgse. De benadering van de Nederlandse rechter is zeer casuïstisch en naar artike] 6 lid 1 en de belangrijke arresten van het Europese Hof over het recht op toegang tot de rechter wordt slechts mondjesmaat verwezen.

In hoofdstuk 6 wordt de rechtspraak naar aanleiding van een aantal grondwettelijke grondrechten onder de loep genomen ten einde de wijze van vaststelling van de reikwijdte van die rechten door de rechter te achterhalen. In par. 6.1 wordt uitgebreid ingegaan op artikel 1 Grondwet (gelijkheidsbeginsel en non-discriminatiebeginsel). Par. 6.1 .12 bevat de conclusies die kunnen worden getrokken uit het onderzoek dat in de voorgaande paragrafen heeft plaatsgevonden. Er blijkt weinig jurisprudentie te zijn waarin een afbakening van het gelijkheidsbeginsel of het nondiscriminatie-beginsel wordt gegeven. Geprobeerd is daarom een beeld te schetsen van de afbakening aan de hand van rechtspraak, literatuur en kamerstukken bij zowel artikel 1 Grondwet als de toepasselijke uitvoeringswetgeving.

In par. 6.2 komen de artikelen 6 lid 1, 7 leden 1 en 3 en 9 lid 1 Grondwet aan bod. In par. 6.2.1 wordt de afbakening van de reikwijdte van de vrijheid van godsdienst en levensovertuiging onderzocht. Uit de behandelde rechtspraak worden in (par. 6.2.1.8) een aantal conclusies getrokken. De belangrijkste daarvan is wellicht dat nauwelijks sprake is van een afbakening van het in artikel 6 lid 1 Grondwet vervatte recht. Een andere belangrijke uitkomst van het onderzoek is dat in een aantal uitspraken beperkingen op artikel 6 lid 1 in orde worden bevonden, zonder dat ze kunnen worden teruggevoerd tot een specifieke, formele wetsbepaling. Het gaat hier om beperkingen die als algemene "ongeschreven" (niet tot een grondwetsbepaling terug te voeren) beperkingen kunnen worden aangemerkt. De methode waarop deze beperkingen worden gesauveerd doet denken aan de in hoofdstuk 3 besproken "redelijke wetstoepassing". De restrictie die uit een aantal van deze zaken voortvloeit is wel dat de bewuste uitoefening van de vrijheid van godsdienst niet "onmogelijk gemaakt" mag worden, wat erop lijkt te duiden dat in elk geval een effectieve uitoefening van het recht nog mogelijk moet blijven ("effet utile").

De rechtspraak naar aanleiding van artikel 7, leden 1 en 3 Grondwet wordt behandeld in par. 6.2.2. Uit de in par, 6.2.2 besproken rechtspraak blijkt dat van de in de leden 1 en 3 van artikel 7 Grondwet vervatte rechten nagenoeg geen afbakening plaatsvindt. De begrippen die werden onderzocht zijn in zekere zin al de uitkomst van de begrenzing door de rechter van de vrijheid van meningsuiting in het artikel 7 van vóor de 
grondwetswijziging van 1983. Deze begrippen, die zijn behouden ten aanzien van het huidige artikel 7 lid 1 en deels zijn overgenomen met betrekking tot lid 3, zijn echter enorm vaag en behoeven meer uitwerking. Dit gebeurt in de jurisprudentie slechts sporadisch.

Tenslotte komt in par. 6.2.3 artikel 9 lid 1 Grondwet aan de orde. In het oog houdend dat de jurisprudentie over artikel 9 lid 1 schaars is (de meeste rechtspraak over artikel 9 betreft het tweede lid), kan worden geconcludeerd dat artikel 9 lid 1 niet alleen een negatieve onthoudingsverplichting aan de overheid oplegt, maar ook een positieve verplichting. Deze laatste verplicht de overheid adequate politiebescherming te bieden aan personen die hun recht tot vergaderen of betogen wensen uit te oefenen tegen intolerant gedrag van derden. De grens ligt daar waar redelijkerwijs - ook bij voldoende politie-inzet - de situatie niet in de hand kan worden gehouden. In dat geval mag tot beperking van het in het geding zijnde recht worden overgegaan. Deze afweging van de situatie impliceert een evenredigheidstoetsing tussen doel (voorkoming van wanordelijkheden) en middel (beperking van het recht). Een afbakening van de reikwijdte van de in artikel 9 lid 1 vervatte rechten heeft in de jurisprudentie niet plaatsgehad, maar is wel te vinden in de literatuur en kamerstukken.

In par. 6.3 vindt een evaluatie plaats van het onderzoek dat in de paragrafen 6.1 en 6.2 heeft plaatsgevonden. In par. 6.3.1 wordt geconstateerd dat er een lijn valt te ontdekken in de rechtspraak naar aanleiding van de artikelen 6 lid 1, 7 leden 1 en 3 en 9 lid 1 Grondwet. Zo kunnen, bijvoorbeeld, de rechten door "een ieder" uitgeoefend worden en blijkt dat de beperkingsclausule die in deze bepaling is opgenomen ("behoudens ieders verantwoordelijkheid volgens de wet") geen rol te spelen bij de afbakening van de respectieve rechten. Dit zou kunnen betekenen dat de rechter voordat hij tot beperking overgaat, eerst los daarvan de reikwijdte van het recht vaststelt (zoals het mijns inziens ook zou moeten), doch gebleken is dat andere beperkingsmogelijkheden wel invloed op de reikwijdte-afbakening hebben. Een voorbeeld hiervan is de eerder geconstateerde praktijk in een aantal zaken, dat (niet expliciet als zodanig aangeduide) algernene beperkingen worden gesauveerd door middel van redelijke wetstoepassing.

Een afbakening van de rechten in de artikelen 6 lid 1, 7 leden 1 en 3 en 9 lid 1 Grondwet vindt nauwelijks plaats. De belangrijkste uitzondering hierop is de volgende. In par. 6.2.1.5 bleek ten aanzien van godsdienstige uitlatingen dat ongenuanceerde, ongemotiveerde en - tegen beter weten in onjuiste en misleidende uitingen niet onder de vrijheid van godsdienst in artikel 6 lid 1 vallen (zaak Goeree). Overige godsdienstige uitlatingen vallen hier wèl onder, ook al zijn ze in strijd met wat algemeen aanvaard 
wordt of pijnlijk zijn voor een bepaalde groep personen. Hier wordt derhalve een grens gesteld aan de toepasselijkheid van artikel 6 lid 1 . In par. 6.3.2 wordt geconcludeerd dat geen noemenswaardige verschillen bestaan in de begrenzing van de reikwijdte van de artikelen $6(1), 7(1$ en 3) en $9(1)$ enerzijds en artikel 1 anderzijds. Zo is niet gebleken dat een recht dat niet is voorzien van een beperkingsmogelijkheid (zoals artikel 1) nauwkeuriger afgebakend wordt dan een recht met een dergelijke mogelijkheid (zoals de overige behandelde artikelen).

In hoofdstuk 7 wordt de in hoofdstuk 1 geformuleerde hoofdvraagstelling - "Op welke wijze stelt de rechter de reikwijdte van de rechten van de mens vast?" - als volgt beantwoord. Onder de in de voorgaande hoofdstukken gevonden criteria ter afbakening van de artikelen 8(1), 6(1) ECRM en van de artikelen 1, 6 lid 1, 7 leden 1 en 3 en artikel 9 lid 1 Grondwet heb ik zowel concrete als open criteria aangetroffen. Deze criteria kunnen grotendeels worden ondergebracht in een aantal categorieën afbakeningscriteria, dat wil zeggen een soort "basis-criteria" waaruit eventueel voor gevallen waarin nu nog geen toetsingsmaatstaven zijn geformuleerd, specifiekere criteria kunnen worden afgeleid. Deze basis-criteria zijn: de rule of law (par. 7.2.1), het effectieve nut van een grondrecht (par. 7.2.2), het proportionaliteitsbeginsel (par. 7.2.3), het recht op een "fair trial" (par. 7.2.4), het non-discriminatie-criterium (par. 7.2.5), het verbod van misbruik van recht (par. 7.2.6) en de (subjectieve) keuze van het rechtssubject (par. 7.2.7).

In par. 7.3 worden verschillende voorbeelden van het bestaan van een verband tussen de vaststelling van de reikwijdte van mensenrechten en de beperking van de uitoefening van die rechten, die uit de voorgaande hoofdstukken naar voren zijn gekomen, op een rijtje gezet. Met deze voorbeelden is de juistheid van de eerste in hoofdstuk 1 geponeerde stelling ("Er bestaat een verband tussen de vaststelling van de reikwijdte van mensenrechten en de beperking van de uitoefening van die rechten") aangetoond. Aan de hand van de gegeven voorbeelden wordt in par. 7.4 de houdbaarheid van de tweede stelling ("Tengevolge van het verband tussen de vaststelling van de reikwijdte en de beperking van de uitoefening van mensenrechten bestaat er een spanning tussen de rechterlijke praktijk ten aanzien van de reikwijdte-afbakening en beperking van mensenrechten enerzijds en de argumentatie die aan de beperkingssystematiek ten grondslag ligt anderzijds.") getoetst. Het door de opstellers van de Conventie met een nauwkeurige definiëring van de rechten en de beperkingsmogelijkheden (zie hoofdstuk 2) beoogde doel, namelijk duidelijkheid omtrent de aard en de reikwijdte van de verdragsverplichtingen, blijkt niet altijd te worden bereikt. Dit is, onder andere, het geval 
bij de toetsing van positieve verplichtingen. Hierbij treedt, zoals eerder is vermeld, een vermenging op tussen de vaststelling van de reikwijdte van het recht op nakoming door de overheid van deze verplichtingen enerzijds en de beperking op dat recht anderzijds. Een afzonderlijke vaststelling van de reikwijdte van positieve verplichtingen vindt niet plaats; hetzelfde geldt in andere gevallen waarin de rechter (met name de Nederlandse) over de vraag naar de afbakening heenstapt en direct de zaak beslist aan de hand van beperkingsmogelijkheden. In par. 7.5.1 wordt getracht een oplossing te bieden ter oplossing van de zojuist geconstateerde spanning tussen de praktijk en de bedoelingen van de opstellers van de Conventie. Hiertoe wordt verwezen naar het - in verband met de positieve verplichtingen voortvloeiende uit het recht op toegang tot de rechter (artikel 6(1) ECRM) - gehanteerde criterium van de effectiviteit van het recht. Ook de reikwijdte van de positieve verplichtingen op grond van artikel 8 ECRM zou aan de hand van dit criterium kunnen worden begrensd. Zo zou de overheid, die beleidsvrijheid geniet ten aanzien van de wijze waarop een positieve verplichting wordt nagekomen, ten minste díe maatregelen moeten nemen die onmisbaar zijn voor een effectieve uitoefening van het ingeroepen recht. Vervolgens zou, indien noodzakelijk, de aldus afgebakende positieve verplichting kunnen worden beperkt als voldaan is aan de voorwaarden van het tweede lid (voor zover deze toepasbaar zijn op positieve verplichtingen).

In par. 7.4.2 wordt de houdbaarheid van de tweede stelling ook aangetoond ten aanzien van de rechterlijke praktijk in verband met de onderzochte grondwettelijke grondrechten, althans voor zover deze praktijk algemene beperkingen en redelijke wetsuitleg of -toepassing betreft. Bij de grondwetsherziening werd beoogd de rechten en beperkingen nauwkeurig te definiëren ten einde "gepreciseerde waarborgen" te bieden. De praktijk ten aanzien van algemene beperkingen, redelijke wetsuitleg en redelijke wetstoepassing biedt een dergelijke waarborg niet. Reden hiervoor is. onder meer, dat het hier gaat om algemene beperkingen door lagere wetgevers die door de grondwetgever zijn afgewezen maar toch noodzakelijk blijken te zijn, omdat aan de voorziene beperkingsmogelijkheden te rigide eisen blijken te zijn verbonden zoals het vereiste van herleidbaarheid tot een specifieke, formele wetsbepaling. Voorts worden deze algemene beperkingen veelal gesauveerd door middel van de "ontsnappingsmogelijkheden" redelijke wetsuitleg en -wetstoepassing, die daarmee hun uitzonderingskarakter lijken te hebben verloren. Bovendien wordt bij gebruikmaking van die "ontsnappingsmogelijkheden" de door de grondwetgever voorgestane toetsing aan het proportionaliteitsvereiste vaak achterwege gelaten. In par. 7.5.2 wordt, ter opheffing van de hier geconstateerde spanningen met de bedoelingen van de grondwetgever, alternatieven 
aangedragen voor de rechterlijke praktijk ten aanzien van ongeschreven, algemene beperkingen en andere niet toegestane beperkingsmethoden. Eén van die alternatieven betreft de opheffing van het vereiste van herleidbaarheid tot een specifieke formele wetsbepaling en toevoeging van een expliciete toetsing aan het noodzakelijkheidsvereiste als gedragscode (vergelijkbaar met de toetsing aan de eis van noodzakelijkheid in een democratische samenleving in de artikelen 8 tot en met 11 ECRM). Het andere alternatief stelt louter toevoeging van een expliciete toetsing aan het noodzakelijkheidsvereiste als gedragscode voor in het geval van redelijke wetstoepassing, evenals afschaffing van de methode van de redelijke wetsuitleg. 
In Chapter 1, it is first of all pointed out that human rights operate within a social context. For this reason, a great many conflicts may arise between the realisation of the purpose of a right and other interests worth protecting. To resolve such conflicts, the Netherlands Constitution and the various human rights treaties offer possibilities to limit the rights laid down in those instruments, providing that the fundamental right in question is applicable. Whether this is the case cannot be directly inferred, as a rule, from the relevant wording in the Constitution or the treaties. Only in a limited number of cases has the scope of a human right provision been expressly defined. As for the remaining cases, an indication of the scope can sometimes be found in legislation implementing the rights guaranteed. In most cases, however, the party involved will have to depend on the court's delimitation of such right. In order to enhance legal certainty and prevent arbitrariness in applying human rights, courts need to define the rights invoked before them. If they fail to do so, optimum protection of the right is not possible, because the party in question cannot be certain as to circumstances under which he is entitled to a particular right. Also there is a greater likelihood that his rights are infringed, because the authorities and (other) individuais are not aware that their decisions or acts impede the exercise of a human right. The central question in this dissertation is therefore: How do courts establish the scope of human rights?

In order to discuss and answer this central question two propositions have been formulated to serve as a point of departure. The first proposition postulates that: 'There is a relation between establishing the scope of human rights and restricting their exercise'. The second proposition reads: 'The relation between establishing the scope of human rights and restricting their exercise causes tension between court practice with respect to establishing the scope of rights and restricting them on the one hand and the legislators' reasoning underpinning the system of limitation on the other'.

By studying both the reasoning behind the system of limitation of the European Convention of Human Rights and that of the Netherlands Constitution of 1983 and the legal practice with regard to a number of rights guaranteed in these instruments, this dissertation attempts to prove the validity of the propositions and to answer the central question of this dissertation.

Chapter 2 discusses the system of limitation of the European Convention. Following an introduction to the historical context in which the Convention was framed and a discussion of the drafting history itself, the reasoning behind the formulation of the rights and the Convention's system of 
limitation is dealt with in 2.4.1. During the drafting of the Convention, apparently the discussion with regard to the formulation of the provisions focused on the question of whether these rights and the possibilities of their limitation should be precisely defined or rather summed up in combination with a general limitation clause, as in the Universal Declaration of Human Rights. Eventually, the drafters opted for a precise, be it not excessively detailed, formulation of the rights and the possibilities of their limitation.

In Section 2.4.2, the different possibilities of restricting human rights in times of peace and tranquillity are discussed. With regard to the possibilities of limitation in Articles 8 through 11 ECHR and Article 2 Protocol IV ECHR, the author points out, in 2.4.2.1, that these limitation clauses are only applicable in cases of interference in these rights by national authorities. Such interference is only justified if several requirements have been met: the interference must be "prescribed by law" (or "in accordance with the law"), pursue a legitimate aim ("in the interes! of ", etc.) and be "necessary in a democratic society." Particularly with respect to this last requirement, substantial case law has developed. There is a margin of appreciation for the State in assessing the necessity of limitation. The European Court has developed severai criteria to delimit this margin: the principle of proportionality, the requirement of subsidiarity, the existence of a "pressing social need", and the submission of "relevant and sufficient reasons" justifying such limitations. Furthermore, the scope of the margin of appreciation proves to be dependent on, inter alia, the nature of the right the State wishes to restrict, the nature of the legitimate aim pursued and the existence of a uniform European standard for the interpretation of a Convention right. Moreover, it is remarkable that the authorities' margin of appreciation is smaller in deciding measures which interfere in a fundamental element of parties' family life, namely parents' and children's enjoyment of each other's company, measures which may set in motion an irreversible process. In these cases, the State's measures must have been taken in a decisionmaking process that offers adequate safeguards, in order to fit the description of being "necessary in a democratic society." The requirement laid down in Article 8 (2) ECRH of having to be "necessary in a democratic society" entails that this paragraph also provides a procedura! guarantee which is accessory to the right expressly protected in par. 1 . Where this accessory right has not been respected, the measure in question is not "necessary in a democratic society."

The limitations allowed in times of war or emergency are dealt with in 2.4.3. The boundaries of the power to limit rights are discussed in 2.4.5. Finally, Article 64 ECHR is discussed in 2.4.6. This Article provides for 
reservations to specific treaty provisions. The provision governing limitation, the boundaries of limitation and the possibility of making reservations are discussed on the basis of legal practice.

Chapter 3 concerns the system of limitation laid down in Chapter 1 of the Netherlands Constitution (1983). The revision of the Constitution, in particular of Chapter 1 (3.1), the legislator's reasoning behind this limitation system and its implementation in practice are discussed in more detail.

Section 3.2 discusses the possibilities of derogation from this constitutional limitation system through the concepts of 'reasonable interpretation of the law' and 'reasonable application of the law'. Unlike the meaning accorded to these notions in the parliamentary records of Chapter I of the Constitution, from this point on in the dissertation, they have the following meaning: the notion 'reasonable interpretation of the law' will be used to indicate a situation in which a human right is narrowly interpreted. As a result, by definition, a particular act or omission falls outside the scope of the right in question. In the case of 'reasonable application of the law', a particular fundamental right is applicable, but this will not cause the unconstitutionality of a particular State measure limiting that right, because a repeal or a quashing of the measure would, in the wording of the Netherlands Supreme Court, would lead to "a blatant disregard for ... what is generally accepted as reasonable." These "escapes" from the limitation system should be applied with the help of the principle of proportionality and the weighing of public and individual interests. Moreover, according to the government, restraint is called for in applying these "escape possibilities", that is, their application should be an exception.

In 3.3, the criticism of the limitation system of the Constitution (1983) is discussed. Although their exceptional character would suggests otherwise, this criticism shows that ample use is made of the possibilities of derogation. As will become clear also in Chapter 7 (see below), the escapes bring relief especially in cases in which limiting human rights is not possible through the possibilities of limitation provided in the Netherlands Constitution. These cases surprisingly often have to do with limitations in legislation by lower authorities, which, contrary to the requirements in the Constitution, do not originate in a specific act of parliarnent, i.e. a statutory provision prescribing which right may be limited and to what extent. Another example is the power of mayors to issue emergency ordinances. All in all, the strict system of limitation in the Constitution proves to be unsatisfactory. 
In Chapter 4, the author discusses the delimitation by the Strasbour organs (4.2) and the Dutch judiciary (4.3) of the rights guaranteed 1 Article 8 (1) ECHR. From the evaluation of the case law discussed in th preceding sections it becomes evident that both the Strasbourg and th national organs have developed a limited number of criteria, be it differet ones, for the purposes of delimiting the right to respect for a person private life. The most important European criterion is the "pubt character"-criterion: the private character of an act or situation depends a the degree to which such act or situation is linked to public life, pubt interest or the interests of others. It is remarkable that precisely th protection of these interests may constitute a legitimate ground $\mathrm{ft}$ limitation within the meaning of Article 8 (2) ECRH. One category $f$ criteria in Dutch case law - mainly pertaining to the observing of persos and the recording of personal data so obtained and the utilization at publication of those data - is the "subjective criteria." These criteria rela to the inner wish of the person whose data are involved, to be left alon. The (personal) choice of that person may therefore be decisive for te scope of the right to respect for a person's private life.

With respect to the delimitation of the right to respect for family life, $t$ can be observed that Dutch case läw is obviousiy tuned to sfrasoburg case law. Authoritative are the judgments of the European Court in the Marckx. Abdulaziz, Cabales and Balkandali and Berrehab cases (confirmed in the Keegan and Kroon cases) and the Netherlands Supreme Court Judgment of 10 November 1989 (NJ 1990, 628). From this case law, it can be inferred that, by definition, the relationship between a mother and her child is to be considered to constitute "family life", irrespective of whether the child is legitimate or illegitimate. This relationship may have ceased to exist afterwards. In other cases it needs be established "whether it [is] in fact possible to point to such a link as can be considered to establish family life within the meaning of Article 8." This is called the "required link"criterion which has been interpreted in case law as follows: there must be "further elements of dependency, involving more than the normal, emotional ties." If a child is born from a marriage or a relationship which is on a par with marriage, the relationship between the father and the child can also be considered to constitute "family life", even if the relationship between the parents had already ceased to exist at the time the child was born. Subsequent events may cause the cessation of family life between the father and the child. Also in these cases, the child's legitimacy or illegitimacy is irrelevant. In this respect, we can conceive of it as a "nondiscrimination' criterion, because, in delimiting "family life", no differentiation is allowed on the ground of the (il)legitimate status of the child. In case of relationships other than those on a par with marriage, 
factual circumstances must be adduced from which the development of a relationship constituting "family life" can be construed. This applies to merely biological fathers such as sperm donors, to grandparents and foster parents in relation to minor children and to all adult relationships. Furthermore, a 'culpa in causa'-criterion ("own fault") can be derived from decided cases. This criterion implies that the fact that a relationship constituting 'family life' is discontinued as a result of the acts of the party itself cannot be used against the State.

A study of the sparse Strasbourg case law with regard to the right to respect for a person's home offers one useful delimitation criterion, the "sufficient continuing links" criterion. A place is a "home" within the meaning of Article $8 \mathrm{ECHR}$ if there is a sufficient link with the house in question. Indications for the existence of such a link are the proprietary relationship with the building, an intended "permanent residence" and whether the parties involved "have established any other home." In the last-mentioned situation, the home must be the "principal residence." The foregoing applies first and foremost to houses, but could, in view of the case law in this matter (Chappell and Niemietz cases) also apply to commercial premises, in the author's opinion, providing that in such cases it would be better to speak of a continuing carrying on of a business or a continuing performing of professional activities in or from a building. Until now, there has been no practicable Dutch case law with respect to this right.

As regards the right to respect for a person's correspondence, a suitable criterion for the delimitation of this right has not been found in decided cases. However, it has become evident that this right has a very wide scope. In the Niemietz case, for instance, the word "documents" is used without further specification. In addition to letters (obviously), also telephone conversations are protected under this right.

Although in essence State obligations under Article 8 ECHR are negative obligations, i.e. obligations of State non-interference, the right to respect for private life, family life, home and correspondence can, under certain circumstances, also lead to an obligation for the State to take action. Section 4.5 deals with these positive obligations. As a result of Strasbourg case law, the existence and, particularly, the substance of positive obligations depend on the outcome of the weighing of individual and public interests. The State has a wide margin of appreciation in this matter and virtually the same principles are at issue as were discussed in the study of negative State obligations, such as the grounds of limitation listed in Article 8 (2) ECHR. Unlike the review of negative obligations, the review of positive obligations takes place within the context of Article 8 (1). This means that, in practice, the delimitation of the positive obligation is 
interconnected with the limitation of these obligations, because, in effect, the existence and the substance of the positive obligation are weighed in the case in question against the public interest. This all happens within the context of the notion of 'respect' as laid down in Article 8 (1) ECHR.

In a small number of cases decided by Dutch courts concerning aliens, the weighing of the interests involved takes place after the court's conclusion that the refusal to grant a residence permit does not constitute "interference" within the meaning of Article 8 ECHR. This seems to indicate that, according to the Dutch courts, in certain circumstances, a positive obligation to grant a residence permit to an alien can be inferred from Article 8 ECHR. Such considerations seem to point in the direction of a recognition of positive obligations emanating from Article 8 ECHR. No express confirmation of this has been found in cases decided by Dutch courts.

Chapter 5 deals with the delimitation of the right of access to a court, which is implicitly safeguarded by Article 6 (first sentence) ECHR. In 5.1.1, this right is introduced and in 5.1.2 the foundation of the right of access is studied. The principle of the rule of law, which is the main principle on which this right is based, plays a decisive part in delimiting the right of access and forms the foundation of the delimitation criteria to be discussed in the subsequent sections.

In Section 5.1.3, the delimitation of the right of access to a court is studied. Inasmuch as this right is protected implicitly by Article 6 ECHR. the assumption that the scope of this right comprises the right itself as well as its equally implicit limitations forms the point of departure for this investigation. As is demonstrated in 5.1.3.1, the most important boundary drawn around the right of access by the courts closely resembles the limitation clauses in the second paragraphs of Articles 8 through 11 ECHR. The State's margin of appreciation in regulating this right of access is limited, inter alia, by the requirement that the limitations of this right must not restrict access to a court in such a way or to such an extent that the very essence of the right is impaired. Furthermore, such a limitation must pursue a legitimate aim, be proportional to this aim and the rules governing the right must be coherent and clear, offering the person seeking justice a clear, practical and effective opportunity to challenge a particular act to which Article 6 is applicable. Besides limitations by the authorities of the right of access to a court, it is also possible for the party itself to limit the exercise of the right to the extent of waiving it. The court's interpretation of the concept of 'waiver' is also relevant for the delimitation of the right of access. 
In 5.1.3.3, it is shown that the right of access to court also entails positive obligations, for example, a State obligation to provide legal assistance. The scope of these obligations depends on the specific circumstances of the case, such as the personal (financial) circumstances of the party involved, the complexity of the case and whether there exists a statutory requirement of representation by counsel. The criterion in delimiting the right of access can be inferred from the Strasbourg case law on positive obligations: exercise of this right must be effective.

In 5.1.4, the meaning of the term 'court' in the right of 'access to a court' is studied. The term 'court' implies an independent and impartial tribunal established by law within the meaning of Article 6 (1) ECHR. The requirements which, according to case law, must be met by the tribunal, are discussed in the subsequent sections.

Dutch case law with respect to the right of access to a court is discussed in 5.2. In these judgments hardly ever criteria are found for the delimitation of this right. Only with respect to the impartiality of tribunals, criteria have been formulated, which, incidentally, closely resemble the Strasbourg criteria. The approach by the Dutch courts is very casuistic; they refer only piecemeal to Article $6(1)$ and to the important judgments of the European Court in this matter.

In Chapter 6, the case law with regard to a number of human rights in the Netherlands Constitution (1983) is scrutinized in order to discover the methods employed by Dutch courts to establish the scope of those rights. In 6.1, a close look is taken at Article 1 of the Constitution (principle of equality and principle of non-discrimination). Section 6.1.12 features the conclusions that could be drawn as a result of the study discussed in the preceding sections. One conclusion is that there are few decided cases, in which criteria for delimiting the principle of equality and the principle of non-discrimination have been developed. An effort is made, therefore, to discuss the delimitation of these principles with the aid of decided cases. academic writings and parliamentary records with regard to Article 1 Constitution (1983) and the legislation implementing this Article.

In 6.2, Articles 6 (1), 7 (1) and (3) and Article 9 (1) of the Netherlands Constitution are discussed. The delimitation of the scope of the freedom of religion and belief laid down in Article 6 (1) is examined. From the case law discussed, a number of conclusions are drawn in 6.2.1.8. Perhaps the most important conclusion is that with regard to the right in Article 6 (1) Constitution there is no delimitation to speak of. Another important result from this study is that, in some court decisions. limitations to Article 6 (1) that have no origin in a specific act of parliament, are accepted. These limitations can be regarded as general, "unwritten" limitations, i.e. 
not originating from a constitutional provision. The method by which these unconstitutional limitations are salvaged by the courts, reminds one of the 'reasonable application of the law' method discussed in Chapter 3. However, as a result of a number cases a limitation can be observed: the exercise of the right to freedom of religion may not be "made impossible", which seems to indicate that at least an effective exercise of the right must be possible ("effet utile").

The case law with regard to Article 7 (1) and (3) of the Netherlands Constitution is discussed in 6.2.2. This case law shows that the scope of the rights contained in these provisions has hardly been delimited. The notions examined are in a way already the result of the courts' delimitation of the freedom of expression as laid down in the old Article 7 of the Constitution prior to its revision. These notions have been preserved with regard to the present Article 7 (1) and have been partially adopted with respect to section 3 . They are rather vague, however, and are in need of development. Only seldom does such development occur through the courts.

Finally in 6.2.3, Article 9 (1) of the Netherlands Constitution is discussed. In view of the fact that there are very few decided cases with regard to Article 9 (1) -most cases concern Article 9 (2)-, it can be concluded that Article 9 (1) does not impose on the authorities negative obligations alone; also a positive obligation is imposed. The latter obliges the authorities to offer persons wishing to exercise their freedom of association or demonstration adequate police protection against the intolerant behaviour of others. The boundary lies where the situation cannot reasonably be kept under control even with adequate deployment of police force. In that case, limitation of the right is allowed. Assessment of the situation implies an assessment of the proportionality between the aim, i.e. prevention of disorder, and the means to achieve the aim, i.e. limitation of the right. Delimitation of the scope of the rights contained in Article 9 (1) has not occurred through case law, but can be found in legal literature and parliamentary records.

The investigation in 6.1. and 6.2 is assessed in 6.3. It is established that the case law with regard to Articles 6 (i), 7 (1) and (3) and Article 9 (1) of the Netherlands Constitution shows a degree of consistency. The rights contained in these articles can, for instance, be exercised by "all" and the limitation clause in these provisions ("except for each person's responsibility under the law") does not play a part in the delimitation of the respective rights. This could mean that, prior to limiting a right, a court will determine the scope of the right irrespective of its limitation (and rightly so, in the author's view). However, other possibilities of limitation have proved to influence the delimitation of the scope. One 
example of this is the practice discussed earlier, that in a number of cases general limitations (although not expressly characterized as such) are salvaged through the 'reasonable application of the law'-method.

Delimitation of the rights in Articles 6 (1), 7 (1) and (3) and Article 9 (1) of the Netherlands Constitution has not really taken place. The main exception to this is with regard to the freedom of religion. As was shown in 6.2.1.5, where religious expressions are concerned, blunt, unsubstantiated and purposely incorrect and misleading expressions are not covered by the freedom of religion guaranteed under Article 6 (1) (see the Goeree case). Other religious expressions do fall within the scope of the freedom of religion, even where they conflict with what is generally accepted or are offensive to a particular group of

persons. Here we find a limit for the applicability of Article 6 (1) Constitution.

The conclusion drawn in 6.3.2 is that there are no significant differences in the delimitation of the scope of the Articles 6(1), 7 (1) and (3) and $9(1)$ Netherlands Constitution on the one hand and that of the scope of Article 1 of the same Constitution on the other. It could not be concluded that a right for which no possibility of limitation has been provided (as in Article 1) is more precisely delimited than a right accompanied by a limitation clause (as in the other provisions discussed).

In Chapter 7, an answer is offered to the central question formulated in Chapter 1: How do courts establish the scope of human rights? The criteria found in the preceding chapters for the delimitation of Articles 8 (1) and 6 (1) (first sentence) ECHR and Articles 1, 6 (1), 7 (1) and (3) and Article 9 (1) of the Netherlands Constitution can be subdivided into specific and open criteria. For the most part, these criteria can be classified under several categories of "basic criteria" from which in future more specific criteria can be deduced in cases for which at present no standards exist. These basic criteria are: the rule of law (7.2.1), the effet utile of a human right (7.2.2), proportionality (7.2.3), fair trial (7.2.4), non-discrimination (7.2.5), the prohibition against abuse of right (7.2.6) and the (subjective) choice of the party itself (7.2.7). In 7.3, several examples, presented in the preceding chapters, of the relation between the establishment of the scope of human rights and the limitation of those rights are discussed once more in a systematic way. These examples show the validity of the first of the proposition postulated in Chapter 1: 'There is a relation between establishing the scope of human rights and restricting their exercise', On the basis of these examples, the author reviews the validity of the second proposition: 'The relation between establishing the scope of human rights and restricting their exercise causes tension between court practice with 
respect to establishing the scope of rights and restricting them on the one hand and the legislators' reasoning underpinning the system of limitation on the other'. The aim pursued by the framers of the European Convention to exactly define the rights and possibilities of limitation (see Chapter 2). i.e. clarity about the nature and the scope of the treaty obligations, is not always achieved. This is the case, for instance, with regard to positive obligations. As has been observed earlier, in practice, their delimitation is interconnected with their limitation. An independent establishment of the scope of positive obligations does not take place; the same holds true for other cases in which the courts (particularly the Dutch courts) do no: consider the question of delimitation and decide the case directly on the basis of the possibilities of limitation. In 7.5.1, an effort is made to offer a solution for the established tension between judicial practice and the intentions of the framers of the Convention. For this purpose, reference is made to the criterion of the effectiveness of the right, which is applied with respect to positive obligations deriving from the right of access to a court (Article 6 (1) ECHR). The scope of the positive obligations arising from Article 8 ECHR can also be established on the basis of this criterion Thus, the authorities, who possess a margin of appreciation in the deciding the means to be used for the implementation of a positive obligation, should at least take measures essential to the effective exercise of the right invoked. If necessary, the positive obligation thus delimited could be subsequently limited on the basis of Article 8 (2), insofar as the requirements prescribed in that paragraph apply to positive obligations. In 7.4.2, the validity of the second proposition is proved also with respect to judicial practice with regard to the constitutional human rights investigated. that is insofar as this practice concerns general limitations and 'reasonable interpretation' or 'reasonable application' of the law. One of the objectives of the revision of the Netherlands Constitution was to precisely define the rights and their restriction so that "well-defined safeguards" could be offered. Judicial practice with respect to general limitations. 'reasonable interpretation of the law' and 'reasonable application of the law' has failed to offer such safeguards. One reason for this is that we are dealing with general limitations imposed by lower authorities, which, although rejected by the national legislator, have proved to be necessary because too rigid requirements had been attached to the limitation possibilities provided. An example is the requirement that limitations must originate in a specific act of parliament. Furthermore, these general limitations are often salvaged by means of the "escapes" of 'reasonable interpretation of the law' and 'reasonable application of the law', which thus seem to have lost their exceptional character. Moreover, testing against the principle of proportionality as has been prescribed by the national legislator for the 
purpose of these "escapes", is often ignored by the courts. In 7.5.2. alternatives are proposed for court practice with respect to unwritten, general limitations and other prohibited methods of limitation, in order to remove the established tension with the national legislator's intentions with regard to the Netherlands Constitution. One of the alternatives is to do away with the requirement that limitations should originate in specific acts of parliament and to introduce an explicit test against the requirement of necessity serving as a code of conduct comparable to the test against the requirement of 'necessity in a democratic society' within the meaning of Articles 8 through 11 ECHR. The other alternative suggested by the author is the introduction of an explicit test against the requirement of 'necessity' serving as a code of conduct in case of 'reasonable application of the law' together with the abolition of the method of 'reasonable interpretation of the law". 


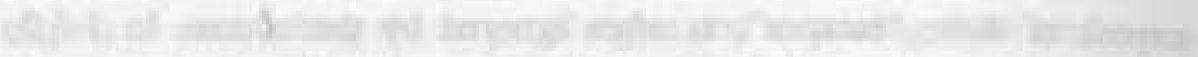

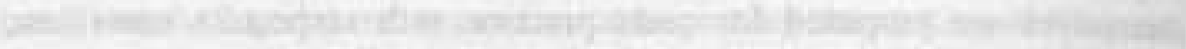

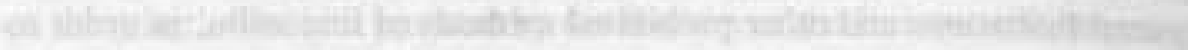

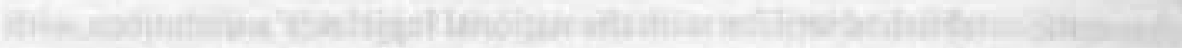

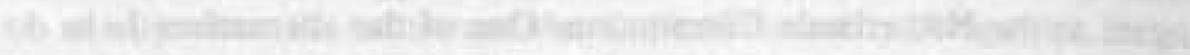

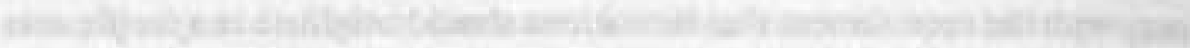

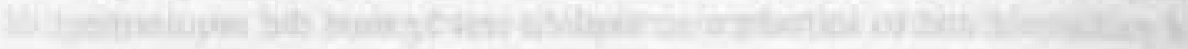

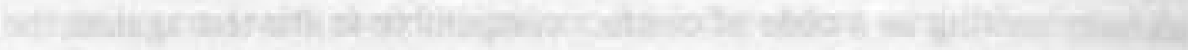

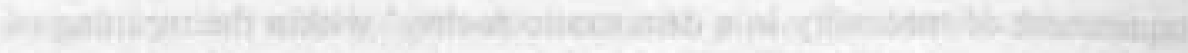

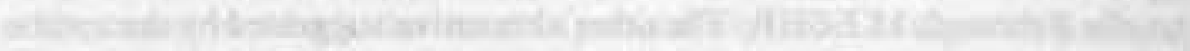

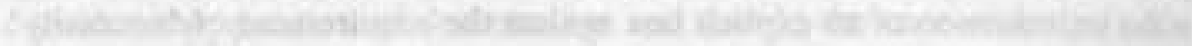

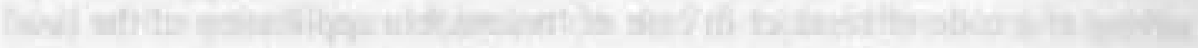

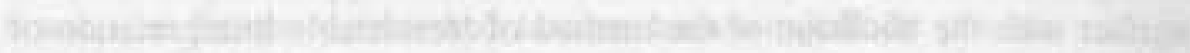

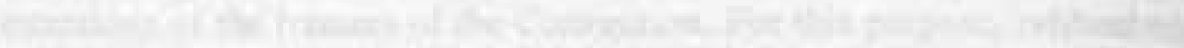

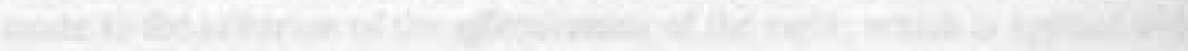

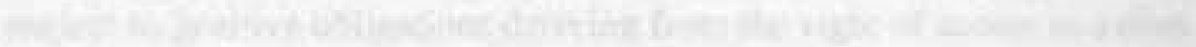

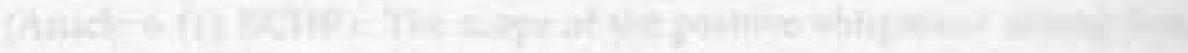

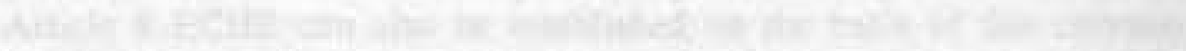
14:

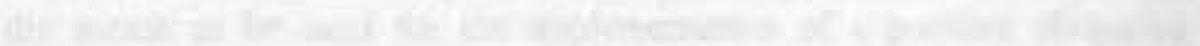

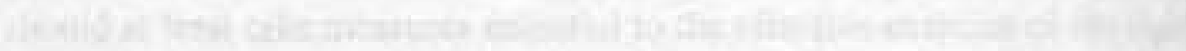

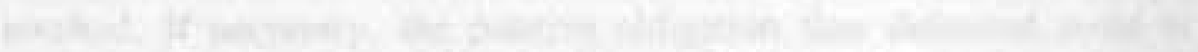

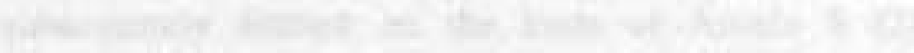

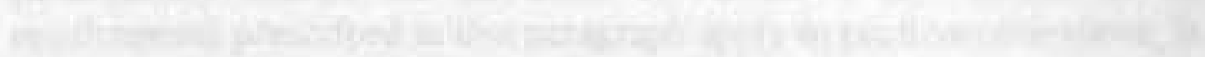

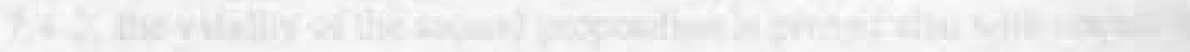

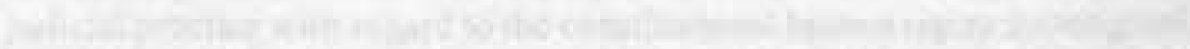




\section{Literatuurlijst}

Akkermans, P.W.C., Artikel I Grondwet, in: De Grondwet, een artikelsgewijs commentaar, red. P.W.C. Akkermans en A.K. Koekkoek, tweede druk, W.E.J. Tjeenk Willink: Zwolle 1992, pp. 38-61

Akkermans, P.W.C., Artikel 9 Grondwet, in: De Grondwet, een artikelsgewijs commentaar, red. P.W.C. Akkermans en A.K. Koekkoek, tweede druk, W.E.J. Tjeenk Willink: Zwolle 1992, pp. 208-222

Akkermans, P.W.C., C.J. Bax, L.F.M. Verhey, Grondrechten, grondrechten en grondrechtsbescherming in Nederland, tweede herziene druk, Open Universiteit/WoltersNoordhoff: Heerlen/Groningen 1993

Alkema, E.A., De Europese Conventie en het Nederlandse recht, preadvies NVIR, Mededelingen van de Nederlandse Vereniging voor Internationaal Recht nr. 73, 1976. pp. $85-206$

Alkema, E.A., Studies over Europese grondrechten, dissertatie Leiden, Kluwer, Deventer 1978

Alkema, E.A., Het arrest-Öztürk en de vereenvoudigde afdoening van (verkeers)overtredingen, in: Verkeersrecht, nr. 11, 1984, pp. 241-244

Alkema, E.A., De betekenis van het EVRM voor de Nederlandse constitutie, in: 40 jaar Europese Conventie voor de Rechten van de Mens en de Nederlandse rechtsorde, Staatsrechtconferentie 1990, Stichting NJCM-Boekerij, nr. 18, Leiden 1991, p. 3-35

Alkema, E.A., Het internationale recht inzake de rechten van de mens en de Nederlandse rechtsorde, in: Rechten van de mens in Mundiaal en Europees perspectief, vierde herziene druk, Ars Aequi Libri - Rechten van de Mens - 1, Nijmegen 1991, hoofdstuk 7, pp. 201227

Asscher-Vonk, I.P., Wat is discriminatie?, NJB, afl. 21 (1982), pp. 634-635

Asscher-Vonk, I.P., Overzicht oordelen Commissie gelijke behandeling. NJCM-Bulletin 18-6 (1993), pp. 674-684

Baarda. Th.A. van, Oordeelsvorming in casus van botsende grondrechten, dissertatie Universiteit Twente 1992, Gouda Quint bv: Arnhem 1992

Bellekorn. Th.L.. Het Hof voor de Rechten van de Mens en de beperkingsclausules van het EVRM, in: 40 Jaar Europees Verdrag voor de Rechten van de Mens, red. A.W. Heringa e.a., Speciaal nummer NJCM-Bulletin, Leiden 1990. pp. 59-74

Biesheuvel, M.B.W., Tien gedachten over discriminatie en recht, in: Verdediging yan collectieve belangen via de rechter, W.E.J. Tjeenk Willink: Zwolle 1988, pp. 214-226

Biesheuvel, M.B.W., en J.A. Peters, Rechten van gedetineerden: heeft de rechter een eigen cliêntèle?, NJB, afl. 39 (1981), pp. 1045-1054 
Bijloos, A.W.M., Administratieve boeten en art. 6 EVRM in Nederland, preadvies ten behoeve van de Vereniging voor de vergelijkende studie van het recht van Belgiê en Nederland, W.E.J. Tjeenk Willink: Zwolle 1989, pp. 21-26

Bleckmann, Albert, Allgemeine Grundrechtslehren, Carl Heymanns Verlag KG: Köln 1979

Boer, J. de, Procederen wegens discriminatie, in: Staatkundig Jaarboek 1985, Amsterdam 1985 " pp. 73-92

Boer, J. de, Art. 8 EVRM. Algemeen, preadvies in het kader van het thema "Artikel 8 van het Europees Verdrag tot Bescherming van de Rechten van de Mens", Handelingen 1990 der Nederlandse Juristen-Vereniging, jrg. 120, no. 1, pp. 1-64

Boer, M.M. den, Artikel 6 Grondwet: vrijheid van godsdienst en levensovertuiging, NJCM-Bulletin 12-2 (1987), pp. 110-127

Boer, M.M. den, Grondwettelijke grondrechten geïnterpreteerd, in: Gegeven de Grondwet Kluwer: Deventer 1988, pp. 63-79

Bokma, M.J., en H.P. Vonhögen, Artikel 6 en artikel 9 Grondwet: zwakke waarborgen gebrekkige uitwerking, in: De wetgeving ter uitvoering van Hoofdstuk I van de Grondwet red. M.C. Burkens en M.J. Sluijs, Tjeenk Willink: Zwolle 1988, pp. 97-119

Bolten, J.J., Mensen en staten, De grote woorden in de Berrehab-zaak, in: Nemesis, december 1988, nr.6, pp. 209-212

Boon, P.J., Zonder voorafgaand verlof, De vrijheid van meningsuiting in het Nederlandse recht, Serie Siaats-en Besiuursrecht - 2, vijfde druk, Ars Aequi Libri: Nijmegen 1993

Boon, C.E.M. van den, Een rechterlijke toetsing van de ontslagbeschikking van de directeur GAB, in: PS afl. 24 (1988), pp. 1677-1684

Brenninkmeijer, A.F.M., Van drukpersvrijheid tot informatievrijheid, in: Grondrechten. commentaar op hoofdstuk 1 van de herziene Grondwet, aangeboden aan H.J.M. Jeukens. red. A.K. Koekkoek e.a.. Serie Staats- en Bestuursrecht - 7, Ars Aequi Libri: Nijmegen 1982, pp. 167-190

Brenninkmeijer, A.F.M. De toegang tot de rechter. Een onderzoek naar de betekenis van onafhankelijke rechtspraak in een democratische rechtsstaat, dissertatie Tilburg (KUB) 1987. W.E.J. Tjeenk Willink: Zwolle 1987

Brenninkmeijer, A.F.M. Het procesrecht als proces, preadvies in het kader van het thema "Harmonisatie van procesrecht bij integratie van rechtspraak", Handelingen 1991-I der Nederlandse Juristen-Vereniging. W.E.J. Tjeenk Willink: Zwolle 1991, pp. I-105

Bruijn-Lủckers, M.L.C.C. de. Het jeugdstrafprocesrecht en de "De Cubber-case", in: NJB. afl. 19 (1986), pp. 569-573

Bruijn-Lückers, M.L.C.C. de, Het familierecht van vreemdelingen, NJCM-Bulletin 19-1 (1994), pp. $34-47$ 
Bürgenthal, Th., International Human Rights in a nutshell, West Publishing Co. - Nutshell Series - St. Paul, Minnesota 1988

Burkens, M.C., Beperking van grondrechten, dissertatie Utrecht, Kluwer, Deventer 1971

Burkens, M.C., Gelijke behandeling, in: Grondrechten, Commentaar op Hoofdstuk 1 van de herziene Grondwet, aangeboden aan mr. H.J.M. Jeukens, red. A.K. Koekkoek e.a., Serie Staats-en bestuursrecht - 7, Ars Aequi Libri: Nijmegen 1982, pp. 49-65

Burkens, M.C., Algemene leerstukken van grondrechten naar Nederlands constitutioneel recht, Handboeken Staats- en bestuursrecht - deel II, W.E.J. Tjeenk Willink: Zwolle 1989

Burkens, M.C., advies naar aanleiding van het verbod (pp. 743-744) van de Burgemeester van Dordrecht van 6 augustus 1990 tot het houden van een persconferentie door de Centrum Partij '86 en het Vlaams Blok. NJCM-Bulletin 15-6/7 (1990), pp. 744-747

Burkens, M.C., J. Bokma, H.P. Vonhögen en W.L.J. Voogt, Actuele ontwikkelingen en problemen op het terrein van de gelding van grondwettelijke grondrechten, in: Recht als norm en als aspiratie: red. J.B.J.M. ten Berge e.a.., Ars Aequi Libri: Nijmegen 1986, pp. 286-303

Burkens, M.C., en H.R.B.M. Kummeling, Het bewijs van discriminatie, NJCM-Bulletin 16-1 (1991), pp. 3-27

Cath, I.G.F., Hebben ondernemingen recht op bescherming van de privésfeer? De zaken Hoechst en Chappel vergeleken, in: NJCM-bulletin 16-1 (1991), pp. 28-54

Clarenbeek, Th.J., Uitzonderingstoestanden in de nieuwe Grondwet, in: NJB, afl. 45/46 (1979), p. 1017

Carlos Closa, Citizenship of the Union and nationality of Member States, Common Market Law Review, vol. 32 (1995), pp. 487-518

Corstens, G.J.M., De onpartijdige strafrechter, in: Begrensde vrijheid, Opstellen over mensenrechten aangeboden aan Prof.dr. D.F. Scheltens, W.E.J. Tjeenk Willink: Zwolle 1989. pp. $177-190$

Corstens, G.J.M. en P.M. Frielink, De Hoge Raad en de fiscale boete: twee maal in de pas, een maal uit de pas, in: Weekblad voor Fiscaal Recht 1989/5857. pp. 216-224

Dekker-van Bijsterveld, S.C. den. De toelating van imams, in: NJB, afl. 34 (1985), p. 1092

Dekker-van Bijsterveld, S.C. den, Het voorstel van Wet openbare manifestaties, Tịjdschrift voor Openbaar Bestuur 1986, pp. 215.219

Dekker-van Bijsterveld, S.C. den, De verhouding tussen kerk en staat in het licht van de grondrechten, dissertatie Tilburg. Tjeenk Willink: Zwolle 1988 
Dijk, P. van, De op Nederland rustende internationale verplichtingen ter zake van een behoorlijke rechtspraak, preadvies, Handelingen 1983 der Nederlandse Juristen-Vereniging. deel 1, eerste stuk, W.E.J. Tjeenk Willink: Zwolle 1983, pp. 4-148

Dijk, P. van, The interpretation of "civil rights and obligations" by the European Court of Human Rights - one more step to take, in: Protecting Human Rights: The Europear Dimension, Studies in honour of Gérard J. Wiarda, Carl Heymanns Verlag KG: Köln. Berlin etc. 1988, pp. 131-143

Dijk, P. van, en G.H.J. van Hoof, De europese conventie in theorie en praktijk, derdt herziene druk, Ars Aequi Libri - Rechten van de Mens - 2, Nijmegen 1990

Dijk, P. van, Toelating en verblijf van vreemdelingen in Nederland; de eerbiediging vat het familie- en gezinsleven op grond van artikel 8 EVRM, NJCM-Bulletin 19-1 (1994) pp. 6-33

Dommering, E.J., Het grondrecht op behoorlijke rechtspraak in het Nederlandse civiel recht, preadvies, Handelingen 1983 der Nederlandse Juristen-Vereniging, deel 1, tweed stuk, W.E.J. Tjeenk Willink: Zwolle 1983, pp. 151-239

Donner, A.M., Grondrechten als constitutionele rechten, in: Speculum Langemeijer W.E.J. Tjeenk Willink: Zwolle 1973, pp. 15-28

Eissen, M.-A., La Convention et les devoirs de l'individu, in: La protection internationale des droits de l'homme dans le cadre européen. Travaux du Colloque org. par la Faculté de Droit et des Sciences Politiques et Economiques de Strasbourg, 14-15 novembre 1960, Librairie Dalloz: Paris 1961, pp. 167-194

Elens, Françoise, La notion de démocratie dans le cadre des limitations aux droits de I'homme, in: Boletin de Ministério da Justiça: Documentaçao e Direito Comparado, 9. 1982. pp. 163-248

Feteris, M.W.C., Belastingen en mensenrechten, NJCM-Bulletin 18-7 (i993). pp. 755-771

Feteris, M.W.C., Fiscale administratieve sancties en het recht op een behoorlijk proces, dissertatie Amsterdam (UvA) 1993. Fiscaie monografieën - nr. 66, Kluwer: Deventer 1993

Fokkens, J.W., Het nieuwe jeugdstrafprocesrecht, FJR (1992), afl. 10, pp. 224-226

Forder, C.J., Legal protection under Article 8 ECHR: Marckx and beyond, in: Netherlands International Law Review, 1990 - vol. XXXVII - Issue 2, pp. 162-181

Forder, C.J., Positieve verplichtingen in het kader van het Europees Verdrag tot Bescherming van de Rechten van de Mens en de Fundamentele Vrịheden, in: NJCMBulletin 17-6 (1992), pp. 611-637

Frowein, J.A., Die Überprüfungsbefugnis im Rahmen von Art. 6 Abs. 1 EMRK. in: Fortschritt im Bewußtsein der Grund- und Menschenrechte, Festschrift für Felix Ermacora. 
Ganshof van der Meersch, W.J. Réflexions sur l'art de juger et l'exercice de la fonction judiciaire, in: Journal des tribunaux, jaargang 1973, pp. 509 e.v.

Ganshof van der Meersch, W.J., Les Méthodes d'interprétation de la Cour Européenne des Droits de l'Homme, in: Perspectives canadiennes et européennes des droits de la personne, Les Éditions Yvon Blais Inc.: Cowansville (Québec), Canada 1986, pp. 189-204

Gerbranda, Tj., en M. Kroes, Grondrechten evaluatie-onderzoek, Documentatierapport - I, Stichting NJCM-Boekerij - 15: Leiden 1991

Gerbranda, Tj.. en M. Kroes, Grondrechten evaluatie-onderzoek, Documentatierapport - 2 , Stichting NJCM-Boekerij - 15: Leiden 1991

Gerbranda, Tj., en M. Kroes, Grondrechten evaluatie-onderzoek, Eindrapport, Stichting NJCM-Boekerij - deel 22: Leiden 1993

Gerbrandy, S., Kort commentaar op de Auteurswet 1912, Gouda Quint bv: Arnhem 1988

Groenhuijsen, M.S., (On)partijdige rechtspraak?. De Nederlandse strafrechtspleging na Hauschildt, in: Het actuele recht, Rechtspraak anno 1993 in 67 Tilburgse bijdragen, red. R.D. Vriesendorp e.a., Koninklijke Vermande B.V.: Lelystad 1993, pp. 57-60

Haas, F.J.P.M. de, Het opleggen en kwijtschelden van verhogingen bij het heffen van belasting, De stand van zaken, Advocatenblad, afl. 4 (1991), pp. 102-105

Hartog, Anita den, Artikel 6 EVRM: Grenzen aan het streven de straf eerder op de daad te doen volgen, dissertatie Groningen 1992, MAKLU Uitgevers: Antwerpen/Apeldoorn 1992

Heerma van Voss, G., Indirecte discriminatie in sociale zekerheid vastgesteld, noot bij CRvB 23 juni 1992. NJCM-Bulletin 18-3 (1993), pp. 292-298

Hennekens, H.Ph.J.A.M., Behoudens ieders verantwoordelijkheid volgens de wet en de gemeentelijke verordeningsbevoegdheid, Bestuurswetenschappen 1986, nr. 7. pp. 459-464

Heringa, A.W., Het discriminatieverbod als sociaal grondrecht, in: Staatkundig Jaarboek 1983-1984, pp. 204-205

Heringa, A.W.. Concept-voorstel van een wet openbare manifestaties, NJCM-Bulletin 10-2 (1985), pp. 156-164

Heringa, A.W., Sociale grondrechten, dissertatie Leiden 1989. T.M.C. Asser Instituut: Den Haag 1989

Heringa, A.W.. De reikwijdte van artikel 6 lid 1 EVRM. NJCM-Bulletin 13-7 (1988), pp. 654-665

Heringa, A.W.. Constitutionele schijnbewegingen, in: Publiekrechtelijke bewegingen, wetenschappelijke reeks, faculteit der rechısgeleerdheid RL. Kluwer: Deventer 1990. pp. 67-81 
Heringa, A.W., Recente EG jurisprudentie gelijke behandeling man/vrouw, NJCM-Bulletin 16-1 (1991), pp. 55-70

Heringa, A.W., Onderscheid en discriminatie, NJCM-Bulletin 17-1 (1992), pp. 12-14

Heringa, A.W. en T. Zwart, De Nederlandse Grondwet, derde, herziene druk, W.E.J. Tjeenk Willink: Zwolle, 1991

Hertoghs, J.J.M., De AWB en de rechtspositie van de contribuabele, in: WFR 1991/5967, pp. $903-910$

Heubel, H., Der "fair trial" - ein Grundsatz des Strafverfahrens?, Strafrechtliche Abhandlungen - Neue Folge - Band 41, Duncker \& Humblot: Berlin 1981

Heumann, Les droits garantis par la Convention Européenne des Droits de l'Homme: Etude des limitations de ces droits, in: La protection internationale des droits de l'homme dans le cadre européen, pp. 143-161

Hins, W., Uitingsvrijheid voor de Staat?!, in: Mediaforum, nr. 4, april 1993, p. 37

Hoeven, J. van der, De plaats van de grondwet in het constitutionele recht, aangevulde heruitgave van het academisch proefschrift (Amsterdam, UvA, 1958), W.E.J. Tjeenk Willink: Zwolle 1988, pp. 205-245

Hoof, G.J.H. van, en A.Ph. Jaspers, Over gelijkheid: enige aspecten van rechterlijke toetsing aan het gelijkheidsbeginsel, in: Recht als norm en als aspiratie: red. J.B.J.M. ten Berge e.a., Ars Aequi Libri: Nijmegen 1986, pp. 136-162

Houps, C. en P. Wattel, Enige grondrechtelijke aspecten van de rechterlijke beoordeling van fiscale boeten, in: WFR 1990/5911, pp. 578-588

Ilsink. J.W. De gevolgen van de eerste tranche van de Algemene Wet Bestuursiecht voor de fiscale beroepsprocedure, in: WFR 1991/5967, pp. 898-903

Jacohs, F.G. Varieties of approach to treaty interpretation: with special reference to the Draft Convention on the Law of Treaties before the Vienna Diplomatic Conference, in: The International and Comparative Law Quarterly. vol. 18. The British Instituse of International and Comparative L.aw: London 1969. pp. 318-346

Jacobs, F.G.. The European Convention on Human Rights. Clarendon Press: Oxford 1975

Jacobs, F., To what extent have restrictions on the enjoyment of freedoms evolved?, in: Proceedings of the fourth international colloquy about the European Convention on Human Rights, Rome, 5-8 November 1975. Council of Europe: Strasbourg 1976. pp. 187-208

Kiss, A.. Les clauses de limitation et de dérogation dans la Convention Européenne des Droits de I'Homme, in: Perspectives canadiennes et européennes des droits de la personne. Les Ếditions Yvon Blais Inc.: Cowansville (Québec). Canada 1986. pp. 119-138 
Kistenkas, F.H., De verspreidingsjurisprudentie in perspectief, in: Tijdschrift voor Openbaar Bestuur, Jaargang 11. nr. 18

Kistenkas, F.H., Vrije straatcommunicatie, dissertatie Amsterdam 1989, Gouda Quint/Kluwer: Arnhem/Deventer 1989

Klerk, Y., De ontstaansgeschiedenis van de Europese Conventie, in: 40 jaar Europees verdrag voor de rechten van de mens, Speciaal nummer NJCM-Bulletin, Leiden 1990 , pp. 3-15

Klerk, Y.S., Het ECRM-toezichtmechanisme: verleden, heden, toekomst, dissertatie Maastricht 1995, Ars Aequi Libri: Nijmegen 1995

Koekkoek, A.K. en W. Konijnenbelt, Het raam van hoofdstuk 1 van de herziene Grondwet, in: Grondrechten, commentaar op hoofdstuk I van de herziene Grondwet, aangeboden aan mr. H.J.M. Jeukens, red. A.K. Koekkoek e.a., Ars Aequi Libri - Serie Staats- en bestuursrecht - 7, Nijmegen 1982, pp. 1-39

Kortmann, C.A.J.M., Algemene en bijzondere beperkingen van grondrechten, NJB, afl. 42 (1978), pp. $922-923$

Kortmann, C.A.J.M., De vrijheid van godsdienst en levensovertuiging in de nieuwe Grondwet, in: Godsdienstvrijheid, Beschouwingen voor de Vergadering van de Rechtskundige Afdeling van het Thijmgenootschap op 28 januari 1983 te Tilburg, Kluwer: Deventer 1982, pp. 55-67

Kortmann, C.A.J.M., Het einde van 219 en 220 gemeentewet?, De Nederlandse Gemeente, 3 juni 1983 , nr. 22, p. 343

Kortmann, C.A.J.M., De grondwetsherzieningen 1983 en 1987, tweede druk, Kluwer: Deventer 1987

Kortmann. C.A.J.M., Grondrechten in de nieuwe grondwet: vijf jaren toepassing in wetgeving en rechtspraak, in: Begrensde vrijheid. Opstellen over mensenrechten aangeboden aan Prof.dr. D.F. Scheltens. W.E.J. Tjeenk Willink: Zwolle 1989, pp. 230241

Kortmann, C.A.J.M., Vrijheid van meningsuiting voor de regering?, in: NJB, afl. 10 (1993), pp. 333-334

Krabbe, H.G.M., Verweren in de zin van art. 358 derde lid Sv., in: Leerstukken van Strafprocesrecht, red. G. Knigge, Wolters-Noordhoff: Groningen 1991, hoofdstuk 9. pp. 171-191

Landelijk Bureau Racismebestrijding. MeI recht rassendiscriminatie bestrijden, Een handleiding bij de hestrijding van rassendiscriminatie met juridische middelen, red. A.C. Possel, Utrecht, W.E.J. Tjeenk Willink: Zwolle 1990

Lange, R. de, Publiekrechtelijke rechtsvinding, dissertatie Amsterdam 1991, W.E.J. Tjeenk Willink: Zwolle 1991 
Langereis, Ch.J., Herziening van het stelsel van administratieve boeten en van het fiscale strafrecht, in: Fiskaal, jrg. 21, nr. 1994-2, pp. 60-69

Lawson, R., Positieve verplichtingen onder het EVRM: opkomst en ondergang van de 'fair balance'-test - deel I, NJCM-Bulletin 20-5 (1995), pp. 558-573

Lemmens, P., Geschillen over burgerlijke rechten en verplichtingen, Publikaties van het Interuniversitair Centrum voor Staatsrecht - XIII, dissertatie Leuven 1987, Kluwer rechtswetenschappen: Antwerpen 1989

Lemmens, P., De Raad van State en Art. 6, lid 1, EVRM, in: Rechtskundig Weekblad 1989-1990, nr. 19, pp. 641-643

Lijnzaad, L., Reservations to UN-Human Rights Treaties, Ratify and Ruin?, dissertatie Maastricht 1994, Martinus Nijhoff Publishers: Dordrecht etc. 1995

Loenen, T., AAW en deeltijdwerkers, noot bij RvB Groningen 10 april 1990, NJCMBulletin 15-4 (1990), pp. 479-493

Loenen, T., Mensenrechtelijke aspecten van de leefvormenproblematiek I: familierecht, NJCM-Bulletin 19-3 (1994), pp. 207-227

Loof-Donker, A.M.F., E.-M. Peeters en P.H. van der Tang-van Loenen, De openbare orde: een te nemen horde?, NJCM-Bulletin 19-5 (1994), pp. 503-518

Marseveen, H. van, Kroongeschil en burgerlijke rechter, in: NJB, aff. 5 (1987), pp. 139140

Meij, J.M. de, Uitingsvrịheid, Otto Cramwinckel Uitgever: Amsterdam 1989

Meij, J.M. de, De feitelijke mogelijkheid tot vrije meningsuiting, Mediaforum. 1989 , nI. 2, pp. 16-18

Meijer, A., De burgemeester in nood(toestand). NJB, afl. 8 (1987), pp. 237-242

Mulder, J.P., en D.J. Hoekstra, De grondwet in de steigers, commentaren op de "Proeve. van een nieuwe grondwet", N. Samsom nv.: Alphen a/d Rijn 1970

Myjer, E., Een nietige rechter-commissaris in kinderstrafzaken?, in: Trema", 1985, nr. 3 , pp. $56-60$

Myjer, E., Strafrecht en Mensenrechten, NJCM-Bulletin 17-5 (1992), pp. 518-521

Myjer, E., De ompartijdige kinderrechter, annotatie bij EHRM 24 augustus 1993. Nortier Case. NJCM-Bulletin 18-8 (1993), pp. $985-990$

Myjer, E., De raadsman en de afwezige verdachte (2), annotatie bij Europees Hof voor de Rechten van de Mens, 22 september 1994: Lala resp. Pelladoah tegen Nederland, NJCMBulletin 19-8 (1994), pp. 1069-1077 
Nederlandse Vereniging voor Rechtspraak, De onafhankelijke rechter, Rapport van een werkgroep van de afdeling rechterlijke organisatie van de Nederlandse Vereniging voor Rechtspraak, in: Trema" Special - 1979-2 - Nederlandse Vereniging voor Rechtspraak: 'sGravenhage 1979

NJCM-commentaar op de gebeurtenissen te Kedichem (29-3-1986), NJCM-Builetin 11-5 (1986), pp. 478-487

NJCM-commentaar op het rapport van de Commissie Moons over de herziening van het gerechtelijk vooronderzoek, NJCM-Bulletin 16-4 (1991), pp. 361-379

NJCM-commentaar bij het Wetsvoorstel inzake regelen omtrent de door de overheid gefinancierde rechtsbijstand, NJCM-Bulletin 18-2 (1993), pp.. 203-209(203-205)

NJCM, Themanummer Rechten, regels, realiteit - Wetgever en mensenrechtenbeleid, NJCM-Bulletin 19.5 (1994)

Ossenbühl, F., Die Interpretation der Grundrechte in der Rechtsprechung des Bundesverfassungsgerichts, Neue Juristische Wochenschrift 1976, pp. 2100-2107

Overkleeft-Verburg, G.. Wetgever en privacy, in: Trias Automatica, Automatisering in wetgeving, bestuur en rechtspraak, Kluwer: Deventer 1985, hoofdstuk 7, pp. 55-72

Pagano, R., Recht op TV, Een onderzoek naar de toelating van televisie-camera"s tot de openbare rechtzitting, dissertatie Rotterdam 1992, Gouda Quint bv: Arnhem 1992

Pelloux, R., L'affaire Golder devant la Cour Européenne des Droits de I'Homme, in: Annuaire Français de Droit International, vol. XXI (1975), pp. 330-339

Peters, J.A., De zaak Kalma en de vrijheid van meningsuiting, NJB, afl. 20 (1978),. pp. 369-377

Reuter, P., La Convention de Vienne sur le droits des rraités, série Problèmes Internationaux, Librairie Armand Colin: Paris 1970

Riezebos, C., Artikel 103, in: de Grondwet, een artikelsgewijs commentaar, red. P.W.C. Akkermans en A.K. Koekkoek, tweede druk, W.E.J. Tjeenk. Willink: Zwolle 1992, pp. $920-934$

Roberison, A.H. Human Rights in Eurrope, Manchester University Press, Manchester 1963

Robertson, A.H., The Political Background and Historical Development of the European Convention on Human Rights, in: The European Convention on Human Rights. A Report of a Lecture and Conference held on November 23 and 24 by the British Institute of International and Comparative Law, International Lawi Series No. 5. The International and Comparative Law Quarterly Supplementary Publication No. 11 (1965), pp. 24-37 
Schalken, T.M., Het grijze domein van de politie, NJB, afl. 22 (1990), pp. 805-811

Schalken, T.M., Jeugdstrafrecht tussen welzijn en de eis van een behoorlijke rechtspleging (Artikel 6 Europees Verdrag), FJR, jrg. 5, afl. 7/8, pp. 233-262

Scheltema, M., Een nieuwe uitdaging voor de administratieve rechtspraak?, in: Kroonberoep en artikel 6 ECRM, Kluwer: Deventer 1986, pp. 39-52

Schilder, A.E., Het recht tot vergadering en betoging, Een vergelijkende studie naar het Nederlandse en Westduitse recht, dissertatie Leiden: 1989, Gouda Quint BV: Arnhem 1989

Schneider, J.W., De vrijheid van godsdienst en levensovertuiging, in: Grondrechten, commentaar op hoofostuk 1 van de herziene Grondwet, aangeboden aan mr. H.J.M. Jeukens, red. A.K. Koekkoek e.a., Ars Aequi Libri - Serie Staats- en Bestuursrecht - 7. Stichting Ars Aequi: Nijmegen 1982, pp. 151-166

Schokkenbroek, J.G.C., De margin of appreciation-doctrine in de jurisprudentie van het Europese Hof, in: 40 jaar Europees Verdrag voor de Rechten van de Mens, Speciaal nummer NJCM-Bulletin, Leiden 1990, pp. 41-58

Schokkenbroek, J.G.C., Commerciële informatie, margin of appreciation en de vrijheid van meningsuiting, Europees Hof voor de Rechten van de Mens, 20 november 1989: De zaak Markt Intern Verlag GmbH en Klaus Beermann, noot II, in: NJCM-Bulletin 15-1 (1990), pp. $85-87$

Scholten, P., Algemeen Deel, Mr.C. Asser's Handleiding tot de beoefening van het Nederlands Burgerlijk Recht, derde druk, W.E.J. Tjeenk Willink: Zwolle 1974.

Staal, C.J., annotatie bij het arrest van het Hof in de zaak Powell and Rayner van 21 februari 1990, NJCM-Bulletin 15-6/7 (1990), pp. 692-703

Staal, C.I., Het recht op rechtsbijstand in verband met het recht op toegang tot de rechier onder artikel 6. EVRM, in: De toenemende betekenis van economische, sociale en culturele mensenrechten, Masstiicht Centrum vooi de Rechten van de Mens. Rijksuniversiteit Limburg, Stichting NJCM-Boekerij - 24: Leiden 1994, pp. 116-129

Steenbergen, J.D.M., annotatie bij het arrest van 21 juni 1988 in de zaak Berrehab. NJCM-Bulletin 13-6, (1988), p. 579 e.v.

Stroink, F.A.M., De plaats van de rechter in het staatsbestel, oratie Maastricht 1990. W.E.J. Tjeenk Willink: Zwolle 1990

Studiekring Familie- en Jeugdrechtspraak van de Nederlandse Vereniging voor Rechtspraak, commentaar op de Memorie van Antwoord en het gewijzigd wetsontwerp 21327 "Herziening van het strafrecht voor jeugdigen ten behoeve van de Vaste Commissie voor Justitie van de Tweede Kamer der Staten Generaal, in: FJR (1992), afl. 10 „ pp. 233-238

Timmermans, C.W.A., Verboden discriminatie of (geboden) differentiatie, Het discriminatieverbod als open ruimte voor een creatieve rechtsvinding in het Europese gemeenschapsrecht, in: SEW, afl. 6 (1982), pp. 426-460 
Tonnaer, F.P.C.L., Schets van het Nederlandse rechtsstelsel, Uitgeverij Lemma B.V.: Utrecht 1990

Velaers, Jan, De beperkingen van de vrijheid van meningsuiting, deel I, Maklu uitgevers: Antwerpen/Apeldoorn 1991

Velde, J. van der, Het "vrije spel der rechterlijke krachten", Over het tweetrapskarakter van de Europese mensenrechtenbescherming en de beoordelingsmarges van artikel 5 en 6 EVRM, in: 40 jaar Europese Conventie voor de Rechten van de Mens. Staatsrechtconferentie 1990, Stichting NJCM-Boekerij - nr. 18: Leiden 1990, pp. 85-115

Velde, J. van der, Beroepstermijn en het recht op toegang tot de rechter, annotatie bij het arrest van 16 december 1992. Case of de Geouffre de la Pradel, NJCM-Bulletin 18-3 (1993), pp. 330-336.

Veli, J., La notion de "tribunal" et les notions avoisinantes dans la Convention de sauvegarde des droits de l'homme et des libertés fondamentales, in: Liber Amicorum Frédéric Dumon, vol. II, Kluwer rechtswetenschappen: Antwerpen 1983, pp. 1287-1315

Verhey, L.F.M., Horizontale werking van grondrechten, in het bijzonder van het recht op̣ privacy, dissertatie Utrecht 1992, W.E.J. Tjeenk Willink: Zwolle 1992

Verhey, L.F.M., Vrijheid van meningsuiting voor de regering?, in: NJCM-Bulletin 18-4 (1993), pp. 410-417

Vermeulen, B.P., De Goerees en de Kardinaal, ofwel: vrijheid van godsdienst versus discriminatieverbod, in: Begrensde vrijheid, Opstellen over mensenrechten aangeboden aan Prof.dr.D.F. Scheltens, W.E.J. Tjeenk Willink: Zwolle 1989, pp. 258-278

Vermeulen, B.P., Algemene beperkingen, redelijke uitleg en redelijke toepassing van grondrechten, Regelmaat 1990 - 4, pp. 78-85

Vermeulen, B.P., Wie bepaalt de reikwijdte van de grondrechten?, preadvies, Handelingen van de Vereniging voor Wijsbegeerte van het recht, in: R \& $\mathbf{R}$ (Nederlands Tijdschrift voor Rechtsfilosofie en Rechtstheorie), W.E.J. Tjeenk Willink: 1992, afl. 1, pp. 16-46

Vermeulen, B.P., Artikel 6 Grondwet, in: de Grondwet, een artikelsgewijs commentaar, red. P.W.C. Akkermans en A.K. Koekkoek, tweede druk, W.E.J. Tjeenk Willink: Zwolle 1992. pp. 106-145

Vermeulen, B.P., en J.J.A. Pelle, Artikel 7 Grondwet, in: De Grondwet, een artikelsgewijs commentaar, red. P.W.C. Akkermans en A.K. Koekkoek, tweede druk, W.E.J. Tjeenk Willink: Zwolle 1992, pp. 146-198

Viering, M.L.W.M., Het toepassingsgebied van artikel 6 EVRM, dissertatie Nijmegen 1994, W.E.J. Tjeenk Willink/NISER: Zwolle/Utrecht 1994

Viering, M., en J. Fleuren, Onschuldpresumptie en recht op hoger beroep: twee grenzen aan eenvoudige afdoening. NJB, aff. 15 (1986), pp. 461-464 
Vlaardingerbroek, P., De 'Blote' verwekker en het omgangsrecht, Het omgangsrecht van de biologische vader, in: Het actuele recht, Rechtspraak anno 1993 in 67 Tilburgse bijdragen, Koninklijke Vermande B.V.: Lelystad 1993, pp. 223-226

Vos, A.T., Een wankel evenwicht tussen rechtsbescherming en pedagogische aanpak, FJR, afl. 10 (1992), pp. 227-232

Waaldijk, C., Motiveringsplichten van de wetgever, dissertatie Maastricht 1994, Koninklijke Vermande bv: Lelystad 1994.

Waldock, Sir Humphrey, Human Rights in Contemporary International Law and the Significance of the European Convention, in: The European Convention on Human Rights, A Report of a Lecture and Conference held on November 23 and 24 by the British Institute of International and Comparative Law, International Law Series No. 5, The International and Comparative Law Quarterly Supplementary Publication No. 11 (1965), pp. 1-23

Wentholt, K., Onderbroken loopbaan en indirecte discriminatie, noot bij Kntr. Zaandam 15 februari 1990, NJCM-Bulletin 15-6/7 (1990), pp. 672-679

Wiarda, G.J., Extensieve en restrictieve verdragstoepassing door het Europese Hof voor de rechten van de mens; een middenkoers?, in: Ad Personam, opstellen aangeboden aan Prof.Mr. Ch.J. Enschedé, W.E.J. Tjeenk Willink: Zwolle 1981, pp. 371-385

Winter, R.E. de, Het ontwerp Wet Openbare Manifestaties en de grondwettelijke toedeling van bevoegdheden, NJB, afl. 34 (1986), pp. 1082-1085

Winter, R. de, Verwijdering van vreemdelingen en spandoeken, over de noodzaak van een subtielere verspreidingsjurisprudentie op artikel 7 lid I Grondwet, NJB, afl. 4 (1989). pp. 119-121

Winter, R.E. de, Het Heerlens tippelverbod: de Hoge Raad als feitenrechter, NJB, afl. 43 (1990), p. 1681

Winter, R.E. de, De heersende leer, Honderd jaar verspreidingsjurisprudentie: 1892-1992. dissertatie Maastricht 1993, Sdu: 1993

Winter, R. de, De 'Auschwitz-Liige' na 50 jaar: strafwaardig?, NJB, afl. 18 (1995), pp. 653-659

Wissen, G.J.M. van, Grondrechten, Studiepockets staats- en bestuursrecht - deel 12. W.E.J. Tjeenk Willink: Zwolle 1992

Woitjer, A., Huwelijksperikelen: een heterosexueel voorrecht?, NJCM-Bulletin !6-4 (1991). pp. 350-357

Zwemstra, S., Bescherming van uitingsrechten door administratieve rechters, diss. Amsterdam 1992, W.E.J. Tjeenk Willink: Zwolle 1992 


\section{Documenten inzake de totstandkoming van de Europese Conventie en de Grondwetsherziening 1983 (chronologisch)}

Council of Europe. Collected Edition of the "Travaux Préparatoires" of the European Convention on Human Rights, Vol. I, Nijhoff: Den Haag 1975

Council of Europe, Collected Edition of the "Travaux Préparatoires" of the European Convention on Human Rights, Vol. II, Nijhoff: Den Haag 1975

Council of Europe. Collected Edition of the "Travaux Préparatoires" of the European Convention on Human Rights, Vol. IV, Nijhoff: Den Haag 1977

Council of Europe, Collected Edition of the "Travaux Préparatoires" of the European Convention on Human Rights, Vol. V. Nijhoff Publishers: Den Haag/Boston/Londen 1979

Council of Europe, Collected Edition of the "Travaux Préparatoires" of the European Convention on Human Rights, Vol. VI, Nijhoff Publishers: Dordrecht/ Boston/Lancaster 1985

Council of Europe, Collected Edition of the "Travaux Préparatoires" of the European Convention on Human Rights, Vol. VII, Nijhoff Publishers: Dordrecht/ Boston/Lancaster 1985

Eindrapport van de Staatscommissie tot herziening van de Grondwet ingesteld bij Koninklijk Besluit van 17 april 1950 No. 25, Staatsdrukkerij en uitgeverijbedrijf: Den Haag 1954

Proeve van een nieuwe grondwet, Ministerie van Binnenlandse Zaken 1966. Staatsuitgeverij: Den Haag 1966

De parlementaire geschiedenis van de Proeve van een nieuwe Grondwet (1950 - begin 1967), red. H.Th.J.F. van Maarseveen, documentatiéreeks Naar een nieuwe grondwet? - deel 1 - Ministerie van Binnenlandse Zaken 1968, Staatsuitgeverij: Den Haag 1968

Eerste rapport van de Staatscommissie van advies inzake de Grondwet en de Kieswet, Ministerie van Binnenlandse Zaken 1968. Staatsuitgeverij: Den Haag 1968

Tweede rapport van de Staatscommissie van advies inzake de Grondwet en de Kieswet, Ministerie van Binnenlandse Zaken 1969. Staatsuitgeverij: Den Haag 1969

Eindrapport van de Staatscommissie van advies inzake de Grondwet en de Kieswet, Ministerie van Binnenlandse Zaken 1971, Staatsuitgeverij: Den Haag 1971

De parlementaire geschiedenis rond de algehele grondwetsherziening, deel II september 1969 - mei 1971, documentatiereeks Naar een nieuwe grondwet? - deel 6 - Ministerie van Binnenlandse zaken 1973. Staatsuitgeverij: Den Haag 1973

De grondwetsherziening 1972, deel I verlaging kiesgerechtigde leeftijd, passief kiesrecht etc., documentatiereeks Naar een nieuwe grondwet? - deel 7 - Ministerie van Binnenlandse Zaken 1974, Staatsuitgeverij: Den Haag 1974 
De grondwetsherziening 1972, deel V grondrechten, documentatiereeks Naar een nieuwe grondwet? - deel 11 - Ministerie van Binnenlandse Zaken 1976, Staatsuitgeverij: Den Haag 1976

Nota inzake het grondwetsherzieningsbeleid, deel I, documentatiereeks Naar een nieuwe grondwet? - deel 12 - Ministerie van Binnenlandse Zaken 1977, Staatsuitgeverij: Den Haag 1977

Nota inzake het grondwetsherzieningsbeleid, deel II, documentatiereeks Naar een nieuwe grondwet? - deel 13 - Ministerie van Binnenlandse Zaken 1977, Staatsuitgeverij: Den Haag 1977

Algehele grondwetsherziening, eerste lezing, deel Ia Grondrechten, documentatiereeks Naar een nieuwe grondwet - deel 15 - Ministerie van Binnenlandse Zaken 1979, Staatsuitgeverij: Den Haag 1979

Algehele grondwetsherziening, eerste lezing, deel VIla Provincies, gemeenten, waterschappen en andere openbare lichamen, documentatiereeks Naar een nieuwe grondwet - deel 16 - Ministerie van Binnenlandse Zaken 1980, Staatsuitgeverij: Den Haag 1980

Algehele grondwetsherziening, eerste lezing, deel lb Grondrechten, documentatiereeks Naar een nieuwe grondwet - deel 18 - Ministerie van Binnenlandse Zaken 1981. Staatsuitgeverij: Den Haag I98I

Algehele grondwetsherziening, eerste lezing, deel Ic Grondrechten, documentatiereeks Naar een nieuwe grondwet? - deel 19 - Ministerie van Binnenlandse Zaken 1981, Statsuitgeverij: Den Haag 1981

Algehele grondwetsherziening, eerste lezing, deel Vc Wetgeving en bestuur, documentatiereeks Naar een nieuwe grondwet - deel 27 - Ministerie van Binnenlandse Zaken 1984, Staatsuitgeverij: Den Haag 1984

Algehele grondwetsherziening, eerste lezing, deel Vd Wetgeving en bestuur, documentatiereeks Naar een nieuwe grondwet - deel 28 - Ministerie van Binnenlandse Zaken 1985, Staatsuitgeverij: Den Haag 1985

Algehele grondwetsherziening, tweede lezing (eerste gedeelte), documentatiereeks Naar een nieuwe grondwet - deel 31 - Ministerie van Binnenlandse Zaken 1987, Staatsuitgeverij: Den Haag 1987

Algehele grondwetsherziening, tweede lezing (tweede gedeelte), documentatiereeks Naar een nieuwe grondwet - deel 32 - Ministerie van Binnenlandse Zaken 1990. SDU uitgeverij: Den Haag 1990 


\section{Geraadpleegde kamerstukken}

Kamerstukken II, 1975-1976, wetsvoorstel 13872, Verklaring dat er grond bestaat een voorstel in overweging te nemen tot verandering in de Grondwet van bepalingen inzake grondrechten, nr. 3 (Memorie van Toelichting), in: Algehele grondwetsherziening, dee! ia Grondrechten, pp. 7-53

Kamerstukken II, 1975-1976, wetsvoorstel 13872, Verklaring dat er grond bestaat een voorstel in overweging te nemen tot verandering in de Grondwet van bepalingen inzake grondrechten, nr. 4, ( (Advies van de Raad van State, Bijlage I, Bijlagen bij de Memorie van Toelichting), in: Algehele grondweisherziening, deel la Grondrechten, pp. 54-71

Kamerstukken II, 1975-1976, wetsvoorstel 13872, Verklaring dat er grond bestaat een voorstel in overweging te nemen tot verandering in de Grondwet van bepalingen inzake grondrechten, nr. 4, (Nader rapport, Bijlage II, Bijlagen bij de Memorie van Toelichting). in: Algehele grondwetsherziening, deel la Grondrechten, pp. 72-100

Kamerstukken II, 1975-1976, wetsvoorstel 13872, Verklaring dat ex grond bestaat een voorstel in overweging te nemen tot verandering in de Grondwet van bepalingen inzake grondrechten, nr. 6 (Voorlopig Verslag), in: Algehele grondwetsherziening, deel la, pp. 119-168

Kamerstuk II, 1976-1977, wetsvoorstel 13872, Verklaring dat er grond bestaat een voorstel in overweging te nemen tot verandering in de Grondwet van bepalingen inzake grondrechten, nr. 7 (Memorie van Antwoord), in: Algehele grondwetsherziening, deel la Grondrechten, pp. 169-213

Kamerstukken II, 1976-1977, wetsvoorstel 13872, Verklaring dat er grond bestaat een voorstel in overweging te nemen tot verandering in de Grondwet van bepalingen inzake grondrechten, nr. 11 (Nota naar anleiding van het eindverslag) in: Algehele grondwetsherziening, deel la Grondrechten, pp. 221-224

Kamerstukken II, 1976-1977, wetsvoorstel 13872, Verklaring dat er grond bestaat een voorstel in overweging te nemen tot verandering in de Grondwet van bepalingen inzake grondrechten, nr. 18 (Amendement Bakker), in: Algehele grondwetsherziening, deel la Grondrechten, p. 231

Kamerstukken II, 1976-1977, wetsvoorstel 13872, Verklaring dat er grond bestaat een voorstel in overweging te nemen tot verandering in de Grondwet van bepalingen inzake grondrechten, Gezamenlijke mondelinge behandeling van de wetsontwerpen 13872 en 13873 door de Tweede Kamer, in: Algehele grondwetsherziening, deel la Grondrechten, pp. 359-517

Kamerstukken I, 1978-1979, wetsvoorstel 13872. Verklaring dat er grond bestaat een voorstel in overweging te nemen tot verandering in de Grondwet van bepalingen inzake grondrechten, Gezamenlijke mondelinge behandeling van de wetsontwerpen 13872 en 13873 in de Eerste Kamer, in: Algehele grondwetsherziening, deel Ib Grondrechten, pp. 107-168 
Kamerstukken II, 1978-1979, wetsvoorstel 15681, Verklaring dat er grond bestaat een voorstel in overweging te nemen tot verandering in de Grondwet van bepalingen inzake inzake uitzonderingstoestanden, nr. 3 (Memorie van Toelichting), in: Algehele grondwetsherziening, deel Vc Wetgeving en bestuur, pp. 162-171

Kamerstukken II, 1979-1980, wetsvoorstel 15681, Verklaring dat er grond bestaat een voorstel in overweging te nemen tot verandering in de Grondwet van bepalingen inzake uitzonderingstoestanden, nr. 11 (Bijlage bij Nota naar aanleiding van het Eindverslag), in: Algehele grondwetsherziening, deel Vc Wetgeving en bestuur, p. 215

Kamerstukken II, 1979-1980, wetsvoorstel 15681, Verklaring dat er grond bestaat een voorstel in overweging te nemen tot verandering in de Grondwet van bepalingen inzake uitzonderingstoestanden, nr. 12 (Tweede Nota van wijzigingen), in: Algehele grondwetsherziening, deel Vc Wetgeving en bestuur, p. 216

Kamerstukken II, 1984-1985, wetsvoorstel 17476, inzake de wijziging van enige bepalingen over verboden rechtspersonen, $\mathrm{nr} .5$ (Memorie van Antwoord)

Kamerstukken II, 1984-1985, wetsvoorstel 19013, inzake verandering in de Grondwet van de bepalingen over het binnentreden in woningen, nr. 3 (Memorie van Toelichting)

Kamerstukken II, 1984-1985, wetsvoorstel 19073, Algemene wet op het binnentreden, B (Advies Raad van State)

Kamerstukken II, 1985-1986, wetsvoorstel 19376, Notitie grondrecht van vrije arbeidskeuze, nr. 2 (Notitie)

Kamerstukken II, 1985-1986, wetsvoorstel 19427, Wet openbare manifestaties (WOM), nr. 3 (Memorie van Toelichting)

Kamerstukken II, 1986-1987, wetsvoorstel 19427, WOM, nr. 5 (Memorie van Antwoord)

Kamerstukken I. 1987-1988. wetsvoorste! 19427. WOM, nr. 135b (Memorie van Antwoord)

Kamerstukken II, 1988-1989, wetsvoorstel 20239, Aanvulling van het Wetboek van Strafrecht met enkele bepalingen tot het tegengaan van discriminatie op grond van ras, godsdienst, levensovertuiging. geslacht of hetero- of homoseksuele gerichtheid. $\mathrm{nr} .5$ (Memorie van Antwoord)

Kamerstukken II. 1988-1989, wetsvoorstel 20239. Aanvulling van het Wetboek van Strafrecht met enkele bepalingen tot het tegengaan van discriminatie op grond van ras. godsdienst, levensovertuiging. geslacht of hetero- of thomoseksuele gerichtheid, nr. 8 (Nota naar aanleiding van het eindverslag)

Kamerstukken I, 1990-1991, wetsvoorstel 20239. Aanvulling van het Wetboek van Strafrecht met enkele bepalingen tot het tegengaan van discriminatie op grond van ras. godsdienst, levensovertuiging. geslacht of hetero- of homoseksuele gerichtheid, nr. 76a (Memorie van Antwoord) 
Kamerstukken II, 1989-1990, wetsvoorstel 21335, Aanpassing aan de Grondwet van de giftenaftrek in de Wet op de inkomstenbelasting 1964 en van enige daarmee samenhangende bepalingen in andere wetten, $\mathrm{nr} .3$ (Memorie van Toelichting)

Kamerstukken II, 1989-1990, wetsvoorstel 21335, Aanpassing aan de Grondwet van de giftenaftrek in de Wet op de inkomstenbelasting 1964 en van enige daarmee samenhangende bepalingen in andere wetten, $\mathrm{nr} .5$ (Memorie van Antwoord)

Kamerstukken II, 1989-1990, wetsvoorstel 21335. Aanpassing aan de Grondwet van de giftenaftrek in de Wet op de inkomstenbelasting 1964 en van enige daarmee samenhangende bepalingen in andere wetten, nr. 7 (Nota naar aanleiding van het eindverslag)

Kamerstukken II, 1990-1991, wetsvoorstel 22014, Algemene wet gelijke behandeling (AWGB), B (Nader rapport)

Kamerstukken II, 1990-1991, wetsvoorstel 22014, AWGB, nr. 3 (Memorie van Toelichting)

Kamerstukken II, 1991-1992, wetsvoorstel 22014, AWGB, nr. 5 (Memorie van Antwoord)

Kamerstukken II, 1991-1992, wetsvoorstel 22014, AWGB, nr. 10 (Nota naar aanleiding van het eindverslag)

Kamerstukken II, 1992-1993, wetsvoorstel 22014, AWGB, nr. 36 (Zesde nota van wijziging)

Kamerstukken II, 1992-1993, wetsvoorstel 22014, AWGB, nr. 39 (Motie Kalsbeek en Krajenbrink)

Kamerstukken I, 1993-1994, wetsvoorstel 21327, inzake de wijziging van het Wetboek van Strafrecht, het Wetboek van Strafvordering en andere wetten in verband met de herziening van het strafrecht voor jeugdigen, nr. 78 (Tweede nader gewijzigd voorstel van wet)

Kamerstukken II, 1993-1994, wetsvoorstel 23790. Coördinatiewet uitzonderingstoestanden. nr. 3 (Memorie van Toelichting)

Kamerstukken II, 1993-1994, wetsvoorstel 23791, Invoeringswe! Cöordinatiewet vitzonderingstoestanden, nr. 3 (Memorie van Toelichting)

Kamerstukken II, 1993-1994, wetsvocrstel 23788, inzake de hernieuwde vaststelling van de Oorlogswet voor Nederland ter aanpassing aan de Grondwet en aan de Coördinatiewet uitzonderingstoestanden, nr. 3 (Memorie van Toelichting)

Kamerstukken II, 1993-1994, wetsvoorstel 23789, inzake de hernieuwde vaststelling van de Wet buitengewone bevoegdheden burgerlijk gezag ter aanpassing aan de Gĩondwet en aan de Coördinatiewet uitzonderingstoestanden, nr. 3 (Memorie van Toelichting) 


\section{Overige documenten}

Aanwijzingen voor de regelgeving, vastgesteld bij Besluit van de Minister-President van 18 november 1992, Stcrt. 230 (inwerkingtreding 1 januari 1993). De tekst van de Aanwijzingen is opgenomen in: $\mathrm{C}$. Borman, Aanwijzingen voor de regelgeving en andere voor de regelgeving relevante aanwijzingen, W.E.J. Tjeenk Willink: Zwolle 1993

Minister van Binnenlandse Zaken, Binnentredingsbepalingen in herziene Grondwet, Circulaire aan de ministers, provinciale en gemeentebesturen, 7 maart 1983, Stcrt. 1983, 57

Minister van Justitie, Binnentredingsbepalingen in herziene Grondwet, Circulaire aan de procureurs-generaal bij de gerechtshoven en de advocaat-fiscaal bij het Hoog Militair Gerechtshof, 18 april 1983, Stcrt. 1983, 77

Council of Europe, Collected Texts, Straatsburg 1979

Rapport van de Commissie herziening strafrecht voor jeugdigen (Cie. Anneveldt), eindrapport "Sanctierecht voor jeugdigen", Den Haag 1982

Recommendation 799 (1977) on the political rights and position of aliens, 25 januari 1977 , Council of Europe, Parl. Assembly, 28th Ord. Sess., Third Part, Texts Adopted (1977)

Recommendation No. R(94) 12 of the Committee of Ministers to Member States on the Independence, Efficiency and Role of Judges, adopted on 13 October 1994, in: NJCMBulletin 20-5 (1995), pp. 620-62.3

Resolution (78)8 on legal aid and advice, aangenomen door het Comité van Ministers op 2 maart 1978, gepubliceerd in: H. Miehsler and H. Petzold, European Convention on Human Rights, Texts and Documents, Vol.II, Carl Heymanns Verlag KG: Köln etc. 1982. Resolutions and Recommendations of the Committee of Ministers, pp. 198-207

United Nations Conference on the Law of Treaties, official records, New York, 1971 


\section{Jurisprudentieregister}

Arresten van het Europees Hof voor de Rechten van de Mens (in alfabetische volgorde)

Abdulaziz. Cabales and Balkandali v. UK, 28 mei 1985, Publ.A. 94; Rechtspraak Vreemdelingenrecht 1985, nr. 105 115, 118, 119, 221, 270, 278, 291, 292, 296 Airey Case, 9 oktober 1979, Publ.A. 32; NJ 1980, 376 met noot E.A. Alkema 302,

$349,350,399,436,604$

Albert and Le Compte v. Belgim, 10 februari 1983, Publ.A. 58 345, 346, 378

Artico Case, 13 mei 1980, Publ.A. 37 315, 349, 604

Ashingdane Case, 28 mei 1985. Publ.A. 93 326, 330, 335, 336, 338, 358, 408, 435, $605,619.625$

Autronic AG case, 22 mei 1990, Publ.A. 178 100, 101

B v. UK, 8 juli 1987, Publ.A. $121 \quad 28,81,219,268,293,607$

B v. France, 25 maart 1992, Publ.A. 232-C 23, 202, 292, 293

Barberà, Messegué and Jabardo v. Spain, 6 december 1988, Publ.A. 176346

Barfod Case, 22 februarí 1989. Publ.A. 149 75, 76

Barthold Case, 25 maart 1985. Publ.A. $90 \quad 72$

Beaumartin Case, 24 november 1994, Publ.A. 296-B 359

Beldjoudi Case, 26 maart 1992. Publ.A. 234-A 67. 68

Belgian Linguisstic Case (voluit: Case "Relating to certain aspects of the laws on the use of languages in education in Belgium"), 23 juli 1968, Publ.A. 6 23, 96, 115-117. 205, 220, 289, 291, 334, 619

Belilos Case, 29 april 1988, Publ.A. 132 128-131, 133, 358-360, 362, 371, 378, 405. 408,423

Bendenoun Case, 24 februari 1994, Publ.A. 284; BNB 1994/175 met noot P.J. Wattel 405

Benthem Case, 23 oktober 1985, Publ.A. 97; AB 1986, 1 met noot Hirsch Ballin 359-361. 417

Berrehab Case, 21 juni 1988, Publ.A. 138; NJ 1988, 746, met noot E.A. Alkema 215 , 217. 260, 268,274, 283

Boyle and Rice v. UK. 27 april 1988. Publ.A. 131234

Bozano Case, 18 december 1986, Publ.A. 111123

Brozicek Case. 19 december 1989. Publ.A. 167346

Burghariz Case, 22 februari 1994, Publ.A. 280-\$ 121

Camphell Case, 25 maart 1992. Publ.A. 233 234. 236

Camphell and Fell v. UK, 28 juni 1984. Publ.A. 80 361, 366, 368, 369, 377, 378. 423

Campbell and Cosans v. UK. 25 februari 1982, Publ.A. $48 \quad 133$

Casado Coca v. Spain. 24 februari 1994. Publ.A. 285-A $59,75,76,78.89$

Castells Case. 23 april 1992. Publ.A. 236: NJ 1994. 102, met noot E.J. Dommering 67, 72, 84-86

Chappell Case, 30 maart 1989. Publ.A. 152-A 208, 232

Chorherr Case. 25 augustus 1993. Publ.A. 266-B 59, 61, 67, 75, 76, 131, 133

Colozza Case. 12 februari 1985. Publ.A. 89; AA 35 (1986) 4, pp. $309-315$ met noot van CFR 346. 350

Cossey Case, 27 september 1990, Publ.A. 184 23, 97, 202, 290, 292, 293, 296, 300 
Costello-Roberts v. UK, 25 maart 1993, Publ.A. 247-C: NJCM-Bulletin 18-5 (1993), pp. 572-578 met noot M.L. van Emmerik 200, 202, 206

Crémieux Case, 25 februari 1993, Publ.A. 256-B 75, 77, 87, 233

Darby Case, 23 oktober 1990, Publ.A. 187 115-116

De Cubber Case, 26 oktober 1984, Publ.A. 86; NJ 1988, 744 met noot E.A. Alkema $326,355,377-380$

de Geouffre de la Pradel v. France, 16 december 1992, Publ.A. 253-B 326, 336, 337, 605,625

de Jong, Baljet and van den Brink v. the Netherlands, 22 mei 1984, Publ.A. 77361

De Wilde, Ooms and Versyp cases ("Vagrancy Cases"), 18 juni 1971, Publ.A. 1260 , $68,71,331,353$

De Wilde, Ooms and Versyp cases ("Vagrancy Cases") (art. 50), 10 maart 1972, Publ.A. 14349

Debled Case, 22 september 1994, Publ.A. 292-B 374, 377

Delcourt Case, 17 januari 1970, Publ.A. $11 \quad 320,326,355,356,369,423$

Demicoli Case, 27 augustus 1991, Publ.A. 210 359, 360, 375, 377, 381

Deweer Case, 27 februari 1980, Publ.A. 35 315, 335, 342-344, 435, 601

Dudgeon Case, 22 oktober 1981, Publ.A. 45 23, 58, 70, 76, 79-81, 200, 615

Engel and others $v$. the Netherlands, 8 juni 1976, Publ.A. 22 65, 66

Eriksson Case, 22 juni 1989. Publ.A. 156 59, 71, 219, 607

Ezelin Case, 26 april 1991, Publ.A. 202; NJ 1992, 455, met noot E.J. Dommering 66, 76, 87

Fv. Switzerland, 18 december 1987, Publ.A. 12898

Fayed Case, 21 september 1994, Publ.A. 294-B 316, 327, 328, 336, 337, 340, 605 Fey Case, 24 februari 1993, Publ.A. 255-A 375, 377, 378, 380-382

Fredin Case, 18 februari 1991. Publ.A. 192 62, 116

Funke Case, 25 februari 1993, Publ.A. 256-A: NJ 1993, 485, met noot $K n \quad 75,77$. 87. 233

Gaskin Case, 7 juli 1989, Publ.A. 160; NJ 1991. 659. me! noot E.J. Dommering: NJCM-Bulletin 15-2 (1990), pp. 206-217 met noot L.F.M. Verhey 12, 201, 247. $29 !, 293,296,300$

Gillow Case, 24 november 1986, Publ.A. 109 61, 86, 228

Golder Case, 21 februari 1975. Publ.A. 18 12, 22, 96, 234, 313, 316, 319-321, 324. $326,330,334,338,348,353,619,620$

Groppera Radio AG and others v. Swizerland, 28 maart 1990. Publ.A. $173 \quad 100$ Guzzardi Case. 6 november 1980, Publ.A. 3923

H v. Betgium, 30 november 1987. Publ.A. 127360

H v. UK, 8 juli 1987. Publ.A. 120-B 83, 219, 268, 293

Hakkansson and Sturesson v. Sweden, 21 februari 1990, Publ.A. 171-A 347

Handyside Case. 7 december 1976, Publ.A. 24: NJ 1978, 236 69, 70, 75, 76, 80, 8I. $84,85,89,124,616$

Hauschildt Case, 24 mei i989. Publ.A. 154 375, 377, 378, 380, 381

Hennings Case, 16 december 1992, Publ.A. 251-A 330

Hentrich Case, 22 september 1994, Publ.A. 296-A 62 
Herczegfalvy Case, 24 september 1992. Publ.A. 244; NJCM-Bulletin 18-4 (1993), pp. 436-444 met noot 7 j. Gerbranda (pp. 444-448) 59, 61, 234

Hoffmann Case, 23 juni 1993, Publ.A. 255-C 118

Hokkanen Case. 23 september 1994, Publ.A. 299-A 215

Holm Case, 25 november 1993. Pub!.A. 279-A 374

Huvig Case, 24 april 1990, Publ.A. 176-B 208, 236

Informationsverein Lentia and others v. Austria, 24 november 1993, Publ.A. 276: NJ 1994, 559, met noot E.J. Dommering $75,76,81,85,88$

Inze Case, 28 oktober 1987, Publ.A. $126 \quad 115,120$

Ireland v. the United Kingdom, 18 januari 1978, Publ.A. 25 109, 111, 290

Jacubowski Case, 23 juni 1994, Publ.A. $291 \quad 72,76,78,87$

James and others $v$. UK, 21 februari 1986, Publ.A. 98 78, 79, 81, 94, 292

Jersild Case, 23 september 1994, Publ.A. 298; NJCM-Bulletin 20-2 (1995), pp. 124-141 met noot van $\boldsymbol{F}$. Janssens $72,76,84,85,90$

Johnston and others $v$, Ireland, 18 december 1986, Publ.A. $112 \quad 28,98,116,120$, $213,291-293,608$

Keegan Case, 26 mei 1994, Publ.A. 290; NJCM-Bulletin 20-1 (1995), pp. $37-44$ met noot $M$. de Bruijn-Lückers 217, 219, 291, 294, 308, 607

Klass and others v. Germany, 6 september 1978, Publ.A. $28 \quad$ 200, 235, 287

Kokkinakis Case, 25 mei 1993, Publ.A. 260-A 59, 61, 72, 75, 76, 87

Kroon and others v. the Netherlands. 27 oktober 1994, Publ.A. 297-C 214, 217, 291. 294, 308

Kruslin Case, 24 april 1990, Publ.A. 176-A: NJ 1991, 523 met noot E.J. Dommering $59-62,200$

Lala Case, 22 september 1994, Publ.A. 297-A 397

Langborger Case, 22 juni 1989, Publ.A. 155233

Lawless Case, 1 juli 1960, Publ.A. 3107

Le Compte, Van Leuven and De Meyere v. Belgium. 23 juni 1981. Publ.A. $43 \quad 345$. 346, 353, 354, 356, 424, 436

Leander Case. 26 maart 1987, Publ.A. $116 \quad 61.201$

Lingens Case, 8 juli 1986. Publ.A 103; NJ 1987. 901. met noot E.A. Alkema 85

Lithgow and others v. UK, 8 juli 1986. Publ.A. 102 78, 81, 327, 330, 335, 336, 353. 372, 392

López Ostra v. Spain, 9 december 1994, Publ.A. 303-C 201, 294

Luberii Case, 23 februari 1984, Publ.A. 7595

Lüdi Case, 15 juni 1992. Publ.A. 238200

Lutz Case, 25 augustus 1987. Publ.A. 123: NJ 1988, $938 \quad 405$

Malone Case, 2 augustus 1984. Publ.A. 82 59. 61, 200

Marckx Case, 13 juni 1979, Publ.A. 31 23, 116, 117, 120, 220, 232, 291, 292, 323, 349. 603

Margareta and Roger Andersson v. Sweden, 25 februari 1992, Publ.A. 226-A 59, 69. 71, 72, 76, 219, 235, 607

Markt Intern Verlag GmbH and Klaus Beermann v. Germany, 20 november 1989 , Publ.A. $165 \quad 70,72,78,181$ 
Mathieu-Mohin and Clerfayt v. Belgium, 2 maart 1987, Publ.A. 113303 McMichael Case, 24 februari 1995, Publ.A. 307-B 83, 84, 220, 607, 608 Mellacher and others v. Austria, 19 december 1989, Publ.A. 16994

Messina Case, 26 februari 1993, Publ.A. 257-H 234

Miailhe Case, 25 februari 1993, Publ.A. 256-C 75, 77, 87

Modinos Case, 22 april 1993, Publ.A. 25958

Moustaquim Case, 18 februari 1991, Publ.A. $193 \quad 87,116,118$

Müller a.o. v. Switzerland, 24 mei 1988, Publ.A. 133 69-71, 80, 81, 85, 88, 616 Murray Case, 28 oktober 1994, Publ.A. 300-A 68, 75, 87

Neumeister Case, 27 juni 1968, Publ.A. 8 353, 359

Neumeister Case (art. 50), 7 mei 1974, Publ.A. 17346

Niemietz Case, 16 december 1992, Publ.A. 251-B 81, 202, 205, 209, 232, 236, 286. 306

Norris Case, 26 oktober 1988, Publ.A. $14258,70,76,80,81$

Nortier Case, 24 augustus 1993, Publ.A. 267 380, 382, 383, 429

$O$ v. UK, 8 juli 1987, Publ.A. 120-A 302

Obermeier Case, 28 juni 1990, Publ.A. 179 354, 358, 408

Oberschlick Case, 23 mei 1991, Publ.A. 204; NJ 1992, 456, met noot E.J. Dommering

$72,85,346,383,436$

Olsson Case (no. 1), 24 maart 1988, Publ.A. $130 \quad 71,219,607$

Olsson Case (no. 2), 27 november 1992, Publ.A. 25069

Open Door and Dublin Well Woman v. Ireland, 29 oktober 1992, Publ.A. 246; NJ 1993,

544, met noot E.J. Dommering: NJCM-Bulletin 18-6 (1993), pp. $700-715$ met noot van $J$. Van Nieuwenhove 70

Ortenberg Case, 25 november 1994. Publ.A. 295-B 355

Otto-Preminger-Institut v. Austria, 20 september 1994, Publ.A. 295-A 59, 69, 72, 75,

$76,80,81,84,85,87,89$

Öztürk Case, 21 februari 1984, Publ.A. 73; NJ 1988, 937 354, 405

Padovani Case, 26 februari 1993. Publ.A. 257-B 375. 377, 378, 380

Pakelli Case. 25 april 1983, Publ.A. 42315

Pelladoah Case. 22 september 1994, Publ.A. 297-B 397

Pfeifer and Plankl v. Austria. 25 februari 1992. Publ.A. 227 341, 345, 383

Philis v. Greece. 27 augustus 1991. Publ.A. 209 326. 335-336, 338, 601

Piermont Case, 27 april 1995. Publ.A. 314 102, 103

Piersack Case, 1 oktober 1982, Publ.A. 53 369. 370, 377, 378, 424

Platform "Ärzle jür das Leben" v. Austria, 21 juni 1988. Publ.A. 139303

Powell and Rayner v. UK. 21 februari 1990. Publ.A. 172: NJCM-Bulletin 15-6/7 (1990),

pp. 692-703 met noot C.J. Staal 201, 294, 623, 640

Procola v. Luxembourg, 28 september 1995. Publ.A. $326 \quad 420$

Quaranta Case, 24 mei 1991, Publ.A. 205351

R v. UK, 8 juli 1987, Publ.A. $121 \quad 28,81,83,219,268,293,607$

Rasmussen Case, 28 november 1984, Publ.A. 87 115, 120

Rees Case, 17 oktober 1986, Publ.A. 106; NJ 1987, 945, met noot E.A. Alkema 97,

$202,248,289,290,292,293,606,623$ 
Rieme Case, 22 april 1992, Publ.A. 226-B 69, 72, 76, 219, 607

Ringeisen Case, 16 juli 1971, Publ.A. 13 359, 366

Salabiaku Case, 7 oktober 1988, Publ.A. 141-A 394

Saraiva de Carvalho v. Portugal, 22 april 1994. Publ.A. 286-B 378, 380-383

Schönenberger and Durmaz v. Switzerland, 20 juni 1988, Publ.A. $137 \quad 68,236$

Schuler-Zgraggen Case, 24 juni 1993. Publ.A. $263 \quad 121,345,347$

Schwabe Case, 28 augustus 1992, Publ.A. 242-B 72

Sigurour A. Sigurjónsson Case, 30 juni 1993, Publ.A. 264: NJ 1994, 223, met noot E.A. Alkema 73

Silver and others v. UK, 25 maart 1983, Publ.A. 61 59, 61

Sporrong and Lönnroth v. Sweden, 23 september 1982, Publ.A. 52292

Sramek Case, 22 oktober 1984, Publ.A. 84 360, 368, 370, 423, 436, 602

Stjerna Case, 25 november 1994, Publ.A. 299-B 89, 205, 291, 294

Sutter Case, 22 februari 1984, Publ.A. 74355

Swedish Engine Drivers 'Union Case, 6 februari 1976, Publ.A. $20 \quad 120$

The Observer and Guardian v. UK, 26 november 1991, Publ.A. 216; NJ 1992, 457 met noot E.J. Dommering $\quad 61,63,75-77,81,84,85$

The Sunday Times Case (no. 1), 26 april 1979, Publ.A. 30 58, 60, 61, 75, 77-80, 120,353

Thorgeir Thorgeirson Case, 25 juni 1992, Publ.A. 239 375, 377, 378, 380

Tyrer Case, 25 april 1978, Publ.A. 2623

Van de Hurk Case, 19 april 1994, Publ.A. $288 \quad 361$

Van der Mussele Case, 23 november 1983. Publ.A. 70 115, 116

W v, UK, 8 juli 1987, Publ.A. $121 \quad 28,81,83,219,268,270,293,607$

Weber Case, 22 mei 1990. Publ.A $177 \quad 75,81,131$

Wemhoff Case, 27 juni 1968, Publ.A. 7 21, 58, 321, 323, 326

Winterwerp Case, 24 oktober 1979, Publ.A. 33: NJ 1980, 114 met noot E.A. Alkema 95, 335

$X$ and $Y$ v. the Netherlands, 26 maan 1985, Publ.A. 91 2(X)

$X v, U K, 5$ november 1981. Publ.A. 46353

Zumtobel Case, 21 september 1993. Publ.A. 268-A 355

Rapporten van de Europese Commissie voor de Rechten van de Mens (in alfabetische volgorde)

Airey Case, zaak nr. $6289 / 73,9$ maart 1978, Publ.B. 30348

Albert and Le Compte, zaken nrs. 7299/75 en 7496/76, 14 december 1981, Publ.B. 50

364

Arrowsmith Case, zaak nr. 7050/75, 12 oklober 1978, D\&R 19, pp. 5-34 63, 66

Ashingdane Case, zaak nr. 8225/78, 12 mei 1983. Publ.A. 93, pp. 35-43 327-330,

435. 601 
Austria v. Italy (Pfunders), zaak nr. 788/60, 30 maart 1963, Yearbook VI (extracts), pp. 742-794 315

Belgian Linguïstic Case, zaken nrs. 1475/62 etc., 24 juni 1965, Publ.B. 3 94, 220 Bozano Case, zaak nr. 9990/82, 7 december 1984, Publ.A. 111, pp. 31-35 124

Bramelid and Malmström, zaken nrs. 8588/79 en 8589/79, 12 december 1983. D\&R 38, pp. 18, 31-41 366, 371, 372, 374, 377

Brïggemann and Scheuten, zaak nr. 6959/75, 12 juli 1977, D\&R 10, pp. 100-122 204

Campbell and Fell, zaak nr. 7511/76, 12 mei 1982, Publ.A. 80, pp. 65-81 326, 335, 366,367

Can Case, zaak nr. 9300/81, 12 juli 1984, Publ.A. 96, pp. 13-22 315

Chappell Case, zaak nr. 10461/83, 14 oktober 1987, Publ.A. 152, pp. 28-35 232

Colozza and Rubinat, zaken nrs. $9024 / 80$ en 9317/81, 5 mei 1983, Publ.B. 72, pp. 10-32 349

Costello-Roberts v. UK, 8 oktober 1991, Publ.A. 247-C 206

De Wilde, Ooms en Versyp cases ("Vagrancy cases"), zaken nrs. 2832/66 etc.. 19 juli 1969. Publ.B. 1024

De Cubber Case, zaak nr. 9186/80, 5 juli 1983, Publ.A. 86 377, 378

De Becker Case, zaak nr. 214/56, 8 januari 1960, Publ.B. 2 106, 107

Deweer Case, zaak nr. 6903/75, 5 oktober 1978, Publ.B. 33 326, 342, 343

Draper v. UK, zaak nr. 8186/78, 10 juli 1980, D\&R 24, pp. 72-84 96

Dudgeon Case, zaak nr. 7525/76, 13 maart 1980, Publ.B. 40204

Engel and others, zaken nrs. $5100 / 71$ etc., 19 juli 1974, Publ.B. $20 \quad 66,213$

Ettl and others, zaak nr. 9273/81. 3 juli 1985. Publ.A. 117. pp. 21-29 354, 355

Gillow Case, zaak nr. 9063/80, 3 oktober 1984, Publ.A. 109. pp. 30-52 228, 230

Goddi Case, zaak nr. 8966/80, 14 juli 1982, Publ.B. 61. pp. 10-27 349

Golder Case, zaak nr. 4451/70, 1 juni 1973, Publ.B. 16 20-22, 316, 318, 319, 322, $325-328,331-333,386$

Greece v. United Kingdom. Bespreking van het rapport van de Commissie in zaak nr. 176/56. Yearbook II (1958-1959), pp.174-178 109

H v. Belgium, zaak nr. 8950/80, 6 oktober 1985, Publ.A. 127, pp. 56-63 353. 359 Hamer v. UK, zaak nr. 7114/75, 13 gecember 1979, D\&R 24, pp. 5-18 96

Handyside Case, zaak nr. 5493/72, 30 september 1975. Publ.B. 22123

Hendriks Case, zaak nr. 9427/78, 8 maari 1982, D\&R 29, pp. 5-26 215, 229

Jespers Case, zaak nr. 8403/78. 14 december 1981, D\&R 27. pp. $61-77316$

Kamma v, the Netherlands, zaak nr. 4771/71, 14 juli 1974, Yearbook XVIII, pp. $302-$ 322: D\&R 1, pp. 4-12 123, 126

Kaplan Case, zaak nr. 7598/76, 17 juli 1980, D\&R 21. pp. 5 e.v. 328

Kjeldsen, Busk Madsen and Pedersen, zaken nrs. 5095/71 etc., 21 maart 1975. Publ.B. 21220 
Le Compte, Van Leuven and De Meyere, zaken nrs. 6878/75 en 7238/75, 14 december 1979. Publ.B. $38 \quad 364,376$

Lithgow and others, zaken nrs. 9006/80 etc., 7 maart 1984, Publ.A. 102, pp. 86-125 122, 327, 329, 366, 392

Marckx Case, zaak nr. 6833/74, 10 december 1977, Publ.B. 29212

McFeeley and others v, UK, zaak nr. 8317/78, 15 mei 1980, D\&R 20, pp. 44-102 200 McVeigh and others, zaken nrs. 8022/77 etc., 18 maart 1981, D\&R 25, pp. 15-59 200

Nielsen Case, zaak nr. 343/57, 15 maart 1961, Yearbook IV (extracts), pp. 494-588 315

Ofner and Hopfinger, zaken nrs. 524/59 en 617/59, 23 november 1962, Yearbook VI (extracts), pp. 680-706 315, 316

Pakelli Case, zaak nr. 8398/78, 12 december 1981. Publ.B. 53, pp. 9-29 316

Pataki and Dunshirn, zaken nrs. 596/59 en 784/60, 28 maart 1963, Yearbook VI (extracts), pp. 718-734 315

Pfeifer and Plankl, zaak nr. 10802/84, 11 oktober 1990, Publ.A. 227, pp. 23-34 341, 344, 365, 383

Piersack Case, zaak nr. 8692/79, 13 mei 1981, Publ.B. 47 363, 366, 375

Silver and others, zaken nrs. 5947/72, 6205/73 etc., 11 oktober 1980. Publ.B. 51, pp. 71-104 235

Sporrong and Lönnroth, zaken nrs. $7151 / 75$ en $7152 / 75,8$ oktober 1980, Publ.B. 46 122. 123

Sramek Case, zaak nr. 8790/79, 8 december 1982, Publ.A. 84 360, 436, 602

Temeltasch Case, zaak nr. 9116/80. 5 mei 1982, D\&R 31, pp. 120, 138-152 128, 130-133

The Greek Case, zaken nrs. $3321 / 67$ eic., 5 november 1969, Yearbook 12 (special volume) 110,122

Thorgeir Thorgeirson Case, zaak nr. 13773/88, 11 december 1990, Publ.A. 239, pp. 32 . $40 \quad 378,380$

Van de Hurk $v$. the Netherlands. zaak nr. 16034/90, 10 december 1992, Publ.A. 288 420

Van Oosterwijck Case, zaak nr. 7654/76, 1 maart 1979, Publ.B. $36 \quad 70,96,97,202$. 204. 290.603

W v. UK, zaak nr. 11095/84. 7 maart 1989. D\&R 63, pp. 34-51

Zand Case. zaak nr. 7360/76, 12 oktober 1978. D\&R 15. pp. 70-87 362, 363, 366. 437 
Ontvankelijkheidsbeslissingen van de Europese Commissie voor de Rechten van de Mens (in chronologische volgorde)

28 september 1956, zaak nr. 180/56, X v. FRG. Yearbook I, pp. 236-238 347 20 juli 1957, zaak nr. 250/57, Kommunistische Partei Deutschland, Documents and/et

Decisions (Yearbook I), pp. 222-225 106, 609

20 juli 1957, zaak nr. 265/57, X v. FRG, Yearbook I, pp. 192-194 347

20 december 1957, zaak nr. 172/56, X v. Sweden, Yearbook I, pp. 211-219 215

9 juni 1958, zaak nr. 214/56, De Becker, Yearbook II, pp. 214-254 106

30 augustus 1958, zaak nr. 332/57, Lawless, Yearbook II, pp. 308-340 106

30 juni 1959, zaak nr. 434/58, $X$ v. Sweden, Yearbook II, pp. 354-376; Coll. 1, pp. 1 -

$15 \quad 221$

4 januari 1960, zaak nr. 530/59, X v. FRG, Yearbook III, pp. 184-196 227

11 januari 1961, zaak nr. 788/60, Austria v. Italy (Pfunders Case), Yearbook IV, pp. $116-182 \quad 315$

10 april 1961, zaak nr. 911/60, Xv. Sweden, Coll. 7, pp. 7-22 68, 70

5 maart 1962, zaak nr. 1197/61, $X$ v. FRG, Coll. 8, pp. 68-74 342

14 december 1962, zaak nr. 1068/61, X v. the Netherlands, Yearbook V. pp. 278-286 69

17 januari 1963 , zaak nr. 1035/61, $X v$. FRG, Coll. 10, pp. 12-19 387

28 maart 1963, zaak nr. 1216/61, $X$ v. FRG, Coll.11, pp. 1-8 227

23 juli 1963, zaak nr. 1476/62, $X$ v. Austria, Coll. 11, pp. 31-49 364

12 december 1963, zaak nr. 1504/62, Xv. Austria, niet gepubliceerd 200

13 december 1963, zaak nr. 1747/62, $X$ v. Austria, Coll. 13, pp. 42-54 63, 64

17 december 1963, zaak nr. 1468/62. Iversen v. Norway. Yearbook VI, pp. 278-332 28

16 juli 1965, zaak nr. 2535/65, $X$ v. FRG, Coll. 17, pp. 28-30 221

23 mei 1966, zaak nr. 2516/65, $X$ v. FRG, Coll. 21. pp. $28-3968$

6 februari 1967, zaak nr. $2566 / 65, X$ v. FRG, Coll. 22, pp. 35-37 68

7 april 1967, zaak nr. 2432/65, $X$ v. Austria, Coll. 22, pp. 124-128 133

8 april 1967, zaak nr. 2942/66, $X$ v. FRG. Coll. 23. pp. $51-65347$

15 juli 1967, zaken nrs. 2991/66 en 2992/66, Khan and Singh v. UK, Yearbook X, pp. 478-506 224

15 decenter 1967, zaak nr. 3325/67, X. Y. Z. V and $W v . U K$. Yearbook X. pp. 528 540. Coll. 25, pp. 117-124 221

6 februari 1968, zaak nr. 2648/65, $X$ v. the Nether!ands. Coll. 26. pp. 26-32 68

6 februari 1968, zaak nr. 2822/66, X v. FRG, Coll. 26, pp. 42-45 68

19 juli 1968, zaak ur. 3110/67, X v. FRG, Yearbook XI. pp. 494-528: Coll. 27, pp. 77-

$96 \quad 213$

17 mei 1969, zaak nr. 3332/67, X v. UK, Coll. 34. pp. 1-9 330, 438

22 mei 1969 . zaak nr. $2857 / 66, X$ v. FRG. Coll. 29 . pp. 15-28 347

6 februari 1970, zaak nr. 3717/68. $X$ v. Ireland. Coll. 31. pp. 96-106 71

16 maart 1970, zaak, nr. $4121 / 69 . X$ v. FRG. Coll. 33, pp. $23-2664$

26 mei 1970 , zaak nr. $4045 / 69, X$ v. FRG. Coll. 34, pp. $33-37 \quad 330,438$

8 februari 1972, zaak ur. 5269/7!, $X$ and $Y v$. UK. Yearbook XV. pp. 564-576: Coll.

39. pp. 104-109 214, 221, 222

24 maart 1972, zaak nr. 4992/71, X v. UK. niet gepubliceerd 64

3 oktober 1972, zaken nrs. 5445/72 en 5446/72, $X$ and $Y$ v. UK, Coil. 42. p. 146222 14 december 1972, zaak nr. 5321/71, $X$ v. Austria. Coll. 42, pp. 105-107 63, 64, 68 
14 december 1972, zaak nr. 5532/72, X v. UK, Coll. 43, pp. 119-121 224

14 december 1972, zaak nr. 5608/72, $\boldsymbol{X}$ v. UK, Coll. 44, pp. 66-70 69, 215

5 februari 1973, zaken nrs. 5260 en $5277 / 71, X$ and $Y$ v. Austria, niet gepubliceerd 98

2 april 1973, zaak nr. 5460/72, Firestone Tire and Rubber Co. v. UK, Coll. 43, pp. 99. $110 \quad 387$

30 mei 1974, zaak nr. 5416/72, $X$ v. Austria, Coll. 46, pp. 88-93 221

30 mei 1974, zaak nr. 5488/72, X v, Belgium , Yearbook XVII, pp. 222-228 227

19 december 1974, zaak nr. 6577/74, X v. FRG, D\&R 1, pp. 91-92 221

16 maart 1975, zaak nr. 6202/73, $X$ and $Y$ v. the Netherlands, D\&R 1, pp. 66, 69-72 347,348

21 mei 1975, zaak 6564/74, X v. UK, D\&R 2, pp. 105-106 64, 99

29 september 1975, zaak nr. 6833/74, Marckx v. Belgium, Yearbook XVIII, pp. 248-

274; D\&R 3, pp. 112, 124-134 213

30 september 1975, zaak nr. 5935/72, X v. FRG, Yearbook XIX, pp. 276-290 200 1 oktober 1975, zaak nr. 6084/73, X v. UK, D\&R 3, pp. 62-69 64, 66, 68, 72, 89 2 oktober 1975, zaak nr. 6859/74, X v. Belgium. D\&R 3, pp. 139, 143-146 367 10 december 1975, zaak nr. 6958/75, $X$ v. Switzerland, D\&R 3, pp. 155, 157-158 347, 348

18 mei 1976, zaak nr. 6825/74, X v. Iceland, D\&R 5, pp. 86-87 203

18 mei 1976, zaak nr. 6886/75, $X$ v. UK, D\&R 5, pp. 100-102 72

19 mei 1976, zaak nr. 6959/75, Brüggemann and Scheuten, D\&R 5, pp. 103-116 70

21 mei 1976, zaak nr. 6741/74, $X$ v. Italy, D\&R 5, pp. 83-85 64

28 februari 1977 , zaak $\mathrm{nr}$. 7768/77, $X$ v. FRG, niet gepubliceerd 214

I maart 1977, zaken nrs. 6782, 6783 en 6784/74, $X, Y$ and $Z$ v. Belgium, D\&R 9, pp.

13. 19-22 70

9 maart 1977, zaak 7048/75, X v. UK, D\&R 9, pp. $42-44 \quad 83$

19 mei 1977, zaak nr. 7816/77, $X$ and $Y$ v. FRG, D\&R 9, pp. 219-221 222

6 juli 1977, zaak nr. 6696/74, Xv. UK, niet gepubliceerd 83

11 juli 1977 , zaak nr. 7626/76, $X v$. UK, D\&R 11, pp. 160, 165-168 221

14 juli 1977 , zaken nrs. $7289 / 75$ en $7349 / 76, X$ and $Y$ v. Switzerland, D\&R 9. pp. 57-76 214

4 oktober 1977, zaak nr. 5947/72, Silver a.0. v. UK. Publ.B. 51. pp. 121-125 7I

12 december 1977, zaak nr. 7911/77, $X$ v. Sweden, D\&R 12, pp. 192-194 69, 215 15 december 1977, zaak nr. 7229/75, $X$ and $Y$ v. UK, D\&R 12, pp. 32-35 22J

8 februari 1978, zaak nr. 7456/76. Wiggins v. UK. D\&R 13, pp, 40-48 228

10 juli 1978. zaak nr. 8257/78, $X$ v. Switzerland, D\&R 13, pp. 248, 251-253 69, 199 13 juli 1978, zaak nr. 8035/77, $X$ v. UK, EuGrZ 1979, pp. 20270

3 oktober 1978, zaak nr. 8166/78, $X$ and $Y$ v. Swirzerland, D\&R 13, pp. 241-244 64, 98

9 oktober 1978, zaak nr. 7610/76. $X$ v. UK, niet gepubliceerd 64

12 oktober 1978, zaak nr. 7308/75, Xv. UK, D\&R 16, pp. $32-3770$

4 december 1978, zaak nr. 8266/78, X v. UK, D\&R 16, pp. 190-192 68

I maart 1979, zaak nr. 8010/77, X v. UK, D\&R 16, pp. 101-103 72

1 maart 1979, zaak nr. 8209/78, Sutter v. Switzerland, D\&R 16, pp. 166, 171-175 367

5 mei 1979, zaak nr. 7805/77, X and Church of Scientology v. Sweden, D\&R 16, Pp. $68-75 \quad 73$

13 juli 1979 , zaak nr. $8615 / 79, X$ v. UK, niet gepubliceerd 213 
2 oktober 1979 , zaak nr. 8344/78, $X v$. UK, niet gepubliceerd 213

2 oktober 1979, zaak nr. 8512/79, X v. UK, niet gepubliceerd 387,388

11 oktober 1979, zaken nrs. 8348 en 8406/78, Glimmerveen en Hagenbeek, D\&R 18, pp. $187-197 \quad 106,609$

5 december 1979, zaak nr. 8157/78, $X$ and others $v$. UK, niet gepubliceerd 214

13 december 1979, zaak nr. 8278/78, $X$ v. Austria, D\&R 18, pp. 154-157 200

13 december 1979 , zaak nr. 8290/78, A, B, C and D v. FRG, D\&R 18, pp. 176-181 200

13 maart 1980, zaak nr. $8427 / 78, X$ v. Netherlands, D\&R 18, pp. 225-231 215

10 juli 1980 , zaak nr. 8158/78, $X$ v. UK, D\&R 21, pp. 95-102 351

16 juli 1980, zaak nr. 8440/78, Christians against racism and facism v. UK, D\&R 21, pp. $138-153 \quad 66$

18 december 1980 , zaken nrs. 8603/79, 8722/79, 8723/79 en 8729/79, Crociani, Palmiotti, Tanassi and Lefebvre d'Ovidio v. Italy, D\&R 22, pp. 147-149, 191-231 363

10 maart 1981, zaak 8924/80, $X$ v Switzerland, D\&R 24, pp. 183, 185-186 212

5 mei 1981, zaak nr. 9101/80, X v. FRG, niet gepubliceerd 203

16 juli 1981 , zaak nr. 8769/79, $X$ v. FRG, D\&R 25, pp. 240-241 387

8 december 1981, zaak nr. 9478/81, $X$ v. FRG, niet gepubliceerd 222

3 maart 1982, zaak nr. 9261/81, $X$ v. United Kingdom, D\&R 28, pp. 177-190 233

13 mei 1982, zaak nr. 8811/79, Seven individuals v. Sweden, D\&R 29, pp. 104-116

225

13 mei 1982, zaak nr. 8962/80, $X$ and $Y$ v. Belgium, D\&R 28, p. 112 e.v. 235

14 juli 1982, zaak nr. 9492/81, Family X. v. UK, D\&R 30, pp. 232-235 214, 280

8 oktober 1982, zaak nr. 9054/80, Xv. United Kingdom, D\&R 30, pp. 113-116 207

12 oktober 1982, zaken nrs. 8588/79 en 8589/79, Bramelid and Malmström v. Sweden.

D\&R 29, pp. 64, 76-86 354

1 maart 1983, zaak nr. 9664/82, niet gepubliceerd 69

5 maart 1983, zaak nr. 9615/81, X. Company v. UK, D\&R 32, pp. 231-236 70

3 mei 1983, zaak nr. 9327/81, $X$ v. the Netherlands, D\&R 32, pp. 187-188 233

3 mei 1983, zaak nr. 9369/81, $X$ and $Y$ v. Switzerland, D\&R 32, pp. 220-222 199

4 juli 1983, zaak nr. 10083/82, $R$ v. UK, D\&R 33, pp. 270-272 69

3 okwober 1983, zaken nrs. $9278 / 81$ en $9415 / 81, G$. and $E$. v. Norway, D\&R 35, pp. 30 -

$38 \quad 201$

3 oktober 1983, zaak nr. 9960/82, X v. Swizerland, niet gepubliceerd 330

12 oktober 1983, zaak nr. 9614/81, G, S and M v. Austria, D\&R 34, pp. 119-123 234

13 oktober 1983, zaak nr. 9870/82, $N$ v. Swizerland, D\&R 34, pp. 208, 210-212 66

17 november 1983. zaak nr. 9276/81. $C$ v. the United Kingdom, D\&R 35, pp. 13-21

292

15 maart 1984, zaak nr. 9639/82, B, R and J v. the Federal Republic of Germany, D\&R 36. pp. 130291

15 mei 1984, zaak nr. 9990/82, Bozano v. France, D\&R 39, pp. 119, 133-146 123 18 mei 1984, zaak nr. 9982/82, $X$ v. Belgium, niet gepubliceerd 387

10 december 1984, zaak 10375/83, $S$ and $S$ v. UK, D\&R 40, pp. 196-199 214

10 december 1984, zaak nr. 10435/83, Acmanne and others v. Belgium, D\&R 40. pp.

$251,255-257 \quad 200$

13 december 1984 , zaak nr. 10078/82, M v. France, D\&R 41, pp. 103, 113-122 63 8 maart 1985, zaak nr. 11002/84, Van der Heijden v. the Netherlands. D\&R 41. pp.

264. 268-271 73 
18 oktober 1985, zaak nr. 10825/84, R. and W. Howard v. United Kingdom, D\&R 52 , pp. $198-206233$

10 december 1985, zaak nr. 11046/84, Lant v. UK, D\&R 45, pp. 236-237 204

11 december 1985, zaak nr. 10473/83, Lundvall v. Sweden, D\&R 45, pp. 121-132 201

8 maart 1986, zaak nr. 10730/84, Berrehab en Koster v. Nederland, D\&R 41, pp. 196. 204-210; Rechtspraak Vreemdelingenrecht 1985, nr. 107273

14 mei 1986, zaak nr. $11716 / 85, S$ v. UK, D\&R 47, pp. 274-280 230, 231

7 juli 1986, zaak nr. 11579/85, Khan v. UK, D\&R 48, pp. 253-255 97, 98

10 juli 1986, zaak nr. 10871/84, Winer v. UK, D\&R 48, pp. 154-172 198

13 oktober 1986, zaak nr. 10153/82, $Z$ and $E$ v. Austria, D\&R 49, pp. 67-76 291

16 oktober 1986, zaak nr. 11366/85. $N$ v. Sweden, D\&R 50, pp. 173-176 291, 293

5 oktober 1987, zaak nr. 12139/86, $X$ v. the Netherlands, Rechtspraak Vreemdelingenrecht 1987, 93 met noot AHJS 223, 282

7 december 1987, zaak nr. 12495/86, Jonsson v. Sweden, D\&R 54, pp. 187-194 217

9 maart 1988, zaak nr. 12402/86, Price v. UK, D\&R 55, pp. 224-237 214

10 maart 1988, zaak nr. 11680/85, F v. Switzerland, D\&R 55, pp. 178-181 208

12 mei 1988, zaak nr. 12194/86, Kühnen v. FRG, D\&R 56, pp. 205-210 106

14 juli 1988, zaak nr. 12763/87, Lawlor v. UK, D\&R 57, pp. 216-233 214

12 oktober 1989, zaak 12774/87, H, W, $P$ and $K$ v. Austria, D\&R 62, pp. 216-221 106

9 november 1989, zaak nr. 14573/89, Eriksson and Goldschmidt v. Sweden, D\&R 63, pp. 213-216 97

25 februari 1991, Beckers v. the Netherlands, NJCM-Bulletin 17-2 (1992), pp. 184-191

met noot E.M. Peeters 81, 448

16 april 1991, zaak nr. 15404/89, Purcell and others v. Ireland, D\&R 70, pp. 262-280 106

9 september 1992, zaak nr. 16810/90, Reyntjens v. Belgium, NJCM-Bulletin 18-3 (1993), pp. 337-339 met noot $A$.W. Heringa 202

\section{Uitspraken van de Hoge Raad}

7 november 1892, Weekblad van het Recht nr. 6259534

31 mei 1939, NJ 1939, $769 \quad 551$

28 november 1950, respectievelijk NJ 1951, 137 (Tilburg), 138 (Sittard I) en 369 (Sittard II) 551

10 juni 1952. NJ 1952, $688 \quad 559$

17 maart 1953, NJ 1953, $389 \quad 559,566,603$

13 april 1960, NJ 1960, $436 \quad 153,189$

24 januari 1967. NJ 1967, 270 met noot W.F. Prins 550

30 mei 1967 , NJ $1968,5 \quad 581$

30 mei 1967. NJ 1968, 64 met noot van Van Eck 153

4 november 1969 , NJ $1970,127 \quad 189$

11 mei 1976, NJ 1976, $540 \quad 583$

15 juni 1976, NJ 1976, $551 \quad 477.495$

20 september 1976, NJ 1977, 28248

26 mei 1977, NJ 1978, $417 \quad 252$

4 november 1977, NJ 1978, 418 met noot E.A.A. Luijten 252

10 april 1979, NJ 1979, 374 met noot Th.W. van Veen 286, 310 
14 april 1980, NJ 1981, 401 met noot Th.W. van Veen 386

2 mei 1980, NJ 1980, 537 met noot E.A. Alkema 251

24 juni 1980 , NJ 1981, $659 \quad 554$

6 januari 1981. NJ 1981, 515 met noot G.E. Mulder, MRT 1981, pp. 535-553 met naschrift W.H. Vermeer 422

17 februari 1981, NJ 1981, $299 \quad 581,583,591$

25 september 1981, 13 november 1981, 19 maart 1982, 16 april 1982, 7 mei 1982 en 25 juni 1982, NJ 1982, 557-562 met noot E.A. Alkema 251

27 oktober 1981, NJ 1982, $103 \quad 554$

2 maart 1982, NJ 1984, 133 met noot $J A B$ onder 5 april 1983, NJ 1984, $134 \quad 179$, 534. 594

25 juni 1982, AB 1983, 37 met noot F.H. van der Burg; NJ 1983, $295 \quad 577,604$

25 juni 1982, NJ 1983, 296 met noot E.A. Alkema 577, 604

10 december 1982, NJ 1983, 411 met noot E.A.A. Luijten 252

5 april 1983, NJ 1984, 134 met noot $J A B \quad 534,561,594$

24 juni 1983, NJ 1984, 801 met noot $M S \quad 568$

28 juni 1983, NJ 1984, 64; DD 1983, $453 \quad 179,534,560,594$

28 juni 1983 , NJ $1984,65 \quad 562$

1 juli 1983, NJ 1984, $128 \quad 252$

23 december 1983, NJ 1985, $170 \quad 248$

27 januari 1984, NJ 1984, 802 en 803 met noot CHJB 568

30 maart 1984, AB 1984, 366 met noot F.H. van der Burg; NJ 1985, 350 met noot E.A.

Alkema; NJCM-Bulletin 9-3 (1984), pp. 253-258 met noot M.B.W. Biesheuvel (pp. 256-258) 516, 530

4 mei 1984, NJ 1985, 510 met noten van E.A. Alkema en E.A.A. Luijten 267

12 oktober 1984, NJ 1985, 230 met noot $G \quad 462$

23 november 1984, NJ 1985, 604455

22 februari 1985, NJ 1986, 3 met noten van E.A. Alkema en E.A.A. Luijten 3, 252

8 maart 1985, NJ 1986, 437, waarin een uitleg van 24 juni 1983, met noot $C H J B \quad 568$

10 mei 1985, NJ 1986, 5 met noot W.H. H 252

19 juni 1985. NJ 1986, 104; BNB 1986/29 met noot J.P. Scheltens; Weekblad FED 1985, 644 met noot Ch.J. Langereis 393, 408

15 juli 1985. NJ 1986, $6 \quad 252$

21 januari 1986. NJ 1986, 441 met noot Th. W. van Veen: AB 1986. 572 met noot $E . A$. Alkema 179,560

II februari 1986, NJ 1986, 673 met noot Th.W. van Veen 186, 193, 556, 623

11 maart 1986. NJ 1986, 613 met noot A.C. 't Hart 477, 495

21 maart 1986, NJ 1986, 585-588 met noten van E.A. Alkema en E.A.A. Luijten 267

16 mei 1986. NJ 1986, $627 \quad 252$

10 juni 1986. NJ 1987, $133 \quad 554,562$

I juli 1986. NJ 1987, $217 \quad 477,484,495$

9 september 1986. NJ 1987, 259 met noot A.C. 't Hart 422

14 oktober 1986. NJ 1988, $511 \quad 237,246$

31 oktober 1986, NJ 1987, 173 met noot Th. W. van Veen (vervolg op Gerechtshof 's-

Gravenhage 13 december 1984) 497, 499, 500,527

12 december 1986. NJ 1988. 188 met noot E.A. Alkema 272

12 december 1986. NJ 1987, 381 met noot MS $4 / 6$ 
9 januari 1987, NJ 1987, 928 met noot E.A. Alkema; AB 1987, 231 met noot F.H. van der Burg: Computerrecht, 1987/2, pp.110-115 met noot E.J. Dommering: NJCMBulletin, 1987, jaargang 12-4, pp.298-305 met noot L.F.M. Verhey 16, 237, 307, 613

6 februari 1987 (ARAL-arrest), NJ 1988, 926 met noot M. Scheltema; AB 1987, 272 met noot F.H. van der Burg; Bouwrecht 1987, p.520-533 met noot N.S.J. Koeman (pp.531-533); De Gemeentestem 1988, pp.88-91 met noot L.J.A. Damen (pp.90-91) 413

27 maart 1987, AB 1987, 273 met noot F.H. van der Burg $\quad 453,457,459$

26 mei 1987, NJCM-Bulletin 12-8 (1987), pp. 620-624 met noot A. W. Heringa 549, 555

5 juni 1987, NJ 1988, 702 met noot E.A. Alkema, AB 1988, 276 met noot J.A. Hofman en B.M.J. van der Meulen; NJCM-Bulletin 14-3 (1989), pp. 296-304 met noot M.M. den Boer (vervolg op: Pres.Rb. Zwolle 13 september 1985, AB 1986, 236 en Gerechtshof Arnhem 29 september 1986, AB 1987, 199) 510, S1I

23 juni 1987, NJ 1988, $222 \quad 561$

16 oktober 1987, NJ 1988, 850 met noot E.A. Alkema 240

20 oktober 1987, NJ 1988, 447 met noot A.C. 't Hart 248, 249

17 november 1987. NJ 1988, 394 met noot Th. W. van Veen 545

11 december 1987, NJ 1990, 73; NJCM-Bulletin 13-1 (1988), p. $121 \quad 541$

18 december 1987, NJ 1988, 844 met noot A.H.J. Swart 274

18 december 1987. NJ 1989, 527 met noot MS, AB 1988, 569 met noot FHvdB, De Gemeentestem 1988, nr. 6858, p. 279 met noot L.J.A. Damen, Bouwrecht 1988, p. $367 \quad 416$

22 december 1987, DD 88.171 (1988, p. 486) 422

5 januari 1988, De Gemeentestem no. 6872, nr. 5 met naschrift Brederveld, NJCMBulletin 14-4 (1989), pp. 439-446 met noot R.E. de Winter 562, 563, 568

9 februari 1988. NJ 1989, 109422

4 maart 1988, NJ 1989, $4 \quad 387$

4 maart 1988, NJ 1989, 361 met noot CJHB 568

15 maart 1988, NJ 1988, 847 met noot Th.W. van Veen 425

25 maart 1988, NJ 1989. 3 met noot WHH 387

8 april 1988, NJ 1989, 170 met noot E.A.A. Luiten 266

17 mei 1988, NJ 1989. $230 \quad 422$

25 mei 1988, NJ 1988, 927: Bouwrecht 1987, p. $761 \quad 413$

25 mei 1988. NJ 1988, 928 met noot $M$. Scheltema en met noot van E.A. Alkema onder NJ $1988,930 \quad 413,417$

25 mei 1988, NJ 1988, 930 met noot E.A. Alkema 413, 419

17 juni 1988, NJ 1988, 956253

22 juni 1988, NJ 1988, 955 met noot Th.W. van Veen; BNB 1988/292 met noot J.P. Schellens 393

1 juli 1988, NJ 1988, 1000 met noot $L W H \quad 241$

8 juli 1988, BNB 1988, 302 met noot Scheltens 448

15 juli 1988, BNB 1988/270, FED 1988/706 394, 405

7 september 1988, BNB 1988/298 405, 410

18 oktober 1988, NJ 1989. 476 met noot GEM: NJCM-Bulletin 14-3 (1989), pp. 296-304 met noot M.M. den Boer (vervolg op: Rb. Zwolle 9 oktober 1986. Migrantenrecht 1986, p. 275 e.v. en Gerechtshof Arnhem 29 mei 1987. NJ 1987. 816. AB 1988, 275. AA 1988, p. 119 e.v.; na verwijzing: Gerechtshof Leeuwarden 16 maart 1989, NJ $1989,810) \quad 510,514$ 
26 oktober 1988, BNB 1989/16 met noot J.P. Scheltens 393, 405

23 november 1988, AB 1989, 120 met noot F.H. van der Burg; BNB 1989/29 met noot J.P. Scheltens 409

24 februari 1989, NJ 1989, 742 met noten van E.A. Alkema en E.A.A. Luijten

267

21 maart 1989, NJ 1989, 864 met noot Th. W. van Veen 245

28 april 1989, NJ 1990, 213 met noot $M S \quad 413,416$

3 mei 1989, NJ 1991, 167 met noot E.A. Alkema; BNB 1989/256 met noot J.P.

Scheltens 388

3 juli 1989 , NJ $1989,857 \quad 387$

15 september 1989, NJ 1990, 322 met noot E.A.A. Luijten en E.A. Alkema 245

18 september 1989, NJ 1990, 94 met noot Th.W. van Veen; NJCM-Bulletin 15-3 (1990),

pp. 291-298 met noot R.E. de Winter 545, 546

25 september 1989, NJCM-Bulletin 14-8 (1989), pp. 950-952 met noot R.E. de Winter 564

3 oktober 1989, NJ 1990, 443 met noot G.E. Mulder 253, 256

11 oktober 1989, BNB 1990/87 met noot J.P. Scheltens 394

13 oktober 1989, NJ 1990, 412394

17 oktober 1989. NJ 1990, 222, AB 1990, 318 met noot F.H. van der Burg. NJCM-

Bulletin 15-4 (1990), pp. 444-450 met noot R.E. de Winter 555, 562, 564

10 november 1989 , NJ 1990, 450 met noot E.A.A. Luijten 266

10 november 1989, NJ 1990, 628 met noten van E.A. Alkema en E.A.A. Luijten; ;

NJCM-Bulletin 15-5 (1990), pp. 581-588 met noot J. van der Velde 3, 210, 256, 260, 268, 307

17 november 1989, NJ 1990, 496 met noot JBMV 394

20 december 1989. BNB 1990/102 met noot $F$. Ploeger 394. 411

12 januari 1990, NJ 1990, 574 met noot $M S \quad 414$

17 januari 1990, BNB 1990/193 met noot J.P. Scheltens 394

24 januari 1990, BNB 1990/287 met noot H.J. Hofstra 405

26 januari 1990. NJ 1992, 602 met noot E.A. Alkema 388

26 januari 1990. NJ 1990, 630. Nemesis 1990, 89, p. 94 (vervolg op Rb.(kinderrechter)

Utrecht 8 november en 14 december 1988, NJ 1989, 237 en Gerechtshof Amsterdam

17 april 1989. NJ 1989.692) 254, 261

31 januari 1990, BNB 1990/93 410

2 februari 1990, NJ 1990, 289 met noot E.A. Alkema (vervolg op: Pres. Rb. Zwolle 6 mei 1987, KG 1987. 236 en Gerechtshof Arnhem 9 februari 1988, beiden uitspraken in: NJCM-Bulletin 14-3 (1989). pp. 317-331) 510,513, 514

23 maart 1990. NJ 1991. 150 met noot E.A.A. Luijten 268

18 mei 1990, NJ 1991, 374 en 375 met noten E.A.A. Luijten en E.A. Alkema 266

6 juni 1990. NJB, afl. 29 (1990), nr. 10, pp. 1176-1177 49I

2 juli 1990. NJ 1990, 692 met noot Th.W. van Veen 403

19 september 1990. BNB 1990/320 met noot G.J. van Leijenhorsi 203

2 oktober 1990. NJ 1991, 130 met noot $C \quad 403$

19 oktober 1990. NJ 1992, 129 met noten van E.A.A. Laijten en E.A. Alkema, en met noot $L$. Mulder in: Tijdschrift voor Bestuurswetenschappen en Publiekrecht 1991, pp. 307-312 (vervolg op Rb.Rotterdam 5 december 1988 en Gerechtshof 's-Gravenhage 2 juni 1989. NJ 1989, 871) 247

6 november 1990, NJ 1991, 218 met noot 't Hart; AB 1991, 109 met noot F.H. van der Burg 466 
13 november 1990, NJ 1991, 219 met noot Th. W. van Veen; BNB 1991/134; FED 1991. $246 \quad 430$

27 november 1990, NJ 1991, 220 met noot Th.W. van Veen 425

30 november 1990, NJ 1992, 94 met noot HJS onder Kig. 's-Hertogenbosch 31 juli 1990. NJ 1992, $95 \quad 424,431$

21 december 1990, NJ 1991, 741 met noten van E.A.A. Luijten en E.A. Alkema 266

1 februari 1991, NJ 1991, 413 met noot Th. W. van Veen 388

8 februari 1991, NJ 1992, 21 (met noot E.A.A. Luijten onder 7 juni 1991, NJ 1992, 25) 260

8 februari 1991, NJ 1992, $22 \quad 261$

19 februari 1991, NJ 1992, 50 met noot G.J.M. Corstens 239, 244, 613

20 februari 1991. NJ 1991, 463 met noot $M S \quad 431$

22 februari 1991, NJ 1991, 376 met noot E.A.A. Luijten 267

26 februari 1991, NJ 1991, 509 met noot Th.W. van Veen 429

5 april 1991, NJ 1992, $24 \quad 261$

14 mei 1991, NJ 1991, 695 met noot 't Hart 429

16 oktober 1991. BNB 1991/343 met noot G.J. van Leijenhorst 395

8 november 1991, NJ 1992, $440 \quad 266$

11 december 1991, BNB 1992/243 met noot J.P. Scheltens 394

13 december 1991. NJ 1992, $575 \quad 271$

13 december 1991, NJCM-Bulletin 17-5 (1991), pp. $522-528$ met noot P. Minderhoud:

LBR-Bulletin, 1992, nr. 1, pp. 12-21 met noot $P$. Rodrigues 474, 486

20 december 1991, NJ 1992, $180 \quad 421$

20 december 1991, NJ 1992, 598 met noot E.A.A. Luijten 266

11 februari 1992. NJ 1992, 692400

20 maart 1992, NJ 1992, 495 met noot PAS 474, 487

24 april 1992, NJ 1992, $478 \quad 262$

24 april 1992, NJ 1992, 672 met noot PAS 387

8 mei 1992, NJ 1992, 708 met noot AHJS; AB 1992, 634 met noot $R$. Fernhout 275

26. mei 1992, NJ 1992, 676 met noot 't Hart 429

9 juni 1992, NJ 1992, 776286

10 juni 1992. BNB 1992/274 394

12 juni 1992. NJ 1992, $589 \quad 245,261$

16 juni 1992 , NJ 1992, $819 \quad 429$

17 juni 1992, BNB 1992/277 401

19 juni 1992, NJ 1993, 487 met noot $M M M \quad 240$

23 juni 1992, De Gemeentestem no. 6961, nr. 4: NJB, afl. 31 (1992), rechtspraak Hoge

Raad (strafkamer), nr. $127 \quad 543$

30 juni 1992, NJ 1993, 194 met noot Sch. $\quad 426,429$

29 september 1992. NJ 1993, 58 met noot $K n .429$

30 september 1992. NJ 1994, 495 met noot E.A. Alkema 447

2 oktober 1992, NJ 1992, $768 \quad 259$

13 oktober 1992, NJ 1993, $142 \quad 429$

10 november $1992, \mathrm{NJ} 1993,197 \quad 542$

18 november 1992 , BNB $1993 / 40$ met noot $P$.J. Wattel 394,412

18 november 1992 , NJ 1993, $174 \quad 388$

15 december 1992. NJ 1993, 550 met noot AHJS 246

8 januari 1993, NJ 1993, 558 met noot HJS 387

22 januari 1993, AB 1993, 198 (Rost van Tonningen) met noot F.H. van der Burg 
26 januari 1993, NJ 1993, $534560,562,566$

9 februari 1993, NJ 1993, 646542

12 februari 1993, NJ 1993, 599 met noten van E.A. Alkema en HJS 246

19 februari 1993, NJ 1993, 624 met noot van A.H.J. Swart 249

28 mei 1993, NJ 1993, 625 met noot A.H.J. Swart 280, 311

11 juni 1993, NJ 1993, 560263

29 juni 1993, NJ 1993, $692 \quad 286,429$

15 juli 1993. NJ 1994, 177 met noot $C \quad 394,405$

17 september 1993, NJ 1994, 373 met noten WH-S en E.A. Alkema 267

22 oktober 1993, NJ 1994, 153 met noot WH-S 261

9 november 1993, NJ 1994, 199405

19 november 1993, NJ 1994, 330 met noot WH-S 269

17 december 1993, NJ 1994, $360 \quad 262,263$

18 januari 1994, FED 1994, 437 met noot M.W.C. Feteris 429,430

21 januari 1994, NJ 1994, 473 met noot DWFV (vervolg op: Gerechtshof Amsterdam 3 december 1992) $242,539,569$

29 maart 1994, NJ 1994, $537 \quad 240,286$

15 april 1994, NJ 1994, $576 \quad 270$

22 april 1994, NJ 1994, 560, met noot E.A. Alkema 455

\section{Uitspraken van de gerechtshoven}

Gerechtshof 's-Gravenhage 16 april 1980, NJCM-Bulletin 5-6 (1980), pp. 368-373 met noot A.H.J. Swart 389

Gerechtshof 's-Gravenhage 3 februari 1984, NJ 1985, $504 \quad 400$

Gerechtshof 's-Gravenhage 13 december 1984, in: HR 31 oktober 1986, NJ 1987, 173 met noot Th.W. van Veen

Gerechtshof 's-Gravenhage 11 oktober 1985, NJ 1987, $454 \quad 255$

Gerechtshof 's-Gravenhage 26 juni 1986, RSV 1987, 39 457, 494

Gerechtshof 's-Gravenhage 5 november 1987, NJ 1988, $1010 \quad 161$

Gerechtshof 's-Gravenhage 2 juni 1989. NJ 1989, 871 (vervolg op Rb.Rotterdam 5 december 1988 en vervolgd in: HR 19 oktober 1990. NJ 1992, 129) 247

Gerechtshof "5-Gravenhage 7 december en 26 april 1991. NJ 1992, $102 \quad 268$

Gerechtshof 's-Gravenhage 26 september 1991, NJ 1992, 347275

Gerechtshof 's.Gravenhage 29 november 1991, in: HR 2 oktober 1992, NJ 1992, 768 (vervolg op $\mathrm{Rb}$.(kinderrechter) ' $\mathrm{s}$-Gravenhage 21 augustus 1991)

Gerechtshof 's-Gravenhage 1 oktober 1992, NJCM-Bulletin 18-3 (1993) met noot A.W. Heringa, pp. 299-302 (vervolg op Pres.Rb. 's-Gravenhage 9 juni 1987, KG 1987, 268) $573,578,609$

Gerechtshof Amsterdam 10 maart 1983, NJ 1984, $352 \quad 568$

Gerechtshof Amsterdam 13 september 1984, NJ 1985, 409544

Gerechtshof Amsterdam 17 februari 1986, KG 1986, $138 \quad 413$

Gerechtshof Amsterdam 9 juli 1987. KGK 1987, 1079; KG 1987, p. 808392

Gerechtshof Amsterdam 10 december 1987. NJCM-Bulletin 14-3 (1989), pp. 312-317 met noot $C$. Waaldijk. pp. 324-331 (hoger heroep van Pres.Rb. Utrecht 5 maart 1987. idem, pp. 305-312) 482 
Gerechtshof Amsterdam 17 april 1989, NJ 1989, 692 (vervolg op Rb.(kinderrechter) Utrecht 8 november 1988 en 14 december 1988, NJ 1989. 237 en bevestigd in HR 26 januari 1990, NJ 1990, 630) 254, 261

Gerechtshof Amsterdam 6 september 1990, LBR-Bulletin 1990, nr. 6, pp. 27-32 met noot Pattipawae: Tijdschrift voor Consumentenrecht 1990. pp. 396-399 486

Gerechtshof Amsterdam 18 maart 1991, NJ 1992, 449285

Gerechtshof Amsterdam 5 maart 1992, KG 1992. 126, met noot L.F.M. Verhey, in: NJCM-Bulletin 17-6 (1992), pp. 643-645 245

Gerechtshof Amsterdam 21 december 1992, NJ 1994, 131266

Gerechtshof Amsterdam 19 januari 1995. NJCM-Bulletin 20-5 (1995), pp. 585-590 met noot $T$. Loenen 265

Gerechtshof 's-Hertogenbosch S september 1989, RV 1989, 96 met noot B.P. Vermeulen; KG 1989, 394; NJCM-Bulletin 15-5 (1990), pp. 589-594 met noot $R$. de Winter en NJ 1990, $377 \quad 517$

Gerechtshof 's-Hertogenbosch 22 december 1989, KG 1990, 487 502, 528

Gerechtshof 's-Hertogenbosch 1 oktober 1990 en 7 mei 1991. NJ 1992, 53248

Gerechtshof 's-Hertogenbosch 18 september 1991, NJ 1991, 796, met noot $F$. Kuitenbrouwer, in: Computerrecht 1992/2, p. 73 e.v. en L.F.M. Verhey, in: NJCMBulletin 17-2 (1992) pp. 156-161 245

Gerechtshof 's-Hertogenbosch 2 september 1993, NJ 1994, 283266

Gerechtshof Arnhem 11 juli 1984, NJ 1985, $536 \quad 500,528$

Gerechtshof Arnhem 16 september 1985, KG 1985, $403 \quad 165$

Gerechtshof Arnhem 29 september 1986; AB 1987, 199; NJCM-Bulletin 14-3 (1989), pp. 296-304 met noot M.M. den Boer (vervolg op: Pres.Rb. Zwolle 13 september 1985, AB 1986, 236; in cassatie: HR 5 juni 1987, NJ 1988, 702, AB 1988, 276) 510

Gerechtshof Arnhem 29 mei 1987, NJ 1987, 816; AB 1988, 275 met noot J.A. Hofman en B.M.J. van der Meulen onder AB 1988, 276; AA 1988, p. 119 e.v. met noot S.A.M. Stolwijk: NJCM-Bulletin 14-3 (1989), pp. 296-304 met noot M.M. den Boer (vervolg op: Rb. Zwolle 9 oktober 1986, Migrantenrecht 1986, p. 275 e.v.; in cassatie: HR 18 oktober 1988, NJ 1989, 476; na verwijzing: Gerechtshof Leeuwarden 16 maart 1989. NJ 1989,810 ) 502, 510, 514

Gerechtshof Arnhem 9 februari 1988, NJCM-Bulletin 14-3 (1989), pp. $317-331$ met noot C. Waaldijk (vervolg op: Pres.Rb. Zwolle 6 mei 1987, KG 1987, 236; in cassatie: HR 2 februari 1990. NJ 1990, 289) 513

Gerechtshof Arnhem 12 juli 1988, KG 1988, $338 \quad 165$

Gerechtshof Arnhem 25 juli 1989, KG 1989, 323568

Gerechtshof Leeuwarden 16 maart 1989, NJ 1989, 810 (vervolg op: Rb. Zwolle 9 oktober 1986, Migrantenrecht 1986, p. 275 e.v.; Gerechtshof Arnhem 29 mei 1987. NJ 1987, 816; AB 1988, 275: AA 1988, p. 119 e.v. en HR 18 oktober 1988, NJ 1989. 476) 510,514 
Pres.Rh. 's-Gravenhage 5 juni 1985, KG 1985, $196 \quad 491$

Pres.Rb. 's-Gravenhage 18 april 1986, KG 1986, $222 \quad 456,494$

Pres.Rb. 's-Gravenhage 3 mei 1986, KG 1986, $248 \quad 483$

Pres.Rb. 's-Gravenhage 9 juni 1987, KG 1987, 268 (bevestigd in Gerechtshof 'sGravenhage 1 oktober 1992, NJCM-Bulletin 18-3 (1993) met noot A.W. Heringa, pp. 299-302) $573,577,604,609$

Rb. 's-Gravenhage 6 juli 1988, NJCM-Bulletin 14-2 (1989), pp. 181-192 met noot $G$. Heerma van Voss 419

Pres.Rb. 's-Gravenhage 14 december 1990, NJCM-Bulletin 16-2 (1991), pp. 128-134 met noot R.E. de Winter 564,611

Pres.Rb. 's-Gravenhage 25 januari 1991, KG 1991, 71 280

Rb.(kinderrechter) 's-Gravenhage 21 augustus 1991, in: HR 2 oktober 1992, NJ 1992, 768

Pres.Rb. 's-Gravenhage 14 mei 1992, KG 1992, $271 \quad 458$

Pres.Rb. 's-Gravenhage 25 mei 1994, TAR 1994, $166 \quad 447,491$

Pres.Rb. 's-Hertogenbosch 25 juni 1985, KG 1985, $217 \quad 520,531,603,623$

Rb. Alkmaar 25 november 1993, TAR 1994, $50 \quad 539$

Pres.Rb. Amsterdam 26 januari 1984, KG 1984, $111 \quad 398,439,604$

Rb. Amsterdam 18 april 1984, NJCM-Bulletin 10-1 (1985), pp. 57-64 met noot $F$. $H$. Kistenkas 563

Pres.Rb. Amsterdam 13 september 1984, KG 1984, 280 474, 483

Pres.Rb. Amsterdam 18 oktober 1984, KG 1984, $320 \quad 568$

Pres.Rb. Amsterdam 22 augustus 1985, KG 1985, $267 \quad 489$

Pres.Rb. Amsterdam 6 februari 1986, KG 1986, $118 \quad 568$

Pres.Rb. Amsterdam 18 juni 1987, KG 1987, $277 \quad 391$

Pres.Rb. Amsterdam 25 februari 1988, KG 1988, $128 \quad 392$

Pres.Rb. Amsterdam 22 september 1988, KG 1988, $423 \quad 513$

Pres.Rb. Amsterdam 11 juni 1991, KG 1991, 242, met noot A. Sas, in: NJCM-Bulletin,

1991, jaargang 16-6, p.560 e.v. (vernietigd in hoger beroep, Gerechtshof Amsterdam

5 maan 1992, KG 1992, 126) 245

Rb. Amsterdam 14 januari 1992, NJ 1992, $401 \quad 267$

Pres.Rb. Amsterdam 28 april 1994, KG 1994, 171546

Rb. Armhem 8 februari 1985, NJCM-Bulletin 10-4 (1985), p. 303, met noot F.H. Kistenkas 563 :

Pres.Rb. Armem 24 februari 1989, KG 1989, $114 \quad 517,530$

Rb. Armhem 22 mant 1990, NJ 1990,671 431

Rb. Assen 16 augustus 1983, NJ 1984, 318; AA 33 (1984) 6, p. 324 e.v. met noot Kormann 166

Pres.Rb. Assen 2I maart 1994, FED 1994, ar. 399, pp. 1769-1771 met noot $M$.W. C. Feteris; NiCM-Bultetin 20-1 (1995), pp. 28-31 met noot $N$. Verheij 402,439

Rb, Breda 4 oktober 1982, in: HR 28 juni 1983, Nj 1984, 65562

Rb. Breda 11 juni 1987, KG 1987, $265 \quad 501,528$

Rb. Breda 30 oktober 1987, KG 1987, 501 502, 528 
Rb. Dordrecht 27 mei 1992, NJ 1993, $128 \quad 249$

Pres.Rb. Groningen 7 okıober 1987, NJ 1987, $455 \quad 24 I$

Pres.Rb. Groningen 26 mei 1994, KG 1994, 320540

Rb. Haarlem 10 maart 1981, NJ 1981, 451; NYLL 1982, pp. 337-338 400

Rb. Haarlem 12 april 1983, NJ 1987, 339568

Rb. Haarlem 28 juni 1988, AB 1989, 213; NJCM-Bulletin 14-1 (1989), pp. 43-51 met noot $P$. Minderhoud 484, 496

Pres.Rb. Haarlem 17 februari 1989, KG 1989, $134 \quad 502,528$

Pres.Rb. Haarlem 4 juli. 1994, KG 1994, 322445

Rb. Leeuwarden 8 juli 1987, NJ 1988. $144 \quad 477,495$

Rb. Leeuwarden 20 september 1993. NJ 1994, $327 \quad 430$

Pres.Rb. Maastricht 1 april 1985, NJ 1985. $618 \quad 569$

Rb. Maastricht 4 juli 1989, AB 1989, $423 \quad 465$

Rb. Maastricht 26, november 1991. NJ 1992, 167

Pres.Rb. Middelburg 5 december 1984, KG 1985, 18568

Pres.Rb. Middelburg 29 januari 1990, KG 1990, 81 564, 611

Pres. Rb. Roermond 12 september 1985, KG 1985, 299: NJCM-Bulletin 11-1 (1986) met noot $T$ j. Gerbranda, pp. 74 e.v. 242

Rb. Roermond 3 januari 1995. NJCM-Bulletin 20-4 (1995), pp. 431-438 met noot J.M.E. Derks $160,165,193$

Rb, (kinderrechter) Rotterdam 29 mei 1985, in: Gerechtshof 's-Gravenhage 11 oktober 1985, NJ 1987, 454

Rb. Rotterdam 5 december 1988, in: Gerechishof 's-Gravenhage 2 juni 1989. NJ 1989. 871 (vervolg: HR 19 oktober 1990, NJ 1992, 129)

Pres. Rb. Rotterdam 10 april 1989, KG 1989, $196 \quad 187$

Rb. Roterdam 27 juh 1990, Migrantenrecht 1990, 10, pp. 143-149 474, 496

Rb.(kinderrechter) Rotterdam 15 augustus 1991, NJ 1991, $847 \quad 426$

Pres.Rb. Rotterdam II mei 1994, KG 1994, 248 445

Pres.Rb. Urrech 5 maan 1987, NICM-Bulletin 14-3 (1989), p1), 305-312 met noot $C$. Waaldijk, pp. 324-331 (hoger beroep: Gerechtshof Ansterdam 10 december 1987 , idem, pp. 312-317) 513

Rb.(kinderrechter) Utrecht 8 november 1988 en 14 december 1988, NJ 1989, 237 (hoger beroep: Gerechtshof Amsterdam 17 april 1989, NJ 1989, 692, bevestigd in HR 26 januari 1990, NI 1990, 630) 254

Rb. Utrecht 10 januari 1990, NI 1990, 624245

Pres. Rb. Utrecht 16 april 1993, KG 1993.223 569

Rb. Zutphen 22 december 1983, NJ 1984, $319 \quad 166$

Rb. Zutphen 14 december 1989, NI 1991, $90 \quad 388$

Rb. Zutphen 3 april 1992, NI 1993, $260 \quad 248$

Rb. Zutphen 11 mei 1995. NJCM-Bulletin 20-5 (1995), pp. 598-605 met noot $G$. Heerma van Voss 472 
Rb. Zwolle 21 mei 1985, NJ 1986, $116 \quad 444,492$

Pres.Rb. Zwolle 13 september 1985, AB 1986, 236 met noot P.J. Boon; NJCM-Bulletin 14-3 (1989), pp. 296-304 met noot M.M. den Boer (hoger beroep: Gerechtshof Arnhem 29 september 1986, AB 1987, 199; cassatie: HR 5 juni 1987. NJ 1988, 702; AB 1988, 276) 510

Rb. Zwolle 6 februari 1986, NJ 1986, $454 \quad 477,495$

Rb. Zwolle 9 oktober 1986. Migrantenrecht 1986, p. 275 e.v.; NJCM-Bulletin 14-3 (1989), pp. 296-304 met noot M.M. den Boer (hoger beroep: Gerechtshof Arnhem 29 mei 1987. NJ 1987, 816, AB 1988, 275; AA 1988, p. 119 e.v.; cassatie: HR 18 oktober 1988. NJ 1989. 476; na verwijzing: Gerechtshof Leeuwarden 16 maart 1989. NJ 1989,810$) \quad 510,514$

Pres.Rb. Zwolle 6 mei 1987, KG 1987, 236 (hoger beroep: Gerechtshof Arnhem 9 februari 1988, beiden uitspraken in: NJCM-Bulletin 14-3 (1989), pp. 317-331 met noot C. Waaldijk; cassatie: HR 2 februari 1990, NJ 1990, 289) 510. 511, 611

Uitspraken van de (Voorzitter van de) Afdeling Rechtspraak van de Raad van State

ARRS 19 oktober 1978, tB/S III, p. $517 \quad 550$

ARRS 28 februari 1980, Vreemdelingenrecht Jurisprudentie D13-52, p. 301 e.v. 282 ARRS 29 juli 1980, RV 1980, 46 met noot redactie; NJCM-Bulletin, jaargang 5-6 (1980), pp.368-373 met noot A.H.J. Swart 388

ARRS 22 januari 1981, De Gemeentestem no. 6692, nr. $2 \quad 554$

ARRS 28 april $1981, \mathrm{AB} 1981,480 \quad 554$

ARRS 20 augustus 1981, De Gemeentestem no. 6692, nr. 3555

ARRS 10 december 1981. AB 1982. $244 \quad 518$

Vz.ARRS 27 mei 1982, AB 1983, 62 met noot J.H. v.d. V.; NJCM-Bulletin 8-2 (1983). pp. 141-146 met noot A. Kors; Ned.Gem. 1982, no. 31, pp. S147/148 met noot M.A.C. van Egdom en J.M.H.F. Teunissen S81, 584

ARRS 7 april 1983, AB 1983, 430 met noot P.J. Boon · 507, 529

Vz.ARRS 30 mei 1983. AB 1984, 85 met noot P.J. Boon: De Gemeentestem no. 6756. nir. 3 met neot J.M. Kan 584

ARRS 26 juli 1983. AB 1983, 587 met noot Crince le Roy 458

ARRS I atgustus 1983, AB 1984. 532 met noot B.J. van der Net; NJCM-Bulletin 9-2 (1984). pp. 156 e.v. met noot J.E. Goldschmidt 449, 494, 505, 529, 609 Vz.ARRS 9 maart 1984, KG 1984, 128, AB 1985, $192 \quad 550$

ARRS 2 juli 1984. AB 1985, 273 met now $R$. Fernhout en J.A. Hofman: RV 1984, 37 met noot C.A. Groenendijk: AA 1985, 488 met noot P.W.C. Akkermans 519. 532 ARRS 21 maart 1985, AB 1986. 16 met noot P.J.J. van Butren 506, 529

Vz.ARRS 20 juni 1985. KG 1985. 281: RV 1985. 118 met not Bo $520.526,531$. $532,606,623$

Vz.ARRS 17 oktober 1985, AB 1986, $288 \quad 521$

ARRS 14 november 1985. AB 1986, $458 \mathrm{met}$ noot P.J.J. van Buuren

549. 555

ARRS 23 januari 1986, AB 1986. 284 met noot J.A.O. Eskes 170

ARRS 10 april 1986. Weekoverzicht RvS/R.3.314/86. :B/S $1986 \mathrm{nr} .73 \quad 541$

ARRS 23 juni 1986, AB 1987, 17 met noot J.H. van der Veen 460, 461, 495

ARRS 18 december 1986. AB 1987, $260 \quad 505,529$

ARRS 19 januari 1987. AB 1988, 58 met noot P.J. Boon

$550,554,560,566,603$ 
ARRS 12 maart 1987, AB 1987, 287 met noot I.C. van der Vlies 506, 529

Vz.ARRS 28 april 1987, Bouwrecht 1987, pp. 600-601 413, 418

Vz.ARRS 22 september 1987, AB 1988, 249585,604

Vz.ARRS 3 november 1987, De Gemeentestem no. 6855, nr. 5 met noot $E$. Brederveld $542,551,553$

Vz.ARRS 6 november 1987, KG 1988, 65 448, 462, 493

ARRS 8 januari 1988, AB 1988, 417575

ARRS 8 april 1988, AB 1988, 357 met noot van J.H.vdV. 541, 551, 553

ARRS 8 april 1988, AB 1989, 88 550, 554, 566

Vz.ARRS 10 mei 1988, AB 1989, 86 met noot J.H. van der Veen 390-391

Vz.ARRS 30 juni 1988, KG 1988, $349 \quad 165$

Vz.ARRS 16 februari 1989, AB 1990, 9 met noot P.J. Boon; tB/S 1989, nr. 20 met noot

M.C.B.; AA 1990, pp. 398-402 met noot P.W.C. Akkermans; De Gemeentestem, no.

6883, nr. 11, pp.359-360 met naschrift J.M.H.F. Teunissen 52I, 531, 593, 623

Vz.ARRS 21 maart 1989, AB 1989, 498 met noot A.E. Schilder onder AB 1989, 499;

KG 1989, $158 \quad 170,585,604$

ARRS 24 april 1989, AB 1990, 300 met noot H.J. Simon en B.M.J. van der Meulen 282 ARRS 8 mei 1989 (zaak Feyereisen), RV 1989. 93276

Vz.ARRS 1 juni 1989, AB 1989, 499 met noot A.E. Schilder; KG 1989, 272 195, 585

Vz.ARRS 10 augustus 1989, KG 1989, 341, De Gemeentestem no. 6889, nr. 4179.

551,553

Vz.ARRS 28 september 1989, KG 1990, 28 448, 462, 466, 493

ARRS 16 oktober 1989 (zaak Augustin, nr. RO2.97.1013) 276

Vz.ARRS 15 maart 1990, De Gemeentestem no. 6904, nr. 9 551, 553

Vz.ARRS 15 maart 1990, De Gemeentestem no. 6907, nr. 3 551, 553

ARRS 20 juni 1990, NJB, afl. 32 (1990), nr. 4, pp. 1287-1289 491

ARRS 3 juli 1990, NJCM-Bulletin 16-5 (1991), pp. $430-436$ met noot $S$.W.E. Rutten 282

Vz.ARRS 17 augustus 1990, AB 1991, 44 met noot P.J. Boon; De Gemeentestem, no.

- 6913, nr. 3 met noot $B \quad 521,523,566-568$

ARRS 14 februari 1991. NJCM-Bulletin 17-2 (1992), pp. 163-164 met noot N. Albayrak (pp. 165-167) 277, 278

Vz.ARRS 14 februari 1991. NJCM-Bulletin 17-2 (1992). pp. 164-165 met noot $N$. Albayrak (pp. 165-167) 278

ARRS 8 april 1991. AB 1991, 624 met noot $R$. Fernhout 277, 311, 604

ARRS 14 april 1991. AB 1991, 625 met noot $R$. Fernhout 277, 278, 311. 604

ARRS 17 april 1991 (zaak Steinmeiz. RO2.88.2462) 275

ARRS 24 juni 1991, AB 1992, 26 met noot P.J. Boon; De Gemeentestem ng. 6930, nr.

3 met noot E. Brederveld 542

ARRS 15 juli 1991, De Gemeentestem no. 6931, nr. $6 \quad 566,567$

ARRS 4 maart 1992 (zaak Bhattoe), AB 1992, 632 met noot $R$. Fernhout onder nr. 634

275

ARRS 13 april 1992, AB 1992, 631 met noot A.H.J. Swarl onder AB 1992, 634276

ARRS 1 mei 1992, AB 1992, 633 met noot $R$. Fernhout onder AB 1992, 634275

ARRS 16 juni 1993, AB 1994, 424 met noot van C. Riezehos 524

ARRS 31 augustus 1993, AB 1994, 14 491

Vz.ARRS 15 oktober 1993. AB 1994, $178 \quad 475$ 
Uitspraken van andere (al dan niet) rechterlijke instanties en de Nationale Ombudsman

\section{Kantongerechten}

Ktg. Dordrecht 14 april 1983, Praktijkgids 1984, 2068 met noot J.W. Soek 400 Ktg. Nijmegen 10 september 1986, RV 1986, 78 met noot $A C P$; Rechtspraak Rassendiscriminatie 1986, 131486

Kıg. Nijmegen 22 februari 1989, Praktijkgids 1989, nr. 3066, pp. 286-288 563

Ktg. 's-Hertogenbosch 31 juli 1990, NJ 1992, 95 met noot HJS 424

Ktg. Amsterdam 25 maart 1992, NJ 1992, 435400

Ktg. Utrecht 28 septernber 1992, in: HR 15 juli 1993, NJ 1994, 177

De (Vooritter van de) Afdeling voor Geschillen van Bestuur van de Raad van State

Vz.AGBRS 26 april 1991. De Gemeentestem no. 6931, nr. 7 met noot Brederveld 556,623

AGvBRS 3 februari 1992, AB 1992, 199503

AGvBRS 3 april 1992, AB 1992, 483 met noot AFMB 506

AGvBRS 10 november 1992, AB 1993, 88 met noot B.J. van der Net 503

AGvBRS 10 november 1992, AB 1993, 522 met noot B.J. van der Net 503

AGvBRS 20 november 1992. AB 1993, 241 met noot I. Sewandono 556

Vz.AGvBRS 14 juni 1993. AB 1993, 458 met noot B.J. van der $\mathrm{Net} 503$

\section{(Centrale) Raad van Beroep}

RvB Roermond 29 augustus 1990. NJCM-Bulletin 16-4 (1991) met noot I.P. AsscherVonk, pp. 309-316 491

CRvB 5 april 1983, RSV 1983, $146 \quad 457,494$

CRvB 14 februari 1984, RSV 1984, 112458

CRvB 17 april 1984, RSV 1984, $194 \quad 515,530$

CRvB 17 aprii 1984, RSV 1984, $195 \quad 515,530$

CRvB 11 mei 1984. RSV 1984, $234 \quad 461.495$

CRvB 7 augustus 1984. RSV 1985, 28 515, 530

CRvB 3 januari 1985. NJB. afl. 8 (1985), ar. 6. p. 262: TAR 1985, nr. 59550

CRvB 23 april 1985, AB 1986, 37, RSV 1985, 218 515, 530

CRvB 23 mei 1985, TAR 1985, $173 \quad 458$

CRvB 12 novemter 1985, AB 1986, 579 met norol C.A.J.M. Kortmann en H.Ph.J.A.M.

Hennekens: NJCM-Bulletin 11-2 (1986), pp. $157-163$ met noot F.H. Kistenkas; reactie R.E. de Winter. in: NJCM-Bultetin 11-3 (1986), pp. 237-238; reactie daarop F.H.

Kistenkas, in: NJCM-Bulletin I1-5 (1986). pp. 449-451 567

CRvB 4 juni 1986. RSV 1987, 16500

CRvB 5 juni 1986, TAR 1986, nr. 208550

CRvB 5 juni 1986, TAR 1986, 2099539

CRvB 13 november 1986. nr. MAW 1985/27, AB 1987, 456 met noot H.Ph.J.A.M. Hennekens 446

CRvB 13 november 1986, nr. MAW 1985/32, ontleend aan TAR 1987, 13446

CRvB 13 november 1986, nr. MAW 1985/41. TAR 1987, 13 met noot C.J.G. Olde Kalter op pp. 254-259 446, 447 
CRvB 12 mei 1987, RSV 1987, $234 \quad 460,495$

CRvB 16 november 1989, nr. AW 1987/313, TAR 1990, 13 en NTOR 2 - 17 mei 1990, pp. 97-102, met noot van L.F.M. Verhey en B.P. Vermeulen 194

CRvB 14 maart 1991, TAR 1991, 105 met noot G.L. Coolen 445, 449, 506, 609

CRvB 25 maart 1993. TAR 1993, 99 met noot C.J.G. Olde Kalter 447, 464, 471-473, 491

CRvB 4 november 1993. TAR 1994, $4 \quad 470,494$

CRvB 4 november 1993, AB 1994, 213 met noot $H H$; TAR 1994, 6 468, 491, 494

\section{Koninklijke Besluiten}

KB 4 december 1984, Stb. 685, AB 1985, 163 met noot B.J. van der Net 502, 528 KB 23 januari 1985 (gemeente Muiden), Stb. 92, AB 1986. 118 met noot B.J. van der Net onder KB 13 november 1985, nr. 18, AB 1986, 119460,495

KB 13 november 1985, nr. 18, AB 1986, 119 met noot B.J. van der Net 460,495

KB 10 januari 1986, nr. 76, Jurisprudentie ABW 1986, 154482

KB 5 juni 1986, Stb. 337, AB 1986, 569 met noot B.J. van der Net 542

KB 22 oktober 1986, AB 1987, $194 \quad 515,530$

KB 29 mei 1987, Stb. $365 \quad 542$

KB 20 april 1989, AB 1989, $304 \quad 557$

Overigen

CBS 3 maart 1989, AB 1990, 182 met noot A.F.M. Brenninkmeijer 452, 492

College van Beroep voor het Bedrijfsleven 31 maart 1988, AB 1988, 567 met noot van R.M. van Male 391

Hof van Justitie Ned. Antillen en Aruba 28 oktober 1986, NJ 1988, 532400

Nationale Ombudsman 3 november 1989, AB 1989, $564 \quad 452,475,492$

Nationale Ombudsman 9 september 1993, AB 1994, 22 met noot PJS 586 


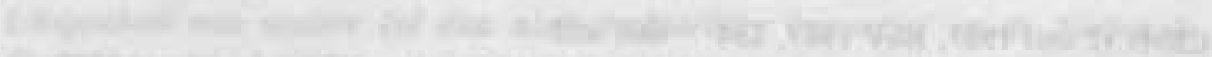

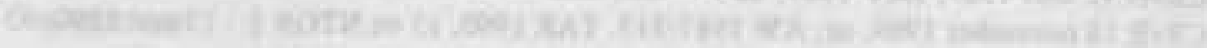

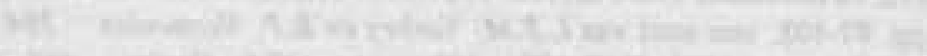

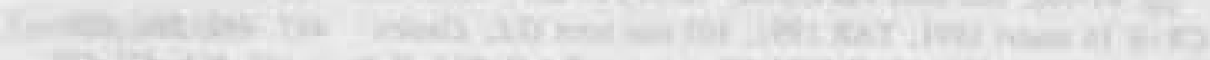

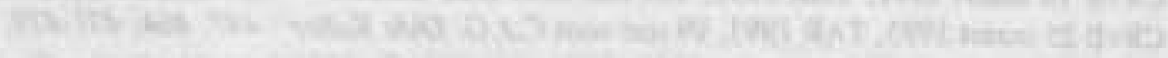

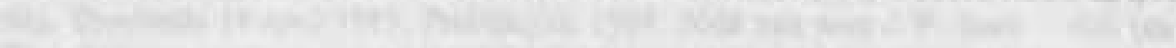

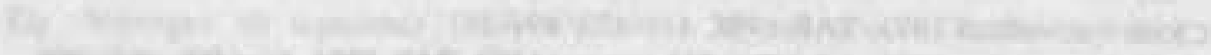

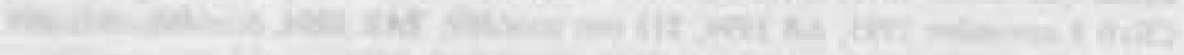
19.

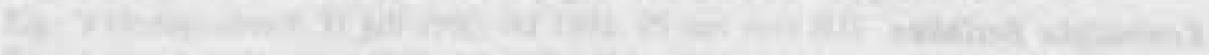

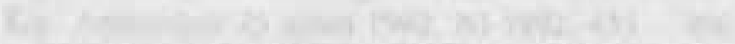

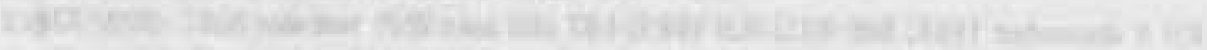

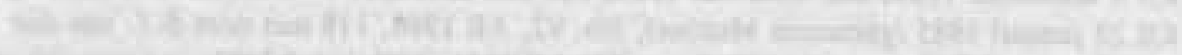

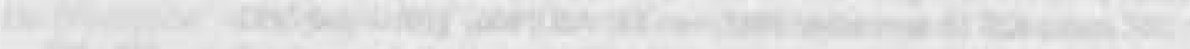

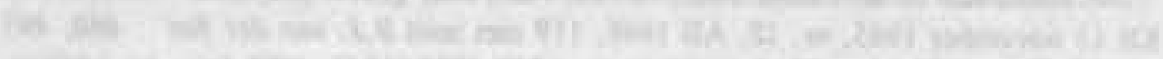

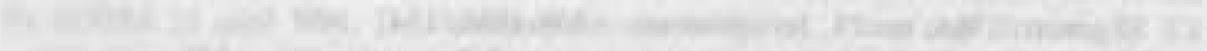

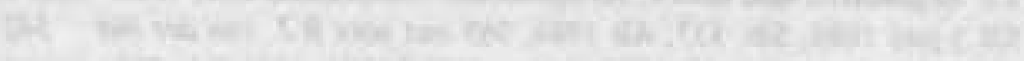
2.

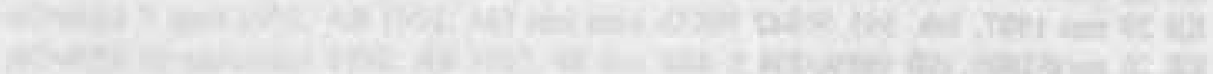

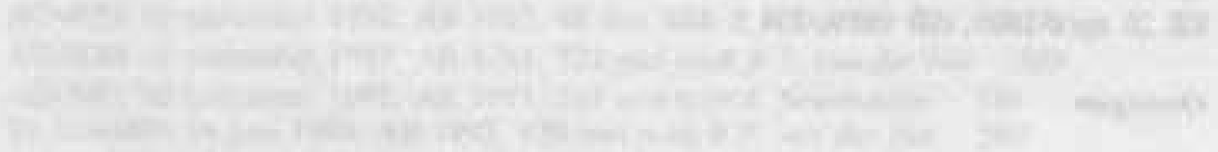

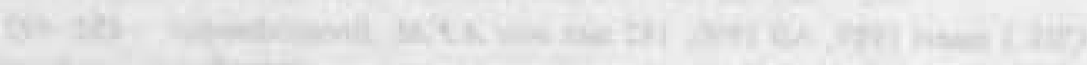
artan

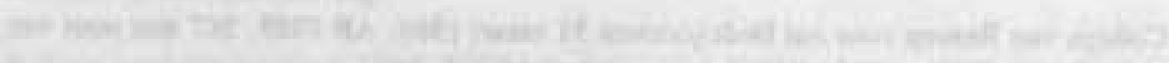

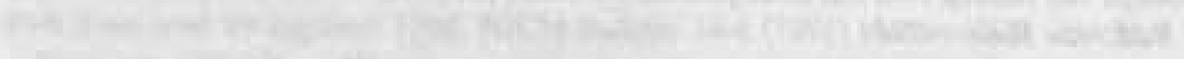

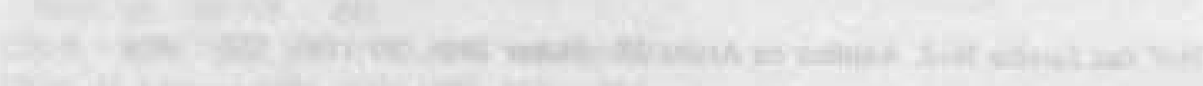

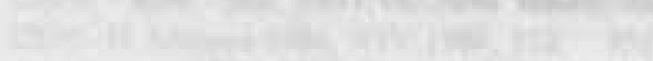

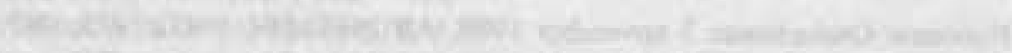

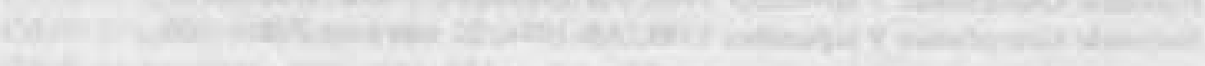

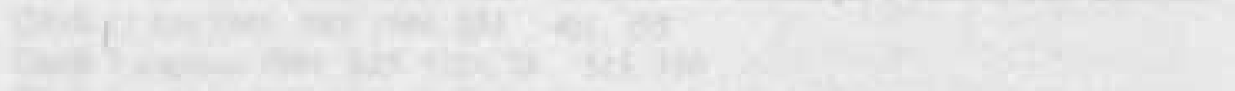

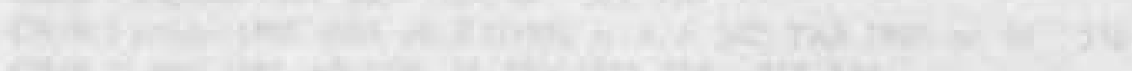

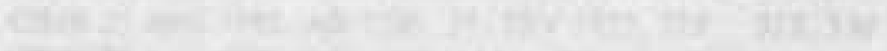

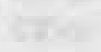

and

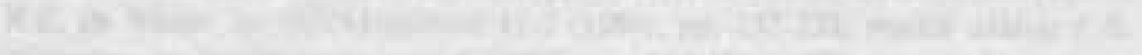

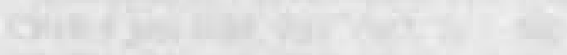

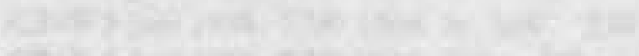

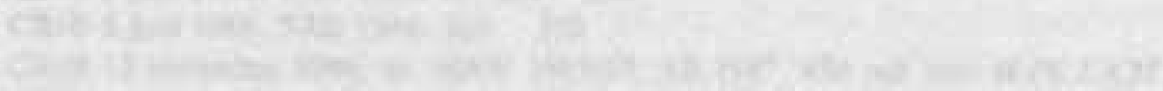

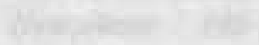

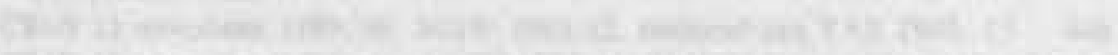

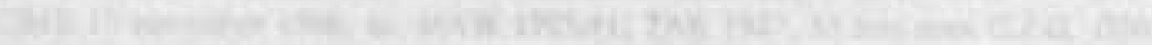

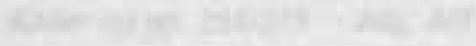




\section{Trefwoordenregister}

\section{Aanwijzingen voor de regelgeving 650-651 \\ aard van het recht, zie ook: beoordelingsvrijheid 637 \\ accessoir karakter $114,121,123-125$ \\ administratieve procedures $354,405,618$ \\ afbakeningscriteria, categorieěn 600 \\ - effectieve nut ("effet utile") 597, 602-604, 607 \\ - het verbod van misbruik van recht 597, 609-615 \\ - non-discriminatie-criterium 608-609 \\ - proportionaliteitsbeginsel 597,604-607 \\ - recht op een "fair trial" 82-84, 92, 607-608 \\ - rule of law 434-438, 600-602 \\ - de (subjectieve) keuze van het rechtssubject 613-614 \\ afstand van recht ("waiver") $341-347,434,435,601,614$ \\ - afwezigheid van dwang 342-345, 435, 601 \\ - vrije wil justitiabele $345,436,601$ \\ - wijze van afstand doen $346,436,601$}

algemeen belang 167,168

Algemene wet gelijke behandeling $165,474-476,477,481,489-492,495-496,638$ autonome verordeningsbevoegdheid gemeente/provincie $154,160,163-165,189$

"behoudens ieders verantwoordelijkheid volgens de wet" $156,158,160,441,496,514$, $531,534,546,547,592-593,608,626$

- repressieve beperking bij formele wet $544-546,547,592-593,608,626$

belangenafweging $25,86-87,91,292-294,297-298,301,311,337,340,435,526,531$.

$532,593,605-606,622,623,625-626,630,635,640,645-646$

beoordelingsvrijheid, -marge ("margin of appreciation") 61, 74-92, 93-94, 96, 108-111,

$120,292,294,295,297-298,299,301,311,336,340,350,357-358,435,471-472$, $494,551,601,602,608,615-617,626,629-630,640-644,645$

- aard van de ingeroepen beperkingsgrond $79,91-92,615$

- aard van het ingeroepen recht $80,91,615$

- bestaan van een Europese maatstaf́ 79, 88-89, 92

beperking, algemene $7,14,18,150-157,186-188,192-194,196,514,520-527,531$ $532,557,593,622,632,634,644-648$

beperking, bijzondere $7,150-158,527,632,645$

beperking door middel van inperking van de reikwijdte van het recht, zie ook: inherente beperking $3,4,5,10,596$

beperking, "ongeschreven" 154, 192-193, 632, 634, 644-645

beperkingsinogelijkheden $2,25,99-100,134,599-600,628,636,644,646-652$

beperkingssystematiek $6,7,9,31,51,149,182,186,615,621-622,631,634,647-648$, 652

beperkingsvoorwaarden

- voorzien zijn bij wet (zie ook: wet; quality of the law; toegankelijkheid; voorzienbaarheid) $55-56,58-62,91,615,643$

- gericht op een legitiem doel (zie ook: nationale veiligheid; openbare veiligheid; openbare orde; wanordelijkheden; strafbare feiten; gezondheid; goede zeden; rechten en vrijheden van anderen) $55-56,62-73,91,337-340,601,605,615,624,626$ 
- noodzakelijkheid in een democratische samenleving (zie ook: democratische samenleving: pressing social need; proportionaliteitsbeginsel; belangenafweging; relevant and sufficient reasons; beoordelingsvrijheid; recht op respect voor gezinsleven, - uitbreiding met procedureel element; gedragscode) 56, 74-92, 171, $526-527,606,615,624,643,648-652$

- zie ook: competentievoorschriften; procedurevoorschriften; doelcriteria betoging, recht op (art. $9 \mathrm{Gw}$ ), zie ook: recht op vergadering 612

- grondrecht-gerechtigde, zie: recht op vergadering

- het begrip "betoging" 579-584

- collectieve uitoefening 579, 583, 591

- in beslotenheid of in het openbaar $579,583,591$

- doel bijeenkomst: uiting geven aan gevoelens of wensen op maatschappelijk en politiek gebied 580-582, 583, 591

- grens: acties met karakter dwangmaatregelen 580, 583, 591

- verband tussen actie en doel (uitoefenen dwang) $580,583,591$

- grens: onaantastbare aantasting van de rechten van anderen, zie ook: bescherming van de rechten en vrijheden van anderen $580,584,591$

- band tussen deelnemers 581,591

- afbakening t.o.v. art. $7 \mathrm{Gw}$ : uitingen of gedragingen als wezenlijk onderdeel betoging 582

- zorgplicht overheid in geval van hostile audience, zie ook: positieve verplichtingen $584-587,589,604,606$

- vrees voor intolerant gedrag derden 584, 589, 594,604,623

- weloverwogen inschatting van omvang verwachte ongeregeldheden 586

- adequate politie-inzet 586, 589, 604,606, 624

- situatie redelijkerwijs niet meer in de hand te houden 586, 589,604, 623-624 - evenredigheidstoetsing, zie ook: proportionaliteitsbeginsel 586, 589,624

- subsidiariteit: kan volstaan worden met lichtere maatregel 586, 590, 624 boete, fiscale of andere administratieve 393-394, 404-413

botsing van grondrechten $\quad 87$

Brussels Treaty Organisation $\quad 34-35$

censuur, zie: vrijheid van meningsuiting: vrijheid van vergadering: vrijheid van betoging coherente en duidelijke regeling van een recht 337-339, 435, 625

communautair recht 103

competentievoorschriften (zie ook: beperkingsvoorwaarden) 158-165, 632, 649

connex recht, zie ook: kern van het recht/kernrecht 82-84, 152. 179-182, 536

correspondentie, recht op respect voor de (art. 8 ECRM) 234-236, 285-287, 310

- begrip "coirespondentie" 234-235, 285-287, 310

- afluisteren 286, 310

Déclaration des droits de l'homme et du citoyen 2

delegatie (van grondrechten beperkende bevoegdheid) 155-156, 158,632, 648

delegatie-terminologie 155, 158

democratische samenleving $57,89,615$

derogatie $107-112,176$

détournement de pouvoir (t.a.v. beperkingsbevoegdheden) (art. 18 ECRM)

184, 629

discriminatie, zie ook: discriminatieverbod: onderscheid

$474-476,493$

123, 172, 
discriminatie-verbod, zie ook: gelijkheidsbeginsel (art. 1 Gw, art. 14 ECRM) 114-12I, $213,220,226,465-467,539,618-620,629$

- pejoratieve betekenis $462-464,466$

- non-discriminatiegronden (persoonsgebonden groepsattributen) 463-473, 494

- gelijkheid van gevallen $116,465,492$

- objectieve en redelijke rechtvaardigingsgrond (legitiem doel) 117-120, 468-473, $485-489,620$

- toetsing aan het discriminatieverbod 467-473, 493, 494

- proportionaliteitsbeginsel 117

doelcriteria, zie ook: beperkingsvoorwaarden, - gericht op een legitiem doel 158, 166 171, 632, 644, 649

drukpers, vrijheid van, zie: vrijheid van meningsuiting

effectiviteit van de uitoefening van een recht (effectieve nut of "effet utile"), zie ook: positieve verplichtingen $348-352,398-403,434,436,438,524,577-579,604,607-$ $608,640-642,645$

Europees Congres 32

Europese Beweging 35, 37

fair trial, recht op een (art. 6 ECRM), zie ook: administratieve procedures 219,618,640

- vaststelling van burgerlijke rechten en verplichtingen $24,302,313-314,315,318$, $326-327,618$

- bepaimg van de gegronaneid van een ingesieiue suarvervorgmg $24,3 x-3 x, x$, , 326,618

- recht op toegang tot de rechter, zie: toegang tot de rechter

formuleren v.d. rechten en beperkingen, wijze van $51,628,634$

- nauwkeurige definiëring $51-54,95,134,151,628$

- opsomming 51,628

gebruik van enige betekenis, zie ook: vrijheid van meningsuiting $524,531,554-558,559$ $569,570-571,579,602-604,612$

gedetineerden 331-334, 338, 369, 573, 577, 619-620

gedragscode 158, 171-173, 181, 526, 606, 624, 648, 652

gelijkheidsbeginsel, zie ook: discriminatieverbod (art. I Gw) 172, 465-467, 539, 573.

$595,618-620,626$

- gelijkheid van gevallen 443-447

- differentiatiecriterium, zie ook: non-discriminatiegronden 443-445, 453-456. $464,473,492$

- differentiatiedoel 443-445, 453-454, 473, 492

- ongelijke behandeling van gelijke gevallen 447-451,626

- objectieve en redelijke rechtvaardiging 447-451, 454-456, 493, 495, 595, 620, 626

- proportionaliteitsbeginsel $\mathbf{4 4 8}$

- subsidiariteitsbeginsel 447.448

- toetsing aan het gelijkheidsbeginsel, zie ook: toetsing aan het discriminatieverbod 449, 494

- ongelijke behandeling van ongelijke gevallen 451-453, 483, 492

- afwijking van vast overheidsbeleid 456-459, 494

- verschillen in beleid in verband met decentralisatie 459-462, 495, 596 
gerecht ("tribunal"), zie ook: jurisdictie rechter 358-362, 436

- bindende beslissing ("power of decision"; "determination of matters") 360

gezinsleven ("family life"), recht op respect voor het (art. 8 ECRM) 201, 211-226, 229. 307-310

- bestaan/ ontstaan van gezinsbetrekking tussen/ in geval van:

- bloedverwanten 212,249,269,271, 281, 308

- onwettige kinderen, zie ook: non-discriminatie-criterium 213, 216-218, 228, 261-267, 301, 608

- biologisch ouderschap 251-256, 264-265, 266

- samenleving op één lijn met huwelijk 262, 265, 266, 307

- bigamie/polygamie 223-224, 281-283, 310

- niet-biologisch ouderschap, zie ook: - feitelijke omstandigheden 256-259

- adoptie 270, 272-274, 275

- uitzetting/toelating vreemdelingen, 221-222, 272-284, 296, 309, 311, 603

- volgen van partner naar ander land, zie ook: "eigen schuld"-criterium 221222, 275-276, 614

- positieve verplichtingen, zie ook: positieve verplichtingen 278-279, 281 . 284

- volwassen kinderen 280,309

- homoseksualiteit, zie ook: recht om te huwen 199, 226, 247-248, 257

- feitelijke omstandigheden $256-265,266,271,273,279,283,304,305,306,307-$ 308

- afbakeningscriteria:

- non-discriminatie-criterium 213, 216, 225-226, 608-609

- "required link"-criterium 213-216, 218, 224, 225, 228-229

- "eigen schuld"-criterium 221-222, 226, 276-278, 309, 614

- "normal emotional ties" 214, 280, 283

familie band niet verbroken door latere gebeurtenissen $261,265,275,307,309$. 614

- keuzevrijheid opvoeding 224-225

- uitbreiding met procedureel element 219-220, 607-608

gezondheid, bescherming van de ("protection of health") $68-69.168,170$

godsdienst, vrijheid van; zie ook: vrijheid van levensovertuiging (art. $6 \mathrm{GW}$ ) $4.611-612$, 622

- begrip "godsdienst" 497-503, 527, 638

- rechterlijke rerughoudendheid 500-503, 517, 528

- begrip "belijden" 506-509

- term "ieder" 509.592

- discriminerende en beledigende uittatingen $510-515,612$

- ongenuanceerde, ongemotiveerde en kennelijk misleidende uitlatingen 512-513. $530,595,611-612$

- inspanningsverplichting bij uitoefening recht $515.5 ! 7,530,593$

- gebruiksbepaling bij bestemmingsplan, zie ook: herleidbaarheid tot een specifieke (formele) wetsbepaling: algemene beperking; restrictieve interpretatie; gebruik van enige betekenis $520-524,603,606,62 !$

goede zeden, bescherming van de ("protection of morals") $\quad 69-71.168,170$ 
grenzen van beperkingsbevoegdheden, zie ook: beperkingsvoorwaarden 113-126, 184, $594,601,618,628-629,632$

- zie: discriminatieverbod; verbod van verdergaande beperking dan bij de Conventie is voorzien; détournement de pouvoir

grondrechten, - functies $I$

grondrechten, klassieke $11,289,302,303$

grondrechten, sociale 11,303

heightened scrutiny-test 467

herleidbaarheid tot een specifieke (formele) wetsbepaling $14,155-157,195,514,520$ $525,532,593,596,633,635-636,644-652$

Hinderwetvergunning, zie ook: vrijheid van meningsuiting, - voorafgaand verlof 185 , $186,555-557,622$

hostile audience, zie: recht op vergadering: recht op betoging

huwen, recht om te $96-99,247$

"ieder" ("everyone") zie: gelijkheidsbeginsel; vrijheid van godsdienst; vrijheid van levensovertuiging

inherent (impliciet) recht $321,433,535,593,601,602,606$

inherente beperking $493,588,595,601,602,605,618-620,625$

- i.v.m. de bijzondere status van een groep justitiabelen (personen in een bijzondere rechtsverhouding tot overheid), zie ook: gedetineerden $5,189,332-333,539,573$, 618-620

- i.v.m. het inherente karakter van het recht dat wordt beperkt $325,331,339,433$, $536,593,601,602,606,619$

inmenging ("interference") 57-58, 91

Internationaal Verdrag inzake Burgerrechten en Politieke Rechten (IVBPR) 4, 9, 34, $111,249,507$

Internationaal Verdrag inzake de Uitbanning van Alle Vormen van rassendiscriminatie (IVRD) 477, 485, 495

interpretatie, autonome 24

interpretatie: context van het verdrag $21,317,318-320$

interpretatie, extensieve $321-325$

interpretatie, objectieve 20,322

interpretatie, restrictieve $3,14,26,31,77,185,188,322-323,326,521-525,548,604$, $617,621,633,645-646,652$

interpretatie: voorwerp en doel van het verdrag $\quad 21,205,317,318,324-325$

interpretatie-methoden $12,13,15,19,317$

interpretatie-methode, grammaticale 16, 317, 324

interpretatie-methode, rechtshistorische 16

interpretatie-methode, systernatische 18, 21

interpretatie-methode, teleologische (sociologische) $17,18-19,22-24,324,642,646,649$ interpretatie-methode, wetshistorische $16,19,22$

interpretatieve verklaringen (zie ook: voorbehouden) $\quad 128-130$

jurisdictie rechter, volledige ("full jurisdiction") 355-357, 406-408

kern van het recht/ kernrecht $10,31,82-84,85,97,152,179-182,334-337,339-340$,

$386,435,536,601,603,607-608,616-617,625,645$

Kroonberoep $\quad 405,413-420$ 
levensovertuiging, vrijheid van, zie ook: vrijheid van godsdienst (art. $6 \mathrm{Gw}$ )

612

- begrip "levensovertuiging" 504-506

- nevenschikking van vrijheid van godsdienst en van levensovertuiging 505,529

- begrip "belijden" 506-509, 529

- term "ieder" 509, 530, 592

- inspanningsverplichting bij uitoefening recht $515-517,593$

meningsuiting, vrijheid van (art. $7 \mathrm{Gw}$, art. 10 ECRM) 84-85, 89-90, 181, 534, 610-

$612,616,622,626$

- "niemand" 539

- gedachten en gevoelens 539-543, 569

- informatie/inlichtingen 540,569

- handelsreclame 540-543, 569

- openbaringsrecht, zie ook: "behoudens ieders verantwoordelijkheid volgens de wet" $152,179,533,544-547,570,626$

- verspreidingsrecht $152,179,533,544-547,570,593-594,596,626$

- zelfstandig middel van bekendmaking 549-551, 570-571, 603

- algemeen verbod 551, 559,570

- gebruik van enige betekenis, zie ook: kwalitatieve toetsing 555-557, 558$569,570-571,595,603$

- voorafgaand verlof 552-559, 571, 593-595

- verbod van (preventieve) censuur 537, 546, 552, 588

- overige preventieve beperking 544, 552, 593,626

* vergunningen- of ontheffingsstelsel 553-558, 571, 593

- inhoud van het geopenbaarde $537,547-549,558,570$

- vorm van het geopenbaarde $537,547-549,570$

- preventieve beperking, zie: verspreidingsrecht

minimum-scrutiny-test 468

misbruik van recht, verbod van (art. 17 ECRM) 103-107, 172, 609-613, 628

nationale veiligheid ("national security") 63

negatieve verplichtingen 9. 10, 289, 293, 295, 297, 299, 300, 302, 310, 434, 602, 604, 605, 608, 643-644

nodstandfeste rechten, zie ook: noodtoestand: uitzonderingstoestand $1 / 3$ non-discriminatiebegiasel, zie: discriminatieverbod

non-discriminatiegronden, zie ook: discriminatieverbod 463-472, 476-491

- burgerlijke staat 475, 483-484

- geslacht $468,472,475,478$

- godsdienst 475, 478, 480

- handicap 489-491

- hetero- of homoseksuele gerichtheid $475,481-484$

- leeftijd 468-472, 489-491

- levensovertuiging 475, 478, 480

- nationaliteit 475, 481, 483-489, 496

- in etnische zin, zie: ras

- in staatkundige zin 486-489, 496

- "op welke grond dan ook" 469-473, 481, 494, 496

- politieke gezindheid 475, 478-479

- ras $467,475,476,484-488,495$ 
- taal 491

noodtoestand, zie ook: uitzonderingstoestand; nodstandfeste rechten (art. 15 ECRM, art. $103 \mathrm{Gw}) \quad 107,109,632$

noodverordeningsbevoegdheid burgemeester 194-196, 636, 648 noodzakelijkheidsvereiste, zie: beperkingsvoorwaarden, - noodzakelijkheid in een democratische samenleving

\section{omgangsrecht 611}

onafhankelijkheid van de rechter ("independence") $359,365-375,422-424,437,602,637$

- onafzetbaarheid/ benoeming voor een vaste periode 366-368, 422-423, 437

- niet onder instructie van het bestuur of van de partijen 368, 370, 422-423

- grondregel "justice must not only be done, but also seen to be done" 369,423

- organisatorische scheiding van het bestuur 370-371, 423

- gelijkheid partijen bij invloed op samenstelling gerecht 376

onderscheid $474-476,493$

- indirect onderscheid 473, 476, 486-487

onpartijdigheid van de rechter ("impartiality") 359, 375-385, 422-432, 436-437, 602, 637

- gelijkheid partijen bij invloed op samenstelling gerecht 376

- objectieve test $377-383,424-430,437$

- subjective test $377-378,383,424,437$

- grondregel "justice must not only be done, but also seen to be done" $375-376,423$

- legitieme reden om gebrek aan onpartijdigheid te vrezen 378-383, 430

- objectief gerechtvaardigde vrees 380-383, 425-430, 437

openbare veiligheid ("public safety") $\quad 64-65$

openbare orde, bescherming van de ("protection of public order) 65-67, 167-170, 625

plakverboden, zie: vrijheid van meningsuiting, - gebruik van enige betekenis positieve actie, zie: voorkeursbehandeling

positieve verplichtingen $6,7,9,84,278-279,281,284,287-303,310-311,347-352$,

$401,434,577-579,602,603,605,623-624,630-631,640-644$

- afbakening "respect" in art. 8 ECRM 289, 294, 298, 302, 310, 603

- beoordelingsvrijheid, zie: beoordelingsvrijheid

- belangenafweging, zie; helangenafweging

pressing social need $76,86,91,615,643,649$

privéleven, recht op eerbiediging van het (art. 8 ECRM) 198-211, 237-250, 304.307

- artikel 10 Nederlandse Grondwet 237, 249

- artikel 11 Nederlandse Grondwet 249

- begrip "privé-leven"

- doelcriterium: ontwikkeling en vervulling van de persoonlijkheid 203-205, 207. $305-306,613$

- zakelijke activiteiten 208-209, 210

- grens: openbaarheids-criterium: de mate waarin het privéleven in verband staat met het openbare leven $3,203-206,305,625$

- ruimtelijke afbakening 210-211, 237, 239

- ohjectief criterium (objectief dynamische inhoud) $243,250,304,305,613$

- "aard en de mate van intimiteit van hetgeen omtrent een ander wordt waargenomen" 241-244, 250, 304, 305

- subjectieve criteria 243, 250, 304, 306, 613

- "onbevangen zichzelf zijin" $240,243-244,250,304,306,613$ 
- "eigen leven leiden zonder inmenging van buitenaf" 238, 250, 304, 307. 613

- bescherming rechtspersonen 246

- informationele privacy $237-247$

- lichamelijke en geestelijke integriteit 206, 248-250, 255

procedurevoorschriften, zie ook: beperkingsvoorwaarden 157, 166, 632, 649

Proeve (tot grondwetswijziging) 140,143, 150,154, 631

proportionaliteitsbeginsel of -vereiste $6,76,86,91,98,117,185,336-340,438,526$ -

$527,531,548,593,601,604-607,615,622,625-626,633-635,643,645-651$

quality of the law 59,60

Raad van Europa, Comité van Experts 43

Raad van Europa, Comité van Ministers 38, 42, 44, 46-47, 50, 53

Raad van Europa, Commissie van ambtelijke deskundigen (Senior Officials) $\mathbf{4 4 - 4 5}$

Raad van Europa, Commissie voor Juridische en Administratieve Zaken 39, 40, 45, 48, 53

Raad van Europa, Raadgevende (=Parlementaire) Vergadering $38,42,47,49,54,198$, 238, 307

Raad van Europa, Statuut 35-36, 320,601, 629

rechten en vrijheden van anderen, bescherming van de ("protection of the rights and

freedoms of others") $\quad 71-73,625$

rechterlijke beoordelingsruimte $12,19,25-26$

rechtsbijstand, recht op (i.v.m. art. 6 ECRM) 348-352, 398, 438, 604, 640-64I

rechtszekerheid 623,636

rechtvaardigingstoets, zie ook: gelijkheidsbeginsel $454-455$

redelijke wetstoepassing $18,184-186,187,523,525,531-532,548,557,593,621-622$, 633. 635, 645-652

redelijke wetsuitleg $3,14,184-186,187,191-193,524-526,547,621,633,635,645-$ 652

reikwijdte $3,4,9,10,25,73,327,348,536,617,629-630,636,641-644$

reikwijdte $v$ mensenrechten, wijze $v$ vaststellen $5,10,12,25,27,313,592-594,597$. 599

- criteria 6, 313, 433, 439, 441, 592, 597, 599-614, 618,630,636

- verband met beperking van mensenrechten $6.7 .31,326,592-593,596,599,615$ $627,631,639,641$

relevante en voldoende redenen ("relevant and sufficient reasons") $76,91,615,649$ "respect", zie: positieve verp!ichtingen

rule of law 22, 59, 318-319, 335, 339, 343, 360, 366, 434-438, 625

specifieke omstandigheden van het geval 348-352, 399-402, 436, 439, 604, 641 specifieke (formele) wetsbepaling, zie: herleidbaarheid tot

staatscommissie Cals/Donner 142-144.631

staatscommissie Van Schaik 137, 138, 150, 631

strafbare feiten, voorkoming van ("prevention of crime") 68

strict scrutiny-test $\quad 467$

subsidiariteitsbeginsel, zie ook: relevante en voldoende redenen $526,645,65 I$ 
toegang tot de rechter, recht op (art. 6 ECRM), zie ook: afstand van recht; beperkingsvoorwaarden; inherent recht; inherente beperking: effectiviteit van de uitoefening van een recht; positieve verplichtingen; toegang tot een onafhankelijk en onpartijdig gerecht dat bij de wet is ingesteld $313-314,315-316,316-325,325-352$, $386-397,398-403,433-440,601-602,603,605,619-620,625,627,640-641$

toegang tot een onafhankelijk en onpartijdig gerecht dat bij de wet is ingesteld (art. 6 ECRM) $352-354,434$

- beperkingen gesteld aan de rechtsmacht van de rechter 386-391

- gerecht ("tribunal"), zie: gerecht

- bij de wet ingesteld ("established by law") 362-365, 421-422

- onafhankelijkheid ("independence"), zie: onathankelijkheid van de rechter

- onpartijdigheid ("impartiality"), zie: onpartijdigheid van de rechter toegankelijkheid van de wet ("accessibility") $60,91,626,643$

toetsing, abstracte of concrete $12,201,338,375,620$

toetsing, doelmatigheids- 389,417

toetsing, kwalitatieve, zie ook: vrijheid van meningsuiting, - gebruik van enige betekenis;

kern van het recht $563-565,568$

toetsing, marginale $389,409-412,419,469,637,644$

toetsing, rechtmatigheids- $358,389,407,414-420$

toetsing, volledige $357,389,406-412$

toetsingsverbod (art. $120 \mathrm{Gw})$ 637, 65I

toezichtmechanisme ECRM $41,75,322$

tuchtrechtelijke procedures 354

uitzonderingstoestand, zie ook: noodtoestand; nodstandfeste rechten (art. $103 \mathrm{Gw}$, art. 15 ECRM) $158,173-179$

Universele Verklaring voor de Rechten van de Mens $34,40-41,51-53,628$

verbod van verdergaande beperking dan bij de Conventie is voorzien (art. 17 ECRM)

$121-122,172,184,629$

vergadering, recht op (art. $9 \mathrm{Gw}$ ), zie ook: recht op betoging

- grondrecht-gerechtigde: een ieder, ook rechispersonen en personen met controversiële opvattingen 574,590

- het begrip "vergadering" 574-579

- collectieve uitoefening 574,591

- in beslotenheid of in het openbaar 574,591

- doel bijeenkomst 575-576, 590

- band tussen deelnemers 576,591

- organisatie 576

- verplichting tot ter beschikking stellen vergaderruimte, zie ook: positieve verplichtingen; effectieve uitoefening van het recht 577-579, 590, 604

- zorgplicht overheid in geval van hostile audience, zie ook: recht op betoging, zorgplicht overheid; positieve verplichtingen $587,589,604,606,624$

- beperkingen

- geen verbod behoudens ontheffing 588

- geen bemoeienis met inhoud uiting of doelstelling manifestatie (geen preventieve censuur) $\quad 588-589$

vergelijkbaarheidstoets, zie ook: gelijkheidsbeginsel $\quad 453-455,492$

verkeer, belang van hei 168,170 
voorbehouden (art. 64 ECRM) 126-134

- niet algemeen van aard 130

- korte uiteenzetting van de desbetreffende wetgeving 131-133

- een wet die op dat tijdstip op zijn grondgebied van kracht is 133

voorkeursbehandeling $\mathbf{4 7 5}$

voorzienbaarheid van de wet ("foreseeability") $61,91,626,643$

vreemdelingen, zie ook: recht op respect voor het familie- en gezinsleven, - uitzetting/ toelating vreemdelingen 101-104, 454, 509, 518-519,603,628

wanordelijkheden, voorkoming van ("prevention of disorder"), zie ook: openbare orde; zorgplicht van de overheid in geval van een hostile audience $586,589,606,624$

Weens Verdragenverdrag $19-20,21,320,322$

werking, horizontale 11,578

werking, verticale 11

wet ("law") $\quad 59-60,91,161-162,165,340,363-364,421-422,514-515,521$

Wet openbare manifestaties (WOM) $165,170,191,575-576,581-582,585,588-589$, 590, 638

willekeur-criterium $328-329,351,358,389,434,601$

woning, recht op respect voor de (art. 8 ECRM) 227-234, 310

- afbakening begrip "woning" ("home") 227-228, 234, 284-285, 310

- "sufficient continuing links" 227-228, 233

- geldige rechtstitel 230-231

- bedrijfspand 231-233

- geen doelcriterium 232

- toepassing Nederlandse rechter 284-285

zorgplicht overheid in geval van hostile audience, zie: recht op betoging, - zorgplicht overheid: zie ook: positieve verplichtingen; recht op vergadering; voorkoming van wanordelijkheden 


\section{Curriculum Vitae}

Claudia Staal werd op 2 oktober 1965 geboren in Den Helder. Zij behaalde aldaar in 1984 haar Atheneum-diploma aan de Openbare Scholengemeenschap Nieuwediep. Vervolgens studeerde zij van 1984 tot 1988 Nederlands Recht aan de Universiteit Utrecht met als afstudeerrichting Internationaal recht. Aan het einde van haar studie liep zij stage bij het Studie- en Informatiecentrum Mensenrechten te Utrecht.

$\mathrm{Na}$ afloop van haar studie was zij enkele maanden als toegevoegd onderzoeker verbonden aan de vakgroep Internationaal Sociaal en Economisch Publiekrecht (ISEP) van de Universiteit Utrecht. Daarna was zij van december 1988 tot oktober 1993 aangesteld bij de Vakgroep Publiekrecht van de Rijksuniversiteit Limburg. In die tijd liep zij van april tot en met juni 1991 stage op het Secretariaat van de Europese Commissie voor de Rechten van de Mens in Straatsburg. Van oktober 1993 tot en met juli 1994 was zij universitair docent bij de vakgroep Staats- en Bestuursrecht van de Universiteit Utrecht en sinds augustus 1994 bij de vakgroep ISEP van dezelfde instelling. 
Colofon

Dit boek is gedrukt door Boekdrukkerij F.E. MacDonald te Nijmegen en gebonden door Boekbinderij Van den Burg te Weurt. 
De Europese Conventie voor de Rechten van de Mens bevat een heel scala aan mensenrechten waarvan de naleving door de verdragsstaten moet worden verzekerd. Ook de Nederlandse Grondwet bevat sinds de grondwetsherziening van 1983 een uitgebreide mensenrechtencatalogus. Daarmee staat echter allerminst vast welke rechtsbescherming beide documenten nu in het concrete geval aan de rechtzoekende bieden. Voor een nadere bepaling van de omvang van de verdragsverplichtingen van de overheid en de daartegenover staande rechten van de justitiabele is deze laatste veelal op de rechter aangewezen. De in dit boek gestelde hoofdvraag luidt dan ook: "Op welke wijze stelt de rechter de reikwijdte van de rechten van de mens vast?". Deze hoofdvraagstelling wordt beantwoord door middel van een onderzoek naar de beperkingssystematiek in de Conventie en de Grondwet. Hierbij wordt ook ingegaan op de argumenten die ten grondslag hebben gelegen aan de wijze waarop de rechten en beperkingsmogelijkheden in deze instrumenten zijn geformuleerd en de uitwerking daarvan in de jurisprudentic. Voorts wordt de rechterlijke praktijk onderzocht terzake van de vaststelling van de reikwijdte van enkele in de Conventie en de Grondwet gewaarborgde rechten, te weten de artikelen 8 lid 1 en 6 lid 1 (eerste zin) ECRM en de artikelen 1, 6 lid 1, 7 leden 1 en 3 en artikel 9 lid 1 Grondwet. Alsdan zal kunnen worden vastgesteld of in de rechterlijke praktijk bruikbare handvatten worden aangereikt aan de hand waarvan de rechtzoekende duidelijkheid kan worden verschaft omtrent de hem in concreto op grond van de gegarandeerde mensenrechten toekomende rechtsbescherming.

Claudia Staal is als universitair docent verbonden aan de sectie Recht der Internationale Organisaties van de Faculteit der Rechtsgeleerdheid van de Universiteit Utrecht.

De Stichting Ars Aequi is sedert 1951 uitgeefster van het juridische studentenblad Ars Aequi (maandelijkse oplage in 1995: 28.000) en sedert 1984 uitgeefster van het tijdschrift Recht en kritiek. Daarnaast geeft de Stichting sinds 1975 boeken uit onder de naam ARS AEQUI LIBRI. Het bestuur van de Stichting bestaat uit (oud)redactieleden.

Stichting A.rs Aequi

Postbus 1043

6501 BA Nijmegen

Administratie \& bestellingen: 0243224441

Redactie maandblad Ars Aequi: 024-3223506

Uitgever Ars Aequi Libri: 024-3229014 